UC-NRLF

UC-NRLF

| || || || || ||||| || || || || || || |||

$B 2936878$ 


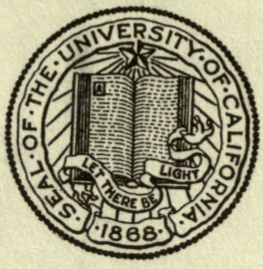

THE LIBRARY OF THE UNIVERSITY OF CALIFORNIA

Landscape Architecture GIFT OF

Professor

Harry W. Shepherd 




\section{TREES AND SHRUBS}

\section{HARDY IN THE BRITISH ISLES}




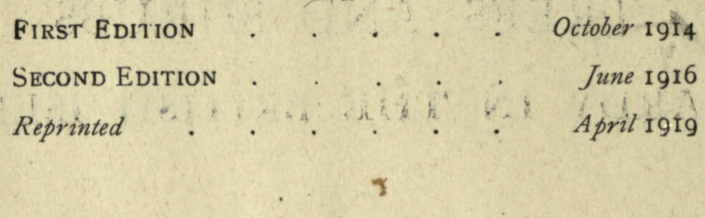




\title{
TREES AND SHRUBS HARDY IN THE BRITISH ISLES
}

\author{
BY W. J. BEAN
}

ASSISTANT CURATOR, ROYAL BOTANIC GARDENS, KEW

WITH ILLUSTRATIONS

VOL. II.

SECOND EDITION

LONDON

JOHN MURRAY, ALBEMARLE STREET, W. 1919 



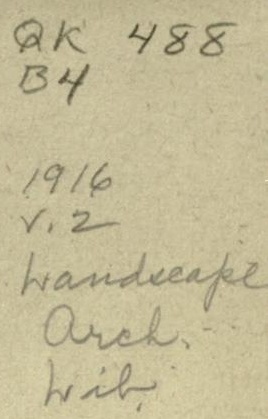

\title{
C O N T E N T S
}

\author{
PART II.-(Continued)
}

Descriptive List of Genera AND SPECIES (LABURnUM-Zizyphus 1

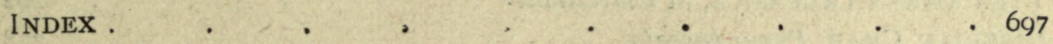




\section{LIST OF PLATES}

[The names of the trees and shrubs illustrated in their place in the text are printed in Small Capitals in the General InDEx.]

SCOTCH LABURNUM, Laburnum alpinum. TO FACE PAGR

LIBOCEDRUS DECURRENS, at Orton Longueville . • • $\quad 23$

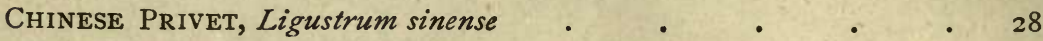

Magnolia SoUlangiana • • • • . • . 74

MUlberRy (Morus nigra), in Syon Park . . . . . . . 86

MOCK ORANGE, Philadelphus coronarius : . . . . 133

Picea Engelmanni, in the Arnold Arboretum, U.S.A. . . . 156

Swiss PINe, Pinus Cembra. . . . . . . 176

St Lucie Cherry, Prunus Mahaleb • . . • 242

JAPANESE CherRy, Prunus serrulata . . . . . 252

PRUNUS TRILOBa (Double-flowered) . $\quad . \quad . \quad . \quad . \quad 256$

Douglas Fir (Pseudotsuga Douglasii), at Murthly Castle, Perth . 260

PTERocarya CaUcasica, at Claremont . . . . . 262

Siberian Crab, Pyrus baccata $\quad$ • $\quad$. $\quad$. 278

JAPANESE CRAB, Pyrus foribunda • . . . . . 282

SWEDISH WhITEBEAM, Pyrus intermedia . . . . . 285

QUERCUS CASTANEAFOLIA. $\quad \cdot \quad \cdot \quad \cdot \quad \cdot \quad \cdot \quad \cdot 304$

LUCOMBE OAK, Quercus Lucombeana . . . . . . 316

RHODODENDRON ARBOREUM var. CINNAMOMEUM . . . 342

CRicket-BAT Willow, Salix ccorulea . . . . . 480

SASSAFRAS (Sassafras officinale), at Claremont . . . . . 501

UMBRELla PINE, Sciadopitys verticillata . . . . . . 506

REDWOOD (Sequoia sempervirens), at Claremont . . . . 510

SOPHORA JAPONICA $\cdot \quad \cdot \quad \cdot \quad \cdot \quad \cdot \quad \cdot \quad 520$

Tsuga Albertiana, at Murthly Castle, Perth . . . . 604

Veronica Traversil . $. \quad \cdot \quad . \quad \cdot \quad \cdot \quad \cdot 640$

WistaRia MULTIJUGa var. ALBA . • . . • . 682

Zelkova CRENATA, at Wardour Castle $\quad$ • $\quad$ • $\quad$ • 694 


\section{PART II (continued)}

\section{DESCRIPTIVE LIST OF GENERA AND SPECIES}




$$
\text { i T) TSAT }
$$

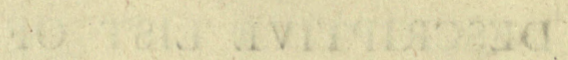$$
\text { and } 0 \times 3
$$ 


\section{LABURNUM. LEGUMINOSÆ.}

A genus consisting of three species, two of them small trees, one shrubby, together with some hybrids and numerous varieties. Laburnum is very closely allied to Cytisus, differing chiefly in the structure of the seed. The leaves are composed of three leaflets, and the flowers are produced in pendent racemes on the arborescent species, and in erect ones on the shrubby one.

Few trees of a similar character are so beautiful as the two common laburnums. When fully in flower, and laden with streaming racemes of golden colour, as they usually are in late May and June, nothing can surpass them in effectiveness. The German popular name, "Golden Rain," is peculiarly appropriate. They look their best in a group of three to six trees, with a dark evergreen mass, like holly or holm oak, behind them. Of very easy culture and raised readily from seed, no special directions are needed for their treatment. They thrive in any soil that is not waterlogged. It is often advisable to remove the seed-pods as soon as the flowers are past. In some seasons the trees develop and ripen enormous crops of pods, and this, besides being of no value or beauty, is apt to induce a stunted condition of growth and reduce succeeding crops of blossom. Laburnums are not particularly long-lived, and attention to this matter will be repaid, especially in the case of valued or fine specimens, by increased longevity.

The seeds contain a poisonous alkaloid, and children have been known to die from eating them in a green state. The heart-wood of the trunk is of a dark colour and very hard; it is sometimes used as a substitute for ebony, occasionally also for furniture making. Many trees and shrubs of the Leguminosæ can be grafted on laburnum, and the abundance of its seed and easy cultivation have made it very much used as a stock for many of its allies.

\section{Adami, Kirchner. Purple Laburnum.}

A deciduous tree with the habit and aspect of L. vulgare, up to $25 \mathrm{ft}$. high ; leaflets oval or obovate, $1 \frac{1}{2}$ to $2 \frac{1}{2}$ ins. long. Racemes 5 to 7 ins. long; flowers yellowish suffused with purple, of the same shape and character as those of L. vulgare, but, like the leaflets, smaller. So far as I have seen, this laburnum is quite sterile.

Although inferior to either of the common laburnums in beauty, there is no more interesting tree in our gardens than this. It appeared in the nursery of Mr Jean Louis Adam, at Vitry, near Paris, in 1825. According to Adam's account, he had grafted the dwarf purpie broom (Cytisus purpureus) on a common laburnum, and on the grafted plant a branch appeared with purplish yellow flowers intermediate in hue between those of scion and stock-L. Adami, 
in fact, as we know it to-day. A few years after L. Adami had been put into commerce, a further remarkable phenomenon was observed in connection with this tree. It was found that it had a tendency to "sport" back more or less to both the parent types. This character it has maintained ever since, and to-day almost every specimen of Laburnum Adami shows on its branches, not only the hybrid itself, but pieces of pure L. vulgare and pure Cytisus purpureus that have sprung spontaneously from its tissues. All three flower together, the curious tufts of the Cytisus suggesting witches' brooms. Many authori.ies have in times past doubted the possibility of a hybrid being produced by grafting, but the correctness of Adam's account has latterly been proved by Prof. Winkler of Tubingen, who has produced graft hybrids between the tomato and black nightshade. Fürther, a similar instance has been brought to light of graft hybrids between medlar and hawthorn (see Cratægomespilus). These graft hybrids have been termed "chimæras," because there seems to be a mixture of the parents in their tissues, rather than a genuine and entire fusion. The outer tissues are often found under the microscope to resemble those of one parent, the inner ones those of the other.

\section{L. alpinum, Presl. Scotch laburnum.}

A deciduous tree, $20 \mathrm{ft}$. (rarely $30 \mathrm{ft}$.) high, with usually a short, sturdy trunk. Leaves trifoliolate, with a stalk I to 2 ins. long; leaflets oval or obovate, 2 to 4 ins. long, deep green, not so downy beneath as in L. vulgare. Racemes pendulous, slender, 10 to 15 ins. long, carrying numerous golden yellow flowers, each $\frac{3}{4}$ in. long on a thin stalk $\frac{1}{4}$ to $\frac{1}{2} \mathrm{in}$. long ; both the flowerstalks and the main-stalk of the raceme are smooth or thinly downy. Seedpods 2 to 3 ins. long, flat, with the upper seam (suture) distinctly winged and forming a knife-like edge.

Native of Central and S. Europe; cultivated in the British Isles for at least three hundred years, probably much longer, but not a native. It was long confused with the common laburnum until its distinctness was noted by Miller in his Dictionary. It differs in the following characters : leaflets larger and less hairy ; racemes longer, and opening two to three weeks later (early June); upper edge of pod flattened out into a thin edge in place of the thickened one of L. vulgare. L. alpinum is undoubtedly the superior species for gardens.

Var. AUTUMNALE.-Usually bears a small second crop of blossom in autumn.

Var. GRANDIFLORUM.-Leaflets broader; flowers larger, racemes longer. Var. MACROSTACHYS is perhaps the same.

Var. PENDULUM.-Branches weeping.

Var. PILOSUM.-Racemes longer, under-side of leaflet furnished with scattered hairs.

An old variety commonly known as "Latest and Longest" is still one of the best of laburnums.

\section{CARAmanicum, Bentham and Hooker.}

\section{(Bot. Mag., t. 7898.)}

Although described as a small tree in its native country, this species has not yet, in Great Britain, got beyond the dimensions of a shrub 3 to $6 \mathrm{ft}$. high. It is deciduous, and has a thin habit, making long, straight, erect shoots, which towards the end of the summer produce near the top a number of short, stiff twigs, each terminated by a raceme of flowers. Leaves grey-green, trifoliolate, short-stalked; leaflets almost stalkless, obovate, with a short abrupt point, from $\frac{1}{4}$ to $\frac{3}{4}$ in. long, the side ones the smaller. Racemes terminal, erect, 3 to 7 ins. long. Flowers golden yellow, $\frac{3}{4}$ in.. long; the stalk 


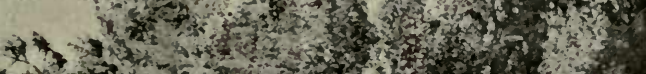

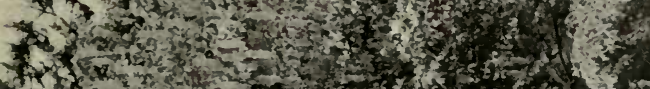

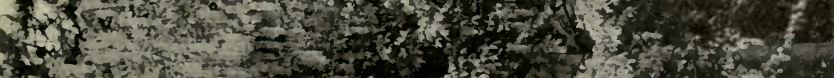

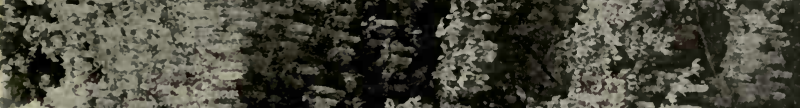

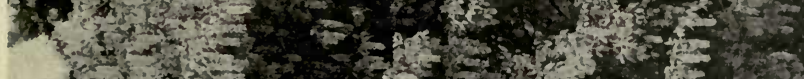

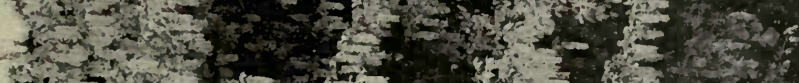

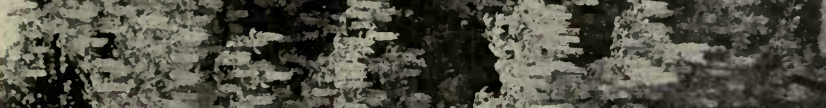

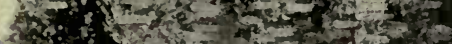

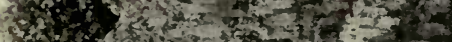

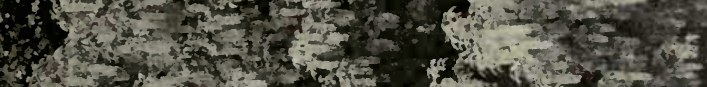

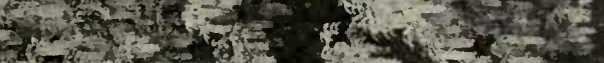

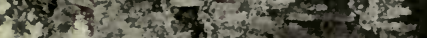

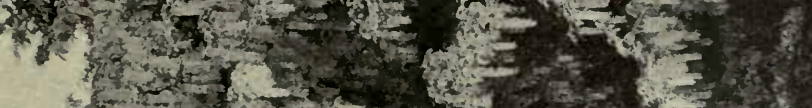

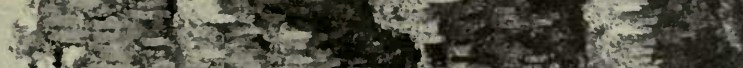

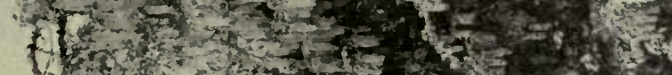

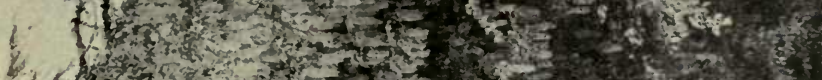

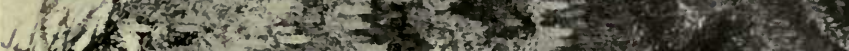

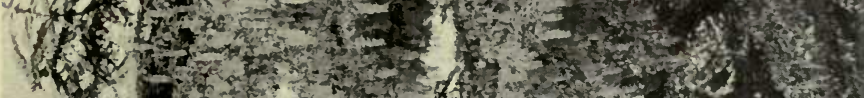

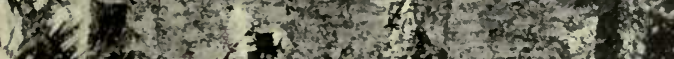

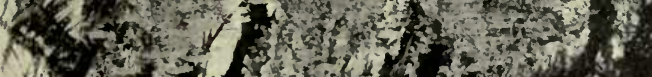

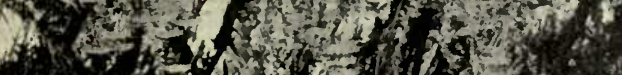

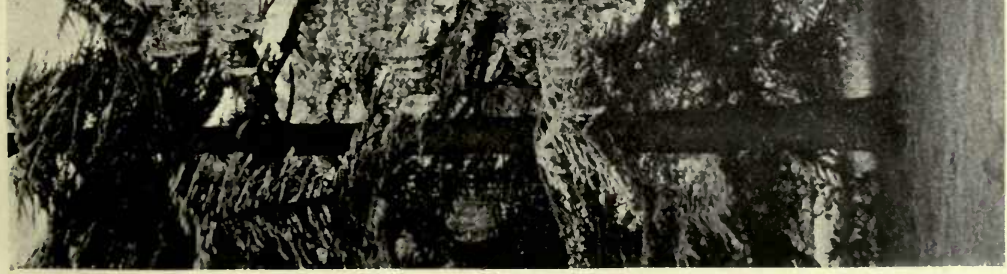



slender, $\frac{1}{4}$ in. long, with a small bract about the middle; standard petal roundish, $\frac{1}{2}$ in. diameter. Seed-pod 2 to 3 ins. long, $\frac{1}{2}$ in. wide, flat, the upper seam distinctly winged, developing one to four seeds.

Native of Greece and Asia Minor; introduced about 1879, but still very

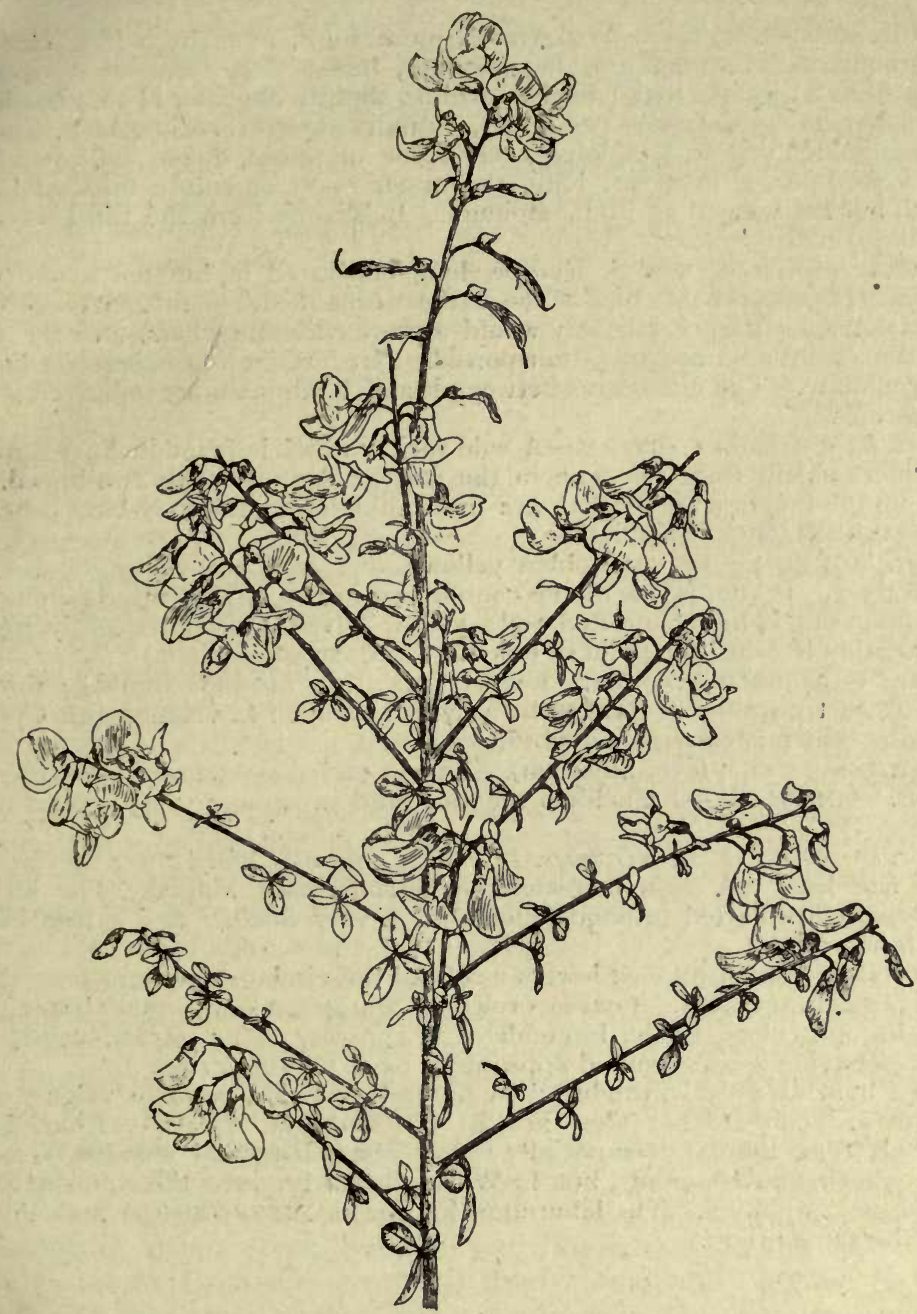

LABURNUM CARAMANICUM.

uncommon. It has lived outside at Kew for a good many years, but the shoots are cut back severely every winter. Owing to its flowering late in the season on the shoots of the year, this does not affect its blossoming, although the plants increase slowly in size. To be seen at its best, no doubt, it needs a hotter, sunnier climate than ours. It flowers too late to ripen seed with 
certainty, but they do occasionally ripen, as in 19I1. Cuttings taken in August will strike root.

\section{L. vulgare, Presl. Common laburnum, Golden Rain.}

A deciduous tree, 20 to $30 \mathrm{ft}$. (rarely more) high, often branching close to the ground and forming a wide-spreading, bushy tree. Leaves trifoliolate, with a stalk 2 to 3 ins. long; leaflets oval or slightly obovate, $1 \frac{1}{2}$ to 3 ins. long, downy beneath. Racemes pendulous, cylindrical, 6 to Io ins. long, downy. Flowers golden yellow, $\frac{3}{4}$ in. long, each borne on a thin, downy stalk $\frac{1}{4}$ to $\frac{1}{2}$ in. long. Seed-pod 2 to 3 ins. long, the upper seam or suture thickened and keeled, but not winged as in L. alpinum. It blooms from the third week of May into June.

Native of Central and S. Europe, long cultivated in, but not a native of Britain. It was probably one of the earliest ornamental plants introduced to this country, as its great beauty would attract early travellers, and the seed could be easily obtained and transported. No foreign tree is better adapted to our climate. The differences between it and L. alpinum are indicated under that species.

Var. Alschingeri, Briquet.-A wild variety which is found in East Europe, and differs chiefly from the type in the calyx being distinctly two-lipped, the lower lip the longer; the leaflets are more silky-hairy and grey-blue beneath. Var. JACQUINIANUM is similar.

Var. AUREUM.-Leaves golden yellow; one of the prettiest of goldenleaved trees. It affords one of the commonest instances showing the influence of scion on stock, for on grafted trees yellow-leaved shoots frequently appear considerably beneath the point of union. (Syn. chrysophyllum.)

Var. CARLIERI, Kirchner.-Leaflets smaller; racemes thinner; flowers more distinctly spotted. Said to be a hybrid between L. vulgare and Cytisus nigricans, which is extremely doubtful.

Var. INVOLUTUM (syn. bullatum).-Leaves curled. A curiosity merely. habit.

Var. PENDULUM.-Branchlets slender and weeping; very graceful in

Var. QUERCIFOLIUM, Kirchner.-Leaflets curiously lobed after the fashion of an oak leaf, the main leaf-stalk being sometimes winged. The leaf is occasionally five-parted (quinquefoliolate). A very distinct and rather handsome form.

Var. SEMPERFLORENS.-Flowers a second time in late summer.

Var. SESSILIFOLIUM.-Leaves crowded, almost stalkless, their bases thus being brought close to the branchlet. A curiosity of no garden value, the branches having a stiff, stunted appearance ; not free-flowering.

Two hybrids at least, produced by natural agencies, between vulgare and alpinum are cultivated. They are L. PARKSII and L. WATERERI, both beautiful trees, the latter especially; they show botanical characters intermediate between the parents, but L. Watereri has retained the full length of raceme of L. alpinum. The laburnums known as INTERMEDIUM and VOSSII are of the same origin.

\section{LARDIZABALA BITERNATA, Ruiz and Pavon.} BERBERIDACE $A$.

(Bot. Mag., t. 450I.)

A vigorous evergreen climber, with ternate, biternate, and triternate leaves. The three, six, or nine leaflets are of hard texture, each 2 to 4 ins. 
long, the middle one of each trio the largest. They vary much in outline, but are mostly ovate, the lateral ones more or less oblique, and often sessile; margins shallowly crenate, with here and there a sharply pointed tooth; leaf-stalks covered with short brown hairs. Flowers unisexual; males 3 in. across, produced in drooping spikes 3 to 4 ins. long from the leaf axils; the sepals form the most striking part of the flower, being broadly ovate, fleshy and dark purple; petals small, narrow, white and mealy. Female flowers on slender stalks $\mathbf{I}$ in. long, solitary in the leaf-axils; rather larger than the male. Fruit sausage-shaped, 2 to 3 ins. long; seeds flattened and about the size of small peas.

Native of Chile; introduced in 1844, it flowered in the Exeter nursery five years later. Seen in flower, it is very striking. The fruit is sweet, pulpy, and edible, and is said to be sold in the markets of Chile. This climber is essentially one for the milder parts of the kingdom. It is too tender to be satisfactory even on a wall at Kew.

\section{LARIX. LARCH. CONIFERA.}

Amongst the comparatively few deciduous conifers, the larches stand out as peculiarly well-marked and distinct. They are all trees of timberproducing size, forming an erect, tapering trunk, carrying usually a coneshaped head of horizontal branches upturned at the ends, and often ultimately pendulous spray. As in the cedars the branchlets are of two kinds: (I) elongated slender ones, growing from a few inches to $2 \mathrm{ft}$. or more yearly, and bearing the leaves singly and spirally; and (2) short, spur-like ones which lengthen a minute fraction of an inch annually, and bear numerous ( 20 to 40 ) leaves crowded in a terminal tuft. Leaves linear or needle-like, falling in autumn. Flowers unisexual, both sexes appearing on the one tree. Males globose to cylindrical, made up of numerous yellow-anthered, short-stalked stamens. Females erect, globose, usually red, developing into a cone composed of thin, concave, rounded, very persistent, woody scales ; bracts either protruded or included. Seeds in pairs on each scale, winged, ripening and falling the first autumn. Of its nearest allies, with a similar leaf arrangement: Pseudolarix differs in the much larger, more woody cone-scales falling away early from the central axis ; Cedrus is, of course, evergreen, and its cones much larger.

The larches are widely spread over the cool 'parts of the northern hemisphere, often in mountainous regions. They like a fairly good, loamy soil, and an abundant rainfall. One species, L. americana, succeeds in damp spots, but the rest like a well-drained site. They should always, if possible, be raised from seeds, which should be sown evenly and thinly, and slightly covered with soil-the common larch outof-doors, usually in raised beds not more than $4 \mathrm{ft}$. wide to facilitate weeding, the rarer ones in unheated frames for better protection. They may be planted out permanently at $\mathrm{I} \frac{1}{2} \mathrm{ft}$. high and upwards. Rarer sorts can be grafted in spring on seedlings of the common larch.

Larches are very liable to be infested with a white woolly insect (Chermes abietis), commonly known as "larch blight." This insect passes 
part of its existence on spruce. It is thought that the punctures caused by it afford one means by which the spores of the fungoid parasite, Dasyseypha calycina, effects its entry. This fungus, commonly known as "larch canker" or "larch blister," has done very much damage to larch plantations during recent decades. The "blight" is best attacked by spraying with paraffin emulsion, especially in spring; the "canker," with Bordeaux mixture. But such measures can of course only be adopted for comparatively small garden specimens. The canker is as yet only seriously affecting the common larch (q.v.).

\section{AMERICANA, Michaux. TAMARACK.}

\section{(L. microcarpa, Desfontaines.)}

A tree 50 to $80 \mathrm{ft}$. high, with a trunk sometimes nearly $2 \mathrm{ft}$. in diameter; young shoots often glaucous, turning yellowish brown, never downy. Leaves three-sided, $\frac{3}{4}$ to $1 \frac{1}{4}$ ins. long, very slender, bluntish. Cones egg-shaped, $\frac{1}{3}$ to $\frac{2}{3}$ in. long, $\frac{1}{4}$ to $\frac{1}{2}$ in. wide ; scales enclosing the bracts.

Native of Eastern N. America, from Newfoundland and Labrador south to Virginia, and west to the Rocky Mountains. It is distinguished from all other cultivated larches by its small cones. Introduced, according to Aiton, in 1760 , it has never been much cultivated, owing, no doubt, to the greater beauty and economic value of the European larch, but as it thrives in places too damp for the latter (occupying swampy ground in some of its native haunts), it is worth trying in such positions. There are trees about $70 \mathrm{ft}$. high at Arley Castle, near Bewdley, and elsewhere. Some confusion exists in gardens between this species and L. dahurica, both having been called "L. pendula," and the latter having at one time been regarded as E. American. L. americana is easily distinguished by its shorter leaves and smaller cones.

\section{DAHURICA, Turczaninoze. DAHURIAN LARCH.}

\section{(L. davurica, Trautvetter.)}

A tree in some parts of its native habitat as large as the common larch; bark scaling, but not fissured; young shoots pale brown, not downy. Leaves I to $1_{4}^{3}$ ins. long, not so tapered at the tip as in the common larch. Cones beautiful bright pink when young in April, ultimately $\frac{3}{4}$ to $1 \frac{1}{4}$ ins. long, eggshaped, tapered towards the top; scales rounded, with the margins distinctly bevelled, and differing from those of $\mathrm{L}$. europæa in not being downy, at least as a rule.

Native of Saghalien, E. Manchuria, and Siberia. The date of its introduction is unknown, but it was cultivated as long ago as 1739, at which time and for long afterwards it was thought to be a native of Newfoundland, where, however, no proof of its being a native exists. It thrives well in Britain, and in several places is from 60 to $80 \mathrm{ft}$. high. At Kew it is $50 \mathrm{ft}$. high and $3 \mathrm{ft}$. 8 ins. in girth. [Prof. Henry (Gard. Chron., Sept. 18, 1915) has pronounced the larch here described to be the true L. PENDULA, Salisb., and maintains that it is a hybrid between europæa and americana, not L. dahurica. (Note, 2nd Ed.).]

\section{EUROPAa, De Candolle. COMmon LaRCh.}

(L. decidua, Miller.)

A tree reaching 100 to $140 \mathrm{ft}$. in height in this country, with an erect, tapering trunk, 2 to $5 \mathrm{ft}$. thick, clothed with fissured, scaling bark; branchlets 
pale yellowish grey, not downy. Leaves light green, $\frac{3}{4}$ to $1 \frac{1}{2}$ ins. long, linear, with the midrib raised beneath, and with two to four lines of stomata at each side of it. Male flowers red, $\frac{1}{2}$ in. long, egg-shaped. Cones at first reddish, ultimately I to $\mathbf{I} \frac{1}{2}$ ins. long, $\frac{3}{4}$ to $\mathbf{I}$ in. wide at the base, tapering slightly towards the top; scales rounded, downy at the base outside.

Native of $\mathrm{S}$. and Central Europe, mostly in mountainous regions ; introduced early in the seventeenth century, but first brought into notice as a forest tree in the British Isles by the third and fourth Dukes of Atholl, roo to I 50 years later. Two of the oldest, or perhaps the very oldest larches in the British Isles are standing near the old cathedral at Dunkeld, planted there in 1738 . No tree ever introduced to Britain has proved of so much value, or been so extensively planted. For many years its economic importance has exceeded that of any other tree-even the oak. About the middle of last century it began to be noticeably attacked by a fungoid parasite, known as the "larch blister" or "larch canker." This is Dasyscypha calycina, and its virulence has increased, so that many plantations have been partially or wholly destroyed. Larches growing in damp, lowland sites, or in pure stands, are more liable to disease than those growing on bleak hill-sides, or mixed with broad-leaved trees.

As a garden tree the larch has much to recommend it; in habit it is singularly beautiful when grown as an isolated specimen, the horizontal or upwardly curved branches being furnished with pendulous branchlets. It attains to an imposing height; its trunk is handsomely coloured, and no tree exceeds it in the beauty and soft tenderness of the young green foliage.

Two weeping forms are in cultivation:-

Var. PENDULA.-A tree with an - erect trunk and horizontal branches, but with the pendulous character of the branchlets extremely developed.

Var. PENDULINA.- Wholly pendulous, the tree forming an umbrellashaped head of branches and branchlets without a leader.

L. SIBIRICA, Ledebour (L. europæa var. sibirica, Loudon). Siberian Larch. - Although closely allied to the common larch, this may be distinguished by the earlier growth in spring, the longer, more slender leaves, and in the more concave scales of the cone. It appears to have no value in this country. Its early growth renders it very subject to injury by late spring frosts. I have only seen plants a few feet high.

\section{Griffithin, Hooker fil. Himalayan LaRCH.}

(Bot. Mag., t. 8181.)

So far as the British Isles are concerned, this larch is only likely to come under the notice of those whose gardens are in the milder counties. Introduced first by Sir Joseph Hooker, in 1848 , and by others subsequently, very few trees now exist in the country, and of them the best are at Coldrenick, in Cornwall, and Strete Raleigh, in Devon. In the former place a tree (see Gardeners' Chronicle, Mar. 2, 1907, fig. 56) has attained about as high a stature as it does in Sikkim, being nearly $60 \mathrm{ft}$. high. From other larches L. Griffithii is well distinguished by the large size of its purplish cones, which are $2 \frac{1}{2}$ to 3 ins. long, I to $1 \frac{1}{4}$ ins. diameter, cylindrical, sliglitly tapering towards the top; scales roundish obovate, straight cut across the top, downy outside; bracts yellowish, longer than the scales, the awllike apex much reflexed, at least when young. The tree has much the habit of common larch, but the branchlets are more markedly pendulous. The young shoots are downy, and the leaves 1 to $1 \frac{1}{4}$ ins. long. They are very subject to the attacks of the white woolly larch blight, and an occasional spraying with paraffin emulsion during the summer may be necessary to keep the trees in health whilst young.

Native of Nepal, Sikkim, and Bhutan. 


\section{KURILENSIS, Mayr. KuRILE LARCH.}

\section{(L. dahurica var. japonica, Maximowicz.)}

A tree up to $70 \mathrm{ft}$. high, forming a stout trunk 2 to $2 \frac{1}{2} \mathrm{ft}$. in diameter; young shoots very downy and dark brown, the down persisting the second season. Leaves $\frac{1}{2}$ to $I$ in. long; rounded at the end, very broad in proportion to their length, of a glaucous green, and with two conspicuous stomatic bands beneath. Cones about $\frac{3}{4}$ in. long, oval-cylindrical, the scales with thin, slightly bevelled, not reflexed, margins, indented about the middle.

Native of the Kurile Islands, especially on the main island (Iturup). It was at first regarded as a variety of $L$. dahurica, from which its broader leaves and persistently downy and much darker coloured young shoots well distinguish it. It was introduced to Kew in 1897 , from Japan. It is at present remarkable there, chiefly for its curious, thin, lanky aspect, due to the scarcity of the elongated branches as compared with the short spurlike ones. This is probably due to want of vigour, but it is still one of the least promising of larches, probably needing colder winters and later springs than obtain in S. England.

\section{LEPTOLEPIS, Endlicher. JAPANESE LARCH.}

\section{(Gardeners' Chronicle, 1883, i., fig. 13.)}

A tree 80 to Ioo $\mathrm{ft}$. high, with a trunk 3 to $4 \mathrm{ft}$. thick, and (in the open) a wide-spreading head of branches; bark scaling, showing a pale grey-

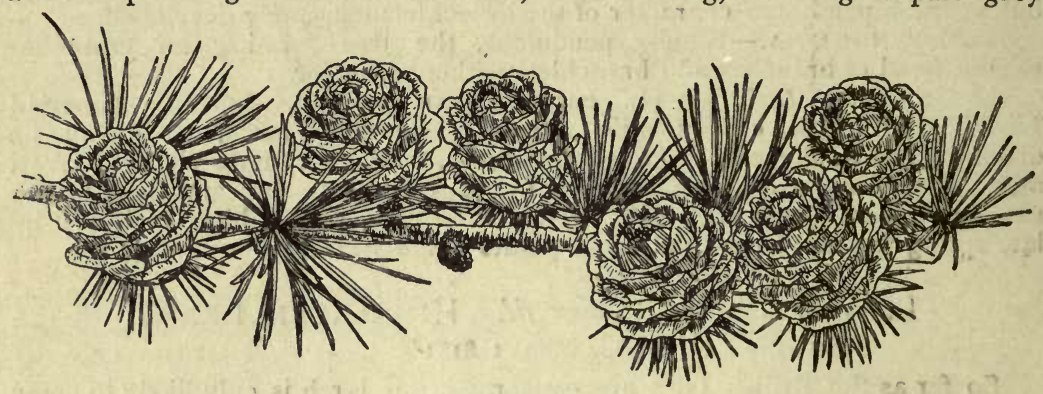

LARIX LEPTOLEPIS.

brown surface beneath; young shoots very downy, rich reddish brown the first winter. Leaves, $I \frac{1}{4}$ to $I \frac{5}{8}$ ins. long, $\frac{1}{16}$ to $\frac{1}{12}$ in. wide ; rather glaucous, flat above, ridged beneath, and with two bands of stomatic lines there. Cones somewhat globose, and broader in proportion to their length than those of any other larch, being about I in. wide and long ; also very distinct in the thin, rounded scales being markedly curved back when ripe.

Native of Japan; introduced in 1861 by John Gould Veitch. A good deal of attention has lately been given to this tree as one likely to take the place of the common larch in places where that tree, through the attacks of larch canker, has ceased to be profitable. Hitherto the Japanese larch has been almost, although not wholly, immune from the attacks of larch canker, but it is well known that newly introduced trees are not so liable to disease as those softened by long cultivation, and the great proportion of planted trees are quite young. It is certainly worth extensive trial under forest conditions. At Dunkeld and Blair Atholl, in Perthshire, both classic sites in regard to larch planting, I saw very promising plantations a few 


\section{LARIX-I.AURELIA}

years ago. It is never likely to rival the European one in size. In the garden it is worth growing as an isolated specimen or in a small group, being very distinct from the common larch in the greater thickness and length of the branches, and in the broader cones and leaves.

\section{OCCIDEntalis, Nuttall. WeSt American Larch.}

(Bot. Mag., t. 8253.)

A tree 100 to $200 \mathrm{ft}$. high, with a narrow, pyramidal head, and a trunk sometimes 6 to $8 \mathrm{ft}$. in diameter; bark scaling. On some of the young trees at Kew the young shoots are smooth, on others downy. Leaves $1 \frac{1}{4}$ to $1 \frac{3}{4}$ ins. long, scarcely distinguishable from those of common larch. Cones oblong to egg-shaped, about $1 \frac{1}{2}$ ins. long, $\frac{3}{4}$ in. wide ; the scales thin, rounded, reflexed at the margin. The cone is rendered very distinct by the conspicuous tonguelike apex of the bracts protruding horizontally $\frac{1}{4}$ in. or more beyond the scales.

Native of Western N. America, from British Columbia southwards. In N. Montana, in the neighbourhood of Flat Head Lake, it is, according to Sargent, sometimes $250 \mathrm{ft}$. high. It is, therefore, the most magnificent of all larches, and as it produces a fine timber it deserves a thorough trial under forest conditions in this country. It was introduced to Kew in $188 \mathrm{I}$ by Prof. Sargent, and trees there are now about $40 \mathrm{ft}$. high, with shapely trunks and short branches, in general appearance very like the common larches close by, except for the prominent bracts of the cones alluded to above and the more slender habit. For many years these were the only trees in the country, but a considerable quantity of seed has lately been imported from which thousands of thriving young trees have been raised. Inhabiting the same geographical region as $\mathrm{L}$. occidentalis is

L. LYALLII, Parlatore. Lyall's Larch.-This is a tree 40 to 50 , occasionally $80 \mathrm{ft}$. in height. Its cones resemble those of $\mathrm{L}$. occidentalis in having conspicuously protruded bracts, but it is quite distinct in other respects. The young wood is densely woolly, almost felted, the leaves four-sided, cones up to 2 ins. long, with the scales distinctly fringed, pink when young. A few small plants have been introduced, but they have a miserable appearance, and the species does not give any promise as yet of succeeding in the British Isles.

\section{Potanini, Batalin. Western Chinese Larch.}

(Gardeners' Chronicle, 1906, i., fig. 68.)

A tree 60 to $70 \mathrm{ft}$. high; young shoots yellowish and slightly downy. Leaves 1 in. long, pointed, somewhat four-sided through the prominence of the midrib above and below. Cones egg-shaped, about $1 \frac{1}{2}$ ins. long, $\frac{3}{4}$ to $I$ in. wide, rounded at the top ; scales rounded, downy outside ; bracts protruded.

Native of W. China ; introduced for Messrs Veitch by Wilson from the neighbourhood of Tatien-lu in 1904. Young trees are thriving in the Coombe Wood nursery and at Kew. Judging by a figure of the tree as it grows in China (see Kew Bulletin, 1910, p. 174), it has much the general aspect of the common larch. Wilson says it yields the most valuable timber in W. China. It differs from all other larches except $\mathrm{L}$. Lyallii in the leaves being ridged on both surfaces, and from that species in the only slightly downy young twigs.

\section{LAURElia serrata, Philippi. monimiace $A$.}

(Bot. Mag., t. 8279; L. aromatica, Masters-not Poiret.)

An evergreen tree with square, downy:young stems. Leaves leathery, opposite, narrowly oval, $2 \frac{1}{2}$ to 5 ins. long, I to $2 \frac{1}{2}$ ins. wide; tapered at 
both ends, coarsely toothed, dark glossy green and smooth on both surfaces, except for a few centrally attached, flattened hairs beneath; stalk $\frac{1}{4}$ in. long, downy. When crushed the leaf has a pleasant, spicy, aromatic fragrance, similar to that of bay laurel. The flowers are packed in short racemes in the leaf-axils, small and very numerous, yellowish green. The most remarkable feature of the plant are the seeds, which, when they escape from the capsules, are seen to be furnished with a tuft of long fine brown hairs which enable them to travel long distances on the wind.

Native of Chile. Of this interesting and peculiar tree there are examples in the milder parts of Ireland and in Cornwall. It is only hardy in such places. It flowered in the garden at Kilmacurragh in April 1904. A tree at Penjerrick, near Falmouth, is about $50 \mathrm{ft}$. high.

\section{LAURUS NOBILIS, Linncus. BAy LAUREL. LAURACEA.}

An evergreen, aromatic tree or shrub, 20 to $40 \mathrm{ft}$., sometimes $60 \mathrm{ft}$. high, usually of dense pyramidal shape, and formed of a cluster of erect, much-branched stems; young shoots and leaves smooth. Leaves alternate, narrowly oval or ovate, $1 \frac{1}{2}$ to 4 ins. long, $\frac{1}{2}$ to $1 \frac{1}{2}$ ins. wide ; usually about equally tapered to each end, of firm texture, dark glossy green, often with wavy margins; stalk $\frac{1}{8}$ to $\frac{1}{3}$ in. long. Flowers greenish yellow, small, very shortly stalked, produced in small umbels in the uppermost leaf-axils; the sexes on different trees. Fruit globose or slightly oval, shining, black, $\frac{1}{2}$ in. long.

Native of the Mediterranean region; cultivated in Britain since the sixteenth century, probably before. It is quite hardy at Kew, although occasionally browned by hard winters. This is the true "laurel" of the ancients, and the one whose leaves were used to make crowns for triumphant heroes, and the fruiting sprays to make wreaths for distinguished poets (poets laureate). It is interesting to note in the latter connection that the term "bachelor" as applied to the recipient of degrees, has been derived through the French bachelier from "baccalaureus," i.e. laurel-berry. Nowadays the leaves are put to a more prosaic use, and are commonly used for flavouring milk puddings. It has no relationship with common or cherry laurel (see Prunus Laurocerasus), or with the Alexandrian laurel (see Danaë Laurus).

The bay laurel bears clipping well, and is very largely grown in tubs and pots on the Continent as formal standards or pyramids for the decoration of entrances to mansions, hotels, etc. Perhaps the finest bay laurels in the kingdom are at Margam Park, Glamorgan. Even in 1837 there was one $60 \mathrm{ft}$. high. At Abbazia, on the East Istrian Coast, and at Fiume, across the Bay of Quarnero, I have seen beautiful woods of primeval bay laurel; in these places, growing on rocky sites, they form thickets of slender stems $50 \mathrm{ft}$. high.

Var. ANGUSTIFOLIA (syn. salicifolia).-The species shows some variation in shape of leaf; of several forms this is the most distinct. The leaves are $I_{2} \frac{1}{2}$ to $3 \frac{1}{2}$ ins. long, but only $\frac{1}{4}$ to $\frac{7}{8}$ in. wide.

Var. UNDULATA.-Leaf-margins conspicuously wavy. 


\section{LAVANDUla SPICA, Cavanilles. Lavender. LABIAT}

An evergreen, bushy shrub, 3 or $4 \mathrm{ft}$. high, with erect branches that are square when young, the whole plant covered with a close minute down which gives it a grey or, when the parts are quite young, a whitish, aspect; bark peeling. Leaves opposite, linear or slightly broadened towards the end, $x_{2} \frac{1}{2}$ to 2 ins. long, $\frac{1}{8}$ to $\frac{1}{4}$ in. wide, blunt, margins recurved. Flowers produced in July and August, at the top of slender, erect stalks up to 18 ins. long; they are arranged in whorls, crowded in dense spikes I to 2 ins. long. Corolla tubular at the base, $\frac{1}{3}$ in. long, pale grey-blue, two-lipped at the mouth; calyx tubular, ribbed, $\frac{1}{6}$ in. long, downy, of a deeper shade than the corolla.

Native of the Mediterranean region, known to have been cultivated in Britain since the middle of the sixteenth century, probably long before. This is the common lavender of gardens, a plant whose charm no other excels. - Its flowers appear when few shrubs are in bloom, and their fragrance is, perhaps, more prized than that of any other except the rose. It is remarkably enduring; as I write, some dried flowering sprays gathered over thirty years ago fill the room with their fragrance. The leaves have a fragrance similar to that of the flowers, but not so strong and pure. The lavender likes a warm, sunny spot, and a soil rather light than heavy. A dense compact habit is induced by clipping the plants over every spring before growth commences. It is easily increased by cuttings made in August and placed under a bell-glass or in a cold frame.

L. VERA, De Candolle. - In former times this lavender does not appear to have been recognised as distinct from L. Spica. De Candolle, who first separated it and gave it the present name in 1815 , points out its differences as follows: Leaves linear or narrowly oblong, never becoming wedge-shaped or spathulate, as is frequent in L. Spica ; usually $\frac{1}{12}$ to $\frac{1}{4}$ in. wide, greener. At the base of each whorl of flowers is a pair of bracts, oval with tapered points ; in proportion to their length they are thrice as broad as those of L. Spica. He observes, too, that the spike is simple (unbranched), but that is not the case in cultivation. L. vera is the superior plant for yielding lavender oil. At Mitcham, in Surrey, an ancient industry is that of growing it in fields, the spikes being hawked about London and bought by housewives for scenting bed-linen. They are also made into lavender water. L. Spica yields the Oil of Spike, which is darker and less agreeable in odour than that obtained from L. vera. A white-flowered variety, ALBA, and a neat dwarf one, NANA, both appear to belong to $L$. vera.

LAVATERA arborea, Linnceus. Tree Mallow. MAlvace $\pi$.

A shrub up to 6 or $8 \mathrm{ft}$. high, with stout, erect, woody, annual or biennial stems, $\mathrm{I}$ to 2 ins. thick, and resembling a small tree in for. $n$. Leaves long-stalked, very variable in size, from 3 to 9 ins. long, and as much broad; they are five- to seven-lobed, the lobes unequally roundtoothed at the margins; the base heart-shaped; both surfaces are densely covered with soft hairs. Flowers borne very abundantly; covering as much as $1 \frac{1}{2}$ to $2 \mathrm{ft}$. of the terminal part of the branches, some on short 
leafy racemes, some clustered in leaf-axils. Each flower is $\mathbf{I}_{2}^{\frac{1}{2}}$ ins. across, enclosed at first by a large, woolly, three-lobed involucre or epicalyx; calyx five-cleft; petals five, broadly wedge-shaped, pale purple-red, marked at the base with a patch of dark purple veins.

Native of S. Europe, this handsome plant is also found wild in Great Britain. It inhabits maritime situations on the south and west coasts from Hampshire to the Isle of Man, and occurs either naturalised or wild on Ailsa Craig, the Bass Rock, and other places on the coasts of Scotland. It is worth cultivating in the warmer parts of the kingdom, especially near the sea, its abundant seed making it easy of increase. It is chiefly known in inland gardens by var. VARIEGATA, whose leaves are handsomely marked with white. This form must be propagated by cuttings.

The genus commemorates two physicians and naturalists of Zurich, named Lavater.

\section{LEDUM. ERICACEÆ.}

A small genus of evergreen shrubs, with alternate, short-stalked leaves and white flowers, produced in terminal roundish clusters. Calyx teeth five ; corolla of five distinct, spreading petals ; stamens from five to eleven, with the anthers opening by two apertures at the top. Seed-vessel a capsule, with five divisions which separate from the base upwards.

L. latifolium and L. palustre inhabit moors and swampy districts in high northern latitudes, and like a peaty soil or sandy loam free from lime. They can be propagated by seeds, treated as recommended for heaths, also by layers and cuttings. No success has hitherto been achieved with $\mathbf{L}$. glandulosum, and its reintroduction is desirable.

\section{GLANDUlosum, Nuttall.}

(Bot. Mag., t. 76ro.)

An evergreen bush, said to become as much as $6 \mathrm{ft}$. high in its native home. Leaves oval or ovate, $\frac{1}{2}$ to 2 ins. long, $\frac{1}{4}$ to $\frac{3}{4}$ in. wide; dark green above, whitish and smooth beneath except for a covering of minute glistening scales ; stalk $\frac{1}{6}$ to $\frac{1}{4}$ in. long. Flowers white, $\frac{1}{2}$ in. across, produced during May in a terminal cluster about 2 ins. across. Petals cupped, obovate, spreading; sepals minute, rounded, hairy on the margin ; stalks $\frac{1}{2}$ to I in. long, and, like the calyx and ovary, covered with tiny, scale-like glands.

Native of Western N. America ; originally discovered by Douglas in 1826. A batch of plánts was raised at Kew in 1894 from native seed, which grew and flowered very well a few years later. For some indiscernible reason the plants died one by one until none was left. It would appear as if some peculiar condition were wanting necessary for its existence, and some knowledge of its native habitats is desirable. The species is possibly no longer in cultivation. It is easily distinguished from the two following species by its smooth stems and leaves.

\section{L. latifolium, Aiton. Labrador Tea. \\ (L. grœnlandicum, Oeder.)}

An evergreen shrub, 2 to $3 \mathrm{ft}$. high and as much in diameter: branches erect, clothed when young with more or less rust-coloured wool. Leaves 
aromatically fragrant when bruised, narrowly oblong or oval ; $\frac{1}{2}$ to 2 ins. long, $\frac{1}{4}$ to $\frac{1}{2}$ in. wide; the margins much recurved, the base tapering or slightly, heart-shaped; dark green with a few loose hairs above, covered beneath with a thich rust-coloured felt. Flowers in rounded terminal clusters 2 ins. across. consisting of one or more corymbs; each flower $\frac{1}{2}$ to $\frac{3}{4}$ in. across, white, borne on a slender, downy stalk $\frac{1}{2}$ to $I$ in. long. Calyx edged with very minute teeth ; petals oblong; stamens five to eight ; seed-vessel somewhat cylindrical in shape.

Native of $\mathrm{N}$. America, also of Greenland; introduced in 1763. A very hardy and pretty shrub, the commonest of the Ledums in gardens and the most useful. It flowers from the end of April to June. From L. palustre it is distinguished by its leaves being twice as wide, by having not more than seven or eight stamens to each flower, and by the seed-vessel being more

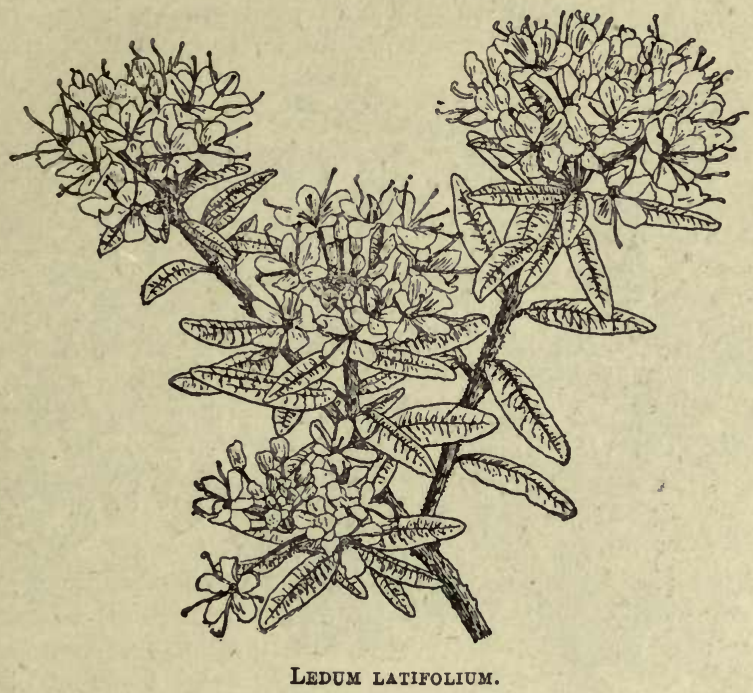

tapered at the top. It extends over an enormous range of country, and varies to some extent in stature and shape of leaf.

Var. COMPACTUM. - Of dwarf habit, with short branches, very woolly stems, short broad leaves, and small flower clusters.

\section{PAlUStRe, Linnaus. MARSH Ledum.}

A dwarf evergreen shrub of thin habit, I to $4 \mathrm{ft}$. high ; young shoots clothed with rust-coloured wool. Leaves linear, $\frac{1}{2}$ to $1 \frac{1}{4}$ ins. long, $\frac{1}{12}$ to $\frac{1}{4}$ in. wide, the margins much recurved and thus reducing their width, dark dull green above, covered with rust-coloured wool beneath. Flowers white, $\frac{1}{2}$ in. across, procluced during April and May in terminal clusters; calyx minutely toothed; stamens more numerous than in L. latifolium, usually seven to eleven; seedvessel egg-shaped.

Native of the northern and Arctic regions of Europe, Asia, and America, not of Britain; introduced, according to Aiton, in 1762. As a garden shrub this Ledum is inferior to L. latifolium, and is much less common. The differences between them are pointed out under that species. 
Var. DILATATUm has leaves wider than the type, and in this respect is intermediate between this and the preceding species.

Var. HYPOLEUCUM.-Leaves with the wool beneath permanently white.

\section{LEIOPHYLlUM Buxifolium, Elliott. SAND Myrtle. ERICACE $A$.}

(Bot. Mag., t. $675^{2}$; Ledum thymifolium, Lamarck.)

A low, much-branched, evergreen shrub of neat, close habit, 9 to I 8 ins. high, the leaves closely set on the branches. Leaves opposite and alternate, ovate, oblong or obovate; $\frac{1}{4}$ to $\frac{1}{2}$ in. long, about half as wide; smooth, glossy, not toothed, dark green, very shortly stalked. Flowers

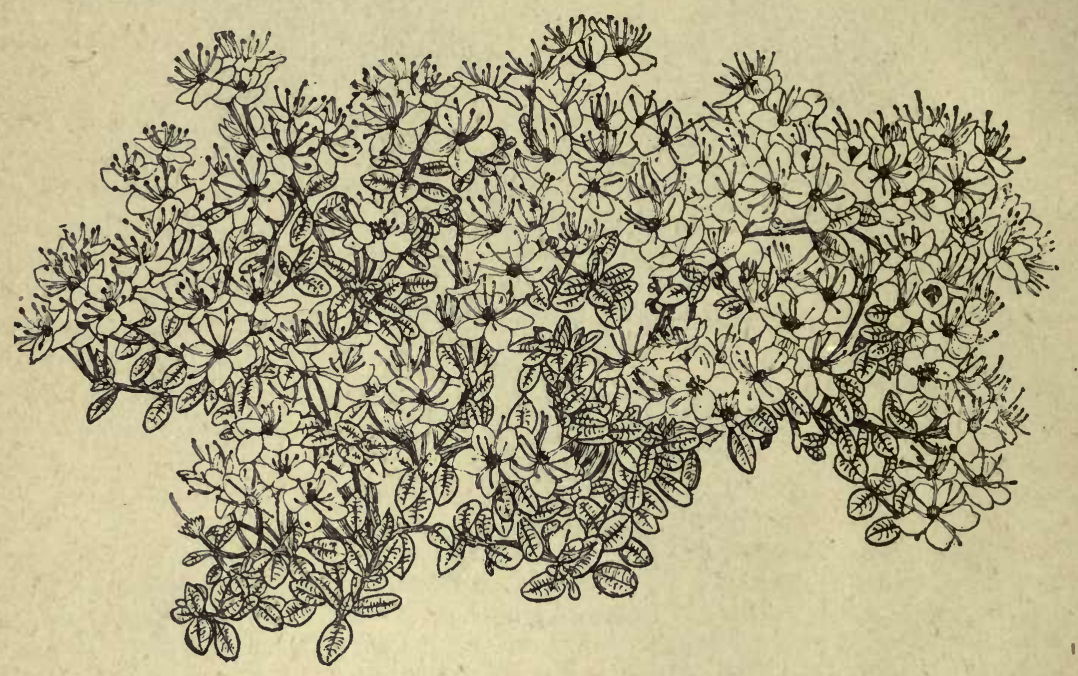

LRIOPHYLLUM BUXIFOLIUM.

rosy in bud, produced in May and June, in crowded terminal clusters $\frac{3}{4}$ to $I$ in. across; each flower is $\frac{1}{4}$ in. in diameter; petals white, tipped with pink, oval, spreading almost to the full extent; sepals narrow lanceshaped, about half as long as the petals. Stamens ten, spreading, their stalks slender; anthers reddish brown, opening down the side. Flowerstalk very slender, $\frac{1}{4}$ in. long. Seed-vessel a two- or three-celled capsule, many-seeded.

Native of Eastern N. America, from New Jersey southwards ; introduced in 1736 by Peter Collinson. From its near allies in the heath family it is distinguished by the quite free petals and small box-like leaves. Ledum is one of its nearest allies, but in that genus the pollen escapes from the anther by a hole at the top. It is a charming little shrub of neat aspect, and is at its prettiest just before the flowers expand, when the buds are very rosy. It blossoms very freely, the flowers almost hiding the 
foliage. The best method of propagating it is by cuttings made of shoots I to $I \frac{1}{2}$ ins. long in July or August, dibbled in sandy peat, and placed in gentle bottom heat; they should be covered with a bell-glass until rooted.

The species exhibits considerable variation in the size of the leaf, and in the comparative lengths of sepals and capsule, and of the petals and stamens. Some botanists make three species, but they appear to be no more than varieties. Ordinary $\mathrm{L}$. buxifolium has the leaves mostly alternate; seed-vessels smooth, and thrice as long as the sepals; stamens twice as long as the petals.

Var. HUGERI.-Leaves mostly alternate, but longer than in the type ; seedvessels smooth, twice as long as the sepals; stamens about the same length as the petals. The commonest garden form (see fig.)

Var. PROSTRATUM.-Leaves mostly opposite; seed-vessels toothed on the outside.

\section{LEITNERIA FLORIDANA, Chapman. CORKWOOD. LEITNERIACE $E$.}

A deciduous shrub or small tree, usually 5 to ro, sometimes $20 \mathrm{ft}$. high, with a stem 3 to 5 ins. in diameter; young shoots downy. Leaves alternate, entire, narrowly oval, tapered at both ends; 3 to 7 ins. long, I $\frac{1}{2}$ to 3 ins. wide; covered with short hairs at first above, grey-felted beneath; stalk downy, I to $I_{2} \frac{1}{2}$ ins. long. Flowers unisexual, the sexes on separate trees. Males in erect, axillary catkins, $\mathrm{I}_{2} \frac{1}{2}$ ins. long, each flower consisting of three to twelve stamens borne on a hairy bract. Female catkins smaller and more slender than the males; all of a greyish hue and of little beauty. Fruit an oval, dry drupe, $\frac{3}{4}$ in. long.

Native of Missouri, Florida, etc., inhabiting swamps; discovered about 1835 ; introduced to Kew in r910. This remarkably interesting tree constitutes in itself the natural order Leitneriacex, and its position in the vegetable kingdom is variously estimated; most botanists, however, concur in placing it near the Myrica or gale family. I saw it in I910 thriving quite well in the Arnold Arboretum, Mass., in Highlands Park, Rochester, N.Y., and in the New York Botanic Garden. It seemed to grow as well in ordinarily moist as in damp spots. All these places have considerably greater extremes than we have of heat and cold, and its capability of supporting our duller climate has yet to be ascertained. Young plants have so far succeeded well. According to Prof. Trelease it often grows in rich soil, mostly covered with 6 ins. or more of water. But many American trees found in such places succeed better here under drier conditions. Still a site moderately moist should be given it. Its wood is probably the lightest known, and only weighs $12 \frac{1}{2}$ lbs. per cubic foot.

\section{LEPTOSPERMUM SCOPARIUM, Forster. MYRTACE}

A compact evergreen bush of rounded, very twiggy habit, attaining the dimensions of a small tree in a wild state; young wood sparsely 
hairy. Leaves alternate, linear-oblong, $\frac{1}{3}$ to $\frac{1}{2} \mathrm{in}$. long, $\frac{1}{12}$ to $\frac{1}{6}$ in. wide; sharply pointed, fragrant when bruised, dotted with transparent oil-glands. Flowers white, $\frac{1}{2}$ in. diameter, produced singly from the leaf-axils in spring; petals round, set well apart from each other, the triangular calyxlobes showing between them. Fruit woody, globose, the size of a pea, many-seeded.

Native of Australia and New Zealand. It thrives outside in the southwestern counties; and at Killerton, in Devon, as well as in other gardens there are bushes 15 to $20 \mathrm{ft}$. high. At Kew it has to be grown against a wall, and even there is apt to be killed in severe weather. Easily increased by cuttings. The var. Nicholli, Turrill (Bot. Mag., t. 84r9), is a remarkable and beautiful form with carmine-red petals. Introduced from New Zealand in 1908, by Capt. Dorrien-Smith; said to have been first found growing on sandhills north of Christchurch.

\section{LESPEDEZA. Bush Clover. Leguminose.}

Of the thirty or forty species belonging to this genus, not more than half a dozen are cultivated in gardens. Many are really semi-herbaceous, dying back to ground-level every winter, but sending up in spring from a woody root-stock a crowd of shoots which flower during late summer and autumn. Leaves trifoliolate; flowers pea-shaped; pods roundish, flat, one-seeded, and thus very distinct from the long, narrow, jointed, several-seeded pods of Desmodiums with which some Lespedezas have been confounded, and which they resemble in mode of growth. The species mentioned in the following notes succeed in ordinary loamy soil in an open position. Where seeds are not available, the most woody ones may be increased by cuttings; others by division. (See under I. Sieboldii.)

\section{BICOLOR, Turczaninore.}

(Garden and Forest, 1892, fig. I8.)

A deciduous shrub becoming in some climates a bush 8 or $10 \mathrm{ft}$. high, although at Kew its stems are only annual and grow from 3 to $7 \mathrm{ft}$. high during the season, dying down to ground-level every winter. Leaves trifoliolate, slender-stalked; leaflets varying in size from $\frac{3}{4}$ to 2 ins. in length by about two-thirds as much wide; broadly oval or obovate, the midrib elongated into a small terminal bristle; the middle leaflet is larger and longer stalked than the others, all being dark green above, pale beneath, and clothed sparsely on both sides with appressed hairs or smooth above. Racemes slender-stalked, 2 to 5 ins. long, produced in the leaf-axils from the uppermost $2 \mathrm{ft}$. of the stem. Flowers rosy purple, less than $\frac{1}{2}$ in. long, confined to the terminal part of the raceme. Calyx $\frac{1}{6}$ in. long, hairy, the teeth not so slender and sharppointed as in L. Sieboldii. Pod ovate, downy, $\frac{1}{3}$ in. long, one-seeded.

Native of Manchuria, China, and Japan; introduced to Europe by Maximowicz, the Russian botanist, in 1856 . It is not so handsome and desirable a plant as L. Sieboldii, with which it has been much confounded. In countries with a hotter summer than ours, the stems made each year do not die back more than half their length, and the plant thus increases gradually in height. In the Arnold Arboretum, Mass., it forms a bush comparable with a Colutea. Flowers in August and September.

Var. ALBA.--Flowers white. 


\section{Cyrtobotrya, Miquel.}

A small deciduous shrub, which in this country sends up from the base every summer a number of erect, woody stems 2 to $3 \mathrm{ft}$. high, that do not survive the winter, but die back to ground-level; bark downy. Leaves trifoliolate, 3 to 5 ins. long; leaflets 1 to $1 \frac{3}{4}$ ins. long, $\frac{1}{2}$ to $\frac{3}{4}$ in. wide; oval or obovate, covered beneath with a fine down especially early in the season; apex rounded or slightly notched, the midrib ending in a short bristle; base tapered. Flowers crowded at the end of umbel-like racemes $1 \frac{1}{2}$ ins. long, which spring from the axils of the upper leaves of the shoot; rosy purple, $\frac{1}{2}$ to $\frac{5}{8}$ in. long. Pod ovate, $\frac{1}{4}$ in. long, one-seeded.

Native of Japan and Corea ; introduced to Kew in 1899. It is a pretty plant scarcely known in cultivation, and blossoms in August.

\section{JunceA, Persoon.}

A semi-woody plant in this country, sending up annually from a woody root-stalk a crowd of slender, grooved stems 2 to $3 \mathrm{ft}$. high, covered with whitish hairs. Leaves trifoliolate, with a slender main-stalk $\frac{1}{4}$ to $\frac{1}{2}$ in. long ; leaflets oblanceolate, $\frac{1}{3}$ to $\frac{3}{4}$ in. long, broadest near the apex, where they are $\frac{1}{12}$ to $\frac{1}{8}$ in. wide and short-pointed, tapering thence to a short stalk, covered beneath with fine grey hairs. Flowers in very short-stalked, twoto six-flowered umbels, produced from the leaf-axils; each flower $\frac{1}{4}$ to $\frac{1}{3}$ in. long, white or partly blue; the calyx half as long, hairy, with slender, linear lobes.

Native of the Himalaya, China, and Siberia; introduced to Kew in 1895. It is not a showy plant, but distinct and striking for its long slender stems of rather broom-like appearance, very densely clothed with the erect, rather appressed leaves. It flowers in September.

Var. Cuneata (L. cuneata, G. Don).-Leaflets wedge-shaped, the end of each one being cut squarely off, except for the bristle-like prolongation of the midrib. Native of China. Other forms of L. juncea have much smaller leaves than those here described.

\section{Sieboldi, Miquel.}

(Garden and Forest, I892, fig. I9; L. bicolor, Hooker fil., Bot. Mag., t. 6602.)

A semi-woody plant, producing stout, pithy, rather herbaceous, grooved stems, 4 to $8 \mathrm{ft}$. high, from a woody root-stock; they die back to groundlevel during the winter, and are replaced by a fresh crop the following year. Leaves trifoliolate; leaflets $1 \frac{1}{2}$ to 2 ins. long, one-third as much wide, becoming smaller towards the upper part of the stem, the centre one longer-stalked than the side ones; oval or oval-lanceolate; coated beneath, especially on the midrib, with appressed greyish hairs. Racemes numerous, up to 6 ins. long, produced from the leaf-axils of the upper part, and at the end of the shoot, the whole constituting a loose panicle 2 to $2 \frac{1}{2} \mathrm{ft}$. in length. Each flower is $\frac{1}{2}$ to $\frac{5}{8}$ in. long, pea-shaped, rosy purple; calyx $\frac{1}{4}$ in. long, covered with greyish hairs, and divided half-way down into five awl-shaped teeth. Pod ovate, flat, silky, $\frac{1}{3}$ in. long.

Native of N. China and Japan; introduced to Europe about 1837 , by Siebold. Although strictly speaking it is scarcely a shrub, it is shrub-like. It is a plant with a luxuriant annual growth of great elegance and beauty, although, flowering late in the season, it does not always reach its best before the frosts come. This is more especially the case after dull wet summers. It commences to flower in September. A single fully grown 
plant will form a mass ro ft. or more across, the outer stems arching outwards. It is not suitable for planting by itself in large groups in conspicuous places, as it starts into growth late in the season and is still bare of leafage when many things are in their full spring greenery. The old dead stems must be cut away in spring. Propagated by pulling or chopping the root-stock into smaller pieces about April. Pieces small enough, with root attached, may be potted and placed in a house where there is bottom heat.

\section{LEUCOTHÖ̈. ERICACEÆ.}

A genus of evergreen and deciduous shrubs, found in 'N. America and Japan. The leaves are alternate; flowers in racemes, white, or slightly pink-tinted. Calyx of five free, or nearly free, sepals ; corolla cylindrical or pitcher-shaped, five-toothed at the top. Stamens ten, enclosed within the corolla. Seed-vessel a round flattened capsule.

The chief cultural need of the Leucothoës is a moist peaty soil, or a sandy loam with abundant leaf-soil added. L. Catesbæi thrives very well in semi-shade, and may be propagated by division.

\section{EVERGREEN.}

I. Davisice. Racemes erect, nearly terminal.

2. Catesbrei. Racemes axillary along the shoot, nodding; petioles up to $\frac{2}{3}$ in. long.

3. Axillaris. Racemes axillary along the shoot, nodding; petioles $\frac{1}{4}$ in. or less long.

\section{Deciduous.}

4. Racemosa. Anthers with four awns; capsule not lobed.

5. Recurva. Anthers with two awns; capsule five-lobed.

\section{AXILlaris, D. Don.}

(Andromeda axillaris, Lamarck.)

An evergreen shrub, 2 to $4 \mathrm{ft}$. high, with spreading branches zigzagged towards the end, clothed with very short down when young. Leaves leathery, ovate-lanceolate, 2 to $4 \frac{1}{2}$ ins. long, $\frac{3}{4}$ to $1 \frac{1}{2}$ ins. wide; usually abruptly pointed, spine-toothed, dark glossy green and smooth above, pale and with scattered hairs beneath; stalk $\frac{1}{4}$ in. or less long. Flowers produced during April and May in axillary racemes $\mathrm{I}$ to 2 ins. long, crowded, and very shortly stalked. Corolla white, cylindrical or pitcher-shaped, narrowing slightly towards the mouth, where are five ovate teeth; sepals ovate; flower-stalks minutely downy.

Native of the south-eastern United States from Virginia southwards; introduced in 1765 . It is not so common in cultivation as L. Catesbæi, which it much resembles, and with which it is much confused. Its leaves, however, are comparatively shorter and broader, and abruptly pointed; their stalks are also shorter, and the sepals are broader. Coming from the lowlands of Virginia, Florida, etc., it is much less hardy than L. Catesbæi, which inhabits the mountains. Personally, I have only seen one or two plants, and they were not in good health. A dwarf form of L. Catesbæi is usually offered for it.

\section{Catesb}

(Andromeda Catesbæi, Walter.)

An evergreen shrub, 2 to $6 \mathrm{ft}$. high, with slender, arching, zigzagged branches, which when young are reddish, and covered with a very short down. 
Leaves smooth and leathery, narrowly lanceolate ; 3 to 5 ins. long, I to $1 \frac{1}{2}$ ins. wide; with a long tapering point, rounded or shortly tapered at the base, spine-toothed; dark lustrous green above, paler and with scattered hairs beneath; stalks $\frac{1}{3}$ to $\frac{2}{3}$ in. long. Flowers produced during May, crowded on axillary racemes I to 2 ins. long, occasionally in panicles 3 ins. long. Corolla $\frac{1}{4}$ in. long, slenderly pitcher-shaped, white ; sepals narrowly ovate, pointed ; flower-stalks very short.

Native of mountainous regions in the south-eastern United States; introduced in 1793. When fully in blossom, a well-grown plant with its long arching branches, laden for 12 to 18 ins. of their length with racemes, is decidedly handsome. But owing to the flowers being all produced on the lower side, the branch often requires elevating for its full beauty to be seen. During the flowering season it is worth while to elevate a few of the branches by means of forked sticks.

Var. Rollisoni.-A variety with smaller, narrower leaves, 2 to 4 ins. long, $\frac{1}{2}$ to $\frac{3}{4}$ in. wide.

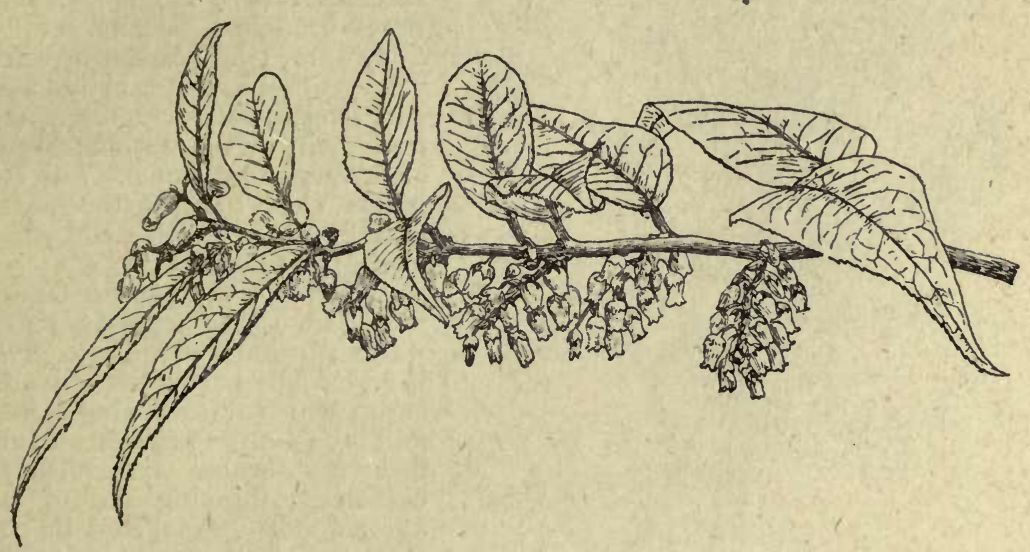

Levcothö̈ Catresbei.

\section{Davisia, Torrey.}

(Bot. Mag., t. 6247 ; Andromeda Davisiæ, C. K. Schneider.)

An evergreen shrub, I to $3 \mathrm{ft}$. high in cultivation, of neat, very sturdy habit ; branches erect, stiff, perfectly smooth. Leaves ovate-oblong, rounded or slightly heart-shaped at the base, short-pointed or blunt at the apex, lustrous dark green, of firm texture, $I \frac{1}{4}$ to $2 \frac{1}{2}$ ins. long, $\frac{3}{4}$ to $I$ in. wide ; very slightly and evenly toothed; stalk $\frac{1}{8}$ to $\frac{1}{4}$ in. long. Flowers produced in mid or late June in a cluster of erect racemes springing from the end of the shoot and its terminal leaf-axilș, each raceme 2 to 4 ins. long, and furnished with short, scattered bristles. Corolla nodding, pitcher-shaped, white, $\frac{1}{4}$ in. long, five-toothed. Sepals short, ovate, edged with a few glandular teeth ; flower-stalk $\frac{1}{8}$ in. long.

Native of the Sierra Nevada, California, at $5000 \mathrm{ft}$., where it was originally discovered, and introduced in 1853 by William Lobb, for Messrs Veitch, and at first distributed by them as "Leucothoë Lobbii." Subsequently found hy 
Miss N. J. Davis, after whom it was named. It is, perhaps, the most beautiful in the genus, because its erect, terminal cluster of racemes stands well above the foliage. It thrives very well in the neighbourhood of London. Propagated by cuttings in August.

\section{Racemosa, A. Gray.}

(Andromeda racemosa, Limnaus: A. spicata, Watson.)

A deciduous shrub of bushy, erect habit, generally 4 to $6 \mathrm{ft}$. high in cultivation, but occasionally twice as high; young shoots usually finely downy. Leaves narrowly oval or inclined to obovate; I to $2 \frac{1}{2}$ ins. long, $\frac{1}{2}$ to $I \frac{1}{4}$ ins. wide; pointed at both ends, shallowly round-toothed, of firm texture, downy

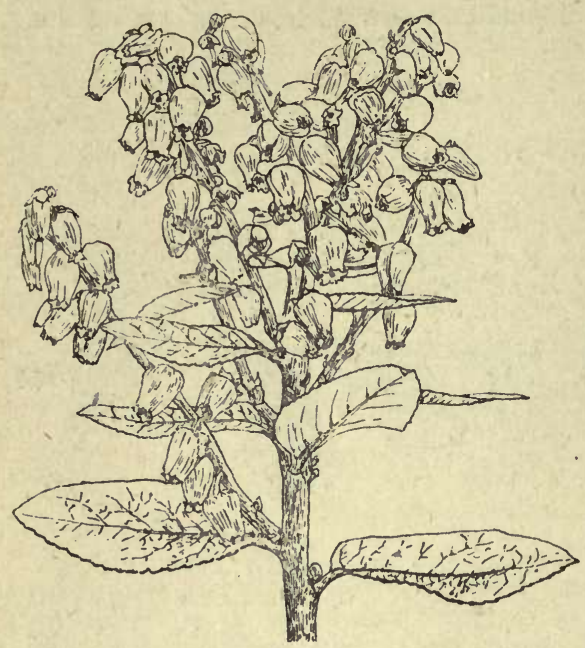

Leucothö Davisia. on the midrib beneath; stalk $\frac{1}{8}$ in. or less long. Flowers produced during June in one-sided racemes I to 4 ins. long, sometimes branched, usually terminating short twigs of the previous year. Corolla white, cylindrical, $\frac{1}{3}$ in. long; sepals triangular-ovate, finely hairy on the margin ; flowerstalk very short, smooth, with two bracts close beneath the calyx ; each anther is terminated by four awns, two to each cell.

Native of the eastern United States from Massachusetts southwards ; introduced in 1736 . This is a perfectly hardy, free-growing shrub which flowers abundantly, and is one of the prettiest of June flowering shrubs. It requires an occasional thinning out of the older wood. Propagated by cuttings of nearly ripened young shoots. Allied to L. recurva (q.v.).

L. ReCURva, A. Gray.

(Garden and Forest, 1896, fig. 33 ; Andromeda recurva, Buckley.)

A deciduous shrub, usually 3 to $5 \mathrm{ft}$. high, the young shoots slightly downy or smooth. Leaves narrowly oval or lanceolate, tapering at both ends, thin but firm, toothed, $\mathrm{I} \frac{1}{2}$ to 4 ins. long; $\frac{1}{2}$ to $I_{4}^{\frac{1}{4}}$ ins. wide ; downy on the veins and midrib beneath; stalk very short. Flowers produced during May and June in decurved racemes, 2 to 3 ins. long, terminating short twigs of the previous year Corolla white, cylindrical, $\frac{1}{4}$ in. long; sepals ovate, pointed; flowerstalk very short and stout ; anthers terminated by two awns, one to each cell.

Native of the southern Allegheny Mountains from Virginia to Alabama; introduced to England by Prof. Sargent about I890, but very rare. It is probably not so hardy, nor so good a garden plant as its near ally, L. racemosa, from which it differs chiefly in its more diffuse habit, the recurved racemes, and very distinctly grooved seed-vessel ; each pollen bag, too, is surmounted by only ons bristle instead of two. 
LEYCESTERIA FORMOSA, Wallich. CAPRIFOLIACEA:

$$
\text { (Bot. Mag., t. 3699.) }
$$

A half-woody, deciduous plant, with erect, hollow stems, 4 or $5 \mathrm{ft}$. sometimes much more high, covered with glaucous bloom, smooth, very leafy. Leaves opposite, ovate, heart-shaped at the base, with long

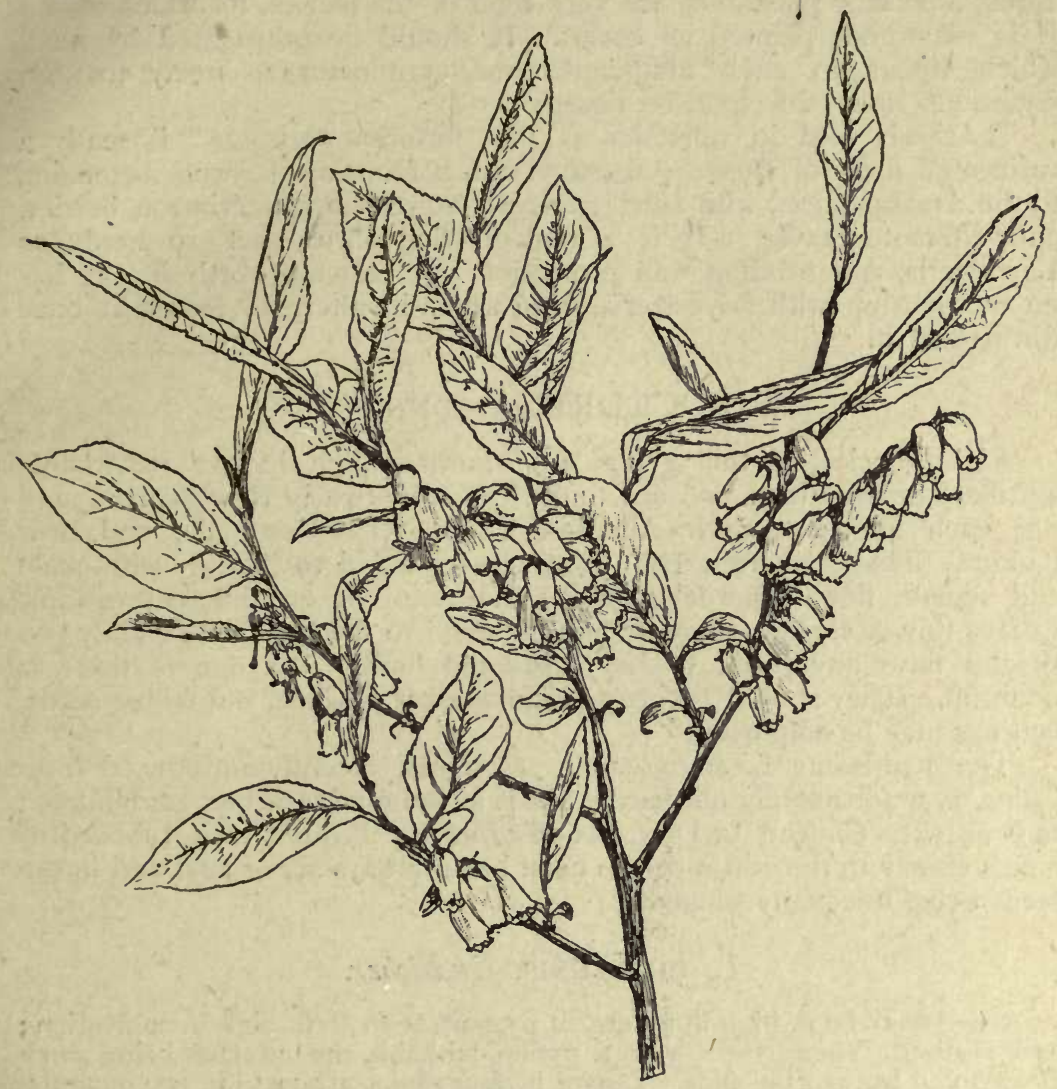

LEUCOTHÖ̈ RACEMOSA.

tapered points ; varying in size according to the vigour of the shoot from 2 to 7 ins. long, about half as wide; entire or with small teeth; deep green above, greyish and slightly downy when young beneath; stalk $\frac{1}{4}$ to I in. long. Flower-spikes produced from June to September, either at the end of the shoot or in the uppermost leaf-axils, I to 4 ins. long. Flowers stalkless, arranged in tiers, each tier supported by handsome claret-coloured bracts of the same shape as the leaves and from $\frac{1}{2}$ to $1 \frac{1}{2}$ ins. long, which persist until the fruit is ripe. Corolla $\frac{3}{4}$ in. long and 
wide, funnel-shaped, five-lobed, purplish, slightly hairy; calyx one-third the length of the corolla, with five erect, awl-shaped, hairy lobes. Berry like a small gooseberry, reddish purple, glandular-downy, about $\frac{1}{2}$ in. long, many-seeded, surmounted by the persistent sepals ; ripe in October.

Native of the Himalaya in shady forests; introduced in 1824 . This handsome shrub likes a rich soil, and, in spite of its natural habitats, a sunny spot. The bracts and fruits colour better under a full exposure. Birds, especially pheasants, are very fond of the berries, for which reason it is sometimes planted as covert. It should be propagated by seed, which ripens in such abundance and germinates so freely that an enormous stock can soon be raised.

A shrub sold in nurseries as "L. formosa variegata" is really a variegated form of Bosea AmHerstiana, a Himalayan shrub belonging to the Amarantaceæ, with small greenish flowers, bright crimson berries, and alternate leaves. It is a rank-growing shrub not so hardy as Leycesteria, and needing wall protection but scarcely worth it. It has no relationship with Leycesteria, from which its alternate leaves at once distinguish it.

\section{LIBOCEDRUS. CONIFERA.}

Eight species of this genus are known, which have a remarkably scattered distribution : two are found in Chile, two in New Zealand, and one each in Western N. America, China, New Caledonia, and New Guinea. They are evergreen trees, closely allied to Thuya, with male and female flowers borne on the same tree but on different catkins. Leaves tiny, scale-like, more or less flattened to the branchlet. Only two species have any claim to be considered hardy, and one of these is doubtful. They should be grown from seed if possible, but failing seeds, cuttings may be employed.

The handsome L. MACROLEPIS, Bentham, recently introduced from China, is unfortunately not hardy, but is an admirable winter-garden tree; as is also the Chilean L. Doniana, Endlicher. From Thuya, Libocedrus differs chiefly in the scales of the cone being always six or less, and in the seeds being unequally winged.

\section{CHILENSIS, Endlicher.}

A tree 60 to $80 \mathrm{ft}$. high in nature, at present 20 to $50 \mathrm{ft}$. high in cultivation; bark peeling. Young trees have a pyramidal habit, the branches being much divided and leafy at the ends. Leaves in four ranks, arranged in two opposite, very unequal pairs ; the top and bottom ones are very small, the lateral ones $\frac{1}{8}$ to $\frac{3}{16}$ in. long, bluntish, dark green on the upper side of the branchlet, with white stomatic bands underneath. Cones $\frac{1}{3}$ in. long.

Introduced from.Chile by $\mathrm{Mr} \mathrm{T}$. Bridges, who sent it to Messrs Low, then of Clapton, in 1847. In gardens it is a very pretty small tree, with frondose, laterally spreading sprays, very distinct from the vertical sprays of L. decurrens, from which it differs also in the unequal size and length of the leaves and their whiteness underneath. It is a rather tender tree, best suited in such places as Cornwall and Devon; at Whiteway in the latter county there is a tree $48 \mathrm{ft}$. high. A couple of plants growing in a very sheltered spot at Kew are healthy, but slow-growing. 



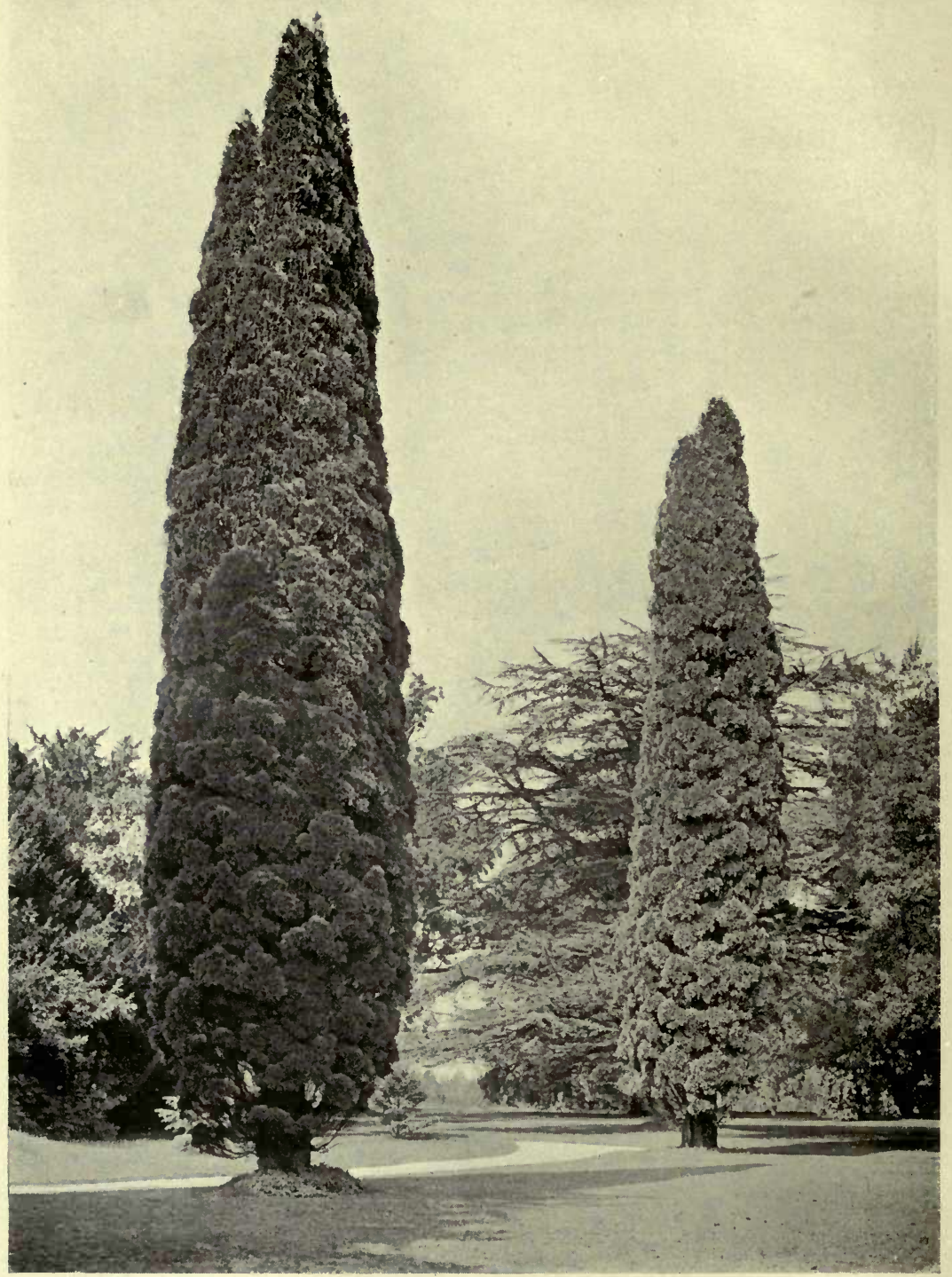

LIBOCEDRUS DECURRENS, at Orton Longueville.

II.)

[Face p. 23. 


\section{DECURREns, Torrey. INCENSE Cedar.}

A tree 125 to $150 \mathrm{ft}$. high in a wild state, with a trunk occasionally $7 \mathrm{ft}$. in diameter. Numerous trees between 50 and $70 \mathrm{ft}$. high are to be found in this country, all marked by a stiff columnar or narrowly pyramidal habit. The branches are erect, and have their branchlets and leaves set vertically or edgewise instead of horizontally, so that they are equally exposed to the light on both sides, and are uniformly green on both surfaces. Leaves in four rows and in opposite pairs ; about $\frac{1}{8}$ in. long, free only at the sharp points, the lower part appressed to and completely covering the branchlet, dark glossy green. Cones erect, $\frac{3}{4}$ in. long, $\frac{1}{4}$ to $\frac{1}{3}$ in. wide at the base, tapered. Seeds four, $\frac{1}{3}$ in. long, awl-shaped, with a large wing on one side and a small one on the other.

Native of Oregon and California ; introduced by Jeffrey for the Oregon Association of Edinburgh in 1853; discovered seven years previously by Col. Fremont. It is frequently called Thuya gigantea (Carrière) in gardens, but is quite distinct from the tree to which that name properly belongs, whose horizontally spreading branchlets showing white stomata beneath are quite different (see Thuya plicata).

Libocedrus decurrens grows rather slowly, but should be represented in every garden large enough to accommodate it, because of its distinct and formal shape-admirable for a group planted as Lombardy poplars sometimes are. A very fine tree about $70 \mathrm{ft}$. high, and quite columnar, perhaps the best in the country, is in the Royal demesne of Frogmore. A hardy species, thriving best in moist, deep loam. In Italy the branches are more spreading and the tree more broadly pyramidal than is usual with us.

Var. VARIEGATA. - Pieces of the shoots entirely yellow. These pieces vary in size from bits of branchlet $\frac{1}{2}$ in. long, to pieces 2 to 3 ins. across, giving the tree a curious spotted appearance.

\section{LIGUSTRUM. PRIVet. OLEACE $A$.}

There are about fifteen hardy species of Ligustrum introduced to this country, all of which are natives of China or Japan, with the exception of the common privet, found in Europe and England. The genus is exclusively Old World, and reaches from China through the Himalaya, etc., to Java, the Philippines, and Australia. Leaves opposite, never toothed. Flowers of some shade of white, borne in terminal panicles. Calyx scarcely or only minutely toothed; corolla tubular, with four spreading lobes. Stamens two, attached to the tube of the corolla. Fruit a berry, usually black, or black with a purplish bloom.

Whilst the privets as a whole are not amongst the most attractive of hardy shrubs, a few of them are either striking or useful. One of the worst points about them is the penetrating odour of the flowers-heavy, and to most people objectionable. The privets are easily cultivated in any soil that is not very impoverished, and they can be rooted from cuttings about as easily as any shrubs, either with or without a little heat. A selection for the garden would be as follows :-

For flower-sinense and Quihoui ; for foliage-lucidum, japonicum, ovalifolium aureum ; for planting in dark damp places-vulgare, ovalifolium; for hedges-ovalifolium (tall), Prattii (dwarf). 


\section{CORIaceum, Carrière.}

(Bot. Mag., t. 75r9.)

An exceedingly stiff-habited evergreen shrub, 4 to $6 \mathrm{ft}$. or perhaps more high; young shoots short, stunted, covered with very minute dark down the first season. Leaves crowded, I to $2 \frac{1}{2}$ ins. long, from two-thirds to fully as wide; broadly oval or round, very blunt or notched at the apex, dark glossy green, thick and leathery; stalk $\frac{1}{5}$ in. long. Flowers white, in erect pyramidal panicles 2 or 3 ins. high, and as much through at the base. Fruit black, globose, about $\frac{1}{5}$ in. diameter.

Native of Japan ; found by Robt. Fortune in a garden there, and introduced in 1860 . It is in all probability a stunted form of L. japonicum obtained under cultivation in Japan, and non-existent in a wild state. It is now grown in many gardens in the south, but surely as a curiosity only, for its flowers have little beauty, and it has no elegance of habit or foliage. It is fairly hardy, but grows better in the south and west than elsewhere.

Var. INVOLUTUM.-A form of freer growth ; leaves more incurved.

\section{Delavayanum, Hariot. Delavay's Privet.}

An evergreen shrub, probably 5 or $6 \mathrm{ft}$. high, with long graceful branches covered with a dense coat of short down which persists on the year-old branches. Leaves oval, $\frac{1}{2}$ to $I_{4}^{\frac{1}{4}}$ ins. long, $\frac{1}{4}$ to $\frac{5}{8}$ in. wide ; tapering towards both ends, quite smooth except for some minute down on the midrib above; dark shining green; stalk $\frac{\pi}{12}$ in. long. Panicle very downy, flowers white; calyx smooth; fruit egg-shaped.

Native of Yunnan, China; raised by Mr Maurice de Vilmorin from seed sent to him by the late Abbé Delavay in 1890 . In its small state this is a pretty, small-leaved, flat-branching bush with the habit of a dwarf Cotoneaster. As it gets older it makes a rounded elegant bush. I have not yet seen it in flower in this country. Allied to L. strongylophyllum, it is apparently hardier.

\section{Henryi, Hemsley. Henry's Privet.}

An evergreen bush, probably 4 to $6 \mathrm{ft}$. high, of neat habit especially when young; young shoots very downy. Leaves smooth, variously shaped, from roundish ovate or almost round to ovate-lanceolate, $\frac{3}{4}$ to $1 \frac{1}{2}$ ins. long, inconspicuously veined, of an almost black, shining green above. Flowers white, scented, in short-stalked terminal pyramidal panicles 2 to 6 ins. long. Corolla $\frac{1}{4}$ in. long; calyx and individual flower-stalk smooth. Fruit oblong, black, $\frac{4}{3}$ in. long.

Native of Central China ; discovered by Henry ; introduced by Wilson in I90I for Messrs Veitch. We only know it yet as a small shrub, but in that state it makes a neat and pleasing evergreen, effective because of the blackgreen iustre of its leaves. Perhaps not absolutely hardy in severe winters.

\section{IвотA, Siebold.}

A deciduous shrub, dense with luxuriant leafage but of graceful habit, ultimately 8 to ro ft. high ; twigs downy. Leaves oval or slightly obovate, 1 to 2 ins. long, $\frac{1}{3}$ to $\mathrm{I}$ in. wide, always tapered at the apex; smooth except on the midrib beneath, and on the margins when young. Flowers white, produced in July in terminal, nodding clusters $1 \frac{1}{2}$ ins. long on short side twigs. Calyx bell-shaped, scarcely toothed, downy ; corolla $\frac{1}{3}$ in. long. Fruit globose, ultimately black, but at first covered with a purplish bloom. 
Native of Japan ; introduced in 1860 . This privet is a strong and vigorous grower, and when well furnished with its short clusters is distinctly ornamental. But it does not make so good a display here as in countries with a hotter summer. I saw it in the Arnold Arboretum in July I910, and was much struck with its beauty and grace. As a flowering or fruit-bearing shrub it is at Kew inferior to L. sinense. It is allied to $\mathrm{L}$. ovalifolium, but is distinct in habit

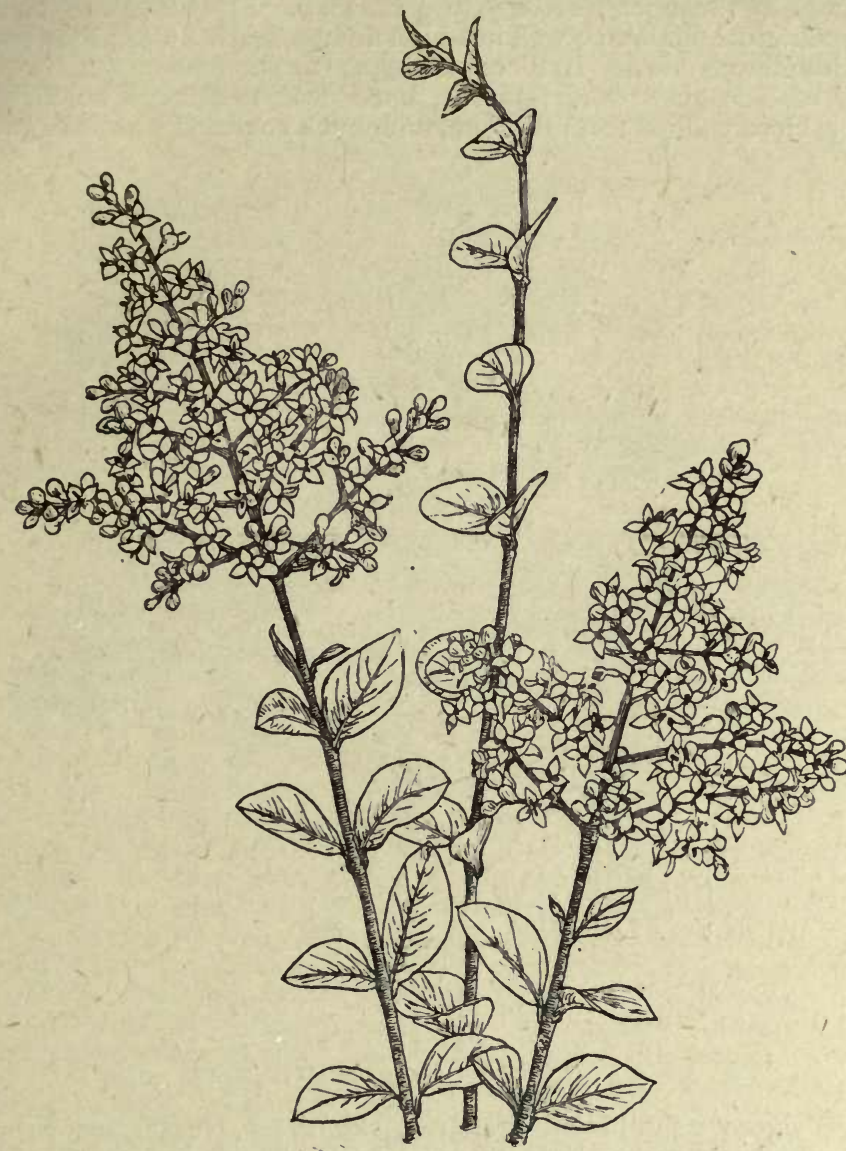

LIGUSTROM HIRRYL.

and in the downy midrib. Both species have a corolla tube two or three times as long as the lobes, but ovalifolium is nearly devoid of down.

Var. REgelianum, Kehder (L. Regelianum, Koehne).-A dwarfer shrub of dense habit, branches spreading horizontally. Leaves oblong or narrowly oval, downy beneath. Calyx hairy; corolla shorter than in L. Ibota; anthers broader and shorter; fruit smaller.

Closely allied to and sometimes considered a variety of $\mathrm{L}$. Ibota is L. ACUMINATUM, Koehne. In gardens it is known as the inferior form of L. Ibota (also as $\mathrm{L}$. ciliatum). It differs in the more lanceolate, longer pointed leaves, glabrous calyx, and smaller, more erect panicles. 


\section{JAPONICUM, Thunberg. JAPANESE PRIVET.}

An evergreen shrub, rarely more than 4 to $8 \mathrm{ft}$. high in this country, of bushy habit; twigs covered when young with minute dark down, becoming quite smooth. Leaves smooth, almost black-green, very glossy, ovate, $\mathrm{I} \frac{1}{2}$ to 4 ins. long, $\frac{3}{4}$ to 2 ins. wide ; usually rounded, sometimes tapering at the base, taper-pointed at the apex; stalk $\frac{1}{4}$ to $\frac{1}{2}$ in. long. Flowers white, borne on terminal pyramidal panicles 4 to 8 ins. high and as much wide. Flower-stalks clothed with minute down. In bloom from July to September.

Native of N. China, Corea, Japan ; introduced to Europe by Siebold in 1845. It is closely allied to L. lucidum, and much confused with it in gardens,

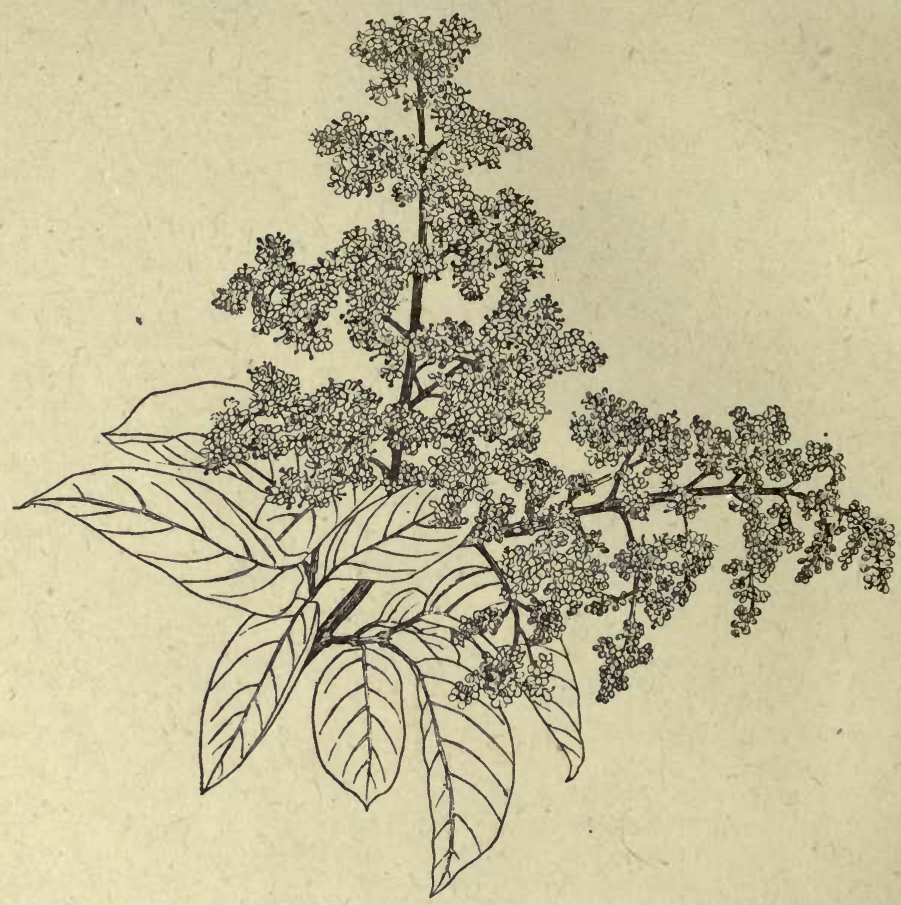

LIGUSTROM JAPONICUM.

but is a less vigorous shrub, its leaves are darker green, shorter, more rounded at the base, and the nerves beneath are raised, whereas in lucidum they are sunken; the inflorescence is looser, and the young shoots minutely downy. It is a useful and effective evergreen because of the intensely dark shining foliage, but needs a sheltered spot.

L. LuCIDUm, Aiton.

(Bot. Mag., t. 2565.)

An evergreen shrub of erect/habit, Io to $18 \mathrm{ft}$. high, or a small tree; devoid of down in all its parts. Leaves narrowly oval or ovate, from 3 to 6 ins. long, I to $2 \frac{1}{2}$ ins. wide ; tapering at the base, long-pointed, glossy 
dark green above; stalk $\frac{1}{3}$ to $\frac{1}{2}$ in. long. Flowers white, produced during August and September in erect terminal panicles 6 to 8 ins. high and nearly as much wide. Fruit oblong, $\frac{1}{3}$ to $\frac{1}{2}$ in. long, blue-black; not frequently produced with us.

Native of China; introduced in 1794. Of the truly evergreen privets, this is the handsomest and best. A well-grown plant with the large lustrous leaves and a crowd of erect panicles is one of the most striking of autumn garden pictures. According to Henry, this privet is 20 to $30 \mathrm{ft}$. high, and the commonest evergreen tree in some parts of Hupeh, China. Wilson, in the Min River Valley, found one example $60 \mathrm{ft}$. high and $10 \mathrm{ft}$. in girth. I have seen it as a tree in the Dalmatian towns-there is one in the public park at Spalato $35 \mathrm{ft}$. high. In China it possesses some economic importance in being the tree on which the "white-wax" insect deposits its eggs. It is sometimes confused with L. japonicum $(q \cdot v$.$) .$

Var. Alivoni.-Leaves longer, narrower, thinner, and less glossy, often variegated; they are 3 to 7 ins. long, and I to 2 ins. wide; yourg twigs minutely' downy; fruit black, rounded at the top. It is not so handsome as L. lucidum, and is perhaps a distinct species.

Var. AUREO-VARIEGATUM. - Leaves variegated with dull yellow; ineffective.

Var. TRICOLOR.-A tender form which needs the protection of a wall. Leaves with a broad but irregular border of white, pinkish when young. Very striking when well grown.

\section{Ovalifolium, Hasskarl. Oval-leaved Privet.}

A semi-evergreen or, in severe winters or in poor soil, a deciduous shrub Io to I $j \mathrm{ft}$. high, of vigorous growth, forming a dense thicket of erect stems ; young shoots usually quite smooth. Leaves I to $2 \frac{1}{2}$ ins. long, $\frac{1}{2}$ to $1 \frac{1}{4}$ ins. wide ; oval, wedge-shaped at the base, blunt or pointed at the apex, glossy green and smooth on both surfaces; stalk $\frac{1}{8}$ in. long. Flowers produced during July in a stiff, erect, terminal panicle, 2 to 4 ins. high and about the same wide; they are very crowded in the panicle, dull white, and have a heavy, unpleasant odour. Corolla $\frac{1}{3}$ in. long. Fruit globose, shining, black. Calyx and individual flower-stalk smooth.

Native of Japan. The oval-leaved privet is a worthy associate of the common one for dark corners or places starved by roots of trees where scarcely anything else will grow. For hedges it is preferable to the common privet because of its more evergreen nature; it has, in fact, almost entirely displaced it for that purpose. It is not worthy of being put to better use, being of stiff, ungainly habit, its flowers dull, and to most people evil-smelling.

Var. ARGENTEUM.-Leaves bordered with creamy white. This pale variegation is not as rich and effective as that of the following.

Var. AUREUM. Golden Privet.-Leaves green only in the centre, with a border of varying width of rich golden yellow. This is the most popular of all variegated shrubs, and has been propagated by hundreds of thousands for town planting. Although it is the fashion to revile it, it certainly produces a very bright effect and brings colour into many a hemmed-in garden or dull city yard where little of any kind will grow. It is also useful in a small state for town window-boxes. In habit it is less rigid and more graceful than the type, and the young shoots, seen under the lens, are th:ckly but very minutely downy.

\section{Prattil, Koehne. Pratt's Privet.}

An evergreen shrub of neat bushy habit, the young shoots densely clothed with short down. Leaves oval or ovate, $\frac{1}{3}$ to 1 in. long, $\frac{1}{4}$ to $\frac{3}{5}$ in. wide; 
tapered about equally at both ends, or more abruptiy towards the base, the apex pointed or blunt; dark glossy green, both surfaces perfectly smooth; stalk $\frac{1}{12}$ in. long. Panicles I to 2 ins. long, $\frac{3}{4}$ to I in. wide, leafy at the base, the main axis downy like the young shoots. Flowers white, $\frac{1}{4}$ in. long, numerous; the calyx and stalk quite smooth.

Native of W. Szechuen in China, and E. Thibet; discovered by MI A. E. Pratt; introduced in 1908 by Mr Wilson. Judging by young plants it ought to prove useful for making small evergreen hedges, being apparently very hardy and retaining its foliage well. It is perhaps most nearly allied to L. Henryi, but that species has larger, darker green leaves, is probably not quite so hardy, and its panicles are naked at the base-not leafy as in L. Prattii. Both are distinguished by their perfectly smooth leaves, calyx, and flowerstalks (pedicels), but downy twigs and peduncles.

\section{Quihoui, Carrière.}

A rounded, deciduous bush of thin, diffuse, but elegant habit, $\sigma$ to ro $\mathrm{ft}$. high; branches thin, wiry, rather rigid, covered with a darkish minute down when young. Leaves I to $I \frac{1}{2}$ ins. long, one-third to half as wide, oval or obovate, tapering to a short stalk at the base, often bluntish at the apex; smooth on both surfaces, but minutely downy on the stalk. Flowers white, fragrant, produced in September and October in slender downy panicles, 4 to 8 ins. long, $1 \frac{1}{2}$ to 3 ins. in diameter. Fruit ovate, shining, purplish.

Native of China ; introduced to France about 1862. The habit of flowering so late in the season gives this species a special value in the garden, for it is one of the prettiest and most elegant of privets in bloom. Its flowers do not always open if September be dull and cold, but it deserves to be more extensively grown. The specific name was given in compliment to $\mathrm{Mr}$ Quihou, once superintendent of the Jardin d'Acclimatation at Paris.

\section{SInense, Loureiro. ChInese Privet.}

A deciduous or, in mild winters, nearly evergreen shrub, 12 to $20 \mathrm{ft}$. high, occasionally taking the form of a small tree, of dense habit, rounded or flattopped; twigs covered with a short, dense; brownish down. Leaves pale green, thin, oval; I to 3 ins. long, $\frac{1}{2}$ to I in. broad; tapering at the base, bluntish or notched at the apex, downy on the midrib beneath; stalk $\frac{1}{8}$ to $\frac{1}{4}$ in. long. Flowers white, produced in July in numerous downy panicles, 3 or 4 ins. long, $1 \frac{1}{2}$ to 2 ins. wide. Fruit globose, black-purple, about $\frac{1}{6}$ in. diameter, remaining on the branches until after the New Year.

Native of China; introduced by Fortune about 1852. I consider this the best and most ornamental of deciduous privets. It bears immense feathery masses of blossom in July, and they are usually followed by a wealth of dark purple fruits about the size of large shot, which make the shrub interesting through the winter. It is never seriously injured by cold, although in hard winters the twigs are occasionally cut back. Still, a sheltered position for it is preferable to one bleak and exposed, as it grows and flowers better then.

Var. MULTIflorum, Paul.-Anthers reddish brown, not yellowish as in the type.

Var. NANUM.-A dwarfer, more spreading form, with smaller leaves (? L. Stauntoni, De Candolle). There is also a variegated form, the leaves irregularly bordered with yellow; of no value so far as I have seen.

\section{STRONGYLOPHYLLUM, Hemsley.}

(Bot. Mag., t. 8069.)

An evergreen shrub of elegant, loose habit, occasionally a small tree in a wild state, sending out long, slender branches each season which, whilst 


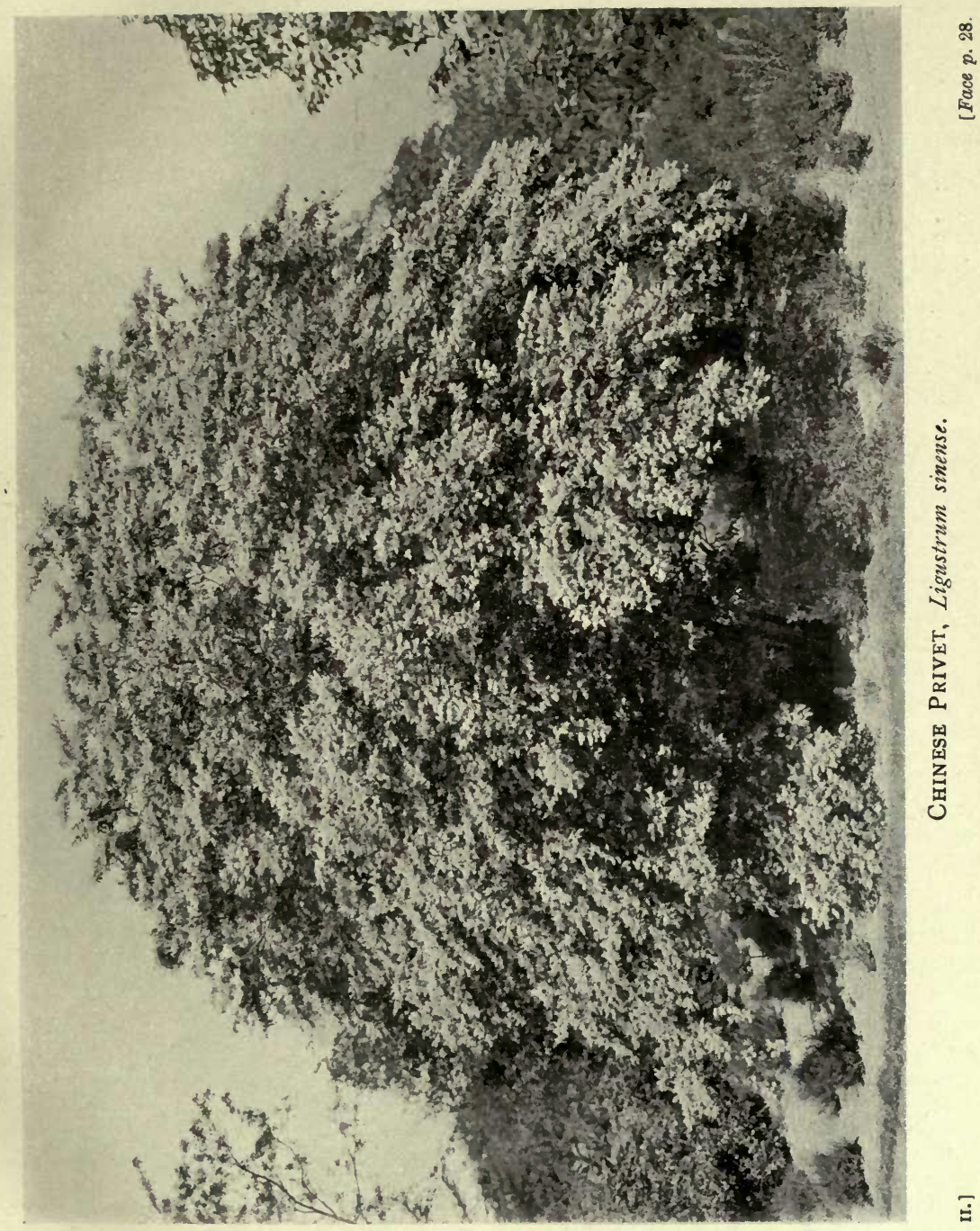



young, are covered with a dense, minute down. Leaves nearly round, broadly oval or ovate, $\frac{1}{3}$ to $\frac{3}{4}$ in. long, often ending in a short abrupt tip; of firm texture, dark glossy green; margins slightly recurved; stalk $\frac{x}{20} \mathrm{in}$. long. Flowers white, $\frac{1}{4}$ in. diameter, produced during July in a terminal pyramidal panicle, 2 to 4 ins. high and as much wide at the base. Corolla tube $\frac{1}{8}$ in. long ; lobes pointed, $\frac{1}{8}$ in. or less long.

Native of China ; introduced by Maries for Messrs Veitch in 1879. Maries no doubt collected it in the Yangtze Kiang valley, about Ichang, where it was afterwards found by Henry. It is an elegant privet, and its numerous, small, almost round leaves give it a distinct appearance. But it is not very hardy, and at Kew has only flowered satisfactorily on a south wall.

\section{L. vulgare, Linncus. Common Privet.}

A deciduous or more or less evergreen shrub, 6 to $10 \mathrm{ft}$. high, of rather lax habit; young shoots covered with minute down. Leaves narrowly oval or lance-shaped, I to $2 \frac{1}{2}$ ins. long, $\frac{1}{4}$ to $\frac{5}{8}$ in. wide, smooth. Flowers dull white, produced during June and July on erect compact panicles I to 2 ins. long, terminating the twigs; they have a heavy odour objectionable to most people. Fruit globose or egg-shaped, black.

Native of Europe, including Britain, where it is considered wild from Yorkshire southwards. The common privet may nowadays be regarded almost as the Cinderella among shrubs. It is relegated to dark corners and other damp out-of-the-way places under the drip of trees, where scarcely anything else will grow. But one can scarcely wish it a better fate. With so many beautiful things available the privet is not needed; even in its own genus it is about the least attractive, and for hedges is now superseded by the oval-leaved species. Its flowers are under suspicion of producing a kind of hay-fever. The berries are eaten by birds.

Var. AUREUM.-A worthless yellow-variegated form.

Var. BUXIFOLIUM.-Leaves oval, scarcely I in. long; habit dense.

Var. GLAUCUM.-Leaves of a grey-green tint, not sufficiently marked to give it any value.

Var. ITALICUM (sempervirens).-A more regularly evergreen shrub than the type.

Besides the ordinary form with black berries, three others, differing in their fruits, are, or have been, in cultivation : CHLOROCARPUM, green-berried; LEUCOCARPUM, white-berried ; and XANTHOCARPUM, yellow-berried.

Allied to the common privet is L. INSULARE, Decaisne, a species of unknown origin with linear-oblong leaves 2 to $4 \frac{1}{2}$ ins. long, $\frac{1}{2}$ to I in. wide, taper-pointed ; young shoots velvety-downy. Flowers in a panicle 3 ins. long and broad ; fruit roundish oblong, $\frac{1}{3}$ in. long, black.

\section{L. yunnanense, L. Henry. Yunnan Privet.}

A deciduous, sometimes partially evergreen shrub, Io to $15 \mathrm{ft}$. high, of open, vigorous habit; branches spreading or somewhat pendent, slightly warted, and at first clothed with a very minute down, which mostly falls away by the end of the year. Leaves oval lance-shaped, tapering at both ends; 3 to 6 ins. long, about one-third as wide; smooth. Flowers creamy white with an odour like common privet, produced in July in numerous terminal panicles 6 or 7 ins. high, and the same or more wide at the base. Fruit $\frac{1}{4}$ in. long, rounded at the top, covered with purple bloom at first, then black.

Native of Yunnan, China; introduced to France by the Abbé Delavay, who sent seeds to the Jardin des Plantes at Paris in 1888 . The plants raised from them flowered in 1902 . In its general aspect it is very like L. lucidum var. Alivoni ; but it flowers before that privet does, and regularly sets its fruit. It is also nearly deciduous. 


\section{LINDERA、 LAURACEÆ.}

The Linderas are spicily aromatic shrubs or small trees allied to the bay laurel. There is in cultivation one hardy American species, and several, scarcely so hardy, from Japan and China. None of them is showy in flower, and they do not bear fruit freely, if at all in this country. The genus is not represented in the European flora; but in Japan, Sargent remarks that the Linderas make a notable feature in the shrubby.growth of the hillsides and on the borders of streams and lakes. Leaves alternate, flowers unisexual, small, yellowish. Fruit a drupe. Besides the species mentioned below, another, L. SERICEA, Blume, is occasionally grown. Its leaves are covered with silky hairs when they unfold, which mostly fall away as the season advances. It flowers freely at Coombe Wood in March and April, bearing its blossoms in small umbels; stalks short, very silky. I have not heard that it develops fruit. On the low levels of Kew it is so injured by spring frosts that it never lives long out-of-doors.

\section{Benzoin, Blume. Spice Bush.}

\section{(Laurus Benzoin, Linnåus; Benzoin æstivale, Nees.)}

A spicily aromatic, deciduous shrub, 6 to $12 \mathrm{ft}$. high, forming a rounded bush as much in diameter; young shoots smooth or slightly downy. Leaves obovate, 2 to 5 ins. long, I to $2 \frac{1}{2}$ ins. wide ; tapered towards both ends, but more gradually towards the stalk; not toothed, thin, smooth above, smooth or slightly downy and glaucous beneath, margins ciliate; stalk $\frac{1}{4}$ to $\frac{1}{2}$ in. long. Flowers greenish yellow, small, and not showy ; produced in tiny clusters during April from the joints of last year's naked shoots; the sexes are on separate plants ; corolla nóne; calyx with six lobes. Fruit dark red or purple, oval, $\frac{1}{3}$ in. long, juicy.

Native of the eastern United States; introduced in 1683 . When crushed the leaf emits a pungent spicy odour too strong to be quite pleasant. This species is perfectly hardy at Kew, where it makes a neat bush of no particular merit or distinction.

\section{Megaphylla, Hemsley.}

An evergreen shrub or tree ; young shoots darkish purple, marked with a few pale lenticels ; terminal bud woolly. Leaves oblong to oblanceolate, entire, pointed, tapered to a wedge-shaped or rounded base ; 4 to 9 ins. long, I to $2 \frac{1}{4}$ ins. wide; brilliantly glossy and dark green above; dull, pale and glaucous beneath, perfectly smooth; midrib yellow; stalk $\frac{1}{2}$ to I in. long. Flowers (not yet seen in cultivation) produced numerously in short-stalked, axillary umbels. Fruit black, egg-shaped, about $\frac{3}{4}$ in. long.

Native of Central China; introduced by Wilson, about 1900 . The above description is based on the plants raised in the Coombe Wood nursery, where it forms a very handsome evergreen and has hitherto proved quite hardy, remaining, however, a shrub. The leaves rather suggest, in their sheen and size, those of a cinnamon; they are aromatic when crushed.

\section{L. obtusiloba, Blume.}

(Benzoin obtusilobum, Kuntze.)

A deciduous shrub or small tree, 20 to $25 \mathrm{ft}$. high, the brown branchlets not downy, but marked with pale, narrow lenticels. Leaves variable in shape; 
mostly broadly ovate, sometimes entire, but usually more or less conspicuously three-lobed towards the apex, the lobes pointing forward; base heart-shaped, rounded or wedge-shaped; $2 \frac{1}{2}$ to 5 ins. long, I $\frac{1}{2}$ to 4 ins. wide ; dark shining green and smooth above; pale and downy on the veins beneath; prominently triple-nerved; stalk $\frac{1}{2}$ to $I$ in. long, downy. Flowers yellowish, produced in March and April from the joints of the leafless wood in small dense clusters; each flower is about $\frac{1}{6}$ in. across, borne on a stalk $\frac{1}{6}$ in. long, clothed thickly with silky hairs. Fruits not seen in this country, but described by Sargent as shining black, globose, $\frac{1}{4}$ in. across, and as forming a very handsome contrast to the yellow autumn foliage.

Native of Japan and Corea ; introduced by Maries in 1880, and grown and flowered in the Coombe Wood nursery. It is a very handsome-leaved shrub, but is hardier and succeeds better in France than with us. Mr de Vilmorin has it very vigorous at Les Barres.

\section{PRAECOX, Blume.}

(Benzoin:praecox, Siebold.)

A deciduous shrub or bushy tree, is to $25 \mathrm{ft}$. high, young shoots shining dark brown, not downy, but prominently warted. Leaves thin, ovate or oval, occasionally rotund; I to $3 \frac{1}{2}$ ins. long, $\frac{1}{2}$ to $1 \frac{1}{2}$ ins. wide; taper-pointed or blunt at the apex, dark green above, pale and glaucous beneath, usually smooth; stalk $\frac{1}{4}$ to $\frac{3}{4}$ in. long. Flowers small, greenish yellow, produced in March and April in small short-stalked umbels about $\frac{1}{2}$ in. diameter. Fruit $\frac{3}{4}$ in. diameter, reddish brown, marked with numerous pale dots.

Native of Japan and Corea. This Lindera is fairly hardy at Kew, but only flowers well on a wall. It forms its umbels usually in pairs or threes during the summer; in the leaf-axils they remain through autumn and winter as little round knobs, bursting in the first warm days of spring. I have not seen it in fruit in this country. The leaves die off yellow.

\section{LINNÆA BOREALIS, Gronovius. TWIN-FLOWER. CAPRIFOLIACEA.}

A creeping evergreen plant, a few inches high, with a woody base; branches long, slender, wire-like, hairy when young. Leaves opposite, obovate, oval or ovate; $\frac{1}{4}$ to $\frac{3}{4}$ in. long, $\frac{1}{8}$ to $\frac{1}{2}$ in. wide; rounded or broadly tapered and coarsely toothed at the apex, wedge-shaped and entire at the base; with scattered hairs on the margin, upper surface, and on the midrib below; stalk $\frac{1}{12}$ to $\frac{1}{6}$ in. long. Flowers produced in summer, in a pair at the top of an erect, thread-like stalk, $I_{\frac{1}{2}}$ to 3 ins. high, terminating short, erect, lateral twigs; each flower has its own secondary stalk $\frac{1}{2}$ to $\frac{3}{4}$ in. long. Corolla pink or white, $\frac{1}{2}$ in. long, nodding, funnelshaped, with five rounded lobes, hairy inside; calyx with five linear lobes ; stamens four; ovary hairy. Fruit dry, one-seeded, downy.

This little plant, named after the great Linnæus, is found in the high latitudes of the northern hemisphere, including a few places in the northeast of Britain. It is a dainty plant, with pretty, fragrant flowers, best adapted for some shady moist spot in the rock garden in rather sandy soil. Allied to Abelia and the honeysuckles. 


\section{LINUM ARBOREUm, Linnaus. TREe Flax. LINACE.}

A low, compact, evergreen, glabrous shrub from 9 ins. to $2 \mathrm{ft}$. high, more in hotter countries. Leaves of a conspicuously blue-white colour, I to 2 ins. long, $\frac{1}{8}$ to $\frac{1}{2}$ in. wide; broadest near the apex, tapering thence to the base, with little or no stalk. Panicles erect, terminal, 3 to 6 ins. long, continuing to produce flowers as they lengthen from May until July or August. Flowers bright, clear yellow, $1 \frac{1}{2}$ ins. across when fully expanded, but opening indifferently in dull weather and lasting in good condition but one day. Petals five, each I to $I_{1}^{\frac{1}{4}}$ ins. long, of very fragile texture. Sepals five; green, narrow-lanceolate, fine-pointed, $\frac{1}{3}$ in. long.

This gay little shrub is a native of the eastern Mediterranean region; introduced in the eighteenth century. It is not so much grown as it deserves, for when it is in flower few plants of its character are so bright. It makes a neat little tuft, and although the flowers are so fugitive, they are borne so freely on fine summer days that the plant is almost hidden by blossom. It is hardy at Kew in all but the severest winters, but is not a long-lived plant in our climate. It is very easily increased by means of cuttings taken whilst the wood is comparatively soft, and placed in brisk heat. Seeds are borne freely, but it helps to prolong the life of the plant if they are not allowed to develop. The soil need not be very rich, but as sunny a spot as possible is desirable. Even out of flower its vividly glaucous foliage is pleasing.

\section{LIPPIA CITRIODORA, Kunth. LEMON-SCENTED VERBENA. VERBENACE E.}

(Aloysia citriodora, Orteg; Verbena triphylla, L'Heritier, Bot. Mag., t. 367.)

A deciduous shrub (naturally a small tree), reaching in the southern parts of the British Isles Io to I $_{5} \mathrm{ft}$. or more in height; young shoots angular. Leaves arranged in threes, very fragrant, lance-shaped; usually 3 to 4 ins. long, $\frac{1}{2}$ to $\frac{7}{8}$ in. wide; wedge-shaped at the base, taper-pointed, not toothed; both surfaces glandular, especially the upper one, pale green; margins set with appressed bristles. The veins are parallel, springing at right angles from the midrib. Flowers numerous, small, pale purple, produced in August in slender, terminal, stalked, downy panicles, 3 to 5 ins. high; corolla tubular, $\frac{1}{6}$ in. long, downy, as is also the cylindrical, toothed calyx.

Native of Chile; introduced in 1784 . Near London this wellknown shrub needs the protection of a wall, and is often grown in cold conservatories for the pleasant lemon-like scent of the leaves. In the Isle of Wight and the Channel Islands it becomes a large bush without any protection. Easily increased by summer cuttings.

\section{LIQUIDAMBAR. HAMAMELIDACEE.}

A small genus of trees with a remarkably scattered distribution in nature; one species being found in Asia Minor, one in Eastern 
$\mathrm{N}$. America, and one or more in China. In general appearance they bear most resemblance to the maples (Acer), but are easily distinguished by their alternate, not opposite leaves. The flowers have no beauty, being greenish or yellowish, and borne in small globose heads. Male and female flowers are in separate heads, the male flower-heads in short racemes; the female heads solitary. The male flowers consist of stamens only; the females of calyx and carpel only.

The best known and most useful of Liquidambars is L. styraciflua, which, like the rest, should, if possible, be raised from imported seeds. 'These frequently do not germinate until the second year. Failing them, layering must be resorted to. Young plants are apt to be injured by late spring frosts.

\section{FORMOSANA, Hance.}

\section{(L. acerifolia, Maximowicz.)}

A tree up to $80 \mathrm{ft}$. high in China ; young shoots hairy. Leaves maple-like, 3 to $4 \frac{1}{2}$ ins. wide, with three or five oblong or triangular lobes ; finely glandulartoothed, hairy on both sides, but especially beneath ; stalks downy, $1 \frac{1}{2}$ to $2 \frac{1}{2}$ ins. long. It has never flowered in this country, but from specimens collected in China the seed-vessels are seen to be in a globular cluster $1 \frac{1}{2}$ ins. across and spiny.

Native of the central and southern provinces of China, where its timber is largely employed for making tea-chests. There is a plant growing on a wall at Kew which was raised from seed sent from Hankow in 1884 . For long this was the only one in the country, but latterly Mr Wilson has introduced seed of what is probably L. formosana, but which he believes to be a hardier form than has previously been known. L. formosana is readily distinguished from the American and Asia Minor species by its hairy young shoots and leaves.

\section{L. orientalis, Miller. Oriental Sweet Gum.}

\section{(L. imberbe, Aiton.)}

A deciduous tree up to $100 \mathrm{ft}$. high ; but rarely one-fourth as high in this country, bushy-headed. It has a rugged trunk covered with small squarish plates of thick bark; young shoots smooth. Leaves $2 \frac{1}{2}$ to $3 \frac{1}{2}$ ins. wide, scarcely as long ; maple-like, five-lobed, the lobes oblong and reaching half or twothirds of the depth of the blade, coarsely toothed or even lobed again, especially the three upper ones, the margins set with fine glandular teeth; quite smooth on both surfaces; stalk I to 2 ins. long. Flowers (rarely or never seen in Britain) greenish, produced in globose heads from the terminal part of the shoot with the young leaves in spring. Seed-vessels woody, in a rounded cluster I in. across.

Native of Asia Minor; introduced about 1750. Fine specimens are to be found on the Continent, the best I have seen being in the Bologna Botanic Garden - 90 to $100 \mathrm{ft}$. high, and $5 \mathrm{ft}$. in diameter of trunk. In Britain it is an interesting small tree, growing very slowly. It is quite hardy, but coming from one of the hottest parts of the Levant it lacks in this country the sunshine necessary for its complete development. From the inner bark of this tree the soft, viscid, balsamic resin known as "liquid storax" is obtained. This substance has certain medicinal properties of reputed value in bronchial affections, and is said to form part of the popular preparation known as "friar's balsam." 


\section{Styraciflua, Linneus. Sweet Gum.}

A deciduous tree up to $\mathrm{I} 50 \mathrm{ft}$. high in a wild state, but not much more than half as high in England. It has a straight, erect trunk, with slender branches forming (as the tree is usually seen in this country) a narrow, pyramidal head. Branchlets smooth and round at first, but during their second year they turn grey, and often begin to form corky wings after the fashion of the English elm. Leaves maple-like, usually five-sometimes seven-lobed, 5 to 7 ins. wide, scarcely as long, heart-shaped at the base ; the lobes minutely toothed, ovatelanceolate; upper surface smooth and glossy, the lower one with tufts of hair in the axils of the veins; stalk slender, $2 \frac{1}{2}$ to 4 ins. long. Male flowers in small round heads arranged on a downy spike 2 or 3 ins. long; female inflorescence rather larger, $\frac{1}{2}$ in. wide. Seed-vessels in a roundish cluster $I$ to $1 \frac{1}{2}$ ins. across.

Native of the eastern United States, often in swampy ground. It was introduced in the seventeenth century, and has long been valued for its stately form and handsome foliage. It is often mistaken for a maple, but from all maples is, of course, distinguished by the alternate leaves. In autumn its foliage turns to brilliant shades of crimson and orange. The tree produces a fragrant resin, known as "sweet gum." The timber, although not of first quality, is largely imported under the name of "satin walnut," for furniture-making. Under cultivation it likes a good loamy soil, and a moderately moist but not a swampy position. Elwes mentions a tree at Godinton, near Ashford, as the tallest known to him in this country; in 1907 it was $82 \mathrm{ft}$. high. The species occasionally bears fruit at Kew.

\section{LIRIODENDRON. MAGNOLIACEE}

A genus of two species, one North American, one Chinese. They are deciduous trees closely related to the Magnolias, but differing from them in the truncate, never pointed leaves, the differently shaped, terminal winter bud, and closed seed-vessels. Leaves alternate; flowers solitary at the end of a short branch; sepals three; petals six; carpels densely packed on a spindle-shaped column.

The tulip trees are gross feeders, and will only attain their best in good deep soil. They are impatient of disturbance at the root, and should be given a permanent place early. Like Magnolias, they are probably most successfully transplanted in May. Seeds are produced in immense, quantities, but comparatively few are fertile. Even in America it is said of the native species that barely ro per cent. can be expected to grow. Still seeds can now be cheaply obtained from American nurserymen, and they afford the best means of increase. The varieties may be grafted on seedlings of L. Tulipifera in March; given a little heat in a propagating case, they unite very readily.

\section{Chinense, Sargent. ChInese Tulip-TREe.}

\section{(L. Tulipifcra var. chinense, Hemsley.)}

Introduced to this country in 190r, but little can yet be said of this tree. It is perfectly hardy, and is growing admirably at Kew, where in 1913 one of the original specimens was $16 \mathrm{ft}$. high. It was first noticed in China in 1875, in the Lushan Mountains, and was subsequently found by Henry, in 


\section{LIRIOIENDRON}

Hupeh, at 3000 to $6000 \mathrm{ft}$. altitude. Living plants were first introduced by Wilson for Messrs Veitch. It never appears to become so large as L. Tulipifera, and the greatest height recorded for it is $60 \mathrm{ft}$. The leaves are very much the same shape as those of the American species, having the same truncate apex, and two lateral lobes; they are, however, more glaucous beneath, and narrower waisted, the sinus between the lobes being deeper. The flowers have not yet been seen in this country, but they are said to be smaller, the petals narrower and expanding more widely, and the fruit more elongated. The apices of the carpels are not so acute, and not recurved as in the American tree. Young trees grow very rapidly-as much as 3 or $4 \mathrm{ft}$. in one season. Failing seeds, it is easily grafted on seedlings of L. Tulipifera.

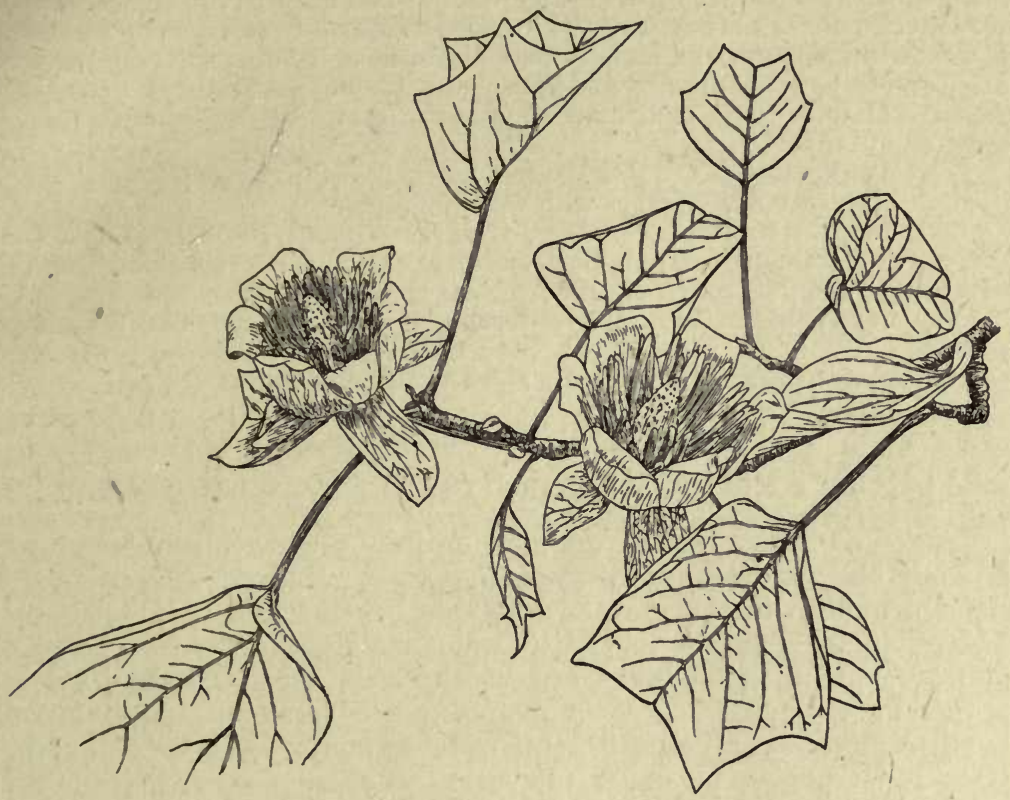

I.IRIODENDRON TULIPIFERA.

\section{Tulipifera, Linncus. Tulip-tree.}

A tree of the largest size, reaching in its native haunts 150 to $190 \mathrm{ft}$. in height, with a magnificent columnar trunk 8 or $9 \mathrm{ft}$. in diameter. In the British Isles it has attained a stature of over $100 \mathrm{ft}$. The leaves vary in size, but are usually 3 to 8 ins. long, and about one-third more in width, and by their form distinguish this from all other hardy trees except its Chinese ally; they are usually saddle-shaped, the apex being broad, and cut off almost square, or to a very shallow notch, the base truncate, or slightly hollowed, and extended at each side into an acute lobe with occasionally one or two more subsidiary ones. The leaf-stalk is slender, 2 to 4 ins. long; the midrib is slightly extended beyond the blade. Flowers produced in June and July, and except for the three deflexed sepals, resemble a tulip in form. Petals oblong, $\mathrm{I}_{2}$ ins. long, greenish white with an orange-coloured spot at the base, erect with their edges overlapping, thus giving the flower, its cupped shape. 
In the centre is the large, pointed pistil surrounded by numerous stamens. The foliage turns rich yellow in autumn.

In a wild state the tulip tree-extends from Nova Scotia south to Florida, reaching its finest development in the south Allegheny region. It was one of the earliest introductions from N. America, and is known to have been cultivated by Bishop Compton at Fulham in 1688; but it was probably introduced some time before, because it is on record that a tree at Waltham Abbey, in 1745, was already $96 \mathrm{ft}$. high and $9 \mathrm{ft}$. in girth of trunk. When once it has attained the adult stage, the tree flowers very abundantly in this country, but the colouring of its blossoms is too dull to render them very striking. It is for its noble trunk and stately dimensions, its fine and unique foliage, that it is so much prized in gardens. The timber is extensively used in N. America under the name of "white wood," especially for indoor purposes. It is yellowish, smooth, and fine-grained, and although not strong, does not split easily. The bark of both root and branches has a pleasant, rather pungent scent.

Several forms are cultivated in gardens, of which the following are the most important :-

Var. AUREO MACULATUM.-Leaves blotched in the centre with jellow,

Var. CONTORTUM.-Leavies with wavy margins.

Var. INTEGRIFOLIUM, Kirchner.-Leaves without the lateral lobes, and therefore of almost rectangular outline. This is the juvenile condition persisting ; the first leaves of all tulip-trees are of this form.

Var. PYRAMIDALE, Lavallée.-A form with erect branches like a Lombardy poplar. The finest specimen I have seen is in the nursery of Messrs Simon-Louis, near Metz-a shapely spire $30 \mathrm{ft}$. high.

\section{LI'IHOSPERMUM PROSTRATUM, Loiseleur. BORAGINACEE.}

A prostrate evergreen shrub, growing from 6 to 12 ins. only above the ground, but forming a wide-spreading mass. Shoots semi-herbaceous, slender, trailing, thickly covered with pale, bristly hairs. Leaves alternate, linear-oblong; $\frac{1}{2}$ to $\frac{3}{4}$ in. long, $\frac{1}{6}$ in. wide; stalkless, blunt at the apex, dark dull green, clothed on both surfaces with pale hairs. Flowers stalkless, borne in the axils of leafy bracts on a terminal leafy elongated inflorescence; of a beautiful gentian blue, faintly striped with reddish violet. Corolla $\frac{1}{2}$ in. long, tubular at the base, spreading into five rounded lobes at the mouth ; calyx with erect, hairy, awl-shaped lobes.

Native of S. Europe; introduced in 1825. A singularly beautiful sub-shrubby plant, very effective in the rock garden, or at the top of banks over which its trailing shoots may hang. It does not need a rich or wet soil, but one of a light nature, and well-drained. It should be planted in full sun. Increased by cuttings in summer, and kept in pots the first winter. Where the soil and exposure are suitable it makes delightful patches in front of a low shrubbery or border, flowering continuously during May and June, often again later.

\section{loiseleuria procumbens, Desvaux. Alpine Azalea. ERICACE $Æ$.}

A procumbent evergreen shrub, much-branched, forming low tufts 3 to 6 ins. high; branches tortuous, very leafy, smooth, rooting freely 
along the ground. Leaves opposite, oval or oblong, $\frac{1}{8}$ to $\frac{1}{3}$ in. long, scarcely half as wide, with the margins so much recurved as to almost hide the under-surface; smooth and dark glossy green above,' smooth or sometimes with a whitish mealy down beneath; stalk one-fourth to half as long as the blade. Flowers rosy or nearly white, about $\frac{1}{4}$ in. diameter, produced in May in short terminal clusters, two to five together. Corolla erect, bell-shaped, with five lobes. Calyx with five deep lobes half as long as the corolla. Stamens five, shorter than the corolla. Seedvessel a dry capsule, with two or three divisions, many-seeded.

Native of the Alpine summits and sub-Arctic regions of the three northern continents, and the only species known. Found on the Scottish highlands. It resembles Leiophyllum in its opposite leaves and small pink flowers, but is readily distinguished by its five (not ten) stamens included within the corolla. It needs a peaty soil. In the south of England it does not thrive well; the summer is usually too hot and dry for it. Some cool damp spot on the lower part of the rock garden should be selected for it.

\section{LOMATIA OBLIQUA, $R$. Brozen. PROTEACE⿸⿻}

An evergreen shrub or small tree, 20 or more $\mathrm{ft}$. high; young stems slightly downy. Leaves alternate, leathery, ovate, $I_{2}^{\frac{1}{2}}$ to 4 ins. long, $\frac{3}{4}$ to $2 \frac{1}{2}$ ins. wide; wedge-shaped or rounded at the base, blunt at the apex, coarsely round-toothed; as they unfold they are covered with tawny down, but afterwards become perfectly smooth, and of a deep glossy green; stalk brownish, about one-fourth the length of the blade. Flowers (not yet seen in this country) borne in axillary racemes 2 to 3 ins. long.

Native of Chile, Peru, etc.; introduced by Mr Elwes in I902. It has hitherto proved hardy at Kew, planted on an outside border near one of the plant-houses, and is $9 \mathrm{ft}$. high; but it would no doubt be better suited if it had the same conditions as Embothrium in Cornwall. L. FERruginea, Brown (L. pinnatifolia, Hort.), is a particularly handsome evergreen bush of rounded habit, Io to $12 \mathrm{ft}$. high, as seen at Castlewellan, Co. Down, and in other mild parts of the British Isles. The leaves are much divided, fern-like, blue-white beneath; the flowers, rosy red and white, are borne on such short stalks that they are largely hidden by the luxuriant foliage. Native of Chile. The Lomatias are allied to Grevillea.

\section{LONICERA. HONEYSUCKLE, WOODBINE. CAPRIFOLIACEA.}

A genus of about ${ }^{5}{ }^{\circ}$ deciduous or sometimes evergreen species of bushy or climbing shrubs, with usually peeling bark, named by Linnæus after Adam Lonicer, a German naturalist who flourished in the middle part of the sixteenth century. The leading generic characters are: Leaves opposite, shortly stalked or stalkless; flowers five-parted, subtended by bracts and usually bractlets; calyx five-toothed; corolla 
tubular or bell-shaped and five-lobed, the lobes sometimes equal, but more frequently forming two "lips," the upper lip composed of four short lobes, the lower lip of a single strap-shaped lobe. Fruit a fleshy berry. The flowers often change from white to yellow with age.

In the British Isles the genus is represented by three species, two of which are typical examples of, and give the name to, two great sections into which it is divided, viz., L. Periclymenum and L. Xylosteum. The leading characteristics of these two sections (many authors have regarded them as distinct genera) are as follows :-

Periclymenum. Woodbine, Honeysuckle-CClimbers or semi-climbers, with hollow branchlets, one or more of the uppermost pairs of leaves, usually (but not in L. Periclymenum itself) joined together by their bases ; flowers stalkless, usually in threes, forming whorls at the end of the branches, often crowded on somewhat elongated spikes. Fruits never united. (This group is also known as CaPRIFOLIUM.)

XyLosteum. Bush Honeysuckle.-Shrubs of bushy habit; leaves never united; flowers always in pairs, produced in the leaf-axils, each pair on one stalk; each pair of fruits often partially, sometimes wholly, cohering. (This group has also been given the generic name of Chamecerasus.)

There is a third group, distinguished as NinTooA, which to some extent combines the characters of the other two. They are climbing or creeping shrubs with usually hollow stems; leaves never joined at their bases ; flowers in axillary pairs ; fruits not cohering in any cultivated species. This group of honeysuckles is commonly represented in gardens by $\mathrm{L}$. japonica and its varieties.

Although the value of the genus in gardens is not commensurate with its size, it does contain a number of extremely beautiful species, and of the Periclymenum or climbing group, every species that is hardy is worth growing. The free-growing woodbines are best accommodated on pergolas or similar supports, or planted to ramble over small trees or bushes; but some of the less rambling ones may be at first trained up stout posts 4 or $6 \mathrm{ft}$. high, and then allowed to form loose, spreading shrubs, needing no further support. The Periclymenum group are very subject to attacks of aphides in summer, especially during hot dry spells; if these are not repelled by applications of some insecticide (tobacco water and soft soap diluted is as good as anything), they sometimes destroy the crop of blossom. All the species like a good loamy soil, and especially cool moist conditions at the root-given these, the attacks of aphides are often naturally overcome.

The bush honeysuckles are in this country somewhat disappointing shrubs. Many of them, especially those of North Asiatic origin, are almost invariably cut by spring frosts and much of their blossom destroyed. Consequently we never see their full beauty of flower or of fruit-and many species are extremely handsome when bearing full crops of red, yellow, black, blue, or white, often translucent; berries. The propagation of those species that do bear fruit is easily effected by seed, but I do not know of any species that cannot be increased by cuttings of firm young shoots, placed in gentle bottom heat about July or August. 
If heat be not available, cuttings of somewhat harder wood may be dibbled in sandy soil under handlights out-of-doors.

\section{Alberti, Regel.}

(Bot. Mag., t. 7394 ; L. spinosa var. Alberti, Rehder.)

A deciduous shrub of low, spreading habit, unarmed, becoming about $4 \mathrm{ft}$. high and twice as much in diameter; young shoots smooth, slender. Leaves linear-oblong, $\frac{5}{8}$ to $I_{\frac{1}{4}}$ ins. long, about $\frac{1}{8} \mathrm{in}$. wide; bluntish at the apex, with often a few teeth near the base; blue-green, smooth; stalks very short. Flowers rosy lilac, fragrant, produced in pairs from the leafaxils, each pair on a stalk about $\frac{1}{4}$ in. long. Corolla-tube $\frac{1}{3}$ to $\frac{1}{2}$ in. long, slender, cylindrical, smooth outside, downy inside; lobes spreading horizontally, oblong, giving the flower a diameter of about $\frac{3}{4}$ in. Stalk of the stamens twice as long as the anthers. Berries $\frac{1}{3}$ in. in diameter, purplish red, not united.

Native of the mountains of Turkestan; introduced by Albert Regel to St Petersburg about 1880. It is sometimes, regarded as a variety of L. spinosa, which inhabits the inner, arid ranges of the north-western Himalaya, and is not, so far as I am aware, in cultivation. This differs from L. Alberti in its sturdier, spiny, sometimes leafless, branches; in the ovate lobes of the corolla, and in the stalks of the stamens being only as long as the anther. L. Alberti is a pleasing shrub of graceful habit, very distinct from cultivated honeysuckles in its narrow bluish foliage.

\section{Alpigena, Linnaus. Cherry WoOdBIne.}

A deciduous shrub, 4 to $8 \mathrm{ft}$. high, with erect branches; young shoots smooth. Leaves oval, oblong, or somewhat obovate; usually tapered, sometimes rounded at the base; slender-pointed ; 2 to 4 ins. long, I to 2 ins. wide; sometimes smooth, but usually, with hairs on the midrib and veins both above and below when quite young; margins always hairy; stalk $\frac{1}{2}$ in. or less long. Flowers yellow, deeply tinged with red, borne during May in pairs at the end of a stalk $I_{2}^{\frac{1}{2}}$ to 2 ins. long ; corolla $\frac{1}{2}$ in. long, with a very short tube protruded on one side near the base, distinctly two-lipped, very hairy inside, the lower part of the stamens hairy. Fruit red, up to $\frac{1}{2}$ in. long, cherry-like.

Native of Central Europe; cultivated since the sixteenth century! The species is very distinct among cultivated bush honeysuckles in its long flower-stalks, large leaves, and large fruits, but has no particular garden value.

Var. NANA, Dippel.-A dwarf form whose leaves have scattered hairs all over the lower surface, more densely on the veins and midrib.

\section{ALSEUOSMOIDES, Graebner.}

A climbing evergreen shrub, with slender, smooth, young shoots. Leaves narrowly oblong, tapered at both ends, $1 \frac{1}{4}$ to 2 ins. long, averaging about $\frac{1}{4}$ to $\frac{1}{3}$ in. wide, the decurved margins furnished with appressed hairs; otherwise smooth. Flowers produced from July to October at the apex of the shoot, and in the terminal leaf-axils, the whole forming a short broad panicle. Corolla purple within, yellow outside, funnel-shaped, $\frac{1}{2}$ in. long, smooth outside, downy within. Fruit globose, $\frac{1}{6}$ to $\frac{1}{4}$ in. in diameter, black covered with purple bloom, borne in a close head.

Native of China; introduced by Wilson for Messrs Veitch about 1904. An interesting and pretty climber, which first flowered at Coombe Wood 
in 1909. Closely allied to L. Henryi, which has hairy young shoots and bigger leaves.

\section{AltmanniI, Regel.}

A deciduous shrub 6 to $8 \mathrm{ft}$. high; young shoots purplish, hairy. Leaves ovate or oval, $\frac{3}{4}$ to 2 ins. long, half to three-fourths as wide; rounded or tapered at the base, mostly pointed, ciliate, more or less hairy ; stalk $\frac{1}{6}$ in. or less long. Flowers in pairs, each pair subtended by two hairy bracts $\frac{1}{4}$ in. long; corolla white, $\frac{1}{2}$ in. long, the slender tubular base rather longer than the lobes, and with a protuberance near the base ; hairy outside ; flower-stalk about $\frac{1}{4}$ in. long.

Native of Turkestan ; introduced from St Petersburg in 1899 , but very rare. It belongs to the same group as hispida, but has comparatively inconspicuous bracts, and the corolla-tube differs in being longer than the lobes. Flowers in April and May.

\section{ANGUSTIFOLIA, Wallich.}

A deciduous shrub, 8 to Io $\mathrm{ft}$. high, of rounded elegant habit, the outer branches pendulous; young shoots smooth. Leaves ovate-lanceolate, rounded or tapering at the base, slender pointed, $\frac{3}{4}$ to 2 ins. long, $\frac{1}{4}$ to $\frac{1}{2}$ in. wide, bright green and smooth above except at first, paler and slightly downy beneath, especially on the midrib ; stalk $\frac{1}{12}$ in. or less. long, woolly. Flowers pinkish white, produced in May and June in pairs from the lower leaf-axils of the young branchlets, each pair on a slender drooping stalk $\frac{1}{2}$ to $\frac{5}{8}$ in. long. Corolla tubular, the tube $\frac{1}{3}$ in. long, the lobes equal, about one-third as long as the tube. Style quite short and hidden. Berries red, edible; each pair united.

Native of the Himalaya; introduced by Sir Joseph Hooker about 1849. If it flowered more freely it would be an attractive shrub, as it is perfectly hardy and of elegant growth; its flowers are fragrant.

\section{CAERULA, Linnaus.}

A deciduous sturdy bush of rounded habit, 2 to $4 \mathrm{ft}$. high ; branchlets stiff, smooth, or hairy only when young. Leaves oval, obovate or oblong, rounded at the apex, $\frac{1}{2}$ to $I \frac{1}{2}$ ins. long, $\frac{1}{4}$ to $I$ in. wide ; more or less (sometimes very) hairy beneath, especially on the midrib and veins; stalk hairy, $\frac{1}{8}$ in. or less long. Flowers twin, produced from the leaf-axils, yellowish white. Corolla $\frac{1}{2}$ to $\frac{3}{4}$ in. long, funnel-shaped, hairy outside, with a sac at the base of the tube; bracts awl-shaped, ciliate. Fruit blue.

A widespread species inhabiting, in one or other of its numerous forms, the higher altitudes and latitudes of the three northern continents. It has little or no merit for gardens, but has some botanical interest. The single oval berry which constitutes the fruit is not, as was long supposed, the wholly united ovaries of each pair of flowers, but really a pair of free ovaries enclosed by the cupula - an upgrowth of the bractlets.

A variable shrub, the leaves and branches in some forms much more hairy or downy than in others, and the fruit sometimes roundish. They are all distinguished by the curious character mentioned, where two flowers appear to rise from one ovary.

\section{Caprifolium, Linnceus. Perfoliate Woodbine.}

A deciduous climber, up to $20 \mathrm{ft}$. high, not downy on any part except sometimes the outside of the corolla. Leaves obovate or oval, usually tapered at the base, rounded at the apex ; 2 to 4 ins. long, about half as wide; glaucous, 
especially beneath. The lower leaves of the shoot are stalked, the higher pairs are sessile; finally, the uppermost one to three pairs are united round the stem, each pair forming a cup, and in their axils the flowers are borne. Flowers in whorls, fragrant, produced from June onwards. Corolla yellowish white, tinged with pink, $1 \frac{1}{2}$ to 2 ins. long, two-lipped, the tube slender. Fruit orange-coloured.

Native of Europe, naturalised in Britain, possibly wild in the south-east of England; also naturalised in the eastern United States. This beautiful fragrant honeysuckle differs from L. Periclymenum in the uppermost pairs of leaves (in whose axils the flowers are borne) being united. It is often confused with L. italica (q.v.), a hybrid between itself and L. etrusca, and a still more ornamental climber.

\section{Ciliosa, Poiret. Western Trumpet Honeysuckle.}

A twining honeysuckle of the same group as L. sempervirens, but differing in having leaves hairy on the margins, but otherwise smooth; the style also is hairy. Leaves ovate or oval, 2 to 3 ins. long, glaucous beneath, the upper pairs united by their bases round the stem. Flowers $I \frac{1}{4}$ to $I \frac{1}{2}$ ins. long, yellow or orange scarlet, sometimes purplish, downy outside ; they are produced in a terminal stalked spike of several whorls. Corolla slightly two-lipped, more so than in L. sempervirens.

Native of Western N. America from British Columbia southwards; introduced in 1824 , but now very rare in gardens.

\section{DEFLEXICALYX, Batalin.}

(Bot. Mag., t. 8536.)

A deciduous shrub of elegant spreading. habit; branches often horizontal or drooping, the branchlets in opposite rows; young shoots purple, downy. Leaves $1 \frac{1}{2}$ to 3 ins. long, scarcely half as wide, rounded at the base, narrowly ovate, pointed, dull green and downy above, greyish and hairy beneath, especially when young ; stalk $\frac{1}{3}$ in. long. Flowers in pairs from each axil along the branchlets, all expanding upwards ; corolla yellow, $\frac{5}{8} \mathrm{in.} \mathrm{long,} \mathrm{downy}$ outside, the lower lip much deflexed, tube shorter than the lobes; stamens hairy at the base, style wholly hairy; stalk $\frac{1}{4}$ in. long ; fruit orange-red.

Native of China and Thibet; introduced in 1904: A strikingly elegant, free-growing shrub, very hardy and floriferous, showing its flowers to good advantage by producing them on the upper side of the long feathered branches. It flowers in May and June, and grows probably $8 \mathrm{ft}$. or so high. (Fig. p. 42.)

\section{Delavayi, Franchet.}

Little is known of this species in cultivation as yet. It was sent to Kew in 1907 from France by Mr Maurice de Vilmorin, who had received it from W. China in 1901, and with whom it first flowered three years later. It is a climber of the same group as L. japonica. Its leaves are ovate-lanceolate, rounded or slightly heart-shaped at the base, taper-pointed ; 2 to 5 ins. long, $\frac{3}{4}$ to 2 ins. wide ; smooth above, grey-felted beneath; stalk $\frac{1}{6}$ to $\frac{1}{4}$.in. long. Flowers sweet-scented, in axillary pairs, and at the end of the shoot forming a kind of panicle. The corolla is pale yellow, and has a very slender cylindrical tube 2 ins. long, and a two-lipped apex; the larger lip $\frac{3}{4}$ in. long, with four short lobes, the smaller one linear; calyx-lobes awl-shaped, edged with hairs. The species was originally discovered in Yunnan by the Abbé Delavay, in 1888. 


\section{DIOICA, Linnceus.}

\section{(L. glauca, Hill.)}

A spreading or twining deciduous shrub; young stems and leaves quite smooth. Leaves oval or oblong, tapered at both ends, $1 \frac{1}{2}$ to 4 ins. long, I to 2 ins. wide ; green above, vividly glaucous beneath. Flowers yellow, tinged with purple, produced during June and July in a terminal cluster, two or more

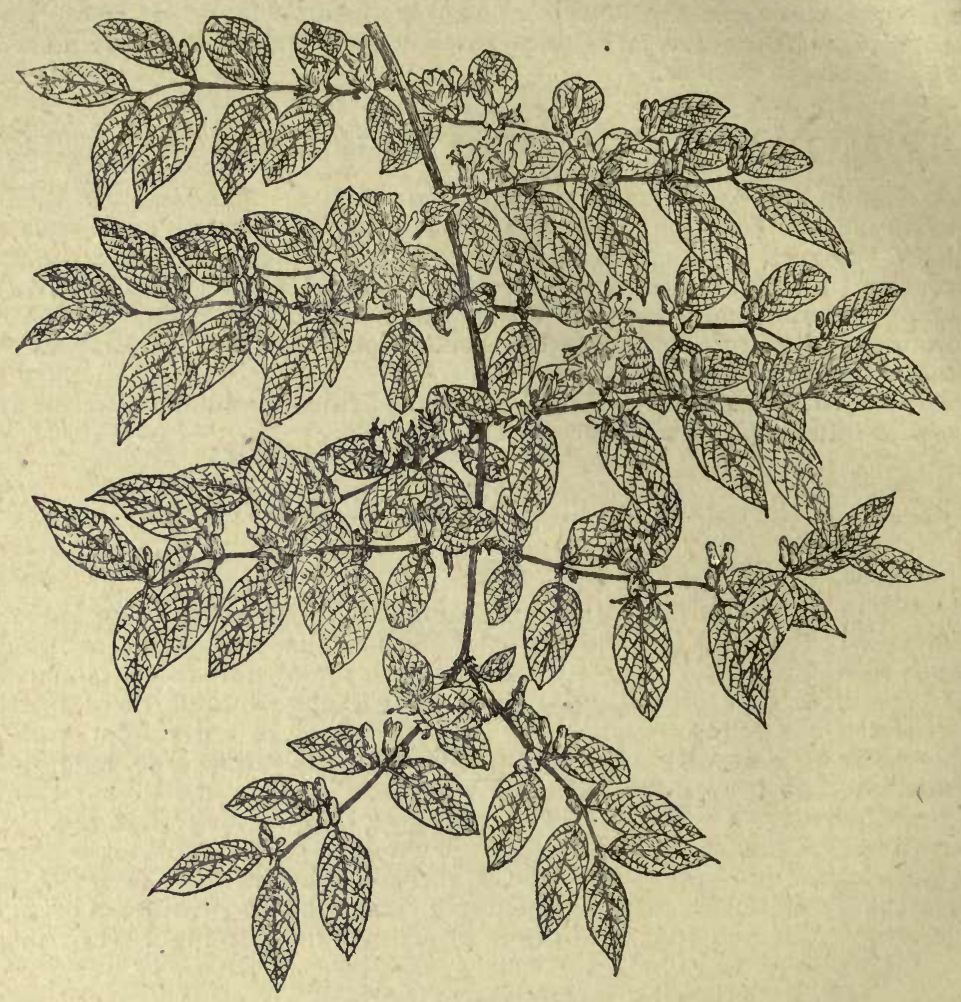

LONICERA DEFLEXICALYX.

pairs of leaves beneath it being united. Corolla $\frac{3}{4}$ in. long, the tube about equal to the lips in length, swollen at the base, smooth outside. Berries red.

Native of Eastern N. America ; introduced in 1776. This honeysuckle succeeds very well under cultivation in good loam; if given the support of a stout central stake, it will form a low, spreading, rather elegant bush, and although without any great beauty of flower is striking for the very glaucous under-surface of the leaf.

Nearly allied to the above, and sometimes confused with it, is L. GLAUCESCENS, Rydberg. This differs chiefly in having the leaves downy beneath and the corolla downy outside ; as a rule only the uppermost pair of leaves is united. The style and the base of the stamens are downy; the corolla-tube rather longer than the lips. 


\section{ETRUSCA, Sanii.}

A very vigorous deciduous climber, young shoots (in the cultivated form) reddish purple. Leaves oval or obovate, rounded at both ends or broadly tapered at the base ; $1 \frac{1}{2}$ to $3 \frac{1}{2}$ ins. long, I to 2 ins. wide ; glaucous and usually somewhat downy beneath. The lower ones are shortly stalked; approaching the top they become stalkless; whilst the uppermost pairs are united at the base (connate). Flowers fragrant, at first yellowish, suffused with red, becoming deeper yellow with age; borne from July onwards in terminal and axillary groups of three long-stalked heads. Corolla $I_{4}^{\frac{3}{4}}$ ins. long, the tube slender, sometimes smooth, sometimes glandular; conspicuously two-lipped.

Native of the Mediterranean region; introduced probably two hundred years ago, but not often seen. At its best, perhaps it is the most gorgeous of all honeysuckles, but I have not seen it at its best out-of-doors, although no doubt it may reach perfection in the south-western counties. Farther north it is hardy, but not wholly satisfactory out-of-doors ; in an unheated greenhouse it is wonderfully beautiful in late summer, the long shoots branching and forming immense bouquets. The species varies very much in the amount of down on the leaves, but the form now cultivated is downy on both sides of the leaf. It is

Var. PUBESCENS, Dippel (also known in gardens as gigantea, gigantea superba, etc.).

Var. viscidulA, Boissier.-Leaves very glandular above, less so beneath ; young shoots also glandular. Native of Asia Minor; rather tender.

\section{Ferdinandi, Franchet.}

A very robust, deciduous shrub, of spreading, open habit, becoming in a few years 8 or $9 \mathrm{ft}$. high and more in diameter; buds awl-shaped, at first hairy; young shoots glandular when quite young. Leaves ovate, rounded or heartshaped at the base, slender-pointed, $1 \frac{1}{2}$ to 4 ins. long, $\frac{3}{4}$ to $1 \frac{3}{4}$ ins. wide ; dull green, hairy on both sides and on the margins. On the vigorous barren shoots the leaf-stalks (each about $\frac{1}{4}$ in. long) are attached to a pair of stipules, which are united and form a shield-like disk surrounding the stem at each joint. These are not present on the flowering branches. Flowers yellow, produced in pairs during early June from the apex of the shoot, and in the upper leaf-axils. Corolla two-lipped, $\frac{3}{4}$ in. across, with a bellied tube $\frac{1}{3}$ in. long, downy outside. Each pair of flowers is sibtended by two leaflike bracts. Fruit red.

Native of Mongolia and China; introduced in 1906. It is a remarkably distinct species, and flowers freely. The shield-like stipules mentioned above persist through the winter and become brown, stiff, and brittle the second year.

\section{FLAVA, Sims.}

\section{(Bot. Mag., t. I3I8.)}

The real $\mathrm{L}$. flava is perhaps not now in cultivation, or, if it be, it is extremely rare. It appears to be very local in its distribution, and was originally discovered on the summit of Paris Mountain, in S. Carolina, by John Fraser; introduced early in the nineteenth century. The plants that go in cultivation under the name are either L. Sullivantii or L. glaucescens, both of which are inferior to it. It is about the most beautiful of American honeysuckles. The bright orange-yellow flowers are about $I_{4}^{\frac{1}{4}}$ ins. long, the corolla-tube smooth outside, slenderly tapered downwards, not bellied. The flowers are produced in two or more whorls on a stalked, terminal inflorescence; style smooth. Leaves rather glaucous beneath, smooth, the uppermost one to three pairs united into disks, not glaucous above as they are in L. Sullivantii. 


\title{
L. Fragrantissima, Lindley and Paxton.
}

\author{
(Flower Garden, iii., fig. 268.)
}

An evergreen, partially evergreen, or deciduous bush, 6 to $8 \mathrm{ft}$. high, smooth except for the bristly margins of the young leaves and sometimes the midrib. Leaves oval, rather stiff and leathery, I to 2 ins. long, two-thirds as wide ; broadly wedge-shaped at both ends, but terminated by a short bristle-like tip, and bristly on the margins when young; dark dull green above, rather glaucous beneath; stalk $\frac{1}{8}$ in. or less long. Flowers produced from December to March in several pairs at the joints, creamy white, very fragrant, $\frac{5}{8}$ in. long ; stalk smooth, $\frac{1}{4}$ in. long.

Native of China; introduced by Fortune in 1845 . This is not a showy plant, but is valued in gardens for its early, charmingly fragrant blossoms. It varies from deciduous to evergreen according to the severity of the winter, but is rarely devoid of foliage. Often confused with L. Standishii, it is, nevertheless, very distinct in the absence of bristles on the young shoots, flowerstalks, and corolla ; the leaf, too, is shorter, and the apex is not drawn out as in L. Standishii. L. fragrantissima, which is the superior shrub, commences to grow very early in the year. Both are distinct in their early flowering from all the rest of the honeysuckles.

\section{GiRAlDir, Rehder.}

(Bot. Mag., t. 8236.)

An evergreen climber forming a dense tangle of twining branches, thickly clothed with yellowish erect hairs when young. Leaves narrowly oblong, with a lance-shaped apex and a heart-shaped base; $I \frac{1}{2}$ to $3 \frac{1}{2}$ ins. long, $\frac{1}{2}$ to $\mathrm{I}$ in. wide; densely hairy on both sides ; stalk $\frac{1}{3}$ in. or less long, hairy. Flowers purplish red, borne in a short terminal panicle $I \frac{1}{2}$ ins. across ; corolla two-lipped, $\frac{3}{4} \mathrm{in}$. wide, yellowish hairy outside; the tube slender, $\frac{1}{2}$ in. long; the entire flower I in. long; bracts inconspicuous. Fruit purplish black.

Native of Szechuen, China, whence it was introduced to France in I899, and first grown by $\mathrm{Mr}$ Maurice de Vilmorin. I first saw it growing against a wall in the garden of Mr Phillipe de Vilmorin at Verrières-le-Buisson, near Paris, in June rgo8, then in flower. Plants were obtained for Kew the following autumn, and these, so far as I am aware, represent its first introduction to Britain. As I saw it, it was a striking honeysuckle forming a dense thicket, the whole plant having a yellowish tinge, very downy, the rather small flower clusters striking in the contrast of lurid red corolla and yellow stamens. It is hardy in the west of England, but may need wall protection in colder places.

\section{Heckrottil, Rehder.}

A deciduous shrub, of loose, spreading, scarcely climbing habit, thought by Rehder to be a hybrid between $L$. sempervirens and $L$. italica. It is a strikingly handsúine honeysuckle, its leaves being oblong or oval, smooth, scarcely stalked, $\mathrm{I}_{\frac{1}{2}}$ to $2 \frac{1}{2}$ ins. long, glaucous beneath. The uppermost pairs are united by their bases (connate). Flowers $\mathbf{I} \frac{1}{2}$ ins. long, rich pink outside, yellow within; produced in whorls on a rather long-stalked, terminal spike. Corolla-tube not downy outside, slender, slightly hairy inside. Blossoms from June onwards. This hybrid originated or was first noticed in the United States, but its history is unrecorded. It is quite hardy, and one of the best of its type of honeysuckle. 


\section{Henryi, Hemsley. \\ (Bot. Mag., t. 8375.)}

An evergreen climber, with slender, very downy young shoots. Leaves oblong, with a lance-shaped apex and a rounded or heart-shaped base ; I $\frac{1}{2}$ to 4 ins. long, $\frac{3}{4}$ to $I \frac{1}{2}$ ins. wide ; dark green above, paler and rather glossy beneath; downy only on the midrib and margins; stalk $\frac{1}{8}$ to $\frac{1}{2}$ in. long. Flowers purplish red, produced during June at the end of the shoot in a cluster 2 or 3 ins. across; each stalk is twin-flowered. Corolla two-lipped, $\frac{3}{4}$ in. across, the lips much reflexed, the tube about $\frac{1}{2}$ in. long, hairy within, smooth outside; stamensslightlydowny; style hairy, protruded $\frac{1}{2}$ in. beyond the corolla ; bracts awl-shaped, about $\frac{1}{4} \mathrm{in}$. long. Fruit blackish purple.

Native of China and Thibet ; introduced by Wilson in 1908 , and first flowered at Nuneham in 1910. It is a free-growing climber of the same character as L. japonica, which is, however, very distinct in the big leaflike bracts. Botanically, it is more closely allied to alseuosmoides and Giraldii.

\section{HiRsuta, Eaton.}

\section{(Bot. Mag., t. 3 I03 ;}

L. Douglasii, De Candolle;

L. pubescens, Sweet.)

A deciduous twiner, with glandular-downy, slender young shoots. Leaves oval, 2 to $3 \frac{1}{2}$ ins. long, $1 \frac{1}{4}$ to 2 ins. wide; dark dull green above, grey beneath, downy on both sides especially beneath, ciliate; uppermost one or two pairs connate, pointed ; lower ones stalked. Flowers

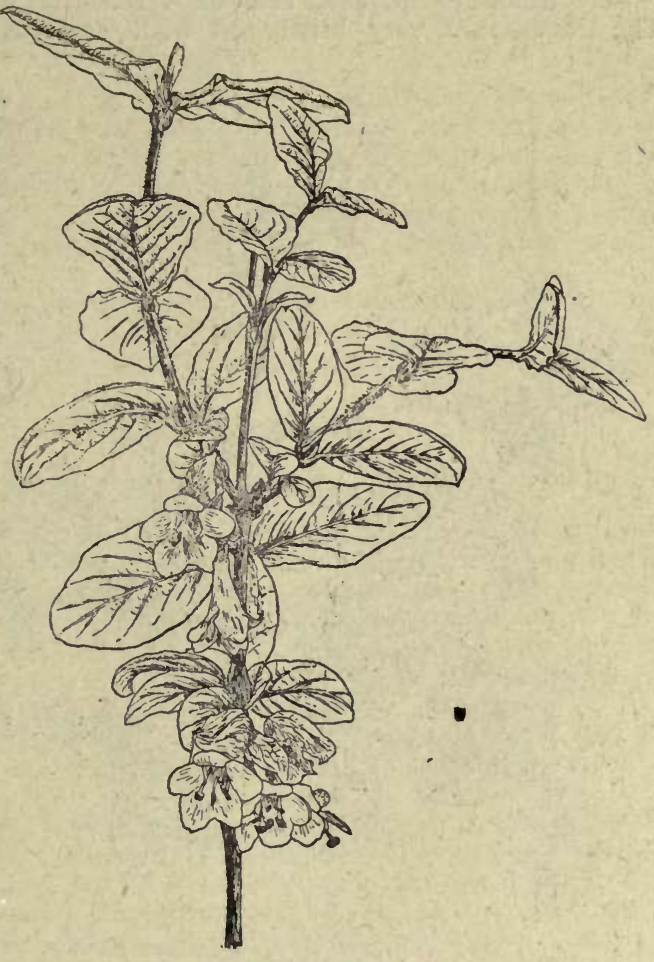

LONICERA CHATOCARPA. orange-yellow, about $\mathbf{I}$ in. long, produced in several whorls on short-stalked spikes at the end of the shoot, and sometimes from the axils of the connate leaves beneath. Corolla two-lipped, the tube slender but slightly swollen towards the base; covered outside with sticky glandular down; hairy within.

Native of N.E. America; introduced in 1822 . It is now uncommon, and L. glaucescens is often made to do duty for it in nurseries and gardens, but that species is not glandular on the branchlets or corolla, and its leaves are not downy above.

\section{HISPIDA, Pallas.}

A deciduous shrub, 3 to $5 \mathrm{ft}$. high, with bristly young shoots. Leaves ovate-oblong, rounded or broadly tapered at the base, often blunt at the 
apex; $1 \frac{1}{2}$ to $2 \frac{1}{2}$ ins. long, about half as wide; hairy on the margins, and more or less so on both surfaces; dark green above, greyish beneath; stalk $\frac{1}{8}$ in. long. Flowers produced at the base of the young shoots at the end of May ; corolla funnel-shaped, about $\mathrm{I}$ in. long, $\frac{5}{8} \mathrm{in}$. wide at the mouth, yellow or yellowish white, the tube longer than the lobes. Each pair of flowers is subtended by two roundish ovate membranous bracts up to I in. long, edged with bristles ; stalk $\frac{1}{3}$ to $\frac{1}{2}$ in. long, bristly.

Native of Turkestan; introduced early last century. Interesting on account of the large bracts.

L. CHETOCARPA, Rehder (L. hispida var. chætocarpa, Batalin).-Very closely allied to hispida, and until recently regarded as a variety of it. The leaves are very bristly on both surfaces, the bracts hairy outside.

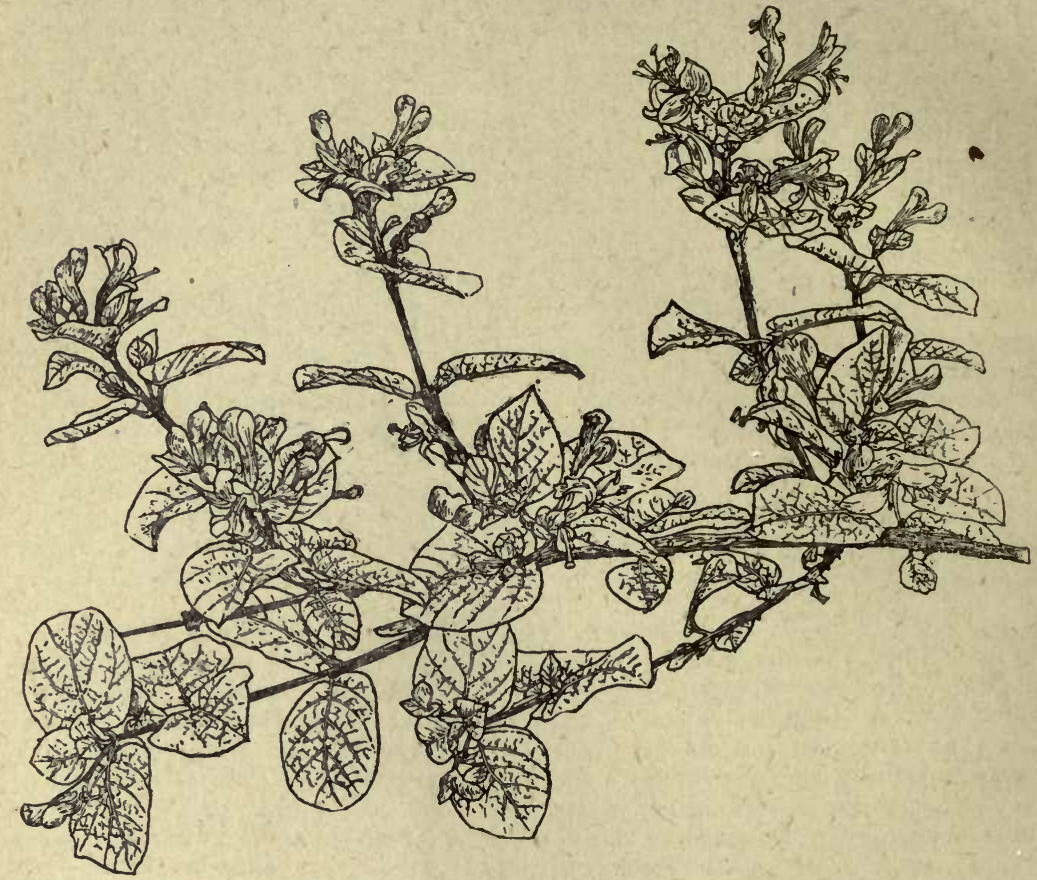

LONICERA IBERICA.

(Fig. p. 45.) Flowers clear primrose-yellow with the ovary glandular and bristly. A very distinct and pretty shrub, introduced by Wilson for Messrs Veitch in 1904, from Central China.

\section{IBERICA, Bieberstein.}

A deciduous shrub, of dense, bushy, rounded habit, up to $\mathrm{Io} \mathrm{ft}$. high and $12 \mathrm{ft}$. through; young shoots hairy. Leaves mostly heart-shaped, sometimes roundish, the apex scarcely pointed; dark dull green above, grey beneath, both surfaces downy. On the vigorous barren shoots some of the leaves are 2 ins. long and nearly as much wide; on the flowering branchlets they are mostly $\frac{1}{2}$ to. I in. long ; stalk $\frac{1}{8}$ to $\frac{1}{3}$ in. long. Flowers produced in pairs from the end and upper leaf-axils of short shoots; corolla 
two-lipped, $\frac{3}{4}$ in. long and the same wide, pale yellow, not fragrant, downy outside, the tube curved and about as long as the slightly lobed limb. Bracts like the leaves but ovate, and $\frac{1}{4}$ to $\frac{1}{2}$ in. long; flower-stalk very short.

Native of the Caucasus, Persia, etc.; introduced in 1824 . A very robust shrub of neat habit, free-flowering without being showy. Botanically, it is distinguished by the bractlets coalescing into a cup-shaped organ enveloping the two ovaries, which, however, grow out of the cup and develop into bright red berries.

\section{Implexa, Solander. Minorca Honeysuckle.}

(Bot. Mag., t. 640.)

An evergreen climber, $8 \mathrm{ft}$. or more high, with slender, purplish, usually smooth young shoots. Leaves oval, ovate or oblong, stalkless, blunt or pointed, $\frac{3}{4}$ to 2 ins. long, $\frac{1}{3}$ to $\mathrm{I}$ in. wide ; very glaucous beneath, smooth. The upper pairs of leaves are united at the base so as to form a kind of cupshaped bract, in the axils of which the stalkless flowers are produced in a whorl. Corolla $I \frac{1}{2}$ to 2 ins. long, yellow suffused with pink outside, white within, changing to yellow.

Native of S. Europe ; introduced in 1772 . It is a pretty honeysuckle, but rather tender and slow-growing, and best with the shelter of a west wall. It flowers from June to August. It probably grows much higher in its native haunts.

\section{ITALICA, Tausch.}

\section{(L. americana, $K$. Koch.)}

This interesting and beautiful woodbine is a hybrid between L. Caprifolium and L. etrusca, with both of which it is often confused. It has most resemblance to L. Caprifolium in growth and foliage; young stems purple, smooth. The uppermost pairs of leaves unite into a cup, as in L. Caprifolium, but the lower ones differ in being more pointed. Flowers in whorls not confined (as in L. Caprifolium) to the axils of the connate leaves, but with several other whorls above them springing from the axils of small bracts. Corolla 2 ins. long, yellow more or less suffused with reddish purple, the tube slender, usually glandular. Downy outside, the two lips giving a diameter of $\mathbf{I}$ to $1 \frac{1}{2}$ ins.

The origin of this lovely hybrid is not known, but it existed in the time of Linnæus, who confused it with $\mathrm{L}$ Caprifolium. According to Rehder, it is very rare in a wild state, but has been found in S. and S.E. Europe, although even there possibly as an escape from cultivation. It is a very effective climber, the terminal part of the shoot often branching and forming a panicle over $\mathrm{I}$ ft. long and $8 \mathrm{in}$. through. Several forms of it are cultivated, such as var. ATROSANGUINEA, with dark red-purple flowers; var. QUERCIFOLIA, with leaves shaped like those of an oak; var. RUBELLA, with pale purplish flowers.

\section{JAPONICA, Thunberg.}

An evergreen climber of vigorous habit, growing 20 to $30 \mathrm{ft}$. high ; stems hollow, twining, hairy. Leaves ovate, oval or oblong, somewhat rounded or broadly wedge-shaped at the base, pointed, $1 \frac{1}{2}$ to $3 \frac{1}{2}$ ins. long, half as wide ; occasionally wavy or lobed at the margin, more or less downy sometimes on both sides. Flowers fragrant, produced from June onwards in pairs from the leaf-axils of the young shoots, towards the end of which they are often much crowded ; flower-stalk $\frac{1}{2}$ to $\frac{3}{4}$ in. long, carrying two ovate bracts similar 
to the leaves, but only $\frac{1}{2}$ to $\frac{3}{4}$ in. long. Corolla $I \frac{1}{4}$ to $I_{2}^{\frac{1}{2}}$ ins. long, two-lipped ; the tube slender, hairy, white changing to yellow with age, and sometimes tinged with red.

At least four forms of this honeysuckle are in cultivation, but which of them is the type as seen by Thunberg it is now difficult to say. Mr Rehder, the greatest authority on honeysuckles, is of opinion that var. Halliana comes nearest to it.

Var. AUREO-RETICULATA, Nicholson (L. brachypoda reticulata).-Leaves mostly less than 2 ins. long, sometimes pinnately lobed, the veins and midrib picked out in bright yellow. A very effective variegated plant in summer, but usually killed back a good deal in winter. Shy-flowering.

Var. FleXuOSA, Nicholson (L. flexuosa, Thunberg, Bot. Reg., t. 7 12):- Stems reddish purple, leaves nearly smooth, except for the ciliated margins and a few hairs on the veins, which are also purple ; flowers pale red outside, white within; young shoots very hairy.

Var. Halliana, Nicholson (L. flexuosa Halliana, Dippel).-Leaves downy on both sides when young, more especially beneath ; flowers white, changing to yellow with age.

The species is native of Japan, whence it was introduced in 1806 , also of Corea and China. During the winter of $1908-9$ it was, in open spots, very much injured at Kew - the var. flexuosa was killed to the ground, but in ordinary seasons and always, I think, in sheltered spots, it is quite hardy. It lasts in flower a couple of months, and its blossoms have a charming odour. In good soil it grows vigorously, and if given the chance will soon cover (and smother) a small tree. It has become naturalised in parts of the United States (Long Island, etc). The name "confusa" is sometimes given to it, but the true L. CONFUSA, De Candolle, is quite distinct in its awl-shaped bracts. Probably tender, and not now in cultivation. China and E. Indies.

\section{Korolkowi, Stapf.}

(Garden and Forest, I894, fig. 4.)

A deciduous shrub of loose, spreading, graceful habit, 6 to ro $\mathrm{ft}$. high ; young shoots very downy. Leaves ovate to oval, usually tapered at the base, pointed, $\frac{3}{4}$ to $1 \frac{1}{4}$ ins. long, $\frac{1}{2}$ to $\frac{7}{8}$ in. wide; pale glaucous green, downy on both surfaces, especially beneath; stalk up to $\frac{1}{4}$ in. long. Flowers produced in pairs from the leaf-axils of short lateral branchlets in June, pale rosecoloured ; corolla $\frac{2}{3}$ in. long, two-lipped, the tube slender and about as long as the lobes, downy inside ; flower-stalk $\frac{1}{3}$ in. long, downy. Berries red.

Native of Turkestan ; first cultivated apparently by the late Mr A. Lavallée, of Segrez, in France, but first distinguished as a species in 1893 from a plant growing in the Arnold Arboretum. Its most striking character when in leaf is the pale grey hue of the whole plant.' I saw it in flower in Mr Spath's nursery near Berlin, a few years ago, and was much struck with its grace and beauty, but it has not flowered so freely in this country.

\section{LedebouriI, Eschscholtz.}

A deciduous shrub, of sturdy, erect habit up to 8 or $9 \mathrm{ft}$. high, and as much through; young shoots stout, four-angled, smooth. Leaves ovate-oblong, rounded or narrowed at the base, pointed; 2 to 4 ins. long, 1 to $1 \frac{3}{4}$ ins. wide ; dull dark green above, bright green and downy beneath; margins downy; stalk $\frac{1}{4}$ in. long. Flowers deep orange-yellow tinged with red, produced in pairs from the leaf-axils in June, each pair on a downy, erect stalk 1 to $x_{4}^{\frac{3}{4}}$ ins. long, and subtended by two large, reddish, heart-shaped, bracts $\frac{5}{8}$ in. wide, and two smaller ones; all glandular. These bracts grow after the flower is 
fertilised. Corolla downy outside, tubular, $\frac{5}{8}$ to $\frac{3}{4}$ in. long, $\frac{3}{16}$ in. wide, with a curious sac at the base; the lobes rounded, erect; stamens not longer than the tube, smooth or nearly so; style longer, also smooth. Berries black. (Bot. Mag., t. 8555.)

Native of California ; introduced in 1838 . A robust species very distinct from all others except involucrata (see below). In habit, foliage, and the long flower-stalk it has some resemblance to L. alpigena, but the short-tubed, twolipped corolla with spreading lobes, and the tiny, linear bracts of that species are very different.

L. INVOLUCRATA, Banks.-Closely allied to L. Ledebourii, but has longer stamens; flowers yellow; the leaves are thinner, not so downy (sometimes smooth), and more tapered at the base ; var. HUMILIS is a dwarf form $2 \mathrm{ft}$. high,; var. SFRotinA, Koehne, flowers later, in July and August. Native of Western N. America.

\section{MAACKII, Maximowicz.}

A deciduous shrub up to $10 \mathrm{ft}$. high, with wide-spreading branches, often arranged in a flat, distichous manner; young shoots downy. Leaves ovallanceolate, with long, slender points, and tapered at the base; $1 \frac{1}{2}$ to 3 ins. long, $\frac{1}{2}$ to $1 \frac{1}{2}$ ins. wide ; dark green, downy on both surfaces; stalk $\frac{1}{3}$ in. or less long. Flowers pure white at first, turning yellowish with age, all produced in pairs on the upper side of the branchlets, where they form a dense row. Corolla two-lipped, the tube $\frac{1}{4} \mathrm{in}$. long, the narrowly oblong, round-ended lobes $\frac{1}{2}$ in. long, the two outer ones of the upper lip deeper than the middle ones; stamens about twice as long as the corolla tube, downy at the base; style hairy. Flower-stalk about $\frac{1}{8}$ in. long. Fruit red.

Introduced to St Petersburg, about 1880, from Manchuria; and from China by Wilson in I900. It is one of the most beautiful of bush honeysuckles, especially the Chinese form, which is distinguished as var. PODOCARPA, Franchet, "having the ovaries, together with the bractlets, on a short, stalk-like elongation above the bracts" (Rehder). This seems also to be of freer growth than the Manchurian form, and is remarkable for the abundance and purity of its blossom. L. Maackii belongs to the same section of the genus as L. Xylosteum and L. Morrowi, from both of which it is distinguished by the very short flower-stalks and pure white corolla. It varies in the amount of down on the leaves, and is sometimes almost smooth.

Of very much the same character as L. Maackii is L. KoenneanA, Rehder; introduced from China by Wilson in 1908. It is a vigorous grower, with often rather diamond-shaped leaves up to 3 or 4 ins. long, and yellow flowers. From L. Maackii it is at once distinguishable by the slender, much longer flowerstalks (up to $I$ in. long).

\section{Maximowiczir, Regel.}

A deciduous shrub of erect habit, up to Io $\mathrm{ft}$. high; young shoots smooth or slightly bristly. Leaves oval, tapered or rounded at the base, pointed, $\mathrm{r} \frac{1}{2}$ to 3 ins. long on flowering shoots (up to $4 \frac{1}{2}$ ins. long on vigorous barren shoots) about half as wide ; smooth, dark green above, furnished more or less with pale down beneath. Flowers deep purplish rose, produced in pairs, each pair on a slender stalk up to $\mathrm{r}$ in. long. Corolla scarcely $\frac{1}{2} \mathrm{in}$. long, two-lipped, short-tubed, smooth outside, hairy within; stamens hairy at the base, style hairy the whole length. Fruit red.

Native of Amurland; cultivated in this country since about 1878. The flowers are rather brightly coloured, but the species has no outstanding merit with us, although favourably mentioned in more sunny climates. 


\section{MICROPHYLLA, Willdenore.}

A deciduous shrub, of stiff, sturdy habit, up to $3 \mathrm{ft}$. high; branchlets short, smooth. Leaves oval or obovate, $\frac{1}{2}$ to $I$ in. long, $\frac{1}{4}$ to $\frac{1}{2}$ in. wide; dull grey green above; glaucous, finely downy, and with well-defined nerves beneath; stalk $\frac{l}{16}$ in. long. Flowers pale yellow, produced in pairs from the leaf-axils, on stalks $\frac{1}{4}$ in. long. Corolla two-lipped, scarcely $\frac{1}{2}$ in. long, the tube about as long as the lips. Berries bright red, united.

Native of the arid parts of the north-west Himalaya, Thibet, Siberia, etc. ; introduced in 1818 . It is a suitable plant for the rock garden, where, however, its chief attraction would be its low, neat habit and grey aspect, for it bears flowers and fruits very sparingly in our climate.

\section{MORRowi, A. Gray.}

A vigorous, deciduous shrub, $8 \mathrm{ft}$. or more high, of loose, spreading habit ; young shoots grey with down. Leaves oval or ovate, I to $2 \frac{1}{2}$ ins. long, half as wide; rounded or tapering at the base, rounded or with a short slender point at the apex; downy and dull green above, greyish and woolly beneath; stalk $\frac{1}{6}$ in. long. Flowers creamy white changing to yellow with age, produced in pairs from the middle or upper leaf-axils of short branchlets, in May and June. Corolla downy, two-lipped, with a slender tube $\frac{1}{4}$ in. long, the deep spoon-shaped lobes $\frac{1}{2}$ in. long, spreading; style hairy; flower-stalk up to $\frac{3}{5}$ in. long. Bracts hairy on the margins ; fruit red.

Native of Japan ; allied to L. Xylosteum, from which it differs in having a smooth, not glandular, ovary. It is useful for furnishing semi-wild parts of the grounds.

L. BELLA, Zabel, is a hybrid between this species and L. tatarica. Its leaves are frequently rounded or slightly heart-shaped as in tatarica.

\section{Myrtillus, Hooker fil.}

A deciduous shrub, of dense, compact, rounded habit, 3 or $4 \mathrm{ft}$. high ; shoots downy when quite young. Leaves oval or ovate, $\frac{1}{3}$ to $\frac{1}{2} \mathrm{in.}$ long; about $\frac{1}{4}$ in. wide; dark green above, rather glaucous beneath, smooth on both surfaces, margins decurved. Flowers pinkish white, fragrant, borne in very shortly stalked pairs; corolla between tubular and bell-shaped, $\frac{1}{4}$ in. long, smooth outside, hairy at the mouth inside; lobes equal, spreading; style much shorter than the tube, smooth; bracts linear, $\frac{1}{6}$ to $\frac{1}{4} \mathrm{in}$. long. Fruit orange-red.

Native of the Himalaya and Afghanistan. It forms a neat, pleasing bush, but our climate is too dull for it to flower sufficiently freely to produce any effect. It is one of the bush honeysuckles which are distinguished by a very short style and a tubular, regularly lobed corolla, hairy at the mouth inside. From the others of this group here mentioned it is distinguished by its -stiff branches and small leaves, and from all except angustifolia by the two-celled ovary. Blossoms in May.

VAR. DEPRESSA, Rehder (L. depressa, Royle.).-Differs only from the above by the flower-stalks being twice as long, and the broader, oval bracts.

\section{NIGRA, Linnaus.}

A deciduous shrub, of stiff, rounded habit, 3 to $5 \mathrm{ft}$. high, with mostly oval leaves, I to 2 ins. long, downy along the midrib beneath, sometimes over the entire surface when quite young. Flowers produced in axillary pairs, each pair on a smooth or slightly downy, slender stalk $\frac{3}{4}$ to over 
I in. long; pink, about $\frac{1}{3}$ in. long and broad; corolla two-lipped, the tube short and broad. Berries black, united only at the base.

Native of the Alpine regions of middle and S. Europe; introduced in the sixteenth century, but of little value in gardens. Several forms, varying chiefly in the degree of pubescence on the leaves, flower-stalks, etc., have been distinguished, but are not of sufficient importance to be noticed here. It is best marked by its slender flower-staiks and black fruit.

\section{NITIDA, Wilson.}

An evergreen shrub, 3 to $5 \mathrm{ft}$. high, of densely lẹafy habit; young shoots slender, erect, purplish, downy, and sparsely bristly. Leaves of stout texture, closely set on the shoot, ovate to roundish, heart-shaped at the base, blunt at the apex; $\frac{1}{4}$ to $\frac{3}{8}$ in. long, dark and glossy above, pale beneath, smooth except for a few minute bristles which ultimately fall away; stalk $\frac{1}{20}$ in. long, minutely bristly. Flowers produced in axillary, short-stalked pairs, creamy white, fragrant. Fruit globular, blue-purple, and about $\frac{1}{4}$ in. across.

Native of W. Szechuen and Yunnan, China, at altitudes of 4500 to 7000 ft. ; introduced by Wilson in 1908. Botanically allied to L. pileata, this is very distinct in its erect habit and smaller leaves. $\mathrm{Mr}$ Wilson informs me it is likely to be hardier. The young plants in cultivation have the aspect of an exceedingly dainty, very leafy, evergreen privet.

\section{ORIENTALIS, Lamarck.}

A deciduous shrub of bushy habit, up to 8 or $9 \mathrm{ft}$. high, rather more in diameter; shoots quite smooth. Leaves oval or ovate, broadly wedge-shaped or rounded at the base, pointed; $1 \frac{1}{2}$ to 4 ins. long, $\frac{1}{4}$ to $1 \frac{1}{2}$ ins. wide ; dull green above, greyish beneath; smooth, or with a few scattered hairs beneath; stalk $\frac{1}{4}$ in. or less long. Flowers borne during May and June in pairs from the leaf-axils of the current year's shoots, pink, slightly fragrant, $\frac{1}{2}$ in. long ; corolla two-lipped; tube very short, much swollen on one side, downy within; stamens and style exposed, both downy ; flower-stalk $\frac{1}{2}$ to $\frac{3}{4}$ in. long, smooth. Fruits black, each pair wholly united by the inner edges.

Native of Asia Minor; introduced in 1825. Apparently variable. The above description applies to the form in cultivation, which is a shrub of no particular merit.

L. KESSELRINGII, Regel (L. savranica, Spath), is by some considered a variety of orientalis and called var. LONGIFOLIA, Dippel. It has oblong or oval-lanceolate leaves $1 \frac{1}{2}$ to $2 \frac{1}{2}$ ins. long, rarely more than $\frac{3}{4}$ in. wide. Flowers pink, smaller than in orientalis, the corolla tube only slightly swollen; stalk $\frac{1}{3}$ in. long. Introduced from Kamtschatka in 1888 .

\section{Periclymenum, Linnaus. Woodbine, Honeysuckle.}

A twining shrub scrambling in a wild state over bushes and hedgerows; stems often over $20 \mathrm{ft}$. long, hollow when young, downy or smooth. Leaves ovate, oval, or obovate, more or less tapered at the base, mostly pointed, sometimes blunt, $1 \frac{1}{2}$ to $2 \frac{1}{2}$ ins. long, I to $I \frac{1}{2}$ ins. wide; green above, rather glaucous beneath, slightly downy or smooth; lower pairs of leaves stalked, uppermost ones almost or quite stalkless, but never united as in L. Caprifolium. Flowers yellowish white and red in varying proportions, produced in a series of close whorls at the end of the shoot, forming a terminal stalked inflorescence. Corolla $1 \frac{1}{2}$ to 2 ins. long, two-lipped, the tube slender, tapering, glandulardowny outside. Berries red. 
The common woodbine, best known of British species, reaches eastward to Asia Minor, the Caucasus, and W. Asia. No wild plant adds more to the charm of our hedgerows and thickets in July and August than this, especially in the cool dewy morning or evening when the fragrance of its blossoms is richest. Of several varieties, the following are the most noteworthy :-

Var. BELGICA, Aiton. Dutch Honeysuckle.-Of more bushy habit; stems purplish and, like the leaves, smooth. Flowers purplish red outside, fading to yellowish; yellow within. (See fig. p. 58.)

Var. QUERCINA, Weston (var. quercifolia, Aiton). Oak-leaved Woodbine.Leaves lobed after the fashion of those of the common oak.

Var. SERotina, Aiton. Late-flowering Honeysuckle. - Flowers dark purple outside, becoming paler with age; inside of lips creamy white, changing to yellow. A late-flowering form and one of the best. Also known as "semperflorens," under which name it was figured in The Garden, April 14th, 1894, pl. 957.

\section{PILEATA, Oliver.}

(Bot, Mag., t. 8060 ; Gard. Chron., April 9, I9I0, fig. IO2.)

An evergreen or partially deciduous shrub of low, spreading, neat habit; branches often horizontal; young shoots purple, very downy. Leaves boxlike, ovate-oblong or somewhat lozenge-shaped, tapered at the base, blunt or rounded at the apex; $\frac{1}{2}$ to $I_{4}^{\frac{1}{4}}$ ins. long, $\frac{1}{6}$ to $\frac{1}{2}$ in. wide; dark lustrous green, smooth on both surfaces, scarcely stalked. Flowers yellowish white, produced in May in very short-stalked pairs ; corolla-tube downy outside, $\frac{1}{4}$ in. long ; stamens hairy, one and a half times the length of the corolla. I have not seen the fruit, which Mr Wilson tells me is purple, and is described as being invested at the top by a curious cuplike outgrowth from the calyx.

Native of China ; discovered by Henry, and introduced for Messrs Veitch by Wilson in 1900. Although it has but little flower beauty, and is (as yet at least) very shy in bearing fruit, its neat habit and dark shining foliage is pleasing. The pairs of leaves are often only from $\frac{1}{4}$ to $\frac{1}{2}$ in. apart on the shoot. Young plants are more inclined to be evergreen than older ones.

\section{Plantierensis, André.}

A twining honeysuckle with a considerable affinity to $\mathrm{L}$. sempervirens, but much hardier. It has lived without protection at Kew (where sempervirens is tender) for upwards of twenty-five years. It is derived from that species and probably some other American one. Leaves downy and glaucous beneath. upper pair united. Flowers I to $I_{\frac{1}{2}}$ ins. long, of a glowing red outside, the mouth and lobes rich orange; corolla-tube glandular, downy outside, hairy within; lobes very short, rounded, and almost regular. Style slightly downy. It flowers from June onwards, bearing the blossom in a terminal stalked spike composed of several whorls. The honeysuckles grown in nurseries as L. Brownii, L. fuchsioides, and L. punicea have probably an origin similar to that of plantierensis, and vary only in slight details. All are beautiful plants, bringing into the outdoor garden much of the beauty of $\mathrm{L}$. sempervirens without having its tenderness.

\section{PROSTRATA, Rehder.}

A deciduous bush, of low, rounded habit, forming a hemispherical mass of slender hollow branches; young shoots slightly hairy and purplish. Leaves oval or ovate, tapered at both ends, but more abruptly at the base ; $\frac{3}{4}$ to $1 \frac{1}{8}$-ins. long, $\frac{1}{4}$ to $\frac{1}{2}$ in. wide; ciliate, upper surface downy at first, becoming smooth; 
midrib and chief veins sparsely downy beneath; leaf-stalk hairy, $\frac{x}{10} \mathrm{in.}$ long. Flowers pale yellow, not fragrant, borne in pairs from the leaf-axils on slightly downy stalks, $\frac{1}{4}$ in. long ; corolla $\frac{5}{8}$ in. long, two-lipped, the tube not so long as the lips, hairy within and without; stamens and style hairy at the base; bracts linear, hairy, $\frac{1}{6}$ in. long ; bractlets rounded, ciliate. Berries distinct egg-shaped, reddish, $\frac{1}{4}$ to $\frac{1}{3}$ in. long.

Native of W. China; discovered and introduced by Wilson about 1904. It does not promise to be of any special beauty in flower, but its prostrate habit is distinct, and will make it useful for ground covering. It thrives in the Coombe Wood nursery, where it flowers about the beginning of June.

\section{PURPURASCENS, Walpers.}

A sturdy bush, 3 to $5 \mathrm{ft}$. high; young shoots stiff, purplish, covered with a soft, fine down. Leaves oblong or somewhat obovate, tapered or bluntish at the apex, rounded or tapered at the base; I to 2 ins. long, $\frac{1}{2}$ to $I$ in. wide ; dull green above, grey beneath, downy on both surfaces but especially

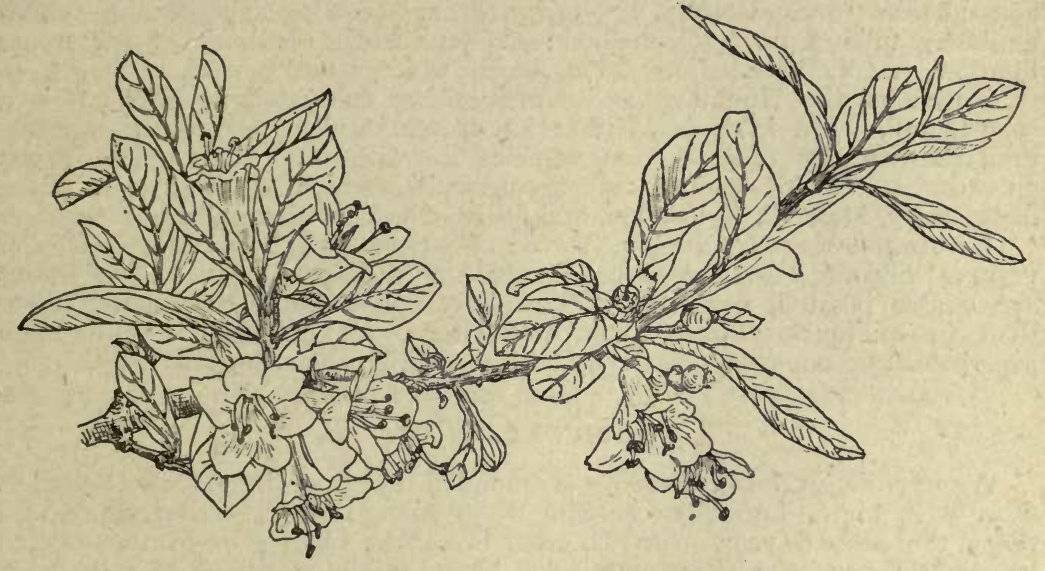

LONICERA PYRFNAICA.

beneath; stalk $\frac{1}{6}$ to $\frac{1}{4}$ in. long, downy, purplish. Flowers in pairs from the leaf-axils on a slender downy stalk, $\frac{1}{3}$ in. or more long. Corolla $\frac{3}{5}$ in. long, with five short nearly equal lobes, which are purple; the tube paler, hairy, funnel-shaped, and protruded at the base; bracts awl-shaped. Berries more or less united, blue-black.

Native of the Himalaya up to altitudes of $\mathrm{I} 3,000 \mathrm{ft}$., and very hardy; introduced to Kew in 1884. A neat bush with a purplish cast, but of little merit.

\section{PYRENAICA, Linncus.}

(Bot. Mag., t. 7774.)

A deciduous shrub, 2 to $3 \mathrm{ft}$. high, branches erect; free from down in all its parts. Leaves obovate to oblanceolate, tapered to a stalkless base, abruptly pointed, $\frac{3}{4}$ to $\mathrm{I} \frac{1}{4}$ ins. long, $\frac{1}{4}$ to $\frac{3}{8}$ in. wide; glaucous, especially beneath. Flowers produced during May and June in pairs from the terminal leaf-axils of short branchlets or the lower leaf-axils of stronger ones, each pair subtended 
by two rather sickle-shaped bracts $\frac{1}{4}$ in. long, and borne on a stalk $\frac{1}{4}$ to $\frac{1}{2}$ in. long. Corolla rosy tinted white, $\frac{5}{8}$ in. diameter; the tube scarcely as much long, swollen on one side at the base ; the lobes roundish ovate, spreading. Berries red, globose, $\frac{1}{4}$ in. diameter ; each pair united only at the base.

Native of the eastern Pyrenees and the Balearic Isles; introduced, according to Aiton, in 1739. A very pretty shrub, perhaps the most pleasing in flower of all the dwarf bush honeysuckles. It blossoms profusely every year in the rock garden at Kew, and is an admirable shrub for such a position

\section{QUINQUELOCULARIS, Hardrick.}

A large deciduous shrub, $\mathbf{I} 2$ to $\mathbf{I} 5 \mathrm{ft}$. high in cultivation, said to be sometimes a small tree where wild; young shoots purplish, very downy. Leaves oval, sometimes inclined to obovate and orbicular, rounded or tapered at the base, mostly short-pointed, but sometimes rounded at the apex; I to $2 \frac{1}{2}$ ins. long, $\frac{5}{8}$ to $I \frac{1}{2}$ ins. wide ; dull green and at first downy above, greyish and more downy beneath. Flowers creamy white changing to yellow; arranged in pairs, produced on a stalk $\frac{x}{12}$ in. long from the leaf-axils in June. Corolla two-lipped, $\frac{3}{4}$ in. across; the upper lip roundtoothed; tube $\frac{1}{4}$ in. long, bellied; stamens about as long as the upper lip, downy at the base. Berries translucent white, round to oval.

Native of the Himalaya and China: long cultivated at Kew. It is a robust, and, when in flower, rather handsome shrub, flowering more freely than the majority of bush honeysuckles do with us. It is very distinct on account of its white transparent fruits, which distinguish it from deflexicalyx, Maackii, Xylosteum, and other of its immediate allies.

L. TRANSLUCENS, Carrière (Revue Horticole, 1872, p. 240). - This is very closely allied to and perhaps only a form of the above. The leaves are longer pointed, more markedly ciliate, and the upper surface rougher than in quinquelocularis: the corolla tube also is shorter and more protuberant on one side. A sturdy bush, ro ft. high, that flowers freely.

\section{RUPICOLA, Hooker fil.}

A very dense bush, forming a rounded mass of interlacing branches 6 to $8 \mathrm{ft}$. high; branchlets smooth when young; bark peeling off in thin strips the second year. Leaves often in threes, oblong or ovate, rounded or slightly heart-shaped at the base, blunt at the apex; $\frac{1}{2}$ to I in. long, about half as wide; dull green and smooth above, paler and downy beneath, often becoming smooth; stalk $\frac{1}{8}$ in. or less long. Flowers produced in May and June in pairs from the shoots of the current year, often six at one joint, fragrant; corolla pale pink, $\frac{1}{2}$ in. across, the tube $\frac{1}{4}$ in. long, downy on both sides; lobes rounded-ovate, equal. Calyx-lobes narrowoblong, downy ; style and flower-stalk very short.

Native of the Himalaya; long cultivated at Kew. It is closely allied to L. thibetica, but is distinguished by the dull green, blunt-ended leaves not being white-felted beneath. These two species differ from all other cultivated honeysuckles in their globose shape and impenetrable mass of branches. It is striking, but does not blossom freely.

\section{SEMPERVIRENS, Linnaus. TRUMPET HoNEYSUCKLE.}

(Bot. Mag., t. $78 \mathrm{r}$.)

A vigorous, climbing shrub, evergreen in mild localities; young shoots smooth, glaucous. Leaves oval or somewhat obovate, $1 \frac{1}{2}$ to $2 \frac{3}{4}$ ins. long. $\frac{3}{4}$ to 2 ins. wide; rich green and smooth above, bluish and slightly downy 
beneath; stalk $\frac{1}{4}$ in. or less long; one or two of the uppermost pairs of leaves are united and form a circular or oblong disk. Flowers unscented, rich orange scarlet outside, yellower within, $1 \frac{1}{2}$ to 2 ins. long, produced in three or four whorls (each whorl of usually six flowers), forming a terminal stalked spike. Corolla-tube slender, slightly swollen near the base; the four upper lobes are smaller than the lower one, but the corolla is not markedly two-lipped; style smooth.

Var. MINOR.- Leaves narrower. Flowers rather longer and more slender.

Native of the south-eastern United States, but reaching as far north as Connecticut; introduced in 1656. Unfortunately this beautiful honeysuckle succeeds only really well in the south and west. Farther north it needs winter shelter. It has, however, given much of its beauty to hybrid progeny, two at least of which are hardy (see Heckrottii and plantierensis).

\section{SPLENDIDA, Boissier.}

This beautiful woodbine is very rare in cultivation; but I had specimens a few years ago from Messrs W. Smith \& Sons of Aberdeen, who informed me that it was a vigorous grower in their nursery, throwing shoots 6 or $8 \mathrm{ft}$. long in one season, perfectly hardy, and free flowering. It belongs to the same group as Etrusca and Periclymenum, but differs from the latter in having the upper pairs of leaves united round the stem (connate); and from etrusca it differs in having the flowers in a terminal stalkless spike, springing directly from the uppermost pair of leaves. The corolla is $1 \frac{1}{2}$ to $1 \frac{3}{4}$ ins. long, reddish purple outside, yellowish within. Perhaps the most distinctive feature of the plant is the very glandular inflorescence. Leaves oval or oblong, stalkless, I to 2 ins. long, smooth, glaucous.

Native of Spain ; distinguished by Boissier as long ago as $188_{3} 8$. In spite of Messrs Smith's experience, I suspect that this honeysuckle may be in some way delicate or tender, otherwise it is difficult to understand why so beautiful and distinct a plant, which fully deserves its specific name, should scarcelv exist in gardens. It ought in any case to thrive in the south-west counties.

\section{Standishi, Carrière. Standish's Honeysuckle.}

$$
\text { (Bot. Mag., t. 5709.) }
$$

A deciduous or partially evergreen bush, 6 or $8 \mathrm{ft}$. high in the open, $12 \mathrm{ft}$. or more against a wall ; the bark of the stem and older branches peeling ; young shoots warted and bristly. Leaves oblong-lanceolate, 2 to $4 \frac{1}{2}$ ins. long, $\frac{3}{4}$ to 2 ins. wide; rounded or broadly wedge-shaped at the base, slenderly pointed, prominently veined beneath; bristly on the margins and on both sides of the midrib, also more or less over the lower surface; stalk bristly, $\frac{1}{8}$ in. long. Flowers produced from November to March (according to the mildness of the season), often in two pairs at each joint ; flower-stalk has downward pointing bristles. The flowers are creamy white, very fragrant, about $\frac{1}{2}$ in. wide, the tube of the corolla bristly outside. Fruit ripe in early June, red, the two ovaries united nearly to the top and forming an inversely heart-shaped berry; stalk $\frac{1}{2}$ in. long, bristly.

Native of China ; introduced by Fortune in 1845 . It is in no way showy, but has always been a favourite because of the early date at which it flowers and for its charming fragrance. Although the first flowers come as early as November, it is usually at its best in February. It is perfectly hardy, and is only grown on walls for the sake of protection for the flowers.

Var. LANCIFOLIA, Rehder.-Leaves narrowly lanceolate, usually under I in. in width. Introduced by Wilson in 1908, from W. China. 


\section{Sullivantit, $A$. Gray.}

\section{(Garden and Forest, I890, fig. 34 ; L. prolifera, Booth.)}

A deciduous spreading shrub, with stems up to $6 \mathrm{ft}$. long, lax, but scarcely climbing. Leaves oval, obovate or oblong, 2 to 4 ins. long, $1 \frac{1}{4}$ to $2 \frac{1}{2}$ ins. wide ; glaucous and slightly downy beneath, more glaucous on the upper side ; one or more of the upper pairs are united at the base, and form a roundish disk clasping the stem ; of thickish substance. Flowers yellow, not fragrant, produced in June at the end of the current season's growth in a terminal stalked spike, composed of two or more whorls, sometimes branched at the base. Corolla two-lipped, about I in. long, the tube longer than the lips, slender, slightly swollen on one side; smooth outside, style slightly hairy. Berries reddish yellow, $\frac{1}{4}$ to $\frac{1}{2}$ in. diameter.

Native of Central N. America ; long grown in gardens-in early times as L.' prolifera, latterly as L. flava, which is a rarer and more showy plant than L. Sullivantii. The latter is closer to $\mathrm{L}$. dioica, a species distinguished by its shorter corolla, the tube of which is about as long as the lips, the leaves and style smooth. L. Sullivantii does not need a support except when quite young, and may be grown in the open as an elegant, loose bush.

\section{SYRINGANTHA, Maximozicz.}

\section{(Bot. Mag., t. 7989.)}

A deciduous shrub of graceful, spreading habit, probably $8 \mathrm{ft}$. high ; young shoots slender, quite smooth. Leaves in pairs; oblong or inclined to ovate, the base rounded or slightly heart-shaped, the apex bluntish or broad-pointed; $\frac{1}{2}$ to $\frac{7}{8}$ in. long, $\frac{3}{16}$ to $\frac{3}{8}$ in. wide; dull rather glaucous green, quite smooth; stalk $\frac{1}{12}$ in. long. Flowers in axillary pairs, produced on a slender stalk $\frac{1}{4}$ in. long during May and June from the middle joints of the young shoots; soft lilac in colour, lilac-scented. Corolla-tube $\frac{1}{3} \mathrm{in}$. long, slender, cylindrical, smooth outside, hairy within; the flower is $\frac{1}{2}$ in. across the rounded-ovate lobes. Calyx-lobes lance-shaped, smooth. Style quite short. Fruit red.

Native of China and Thibet; introduced about 1890 . A very elegant and pleasing shrub, with delicately coloured and charmingly fragrant flowers, which are not always abundantly borne. It is allied to thibetica and tomentella, differing in the quite smooth leaves.

\section{TATARICA, Linnaus.}

A deciduous shrub of vigorous growth and bushy habit, 8 to to $\mathrm{ft}$. high ; young shoots smooth. Leaves oblong-ovate, slightly heart-shaped or rounded at the base, pointed; on vigorous growths they are $1 \frac{1}{2}$ to $2 \frac{1}{2}$ ins. long, $I$ to $1 \frac{1}{2}$ ins. wide ; on the flowering branches less than half the size; green above, rather glaucous beneath, smooth; stalk $\frac{1}{8}$ in. long. Flowers white or pinkish, borne in pairs on a slender stalk, $\frac{1}{2}$ to I in. long; corolla two-lipped, smooth outside, hairy within, $\frac{3}{4}$ to $\mathbf{I}$ 'in. long; tube much shorter than the reflexed oblons lobes. Berries red.

In a wild state this species reaches from Central Asia to Russia. It was introduced in 1852 , and is so perfectly adapted to our conditions that it is now the commonest of bush honeysuckles, running semi-wild in some gardens. It is a variable plant so far as the colour of the flowers is concerned, and the best red forms should only be selected. They are often very showy at flowering time, which is May and early June.

Var. LATIFOLIA, Loudon (also known as speciosa and splendens), is perhaps the best, having rich, rosy red flowers. 
Var. NANA, Alphand.-A shrub of low, compact habit; leaves tapered at the base.

Var. SIBIRICA, Persoon (also known as var. rubra), is a handsome redflowered sort; the leaves are larger than in the typc, and as much as $3 \frac{1}{2}$ ins. long. The "L. punicea," Sims, of the Bot. Mag., t. 2469, appears to be this plant.

\section{THIBETICA, Bureau and Franchet.}

A deciduous shrub of low, spreading habit when young, forming in the adult state a dense rounded mass of intertwined branches $6 \mathrm{ft}$. high and ro $\mathrm{ft}$. or more through; young shoots reddish, downy, the bark peeling in thin strips the second year. Leaves often in threes, narrowly oblong, rounded at the base, pointed, $\frac{1}{3}$ to $I$ in. long, $\frac{1}{8}$ to $\frac{1}{3}$ in. wide; dark glossy green and smooth

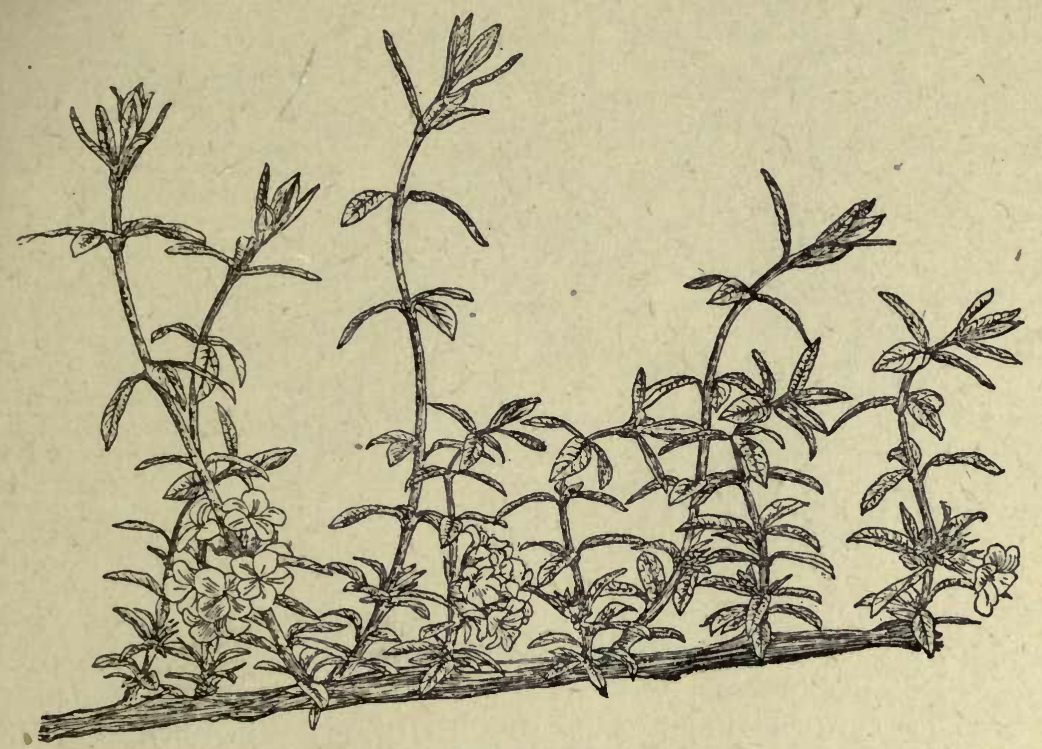

LONICERA THIBETICA.

above, covered with a dense white felt beneath; stalk $\frac{1}{12}$ in. or less in length. Flowers produced in pairs during May and June from the leaf-axils of the young shoot, often six flowers at each joint, fragrant, $\frac{1}{3}$ in. across, lilac-coloured. Corolla-tube $\frac{1}{2}$ in. long, downy within and without; lobes equal, roundish ovate. Calyx-lobes awl-shaped, downy, as long as the style. Berry red, oblong, $\frac{t}{t}$ in. long, three-celled.

Native of Thibet; introduced in 1897. A very pretty and distinct honeysuckle, allied to L. rupicola, but easily distinguished by the white-felted undersurface of the leaves, and deeper coloured smaller flowers. The flowers are perfumed like lilac.

\section{TOMENTELla, Hooker fil.}

(Bot. Mag., t. 6486.)

A deciduous shrub of erect habit, Io or $12 \mathrm{ft}$. high; branchlets woolly, outer bark splitting and becoming detached the second season. Leaves ir 
pairs, ovate, sometimes inclined to oblong ; $\frac{3}{4}$ to $I \frac{1}{2}$ ins. long, $\frac{1}{4}$ to $\frac{2}{5}$ in. wide ; rounded or slightly heart-shaped at the base, bluntish or broad-pointed at the apex; dull green and sparsely downy above, grey-woolly beneath; stalk $\frac{1}{16}$ in. long. Flowers produced towards the end of June, pendulous, in pairs from the leaf-axils of the young shoots, white with a pinkish tinge. Corolla about $\frac{1}{2}$ in. long, downy ; calyx-lobes ovate, very short, pink-tipped ; style as long as the corolla-tube. Berries blue-black.

- Native of Sikkim ; introduced by Sir Joseph Hooker in 1849 . This species has some affinity with and resemblance to $L$. rupicola, but is more erect; the leaves are in pairs, the style is longer, and the calyx-lobes shorter.

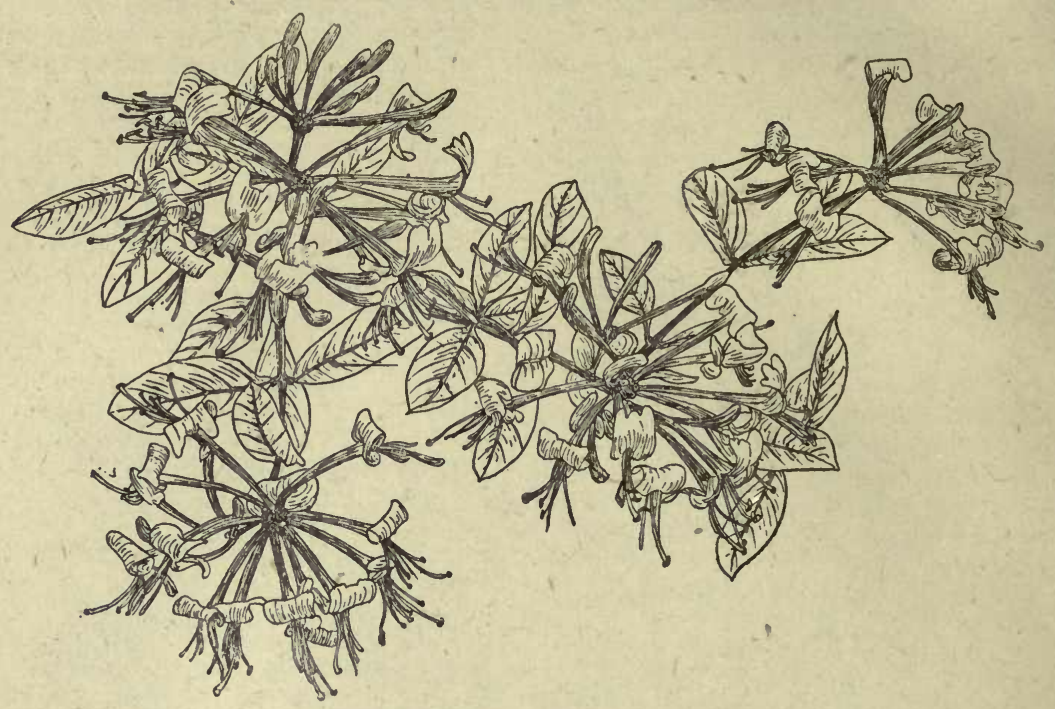

Lonicera Pericly menom var. Belgica.

L. tragophylla, Hemsley. Chinese Woodbine.

(Bot. Mag., t. 8064.)

A deciduous climbing shrub, with smooth young shoots. Leaves oval, tapering about equally to both ends; 2 to $4 \frac{1}{2}$ ins. long, $\frac{3}{4}$ to 2 ins. wide; slightly glaucous above, glaucous and slightly downy beneath. The uppermost pair of leaves are wholly united by their bases forming a diamond shape; the next pair lower down is less united, but still clasp the stem ; still lower down come short-stalked leaves. Flowers bright yellow, produced in a terminal head of ten to twenty. Corolla-tube $2 \frac{1}{2}$ to $3 \frac{1}{2}$ ins. long, slenderly cylindrical, smooth outside, downy within; across the two lips the corolla measures $\mathrm{I}$ in. or more in width. Berries red.

Native of the province of Hupeh, China; discovered by Henry and introduced for Messrs Veitch by Wilson in 1900. It flowered for the first time at Coombe Wood in July 1904. L. Caprifolium is closely related, but differs in its whorled flowers and in the smooth interior of the corollatube. L. tragophylla is the largest flowered and most showy of the true honeysuckle (Periclymenum) group. It likes a deep moist loam, and $\mathrm{Mr}$ Wilson recommends for it a semi-shaded position. 


\title{
L. TRICHOSANTHA, Bureau and Franchet.
}

\author{
(L. ovalis, Batalin.)
}

A deciduous bush, of vigorous growth and rounded, dense, leafy habit, probably $8 \mathrm{ft}$. or more high, the whole plant with a pale greyish aspect; young shoots at first downy, becoming smooth later in the season. Leaves oval, often inclined to obovate, rounded or broadly wedge-shaped at the base and short pointed or rounded at the apex, I to 2 ins. long, $\frac{1}{2}$ to $1 \frac{1}{4}$ ins. wide; dull grey-green above, paler beneath, both sides at first downy becoming almost smooth, especially above; stalk $\frac{1}{8}$ to $\frac{1}{4}$ in. long. Flowers pale yellow, fading to a deeper shade; corolla $\frac{1}{2}$ to $\frac{3}{4}$ in. long, hairy outside. Calyx bell-shaped, but split into two parts. Berries red.

Native of Szechuen, China; discovered by the Russian traveller Potanin. Introduced in quantity by Wilson about 1908. A robust species of the same class as deflexicalyx and quinquelocularis.

\section{Xylosteum, Linnaus. Fly Honeysuckle.}

A deciduous shrub up to $10 \mathrm{ft}$. high, more in diameter, very bushy ; young shoots downy. Leaves oval or obovate, rounded or broadly tapered at the base; mostly with a short abrupt apex, $1 \frac{1}{4}$ tb $2 \frac{1}{2}$ ins. long, half or more than half as wide; downy on both surfaces; stalk $\frac{1}{4}$ in. long, downy. Flowers not scented, yellowish white, tinged sometimes with red, produced in pairs on downy stalks up to $\frac{5}{8}$ in. long. Corolla very downy, conspicuously two-lipped, $\frac{5}{8}$ in. across, the tube short and bellied. Fruits red, often showy in August.

Native of Europe and W. Siberia, found wild in parts of S.E. England, where it may be a true native.

Var. LUTEA. - Fruits yellow. There are numerous other varieties varying in the degree of pubescence on the plant, etc., which need not be adverted to further.

\section{YUNNANENSIS, Franchet.}

A low creeper, with slender, smooth stems. Leaves oblong or narrowly obovate, $1 \frac{1}{2}$ to 3 ins. long, about one-third as wide; smooth above, glaucous and smooth or slightly downy beneath, very shortly stalked. The upper pair or pairs of leaves are united into a round or oblong disk, in the axils of which the stalkless flowers are borne. Corolla yellow, $\frac{3}{4}$ to $\mathbf{I}$ in. long, smooth outside, hairy within.

L. dioica.

Native of Yunnan; discovered by Delavay. It is allied to the American

Var. TENUIS, Rehder.-A smaller-leaved form found by Henry at Mengtze in Yunnan, inhabiting rocky mountains up to 6000 to $7000 \mathrm{ft}$. Corolla $\frac{3}{4}$ in. long, white changing to yellow. It has been introduced by Wilson to the Coombe Wood nursery.

\section{LOROPETALUM CHINENSE, Oliver. HAMAMELIDACEA.}

(Gardeners' Chronicle, 1883, i., fig. 23.)

An evergreen shrub of bushy, very twiggy habit, 5 or $6 \mathrm{ft}$. high; branchlets crooked, wiry, covered thickly with brownish stellate down. Leaves ovate or oval, I to $2 \frac{1}{2}$ ins. long, $\frac{3}{4}$ to $I \frac{1}{4}$ ins. wide; markedly unequal at the base, pointed at the apex; rough and with scattered hairs 
above, paler beneath; margin finely toothed; stalk about $\frac{1}{8}$ in. long, hairy. Flowers very like those of witch-hazel in appearance, but white; they are produced in February and March, three to six crowded in a head; petals four to each flower, strap-shaped, $\frac{3}{4}$ in. long, $\frac{1}{16}$ in. wide; flower-stalk and outside of calyx clothed with white down. Seed-vessel a woody, ovoid, nut-like capsule.

Native of China; introduced by Maries for Messrs Veitch in I880. This singular and pretty shrub is too tender to thrive near London without protection, and can only be recommended for trial in the mildest parts of these islands. In its narrow, strap-shaped petals and four-parted flowers it resembles Hamamelis, but its white flowers and evergreen nature amply distinguish it. Grown out-of-doors in summer, and wintered in the coolest conservatory, it makes a very pretty shrub in February when covered with blossom. It likes a proportion of peat in the soil, and is easily increased by cuttings.

\section{LUPINUS arboreus, Sims. Tree Lupin. Leguminose. \\ (Bot. Mag., t. 682.)}

An evergreen shrub of remarkably quick and luxuriant growth, becoming 6 to $9 \mathrm{ft}$. high, and nearly as much through, in three or four years when planted in rich soil. Branchlets round, semi-woody, covered with silky hairs. Leaves alternate, digitate, with seven to eleven (usually nine) grey-green leaflets; each $\frac{3}{4}$ to 2 ins. long, varying in size according to the vigour of the plant ; they are oblanceolate, pointed, downy beneath, the common leaf-stalk rather longer than the leaflets. Flowers in erect, terminal racemes 6 to ro ins. long, fragrant, sulphur-yellow in the type, but in the varieties blue, purplish, or white. Seed-pods $1 \frac{1}{2}$ to 3 ins. long, $\frac{1}{2}$ in. wide; covered with a sort of felt, and containing five to twelve blackish seeds.

Native of California in the coast region; of unrecorded introduction. This beautiful, half-woody shrub is apparently quite hardy near London, but is sometimes short-lived, especially if grown in rich soil. Young plants, it has been noticed, will pass through a winter quite unharmed which, a few years later, will succumb during another winter not any more severe. This is not an unusual characteristic of plants which grow so rapidly and produce seed in such abundance as this does. It points to the advisability of removing all seed-pods that are not required as soon as they are formed, also to the necessity of renewing the stock from seed (or, in the case of special varieties, from cuttings) every few years. For so beautiful a shrub this is trouble well repaid. Cuttings should be made in July and August of short side-shoots with a heel attached, and placed in gentle heat. This lupin likes a good but not close or heavy soil, and it should have a sunny position. It succeeds well on dryish banks, but does not grow so large there. The typical yellow form is very beautiful, as is also a comparatively new white variety, "Snow Queen." Varieties are also obtainable with flowers pale blue, blue and white, various shades of purple, lavender, etc. The flowers continue to appear from May to August, but are at their best in June and July. 


\section{LYCIUM. BOX THORN. SOI.ANACEE.}

$\Lambda$ genus of eighty or more species of loose-habited shrubs allied to the deadly nightshade (Atropa Belladonna), with usually spiny branches. Leaves alternate, often in clusters. Flowers from one to four in the leaf-axils, their parts usually in fives; corolla funnel-shaped or tubular. Fruit a berry, very ornamental.

The Lyciums or box thorns are easily cultivated; they do not need a rich soil,-flowering and fruiting better in a well-drained one of moderate quality. L. afrum needs a wall, but the others here described are perfectly hardy. They are best propagated by seeds when these are obtainable, but cuttings and layers may also be used. The nomenclature of the few hardy species is rather involved, owing to the many names under which the common L. chinense is grown. The two commonest names met with in gardens - "L. europæum" and "L. barbarum "-both rightly belong to plants that are not in cultivation.

\section{AFrum, Linnaus. African BOX ThORn.}

A deciduous shrub, much branched, spiny, growing 8 to ro $\mathrm{ft}$. high against a wall; young shoots pale, slightly angled, smooth. Leaves clustered, $\frac{1}{2}$ to I in. long, $\frac{1}{12}$ to $\frac{1}{8}$ in. wide; linear, tapered at the base, grey-green, smooth. Flowers on stalks $\frac{1}{3}$ in. long, produced in May and June. Corolla tubular, $\frac{1}{4}$ in. wide, $\frac{3}{4}$ to I in. long, with five shallow, erect lobes; very dark purple. Calyx bell-shaped, $\frac{1}{4}$ in. long, with five triangular teeth; stamens enclosed within the corolla, each with a tuft of hairs half-way down. Berry red, finally purple-black, egg-shaped, $\frac{1}{3}$ in. long, with the calyx persisting at the base.

Native of the Cape of Good Hope; introduced in 17.12. This species requires a sunny wall for it to be seen at its best. It was highly spoken of by early writers growing in such a position, and it has flowered with great freedom in Canon Ellacombe's garden at Bitton. It is cultivated in N. Africa, about Algiers, etc., but does not appear to be a genuine native of that region.

\section{Chinense, Miller. Chinese Box THorn.}

A rambling or scandent shrub, of very vigorous, quick growth, especially when young; branches long, arching or pendulous, angled, small ones occasionally spine-tipped. Leaves variable in size and shape; on vigorous shoots 2 to 4 ins. long, $\frac{1}{2}$ to over $I$ in. wide; ovate-lanceolate, but on others obovate to linear, and down to $\frac{1}{2}$ to $\frac{3}{4}$ in. long. Flowers usually in pairs or threes at each joint, each on a slender stalk $\frac{1}{2}$ to $\frac{3}{4}$ in. long. Corolla purple, $\frac{1}{2}$ in. long, short-tubed, the five spreading, ovate lobes being rather longer than the tube. Calyx lobed to various depths, persistent. Stamens bearded at the base. Berry scarlet or orange, oblong or egg-shaped, $\frac{3}{4}$ to 1 in. long, half as wide.

Native of China ; long known in gardens, and now naturalised in many parts of Britain and Europe. This is the shrub very common on the cliffs of south coast towns like Eastbourne and Bournemouth. It is very often grown as L. europæum and L. barbarum, neither of which is in cultivation or probablylhardy. Few plants are better for seaside planting than L. chinense, and when laden with its abundant, pendent, highly coloured fruits it is extremely ornamental. Birds appear to eat the fruits, as plants may frequently be seen growing on the tops of old walls, and suchlike places. In villages 
between London and the south coast, plants may often be seen beautifully in fruit on cottage walls in August and September.

Var. MEGISTOCARPUM.-A name sometimes given to a form with larger fruits, but probably not really distinguishable.

Var. RHOMBIFOLIUM (L. rhombifolium, Dippel).-Leaves broader and more lozenge-shaped than in the type. Fruits blunter at the end.

\section{Grevilleanum, Gillies.}

A deciduous shrub, 4 to $6 \mathrm{ft}$. high, forming a dense mass of overlaying branches; young shoots pale, more or less downy or scurfy. Leaves obovate or oblanceolate, $\frac{1}{2}$ to 2 ins. long, $\frac{1}{8}$ to $\frac{1}{2}$ in. wide ; tapered to the base, more abruptly towards the apex, densely arranged, ciliate, rather fleshy. The larger-sized leaves are only on young vigorous sucker-growths; most of the leaves are less than I in. long. Flowers solitary or in pairs in the leaf-axils, $\frac{1}{2}$ in. diameter ; corolla funnel-shaped, deeply five-lobed (the lobes longer than the tube), purple and yellowish white; calyx bell-shaped, the triangular-pointed lobes ciliate; stamens hairy at the base. Fruit orange-red, globular, $\frac{1}{3}$ in. diameter.

Native of the Argentine, but hardy. It flowers freely, but does not develop fruit well ; distinct from all the other hardy species in the downy stems, leaves and calyx, although this character is much more evident in wild than in cultivated examples.

\section{HALimifolium, Miller.}

(L. vulgare, Dunal.)

A deciduous shrub, with slender, smooth branches, and sometimes 8 or $9 \mathrm{ft}$. high; twigs smooth, spiny. Leaves variable, narrowly oval or lance-shaped, I to $2 \frac{1}{2}$ ins. long, blunt or pointed at the apex, wedge-shaped at the base, greygreen. Flowers axillary, produced each on a slender stalk singly, in pairs, or threes ; corolla dull lilac-purple, $\frac{1}{2}$ in. across, the tube longer than the lobes; stamens bearded at the base. Berry scarlet, oval, $\frac{2}{3}$ in. long.

The origin of this box thorn is not definitely known, but it is perhaps S. European. It is very closely allied to $\mathrm{L}$. chinense, and scarcely specifically distinct. It is considered to be of less vigorous growth and of more bushy, less rambling habit. The lobes of the corolla as compared with the tube are distinctly shorter in halimifolium than in chinense, neither is the fruit so long.

This species, like L. chinense, is often grown as L. EUROPÆUM, a species that differs from both in having quite smooth stamens (not bearded at the base), in the longer-tubed corolla, and smaller narrow leaves.

\section{L. pallidum, Miers. Fremont's Box Thorn.}

(Bot. Mag., t. 8440.)

A deciduous shrub of rather thin, lax, sprawling habit, at present 5 or $6 \mathrm{ft}$. high in cultivation; branches long, tortuous, or semi-pendulous, quite smooth, but armed with spines which are really arrested branches, often bearing leaves, sometimes flowers. Leaves oval lance-shaped, up to 2 ins. long by $\frac{3}{8}$ in. wide on the young, non-flowering shoots; but narrowly obovate, I in. or less long, and produced in rosettes on the year-old, flowering shoots; quite smooth, entire, of a glaucous green; tapering at the base to a short stalk. Flowers nodding on stalks $\frac{1}{4}$ in. long, often solitary or in pairs at each joint. Corolla funnel-shaped, $\frac{3}{4}$ in. long, $\frac{1}{2}$ in. wide at the mouth, where are five shallow, rounded lobes; pale green veined with darker lines, and tinged with purple. Calyx bell-shaped, about $\frac{1}{8}$ in. long, with five-pointed lobes. Style much 
protruded ; stamens rather shorter. Fruit scarlet, globose, $\frac{3}{5}$ in. long ; ripe in August.

Native of the south-eastern United States; discovered by Fremont on one of the tributaries of the Colorado River in 1844; introduced to Kew in 1886. It is a striking and quite hardy shrub, whose prettily coloured flowers hang in profusion from the under-side of the branches, and make it the best of the Lyciums in flower. It is also ornamental in fruit, but with us the crop is uncertain. It is best propagated by layering, in the absence of seed. The foliage varies in the intensity of its glaucous hue.

\section{LYONIA ligustrina, De Candolle. ERICACEA.}

A deciduous shrub, 3 to $8 \mathrm{ft}$. high; young shoots either covered with a close soft down or nearly smooth, and of a rather zigzag growth. Leaves alternate, oval or obovate, 2 to 3 ins. long, $\frac{1}{2}$ to $\mathrm{I} \frac{1}{4}$ ins. wide; entire or nearly so, pointed, covered with short down and dark green above, more downy beneath and paler, the nerves very prominent; stalk $\frac{1}{8}$ in. long. Flowers produced in July and August on the leafless terminal portion of the preceding year's growth, in downy racemes or small panicles I to $x_{2}^{1}$ ins. long, - the whole forming a compoundpaniclefrom 3 to 6 ins. long. Corolla downy, dull white, $\frac{1}{8}$ to $\frac{3}{18}$ in. wide, globose or orange-shaped, with five small, reflexed teeth at the nearly closed mouth. Calyx pale green or white, downy, appressed to the corolla. Seedvessel a dry, five-celled capsule, with the calyx persisting at the base.

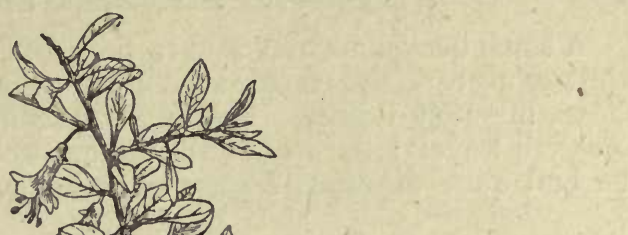

Native of Eastern N. America ; introduced in 1748 . This is not one of the most attractive of the heath family, but is desirable through flowering so late in the season. It grows naturally in moist situations, but 
in cultivation thrives in ordinary peat or light sandy loam. Propagated by seed or by cuttings taken with a slight heel from the shoots that spring freely from beneath the flower panicle. The genus commemorates John Lyon, a famous collector of North American plants, who died about I 8 r 8 during one of his expeditions to the mountains of the south-eastern United States-the "savage and romantic mountains which had so often been the theatre of his labours."

Var. PUBESCENS, Gray.-The most pubescent form of this species (which varies considerably in this respect), and entirely of a greyish aspect.

\section{MAACKIA AMURENSIS, Ruprecht. LEGUMINOSA.}

(Cladrastis amurensis, Bentham, Bot. Mag., t. 655I.)

A small deciduous tree, said to be $40 \mathrm{ft}$. or more high in a wild state, with peeling bark, but usually shrubby in cultivation in this country; young shoots minutely downy. Leaves 8 to $\mathbf{I} 2$ ins. long, pinnate, with seven to eleven leaflets; the main-stalk rather swollen at the base, but leaving the bud quite exposed; leaflets opposite, ovate, blunt at the top, $I_{\frac{1}{2}}$ to

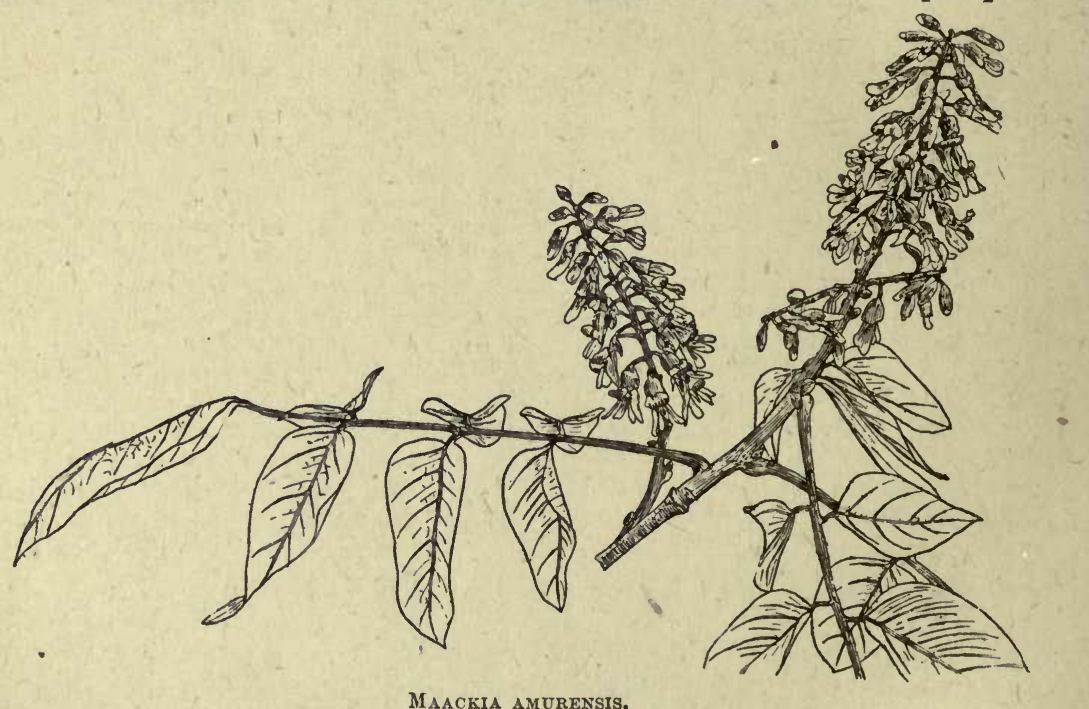

3 ins. long, dark green above, paler and downy beneath. Flowers peashaped, dull white, closely set on stiff, erect racemes, 4 to 6 ins. long, sometimes branched at the base. Each flower is $\frac{1}{2}$ in. long on a short stalk about half its length; calyx bell-shaped, $\frac{1}{6}$ in. long, covered like the flower-stalk with a thick brown down. Pod 2 to 3 ins. long, $\frac{1}{3}$ in. wide, flat, with the seam slightly winged.

Native of Manchuria, Corea, and Japan; introduced in 1864. The separation of this tree from the true Cladrastis is now generally accepted; 
the two are really very different, and Maackia may be distinguished as follows :-Wood not brittle; leaf-buds solitary, and not hidden by the base of the leaf-stalk; leaflets opposite; flowers densely packed in stiff, more or less erect racemes. M. amurensis is neither so handsome nor so striking as Cladrastis tinctoria, but, unlike it, flowers regularly when even quite small -3 or $4 \mathrm{ft}$. high. The Japanese form, which appears to attain to Jarger and more tree-like dimensions than the Manchurian one $(50 \mathrm{ft}$. in height and $7 \mathrm{ft}$. in girth of trunk), is known as var. BuERGERI; its leaves and young wood are more distinctly downy than in the type. In cultivation neither of them gives promise of making trees. They flower in July and August, and occasionally bear seed.

M. TASHIRoI (Cladrastis Tashiroi, Yatabe), from the Loochoo Islands, appears to be a small form of M. amurensis, always shrubby. It is not in cultivation.

\section{MACLURA aurantiaca, Nuttall. Osage Orange. URTICACE $A$.}

(Gardeners' Chronicle, 1894, ii., fig. 88 ; Ioxylon pomiferum, Rafinesque.)

A deciduous tree, occasionally $40 \mathrm{ft}$. or more high; branches armed with spines up to $\mathbf{I}_{4}^{\frac{1}{4}}$ ins. long; young shoots downy, soon becoming smooth. Leaves alternate, ovate or oval to oblong lanceolate; $I_{2} \frac{1}{2}$ to 4 ins. long, about half as wide; pointed, mostly rounded at the base; dark green and smooth above, paler and downy beneath, especially on the veins and midrib; stalk $\frac{1}{2}$ to $\mathrm{I}_{2} \frac{1}{2}$ ins. long. Male flowers green, produced in June along with one or two leaves from the joints of the previous year's wood, numerous in a short-stalked roundish cluster; they are quite inconspicuous, as are also the female ones, borne on separate trees. Fruit like an orange in shape, 2 to 4 ins. across, yellowish green.

Native of the South and Central United States; introduced in 1818. This tree is remarkable for its large, ornamental, but quite inedible fruits, rarely seen in this country, perhaps because the two sexes are not associated. They are full of a milky juice. In the United States this tree is largely used as a hedge plant, and I have also seen it used for the same purpose in Central Europe. It is an ally of the mulberry, and the only species known. Named in honour of William Maclure, an American geologist. Propagated by layers or root-cuttings, in the absence of seeds. Where only one tree is grown, an endeavour should be made to graft the other sex upon it.

Var. INERMIS, Andre, is without spines, and worth noting as being female.

Var. PULVERULENTA. - Leaves spotted with white; I only know it as a small plant, but it appears to be of little value.

\section{MAGNOLIA. MAGNOLIACEE.}

$A$ genus of deciduous or evergreen trees and shrubs named by Linnæus in honour of Pierre Magnol, a professor of botany and medicine 
at Montpelier, who died in I7 15 . The species in cultivation come from two widely separate areas, one group being native of the eastern United States, the other and larger one native of India, China, and Japan. Outlying members of each group occur in Mexico and Malaya. In one respect Magnolias are the most splendid of all hardy trees, for in the size of their individual flowers they are easily first ; the evergreen species, too, have about the largest leaves of all evergreen trees hardy with us. The flowers are produced singly at the end of a shoot, the calyx consisting of three sepals, the corolla of usually six or nine, sometimes fifteen or eighteen, petals. The fruit is more or less cone-shaped, and, like the seeds, often richly coloured. The young branches are very pithy; the leaves alternate and always entire. In most of the species, the bark when crushed emits a pleasant aromatic odour, and some of the American species, as well as the Chinese M. hypoleuca, have medicinal properties.

Perhaps no group of exotic trees gives more distinction to a garden than a complete collection of Magnolias. There is not one that is not worthy of cultivation, the early-flowering or Yulan section being especially noteworthy for the brilliant effect they produce in spring.

The only difficulty experienced in cultivating these trees is in establishing some of them after transplanting. The roots are thick and fleshy, and apt to decay if disturbed and lacerated when the trees themselves are at rest. Any planting, therefore, which involves root injury should be done when active growth has commenced, so that the wounds may heal and new roots be formed immediately. May is a suitable month. The more delicate-rooted species like parviflora and stellata undoubtedly like a proportion of peat in the soil, more especially when they are young. But for the strong-growing sorts like Soulangiana, tripetala, acuminata, etc., a good loam is very suitable. All of them like abundant moisture, and where the soil is shallow and poor, holes 18 ins. deep and 2 to 4 yards in diameter should be prepared by mixing good loam, and if possible one-fourth peat and decayed leaves with the ordinary soil. The dimensions of the prepared ground should, of course, be proportionate to the vigour of the species. In most gardens the ordinary soil, well trenched and improved by adding decayed leaves, will be found suitable, but for such delightful plants as these a little extra labour and expense at the outset will be repaid.

Magnolias are propagated by seed, layering, and grafting. For the pure species, seeds no doubt are preferable, but their production in this country is uncertain, and it has to be remembered that being of an oily nature they retain their vitality but a short time. It is advisable to sow them singly in small pots of light soil under glass. Layering is a very useful means of increase; it is now much practised in the great I)utch nurseries, whence Magnolias are sent to England every year in large quantities for forcing. Where layering is inconvenient or impossible, grafting will have to be employed. One of the best stocks is the American M. acuminata. For M. stellata the Japanese gardeners use M. Kobus as a stock, and for M. Watsoni they use stocks of M. hypoleuca. But grafting should be the last resource. 


\section{M. acuminata, Linnceus. Cucumber Tree.}

(Bot. Mag., t. 2427.)

A large deciduous tree, 60 to $90 \mathrm{ft}$. high, forming a trunk 6 to $12 \mathrm{ft}$. in girth. Branches at first erect, ultimately arching. Leaves oval to oblong, 5 to 10 ins. long, about half as wide; green on both sides, downy beneath; they narrow to a point at the end, the base is rounded. Flowers comparatively inconspicuous, dull greenish yellow; sepals I to $\mathbf{I} \frac{1}{2}$ ins. long; petals erect, 2 to 3 ins. long, in two sets of three each. Fruit dark red, columnar, 3 ins. long.

Native of Eastern N. America, from New York State southwards, reaching its finest development in the S. Allegheny region. This tree, the noblest of American Magnolias in growth and the least effective in blossom, was discovered by John Bartram, and introduced by him to England in 1736. It was raised from seed by Peter Collinson, and flowered with him for the first time May 20, 1762. The flowers have a slight fragrance. The popular name of "cucumber tree" refers to the shape and colour of the fruits when quite young. It ripens seed freely, and young plants make perhaps the best stocks for grafting other Magnolias upon. A fine tree at Kew is $5 \mathrm{ft}$. 3 ins. in girth of trunk.

Var. MAXIMA. - Trees under this name are grown at Kew, but except for a possibly more vigorous growth and larger foliage there is nothing to distinguish them. Sent out by the firm of Loddiges about 1830 .

Var. VARIEGATA. - Leaves handsomely blotched with golden yellow.

\section{CAMPBellit, Hooker fil.}

(Bot. Mag., t. 6793 ; Garden, Aug. 24, I895 (plate).)

A deciduous tree, occasionally $150 \mathrm{ft}$. high, with oval leaves tapering towards both ends, from 6 to ro ins. long, smooth above, covered with appressed hairs beneath. Flowers produced in spring before the leaves; very fragrant, cup-shaped at first, the petals very thick, 4 to 5 ins. long and about 2 ins. wide, varying in colour from deep rose to crimson.

Native of the Sikkim Himalaya at 8000 to $10,000 \mathrm{ft}$. altitude. It is only in the milder parts of the kingdom, like the south and west, that this fine tree-perhaps the most magnificent of Magnolias-can be expected to really thrive. It flowers from February to early April, and its flower-buds are susceptible to injury by storm and frost. It has flowered with Sir E. Loder at Leonardslee, Horsham; and a tree outside at Kew, $9 \mathrm{ft}$. high, has been. raised from seed that may have been gathered at the highest part of its altitudinal range, which is considerable. Hooker described it, wild near Darjeeling, as an immense, black-barked, sparingly branched tree.

\section{CONSPicua, Salisbury. Yulan, Lily tree.}

(Garden, Sept. 22, I888 (plate); M. Yulan, Desfontaines, Bot. Mag., t. I621 ; M. precia, Correa.)

A rather low, rounded, deciduous tree, much branched, rarely more than 30 , but sometimes $45 \mathrm{ft}$. high. Leaves 3 to 6 ins. long, 2 to $3 \frac{1}{2}$ ins. wide; oval to obovate, the apex contracting abruptly to a point, downy beneath. Flower-buds conspicuous all the winter by reason of their large scales covered with grey, shaggy hairs. Flowers pure white, opening from March to May according to the season; petals 3 ins. long, at first erect, afterwards spreading, thick, about nine in number. Fruit spindle-shaped, 6 ins. long. 
Native of China; introduced in 1789 . One of the most beautiful and striking of all flowering trees, this Magnolia is, unfortunately, an occasional victim to the inclemency of an English spring. Its flowers respond quickly to premature warmth in late February or March, only too often to be trapped by succeeding frost. A cold February and March suits it best. It never fails to set an abundance of blossom, and the white flowers gleaming in the sunshine of an early spring day render it the most conspicuous of all trees at that season. It was for long an uncommon tree, the most famous specimens being at Kew, Syon, and Gunnersbury House. It is now propagated in the Dutch nurseries by grafting on $M$. Soulangiana, and sold cheaply for forcing early into flower. By the Chinese the yulan has been cultivated for at least thirteen hundred years, especially near temples and in the Imperial gardens.

\section{CORDATA, Michaux.}

(Bot. Mag., t. 325 ; M. acuminata var. cordata, Sargent.)

Although this Magnolia is said to have been found by the elder Michaux growing near rivers in Georgia, its exact counterpart, according to Sargent, is not now known in a wild state. Sargent regards it as a variety of M.

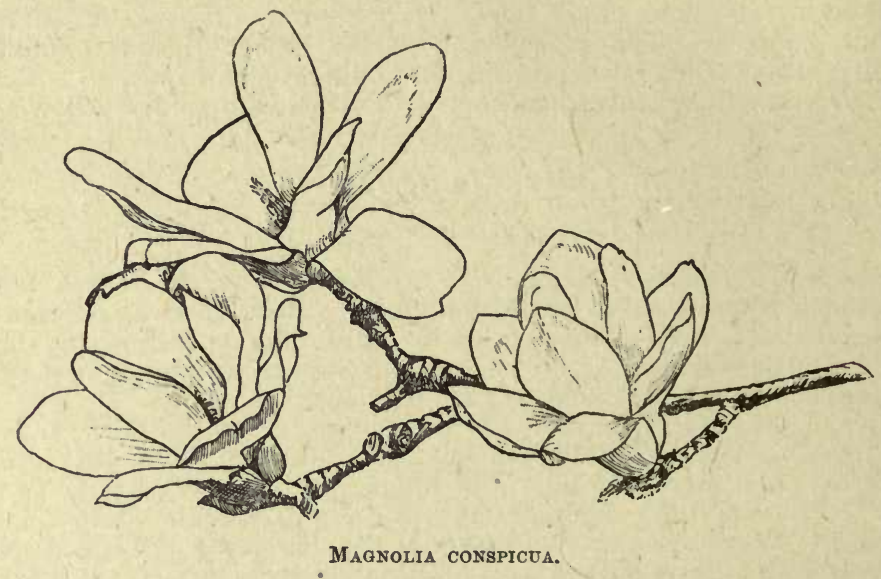

acuminata, from the typical form of which it is very distinct. The leaves are 3 to 5 ins. long, comparatively broader and less pointed than those of M. acuminata, but rarely cordate as the name implies. The flowers are faintly and not agreeably scented, canary yellow; petals $I \frac{1}{2}$ to 2 ins. long. Compared with the free-growing $M$. acuminata, of which it may be a high mountain form, it is a low, stunted tree. At Kew, where M. acuminata succeeds exceptionally well, a tree of M. cordata fifty years old is only $15 \mathrm{ft}$. high, and others only 3 or $4 \mathrm{ft}$. high flower abundantly. In beauty of blossom it is superior to its ally. Introduced in 1801.

\section{Delavayi, Franchet.}

(Bot. Mag., t. 8282.)

A spreading, flat-topped, evergreen tree, up to $30 \mathrm{ft}$. high. Leaves 8 to I 4 ins. long, 5 to 8 ins. wide; greyish dull green above, glaucous and with fine 
down beneath; the stalk one-fourth the length of the blade, stout; the midrib prolonged beyond the blade into a short tip. The flowers are 7 to 8 ins. across, cup-shaped and fragrant ; the petals about 4 ins. long, half as wide, dull, creamy white. The cone-like fruit is 6 ins. long.

Native of Yunnan, China ; introduced by Wilson in 1899. It grows on mountain-sides at from 4500 to $7500 \mathrm{ft}$. elevation, but in spite of these considerable altitudes it has not proved hardy at Kew in the open ground. Against a wall, both there and at the Coombe Wood nursery, it succeeds admirably. It flowered first in 1908. From the other (and hardier) evergreen cultivated Magnolia-M. grandiflora-this is very distinct in the larger leaves, dull green above, glaucous beneath. It ought to be a valuable tree in the south-western counties.

\section{Fraseri, Walter. Fraser's Magnolia.}

\section{(M. auriculata, Lamarck, Bot. Mag., t. I 206.)}

A deciduous tree, 30 to $40 \mathrm{ft}$. high, of open, spreading habit. Leaves produced in a cluster at the ends of the branches, pale green, of thin texture, smooth on both sides, obovate, pointed and with two distinct auricles (or lobes) at the base, extending below the point where the stalk joins the blade; the entire blade is from 8 to 15 ins. long, about half as wide; the stalk 2 to 4 ins. long. Flowers 8 ins. or more across, strongly and not very agreeably scented -at anyrate close at hand; produced on the leafy shoots in May and June. Sepals three, oblong-obovate, greenish, larger than the petals, deflexed. Petals six, at first pale yellow, afterwards milky white; narrowly obovate, 3 to 4 ins. long; at first erect, afterwards spreading. Seeds red, produced on a rose-coloured cone 4 or 5 ins. long.

Native of the south-eastern United States ; first discovered in S. Carolina, in 1776 , by William Bartram, and introduced to England ten years later. This handsome and striking tree is distinguished from all other Magnolias, except the rare M. pyramidata and the much larger-leaved M. macrophylla, by the auricles at the base of the leaves. It is well worth growing as a lawn tree. The specific name commemorates John Fraser, who sent to England many North American plants between 1780 and 1810 -including this Magnolia.

\section{GLAUCA, Linnceus. SWAMP BAy.}

A shrub or small tree in Great Britain, but said to be occasionally $50 \mathrm{ft}$. high in its native localities. Leaves oval or oblong, sometimes obovate, $2 \frac{1}{2}$ to 5 ins. long, scarcely half as wide; often blunt at the apex; lustrous green and smooth above, blue white and downy beneath, especially when young. Flowers globular, 2 to 3 ins. wide, delightfully scented ; produced in no great numbers, but continuously, on leafy shoots, from June to September. Petals oblong or slightly obovate, $\mathrm{I} \frac{1}{2}$ to 2 ins. long, at first creamy white, becoming deeper with age. The fruit develops indifferently in this country, but in the eastern United States the fine red cones produce a bright effect. This Magnolia varies in the persistence of its leaves; and of two trees at Kew, growing within a few yards of each other, one retains some of its foliage all the winter, the other, var. DECIDUA, is quite deciduous.

Native of the eastern United States from Massachusetts to Florida, often in swampy places. It was one of the early introductions from America, and is known to have been cultivated by Bishop Compton at Fulham Palace Gardens before the end of the seventeenth century. It is a most charming plant, readily distinguished by its comparatively small leaves, vividly glaucous beneath (but see also M. Thompsoniana). It is, or has been, valued in medicine for its tonic and diaphoretic properties. 


\section{GRANDIFlora, Linnaus. LAUREL MAGNolia.}

\section{(M. fœtida, Sargent.)}

An evergreen tree, 60 to $80 \mathrm{ft}$. high, of dense pyramidal form, but as usually seen with us less than half as high and more rounded. Leaves oval to oblong and obovate, from 6 to Io ins. long, less than half as wide ; tapered to both ends; leathery in texture, glossy dark green above, covered beneath, especially when young, with a thick red-brown felt; stalk I to 2 ins. long. Flowers among the finest in the genus, globular, 8 to io ins. across, very fragrant with a spicy or fruity odour, produced continuously during the late summer and autumn. Petals thick and concave, creamy white, broadly obovate, and 4 or 5 ins. long.

Introduced from the southern United States to England early in the eighteenth century, this still remains the finest flowered of evergreen trees; and until the advent of the Chinese M. Delavayi it was the only really evergreen hardy Magnolia. It never suffers from cold at Kew, but grows slowly, especially in height, and is very different to the magnificent pyramids one sees along the Riviera and in Italy. It is apt to have its branches broken during heavy falls of snow, for which reason it is wise to brace the main branches together by stout wires. In cold localities it makes an admirable wall tree. Many varieties, mostly of S. European origin, have been, and continue to be, put on the market.

Var. ANGUSTIFOLIA (syn. M. Hartwegii).-Leaves narrow, 6 to 8 ins: long, I $\frac{1}{2}$ to 2 ins. wide, with little or no brown-red felt beneath.

Var. GLORIOSA.-A broad-leaved form which bears flowers of great size and substance-one of the finest.

Var. Lanceolata, Aiton (var. exoniensis, Loddiges).-Exmouth Magnolia. Leaves rather narrower than in the type, lanceolate or oval, rusty coloured beneath; of a rather erect or fastigiate habit. Said to have originated in the garden of Sir John Colliton at Exmouth in the eighteenth century; hardier, and flowering younger.

Var. UNDULATA.- - Broad-leaved, with conspicuously wavy margins.

It is neither necessary nor possible to distinguish the various other forms that have been named. The tree ripens seeds freely in the south of Europe, and it is among the plants raised from them that these forms appear.

\section{HYPOLEUCA, Siebold.}

\section{(Bot. Mag., t. 8077.).}

A deciduous, erect-growing tree, 50 to 80 , sometimes $100 \mathrm{ft}$. high, with a trunk 6 to $9 \mathrm{ft}$. in girth; young bark dark brown. Leaves in a cluster at the end of the shoot, leathery, obovate, 8 to 18 ins. long, half as much wide; tapering at the base to a stalk $I$ to $2 \frac{1}{2}$ ins. long; glaucous green above, blue-white and slightly downy beneath. Flowers produced in June, 8 ins. across, strongly scented, sepals and petals creamy white; stamens bright purplish red, forming, with the yellow anthers, a conspicuous circular mass 3 ins. across in the centre of the flower. The fruit is brilliant red until mature, cone-shaped, rather pointed, 5 to 8 ins. high.

Native of Japan; introduced in $\mathbf{1} 884$. It attains apparently its largest size in the forests of Yezo, where it is highly valued for its light, soft, easily worked timber. One of the most beautiful of all northern trees both in leaf and flower, this Magnolia is also quite hardy. When young its habit is open and sometimes rather gaunt. A close ally, M. OFFICINALIS, Rehder, was introduced from China, in 1900, by Wilson. Its fruit is truncate at the apex and its bark is yellowish the first year, afterwards pale grey. 


\section{Kobus, De Candolle.}

(Bot. Mag., t. 8428 ; M. Thurberi, Parsons.)

A deciduous tree, ultimately 70 or $80 \mathrm{ft}$. high, with a trunk $6 \mathrm{ft}$. in .girth, of quick growth and pyramidal form when young, but eventually round-headed. Young branches aromatically fragrant when crushed; winter leaf-buds downy. Leaves obovate, 4 to 7 ins. long, often contracted at the apex to a short point, tapering at the base to a short stalk. Flowers amongst the smallest in the genus, often under 4 ins. in diameter when fully expanded; petals six, creamy white, obovate ; sepals small, soon falling ; flower-stalk downy. Fruit pinkish, seeds bright red.

Native of Japan. Although one of the least attractive of Magnolias, at anyrate when young, when it does not flower freely, this species is an interesting addition to cultivated Japanese trees on account of its vigorous constitution. It is much used by Japanese gardeners as a stock on which they graft M. stellata. There are two forms of it, one more robust and with larger leaves than the other-var. BOREALIS, Sargent. The tree referred to by Loudon in vol. i. of the Arboretum and Fruticetum, p. 283, as M. Kobus cannot, from the description, be this species. It was probably first introduced to England by Maries; there is a fine tree in the Coombe Wood nursery sent home by him in 1879 .

\section{LenneI, Van Houtte.}

(Flore des Serres, t. I693.)

One of the most beautiful of all hybrid Magnolias, this tree is said to have had the same origin as M. Soulangiana, viz. conspicua $\times$ obovata, or probably its var. purpurea. It is, at anyrate, very different from the average forms of that hybrid, the leaves being larger and broader (as much as 8 ins. by 5 ins.), and more strongly ribbed; the flowers, too, are finer and more richly coloured. Petals very fleshy, broadly obovate, often 4 ins. deep and 4 ins. wide ; concave like a broad spoon, and of a beautiful shade of rose-purple outside, white inside. The main crop of flowers commences to open in late April. and lasts through May, so that they are not often injured by frost. It occasionally flowers a second time in autumn.

This remarkable Magnolia is said to have originated accidentally in Lombardy, where it was noticed by an Erfurt nurseryman named Topf in 1850, and by him introduced to Germany. It was figured by Van Houtte in the place quoted above, and named in honour of Mr Lenné, a royal gardener in Berlin. There is a fine tree at Enys, in Cornwall.

M. RUSTICA RUERA is of a similar type to $M$. Lennei, and was raised in a nursery at Boskoop, near Gouda, in Holland, in a batch of seedlings from M. Lennei. In this variety the petals are more rose-coloured than in M. Lennei, and proportionately shorter and broader. It is much grown in the Boskoop nurseries from layers which are used as a stock for grafting M. conspicua, etc., on.

\section{MACROPHYLLA, Michaux.}

$$
\text { (Bot. Mag., t. 2189.) }
$$

A deciduous tree, 20 to $50 \mathrm{ft}$. high, with an open, spreading head of branches, and a trunk I to $I \frac{1}{2} \mathrm{ft}$. in diameter. Leaves the largest of all Magnolias, measuring 15 to 25 ins., sometimes 3 ft. in length, and from 7 to 12 ins. wide; 
oblong-obovate, widest above the middle, bluntish at the apex, broadly heartshaped or auriculate at the base; bright green and smooth above, silvery grey and downy beneath. Flowers on leafy shoots 8 to Io, sometimes 14 ins. across, fragrant ; petals six, dull creamy white, fleshy, 5 to 7 ins. long, half as wide. Fruit roundish, egg-shaped, rose-coloured, 3 ins. long.

Native of the south-eastern United States, where it is rare, and only occurs in small isolated stations. It was discovered by the elder Michaux in 1759 in the mountains of S. Carolina; introduced to Europe in I800. In foliage this is the most remarkable of Magnolias ; and is indeed one of the most interesting of the 'world's trees; but it is, unfortunately, spring tender in a young state. That it will withstand severer frosts than any we experience is shown by two healthy trees growing near the museum of the Arnold Arboretum, Boston. The most famous specimen in England is at Claremont, where, in a sheltered spot, is a healthy tree now $40 \mathrm{ft}$. high, with a trunk $3 \mathrm{ft}$. in girth.

\section{OBOVATA, Thunberg.}

(M. denudata, Lamarck; M. purpurea; Curtıs, Bot. Mag., t. 390.)

A deciduous bush of rather straggling growth, rarely more than $12 \mathrm{ft}$. high in the open (although twice as high on walls); young wood aromatic. Leaves ovate, oblong, or obovate, 3 to 8 ins. long, 2 to 5 ins. wide, ; tapering rather abruptly to a point, dark green above, downy beneath. Flowers opening from April to June ; petals 3 ins. long, I $\frac{3}{4}$ ins. wide, erect, obovate, vinous purple and white outside, white within.

Introduced from Japan in 1790 , this handsome shrub is now considered to be a native of China, and as existing in Japan as a cultivated plant only. It varies to a considerable extent in the colour of the flowers when raised from seed, but is always purple or a combination of purple and white outside, and white within.

Var. PURPUREA has larger flowers than the type, wholly purple outside, very deep towards the base of the petals (see Bot. Mag., figure quoted above); but there appears to be no well-marked distinction between them.

Quite hardy near London, it usually requires wall protection in the north. The later flowers are accompanied by full-sized leaves.

\section{PARVIFLORA, Siebold.}

$$
\text { (Bot. Mag., t. 74Ir.) }
$$

A small deciduous tree or large shrub, with slender branches. Leaves oblong or obovate-oblong, 4 to 6 ins. long, the apex contracting rather abruptly to a point, rounded at the base, dark green and smooth above, glaucous and downy beneath, usually with seven to nine pairs of veins; leaf-stalk $\frac{3}{4}$ to $\frac{1}{2}$ in. long, pubescent when young. Flowers fragrant, at first cup-shaped, borne on a stalk I to $2 \frac{1}{2}$ ins. long; petals pure white, about 2 ins. long, obovate, very concave. Stamens numerous, forming when spread out, a rosy crimson disk $I$ in. across.

Native of Japan and Corea. The most distinctive character of the species is the comparatively long flower-stalk. The flowers are not borne in one large crop, but appear a few at a time from May until August on the leafy shoots. The crimson stamens show in attractive contrast with the white sepals. It is not so robust a grower as most Magnolias are, and even more than most, likes a proportion of leaf-soil and peat in the soil. It has ripened seeds at Kew from which plants have been raised. 


\section{PyRamidata, Pursh.}

Originally discovered by William Bartram in Georgia, on the banks of the Altamaha River, and recognised by him as a species, this Magnolia was by later botanists confused with M. Fraseri. Although closely allied, the two are now considered quite distinct. The leaves of the present species are much smaller (usually less than 8 ins. long), of thinner texture, narrowing to a waist near the base, the basal lobes spreading. The flowers, too, are smaller, 3 to 5 ins. across, and the tree more erect and pyramidal, as is implied by the name. Whilst M. Fraseri is an inland mountain plant, this species affects low-lying regions of Georgia and the Carolinas. Whether it is at present in cultivation I am not aware. It was introduced early in the nineteenth century, and grew in Messrs Loddiges' nursery at Hackney about 1837 . The late Mr G. Nicholson saw it in the Trianon Gardens in 1887 , and quite possibly it survives in some of the old gardens in the warmer parts of the country under the name of Fraseri. It is, no doubt, more tender than M. Fraseri.

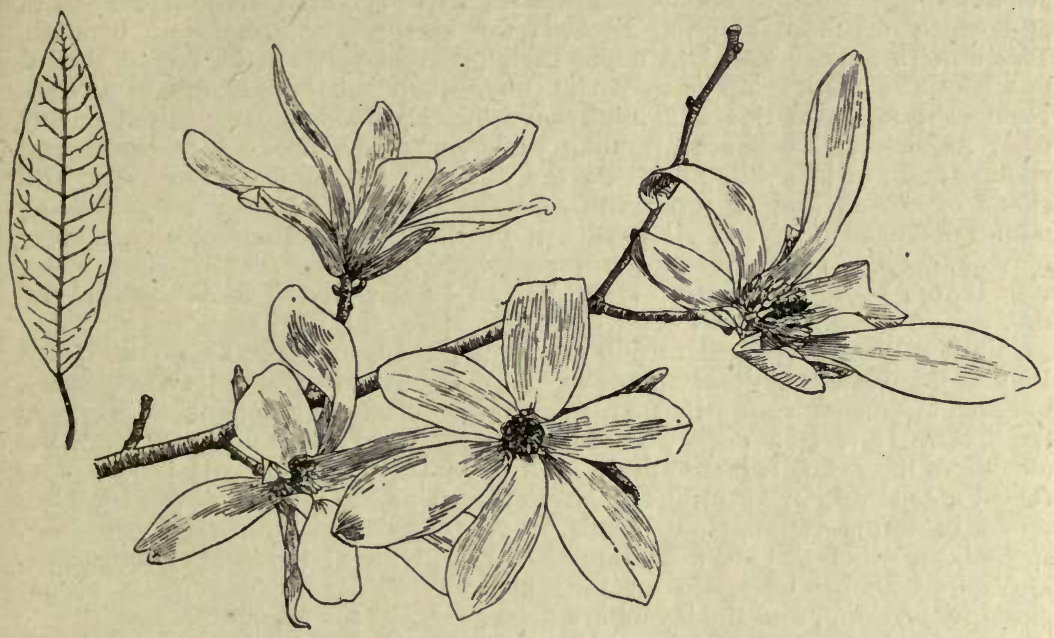

Magnolia salicifolia.

\section{SALICIFOLIA, Maximozicz.}

(Bot. Mag., t. 8483.)

A slender deciduous tree, 15 to $20 \mathrm{ft}$. high, with a trunk I ft. in girth; young shoots very slender, smooth the first year, slightly warted the second; leaf-buds quite smooth. Leaves narrowly oval to lanceolate, tapered at both ends, blunt or pointed at the apex; $1 \frac{1}{2}$ to 4 ins. long, $\frac{5}{8}$ to $1 \frac{1}{2}$ ins. wide ; dull green and smooth above, slightly glaucous and covered with minute down beneath; stalk slender, $\frac{1}{4}$ to $\frac{5}{8}$ in. long. Flowers 3 to 4 ins. across; petals six, pure white; the three outer ones 2 ins. long, $\frac{1}{2}$ in. wide, oblong, pointed; the three inner ones rather shorter and wider, slightly obovate; sepals short, lanceolate, very soon falling; flower-stalks quite smooth; flower-buds hairy. Fruit rosy pink, 2 to 3 ins. long; seeds scarlet.

Native of Japan, chiefly of Mount Hakkoda, at 2000 to $30 c 0 \mathrm{ft}$. ; introduced in I906. A very distinct species which promises to make an elegant tree, 
apparently perfectly hardy. It blossoms in April on the naked shoots. The flower is similar to that of M. Kobus, but otherwise the species is very distinct in its narrow leaves, smooth leaf-buds and flower-stalks. It first flowered at Kew in I9II. The bark when bruised emits a pleasant odour, like that of Lippia citriodora (lemon-scented verbena).

\section{Soulangiana, Soulange-Bodin.}

\section{(M. Yulan var. Soulangiana, Lindley, Bot. Reg., t. I164.)}

A hybrid raised in the garden of $\mathrm{Mr}$ Soulange-Bodin at Fromont, near Paris, from seed borne by $M$. conspicua fertilised by pollen of M. obovata. The plant first flowered in 1826, and has since become the most popular of all Magnolias in European gardens. In habit it is similar to conspicua, forming a low, spreading, but more shapely tree. It flowers in April, rather later than the yulan, and is usually at its best when the flowers of that species are fading. Leaves 3 to 6 ins. long, mostly narrower than those of the yulan, and especially more tapering towards the apex; they are downy beneath. The flowers appear first and make their great display on the naked shoots, but continue to develop until early June, when the tree is full of foliage. Numerous forms of this Magnolia have appeared since 1826 , raised mostly from its seeds. They are all alike in having the petals white inside and stained more or less with purple on the outside; but they vary in depth and shade of colour, and in the width and shape of the petals. The following names have been given: Alexandrina, cyathiformis, Hammondii (with very narrow petals), Norberti, speciosa, superba, spectabilis (nearly pure white, very large), triumphans, etc. Many are so similar that it is not possible to distinguish them from each other in words.

Var. NIGRA, Veitch.-Introduced from Japan in I86I by John Gould Veitch, this variety is deserving of special mention not only for its distinctness, but also because it shows that $M$. Soulangiana had an independent origin in the East. It is of a deeper shade of purple than any European form, the outside of the petals being entirely of a deep vinous purple. It is not of so robust a constitution as ordinary $M$. Soulangiana. There is now a complete series of forms ranging in colour from this remarkable variety to var. spectabilis, which has but the faintest stain of purple at the base of the petals, and might almost be taken for the yulan itself. M. Soulangiana is propagated by layering, and the layers are used as stocks for M. conspicua.

\section{Stellata, Maximorvicz.}

\section{(Bot. Mag., t. 6370 ; M. Halleana, Hort.)}

A much-branched deciduous shrub of rounded, compact habit, 1o to $15 \mathrm{ft}$. high, usually half as much more in diameter; young bark very aromatic, at first silky hairy; winter buds shaggy. Leaves $2 \frac{1}{2}$ to 4 ins. long, narrow oblong or obovate, tapering at the base to a short stalk. Flowers fragrant, pure white at first changing to pink; produced on the naked shoots in March and April. Petals twelve to eighteen, more numerous than in any other Magnolia, $\mathbf{I} \frac{1}{2}$ to 2 ins. long, narrowly oblong or strap-shaped, at first spreading, then reflexed. In var. ROSEA, Veitch, the flowers are rosy on first opening.

Native of Japan in the woods of Fujiyama ; introduced to England about 1877. For small gardens this is the most desirable of all Magnolias. Its only defect is that its delicate petals are very susceptible to injury by frost, or even excessive wind and rain. But it flowers most profusely, and the first crop of blossoms if destroyed is succeeded by others. It sets its flowers 


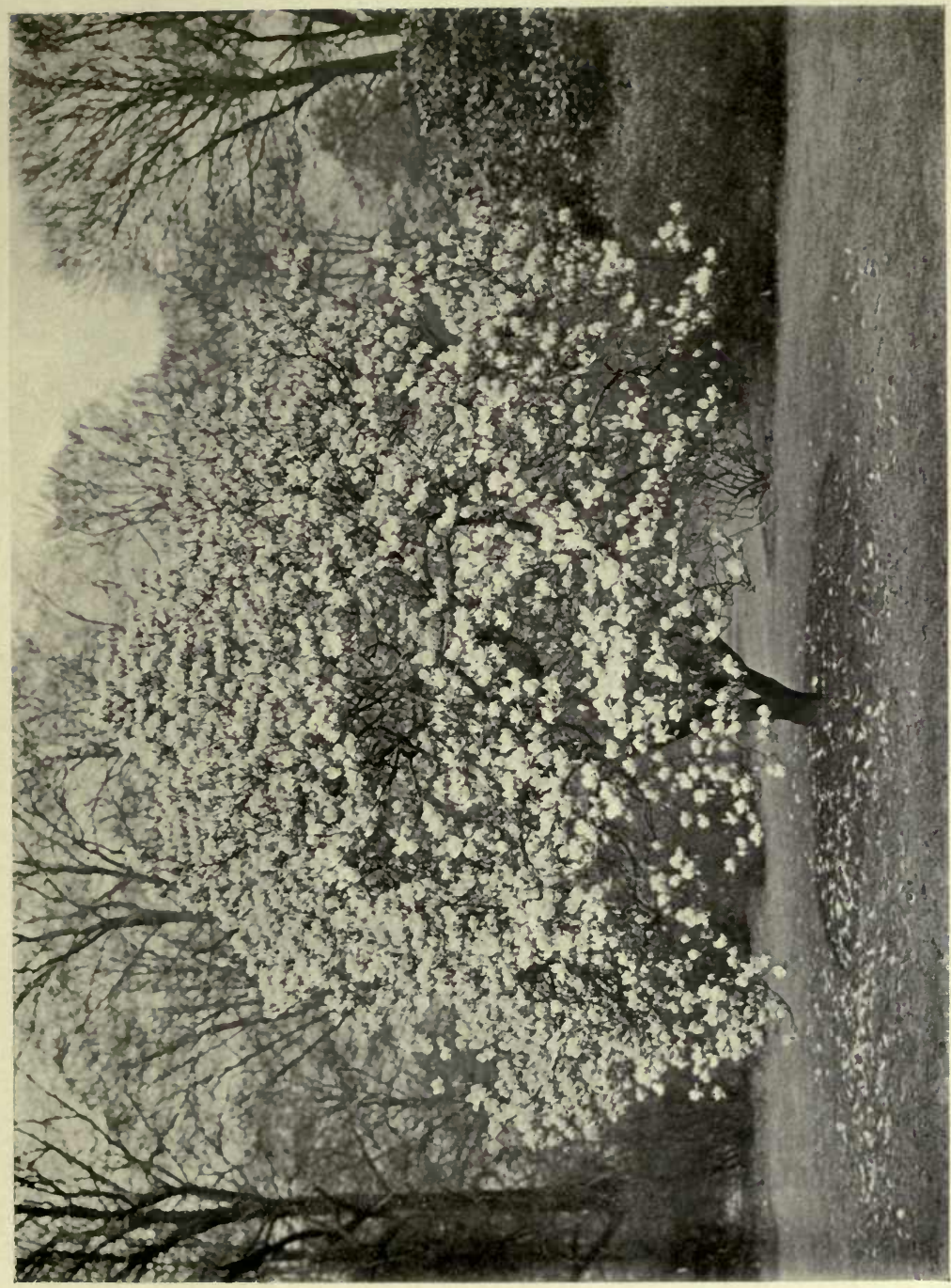

\&:

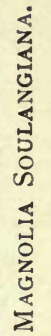



unfailingly, and flowers even when less than I foot high. An attractive picture is made by planting this shrub in a group and growing beneath it, thickly, the blue grape hyacinth (Muscaricomosum). The two flower together. This Magnolia is much benefited by an admixture of peat in the soil, even to the extent of one-third. (See plate Vol. i., p. 83.)

\section{Thompsoniana, Hort.}

\section{(M. glauca var. major, Sims; Bot. Mag., t. 2164.)}

About the year 1808 a Mr Thompson, then a nurseryman at Mile End, noticed a distinct plant amongst some of his seedlings of Magnolia glauca. He propagated it and ultimately distributed it under the above name. It is now usually regarded as a hybrid between glauca and tripetala, although there is much less evidence of tripetala than of glauca. It is a shrub of loose, ungainly habit, producing very vigorous unbranched growths of great length in one season. The leaves are 4 to ro ins. long, very glaucous beneath, and otherwise similar to those of M. glauca. The flowers are creamy white, much larger and less globular than those of M. glauca, the petals being from 2 to $3 \frac{1}{2}$ ins. long. I have not seen or heard of its producing seeds, but if it did and these were sown, the question of its hybrid or other origin would probably be settled.

\section{TRIPETAla, Linnaus. UMbrella TREe.}

(M. umbrella, Lamarck.)

A deciduous tree, 30 to $40 \mathrm{ft}$. high, with a wide-spreading, open head of branches. Leaves among the largest in the genus, usually 12 to 20 ins. long, and 6 to 10 ins. wide (sometimes still larger); broadly oblanceolate, acute, tapered at both ends, pubescent beneath when young, strongly ribbed; stalk 1 to 2 ins. long. Flowers produced in May and June, heavily and not agreeably scented. Petals six or nine, creamy white, 4 to 5 ins. long, 2 ins. wide (inner ones smaller). Fruit 4 ins. long, cone-shaped, of a fine rosy red; produced freely in this country, and very handsome ; seeds scarlet.

Native of Eastern N. America in the Allegheny region, from Pennsylvania southwards; introduced in 1752, and first flowered with Peter Collinson, May 24, 1760. Once the commonest and best known of American Magnolias. It is called the "umbrella tree" from the pose of its radiating cluster of large decurved leaves produced at the apex of the shoots. From the other big-leaved American species it is distinguished by the tapering base of its leaves. As a fruit-bearing tree it is the handsomest of all the Magnolias in this country. The finest specimen I know of is in the gardens at Sandon Hall, Weston, Stafford, which has a main trunk $9 \mathrm{ft}$. 9 ins. in girth near the ground, and is about $25 \mathrm{ft}$. high and through. There is another at Hartlebury Rectory, Kidderminster, whose trunk is $6 \mathrm{ft}$. in girth at $1 \mathrm{ft}$. from the ground.

\section{WAtsoni, Hooker fil.}

\section{(Bot. Mag., t. 7 I 57.)}

A deciduous shrub or small tree, of stiff habit. Leaves obovate, 4 to 8 ins. long, tapering at the base to a stalk $\frac{1}{4}$ to I in. long; apex blunt; dark green above, rather glaucous and slightly hairy beneath. Flower 5 or 6 ins. across, with a powerful aromatic odour. Petals obovate, the inner ones ivory white, the outer ones tinged with rose; stamens crimson, forming a conspicuous mass of rich colour 2 ins. across in the centre of the flower. 
Whether this species be a true native of Japan is uncertain. It has long been cultivated there, but may really be from Corea. It first appeared in Europe at the Paris Exposition of 1889 , when it was exhibited in the Japanese Court. Like many imported Japanese plants, those originally introduced were badly grafted, and many of them died; the species thereby got the reputation of being difficult to manage. It thrives admirably when once established, and flowers freely in June and July on leafy shoots. It is quite hardy at Kew, and in Devonshire is already $20 \mathrm{ft}$. high. Often confused with M. parviflora, this species is readily distinguished by its shorter-stalked, larger flowers, and by the larger, more leathery leaves, with ten to fifteen pairs of nerves.

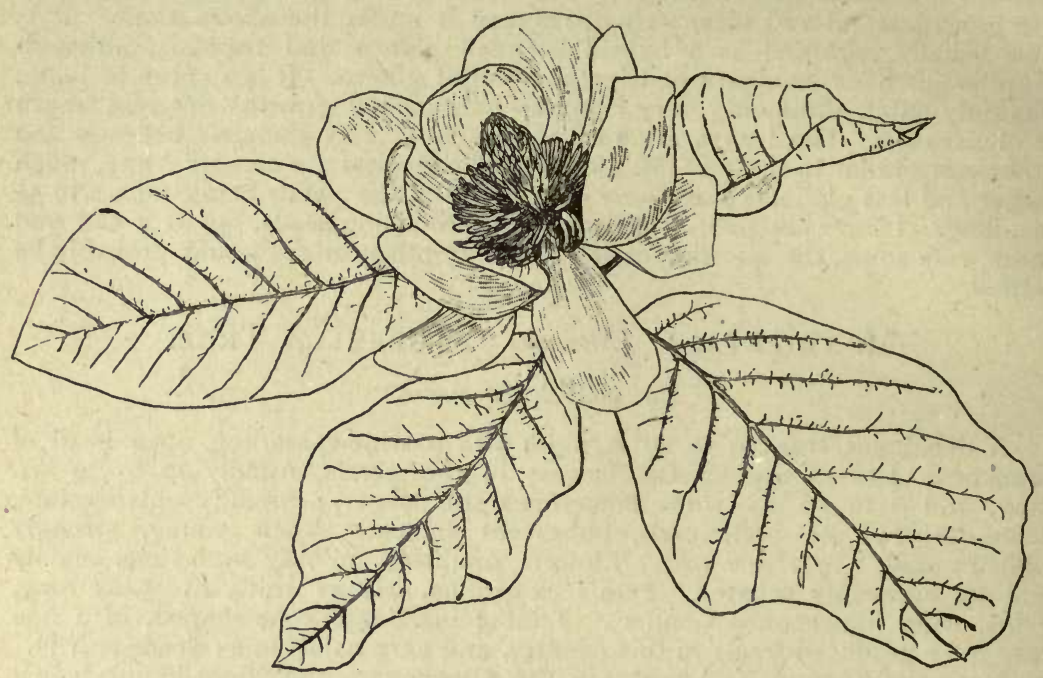

Magnolia Watsoni.

\section{MALLOTUS JAPONICUS, Mueller. EUPHORBIACEA. \\ (Rottlera japonica, Sprengel.)}

A deciduous shrub, 1o or $12 \mathrm{ft}$. high, with very pithy young wood, covered at first with minute specks of white starry down. - Leaves like those of a Catalpa, ovate, rounded or broadly tapered at the base, gradually tapered at the apex to a long slender point; they vary much in size, the largest being 9 or ro ins. long by 6 ins. wide; the smallest less than one-third those dimensions ; at first they are clothed with down like that on the shoots, but this soon falls away, leaving them nearly or quite smooth; the lower surface is specked with minute, transparent glands. Flowers small, crowded on erect, terminal, pyramidal panicles, 3 to 6 ins. high; they have little beauty, being small and covered with white down. Males and females occur on separate plants.

Native of Japan and Central China. The best plant I have seen was in Mrs Chambers' garden at Haslemere, where it flowers in autumn. It is only worth growing for its handsome foliage. 


\section{MARGYRICARPUS setosus, Ruiz and Pavon. PEAri, Fruit. ROSACEA.}

A low, prostrate shrub, with smooth, pale, straw-coloured branches, nearly covered by large, similarly coloured, clasping stipules. Leaves pinnate, about $\frac{3}{4}$ in. long; leaflets green, finely linear, $\frac{1}{8}$ to $\frac{1}{3}$ in. long ; stipules membranous, furnished at the edges with white, silky hairs. Flowers solitary, stalkless, very inconspicuous, without a corolla; produced singly in the leaf-axils. Fruit a small white berry, about the size of a peppercorn, with a pleasant acid flavour.

Native of the mountains of Chile, on dry mountain-sides. This curious little shrub may be grown by those interested in out-of-the-way plants; but beyond its finely cut leaves it has little to recommend it, although when its pearl-like fruits are borne freely it is striking. It appears to be hardy except during the hardest winters. It should have a sunny position on the rock garden, and not a rich soil. I have seen it bearing fruit freely in Mr Notcutt's nursery at Woodbridge, where probably the dry, sunny East Anglian climate suits it.

\section{MÅRSDENIA ERECTA, $R$. Brown. ASCLEPIADACE}

(Cynanchum erectum, Linnous.)

A deciduous climber, with slender, twining stems, $20 \mathrm{ft}$. or more high, furnished with a little loose down when young. Leaves opposite, heartshaped, $\mathrm{I} \frac{1}{2}$ to $2 \frac{1}{2}$ ins. long, from two-thirds to as much wide; with short, abrupt points; pale rather glaucous green, with a little loose down on the midrib and veins beneath; stalk $\frac{1}{2}$ to $1 \frac{1}{4}$ ins. long. Corymbs terminal and axillary, the latter often in pairs, but only borne in the axil of one of each pair of leaves, 2 to 4 ins. long, erect. Flowers white, $\frac{1}{3}$ in. across, sweetly scented, the five segments of the corolla narrow oblong, $\frac{1}{4}$ in. long, rounded at the end. Calyx-lobes ovate, transparent at the margins. Fruit narrowly cone-shaped or spindle-shaped, 3 ins. long, $\frac{1}{2}$ in. wide at the base, tapering to a point; each seed has a brush-like attachment of silky white hairs $\mathrm{I}$ in. long.

Native of S.E. Europe and Asia Minor; cultivated in England in the sixteenth century, but long regarded as a greenhouse plant. It is the hardiest member of a large genus, and succeeds very well against a sunny wall, but is liable to be killed in the open. It is not quite so hardy as its ally, Periploca græca. When cut, the stems exude a milky juice, which has a blistering effect on the skin, and is very poisonous taken internally.

\section{MEDICAGO ARBorea, Linnaus. MoON Trefoll. LEGUMINOSE.}

This shrub is chiefly interesting as a woody member of a genus represented in the British flora by about half a dozen herbaceous plants 
known as "medicks," and including the "lucerne." It is not hardy at Kew in the open, but will live against a wall; it is said to have been I I ft. high at one time in the Chelsea Botanic Garden. It is best adapted for the extreme south-western counties. A shrub, evergreen where it thrives, usually 6 or $8 \mathrm{ft}$. high; its stems very leafy but little branched, covered with grey down. Leaves trifoliolate, I to $\mathbf{I} \frac{1}{2}$ ins. long; leaflets $\frac{1}{4}$ to $\frac{3}{4}$ in. long, wedge-shaped, sometimes toothed, sometimes notched at the apex, silky beneath, smooth above. Flowers yellow, $\frac{1}{2}$ in. long, crowded at the end of short axillary racemes which continue to appear as the shoot extends, from June well into autumn, but never making a great display at one time. Easily increased by soft cuttings in bottom heat. The leaves are produced in clusters at each joint, and as the joints are usually about $\frac{1}{2}$ in. apart, the stem has a very leafy aspect. The pod is flat, but curled round like a ram's horn. In the south of Europe it makes a pleasing undergrowth in thinnish woodland and at the outskirts of plantations, especially in maritime districts.

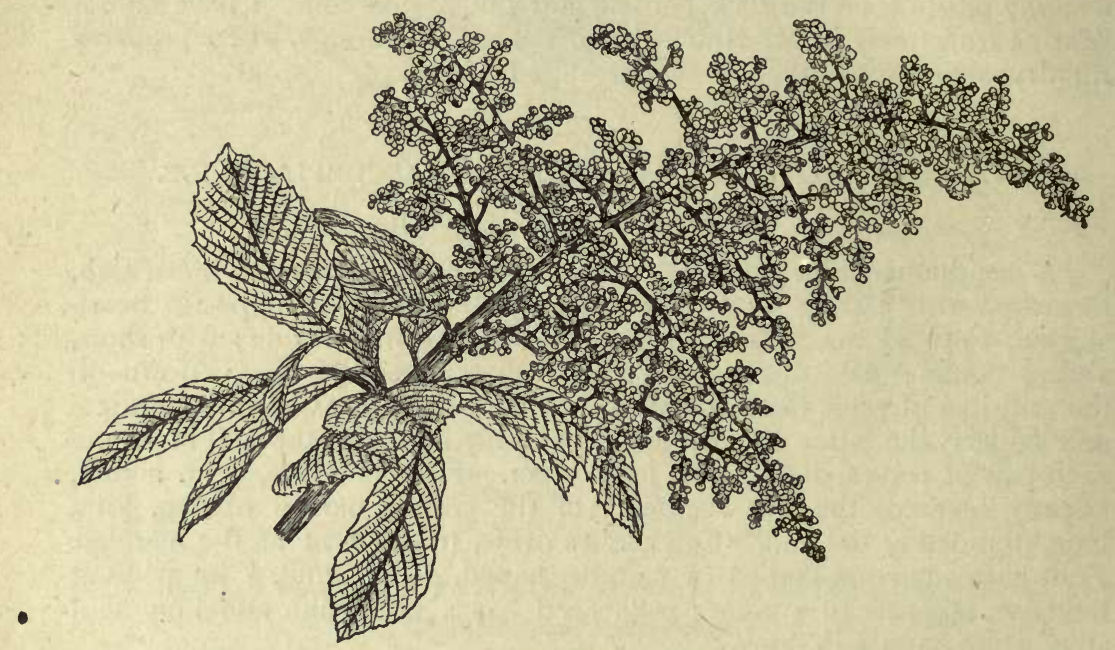

Melosma cuneifolia.

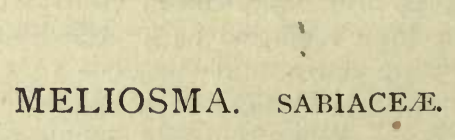

A genus of trees and shrubs, with alternate, simple or pinnate leaves, natives of Eastern Asia and America-the hardy ones all from China and Japan, and deciduous. They produce their flowers, which are small and white, in large terminal panicles. Petals five, the three outer ones concave, orbicular, and larger than the two inner ones. Fruit a drupe containing one seed, which is remarkable for its twisted radicle.

Until quite recently the only species grown out-of-doors was M. myriantha, which is tender in many places. Wilson introduced several species from China, two of which are described below, the remainder 
have not yet been named. The Meliosmas like a good loamy soil, and a fairly sunny spot.

\section{CUNEIFOlia, Franchet.}

(Bot. Mag., t. 8357.)

A deciduous shrub, described as up to $20 \mathrm{ft}$. high in nature ; branches erect, smooth. Leaves 3 to 7 ins. long, I $\frac{1}{2}$ to 3 ins. wide ; obovate or wedge-shaped, broadest near the apex, where it narrows abruptly to a point; upper surface rough to the touch, lower one clothed at first with a brownish down, especially on the midrib and axils of the veins. The veins of the leaf are in fifteen to over twenty pairs, parallel, and about $\frac{3}{16}$ in. apart ; margins set with bristle-like teeth. Flowers yellowish white at first, then almost pure white, deliciously scented, $\frac{1}{6}$ in. across; produced in striking pyramidal panicles terminating the branches, 5 to 9 ins. high, and as much through. Fruit globose, about the size of peppercorns, black.

Native of W. China; introduced by Wilson in I90I for Messrs Veitch, and first flowered in their nursery at Coombe Wood in July 1909, when I saw it, and was much attracted by its fine panicles, and especially by the hawthornlike fragrance. It is, no doubt, allied to the older $M$. myriantha, but is a hardier plant, easily distinguished by the shape of the leaves, the lower twothirds of which is uniformly and distinctly wedge-shaped.

\section{MYRIANTHA, Siebold.}

A deciduous shrub or small tree of spreading habit, $20 \mathrm{ft}$. high. Leaves oval-lanceolate, 3 to 8 ins. long, $1 \frac{1}{2}$ to 3 ins. wide; pointed, sharply and regularly toothed, the stalk ( $\frac{1}{2}$ to $I$ in. long) and midrib covered with reddish brown hairs; veins parallel, as in' a sweet chestnut. Panicles terminal, 6 ins. or more long, and about the same wide, much branched; the main-stalk and all its ramifications covered with brown hairs. Flowers minute, about $\frac{1}{8}$ in. diameter, very numerous, yellowish white, very fragrant. Fruit crowded in a broad panicle, each one about the size of a peppercorn, dark red.

Native of Japan and the Corean Archipelago; introduced from the former to the Coombe Wood nursery in 1879 by Maries. The original plant, now at Kew, is a fine spreading bush about $8 \mathrm{ft}$. high and $12 \mathrm{ft}$. through, and flowers with freedom every year in late June and July. It is, nevertheless, a rather tender subject when young; plants unprotected in the open at Kew have often perished. When once a strong woody base has been formed it will probably survive, but until then some winter protection is necessary. It will certainly thrive in the warmer counties.

\section{Veitchiorum, Hemsley.}

A deciduous tree, 30 to $40 \mathrm{ft}$. high, with very stout, rigid, erect branches. Leaves pinnate, $1 \frac{1}{2}$ to $2 \frac{1}{2} \mathrm{ft}$. long, with about nine or eleven leaflets, which are each $3 \frac{1}{2}$ to 7 ins. long, about half as much wide; of ovate or oblong outline, occasionally rather heart-shaped at the base, smooth, except on the midrib beneath; margins entire or sparsely toothed. Panicles as much as is ins. long, and 12 ins. wide at the base, more open and less densely furnished with flowers than either of the simple-leaved species before mentioned; flowers white, $\frac{1}{4}$ in. or less across. Fruit purplish black, about the size of a large pea.

Native of W. China at elevations of 5000 to $7500 \mathrm{ft}$., whence it was introduced by Wilson in 1901 . It is in cultivation in several places including Kew, and is noteworthy for its fine pinnate foliage, and 
curiously stout, rigid branchlets. It is evidently quite a hardy tree, but has not yet flowered in cultivation. It has the general aspect of a pinnate-leaved sumach.

\section{MENISPERMUM. MOONSEED. MENISPERMACEA.}

Climbing, woody or semi-woody plants, with alternate, peltate leaves, and separate male and female flowers. Sepals six ; petals six or eight; stamens nine to twenty-four. The black or purple-black fruit encloses one half-moon or crescent-shaped seed-giving the popular name. The plants spread rapidly by means of underground stems, and are easily increased by division. Cocculus is nearly allied, but has the leaf-stalk attached at the margin of the leaf, and only six stamens.

\section{Canadense, Linnaus. Canadian Moonseed.}

\section{(Bot. Mag., t. ig10.)}

A deciduous climber, producing a very dense tangle of smooth, slender, twining shoots 12 or $15 \mathrm{ft}$. high. Leaves ovate to heart-shaped and roundish, with usually three, five, or seven angular lobes; strongly veined and pale beneath, dark green above. Leaf-stalk slender, 3 to 4 ins. long, attached to the blade near, but not at the base (peltate). Flowers numerous, inconspicuous, greenish yellow, borne on a slender, long-stalked raceme, one of which is produced a little above each leaf-axil., Fruit in long loose racemes, nearly black when mature, about the size of a black currant. Each fruit contains one crescent-shaped seed.

Native of Eastern N. America, where it is widely spread; cultivated in England since the end of the seventeenth century. Its stems although truly woody have a herbaceous appearance, and do not live long. The exceptional vigour of the plant and its habit of spreading rapidly by means of underground suckers render it unsuitable for planting near delicate or slow-growing shrubs, which it is apt to smother. But it makes a good summer covering for a wall or summer-house, and is distinctly ornamental when in fruit. It can be pruned back to the ground every winter.

\section{Dauricum, De Candolle. Davurian Moonseed.}

Scarcely different from the American species in stem, leaf, and general aspect, this can be recognised when in bloom by the flowers being more closely packed together in a shorter raceme, and by the racemes being produced in pairs a little above each leaf-axil. The leaves have the same three or five lobes, but the apex is usually more drawn out, the spaces between the lobes are more deeply hollowed, and the stalk is attached to the blade farther away from its margin.

Native of N.E. Asia from Siberia to China, requiring the same conditions and treatment as the American species.

\section{MENZIESIA PILOSA, Jussieu. ERICACEÆ.}

(M. globularis, Salisbury; M. ferruginea var. globularis, Sims, Bot. Mag., t. I 57 r.)

A deciduous shrub, 3 to $6 \mathrm{ft}$. high, rigid and erect in habit, the bark on the older branches hanging in loose shreds; young shoots downy and 
hairy. Leaves alternate, obovate or narrowly oval; $\frac{3}{4}$ to 2 ins. long, $\frac{3}{8}$ to $\mathrm{I}$ in. wide; tapered at both ends, more or less glandular-hairy on the upper surface and on the margins, with a few bristles on the midrib beneath. Flowers yellowish white, nodding, produced along with the young shoots in May in few-flowered clusters terminating the previous year's branches. Corolla bell-shaped, $\frac{1}{4}$ in. long, mostly four-lobed; sepals with small, slender teeth; flower-stalk decurved, glandular-downy, $\frac{1}{4}$ to $\frac{3}{4}$ in. long. Seed-vessel dry, egg-shaped, $\frac{1}{4}$ in. long, covered with gland-tipped hairs.

Native of Eastern N. America from Pennsylvania southwards, mostly in mountain woods; introduced in 1806 . This is not one of the most attractive of the American Ericaceæ, but was commonly grown in the older collections, and is still obtainable in nurseries. It likes a peaty soil, and should be increased by seeds.

Nearly allied to it, and often associated with it as a variety, is

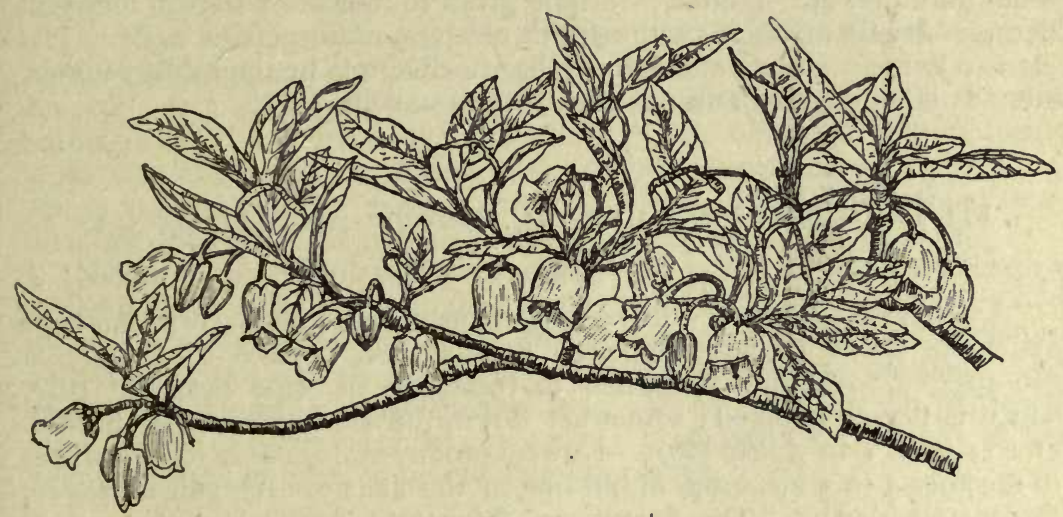

MeNZIKSTA PILOSA.

M. GLabella, A. Gray. This differs in having downy stamens (those of pilosa being glabrous); the leaves are almost smooth, as is also the seed-vessel. It is a native of the North Central and North-West United States. For other plants often called Menziesia in gardens, see Dabœcia and Phyllodoce. The name commemorates Archibald Menzies, who served as surgeon-botanist on Vancouver's great expedition of survey, I790-5, during which he discovered and introduced many plants-a western North American Menziesia among them.

\section{MESPILUS GERMÁNiCA, Linncus. MEdLAR. ROSACEA.}

A low deciduous tree of crooked, picturesque habit, usually under $20 \mathrm{ft}$. high; young branchlets very hairy, older ones armed with stiff, straight spines $\frac{1}{2}$ to $\mathbf{I}$ in. long. Leaves almost without stalks, lanceolate or oval, 2 to 5 ins. long, minutely toothed; downy on both surfaces, but more so beneath. Flowers solitary at the end of short leafy branches; 
about I in. across, white or slightly pink, produced on a very short woolly stalk, in May or early June. Petals five, roundish; sepals covered with grey wool, triangular at the base, drawn out into a long, narrow point standing out beyond the petals. Fruit five-celled, apple-shaped, brown, with a broad open eye, surrounded by the persistent calyx, and showing the ends of the bony seed-vessels.

The wild medlar is a rative of Europe and Asia Minor, and is found wild in the woods of several counties in the south of England, notably Sussex and Kent, but it is not believed to be truly indigenous. It has long been cultivated for its fruit in English orchards, and several named varieties exist. The cultivated forms are distinguished by thornless or nearly thornless branches, by larger, broader leaves, and by larger fruits up to $1 \frac{1}{2}$ or 2 ins. across. Although much esteemed by those who have acquired the taste for them, medlars are not a popular fruit. They should be left on the tree until the end of October or later, then stored in a fruitroom until they are "bletted"-a term given to indicate a state of incipient decay. A jelly made from the fruits meets a more general taste. The medlar is most closely. allied to Cratægus, differing in the solitary flower, etc. It is very hardy, and not particular as to soil.

\section{METAPLEXIS Stauntoni, Roemer. ASCLEPIADACEA. \\ (M. japonica, Makino.)}

A deciduous climber, with twining stems covered at first with more or less loose down. Leaves opposite, heart-shaped, tapered to a point at the apex, 2 to $4 \frac{1}{2}$ ins. long, half to two-thirds as wide near the base, which is deeply notched; somewhat downy on the midrib beneath, dull green; stalk I to 3 ins. long. Flowers produced from July to September in racemes 3 to 5 ins. long, in but one of the axils of each pair of leaves; flower-stalk downy. The flowers are frequently crowded at the end of the inflorescence as in an umbel. Corolla dull rosy white, about $\frac{1}{2}$ in. diameter, with five reflexed lobes united into a bell-shaped base; the lobes are narrow, curled back at the points, and covered with pale hairs on the upper side. Seed-vessel 4 ins. long, spindle-shaped, the seeds furnished at one end with a tuft of beautiful silky hairs $1 \frac{1}{4}$ ins. long.

Native of China and Japan; introduced in I862. It is not often seen in gardens, but it flowers and has borne seed with Canon Ellacombe, at Bitton, near Bristol. It usually dies back to the ground in winter in the open. It is interesting, but not particularly attractive, being allied to Marsdenia erecta, which has smaller leaves, sturdier stems, and more rounded petals.

\section{MICHELIA COMPRESSA, Sargent. MAGNOLIACE}

This is the only hardy species of a genus of trees closely allied to Magnolia, but distinguished by the flowers being axillary, and the ovules more numerous in each carpel. M. compressa is an evergreen tree, at 
least $40 \mathrm{ft}$. high, with a trunk I ft. or more in diameter, and a compact, rounded head of branches. Leaves 3 ins. in average length, oblong or obovate, tapering at the base to a slender stalk $\frac{1}{2}$ to $\mathbf{I}$ in. long; smooth, leathery, and glossy green. Flowers (not yet seen in this counry) $\mathbf{I}_{2}^{\frac{1}{2}}$ to 2 ins. across when fully expanded, Magnolia-like, fragrant; sepals and petals pale yellow. Fruits on a cone 2 ins. long, each containing usually three seeds.

Native of Japan, and confined in a wild state to that country; introduced to England in 1894 . It has proved hardy at Kew, although slow-growing, increasing in height about 3 or 4 ins. annually. Still rare.

\section{MICROGLOSSA Albescens, C. B. Clarke. COMPOSIT}

(Bot. Mag., t. 6672 ; Aster cabulicus, Lindley; Amphiraphis albescens, De Candolle.)

A plant with semi-woody, erect stems, growing in tufts about $3 \mathrm{ft}$. high, very pithy, and clothed with a grey down. Leaves alternate, lanceshaped, 2 to 5 ins. long, $\frac{1}{2}$ to $I$ in. wide; tapered to both ends, the margins entire or with minute teeth; grey and downy beneath. Flower-heads $\frac{1}{3}$ in. diameter, produced during July, in compound corymbs 3 to 6 ins. across, terminating the current season's growth. Ray florets about fourteen, narrow ; pale lilac-blue or bluish white; centre flowers yellow.

Native of the Himalaya, up to $12,000 \mathrm{ft}$. ; introduced to the Chiswick gardens of the Royal Horticultural Society about 1840 . It is nearly allied to the Aster. The shoots made during the summer die back considerably during the winter, almost to the ground in severe seasons. The flowers are of a rather indeterminate blue, and the plant has no particular merit except in flowering in late summer. Propagated by cuttings of the young growths in heat, or by dividing old plants.

\section{MOLTKIA PETRÆA, Reichenbach. BORAGINACEE.}

(bithospermum petræum, De Candolle, Bot. Mag., t. 5492.)

A small semi-evergreen, bushy shrub, 1 to $2 \mathrm{ft}$. high; stems erect, and covered with grey hairs pointing upwards. Leaves alternate, narrowlinear, $\frac{1}{2}$ to $1 \frac{1}{2}$ ins. long, about $\frac{1}{8}$ in. wide; covered like the stems with appressed, forward-pointing hairs on both surfaces. Flowers produced during June, in small crowded clusters terminating the young shoots, the whole inflorescence $\mathbf{I}$ to $I_{2} \frac{1}{2}$ ins. across. Corolla pinkish purple in bud, becoming violet-blue on opening, tubular, $\frac{1}{3}$ in. long, with five short, erect, rounded lobes.

Native of Dalmatia, Albania, etc. ; first introduced about 1840 , and treated as a cool greenhouse plant. It was afterwards lost to cultivation, but was reintroduced by Messrs Backhouse of York, thirty years later. It is not a robust plant and is certainly not adapted for shrubberies, but on a well-drained ledge in the rock garden at Kew it has lived for thirty years, Probably damp is more detrimental to its welfare than cold. 
Certainly no little shrub of its type deserves better care ; it lasts in flower a good while, and no prettier or more dainty plant exists when every twig is crowned by the brilliantly coloured blossoms. The flowers have much the same arrangement as in the common borage; they are closely set, and open successively on the upper side of a stalk which becomes decurved. Summer cuttings take root readily. It needs a light, welldrained soil and a sunny position. Out of flower it has much the appearance of lavender.

\section{MORUS. MULBERRY. URTICACE .}

Of the dozen or so species of Mulberry known, three or four can be grown without protection in the south of Britain. These are (with us) small, bushy-headed trees, with alternate, deciduous, toothed, and often variously lobed leaves. The flowers are unisexual, the sexes borne on separate spikes, which are small, more or less cylindrical, and of no beauty. The "fruit" of the mulberry is really a fruit cluster, composed of closely packed drupes, each enclosed by the persistent, enlarged, succulent sepals.

Mulberry trees like a warm, well-drained, loamy soil, and M. nigra especially is worth growing for its luxuriant leafage and picturesque form. It is not much planted now, but nothing gives to a garden fortunate enough to possess it a greater sense of old-world charm and dignity than a rugged old mulberry standing on a lawn. It can be increased by summer cuttings with the greatest ease-the old writers say pieces $8 \mathrm{ft}$. or more long will grow. Branches broken down but not detached will usually take root if they touch the ground. M. alba will also root from autumn or winter cuttings.

\section{AlbA, Linnceus. White Mulberry.}

A deciduous tree, 30 to $45 \mathrm{ft}$. high, with a rounded head of branches and a trunk $6 \mathrm{ft}$. in girth ; young shoots downy at first, becoming more or less smooth by autumn. Leaves broadly ovate with a heart-shaped base, usually pointed sometimes rounded at the apex, frequently three-lobed; varying much in size, from 3 to 8 ins. long and up to 6 ins. wide; coarsely toothed, lightish green and only slightly roughened above, downy near the veins and midrib beneath; stalk $\frac{1}{2}$ to $I$ in. long. Flowers produced during May in the leafaxils and at the base of the new shoots; females on stalked cylindrical spikes $\frac{1}{3}$ to $\frac{1}{2}$ in. long; male spikes longer. Fruit-clusters $\frac{1}{2}$ to $I$ in. long, white or pinkish, sweet, insipid.

Native of China, and possibly of other parts of temperate Asia ; cultivated from time immemorial in many South European and Eastern countries. In the old Dalmatian towns, like Ragusa and Spalato, old trees with rugged trunks give great charm to the streets; they are pruned back every winter. The white nulberry is the tree on which the silkworm is fed. It succeeds quite well in the south of England, but no success has ever been achieved in establishing the silkworm industry there in spite of several attempts, the first of which was made under the auspices of James I. The climate is considered to be too dull and damp. Nevertheless the tree is quite hardy at Kew, and over $30 \mathrm{ft}$. high, with a trunk 12 to 18 ins. in diameter; succulent, over- 
vigorous shoots are injured by frost. The tree, however, lacks the quaint charm of the common mulberry.

Many varieties of white mulberry are in cultivation, but those that differ chiefly in their influence on the silk produced by worms that feed on them have little interest to British arboriculturists. The following deserve mention :-

Var. FEgYVERNEKIANA.-A pigmy, usually under $3 \mathrm{ft}$. high.

Var. HETEROPHYLLA. - Leaves variously and unequally lobed.

Var. LACINIATA.- - Leaves raggedly and deeply toothed.

Var. MACROPHYLla, Loddiges.-One of the largest-leaved forms; leaves 7 to 9 ins. long.

Var. PENDULA.-A tree of very weeping habit forming an umbrella-like head. It is of so pendulous a nature that it is necessary to tie up a leading shoot every year to enable a trunk to be formed of the desired height. It should be trained up $20 \mathrm{ft}$., and will then make one of the most striking of weeping trees.

Var. VENOSA.-Leaves tapered at both ends, the veins very prominent, yellowish.

\section{Cathayana, Hemsley.}

A tree Io to $20 \mathrm{ft}$. high, young shoots downy at first, becoming smoother and greyish. Leaves heart-shaped, 3 to 6 ins. long on adult plants, threefourths as wide (considerably larger on young vigorous plants), terminated at the apex by an abrupt slender point, margins roundish-toothed (often threelobed in young trees); rough with short hairs above, softly downy beneath; primary veins in five or six pairs; stalk about I in. long, hairy. Male spikes $\frac{3}{4}$ in. long, borne on a slender stalk about the same length; female spikes of similar size, but with the flowers more closely packed. Fruit not seen.

Native of Central China ; first discovered about I 888 , by Henry, in Hupeh ; introduced twenty years later by Wilson. Young trees have hitherto grown freely, and promise to be quite hardy.

\section{NIGRA, Linnceus. COMmon MulberRy.}

A deciduous tree, 20 to $30 \mathrm{ft}$. high, of rugged, picturesque aspect, forming a dense spreading head of branches usually wider than the tree is high, and a short rough trunk; young shoots downy, exuding a milky juice when cut. Leaves broadly ovate or two- to five-lobed, always heart-shaped at the base, and with a short, tapered point ; coarsely toothed ; upper surface rough with short flattened hairs, deep glossy green ; lower surface paler and downy. On vigorous barren growths the leaves will be 6 to 9 ins. long, and both lobed and unlobed; on fruiting shoots they are $2 \frac{1}{2}$ to 5 ins. long; stalk I in. or less long. Flower-spikes cylindrical, those carrying male flowers about $\mathbf{I}$ in. long, the females half as long; both on very downy stalks. Fruit clusters oval, $\frac{3}{4}$ to I in. long, dark red, with an agreeable sub-acid flavour.

The black mulberry is, no doubt, a native of one or more Oriental countries, but having been cultivated for thousands of years and naturalised, its original limits have long been obliterated. It is known to have been cultivated in England since the early part of the sixteenth century, quite possibly long before. Trees at Syon, in Middlesex, are believed to have been planted there in 1548 . It is better adapted for the southern part of Britain than the northern, but is always of slow growth. The famous "Shakespeare mulberry" (of which descendants are at Kew) was planted in the poet's garden at Stratford-on-Avon in 1609 . Although not so good for the purpose as M. alba, the common mulberry has been much used to feed silkworms upon. The fruits are sometimes eaten at dessert, and they are also made into 
various conserves and drinks. So far as I am aware, the mulberry has never produced any variation from the type-a very unusual circumstance in a tree so long cultivated.

\section{RUBRA, Linnaus. RED . MulberRy.}

A deciduous tree, 40 to over $60 \mathrm{ft}$. high in a wild state, with a trunk 3 or 4 $\mathrm{ft}$. in diameter. Leaves broadly ovate to roundish, heart-shaped at the base, slender-pointed, occasionally two- or three-lobed, toothed, 3 to 5 (occasionally 7 or 8) ins. long, three-fourths to about as much wide; somewhat rough above

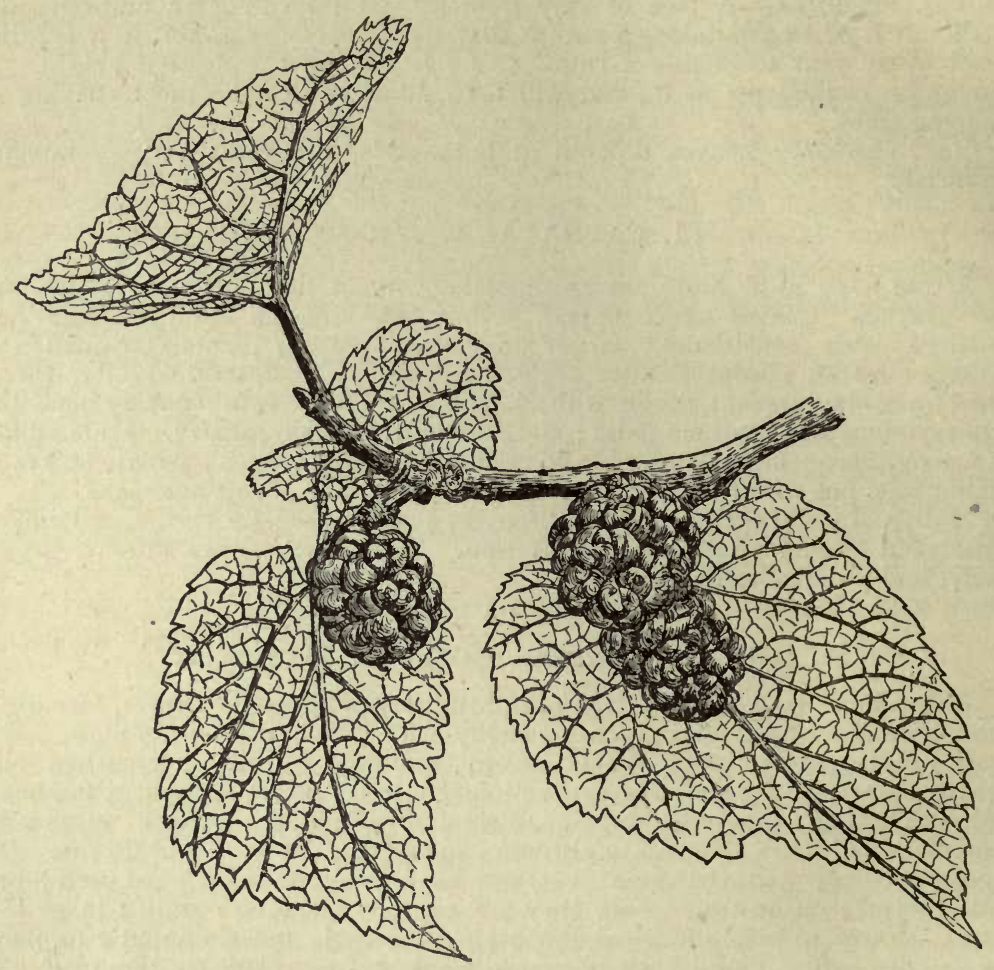

MoRUS NIGRA.

with scattered stiff hairs, or the remains of them, very downy beneath ; stalks $\frac{1}{2}$ to $\mathrm{I}$ in. long. Male spikes I to 2 ins. in length, slender and catkin-like ; females I in. long; both downy. Fruit cluster $I$ to $I \frac{1}{4}$ ins. long, cylindrical ; at first red, then dark purple ; sweet.

Native of the eastern and Central United States ; introduced in 1629. In my experience this mulberry thrives the worst of those here mentioned. At Kew it always has an unhappy appearance, and I do not know of good trees elsewhere. Probably our climate is as unsuited for it as for several other trees from the same region. In the United States it produces a light, tough, durable timber, and, according to Sargent, is planted in the south States for 


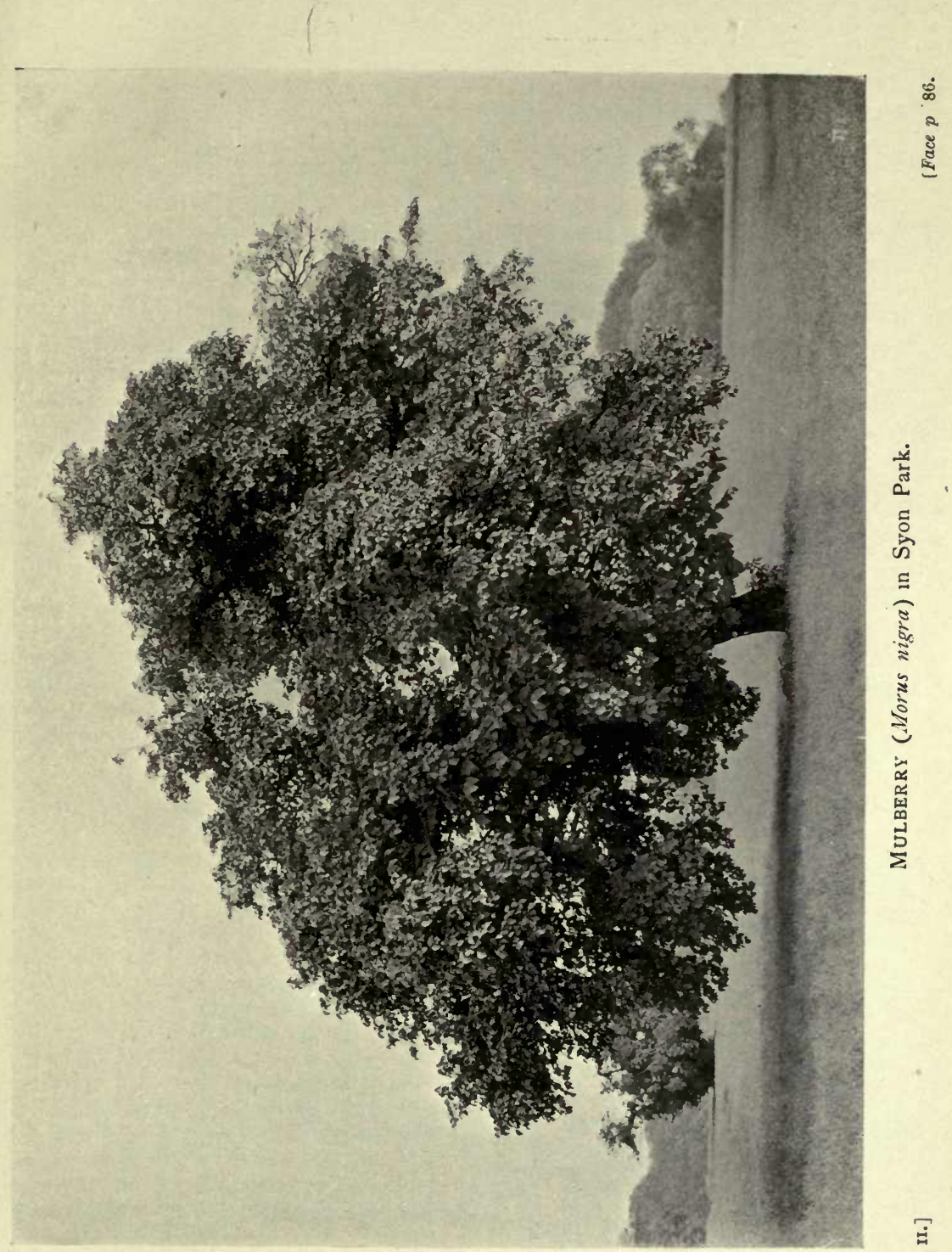



the value of its fruit, as food for poultry and hogs. Several named varieties are also cultivated there for human use. It is distinguished from alba and nigra by the leaves being much more downy beneath.

\section{MUEHLENBECKIA. POLYGONACEA.}

A genus of about fifteen species of shrubs or semi-woody climbers, chiefly Australasian, some South American. Leaves alternate, stalked; flowers small, greenish or whitish, of little or no ornament, the sexes sometimes on separate p'ants. Perianth deeply five-lobed, stamens eight; fruit a nutlet, three-angled, and enclosed in the perianth, which persists and sometimes becomes fleshy. The species are so variable that it is difficult to define their limits, but I believe there to be only two species commonly grown out-of-doors in this country, viz., M. axillaris, a tiny creeping shrub, and M. complexa, a climber. The latter is sometimes met with as "australis" and "adpressa," names which really belong to species with much larger leaves up to 3 ins. long. M. AUSTRALIS, Meissner, is from New Zealand, and M. ADPRESSA, Meissner (nearly allied to it), is Australian; both have panicled inflorescences, and neither is likely to be hardy, except in our very mildest localities. Of the real M. varians I am able to ascertain little. It was described by Meissner in $185_{2}$ as having panicled inflorescences 3 to 4 ins. long; its country unknown. Cheeseman in his recent Monograph of the Nere Zealand Flora does not mention it. It is, perhaps, a form of australis or adpressa, with smaller, often fiddle-shaped leaves, usually $\mathrm{I}$ to $\mathrm{I}_{2}^{\frac{1}{2}}$ ins. long.

\section{AXILlaris, Meissner.}

(M. nana, Hort.)

A tiny, deciduous, creeping shrub, $\mathrm{I}$ or 2 ins. high, forming a dense mat upon the ground of thin wiry. branches, and spreading indefinitely by underground stems. It will, however, climb a few inches high if support be available. Young shoots minutely downy. Leaves ovate to round, $\frac{1}{8}$ to $\frac{1}{3}$ in. long, smooth, not toothed; the stalk scarcely so long. Flowers pale green, very tiny, produced singly or in pairs in the axils of the terminal leaves during July.

Native of the mountainous districts of New Zealand, Tasmania, and Australia. This little shrub, which is one of the very dwarfest in cultivation, may be recommended to lovers of curiosities. Its flowers are scarcely perceptible, but its thread-like stems, tiny round leaves, and matted growth, make it interesting. It may be grown on some rock garden ledge. Easily increased by division or cuttings.

\section{COMPleXa, Meissner.}

(Bot. Mag., t. 8449.)

A climbing deciduous shrub, forming dense masses of slender, wiry, much interlaced stems; minutely warted when youug. Leaves very variable in shape and size, being roundish, heart-shaped, oblong and fiddleshaped, sometimes on the same plant; they are thin, dull green, quite smooth, 
$\frac{1}{8}$ to $\frac{3}{4}$ in. long; stalk rough with minute warts, $\frac{1}{8}$ to $\frac{1}{4}$ in. long. Flowers greenish white, $\frac{1}{6}$ in. long, produced in autumn in small terminal and axillary spikes about $\frac{2}{3}$ in. long; the perianth with its five erect, oblong, blunt-ended lobes persists to the fruiting stage, becoming enlarged and glistening waxy white.

Native of New Zealand, often found at considerable altitudes. It differs from australis in its usually smaller leaves and in having its flowers nearly always in short spikes. It makes a dense and interesting cover for old tree-stumps and rubble-heaps; and it is even worth while allowing it to ramble over a common or unimportant shrub 6 to $10 \mathrm{ft}$. high, which it will in time smother by an amazingly thick tangle of dark wiry stems. Hardy in the south and west; killed to ground-level by severe frost at Kew.

\section{MUTISIA DECURRENS, Cavanilles. COMPOSITA.}

(Bot. Mag., t. 5273.)

A climbing evergreen shrub, growing 8 to Io $\mathrm{ft}$. high; stems slender, smooth, but little branched. Leaves narrow-oblong, stalkless; the blade 3 to 5 ins. long, $\frac{1}{2}$ to $I$ in. wide; the base being continued down each side of the stem as a pair of narrow wings, the apex terminating in a forked tendril which curls round any available support, and thus holds up the stem. Flower-heads 4 to 5 ins. across, solitary at the end of the shoot, and borne on a smooth stalk 3 to 5 ins. long. Ray florets about fifteen, each $\frac{1}{2}$ in. wide, and of a brilliant orange or vermilion colour; disk florets yellow. The flower-head is supported at the base by a columnar mass of overlapping thin scales tipped with greyish hairs, and has much the aspect of a Gazania or single dahlia.

Native of Chile; introduced for Messrs Veitch in 1859 by Richard Pearse. Except in comparatively few places it has not proved a success in this country, and is now uncommon. One of the greatest successes with it has been obtained in Sir Thomas Acland's garden at Killerton, near Exeter. A plant there is grown against a wall facing south-west, and $\mathrm{Mr}$ J. Coutts, who planted it and cultivated it for several years, tells me that it has borne over three hundred flower-heads during one summer. $\mathrm{He}$ ascribes his success with it, first, to the position and climate; second, to the soil, which is not the ordinary red soil of Devon, but volcanic trap; and lastly, to the practice of placing stones on the ground about the roots. The Killerton plant produces suckers freely, and by them can be propagated; it also ripens seed from which many plants have been raised. This Mutisia is capable of withstanding severe cold; soon after it was introduced it experienced $26^{\circ}$ of frost at Exeter without injury.

\section{MYRICA. GAle, Bayberry. myricacele:}

Deciduous and evergreen shrubs or small trees, with scented alternate leaves and unisexual flowers, the sexes sometimes on the same plant, sometimes separated. Flowers in catkins, and produced in the axils of bracts. There are neither sepals nor petals, the male flower consisting 
of a varying number of stamens, the female of a one-celled ovary with two stalkless stigmas.

'The Myricas are not much grown in gardens, but are worth a place for their sweetly scented leaves, and, in the American kinds, their white, wax-coated fruits. They thrive in any ordinary soil. Increasid by seed or layering.

\section{Californica, Chamisso. Californian Bayberry.}

An evergreen shrub, to to $14 \mathrm{ft}$. high, with erect, vigorous shoots, hairy when young. Leaves oblanceolate or somewhat oval, tapered at both ends, regularly and angularly toothed, sometimes almost to the base; 2 to 4 ins. long, $\frac{1}{2}$ to $\frac{3}{4}$ in. wide ; dark glossy green, glandular on both surfaces, especially beneath, downy only on the midrib above, slightly fragrant when crushed; stalk $\frac{1}{4} \mathrm{in}$. or less long. Male catkins borne in the axils of the year-old leaves, about I in. long; female catkins usually on the same plant. Fruit globular, $\frac{1}{6}$ in. across, covered with white wax.

Native of California, where it is sometimes a tree $40 \mathrm{ft}$. high. "In very hard winters this shrub is cut back to ground-level at Kew, but in ordinary winters survives without injury except to the tips of the young shoots. It is a cheerful, vigorous evergreen, but its leaves are not so strongly scented as those of the other species here mentioned. Very well adapted for the milder parts of the country.

\section{CERIFERA, Linncus. WAX MyrtLE.}

A deciduous, or more or less evergreen shrub in this country, but said to be at times a small evergreen tree, 20 to $40 \mathrm{ft}$. high in a wild state; young shoots downy. Leaves narrowly obovate or oblanceolate, very variable in size in different forms, the largest $4 \frac{1}{2}$ ins. long and 2 ins. wide, but normally $1 \frac{1}{2}$ to 3 ins. long, $\frac{1}{3}$ to $\frac{3}{4}$ in. wide; usually toothed towards the apex, glossy green and smooth above, dotted with yellowish resin-glands beneath, and downy on the midrib; stalk $\frac{1}{8}$ to $\frac{1}{4}$ in. long. Male catkins $\frac{1}{4}$ to $\frac{1}{2}$ in. long. Fruits globular, $\frac{1}{8}$ in. wide, coated with white glistening wax, stalkless, densely crowded in clusters of two to six on the growths of the previous year.

Native of the south-eastern United States; introduced in 1699. In the early part of the occupation by Europeans of its native region, this shrub was valued by the settlers for the wax yielded by the fruits. This white, waxy coating, which gives so distinctive a character to the plant in autumn, was removed by boiling, and then made into candles. According to Kalm, the Swedish traveller, these candles burnt better and more slowly than ordinary tallow ones, and gave an agreeable smell when extinguished. The species is very variable in leaf, especially in size and toothing.

Var. LATIFOlia, Aiton.-A form grown for many years at Kew. It has obovate leaves 2 to $4 \frac{1}{2}$ ins. long, 1 to 2 ins. wide; dark glossy green and smooth above, hairy over the whole surface beneath, especially on the midrib; young shoots hairy. It is a shrub $9 \mathrm{ft}$. high and $\mathrm{I} 2 \mathrm{ft}$. through.

Closely allied to $M$. cerifera, and perhaps a more northerly form of it, is the "Bayberry"-M. CAROLINENSIS, Miller. This reaches into Canada, and extends in a wild state from Nova Scotia, New Brunswick, and Prince Edward Island south to Florida, etc. It differs in its leaves being more often oblong and oval than obovate, more abruptly tapered at the base, and blunter at the apex than in M. cerifera ; downy above. Young wood downy. The fruit is coated with white wax, as in the other, but is somewhat larger ( $\left(\frac{1}{6}\right.$ in. wide). This species is always shrubby, and up to 8 or $9 \mathrm{ft}$. high. It is, no doubt, 
hardier than the true cerifera, and probably is grown under that name in many gardens.

\section{GALE, Linncus. SwEET GALE. \\ (Gale palustris, Chevalier.)}

A deciduous shrub, 2 to $4 \mathrm{ft}$. high, bushy; wood and leaves fragrant when crushed. Leaves oblanceolate, tapering and entire at the base, toothed and broadest near the apex; 1 to $2 \frac{1}{2}$ ins. long, $\frac{1}{3}$ to $\frac{3}{4}$ in. wide; glossy and dark green above ; paler, more or less downy, and with scattered shining glands beneath; stalk $\frac{1}{8}$ in. long. Flowers of the male plant produced during May and June in crowded, stalkless catkins, each catkin $\frac{1}{3}$ to $\frac{5}{8}$ in. long, set with close, overlapping, shining, concave scales. Fruit catkins about as long, but stouter; composed of closely set, resinous nutlets $\frac{1}{12}$ in. wide. The flowers are borne on the naked wood of the previous year; the sexes usually on separate plants.

Native of the higher latitudes of all the northern hemisphere ; common in Great Britain, especially in the north, usually in moist peaty places, and on moors. In gardens the sweet gale is sometimes grown for the sake of its pleasant fragrance when handled. On the Yorkshire moors branches were, and perhaps still are, used to flavour a kind of home-made beer known as "gale beer," considered to be very efficacious for slaking thirst.

Var. TOMENTOSA.-Young wood, both surfaces of the leaf (but especially the lower one), very downy.

\section{MYRICARIA GermanicA, Desvaux. TAMARICACE $A$.}

A deciduous shrub, 6 to $8 \mathrm{ft}$. high, glaucous grey, and of rather gaunt habit. Branches erect, plume-like, clothed with flat, round-pointed, linear leaves, from $\frac{1}{16}$ to $\frac{3}{16}$ in. long. Flowers densely set in slender racemes 3 to 8 ins. long, which terminate the branchlets all over the top of the shrub; each flower is about $\frac{1}{4}$ in. long, produced in the axil of a bract longer than itself; petals narrow, pink or pinkish white. Stamens ten; seeds feathery.

Native of Europe, Himalaya, Afghanistan, etc. ; cultivated in England since $x_{582}$. It inhabits river banks, mountain streams, and other sandy, occasionally inundated places, where it often fills the ground over long distances. Closely allied to Tamarix (from which it differs chiefly in the more numerous and united stamens), it is not so ornamental as various members of that genus. It is easily propagated by cuttings made of stout wood of the current year placed in sandy soil in the open ground in October. It flowers from May to August.

\section{MYRSINE AFRICANA, Linneus. MYRSINACEÆ.}

An evergreen shrub, usually from I to $3 \mathrm{ft}$. high, bushy, and very leafy; young shoots angled, covered with short down. Leaves alternate, about $\frac{1}{8}$ in. apart on the twigs, oval to narrowly obovate, rounded or tapering at the apex, always tapered at the base ; $\frac{1}{4}$ to $\frac{3}{4} \mathrm{in}$. long, $\frac{3}{16}$ to $\frac{1}{2}$ in. wide; toothed at the terminal half only, smooth on both surfaces, lustrous dark green above; ștalk downy, $\frac{1}{16}$ in. long. Flowers of one sex only on 
a plant, very tiny, pale green, produced in stalkless clusters of three to six at the leaf-axils. Berries on the female plant dull red, orange-shaped, $\frac{1}{8}$ in. or less across, with the persistent calyx at the base containing a single seed.

Native of the Himalaya, China, Azores, and the mountains of E. and S. Africa. This curious little shrub, which is of neat habit and has a general resemblance to Ilex crenata, is spread widely over the Old World. It has no flower-beauty. The plants in cultivation are mostly, if not entirely, of Himalayan or Chinese origin. It appears to be very hardy; a plant raised from seed in $\mathbf{I} 895$ at Kew has grown ever since in the rock garden unprotected; now only about I ft. high. There is a female plant which bears fruit in Lord Ilchester's garden at Abbotsbury, near Weymouth; and there is, or used to be one, in Mr A. Waterer's nursery at Knap Hill. I have had it also in' fruit from Devonshire, Ireland, etc. Wilson has recently sent seeds from China.

\section{MYRTUS COMmUnis, Linneus. MYRTLE. MYRTACEA.}

An evergreen, very leafy shrub, up to Io or I $2 \mathrm{ft}$. high, sometimes a small tree; young wood downy. Leaves opposite, ovate or lanceolate, pointed, I to 2 ins. long; $\frac{1}{3}$ to $\frac{3}{4}$ in. wide; dark glossy green above, paler beneath, smooth on both sides, fragrant when crushed, and covered with transparent dots; margins entire, decurved; stalk very short or none. Flowers white, $\frac{3}{4}$ in. across, fragrant, nearly always solitary on a slender stalk $\frac{3}{4}$ to $I$ in. long arising from the leaf-axils, the most conspicuous features being the crowded stamens $\frac{1}{3}$ in. long, produced in a brush-like cluster, and the five rounded petals; calyx green, with five erect, short, broadly ovate lobes. Fruit a purplish black berry, roundish oblong, $\frac{1}{2}$ in. in length (white in variety LEUCOCARPA, De Candolle).

The common myrtle is now very abundant in S. and E. Europe and the Mediterranean region generally, but is believed to have been introduced there from W. Asia, probably Persia or Afghanistan. It was probably one of the first shrubs introduced to our islands from the Levant, and was well known in the sixteenth century. One of the favourite plants of the ancients, and held sacred by them to the goddess of Love, a sprig of myrtle still carries its ancient significance in being indispensable in the composition of wedding bouquets. It is not hardy except in the mildest parts of the country, but thrives well upon a south wall.

Of the several varieties of myrtle, which vary in the colour of the fruit (sometimes yellowish white) and in the form of the leaves, the following only need be mentioned here. Most of them pertain rather to the cold greenhouse than the open air.

Var. TARENTINA, Linnaus. Tarentum Myrtle.-Leaves small, narrowly oval; $\frac{1}{2}$ to $\frac{3}{4} \mathrm{in}$. long, $\frac{1}{8}$ to $\frac{1}{4}$ in. wide, often alternate ; young shoots, leaf-stalks, and base of midrib very downy. This appears to be rather hardier than the bigger-leaved type, but still needs wall protection. It bore its whitish fruits at Kew, and with Canon Ellacombe at Bitton, in I9II. An open well-drained loam suits the myrtles, and cuttings readily take root in gentle heat. 
M. Luma, Molina (Eugenia apiculata, De Candolle; E. Luma, Berg., Bot. Mag., t. 5040).-In Ireland this handsome evergreen succeeds remarkably well. At Kilmacurragh, Co. Wicklow, there is a bush $20 \mathrm{ft}$. high and $25 \mathrm{ft}$. in diameter, but it can only be grown against a wall in the average climate of this country. At Kew, it has more than once been killed, even with that protection. Branchlets clothed with a fine reddish down. Leaves $\frac{1}{2}$ to $I$ in. long, rather more than half as wide, oval, usually tapered at the base, and terminated by a short, abrupt point; dark dullish green, paler beneath, with a well-defined marginal vein. Flowers white, about $\frac{5}{8}$ in. diameter. Fruit black, sweet, insipid. Introduced by W. Lobb from Chile. It differs from M. Ugni in having four petals; roundish, not reflexed sepals; and more conspicuous stamens.

M. UGNI, Molina. Myrtilla.-A Chilean evergreen, with leathery ovate leaves very like those of the myrtle, but with smaller flowers, shorter inclosed stamens, and reflexed, awl-shaped sepals. Petals five. It is sometimes grown on walls, and is only about as hardy as the myrtle itself. It bears a blueblack, juicy, and very palatable fruit. (See Bot. Mag., t. 4626.) Syns. Eugenia Ugni, Hooker; Ugni Molinæ, Turczaninow.

\section{NANDINA DOMESTICA, Thunberg. BERBERIDACE在.}

(Bot. Mag., t. I Iog.)

An evergreen shrub, with erect, unarmed, and unbranched stems, 6 to $8 \mathrm{ft}$. high in this country, even taller in warmer ones, the lower part covered with the bases of fallen leaves. Leaves I to $I \frac{1}{2} \mathrm{ft}$. long, much divided (doubly or trebly pinnate), composed of numerous, linearlanceolate leaflets, which are $\mathrm{I}_{\frac{1}{2}}$ to 4 ins. long, long-pointed, quite smooth, tinged with red when young, becoming purplish in autumn. Flowers in an erect panicle, 8 to $I_{5}$ ins. long borne at the top of the stem, each flower $\frac{1}{4}$ in. across, white, with large yellow anthers. Berries twoseeded, globular, $\frac{1}{3}$ in. in diameter, bright red normally, but in some forms more purplish red; the stigma persisting, as in barberry fruits.

Introduced in 1804 from Japan, where it is much cultivated, but really a native of China. Its chief merit in this country is its elegant bamboo-like form, for its flowers are not very showy, nor are its fruits freely produced. It has lived outside at Kew for many years in a sheltered spot, but has never really succeeded. It requires the greater warmth of the south-western counties, where, given a good moist soil and shelter from wind, it thrives admirably. It is best propagated from seeds, which, however, do not, as introduced, germinate freely. Cuttings put in a mild heat will root in time, but they too are. slow. The young plants should be grown under glass for a year or two. Most of the plants in cultivation have been introduced direct from the nurseries of Japan.

\section{NEILLIA. ROSACE .}

A genus represented on both sides of $\mathrm{N}$. America, in the Himalaya, Burmah, Manchuria, and China. It is allied to Spiræa (under which generic name some of the following species were at one time known), but differs in the shining, very albuminous seeds. It is itself now frequently 
divided into two genera, viz., Neillia proper and Physocarpus. The former-represented in gardens by $\mathrm{N}$. sinensis and $\mathrm{N}$. thyrsiflora, and confined in a wild state to Asia-are distinguished by a racemose inflorescence and a solitary, podlike, many-seeded fruit. The Physocarpus section, represented in most gardens by $\mathrm{N}$. opulifolia and its golden-leaved variety, has a corymbose inflorescence, and the fruit is composed of two to five pods. Leaves alternate, lobed, and toothed. Flowers white or pale rose. Sepals and petals five.

In gardens this genus (named in honour of Dr Patrick Neill, a prominent member of the botanical circle in Edinburgh at the beginning of the nineteenth century), is chiefly known by $\mathrm{N}$. opulifolia. All the species are of easy culture, loving a moist loamy soil ; they are propagated by cuttings of half-ripened wood.

\section{N. AMURENSIS, Bentham and Hooker fil. MANCHURIAN NINE BARK.}

(Physocarpus amurensis, Maximowicz.)

A deciduous shrub, 6 to $8 \mathrm{ft}$. high, the larger branches covered with a loose peeling bark. Leaves three- or five-lobed, up to 4 ins. long by 3 ins. wide; more or less downy beneath, the lobes pointed, margins double-toothed. Flowers white, $\frac{1}{3}$ in. across, produced each on a slender downy stalk in corymbs $1 \frac{1}{2}$ to 2 ins. across, terminating short twigs. Calyx with five thickly downy, triangular lobes. Stamens about forty, purple ; petals downy on the outside. Fruit downy.

Native of Manchuria ; much resembling N. opulifolia. The leaves appear generally to be larger, more downy beneath and more distinctly five-lobed; the downy pods too are distinctive, and much shorter in proportion to the calyx.

\section{N. Capitata, Greene. Western Nine BARK.}

(Spiræa opulifolia var. mollis, Torrey; S. capitata, Pursh.)

A deciduous shrub, 6 to $10 \mathrm{ft}$. high (in a wild state over $20 \mathrm{ft}$.). Leaves three-lobed, broadly ovate, 2 to 4 ins. long, doubly toothed, downy beneath. Flowers white, produced in a coryinb, each flower on a downy stalk about $\frac{1}{2}$ in. long; calyx very downy. Fruit smooth or nearly so, composed of three to five inflated pods $\frac{1}{3}$ in. long, containing usually two obliquely pear-shaped seeds.

Native of Western N. America frorn British Columbia to California, where it is said to have stems often more than $20 \mathrm{ft}$. long interlaced with willow branches, and forming impenetrable thickets on the banks of streams (Greene). It is really a western form of $\mathrm{N}$. opulifolia, from which it differs chiefly in the more downy leaves and in the pear-shaped seeds. Introduced in 1827 .

\section{N. MALVACEA, Greene.}

(Bot. Mag., t. $775^{8}$ (as N. Torreyi).)

A deciduous shrub, 3 to $5 \mathrm{ft}$. high, with erect stems. Leaves three-lobed, sometimes obscurely five-lobed on the non-flowering shoots; from $1 \frac{1}{2}$ to 3 ins. wide, scarcely so long ; usually roundish or broadly oval in general outline ; variable in the amount of down on the lower surface. Flowers $\frac{1}{3}$ in. wide, white, produced in corymbs $1 \frac{1}{2}$ ins. wide; calyx downy. Fruit composed of two or three pods, each one- or two-sseded. 
Native of Western N. America, reaching from Oregon and Idaho through Utah and Nevada to W. Texas. It is allied to N. Torreyi, which has a more eastern distribution, differing chiefly in the more robust habit, larger leaves, and sometimes more numerous carpels. Introduced to Kew in I897. The pods are described as indehiscent.

\section{N. OPUlifolia, Bentham and Hooker fil. NINE BARK.}

(Physocarpus opulifolius, Maximowicz; Spiræa opulifolia, Linnoeus.)

A deciduous shrub, 6 to $10 \mathrm{ft}$. high, occasionally much more in diameter; bark smooth, peeling. Leaves usually broadly ovate and three-lobed, sometimes only very slightly lobed or not at all; doubly toothed, $\mathrm{I} \frac{1}{2}$ to 3 ins. long and from half to fully as wide, smooth; stalk $\frac{1}{4}$ to $\frac{3}{4}$ in. long. Flowers in a hemispherical corymbose cluster, produced in June at the end of leafy twigs from the previous year's branches. Each flower is white tinged with rose, $\frac{1}{4}$ to $\frac{1}{3}$ in. across, and borne on a slender downy or glabrous stalk. Stamens about thirty, purplish. Fruit consisting of three to five pods $\frac{1}{4} \mathrm{in}$. long, which are inflated, smooth or nearly so, and usually carry two egg-shaped seeds.

Native of Eastern N. America ; introduced, according to Aiton, in 1687, and a common shrub in gardens. The largest I have seen is in Sir A. Smeaton-Hepburn's garden at Smeaton, N.B., which was $30 \mathrm{ft}$. across and Io ft. high when I measured it a few years ago. The shrub is a handsome one in blossom, and useful for rough shrubberies where plants are left largely to take care of themselves.

Var. LUTEA.-Leaves of a beautiful golden yellow when young, but soon becoming green and almost of the same shade as the type. Once popular, this, like others of its class of golden-leaved shrubs, is being superseded by varieties which retain their colour until autumn.

\section{N. SINENSIS, Oliver.}

(Hooker's Icones Plantarum, t. I540.)

A deciduous shrub, 5 or $6 \mathrm{ft}$. high, with smooth, brown, peeling bark. Leaves ovate, 2 to 4 ins. long, $1 \frac{1}{4}$ to $2 \frac{1}{2}$ ins. wide; the apex long drawn out, the margins set with coarse teeth or small lobes which are again sharply toothed; there is down on the main veins and in their axils at first, but both surfaces become almost or quite smooth. Flowers nodding, produced in a slender, terminal raceme I to $2 \frac{1}{2}$ ins. long, carrying twelve to twenty flowers. The remarkable feature of the flower is the smooth cylindrical white calyx, $\frac{1}{2}$ in. long and $\frac{1}{8}$ in. wide, dividing at the end into five narrow triangular lobes. Petals small, broadly ovate, about as long as the calyx-lobes. Fruit manyseeded.

Native of Central China ; discovered by Henry, and introduced to cultivation by Wilson in Igor. It has flowered and borne fruit in the Coombe Wood nursery, and is a shrub of elegant habit, but $\mathrm{Mr}$ Wilson tells me it has not yet shown its full beauty under cultivation. It is very distinct in its racemose inflorescence from all cultivated Neillias, except the Himalayan N. thyrsiflora, and it is hardier and altogether better than that species, which has a shorter, bell-shaped hairy calyx.

\section{N. Thy RSiflora, D. Don.}

A low deciduous bush, of neat, rounded habit, about $3 \mathrm{ft}$. high; young bark sometimes reddish. Leaves $\mathrm{I} \frac{1}{2}$ to 3 ins. long, two-thirds as wide; threelobed (most markedly so on the barren shoots), ovate with a long, narrow 
point; sharply, often doubly toothed; the base mostly heart-shaped; dark green and smooth above, the bright green under-surface downy on the chief veins; stalk $\frac{1}{4}$ to $\frac{1}{2}$ in. long. Flowers in a downy raceme, terminating the shoot, or springing from the axils of the uppermost leaves. Each flower is about $\frac{1}{3}$ in. long; the calyx bell-shaped, five-lobed, silky hairy, the lobes lance-shaped and pointed; petals roundish ovate, white. Fruit consisting of one pod enclosed by the persistent calyx, and containing four to eight seeds.

Native of Sikkim and the Khasia Hills, where it is common. It suffers during hard winters, and is said to prefer a semi-shaded as well as a sheltered position. Allied to N. sinensis (q.v.).

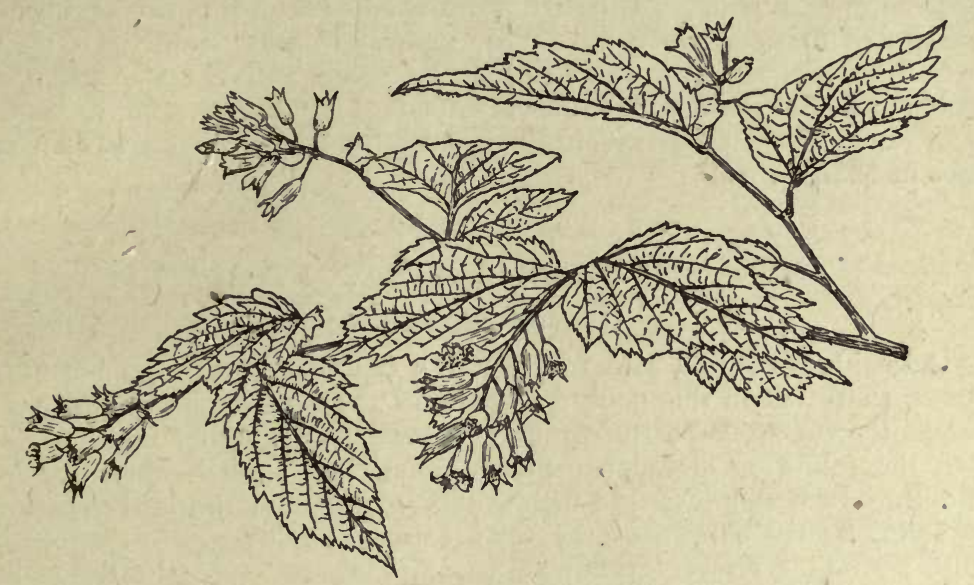

Neillia sineensis.

N. TORREYi, S. Watson.

(Garden and Forest, I889, fig. 84; Physocarpus Torreyi, Maximozvicz.)

A dwarf deciduous bush, about $2 \mathrm{ft}$. high in a wild state, with erect, muchbranched stems. Leaves $\frac{3}{4}$ to $1 \frac{1}{2}$ ins. long, roundish ovate, three-lobed; the lobes irregularly and doubly toothed, sometimes very downy beneath, sometimes only slightly so. Flowers $\frac{1}{4}$ in. diameter, of a clear or slightly rosetinted white, produced in early June in few-flowered corymbs $\frac{3}{4}$ to $I_{\frac{1}{4}}$ ins. across. . Fruit downy, usually composed of two pods cohering for more than half their length, but sometimes only one ; each contains one obovoid seed.

Native of the Rocky Mountains of Colorado up to elevations of $9000 \mathrm{ft}$. It is a pretty little shrub with small leaves often lobed and toothed, like a Ribes. Its dwarf habit, small leaves, and few downy seed-vessels well distinguish it in the Physocarpus group.

\section{NEMOPANTHUS CAnadensis, De Candolle. Mountain HOLLY. AQUIFOLIACE}

A deciduous shrub, 3 to $10 \mathrm{ft}$. high, with smooth young wood. Leaves alternate, oval, oblong or ovate, thin, not (or very slightly) toothed, tapered more abruptly towards the base than the apex, quite smooth; I to $2 \frac{1}{2}$ ins. long, $\frac{1}{2}$ to $I \frac{1}{8}$ ins. wide; stalk $\frac{1}{4}$ to $\frac{1}{2}$ in. long. Flowers often 
unisexual, small, of no beauty; produced from the leaf-axils usually singly, occasionally a few together on a thread-like stalk $\frac{1}{2}$ to $\mathrm{I}$ in. long. Fruit a globose berry, $\frac{1}{4}$ to $\frac{1}{3}$ in. wide, pale crimson, containing four or five hard bony seeds (nutlets).

Native of Eastern N. America; introduced in 1802 . It is similar in aspect and nearly related to the deciduous (or Prinos) group of hollies, from which it differs botanically in having strap-shaped petals free from the stamens (they are attached together in the hollies). Whilst some plants have flowers of both sexes as well as perfect flowers, others have those of one sex only. Although introduced so long ago, this shrub never appears to have obtained much recognition in this country. Unless it bears its fruits freely it is of no garden value, and our summer sun is probably not hot enough to develop its best qualities in that respect. I have never seen it bearing fruit anything like so freely in Britain as it does in N. America.

\section{NES EA SALICIFOLIA, Kunth. LYTHRACEA.}

(Heimia salicifolia, Link.)

A deciduous shrub, said to grow to a height of 5 or $6 \mathrm{ft}$., but usually shorter than that in this country, where, in the open ground, its stems are frequently cut back to the ground in winter, springing up 2 to $4 \mathrm{ft}$. high the following summer. Stems erect, leafy, much-branched, quite smooth. Leaves linear and willow-like, opposite on the lower portion of the stem, alternate towards the top; I to 2 ins. long, $\frac{1}{8}$ to $\frac{1}{4} \mathrm{in}$. wide; quite smooth. Flowers yellow, $\frac{1}{3}$ to $\frac{1}{2}$ in. across, very shortly stalked, produced singly in the leaf-axils of the current year's growth from July to September.

Native of N. and S. America, reaching from Mexico to Buenos Ayres, in many places a weed; introduced in $182 \mathrm{I}$. It will live in the open ground at Kew, and flowers there, but its stems do not become more than half woody, and do not survive the winter.

Var. GRANDIFLORA, Lindley (Bot. Reg., vol. 27, t. 60), is the Buenos Ayres variety. The flowers are $I$ to $I \frac{1}{2}$ ins. across, and the leaves often $\frac{1}{2}$ in. wide. It is a much finer plant than the type and decidedly prettier in flower, but is not so hardy. It is said to be common on the pasture-lands about Buenos Ayres. Introduced in 1839 . Both can be propagated by cuttings in late summer.

\section{NEVIUSia alabamensis, $A$. Gray. Rosace .}

(Bot. Mag., t. 6806.)

A deciduous shrub, 4 to $6 \mathrm{ft}$. high, with erect stems and spreading branches, making a rounded bush, wider than it is high; branchlets at first covered with fine down. Leaves ovate-oblong, I to $3 \frac{1}{2}$ ins. long, those of the barren shoots shallowly lobed, finely double-toothed; downy on the veins beneath; stalk up to $\frac{1}{3}$ in. long, downy. Flowers produced in a cluster at the end of short leafy side-shoots in April and May. Each flower is borne on a slender, downy stalk $\frac{3}{4}$ to $I$ in. long; it has no petals, 
but a conspicuous bunch of white stamens $\frac{1}{4}$ to $\frac{1}{3}$ in. long, and a calyx about $\frac{3}{4}$ in. across, with leaflike, toothed lobes.

Native of Alabama, where, apparently, it is only known in one or two spots: It was found on the cliffs of Black Warrior River, at Tuscaloosa, in 1858 , by the Rev. R. D. Nevius, after whom the genus was named by Asa Gray. It is quite hardy in England, and is easily increased by fairly soft cuttings placed in heat. Its beauty in some parts of $\mathrm{N}$. America is so great that it has been called the "Alabama Snow-wreath," owing to the snowy whiteness and profusion of its feathery blossom. But out-of-doors in England it is never really pure white, but of a dull greenish white. Forced early into blossom under glass, its colour is much purer, and it is then very elegant and beautiful. In March I907, about fifty years after its discovery, a letter was received at Kew from Mr Nevius, then at Tacoma, Washington, from which it appears that this shrub is not always a success in its native land. He says: "I have had it growing in many places in the open, but it does not do well. Even at Tuscaloosa, where I discovered it, a hedge I planted of it in the churchyard flowered but sparingly." Neviusia is related to Spiræa, Kerria, etc., from which, and other allied genera, its apetalous flowers distinguish it.

\section{NOTHOFAGUS. SOUTHERn Beeches. CUPUlifere.}

The northern beeches, of which Fagus sylvatica is the type, form a very homogeneous group of invariably deciduous trees with broad leaves; they are confined to the temperate latitudes of the northern hemisphere. The beeches found in S. America and Australasia are evergreen as well as deciduous, and have usually much smaller leaves. At first classed under Fagus, they are now commonly regarded as generically distinct, and are distinguished as Nothofagus. They have the characteristic three-cornered nuts of the beeches, but the male flowers, instead of being borne numerously in globose heads as in Fagus proper, are usually solitary, never in more than threes; the nuts too are frequently three in each husk (invariably two in Fagus). The differences in general aspect are, however, much more strikingly apparent than mere botanical details.

The southern beeches are only adapted for the milder parts of the country, especially the evergreen ones. The hardiest appear to be $\mathrm{N}$. antarctica and N. obliqua. They like abundant moisture, and all that have been tried can be increased by layering.

\section{A. EVERGREEN.}

I. Betuloides. Leaves round-toothed, dotted beneath.

2. Cunninghami. Leaves round-toothed, not dotted beneath.

3. Menziesii. Leaves doubly round-toothed, with one or two downy pits beneath.

4. Fusca. Leaves coarsely toothed; up to $I \frac{1}{2}$ ins. long.

5. Moorei. Leaves sharply toothed; up to 3 ins. long.

6. Cliffortioides. Leaves not toothed.

\section{$B$. Deciduous; leaves toothed.}

7. Antarctica. Leaves usually less than $I \frac{1}{4}$ ins. long; shoots very downy.

8. Oblryua. Leaves 2 to 3 ins. long; shoots smooth. 


\section{N. antarctica, Oerstedt. Antarctic Beech.}

(Bot. Mag., t. 8314 ; Fagus antarctica, Forster.)

A deciduous tree of large size; young shoots very downy. Leaves $\frac{1}{2}$ to I $\frac{1}{4}$ ins. long, often nearly as much wide; broadly ovate, or somewhat triangular, heart-shaped or truncate at the base, rounded at the apex, sometimes slightly lobed, always irregularly and minutely toothed, the teeth often rounded; smooth on both sides except for a minute down on the midrib beneath; stalk downy, $\frac{1}{12}$ to $\frac{1}{6}$ in. long. Flowers produced during May, the

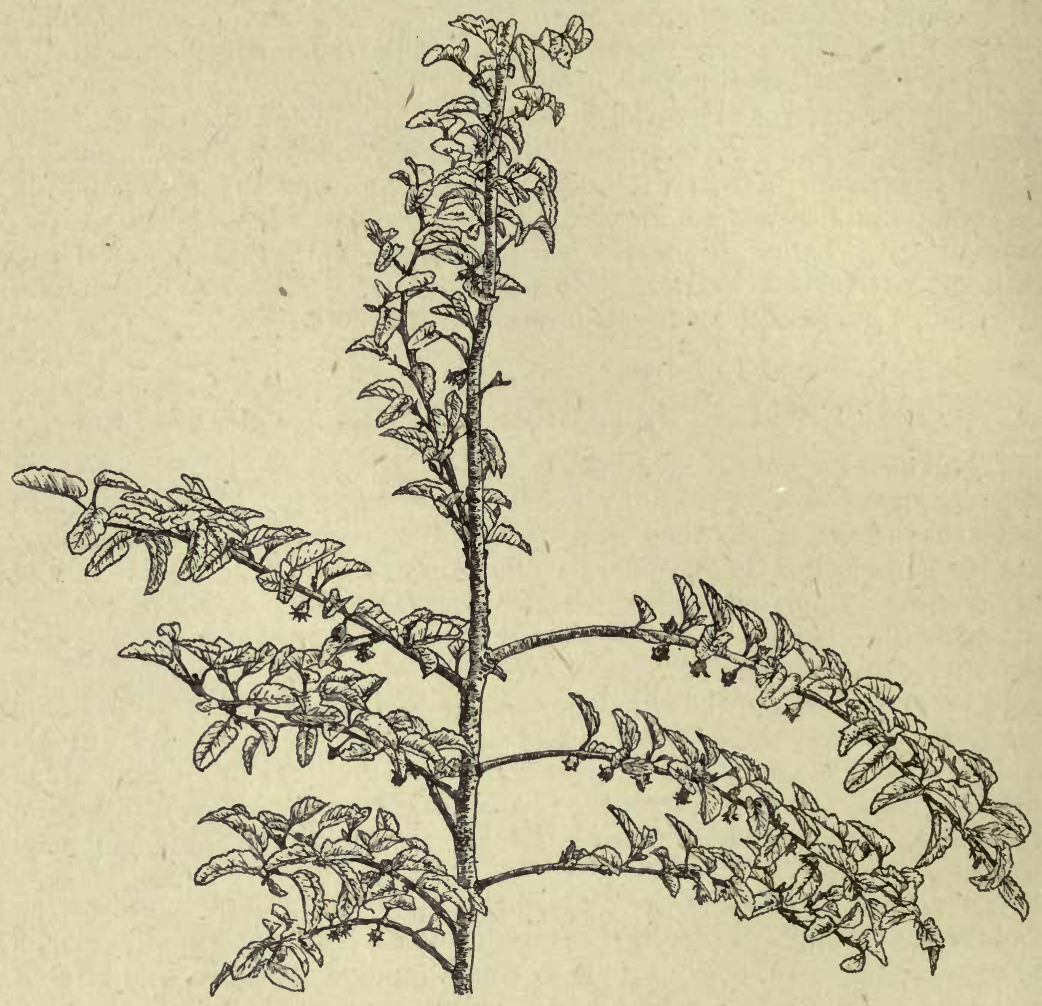

Nothofagus ANTARCTICA.

males singly, in pairs, or in threes in the basal leaf-axils of small twigs, pendulous, each about $\frac{1}{6}$ in. across; calyx broadly funnel-shaped, five-lobed. Husk of fruit four-lobed, enclosing three nuts.

Native of S. America from Tierra del Fuego northwards to Chillan; first introduced, according to Loudon, in 1830 . Seeds were again sent home by Sir Joseph Hooker to Kew about 1843 , and it has, no doubt, been introduced several times subsequently. All the trees at present in cultivation, with the exception of one at Hafodunos in Denbighshire, were introduced by means of seeds collected by $\mathrm{Mr} \mathrm{H}$. J. Elwes, in 1902. These plants have hitherto succeeded very well at Kew and other places, but seeing that almost all those 
introduced during the previous seventy years have disappeared, it would be rash to conclude that the species is going to survive permanently. In the south-western counties and similarly situated places it will almost certainly be hardy, but elsewhere I am afraid there are potentialities in the English climate that may be fatal to it.

Few trees have greater elegance and distinction than this when it is young. It makes unbranched shoots as much as $3 \mathrm{ft}$. long in a season, furnished over the whole length with small crumpled leaves $\frac{1}{4}$ to $\frac{3}{4}$ in. apart. The habit is thin and open. Increased by layers.

\section{N. BETUloIDES, Blume.}

\section{(Fagus betuloides, Mirbel.)}

An evergreen tree of large size, and dense, very leafy habit; young shoots sticky, minutely downy. Leaves set about $\frac{1}{4}$ in. apart on the twigs, ovate, wedge-shaped, or rounded at the base, pointed or blunt at the apex, minutely and regularly toothed ; $\frac{1}{2}$ to $I$ in. long, $\frac{1}{4}$ to $\frac{3}{4}$ in. wide, smooth ; upper surface dark varnished green; lower surface paler, finely net-veined, often sprinkled with minute dark glands; stalk $\frac{1}{8}$ in. long. Flowers (male) produced in May ; the calyx funnel-shaped, downy, many-lobed, $\frac{1}{4}$ in. long, enclosing numerous stamens. Husk of fruit four-lobed.

Native of S. America from Valdivia to Tierra del Fuego ; introduced in 1830, and again by Sir Joseph Hooker in 1843. It has since, no doubt, several times been introduced, and has obtained a firmer foothold in Great Britain than its close associate N. antarctica, although, judging by their relative habitats the latter ought to be the hardier, seeing that it occurs at higher elevations. There are several trees in the south and west of England from 30 to $50 \mathrm{ft}$. high. The best I have seen near to London is in Mrs Chambers' garden at Haslemere. For many years one grew in Mr A. Waterer's nursery at Knap Hill, Woking. Perhaps as fine a tree as any is one at Pencarrow, Cornwall; this flowers, but does not give good seed.

\section{N. Cliffortioides, Oerstedt. Mountarn BeECH.}

\section{- (Fagus cliffortioides, Hooker fil.)}

An evergreen tree, becoming $50 \mathrm{ft}$. high in New Zealand; young shoots brownish, thin and wiry, covered with down. Leaves oval, oblong or ovate; $\frac{1}{4}$ to $\frac{1}{2}$ in. long, $\frac{3}{16}$ to $\frac{1}{4}$ in. wide ; set alternately and very regularly along the branches, $\frac{1}{8}$ to $\frac{1}{4}$ in. apart, in two rows ; they are blunt or rounded at the apex, obliquely rounded or broadly wedge-shaped at the base ; not toothed, smooth on both surfaces, net-veined, with four or five pairs of distinct veins; stalk very downy, short. On adult trees the leaves are said to be downy beneath.

Native of New Zealand. The largest trees in the country are at Enys in Cornwall. A smaller one has long stood in Messrs Veitch's nursery at Coombe Wood. The tree is essentially one for the milder parts of the kingdom. From all the cultivated southern beeches, this is distinguished by its evergreen leaves being entire. It is sometimes offered as Fagus Solandri, a different but nearly allied species, also from New Zealand.

\section{N. Cunninghami, Oerstedt. Cunningham's Beech.}

(Fagus Cunninghami, Hooker fil.)

An evergreen tree of large size, young shoots wiry, covered with short dark down. Leaves ovate, approaching diamond-shape or often almost 
equilaterally triangular; $\frac{1}{4}$ to $\frac{5}{8}$ in. long, from half to quite as much wide; the base broadly wedge-shaped or truncate, and entire; the upper part more tapering, pointed and blunt toothed; both surfaces smooth; stalk downy, very short.

Native of Tasmania, where, according to the elevation at wlich it grows, it varies from a shrub to an enormous timber tree. There is a good specimen in the Royal Gardens at Osborne, Isle of Wight, which I saw abundantly in flower in September 1907. The husk, which encloses three nuts, is very curious; it is divided into four narrow lobes scarcely $\frac{1}{4}$ in. long, each bristled over with short decurved scales terminated by a globular gland-very much resembling the stigma of many flowers. Two of the nuts are three-sided, the third is two-sided. The tree is rare in cultivation, and is only suited for the milder counties. The best specimen is at Fota, near Cork (50 ft. high).

Bearing a close resemblance in general habit to $\mathrm{N}$. Cunninghami is a New Zealand species-N. Menzresir, Oerstedt (Fagus Menziesii, Hooker fil.). Its foliage and twigs are very much like those of Cunningham's beech, but the leaves are readily distinguished by having the margin doubly instead of singly round-toothed, and still more by one or two curious little pits situated beneath the leaf. These pits are placed in the axils of the second pair of veins from the base, and are lined with brownish down. The trunk of this tree is said to be silvery, like a birch.

\section{N. FUSCA, Oerstedt. \\ (Fagus fusca, Hooker fil.)}

An evergreen tree of the largest size, described as Ioo ft. high in nature ; young shoots minutely downy, and in cultivated specimens very zigzagged. Leaves broadly ovate to roundish, $\frac{3}{4}$ to $I \frac{1}{2}$ ins. long, smooth except on the coarsely toothed margins, which are ciliate, especially on the notches, wedgeshaped to truncate at the base ; leaf-stalk downy, about $\frac{1}{8}$ in. long; veins in usually three or four pairs. Husk of fruit nearly $\frac{1}{2}$ in. long, four-lobed, containing three nuts.

Native of New Zealand, where it yields a useful timber. The largest I have noted in the British Isles is at Castlewellan, Co. Down, which, when I saw it in February 1913, was from 20 to $25 \mathrm{ft}$. high. There is a healthy young tree in the Coombe Wood nursery, of bushy habit and about $12 \mathrm{ft}$. high, which seems to show that it is hardier than is generally supposed. The old leaves turn red before they fall.

\section{N. Moorei, Krasser. Australian BeEch.}

\section{(Fagus Moorei, Mueller.)}

Of the Nothofagus group of beeches, this has the largest leaves of any cultivated out-of-doors in this country. They are glossy dark green, ovatelanceolate or ovate; $I \frac{1}{2}$ to 3 ins. long, $\frac{3}{4}$ to $I \frac{1}{2}$ ins. wide; the base wedgeshaped, the apex taper-pointed; sharply toothed; stalk $\frac{1}{12}$ in. long. The whole leaf is smooth except the stalk and the upper surface of the midrib; the lateral veins are prominent, and in nine to fifteen pairs. Young twigs covered with brownish down; stipules very narrow, $\frac{1}{3}$ to $\frac{1}{2}$ in. long.

This is an evergreen tree described as becoming $\mathrm{I}_{50} \mathrm{ft}$. high, and was discovered in New South Wales by the late Charles Moore of Sydney. There is a tree over $20 \mathrm{ft}$. high growing in the grounds of Kilmacurragh, Co. Wicklow, but this beech is only likely to be hardy in the very mildest parts of the British Isles. Introduced to Kew in 1892 . 


\section{N. OBliqua, Blume: ROBLE BEeCH. \\ (Fagus obliqua, Mirbel.)}

A large deciduous tree, up to $100 \mathrm{ft}$. high in a wild state; young shoots smooth. Leaves arranged alternately in two opposite rows, ovate to oblong, mostly blunt at the apex, rounded or broadly wedge-shaped at the base, unequal sided; $1 \frac{1}{2}$ to 3 ins. long, $\frac{3}{4}$ to $1 \frac{1}{2}$ ins. wide ; irregularly set with small, triangular teeth, and with shallow round lobes also near the base; dark green above, pale and rather glaucous beneath, smooth; stalk $\frac{1}{8}$ in. long. Male flowers produced singly in the leaf-axils, consisting of a calyx and thirty to forty stamens. I'usk of fruit four-lobed, containing a pair of three-sided nuts and one flattened one.

Native of Chile, and according to Elwes the most northerly of the South American beeches. It was first introduced by Wm. Lobb for Messrs Veitch in 1849 , but like $\mathrm{N}$. antarctica seems to have died out. The largest trees at present in cultivation were introduced by $\mathrm{Mr}$ Elwes in 1902. At Kew and elsewhere they have grown with remarkable rapidity and have withstood, the frosts of the last ten years uninjured, but one cannot yet say with certainty that the species is hardy near London. As a young tree it is of elegant habit, making long, slender shoots annually. In Chile it is a valuable timber tree, known as "Roblé." It flowered at Kew and in several other gardens in the spring of 1912.

NOTOSPARTIUM CARMICHAELIE, Hooker fil. LEgumiNOSF. (Bot. Mag., t. 674I.)

An almost leafless shrub, 4 to ro $\mathrm{ft}$. high in its native state, with slender, rush-like, mostly arching or pendulous branches, which are slightly flattened and grooved. Leaves (only seen on young plants) simple, roundish or orbicular, often notched at the apex, $\frac{1}{4}$ in. long. Racemes downy, $\mathrm{I}$ to 2 ins. long, axillary, carrying from twelve to twenty flowers. Each flower is $\frac{1}{3}$ in. long, pea-shaped, purplish pink; calyx densely covered with silky down, five-toothed; teeth triangular; flowerstalk hairy, $\frac{1}{8}$ in. long. Pod $\frac{3}{4}$ to $\mathbf{I}$ in. in length, slender, three- to eightjointed, with one seed to each joint.

Native of New Zealand, in the South Island, where it is said to be rare and local. It is not absolutely hardy at Kew, a fine plant about $4 \mathrm{ft}$. high being killed by the trying winter of 1908-9. It had flowered beautifully for ten or twelve years previously, and ripened seed freely. Young plants are better with some protection during winter for the first few years of their existence, and may be grown in pots, for although not killed entirely the branches are so badly cut back that the progress of the plant is very slow. When once a firm woody base has been formed, they weather ordinary winters quite well. Seeds afford the best means of increase. The best soil is a light loam, and the position should be well drained and sunny. So lovely a plant deserves special care.

NUTTALLIA CERASIFORMIS, Torrey. OSO BERRY. ROSACEF.

A deciduous shrub, usually 6 to $8 \mathrm{ft}$. (occasionally more) high, with the habit of a black currant, the stems springing erect from the ground 
in great numbers, and forming ultimately a dense thicket several feet through; branchlets smooth, bright green. Leaves alternate, narrowoblong or lance-shaped; 2 to $3 \frac{1}{2}$ ins. long, $\frac{3}{4}$ to $1 \frac{1}{4}$ ins. wide; of thin texture, green and quite smooth above, greyish beneath; margin entire; narrowed at the base to a stalk $\frac{1}{4}$ in. or less long. Male and female flowers usually on different plants; both borne on stiff, pendent, copiously bracted racemes $I \frac{1}{2}$ to 2 ins. long. Each flower is about $\frac{1}{4}$ in. across, the five petals white; the calyx green, bell-shaped, five-lobed. Male flowers have fifteen stamens; females five carpels. Fruit plum-like, oval, $\frac{3}{4}$ in. long, purple when ripe, usually not more than two of the carpels of each flower developing.

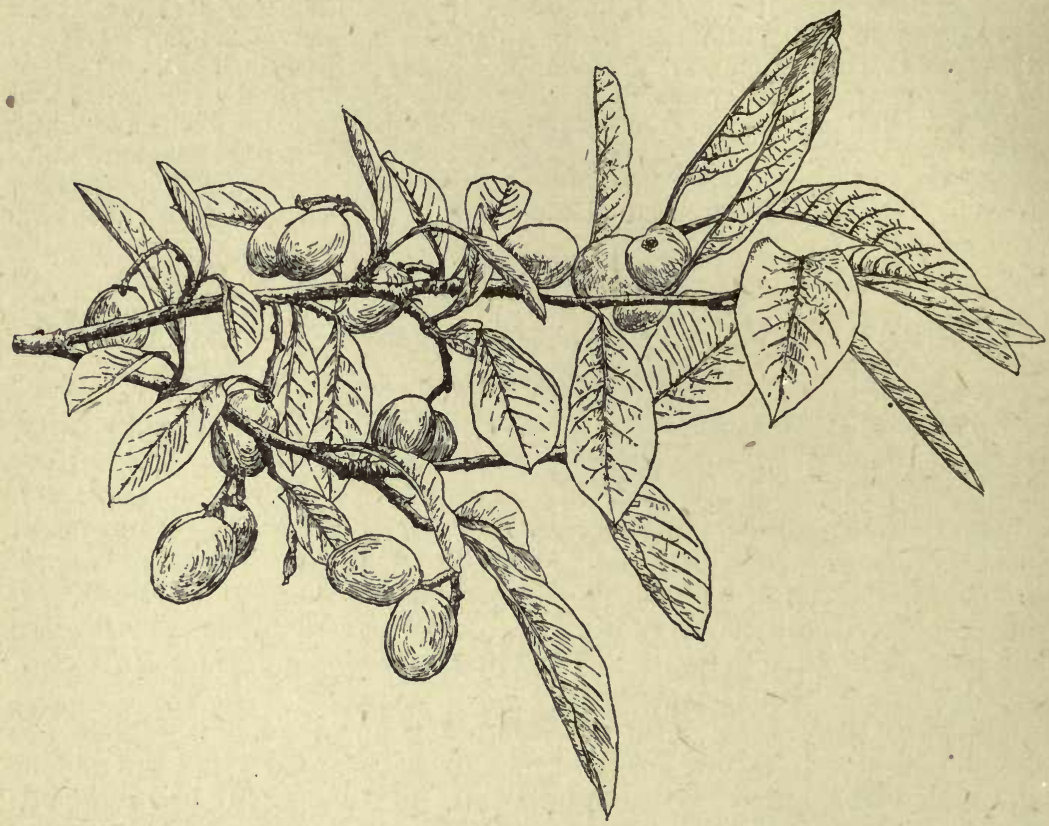

NutTallia CERASIFORMis (in fruit).

Native of California ; introduced in 1848 , and a close ally of Prunus, from which it differs in the five-carpelled female flower. In gardens the Oso berry is useful for its early, almond-scented blossoms, which are usually fully open by the third week in March, being. produced from the leafless shoots of the previous year." The female plant is of coarser habit than the male and not so pretty nor so free in blossom, but it is worth associating with the male for the sake of its abundant fruits. The species is very hardy and thrives in a well-drained, loamy soil. It is easily propagated by taking off small pieces from old plants, also by seeds. The fruits are very bitter and strongly almond-scented. A form with hermaphrodite or self-fertilising flowers has recently been introduced. 
The generic name was given in honour of Thomas Nuttall, a famous botanist (I 786-1 859).

\section{NYSSA. CORNACEA.}

Of the half-dozen or so species of Nyssa known, which are natives of N. America, Himalaya, and China, only one (N. sylvatica) has hitherto succeeded in the British Isles. A new species from China is promising, but is long likely to be toc scarce to count. They belong to the Cornel family, but except in the fruit, have little obvious relationship to the other hardy members of that order. They transplant badly and should be given a permanent place as early as possible, preferably in good moist loam.

Besides N. sinensis and N. sylvatica, which are described below, another American species is occasionally seen, viz., N. AQUATICA, the : "Tupelo gum." According to Henry there is a fair specimen of it at White Knights, near Reading. It is easily distinguished from N. sylvatica by the shape of its ovate-oblong, pointed leaves, often with a few distant coarse teeth, and by the under-surface of the leaves and the young twigs being downy. A third American species, N. OGeche, the "sour Tupelo tree," has been more than once introduced to Kew, but has never become established. It is probably tender.

\section{N. Sinensis, Oliver. Chinese Tupelo.}

\section{(Hooker's Icones Plantarum, t. 1964.)}

A deciduous tree, 20 to $40 \mathrm{ft}$. high, with downy young shoots. Leaves thin, narrowly oval, tapering at both ends; 4 to 6 ins. long, $1 \frac{1}{2}$ to 2 ins. wide; hairy at the margins and on the midrib, dull dark green above, pale and lustrous beneath; stalk $\frac{1}{4}$ in. long, hairy. Male flowers produced in a rounded head $\frac{1}{2}$ in. across at the end of a slender, downy stalk 1 to $\mathrm{I} \frac{1}{2}$ ins. long; females few on longer stalks, neither of any beauty. Fruit oblong, $\frac{1}{2}$ in. long, bluish.

Native of Central China, where it was originally discovered in 1888 by Henry, who describes it as a rare tree occurring in mountain woods. Seeds were sent to Messrs Veitch by Wilson in 1901-2, but only one plant was raised. This tree is now in the Coombe Wood nursery, where it is in the best of health and apparently quite hardy.

\section{N. Sylvatica, Marshall. Tupelo, Pepperidge. \\ (N. multiflora, Wangenheim.)}

A deciduous tree, occasionally $100 \mathrm{ft}$. high in a wild state, with a trunk $5 \mathrm{ft}$. in thickness. Leaves of variable shape, but oftenest obovate or oval, with a tapering base; 3 to 6 ins. long, $1 \frac{1}{2}$ to 3 ins. wide; entire, usually perfectly smooth in this country except on the young stalks and midrib, which are slightly hairy; stalk $\frac{1}{2}$ to $I$ in. long, frequently reddish. Flowers appearing in June, males and females on separate heads, $\frac{1}{2}$ in. or less across, greenish, produced on a slender downy stalk about $I$ in. long in the axils of the scales or lowermost leaves of the young shoots; male flowers numerous, female ones usually two to four in a head; they have no beauty. Fruit usually in pairs, each one $\frac{1}{3}$ to $\frac{2}{3}$ in. long, egg-shaped, bluish black. 
Native of Eastern N. America, chiefly found in swamps and ill-drained land; introduced sometime in the first half of the eighteenth century. It is quite scarce in cultivation, and few trees of any size exist in Britain. $\mathrm{Mr}$ Elwes gives the palm to one at Strathfieldsaye, which is probably about $80 \mathrm{ft}$. high and $6 \mathrm{ft}$. in girth. There is a curious diversity in the leaves, not only in shape, but in lustre. Of two small healthy trees at Kew growing within a few yards of each other, one has dull-surfaced leaves, the other has larger shining ones. The chief value of the tupelo in gardens, over and above its great interest, is the brilliant red and yellow of its autumnal foliage. Like many other American trees growing in wet situations at home, it thrives best in ordinary good loam when transplanted to our gloomier climate.

\section{OLEA EUROPAa, Linncus. Olive. Oleace}

An evergreen tree of rugged, much-branched habit and slow growth, generally 20 to $40 \mathrm{ft}$. high, with grey-green foliage. Leaves opposite, narrowly obovate or oval; $1 \frac{1}{2}$ to 3 ins. long, $\frac{1}{3}$ to $\frac{3}{4}$ in. wide; glaucous or silvery beneath, leathery. Flowers white, $\frac{1}{5}$ in. diameter, in axillary racemes I to 2 ins. long, the corolla with four ovate lobes; stamens two. Fruit an oval, oily drupe, $\frac{3}{4}$ in. long, containing a bony seed.

Native of Asia Minor and Syria, now largely cultivated all over the Mediterranean region. In many parts of Italy, as in the environs of Florence, its grey tints give the prevailing tone to the landscape. In Britain it can only be cultivated out-of-doors in the mildest parts. It has borne fruit in Lord Mount Edgcumbe's garden, near Plymouth, and probably other places in the south-west. At Kew it has lived for a good many years on a south wall, but in such a place is only worth growing for its interest and associations.

\section{OLEARIA. DAISY Bushes. COMPOSITE.}

Of this large group of evergreen shrubs and small trees, numbering over one hundred species, all of which belong in nature to the Australasian region, only one has yet been proved generally hardy. This is O. Haastii. 0 . myrsinoides is promising, and in the southern and western counties, in various parts of Ireland and the west of Scotland, some ten or twelve species are grown. They, are probably the most ornamental shrubs of the Composite order that are as hardy in the British Isles. They like a light loamy or peaty soil free from lime, and most of them can be increased by cuttings made of moderately ripened wood and placed in gentle heat.

Olearias are nearly allied to asters and have much the same type of flowers. The leaves are opposite or alternate, and more or less felted beneath. Besides the species described more fully below, there are :O. Forsteri, Hooker fil., over $20 \mathrm{ft}$. high in the Marquis of Lansdowne's garden at Derreen; O. INsignis, Hooker fil., a low shrub which thrives at Old Conna Hill, Belgrove, near Cork, and elsewhere in Ireland; O. nUMMULARIFolia, Hooker fil., with very numerous closely set, roundish, thick, stalkless leaves, $\frac{1}{4}$ to $\frac{1}{3}$ in. long; O. NiTiD.2, Hooker fil., 
with leaves silvery beneath, shining green above, bearing corymbs of white flowers 6 ins. across. The last two both succeed well in the open in Miss Willmott's garden at Warley Place, in Essex.

\section{O. HAAstiI, Hooker fil.}

(Bot. Mag., t. 6592.)

An evergreen shrub of bushy, rounded habit, 4 to $9 \mathrm{ft}$. high; young branches covered with a close, greyish white down. Leaves crowded on the branches, alternate, oval or ovate, $\frac{1}{2}$ to $I$ in. long, about half as wide; not toothed, rounded or blunt at the apex, thick and leathery, dark shining green and smooth above, white-felted beneath ; stalk about $\frac{1}{8}$ in. long. Flower-heads produced during July and August in a series of axillary corymbose clusters standing out beyond the leaves, the whole forming a flattish cluster 2 to 3 ins. across at the end of each twig. Ray florets white, disk florets yellow; each flower-head is $\frac{1}{3}$ in. across.

Native of N. Zealand, in the province of Canterbury, at $4000 \mathrm{ft}$. to $5000 \mathrm{ft}$. elevation; introduced in 1858 by Veitch of Exeter. This is the only Olearia at Kew of proved hardiness. I have never seen it killed outright by cold, although in February 1895 it was cut to the ground, but sprang up again freely a few months later. It flowers when there are few shrubs in blossom, and its abundant white flowers show up well against the dark green leaves; they have besides the charm of a sweet hawthorn-like fragrance. The flower-heads in the seeding state are covered with brown-grey down, which some people object to and cut off, as it persists through the winter. This shrub is admirable for maritime districts. In Sir Herbert Maxwell's garden at Monreith some years ago I saw a specimen $9 \mathrm{ft}$. high and $15 \mathrm{ft}$. in diameter. I believe it thrives extremely well in the Orkneys. Pruning, which it bears well, should be done in early spring. It should consist merely of a shortening back of plants that have become lanky or too large for their place.

\section{O. MACRODONTA, Baker.}

\section{(Bot. Mag., t. 7065.)}

An evergreen shrub up to $20 \mathrm{ft}$. high, or even a small tree in a wild state, with bark peeling in long strips; young shoots angled, downy. Leaves alternate, firm and leathery, ovate to narrowly oval, rounded or tapering at the base, pointed at the apex; 2 to 5 ins. long, 1 to 2 ins. wide; the margins wavy and furnished with coarse sharp teeth, the hollows between them rounded; upper surface dark glossy green, downy only when quite young, lower surface covered with a close, silvery white felt ; leaf-stalk $\frac{1}{2}$ to $\frac{3}{4}$ in. long. Flower-heads produced in one or more branched clusters 3 to 6 ins. across, at the termination of the previous season's growth, each cluster on a silvery white, downy stalk 3 to 6 ins. long. The flower-head is $\frac{1}{2}$ in. across, with ten or more white ray florets and a few reddish disk florets.

Native of New Zealand up to elevations of $4000 \mathrm{ft}$., and only hardy in the mild parts of the kingdom. It succeeds in Ireland, Cornwall, and on the west coast of Scotland up to Ross-shire, where in July I have seen bushes $15 \mathrm{ft}$. through, almost hidden by their own white blossom. At Kew it has to be grown on a wall, where it flowers in June. The plant has a musky odour when crushed./ This species is often grown as O. dentata, but the true shrub of that name has its leaves clothed with a thick red-brown felt beneath, and is very uncommon. leaves.

Var. MINOR (syı. nana).-A very dwarf, compact form with much smaller 


\section{O. MYRSINOIDES, Mueller.}

(Gardeners' Chronicle, I909, i., fig. 92.)

An evergreen shrub, 3 or $4 \mathrm{ft}$. high, its rigid branches covered with pale brownish down. Leaves alternate, scarcely stalked, hard, stiff and leathery, narrowly oval; $\frac{1}{2}$ to $1 \frac{1}{2}$ ins. long, $\frac{1}{4}$ to $\frac{1}{2}$ in. wide ; dark glossy green and smooth above, covered beneath with a pale, tawny felt; margins wavy and toothed. Flower-heads I in. across, produced in May and June singly on slender downy stalks I to 2 ins. long; they come from the leaf-axils on short branches which spring from the growths of the previous year, the whole forming an elegant, densely flowered, cylindrical panicle sometimes 12 to 18 ins. long. Ray florets about five, strap-shaped, pure white; disk florets yellow.

Native of Tasmania ; cultivated at Kew more than sixty years ago, but still not common. It thrives very well on a south wall, and healthy plants flower with remarkable profusion. In mild districts it will succeed in the open ground.

\section{O. ODORATA, Petrie.}

A shrub of thin, sparse habit, with slender, wiry, terete, little-branched stems ; leaves opposite, linear or spathulate, $\frac{3}{4}$ to $1 \frac{1}{2}$ ins. long, $\frac{1}{8}$ to $\frac{1}{4}$ in. wide near the rounded apex; bright green and smooth above, silvery beneath with appressed, glistening, white hairs; tapering at the base to a short stalk. Flower-heads $\frac{1}{4}$ in. across, borne on short, arrested, bud-like branches, which usually also carry a pair of leaves; they are scented and dull greyish brown; the bracts of the involucre brown, and viscous-glandular.

Native of New Zealand, where it is very common in the lake district of Otago. It is a curious, not particularly ornamental, shrub introduced a few years ago, and put in commerce as "O. virgata." The true virgata has fourangled instead of cylindrical stems.

\section{O. Gunniana, Hooker fil.}

(Bot. Mag., t. 4638 ; O. stellulata, Bentham (in part).

An evergreen shrub, 5 to Io $\mathrm{ft}$. high, naturally much branched; young shoots covered with a close white felt. Leaves alternate, oblong or narrowly obovate, $\frac{1}{2}$ to $I \frac{1}{2}$ ins. long, about one-fourth as wide, roundish at the apex, tapering towards the base, the margins sinuously or very shallowly toothed, dark dull green above, white, and closely felted beneath; very shortly stalked. Flowerheads pure white with a yellow disk, I to $I_{4}^{\frac{1}{4}}$ ins. across, produced during summer in erect, loose, slender-stalked corymbs. Ray florets ten to sixteen.

Native of Tasmania ; introduced to Kew about I848. It is the least hardy of the Olearias here described, and can only be grown out-of-doors permanently in the mildest districts. It is a handsome plant when grown outside in pots during the summer, and housed through the winter. Grown in this way it comes into flower in March and April. This species was by Bentham united with O. STEllulata, De Candolle. The true plant of that name is very distinct and has leaves up to 4 ins. long. Probably not in cultivation.

\section{ONONIS. LEGUMINOSÆ.}

Of this genus - to which belongs the common "rest-harrow" (O. arvensis) of our waysides and fields-only two or three species can be 
included amongst hardy shrubs, the majority being herbaceous or only slightly woody. They are natives of S. Europe. The leading characteristics of the genus are the alternate, trifoliolate, toothed leaves, the five long, narrow divisions of the calyx, the pea-shaped flowers, the stamens united in one bundle, and the slightly swollen seed-pods. The under-mentioned are useful in flowering later in the season than the

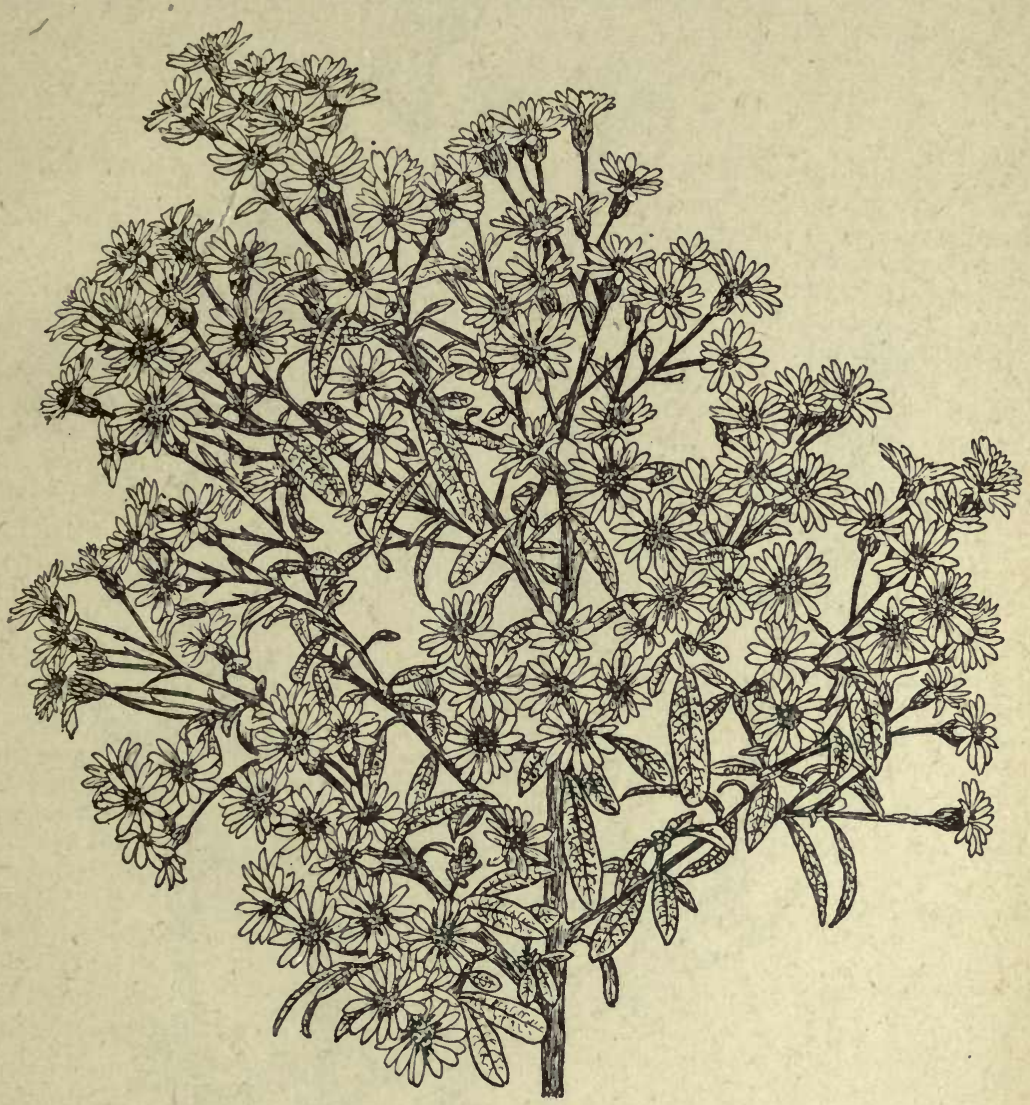

Olearia Gunniana.

bulk of hardy shrubs, and are easily cultivated in moderately good soil in a sunny spot. Propagated by seeds, or, failing them, cuttings. Besides the three here described, O. Natrix, Linnaus (Bot. Mag., t. 329), is sometimes included in lists of shrubs. It is a rather showy plant with yellow flowers, the standard petal $\mathbf{I}$ in. across, but it is only partially woody and not long-lived. A native of S. Europe and popularly called "Goat-root." 


\section{O. aragonensis, Asso.}

A deciduous bushy shrub, $\mathrm{I} \frac{1}{2}$ to $2 \mathrm{ft}$. high, of sturdy habit, with crooked branches and pale greyish young' shoots. Leaves from $\frac{1}{2}$ in. long on the flowering twigs, to $\mathrm{I} \frac{1}{2}$ ins. long on the stronger flowerless shoots of the year; leaflets three,

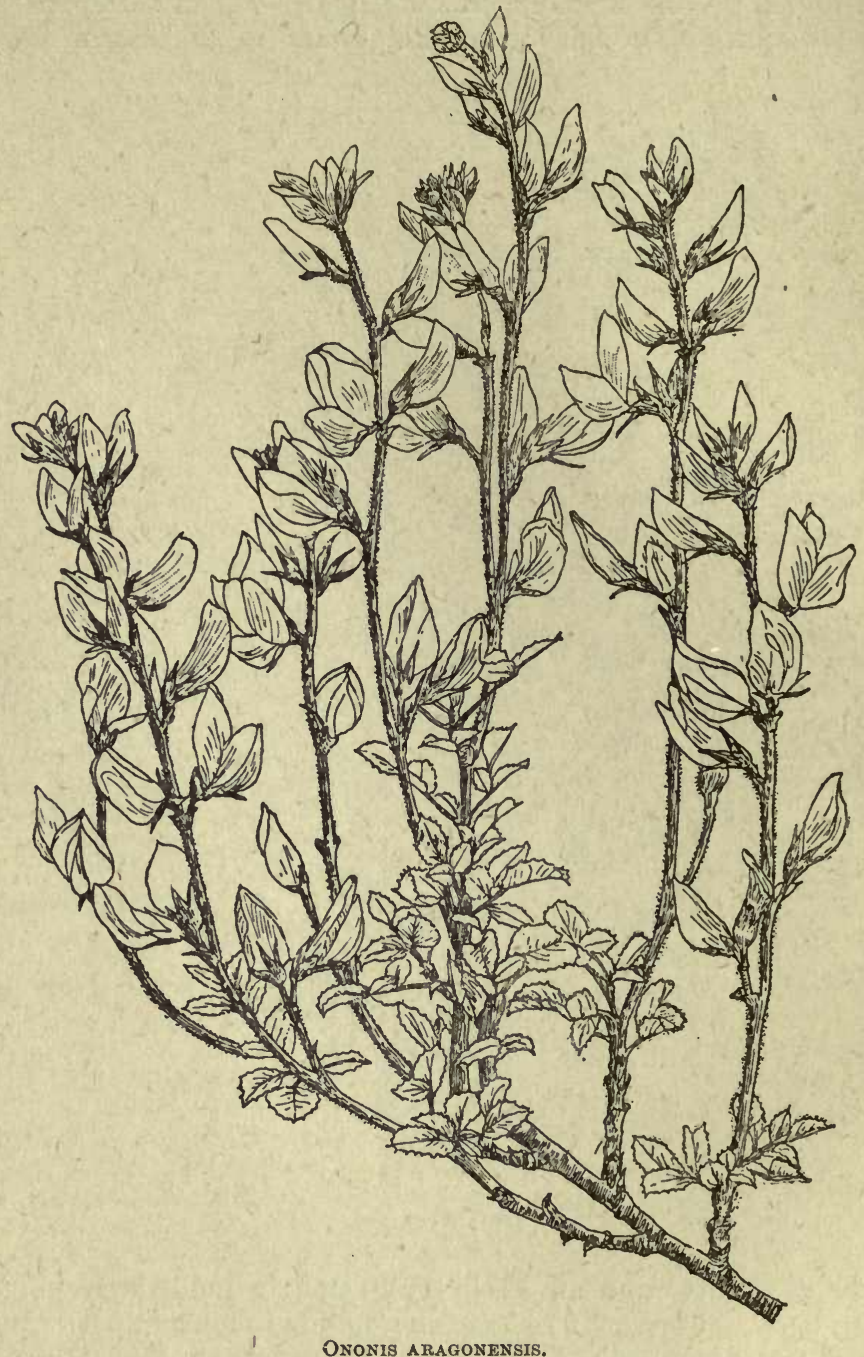

glossy green, roundish, irregularly toothed, smooth, from $\frac{1}{8}$ to $\frac{5}{8} \mathrm{in}$. wide, the middle one stalked and larger, the side ones stalkless, or nearly so. Flowers yellow, $\frac{1}{2}$ in. long, produced often in pairs along a crooked, hairy, terminal raceme, 3 to 6 ins. high. The standard petal is $\frac{1}{3}$ in. across, and the calyx 
consists of five-pointed, awl-shaped lobes covered with glandular hairs. Pod glandular-hairy, with the calyx persisting at the base.

Native of the Pyrenees southward into Spain; introduced in 1816. This is a pretty dwarf shrub, flowering from mid-May onwards. It bears its erect racemes very freely, the larger ones carrying ten or twelve pairs of blossoms. It does not ripen seed freely here, but can be increased by cuttings of halfripened wood. It must have a sunny position, and the soil should be light loam. Suitable for the rock garden. It is perfectly hardy.

\section{O. FRUTICOSA, Linncus.}

(Bot. Mag., t. 317.)

A deciduous shrub of spreading habit, 2 or $3 \mathrm{ft}$. high, with pale, crooked branchlets. Leayes trifoliolate, short-stalked, clasping the stem by the stipule at the base; the stipule is terminated by four slender teeth-two long and two short; leaflets narrowly obovate, $\frac{1}{2}$ to I in. long, $\frac{1}{8}$ to $\frac{1}{4}$ in. wide ; not downy, but wrinkled, unevenly toothed, all stalkless. Flowers $\frac{3}{4}$ in. long, pale pinkish purple, borne (usually three on a stalk) on a short terminal panicle 2 to 3 ins. long. Pod $\frac{3}{4}$ to $I$ in. long, stout, covered with bristly hairs, and containing two to five seeds.

Native of S. Europe, especially in the Dauphiné Alps; known in our gardens since 1680 . It flowers from June to August, and should only be propagated by seeds, which it ripens in plenty. Well distinguished from the other two by the shape of the leaflets, and by all three of them being stalkless.

\section{O. ROTUNDIFOLIA, Linnaus.}

(Bot. Mag., t. 335.)

A deciduous, half-shrubby species, $I \frac{1}{2}$ to $2 \mathrm{ft}$. high, with very glandularbairy, zigzag stems ; the leaf-stalk, flower-stalk, and calyx are also glandularhairy. Leaves trifoliolate, I to 3 ins. long; leaflets roundish, sometimes obovate, the terminal one the largest, stalked, and $\frac{1}{4}$ to $1 \frac{1}{4}$ ins. long; side ones half to two-thirds as large, stalkless; all are toothed and hairy, especially below and on the margins. Flowers $\frac{3}{4}$ in. long, pink, produced from the axils of the leaves, three together towards the end of a stalk $\frac{1}{2}$ to $2 \frac{1}{2}$ ins. long. Pod very hairy, I to $1 \frac{1}{4}$ ins. long.

Native of S. and Central Europe; cultivated for more than three hundred years in England. Increased by seeds.

\section{ORIXA JAPONICA, Thunberg. RUTACEE.}

(Evodia ramiflora, A. Gray; Celastrus japonica, Koch.)

A deciduous shrub of graceful, spreading habit, with long slender branches, and 6 to $8 \mathrm{ft}$. high. Leaves aromatically scented, obovate or oblanceolate; 2 to 5 ins. long, $\mathbf{I}$ to 2 ins. wide; dark green, quite entire, and smooth except on the nerves of the young leaves. Flowers unisexual; the parts in fours; males in short racemes produced from the joints of the previous year's wood, green, scarcely $\frac{1}{4}$ in. across, with downy stalks. Female flowers on separate plant, solitary. Fruits about $\frac{3}{4}$ in. across, brown, and composed usually of four compressed, one-seeded carpels.

Native of China and Japan. As this pleasing and elegant shrub bears 
its male and female flowers on different plants, its fruits are only obtainable when both sexes are grown. Mr Wilson, who saw them in China, tells me they have the curious and interesting faculty when ripe of shooting out the seed a distance of several feet in the same way as Impatiens do. I have not seen this shrub anywhere except at Kew, and as only the male plant exists there the fruit is unknown to me on the living plant. The leaves have a pleasant, spicy odour when crushed. This shrub is said to be largely used by the Japanese as a hedge plant. In the Genera Plantarum of Bentham and Hooker it was erroneously put under Celastrus.

\section{OSMANTHUS. OLEACEA.}

A small group of evergreen shrubs and small or medium-sized trees, two of which inhabit the southern United States, the rest being Asiatic. The species cultivated out-of-doors in Britain are all from China and Japan. They are closely allied to the olive (Olea), and have opposite leaves; flowers white or yellowish, in small axillary or terminal clusters. Calyx and corolla four-lobed; stamens two. Fruit an oval drupe, usually dark blue or violet.

These shrubs are handsome evergreens with a holly-like appearance. They are sometimes propagated by grafting on privet-an undesirable method-for they are healthier and better on their own roots. Cuttings taken about the end of July strike readily if given a little bottom heat. They like a good loamy soil.

O. FRAGRANS, Loureiro (Olea fragrans, Thunberg), is too tender for general cultivation. It has large, broad leaves shining green beneath, and white flowers so strongly fragrant that one or two of them, tiny though they are, will fill a fair-sized conservatory with sweet perfume. The Chinese use them for perfuming tea.

\section{O. Aquifolium, Siebold.}

An evergreen shrub of rounded, dense, bushy habit, Io ft. or more high near London, twice as high in milder localities; young shoots minutely downy. Leaves oval, $I \frac{1}{2}$ to $2 \frac{1}{2}$ ins. long, I to $I \frac{1}{2}$ ins. wide, with two to four large spine-tipped teeth down each side; the largest teeth $\frac{1}{2}$ in. long, triangular. In the adult stage the leaves on the top of the plant become oval or ovate, and quite entire at the margins, like a myrtle. The upper surface is of a dark, very glossy green, the lower one paler, both quite smooth; stalk $\frac{1}{4}$ to $\frac{1}{2}$ in. long. Flowers white, fragrant, $\frac{1}{8}$ to $\frac{3}{16}$ in. across, borne during September and October, four or five together, in short-stalked, axillary clusters. Fruit oblong, $\frac{5}{8}$ in. long, $\frac{3}{8}$ in. wide, blue; not often seen in this country.

Native of Japan, where it is described by Sargent as attaining the dimensions of a tree sometimes $30 \mathrm{ft}$. high, with a trunk I ft. or more in diameter. Introduced by Thomas Lobb in 1856. As far as its foliage is concèrned, it is one of the handsomest of evergreens. Its leaves are very like those of the holly, and the shrub is often mistaken for one, but it can, of course, even without flower or fruit, be at once distinguished by its opposite leaves. It has a number of varieties, of which the following are the most important :-

Var. MYRTIFOLIUS.-As stated above, when O. Aquifolium gets to the 
adult stage the upper part of the shrub bears quite entire leaves, 1 to 2 ins. long, narrow oval, and unarmed except for the sometimes spine-tipped apex. A similar transformation in the shape of the uppermost leaves is seen in the holly, the assumption being that having grown out of reach of browsing animals, the armature of spines on the leaves is no longer needed. Cuttings of these uppermost branches take root easily, and as they do not revert to the spiny-leaved type, they are known as the "myrtle-leaved Osmanthus." On its own roots this state of $O$. Aquifolium is dwarfer and more spreading than the type with toothed leaves.

Var. PURPUREUS.-In this variety, which was raised at Kew in 1880 , the young leaves are of a black-purple shade; they and the very young shoots, in their black glossiness, have much the aspect of having been dipped in tar. It is the hardiest of all the forms of this Osmanthus. The frosts of February 1895 left it quite unaffected, whilst all the others here mentioned were more or less seriously injured at Kew.

Var. ROTUNDIFOLIUS.-A dwarf, very slow-growing shrub, with rigid, leathery leaves, I to $I \frac{1}{2}$ ins. long, half to two-thirds as wide, more or less obovate, with a marginal vein, wavy at the margins. It is usually regarded as a variety of $O$. Aquifolium, but $I$ think it may, when it flowers, prove to be a distinct species.

There are several variegated forms of $O$. Aquifolium whose leaves are bordered with creamy white or yellow, and one of var. myrtifolius bordered with yellow. They are less hardy than the type.

\section{O. ARmatus, Diels.}

An evergreen shrub or small tree, 8 to $\mathrm{I} 5 \mathrm{ft}$. high; young shoots stiff, at first clothed with minute down, turning greyish white by autumn; slightly warted. Leaves very leathery, oblong-lanceolate, 3 to 6 ins. or even more long on young specimens, $\frac{3}{4}$ to $I \frac{1}{2}$ ins. wide, abruptly narrowed to the rounded or slightly heart-shaped base, taper-pointed; coarsely toothed, the teeth triangular and with slender spiny points, dark dull green, prominently netveined and quite smooth, minutely dotted beneath; $\frac{1}{8}$ to $\frac{1}{4} \mathrm{in}$. long, downy, reddish. Flowers produced during autumn in clusters in the leaf-axils, creamy white, $\frac{1}{4}$ in. diameter, fragrant ; each on a slender smooth stalk $\frac{1}{4}$ in. long. Fruit dark violet, egg-shaped, $\frac{3}{4}$ in. long.

Native of W. China ; introduced for Messrs Veitch by Wilson in 1902, and strikingly distinct in the length of the leaf from the other hardy species. Although the spine-tipped teeth are a prominent feature of the leaves of young plants, they are often quite absent in adult specimens. According to Wilson, it grows on humus-clad cliffs and boulders, either in dense shade or fully exposed to sunshine.

\section{O. Delavayi, Franchet.}

(Bot. Mag., t. 8459.)

An evergreen shrub, described as reaching $6 \mathrm{ft}$. in height; its branches spreading, stiff, downy when young. They are densely clothed with stiff leathery leaves that are dark glossy green above, dotted with tiny dark spots beneath, ovate or oval, tapered about equally at both ends, toothed; $\frac{1}{2}$ to $\mathrm{I}$ in. long, half as wide; shortly stalked. Flowers fragrant, pure white, in terminal and axillary clusters of four to eight ; corolla with a cylindrical tube $\frac{1}{2}$ in. long. spreading at the mouth into four reflexed oblong lobes, and about $\frac{1}{2}$ in. across, Fruit roundish egg-shaped, blue-black.

Native of Yunnan, China; raised from seeds sent to M. Maurice de Vilmorin in 1890 by the Abbé Delavay, of which only one germinated. This 
charming little shrub is very distinct from the well-known Aquifolium group in having terminal as well as axillary flower clusters that open in April ; in the long-tubed corolla ; and in the small leaves. It appears to be hardy, but has only been cultivated in Britain a few years.

\section{O. Fortunei, Carrière.}

(O. ilicifolius, Hort. ; Gard. Chron., I877, vii., fig. 37 (as O. Aquifolium).)

An evergreen shrub of rounded, bushy habit, rarely more than $6 \mathrm{ft}$. high in inland counties, but I 5 to $20 \mathrm{ft}$. high in Cornwall, the whole plant devoid of down. Leaves leathery, $2 \frac{1}{2}$ to 4 ins. long, $1 \frac{1}{2}$ to 3 ins. wide; oval or slightly

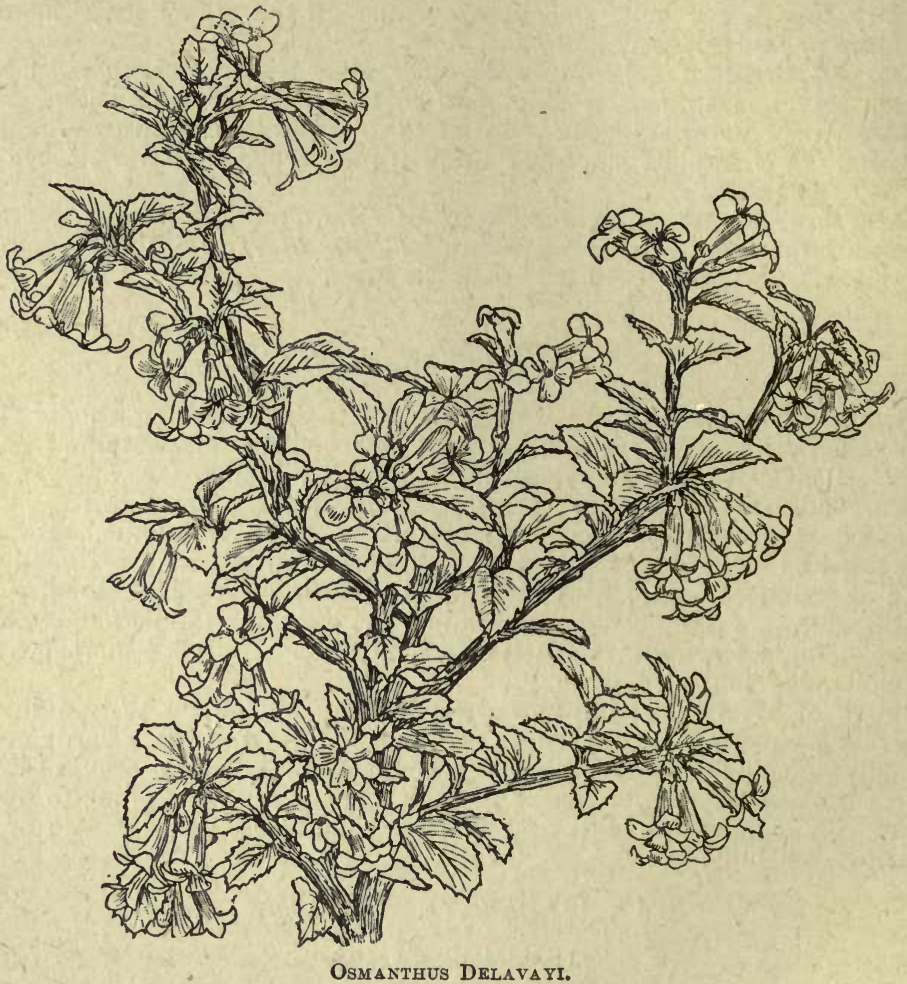

ovate, broadly wedge-shaped at the base, taper-pointed and spine-tipped, the margins armed like one of the large broad-leaved forms of common holly with large, triangular, spine-tipped teeth; stalk $\frac{1}{3}$ in. long. Some of the leaves, however, especially those at the base of the twig, are not toothed at all. Flower about $\frac{1}{3}$ in. across, white and delightfully fragrant, produced in clusters in the leaf-axils during autumn.

A hybrid of Japanese origin between O. Aquifolium and O. fragrans; introduced by $T$. Lobb in 1856 and by Fortune in 1862 . It is usually cultivated in gardens either as $\mathrm{O}$. ilicifolius or $\mathrm{O}$. Aquifolium, and in this 
country appears io be known only in the male state. It is quite hardy at Kew, and has only once been seriously injured in my recollection, which was in the great frosts of February 1895 , when the temperature fell to nearly zero on three successive nights. It does not flower profusely except in such places as Cornwall. It is easily distinguished from $O$. Aquifolium by its larger, broader leaves, less glossy on the upper surface, and with more numerous (eight to ten) teeth on either margin. For the history of this shrub and the elucidation of its confused naming, see Kerw bulletin, 1911, p. 177.

\section{OSTEOMELES. ROSACE}

A genus of trees and shrubs found in the Andes of S. America, and in various parts of Asia from the west of China to New Zealand. Two Asiatic species are in cultivation, both rather tender evergreen shrubs of very distinct appearance, with unequally pinnate leaves, white flowers, and hawlike fruits containing five seeds. From other genera of the pomaceous group of Rosacer with pinnate leaves, they are distinguished by the entire-margined, bristle-tipped leaflets of small size. They need wall treatment, and grow well in loam.

Wilson, in 1908, introduced an Osteomeles from W. China which is allied to O. Schwerinæ but promises to be a distinct species. It is distinguished at present by its dainty foliage and dwarf habit, and appears to be hardier. (No. ror6, Wilson.)

\section{O. Schwerinf, $C$. K. Schneider.}

(Bot. Mag., t. 7354 (as O. anthyllidifolia).)

An evergreen shrub, growing probably 6 to $8 \mathrm{ft}$. high in the open, considerably more against a wall ; the long, slender, flexible branchlets covered with short grey hairs. Leaves pinnate, 2 to 4 ins. long, composed of eight and a half to fifteen and a half pairs of leaflets, covered, more especially beneath, with grey down; main-stalk hairy, channelled above. Leaflets oblong-oval or obovate, with a short abrupt point, stalkless; $\frac{1}{4}$ to $\frac{5}{8}$ in. long, about onethird as wide. Flowers white, $\frac{1}{2}$ to $\frac{2}{3}$ in. diameter, produced in June in branching corymbs $1 \frac{1}{2}$ to 3 ins. across, terminating lateral twigs; calyx-lobes ovate-lanceolate, hairy outside, smooth within. Fruit egg-shaped, $\frac{1}{4}$ to $\frac{3}{8} \mathrm{in}$. long, at first dark red, blue-black when ripe, smooth, crowned by the persistent calyx ; five-seeded.

Native of Yunnan and other parts of W. China, originally raised in the Jardin des Plantes at Paris from seed which had been sent from Yunnan by the Abbé Delavay in 1888 ; introduced to Kew in 1892 . Forms nearly allied to this Chinese plant occur through the south-east Pacific region as far as the Sandwich Islands and New Zealand. The whole were at first included under O. ANTHYLLIDIFOLIA, Lindley, but the west Chinese plant has been separated on the strength of its smooth fruit, less hairy calyx-lobes, and usually but not always narrower leaves, thus leaving Lindley's name for the tropical and subtropical woolly-fruited plants. They are extremely closely allied, but perhaps the latter could not be grown out-of-doors with us.

$\mathrm{O}$. Schwerinæ is a shrub of distinct appearance, its foliage very suggestive of some of the Leguminosæ; it is also very elegant in habit and attractive in blossom. But we do not find it hardy in the open, although it survives 
mild winters. It makes a very delightful wall plant. It can be increased by cuttings made of moderately ripened wood placed in gentle heat. Seed only ripens in favourable years.

\section{O. Subrotunda, C. Koch.}

A dwarf, slow-growing, evergreen shrub, the tortuous branches covered with silky down when young. Leaves pinnate, $\frac{3}{4}$ to $I \frac{1}{2}$ ins. long, composed

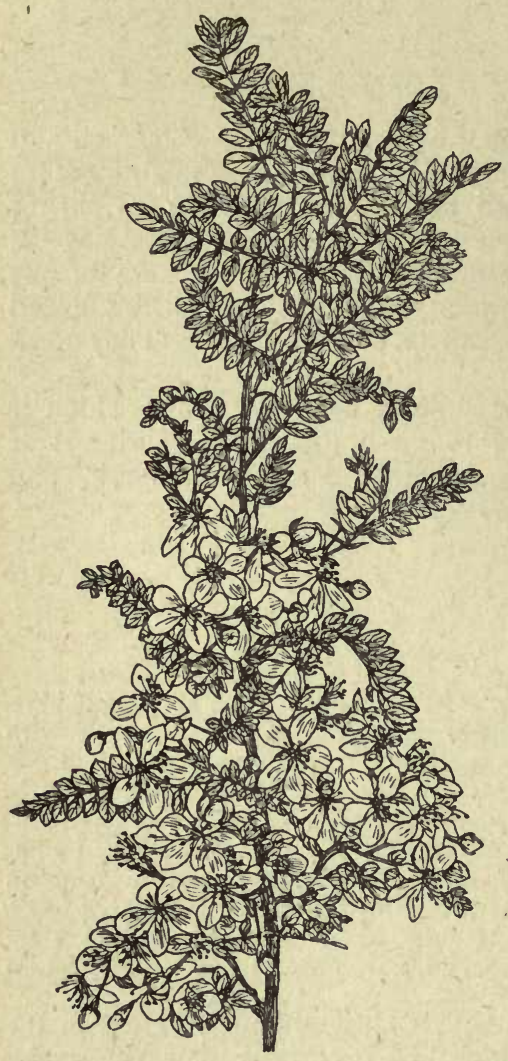

Osteomeles SchWerinæ. of four and a half to eight and a half pairs of leaflets, the main-stalk hairy and grooved above. Leaflets obovate or oblong, $\frac{1}{8}$ to $\frac{1}{4}$ in. long, stalkless, the apex broad and rounded; lower surface silky-hairy, the upper one less hairy and shining. Flowers white, $\frac{1}{2}$ in. across, borne in axillary leafy corymbs.

Native of China ; first introduced to the Jardin des Plantes at Paris from Japan (of which country it may also be a native), thence to Kew in 1894. The original plant, growing on a south wall and perfectly healthy, is still only about $3 \mathrm{ft}$. high, and has never flowered. Botanically, this species is, no doubt, closely allied to the two species discussed in the preceding note, but its stunted branches, slow growth, and obovate smaller leaflets amply distinguish it. Increased by cuttings. Not very hardy in the open.

\section{OSTRYA. HOP HORNBEAM. CORYLACEA.}

Four species of Ostrya are usually recognised, three of which are in cultivation. They are curiously isolated in nature, one species occurring in Europe and Asia Minor, one in Eastern Asia, one in Western and one in Eastern $\mathbf{N}$. America. They are medium-sized trees, with deciduous, alternate, parallel-nerved leaves, quite closely related to the hornbeams (Carpinus), and in the foliage especially similar. The chief botanical differences are in the female flowers and fruits. In both genera the female flowers are borne on slender catkins, and in pairs at the base of deciduous scales. In Ostrya, however, each flower is set in a bag-like husk (involucre), which at first is open at the top, but closes up after fertilisation takes place. The husk afterwards grows very considerably, and is the pale, membranous, ovate, flattish, bladder-like organ which, 
congregated and overlapping in hop-like clusters, and completely enclosing the nutlet, gives the trees of this genus their popular name. In Carpinus this involucre remains open and does not enclose the nutlet.

These three Ostryas should be raised from seed; they thrive in any soil of good or moderate quality, all being perfectly hardy. By some authorities the three following are regarded as geographical forms of one species. O. japonica, however, is very distinct from the other two.

\section{O. CARPINIfolia, Scopoli. Hop Hornbeam.}

\section{(O. vulgaris, Willdenow.)}

A tree 50 to $60 \mathrm{ft}$. high, with a short, stout trunk covered with greyish, ultimately rough, bark, and a rounded head of branches; young shoots covered with short hairs (not gland-tipped). Leaves ovate, sometimes inclining to oval, rounded at the base, pointed and tapered at the apex; $2 \frac{1}{2}$ to 4 ins. long, half as wide; prettily double-toothed, dark green above, with appressed hairs mostly between the ribs; paler beneath and sparsely hairy, chiefly on the midrib and veins, and in the axils of the latter; stalk about $\frac{1}{4}$ in. long, hairy. Male catkins nodding; $1 \frac{1}{2}$ to 3 ins. long, $\frac{1}{4}$ in wide; scales finely and abruptly pointed. Fruit clusters $1 \frac{1}{2}$ to 2 ins. long; the nutlets (commonly called "seeds") $\frac{1}{6}$ in. long, stalkless, enclosed at the base of an ovate, hairy, flat, bladder-like husk, $\frac{1}{2}$ in. long.

Native of S. Europe and Asia Minor; introduced early in the eighteenth century. This tree has very much the aspect of the American species $(q . v$.$) ,$ but is distinguished by never having any glands on the hairs of the twigs. It is pretty and rather striking when furnished with the pendent hop-like fruit clusters in autumn. The timber has the same bony texture and hardness as hornbeam.

\section{O. JAPONICA, Sargent. JAPANESE HoP HoRnbeAM.}

A tree occasionally $80 \mathrm{ft}$. high in nature, trunk 18 ins. in diameter; winter buds ovoid, shining; young shoots clothed with soft pale hairs, which persist through the winter. Leaves ovate or ovate-oblong; 3 to 5 ins. in length, $1 \frac{1}{2}$ to $2 \frac{1}{4}$ ins. in width, on young trees; rounded or slightly heart-shaped at the base, tapered at the apex to a long slender point, coarsely, sharply, and irregularly toothed; dark green and hairy above, paler, more downy and velvety to the touch beneath. Fruit clusters $1 \frac{1}{2}$ to $1 \frac{3}{4}$ ins. long, $\frac{3}{4}$ in. wide.

Native of Japan, where it is said to be somewhat uncommon; introduced to Kew by Prof. Sargent in 1897. It succeeds well, and is now nearly $30 \mathrm{ft}$. high, being easily distinguished from the European and American species by the veins each side the midrib (nine to twelve) being fewer and farther apart, and by the more uniformly downy, softer, more velvety surfaces of the leaves. According to Henry, the same tree is sometimes, though very rarely, found in Central China.

\section{O. VIRGINICA, Willdenore. IRONWOOD.}

A round-headed tree, 30 to $50 \mathrm{ft}$. high, similar in habit to $\mathrm{O}$. carpinifolia ; young shoots furnished with gland-tipped hairs. Leaves 2 to $4 \frac{1}{2}$ ins. long, I to 2 ins. wide; oval-lanceolate, rounded or sometimes slightly heartshaped at the base, taper-pointed, sharply toothed (not so markedly doubletoothed as in $\mathrm{O}$. carpinifolia); dark green and hairy on the midrib and between the veins above, paler and more downy beneath; stalk $\frac{1}{4}$ in. 
long, glandular downy. Male catkins 2 ins. long. Fruit clusters $1 \frac{1}{2}$ to $2 \frac{1}{2}$ ins. long, $\frac{2}{3}$ to $1 \frac{1}{2}$ ins. wide. Nutlet $\frac{1}{3}$ in. long, the pale bladder-like membranous bag enclosing it being ovate, $\frac{3}{4}$ to $I$ in. long, hairy at the base.

Native of Eastern N. America; introduced by Compton, Bishop of London, in 1692. Cultivated specimens differ from the closely allied O. carpinifolia in the glandular hairs on the twigs and leaf-stalks, in the usually fewer ribs of the leaf, and in the larger nut. The timber, as the common name denotes, is very hard and durable, and is used for mallets, handles of tools, etc. Although not very common in English gardens, this interesting tree thrives well. At Kew there are several specimens 25 to 30 $\mathrm{ft}$. high, of handsome pyramidal form and very healthy.

\section{OSTRYOPSIS Davidiana, Decaisne. CORYlace}

A deciduous shrub of bushy, rounded habit, 3 to $5 \mathrm{ft}$. high, suckering from the base like a hazel; young shoots downy. Leaves alternate, broadly ovate, heart-shaped at the base, short-pointed, I to 3 ins. long, $\frac{3}{4}$ to 2 ins. wide; sharply, irregularly and often doubly toothed; upper surface dull green with scattered hairs, lower surface much more downy; stalk $\frac{1}{4}$ in. or less long. Flowers unisexual, both sexes on the same bush. Male catkins $\frac{1}{2}$ to $\frac{3}{4}$ in. long, slender, nodding, produced from the joints of the old wood. Female inflorescence terminal on the new shoot of the year, erect, very short. Fruit a conical nut enclosed in an outer covering or husk (involucre), which is also narrowly conical, $\frac{1}{2}$ to $\frac{3}{4}$.in. long, downy, terminating in three slender points. At first this husk completely encloses the nut, but finally liberates it by splitting down one side. The fruits are crowded eight to twelve together in a cluster at the end of the twig.

Native of N. China and Mongolia; discovered by the Abbé David, after whom it is named. It was introduced from the mountains near Pekin to Kew, in 1883 , by the late Dr Bretschneider. It is an interesting little shrub, with the habit and foliage of a hazel, to which it is closely allied, but differs much in the shape of the nut. It has no ornamental qualities to recommend it, but is quite hardy.

\section{OXYCOCCUS. CRANBERRIES. VACCINIACEA.}

Only two species of Oxycoccus are known, which, although closely allied to Vaccinium, are very distinct in their long, slender, wiry, creeping stems, clothed with alternate leaves, and still more in the corolla, the four parts of which are so deeply divided that they become practically separate petals.

The cranberries like a moist or semi-boggy, peaty soil, and can be increased by secd or by layers. They have little garden value, although a broad patch of either kind forming a dense mass of interlacing stems is interesting and unusual. The berries are used for making tarts and in confections of various kinds. 


\section{O. macrocarpus, Pursh. American Cranberky.}

(Vaccinium macrocarpum, Aiton.)

A creeping evergreen shrub of prostrate habit, with long, thin, wiry stems. Leaves oval or oblong, $\frac{1}{3}$ to $\frac{2}{3}$ in. long, $\frac{1}{8}$ to $\frac{1}{3}$ in. wide ; rounded at both ends, entire, very short stalked, pale or bluish white beneath, usually recurved at the margins. Flowers produced during the summer in a raceme about $I$ in. long, beyond which the leaf-bearing shoot continues to grow; each flower is borne on a curving, slightly downy stalk, but is itself drooping. Petals pink, $\frac{1}{3}$ in. long, rolled back so as to fully reveal the eight stamens, which stand up in a close cluster. Calyx with shallow, triangular lobes. Berry red, acid, $\frac{1}{2}$ to $\frac{3}{4}$ in. diameter, globose.

Native of Eastern N. America from Newfoundland to N. Carolina, generally inhabiting boggy ground. It has much the same general appearance as our native cranberry, but differs in its larger, rounder-tipped leaves and larger berries, in having a leafy shoot above the raceme, and in the stalk of the stamens being shorter in comparison with the anthers. This shrub is now being largely cultivated in the United States for its fruit. Hundreds of acres have been specially adapted for it by means of a watersupply which admits of the land being flooded at will. On well-prepared ground a crop of 500 bushels per acre has been gathered in a single season.

\section{O. Palustris, Persoon. Small Cranberry.}

(Vaccinium Oxycoccus, Linnoeus.)

A prostrate, evergreen shrub with long, thin, wiry stems. Leaves ovate, $\frac{1}{4}$ to $\frac{3}{8}$ in. long, pointed, dark green above, very glaucous beneath. Flowers nodding, produced during summer in a terminal cluster of one to four, each flower on a slender downy stalk, $\frac{3}{4}$ to $\mathrm{I}$ in. long. Petals rosy pink, bent backwards, $\frac{1}{4}$ in. long. Berry red, globose, $\frac{1}{3}$ in. across.

Native of N. Europe, N. Asia, and N. America ; widely spread in the British Isles, but most abundant in the north of England and the south of Scotland. At one time the gathering of cranberries was a considerable industry for women and children of that part of Great Britain, and in some of the markets of the northern towns (at Longtown in Cumberland, near the Solway Firth, for instance), $£ 30$ worth of cranberries would be sold in a day. But the draining and enclosing of boggy land induced by the high prices for corn during and after the Napoleonic wars destroyed many extensive and favourite haunts of the cranberry, and the plant is much less abundant than in former times. The berries are perhaps the most pleasantly flavoured of wild fruits.

\section{OXYDEndRUM arboreum, De Candolle. Sorrel Tree. ERICACEA.}

(Andromeda arborea, Linnacus, Bot. Mag., t. 905.)

A deciduous tree, occasionally over $50 \mathrm{ft}$. high in a wild state, the slender trunk $\mathrm{I}$ to $\mathrm{I} \frac{1}{2} \mathrm{ft}$. in diameter. In this country it is occasionally 25 to $30 \mathrm{ft}$. high, but is more often a tree-like shrub under ro ft. high ; young shoots quite smooth. Leaves alternate, oblong-lanceolate, with a long, tapering point; 4 to 6 ins. long, $1 \frac{1}{2}$ to $2 \frac{1}{2}$ ins. wide; almost or 
quite smooth; midrib sometimes bristly beneath; entire or minutely toothed, thin in texture, dark green, sometimes turning red in autumn; leaf-stalk $\frac{1}{2}$ to $\mathrm{I}$ in. long. Flowers white, $\frac{1}{4}$ in. long, cylindrical, but narrowing towards the mouth, produced during July and August in a lax panicle 6 to ro ins. long, composed of several slender racemes from the end of the shoot or the terminal leaf-axils; flower-stalks, calyx, and corolla downy, the two latter five-lobed; stamens ten, enclosed within the corolla. Fruit a dry, woody, five-celled capsule, many-seeded.

Native of Eastern N. America; introduced in $175^{2}$. It is the only species of its genus. Belonging to the heath family, this tree thrives under the same conditions as azaleas and rhododendrons. The finest specimens I have seen are in Mr Waterer's nursery at Knap Hill, near Woking, where they are about $30 \mathrm{ft}$. high, with well-formed trunks and a slender head of branches. It is usually propagated by seed obtained from the United States. The leaves have a pleasant acid taste, to which its popular and scientific names refer.

\section{PACHYSANDRA. EUPHORBIACEA.}

A group of four or five species of curious semi-woody plants of tufted habit, allied to Buxus, but very distinct in general appearance, being in habit low and more or less prostrate. Leaves dullish green, alternate, mostly aggregated near the apex of the season's growth. Flowers unisexual on erect spikes, the males numerous, the females solitary or few; both sexes on the same spike, the females at the base. Petals none; sepals and stamens four in the male; sepals four to six, and ovary threecelled in the female. Fruit a three-celled capsule, with the styles persisting at the top like three curved horns. The generic name is in allusion to the thick stamens.

The Pachysandras thrive in any moist soil, and do not mind shade; they make neat tufts, but are of only moderate decorative value. Easily increased by summer cuttings. The three following species are easily differentiated by their inflorescence as follows :-

I. Axillaris. Inflorescences in the leaf-axils.

2. Procumbens. Inflorescences clustered at the naked base of the stem.

3. Terminalis. Inflorescences solitary at the end of the stem.

\section{P. AXILLARIS, Franchet.}

An evergreen, semi-woody plant with prostrate root-stocks, from which rise the young stems 4 to 10 ins. high, at first minutely downy. Leaves three to six near the summit of each stem; ovate, broadly wedge-shaped or rounded and entire at the base, coarsely toothed at the upper part, 2 to 4 ins. long, $\mathbf{I} \frac{1}{4}$ to $2 \frac{1}{4}$ ins. wide. Flowers white, produced in April in erect spikes $\frac{3}{4}$ to $I$ in. long, from the axils of the leaves. Fruit about the size of a pea, with the three long, curly-ended styles persisting at the top.

Native of China ; discovered in Yunnan by the Abbé Delavay ; introduced by Wilson in 190 I. Of little beauty, it may by lovers of curiosities be given a place in some shady corner of the rock garden. 


\section{P. Procumbens, Michaux, Allegheny Spurge. (Bot. Mag., t. 1964.)}

A semi-herbaceous plant forming low masses, with stems 6 to $\mathbf{1 2}$ ins. high, springing unbranched from a root-stock; downy, bearing the leaves in a cluster at the top. Leaves broadly ovate, obovate, or somewhat rhomboidal ; 2 to $3 \frac{1}{2}$ ins. long, often almost as wide; the upper part usually very coarsely toothed, the lower part entire and tapering to a stalk $\frac{1}{2}$ to $1 \frac{1}{2}$ ins. long. The lower leaves are the largest and longest stalked; all are furnished with minute, scattered hairs. The unisexual flowers are borne at the base of the stem '(between the flowers and the leaves the stem is bare), crowded on several erect, cylindrical spikes 2 to 4 ins. high; female flowers few, and confined to the base. The most conspicuous part of the spike is the stamens, with their pale, flattened stalk $\frac{1}{3}$ in. long; the sepals are greenish or purplish.

Native of the south-eastern United States from Virginia and Kentucky southwards; introduced in 1800 . It is best grown on some shelf in the rock garden in a half-shaded spot. The inflorescence is formed in autumn, and expands in spring. Flowers unpleasantly scented.

\section{P. TERMINALIS, Siebold.}

An evergreen, semi-woody plant, 6 to 8 ins. high; stems smooth, the lower portion procumbent and matted. Leaves diamond-shaped, I to $2 \frac{1}{4}$ ins. long, $\frac{1}{2}$ to $I \frac{1}{4}$ ins. wide ; coarsely and bluntly toothed on the upper half, entire and tapering below, smooth, prominently three-veined at the base; stalk $\frac{1}{4}$ to $\frac{3}{4}$ in. long. The leaves persist two or three years, and each year's crop is produced in a whorl-like cluster at the end of its growth, being separated from the previous one by several inches of naked stem. Flowers green tinged with purple, produced in spring at the end of the previous year's shoot in a spike about $\mathrm{I}$ in. long.

Native of Japan. Not so striking a plant as the American P. procumbens, from which it is readily distinguished by its terminal spikes and smaller leaves, but hardier. It ultimately forms a dense low mass several feet across.

Var. VARIEGATA.-Leaves bordered and striped with white.

\section{PACHYSTIMA. CELASTRACEA.}

Two North American, low, glabrous shrubs, with small evergreen, opposite, leathery leaves and tiny inconspicuous flowers. They have four petals, four stamens, and a two-celled ovary; the fruit is small, oblong, white. These two shrubs thrive best in a soil that is partly peat, partly sandy loam, and are, perhaps, best adapted for a nook in the rock garden, where, however, their interest will be chiefly botanical. They need only be recommended to people who love rare, out-of-the-way plants, irrespective of their beauty. At the same time the Pachystimas make neat, rather dainty tufts. Both are easily increased by cuttings. The name implies "thick stigma."

\section{P. Canbyi, A. Gray.}

A low evergreen shrub up to $1 \mathrm{ft}$. in height, with linear or narrow-oblong leaves, $\frac{1}{2}$ to $\mathrm{I}$ in. long, $\frac{3}{18}$ in. or less wide, shallowly toothed towards the apex, 
the margins decurved; quite smooth. Flowers very small, greenish, borne on very slender-stalked cymes $\frac{1}{2}$ in. long in the leaf-axils. Fruit $\frac{3}{16}$ in. long, white.

Native of steep rocky slopes on the mountains of Virginia and N. Carolina; introduced to Kew in 1893 , where it has proved hardy. It has no beauty of flower, and its only merit as a garden shrub is its neat low habit, for it does not bear fruit freely with us. It is also of scientific interest in being confined to comparatively small areas in a wild state. It blossoms from May to August.

\section{P. Myrsinites, Rafinesque.}

An evergreen shrub, 6 to 18 ins. high, ultimately spreading in habit. Leaves oblanceolate to narrow-oblong or ovate, from $\frac{1}{3}$ to $1 \frac{1}{4}$ ins. long, from $\frac{1}{16}$ to $\frac{1}{4}$ in. wide, toothed towards the tip. Flowers $\frac{1}{8}$ in. across, reddish, produced singly, or two or three together in the leaf-axils. Fruit white, $\frac{1}{6}$ in. long.

This is the Western representative of the genus, being found in woods on the north-western coast of N. America, and in the valleys of the Rocky Mountains. It is much more widely spread and abundant than its Eastern ally, but has no more value in the garden. It differs from P. Canbyi in its freer more robust growth, its wider, larger leaves not so much decurved at the margins, and in its shorter flower-stalks. It blossoms in April and during the two or three succeeding months.

\section{PÆONIA. PAONY. RANUNCULACE⿸.}

A genus composed mainly of herbaceous plants, but including the two following shrubs. Leaves alternate, deeply divided; flowers solitary, produced at the end of the shoot. Fruit consisting of five carpels.

\section{P. Moutan, Sims. Moutan or Tree Peony.}

\section{(Bot. Mag., tt. II 54, 2 I75; P. arborea, Donn.)}

A stiff-branched, deciduous shrub, of rather gaunt habit when in the leafless state, but of luxuriant aspect when in full leaf; rarely more than $5 \mathrm{ft}$. high in this country, but said to be twice that height in China. Branchlets thick, rugged, soft with abundant pith, dying back more than half their length after flowering. Leaves doubly pinnate or doubly ternate ; 9 to 18 ins. long. In the typical state, now rarely seen, the flowers have from five to ten petals and numerous stamens; but in the popular double varieties petals have taken the place of stamens, and, being very numerous, form a full, exceedingly "double" flower from 6 to 12 ins. across. The original type has rosy purple flowers, but in the varieties the colours range from white to pink, deep rose, vermilion, and crimson, sometimes striped, the petals having a crinkled, satiny appearance. Such odour as the flowers possess is not pleasant. They expand in May and June.

This shrub, one of the most gorgeous of all exotics hardy in England, has been cultivated for centuries by the Chinese and Japanese. The name "Moutan" is derived from "Meu-tang," the king of flowers in Chinese myth. It is said to grow wild in the province of Kansu, China, north of the river Hoang-ho. It was introduced in 1789 from China to Kew, where the original plant remained until 1842 , when, owing to building operations, it had to be removed. In many parts of the country the tree prony is very unsatisfactory. At Kew it grows too early in spring, and the young 
growths and flowers are almost invariably destroyed by late frosts. It is these, not genuine winter cold, that have to be feared. In the northeastern counties, where it is not excited into growth so easily, one may see fine robust bushes 4 or $5 \mathrm{ft}$. high and more in diameter, such as it is hopeless to obtain in low-lying districts near London. But no doubt the fine highly bred varieties now in favour are more delicate than the old sorts first imported from China. The unnatural practice, too, of grafting the plant on the herbaceous prony is probably also responsible for many failures. Propagation is best effected by layering, first slitting the stem and, when pegged down, covering it with 2 or 3 ins. of soil. This should be done before the growing season commences. The layers when rooted should be established in pots.

The tree pæony is seen to best advantage as an isolated shrub on a sheltered lawn where the early morning sun does not strike the plants, and thus induce rapid thawing after frosty nights. It is a gross feeder, and may be grown in good loamy soil. An occasional dressing of manure is advisable.

\section{P. LUTEA, Franchet. Yellow PAENY.}

(Bot. Mag., t. 7788.)

A dwarf, sub-shrubby, deciduous plant, with a short woody stem; entirely glabrous. Leaves leathery, 12 to 15 ins. long, strongly nerved, deep green above, glaucous beneath; ternate, with the three divisions pinnatifid and deeply cut at the margin. Outer sepals narrow-lanceolate, acuminate; inner ones roundish concave, yellowish green. Petals six to ten, golden yellow, roundish concave, with usually crenate margins and a carmine stain at the base. The flower is $2 \frac{1}{2}$ ins. across, and is sometimes slightly "double," both in a wild state and cultivated.

Native of the mountains of Yunnan, where it was originally discovered by the French missionary, Delavay, in 1882. This beautiful pæony is not so decidedly a shrub as P. Moutan, but it forms a short, woody stem. Its large, rich yellow blossoms make it a splendid acquisition to gardens, although, in some forms at least, the flowers are apt to be hidden by the foliage. Messrs Lemoine of Nancy have sent out a fine variety called SUPERBA, with larger flowers and a stronger and more robust habit.

\section{PALIURUS AUSTRALIS, Gaertner. CHRIST'S THORN. RHAMNACEE.}

\section{(P. aculeatus, Lamarck; P. Spina-Christi, Miller.)}

A deciduous shrub or small tree, up to $20 \mathrm{ft}$. high in this country, with shoots downy when young, and armed at each joint with a pair of spines, one straight and pointing more or less upwards, the other shorter, curved, and pointing downwards. Leaves alternate, I to $I_{2}^{\frac{1}{2}}$ ins. long, broadly ovate, three-nerved, and entire or slightly toothed; stalk $\frac{1}{2}$ in. or less long. Flowers very numerous, and produced in a short branching umbel from each leaf-axil of the current year's shoots; the individual flowers small, greenish yellow, but rather striking, wreathed as the shoot is with them. Fruit $\frac{3}{4}$ to $\mathbf{I}$ in. wide, consisting of a three-celled, roundish body, developing at the top a curious flat wing which runs all round, giving the whole fruit the aspect of a low-crowned, wide-brimmed hat. 
Native of S. Europe eastwards to W. Asia ; cultivated in this country for over three hundred years. In some of its native piaces it is used as a hedge plant. I remember seeing it put to this use on the road between Spalato and Salona, in Dalmatia. It is perfectly hardy at Kew, and I have never seen it even touched by frost there. It grows very well in ordinary loam, and although the flowers have no great beauty they are pretty, and abundantly produced in rows of umbels on the upper side of the shoot. The flat, disk-like, greenish yellow fruits, too, have an interesting appearance, quite distinct from that of any other hardy shrub. The branches are pliable and excessively spiny, and the tree has a legendary interest as the one of whose branches the Crown of Thorns was believed to have been made. It flowers in July and August. Well worth cultivation.

\section{PARROTIA. HAMAMELIDACE $Æ$.}

Two deciduous, small trees, with alternate leaves and small flowers crowded in terminal globose heads, subtended by several bracts. The flowers have no petals, but numerous stamens, which furnish their chief attraction; although in P. Jacquemontiana this is supplemented by the large white bracts. Both species are quite hardy, and thrive in good loamy soil. Seeds afford the best means of increase, but failing these, both may be propagated from layers. P. Jacquemontiana can be raised from cuttings-possibly the other also. Their nearest allied genera, are Sycopsis, which is evergreen, and Fothergilla, which has no bracts beneath the head of flowers. The genus is named after the Russian, Mr Parrot, who made the first ascent of Mt. Ararat in 1829. The two species are very distinct, and P. Jacquemontiana has been made into a separate genus.

\section{P. JaCQuemontiana, Decaisne.}

(Bot. Mag., t. 7501 ; Parrotiopsis involucrata, C. K. Schneider.)

A deciduous tree, ultimately 15 to $20 \mathrm{ft}$. high, with a smooth grey trunk and a much-branched bushy head; sometimes a shrub; young twigs covered with clustered (stellate) hairs. Leaves roundish or very broadly ovate, 2 to $3 \frac{1}{2}$ ins. long and nearly as wide; margins set with broad open teeth; both surfaces furnished with stellate hairs, the upper one thinly so and finally almost smooth, the lower one densely on the nerves; stalk $\frac{1}{4}$ to $\frac{1}{2}$ in. long. Flowers stalkless, produced from April to July, about twenty together in a shortly stalked globose head about $\frac{5}{8}$ in. across, the chief feature of which are the numerous yellow stamens. Beneath the head of flowers are four to six conspicuous petal-like bracts of the same shape as the leaves, but only $\frac{1}{2}$ to $\mathrm{f}$ in. long, and white; they constitute the chief feature of the inflorescence. Seeds shining, oblong, $\frac{1}{6}$ in. long.

Native of the western Himalaya, especially in Cashmere ; where it was discovered by Dr Falconer in 1836 . It does not appear to have reached cultivation until 1879 , when seeds were sent to Kew. The largest specimen is now about $12 \mathrm{ft}$. high, quite hardy and vigorous in an exposed position, and flowers annually. It has no claim to a place among showy plants, but belongs 
to a family of exceptional interest, and when well furnished with its flowerheads it is at least pretty. The leaves remain long on the tree after those of P. persica have fallen. The largest inflorescences, with the surrounding bracts, are sometimes 2 ins. across, especially those that open late. The main crop is borne in April and May, but flowers continue to open intermittently through the summer. The twigs are very tough and are largely used for making rope bridges in the western Himalayas. The wood, too, is useful in being hard and close-grained.

\section{P. PERsiça, C. A. Meyer.}

(Bot. Mag., t. 5744.)

A deciduous tree, 30 to $40 \mathrm{ft}$. high, with a stout trunk from which the smooth, grey bark comes away in flakes, as in the plane, and horizontal wide-

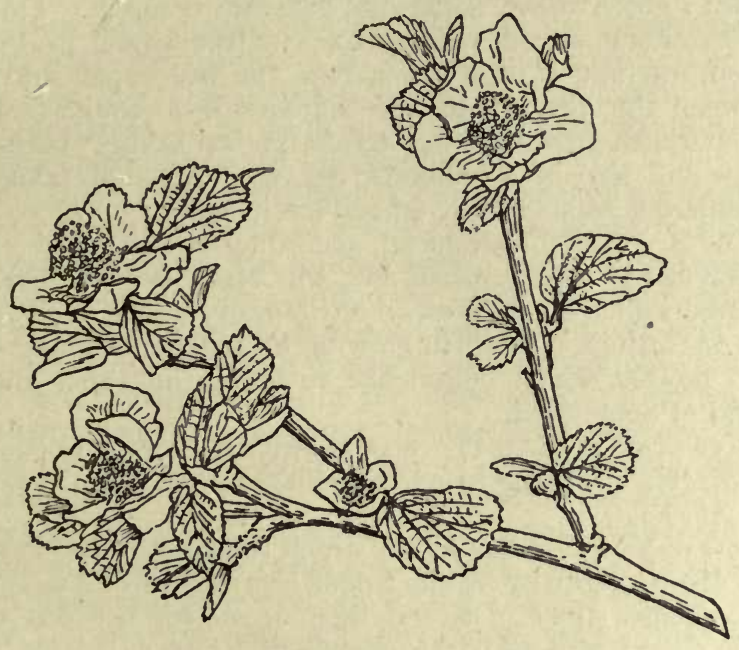

Parrotia Jacquemontiana.

spreading branches; young twigs at first furnished with stellate hairs. Leaves ovate, oblong or obovate; $2 \frac{1}{2}$ to 5 ins. long, I to $2 \frac{1}{2}$ ins. wide; rounded or tapering at the base, coarsely, shallowly and unevenly toothed, or merely wavy towards the apex; almost smooth above, sparsely furnished beneath with stellate hairs; stalk $\frac{1}{4}$ in. long, downy. Flowers produced during March in short clusters $\frac{1}{2}$ in. across, often terminal on short leafy twigs, and only conspicuous for their numerous red stamens. Bracts brown and hairy outside, green within, $\frac{1}{4}$ to $\frac{1}{3}$ in. long, ovate. Seed-vessels nutlike, opening. at the top ; seeds $\frac{3}{8}$ in: long, bright brown, pointed at one end.

Native of N. Persia to the Caucasus; introduced to Kew about I84I. The great charm of this tree is in the beautiful tints of gold and crimson its foliage assumes in autumn. Few trees are so effective then. In the early spring, too, when in flower, the numerous red-anthered stamens and rich brown bracts give to the still leafless branches a hazy effect of red which is very pleasing in sunshine. The species is very hardy, but unless trained up in its early stages and its lower branches pruned away, it is apt to remain 
stunted and shrubby. There is a fine tree at Vicar's Hill, Lymington, which frequently bears fruit, as does another across the Solent in Osborne gardens. Doubtless there are others, and the numbers will increase as the years go by ; but Parrotia persica is not so plentiful as its charm and interest entitle it to be.

\section{PASSIFLORA CCERULEA, Linnceus. PASSION-FLOWER. PASSIFLORACEE.}

(Bot. Mag., t. 28.)

A climbing plant of great vigour and more or less evergreen, attaching itself to its supports by tendrils; devoid of down in all its parts. Leaves palmate, five- or seven-lobed, 4 to 7 ins. across; lobes oblong with rounded ends; green above, somewhat glaucous beneath. Flowers borne on long, slender stalks from the leaf-axils of the young growing shoots; flat and open, fragrant, 3 to 4 ins. across, the five sepals and five petals blue. Between the petals and the stamens is a conspicuous ring of thread-like, purplish growths 2 ins. across, known as the "corona." Fruit of the shape and size of a bantam's egg, with a tough, orange-coloured rind and numerous seeds inside, embedded in pulp.

Native of S. Brazil ; introduced, according to Aiton, in r699. It is not genuinely hardy near London, but will often survive several winters on a sheltered wall. As it grows very rapidly and is easily propagated from seeds or cuttings, it is worth growing for its beautiful and remarkably constructed flowers, which commence to appear in June, and continue until the end of September.

Var. "Constance Elliotr," first shown by Messrs Lucombe, Pince, \& Co., of Exeter, in I884, has ivory-white flowers (see Gard. Chron., I 884 , i., p. 701).

The name of "passion-flower" by which this and all the Passifloras are known was given originally by the Spanish priests in S. America, because of the resemblance their piety led them to detect between the various parts of the flower and the instruments of Christ's Passion. The late Dr Masters, the historian of the family, has pointed these out to be as follows: The three stigmas represent the three nails, two for the hands and one for the feet; the five anthers represent the five wounds; the corona represents the crown of thorns or the halo of glory; the five sepals and five petals stand for ten apostles-Peter and Judas being, absent; the hand-like leaves and whip-like tendrils represent the hands and scourges of His persecutors.

\section{PAULOWNIA IMPERIALIS, Siebold. SCROPHULARIACE.}

(Bot. Mag., t. 3853 ; Garden, I892, April 2 ; P. tomentosa, Koch.)

A round-topped, deciduous tree 30 to $50 \mathrm{ft}$. high, with thick, stiff branches and rather open habit; all the parts more or less downy. Leaves opposite, the small ones ovate, the larger ones three- to fivelobed, the lobes pointed but shallow, the base deeply notched; the 
dimensions are very variable; in adult trees they are 5 to 10 ins. long and wide, dark green, and with scattered hairs above, covered beneath with a soft, thick, greyish wool; stalk nearly as long as the blade. Panicle terminal, up to I ft. long, the flowers forming in autumn but not opening until the following May. Corolla blue-purple, $\mathrm{I} \frac{1}{2}$ to 2 ins. long, shaped like a huge foxglove; calyx woolly, $\frac{1}{2}$ in. long, bell-shaped, with five ovate teeth. Seed-vessel an ovoid, pointed capsule, $\mathbf{I}_{2}^{\frac{1}{2}}$ to 2 ins. long, containing numerous winged seeds.

Native of China, but introduced from Japan to France in 1834 . Few more beautiful flowering trees than this exist, but although the tree is fairly hardy and sets its flowers, they often do not develop in this country, owing to its curious habit of exposing them in bud through the winter. Perhaps they do not derive sufficient stamina from our dull summers, but more likely the unrest of our winters, with their alternate frosts and mild spells, prevents their proper development. In the milder counties, as at Abbotsbury, near Weymouth, in S. Wales, and even at Leonardslee in Sussex, the tree flowers and ripens seeds. In the Jardin des Plantes at Paris there are trees 40 or $50 \mathrm{ft}$. high, with trunks about $8 \mathrm{ft}$. in girth, which make a splendid picture when in bloom.

But whilst many gardens in Great Britain are denied the blossoms of this tree, it may, by another mode of cultivation, be made to provide a fine feature anywhere but in the coldest parts. This is to treat it simply as a fine-foliaged plant. To get the best effect the plants should be set out 3 or $4 \mathrm{ft}$. apart in a group of at least twenty, and be kept to a single stem, the object being to obtain leaves as large as possible. In spring the stem is cut back to within 2 ins. of the older wood. From the crowd of young growths that then push out the two strongest are selected, the rest rubbed off. Two are left for fear of accident only, and after they are fairly established the weaker one is removed. It only then remains to water when necessary and to feed the plants with manure. Wellgrown plants will have huge pentagonal leaves 2 to $3 \mathrm{ft}$. across, and the sturdy erect stems will grow over $\mathrm{I} 2 \mathrm{ft}$. high in the season. Paulownias need a rich soil and are best propagated from seed, which is produced in plenty on the Continent. Root-cuttings may also be used. Several other species of Paulownia have been described and named recently; of these,

P. FARGESII, Franchet, from Szechuen, China, flowered with the late $\mathrm{Mr}$ Boucher in France, about 1907. It had been introduced by means of seed sent by the Abbé Farges to Mr Maurice de Vilmorin. The flowers are white, and the leaves are described as shorter and broader than in P. imperialis, and less downy beneath. Whether it will flower more successfully in this country than the older species remains to be seen.

PENTSTEMON SCOUleri, Douglas. SCROPHulariace.e.

(Bot. Reg., t. I 277.)

A semi-shrubby plant only woody at the base, I to $\mathrm{I} \frac{1}{2} \mathrm{ft}$. high; young shoots minutely downy. Leaves opposite, narrowly oblanceolate, I to 
2 ins. long, $\frac{1}{8}$ to $\frac{1}{4}$ in. wide; pointed, tapered to both ends, toothed, the smaller basal leaves of the shoot entire; scarcely stalked. Flowers bluepurple, arranged oppositely on erect terminal racemes opening in June; the funnel-shaped, two-lipped corolla is $\mathrm{r}_{2}^{\frac{1}{2}}$ ins. long, expanded at the mouth into three lower lobes and two upper ones, and there $\mathrm{I}$ in. or more across. Stamens five, two-thirds as long as the corolla, one of them sterile; anthers very hairy; calyx-lobes awl-shaped.

Native of Western N. America; introduced in 1828 by Douglas. It is, perhaps, no more than one of the more shrubby forms of a very variable species to which P. Menziesil, Hooker, a dwarfer plant, with oval or obovate leaves, also belongs. Both these showy little plants like a warm sunny position and a sandy, loamy soil. Easily increased by cuttings.

Another fairly hardy Pentstemon is P. Heterophyllus, Lindley. It is of a shrubby nature, growing $I_{2}^{\frac{1}{2}}$ to $3 \mathrm{ft}$. high, and has slender stems furnished with smooth, opposite, stalkless, linear leaves, I to 4 ins. long, $\frac{1}{8}$ to $\frac{1}{4}$ in. wide. Flowers reddish purple, $\mathrm{I}$ to $\mathrm{x}_{4}^{\frac{1}{4}}$ ins. long, anthers hairy at the margins. Introduced in 1828 for the Horticultural Society by David Douglas (Bot. Mag., t. 3853).

P. CORymbosus, Bentham, is sometimes grown against a wall, where it is $4 \mathrm{ft}$. high, its oval or ovate leaves $\frac{1}{2}$ to $\mathrm{I} \frac{1}{4}$ ins. long; flowers bright red, the tube about I in. long; anthers not hairy. Both these species are Californian.

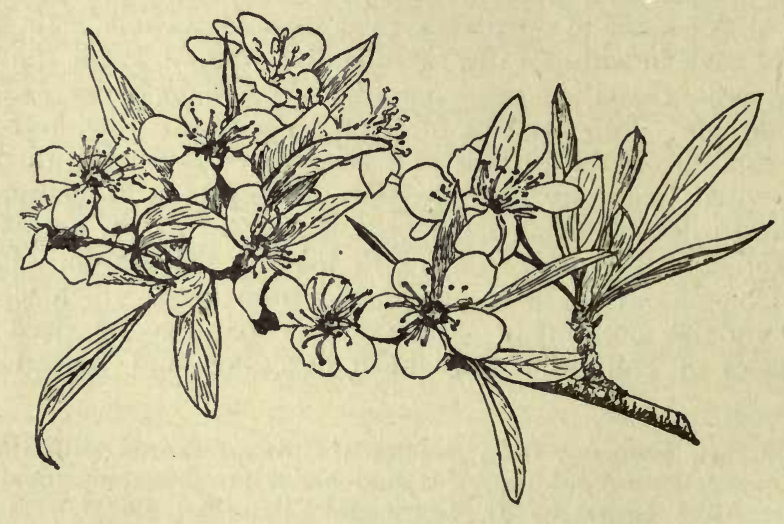

PeraphylLum raMosissimem.

\section{PERAPHYLLUM RAMOSISSIMUM, Nuttall. ROSACEA.}

(Bot. Mag., t. 7420.)

A deciduous shrub, 6 to Io $\mathrm{ft}$. high in some of its native haunts, of spreading habit; branchlets at first downy, ultimately smooth and bluish grey. Leaves $I$ tó 2 ins. long, about $\frac{1}{4}$ in. wide; narrowly oblanceolate, 
entire, tapering to a short stalk at the base, rather more abruptly to the point; downy beneath when young, becoming smooth. On the young shoots the leaves are alternate; on one-year-old shoots they are in tufts. Flowers in short-stalked corymbs, produced in April and May with the leaves from the joints of the previous summer's wood; there are from one to three flowers in the cluster, each $\frac{5}{8}$ in. diameter; calyx and flower-stalk silky; petals white, orbicular. Fruit a berry, $\frac{1}{3}$ to $\frac{1}{2}$ in. diameter, globose, yellowish, edible.

Native of Western N. America on dry hillsides; introduced to Kew in 1870 . It is closely allied to the Amelanchiers, but differs in the narrow entire leaves, longer calyx-tube, and rounded petals. In English gardens it must be regarded more as a curiosity (being the only species of its genus) than as an ornamental shrub, for it flowers indifferently and rarely bears fruit. It comes from regions (Colorado, Utah, California, etc.) where the summers are infinitely hotter and brighter than ours, and this summer heat, no doubt, is what it misses here. It is, however, quite hardy, and can be increased by layers.

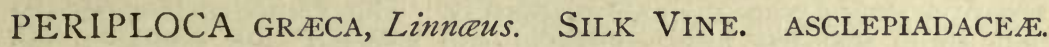

\section{(Bot. Mag., t. 2289.)}

A deciduous climber of vigorous, twining habit, reaching 20 to $30 \mathrm{ft}$. in height; stems brown, quite smooth, exuding a milky juice when cut. Leaves opposite, mostly oval or ovate; 2 to 4 ins. long, about half as wide; not toothed, pointed at the apex, rounded or wedge-shaped at the base, with prominent parallel veins merging into a marginal one; stalk $\frac{1}{4}$ to $\frac{1}{2}$ in. long. Cymes 2 or 3 ins. across, terminating short lateral shoots, produced in July and August, and consisting of eight to twelve flowers. Flowers $\mathrm{I}$ in. across, the corolla composed of five narrow, oblong segments, $\frac{3}{16}$ in. wide, rounded at the end and downy, especially at the edges, brownish purple inside, greenish yellow outside ; calyx $\frac{1}{4}$ in. across, with five ovate lobes. Seed-pods in pairs; cylindrical, 5 ins. long, $\frac{1}{4}$ in: wide, tapering to a point; full of seeds, each with a remarkable tuft of silky hairs at the end $1 \frac{1}{4}$ in. long.

Native of S.E. Europe (Greece, etc.); cultivated since the sixteenth century. It thrives in any soil of moderate quality, and requires a sunny position. Best propagated by division of the root in spring. It is a free-growing, hardy climber, interesting in its curious flowers, and may be used for pergolas, etc. The milk that exudes from the broken stems is poisonous, and in the south of Europe it is believed to be injurious to health to inhale the heavy odour of the flowers.

\section{PERNETTYA MUCRONATA, Gaudichaud. ERICACE\&. (Bot. Mag., t. 8023.)}

An evergreen shrub, 2 to $5 \mathrm{ft}$. high, spreading freely by suckers and forming ultimately a dense, low thicket; young branches thin and wiry, 
sometimes furnished with a few appressed, forward-pointing bristles or short down, but usually becoming smooth in a short time. Leaves alternate, dense upon the branches, ovate to oblong, very shortly stalked; $\frac{1}{3}$ to $\frac{3}{4}$ in. long, $\frac{1}{8}$ to $\frac{1}{4}$ in. wide; toothed and spiny-pointed, hard in texture. Flowers produced singly in the leaf-axils near the end of the shoot, in May. Corolla white, nodding, cylindrical, about $\frac{1}{4}$ in. long, five-toothed. Calyx five-lobed, green; stamens ten; flower-stalk $\frac{1}{4}$ in. long. Fruit a globose berry $\frac{1}{3}$ to $\frac{1}{2}$ in. diameter, containing many very small seeds; it varies in colour from pure white to pink, lilac, crimson and purple, or almost black.

Native of the region about the Straits of Magellan; introduced in 1828. This is one of the hardiest of South American shrubs, and is rarely severely injured by frost in the neighbourhood of London. Certainly it is one of the finest ornamental berry-bearing shrubs we have. Its berries attain their colour by early autumn, and remain on the branches through the winter and following spring. The Pernettya was long strangely neglected; but a great fillip to its cultivation was given by an exhibit in London made about 1882 by an Irish nurseryman, Mr T. Davis, who showed a number of remarkably beautiful varieties he had raised during the previous twenty or more years in his own nursery. The Pernettya is about the only shrub that has been cultivated and selected with a view to the beauty and variety of its fruit, apart from edible qualities. In Kew, the fruits are never touched by birds, although in some gardens they are said to be stripped in winter-possibly by pheasants.

The chief cultural requirements of Pernettya are a cool, moist bottom, and a peat soil, or a loam with which either peat or decayed leaves or both should be freely mixed. It likes full sunshine, and can be propagated by seeds, division, or cuttings. The last two are best for selected varieties. I have been told that it grows well on limestone.

Besides the various forms differing in colour of fruit, there is some variation also in the size and shape of leaf. The plant known in gardens as P. angustifolia is a narrower leaved form, but it is not the true P. ANGUSTIFOLIA, Lindley, a distinct and perhaps not hardy species.

\section{PEROWSKIA ATRIPLICIFOLIA, Bentham. LABIAT $Æ$.}

(Bot. Mag, t. 844I.)

A deciduous, semi-woody plant, 3 to $5 \mathrm{ft}$. high, with a sage-like odour; branches long, stiffly erect, covered with a white, close down. Leaves opposite, I to 2 ins. long, $\frac{1}{3}$ to $I$ in. wide ; rhomboidal or slightly obovate, tapered at both ends, coarsely toothed, grey-green, and slightly downy; stalk $\frac{1}{12}$ to $\frac{1}{3}$ in. long. Panicles terminal, 9 to I $2_{2}$ ins. long, produced in August and September, and composed of numerous slender, opposite, leafless spikes, 2 to 5 ins. long. Flowers beautiful violet-blue, $\frac{1}{3}$ in. long, produced in whorls ; corolla two-lipped, tubular at the base; calyx shaggy, with white hairs. The whole inflorescence is covered like the stem with a white, powder-like down, which brings the colour of the blossoms into greater prominence. 
Native of the Himalaya and Afghanistan. It covers large areas in the Chitral Valley, to the exclusion of other vegetation. Although woody at the base, the stems made during the summer die back considerably during winter. It should be planted in good loam, in a group of at least half a dozen plants, and then makes a strikingly pretty effect in late summer. A heat-lover, it should have the sunniest position available. The plants should be pruned over in spring, cutting off the dead portion and perhaps a little more. It rarely produces seed with us, but can easily be increased by July cuttings.

\section{PERTYA SINENSIS, Oliver. COMPOSIT⿸.}

A deciduous bush, 4 to $6 \mathrm{ft}$. high, with glabrous, slender, ribbed branches. Leaves alternate on the shoots of the year, ovate-lanceolate, long and taper-pointed; 2 to 3 ins. long, $\frac{3}{4}$ to $x$ in. wide; deep green, usually with one to three sharp teeth on each margin, but sometimes not toothed. On the year-old branches they are produced four to six together in rosette-like clusters from each joint, and are only half or less than half the size of the others, and without teeth. The leaves are either smooth or have some small bristles on the midrib; stalks $\frac{1}{8}$ in. or less long. Flower-heads pinkish purple, $\frac{1}{2}$ in. across, surrounded by a series of oval, membranous, overlapping bracts; they are produced from the centre of each leaf cluster on the year-old shoots, each on a slender, slightly bristly stalk about $\frac{1}{4}$ in. or more long. It flowers in June and July.

Native of Hupeh, China; discovered by Henry in $\mathrm{r} 889$, and introduced by Wilson in I $90 \mathrm{I}$ for Messrs Veitch. It is a neat shrub, but of more botanical than garden interest. The leaves have an intense, Quassia-like bitterness. The chief interest of this shrub is in its being an addition to the few shrubby composites that are hardy in cultivation.

\section{Petteria ramentacea, Presl. Dalmatian Laburnum. LEGUMINOSA.}

\section{(Cytisus Weldenii, Visiani ; Bot. Fieg. 39, t 40.)}

A deciduous, tree-like shrub of sturdy habit, 6 or $8 \mathrm{ft}$. high, closely allied to Laburnum and Cytisus. Leaves trifoliolate, with a slender stalk I to $I_{2}^{\frac{1}{2}}$ ins. long; leaflets oval or obovate, very shortly stalked, I to 2 ins. long, half as much wide, rounded at the apex, smooth. Racemes terminating short twigs of the year, erect, $\mathrm{I} \frac{1}{2}$ to 3 ins. long; flower-stalks short, hairy. Flowers fragrant, densely arranged, yellow, $\frac{3}{4}$ in. long, resembling those of a broom; calyx tubular, downy; standard petal erect. Seed-pod $1 \frac{1}{2}$ to 2 ins. long, pointed at the end, dark brown when ripe, containing five or seven seeds.

Native of Dalmatia and Montenegro; one may see it growing on the 
sides of the beautiful road that joins those two countries, between Cattaro and Cettinje. It was introduced in 1837 , but is not common.

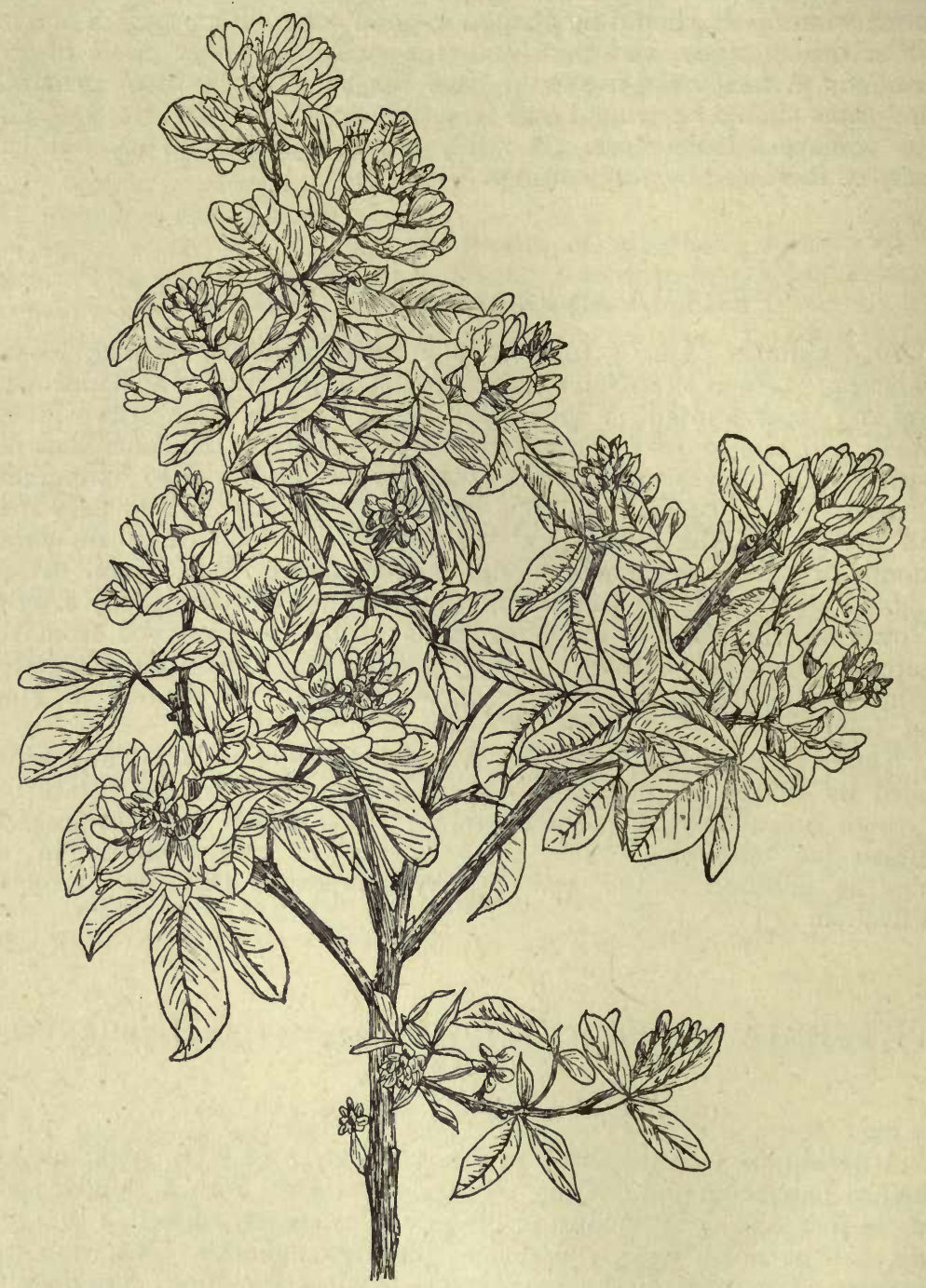

Petteria ramentacea.

It is perfectly hardy, and flowers regulariy in May and June, and ripens seeds which (like those of Laburnum) are poisonous. It differs from Laburnum in the longer tubular calyx and shortly stalked pods. 


\section{PHELLODENDRON. RUTACEA.}

A small genus of deciduous trees found in N.E. Asia, with opposite, pinnate leaves which give off a rather aromatic odour when crushed, and whose leaf-stalks, swollen at the base, completely hide the bud. The inner bark is yellow. Male and female flowers appear on different trees, but both are inconspicuous; the fruits are roundish, about the size of large peas, juicy and aromatic, with a black, tough skin. The chief attraction of the Phellodendrons is in their foliage and often picturesque habit. P. japonicum has fruited in this country, and the seed germinates freely. When seeds are not available, cuttings taken from the tree in July may be rooted in gentle heat; they should be made of short twigs with a "heel" of older wood. These trees are gross feeders, and like a deep rich loam.

\section{P. AMURENSE, Ruprecht.}

A deciduous tree, 20 to $40 \mathrm{ft}$. high, of stiff habit, with a trunk I ft. or more in diameter, corky-barked; young shoots smooth. Leaves pinnate, 10 to 15 ins. long, with five to eleven leaflets which are $2 \frac{1}{2}$ to $4 \frac{1}{2}$ ins. long, ovate or ovate-lanceolate, long-pointed, hairy only on the margin and at the base of the midrib, glossy green above. Panicles erect, 3 ins. high, $\mathrm{I}_{2}^{\frac{1}{2}}$ to 3 ins. wide ; few-branched. Flowers small, yellow green, $\frac{1}{4}$ in. long. Fruit about $\frac{1}{2}$ in. in diameter, black.

Native of Amurland, Manchuria, etc. Although in a wild state this tree is perhaps handsomer than P. japonicum, it is not so in cultivation here. Like many other trees from the same habitat, it is very liable to have its young shoots injured by late frosts. This induces excessive branching and an unnaturally dwarfed, bushy habit. It has been in cultivation at Kew for over thirty years. There is a fine tree $40 \mathrm{ft}$. high in Spath's nursery near Berlin ; and it thrives well in the Arnold Arboretum, Mass., but both these places have a more decided winter and a later spring than ours. It is distinguished from the following species by its bright green leaves and the silvery down on the winter buds.

\section{P. JAPONICUM, Maximowicz.}

A deciduous, bushy-headed tree, of stiff habit, 20 to $35 \mathrm{ft}$. high, its trunk 8 to 12 ins. in thickness. Leaves 10 to 15 ins. long, pinnate, with seven to fifteen leaflets, which are very downy beneath, dull green, and soon nearly or quite smooth above, broadly ovate, pointed, oblique at the base, 2 to 3 ins. long, with a short stalk. Panicle of male flowers about 4 ins. long, and 2 ins. wide, erect; the female one more slender. Flower $\frac{1}{4}$ in. across, yellowish green. Fruits orange-shaped, black, each nearly $\frac{1}{2}$ in. across, borne on an erect downy panicle.

Native of China and Japan; introduced about 1870. It is distinguished from the other species by the thick, greyish down beneath the leaflets, and by their broader proportions. A well-grown tree is handsome when in full leaf and fruit. It flowers in July.

P. CHINENSE, C. $K$. Schneider.-Amongst the new plants introduced by Wilson from W. China is a Phellodendron which has been given this name. It is allied to P. japonicum, and has the same dull-surfaced leaflets, but they are longer, more oblong-lanceolate, and the fruit clusters are only $\mathrm{I}$ to 2 ins. wide and 2 to $3 \frac{1}{2}$ ins. long, closely set to the main-stalk; ovary downy. (In 
japonicum and sachalinense the fruit clusters are distinctly branched and twice as wide.)

\section{P. SACHALINENSE, Sargent.}

A deciduous tree, with a taller, straighter trunk than either of the preceding species. Leaves 9 to 12 ins. long, with seven to fifteen leaflets, which are $2 \frac{1}{2}$ to $4 \frac{1}{2}$ ins. long, taper-pointed, ovate, downy beneath on the midribs, especially towards the base, dull green. Panicles glabrous, 2 to 4 ins. long. Flowers greenish yellow; females $\frac{3}{8}$ in. long ; males longer, with protruding stamens. Fruit $\frac{1}{3}$ in. diameter, black.

Native of Japan, Corea, Saghalien ; introduced to the Arnold Arboretum, Mass., in 1877 ; thence to Kew in 1904 . It promises from its quick growth and erect habit soon to outstrip the two older species. From japonicum it can be distinguished by its nearly smooth, longer, narrower leaflets, and glabrous inflorescence; and from P. amurense, which it more closely resembles in foliage, by its dull green leaves, and the brown-red down on the winter buds. Sargent also observes that the bark is thinner, and not corky.

\section{PHILADELPHUS. MOCK ORANGE, SyRINGA. SAXIFRAGACEA.}

A genus of deciduous shrubs most nearly allied to Deutzia, from which they chiefly differ in having four petals and four calyx-lobes, and twenty to forty stamens, whilst in Deutzia the petals and the calyx-lobes are in fives and the stamens ten; the hairs in Deutzia, too, are stellate, in Philadelphus they are simple. Leaves opposite, stalked, often threeor five-nerved. Flowers often strongly scented, mostly pure white, occasionally yellowish or blotched with purple at the base of the petals. The inflorescence is always terminal, but varies from a solitary flower to a raceme or panicle. Fruit usually four-valved, dry, and woody, splitting lengthwise to liberate the numerous seeds. Flowers are not infrequently seen with the flower-parts in fives. In the majority of species the leafbuds on the young shoots are completely hidden by the base of the leaf-stalk.

Perhaps no genus of shrubs present so many difficulties in the differentiation of its species as this. A few of them are well marked, like microphyllus, with small entire leaves; hirsutus, with exposed leafbuds and united stigmas; and mexicanus, with similar leaf-buds but divided stigmas; but the majority offer no really well-marked characters. The difficulty is further increased by free hybridisation under cultivation, so that now a large proportion of cultivated plants are not species at all, but garden hybrids.

These beautiful shrubs, commonly known as "Syringa"-a name which properly belongs to the lilacs - need no recommendation. They contribute to our gardens their most attractive pictures during June and July, when the great flowering time of shrubs is rapidly waning. They are useful in shrubberies where the vigorous ones can take care of themselves in competition with most things, and they also make very charming objects isolated on lawns. They grow best in a loamy soil, in a position at least moderately sunny, and are easily increased by cuttings made of 


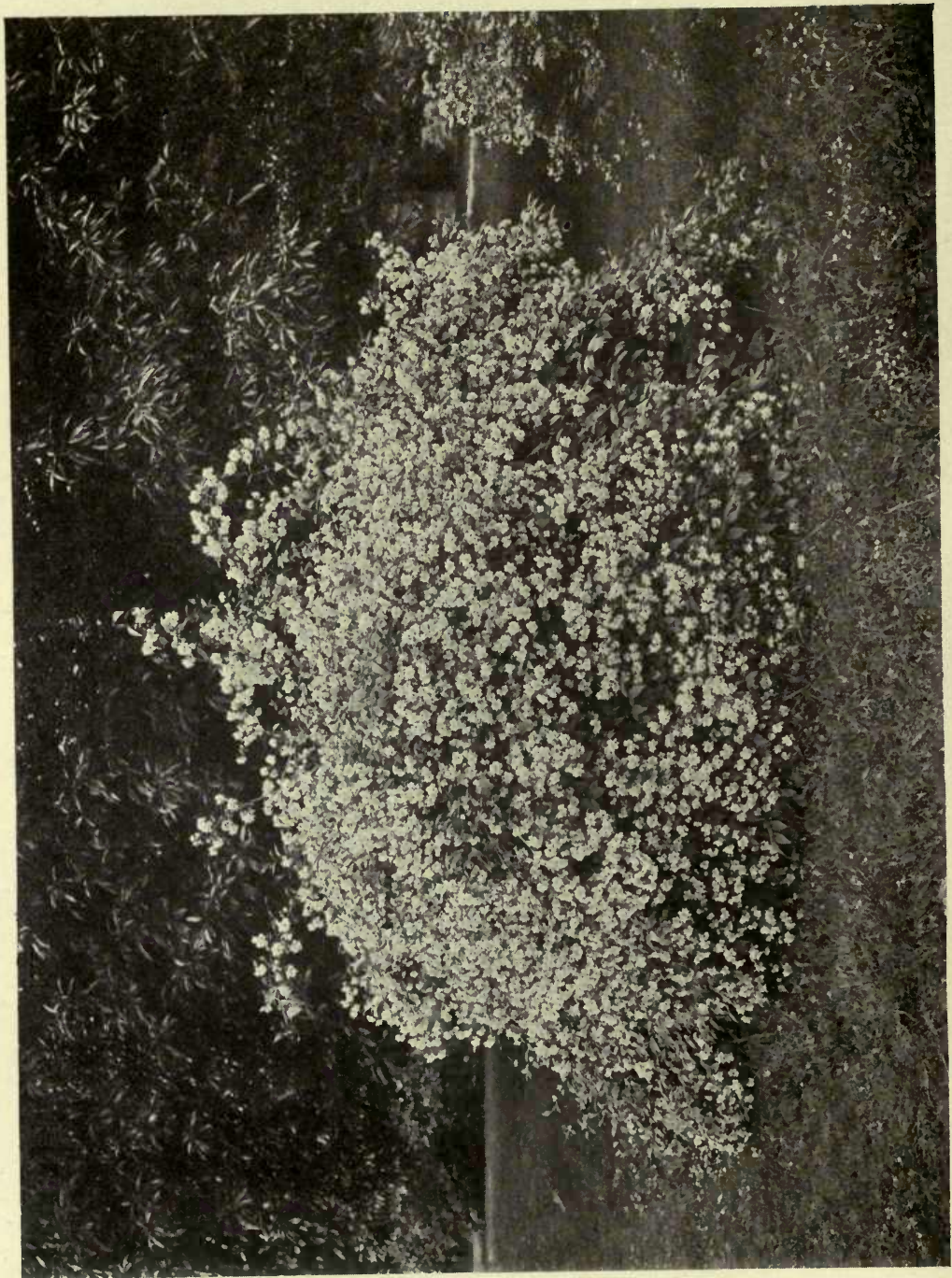


softish young wood placed in bottom heat. They flower on short lateral twigs which spring from the shoots made the previous year, so that whatever pruning has to be done should consist of taking out old branches that have flowered, and leaving the long vigorous shoots of the current year to provide the succeeding crop of blossom. No mere shortening back should be done unless from considerations of space. The following selection may be recommended:-microphyllus, Lemoinei, latifolius, insignis, Lewisii, "Virginal," and grandiflorus.

\section{P. CALIFORNICUS, Bentham.}

An elegant, pendulous-branched shrub up to ro ft. high, the young shoots smooth, the year-old bark peeling. Leaves three-nerved, ovate, $1 \frac{1}{2}$ to 3 ins. long, $\frac{3}{4}$ to 2 ins. wide; shortly and broadly toothed, or nearly entire (especially on the flowering twigs), either smooth or slightly downy beneath. Flowers I in. or less wide, pure white, scentless, produced numerously in panicles at the end of the shoot, often over twenty flowers in each. Petals oblongobovate; calyx smooth outside the lobes, downy on the margins, and near the apex inside ; styles united, stigmas separated.

Native of California. Although much confused with P. Lewisii, and sometimes regarded as a variety of it, this is really one of the most distinct of American species. On weak shoots its inflorescence may be only a simple raceme, but normally it is composed of several racemes, thus forming a true panicle. Flowers small and crowded. The base of the leaf-stalk does not hide the axillary bud, as it does in P. Lewisii.

\section{P. Coronarius, Linnceus. Mock Orange. Syringa.}

A shrub up to $12 \mathrm{ft}$. high, with erect stems, the year-old bark brown and peeling; young shoots ribbed. Leaves ovate to oval-lanceolate, broadly wedge-shaped or nearly rounded at the base, distantly toothed; $1 \frac{1}{2}$ to 4 ins. long, $\frac{5}{8}$ to 2 ins. wide; smooth except for a few hairs on one or both surfaces and on the leaf-stalk, which is $\frac{1}{6}$ to $\frac{1}{3}$ in. long. Flowers yellowish white, heavily scented, about $\mathbf{I}$ in. across, produced in terminal racemes of five to nine blossoms. Petals oval, ${ }^{3} \frac{3}{8}$ in. wide ; calyx-lobes downy at the margins, the tube and flower-stalk either smooth or slightly downy; styles separated at the upper third.

Native of S.E. Europe and Asia Minor; cultivated in Britain since the sixteenth century, probably before. It flowers in early June. This is the best known species of mock orange in gardens, but is not in the first rank. The fragrance of its flowers is pleasing out-of-doors, but may become too insistent if the plants are numerous or near sitting-room windows. The odour is too strong for the flowers to be enjoyed in a cut state indoors. Over three hundred years ago Gerard, the herbalist, wrote :-

"They have a pleasant sweete smell, but in my judgment troubling and molesting the head in very strange manner. I once gathered the flowers and laid them in my chamber window, which smelled more strongly after they had lain together a few howers, but with such a pontick and unacquainted savor that they awaked me from sleepe, so that I could not take rest till I had cast them out of my chamber."

Var. DIANTHIFLORUS and var. FLORE PLENO. Both double flowered; the former divarf.

Var. FOI.IIS AUREIS.-Leaves bright yellow, and very effective in spring, becoming duller after midsummer.

Var. NANUS.-Dwarf, and only 2 to $3 \mathrm{ft}$. high ; rarely seen in flower. 
Var. SALICIFOLIUS.-Remarkably distinct; leaves 2 to 4 ins. long, $\frac{1}{2}$ to $\frac{3}{4}$ in. wide, sparsely toothed; shy-flowering.

Var. VARIEGA'I US. - Leaves with a broad irregular border of creamy white.

\section{P. Delavayi, L. Henry.}

A shrub up to to $\mathrm{ft}$. high; young shoots slightly hairy. Leaves ovate, rounded or heart-shaped at the base, slender-pointed, toothed, dark green and hairy above, felted with whitish hairs beneath, I to 3 ins. long, $\frac{1}{3}$ to $I \frac{1}{2}$ ins. wide. Flowers fragrant, pure white, $\mathrm{I}$ to $\mathrm{I} \frac{1}{2}$ ins. across, produced in clusters of seven to eleven. Petals ovate, with tapered ends, often lobed or undulated at the margins, spotted or margined with purple at the back; calyx smooth outside, the lobes triangular-obovate, downy towards the tips inside ; style as long as the stamens, smooth ; stigmas separate. Fruit $\frac{1}{4}$ in. long.

Native of W. China; discovered and introduced to Europe by the Abbé Delavay in 1887. It flowered first at the Jardin des Plantes in 1890 . In many of its characters it resembles P. tomentosus, Wallich, but the leaves are more hairy above, and strongly felted beneath, and the fruits are smaller. A pretty fragrant species, producing its flowers in neat dense clusters in June.

The Philadelphus figured Bot. Mag., t. 8324, under this name is P. BRACHYBOTRYS var. PURPURASCENS, Koehne. It was introduced by Wilson about 1904. From P. Delavayi it differs in the much less hairy leaves, narrower flowers less numerous in the clusters, and in the more rounded petals.

\section{P. FALCONERI, Sargent.}

(Garden and Forest, 1895, fig. 68.)

A shrub up to so or $12 \mathrm{ft}$. high, forming a dense mass of slender, arching branches, which become a dark purplish brown the second year; young shoots quite free from down, slightly ribbed. Leaves ovate to ovate-lanceolate, broadly wedge-shaped at the base, slender-pointed, distantly and minutely toothed ; I $1 \frac{1}{4}$ to $3 \frac{1}{2}$ ins. long, $\frac{1}{3}$ to $1 \frac{5}{8}$ ins. wide ; smooth except for a few hairs on the margins and ribs beneath when young. Flowers delicately scented, pure white, $1 \frac{1}{2}$ to 2 ins. across, produced at the end of twigs 2 to 4 ins. long in racemes of three to seven flowers. Petals oblong-lanceolate, $\frac{1}{4}$ in. wide, slender-pointed ; calyx smooth, except for minute down at the margins of the lance-shaped lobes ; styles separated half-way down.

The origin of this mock orange is not known; it was first distinguished in Parson's nursery at Flushing, Long Island, U.S.A., and is thought probably to be a native of Japan. It is not one of the best of the genus, and although elegant in habit, is shy-flowering, at least in this country. Its long, narrow petals make it one of the best distinguished of the genus.

\section{P. GRANDIFLORUS, Willdenow.}

A shrub up to $15 \mathrm{ft}$. high, with the year-old bark peeling, young bark smooth, becoming chestnut brown. Leaves ovate to ovate-lanceolate, rounded or tapered at the base; slender-pointed, sharply toothed, prominently three- or five-nerved ; $1 \frac{1}{2}$ to 5 ins. long, $\frac{3}{4}$ to $2 \frac{1}{2}$ ins. wide ; smooth except for tufts of down in the vein-axils, and bristles along the chief veins. Flowers scentless, 2 ins. wide, pure white, produced at the end of leafy twigs, singly or in threes, and sometimes (in cultivated plants) in cymes of five flowers. Petals orbicular; calyx smooth outside, the lobes slenderly pointed, downy 
at the margins and near the points outside. Fruit top-shaped, $\frac{1}{2}$ in. long, gradually tapered to the stalk.

Native of the south-eastern United States; introduced in 1811 . It is a vigorous and beautiful mock orange, useful in flowering later than most species, usually into July. It is allied to P. inodorus (q.v.). P. I.AXUS, Schrader, is now usually regarded as a variety of $\mathrm{P}$. grandiflorus, differing in its narrower leaves, more densely covered beneath with appressed down. Flowers small, I to $1 \frac{1}{2}$ ins. across, often solitary, not scented. (P. grandiflorus var. laxus, Torrey.)

\section{P. HIRSuTUS, Nuttall.}

\section{(Bot. Mag., t. 5334.)}

A shrub up to 6 or Io $\mathrm{ft}$. high, of thin habit; young shoots covered with pale bristles; axillary buds not hidden by base of leaf-stalk. Leaves threenerved, ovate (broadly so on the barren shoots), rounded or tapered at the base, taper-pointed; margins set with irregular, coarse, outstanding teeth;

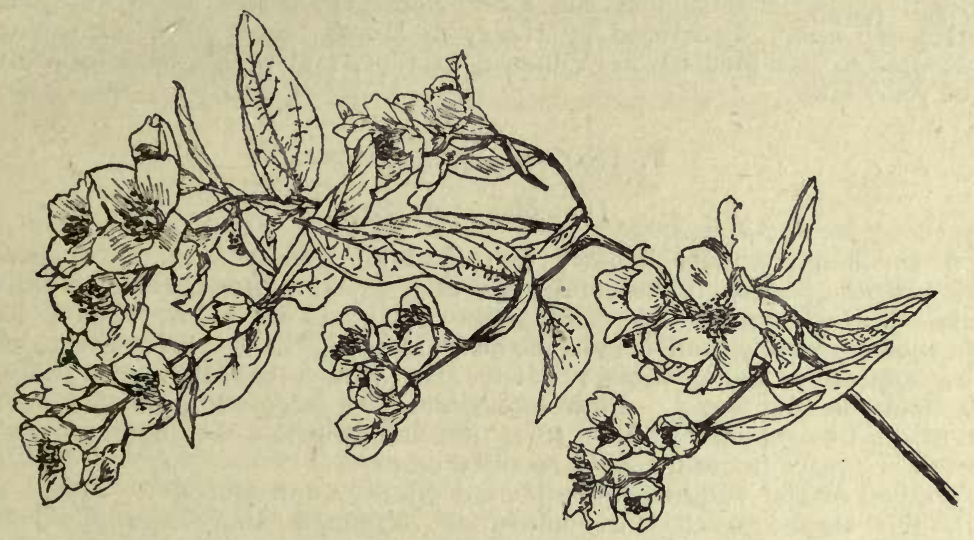

Philadilaphus incanos.

$\frac{3}{4}$ to 3 ins. long, $\frac{1}{2}$ to $\mathrm{I} \frac{3}{4}$ ins. wide ; downy and dull green above, shaggy beneath; stalk $\frac{1}{3}$ in. or less in length. Flowers 1 to $1 \frac{1}{4}$ ins. across, often solitary, sometimes in threes on lateral twigs I in. or less long, bearing as a rule one pair of leaves. Petals creamy white ; calyx shaggy, with triangular lobes ; stigmas united.

Native of the south-eastern United States; introduced in I820. Although one of the most easily recognised of a confusing genus, this species is one of the least attractive. Its flowers are scentless, and comparatively few. Its distinguishing marks are its exposed axillary buds, its short one- or threeflowered twigs, its dull shaggy leaves, etc., and united stigmas.

\section{P. InCANus, Koehne.}

A shrub up to $6 \mathrm{ft}$. or more high; young shoots more or less hairy. Leaves ovate or oval, broadly wedge-shaped or almost rounded at the base, slender-pointed, finely toothed; $2 \frac{1}{2}$ to 4 ins. long, $1 \frac{1}{4}$ to $2 \frac{1}{4}$ ins. wide on the barren shoots; those of the flowering twigs mostly I to 2 ins. long; 
upper surface set with sparse minute hairs, the lower one thickly covered with appressed pale, stiff hairs giving it a dull grey hue; stalk $\frac{1}{12}$ to $\frac{1}{2}$ in. long, bristly. Flowers white, fragrant, about I in. across, produced five to nine (usually seven) together on racemes about 2 ins. long, at the end of leafy shoots of about the same length. Petals roundish; style about the average length of the stamens, smooth, divided quite half-way down. Calyx and flower-stalk shaggy, like the under-surface of the leaves. Fruit top-shaped, $\frac{3}{8}$ in. long.

Native of Hupeh and Szechuen, China; discovered by Henry about 1887 ; introduced by Wilson in I904. The plants at Coombe Wood flower late-from middle to late July - and the species is desirable on that account. It is also charmingly fragrant with an odour like that of hawthorn. It differs from P. Magdalenæ in its glabrous style.

P. SERICANTHUS, Koehne.-This is, perhaps, most nearly allied to P. incanus, but has narrower leaves with only scattered hairs beneath and tufts of pale down in the vein-axils; there are also fewer teeth (three to nine) on each margin. The calyx is bristly hairy and the style is smooth and divided, as in incanus, and the other floral characters are very similar. Native of China ; discovered by Henry in Hupeh, about 1888 . Introduced to France by Mr Maurice de Vilmorin in 1897, and to England by Wilson three years later.

\section{P. INODORUS, Linnceus.}

\section{(Bot. Mag., t. 1478.)}

A shrub of compact habit, 4 to $6 \mathrm{ft}$. high, usually more in diameter; bark smooth, peeling the second year, of a chestnut-brown colour. Leaves Dvate, with a rounded base and a fine point; I $\frac{1}{2}$ to 4 ins. long, $\frac{3}{4}$ to 2 ins. wide; sparsely and inconspicuously toothed; dark glossy green, with pale, appressed hairs above; paler, also glossy beneath, with only a few hairs on the veins. Flowers solitary, not scented, produced at the end of short twigs, pure white, 2 to $2 \frac{1}{4}$ ins. across, petals overlapping, making the flower square in outline, with rounded corners.

Native of the south-eastern United States; introduced in 1738. For long this shrub was lost to cultivation, although many spurious plants were sold under the name. Through the Arnold Arboretum the true thing is again in gardens-one of the finest and most striking of the genus. It is distinguished by its glossy dark green leaves, and solitary, large, squarish flowers. Allied to $P$. grandiflorus, it differs in its less dentate, shorter pointed leaves and more abruptly pointed calyx.

\section{P. INSIGNIS, Carrière.}

\section{(P. "Souvenir de Billiard"; P. Billiardi, Koehne.)}

The origin of this handsome mock orange is not known, but it is probably a hybrid in whose origin P. grandiflorus has shared. It is a vigorous bush up to Io or $12 \mathrm{ft}$. high; young shoots smooth or nearly so ; bark of yearold ones not peeling. Leaves ovate or sometimes heart-shaped; $1 \frac{1}{2}$ to $3 \frac{1}{2}$ ins. long, $1 \frac{1}{4}$ to $2 \frac{1}{2}$ ins. wide; minutely and sparsely toothed, smooth and glossy green above, shaggy with pale hairs beneath. Flowers faintly perfumed, pure white, cupped, a little over I in. across, produced during late June in leafy terminal panicles of fifteen to over twenty blossoms. Petals roundish, $\frac{3}{4}$ in. long, overlapping; calyx and flower-stalk hairy outside ; style shorter than the stamens, divided just below the stigmas.

Although cultivated for over forty years, this is not much grown in 
gardens yet, although certainly one of the most attractive of mock oranges. It is distinct in its many-flowered inflorescences, combined with its glossy green leaves, its cupped flowers, and overlapping petals. It is useful in flowering well into July.

\section{P. LATIFolius, Schrader.}

(P. grandiflorus var. floribundus, Torrey.)

A robust shrub, ro to $20 \mathrm{ft}$. high, as much or more in diameter ; young shoots smooth, green ; the year-old shoots grey, not peeling. Leaves of the barren shoots oval or ovate, broadly tapered or rounded at the base, pointed, sparsely and irregularly toothed; 2 to 5 ins. long, about half as wide; dull and almost smooth above, downy beneath; with three or five prominent veins. Leaves of the flowering twigs smaller. Flowers pure white, $1 \frac{3}{4}$ ins. wide, not much scented; produced in June at the end, and in the uppermost leaf-axils of lateral twigs, usually seven or nine each. Calyx-lobes $\frac{2}{5}$ in. long, lanceolate, and, like the individual flower-stalks, downy.

Native of the S.E. United States ; introduced early last century. It is a fine free-flowering shrub, not uncommon in gardens, distinguished chiefly by the year-old wood not peeling, the numerous flowers in each raceme, and the downy calyx. One of the finest and noblest of mock oranges.

\section{P. LeMoINeI, Hort.}

A deciduous bush of graceful habit, round-topped, and $6 \mathrm{ft}$. or more high ; young stems covered with pale hairs. The leaves of the strong barren shoots of the year are ovate, with a rounded base, slender-pointed, with usually three to six coarse teeth on either margin about the middle; I to $2 \frac{1}{2}$ ins. long, about half as wide; dull green and with scattered hairs above, glossy and more hairy beneath. The leaves of the flowering shoots are about $I$ in. long, narrowly ovate, and with few or no teeth. Flowers pure white, very fragrant, I in. across, produced during June in the leaf-axils, and at the end of short lateral branchlets, three to seven on each.

A hybrid between microphyllus and coronarius raised by $\mathrm{Mr}$ Lemoine of Nancy, about I883. It represents one of the greatest successes ever achieved by the hybridiser's art, being the forerunner in gardens of a new and distinct type of Philadelphus, and the first of a most beautiful race of summer-flowering shrubs. By a system of annual pruning, P. Lemoinei may be kept comparatively dwarf. The flowers are produced along slender wands (the barren shoots of the previous year), giving wreaths of blossom often $1 \frac{1}{2}$ to $2 \mathrm{ft}$. long. To keep the plants dwarf, these should be cut clean out to the base as soon as the flowers are past, leaving only the crowd of young barren shoots springing from the base, and already, at the time of pruning, 6 to 12 ins. long. These will provide the following year's crop of blossom, and if too numerous to develop properly should be thinned. This system of culture gives enormous quantities of flower, and keeps the plants about $3 \mathrm{ft}$. high, thus rendering them suitable for positions where, left to grow naturally, they might be too big.

There are numerous varieties now in cultivation of the Lemoinei race: they have not, however, all the same origin :-

Single.-Avalanche, Gerbe de Neige, Fantaisie, Pavillon blanc.

Double.-Boule d'argent, Manteau d'hermine, Virginal. The last has flowers $1 \frac{1}{2}$ to 2 ins. across, pure white, in dense clusters. Given a first-class certificate by the Horticultural Society, 2oth June I9I I.

P. Lemoinei, as well as all these varieties, is very quickly and easily increased by cuttings of soft wood in June, placed in brisk bottom heat. 


\section{P. LeWISII, Pursh.}

A shrub up to $12 \mathrm{ft}$. high, of graceful, pendulous habit; year-old branches with greyish brown, non-peeling bark. Leaves broadly ovate to ovatelanceolate; $I \frac{1}{2}$ to 4 ins. long, I to $2 \frac{1}{2}$ ins. wide ; coarsely and distinctly toothed or, especially on the flowering twigs, entire; with scattered hairs beneath, still fewer above. Flowers five to nine, in racemes, scentless, white, $\mathbf{I} \frac{1}{3}$ in. across; petals oval ; calyx smooth outside like the flower-stalk, downy at the margins, and near the apex of the lobes inside; styles divided halfway down.

Native of Western N. America, from British Columbia to California ; introduced about 1823 . It is one of the most elegant and floriferous of all the taller species. P. GoRDonianus, Lindley, figured in the Botanical Register in 1839 (vol. 25 , t. 32), appears to be scarcely distinguishable from this species, but has larger flowers, $1 \frac{1}{2}$ to $1 \frac{3}{4}$ ins. across.

\section{P. MAGdalen $Æ$, Koehne.}

A shrub of bushy habit, up to $6 \mathrm{ft}$. high ; young shoots downy ; year-old bark peeling, smooth. Leaves ovate-lanceolate or narrowly oval, tapered at both ends, finely toothed except towards the base ; I to $2 \frac{1}{2}$ ins. long, $\frac{1}{2}$ to $\frac{7}{8}$ in. wide; furnished both above and below with pale, bristle-like, minute, appressed hairs, but especially dense and grey with them beneath. Flowers white, $\frac{3}{4}$ to I in. diameter, borne during early June in racemes of three to nine, sometimes more, blossoms; flower-stalk and calyx hairy, purplish; style downy towards the base, shorter than the stamens; stigmas separate; fruit top-shaped.

Native of Szechuen, China; introduced to France by $\mathrm{Mr}$ Maurice de Vilmorin in 1895, and sent by him to Kew in 1897 . It belongs to the same Asiatic group as Satsumi, sericanthus, and incanus. Neither of the two former has the close leaf-covering of bristle-like down of Magdalenæ; in addition, sericanthus differs in its smooth style, as does incanus also.

\section{P. MEXICANUS, Schlechtendahl.}

(Bot. Mag., t. 7600.)

A shrub up to $6 \mathrm{ft}$. high, with hairy young shoots; axillary buds not hidden by base of leaf-stalk. Leaves ovate-lanceolate, rounded at the base, slenderly pointed, sparsely toothed, three-nerved; I to $2 \frac{1}{2}$ ins. long, $\frac{1}{2}$ to I in. wide, with appressed pale hairs on both surfaces, but more abundant beneath. Flowers cupped, solitary (rarely in threes) at the end of short, leafy shoots; $1 \frac{1}{2}$ to 2 ins. across, strongly fragrant, yellowish white ; petals roundish, overlapping ; calyx hairy, the lobes sometimes toothed; flower-stalk very short hairy; style about as long as the stamens; stigmas separate.

Native of Mexico; and not hardy except against a warm wall. It is a handsome and distinct species, most nearly allied to P. hirsutus, and, like it, distinguished by the buds being exposed at the base of the leaf-stalk. P. hirsutus, however, has smaller white flowers and the stigmas are united. (See also californicus, with exposed buds.)

Var. COULTERI, "Rose Syringa."-Petals with a blotch of rich purple at the base. Neither species nor variety are very free-flowering in cultivation.

\section{P. Microphyllus, A. Gray.}

A deciduous shrub of densely bushy, rounded habit, ultimately about $4 \mathrm{ft}$. high; branchlets slender but rigid, downy; bark shining brown the first year, 
peeling and almost black the second. Leaves ovate, pointed, not toothed ; $\frac{1}{2}$ to $\frac{3}{4} \mathrm{in}$. long, $\frac{1}{4}$ to $\frac{1}{3}$ in. wide; bright green and almost smooth above, grey and covered with pale, appressed hairs beneath; stalk $\frac{1}{16}$ in. long. Flowers very fragrant, pure white, about $\mathrm{I}$ in. across ; produced in June, usually singly, at the end of iateral branches I to 2 ins. long, which spring from the joints of the previous year's shoots.

Native of Colorado, Arizona, etc. ; introduced by Prof. Sargent to Britain about 1883. It is quite distinct from all other cultivated species of Philadelphus in its small entire leaves and low, compact habit. The leaves in a state of nature are much more hairy than with us. The flowers have a strong pineapple-like odour, very pleasant in the open air. Although coming from

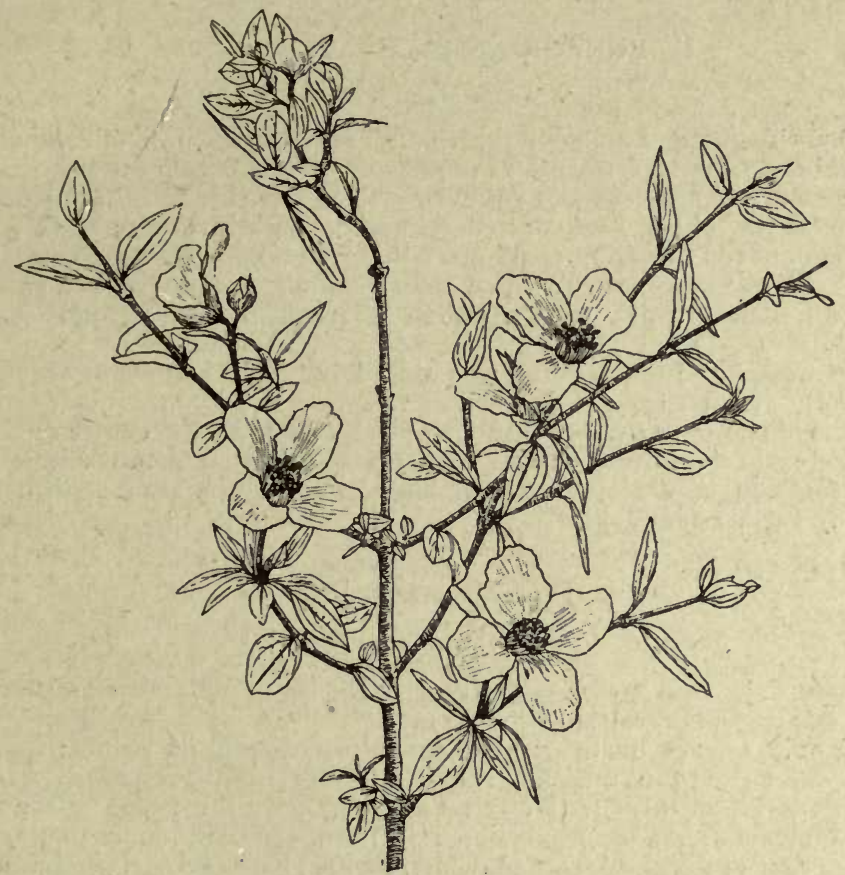

PHILADELPHCS MICROPHYLLÚS.

such a hot and sunny climate, it succeeds remarkably well in Britain, and flowers profusely. For small gardens and limited spaces it and its progeny are the most charming representatives of their kind. Hybridised with $P$. coronarius it has given birth to the beautiful race of Philadelphuses of which P. Lemoinei was the first to appear.

\section{P. PEKINENSIS, Ruprecht.}

A shrub up to $8 \mathrm{ft}$. high; young shoots smooth, the bark peeling off the year-old branchlets. Leaves ovate to ovate-lanceolate, slender-pointed, toothed; $\mathrm{I}_{2}^{\frac{1}{2}}$ to $3 \frac{1}{2}$ ins. long, $\frac{3}{4}$ to 2 ins. wide ; three-nerved, smooth or nearly so ; stalk and veins beneath purplish. Flowers yellowish, about $\mathbf{I}$ in. across, slightly fragrant, produced in racemes of five to nine (sometimes eleven). 
Petals oval, rounded at the top; calyx smooth outside, downy towards the points of the lobes inside; styles separated at the top only; flower-stalk smooth.

Native of N. China, Mongolia, Corea. It flowers in late May and June, and is distinct in its yellowish flowers, smooth leaves with purplish stalks, and smooth flower-stalks; but it is not one of the best, although free-flowering. Near it, and sometimes made a variety of it, is P. BRACHYBOTRYS, Koehne, introduced by $\mathrm{Mr}$ Maurice de Vilmorin from China in 1892 . This also has yellowish flowers but smaller, and the young shoots are furnished with a few stiff hairs; the leaves entire or indistinctly toothed. It forms a rounded, dense-habited bush. (See also p. 134.)

\section{P. PURPUREO-MACUlATUS, Lemoine.}

\section{(Bot. Mag., t. 8193.)}

A hybrid of the Lemoinei type, but more bushy in habit; young wood reddish brown, hairy. Leaves of the barren shoots broadly ovate or roundish, the base slightly heart-shaped; the largest $1 \frac{3}{4}$ ins. long, $1 \frac{1}{2}$ ins. wide ; one to three teeth on either side, dull dark green, slightly hairy; stalk $\frac{1}{6}$ in. long. The leaves of the flowering twigs are I in. or so long, with usually one tooth, or entire. Flowers fragrant, $1 \frac{1}{2}$ ins. across, solitary at the end of a short lateral branchlet, petals white, with a blotch of purplish rose at the base, opening in mid-June.

This beautiful Philadelphus was raised by $\mathrm{Mr}$ Lemoine of Nancy, and is apparently derived from P. mexicanus var. Coulteri (q.v.), crossed with one of the microphylla hybrids. It is the patch of colour in the centre of the flower, inherited from the former parent, that gives this Philadelphus its value and distinctness in gardens. Although hardy in ordinary seasons, it is not quite so hardy as P. Lemoinei.

\section{P. Satsumi, Siebold.}

\section{(P. acuminatus, Lange.)}

An erect shrub, 6 to $8 \mathrm{ft}$. high; young shoots smooth; bark of the previous year's shoots dark greyish brown, more or less split lengthwise, but not peeling off. Leaves ovate or oval, with long drawn-out points; those of the barren shoots 2 to 6 ins. long, half as wide, toothed, usually five-nerved, smooth above, downy in the vein-axils beneath; the leaves of the flowering shoots are smaller and proportionately narrower, and often quite or nearly entire. Flowers slightly scented, white, about $I_{4}^{\frac{1}{4}}$ ins. across, produced in erect racemes of five to eleven flowers; petals oval, rounded; style rather shorter than the stamens, the stigmas separate; calyx-lobes ovate, smooth outside or nearly so.

Native of Japan; introduced in $185 \mathrm{I}$.

\section{P. TOMENTOSUS, Wallich.}

A shrub 6 or $8 \mathrm{ft}$. high; young shoots smooth, or slightly hairy when quite young only. Leaves $1 \frac{1}{2}$ to 4 ins. long, $\frac{3}{4}$ to 2 ins. wide; oval or ovate, with long slender points and a rounded or tapered base, unevenly toothed ; dark green and hairy above, especially when young, grey and felted bentath; stalk $\frac{1}{5}$ to $\frac{2}{5}$ in. long. Petals oval, rounded at the end; calyx smooth outside, downy inside : style about as long as the stamens; stigmas separate.

Native of the Himalaya ; introduced, according to Loudon, in 1822 . It is often regarded as a variety of $\mathrm{P}$. coronarius, but is amply distinguished from 
it by the grey-felted under-surface of the leaves. It is more nearly related to r. Delavayi (q.v.).

\section{P. Zeyheri, Schrader.}

A deciduous shrub of very vigorous spreading habit, up to $8 \mathrm{ft}$. high, considerably more in width; bark deep brown, slightly peeling; young shoots smooth. Leaves broadly ovate to lanceolate, tapered at the base, slenderpointed, varying from coarsely toothed to nearly entire; $2 \frac{1}{2}$ to 4 ins. long, $\frac{3}{4}$ to 2 ins. wide; smooth above, downy beneath along each side of the midrib and chief veins, with occasional hairs between. Flowers pure white, $1 \frac{1}{2}$ to $1 \frac{3}{4}$ ins. across, produced during June in a terminal corymb of three to seven blossoms (sometimes solitary). Petals oval; style distinctly longer than the stamens; calyx smooth, with slender lobes $\frac{1}{2}$ in. long.

A hybrid of unrecorded origin, but with grandiflorus probably as one parent. The flowers have little or no fragrance, and the sepals are acuminate, as in that species. The young shoots are apt to be killed back in winter, which may be due to their sappy vigour. The plant is very distinct in its comparatively low, spreading habit, but it blossoms poorly, and is of inferior quality.

\section{PHILESIA BUXIFOLIA, Lamarck. LILIACE Æ.} (Bot. Mag., t. 4738.)

A dwarf evergreen shrub, said to be $3 \mathrm{ft}$. high in its native country, but usually 6 to $\mathbf{I} 2$ ins. high in this; stems erect, bearing alternate, angled, smooth branchlets. Leaves alternate, stiff and hard, dark green above, glaucous white beneath; about $I_{2} \frac{1}{2}$ ins. long, $\frac{1}{4}$ to $\frac{3}{8}$ in. wide, but made narrower by the reflexed margins, quite smooth; midrib prominent beneath; stalk $\frac{1}{8}$ in. long. Flowers solitary, nodding, terminal; 2 ins. long, rich rosy crimson; petals three, oblanceolate, pointed, not expanding, and thus giving a tubular form to the flower. Calyx of three oblong sepals about $\frac{1}{2}$ in. long, appressed to the petals. Fruit a roundish berry.

Native of S. Chile; introduced by W. Lobb in 1847 . It is one of the remarkable group of shrubs allied botanically to the lilies, to which Ruscus, Smilax, Lapageria, etc., belong. It is strikingly handsome, and quite distinct in its long red flowers from any other cultivated plant except Lapageria, and that is a climber. Philesia is grown out-of-doors in several parts of the country, and should be planted in peaty soil. In October I9II I saw it flowering on the rockery in Messrs Cunningham \& Fraser's nursery at Edinburgh. It thrives in Ireland, Devonshire, and Cornwall, etc. Propagated by division. Philageria Veitchil, Masters, is a hybrid between this and Lapageria rosea.

\section{PHILLYREA. OLEACE $E$.}

A group of evergreen shrubs or small trees, the hardy ones of which are natives of the Mediterranean region, and of the country south-east of the Black Sea. They are nearly allied to Osmanthus, and have opposite 
leaves, toothed or entire, and small white or greenish flowers borne in clusters in the leaf-axils of the previous year's growths. Calyx and corolla four-lobed; stamens two. Fruit a roundish oval, mostly oneseeded drupe.

They are all easily cultivated, and thrive in, any soil that is of average quality. Cuttings made of the current season's wood in July take root readily. Except $\mathrm{P}$. decora, they bear clipping well.

\section{P. ANGUSTIFOLIA, Linnceus.}

A shrub of dense habit, up to ro $\mathrm{ft}$. high, and occasionally more in diameter; branches minutely downy and slightly warted. Leaves linear, 1 to $2 \frac{1}{2}$ ins. long, $\frac{3}{16}$ to $\frac{3}{8}$ wide; tapering towards both ends, rarely toothed, dark dull green; smooth on both surfaces. Flowers fragrant, dull white, produced during May and June in short axillary clusters $\frac{1}{2}$ in. or less long; flower-stalks minutely downy. Fruit blue-black, roundish-oval, $\frac{1}{4}$ in. long.

Native of N. Africa and S. Europe; cultivated in England before 1597. It is a neat, quite hardy evergreen, without any striking features, but easily distinguished from all the rest by its entire, long, narrow leaves.

Var. ROSMARINIFOLIA, Aiton (P. rosmarinifolia, Miller).-Leaves narrower and smaller than those of the type, $\frac{1}{8}$ to $\frac{3}{16}$ in. wide, and of a greyer, rather glaucous shade.

\section{P. DECORA, Boissier.}

\section{(P. Vilmoriniana, Boissier, Bot. Mag., t. 6800; P. laurifolia, Hort.)}

A rigidly branched shrub, 5 to $10 \mathrm{ft}$. high, more in diameter; young shoots slightly warted, but not downy. Leaves pointed, narrowly oval or oblong, 2 to 5 ins. long, $\frac{1}{2}$ to $1 \frac{3}{4}$ ins. wide, tapering at the base ; of firm, almost hard texture ; very dark, glossy green above, paler below. They are either quite entire, or there are a few scattered teeth on the margins; stalk $\frac{1}{2}$ in. or less long. Flowers about $\frac{1}{4}$ in. across, pure white, crowded in dense, axillary clusters, produced during April. Fruit oval, $\frac{1}{2}$ in. long, borne on slender stalks $\frac{1}{2}$ in. long, ripe in September, first reddish, then blackish purple.

Native of Lazistan, near the south-eastern coast of the Black Sea ; discovered in 1866 by Balansa, and introduced to France by seeds the same year. The first record I have of its flowering in this country is at Mr Waterer's nursery, Knap Hill, in April 1883. It is the most striking of the Phillyreas, and very distinct from the others in size and shape of leaf; its flowers, too, are of a purer white. Owing to its being grafted on privet (an evil practice) in the early days of its cultivation, many of the plants were short-lived, and the reputation of the plant suffered. Raised, from seeds or cuttings, it is quite satisfactory. It is very hardy. There is some variation in the foliage, one form being much narrower in leaf.

\section{P. LATIFOlia, Linnœus.}

Of the three commonly grown Phillyreas from S. Europe, viz., this, P. media, and P. angustifolia, the name latifolia is given to the one with largest and broadest leaves. P. angustifolia is distinct enough, but I cannot see that any definite distinction between P. latifolia and P. media can be made; there appears to be no gap between the largest leaves of P. media and the smallest ones of P. latifolia; nor is there any other character discernible, as they grow in this country, sufficient to separate them. The largest leaves of what I regard as P. latifolia are ovate or roundish ovate; 2 to $2 \frac{1}{2}$ ins. long, 
I to $1 \frac{1}{2}$ ins. wide ; pointed, sharply toothed, rounded or even slightly heartshaped at the base; the smaller ones are often oval, indistinctly toothed, broadly tapered at the base. Young wood and flower-stalks minutely downy. Flowers dull white, in short axillary clusters. Fruit blue-black, roundish or orange-shaped, scarcely $\frac{1}{4}$ in. long. It is sometimes a small tree $15 \mathrm{ft}$. or more high.

Var. ILICIFOLIA (P. spinosa, Miller).-A form with strongly toothed leaves, $I$ to $1 \frac{1}{2}$ ins. long; ovate and rounded at the base.

Native of S. Europe and N. Africa ; cultivated in England in the sixteenth century.

Of P. MEDIA, Linnaus, there is little to be added to what is said above. It is scarcely specifically distinct from latifolia, but the plant to which the name is attached has smaller leaves, ovate or oval, $\frac{1}{2}$ to $1 \frac{1}{2}$ ins. long, slightly

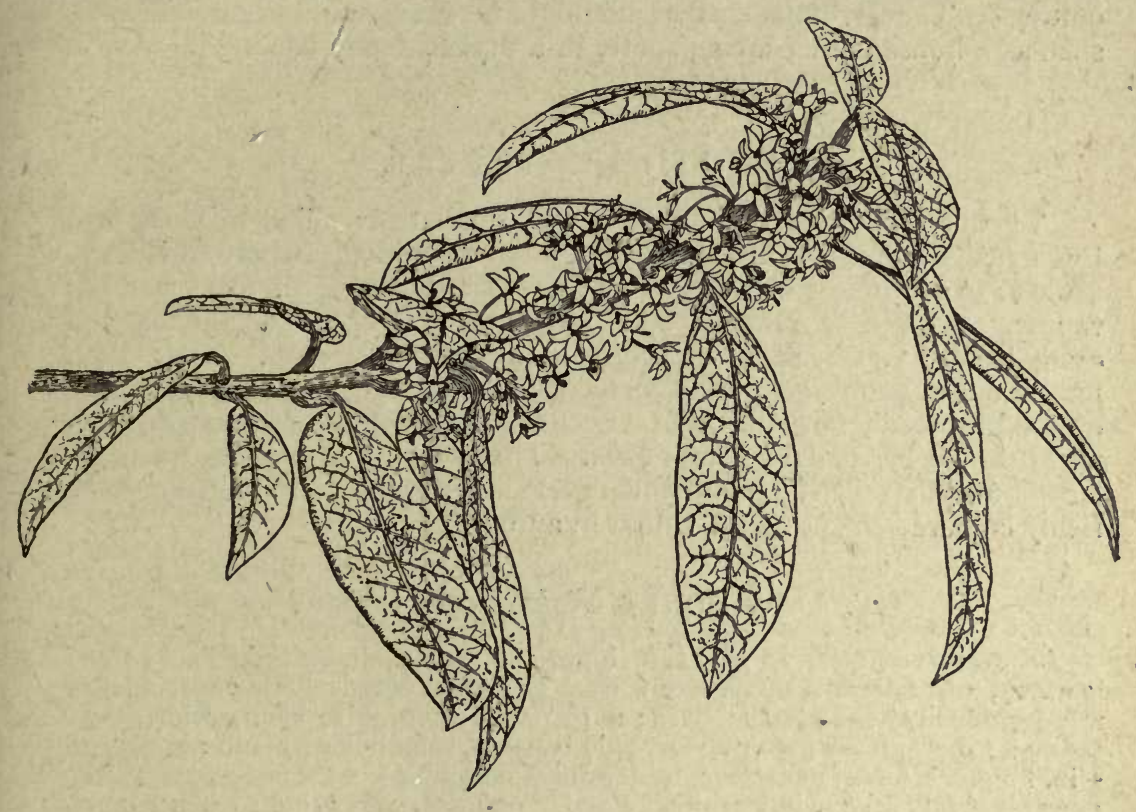

Phillyrea DECORA.

and bluntly toothed (not sharply as in latifolia), or quite entire. The form known as BUXIFOLIA has small, almost wholly entire leaves. There is a good bush 6 or $8 \mathrm{ft}$. high in Messrs Paul \& Son's nursery, Cheshunt.

PHLOMIS FRUticosa, Linnaus. JERUSALEM SAGE. LABIATA:. (Bot. Mag., t. I843.)

A vigorous evergreen shrub; branchlets soft, herbaceous, stout, square, thickly covered with grey, branched hairs. Leaves opposite, dull green, wrinkled, and with prominent veining like common sage; 
- 2 to 5 ins. long, $\mathrm{I} \frac{1}{2}$ to $\mathrm{I} \frac{3}{4}$ ins. wide, ovate-lanceolate; covered with branched hairs, sparsely above, thickly beneath; stalks $\frac{1}{4}$ to I in. long. Flowers stalkless, bright yellow, crowded at the leaf-bases in two dense clusters which together form a circular tier 2 ins. across. Corolla $I_{4}^{1}$ ins. long, two-lipped, the upper lip hood-shaped; calyx green, funnel-shaped, hairy, with five projecting narrow teeth at the top.

Native of S: Europe; cultivated in England since the sixteenth century. It is only half hardy near London, and succumbs in severe winters. The flowers develop in autumn, and are very bright and interesting, forming curious, short, crowded clusters. The foliage is like that of a giant sage, but is weakly scented. The plant is seen at its best in the south-western counties and Ireland. Easily propagated by cuttings. The Jerusalem sage should have some sunny sheltered spot, such as a house corner facing south, or a dryish, sunny bank.

\section{PHOTINIA. ROSACE .}

A genus of North Asiatic shrubs and small trees allied to Pyrus and Cratægus. The leaves are simple and often somewhat leathery in texture. Flowers in corymbose clusters, white; petals and calyx-lobes five; stamens twenty. Fruit red, haw-shaped. Whilst P. villosa is deciduous and quite hardy, P. serrulata is evergreen and rather tender. They both like a warm, loamy soil, not too heavy and close. Propagation is best effected by seeds, but failing them cuttings of half to nearly ripened young wood should be tried in gentle heat. The practice of grafting them on hawthorn can only be condemned. P. serrulata has its foliage most richly coloured in spring, $\mathrm{P}$. villosa in autumn.

\section{P. DAVIDSONIE, Rehder and Wilson.}

An evergreen tree, 20 to $45 \mathrm{ft}$. high, the young shoots reddish. Leaves leathery, oblanceolate to narrowly oval, tapered towards both ends, usually more gradually towards the base; 2 to 6 ins. long, $\frac{3}{4}$ to $1 \frac{3}{4}$ ins. wide, finely toothed; dark glossy green above, pale beneath, soon quite smooth; stalk $\frac{1}{4}$ to $\frac{1}{2}$ in. long. Flowers numerous, in terminal corymbs 3 or 4 ins. across ; each flower scarcely $\frac{1}{2}$ in. wide, white. Petals roundish, spreading; calyx funnelshaped, with broadly triangular lobes, downy like the flower-stalks. Fruit roundish, orange-red, smooth, about $\frac{1}{3}$ in. long, the calyx-lobes persisting and incurved.

Native of W. Hupeh, China ; discovered in 1900 by Wilson, who describes this as one of the handsomest evergreen trees in Central China, where it is frequently planted round shrines and tombs. It is most closely allied to $P$. serrulata, but is well distinguished by its shorter-stalked leaves and downy inflorescence; the fruit and flowers are also smaller in P. serrulata. It appears to be hardy.

\section{P. SERrulata, Lindley.}

An evergreen shrub, or a tree ultimately 30 to $40 \mathrm{ft}$. high in favoured situations; branchlets stout, smooth. Leaves oblong, very firm and leathery, reddish when young, 4 to 8 ins. long and from $1 \frac{1}{2}$ to $3 \frac{1}{2}$ ins. wide, rounded 


\section{PHOTINIA-PHYGELIUS}

or tapering at the base, shallowly toothed, perfectly smooth on both surfaces; the stalk, however, which is from I to $1 \frac{1}{2}$ ins. long, is clothed with whitish hairs which also extend up the midrib when young. Flowers white, $\frac{3}{8}$ in. in diameter, produced in April and May in large, terminal corymbose panicles 4 to 6 ins. through. Fruit about the size of common haws, red.

Native of China; first introduced by Captain Kirkpatrick of the East India Co., in 1804. Where it thrives, this is undoubtedly one of the finest evergreens ever introduced, but is only seen at its best in the southwestern counties of England, etc. At Kew it is hardy in all but exceptional winters, but every plant was cut to ground-level by the frosts of February 1895, springing up again a few months later. It thrives remarkably well, in Cornwall, where at Enys and at Pengreep there are trees $35 \mathrm{ft}$. high. It is also very fine at various places in Co. Cork, Ireland. It is most beautiful in spring, when the white flowers are associated with the rich brownish red, shining young leaves, but near London the latter are apt to be spoilt by late spring frosts.

Var. ROTUNDIFOLIA has shorter, proportionately broader leaves.

\section{P. villosa, De Candolle.}

\section{(P. variabilis, Hemsley.)}

A deciduous shrub or a small tree. Leaves obovate, or ovate-lanceolate, $I \frac{1}{2}$ to $3 \frac{1}{2}$ ins. long, $\frac{3}{4}$ to $I \frac{1}{2}$ ins. wide; the apex drawn out into a long fine point, tapered at the base, finely and regularly toothed, each tooth glandtipped. Flowers white, in corymbs 1 in. long and $1 \frac{1}{2}$ ins. wide, produced in May ; stalks conspicuously warted; each flower about $\frac{1}{2}$ in. in diameter. Fruit the size and shape of common haws, red. The foliage, too, is often a beautiful red in autumn.

Native of Japan, China, and Corea. It is a variable plant especially in the amount of down on the leaves, young shoots, and flower-stalk. In the typical villosa the leaves are, as a rule, more obovate, and all the younger parts of the plant hairy; the flower-stalk is felted with grey down, and the fruit is about $\frac{1}{3}$ in. long. In

Var. LÆVIS, Dippel (P. lævis, De Candolle), the leaves are usually longer pointed, and like the branchlets and flowers, smooth or only slightly downy; the brilliant red fruits are $\frac{1}{2} \mathrm{in.} \mathrm{long.} \mathrm{These} \mathrm{two} \mathrm{forms,} \mathrm{whilst} \mathrm{distinct}$ enough in themselves, are united by various intermediate forms.

This Photinia is sometimes met with as "Pourthiæa arguta," but the true plant of that name is not, so far as I know, in cultivation, and is possibly not hardy. It is from the Khasia Hills, India.

\section{PHYGELIUS CAPENSIS, E. Meyer. SCROPHUlariace e.}

A shrub up to 6 or $7 \mathrm{ft}$. high in the warmest parts of our islands but of semi-herbaceous habit near London; shoots erect, stout, angled, very pithy, smooth. Leaves opposite, smooth, ovate; $1 \frac{1}{2}$ to 5 ins. long, $\frac{3}{4}$ to $I_{4} \frac{3}{4}$ ins. wide; finely blunt-toothed, rounded or slightly heart-shaped at the base, tapered but blunt at the point; stalk $\frac{3}{4}$ to $1 \frac{1}{4}$ ins. long, winged at its junction with the stem. Flowers in a terminal, erect panicle 12 ins. high and 6 ins. through; corolla tubular, I to $1 \frac{1}{4}$ ins. long; $\frac{1}{6}$ in. wide, five-lobed at the mouth, scarlet, yellowish in the throat. 
Native of S. Africa; introduced about 1850 . The finest specimen I have seen is in Mr Osgood Mackenzie's garden at Inverewe, in Rossshire, which in 1906 was a bush $7 \mathrm{ft}$. high. At Kew it dies to the ground every winter, and needs some light covering in severe frost. It grows about $2 \mathrm{ft}$. high during the summer, and flowers in September. The best place for it is some warm, sunny corner, such as the angle formed by two walls opening south. The shade of red in the flowers varies considerably in depth. Easily increased by cuttings in heat.

\section{PHYLLODOCE. ERICACEA.}

A small group of some five or six species of dwarf evergreen shrubs, similar in habit to the heaths, but with stouter stems and larger leaves, Leaves alternate, linear. Flowers bell-shaped or pitcher-shaped, slenderstalked, produced in terminal racemes, umbel-like clusters, or even solitary. Corolla and calyx five-parted; stamens usually ten; seed-vessel a dry, subglobose, five-celled capsule, carrying numerous small seeds.

The genus has by some botanists been united with BRYANTHUS, but the general practice now is to keep them apart and to confine Bryanthus to one species, B. Gmelini, Don, on which the genus was originally founded. It has four-parted flowers, and a deeply divided corolla, and is a dwarf, moss-like shrub from Kamtschatka; etc.; not, so far as I am aware, in cultivation at present.

With the exception of $\mathrm{P}$. empetriformis, these little shrubs require rather special care in the south of England. They inhabit cool, moist altitudes and latitudes, and dislike dryness in the air or at the root. A cool, moist nook on the lower levels of the rock garden, where the soil is peaty, is as good a place as any. Propagation is effected in the same way as recommended for Erica.

\section{P. AMABILIS, Stapf.}

(Bot. Mag., t. 8405.)

An evergreen shrub about 4 to 8 ins. high, forming compact tufts of erect, stiff branches; young stems minutely downy, with erect, gland-tipped bristles interspersed. Leaves closely set on the branches (about twenty to the inch), linear, toothed, rounded at the end; $\frac{1}{4}$ to $\frac{3}{8}$ in. long, $\frac{1}{16}$ in. or less wide; smooth and glossy dark green above, midrib white beneath with minute down. Flowers on slender, erect, glandular-downy stalks $\frac{1}{2}$ to $\mathrm{I}$ in. long, which are produced singly in from three to seven of the terminal leaf-axils in early May. Corolla open bell-shaped, about $\frac{1}{4}$ in. long, rather more wide, with shallow, rounded lobes; white tinged with pink on the lobes; sepals about $\frac{1}{12}$ in. long, pointed, ciliate. Stamens and style enclosed within the corolla. Seed-vessel globose, depressed at the top where it is roughened with short, hardened glandular hairs.

This delightful little shrub, one of the daintiest of the heath family, is, no doubt, a native of Western N. America, but its origin is not definitely known. It flowered at Kew in I9II, but owing to some misplacement of labels its history was lost. It appears to be most closely allied to P. intermedia, a species not at present in cultivation 


\section{P. BREWERI, A. A. Heller.}

(Bot. Mag., t. 8I46; Bryanthus Breweri, A. Gray.)

A dwarf evergreen shrub, 6 to 12 ins. high, of tufted habit; young shoots erect, very leafy. Leaves almost stalkless, linear, blunt; $\frac{1}{2}$ to $\frac{3}{4}$ in. long (shorter immediately beneath the raceme), $\frac{1}{16}$ to $\frac{x}{12}$ in. wide ; the margins decurved; dark glossy green. Flowers produced during May in a terminal raceme I to 3 ins. long, each flower on a slender, glandular stalk about $\frac{1}{2}$ in. long, from the axil of a short, leaflike bract. Corolla bright purplish rose, $\frac{1}{2}$ in. diameter, saucer-shaped, the five lobes ovate and rounded at the apex; stamens protruded. Calyx half as wide as the corolla, with five

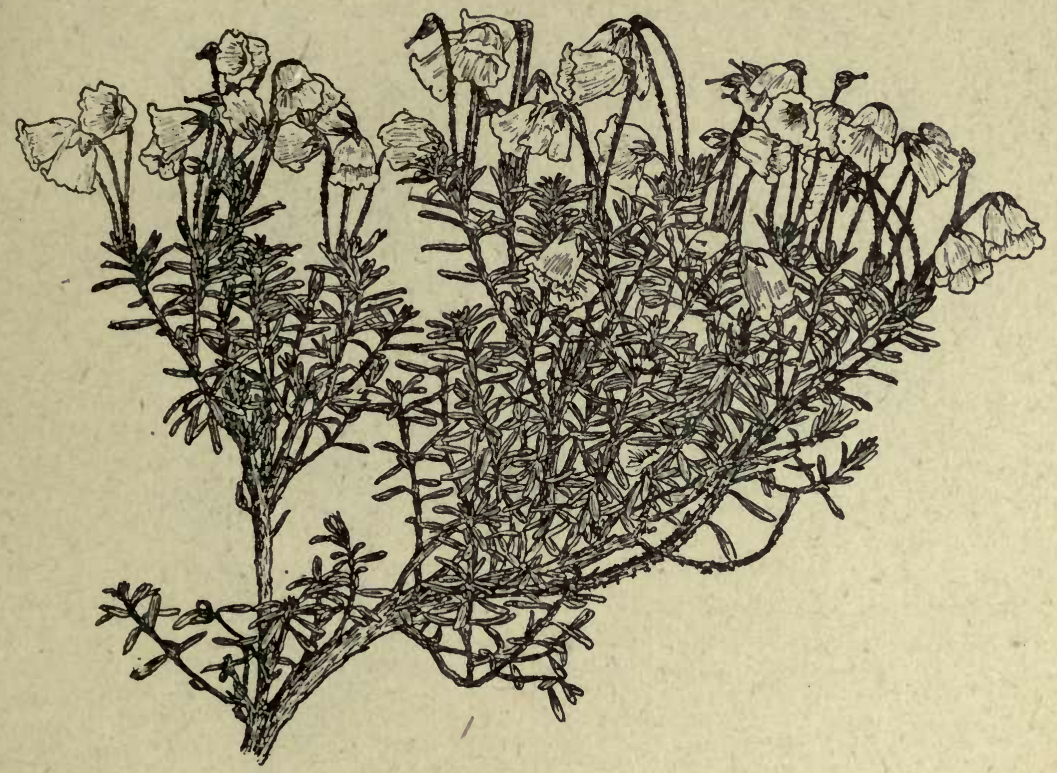

Phyllodoce amabilis.

ovate, pointed, ciliate, but otherwise smooth lobes. Seed-vessel globose, $\frac{1}{6}$ in. in diameter.

Native of California, and found on the Sierra Nevada at 9000 to $10,000 \mathrm{ft}$. altitude; first discovered by $\mathrm{Mr}$ W. H. Brewer about $\mathrm{I} 862$. In some places it is said to cover extensive areas. It is a charming rock garden plant, delighting in a moist, peaty soil and a cool spot. The racemes vary considerably in length and in the density of the blossoms. The expanded corolla, elongated raceme, and protruded stamens distinguish it from the other three cultivated species, and bring it nearer than any to the true Bryanthus.

\section{P. CAERULA, Babington.}

(Andromeda cærulea, Linnoeus; Bryanthus taxifolius, A. Gray.)

A dwarf, much-branched evergreen shrub about 6 ins. to 9 ins. high, of tufted habit. Leaves linear, blunt, much crowded; $\frac{1}{4}$ to $\frac{1}{2}$ in. long, $\frac{1}{16}$ in. or 
less wide; not recurved at the margins, but minutely toothed there; dark glossy green. Flowers produced in June and July singly on a slender, glandular stalk up to $I \frac{1}{2}$ ins. long, or in an umbel of three or four flowers. Corolla bluish purple, pitcher-shaped, nodding, five-toothed, $\frac{1}{3}$ in. long. Calyx with five lance-shaped, downy lobes; stamens ten, and, like the style, included within the corolla.

Native of high alpine summits and high latitudes in Europe, Asia, and N. America. It is found in Perthshire. Under cultivation it succeeds better in the north of England and in Scotland than in the south, where the summers are too dry and hot for it, and cause its foliage to drop prematurely. It is, consequently, uncommon. In the Botanic Garden of Edinburgh and in nurseries about that city it thrives very well. It should be planted in peat and

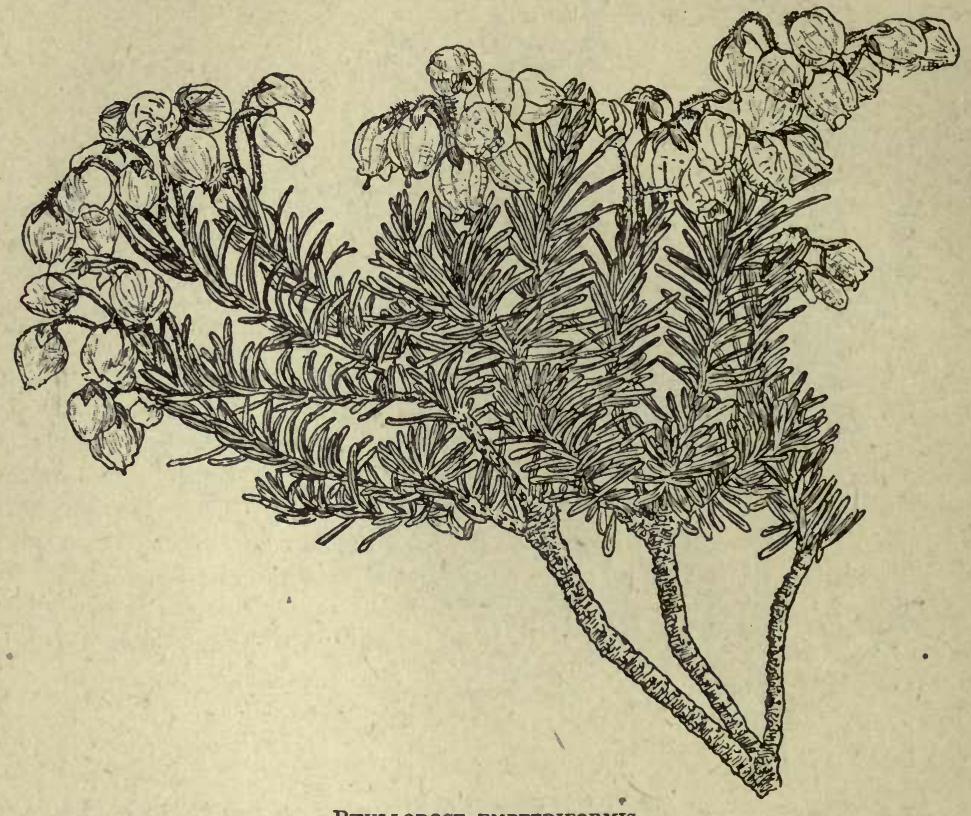

PHYLLODOCE EMPETRIFORMis.

sphagnum moss mixed, and have a surfacing of the latter also. One of the most interesting of British plants, and distinct in this genus because of its colour.

\section{P. EMPETRIFORMIS, Don.}

(Bryanthus empetriformis, A. Gray; Menziesia empetriformis, Smith; Bot. Mag., t. 31 76.)

A low evergreen shrub, 6 to 9 ins. high, of tufted habit, densely furnished with leaves. Leaves $\frac{1}{4}$ to $\frac{5}{8}$ in. long, $\frac{1}{16}$ to $\frac{1}{12}$ in. wide; linear, rounded at the tip, very shortly stalked, minutely toothed on the margin, dark glossy green. Flowers solitary, on slender, glandular-hairy stalks $\frac{1}{2}$ to $\frac{3}{4}$ in. long, produced during April from the leaf-axils near the end of the twigs. Corolla pitcher-shaped, bright reddish purple, $\frac{1}{4}$ in. long, scarcely so wide; ; with five rounded teeth at the orifice. Calyx-lobes five, ovate, $\frac{1}{8}$ in. long, smooth; style exposed. 


\section{PHYLLODOCE-PHYLLOSTACHYS}

Native of Western N. America; introduced in 1810 . It is the most useful of the members of this genus, being quite hardy and thriving in any position suitable for heaths. A group of plants well in bloom makes one of the daintiest of spring pictures. It is, of course, quite distinct from its neighbour, the racemed P. Breweri ; and from P. cærulea and P. amabilis it differs in the colour of the corolla and the glabrous calyx.

\section{PHYLLOTHAMNUS ERECTUS. $C$. $K$. Schneider. ERICACEA.}

(Bryanthus erectus, Lindley; Phyllodoce erecta, Drude.)

A dwarf evergreen bush, 6 to ro ins. high, with numerous erect, very leafy branches, minutely downy when young. Leaves alternate, $\frac{1}{2}$ to $\frac{5}{8} \mathrm{in}$. long, linear, tapering towards each end, recurved slightly at the margins, finely toothed, deep glossy green, crowded on the branchlets. Flowers solitary on slender, downy, glandular stalks $\frac{1}{2}$ to $\frac{3}{4}$ in. long; produced in April in a cluster of four to ten at the end of each twig. Corolla delicate rose, broadly funnel-shaped, $\frac{1}{2}$ in. across, with five triangular, pointed lobes. Calyx-lobes ovate, $\frac{1}{8} \mathrm{in}$. long, smooth; style protruded.

A hybrid raised about 1845 in the nursery of Messrs Cunningham \& Fraser at Comely Bank, Edinburgh (still noted for the cultivation of this class of shrub), between Rhodothamnus Chamæcistus and, so its raisers stated, Phyllodoce cærulea. The general belief is, however, that P. empetriformis was the other parent. It is a very pretty shrub, but requires considerable care to keep it in permanent health in the south, where the dry heats of July and August cause it to suffer. A cool, moist spot in the rock garden where the soil is peaty may be recommended for it. It is usually known in gardens as "Bryanthus," but being a bigeneric hybrid with neither of its parents a true Bryanthus, the name here adopted is to be preferred.

\section{PHYLLOSTACHYS. GRAMINEA.}

For a general discussion of the bamboos belonging to this genus, see ARUNDINARIA. The distinctive characters of Phyllostachys are in the stems, which are always more or less zigzag and flattened on each side alternately above the joint; and in the two or three branches only at each joint, those at the base of the stem developing first. The dwarf P. ruscifolia may eventually prove to belong to a different genus.

\section{P. AUREA, Rivière.}

(Bambusa aurea, Hort.)

Stems pale yellowish green, Io to $15 \mathrm{ft}$. high in this country, stiffly erect, growing in tufts and spreading slowly, the joints often 5 or 6 ins. apart, except 
at the base, where they are crowded. Beneath each joint there is a curious swollen band, about $\frac{1}{4}$ in. wide, which distinguishes this from all other hardy bamboos. Leaves 2 to $4 \frac{1}{2}$ ins. long, $\frac{1}{3}$ to $\frac{7}{8}$ in. wide, broadly tapered at the base, slenderly pointed, dark green above, glaucous beneath, smooth on both surfaces, minutely toothed on the margins; secondary nerves four or five each side the midrib; stalk $\frac{1}{6}$ in. or less long; the leaf-sheath surmounted by two tufts of bristles at the summit.

Native of Japan, cultivated in Europe since the "seventies" of last century. It flowered at Bitton with Canon Ellacombe, and with the late Signor Fenzi, at Florence, in 1876. It is a pleasing bamboo if planted in a goodly sized mass, although not so graceful as the majority. It is "only likely to be confused with P. mitis, which is, however, a taller bamboo without the crowded joints at the base of the stem, and without the swollen band beneath the joint, which is so distinctive a character in P. aurea.

\section{P. Castillonis, Mitford.}

(Bambusa Castillonis, Marliac. Kimmei-chiku of the Japanese.)

Stems 8 to $10 \mathrm{ft}$. high (more no doubt in warmer climates), very hollow ; bright yellow except on the flattened portion which extends from joint to joint either side alternately, and that is dark green. Leaves 2 to 5 ins. long as a rule, and $\frac{1}{3}$ to $\frac{3}{4}$ in. wide ; usually but not uniformly striped with creamy yellow lines; sometimes they are more yellow than green, sometimes wholly green; glaucous beneath; midrib and leaf-stalk downy; secondary veins four to eight each side the midrib; leaf-sheath furnished at the top with conspicuous bristles, sometimes nearly $\frac{1}{2}$ in. long. Occasionally the leaves are much larger; I have seen them 8 or 9 ins. long, and $I \frac{1}{2}$ ins. wide.

Native of Japan; introduced about 1890 . This is the most beautifully coloured in its stems of all hardy bamboos. The curious alternation of green and yellow, together with the often variegated leaves, make it very distinct. It flowered in 1903 and 1904 , and, according to Dr Stapf of Kew, there is nothing in its floral characters to distinguish it from $\mathrm{P}$. nigra. In vegetative characters, however, it is near to P. Quilioi. Many plants died after flowering, and it is now uncommon.

\section{P. FLEXUOSA, Rivière.}

A bamboo of elegant but compact, rounded habit, and as far as I have seen, rarely exceeding 6 or $8 \mathrm{ft}$. in height; stems at first bright green, becoming darker with age, sometimes almost black like those of P. nigra. Leaves 2 to 4 ins. long, $\frac{1}{3}$ to $\frac{5}{8}$ in. wide; dark green and smooth above, glaucous beneath and downy at the base of the midrib, secondary nerves four to six each side the midrib; one margin toothed.

Native of China; introduced to France in 1864. In the characters of leaf and stem this bamboo bears much resemblance to P. viridi-glaucescens, but it is much dwarfer and more compact, and the change of the old culms to black does not, so far as I have observed, occur in that species. The stem sheaths also differ, as pointed out under P. viridi glaucescens. P. flexuosa is a pleasing bamboo of the middle size, graceful and very hardy.

\section{P. Henonis, Mitford.}

\section{(Bambusa Henonis, Hort. Ha-chiku of the Japanese.)}

A very graceful and luxuriant bamboo, reaching in favourable situations $14 \mathrm{ft}$. in height, laden when in good health and well-established with heavy 
plumose masses of foliage, which make the outer stems arch outward; stems bright green at first, very hollow. Leaves rather uniform in size, and from 2 to $3 \frac{1}{2}$ ins. long and $\frac{1}{3}$ to $\frac{5}{8}$ in. wide, tapering at the base to a well-developed stalk $\frac{1}{8}$ in. long, slender-pointed; dark lustrous green above, glaucous and downy at the base of the midrib beneath ; secondary veins four to seven.

Native of Japan; introduced about 1890 . In the richness of its verdure combined with a remarkable elegance of form this bamboo is probably the loveliest of all its kind. From about 1894 to 1900 it made perhaps the most delightful feature of many gardens from October to January. In 1900 it commenced to flower all over the country, and by 1905 nearly every specimen was either dead or very severely crippled. A proportion of them recovered, and from these as well as from plants imported afresh from Japan, it is now getting re-established in gardens. In its floral characters $\mathrm{P}$. Henonis differs but little from P. nigra. According to a Japanese botanist it is the same as Bambusa puberula, Miquel.

The bamboo known as P. Boryana, Mitford (Bambusa Boryana, Marliac), which flowered in this country in 1905 , is a near ally of $\mathrm{P}$. Henonis, and of about equal beauty. Very few plants of it now exist.

P. FULva, Mitford, appears also to belong to P. Henonis, differing chiefly in the yellow colour of the stems which is developed the second year.

\section{P. MITIS, Rivière.}

\section{(Bambusa mitis, Hort. Môsô-chiku of the Japanese.)}

Stems reaching sometimes nearly $20 \mathrm{ft}$. high in this country and bent somewhat stiffly, $1 \frac{1}{2}$ ins. in diameter, deep yellow when mature. Leaves 2 to 5 ins. long, $\frac{1}{4}$ to $\frac{3}{4}$ in. wide, tapering or rounded at the base, slenderpointed, dark green above, glaucous beneath, smooth except at the base of the midrib beneath, and toothed-especially on one margin; stalk $\frac{1}{8}$ in. or less long; leaf-sheath with a tuft of bristles at each side near the top; secondary nerves three to six each side the midrib.

Native of Japan ; introduced about 1890 . In foliage it resembles P. aurea, under which the distinctions are pointed out. It requires a sheltered spot and abundant sunshine to develop its best qualities, and does not recover from injury by cold so rapidly as P. aurea. The stems are never truly erect, but are bowed, with usually also an inclination to twist. The stems when young grow with great rapidity, sometimes nearly I foot in twenty-four hours in this country-more in hotter ones. They are the stoutest among our hardy bamboos. In Japan the young shoots are cooked and eaten; according to Lord Redesdale they are flavourless, but have a crisp and pleasant consistency.

The curious so-called "Tortoise-shell" bamboo - P. HETERocycLA, Carric̀re-is considered to be a variety of $P$. mitis. It is distinguished by the joints of the stems near the base not circling them in the ordinary way, but taking diagonal directions, the normal space between the joints being suppressed at each side alternately. Thus the scars join at opposite sides alternately for I or $2 \mathrm{ft}$. up the stem, when it assumes its normal form and the scars become horizontal rings. The plant is not well adopted for this country, and I have never seen a single characteristic stem produced here. The popular name-of Japanese origin-refers to the humped appearance of the space between the joints. This distortion is a freak of nature, and is not, as was once believed, due to the handiwork of Japanese gardeners. Introduced from Japan to France about 1877 , and to England in 1893.

P. SULPHUREA, Rivière, has yellow stems scarcely so robust as typical P. nuitis, but otherwise almost identical. In my experience it is more tender 
than P. mitis, but that is based on the behaviour of two plants only, and differs from the opinion of it held by others.

\title{
P. NigRA, Munro. BLACK-STEMmed BAmboo.
}

\author{
(Bambusa nigra, Loddiges.)
}

Stems varying from to to $20 \mathrm{ft}$. high in different parts of the country, and from $\frac{1}{2}$ to $1 \frac{1}{4}$ ins. in diameter, very hollow; at first green, they become with age quite black; the branchlets usually mottled. Leaves in plume-like masses; usually 2 to $3 \frac{1}{2}$ ins. long, $\frac{1}{4}$ to $\frac{5}{8}$ in. wide (sometimes larger); of thin texture, dark green above, rather glaucous beneath, smooth on both surfaces, the margins roughened with minute teeth; secondary veins three to six each side the midrib. When quite young there is a slight downiness at the base of the midrib beneath. The leaf-sheath is terminated by a few erect bristles.

Native of China and Japan, and one of the most elegant of bamboos ; very distinct because of its black stems. It is a quite hardy species when once established, although it grows much larger in hotter climates. It is the oldest of Phyllostachys in English gardens and, according to Loudon, was $7 \mathrm{ft}$. high in the Horticultural Society's gardens in 1837.

Var. PUNCTATA.-A more robust form than the type, differing in the stems not becoming wholly black, but mottled. It flowered over Europe between 1900 and 1908, and many plants died in consequence.

\section{P. Quilioi, Rivière.}

(Bambusa Quilioi, Carrière; Bambusa Mazeli, Hort. Madaké of the Japanese.)

Stems 10 to $18 \mathrm{ft}$. high in this country, $\frac{3}{4}$ to $I \frac{1}{4}$ ins. thick at the base, deep green. Branches long; stem sheaths pinkish when young, conspicuously mottled with deep purple. Leaves among the largest in the hardy Phyllostachys group, varying from $2 \frac{1}{2}$ to 6 ins. long, $\frac{1}{2}$ to $1 \frac{1}{4}$ ins. wide (occasionally they are even larger); bright green above, glaucous beneath; smooth except for some down at the base of the midrib beneath; one margin toothed; secondary veins five to seven each side the midrib; leaf-sheath with a conspicuous tuft of bristles at the top, $\frac{1}{4}$ to $\frac{1}{2}$ in. long.

Native of Japan ; introduced to France by Admiral Du Quilio in 1866. It is one of the finest of hardy bamboos, very hardy and free-growing. $P$. viridi-glaucescens is the only species with which, in the adult state, it is likely to be confused, and from that species it is distinguished by the mottled leaf-sheaths (in P. viridi-glaucescens they are simply striated or tinged with purple), by the larger leaves and longer branches.

Var. MARliaceA (P. Marliacea, Mitford). Marliac's Bamboo.-A form of P. Quilioi, distinguished by the curious wrinkling of the stems especially towards the base. It does not appear to be so vigorous as P. Quilioi, and behaves more like P. mitis in regard to hardiness.

\section{P. RUSCIFOLIA, Nicholson.}

\section{(Bambusa ruscifolia, Siebold; P. Kumasaca, Munro.)}

Stems erect, but very zigzagged, I to $2 \mathrm{ft}$. high, very much flattened between the joints, $\frac{1}{8}$ in. diameter, the central hollow only large enough to admit a horse hair; joints $\mathrm{t}$ to $3 \frac{1}{2}$ ins. apart. Branches three or four at each joint, I to $2 \frac{1}{2}$ ins. long, bearing one to three leaves. Leaves narrowly ovate: 
broadly tapered at the base, slenderly at the apex ; 3 to 4 ins. long, $\frac{3}{4}$ to $I$ in. wide; glossy dark green and smooth above, slightly glaucous and downy beneath, both margins toothed; secondary veins, five to seven each side the midrib.

Native of Japan; cultivated by Messrs Veitch at Coombe Wood in the "seventies" of last century as "Bambusa viminalis," and probably introduced for them during the previous decade by John Gould Veitch. A pretty bamboo suitable for a damp spot in the rock garden, being of a neat, tufted habit. It is one of the most distinct of all hardy bamboos, especially in its sturdy, zigzag stems, the great proportionate width of the leaves, their length of stalk, and the uniformly short branches. It appears to have little in common with the rest of Phyllostachys, and is probably generically distinct.

\section{P. VIRIDI-GLAUCESCENS, Rivière.}

(Gardeners' Chronicle, I894, i., fig. 53; Bambusa viridi-glaucescens, Carrière.)

Stems 14 to $18 \mathrm{ft}$. long, about $\frac{3}{4}$ in. diameter, very hollow, yellowish green, except at the joints, which are purplish; the outer stems of vigorous plants growing in the open arch outwards and downwards to the ground. Stemsheaths striped with close lines of purple and suffused with purple when young. Leaves 2 to 5 ins. long, $\frac{1}{3}$ to $\frac{7}{8}$ in. wide ; abruptly tapered at the base, slenderpointed, bright green above, glaucous beneath, downy only at the base of the midrib beneath ; toothed on one margin ; secondary veins four to seven each side the midrib ; leaf-sheath purplish, with two clusters of bristles at the top.

Native of China ; introduced to France about 1846 , and a very elegant, vigorous, and useful bamboo. It is liable to be confounded with P. Quilioi and with P. flexuosa, but the former is well distinguished by its mottled stemsheaths, its stouter stems, and larger leaves, whilst P. flexuosa is altogether a smaller plant whose old stems are often almost black. There are also two little, fringed, ear-like projections at the top of the stem-sheath that are missing in P. flexuosa. P. viridi-glaucescens requires an isolated position, when it will in time form a graceful mass at least $25 \mathrm{ft}$. in diameter, with pendulous plumes of foliage. It spreads at the root with some freedom, and is easily propagated by offsets. It never appears to have flowered under cultivation.

P. VIOI.ASCENS, Rivière.-Allied to P. viridi-glaucescens, this is less hardy. It is very distinct in having the young stems of a deep violet, almost black, changing the second year to yellowish brown. The sheaths are also violet. Leaves from 2 to 7 ins. long, by about one-fourth as wide; secondary veins three to eight; stalk purplish. The best plant I have seen is at Shrublands, near I pswich, about 12 ft. high ; but frequently it is not a success, growing late, and having its summer growth cut back during the ensuing winter. Native of China or Japan.

\section{PICEA. SPRUCE. CONIFERA.}

A group of evergreen trees found in most of the cool temperate regions of the northern hemisphere, of pyramidal form, especially in a young state, with branches in tiers. Leaves linear or needle-like, mostly foursided, arranged spirally on the shoots, but the undermost ones usually twisted at the base, so as to crowd them more on the upper side of the twig than on the lower. Each leaf is seated on a slight cushion which, if the leaf be gently pulled off downwards whilst fresh, it brings mostly away. When, however, the leaf falls naturally, or the twig is dried for 
herbarium purposes, it leaves at the base a peg-like stump. These leafstumps thickly studded on the shoot are extremely characteristic of the spruces, and well distinguish them from the firs (Abies). Flowers unisexual, both sexes produced on the same tree at or near the end of the twigs; the males solitary, stalked, composed of numerous anthers. Female cones nearly always pendulous, their scales persisting until they fall. Seeds winged.

There are two well-marked groups of Picea :-

I. PICEA proper.-Leaves quadrangular in section, with lines of stomata on all four sides.

2. OMORIKA group.-Leaves more flattened, with stomata usually on the dorsal surface only. By a twisting of the leaf-base this becomes usually the undermost or less exposed side. Of the species described in the following notes, those belonging to the Omorika group are:-Breweriana, complanata, hondoensis, morindoides, Omorika, sitchensis. The rest are of No. I group.

The spruces have scarcely the garden value of the firs, but the following are handsome and striking; hondoensis, Morinda, Omorika, orientalis, polita, and pungens, and a well-grown isolated common spruce is scarcely inferior to any of them. Spruces are very frequently called "Abies" in British gardens, whilst the true silver-firs, or Abies, are called "Picea." This inversion of names seems to date from Loudon's time, but is nowhere in vogue except in this country. It is time the true designations were given to these genera, for they are easily distinguished:-

PICEA (Spruces).- - Leaves as described above. Cones pendent, with the scales persistent on the central axis.

ABIES (Silver-firs).- - Leaves flatter, often notched at the apex, not falling away in drying, nor leaving the peg-like stumps of Picea; cones erect, with the scales falling away from the central axis. (See also under ABIES.)

The spruces should always be raised from seeds; cuttings of some species take root, and grafting must be practised for forms coloured or abnormal in habit, but trees so raised are not so fine or long-lived as seedlings. They like abundant moisture at the root, most of them coming from regions with an abundant rainfall. If the rainfall be deficient it may be compensated for by planting in a deep moist soil. $\mathrm{P}$. pungens is one of the best in a dry climate. Few conifers withstand town conditions worse than the spruces. Many of them produce a useful "timber, especially P. excelsa in Europe. P. alba is cultivated in some of the northerly regions of Scandinavia too inclement for any other tree to live. Some of the species, P. excelsa in particular, are attacked by a gall-making insect (Chermes), the gall being a cone-like structure growing round the shoot. The best remedy is to spray with an emulsion of soft soap and paraffin in late March and April.

Of species not given detailed notice in the following pages, mention may be made of the two following, neither of which is of any importance in gardens :-

P. GLeHnil, Masters.-Originally discovered in the island of Saghalien by Schmidt in 186r. A tree up to $100 \mathrm{ft}$. high, the branchlets downy between 
the "cushions" on which the leaves are seated. Leaves $\frac{1}{3}$ to $\frac{1}{2}$ in. long, quadrangular, abruptly and sharply pointed, one to four stomatic lines on each side. Cones $1 \frac{1}{2}$ to 2 ins. long, cylindric, shining brown; scales rounded, and minutely toothed at the apex. This spruce resembles P. orientalis in its short, lustrous leaves. Introduced from Yezo by Maries about 1877.

P. MaximowicziI, Regel.-An unimportant spruce collected on Mount Fujiyama, Japan, in 1864 . There are only small trees in cultivation, the largest mentioned by Henry being at Handcross Park in Sussex, and $32 \mathrm{ft}$. high ; it does not appear to be tall in nature. The young shoots are quite smooth, the winter buds covered with smooth resinous scales. Leaves averaging scarcely $\frac{1}{2}$ in. in length, pointed, four-sided, with two to five stomatic lines on each face, dark glossy green. Cones $1 \frac{3}{4}$ to 2 ins. long, cylindrical, tapered at both ends; scales rounded, not toothed, reddish brown at maturity.

\section{P./AlBA, Link. Whitte SPRUCE.}

\section{(P. canadensis, Britton.)}

A tree usually 60 to $100 \mathrm{ft}$. high; young specinens with much the habit of the common spruce, but of a greyer green; branchlets very pale brown, not downy; buds resinous. Leaves arranged mostly on the upper side of the branches, evil-smelling when crushed; they are $\frac{1}{2}$ to $\frac{3}{4}$ in. long, pointed, but not prickly, four-angled, grey-green, with two to five lines of stomata on each face. Cones cylindrical, $1 \frac{1}{2}$ to 2 ins. long, pale shining brown when mature; scales very thin and flexible, broad and rounded, nearly entire at the margins.

Native of $\mathrm{N}$. America ; introduced about the end of the seventeenth century. It is very widely spread in a wild state, reaching, according to Sargent, from Labrador to Alaska, extending southwards along the eastern side of the Rocky Mountains to Montana, and to New York, Michigan, etc. It reaches a higher latitude than any other evergreen tree, and nearly to the Arctic Sea, on ground which only thaws 3 or $4 \mathrm{ft}$. down in summer. It possesses little merit as an ornamental tree in Britain, especially in the south, but on the vast "Danish heaths and dunes of Jutland which are continually swept by the gales of the North Sea it has been extensively planted, especially as a shelter tree. It serves this purpose so well, that no other known tree could take its place there" (Rafn). In the rank smell of its foliage it resembles P. Engelmannii, but that species has longer leaves and more tapered cone-scales, and it, as well as the more nearly allied P. nigra and $P$. rubra, are further distinguished by their downy shoots.

Var. AUREA has foliage of a yellowish tinge.

Var. CERULEA is more glaucous than the type. There are also dwarf forms such as COMPACTA and ECHINIFORMIS.

P. Albertiana, S. Brown. Introduced by Mr H. J. Elwes in 1906, but little can as yet be said of this spruce under cultivation. It is closely allied to, perhaps only a geographical form of, P. alba, differing in the slightly downy young shoots and resinous buds. It is a finer tree than P. alba, and is said to reach a stature of $160 \mathrm{ft}$. Native of western N. America.

\section{P. Alcockiana, Carrière. Alcock's Spruce.}

(P. bicolor, Mayr.)

A tree So $\mathrm{ft}$. high in Japan; in cultivation a small pyramidal tree, with stiff branches ; young shoots sparsely downy or glabrous, pale brown. Leaves very crowded, especially on the upper side of the shoots; $\frac{1}{2}$ to $\frac{3}{4}$ in. long, blunt at the apex, quadrangular; glossy green, with usually two lines of stomata on the uppermost surfaces and four to seven lines on the lower ones. 
Cones 2 to $3 \frac{1}{2}$ ins. long, I to $I \frac{1}{2}$ ins. wide; tapered from the middle to the apex ; scales slightly toothed on the margin.

Native of Japan, where it is a valuable timber tree ; introduced by John Gould Veitch in 1861 . At first, owing to a mixing of the seeds, it was much confused with P. hondoensis-a more striking spruce with no stomata on the uppermost surfaces, and belonging to the Omorika or flat-leaved section. So far as I have seen, this spruce (named in honour of Sir Rutherford Alcock, British Minister at Yedo at the time of its introduction) has little to recommend it for British gardens generally.

\section{P. Breweriana, S. Watson. Brewer's Weeping Spruce.}

A tree up to $100 \mathrm{ft}$. high in a wild state, the trunk 2 to $3 \mathrm{ft}$. in diameter, the branches ultimately pendulous, with the final ramifications slender, whiplike, and often 7 to 8 or even $12 \mathrm{ft}$. long, but no thicker than a lead pencil, and hanging perpendicularly; pyramidal and stiffly branched when young. Leaves pointing forwards, and arranged about equally all round the shoot, $\frac{1}{2}$ to $I$ in. long, $\frac{1}{20}$ to $\frac{1}{12}$ in. wide, blunt at the apex, somewhat tapered at the base; one side dark glossy green without stomata, the other grey with stomatic lines. Cones cylindrical-oval, about 3 ins. long, purple, the scales rounded and entire at the margins.

Native of the Siskiyou Mountains of California and Oregon, where it occurs in comparatively small numbers in a few places at about $7000 \mathrm{ft}$. altitude, discovered by $\mathrm{Mr} \mathrm{T}$. Howell, the Californian botanist, in r884. A single plant was sent by Prof. Sargent in 1897 to Kew, where it thrives very well but grows slowly in height. As a small tree $6 \mathrm{ft}$. high, it gives not the least indication of the remarkably pendulous habit it eventually assumes, being a stiff, dense, very leafy bush. It has, however, an irregular mode of branching quite different from the flat, whorled arrangement seen in the branching of most spruces. The leaves are much more slender than in adult specimens. A stock of seeds was imported in I9II.

\section{P. COMPlanata, Masters.}

A species apparently allied to P. morindoides, but native of W. Szechuen, China, where it was discovered about 1904 by Wilson. It belongs to the Omorika group, distinguished by having no stomata on the uppermost side of the leaves. Young shoots pale, yellowish, not downy. Leaves arranged mostly on and above the horizontal plane, a few standing out beneath, those on the top somewhat appressed to the branch and pointing forward; they are needle-like, $\frac{1}{2}$ to $\mathrm{I} \frac{1}{8}$ ins. long, sharply bevelled off at the apex to a fine point; dark green on the exposed surface, blue-white with stomatic lines beneath. Cones 4 to 5 ins. long, $I \frac{1}{4}$ ins. wide ; tapered towards the top and bottom; scales slightly jagged. These have not yet been produced in cultivation, and the plants we possess are quite small. It is difficult at present to see how it differs from P. morindoides. Probably it is one of numerous instances among West Chinese plants, which, whilst not the same as their Himalayan congeners, yet scarcely differ enough to be specifically distinct.

\section{P. Engelmanni, Engelmann.}

A tree 80 to 100 , occasionally $150 \mathrm{ft}$. high, assuming as a young tree in cultivation a pyramidal form, with slightly ascending branches; young shoots pale yellowish brown, clothed with stiff, erect down. Leaves with an unpleasant odour when rubbed, arranged all round the twig, but thinly beneath; they are $\frac{3}{4}$ to $1 \frac{1}{8}$ ins. long, quadrangular, bluntish at the tips, 


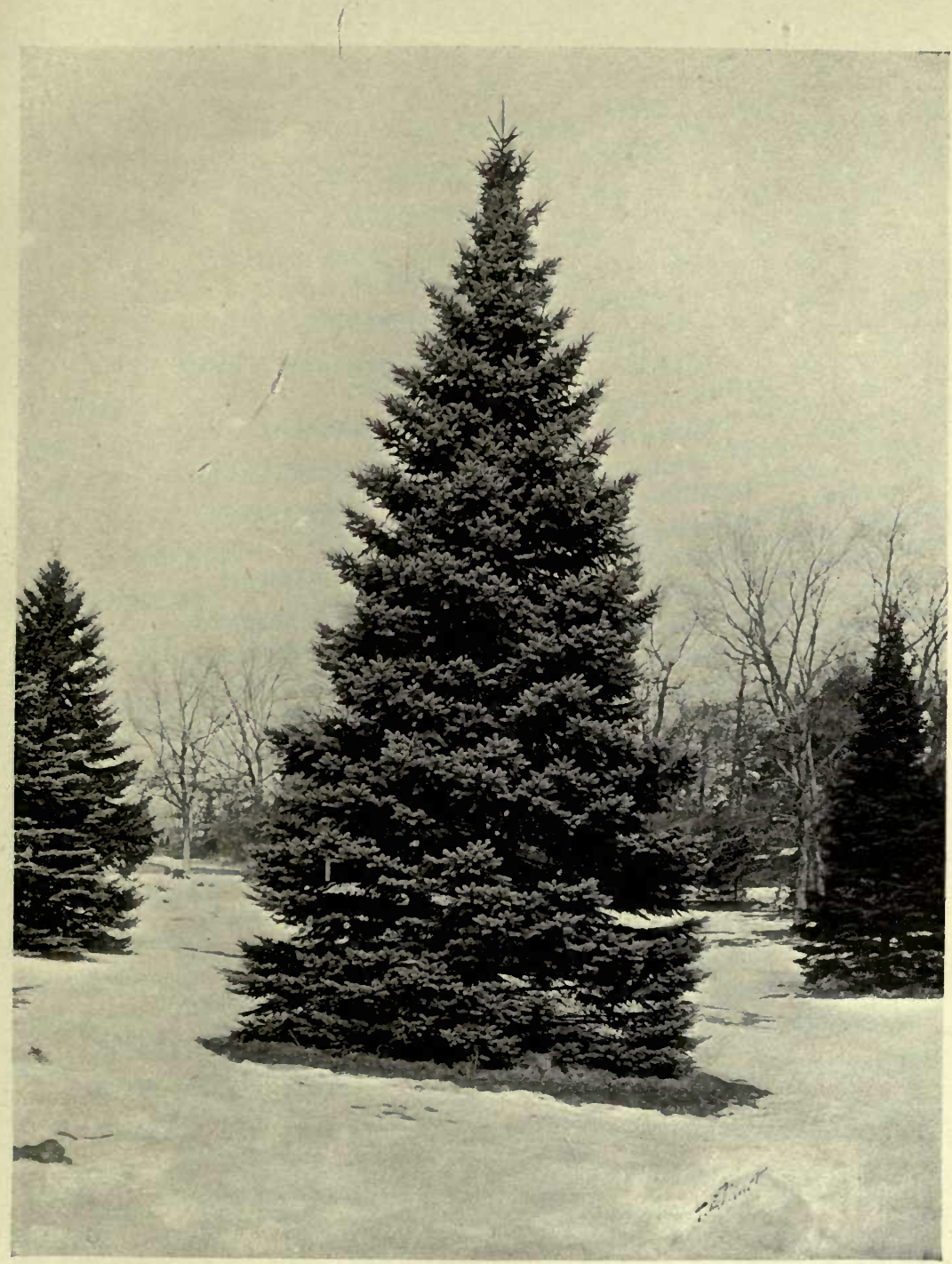

Picea Engelmanni in the Arnold Arboretum, U.S.A. 

flexible, dull, slightly glaucous green, with three or four lines of stomata on all four surfaces. Cones $I \frac{1}{2}$ to 2 ins. long, $\frac{3}{4}$ to $I$ in. in diameter; tapered towards the top, pale shining brown when mature; scales with a truncate apex and jagged margins.

Native of the mountains of Western N. America from Alberta and British Columbia (where it attains its greatest size), south to New Mexico and Arizona. This handsome spruce is very hardy, and thrives better in N. Continental Europe and New England, where the winters are severe, than it does in places with a mild winter and late spring frosts. It is comparatively rare in gardens, the tree grown under the name being frequently the glaucous form of P. pungens. The two species, although so much confused, are really very distinct. P. Engelmanni is easily recognised by its downy shoots; its unpleasant smelling leaves, soft and flexible to the touch and not spine-tipped; also by its shorter cones.

Var. GLAUCA has leaves of a more pronounced glaucous hue.

\section{P. EXCElsa, Link. COMmon SPRUCE.}

(Abies Picea, Miller; Pinus Abies, Linncus.)

A tree 100 to 120 , sometimes $150 \mathrm{ft}$. high, of tapering, pyramidal form, densely clothed with branches and leaves; bark thin and scaling; branchlets pale brown, usually more or less downy, sometimes glabrous. Leaves mostly arranged in two sets in or near the horizontal plane; $\frac{1}{3}$ to $\frac{3}{4}$ in. long; very deep glossy green, quadrangular, with a few faintly defined lines of stomata on each face. Cones cylindrical, tapered at the top, usually about 5 ins. long and $I_{2}^{\frac{1}{2}}$ to 2 ins. wide; light shining brown; scales bluntly triangular at the apex, the end jagged as if bitten off.

Native of most of the mountainous parts of Central and Northern Europe, but not of Britain, where, however, it has been cultivated for at least four hundred years. Although handsome as an isolated tree and imposing in its height, it is known rather as a forest tree with us than in the garden The best timber comes from places where growth is slowest, like Norway. It is often called "Norway Spruce," and is imported in large quantities from that country as "white deal." In the dry Thames valley it is not often found thriving well. Of a great number of garden varieties the following is a selection of the most distinct:-

Var. ARGENTEO-SPICA. - Young shoots of a clear creamy white, approaching afterwards the normal colour; very striking and ornamental. Var. FINEDONENSIS is of the same character.

Var. Clanbrassiliana.-An interesting variety of low, dense, rounded habit, usually wider than high. A plant thirty years old will be under 3 $\mathrm{ft}$. in height. According to the late Earl Annesley, "it was named after Lord Clanbrassil, who first discovered it in his beautiful demesne of Tullymore, Co. Down, now the seat of the Earl of Roden, and the original plant is still to be seen there." Other dwarf forms are DUMOSA; GREGORYANA, a dense rounded bush, with crowded branchlets making growths $\frac{1}{4}$ to $I$ in. long annually, the leaves standing out all round the twig; PYGMÆA, very close and dwarf; PUMILA GLAUCA, somewhat similar, but glaucous; GLOBOSA NANA, similar to Clanbrassiliana in leaf and shoot, but less spreading; REMONTII, shoots erect-growing.

Var. CRANSTONi, var. DENUdATA, and var. MONSTROSA are remarkable forms, with long snake-like branches, almost without branchlets; leaves rigid, stiff, thicker and longer (about $I$ in.) than in the type. Of no beauty, and only worth growing as grotesque curiosities.

Var. INVERTA has stiff pendulous branches hanging close to the stem-a curiosity merely. First discovered by Mr R. S. Carrington, of the firm 
of Richard Smith \& Co., of Worcester, in a plantation not far from Kinlet House, in Shropshire, about 1858. Var. PENDULA is not so strikingly pendulous.

Var. EREMITA, var. GIGANTEA, and var. DiCKSONi have large stout leaves, the habit stiff and rather open.

Var. STRICTA, of slender, spire-like form, the branches erect ; very distinct and striking.

Var. VIRGATA has thin, slender branchlets with the leaves appressed to the twig.

\section{P. HONDOENSIS, Mayr.}

\section{(P. ajanensis, Hort., Bot. Mag., t. 6743-not of Fischer.)}

A tree up to $80 \mathrm{ft}$. high, with scaly, peeling bark; young shoots yellowish, without down; bud-scales flattened, shining brown. Leaves confined to the upper side of the shoot, the lower ones spreading horizontally, upper ones pointing forwards; they are linear, blunt, or with short points at the apex; $\frac{1}{2}$ to $I$ in. long, $\frac{1}{20}$ to $\frac{1}{15}$ in. wide; dark glossy green and without stomata above; vividly blue-white beneath, and almost covered with stomatic lines. Cones cylindrical, bright crimson when young, afterwards pale brown; I I to $2 \frac{1}{4}$ ins. long, about I in. wide; scales with jaggedly toothed margins.

Native of Japan, where it occurs on the mountains of the main island; introduced in $186 \mathrm{r}$ by John Gould Veitch. Owing to a mixing up of the seeds it was originally distributed as P. Alcockiana (true examples of which have four-sided leaves, with stomata on all surfaces and much less vividly white beneath; also cone-scales almost entire). It is generally grown in gardens now as P. ajanensis, but was distinguished from the true species of that name by Dr Mayr in 1890. The true P. AJAnensis, Fischer, is perhaps not in cultivation, and so far as Japan is concerned is only found in Yezo, the Kurile Islands, and Saghalien; but it occurs also in Manchuria, Amurland, etc. It appears to be a taller tree, with non-peeling bark, longer leaves, and more slender cones, but is closely allied to P. hondoensis.

$\mathrm{P}$. hondoensis as seen in British gardens is a particularly handsome pyramidal tree, with stiff branches, leaves more beautifully blue-white beneath than those perhaps of any other spruce, and with handsome cones. It approaches $50 \mathrm{ft}$. in height in the pinetum at Ochtertyre, Perthshire, and no doubt elsewhere.

\section{P. Morinda, Link. West Himalayan Spruce. (P. Smithiana, Boissier; Abies Khutrow, Loudon.)}

A tree 100 to 120 , sometimes $200 \mathrm{ft}$. high, with horizontal branches, but perfectly pendulous branchlets; young shoots stiff, pale grey, shining, not downy; buds conical, often resinous, up to $\frac{1}{2}$ in. long. Leaves arranged all round the twigs (rather more thinly beneath), standing out at an angle of about $60^{\circ}$; they are quadrangular, rigid, needle-like, with prickly points, $1 \frac{1}{2}$ to 2 ins. long, often slightly curved, green with a few stomatic lines on each of the four faces. Cones cylindrical, tapered towards the apex, 4 to 6 ins. long, $1 \frac{1}{2}$ to 2 ins. wide, brown when mature; scales broadly rounded and entire at the margin.

Native of the western Himalaya ; introduced to Scotland in 1818 by cones sent to Lord Hopetoun. The specific name "Smithiana," by which it is frequently known, refers to the gardener at Hopetoun who first raised this tree. It is distinct from all the other spruces in the greater length of leaf, and is also one of the most striking from the weeping character of its 
branchlets, which, perhaps, give it a somewhat funereal aspect. It is subject to injury by spring frost especially in the young state, and will thrive best in a situation shaded from early morning sun. It likes a moist, loamy soil.

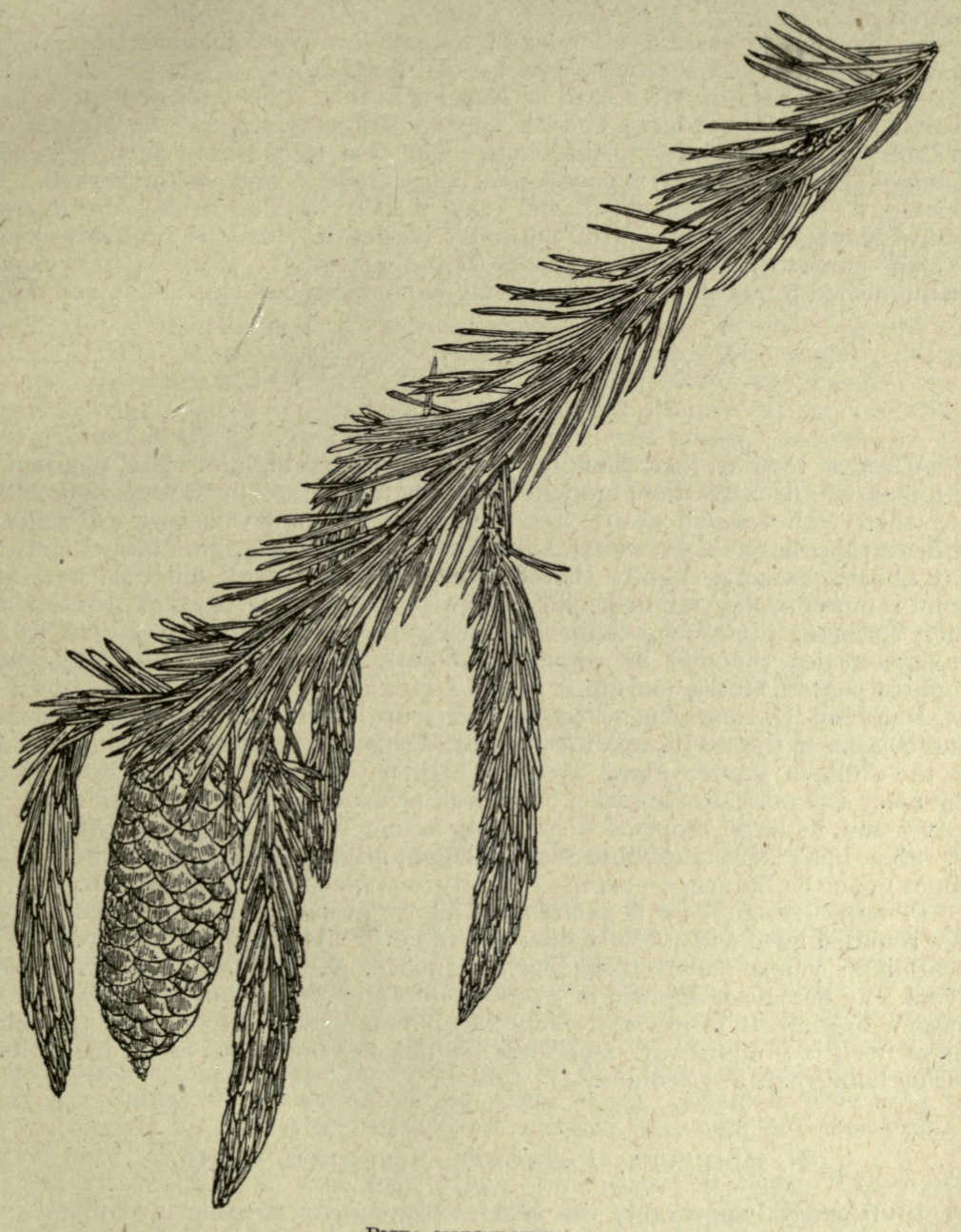

Picea MORINDOIDEs.

\section{P. Morindoides, Rehder. E. Himalayan Spruce.}

(Bot. Mag., t. 8169; P. spinulosa, A. Henry.)

A tree of large size, over $200 \mathrm{ft}$. high, branches pendulous at the ends; young shoots pale, yellowish, without down. Leaves arranged all round the shoot, most thinly underneath, the upper ones appressed to the branch and 
pointing forward; they are needle-like, $\frac{1}{2}$ to $\mathbf{I} \frac{1}{3}$ ins. long, sharply pointed; green and without stomata on the uppermost side, glaucous, with stomatic lines beneath. Cones cylindric, $2 \frac{1}{2}$ to $3 \frac{1}{2}$ ins. long, I to $1 \frac{1}{4}$ ins. wide ; purple when young, pale brown when mature ; scales blunt at the apex, the margins jagged.

Native of the eastern Himalaya; date of introduction uncertain, being first distinguished as a new species by $\mathrm{Mr}$ Rehder, in 1902, by a cultivated tree in the garden of $\mathrm{Mr}$ Allard of Angers, France, who informed me a few years ago that his tree bears infertile cones every year. A tree at Menabilly, in Cornwall, has produced fertile seeds. The best tree I have seen is in Sir Edmund Loder's park at Leonardslee, very graceful and well-furnished. It belongs to the Omorika group and may be described as having the foliage and twigs of $\mathrm{P}$. sitchensis with the habit of $\mathrm{P}$. Morinda. It probably exists in some gardens under either of these names. From P. Morinda it is easily distinguished by its shorter leaves having stomata on one side of the leaf only.

\section{P. NIGRa, Link. Black Spruce.}

\section{(P. mariana, Britton.)}

A tree 20 to $30 \mathrm{ft}$. (occasionally twice or thrice as) high, of close, pyramidal habit as seen in cultivation, branches densely twiggy; young shoots abundantly furnished with reddish down; terminal buds with a few downy awl-shaped scales at the base. Leaves arranged all round the twig, but thinly beneath, $\frac{1}{4}$ to about $\frac{1}{2}$ in. long, slightly curved, quadrangular, with a bluntish, bevelled point; more or less glaucous in hue, with two to five lines of stomata on each surface. Cones egg-shaped, $\frac{3}{4}$ to $I_{4}^{\frac{1}{4}}$ ins. long, brownish purple when

- young; scales rounded or somewhat bluntly triangular at the apex, and slightly jagged at the margin.

Native of N. America, where it covers an immense tract from Labrador and Alaska in the north, to Virginia and Wisconsin in the south ; introduced to the Fulham garden about 1700 by Bishop Compton. This is not one of the most ornamental of spruces, but is still pleasing in its dense furnishing of leaves and its large crops of rich purple young cones. It is nearly allied to $P$. rubra, but differs in its blue-green foliage and in the long persistence of its cones upon the branches - twenty to thirty years, according to Sargent.

P. ERICOIDES, Hort., is probably a pigmy form of the black spruce, and is a rounded bush with very slender leaves never more than $\frac{1}{3} \mathrm{in}$. long, almost heathlike; young shoots thin, much branched, downy the first two or three years. It has been known in gardens for fifty years, and is probably of garden origin. It grows extremely slowly. Intermediate between this and nigra itself is P. nigra var. DOUMETTI, which has longer leaves and is of less bushy habit than $\mathrm{P}$. ericoides.

\section{P. Obovata, Ledebour. Siberian Spruce.}

In its general appearance this species bears a considerable resemblance to the common spruce, having similar leaves and very downy young shoots. It is, however, distinct in the cones, which are smaller (about 3 ins. long) and have the scales rounded and entire at the apex (not jagged as in P. excelsa). It is widely spread in Siberia and north-east Russia, and in places reaches a stature of $100 \mathrm{ft}$., valuable in supplying timber and fuel in cold, inclement regions. It has little garden value, being less to be preferred than the common spruce.

P. SCHRENKIANA, Fischer (P. obovata var. Schrenkiana, Carrière).Although sometimes placed under $\mathrm{P}$. obovata as a variety this species is quite 
distinct. The branchlets are greyish white, smooth or nearly so; the leaves arranged all round the twig, spine-tipped in young trees, blunter in adult ones, $\frac{3}{4}$ to $1 \frac{1}{4}$ ins. long, quadrangular, dark green, with two to four very indistinct lines of stomata on all four surfaces. Cones 3 to 4 ins. long, cylindrical; scales rounded, and not toothed at the apex. Native of W. Central Asia in the region of the Thian Shan mountains; discovered in 1840 . It is very distinct from $P$. obovata in the longer, more spreading leaves. It succeeds fairly well in cultivation.

\section{P. Omorika, Bolle. Servian Spruce.}

A narrow, short-branched tree, described as occasionally attaining over IoO ft. in height, with a remarkably slender trunk, 3 to $5 \mathrm{ft}$. in girth; juvenile trees assume a very slender, tapering, and elegant form; shoots covered with stiff down, persisting several years. Leaves mostly disposed in or above the horizontal plane, but with a few standing out beneath; those on the upper side appressed, pointing forwards and hiding the branch; they are $\frac{1}{2}$ to $\mathrm{I}$ in. long, $\frac{1}{16}$ to $\frac{1}{12}$ in. wide; abruptly and sharply pointed on young trees, rounded on old ones; dark glossy green, and without stomata on the uppermost side; greyish beneath, with stomatic lines. Cones egg-shaped, tapered at the top, $1 \frac{1}{4}$ to 2 ins. long; scales broad and rounded, with jagged margins.

Native of Servia and Bosnia, in the valley of the Drina River; discovered by $\mathrm{Dr}$ Pancic in 1875. According to Elwes, it grows on limestone. It was introduced to Kew in 1889 by means of seed from Belgrade, but may have been in cultivation a few years previously elsewhere. The plants raised from these seeds have grown very well, and the species is in my opinion one of the best spruces introduced. Near London it thrives better than any other, remaining well furnished with its dark green leaves, growing rapidly, and retaining a slender very elegant form. It deserves, I think, to be planted extensively.

\section{P. ORIentalis, Carrière. Oriental Spruce.}

A tree over $100 \mathrm{ft}$. high in nature, forming in a young state a densely branched, very leafy, pyramidal tree, with the shape of the common spruce, but smaller-leaved and more slenderly branched; branches stiffly horizontal; young shoots furnished with short, erect, bristle-like hairs. Leaves arranged mostly at and above the horizontal plane, the upper ones appressed to and hiding the twig ; they are dark shining green, $\frac{1}{4}$ to $\frac{1}{3}$ in. long, bluntish at the apex, quadrangular in section, with one to four lines of stomata on each surface. Cones of a beautiful purple when young, ultimately brown, $\mathrm{I}_{\frac{1}{2}}$ to 3 ins. long, $\frac{3}{4}$ to I in. wide ; cylindrical, slender, and pointed when young; scales entire at the margin.

Native of Caucasus and Asia Minor; introduced in 1839. This is undoubtedly one of the most attractive of all the spruces, its foliage being of a brilliant dark green, the habit neat and dense. It has the shortest leaves of all spruces, except, perhaps, some of the pigmy forms of other species. Near London, and in localities with a deficient rainfall, it is much to be preferred to P. excelsa, although slower-growing. In a small state it is one of the daintiest looking of spruces, and older, when bearing a crop of its richly coloured cones, it is very ornamental. It is over $70 \mathrm{ft}$. high in several places in England, and succeeds admirably also in Scotland.

Var. AUREA has leaves of a yellowish tinge.

- Var. GRACILIS.-A pigmy variety. 


\section{P. POlita, Carrière. Tiger-tail Spruce.}

A lofty tree in Japan; in cultivation a small pyramidal tree of very stiff habit ; branches rigid and densely clothed with leaves; young shoots not downy, pale and yellowish the first year; terminal buds conical, shining brown, with closely appressed scales. Leaves set all round the shoot except for

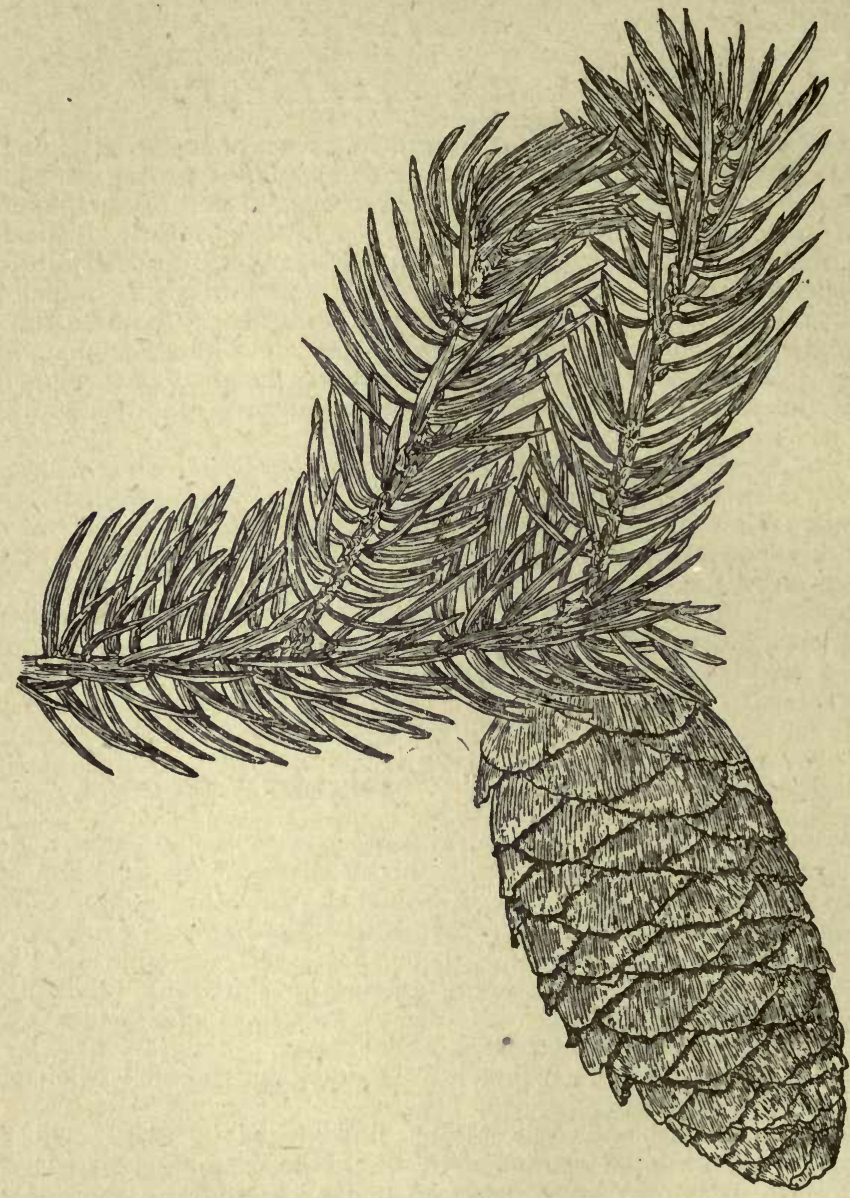

Picka polita.

an open $\mathbf{V}$-shaped groove beneath ; they are $\mathrm{I} \frac{3}{4}$ ins. long, $\frac{1}{12}$ in. wide ; diamondshaped in cross-section, very rigid, somewhat curved, spine-tipped; dark glossy green, with four to seven faint lines of stomata on all four surfaces. Cones $2 \frac{1}{2}$ to 4 ins. long, $1 \frac{1}{4}$ to $\mathrm{I}_{4}^{3}$ ins. wide before opening ; brown when mature ; scales minutely toothed.

Native of Japan; introduced by J. G. Veitch in $186 \mathrm{r}$. This spruce is 
decidedly one of the most distinct and striking in the genus, especially in the comparatively long, thick, rigid, spine-tipped leaves standing out at almost right angles to the shoot. It is also one of the handsomest, and in a young state forms a shapely tree suitable for an isolated position on a lawn; in the adult state the branches are said to become long and pendulous, but cultivated trees as yet show no indication of assuming that character. It is a very hardy spruce, but not quick-growing. The "pegs," or persisting bases of the leaves, left on the shoot are unusually large and prominent.

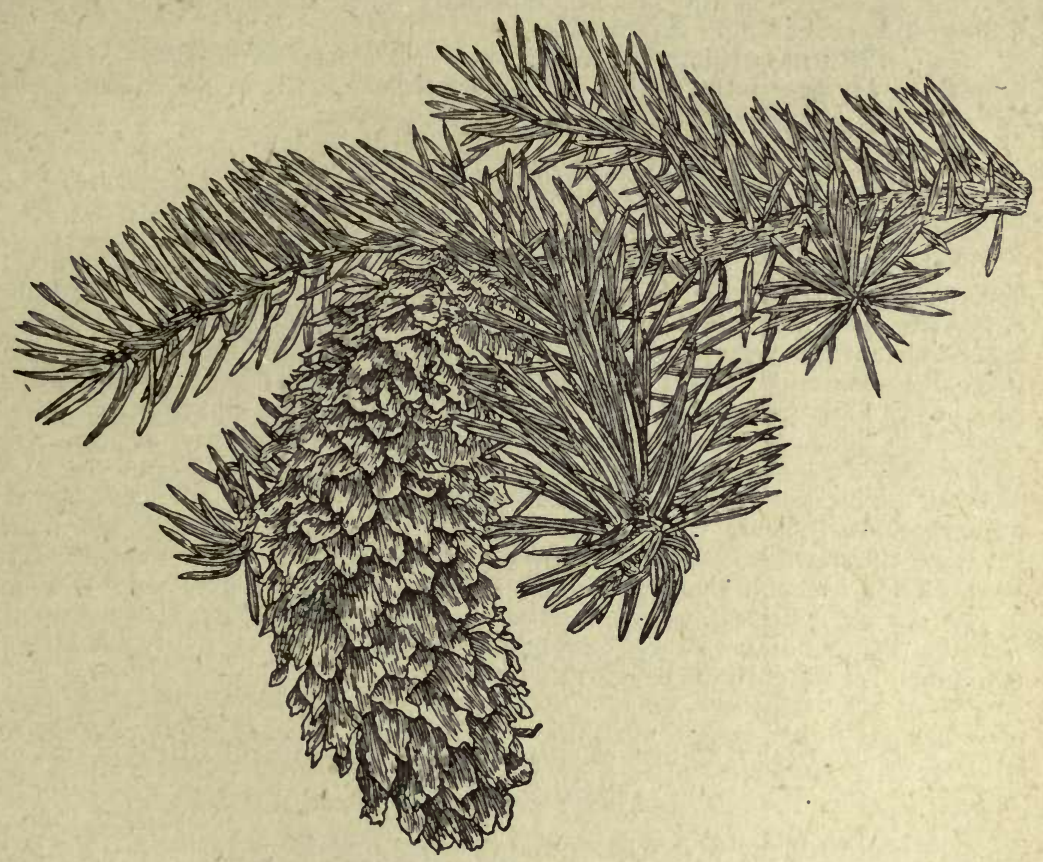

Picisa punarass.

\section{P. PUNGENS, Engelmann.}

\section{(P. Parryana, Sargent; P. commutata, Hort.)}

A tree 80 to 100 , occasionally $150 \mathrm{ft}$. high; pyramidal as a small tree in cultivation with stiff horizontal branches; young twigs not downy; buds brownish yellow. Leaves arranged all round the branchlets, more thinly beneath, the upper ones pointing forward; they are $\frac{3}{4}$ to $I_{4}^{\frac{1}{4}}$ ins. long, stiff, quadrangular, spine-tipped, dark green in the type, with three or four lines of stomata on all four faces. Cones cylindrical, shining, straw-coloured when ripe ; 3 or 4 ins. long, about $1 \frac{1}{4}$ ins. wide; scales wavy, oval, blunt and jaggedly toothed at the apex; seeds $\frac{1}{8}$ in. long, with a wing $\frac{1}{4}$ in. long.

Native of Colorado, Utah, and Wyoming ; discovered by Dr Parry in 1872. The type is but little known in gardens, where the species is almost wholly represented by the glaucous forms. The green type nevertheless is very handsome-usually of slender, pyramidal form. 
Var. GLAUCA, Veitch. Blue Spruce.-Forms of P. pungens vary much in the more or less glaucous hue of the foliage. In the variety glauca (known also as Annesleyana, Sargentii, Parryana glauca, and, erroneously, as Engelmannii glauca) the leaves are covered with a blue-white bloom. This is still more pronounced in the var. ARGENTEA and other selected forms. But it is all a matter of degree, and various shades may be selected in any batch of seedlings. To those who admire these silvery trees the "blue spruce" may be recommended as one of the most striking and handsome. This applies to it more as a young specimen; with age it is apt to become rusty and thin of foliage at the bottom, especially those selected forms that have been grafted on common spruce.

Var. PENDULA (Kosteri pendula).-A glaucous form with pendulous branches, very fine in the nursery of Messrs Koster \& Co. at Boskoop.

\section{P. RUBRA, Link. RED SPRUCE. \\ (P. rubens, Sargent.)}

The red spruce is a close ally of P. nigra, but appears to be extremely uncommon in cultivation. It is, apparently, on the average a considerably larger tree than nigra, being usually 70 to $80 \mathrm{ft}$. high ; it has similar although less persistently downy young shoots. The leaves are quadrangular, $\frac{1}{2}$ to $\frac{3}{4}$ in. long, with stomatic lines on all four surfaces; they differ from those of nigra in being of a dark yellowish, rather than glaucous, green, and somewhat more slender. Cones up to 2 ins. long, and thus larger than those of nigra ; the scales, too, are entire, or only slightly toothed at the apex. But the most marked distinction between the two is in the duration of the cones on the branches. In P. rubra they begin to fall as soon as the scales open, but in P. nigra they persist sometimes twenty or thirty years. In a wild state P. rubra has a much more restricted distribution than nigra, being confined to Eastern N. America, where it extends from Prince Edward Island southward to the mountains of $\mathrm{N}$. Carolina. Introduced in 1755 . It has little to recommend it for gardens beyond its interest.

\section{P. SITCHensis, Trautvetter. SITKA SPRUCE.}

\section{(Abies Menziesii, Lindley.)}

A tree already over $100 \mathrm{ft}$. high in Great Britain, occasionally $200 \mathrm{ft}$. in its native state, bark scaling; young shoots very stiff, not downy, yellowish. Leaves standing out stiffy all round the branchlet, but thinnest underneath; $\frac{1}{2}$ to $\mathrm{I} \frac{1}{4}$ ins. long, $\frac{1}{20}$ to $\frac{1}{12}$ in. wide ; prickly pointed; green, mostly without stomata on the upper surface; silvery, with two bands of stomata beneath. Cones blunt, cylindrical, shortly stalked, $2 \frac{1}{2}$ to 4 ins. long, about $1 \frac{1}{4}$ ins. wide, pale brown; scales oval-oblong, $\frac{1}{2}$ to $\frac{5}{8}$ in. long, rounded and toothed towards the apex; seeds $\frac{1}{8}$ in. long, with a wing thrice as long.

Native of Western N. America, near the coast, from Alaska to California ; discovered in 1792 by Menzies; introduced by Douglas in 1831. The Sitka spruce is, above all, a moisture-loving tree, thriving best where the soil is permanently on the wet side. Planted in a moist gully near a stream in $\mathrm{Mr}$ Robinson's property at Gravetye, in Sussex, it is making growths $4 \mathrm{ft}$. long in a season. It also thrives admirably in the wet valleys of Scotland, forming in the open a broad pyramid. As an isolated tree it has, even in Scotland, the defect of retaining its inner branches and twigs after they are dead, and these the outer fringe of living growth is not dense enough to hide. In many places it is over $100 \mathrm{ft}$. high, with trunks $3 \frac{1}{2}$ to $5 \mathrm{ft}$. in girth. Planted closely, it is one of the most promising of timber trees for moist places. 
PICRASMA aIlanthoides, Planchon. SimarubaCE瓜.

(P. quassioides, Bennett, in part.)

A slender, deciduous tree, 20 to $40 \mathrm{ft}$. high, with very handsome young bark of a reddish brown, conspicuously marked with yellow spots. Leaves pihnate, Io to 15 ins. long, glabrous, consisting of nine to thirteen leaflets, which are glossy green, I to 4 ins. long, ovate, unequal at the base, round or pointed at the apex, sharp-toothed at the margin, and with a very short stalk. Flowers green, $\frac{1}{3}$ in. across, in a lax, branching corymb 6 to 8 ins. long, and often nearly as wide; stalks downy. Fruit a berry, about the size of a pea, rather obovoid, with the calyx still attached.

This tree, according to some authorities, is a form of P. quassioides, a species which, in that sense, is spread in a wild state from Japan and China through the Himalaya as far south as Java. This is no doubt extending the specific limits of P. quassioides too far. No tree from Java would be as perfectly hardy in our climate as is this. The above description is based on trees growing at Kew which were introduced from Japan in 1890 . They have flowered and borne fruit several times, and young plants have been raised from the seed. They have no beauty of flower or fruit, but of the foliage in autumn Sargent observes, "few Japanese plants I saw are as beautiful as this small tree." The leaves turn first orange then scarlet. The whole tree is permeated by a singularly bitter principle. Its nearest ally among hardy trees is Ailanthus.

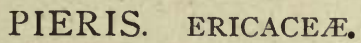

A genus of about ten species, the hardy ones of which are found in N. America, Himalaya, Japan, and China. They are evergreen or deciduous shrubs, sometimes tree-like, with alternate leaves; flowers in terminal or axillary racemes or panicles, produced on the growth of the previous year. Corolla more or less pitcher-shaped, five-toothed; calyx five-lobed and persistent; stamens ten. Seed-vessel a globose capsule.

All the Pierises are handsome shrubs of neat habit, and great freedom in blossoming. They need the same conditions and treatment as Rhododendron; that is, either a peaty soil or a light loam improved by the addition of decayed leaves. They are also moisture-lovers at the root. Propagation is effected by seed, but more quickly by layering, for the purpose of which stools of P. japonica and P. floribunda are laid down in nurseries. These two species, as well as P. formosa, flower early in spring, and it is an advantage if they can be given a western exposure with shelter on the north and east sides.

\section{P. FLORIBUNDA, Bentham.}

(Andromeda floribunda, Pursh; Bot. Mag., t. 6566.)

An evergreen shrub, from 3 to $6 \mathrm{ft}$. high, of bushy, rounded habit, and when in good condition furnished right to the ground, the branches rather 
stiff; shoots and leaf-stalks furnished with dark bristles appressed to the stem, and pointing forwards. Leaves ovate, $\mathrm{I} \frac{1}{2}$ to 3 ins. long, $\frac{1}{2}$ to $\mathrm{I}$ in. wide ; pointed, rounded or tapering at the base, slightly toothed, bristly at the edges; dark glossy green above, paler beneath, sprinkled with very short black hairs on both surfaces; stalk $\frac{1}{4}$ to $\frac{3}{8}$ in. long. Flowers produced in March and April in erect terminal panicles 2 to 5 ins. high, each consisting of several slender, downy racemes; corolla pure white, pitcher-shaped, $\frac{1}{4}$ in. long, calyx-lobes ovate; flower-stalk decurved so as to bring all the flowers to the lower side, and furnished with two linear bracts.

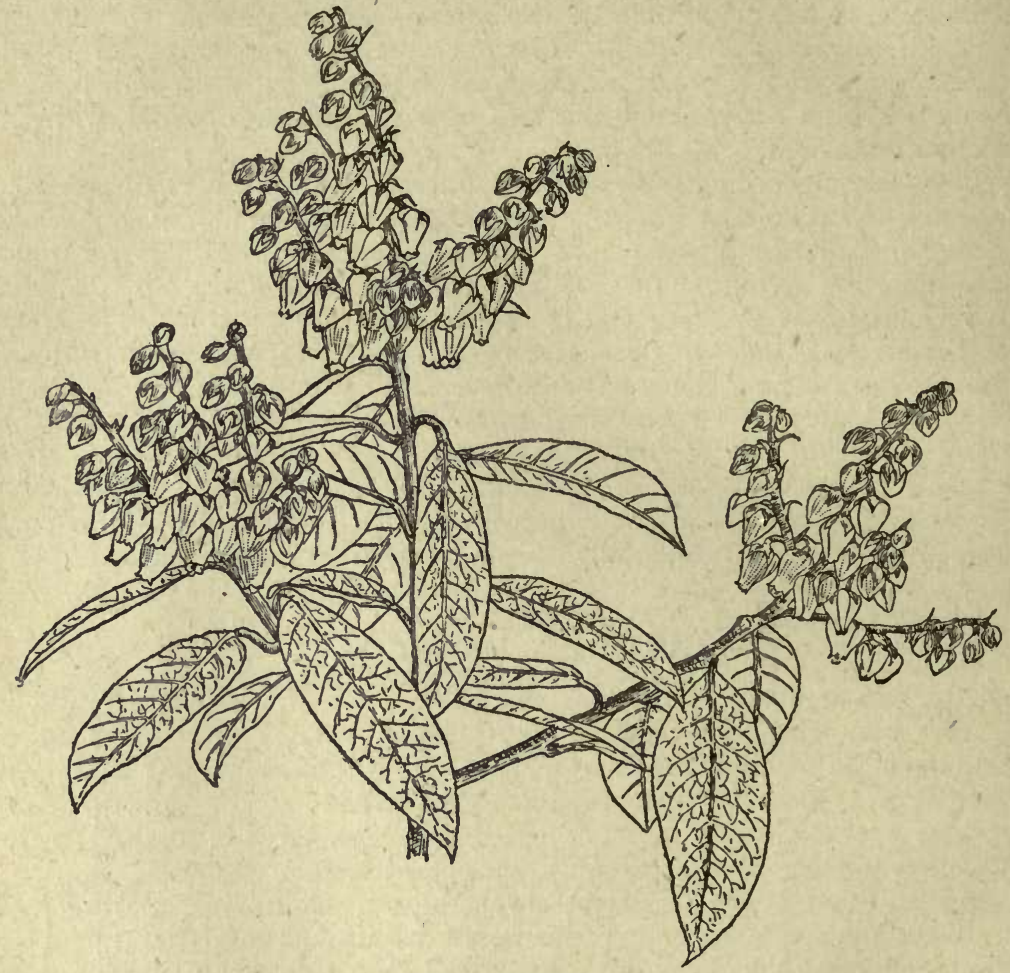

Pieris Floribunda.

Native of the south-eastern United States; introduced in 1800 . This is . one of the most beautiful and hardy of flowering evergreens, slow-growing and of neat bushy habit, admirable for planting in groups. A fine specimen in the Wisley Gardens was some years ago $14 \mathrm{ft}$. wide and $6 \mathrm{ft}$. high.

\section{P. Formosa, D. Don.}

(Bot. Mag., t. 8283; Andromeda formosa, Wallich.)

A large evergreen shrub, 8 to $\mathbf{3}$, or sometimes $20 \mathrm{ft}$. high, spreading - half as much more in diameter; young wood smooth. Leaves lanceolate, 3 to 7 ins. long, I to $2 \frac{1}{4}$ ins. wide; pointed, tapering at the base, finely 
toothed, smooth, and dark glossy green, of firm, leathery texture. Flowers produced during May in a cluster of panicles, terminating the shoots of the previous year, and from 4 to 6 ins. long and wide. Corolla pendent, white, pitcher-shaped, $\frac{1}{4}$ to $\frac{3}{8} \mathrm{in}$. long, contracted at the mouth, where are five shallow, rounded teeth; calyx-lobes $\frac{1}{8}$ in. long, green, narrowly ovate ; flower-stalk $\frac{1}{4}$ in. or less long, with a pair of bracts.

Native of the Himalaya at 6000 to $10,000 \mathrm{ft}$., from Nepal eastwards. This shrub is seen at its best in Cornwall, where it grows and blossoms to perfection. At Kew it is hardy in sheltered places, but does not grow more than 6 to $8 \mathrm{ft}$. high, flowering uncertainly. It is the most beautiful of this genus. The same shrub, or a slightly differing form of it, has been found in W. Hupeh, China, by Wilson.

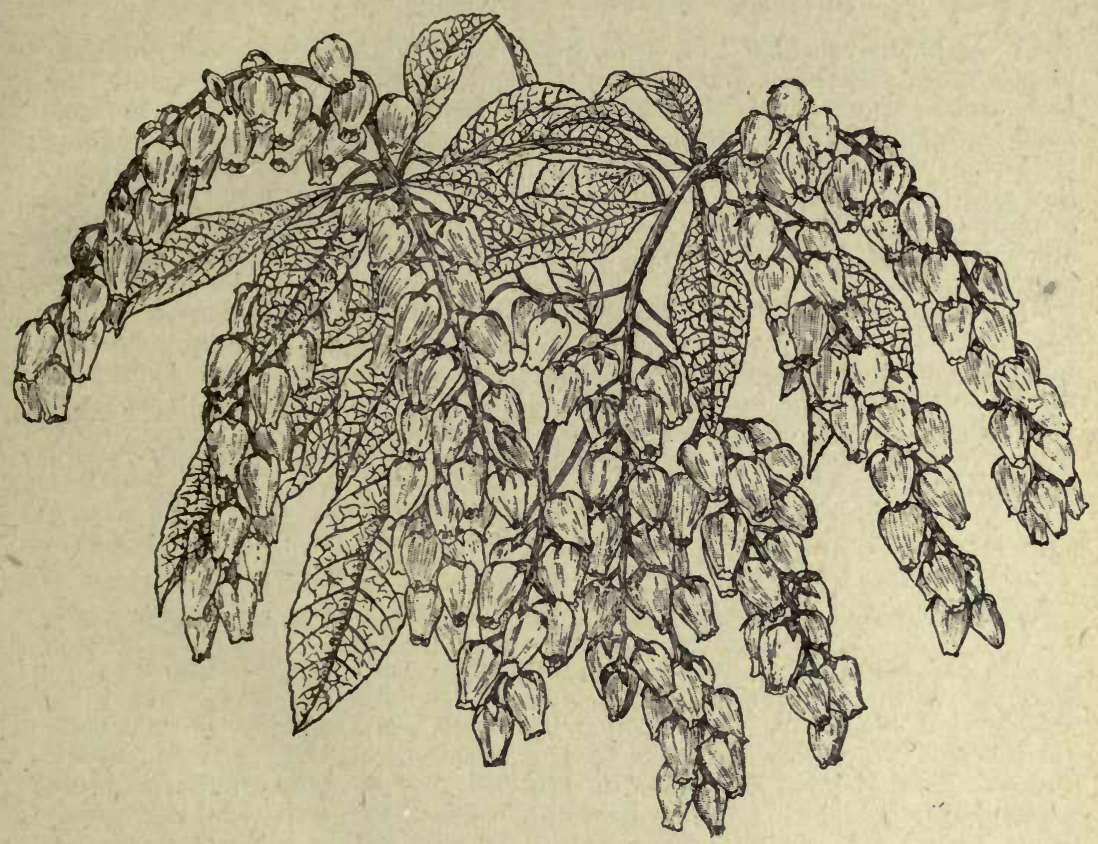

Pieris japonica.

P. JAPONICA, D. Don.

(Gardeners' Chronicle, 1882, i., fig. 120; Andromeda japonica, Thunberg.)

An evergreen shrub, ultimately 9 or Io ft. high, of bushy habit, and clothed to the ground with branches; young shoots usually smooth. Leaves leathery, oblanceolate or narrowly oval, usually widest above the middle, tapering towards both ends; $\mathbf{I}^{\frac{1}{4}}$ to $3^{\frac{1}{2}}$ ins. long, $\frac{1}{3}$ to $\frac{3}{4}$ in. wide ; shallowly toothed, dark glossy green above, paler beneath, smooth on both surfaces. Flowers in a terminal cluster of slender pendulous racemes each 3 to 6 ins. long; corolla pitcher-shaped, $\frac{1}{4}$ to $\frac{3}{8}$ in. long, much narrowed towards the mouth, where are five shallow, rounded teeth; calyx-lobes lanceolate, scarcely half as long as the corolla; flower-stalk $\frac{1}{8}$ in. long, smooth. 
Native of Japan. This shrub is not so hardy as P. floribunda, from which it is easily distinguished by the leaves being narrower and more tapering at the base, by the pendulous inflorescence, and by the absence of hairs on the young wood and flower-stalks. It flowers in March and April, and is often injured by frost. At its best it is a very beautiful shrub. It should be given a sheltered spot, with a western exposure.

Var. VARIEGATA has narrower leaves than the type, edged, especially towards the apex, with yellowish white. Well grown, it is one of the most striking of variegated evergreens.

\section{P. MARIANA, Bentham and J. D. Hooker. \\ (Andromeda mariana, Linnaus, Bot. Mag., t. 1579.)}

A deciduous shrub, 3 or $4 \mathrm{ft}$. high, with rather stiff, open branches; young shoots smooth. Leaves thin, but rather leathery; $1 \frac{1}{2}$ to 3 ins. long, $\frac{1}{2}$ to $1 \frac{1}{3}$ ins. wide; oval, tapering towards both ends, smooth, not toothed; veins rather prominent beneath ; stalk $\frac{1}{8}$ in. or less long. Flowers nodding, borne in June at the naked ends of the previous year's shoots, below which the new growths spring; they are arranged at each joint in a cluster of four to eight blossoms. Corolla white, or tinged with red, cylindrical, about $\frac{1}{2}$ in. long, with five small teeth; calyx-lobes lanceolate; flower-stalks $\frac{1}{2}$ in. long, smooth.

Native of the eastern United States; introduced in 1736 , but never very common. It is really a very hardy shrub, and succeeds admirably, planted in large masses, at the Arnold Arboretum, Mass., where the winters are much more severe than ours. But it does not thrive so well with us, owing no doubt to our lack of summer sun, through which the growths ripen badly. I saw it in June 1910 at the Arnold Arboretum almost rivalling Zenobia speciosa in beauty.

\section{P. NITIDA, Bentham and J. D. Hooker.}

(Andromeda nitida, Bartram; A. coriacea, Ailon, Bot. Mag., t. I095.)

An evergreen shrub, $6 \mathrm{ft}$. or more high, with smooth branches and smooth, leathery, shining green, scarcely stalked leaves, which are I to $3 \frac{1}{2}$ ins. long, $\frac{3}{4}$ to $1 \frac{1}{2}$ ins. wide ; narrowly oval, tapering at both ends ; the margins not toothed, but thickened or slightly decurved. A vein traverses the leaf parallel with, and close to, the margin. Flowers produced in June and July in short clusters from the leaf-axils, four to eight together. Corolla white, tinged with red, cylindrical, $\frac{1}{4}$ to $\frac{3}{8}$ in. long, rather inflated at the base, and slightly tapering thence to the narrow orifice, where are five tiny, erect lobes ; calyx-lobes linear-lanceolate, shining, reddish, $\frac{1}{5}$ in. long.

Native of the south-eastern United States; introduced in 1765 , but very rare on account of its tenderness. It is only suited for the milder parts of Great Britain. Very distinct because of its thick lustrous leaves with their thickened edges and marginal vein, and its long, narrow calyx-lobes.

\section{PINUS. PINE. CONIFERE.}

Among coniferous trees the pines constitute by far the most important group, regarded either from the point of view of number of species or that of economic value. As timber trees they easily predominate over 
any other genus in the northern hemisphere. They are evergreen, and range from trees over $200 \mathrm{ft}$. high to mere shrubs; very resinous, producing their branches in tiers.

The leaves of pines are nearly always produced in clusters or bundles of from two to five, occasionally there are six, and in one speciesmonophylla - they are solitary. The seedling leaves of all pines are solitary, the adult condition commencing to appear in the second and third years. The individual leaf or "needle" is long and narrow, mostly finely toothed at the margin, and always more or less conspicuously lined with rows of minute white, or whitish, dots called stomata. Where the leaves are in bundles of two the transverse section of each is semicircular, in the bundles of three to five they are three-sided. Each bundle of leaves, whatever their number, forms in the aggregate a slender cylinder. At the base of each bundle is a "sheath," whose varying length and duration give very useful indications of the identity of the species. The leaf-bearing shoots of each season are always to a greater or less extent naked at the base, being furnished there with "scale-leaves" only-small, thin, membranous bodies, often fringed, and usually falling away quickly. The terminal winter bud is an important differentiating character according to its shape and size, the character of the scales by which it is covered, and whether it be resinous or not, although in some species the last character is uncertain.

The flowers of pines are unisexual and borne in conical clusters, the males at the base, the females at the apex of the year's growth; the female inflorescence develops the second year into a woody fruit often of great size and weight, commonly known as a "cone," and of egg-shaped, cylindrical, or tapered form. These cones are composed of a number of woody scales which vary in length, in thickness, and in the character of the scar or boss at the end, and in the presence or absence of spines. When the cone is ripe (most frequently at the end of the second year), the scale opens and allows the two seeds at its base to escape; but some species take longer, and several appear never to release their seeds at all unless through some outside agency such as fire (in the West American forests), or squirrels, or birds. Some species have small seeds which are furnished with a large membranous wing whose object is to assist in their dispersion. The larger, edible seeds have only rudimentary wings or none at all.

As garden or park trees the pines are of varying merit, but the best of them are amongst the noblest of evergreens. They do not need a rich soil so much as an open, well-drained one. The hardier ones, like montana, sylvestris, and Banksiana, grow in some of the most inclement parts on the globe. On nearly all the mountains of the northern world it is some member of this genus that makes the highest timber line. For chalky soils, Brutia, halepensis, excelsa, Laricio, Pinea, and others succeed very well; whilst for spots exposed to sea-gales and in maritime situations generally, the Austrian pine, radiata, Pinaster, and Thunbergii are extremely useful in building up the first line of protection from seawinds. The purely garden varieties have to be increased by grafting on the types to which they belong, but all other pines must be grown from 
seed. With few exceptions it is desirable to get them planted in their permanent places as young as possible.

A few pines well known by name are not given detailed description in the following pages because their garden value is nil; the three following species may be briefly mentioned:-

P. PALUSTRIS, Miller (P. australis, Michaux), is the true PITCH-PINE of the south-eastern United States, and one of the most valuable timber trees of the world. Its leaves are in threes, and measure from 8 to 18 ins. long, standing out stiffly all round the branches like the bristles of a sweep's brush. A remarkable pine, up to $120 \mathrm{ft}$. high in nature, but too tender to succeed well in our climate.

P. TAEdA, Linnaus. Loblolly PINE.-This is from the same region as palustris, and can only be grown in the mildest parts of our islands. It is a three-leaved pine, the leaves 5 to 9 ins. long, and is chiefly distinguished amongst that group by the non-resinous winter-buds clothed with fringed scales recurved at the top.

P. TORReyana, Parry, is found only in two places in South California. It is a distinct species, with leaves in fives and up to $\mathrm{r} f$. long, but too tender for our average climate. It has several times been killed at Kew. One of the natural sites of the tree is now under public protection.

As indicating broadly the affinities and leading distinctions of the species here dealt with, the following rough classification is given. Those marked * are most to be recommended for gardens :-

Monophylla.

\section{LEAVES SOLITARY.}

\section{LEAVES IN PAIRS.}

\section{(a) Buds cylindrical, resinous.}

Banksiana. Leaves $\mathrm{I}$ to $\mathrm{I} \frac{3}{4}$ ins. long; cones bent at the end.

* Muricata. Leaves 3 to 5 ins. long.

Virginiana. Leaves $I_{\frac{1}{2}}$ to 3 ins. long; young shoots purple-violet.

Pungens. Leaves stiff, sharply pointed; young shoots brown.

* Sylvestris. Leaves glaucous; bark of trunk scaling, reddish.

Densiflora. Leaves green; bark of trunk scaling, reddish.

* Montana. Leaf-sheath up to $\frac{5}{8} \mathrm{in}$. long; bud -scales appressed. Contorta. Leaf-sheath about $\frac{1}{4}$ in. long ; bud-scales appressed. Murrayana. Like contorta, but with scaling bark on trunk.

\section{(b) Buds broadly ovoid, resinous.}

*Laricio. Leaf-sheath $\frac{1}{2}$ in. long: leaf 4 to 7 ins. long.

* Thunbergii. Leaf-sheath $\frac{1}{2}$ in. long; leaf 2 to $4^{\frac{1}{2}}$ ins. long; bud resinous at base only.

Resinosa. Leaf-sheath $\frac{3}{4}$ in. long.

Leucodermis. Leaves stiff; young shoots shining brown, turning grey the second year.

(c) Buds non-resinous.

*Pinaster. Bud-scales with fringed margins and recurved points.

* Prnea. Bud-scales as in Pinaster; leaves much shorter.

Halepensis.
Brutia. Young shoots pale, and leaves more slender than in either of above.

Echinata. Young shoots blue-white; leaves often in threes.

* Edulis. Young shoots blue-white; leaves often in threes; leaf-sheath rosette.like. 
III. LEAVES IN THREES.

(a) Leaf-sheath deciduous.

* Bungeana. Leaf-sheath falling the first year.

Gerardiana. Leaf-sheath falling the second year.

(b) Leaf-sheath rosette-like.

Cembroides. Leaves sometimes in pairs.

(c) Leaf-sheath persistent; buds resinous.

* Coulteri. Buds conical : leaf up to I $\mathrm{ft}$. long.

Sabiniana. Buds cylindrical; leaf up to I ft. long. Young shoots orange-scented

* Ponderosa. Shoots brown; leaf 5 to 10 ins. long.

Jeffreyi. Shoots glaucous; leaf 5 to Io ins. long.

Rigida. Trunk furnished with small twigs.

* Radiata. Cones persisting long ; foliage grass green.

Tuberculata. Cones persisting long; leaf longer; grey-green.

1V. LEAVES IN FIVES.

(a) Leaf-sheaths persistent.

Hartwegi. Leaves 5 to 6 ins. long.

Montezume. Leaves 7 to 12 ins. long.

\section{(b) Leaf-sheaths rosette-like; leaves not toothed.}

* A ristata. Leaves resin-dotted; persisting twelve or fifteen years.

"Ba'fouriana. Leaves not resin-dotted; persisting twelve to fifteen years.

Parryana. Leaves often in fours; persisting two or three years.

(c) Leaf-sheaths deciduous; shoots downy.

Armandii. Shoots sometimes glabrous like excelsa, but cones stouter (see figures).

* Ayacahuite. Basal scales of cone recurved.

Koraiensis. Bud-scales free at tips and spreading.

* Cembra. Young shoots almost shaggy.

* Lambertiana. Winter buds rounded or blunt.

Strobus. Shoots downy only at base of leaf-bundle as a rule.

* Monticola. Shoots downy all over, otherwise similar to Strobus.

Parvifiora. Leaves $I \frac{1}{2}$ to $2 \frac{1}{2}$ ins. long, the shortest of this group.

(d) Leaf-sheaths deciduous; shoots glabrous.

* Excelsa. Leaves 5 to 7 ins. long.

Peuke. Leaves 3 to 4 ins. long.

(e) Leaf-sheaths deciduous; leaf-margins not toothed.

Albicaulis. Cones short and thick.

* Flexilis. Cones more slender.

\section{P. Albicaulis, Engelmann. White Bark Pine.}

A shrub Io to $20 \mathrm{ft}$ high, rarely a tree twice as high; in the smaller state usually with two or three main stems. Young branchlets yellowish brown, minutely downy or smooth, becoming grey the second or third year, finally whitish. Leaves in fives, persisting five to seven years, I to $2 \frac{1}{2}$ ins. long, green with whitish stomatic lines on all three surfaces, stiffly pointed; not 
toothed at the margins; leaf-sheaths $\frac{5}{8}$ in. long, soon falling. Cones indehiscent, $\mathrm{I} \frac{1}{2}$ to 3 ins. long, and nearly as thick; scales very thick, with a spine-tipped boss. Seeds about $\frac{1}{2}$ in. long, with little or no wing, sweet, edible.

Native of Western N.America at high elevations, becoming in cold bleak sites reduced to dwarf scrub. It was introduced by Jeffrey in 18.52 , but subsequently, disappeared from cultivation. A few years ago it was reintro-

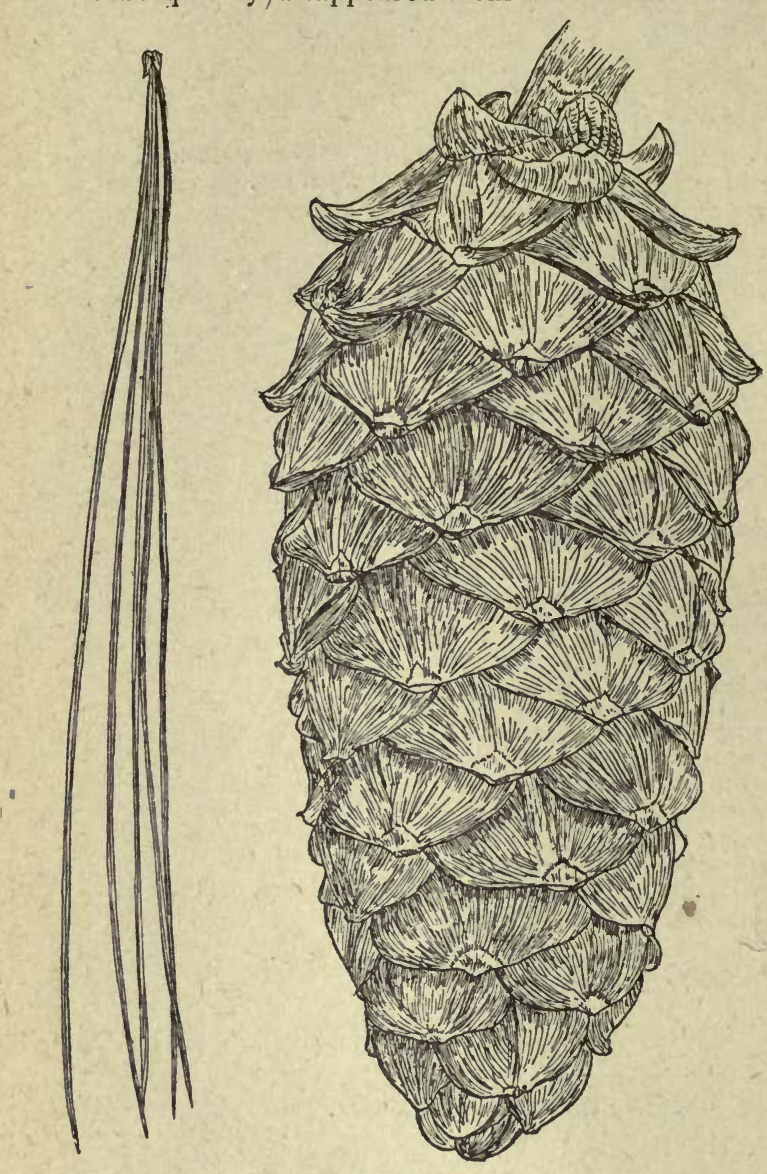

Pinus Armandi. duced to Kew, where small plants are quite healthy but slow-growing. They already show the characteristic tendency to form several leaders. Closely allied to P. flexilis, and with the same toothless leaves and nearly wingless seeds, but very different in the cones.

\section{P. ARMANDII,} Franchet. ARMAND's PINE.

(Bot. Mag., t. 8347.)

A tree described as becoming $60 \mathrm{ft}$. high in nature, with very much the aspect in a young state of $P$. excelsa ; young shoots greyish green, usually furnished with a minute, dark, often scattered down. Leaves in fives, mostly falling the second year; 4 to 6 ins. long, white with stomata on two sides, glossy green on the third; pointed, minutely toothed on the margin ; leaf-sheath soon falling away. Cones 4 to 8 ins. long, $2 \frac{1}{2}$ to 3 ins. thick before expanding, tapering slightly from the base. Scales thick, broadly triangular, about $\mathrm{I}_{4}^{\frac{1}{4}}$ ins. long.

Native of the mountains of W. China ; first introduced to England by Henry, who sent seeds to Kew from Mengtse, Yunnan, in 1897. But two years previously seeds had reached Mr Maurice de Vilmorin from Père Farges. The trees raised from Henry's seed grew quickly when once established, and first bore cones (infertile) in 1909. In habit and foliage they scarcely differ from P. excelsa, and promise to have about the same garden value. The leaves often show the same kink towards the base as, in excelsa. The cones, as may be seen from our figures, are very distinct. 
P. Ayacahuite, Ehrenberg. MEXICAN White Pine.

A tree said to be 100 $\mathrm{ft}$. high in nature, and already between 60 and 70 ft. high in this country; in habit very similar to P. excelsa. Young shoots brownish, downy. Leaves in fives, very slender and pointed, falling the third year, 4 to 7 ins. long ; three-sided, two surfaces with three or four white lines of stomata, the other bright green; margins toothed; leaf-sheaths $\frac{3}{4}$ in. long, soon falling completely away. Cones 6 to 12 ins. sometimes 18 ins. long, I to $2 \frac{1}{2}$ ins. wide before expanding, cylindrical, with a tapered slightly curved apex. Scales obovate, 2 ins. or more long, the edges thin. Seed with a narrow wing nearly I in. long. The scales at the base of the cone are always curled back almost or quite to the stalk, which they never are in P. excelsa.

A native of Mexico, where it is widely spread and very variable. Introduced by Hartweg for the Royal Horticultural Society in 1840 , and afterwards under numerous names by Roezl. It varies in hardiness, but the shorter - coned form here figured is hardy at Kew.

Var. Veitchil, Shaw (P. Veitchii, Roezl), is one of the more tender, larger-coned forms. Only hardy in Cornwall and similar places.

The cones of this pine are quite distinct from those of P. Armandii, but

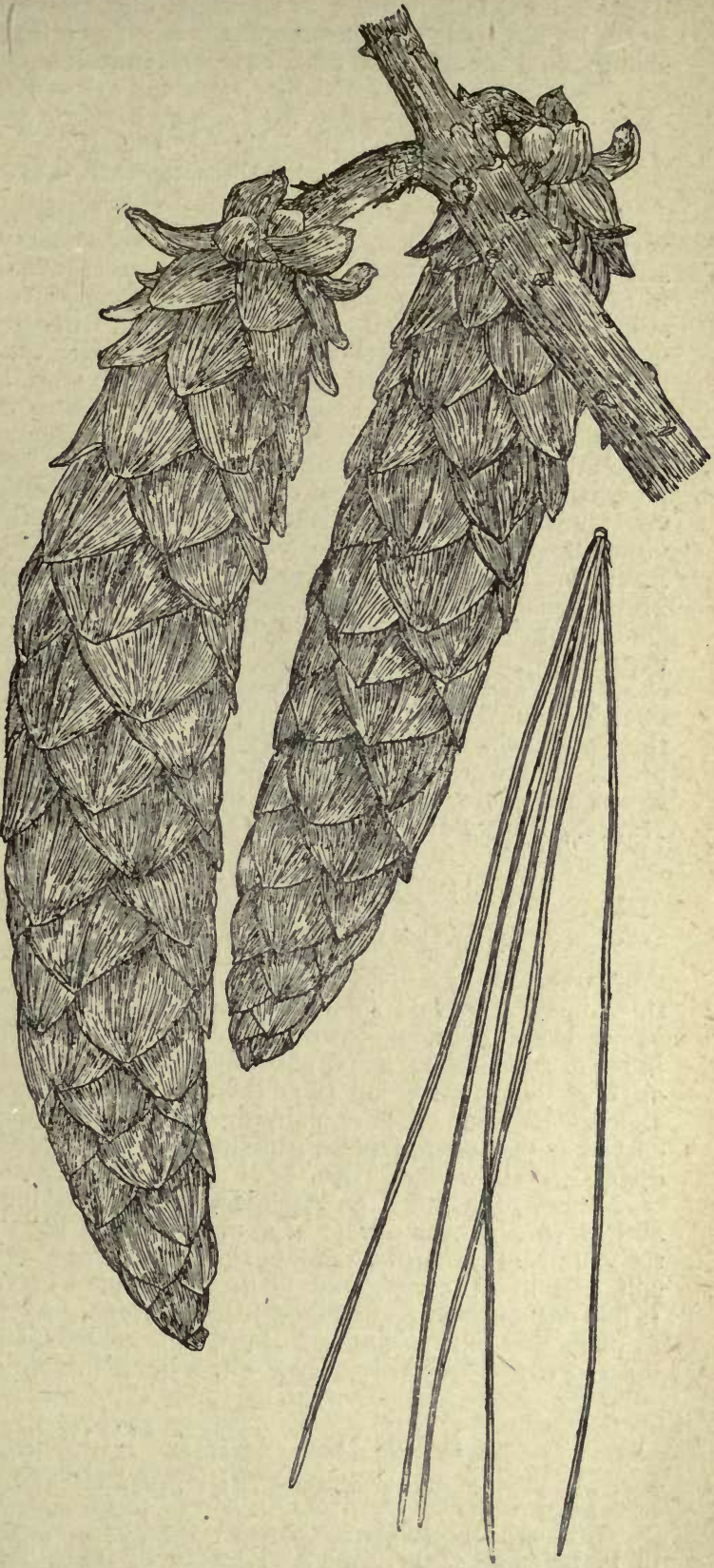

Pinus Axacahuite. 
its shoots and foliage are very similar to the more downy states of the latter. But in P. Armandii the leaves fall usually a year earlier, the shoots are more slender, and the terminal buds have closer scales.

\section{P. Balfouriana, Jeffrey. Fox-tail Pine.}

\section{(Gardeners' Chronicle, I876, i., fig. 58.)}

A small tree, 20 to 40 , rarely over $50 \mathrm{ft}$. high, forming in a small state a very densely branched, bushy tree; young shoots covered with minute but scarcely visible down, so closely packed are the leaf-bundles. Leaves mostly in fives, sometimes in fours, persisting as long as twelve or fifteen years, very stiff and sharply pointed, about $\mathrm{I} \frac{1}{2}$ ins. long, three-angled, two surfaces at first white with stomata, becoming nearly green like the third with age; margins not toothed. The scales of the leaf-sheath curl back and make a sort of rosette surrounding the base of the leaf cluster, and persist in that shape. Cones $2 \frac{1}{2}$ to 5 ins. long, each scale armed with a minute, incurved prickle.

Native of California ; introduced in 1852 by Jeffrey. Still an uncommon pine, it is one of the most distinct and attractive for a limited area. It grows very slowly, but its long retained, closely packed leaves give it a healthy, vigorous aspect. It and its close ally $P$. aristata (see below) are quite distinct in appearance, and differ from all other five-leaved pines in the rosette-like arrangement of the leaf-sheath.

P. ARISTATA, Engelmann (P. Balfouriana var. aristata, Engelmann), is very closely allied to the above, but is always distinguishable by conspicuous exudations of whitish resin on the leaves, giving them very much the appearance of being infested with some scale insect. The branches are more drooping, the young shoots more distinctly downy, and the cones of P. aristata are armed with considerably longer, slender prickles. Introduced in 1863 from Colorado, where it grows on the outer range of the Rocky Mountains, also in Nevada, Utah, and California.

\section{P. Banksiana, Lambert. Jack Pine.}

\section{(P. hudsonica, Parlatore; P. divaricata, Dumont de Courset.)}

A tree varying in height from a scrubby bush to a tree 20 to $45 \mathrm{ft}$. high in this country, but said sometimes to become 70 to $90 \mathrm{ft}$. high in N. America ; young shoots without down; terminal buds egg-shaped, $\frac{1}{3}$ in. long, encased in resin. Leaves in pairs, persisting two to four years, 1 to $1 \frac{3}{4}$ ins. long, flat on one side, convex on the other, dark green, much curved; leaf-sheaths about $\frac{1}{6}$ in. long. Cones pointing forward, slender, conical, but very much curved at the tapered point ; about $1 \frac{1}{2}$ ins. long, $\frac{3}{4}$ in. wide at the base before opening; yellow when ripe.

Native of Eastern N. America, where it is the most northerly of pines, and is spread over a vast region, usually in poor soil ; introduced early in the eighteenth century. It appears to be very well adapted for poor sandy soil, and has been planted in great numbers in Germany on that account. It has not much to recommend it for gardens. Among pines with short leaves in pairs and with resinous buds, this is to be distinguished by its slenderly tapered cones, curiously curved like a bent little finger at the apex.

\section{P. BRUtia, Tenore. CAlabrian Pine.}

(P. pyrenaica, Carrière; P. halepensis var. Brutia, Henry.)

Although by some authorities regarded as nothing more than a form of $\mathrm{P}$. halepensis, this seems to me to be a distinct species. The tree itself 
is of thin, ungainly habit ; its leaves (in pairs) are 4 to 6 ins. long, its young shoots are green, and more flexible than those of halepensis ; finally, its cones point forwards instead of backwards, and are thicker ( 2 ins.) at the base. It is rather lacking in attractive qualities, being thin in branch and leaf and inferior in this respect to halepensis. It is said to grow $80 \mathrm{ft}$. high, and is a native of S.E. Europe (not of the Pyrenees, as a name under which it is frequently grown would imply), with much the same general distribution as $P$. halcpensis, except that it reaches not farther west than Southern Italy.

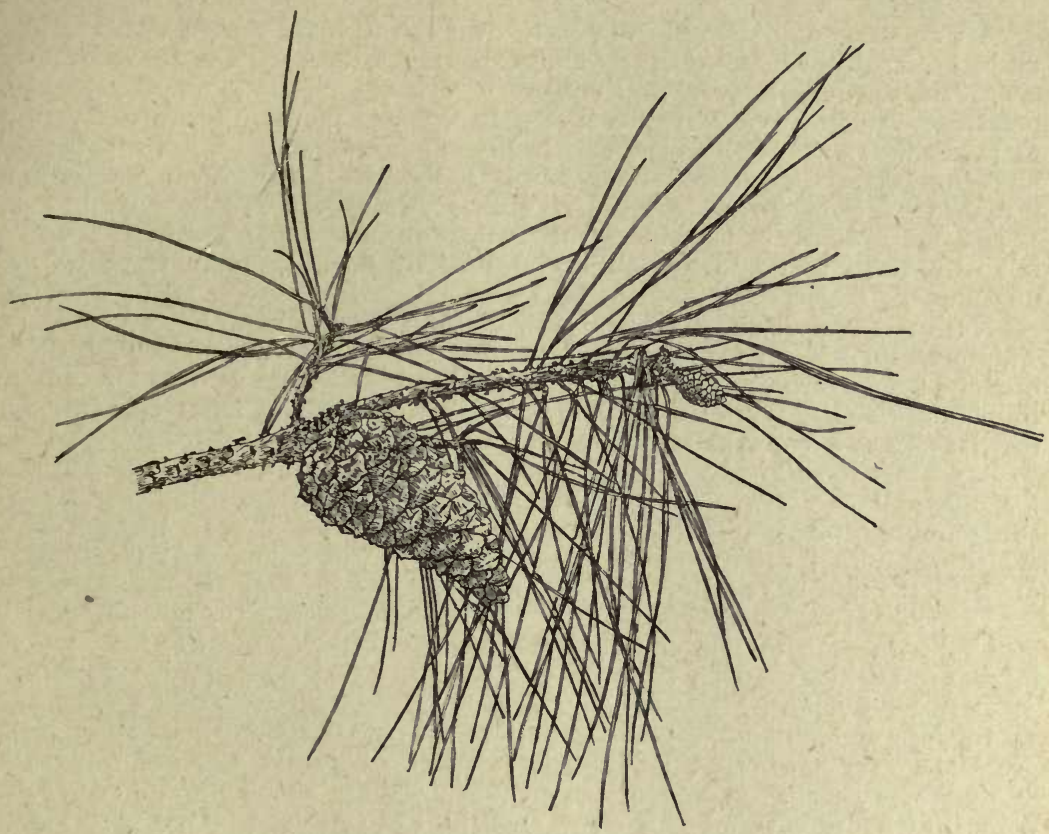

Pixus Brctia.

P. Bungeana, Zuccarin. Bunge's Pine, Lace-Bark Pine.

(Bot. Mag., t. 8240.)

A tree sometimes forming a rounded, bushy head, but frequently branching near the ground and forming several stems which grow erect to a height occasionally of 80 to $100 \mathrm{ft}$. The bark is smooth and peels off the trunk like that of a plane; in young specimens it is brown, but in old ones becomes quite white and gives to this pine its most remarkable character. Young shoots perfectly smooth, shining, greyish green. Leaves in threes, persisting four or five years, about 3 ins. long, two-edged, stiff, sharply. pointed, bright green, very minutely toothed, marked all round with faint stomatic lines; leaf-sheath $\frac{1}{2}$ to $\frac{3}{4}$ in. long, soon falling. Cones 2 to $2 \frac{1}{2}$ ins. long, $I \frac{1}{4}$ to $I \frac{1}{2}$ ins. wide, shortly stalked, the scales terminated by a decurved, triangular spine; seeds $\frac{1}{3}$ in. long, without wings.

Native of China; first seen by Dr Bunge in $18_{3} I$ in the environs of 
Pekin, where it has been largely planted for the sake of its remarkable white trunk; introduced by Fortune in 1848. It has lately been seen in quantity by Wilson in Central China. It is distinct from all other threeleaved pines, except P. Gerardiana, in the deciduous leaf-sheaths. It succeeds very well at Kew, where are trees approaching $30 \mathrm{ft}$. in height -not yet, however, showing the white bark. This is said not to appear, even in China, until the trees are fifty years old.

\section{P. Cembra, Linnaus. Arolla Pine.}

A tree varying in height from 60 to over Ioo ft. high, usually of pyramidal form, especially when young; young shoots clothed with a thick coat of brownish down. Leaves in fives, very densely packed on the shoots, persisting three to five years according to vigour ; pointing forward, fragrant in summer, $I \frac{1}{2}$ to $3 \frac{1}{2}$ ins. long, rich green; triangular, with three to five lines of stomata on two faces; margins toothed except near the point; leaf-sheaths $\frac{3}{4}$ or $\frac{7}{8}$ in. long, soon falling away. Cones egg-shaped, 2 to 3 ins. long, scarcely as wide ; the scales do not expand, and the seeds fall with the cones and are either released by birds or animals, or by the decay of the scales.

Native of the Alps of Central Europe and Siberia; introduced in 1746. This well-known pine makes a very pretty small tree, pyramidal, densely branched and very leafy, especially from 8 to $20 \mathrm{ft}$. high. It does not appear to be long-lived nor produce cones freely in the south of England, although there are a few trees between 60 and $80 \mathrm{ft}$. high in old gardens. Young trees often die suddenly. It is, of course, a purely Alpine tree in Europe, its rugged line marking the highest frontier of tree growth on many of the mountain-sides of Switzerland, France, and the Tyrol. In the more sheltered upland valleys visitors to those parts will have noted picturesque old veterans that have braved the storms, doubtless, for hundreds of years.

Var. SIBIRICA, Loudon.-A taller tree of quicker growth, but apparently less well adapted to our climate than the Central European form. Native of vast areas in European and Asiatic Russia. There is a garden varietyAUREA - with yellowish leaves.

In Japan, Manchuria, Siberia, and other cold regions of Eastern Asia grows P. PUMILA, Regel, botanically a close ally of P. Cembra, although of different aspect. It is a dwarf, mostly prostrate shrub never over io $\mathrm{ft}$. high, the shoots covered with down and the five-clustered leaves $I_{2}^{\frac{1}{2}}$ to 2 ins. long. They differ from those of P. Cembra in being usually entire at the margins. Cones $\mathrm{I} \frac{1}{2}$ ins. long, orange-brown, similar to those of P. Cembra in never opening. It was in cultivation early last century, but appears to have been lost sight of until recently, when Capt. Clinton Baker, R.N., collected plants in Japan and sent them to the Bayfordbury collection. Prof. Sargent says that on Mt. Hakkoda, Japan, at $6000 \mathrm{ft}$., he saw impenetrable thickets of it a few feet high covering hundreds of acres.

\section{P. Cembroides, Zuccarini. Three-leaf Nut Pine.}

A bushy tree usually 15 to $20 \mathrm{ft}$. high, sometimes 40 or $50 \mathrm{ft}$., the young branches slender, glaucous. Leaves mostly in threes, sometimes in pairs, persisting for about three years; I to 2 ins. long, dark green; in each cluster the inner faces of the leaves are pressed together, especially when young; margins not toothed; leaf-sheath at first $\frac{1}{4}$ to $\frac{3}{8}$ in. long, the scales afterwards becoming reflexed and forming a rosette round the base of each cluster. Cones roundish, egg-shaped, $I \frac{1}{2}$ to 2 ins. long, I to $I \frac{1}{2}$ ins. wide, with very few scales. Seeds $\frac{1}{2}$ in. long, edible. 


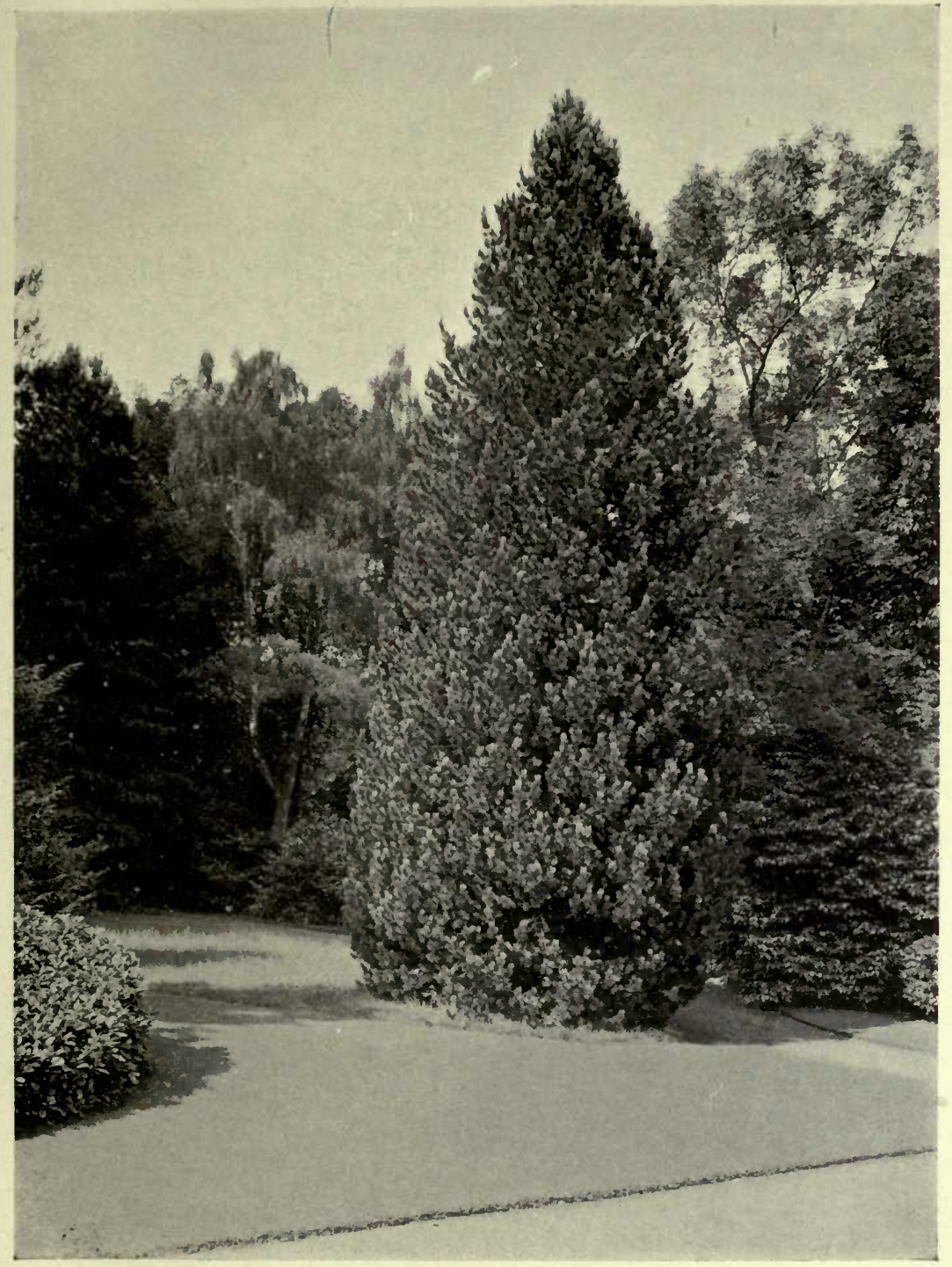

Swiss Pine, Pinus Cembra.

II.]

¿Face $p .176$. 

Native of Mexico, Arizona, and Lower California ; introduced by Hartweg in 1839. The seeds are sold in Mexican markets as "piñones" along with those of $\mathrm{P}$. edulis, to which the present species is closely allied. The leaves of that species, however, are chiefly in pairs instead of threes; the branches are stouter, and the leaves usually thicker. These two are the only pines with two or three leaves in a cluster that have rosette-like leaf-sheaths.

\section{P. COntorta, Loudon. Beach Pine.}

A tree 20 to $30 \mathrm{ft}$. high in a wild state, but apparently likely to grow higher in cultivation; bark thick, roughly fissured; young shoots often curiously twisted, not downy; terminal buds narrowly cylindrical, $\frac{3}{4}$ to $\mathbf{I}$ in. long, resinous. Leaves in pairs, $1 \frac{1}{2}$ to $2 \frac{1}{4}$ ins. long, $\frac{1}{12}$ in. or less wide ; dark green ; persisting three, four, or more years; leaf-sheath $\frac{3}{16}$ in. long, persistent. Cones obliquely conical, up to 2 ins. long, $\frac{3}{4}$ in. wide at the base before expanding; the scales terminated by a slender spine which wears away in time. The cones remain on the tree for four or five years, or even longer, before shedding their seed.

Native of the coast region of Western N. America, from Alaska to S. California ; discovered by Douglas in 1825 ; introduced later at some uncertain date. (See also P. Murrayana.)

\section{P. Coulteri, D. Don. Coulter's Pine.}

A tree 50 to $80 \mathrm{ft}$. high, with a stout, erect trunk, 3 to $4 \mathrm{ft}$. in thickness, whose bark is divided into deep broad ridges. Young shoots very thick, often glaucous, not downy ; the terminal part carrying a cluster of crowded leaves, the lower part furnished with fringed, slender-pointed scales, I in. long. The older portions of the branchlet are rough with the remains of these scales, and the prominences on which the leaf-bundles were seated. Buds conical, resinous, slender-pointed, $1 \frac{1}{2}$ ins. long, $\frac{3}{4}$ in. wide. Leaves in threes, falling the fourth year; 10 to 12 ins. long, minutely toothed, grey-green, with lines of stomata on all three faces; leaf-sheaths persistent, I in. long. Cones Io ins. to 12 ins. long, 5 to 7 ins. thick; the scales terminated by a stout triangular spine.

Native of California ; discovered by Dr Coulter in 1832 ; introduced by Douglas the same year. The cones of this remarkable pine are the heaviest and most formidably armed among three-leaved pines, but are not often borne in this country. It resembles P. ponderosa in leaf and shoot, but is a shorter tree with more spreading branches. The cones are very different, and more like those of P. Sabiniana; which, however, has smoother, more slender shoots, and greyer leaves. Coulter's pine is not common in cultivation, but is very striking in its somewhat gaunt branching, and terminal bunches of leaves, spreading like a sweep's brush. (See plate, Vol. i., p. 8.)

\section{P. Densiflora, Siebold. Japanese Red Pine.}

A tree 100 to $120 \mathrm{ft}$. high in Japan, with a trunk 3 to $4 \mathrm{ft}$. through; bark of trunk reddish, scaling ; young shoots blue-white, smooth ; buds cylindrical, brown, resinous. Leaves in pairs, falling the third year, $2 \frac{1}{2}$ to 4 ins. long, slender, dark green on both surfaces, margins very minutely toothed; leafsheath $\frac{1}{4}$ to $\frac{3}{8}$ in. long, persistent, terminated often by one or two slender threads. Cones $1 \frac{1}{2}$ to 2 ins. long, $\frac{3}{4}$ to I in. wide before expansion, conical, pointed ; seed $\frac{1}{4}$ in. long, with a wing about thrice as long.

Introduced by Siebold from Japan to Europe in 1854 . It is a useful timber 
tree in its native country, filling much the same place in the flora there that the Scotch pine does in Europe. It is one of the favourite plants upon which the Japanese gardeners exercise their dwarfing arts. There is a group of trees at Kew 30 to $35 \mathrm{ft}$. high, rather striking in their reddish crooked trunks. The species is not likely to have any timber value with us. It resembles $P$. sylvestris in the resinous buds and reddish trunk, but is very different in general appearance, the leaves being green (not grey) and the young shoots glaucous (not green). Both this pine and $\mathrm{P}$. Thunbergi are found in gardens as "P. Massoniana," but the true P. MASSONIANA, Lambert, is a more southern tree, not, so far as I am aware, in cultivation, and probably too tender for our climate.

Var. AUREA behaves exactly like P. sylvestris aurea in the leaves turning yeliow in autumn and winter, changing to green again in spring and summer.

\section{P. echinata, Miller. Eastern Yellow Pine. \\ (P. mitis, Michaux.)}

A tree 30 to $50 \mathrm{ft}$. high in this country, over $100 \mathrm{ft}$. high in a wild state ; young shoots quite smooth, covered with blue-white bloom, slender, very brittle after they are one year old, the bark peeling the third year; terminal bud cylindrical, $\frac{1}{4}$ to $\frac{1}{3}$ in. long, not resinous, scales fringed. Leaves in pairs or in threes, mostly falling the second year; $1 \frac{1}{2}$ to 4 ins. long, slender, dull green; leaf-sheath $\frac{1}{4}$ to $\frac{1}{2}$ in. long, persistent. Cones $I \frac{1}{2}$ to $2 \frac{1}{2}$ ins. long, $\frac{3}{4}$ to $\mathrm{I}$ in. wide at the base before expanding; conical, with a short, distinct stalk.

Native of the eastern United States from New York State southwards; cultivated in this country since early in the eighteenth century. It is but little known, and has, indeed, no conspicuous qualities to recommend it for garden or park. It is distinct in its blue-white young shoots, occasionally threeleaved clusters, and brittle shoots covered with peeling bark after the second year. In N. America it is a very valuable timber tree.

\section{P. Edulis, Engelmann. Two-leaf Nut Pine.}

A small tree rarely more than 20 to $30 \mathrm{ft}$. high, often a mere bush in gardens; young shoots somewhat glaucous. Leaves in pairs, occasionally in threes, persisting three or four years; $\frac{3}{4}$ to $I \frac{1}{2}$ ins. long, stiff, pointed, without marginal teeth, dark green outside, inner faces glaucous with stomatic lines. The leaves in each bundle are inclined to remain with their inner faces close together; when they are in pairs they are semi-terete, when in threes triangular in section; leaf-sheath $\frac{1}{4}$ in. long at first, the scales afterwards reflexed, forming a rosette. Cones $\frac{3}{4}$ to 2 ins. long, composed of a few large woody scales, terminated by a small spine.

Native of the eastern foothills of the outer ranges of the Rocky Mountains, from Colorado to New Mexico. The edible seeds are sold in the markets there. It is a pleasing small tree of neat dense habit, but very rare in gardens. It is not easy always to discriminate between this species and P. cembroides, both of which have rosette-like leaf-sheaths, but this appears to be sturdier in branch, and shorter and stiffer in leaf, and the leaves are more frequently in pairs than in thrces.

\section{P. excelsa, Wallich. Himalayan Blue Pine.}

A tree reaching $150 \mathrm{ft}$. in height in a wild state, and already over $100 \mathrm{ft}$. high in cultivation; young shoots blue-green, perfectly free from down, slightly ridged below each bundle of leaves towards the apex. Leaves in fives, 
falling the second and third years, 5 to 7 ins. long, triangular in section, two faces white with stomatic lines, the third bright green ; margins minutely toothed, sharply pointed ; leaf-sheath $\frac{5}{8}$ to $\frac{3}{4}$ in. long, soon falling wholly away. The leaves are often bent abruptly near the base, so that the greater part of the leaf is pendulous. Cones at first cylindrical, 6 to ro ins. long, $1 \frac{1}{2}$ to $1 \frac{3}{4}$ ins. wide, before opening; each on a stalk 1 to 2 ins. long; scales $1 \frac{1}{2}$ ins. long, I in. wide, with a small, pointed, thickened apex.

Native of the Himalaya; introduced by A. B. Lambert in 1823. It is a handsome tree especially when of middle age, and grows with great rapidity when young, the leading slioot increasing by 2 to $3 \mathrm{ft}$. annually. It thrives best in a good sandy loam, and in a position sheltered from fierce gales, which give it a bedraggled appearance. Very hardy, and bearing cones early. It is only likely to be confused in gardens with P. Armandii, and P. Ayacahuite, both of which have more or less downy shoots and different cones. Its glabrous shoots, its five-clus: tered leaves and quickly falling leaf-sheath, distinguish it from all other pines except P. Peuke (q.v.)

\section{P. FLEXILIS, James. Limber Pine.}

(Bot. Mag., t. 8467.)

A tree 40 to 60 , sometimes $80 \mathrm{ft}$. high; branches long, slender; the young parts so flexible that they can be bent double without breaking; young shoots shining green, perfectly smooth or with minute brownish down. Leaves in fives, persisting for about seven years, often pointing forwards, or the youngest ones even appressed to the branchlet; $2 \frac{1}{2}$ to 3 ins. long, triangular in section, all three sides marked with three

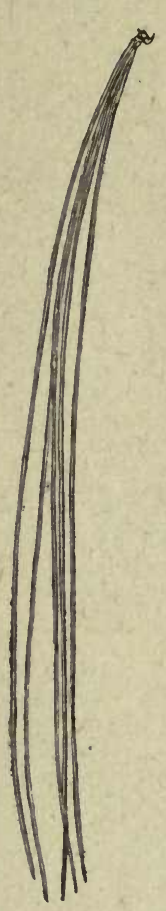

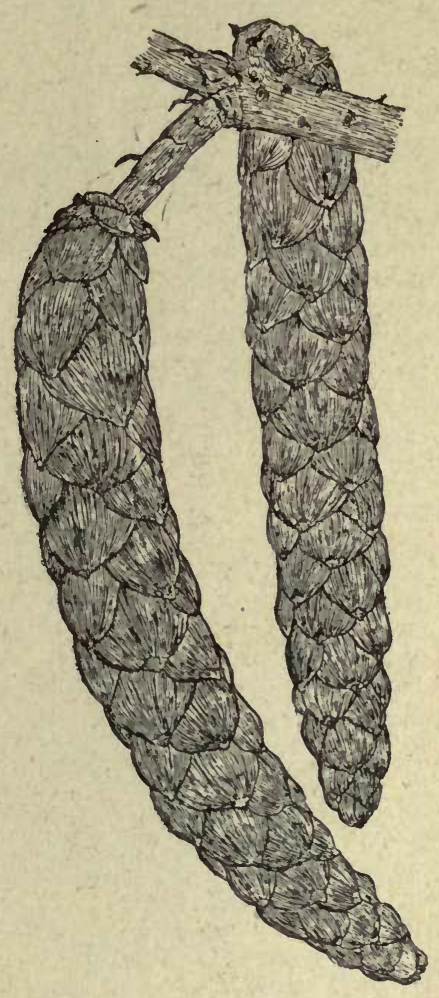

PinUs exCelsa. or four white lines of stomata ; margins quite entire, apex finely pointed; leaf-sheaths $\frac{1}{2}$ to $\frac{5}{8} \mathrm{in}$. long, soon falling away. Cones 3 or 4 ins. long, $I \frac{1}{2}$ ins. thick before the scales open.

Native of Western N. America; introduced by Jeffrey in $I S ; 1$. Trees at Kew between 30 and $40 \mathrm{ft}$. high thrive well in gravelly soil, and bear cones most seasons. It is a very distinct and striking pine, resembling P. Balfouriana in its long-persisting leaves, but very different in other respects. From all cultivated five-leaved pines, except $\mathrm{P}$. albicaulis $\left(q \cdot v_{0}\right)$, it is easily distinguished by the absence of teeth on the leaf-edges, combined with often smooth branchlets and deciduous leaf-sheaths. Although a fairly lofty tree in favourable localities, it becomes at high elevations reduced to mere prostrate 
scrub, barely I $\mathrm{ft}$. high. In this state, according to Sargent, it holds in possession the bleak summits of the Cascade Mountains in California undisputed by an other tree.

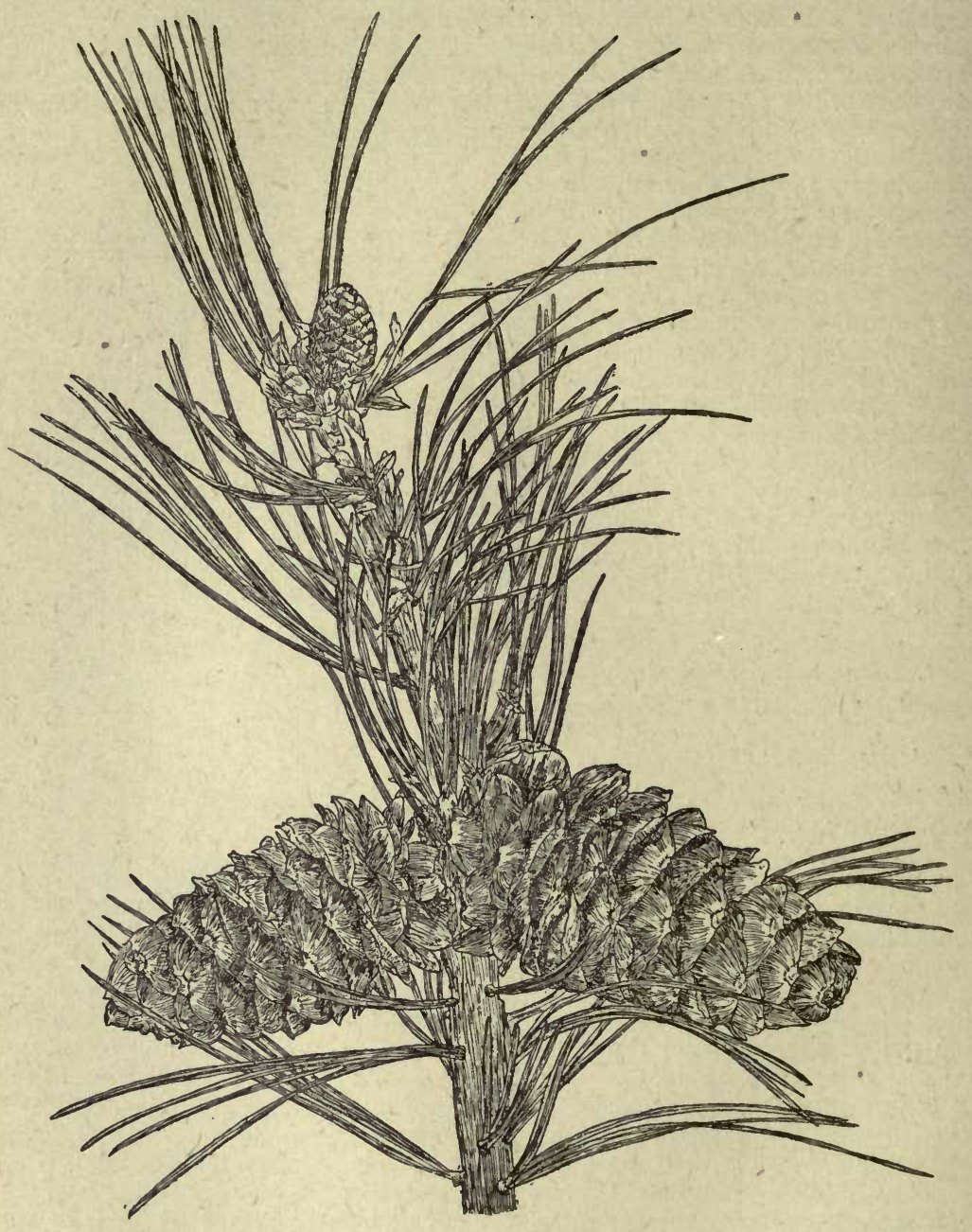

PINUS FLEXILIS.

P. Gerardiana, Wallich. Gerard's Pine.

One of the rarest of pines in cultivation, the only good specimen in England of which there is general knowledge being in the Cambridge Botanic Garden. This, when I saw it in February I9I I, was a little under $15 \mathrm{ft}$. high, of shapely form and in perfect health. Small plants have 
from time to time been raised at Kew, but are spring tender and grow slowly. Except in the south-western gardens it has little interest to cultivators. In the Himalaya it is a tree $80 \mathrm{ft}$. high; its shoots are smooth, and its leaves three in a bundle. The leaves of the Cambridge tree are 2 to 4 ins. long, dark dullish green, sharply pointed; leaf-sheath $\frac{1}{2}$ in. long, the scales becoming loose by winter and falling away the second year. In branch and leaf it is like P. Bungeana, and has a similar peeling bark; the trunk, however, does not become white in old trees like that of Bungeana, which differs also in its brighter leaves and quickly deciduous leaf-sheath. The cones of P. Gerardiana are described by Brandis as 6 to 9 ins. long, 4 to 5 ins. wide--thus many times larger than those of P. Bungeana.

\section{P. halepensis, Miller. Aleppo Pine.}

A tree rarely more than 30 to $50 \mathrm{ft}$. high in this country, but 70 to $80 \mathrm{ft}$. in favourable conditions; here it usually forms a rounded head of branches, but is more pyramidal in the south of Europe; young shoots pale grey, smooth ; buds slenderly conical, pointed, non-resinous, about $\frac{1}{2}$ in. long, with the points of the scales slender, fringed, and recurved. Leaves in pairs (rarely in threes), falling the second and third years; $2 \frac{1}{2}$ to $4 \frac{1}{2}$ ins. long, very slender; leaf-sheath $\frac{1}{4}$ to $\frac{1}{3}$ in. long. Cones pointing backwards, $2 \frac{1}{2}$ to $3 \frac{1}{2}$ ins. long, I to $I \frac{1}{2}$ ins. wide at the base, tapering to a slender point ; scales unarmed; stalk $\frac{1}{4}$ to $\frac{1}{2}$ in. long; they are produced in whorls and remain several years on the branches.

Native of S. Europe as far west as Spain and east to Asia Minor; introduced in the seventeenth century. Although tender in a young state it is hardy enough when once established; several examples at Kew have withstood $31^{\circ}$ of frost, and are quite healthy. This species and P. Brutia are distinguished among two-leaved pines by the non-resinous buds having recurved scales. The newly cut or bruised young wood has a most pleasant aromatic odour. It is the commonest pine along the south coast of Europe, and reaches perhaps its finest development along the Dalmatian coast, where I have seen it 70 to $80 \mathrm{ft}$. high, remarkably handsome in its heavy plumose masses of foliage. It covers bleak rocky promontories near Ragusa. (See P. Brutia for differences between it and the present species.)

\section{P. Hartwegi, Lindley. HaRtweg's Pine.}

\section{(P. Montezumæ var. Hartwegi, Engelmann.)}

A very near relative of Montezuma's pine, but found in Mexico at higher levels and under colder conditions. It is, in consequence, a much hardier tree. There is a good specimen, perhaps $30 \mathrm{ft}$. high, in Windsor Forest, which is the nearest to London that I know of, of any size. I have had it also in cone from Luscombe Castle, Dawlish, and it is at Bayfordbury and Westonbirt. Leaves mostly in fives, but also in fours; 5 to $6 \frac{1}{2}$ ins. long, crowded at the end of the shoot; stiff, grey-green, closely and minutely toothed on the margin, sharply pointed; leaf-sheaths quite persistent, $\frac{3}{4}$ to $I$ in. long. Cones 3 or 4 ins. long, I $\frac{1}{2}$ ins. wide; scales with a decurved spine-tipped boss. It differs chiefly from P. Montezumæ. in its shorter leaves and much hardier constitution. It is a tree up to $70 \mathrm{ft}$. high, with stout young shoots.

Discovered and introduced by Hartweg in 1839 . 


\section{P. JefFreyi, Greville. JefFrey's Pine.}

(Bot. Mag., t. 8257.)

So closely allied is this to $P$. ponderosa that it is very frequently regarded as a variety only of that species. It has the same lofty, columnar trunk (occasionally nearly $200 \mathrm{ft}$. high), stout branches with clusters of large spreading leaves in bundles of threes at the ends, and an orange-like odour when cut. It differs in the following respects : young shoots of a blue-white colour, leaves stiffer, and the cones much larger, 5 to 10 ins. long, 2 to 3 ins. wide. It is confined to California in a wild state, where, in the Shasta Valley, it was discovered in 1852 by Jeffrey, and introduced for the Oregon Association the same year. Jepson says it merges insensibly into P. ponderosa.

\section{P. KORAIEnsis, Siebold. COREAN PINE.}

A tree reaching at its best 100 to $\mathrm{I} 50 \mathrm{ft}$. in height; young shoots thickly clothed with short, reddish brown wool; winter buds $\frac{1}{2}$ in. long, cylindrical, with a tapered point, resinous. Leaves in fives, persisting to the third year; $3 \frac{1}{2}$ to $4 \frac{1}{2}$ ins. long, dark glossy green, with white stomatal lines on two faces; margins toothed the whole length, the apex bluntish; leaf-sheaths about $\frac{1}{2}$ in. long, soon falling. Cones about 5 ins. long, $2 \frac{1}{2}$ to 3 ins. wide at the base, tapering thence towards the apex. Scales $I_{4}^{\frac{1}{4}}$ ins. wide, thick and woody. Seeds $\frac{5}{8}$ in. long, not winged, edible.

Native of Corea, Japan, Manchuria, etc. ; introduced by J. G. Veitch in 1861. It is, perhaps, most closely allied to P. Cembra, but the growth is more open, the leaves are much more spreading, blunter, and toothed quite to the apex. The cones, too, are twice as long. P. koraiensis is not a first-class pine in this country, growing slowly. The best example I have seen is in Mr Hunnewell's garden, at Wellesley, Mass., U.S.A., about $40 \mathrm{ft}$. high in I9Io. There are good specimens at Kilmacurragh and Fota in Ireland, and at Segrez in France, all 35 to over $40 \mathrm{ft}$. high.

Var. VARIEgata, Hort., has some of the leaves yellow, others striped longitudinally in yellow and green, others wholly green-all sometimes in the same bundle.

\section{P. Lambertiana, Douglas. Sugar Pine.}

A tree 70 to sometimes well over $200 \mathrm{ft}$. high, and with a trunk 3 to $8 \mathrm{ft}$. in diameter; young shoots minutely downy; winter buds $\frac{1}{4}$ in. long, usually round or blunt at the apex, the scales closely flattened. Leaves in fives, falling the third year; 3 to $4 \frac{1}{2}$ ins. long, minutely toothed at the margins, bluish green, often spirally twisted; leaf-sheaths $\frac{1}{2}$ to $\frac{5}{8}$ in. long, soon falling completely away. Cones borne at the ends of the uppermost branches ; 12 to 20 ins. long, about 3 ins. thick before expanding; the woody scales 2 to $2 \frac{1}{2}$ ins. long, with a broadly pointed apex. Seeds $\frac{1}{2}$ to $\frac{3}{4}$ in. long, nutty in flavour, the wing nearly twice as long.

Native of Western N. America, in Oregon and California ; introduced in 1827 by Douglas, who had also discovered it. It is probably the noblest of all pines. The popular name refers to a sugary exudation from the trunk. In this country it has rarely borne its remarkable cones. It is allied to, as well as a neighbour of, P. monticola, but besides the differences in cones, the buds are more rounded and the leaf is more sharply pointed in Lambertiana. From P. Strobus its uniformly downy shoots distinguish it. It 
likes a sheltered situation and a good loamy soil. Even then it grows but slowly, but is handsome nevertheless. Trees approaching $100 \mathrm{ft}$. exist in this country, perhaps the finest one being at Arley. Castle, near Bewdley. A tree at Dropmore has borne cones at intervals since 1872 .

\section{P. Laricio, Poiret. Corsican Pine.}

A tree from 100 to $150 \mathrm{ft}$. high, and 4 to $6 \mathrm{ft}$. in thickness of trunk, the bark pale brown and deeply fissured on old trees. Young shoots light brown, not downy; terminal buds resinous, $\frac{1}{2}$ in. or more long, cylindrical at the base, narrowing abruptly at the apex to a slender point. Leaves in pairs, 4 to 7 ins. long, falling in their fourth year, semi-terete, very minutely toothed, dark green; leaf-sheath about $\frac{1}{2}$ in. long. Cones often in pairs or in threes, 2 to 3 ins. long, $1 \frac{1}{4}$ ins. wide before opening, conical, bright brown; the scales terminated sometimes by a minute prickle, but mostly unarmed.

This pine is a very variable one, and is found over a great range of country -from Spain in the West, to Greece, Asia Minor, and the Caucasus in the East ; introduced in 1759 . It reaches, perhaps, its finest development in Corsica, where it is sometimes 140 to $150 \mathrm{ft}$. high. Henry mentions a tree there with a short trunk $23 \mathrm{ft}$. in girth. In Britain it has been planted largely as a forest tree, and among introduced coniferous trees promises to be second in value only to the larch. It is bad to transplant if allowed to remain more than two years in one spot. The best results, perhaps, are obtained by planting trees not more than I ft. high. Rabbits are said not to touch it, although they eat the variety nigricans (Austrian pine), and it has the faculty of fighting its way through grass on all but the richest of land. As a garden tree it forms a handsome and stately specimen.

Var. NIGRICANS, Parlatore (P. austriaca, Hoess). Austrian Pine.-This well-known tree, introduced from S.E. Europe in 1835 , is very distinct in general appearance from, and decidedly inferior to, the Corsican pine. It has a rougher, shorter trunk, with more numerous branches, and heavier masses of darker green leaves, which on the whole are shorter, stiffer, and straighter than those of P. Laricio. The whole tree has a coarser, heavier aspect. It is very useful for growing on poor chalky soil, and as a shelter tree in bleak situations, especially near the sea. Its value as a timber tree is much less than that of P. Laricio.

Var. Pallasiana, Endlicher.-Distinct in habit, being more or less pyramidal, with the main branches growing erect ; cones 3 to 4 ins. long. A handsome garden tree, native probably of the Crimea. The tree described by Loudon under the above name appears to be something quite different.

Var. TENUIfolia, Parlatore (P. pyrenaica). Pyrenean Pine.-A distinct variety with orange-coloured young bark, and very slender leaves 6 or 7 ins. long (in gardens); often a bushy tree. It is the most Western form of the Laricio pine, being found on the Spanish side of the Pyrenees, and in France in the Cevennes.

Of purely garden varieties are the following: AUREA, a form of Austrian pine whose young growths are tipped with gold; PUMILA (pygmæa), a dwarf, rounded bush, a specimen of which, at least forty years old, is only $8 \mathrm{ft}$. high at Kew.

Closely allied to P. Laricio is

P. LEUCODERMis, Antoine (P. Laricio var. leucodermis, Christ).-A tree up to $90 \mathrm{ft}$. in height, young shoots light brown the first year, turning grey the second. Leaves in pairs, very rigid and erect, persisting five years, up to $4 \frac{1}{2}$ ins. long, dark green. Native of Bosnia, Herzegovina, and Montenegro ; discovered in 1864 , and introduced to Kew in 1890 . A purely mountain tree, very hardy. It is, no doubt, very close to P. Laricio-perhaps only a geographical form. 
In young plants the chief distinction is in the short, stiff leaves. According to Elwes, it makes a much better root system than either the Austrian or Corsican pine, and therefore transplants better. It is worth looking after for forestry purposes.

\section{P. monophylla, Torrey. One-leaf Nut Pine \\ (P. Fremontiana, Endlicher.)}

A tree usually $\mathrm{I}_{5}$ to $20 \mathrm{ft}$. high, pyramidal as represented by cultivated plants; young shoots grey, smooth or nearly so. Leaves solitary and terete, or occasionally in pairs, and then semi-terete, not toothed at the miargin ; I to $\mathbf{I} \frac{3}{4}$ ins. long, sharply pointed, curved; marked all round with stomatic lines, grey-green; leaf-sheaths at first about $\frac{1}{4}$ in. long afterwards curled back round the base of the leaf like a rosette. Cones $I \frac{1}{2}$ to 2 ins. long, with few thickened spoon-like scales ; seeds $\frac{5}{8}$ in. long.

Native of Utah, Nevada, Arizona, and Lower California ; discovered in 1844 , and introduced by Hartweg in 1848 . This curious pine is distinct from all others in the mostly solitary leaves, although in the rosette-like sheath it clearly shows its affinity to the cembroides and edulis group. It is an interesting curiosity, but grows too slowly to have much value in the garden. The seeds, like those of its allies, are eaten by the Indian tribes of Nevada, and have a sweet, nutty flavour, improved by roasting. The healthiest tree I know is in Messrs Paul \& Son's nursery at Cheshunt, I $7 \mathrm{ft}$. high, and there is one about as large at Old Conna Hill, near Bray, Ireland.

\section{P. montana, Miller. Mountain Pine.}

This name is applied to a group of pines varying in stature from dwarf shrubs to trees 60 to $80 \mathrm{ft}$. high, yet in botanical characters almost identical ; young shoots rough with scale leaves, not downy; terminal buds resinous, $\frac{1}{4}$ to $\frac{1}{2}$ in. long. Leaves in pairs, persisting five or more years; $1 \frac{1}{2}$ to 3 ins. long, conspicuously curved and twisted, stiff, dark green, pointed; leaf-sheath $\frac{1}{3}$ to $\frac{5}{8}$ in. long. Cones $I$ to $2 \frac{1}{2}$ ins. long.

Native of S. and Central Europe, always in mountainous regions, where it is often the highest woody plant. The form most commonly cultivated in Britain is a dwarf one known as

P. PUMilio, Haenke, or P. montana var. pumilio, Willkomm.-This grows 5 to $10 \mathrm{ft}$. high, forming not one leader, but a cluster of several stems curving out from the bottom. The cone is about $\mathrm{I} \frac{1}{2}$ ins. long. Native of Central and S.E. Europe, from the Jura Mountains of W. Switzerland to Montenegro. In gardens this pine is extremely useful as an evergreen covering for dry slopes and mounds, and thrives in the poorest soil. It transplants very well. Not often distinguished from this in gardens is P. MUGHUS, Scopoli, which is similar in habit, and differs in no important matter, but has a more Eastern distribution, reaching into Bulgaria and Servia. It is P. montana var. Mughus, Willkomm.

P. UNCINATA, Ramond, or P. montana var. uncinata, Willkomm.-This is the largest form of P. montana, and becomes a tree 60 to $80 \mathrm{ft}$. high. It is also quite distinct in the cones, the scales of which are remarkably deflexed at their bluntly pyrainidal apex. This is the Western form of P. montana, and occurs in Spain and France. So far as I have seen, it has little value as an ornamental tree in this country. Among two-leaved pines with resinous cylindric buds, the scales of which are appressed, all the forms of $\mathrm{P}$. montana are distinguished by the greater length of the leaf-sheath. 


\section{P. Montezunie, Lambert. Montezuma Pine.}

A tree up to $70 \mathrm{ft}$. high, with very thick, reddish brown young branchlets that are rough with fringed scale-leaves, the scaly bases of the fallen leafbundles and the prominences on which they were seated; not downy. Winter buds $\mathrm{I}$ in. long, $\frac{1}{3}$ in. thick, clothed with long, fringed scales. Leaves in fives, very crowded, persisting three years; from 7 to 12 ins. long, blue-green, minutely toothed on -the margin; leaf-sheaths up to 2 ins. long, persistent. Cones very variable, usually from 4 to 8 ins. long, 2 to $3 \frac{1}{2}$ ins. wide at the base, tapering upwards.

Native of Mexico, where it is very widely spread and abundant; introduced by Hartweg in 1839. In some respects, especially in size of leaf (known sometimes to be I8 ins. long), this is the most remarkable of all pines, but it is only hardy in Cornwall, the south-west of Ireland, and suchlike places. There are good specimens at Fota in Ireland, Bicton in Devon, Pencarrow, Menabilly, Tregothnan, and other places in Cornwall. It belongs to the small group of five-leaved pines, with persistent leafsheaths, the hardiest of which is P. Hartwegi. The pines known in the gardens of the south-west as P. Russelliana, Devoniana, and Lindleyana are forms of P. Montezumæ.

Nearly allied to it is P. PSEUDO-STROBUS, Lindley, which is, however, easily distinguished by its very glaucous, more slender shoots. It is as tender as P. Montezumæ, and appears only to exist in this country at Pencarrow and Tregothnan. The Pencarrow specimen has leaves 10 ins. long, more slender than in P. Montezumæ, but in other respects similar. Native of Mexico; introduced in 1839.

\section{P. monticola, Don. Western White 'Pine.}

A tree up to $125 \mathrm{ft}$. high, with a trunk $4 \mathrm{ft}$. or more in diameter; young shoots downy; winter buds ovoid, with flattened scales. Leaves in fives, 3 to $4 \frac{1}{2}$ ins. long, rough at the margins (minutely toothed under the lens), glaucous green, with several lines of stomata on the inner sides; leaf-sheath about $\frac{5}{8}$ in. long, soon falling. Cones 5 to 8 ins. long, $I_{4}^{\frac{1}{4}}$ ins. wide before expanding, cylindrical, tapered, and curved towards the end; scales thin, smooth, rounded at the apex, terminated by a dark resinous scar (umbo).

Native of Western N. America from British Columbia and Vancouver Island to California; introduced by Douglas in 183I. Although not so well known in this country as its eastern ally-P. Strobus, it is a handsome tree for gardens, assuıning a shapely, slender, pyramidal shape. It is liable to be confused with P. Strobus, but the short down all over the shoot usually distinguishes it. Its leaves also are stiffer and stouter. It yields a useful timber in its native home, but in Europe is planted for ornament only. A tree at Murthly and another at Scone in Perthshire are both over $8 \mathrm{oft}$. high.

\section{P. Muricata, Don. Bishop's Pine.}

\section{(P. Edgariana, Hartweg.)}

A tree 50 to $90 \mathrm{ft}$. high, with a rough brown bark, often flat-topped and with wide-speading branches; young shoots densely leafy, smooth, brown; terminal buds cylindrical, pointed, $\frac{1}{2}$ to I in. long, coated with resin. Leaves in pairs, falling the third or fourth year, rigid, 3 to 5 (sometimes 7 ) ins. long, semi-terete, dark green; leaf-sheath persistent, $\frac{1}{2}$ to $\frac{5}{8}$ in. long. Cones obliquely egg-shaped, $2 \frac{1}{2}$ to $3 \frac{1}{2}$ ins. long, the boss on the scales terminated by a stiff, slightly hooked spine. (See plate, Vol. i., p. I04.) 
Native of California ; originally discovered in 1832 at San Luis Obispo, from which it gets its popular name; introduced by Hartweg in 1846 . This remarkable pine bears its cones in whorls of three to seven; they are deflexed, and the inner or less exposed side being less developed gives them their unsymmetrical shape. They remain on the tree and retain their seed for an indefinite period, at least twenty-five to thirty years, and often until the branch bearing them is 5 or 6 ins. in diameter. This enables the species to survive forest fires, which, although they destroy the old trees, only affect the cones sufficiently to expand the scales and allow the uninjured seed to escape. The tree grows on exposed bluffs and headlands in Monterey and other places along the coast of California, where it is at times drenched with ocean spray. I have a letter from a correspondent in Guernsey, who says that it withstands the salt winds of that island even better than P. radiata (insignis). In such places it will be chiefly valuable as a shelter tree, its timber being inferior; but it is also handsome, and worth growing for its interest. The finest tree I have seen is at Claremont; in 1910 this was between 70 and $75 \mathrm{ft}$. high. Among two-leaved pines with persistent leaf-sheaths this is distinguished by its cylindrical, resin-covered buds and long, deep green leaves.

\section{P. Murrayana, Balfour. Lodge-Pole Pine.}

\section{(P. contorta var. Murrayana, Engelmann.)}

By many authorities this is considered to be no more than a variety of P. contorta, but the aspect of the trees in cultivation is so distinct that the retention of the more convenient specific name seems desirable. P. Murrayana is most conveniently distinguished from contorta by the thin bark of its trunk (rarely more than $\frac{1}{4}$ in. thick), of a pale grey or brown, covered with thin scales, but comparatively smooth; also by its larger, broader leaves, 2 to 3 ins. long, about $\frac{\lambda}{12}$ in. wide. The tree itself attains to a considerably larger size than P. contorta, and is usually 70 to $80 \mathrm{ft}$. high. On the Sierra Nevada it becomes 100 to $125 \mathrm{ft}$. high. Whilst $P$. contorta inhabits the coast region, this is found at elevations of 5000 to $\mathrm{II}, 000 \mathrm{ft}$. According to Elwes, there are trees at Westonbirt $59 \mathrm{ft}$. and $54 \mathrm{ft}$. high, and I saw one at Bayfordbury a few years ago, $50 \mathrm{ft}$. high. Introduced in 1854 , by Jeffrey. In a small state P. contorta, with its narrower, richer green leaves appears to be usually the handsomer tree.

These two trees belong to the group of two-leaved pines with persistent leaf-sheaths, and cylindrical, resinous winter buds. Branches alone would be most likely to be confused with the European P. montana, which has all the characters just mentioned, but whose leaf-sheath is twice or more than twice as long ( $\frac{1}{5}$ to $\frac{3}{5}$ in.). The two are, of course, very different in habit.

\section{P. PARRYANA, Engelmann. \\ (P. quadrifolia, Sudworth.)}

A tree 20 to $40 \mathrm{ft}$. high ; young shoots slightly downy. Leaves $\mathrm{I} \frac{1}{4}$ to $\mathrm{I}_{4} \frac{3}{4}$ ins. long, usually in fours, occasionally in fives or threes, mostly falling the third year, finely pointed, sharply triangular in section, white with stomata on the two inner sides, not toothed at the margin; scales of the leaf-sheath curled back in the form of a rosette. The first year each bundle of leaves keeps almost closed, showing little but the bright green outer side of each leaf. Cones roundish, $1 \frac{1}{2}$ to 2 ins. wide, with comparatively few scales. Seeds $\frac{5}{8}$ in. long, edible.

Native of S. California and Lower California ; discovered by Dr Parry, after whom it is named, in 1850 . It is one of the group well-marked by their 
entire marginal leaves and rosette-like leaf-sheaths. 'In this group monophylla has its leaves solitary; edulis has them in pairs; cembroides in threes, Parryana in fours; and Balfouriana and aristata in fives. This, however, is the general rule; all of them vary to some extent in this matter. There are small trees at Kew, but the species is very rare.

\section{P. Parviflora, Siebold. Japanese White Pine.}

A tree 30 to $40 \mathrm{ft}$. high at present in this country, but twice as high in Japan ; young shoots minutely downy; winter buds ovoid, $\frac{3}{16} \mathrm{in}$. long, some of their scales free at the tips. Leaves in fives, falling the third year, $1 \frac{1}{2}$ to $2 \frac{1}{2}$ ins. long, very slightly toothed on the margins, with silvery lines of stomata on the inner surfaces ; leaf-sheath $\frac{3}{8}$ in. long, soon falling completely away. Cones eggshaped, 2 to 3 ins. long, $1 \frac{1}{4}$ to $1 \frac{3}{4}$ ins. wide before expanding, usually produced in whorls of three or four, and in extraordinary profusion even when quite young.

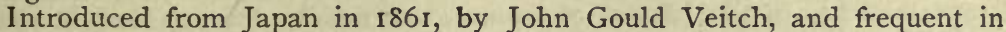
gardens where its small size renders it easily accommodated, and where it is appreciated for its neat growth. Its cones open widely and persist six or seven years; a tree heavily laden with them has its aspect somewhat spoilt. There are two well-marked forms in cultivation : one with stiffer leaves, very glaucous inside, and quite pale shining shoots, distinguished as var. GLAUCA; the other with softer, more grass-like foliage, and dark brown, more downy shoots. Many of the dwarfed pines so largely imported from Japan during the last two decades belong to this species. It likes a moist, 'well-drained, loamy soil.

P. PENTAPHYLla, Mayr, is apparently a form of P. parviflora, with longer cones ( $3 \frac{1}{2}$ ins.) and thicker leaves. It has a more northerly habitat in Japan, whence it has recently been introduced.

\section{P. Peuke, Grisebach. Macedonian Pine.}

A tree not yet more than 40 to $50 \mathrm{ft}$. high in this country, but twice as high in Bulgaria; densely branched, and slenderly pyramidal ; young shoots glossy green, quite smooth. Leaves in fives, mostly falling in their third year; 3 to 4 ins. long, very densely borne on the shoots, pointed forwards, three-sided; two of the sides have three or four lines of white stomata, the other one is bright green; margins roughened with tiny teeth; leaf-sheaths soon falling. Cones on stalks about $\frac{1}{3}$ in. long; themselves 4 or 5 ins. long, $1 \frac{1}{4}$ to $1 \frac{1}{2}$ ins. wide before expanding; scales in the middle about $1 \frac{1}{2}$ ins. long, half as wide, thin at the margins.

Native of Macedonia, where it was first found by Dr Grisebach in I839, also of Bulgaria and Montenegro; introduced in 1864. One of the smaller and slower growing pines, this is suitable for small gardens. Trees raised in I 864 are now $45 \mathrm{ft}$. high at Kew. It grows about I ft. in height yearly. It is considered to be very closely allied to P. excelsa, but the two are extremely disținct in general appearance. P. Peuke is much denser in leaf and branch ; its leaves are shorter, greener, and never have the kink near the base seen in excelsa. The cones also are shorter and thicker. It resembles $\mathbf{P}$ Cembra more as a young tree, but that species has very shaggy young shoots.

\section{P. Pinaster, Solinder. Cluster Pine, Maritime Pine.}

A tree reaching 100 to $120 \mathrm{ft}$. in height, forming a tall, rugged, dark trunk. Young shoots not downy, pale brown ; terminal winter buds, I to $\mathbf{I} \frac{1}{4}$ ins. long, $\frac{1}{3}$ to $\frac{1}{2}$ in. wide, cylindrical with a conical apex, clothed with awl-shaped, outwardly curving scales conspicuously fringed with silvery threads. Leaves 
in pairs, 4 to 8 ins. long, $\frac{x}{2}$ in. wide, stiff and stout, dark green, falling the third and fourth years; slightly roughened at the margins; leaf-sheath $\frac{5}{8}$ to $\frac{3}{4}$ in. long, persistent. Cones usually borne in whorls, deflexed, 4 or 5 (sometimes) 7 ins. long, 2 to $2 \frac{1}{2}$ ins. wide at the base before opening, tapering to a point, bright brown, often persisting for many years.

Native of S. Europe, from W. France to Greece; cultivated since the sixteenth century. As an old tree it is singularly picturesque, its dark, deeply fissured trunk being naked for two-thirds of its height. As a young tree it grows with great rapidity $-2 \mathrm{ft}$. per annum - and has a coarse, gaunt aspect. The leaves of this pine are the largest and stoutest of all hardy Old World pines and of all two-leaved pines, although they are of course exceeded in size by those of Californian and Mexican species. It is, as its common name implies, admirably adapted for maritime localities. The famous pine plantations of Bournemouth are largely composed of this tree. It is also one of the very best for light sandy soils. It yields a valuable produst in its resin, but its timber is poor. Nowhere has its economic value been so efficiently demonstrated as in the Landes of France, south of Bordeaux. Here in 1904, mostly planted by man, it covered an area of about $\mathbf{I} \frac{3}{4}$ million acres, yielding an annual revenue of $£ 560,000$, and this from land which previously was mainly desert. Among two-leaved pines it is distinguished by the size and length of leaf, and by the curly, fringed bud-scales. (Syn. P. maritima, Lamarck.)

\section{P. Pinea, Linnceus. Stone Pine.}

A tree varying in height according to the position in which it grows, from 40 to $100 \mathrm{ft}$. ; forming in the open a comparatively low tree with a short, deeply fissured trunk, supporting a broad spreading head of branches more in diameter than it is high. When the tree has been drawn up by others it becomes much taller, but develops the characteristically shaped head as soon as the opportunity comes. Young shoots not downy, pale yellowish brown, more or less devoid of leaves at the base. Buds very characteristic on account of the curly pointed scales edged with long silvery threads by which they are matted together; $\frac{1}{4}$ to $\frac{5}{8}$ in. long. Leaves in pairs, occasionally in threes ; 3 to 5 ins. long, 3 to 4 ins. wide ; roundish egg-shaped, rounded at the top; glossy, pale brown. Seeds kidney-bean shaped, $\frac{3}{4}$ in. long.

Native of S. Europe from Spain and Portugal eastwards to Greece and Asia Minor; cultivated in England for probably four centuries at least. Its flat spreading head of branches is one of the most picturesque and characteristic objects of Italian scenery. A famous forest of this pine is that of Ravenna, near the coast of the Adriatic, about 16 miles long, and I mile wide, very much damaged in the great frost of 1879 , when all the younger trees were killed. The tree has always been valued in I taly for its edible seeds, and as their husks have been found in the refuse heaps of Roman encampments in Britain, they would appear to have been sent over for the use of the army in occupation. Young plants are apt to be cut by severe frosts, and transplant badly if allowed to remain more than two or three years in one place. The solitary, very glaucous needles about I in. long, characteristic of seedling one- or two-year-old plants are frequently to be observed on scattered shoots over much older plants. Amongst two-leaved pines this is well distinguished by its habit, its large rounded cones; and by the fringed scales of the winter bud.

\section{P. ponderosa, Douglas. Western Yellow Pine.}

A tree occasionally over $200 \mathrm{ft}$. high in nature, with a perfectly erect, columnar trunk sometimes $8 \mathrm{ft}$. thick, and comparatively short, often deflexed branches, forming a columnar or slenderly tapered head. Young 
shoots shining, reddish brown, not downy, smelling like an orange when cut, the older parts rough with remains of the fringed scale leaves. Buds cylindrical with a tapered apex, resinous, $\frac{3}{4}$ to $\mathbf{I}$ in. long, $\frac{1}{2}$ in. thick. Leaves in threes, falling the third or fourth year, 5 to Io ins. long, three-sided (one side much broader and more rounded than the other two), all with numerous stomatic lines; margins minutely toothed; leaf-sheath persistent, $\frac{5}{8}$ to $\frac{7}{8}$ in. long. Cones elongated oval, 3 to 6 ins. long, $1 \frac{1}{2}$ to $2 \frac{1}{2}$ ins. thick before opening ; scales terminated by a short, decurved prickle.'

Native of Western N. America, from British Columbia to New Mexico. Introduced in 1827 by Douglas. This pine is very variable in the size of its leaves and cones, the former sometimes approaching those of P. Coulteri in dimensions. Thinly furnished with branches, it is, nevertheless, one of the most imposing of all pines. There is a splendid example at Bayfordbury over $100 \mathrm{ft}$. high, with a trunk a yard thick. It likes a good loamy soil, but is very averse to redundant moisture.

Var. SCOPULORUM, Engelmann, has leaves frequently in pairs as well as in threes, and cones seldom exceeding 3 ins. in length. It has a more eastern distribution than the type, and is found in Nebraska, Texas, Cólorado, etc. Only represented in cultivation by small plants.

\section{P. PUngens, Lambert. Hickory Pine.}

A tree usually 20 to $40 \mathrm{ft}$. high; young shoots reddish brown, shining, not downy, very stiff and sturdy, with the crowded leaves of the lateral branches more or less erect; buds cylindrical, $\frac{3}{4}$ to I in. long, very resinous. Leaves in twos, falling the third year; very rigid and sharply pointed, deep green, 2 to 3 ins. long, somewhat spirally curved; leaf-sheath $\frac{1}{4}$ in. long, persistent. Cones usually in clusters of three or more, each cone 3 or $3 \frac{1}{2}$ ins. long, 2 to $2 \frac{1}{2}$ ins. wide at the base; the boss of each scale terminated by a broad, hooked spine.

Native of Eastern N. America; introduced in 1804. This pine retains the cones on its branches frequently fifteen or twenty years. It is one of the least ornamental of pines in cultivation and its timber is of little value. It is allied to the Western American P. muricata, and, in the group of two-leaved pines with persistent leaf-sheaths and cylindrical resinous buds, is distinguished by its stiff, spine-tipped leaves and bright red-brown branchlets.

\section{P. Radiata, Don. Monterey Pine.}

\section{(P. insignis, Douglas.)}

A tree up to $115 \mathrm{ft}$. high, with a trunk occasionally $6 \mathrm{ft}$. thick; bark very rugged, dark brown; young shoots smooth, yellowish brown; buds resinous, cylindrical. Leaves in threes, falling the third year; 2 to 5 ins. long, soft and flexible, very dense on the branchlets, of a rich grassy green, convex on the outer face, faintly lined with stomata; margins minutely toothed; leaf-sheath persistent, $\frac{1}{4}$ to $\frac{1}{2}$ in. long. Cones obliquely conical, rich bright brown; 3 to 5 ins. long, 2 to 3 ins. wide near the base; shortly stalked and more or less deflexed, so that the inner side is close to the branch and is imperfectly developed; the boss of the scale is diamond-shaped, with a minute prickle in the centre. The cones are usually borne in whorls of two or three, and remain closed for years upon the branches.

Native of Monterey, California, where it is confined to a few hills near the sea; introduced in 1833 by Douglas. In maritime situations in the south and west of Britain this pine thrives splendidly, growing at the rate of $3 \mathrm{ft}$. annually. The late Mr E. H. Pember, some years ago, showed me some trees in his grounds at Vicar's Hill, near Lymington, which, 
in twenty-one years from planting, had reached well over $60 \mathrm{ft}$. in height. But it is of no value in a climate like that of Kew, where the trees turn a sort of foxy-brown almost every winter, and are occasionally killed outright by cold. This tree, by its rich green leaves without any trace of the typical greyness of pines; by its persistent leaf-sheaths and long persisting cones, is unmistakable among three-leaved pines.

\section{P. RESInOSA, Solander. RED Pine.}

A tree 50 to $70 \mathrm{ft}$. high in this country, rarely twice as high in nature, with somewhat pendulous branches; young shoots deep yellowish brown, not downy; winter buds resinous, conical, $\frac{5}{8}$ in. long. Leaves in pairs, semi-terete; 5 to $6 \frac{1}{2}$ ins. long, falling the fourth year, and leaving the branchlets rough with the remains of the prominences on which each bundle was seated; dark lustrous green, minutely toothed on the margin; densely crowded on the branchlets, so that each year's crop is continuous with the preceding one ; leaf-sheaths $\frac{5}{8}$ to $\frac{7}{8}$ in. long, persistent. Cones egg-shaped, 2 to $2 \frac{1}{4}$ ins. long, I to $1 \frac{1}{4}$ ins. wide before opening; pale shining brown, scarcely stalked; scales unarmed.

Native of Eastern N. America from Nova Scotia to Pennsylvania ; introduced in 1756 by the Duke of Northumberland. It is a handsome pine as seen in its native country and yields a useful timber, but with us is inferior as a garden tree to both Thunbergii and Laricio, of which it may be said to be the American representative. It is only likely to be mistaken for Laricio, which has a denser, more horizontal branching. The best ready distinction between the two is in the leaf-sheath of P. Laricio being only two-thirds as long as that of $\mathrm{P}$. resinosa. A tree at Bayfordbury is well over $50 \mathrm{ft}$. high. I saw this bearing cones in 1908.

\section{P. Rigida, Miller. Northern Pitch Pine.}

A tree reaching about $80 \mathrm{ft}$. in height, with a trunk 2 to $3 \mathrm{ft}$. thick, often sending out adventitious shoots; young shoots smooth, pale brown; buds cylindrical, resinous. Leaves in threes, falling the third year; 3 to $4 \frac{1}{2}$ ins. long, rigid, twisted, dark green, margins minutely toothed; leaf-sheath $\frac{1}{3}$ to $\frac{1}{2}$ in. long. Cones very variable, ranging from conical to almost globose, and from I to $3 \frac{1}{2}$ ins. long; occasionally small and numerous in clusters, long persisting; scales terminated by a short prickle.

Native of Eastern N. America from New Brunswick to Georgia ; introduced in the early eighteenth century. In a few places it has made a fine tree. At Arley Castle, near Bewdley, there are three fine specimens, the tallest of which is $79 \mathrm{ft}$. high ; and according to Elwes, there is one at Dropmore $84 \mathrm{ft}$. high. As a rule it is rather a scrubby tree of little ornament, very well distinguished by the small branches springing directly from the trunk. Some trees produce these twigs so freely that the trunks are almost covered with foliage, but they never get very large, and mostly die after a few years.

P. Serotina, Michaux. Pond Pine.-This is closely allied to P. rigida, and seems to differ chiefly in its greater length of leaf (twice as long). It seems doubtful if it be in cultivation in this country, and in any case it is tender, and only likely to succeed in the south-western counties. Native of the southeastern United States from N. Carolina to Florida.

\section{P. Sabiniana, Douglas. Digger Pine.}

A tree 40 to 50 , occasionally $90 \mathrm{ft}$. high, of curiously thin habit; young shoots blue-white, not downy, with the leaves clustered at the apex only, the major part naked except for the awl-shaped scale-leaves, $\frac{1}{2}$ in. long. Leaves 
in threes, mostly falling the third year, 8 to 12 ins. long, of a pale greyish green, with two narrow flat faces, and one rounded broad one, all lined closely with stomata; extremely minutely toothed at the margin, slenderly and sharply pointed; leaf-sheath $\frac{3}{4}$ to $I$ in. long, persistent. Cones produced on stout stalks about 2 ins. long, ovoid, 6 to ro ins. long, 4 to 6 ins. thick, often remaining on the branch long after the seeds have fallen; scales terminated by a large, triangular, hooked spine.

Native of California, whence it was introduced by Douglas in 1832. Most nearly allied to P. Coulteri, and with similar large, heavy, spiny cones, it is very readily distinguished by its thin foliage, smoother and more slender young shoots, and narrow cylindrical winter buds. The young shoots when cut have the same orange-like odour as in Coulteri, ponderosa, and Jeffreyi. The seeds are large like those of P. Coulteri (but with much shorter wings), and were formerly much eaten by the Digger tribe of Indians. It is not a particularly ornamental tree, being thinly furnished with foliage, but is interesting in the curious contrast between the heavy trunk and the thin, light, shadeless head of branches.

\section{P. Strobus, Linnceus. Weymouth Pine.}

A tree usually 60 to 80 , rarely above $100 \mathrm{ft}$. high in this country, but known occasionally to have exceeded twice that height in the United States; bark of trunk shallowly fissured. Young shoots with a tuft of down extending downwards from each leaf-bundle, much of which soon falls away; winter buds ovoid, with closely flattened scales. Leaves in fives, mostly falling the third year, 3 to 5 ins. long, roughened on the margins, soft bluish green, with lines of white stomata on the inner sides; leaf-sheath about $\frac{1}{2}$ in. long, soon falling completely away. Cones 5 to 8 ins. long, about $\mathbf{I}$ in. diameter before opening, cylindrical, tapering at the apex, curved; scales of cones thin, smooth, rounded, I to $\mathrm{I} \frac{1}{4}$ ins. long, half as wide.

Native of Eastern N. America ; introduced in 1705. The common name of "Weymouth" pine does not refer to the town, but to a Lord Weymouth, who is recorded to have planted it largely at Longleat about two hundred years ago. In France, the name has been contracted to "Pin du Lord." This pine has at various times been largely planted both in England and on the Continent, and is, no doubt, a valuable timber tree, especially in sunnier climates than ours, producing a white, easily worked, light timber, very useful for many purposes, but not remarkable for strength. One hundred years ago this tree covered enormous areas in Eastern N. America, and was one of the richest assets of the country. Now fine specimens are comparatively scarce there. It is an ornamental tree for gardens where the soil is not a heavy clay, especially up to its middle age, though its value is impaired through its being frequently infested on the lower side of the branches by a white chermes, very similar to the beech coccus in appearance. It is only likely to be confused with P. monticola, which differs in having young shoots wholly covered with down, thicker leaves, and cones of greater average length.

Var. NANA, Knight.-A dwarf form of dense, compact habit, and leaves less than half as long as the type. The forms known as COMPACTA, DENSA, and UMBRACULIFERA are of the same character.

Var. PROSTRATA is an absolutely prostrate form introduced from the United States about 1893. A plant in the rock garden at Kew hangs vertically over the face of a stone. Raised in the Arnold Arboretum.

\section{P. Sylvestris, Linnaus. Scotch Pine.}

A tree rarely more than 100 to I ro ft. high, with a trunk $3 \mathrm{ft}$., sometimes $5 \mathrm{ft}$. in thickness. The trunk has a beautiful red tinge, and is smooth, 


\section{PINUS}

although in old trees it becomes fissured at the base; young shoots smooth, green; winter buds resinous. Leaves in pairs, 2 to $3 \frac{1}{2}$ ins. long, falling in their third year, grey-green, twisted, stiff; leaf-sheath persistent, $\frac{1}{4}$ to $\frac{1}{3}$ in. long. Cones I to $2 \frac{1}{2}$ ins. long, conical.

Native of nearly all Europe, including Britain, and extending across Siberia to the Amur River region. It has the widest distribution of any pine. In early ages it must have covered much of the poorer land in the British Isles, but primeval forests of it are now confined to a few places in the Scottish Highlands. It provides one of the most valuable timbers of its class, especially when grown in regions with a hot summer and cold winter. Much of it is imported from N. Europe as "Riga," "Dantzic," or "yellow" deal. For gardens there is scarcely any tree more picturesque than an old Scotch pine, or with a greater beauty of trunk, especially when lit up by the low rays of the winter sun. There are several forms that have been selected for their timber by continental foresters. An interesting series of these forms was planted, each in a large block, at Les Barres in France, by one of the de Vilmorins in the third and fourth decades of last century, which now clearly show certain differences in colour of trunk, character of bark, branching, etc. The best of them is considered to be var. RIGENSIS, or "Riga Pine." As purely garden varieties the following may be mentioned:-

Var. ARGENTEA, Steven.-Foliage of a distinctly more glaucous or silvery hue. Native of the Caucasus.

Var. AUREA. - A curious variety whose leaves turn golden yellow in autumn, and remain so through the winter, changing in spring to green again. Each leaf must, of course, make both these changes twice or thrice before falling.

Var. FASTIGIATA, Carrière.-A tree of spire-like form ; branches erect.

Vars. GLOBOSA, NANA, PUMILA.-All dwarf rounded bushes of neat and interesting appearance. Leaves about $I$ in. long; cones $\frac{3}{4}$ in. long.

Var. VARIEGATA. - Leaves occasionally creamy white.

Of these varieties, aurea and fastigiata are best worth planting.

\section{P. Thunbergir, Parlatore. Black Pine.}

\section{(P. Massoniana of gardens-not of Lambert.)}

A tree 80 to soo $\mathrm{ft}$. (sometimes more) high, with a trunk 3 to $5 \mathrm{ft}$. through ; bark deeply fissured and darkly coloured; young shoots light brown, not downy; buds egg-shaped to almost globose, narrowing at the top to a short, slender point, not resinous, but with pale brown scales edged with conspicuous whitish threads. Leaves in pairs, $2 \frac{1}{2}$ to $4 \frac{1}{2}$ ins. long, persisting three to five years; straight, stiff, sharply but abruptly pointed; the margins are so minutely toothed as to be only just perceptible to the touch; leaf-sheath $\frac{1}{2}$ to $\frac{5}{8}$ in. long, persistent, with two grey curly threads at the top. The lower part of each year's shoot is furnished with scale leaves only. Cones narrowly egg-shaped, $I \frac{1}{2}$ to 2 ins. long, about $I$ in. wide ; scales unarmed; although usually solitary or in pairs, the cones are sometimes clustered as many as fifty or sixty together, and then much smaller.

Native of Japan, and one of the chief timber-producing trees of that country ; introduced by John Gould Veitch in $186 \mathrm{I}$. It is a very picturesque tree, with stiff, horizontal branches of often very unequal length, and although not likely ever to reach its natural dimensions in this country, well worth growing as an interesting and characteristic pine. The Japanese train it into many grotesque shapes. It is allied to Laricio, but besides the marked difference in habit is easily distinguished by its broad grey-white buds, and shorter, stiffer leaves. It is promising as a seaside tree. 


\title{
P. tuberculata, Gordon. Knob-Cone Pine.
}

\author{
(P. attenuata, Lemmon; P. californica, Hartweg.)
}

A tree 20 to $50 \mathrm{ft}$. high in this country, occasionally twice as high in a wild state; young shoots smooth, bright brown; buds cylindrical, $\frac{3}{4}$ to I in. long, $\frac{1}{8}$ to $\frac{1}{4}$ in. wide, resinous. Leaves in threes, falling the third or fourth year ; 4 to $7 \frac{1}{2}$ ins. long, slender, bright green, finely pointed, minutely toothed; leaf-sheath $\frac{1}{3}$ to $\frac{1}{2}$ in. long, persistent. Cones slenderly conical, usually 4 to 5 ins. long, 2 ins. wide at the oblique base; deflexed, with the scales near the base on the upper side developing the conical, spinetipped knobs or prominences referred. to in the popular name; the cones are produced in whorls of three or more, and persist on the branches for sometimes thirty or forty years, or until the death of the tree. At first they have a stalk $\frac{3}{4}$ in. long, which gradually becomes enclosed in the thickening branch.

Native of Oregon and California; discovered and introduced in 1847 by Hartweg. It has no special merits as an ornamental tree, although on account of its long persisting cones it is a very interesting one. On a piece of branch, 4 ft. long, from a tree grown at Bayfordbury and now preserved at Kew, there are over forty cones. It is botanically allied to P. radiata, but differs in the larger, stiffer, grey-green leaves and narrower cones. It is also a hardier tree, and, according to Jepson, inhabits the most desolate and inhospitable stations for tree growth in the Californian mountains. As may be judged from the life-history of its cones, it is admirably adapted to survive as a species on fire-swept zones. (See also $P$. muricata.)

\section{P. virginiana, Millex. Jersey Pine, Scrub Pine. (P. inops, Solander.)}

A tree 30 to $50 \mathrm{ft}$. high, but often of scrubby habit; young shoots covered with a vivid, pale, purplish bloom, smooth. Leaves in pairs, falling the third year; $1 \frac{1}{2}$ to 3 ins. long, twisted and curved ; leaf-sheath persistent, $\frac{3}{16}$ in. long. Cones $1 \frac{1}{2}$ to $2 \frac{1}{2}$ ins. long, I to $1 \frac{1}{4}$ ins. wide at the base, conical, prickly.

Native of Eastern N. America ; introduced early in the eighteenth century or perhaps before. Of all really hardy species this has, perhaps, less to be said in its favour as a tree for gardens than any. Apparently the best tree in the country is one at Bayfordbury, planted in 1842, now nearly $50 \mathrm{ft}$. high. The brightly coloured, slender young shoots of this species distinguish it among pines with short leaves in pairs. P. echinata, with slender, glaucous shoots, has its leaves often in threes.

\section{P. yunnanensis, Franchet. Yunnan Pine.}

(Gardeners' Chronicle, 1905, ii., fig. 86.)

A tree up to $100 \mathrm{ft}$. high in a wild state, with a trunk 8 to $12 \mathrm{ft}$. in girth ; young shoots yellowish brown; buds cylindrical, brown, non-resinous, with a slender pointed apex, $\frac{3}{4}$ to $I_{\frac{1}{4}}$ ins. long, and fringed, linear scales. Leaves in pairs or in threes, 6 to 9 ins. long, slender, much twisted and contorted in young specimens, toothed on the margins, finely pointed; sheath $\frac{3}{4}$ in. long. Cones shortly stalked, 4 to 5 ins. long, 2 to 3 ins. wide before expanding, brown, remaining on the branches four or five years.

Native of W. China and E. Thibet ; introduced by Wilson about 1909 , and only known in cultivation by quite young plants which appear very healthy at present, but whose capability of withstanding severe frost has yet to be ascertained. These young plants already show the mixture of two-leaved and three-leaved bundles. 


\section{PIPTANTHUS NePALENSIS, Sweet. LEguminose.}

A shrub or low tree with very pithy young shoots; naturally 8 to I 2 ft. high, but growing taller against walls, where it is generally placed in England. At Kew it is deciduous, but in milder climates it retains more or less foliage during the winter. Leaves alternate, consisting of three lanceolate, stalkless leaflets, 3 to 6 ins. long, about one-third as wide, with a marginal nerve ; smooth except when quite young, dark green above, glaucous beneath; the common leaf-stalk $\mathrm{I}_{2}^{\frac{1}{2}}$ to 2 ins. long. Racemes stiff, erect, 2 to 3 ins. long, and as much broad, hairy, and set with hairy bracts. Flowers pea-shaped, $\mathrm{I}_{2} \frac{1}{2}$ ins. long, the stalk up to $\mathrm{I}$ in. long and, like the brown calyx, very hairy; petals bright yellow. Pod 3 to 5 ins. long, $\frac{3}{4}$ in. wide.

Native of the Himalaya; introduced to England in 1821 . It thrives well against a wall, where it flowers in May, but is not permanently hardy in the open air at Kew. A shrub of exceptionally vigorous appearance, it is, nevertheless, not long-lived. It is easily propagated by seeds, which it ripens in quantity, and owing to its dislike of root disturbance should be grown in pots until planted in permanence. Its flowering sprays resemble those of the herbaceous genus Thermopsis. Wilson has recently introduced from China a Piptanthus almost or quite identical with P. nepalensis which may, he thinks, prove hardier.

\section{PISTACIA. MASTIC TREes. ANACARDIACE}

A genus of deciduous or evergreen trees of considerable economic importance in their native countries, but as a rule too tender to be of much garden value in this. Two species may be grown without protection in the open, viz., P. Terebinthus and P. chinensis, the latter, although still rare, appears to be especially well adapted for our climate. The leaves of Pistacia are either trifoliolate or pinnate, and the pinnate leaves are either equally or unequally so. Flowers inconspicuous, and without petals; male and female flowers sometimes occur on separate trees. The nearest ally in gardens to this genus is Rhus, from which Pistacia differs in the absence of petals.

The two species mentioned above may be grown in the open ground, but for the rest it will be necessary to provide wall space. Any ordinary garden soil suffices for them.

The species of Pistacia may be arranged as follows :-

I. LEAVES EQUALLY PINNATE (without an odd terminal leaflet).

Chinensis. Deciduous.

Lentiscus. Evergreen.

\section{Leaves uneQually pinnate.}

Vera. Leaflets three or five ; large, downy. $\left.\begin{array}{l}\text { Atlantica. } \\ \text { Terebinthus. }\end{array}\right\}$ Leaflets five to nine; smooth. 


\section{P. Atlantica, Desfontaines. MT. Atlas Mastic.}

A deciduous tree up to $40 \mathrm{ft}$. high in N. Africa. Leaves pinnate, consisting of five to nine leaflets, the common stalk winged. Leaflets lanceolate, $I$ to $I \frac{1}{2}$ ins. long, rounded at the apex, smooth. Flowers in axillary pyramidal panicles 2 to 4 ins. long. Fruit obovoid, rather depressed at the end, $\frac{1}{3}$ in. long, dark blue when fully ripe.

Native of Algeria ; producing a resin somewhat similar to that of $P$. Lentiscus, which is chewed by the Arabs as a dentifrice. It needs some protection in the ordinary climate of Great Britain, but will probably succeed in the southwestern counties.

\section{P. Chinensis, Bunge. Chinese Pistachio.}

A large deciduous tree up to $80 \mathrm{ft}$. high in Central China. Leaves evenly pinnate, about 9 ins. long, composed of usually ten or twelve leaflets, generally but not invariably without the terminal odd one. Leaflets ovate-lanceolate, long-pointed, unequally divided by the midrib, $2 \frac{1}{2}$ to $3 \frac{1}{2}$ ins. long, $\frac{3}{4}$ in. wide ; smooth except when quite young. Flowers in a cluster of panicles near the end of the shoot, the male flowers crowded on an inflorescence 3 ins. long, the female ones on a much more open, lax panicle 7 to 9 ins. long. Fruit the size of large peppercorns, first red, then blue.

Native of Central and W. China, where the young shoots and leaves are eaten cooked as a vegetable by the Chinese. This is undoubtedly the best of the Pistacias to cultivate in England. It was originally introduced to Kew by means of seed in 1897 , and is apparently perfectly hardy, never having suffered in the least from cold up to now, although quite unprotected. It has no beauty of flower, but the foliage is of a glossy, cheerful green, and Mr Wilson (who sent home seeds during his 1908 and 1910 journeys in China) tells me that it turns a gorgeous crimson before falling in autumn, rendering a large tree one of the most glorious pictures conceivable.

\section{P. Lentiscus, Linnaus. Mastic.}

An evergreen bush or small tree, occasionally 15 or $20 \mathrm{ft}$. high; young shoots warted, not downy. The leaves are evenly pinnate, consisting of four to ten leaflets without a terminal odd one; the common stalk is winged. Leaflets $\frac{3}{4}$ to $\mathrm{I} \frac{1}{2}$ ins. long, $\frac{1}{4}$ to $\frac{1}{2}$ in. wide ; narrowly oblong to obovate, smooth, with a very short, abrupt point. Flowers very densely packed in short axillary panicles $I$ to 2 ins. long. Fruit first red, then black, about the size of large peppercorns.

Native of the Mediterranean region, especially of the Grecian Archipelago; introduced in 1664. In the islands of the Archipelago, especially Scios, it produces by incision of the bark the resinous substance known as "mastic." Mastic is chiefly used by the Greeks and Turks for chewing, to sweeten the breath and preserve the teeth. The tree is tender and needs the protection of a warm wall. There is a larger, broader-leaved variety with leaves up to 2 ins. long and $\frac{3}{4}$ in. wide, known as LATIFOLIA.

\section{P. Terebinthus, Linnaus. Chian Turpentine Tree.}

A deciduous tree $30 \mathrm{ft}$. or more high, sometimes a. bush; with smooth, pinnate leaves up to 6 or $\delta$ ins. long, Leaflets usually seven or nine, ovatelanceolate to oblong, $I_{2}^{\frac{1}{2}}$ to $2 \frac{1}{2}$ ins. long, entire, lustrous dark green, glabrous. 
Flowers in panicles 2 to 6 ins. long, small, greenish: Fruit roundish oval, $\frac{1}{3}$ in. long, turning first red, finally purplish brown.

- Native of Asia Minor and the shores and islands of the Mediterranean; introduced in 1656. The bark yields the valuable resinous juice known as Chian turpentine, from its being chiefly collected on the island of Scios; this has certain medicinal properties, and is also used as flavouring. The kernel of the nut yields a pleasant-smelling oil. The tree is hardy at Kew, and a few specimens have lived unprotected in the open there for at least twenty years, although their growth is very slow. The flowers have no beauty, but the leaves have a pleasant resinous odour.

\section{P. VERA, Linnaus. Pistachio.}

A small deciduous tree, $20 \mathrm{ft}$. high, with long-stalked, pinnate leaves consisting usually of three or five leaflets, which are $1 \frac{1}{2}$ to $2 \frac{1}{2}$ ins. long, ovate or obovate, stalkless, entire, downy on both sides. Flowers in erect panicles 3 or 4 ins. long, small and of no beauty; the male panicles much denser than the female. Fruit reddish, oval, $\frac{3}{4}$ in. long.

Native of the Levant and W. Asia, long cultivated and naturalised over the Mediterranean region; introduced to England in 1770 . This is the tree that produces the well-known pistachio-nuts, the kernels of which are eaten raw, or cooked, or made into confectionery. It has not much beyond its economic interest to recommend it, for it needs the protection of a warm wall, and even then is occasionally injured by cold; with us its fruits are never developed. In warm climates the leaflets are as much as $3 \frac{1}{2}$ ins. long by $2 \frac{1}{2}$ ins. wide.

\section{PITTOSPORUM. PITTOSPORACE}

An interesting genus of evergreen shrubs and small trees whose headquarters are in Australia and New Zealand, whence come most of the species cultivated in the open air in the British Isles. One well-known species is native of Japan, and others are found in the Canary Islands, Cape of Good Hope, and China. The genus is not represented in the New World. Leaves arranged alternately; flowers with five sepals, five petals, and five stamens ; fruit dry, many-seeded.

The Pittosporums are essentially shrubs for the milder parts of the British Isles. At Kew they can only be grown against a wall-with the possible exception of the new P. pauciflorum. Several of the species are very handsome evergreens, and all here mentioned are charmingly fragrant when in flower. They are easily cultivated, and thrive in a light loamy soil. Cuttings taken from the half-ripened wood will root in gentle heat. Seeds ripen in favourable localities, and may also be used. Many more species than those here mentioned are grown in Ireland, Cornwall, etc.

\section{P. CRASSIFOLIUM, Solander.}

(Bot. Mag., t. 5978.)

An evergreen shrub or small tree, $15 \mathrm{ft}$. or more high, of dense habit. Leaves $I \frac{1}{2}$ to 4 ins. long, obovate to oblong, always narrowed at the base to a stalk $\frac{1}{2}$ to I in. long; leathery, covered beneath with a pale brown or whitish felt, the margins recurved. Flowers unisexual in terminal clusters; 
males up to ten in each cluster, females up to five; petals strap-shaped, recurved, dark purple. Fruit roundish, dry, $\frac{2}{3}$ in. across, containing numerous black seeds.

Native of the N. Island of New Zealand ; not hardy at Kew except on a wall, where it makes an interesting evergreen, but does not flower freely. It is suitable for the milder counties.

P. RALPHII, Kirk, another New Zealand species, is closely related to the above. It differs in its larger, oblong leaves more abruptly narrowed towards the stalk, in their margins not being recurved but flat, and in the smaller fruits.

\section{P. PAUCIFLORUM, Hooker and Arnott.}

An evergreen shrub, 4 to $6 \mathrm{ft}$. high, with quite smooth young shoots, bearing the leaves in a cluster at the end. Leaves obovate to oblanceolate, tapered at both ends, but more gradually towards the base ; 3 to 5 ins. long, $\frac{3}{4}$ to $1 \frac{1}{2}$ ins. wide; with entire, membranous margins; quite smooth on both surfaces; dark green above, pale beneath; stalk $\frac{1}{2}$ in. or less long. Flowers fragrant, dull yellow, produced singly or in few-flowered racemes in the leafaxils of the young shoots in May; corolla $\frac{1}{3}$ to $\frac{1}{2}$ in. long, cylindrical at the base, dividing at the mouth in five oblong, recurved lobes, $\frac{1}{6}$ in. long ; flowerstalks usually $\frac{1}{2}$ to $\frac{3}{4}$ in. long, smooth. Fruit a smooth, woody capsule, $\frac{5}{8}$ in. long.

Native of China, introduced in 1908 from near Ichang to Kew. Wilson had previously found it at $10,000 \mathrm{ft}$. elevation in Hupeh. It is interesting as an apparently hardy Pittosporum, but is not a shrub of much promise.

\section{P. TENUIFOLIUM, Banks.}

(P. Mayi, of gardens.)

An evergreen tree up to $30 \mathrm{ft}$. in height, with a slender trunk and dark coloured, almost black young wood, and forming a dense mass of twiggy shoots. Leaves I to $2 \frac{1}{2}$ ins. long, oblong, obovate or elliptic, smooth, of a pale shining green; the margins entire but wavy. The flowers come in the axils of the leaves, usually singly, but occasionally two or more together, and have dark chocolate-purple petals $\frac{1}{4}$ to $\frac{1}{2}$ in. long. The fruit is a capsule $\frac{1}{2}$ in. in diameter, wrinkled when old, the valves thin.

Native of both the North and South Islands of New Zealand, reaching up to $3000 \mathrm{ft}$. altitude. It is, perhaps, the hardiest of the Australasian Pittosporums, and in several parts of Ireland is 20 to $30 \mathrm{ft}$. high. In Miss Willmott's garden at Warley it is $18 \mathrm{ft}$. high, a stately cone-shaped bush; and at Aldenham in Herts it has reached 8 or $9 \mathrm{ft}$. in height. The flowers are borne very abundantly where it thrives, but are not conspicuous ; their chief attraction is an exquisite honey-like fragrance, strongest in the evening, and then apparent yards away from the tree. Often known in gardens as P. Mayi. The black young shoots and pale green leaves make a strong contrast.

\section{P. Tobira, Aiton. \\ (Bot. Mis., t. I396.)}

An evergreen, bushy shrub of stiff habit, sometimes 20 or more $\mathrm{ft}$. nigh. Leaves obovate, blunt or rounded at the apex, tapering at the base to a short stalk; $1 \frac{1}{2}$ to 4 ins. long, $\frac{3}{4}$ to $1 \frac{1}{2}$ ins, wide, leathery and smooth, dark lustrous green, with a pale midrib. Flowers about I in. across, fragrant, produced at the end of the shoot in clusters 2 or 3 ins. across, the petals 
broadly oblong, creamy white, becoming yellowish with age. Fruit a pear-shaped capsule.

Native of Japan and China; first introduced to Kew in 1804. This shrub is not strictly hardy, and at Kew requires wall protection. In the south-western counties and at Castlewellan in Co. Down it succeeds admirably unprotected, being there a densely furnished, healthy-looking evergreen. In the gardens of the south of France, Italy, Dalmatia, etc., it is one of the commonest of evergreens, producing its flowers from April onwards. The largest examples I have seen are on the Isle of Lacroma, near Ragusa, in Dalmatia, picturesque, spreading bushes, 20 to $25 \mathrm{ft}$. high. The flowers have a scent like orange blossom.

\section{P. UNDUlatum, Ventenat.}

An evergreen tree, 30 to $40 \mathrm{ft}$. high in this country; leaves large, laurel-like; 3 to 6 ins. long, I to 2 ins. wide, tapering towards both ends; smooth, dark lustrous green above, pale beneath, quite entire, but wavy at the margins. Flowers in a terminal cluster of umbels 2 to 3 ins. diameter; each blossom creamy white, $\frac{1}{2}$ to $\frac{3}{4}$ in. across.

Native of Australia, whence it was introduced in 1789. It is, of course, only hardy in the mildest counties; and probably the finest specimen in the British Isles is at Rossdohan, Co. Kerry, in the garden of Mr Herd. It flowers from May to July, and the blossoms are pleasantly fragrant. The leaves are bright and handsome, the undulations of the margin not more marked than in some other species.

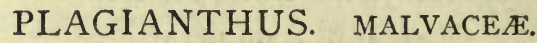

A small genus of Australasian trees and shrubs, remarkable for their tough, fibrous bark. The flowers are mostly unisexual, but not in P. Lyallii, for which reason that species is sometimes removed to GAYA. They are all more or less tender in this country, but quick-growing and easily increased by layers or cuttings. They like a good loamy soil.

\section{P. Betulinus, A. Cunningham.}

A deciduous tree, from 30 to $40 \mathrm{ft}$. high in New Zealand, with a trunk sometimes $3 \mathrm{ft}$. in diameter. In the milder parts of the British Isles it thrives very well, and there is a tree over $50 \mathrm{ft}$. high in the Earl of Ilchester's garden at Abbotsbury, in Dorset. In a young state its growth is remarkably elegant, consisting of a mass of slender, tortuous, interlacing branches, thinly furnished with foliage. At this stage the leaves are $\frac{1}{2}$ to $\mathrm{I}_{2}^{\frac{1}{2}}$ ins. long, narrowly or broadly ovate, deeply and irregularly toothed and lobed; they are borne on slender, downy stalks, nearly or quite as long as the blade. As the trees approach the adult state, the growth becomes less straggling, the leaves increase in size until they are 3 ins. long, and become less deeply lobed. Flowers produced very numerously on racemes at the end of the shoot and in the leaf-axils near, the whole forming a panicle as much as 9 ins. long; individually the flowers are unisexual; the male flowers yellowish white, the females greenish.

Native of the South Island of New Zealand; introduced about 1870. Besides the Abbotsbury tree there are fine ones in Ireland (at Castlewellan) and in other places. It is not hardy at Kew, and sometimes suffers in cold winters against a wall. There is a nice specimen at Warley Place, $12 \mathrm{ft}$. high. 


\section{P. LYalliI, Hooker fil.}

(Bot. Mag., t. 5935 ; Gaya Lyallii, Cheeseman.)

A deciduous shrub in this country, but attaining the dimensions of a small tree up to $30 \mathrm{ft}$. high in New Zealand, and said to be evergreen at the lower levels of its native habitat. Leaves 2 to $4 \frac{1}{2}$ ins. long, $1 \frac{1}{2}$ to 2 ins. wide; ovate, with a heart-shaped base, bright green above, paler or even whitish beneath, the margins jaggedly toothed; stalk half to fully as long as the blade. Sometimes the whole leaf is downy, sometimes nearly or quite smooth. Flowers in clusters of from two to five (usually three) at the leaf-axils of the current season's growth; each flower $\mathbf{I} \frac{1}{2}$ ins. across, solitary on a slender, drooping stalk $\mathrm{I}$ to $\mathrm{I}_{\frac{1}{4}}$ ins. long. Petals overlapping,

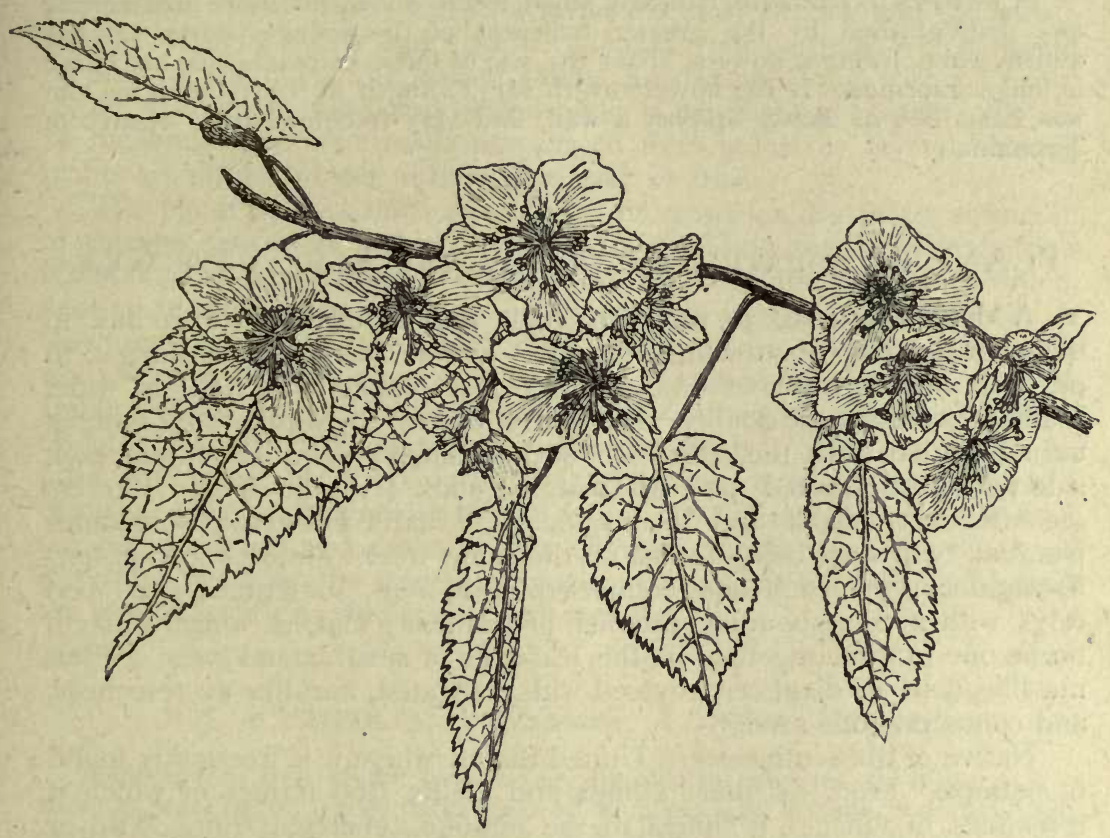

Plagianteus Lyaliit.

white, almost translucent; stamens numerous, yellow; calyx with five triangular lobes. Fruit globose, $\frac{3}{4}$ to $\mathrm{I} \frac{1}{2}$ ins. across.

Native of New Zealand. This beautiful shrub, which flowers in late June and July, is not absolutely hardy. During the winter of 1908-9, a fine specimen at Kew, ro $\mathrm{ft}$. high and as much through, which had flowered profusely for several years previously, was killed down to the ground. It subsequently sprang up from the base again, but one has to be prepared for the same thing happening any winter. The species is represented in gardens by two forms, one of stiffer, sturdier habit, and more downy in foliage than the other; also, I think, hardier; this is regarded as the type. Both forms are extremely beautiful, and when the branches are wreathed with the tissue-paper like flowers there is no shrub more attractive at the time, and few at any other. 


\section{P. Pulchellus, A. Gray.}

An evergreen shrub or tree. Leaves ovate, with a heart-shaped base, $2 \frac{1}{2}$ to $4 \frac{1}{2}$ ins. long, green both sides, coarsely and irregularly toothed, often with two lateral lobes near the base; leaf-stalk slender, half as long as the blade. When young, the leaves and young wood are dotted with stellate hairs. Flowers produced on short racemes or singly, white, each $\frac{1}{4}$ in. across.

Native of S. Australia. Of the species of Plagianthus here dealt with, this has least merit in this country, whatever it may have in its own. It is a quick grower and flowers in July, but its blossoms have little of the beauty of P. Lyallii, nor has it shown the graceful and distinct growth of P. betulinus. It is also tender, and only hardy in mild districts.

P. LAMPEN1I, Bentham, is nearly allied to the above, but more ornamental, and distinguished by the greater hairiness of the younger parts. It has dullish white, fragrant flowers, about the size of those of pulchellus, but borne in longer racemes. It has flowered with $\mathrm{Mr} \mathrm{T}$. Smith of Newry, and, by him was described as hardy against a wall, and very free-flowering. Native of Tasmania.

\section{PLANERA aquatica, Gmelin. WATER Elm. URTiCaCe}

A deciduous tree, 30 to $45 \mathrm{ft}$. high, with a trunk I5 to 20 ins. in diameter; young shoots thin, downy. Leaves alternately arranged in opposite ranks, ovate or oval, I to 3 ins. long, about half as wide, toothed (sometimes doubly so), scurfy downy beneath when young, ultimately harsh to the touch on both surfaces; veins about ten each side the midrib, forked near the margin; stalk $\frac{1}{8}$ to $\frac{1}{4}$ in. long. Flowers greenish, very small and inconspicuous, usually unisexual, sometimes bisexual, both sorts being found on the same tree. Males borne in fewflowered clusters, each one composed of a fnur-, sometimes five-lobed calyx with a corresponding number of stamens; females longer-stalked, borne one to three together in the leaf-axils of small lateral twigs. Fruit nut-like, $\frac{1}{2}$ in. in diameter, covered with elongated, wart-like excrescences, and containing one seed.

Native of the south-eastern United States, where it is frequently found in swamps. From its allies, Ulmus and Celtis (the former of which it resembles in foliage), it differs in the nut-like, tubercled fruit. Two or three trees sent from the Missouri Botanic Garden to Kew in 1897 thrive quite well in ordinary loamy soil, but the tree is extremely rare in cultivation. What is found usually under the name is Zelkova crenata, a Caucasian tree.

\section{PLATANUS. PlaANE. PlatanaCEÆ.}

The planes are very distinct from any other group of trees, constituting in themselves a natural order. In foliage they bear some resemblance to the maples, but the leaves are alternate. The flowers are unisexual, both sexes occurring on the same tree. The most characteristic feature of the planes is the production of the seed-vessels (achenes) in spherical balls, 
which are sometimes solitary, but more often strung two tu six together on a pendulous stalk. They persist on the tree more or less throughout the winter. The bark peels off in large flakes, and after a stormy spring day the ground beneath a large plane will frequently be seen strewn with pieces of bark torn off by wind.

Some of the noblest trees of the northern hemisphere belong to this genus. Specimens of the European P. orientalis are known to have trunks $40 \mathrm{ft}$. in circumference, and the American P. occidentalis growing in the Mississippi Valley has trunks about as large, and it occasionally reaches $\mathrm{I} 70 \mathrm{ft}$. in height. They like a deep, moist, loamy soil, and thrive better in the south of England than in the north. They are essentially sun-lovers. Seeds ripen on P. acerifolia and orientalis, and germinate readily. Young plants may also be obtained from cuttings, which should be made at the fall of the leaf, of shoots 8 to $\mathbf{I} 2$ ins. long, with a "heel" of old wood at the base, and placed under a handlight in a sheltered spot. In nurseries they are usually propagated from stools by layers. Young plants are rather subject to being cut back by frost.

The plane trees of town streets and promenades are under suspicion of causing serious bronchial irritation by shedding the hairs from their leaves, and especially fruits. These break up into minute particles which, floating in the air, are inhaled. Although the alleged evil influences of these particles on the throat and lungs (and even on the eyes and ears as well) were suspected and written about by the ancients-among others by Gảlen and Dioscorides-they never appear to have deterred either them or later generations from planting the tree freely. There seems to be little doubt that on the Continent it produces, or helps to produce, a catarrhal affection analogous to hay fever. In Britain the crops of fruit are not so large, and probably our damper climate prevents the hairs travelling far from the tree; at anyrate, nothing has been proved against the tree to justify its wholesale condemnation.

\section{P. ACERIfolia, Willdenow. London Plane.}

A deciduous tree of the largest size, frequently over $100 \mathrm{ft}$. high, with a smooth, erect trunk, whose park peels off in flakes, and a huge, rounded head of branches, the terminal parts of which in large trees are pendulous; young shoots and leaves covered at first with a dense, pale brown wool much of which falls away by autumn. Leaves 5 to 10 ins. wide, usually rather less in length ; five-lobed, the lobes triangular and extending from one-third to one-half the depth of the blade, more or less coarsely toothed; stalk 1 to 4 ins. long. Fruit-balls two to as many as six in a pendulous string, each 1 to $1 \frac{1}{2}$ ins. across, rendered burr-like by the long, persistent remnant of the style at the apex of each fruit.

The origin of this plane is not known. Like the red horse-chestnut, it has never been found wild, and all the old historical planes of the Orient are P. orientalis. Now the commonest of planes, it first came into notice early in the eighteenth century. In London it is planted in greater numbers than all the other sorts of trees put together. It certainly has the power to withstand a smoke-laden city atmosphere better than any other tree at present known. Years ago some ingenious person suggested that this faculty was duc to its habit of casting its bark, and this theory has been religiously 
repeated by nearly every writer since. There is no proof of this, for atmospheric influences do not affect branches large enough to shed their bark, but rather the leaves and other breathing parts of the tree. It is remarkable that a tree which, by descent at least, belongs to the sun-baked isles of Greece should be able to adapt itself so completely to the pavements and atmosphere of London. Messrs Elwes and Henry suggest that it may be a seedling variation of $\mathrm{P}$. orientalis, a view supported by the existence of forms intermediate in leaf. The difference in habit, for it is a taller, cleaner grown tree, requires more explanation. A continental authority regards it as a hybrid between $\mathrm{P}$. orientalis and $\mathrm{P}$. occidentalis.

There are some very fine trees near London; at Ranelagh is one whose height in 1903 was $105 \mathrm{ft}$., and its girth $20 \mathrm{ft}$. 4 ins. (Elwes). A fine specimen stands near the northern end of the Rhododendron dell at Kew. In a small state the London plane is somewhat formal and without distinction, but nothing in our gardens is more majestic than a fully-grown tree. It ripens its seeds in this country, and young plants raised from them show considerable variation, and at least half a dozen have been named. The characteristics of the following (whether constant or not is perhaps doubtful) are indicated by the names: INTEGRIFOLIA (scarcely lobed); MACROPHYLLA (large-leaved); PYRAMIDALIS (of pyramidal habit).

Var. SUTTNERI (P. occidentalis argenteo-variegata) is a handsome, variegated tree, its leaves being conspicuously blotched with creamy white; sometimes almost wholly of that colour. It is far from being as robust as the type.

\section{P. CUNEATA, Willdenow.}

\section{(P. orientalis var. cuneata, Loudon; P. nepalensis, Hort.)}

By some writers this tree is considered to be a variety of the Oriental plane, and it is no doubt closely allied to it. It differs in the leaves being three-lobed as well as five-lobed, with the base wedge-shaped and tapering gradually to a stalk ; they are also smaller, usually 3 to 6 ins. long and wide, occasionally half as long again. The tree is not so large, vigorous, or hardy as P. orientalis. Young plants raised at Kew from seed obtained from the north-western Himalaya (where it is probably only cultivated) are stunted, very slow-growing, and subject to injury by spring frosts ; they have a narrow, pyramidal habit. The typical $P$. cuneata rarely bears fruit near London, and is scarcely worth a place in gardens, but there are forms intermediate between it and P. orientalis that make handsome small trees.

\section{P. occidentalis, Linnceus. Buttonwood.}

One of the most widely spread and persistent of errors connected with the identity of trees has centred round this species. There is probably not a single specimen of the true thing in the British Isles with a trunk 3 ins. in diameter-yet scores of nurserymen still offer it in their catalogues. The tree they offer, and the tree discussed by Loudon and other writers under the name, is P. acerifolia, or the common London plane. The true P. occidentalis is a native of the southern and eastern United States, where, in the region of the Ohio and Mississippi rivers, it grows I 40 to $I 70 \mathrm{ft}$. in height, with a trunk $30 \mathrm{ft}$. in girth. It differs from P. acerifolia in the leaves being only shallowly lobed, with a wide, roundish sinus between the lobes. Then the tree very rarely bears more than one ball of fruits on each stalk (the European ones have two to six), and the surface of the ball is smoother and, less burrlike than in acerifolia or orientalis. From what has been said above, it will be gathered that the species has no value in British gardens. It has many 
times been raised from seed at Kew, and the young plants grow freely enough for a time, but owing to injury by spring frost and the attacks of parasitic fungi they rarely get beyond $6 \mathrm{ft}$. in height. In my experience at Kew only one plant ever reached the height of $12 \mathrm{ft}$. Our winter frosts will not harm it. The winter cold of Massachusetts is greater than we ever experience, but I remember seeing, near Lancaster in that State, a tree with a trunk $20 \mathrm{ft}$. in girth. In habit and in its tall trunk it resembles P. acerifolia.

\section{P. ORientalis, Linnaus. ORiental Plane.}

A deciduous tree of the largest size, in this country occasionally so to roo $\mathrm{ft}$. high, and $\mathrm{I} 4$ to $20 \mathrm{ft}$. in girth of trunk; in open situations it usually branches a few feet from the ground into several large spreading limbs; young shoots at first covered with pale brown hair tufts, becoming smooth later. Leaves palmate, 6 to Io ins. wide, somewhat less in length, with five large lobes, and usually a smaller one on each side at the base; the lobes, which are half to two-thirds the depth of the blade, and lance-shaped, have each one to three large teeth or minor lobes at the sides. When they first unfold, the leaves are covered with a thick whitish brown felt composed of stellate hairs which later falls away, leaving the leaf smooth except near the veins beneath, and glossy above; stalk $1 \frac{1}{2}$ to 3 ins. long. Fruit-balls two to six on each stalk, I in. wide, bristly.

Native of S.E. Europe and Asia Minor; cultivated in England in the middle of the sixteenth century. The true Oriental plane is comparatively rare in gardens, having been ousted by the more rapidly growing "London" plane, which is not so picturesque nor so pleasing as an isolated lawn tree. It is easily distinguished from acerifolia by its shorter, more rugged trunk, and its deeper, often doubly lobed leaves. Few trees are longer-lived than this. On the banks of the Bosporus, there is a group of trees under which the knights of Godfrey de Bouillon on their way to the crusades, are said to have sheltered in 1069. Under a tree still living on the island of Cos in the Egean Sea-its trunk 18 yards in circumference-tradition says that Hippocrates sat more than 400 years B.C. There is no direct evidence to support these stories, but they point to the perhaps unequalled longevity of the plane among European trees. In his account of fine British specimens $\mathrm{Mr}$ Elwes gives first place to one in the Palace Gardens at Ely, planted by Bishop Gunning between 1674 and 1684 . It is over $100 \mathrm{ft}$. high, and more than $20 \mathrm{ft}$. in girth. A fine specimen at Kew, near the sundial, and on the site of the famous seventeenth-century gardens of Sir Henry Capel of Kew House, has a trunk $15 \mathrm{ft}$. in girth.

\section{P. RACEMOSA, Nuttall.}

A tree 40 to $100 \mathrm{ft}$. high in California, with a trunk 2 to $6 \mathrm{ft}$. in diameter; young shoots clothed with a thick wool which falls away during the summer. Leaves usually five- sometimes three-lobed; the lobes reaching half-way or more than half-way to the midrib, pointed and shallowly, often distantly, toothed, slightly heart-shaped at the base ; thickly clothed below with pale, persistent down, especially along the midrib and veins; 6 to 12 ins. wide, rather more in length; stalks stout, downy, I to 3 ins. long. Flowers in balllike clusters, two to seven of which occur on the pendulous stalk; by the time the fruits have developed the balls are $\frac{3}{1}$ in. across.

Native of California ; introduced by Mr F. R. S. Balfour in 1910. Healthy trees raised from his seed are now $9 \mathrm{ft}$. or more high; the hardiness of this plane has yet to be proved but does not seem doubtful. 


\section{PLATYCARYA STROBILACEA, Siebold. JUGLANDACE}

(Fortunæa chinensis, Lindley; Journ. Hort. Soc., i., p. I50.)

A small or medium-sized, deciduous tree, with pinnate leaves, 6 to I 2 ins. long. Leaflets five to fifteen, stalkless, ovate-lanceolate, obliquely wedge-shaped or rounded at the base, long and taper-pointed, sharply and often doubly toothed; $I \frac{1}{2}$ to $4 \frac{1}{2}$ ins. long, $\frac{1}{2}$ to $\mathbf{I} \frac{1}{4}$ in. wide; with at first scattered hairs above and along the midrib and veins beneath, becoming smooth later. Flowers unisexual, both sexes borne on the same tree, but on separate inflorescences. Male catkins slender, cylindrical, drooping, 2 to $3 \frac{1}{2}$ ins. long, $\frac{1}{4}$ in. wide; borne four to twelve together in a hairy raceme terminating the current year's growth; female inflorescence also terminal, surrounded by the male catkins, erect, usually solitary, $\mathrm{r} \frac{1}{4}$ ins. long, I in. wide, resembling a cone. In both sexes, the flowers are produced in the axils of small, lanceolate scales, followed in the female by tiny winged nutlets which, with the wings, are only $\frac{1}{8}$ to $\frac{1}{8}$ in. across.

Native of China; first discovered and introduced by Fortune in $\mathbf{1} 845$; said also to be found in Japan. Allied to the walnuts and hickories, and resembling them in leaf and male catkins, it is very distinct in the female inflorescence and tiny nuts. It succeeds well in Central and S. France, but I am afraid is only adapted for the milder parts of Britain. It lives out-of-doors at Kew, but does not thrive.

\section{PLATYCRATER ARGUTA, Siebold. SAXIFRAGACE $A$.}

A low, deciduous, sometimes creeping shrub, with slender, smooth stems. Leaves narrowly oval-lanceolate, the largest 5 to 8 ins. long and $\mathrm{I}$ to 2 ins. wide, tapering at both ends, the margins set with slender teeth, bristly hairy beneath; stalk $\frac{1}{4}$ in. long. Flowers of two kinds, viz. perfect and sterile, as in Hydrangea, produced in a lax terminal corymb. Perfect flowers I in. across, with four white, broadly ovate petals, two styles, very numerous yellow stamens, and a four-lobed calyx; the lobes $\frac{1}{2}$ in. long, pointed, narrowly triangular. Fruit top-shaped, with the calyx-lobes persisting. Sterile flowers consisting only of the united calyxlobes, and forming a white, flat, three- or four-sided disk, $\frac{3}{4} \mathrm{in}$. across, all the other parts of the flower being absent.

Native of Japan; introduced by way of St Petersburg about r868. The plant is rather tender and apt to be cut to the ground in winter, or killed outright in severe frosts. I have never seen the sterile flowers above described on cultivated plants, usually there have been three perfect flowers produced in a corymb, the middle one opening first, each on a slender stalk I in. or less long. Both Siebold and Regel include sterile flowers in their figures (see Flora Japonica, t. 27 , and Gartenflora, t. 516). Siebold says he found the plant growing on humid rocks with its branches flat on the ground. He mentions a curious use the Japanese 
made of the plant; this was to make an infusion of the leaves with which the images of Buddha were washed or baptized. But that was in 1835 . The plant is easily increased by rather soft cuttings.

\section{PLATYOSPRION PLATYCARPUM, Maximowic.,. LEGUMINOSE.}

(Sophora platycarpa, Maximowicz; Cladrastis platycarpa, Makino.)

A deciduous tree, similar in habit and general appearance to Sophora japonica; branchlets smooth, dark brown. Leaves pinnate, 8 to ro ins. long; leaflets in five and a half to seven and a half pairs, obliquely ovate, pointed; $\mathrm{I} \frac{1}{2}$ to 4 ins. long, I to $\mathrm{I} \frac{1}{2}$ ins. wide; bright green above, downy on the midrib and stalk, otherwise smooth at maturity. Flowers white, pea-flower-shaped, $\frac{5}{8}$ in. long, produced on slender, downy stalks about $\frac{1}{4}$ in. long, in panicles 4 to 6 ins. high, $2 \frac{1}{2}$ to 4 ins. wide. Pod flat, 2 ins. long, $\frac{1}{2}$ in. wide, tapered to a point at both ends and winged on the seams; seeds three or four, often only one developing.

Native of Japan. This interesting tree was first placed in Sophora, from which its' flat (not necklace-shaped) fruit distinguishes it. A Japanese botanist has placed it in Cladrastis, which it certainly resembles in the fruit. It is not common in cultivation, although offered by several continental dealers; Maackia amurensis is sometimes supplied for it. It has not yet flowered in this country, but will no doubt thrive wherever Sophora japonica does. In N. America it is said to have proved hardier.

\section{PODOCARPUS. TAXACEE.}

There are some forty or fifty species of Podocarpus known, which are found in Australasia, S. America, and E. Asia, only two or three of which can be regarded as hardy in our average climate, although a considerably larger number will thrive in Ireland, in Cornwall, and other mild counties. They are allied to the yews, and have rounded, or egg-shaped, plum-like fruits consisting of a single seed or nut with a fleshy covering. They require in cultivation a sheltered spot and a well-drained, loamy, or peaty soil.

\section{P. ALPINA, R. Brown.}

A low evergreen shrub, forming a neat, dense, almost hemispherical mass of drooping branches at present 3 to $4 \mathrm{ft}$. high with us; branchlets produced in whorls, very slender and interlacing, smooth and green when young. Leaves $\frac{1}{4}$ to $\frac{1}{2}$ in. long, $\frac{1}{16}$ to $\frac{1}{12}$ in. wide; linear, tapered at the base and either rounded at the apex or terminated by a small fine point ; dark dull green above; slightly pale, with rows of stomata beneath. Fruit a small, bright red, plum-like body $\frac{1}{4}$ in. across, containing one seed.

Native of Tasmania and the mountains of Victoria, but quite hardy at Kew, where it has withstood $30^{\circ}$ of frost without injury. It is a distinct shrub, and although quite healthy has only attained $4 \mathrm{ft}$. in height in thirty years, or perhaps longer. A plant occasionally bears female flowers at Kew, 
and in 1892 one in the rock garden produced a few fruits. It leaves fall about their fourth year.

\section{P. CHILINA, Richard.}

\section{(P. andina of gardens-not Poeppig.)}

A unisexual evergreen tree, 40 to $60 \mathrm{ft}$. high, but in this country a shrub except in the south and west; branchlets green, terete, quite smooth. Leaves persisting two years, falling the third, linear, often sickle-shaped, tapered at the base, pointed at the apex; 2 to $3 \frac{3}{4}$ ins. long, $\frac{1}{8}$ to $\frac{3}{16}$ in. wide ; dark rather bluish green above, paler beneath, with numerous rows of minute stomata. Male flowers in a cluster of slender spikes $I$ to $I \frac{1}{2}$ ins. long. Fruits egg-shaped, $\frac{1}{3}$ in. long, solitary or in pairs on a stalk $\frac{1}{2}$ to $\frac{5}{8}$ in. long and standing out at right angles from it.

Native of the Andes of Chile; introduced in 1853. At Kew it was killed during the frosts of February 1895, but survived in Messrs Paul's nursery at High Beech, on higher ground, whence a fresh stock was obtained that has not been injured since. Its chief value is in the south-western counties. There is a male tree in Mr Robert Fox's garden, Penjerrick, Cornwall, $30 \mathrm{ft}$. high, which makes a very striking pyramidal mass of foliage. It is frequently called "P. andina" in gardens, a name that is really a synonym of Prumnopitys elegans, a tree very distinct from the present.

\section{P. Macrophylla, $D$. Don.}

An evergreen small tree, 25 to $50 \mathrm{ft}$. high, usually shrubby in this country, and forming a densely leafy, rounded bush. Leaves linear, tapering at both ends; 3 to 4 ins. long, $\frac{3}{16}$ to $\frac{1}{4}$ in. wide; of firm, rather leathery texture, perfectly smooth, the midrib prominently raised above and below; margin thickened below; dark glossy green above, yellowish green beneath.

Native of China and Japan. According to Sargent it is a common hedge plant in Tokyo gardens, and is often clipped into fantastic shapes. It is fairly hardy in the south of England. It may be confused with P. chilina, but has larger, broader leaves of a yellower green, and they have not the sickle-like shape frequent in the Chilean species. In Japan the leaves are as much as 7 ins. long by $\frac{1}{2}$ in. wide.

In Cornwall and Ireland there may occasionally be seen P. NUBIGENA, Lindley, a Chilean species very distinct from any of the preceding, but unfortunately only hardy in our mildest districts. The leaves (very closely set on the branchlet) are I to $I_{\frac{3}{4}}$ ins. long, $\frac{1}{8}$ to $\frac{3}{16}$ in. wide, tapering to a sharp point, of a rather pale, charmingly fresh green, with a broadish band of stomatic lines each side the midrib beneath. The young shoots are bright yellow. The best trees I have seen are two at Kilmacurragh, Co. Wicklow, about $25 \mathrm{ft}$. high, nearly as much through.

\section{POLIOTHYRSIS SINENSIS, Oliver. BIXACEA.}

(Hooker's Icones Plantarum, t. 1885.)

A deciduous tree, up to 30 or $40 \mathrm{ft}$. high, with ovate, slenderly pointed leaves $4 \frac{1}{2}$ to 6 ins. long and $2 \frac{1}{2}$ to 5 ins. wide; rounded or sometimes heart-shaped at the base, very downy beneath, becoming smoother as the season advances; stalk slender, downy, $\frac{3}{4}$ to $I \frac{3}{4}$ ins. long. 
Flowers in a terminal inforescence, each flower $\frac{1}{3}$ in. across, white, soon changing to yellow; they are unisexual, with both sexes on the same inflorescence; calyx-lobes ovate, pointed; styles three. Fruit an ellipsoid capsule $\frac{1}{2}$ to $\frac{3}{4}$ in. long, many-seeded; seeds winged.

Native of China; discovered by Henry in the province of Hupeh about r889. It did not reach English gardens until 1908, when Wilson sent seeds to the Arnold Arboretum, some of which were distributed in Europe. Some of the young seedlings raised at Kew perished in the severe winter of r $908-9$, but others survived, and there is every probability that established plants will be hardy. It is the only known member of its genus, and is nearly allied to Idesia polycarpa, but differs in having a dry capsular fruit instead of a berry. Of its merits as a garden tree nothing can yet be said. Wilson observes that the bark in adult trees is grey and deeply furrowed, and that the leaves vary in toothing and pubescence.

\section{POLYGala Chamebuxus, Linnaus. Milkwort. POLYGALACE}

$$
\text { (Bot. Mag., t. 3I6.) }
$$

A dwarf, creeping, evergreen shrub, from 6 to 12 ins. high, with smooth, alternate, box-like, dull green leaves, $\frac{1}{2}$ to $\mathbf{I}$ in. long, oval or narrow oblong, not toothed, but with a small pointed tip. Flowers $\frac{1}{2}$ in. long, produced from the leaf-axils near the end of the shoot, singly or in pairs; they rather resemble the flowers of the pea family, and are creamy white, with the end of the keel bright yellow. The fruit is a flat, two-seeded capsule; seeds downy.

This charming little shrub is a native of the mountainous regions of Central Europe, where it occurs most abundantly on calcareous formations. It succeeds in cool, moist positions, forming neat tufts covered with the delightful flowers in April and May. Under cultivation it seems to thrive very well in a peaty soil or in a sandy loam. In positions where it thrives (and the Thames Valley with its dry, hot spells is not the most suitable) it is readily propagated by taking off the sucker growths with roots attached.

Var. PURPUREA (syn. var. grandiflora).-Wing-petals purple, the keel yellowish at the apex.

\section{POLYGONUM baldschuanicum, Regel. POlygonacea.}

(Bot. Mag., t. 7544.)

A vigorous, deciduous climber, its shoots growing as much as $20 \mathrm{ft}$. in one season, ultimately 40 or more ft. high; stems slender, smooth, grey. Leaves alternate, broadly ovate, heart-shaped or spear-shaped at the base, pointed or rounded at the apex; $1 \frac{1}{2}$ to 4 ins. long, I to $2 \frac{1}{2}$ ins. 
wide; smooth, pale green. Panicles produced in summer and autumn in such abundance as to envelop the plant in a cloud of blossom; they are terminal on lateral shoots, much branched, 8 to 16 ins. long. Flowers pale pink or almost white; each $\frac{1}{3}$ in. across, with transparent ovate sepals in two whorls, the three in the outer whorl winged at the back, the wing passing downwards to the flower-stalk. As these wings persist on the pinkish young seed-vessel, they give it the characteristic three-angled shape.

Native of Bokhara ; discovered by Dr A. Regel in 1883 ; introduced to gardens by way of the St Petersburg Botanic Garden about r894. No more beautiful climber has been introduced for many years, and its value is enhanced by the late date of its blossoming and the beauty of its young fruits. The best way to cultivate it is to give up to it some worn-

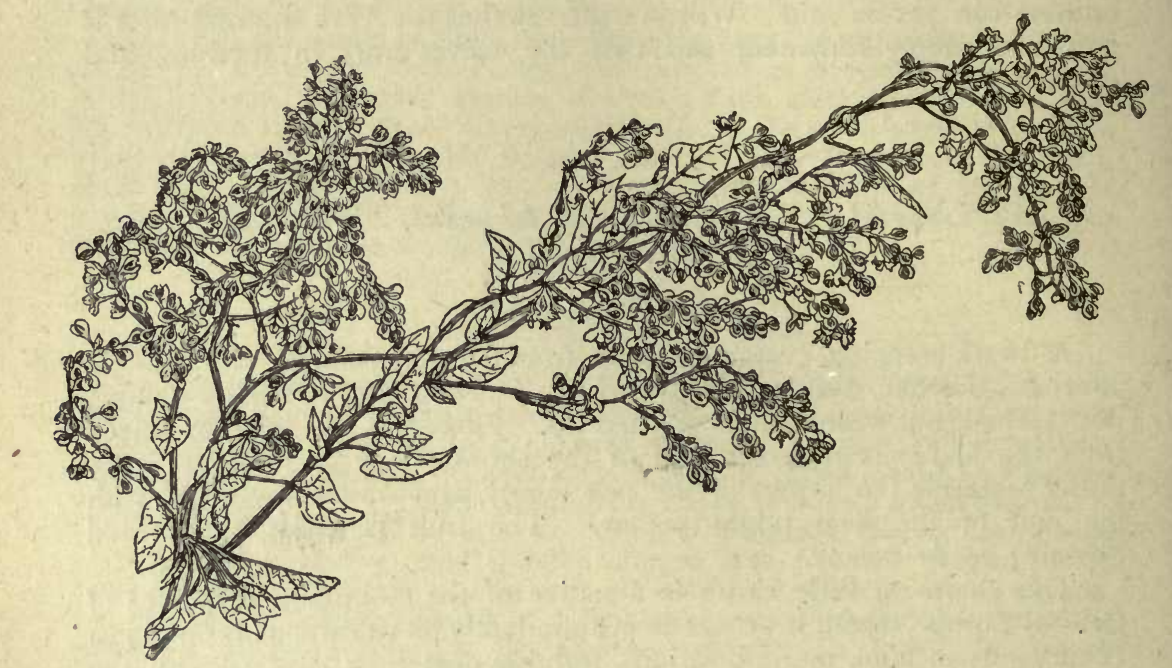

Polygondm baldschónicum.

out tree which it may be allowed to ramble over 'or envelop at will. Failing that, a stout spruce pole with the side branches left several feet long, or some such support, may be given it. Few climbers give so charming an effect in so short a time. It likes a rich loamy soil and a fully exposed position. Seeds rarely or never set with us, and the plant is best propagated by cuttings. These should be made in summer of pieces of the current year's growth, with a "heel" of older wood attached, and placed in gentle heat. Cuttings of leafless wood, made in February with a heel, will also take root.

P. Aubertil, L. Henry, is a new species from W. China, closely allied to baldschuanicum. Flowers smaller, greenish white tinged with rose; said to be not so desirable.

P. EQUISETIF. RME, Sibthorp, from the Mediterranean region, is well worth growing for its distinct growth and abundant milky white flowers produced in autumn. The plant consists of a dense mass of slender, mare's tail-like stems about as thick as a knitting needle and 2 or $3 \mathrm{ft}$. high. It needs a warm sunny corner, and even then is often cut back by winter cold. 


\section{POPULUS. POPLAR. SALICACEA.}

A group of large, usually quick-growing, deciduous trees, with alternate leaves pinnately veined or three-nerved at the base, those on vigorous leading shoots larger, and often different in shape and character from those on lateral twigs. Flowers produced in catkins on the naked shoots in spring, the sexes nearly always on separate trees. Male catkins more densely flowered than the female, the flowers composed of usually numerous stamens attached to a disk, and springing from the axil of a toothed or fringed scale, which soon falls away. Anthers red or purple. Female catkins lengthening until mature, the egg-shaped or rounded ovary seated in a cuplike disk, and crowned by two to four stigmas. The seed is surrounded by a conspicuous tuft of white, cottony hairs which enables it to be carried long distances by wind. Poplars occur in most parts of the northern hemisphere, from subarctic regions to subtropical ones, some inhabiting arid places, others always found in association with moisture.

There are four well-marked groups of poplars:-

I. Balsam Poplars. - These burst into leaf the first, and are distinguished by very gummy winter leaf-buds and leaves, which emit a pleasant balsamic odour, especially when just expanding in spring. Leaves usually whitish, but not woolly beneath; leaf-stalk not compressed. This group includes angustifolia, balsamifera, candicans, laurifolia, Simoni, suaveolens, trichocarpa, tristis. Most of these can be increased by cuttings of leafless shoots in the open ground or by suckers.

II. White Poplars. - Leaves woolly, and white or grey beneath, coarsely toothed or lobed, the younger trunks and main branches at first pale and smooth, then pitted with numerous diamond-shaped holes. It includes alba and canescens. Increased by leafless cuttings in the open ground.

III. AsPENS. - Leaves with long, laterally flattened stalks, and noted for their restless movement. It includes grandidentata, tremula, tremuloides, none of which root readily from branch cuttings.

IV. BLACK Poplars. - The latest group to break into leaf. Leaves green on both sides and with compressed, slender stalks, nearly always in motion; margins cartilaginous. Trunks with a corrugated bark like an oak. This group includes angulata, Eugenei, Fremontii, marilandica, monilifera, nigra, regenerata, robusta, serotina, Wislizeni. All the black poplars except some forms of angulata are easily increased by cuttings of leafless shoots I ft. or more long, placed in the open ground in November. Many of the male black poplars in spring are handsome on account of their richly coloured catkins.

The production of hybrids on the Continent, where the poplars seed freely, has produced much confusion in the nomenclature of the black poplar group. Students are much indebted to Prof. A. Henry for a laborious investigation into the tangled identity of these hybrids, the results of which have been recently published. Several hybrids of the balsam poplar group are not of sufficient importance or merit to be given 
detailed description, such as Petrowskyana, Schroeder; Rasumowskyana, Schroeder; and Wobstil, Schroeder - all of Russian origin. The two first are hybrids between some black poplar and laurifolia and suaveolens respectively; Wobstii is thought to be between tristis and laurifolia.

Poplars do not produce good seed freely as a rule, and one does not often see seedling plants of the majority. All of those worth cultivating thrive best in a good moist loam, but many (of the black poplar group especially) also succeed well in heavy, wet ground, and are valuable on that account.

\section{P. ALBA, Linnaus. White Poplar.}

A tree said to be 90 to $100 \mathrm{ft}$. high, but I have seen none more than halt that size in this country; bark of trunk smooth; young shoots and lower surface of the leaves covered with a thick, vividly white wool, which on the lobed leaves persists and keeps white until the fall of the leaf. Leaves variable; rounded to slightly heart-shaped at the base, blunt-pointed; on short twigs they are broadly ovate or almost round, irregularly wavy at the margins, I to 2 ins. long; on vigorous shoots and young trees they are much larger, usually of maple-like form, being deeply three- or five-lobed and from $1 \frac{1}{2}$ to 5 ins. long, each lobe with a few large teeth. When the leaves first expand they are covered above with a loose white floss which falls away during the summer, leaving the upper surface very dark green and smooth; stalk $\frac{1}{2}$ to $I_{2}^{\frac{1}{2}}$ ins. long, woolly. Male catkins about $I$ in. long.

Native of Europe, but not, as is usually believed, of Britain, where it is much confused with $\mathrm{P}$. canescens. The true white poplar is not particularly common, and all the trees I have seen are comparatively small. Large trees so called are invariably $\mathrm{P}$. canescens. In gardens it is called " $\mathrm{P}$. alba var. nivea," and "P. Arembergiana," to distinguish it from P. canescens figuring as P. alba. The true P. alba is easily recognised by the leaves, especially the lobed ones, remaining white and woolly beneath until they fall, and by their being palmately lobed on vigorous shoots. The foliage sometimes turns a fiery red in autumn.

Var. GLOBOSA, Spath.-A dwarf form making a rounded, bushy head. Leaves of the rounded form, with slightly lobed or undulated margins. Very slow-growing.

Var. PYRAmidalis, Bunge (P. Bolleana, Carrière). Bolle's Poplar.-A slender pyramidal tree of great beauty, resembling the Lombardy poplar in habit, but wider in proportion to its height, and distinguishable in winter by its pale smooth trunk. There is a fine specimen about $70 \mathrm{ft}$. high near the Sun Temple at Kew. Seen in a breeze, this tree has an enlivening effect, caused by swift flashes of white when the under-surface of the leaf is revealed. According to a statement in the Garden for Dec. 10, 1887, p. 543, it was originally found in September, $184 \mathrm{I}$, forning a little grove on the north side of the Karataw mountains, between Bokhara and Samarcand, and apparently wild. It was introduced to W. Europe between I875 and I878.

Var. RICHARDII.-In this form the upper surface of the leaf is a dull golden yellow, the under-side and the young shoots felted with white wool as in the type. First shown at the International Exhibition, Chelsea, I9I2.

\section{P. angulata, Aiton. Carolina Poplar.}

A large tree whose angular or ribbed young shoots are without down, but marked by long, narrow, pale lenticels. Leaves heart-shaped (sometimes 
truncate at the base), with short or slender points ; 4 to 7 ins. long, 3 to 5 ins. wide; the cartilaginous margins regularly set with comparatively small, rounded, incurved, gland-tipped teeth, and minutely hairy; both surfaces smooth, except when just unfolding, and glossy green ; there are one or two pairs of glands at the base of the leaf on the upper side; stalk smooth, flattened. Female catkins 2 to 4 ins. long; flower-scales not fringed, but only slightly lobed at the margins; stigmas three or four.

Var CORDATA.-Messrs Simon-Louis have in their nursery at Plantières, near Metz, a fine form of $\mathrm{P}$. angulata which they call var. cordata. Mr Jouin informs me that it is hardier than the type. It produces very fine foliage; many of its heart-shaped leaves being 6 or 8 ins. long, and 5 or 6 ins. wide. Crossed with P. Eugenei, this variety has produced a very vigorous hybridP. ROBUSTA, C. K. Schneider (known in nurseries as "P. angulata cordata robusta ").

P. angulata is believed to be a native of the south-eastern United States, but if really wild there, its whereabouts do not appear at present to be known. It has been cultivated in England since early in the eighteenth century. It is allied to P. monilifera, but is a more striking tree, especially in its foliage, differing from that species in its angled or ribbed young shoots, and its larger, but comparatively narrower, smaller-toothed leaves and shallowly lobed (not fringed or laciniated) catkin scales. There is a male tree in the Syon Gardens 1 I $1 \mathrm{ft}$. high.

\section{P. ANGustifolia, James. Willow-Leaved Poplar.}

\section{(P. balsamifera var, angustifolia, S. Watson.)}

A tree 50 to $60 \mathrm{ft}$. high in a wild state (Sargent), but, as seen in cultivation here at present, a low bushy-headed tree with short, much-forked, crooked branches; young shoots round, smooth or minutely downy, especially towards the apex; winter buds sticky, slender-pointed. . Leaves lanceolate or ovatelanceolate $; 2$ to 5 ins. long, $\frac{1}{2}$ to $I \frac{1}{2}$ ins. wide; wedge-shaped at the base, tapering gradually to a point at the apex, minutely and evenly round-toothed, green on both sides, although paler beneath, smooth except sometimes for minute down beneath; stalk ordinarily about $\frac{1}{2}$ in. long. Catkins not seen in this country, but the male ones described by Sargent as $1 \frac{1}{2}$ to $2 \frac{1}{2}$ ins. long, densely flowered; the female catkins are 2 to 4 ins. long when mature.

Native of Western $N$. America, but not of the Pacific side of the Rocky Mountains. It is one of the balsam group with the characteristic odour, and is distinguished by its willow-like leaves, not white beneath. In foliage it most resembles $P$. laurifolia, but that species has angular, more downy young shoots, and leaves pale beneath.

\section{P. Balsamifera, Linnceus. Balsam Poplar.}

A tree $100 \mathrm{ft}$. high in a wild state, but rarely more than half as high in this country, producing suckers freely; young shoots smooth, round ; winter buds thickly covered with a balsamic, very fragrant, viscid, yellowish resin, often $\mathbf{I}$ in. long, long-pointed. Leaves broadly ovate, rounded or slightly heartshaped at the base, slender-pointed, very variable in size, round-toothed, ordinarily 2 to 5 ins. long, $1 \frac{1}{4}$ to 3 ins. wide ; quite smooth and dark shining green above, smooth or slightly. downy beneath, the pale or whitish ground conspicuously net-veined; stalk $\frac{2}{3}$ to 2 ins. long. Male catkins 3 ins. long; female ones 4 or 5 ins. long.

Native of N. America, where it is widely spread and abundant in the northern altitudes. It was introduced sometime in the seventeenth century. The 
true balsam poplar is an erect-branched tree now rarely seen in this country, where nearly all poplars so-called are the closely allied, broader-topped P. candicans. It produces suckers freely, which afford the best means of increase. The great charm of this tree is the balsamic odour of its unfolding leaves in spring which fills the air around. It is the type of a group of poplars with the same quality more or less developed, but it is not so valuable a tree as its W. American ally, P. trichocarpa. The leaves on vigorous suckers are occasionally of enormous size. I have measured one 13 ins. long, and 10 ins. wide. Only the male plant appears to be in cultivation.

\section{P. Berolinensis, Dippel. Berlin Poplar. \\ (P. certinensis, Hort.)}

A supposed hybrid between P. laurifolia (female) and the Lombardy poplar, said by Koch (Dendrologie, ii. p. 497) to have first appeared in the Botanic Garden of Berlin. Although described nearly fifty years ago, it has spread but little in cultivation, although a handsome tree of slender columnar shape. Its young shoots are downy, slightly angled. Leaves broadly ovate and rounded at the base, or somewhat diamond-shaped and wedge-shaped at the base, slender-pointed, finely toothed like P. laurifolia; $1 \frac{1}{2}$ to 4 ins. long; upper surface bright green, lower one pale, scarcely whitish ; both sides soon quite smooth ; stalk slender, downy at first, $\frac{3}{4}$ to $I \frac{1}{2}$ ins. long. This tree thrives remarkably well in the vicinity of Berlin, where it originated. Some years ago, I saw some particularly handsome examples in Mr Spath's nursery near that city. It is strongly recommended by him for street-planting, but is perhaps better adapted for the cold winters and hot summers of middle Europe than for this country. The larger of two trees planted at Kew in 1880 is now $57 \mathrm{ft}$. high, and $3 \mathrm{ft}$. 3 ins. in girth; these trees are males (generally known as "P. certinensis"), and for this country appear to be preferable to the female.

\section{P. Candicans, Aiton. Balm of Gilead, Ontario Poplar. (P. ontariensis, Desfontaines.)}

This is the tree generally called balsam poplar in Britain, and much more common in gardens than the true P. balsamifera $(q . v$.$) . It is, no doubt, very$ nearly allied to that tree, and Sargent (Trees of $N$. America, p. 159) only admits it as a form. Most other authorities now regard it as a species, as did Aiton and Loudon. It has the general character of P. balsamifera, the same sucker-producing habit, balsamic resin-covered buds, and odoriferous young foliage; also the whitish under-surface of the leaf conspicuously netted over with veins. But it differs in the following respects:-its branches are more spreading than in $\mathrm{P}$. balsamifera, and it thus forms a broader, more open crown; its leaves are broader and more generally heart-shaped, more downy beneath, and ciliate ; and its leaf-stalks and young shoots are downy. It has been in cultivation since 1773 , but there is considerable doubt as to its origin, the general opinion being that it is N. American, where, however, there appears to be some difficulty in distinguishing between escapes from cultivation and genuinely indigenous specimens. The authors of the last edition of Gray's Manual of Botany put it down as "introduced, perhaps of Asiatic origin." (In this, possibly, they have in mind P. tristis-see below.) For cultivation in this country P. candicans is a better tree than P. balsamifera, but not so good as P. trichocarpa. It may often be seen in out of the way places in London suburbs producing a swarm of suckers, and scenting the air around on moist spring days. 
P. TRISTIS, Fischer, is a balsam poplar allied to the above, with similar downy shoots and leaf-stalks; the ovate or ovate-lanceolate leaves are also slightly downy beneath, but narrower in proportion to their length ; 2 to 5 ins. long, I $\frac{1}{2}$ to 3 ins. wide. Brandis, alluding to it as P. balsamifera, says it occurs in arid valleys of the inner north-western Himalaya. Probably our climate is too moist and dull for it. Although introduced in 1896, from Spath's nursery at Berlin, it has never succeeded; and although it makes vigorous growths during the summer, they are frequently cut back in winter, and it has never got beyond a few feet high. Easily increased by cuttings. The leaves of this poplar have a curious habit of hanging on the branches after they are dead.

\section{P. CANescens, Sinith. Grey POPLAR.}

A tree $100 \mathrm{ft}$. high, with a trunk $12 \mathrm{ft}$. or more in girth ; bark of the young trunk and branches yellowish grey, with horizontal, angular scars, becoming furrowed like an oak or ash with age. Both the terminal part of the young shoots and the under side of the terminal leaves are covered with white or grey felt, but much of this disappears by the fall of the leaf, and it is never abundant on the short twigs or on the lower leaves of the strong shoots, which become usually green and smooth by the end of the season. Leaves roundish on lateral twigs, much larger and ovate on strong leading shoots, the smaller ones 1 to 2 ins. long, the larger ones 3 to 4 ins. long; all with large, blunt, rounded teeth, and rounded or slightly theart-shaped at the base; stalk flattened, $\frac{1}{2}$ to 3 ins. long, carrying about the same amount of wool as that part of the shoot to which it is attached.

Native of W. Europe, including the southl of Britain, where the tree usually called abele, or white poplar, is really this species. It differs from $\mathrm{P}$. alba in the leaves being grey rather than white beneath, except when quite young, and in those at the base of the shoot becoming smooth or almost smooth by autumn; the leaf-stalks are generally much longer and more naked, and the catkins are longer. The leaves are never maple-like in form, as in $\mathrm{P}$. alba. This is a very vigorous and handsome poplar which produces suckers freely. It affords a useful timber. Some authorities regard it as a hybrid between P. alba and P. tremula, but this is extremely doubtful, seeing that it is a native of Britain, and P. alba is not.

Var. AUREO-VARIEGATA.-Leaves usually smaller than in the type, and marbled with yellow ; poor, and apt to revert to the green type.

Var. MACROPHYLLA. Picart's Poplar.-An exceptionally vigorous form of P. canescens, the leaves being often 6 ins. long on vigorous shoots. It is usually sold in nurseries as "P. alba macrophylla" and "P. Picartii."

Var. PENDULA.-Branches slender and gracefully arching or pendulous.

All the forms are easily increased by leafless cuttings.

\section{P. Eugenei, Simon-Louis.}

A tree of the largest size, believed to be a hydrid between the Lombardy poplar and $\mathrm{P}$. marilandica or $\mathrm{P}$. regenerata, but its origin is not definitely known. It is a tree of columnar habit, producing short, comparatively weak, but spreading side branches; young shoots smooth, somewhat angular. Leaves on ordinary branches 2 or 3 ins. across (considerably larger on vigorous leading shoots), broadly triangular, widely tapered to nearly straight across at the base, slender pointed; the margins set with rather coarse, incurved, gland-tipped teeth, and furnished more or less with minute hairs. It is a male tree ; catkins $2 \frac{1}{2}$ to $3 \frac{1}{2}$ ins. long; anthers red.

This fine tree originated in the nursery of Messrs Simon-Louis near Metz, about 1832 , as a seedling. The original tree still stands where it was planted 
in 1837 , and is now one of the most remarkable objects in that famous establishment. I saw it in July 1904, and $\mathrm{Mr}$ Jouin gave me its dimensions as follows :- Height, I $50 \mathrm{ft}$. ; girth of trunk at base, $38 \mathrm{ft}$; girth at $4 \mathrm{ft}$. up, $23 \mathrm{ft}$. The extraordinary vigour indicated by these figures seems to show that this tree should be tried as a timber-producing tree in this country in places where there is a demand for soft wood suitable for packing-cases, toys, etc. Even in poor soil at Kew a tree planted in 1888 is over $80 \mathrm{ft}$. high and $5 \mathrm{ft}$. in girth of trunk. It produces remarkably little brushwood in proportion to its trunk.

\section{P. Fremontil, S. Watson. Fremont's. CotTonwood.}

This is the common cottonwood of California, and of other W. United States, which does not appear to have been introduced to Britain previous to 1904. It is one of the black poplars with the characteristic compressed leaf-stalk of that group. Leaves broadly diamond-shaped, triangular, or somewhat kidney-shaped; $1 \frac{1}{2}$ to 4 ins. wide, usually less in length; the margin coarsely round-toothed, except at the short, abrupt point, and at the straight, broadly wedge-shaped or slightly heart-shaped base; stalk $1 \frac{1}{2}$ to 3 ins. long, and, like the young shoots and leaves, soon quite smooth. Catkins 2 to 4 ins. long. From the black poplars of Eastern N. America (P. monilifera and P. angulata) this appears to differ in its proportionately broader leaves without glands at the base. According to Jepson it is 40 to $90 \mathrm{ft}$. high in California, having a round-topped, massive head of branches. It appears to be quite hardy, but so far as is known has no particular value for the garden.

P. WislizeniI, Sargent, differs from P. Fremontii in having the stalks of the female flowers conspicuously longer; they are $\frac{1}{2}$ in. long, but only $\frac{1}{12}$ to $\frac{1}{8}$ in. long in P. Fremontii. Its habitat in Texas, New Mexico, etc., is soutb and east of that of P. Fremontii.

\section{P. Grandidentata, Michaux. Large-toothed Aspen.}

A tree up to 60 or $70 \mathrm{ft}$. high in a wild state, but never so high in this country; young shoots at first downy, becoming smooth and glossy later ; winter buds coated with fine down. Leaves roundish ovate, the smallest sometimes oval ; I $\frac{1}{2}$ to 5 ins. long, mostly short-pointed, and with a broadly tapered or rounded base, the margin set with large broad teeth; at first they are covered with a loose grey wool which soon falls away, leaving them dark green above; stalk I to $2 \frac{1}{2}$ ins. long, slender, compressed towards the top. Catkins $1 \frac{1}{2}$ to $2 \frac{1}{2}$ ins. long, the female ones becoming twice the length at maturity.

Native of Eastern N. America ; introduced in $\mathbf{1 7 7 2}$, according to Loudon. The tree is exceedingly rare in Britain at the present time, and does not appear to thrive well. It appears to be most closely allied to P. tremula, from which it differs in the downy young shoots and more downy winter buds. Its deep toothing distinguishes it from $P$. tremuloides. It appears to be difficult to increase by cuttings, and is usually grafted on P. canescens.

\section{P. heterophylla, Linnaus. SWAMp Cottonwood.}

A tree 40 or more $\mathrm{ft}$. ligh, young branches clothed at first with a thick felt as in P. alba, much of which falls away by late summer; winter buds slightly guminy, bright red-brown. Leaves heart-shaped, up to 7 or 8 ins. long and nearly as wide, rounded at the apex, shallowly and rather evenly toothed, covered on both surfaces when they unfold with a thick whitish down, which soon falls away from the upper surface, leaving it dark green, 
but remains longer on the lower surface, especially on the midrib and veins. The leaves hang laxly on their stalks, which are round, felted at first like the shoot, $1 \frac{1}{2}$ to $3 \frac{1}{2}$ ins. long. Male catkins 2 to $2 \frac{1}{2}$ ins. long; female catkins longer.

Native of the eastern United States; introduced in 1765 . Excepting the new Chinese P. lasiocarpa, this striking poplar has the largest leaves of any in cultivation, but unfortunately it does not thrive well with us. Loudon observes that he had not seen plants more than 5 or $6 \mathrm{ft}$. high, and to-day I know of no tree any bigger. P. angulata, which has leaves almost as large, is distinguished by its compressed leaf-stalks, leaves green on both sides, and smooth, angular shoots.

\section{P. LASIOCARPA, Oliver.}

\section{(Hooker's Icones Plantarum, t. 1943.)}

A tree 40 to $60 \mathrm{ft}$. high; young shoots very stout, downy. Leaves on adult trees 6 to 10 ins. long, 4 to 8 ins. wide ; heart-shaped, with a deep notch where the stalk joins the base, pointed, the margin regularly set with shallow, rounded, incurved, gland-tipped teeth; both surfaces are at first downy, but the upper one soon becomes quite smooth, the midrib and chief veins of a rich red; the lower surface remains downy until the fall, especially on the veins; stalk 2 to 4 ins. long, round, red like the midrib. Male catkins about 4 ins. long, $\frac{3}{4}$ in. thick, with numerous stamens; female catkins 6 or 8 ins. long when mature.

Native of Central China; discovered by Henry in 1888 , and introduced for Messrs Veitch by Wilson in 1900 . In regard to its foliage this is the most remarkable and striking of all cultivated poplars. I gathered a leaf on a small tree in the Coombe Wood nursery in October 1908, I4 ins. long by 9 ins. wide (without the stalk). The leaves do not decrease much in size as the tree grows older. The beauty of the leaf is also increased by the rich rhubarb-like red of the stalk and midrib. Wilson describes it as a shapely tree inhabiting moist woods. I doubt if the tree will succeed as well grafted as on its own roots; after a while there ought to be no difficulty in getting cuttings to take root. $\mathrm{Mr}$ Wilson told me that on one of his journeys he came to a little Chinese farm where the farmer had made an enclosure for his animals by driving stakes in the ground. These were of Populus lasiocarpa, and they had taken root and grown freely.

\section{P. LAURIFOLIA, Ledebour.}

\section{(P. balsamifera var. viminalis, Loudon.)}

A tree 40 to $70 \mathrm{ft}$. high, of spreading, lax growth, branches ultimately pendulous, with conspicuously angular, grey young shoots, downy chiefly in the grooves; winter buds covered with balsamic gum. Leaves lanceolate, narrowly oval or obovate, rounded or tapering at the base, taper-pointed, minutely and evenly toothed, the teeth gland-tipped; I to 5 ins. long, $\frac{1}{3}$ to 2 ins. wide; dark green and smooth above; slightly downy and conspicuously net-veined on a greyish ground beneath; stalk very variable in length even with leaves of the same size on the same shoot, $\frac{1}{4}$ to $1 \frac{1}{4}$ ins. long, downy. Male catkins $I \frac{1}{2}$ to 2 ins. long, at first erect, then drooping; stamens very numerous.

Native of the Altai Mountains; introduced about 1830 . This tree has never become common, and has not much to recommend it for English gardens, although a tree at Kew growing in damp clayey soil is a rather elegant pendulous-branched tree $50 \mathrm{ft}$. high: It is evidently very hardy. 
It belongs to the group of balsam poplars, with narrow leaves and angular branches.

\section{P. MARILANDICA, Bosc.}

A large tree of spreading habit, with a corrugated, not burred, trunk; young shoots smooth. Leaves smooth, triangular-ovate, inclined to diamond shape, nearly always widely tapering at the base, and with a long, slender point ; 3 to 6 ins. long, three-fourths as wide; shallowly round-toothed, teeth incurved ; glands at base none to two; stalks $I \frac{1}{2}$ to 3 ins. long, compressed. Catkins always female, ultimately 4 to 6 ins. long; stigmas two to four.

A female hybrid between nigra and probably monilifera, bearing some resemblance to $P$. serotina, but with longer points and more wedge-shaped bases to the leaves, and not so erect and straight-growing a tree-the sex also is different. There is a fine tree on the lawn near the Water-lily House at Kew, now $92 \mathrm{ft}$. high and $9 \mathrm{ft}$. 8 ins. in girth, no doubt planted there about 1843. Although handsome and imposing, it is not a perfect lawn tree, owing to the litter its cottony seeds make on the ground at seeding-time. It is one of the trees commonly known as "Canadian poplar," coming earlier into leaf than P. serotina. The ordinary young shoots are round or very slightly angled; the vigorous ones ribbed.

\section{P. Monilifera, Aiton. Necklace Poplar.}

(P. canadensis, Michaux; P. deltoidea, Marshall (in part).)

A tree up to $100 \mathrm{ft}$. high ; young shoots rounded or slightly angled, green, marked with long, light-coloured lenticels; smooth. Leaves broadly heartshaped with a long, slenderly tapered apex, the cartilaginous margins set with minute hairs and coarse, incurved, gland-tipped teeth, except at the base and apex; 3 to 5 ins. long and wide, smooth and bright green on both surfaces, but darker above; there are one or two pairs of glands at the base close to the stalk; stalk slender, smooth, $2 \frac{1}{2}$ to $3 \frac{1}{2}$ ins. long, flattened. Male catkins densely flowered, 3 to 4 ins. long ; females twice as long, stigmas three or four.

Native of Eastern N. America; introduced in I772. This tree with P. angulata $(q . v$.$) forms, in the opinion of some botanists, one species known$ as P. deltoidea. In a broad sense this may be so, but the tree cultivated as P. angulata is so distinct, that for garden purposes at least it is better to keep it apart. The true P. monilifera is now exceedingly uncommon in Britain. It hybridised many years ago with the Old World P. nigra, and has been ousted from gardens by its more vigorous progeny. Its distinguishing marks among black poplars are the ciliate margins and basal glands of the leaf, which distinguish it from P. nigra; and the round or only slightly angled young shoots and coarse teeth of the proportionately broader leaf, which distinguish it from $\mathrm{P}$. angulata.

\section{P. NIGRA, Linnceus. BLACK POPLAR.}

A tree roo $\mathrm{ft}$. or more high, with a rugged trunk 5 or $6 \mathrm{ft}$. in diameter, often forming large burrs on the surface; young shoots smooth and round; buds glutinous. Leaves variable, broadly diamond-shaped, triangular or ovate $; 2$ to $4 \frac{1}{2}$ ins. long ; some are wider than they are long, others twice as long as they are wide; usually broadly tapered, sometimes straight across at the base; broad or slender pointed; both surfaces green, quite smooth, the cartilaginous margins regularly and shallowly round-toothed; the teeth glandtipped; stalk $\frac{3}{4}$ to $2 \frac{1}{4}$ ins. long, compressed to a knife-like form. Catkins 2 to 3 ins. long; anthers deep red; stigmas two in female flowers.

Native of Europe. The true black poplar is not very frequently seen now, 
being supplanted to a great extent by hybrids which have sprung up between it and $\mathrm{P}$. monilifera or $\mathrm{P}$. angulata ; possessing a superior vigour, the latter are favoured by planters. It is not easy to distinguish it always from its hybrid progeny, but from the two American species just mentioned it is to be recognised by the absence of marginal hairs and basal glands on the leaves. The hybrids also have these characters in a greater or less degree. As a timber-producing tree, P. nigra is not equal to P. serotina and P. marilandica, which are discussed in their place, but as a tree for parks and gardens it has advantages. It is more leafy, has a more compact and shapely habit, branches more freely and finely, and it does not grow so rampantly.

Var. BETUlifolia, Torrey (P. hudsonica, Michaux). Downy Black Poplar (Bot. Mag., t. 8298).-A variety differing from the type in the young shoots, leaf-stalks, midrib, and main flower-stalk being downy. The tree, or rather its naming, has a curious history. It was first recognised by Michaux early in the nineteenth century growing on the banks of the Hudson River, near Albany, in New York State; he thereupon named it P. hudsonica. There is no doubt, however, that it is of European origin, and trees are known to have existed in England in the eighteenth century. Indeed black poplars with downy shoots, collected in England, are common in the older herbaria. This variety, like the type, produces great burrs on the trunk, and up to its middle age at least is a neat, densely branched, leafy tree, very much superior to the gaunt rampant hybrids now almost exclusively planted.

Var. ITAlicA, Duroi (var. pyramidalis, Spach; P. fastigiata, Desfontaines). Lombardy Poplar.-This well known and beautiful tree, the most valuable of all fastigiate trees, differs only from the type in its slender tapering form and quite erect branches. Nearly all the Lombardy poplars in cultivation are male, but a few female ones are known. There is one near Kew Palace over $50 \mathrm{ft}$. high, but it is not so slender as the common male tree. For this reason, and still more because it litters the ground near with its cottony tufts at seeding-time, it is much less desirable. As the Lombardy poplar is propagated only by cuttings, the female tree must be of independent origin. The male, which is occasionally 100 to $125 \mathrm{ft}$. high, is recorded to have been brought to England from Turin by Lord Rochford in 1758, and according to Loudon, one of the first importation existed at Purser's Cross in 1838 .

Var. Plantierensis, $C$. $K$. Schneider (P. plantierensis, Simon-Louis).Very similar in habit to the Lombardy poplar (scarcely so slender), this differs from it in having slightly downy twigs and leaf-stalks. For this reason it is considered to have sprung from var. betulifolia, perhaps crossed with the Lombardy. It originated at Plantières, near Metz, in the nursery of Messrs Simon-Louis, who offer it in both sexes. It grows very well, but so far as I can see has nothing to recommend it before the ordinary Lombardy poplar.

Var. Thevestina (P. Thevestina, Dode).-This appears to be a form of Lombardy poplar with a white bark, very striking as seen in Algeria, where it has been abundantly planted on the outskirts of towns, to keep bark the drifting sand. Female specimens collected in Algeria show the catkins to be $I$ to $I \frac{1}{2}$ ins. long, the leaves triangular-ovate, with a broadly wedge-shaped base, without glands; the leaf-stalks and young shoots downy. It has been introduced to Kew, and shows the fastigiate habit, but owing perhaps to reasons of climate or insufficient age, the bark does not yet show the vivid whiteness of Algerian trees.

Var. VIADRI (P. viadri, Ruediger).-A slender, rather erect form of nigra (not so much so as the Lombardy poplar). Introduced to Kew in 1893.

\section{P. SERotina, Hartig. Black Italian Poplar.}

A large tree, always male, frequently over roo $\mathrm{ft}$. high, with an open, rather gaunt habit, and extremely vigorous; young shoots smooth, green, slightly 
angled. Leaves ovate-triangular, with a broad, straight base, and a short, abrupt, slender apex; 2 to 6 ins. wide and long, regularly round-toothed, the margin cartilaginous and at first minutely hairy; one or more glands occur at the base near the stalk, which is $I \frac{1}{2}$ to $2 \frac{1}{2}$ ins. long, smooth, compressed. Catkins 3 to 4 ins. long; flower-stalks smooth; anthers rich red.

A hybrid between P. nigra and probably P. monilifera, which was introduced to Britain about the middle of the eighteenth century. It appears to have originated earlier in the century in France, where it is known as the Swiss poplar peuplier suisse), and is now the commonest of poplars in that country-also in this, where it is often known as the "Canadian poplar." It is probably the quickest growing of all trees in Great Britain that attain large size, and produces a given bulk of timber in a shorter time than any. Starting late in growth and very hardy, it is never injured by late frosts, and it possesses great value as a timber tree in localities where its wood can be disposed of, or readily converted into planks. Although too soft to be of much use for permanent work, it is valuable for the many temporary uses for which wood is needed nowadays, such as cotton reels, packing-boxes, toys, domestic utensils, etc. It is propagated very readily from cuttings not less than I $\mathrm{ft}$. long, put in the open ground after the leaves have fallen.

Var. AUREA, Henry (P. canadensis var. aurea, Van Geert).-A form with leaves very yellow in spring and early summer, becoming yellowish green later. It originated in the nursery of Van Geert at Ghent, in I87I, as a sport.

Var. ERECTA, Henry (P. monilifera var. erecta, Selys; P. canadensis var. erecta, Dippel).-A columnar or semi-fastigiate tree, resembling in other respects $\mathrm{P}$. serotina, being also a male. It originated in Belgium about 1820 .

P. REgenerata, Hort. (P. grandifolia, and the peuplier régénéré of the French), is another hybrid of the black poplar group, probably between nigra and monilifera. It originated in a nursery near Paris, in 1814 , and is a female tree with the shoots and foliage of $\mathrm{P}$. serotina. The catkins are about 3 ins. long, lengthening out by June to 6 or 8 ms. ; stigmas usually two. Leaves often broader than long, triangular, with short points and a straight cut base. It is sold in nurseries as "P. canadensis var. grandis."

\section{P. Simoni, Carrière.}

A medium-sized tree with pendulous branches and elegant habit, bursting into leaf early; young shoots smooth, prominently angled. Leaves diamondshaped or obovate, tapering about equally to both ends, sometimes more abruptly towards the apex; minutely and regularly blunt-toothed; 2 to 5 ins. long, $1 \frac{1}{4}$ to $3 \frac{1}{2}$ ins. wide ; dark green above, very pale beneath ; smooth on both sides; stalk often very short, even on the leaves of vigorous shoots, and only $\frac{1}{8}$ to $\frac{1}{3}$ in. long.

Native of N. China; introduced to the Simon-Louis nursery at Metz in 1862. As represented at Kew it is one of the balsam group breaking into leaf early, and fragrant then. Its distinguishing characters are its angular young shoots devoid of down, and the variable but often very short leaf-stalk. The original tree at Plantières, near Metz, has a trunk white almost as a birch.

\section{P. SUAVEOLENS, Fischer.}

One of the balsam poplars with a balsamic odour, especially noticeable when the young leaves are developing. It has smooth, ovate, or ovatelanceolate leaves, rounded or broadly tapered at the base, $1 \frac{1}{2}$ to $3 \frac{1}{2}$ ins. long, two-thirds as wide, finely and bluntly toothed; margins and leaf-stalk downy. Young shoots round, slightly downy. A tree up to $50 \mathrm{ft}$. high.

Native of Siberia, Manchuria, etc. It was mentioned by Loudon in $18_{3} 8$ 


\section{POPULUS}

as "the new sweet-scented poplar of the nurseries," and was stated to have been offered in Loddiges' catalogue of 1836 ; but if the tree he mentioned was the true P. suaveolens it has not made any progress in this country. It is

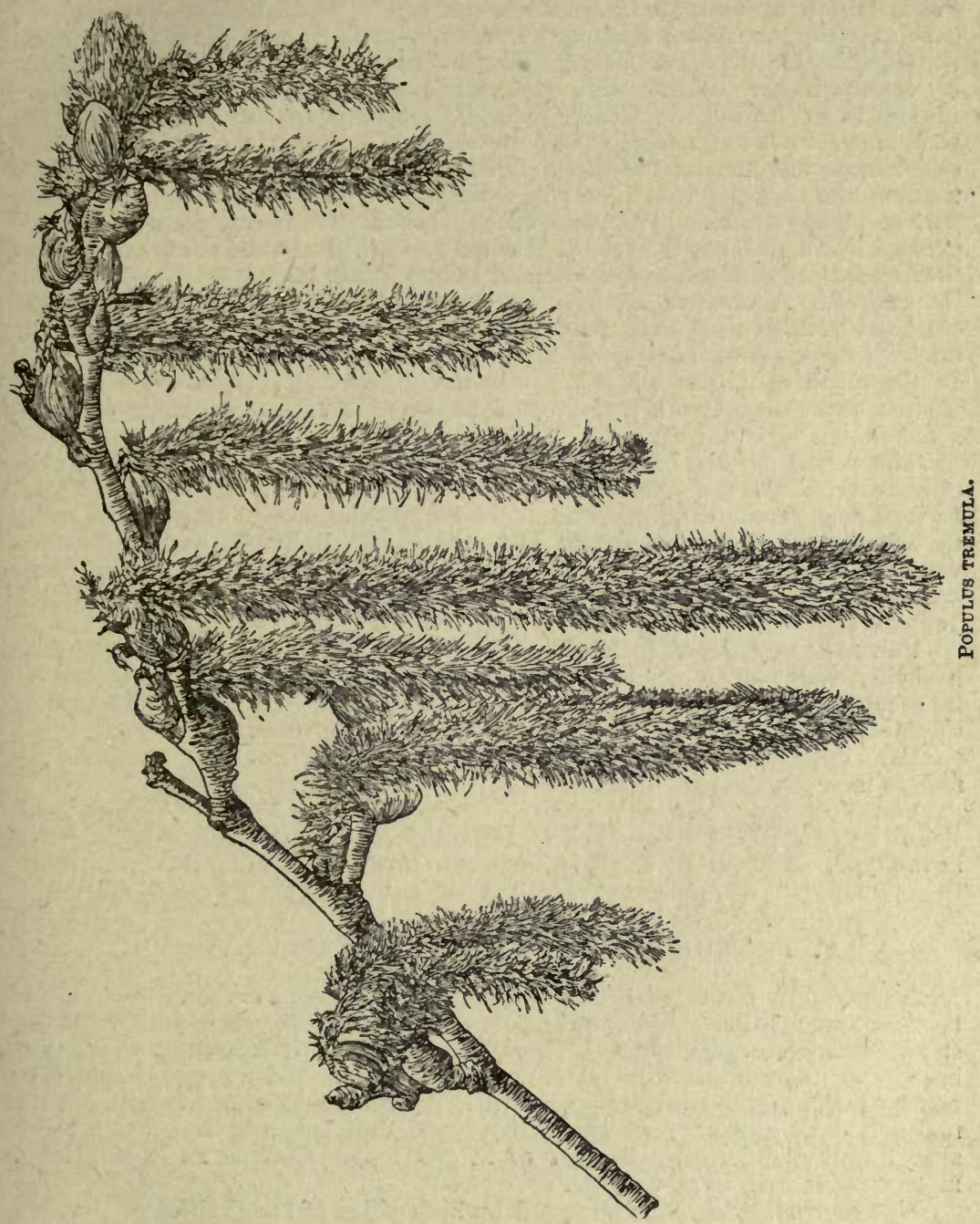

now rarely seen, although it succeeds well in the Arnold Arboretum, and in continental European nurseries.

P. TREMUla, Linnaus. Aspen.

A tree rarely more than $50 \mathrm{ft}$. high in this country; winter buds bright brown; young shoots smooth. Leaves greyish green, roundish to broadly 
ovate; from $\frac{1}{2}$ to 2 ins. wide on the short lateral twigs, as much as 4 ins. wide on vigorous long shoots ; apex pointed, base rounded or straight ; prominently toothed, the teeth being few, large (often $\frac{1}{8}$ to $\frac{1}{6}$ in. deep), blunt, and somewhat incurved; margin thickened; more or less woolly when young, becoming quite smooth by autumn, or with remains of the down beneath towards the base near the leaf-stalk ; stalk very slender, usually smooth, $\frac{1}{2}$ to $2 \frac{1}{2}$ ins. long, two-edged. On the leaves of vigorous shoots there is a pair of glands where it joins the blade. Male catkins grey, 2 to 4 ins. long, produced in February.

Native of Europe (including Britain), eastward to Asia Minor and the Caucasus. It is more common in the north of Britain than the south. The best known attribute to the aspen is the perpetual quiver of the leaf. "To tremble like an aspen leaf" is a phrase whose use goes back to Spenser's time, perhaps long before. This movement is seen in other poplars with compressed leaf-stalks, but is never so marked as in this. In the south of England the aspen does not succeed as well as in the north, but is worth planting for its interest. A curious superstition prevailed in the Scottish Highlands (perhaps does so now) that the cross on which the Saviour was crucified was made of the wood of this tree, and it was, in consequence, held in abhorrence. In the north of England it is (or was, thirty years ago) regarded by peasant women and children with a feeling of dislike akin to fear, probably owing to some similar legend.

The aspen is only likely to be confounded with two other poplars-the one, P. tremuloides, an American species distinguished by the pale yellowish bark of young trunks and main branches, and by the smaller type of leaf, being very finely and evenly toothed, and. furnished with hairs on the margin when young, but otherwise smooth; the other, P. canescens, is easily distinguished by the whitish wool on the under-surface of the leaf, and also pale bark of the young trunk.

Var. PENDULA, Loudon. Weeping Aspen.-A male form with stiff, pendulous branches, well known as a lawn tree grafted on P. canescens. It is valued for its great wealth of grey purplish catkins produced in February, and is one of the most conspicuous and beautiful of early-flowering trees.

Var. PURPUREA.-Leaves with a purplish tinge, not very marked. A female tree.

Var. villosa, Syme (P. villosa, Lang). Downy Aspen.-A form with shoots hairy until the second year. Leaves also more persistently downy than in the type. The variety does not appear to be common in cultivation.

\section{P. TRemuloides, Michaux. American Aspen.}

A tree up to roo $\mathrm{ft}$. high in a wild state, but never even half that size in this country; trunk slender, paler than in P. tremula when young; young shoots reddish brown, smooth. Leaves I to $2 \frac{1}{2}$ ins. long and wide, very broadly ovate or roundish, with a short, abrupt apex, and a broad, rounded or nearlv straight base ; very finely toothed, and furnished with fine hairs on the margin; dark glossy green above, pale and dull beneath, smooth on both sides; stalk slender, two-edged, I to $2 \frac{1}{2}$ ins. long. Catkins 2 to $2 \frac{1}{2}$ ins. long, more slender than in P. tremula.

Native of N. America, and found on both sides of the Continent. Jepson observes that it is the most widely distributed of N. American forest trees, and is the only Californian tree that reaches the Arctic Circle. It is often confused in gardens with the Old World P. tremula, from which it differs in characters pointed out under that species. According to Aiton, it was introduced in 1812, but there is some doubt as to this; a poplar grown under the name of P. græca, but identical with P. tremuloides, is said to have been cultivated in 1779 . P. tremuloides has never succeeded very well in this country. 
Var. Pendula. Parasol de St. Julien.-A pendulous variety. According to a note by M. Ferdinand Cayeux in the Garden for January 21, 1886, p. 65, it was found by a foreman in the employ of Messrs Baltet at St. Julien, near Troyes, in 1865 . It has more slender twigs than the weeping variety of P. tremula, but it is a female, and the catkins are not so striking as the male ones of the weeping aspen.

\section{P. TRICHOCARPa, Hooker. Black CotTonwoOd.}

A tree often (according to Sargent) $200 \mathrm{ft}$. high in certain parts of its habitat; young trees marked by a slender, pyramidal habit, and by peeling, ultimately smooth, yellow-grey bark; winter buds coated with fragrant balsamic gum, brown and slender; young shoots slightly angled, furnished at first with a slight down, soon nearly or quite smooth. Leaves ovate, slightly heart-shaped at the base or broadly wedge-shaped, slender-pointed, finely and shallowly toothed, very variable in size; as much as 8 or ro ins. long, and half as wide on very vigorous leading shoots, down to 2 ins. long, and $I$ in. wide on lateral twigs; dark lustrous green above, very white and conspicuously net-veined beneath, soon quite smooth on both surfaces; stalk $I$ to 2 ins. long. Male catkins 2 to $2 \frac{1}{2}$ ins. long, female ones twice as long at maturity.

Native of Western N. America, and undoubtedly the finest of the balsam poplars, if not of all poplars. It is remarkable that although distinguished sixty years ago, it was introduced to this country only about twenty years since. A tree planted on the banks of the ha-ha between Kew Gardens and the Thames, became in thirteen years $55 \mathrm{ft}$. high, and about $4 \mathrm{ft}$. in girth. A fine tree in the Dresden Botanic Garden was in 1908 about $70 \mathrm{ft}$. high and $5 \mathrm{ft}$. Io ins. in girth. In the early stages of its growth in spring, this tree fills the air around with its balsamic odour. It is the quickest grower of the balsam group, amongst which its peeling young bark distinguishes it. Easily increased by cuttings, and worth trying extensively as a timber-producing tree.

\section{POTENTILla. Cinquefoil. Rosace.}

Of this large genus the vast majority are hardy herbaceous plants, but three species are shrubby, and quite hardy in Britain. They have compound leaves, and white or yellow flowers resembling a small single rose in form. From all other hardy trees and shrubs at all allied to them these Potentillas are distinguished by the bracteolate calyx ; i.e., alternating with and outside the ordinary lobes of the calyx are five bracts, narrower and shorter than they are. The cinquefoils are nearly allied to the strawberries, but differ in having the tiny fruits (achenes) crowded on a dry, not fleshy or succulent, receptacle.

The following species like a good loamy soil with plenty of moisture. Propagation is best effected by seeds, but cuttings of late summer wood will take root, even of Salesoviana, which, however, does not root readily. All three species are useful in flowering after most shrubs are out of bloom.

\section{P. Davurica, Nestler. Dwarf Shrubby Cinquefoil.}

(P. glabra, Loddiges, Bot. Mag., t. 3676.)

A very dwarf, compact, deciduous shrub, usually below $\mathrm{I} \frac{1}{2} \mathrm{ft}$. in height, with erect stems and drooping twigs. Leaves smooth, 1 in. or less long, composed 
of five leaflets which are stalkless, oblong-obovate, $\frac{3}{8}$ to $\frac{1}{2} \mathrm{in}$. long, the three terminal ones united at the base. Flowers white, $\frac{3}{4}$ to $1 \frac{1}{4}$ ins. across, usually solitary on a slender downy stalk I in. long; petals roundish, calyx-lobes lanceolate; bracts green, obovate, or ovate.

Native of China and Siberia ; introduced by way of St Petersburg in I822. This charming little shrub from its dense close habit and very slow growth, is well adapted for the rock garden. It is much confused with white-flowered forms of $\mathrm{P}$. fruticosa, but the combination of a dwarf habit with white flowers and glabrous leaves distinguishes it well enough. The late Mr Greshoff found that the leaves yielded a principle very similar in odour to attar of roses.

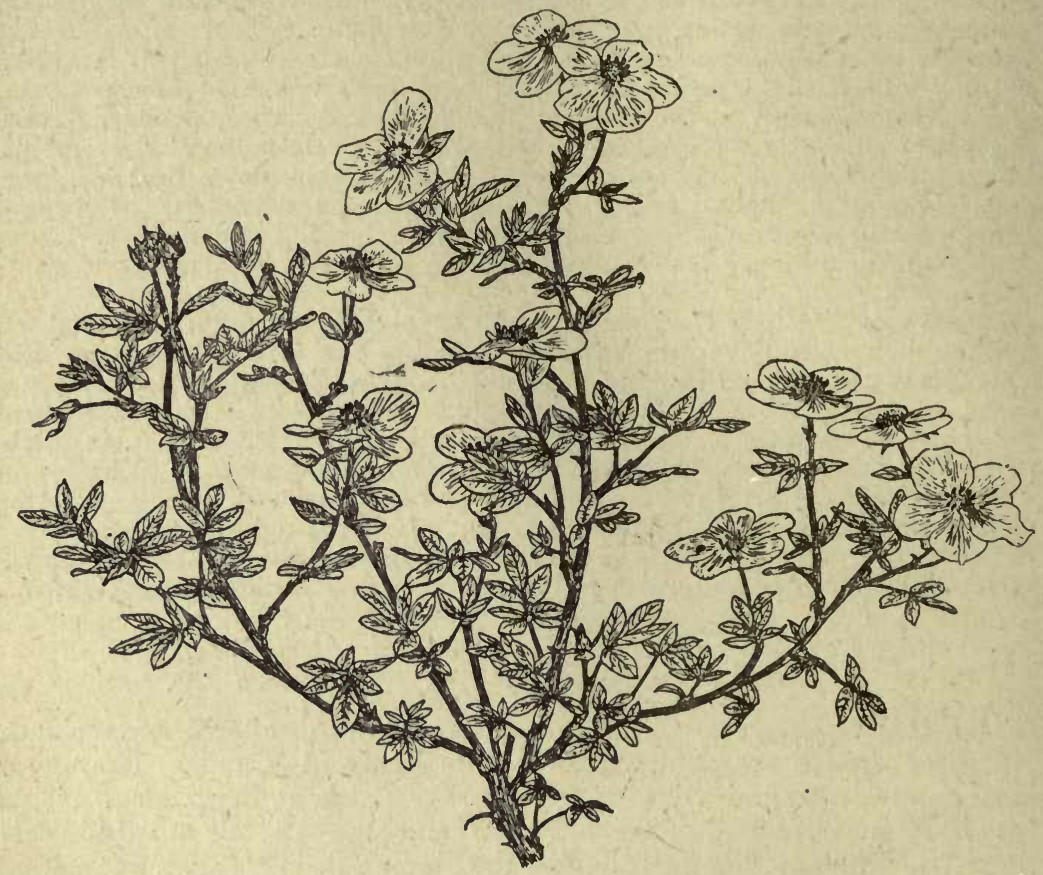

Potentilla Froticosa var. Veitchit.

\section{P. FRIEDRICHSENi, Spath.}

A reputed hybrid between $P$. fruticosa and $P$. davurica, sent out by Messrs Spath of Berlin in 1897 . It is a vigorous growing bush, and, if really a hybrid has inherited none of the dwarf, compact form of davurica. The leaves are hairy like those of $P$. fruticosa, and the shrub is perhaps even more vigorous than that species, some of the bushes at Kew being over $6 \mathrm{ft}$. high. It flowers from early June to September, the blossoms being pale yellow, or intermediate between the colours of the reputed parents. Calyx-lobes and bracts hairy.

\section{P fruticosa, Linnaus. Shrubby Cinquefoll.}

A deciduous shrub of varying height and habit, usually a rounded bush 2 to $4 \mathrm{ft}$. high, and more in diameter, with erect branches, and a bright brown, 
ultimately pecling bark, largely covered when young by the stipules. Leaves pinnate, I to $I \frac{1}{2}$ ins. long, composed generally of five leaflets, occasionally three or seven. Leaflets $\frac{1}{2}$ to $I$ in. long, $\frac{1}{8}$ to $\frac{1}{4}$ in. wide ; lanceolate, pointed, entire ; downy beneath, stalkless; the three terminal ones sometimes united at the base. Flowers bright butter-cup yellow, each $I$ to $I \frac{1}{2}$ ins. across, solitary or a few together. Calyx green, with five broad triangular lobes alternating with five narsow linear bracts, all hairy like the flower-stalk.

Native of the north of England and of the west of Ireland, and scattered over many parts of the northern hemisphere, both in the New and Old Worlds. With such an extensive habitat it naturally varies a great deal, and the following varieties may be briefly distinguished :-

Var. GRANDIFLORA, Willdenow.-Leaves and flowers larger than ordinary, the latter averaging It ins. across, yellow.

Var. LEUCANTHA, Spath.-Flowers white.

Var. MICRANDRA, Koehne.-Differs from the type in its low-spreading habit, its broader leaflets, and shorter stamens. Flowers yellow.

Var. OCHROLEUCA, S.path.-Flowers of a soft sulphur-yellow.

Var. PYRENAICA, Willdenow (P. prostrata, Lapeyrouse).-A dwarf mountain form, 6 to 18 ins. high, of close habit. Flowers yellow.

Var. TENUIFOLIA, Lehmann.-Native of Western N. America, with narrower leaflets than ordinary, also distinguished by being more hairy, and of a greyer aspect.

Var. VEITCHII (P. Veitchii, Wilson).-Leaves silky-hairy, grey-green, not silvery above, glaucous beneath; flowers white. A very fine form from Hupeh, China. Syn. P. davurica var. Veitchii, Jesson (Bot. Mag., t. 8637).

Var. VILMORINIANA.-Leaves of a marked silvery hue; flowers creamy white. The most striking of the white-flowered sorts.

In all its forms P. fruticosa is useful, because it flowers after the great bulk of hardy shrubs are past, and remains for many weeks in beauty. It commences to bloom in July, and continues until the end of September.

\section{P. Salesoviana, Stephan.}

(Bot. Mag., t. 7258.)

A deciduous shrub of lax habit, 3 to $4 \mathrm{ft}$. high, making coarse, erect, reddish growths, but little branched, silky, half covered with the large silvery stipules. Leaves pinnate, 2 to 4 ins. long; leaflets five to nine, shortly stalked, oblong, $\frac{3}{4}$ to $\mathrm{I} \frac{1}{2}$ ins. long, $\frac{1}{4}$ to $\frac{5}{8}$ in. wide, increasing in size towards the end of the leaf, with broad angular teeth; dark green and smooth above, grey-woolly beneath. Flowers rosy-tinted white, produced in June and July at the summit of a long-stalked corymb 4 to 6 ins. high, each of the three to seven flowers $\mathrm{I} \frac{1}{2}$ ins. across ; petals obovate ; calyx-lobes lanceolate, and as long as the petals, the five bracts smaller, linear, and about half as long, very downy.

Native of Siberia; introduced in 1823 . This species is very distinct from the other shrubby species in its larger, more numerous, toothed leaflets, and. in its coarser growths, which are hollow and die back considerably in winter.

\section{PRINSEPIA SINENSIS, Oliver. ROSACE E.}

(Plagiospermum sinense, Oliver; Hooker's Icon. Plant., t. I526.)

A deciduous shrub of rather lax, spreading habit, about $6 \mathrm{ft}$. high ; stems armed with solitary, stiff, short spines, from beneath which spring the leaves; pith chambered (divided into thin plates). Leaves alternate 
on the shoots of the year, oblong lanceolate; $x \frac{1}{2}$ to 3 ins. long, about $\frac{1}{2}$ in. wide; produced in clusters on the year-old shoots. Flowers borne

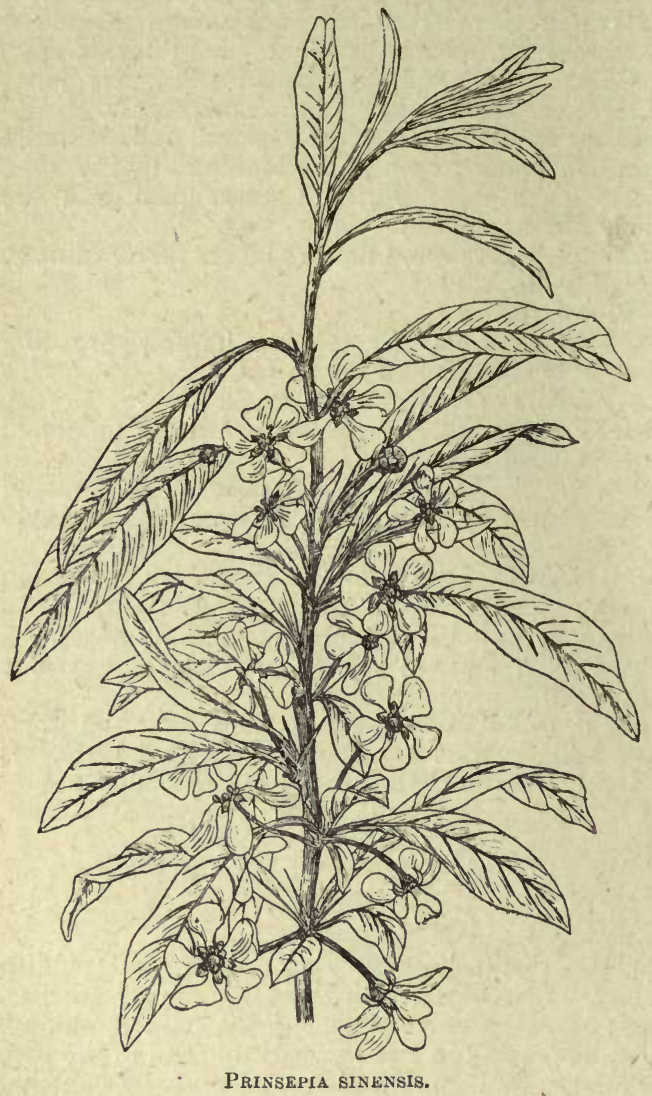
singly in the leaf-axils on slender stalks $\frac{1}{2}$ in. long; they are solitary, or two to four together; each flower $\frac{1}{2}$ to $\frac{3}{4}$ in. diameter, petals five, bright yellow, roundish, tapered to a short claw. Fruit red and juicy, $\frac{3}{5}$ in. long, ripening in August.

Native of Manchuria; first described from dried material and in the absence of fruit in 1886 as Plagiospermum, but afterwards, when fruit became available, it was found to belong to Prinsepia, a small North Asiatic genus allied to Prunus. It was introduced from France in I 908 , and appears to be hardy. Our illustration is from a German source, and should this shrub flower in this country as freely as there depicted, it should be of value in gardens. In Feb. I916 I had a spray from Glasnevin very prettily in flower.

\section{PRUMNOPITYS ElEgans, Philippi. TAXaCEA.}

\section{(Podocarpus andina, Poeppig.)}

An evergreen tree, 40 to $50 \mathrm{ft}$. high in a wild state, but in gardens as yet usually a pyramidal or rounded bush less than half as high; very dense in habit; young shoots green, quite smooth. Leaves linear, $\frac{1}{3}$ to $I \frac{1}{8}$ ins. long, $\frac{1}{16}$ to $\frac{1}{8}$ in. wide ; tapered to a short stalk at the base, bluntish or abruptly pointed at the apex; dark green above, with a dull glaucous strip each side the midrib beneath; they are densely and spirally set on the shoot (ten to fifteen to the inch), falling the third year. Male flowers in axillary and terminal panicles about $\mathrm{I}$ in. long. Fruit yellowish white, plum-like, $\frac{3}{4}$ in. long, consisting of a stone surrounded by a thin 
layer of flesh. The seed has no resinous odour, and is eaten by the Chileans. Flowers of both sexes appear on the same plant.

Native of Chile; introduced in I860 by Pearce, for Messrs Veitch. It is very closely allied to, perhaps scarcely generically distinct from, Podocarpus. It requires a sheltered spot, especially one shielded from north and east winds, and in such a position will be found quite hardy in most gardens. It thrives in either a loamy or peaty soil, enriched with a plentiful mixture of decayed leaves. Increased by cuttings made of late summer wood with a "heel." It has borne fruit in the Fota Gardens, Cork. The name, "Podocarpus andina," originally given to this plant, is often erroneously applied to Podocarpus chilina.

\section{PRUNUS. ROSACE⿸.}

There is no genus of flowering trees which contributes so much to the beauty of English gardens in March, April, and early May as Prunus. Following the now generally accepted signification of the word, not only the plums (or PRUNUS proper) are dealt with under this heading, but the almonds and peaches (AMYGDalus), apricots (ARMENIACA), cherries (CERASUS), bird cherries (PADUS), and the cherry laurels (LAUROCERASUS) also. With even this extended interpretation the genus is well distinguished by its fruit, which is always a one-celled, one-seeded drupe. The leaves are alternate, either deciduous or evergreen; the flowers white or rose-coloured, rarely yellowish; petals five, calyx five-lobed, stamens numerous.

In order to facilitate recognition of the species it will be necessary to denote the characters roughly distinguishing each section. It should be said, however, that some species (perhaps hybrids) are of uncertain position.

\section{Amygdalus. Almonds and Peaches.}

Leaves conduplicate in bud (i.e. the two halves of the leaves are folded together lengthwise like a sheet of notepaper). Flowers and fruit very shortly stalked; fruit covered with velvety down (nectarine an exception, see P. Persica): Amygdalus Davidiana, nana, orientalis, Persica, triloba.

\section{Cerasus. CherRies.}

Leaves conduplicate in bud. Flowers in clusters, racemes, or short corymbs, produced from the previous year's wood; fruit smooth, usually without bloom: acida, Avium, Biesseyi, canescens, Cerasus, emarginata, eminens, fruticosa, graca, humilis, incana, Jacquemontii, japonica, Mahaleb, Maximowiczii, microcarpa, microlepis, pendula, pennsylvanica, prostrata, pseudocerasus, pumila, rufa, Sargentii, serrulata, subhirtella, tomentosa.

PRUNUS. PLUMS.

Leaves convolute in bud (i.e. each half of the leaf is rolled inwards). Flowers solitary or in clusters of one to four (sometimes six or seven); fruit smooth, rarely downy, but often covered with a blue or purplish bloom. The American species, with the exception of $P$. subcordata are connecting links between plums and cherries, having leaves conduplicate in bud, but plum fruits: alleghaniensis, americana, angustifolia, cerasifera, Cocomilia, communis, curdica, divaricatu, hortulana, insititia, maritima, monticola, nigra, orthosepa a, spinosa, subcordata, triftora, Watsoni. (Simoni may be a hybrid between this group and Amygdalus or Armeniaca.) 


\section{ARMENIACA. APRICOTS.}

Leaves convolute in bud. Flowers and fruit very shortly stalked, fruit velvety: Armeniaca, brigantiaca, Mume, sibirica. ( $P_{0}$ dasycarpa may be a hybrid between this group and Prunus.)

\section{PADUS. BIRD CHERRIES.}

Leaves conduplicate in bud. Flowers in racemes produced on the young branches of the year: cornuta, Cuthbertii, demissa, Grayana, nepaulensis, Padus, serotina, Ssiori, virginiana. ( $P$. Maackii is intermediate between between this group and Laurocerasus, its racemes being axillary, but its leaves deciduous.)

\section{LAUROCERASUS. CHERRY LAURELS.}

Evergreen. Flowers in racemes like those of the bird cherries, but produced from the axils of the still persisting leaves of the previous year : caroliniana, ilicifolia, Laurocerasus, lusitanica.

The cultivation of Prunus generally is somewhat varied owing to the wide variety of the species composing it. Generally they are very hardy; where they are not, the fact is noted. All the deciduous species enjoy full exposure to sunlight; it is on this more than anything else that the flower crop depends. They all thrive on loamy soil, and most of them, the plums especially, are at home on limestone formations.

Many of the species, or most, can be increased by cuttings. This method of propagation is well worth trying for those that are found to be short-lived when grafted or budded. The cuttings should be made of young wood getting firm, with a "heel" attached, and put in gentle heat. Peaches and almonds are usually grafted or budded on plum stocks because of the greater hardiness of the plum. The various cherries may be worked on P. Avium, and the bird cherries on P. Padus. The laurels may be increased by cuttings.

\section{P. ACIDA, Ehrhart.}

\section{(Cerasus acida, Borkhausen.)}

A deciduous rounded bush, rarely more than 8 to $10 \mathrm{ft}$. high, with sturdy, erect branches, and smooth branchlets. Leaves oval, $\mathrm{I}_{2}^{\frac{1}{2}}$ to 3 ins. long, smooth, doubly toothed, and shining. Flowers white, $\frac{3}{4}$ in. across, produced in early May in crowded clusters. Fruit dark red, sour.

The origin of this cherry is doubtful, but it is probably East European, either cultivated or wild. It is very nearly allied to P. Cerasus ( $q . v$.$) , and by$ some authorities is not separated from it.

Var. DUMOSA. - When budded or grafted on low standards, this makes a dwarf, round-headed tree, profuse in flower, and of very slow growth. A charming tree for a small lawn, where it may stand for many years and cause no inconvenience by over-growing.

Var. SEMPERFLORENS (Cerasus semperflorens, De Candolle). All Saints Cherry. - This remarkable variety has been cultivated in gardens since the eighteenth century, but its origin is not known. It is usually grafted on standards of cherry, and thus makes a small round-headed tree, with pendent, slender branches and curiously clustered twigs, which in the leafless state render it easily distinguishable. The most interesting and attractive thing about it is its method of flowering. It bears a small crop of blossom in 
April when in ordinary leafless condition, and in ordinary clusters; it then goes out of flower until the new shoots are a few inches long (early June), when it commences to blossom again, and continues to do so until September. These second flowers, however, are produced singly from the leaf-axils, and from the ends of the young leaf-bearing shoots. This variety in reality produces during the growing season the flowers which ought normally to be (and are in other cherries) produced simultaneously the following spring. By the time the later flowers are open the earlier ones have developed fruit, which is acid, but pleasantly flavoured. An interesting and attractive lawn tree.

P. EMINENS, Beck, a pretty small tree similar to P. acida in flower, but of more open growth; is described as a hybrid between it and P. fruticosa.

\section{P. alleghaniensis, Porter. American Sloe.}

\section{(Garden and Forest, 1890, fig. 53.)}

A small deciduous tree, sometimes up to $20 \mathrm{ft}$. high, but often a shrub a few feet high ; branches erect, rigid, smooth except when quite young, ultimately almost black, the spur-like growths sometimes terminating in a spine. Leaves ovate or oval-lanceolate, pointed, finely and sharply toothed; 2 to $3 \frac{1}{2}$ ins. long, $\frac{3}{4}$ to $1 \frac{1}{4}$ ins. wide; downy on the midrib beneath; stalk $\frac{1}{4} \mathrm{in}$. long, downy, without glands. Flowers $\frac{1}{2}$ in. across, produced in April in stalkless umbellike clusters of two to five, each flower on a slender stalk $\frac{1}{4}$ to $\frac{1}{2}$ in. long ; petals rather dull white, turning pink with age; calyx funnel-shaped at the base, with ovate-oblong lobes, downy. Fruit round or slightly elongated, $\frac{1}{2}$ to $\frac{2}{3}$ in. diameter, reddish purple, covered with blue bloom.

Native of the Allegheny Mts. in Pennsylvania, where its fruits are known as sloes, and used for preserving, etc. It does not appear to have been recognised in the United States as a distinct species until 1877 , when it was named as above. First introduced in 1892 from the Arnold Arboretum to Kew, where it has grown and flowered very well, but has not fruited. It is allied to P. americana, but differs in its blue fruits.

\section{P. AMERICANA, Marshall. AMERICAN Red Plum.}

A deciduous tree, 12 to 20 , occasionally over $30 \mathrm{ft}$. high, of graceful habit, with the trunk dividing low down; branches pendulous towards the ends; young shoots smooth or slightly downy. Leaves oval or obovate, tapering abruptly to a drawn-out point ; 3 to 4 ins. long, $1 \frac{1}{4}$ to $1 \frac{3}{4}$ ins. wide ; sharply and often doubly toothed, smooth except for tufts of down along the midrib in the axils of the veins; stalk $\frac{1}{3}$ to $\frac{3}{4}$ in. long; downy and without glands. Flowers $I$ in. across, pure white, produced two to five together in stalkless umbels, each flower on a slender smooth stalk $\frac{2}{3}$ to $I$ in. long; calyx reddish, lobes entire, hairy within. Fruit round or nearly so, I in. or less in diameter, first yellow, finally bright red; flesh yellow.

Native of the United States, where it is widely spread, reaching as far west as the eastern slopes of the Rocky Mountains. It and varieties derived from it are now largely grown in the eastern United States for the fruits. It has not yet borne fruit freely in Britain, although it flowers very well. The flowers have a faint and rather unpleasant odour. It is said to be extremely handsome when loaded with its red and yellow fruits. It may be distinguished from $\mathrm{P}$. hortulana and $\mathrm{P}$. nigra by the non-glandular leafstalks, and from P. alleghaniensis by the colour of its fruits and more graceful habit. 


\section{P. Amygdalus, Stokes. Almond.}

(Amygdalus communis, Linnceus.)

A deciduous tree, 20 to $30 \mathrm{ft}$. high, erect branching when young, of bushy habit when old ; branchlets quite smooth. Leaves smooth, lanceolate, 3 to 5 ins. long, $\frac{3}{4}$ to $1 \frac{1}{2}$ ins. wide; long-pointed, margins finely toothed; stalk glandular, up to $\mathrm{I}$ in. long. Flowers I to 2 ins. across, borne in March and April, singly or in pairs from the buds of the previous summer's twigs, each on a short stalk scarcely longer than the bud-scales. Calyx bell-shaped at the base, the five lobes $\frac{1}{6}$ in. long, oblong, rounded, downy 'towards the edges; petals rosy or nearly white. Fruit $1 \frac{1}{2}$ to $2 \frac{1}{2}$ ins. long, not quite so much wide, covered with a velvety down; flesh rather dry, enclosing a smooth nut with a pitted shell.

The almond is naturalised in many countries of S. Europe and W. Asia, and it is now, perhaps, impossible to determine the original limits of its distribution; but it has been found undoubtedly wild in Algeria. The dimensions of flower and leaf in wild specimens are about half those given above. It was cultivated in Britain early in the sixteenth century, perhaps long before. Of the earliest blossoming trees it is the most beautiful, flowering in early spring when almost all other deciduous trees and shrubs are merely showing signs of reawakening growth, and providing then a delightful feast of softest colouring, which gives, perhaps, a deeper pleasure than any of the great Prunus tribe. To see the almond at its best it should be given some sunny bay with evergreens like holly or holm oak as a background. With no other backing than the cold March sky, almond flowers lose half their charm. In Britain it is propagated chiefly by budding on the plum stock, and thrives very well. Seeds or seedlings can be obtained at very cheap rates from continental nurseries, but on its own roots it is said to be less hardy and more fastidious as to soil than it is when worked on the plum. The soil need not be particularly rich, but it should be warm and well-drained. Although the almond occasionally produces good eatable nuts in England, it is never likely to be valued in gardens on that account. It is for its beauty of flower alone that it is cultivated. We can therefore ignore the numerous varieties that are grown in the south of Europe for their nuts. The following named varieties are obtainable in this country :-

Var. AMARA. Bitter Almond.-Flowers larger than ordinary, darkest in the centre, almost white towards the tips of the petals. Leaves broadest about the middle. This variety produces the nuts used so largely in confectionery, for macaroons, etc.

Var. DULCIS. Sweet Almond.-The flowers do not differ materially from those of the bitter almond, except that the style stands well out beyond the stamens. Leaves rather glaucous green, broadest close to the base. This tree produces dessert almonds.

Var. MACROCARPA.-Notable for its large fruits, 3 ins. in diameter ; flowers up to 2 ins. across.

Var. PENDULA.-Branches pendulous.

Var. PRACOX.-Flowers produced a fortnight earlier than in the type, frequently in February (also grown as var. persicoides).

\section{P. Angustifolia, Marshall. Chickasaiw Plum.}

\section{(P. chicasa, Michaux ?)}

A deciduous tree, I 5 to $20 \mathrm{ft}$. high, with smooth, lustrous, reddish young branchlets. Leaves $\mathrm{I}$ to 2 ins, long, one-third as wide; oval-lanceolate, 
pointed, sharply toothed, tapering at the base to a reddish stalk $\frac{1}{4}$ to $\frac{1}{2}$ in. long. Flowers white, $\frac{1}{2}$ in. across, in clusters of two to four ; calyx smooth outside. Fruit bright red and shining, $\frac{1}{2}$ in. across, round or nearly so.

The native country of this plum, according to Sargent, is still uncertain, but it is either native or widely naturalised in the south-eastern United States. It is the source of several varieties of plums cultivated in the Southern States. Several times introduced to Kew, it never thrives, and it is probably only adapted for the warmest parts of the British Isles, and unless it bears fruits it is scarcely ornamental enough to be worthy of cultivation there. Its close ally, P. Watsoni, is better worth growing. The P. chicasa of Michaux, usually regarded as synonymous with $\mathrm{P}$. angustifolia, is said by $\mathrm{Mr}$ Hedrick to be different.

\section{P. ArmeniacA, Linnaus. Apricot.}

(Armeniaca vulgaris, Lamarck.)

A round-headed, deciduous tree, 20 to $30 \mathrm{ft}$. high, with sturdy, tortuous branches; branchlets smooth. Leaves broadly ovate to roundish, $2 \frac{1}{2}$ to $3 \frac{1}{2}$ ins. long, $\mathrm{I} \frac{1}{2}$ to 2 ins. wide; abruptly pointed, deep lustrous green, smooth or with axil tufts beneath, evenly set with rounded teeth; stalk up to I in. long. Flowers white or pinkish, $\mathrm{I}$ in. across, produced singly on very short stalks from the previous year's wood, of ten crowded on short spur-like twigs. Fruit round, $1 \frac{1}{4}$ ins. wide in a wild state, larger under cultivation, yellow tinged with red, the nut having a thickened furrowed margin.

Native of N. China, where it was found genuinely wild by Dr Bretschneider, and raised at Kew from seeds sent by him. It is, of course, best known as a fruit tree on walls, but is quite hardy in the open, where, however, it does not bear fruit satisfactorily. The fruiting apricot is believed to have been cultivated by the Chinese many centuries anterior to the Christian era, gradually spreading westwards to Europe. It existed in English gardens early in the sixteenth century, probably long before. Flowering in March and early April, the apricot has something to recommend it, but it must be regarded as an inferior flowering tree, not in the same class as the almond and peach. The specific name refers to its supposed Armenian origin.

\section{P. Avium, Linnceus. Gean, Mazzard.}

(Cerasus sylvestris, Loudon.)

A deciduous tree up to $60 \mathrm{ft}$. or more high, with a trunk occasionally $2 \mathrm{ft}$. and upwards in diameter, the bark shining and peeling horizontally; young twigs smooth. Leaves ovate to oval with a drawn-out point ; 3 to 5 ins. long, $1 \frac{1}{2}$ to 2 ins. wide (sometimes considerably larger on vigorous young trees); rather coarsely and irregularly toothed, hairy along the veins and midrib beneath; leaf-stalk I to $\mathbf{I} \frac{3}{4}$ ins. long, with reddish glands near the blade. Flowers pure white, about $I$ in. across, produced on stalks from $I$ to $I \frac{3}{4}$ ins. long, in stalkless clusters from the previous year's shoots, and from spur-like branches of earlier date. Fruit round, blackish red, $\frac{3}{4}$ in. diameter, sweet or bitter but not acid.

Native of Europe, including Britain, and one of the parents of cultivated fruiting cherries, especially the black ones. In the woodland the gean is very desirable, and in suitable places makes a big tree ; in plantations separated from the house by a valley it might be planted in numbers for its effect in April and early. May, but in the garden itself it should give place to the improved varieties. There is a good deal of confusion in botanical works between this species and P. Cerasus and P. acida. But P. Avium differs from 
the other two in the following respects : it is a tree sometimes of full middle size (they are more or less dwarf or shrubby); the leaves are more coarsely toothed and hairy beneath; the fruit is not acid. The following varieties are the most notable of those in cultivation :-

Var. ASPLENIFOLIA.-Leaves deeply and irregularly toothed. Var. LACINIATA is the same or very similar.

Var. DECUMANA, Koch (P. macrophylla, Poiret).-A remarkable variety with large single flowers and enormous leaves, often 8 to ro ins. long, and broad in proportion.

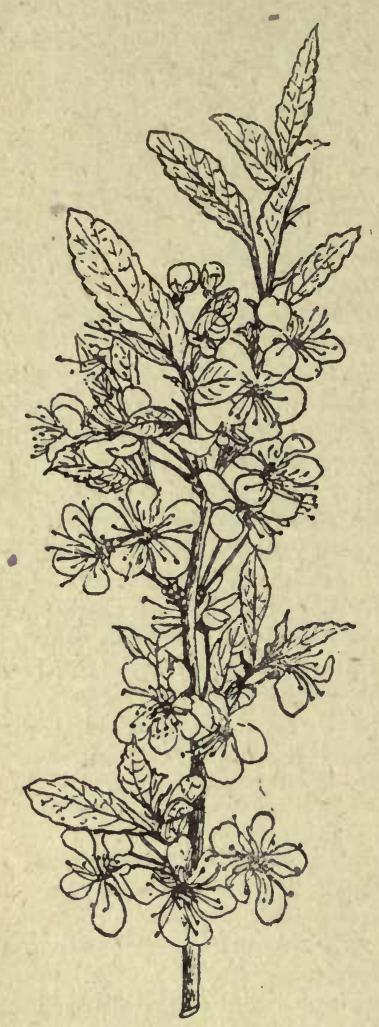

Pronus Braseyi.

Var. FLORE PLENO. - This, the most beautiful of gean cherries, and one of the most beautiful of all flowering trees, has been known perhaps for two centuries. Healthy trees never fail to flower in the utmost profusion, every branch and twig being wreathed from end to end with thick pendulous masses of the purest white blossom. Each flower is about $I \frac{1}{2}$ ins. across, and consists of, perhaps, thirty to forty petals lasting long in beauty; fruits are rarely or never formed.

Var. NANA.-A dwarf stunted form with single flowers. Useful to represent the species where space is limited.

Var. PENDULA. - Branches pendulous, but too stiffly so to be attractive.

Var. PRAMORSA.-Leaves of curious shape, with the appearance of the ends having been bitten off.

\section{P. Besseyi, Bailey. Rocky Mountain Cherry.}

$$
\text { (Bot. Mag., t. 8156.) }
$$

A dwarf deciduous shrub, 2 to $4 \mathrm{ft}$. high, with smooth branchlets. Leaves grey-green, oval or oval-lanceolate, sometimes obovate, I to $2 \frac{1}{2}$ ins. long, shallowly toothed on the upper two-thirds, smooth. Flowers in stalkless clusters of two to four from the buds of the previous year's shoots; each flower pure white, $\frac{5}{8}$ in. across, on a stalk $\frac{1}{3}$ in. long ; calyx green, with ovate, slightly toothed lobes. Fruit on more or less pendent stalks, oblong or nearly round, $\frac{3}{4} \mathrm{in}$. long, covered with a purplish bloom at first, finally black.

Native of the hot, dry plains east of the Rocky Mountains in Colorado, Nebraska, Kansas, etc., where it promises to be a valuable fruit-bearing shrub. It is remarkably prolific there, and in Colorado sixteen quarts of fruit have been gathered from a bush three years old, and eighty fruits from a branch $\mathrm{I} \mathrm{ft}$. long. It was introduced to Kew in 1900 , and has proved to be an ornamental little shrub, flowering so freely in late April or early May as to make each twig a cylindrical mass of blossom. Its fruits are only sparingly borne in England, but the species is worth the notice of fruit-growers in S. Africa, Australia, and other colonies with a dry sunny climate. P. UTAHENSIS, Koehne, is believed to be a hybrid between P. Besseyi and P. Watsoni; it 
originated as an accidental cross in the grounds of Mr J. E. Johnson, at Red River, Nebraska. Fruits blue-black. (See also P. pumila.)

\section{P. BRIGANTIACA, Villars. BRIANÇON APRICOT.}

(Armeniaca brigantiaca, Persoon.)

A small, deciduous, bushy tree, 10 to $20 \mathrm{ft}$. high, with a short trunk. Leaves ovate or oval, often slightly heart-shaped at the base, shortly and abruptly pointed, the margins doubly and rather jaggedly toothed; $1 \frac{1}{2}$ to 3 ins. long, $I$ to $2 \frac{1}{2}$ ins. wide ; hairy beneath, especially on the veins and midrib; stalk $\frac{1}{3}$ to $\frac{2}{3}$ in. long. Flowers white or pinkish, $\frac{3}{4}$ in. or so across, two or more together. Fruit like a small apricot, of a rather clear yellow, smooth.

This tree grows spontaneously in the neighbourhood of Briançon, and it is said also to occur wild in Piedmont. From the seeds the Briançonnais express an inflammable, agreeably psrfumed oil, known as huile de Marmotte. This apricot has little to recommend it for gardens.

\section{P. Canescens, D. Bois. Grey-leaved Cherry.}

A deciduous shrub of dense, rounded, bushy form, probably 6 to $8 \mathrm{ft}$. high eventually; branchlets more or less hairy. Leaves lanceolate or narrowly ovate, $I \frac{1}{2}$ to $2 \frac{1}{2}$ ins. long, $\frac{1}{2}$ to I in. wide ; coarsely and doubly toothed, the base rounded or tapering, the apex long-pointed; both surfaces, especially the lower one, furnished with persistent, soft, greyish hairs; stalk $\frac{1}{4}$ to $\frac{1}{3}$ in. long, hairy, issuing from between two leaf-like, deeply toothed, hairy stipules $\frac{1}{4}$ in. long. Flowers rosy white, scarcely $\frac{1}{2}$ in. wide, produced (each on a sparsely hairy stalk $\frac{1}{3}$ in. long) in clusters of three to five ; calyx tubular, with five triangular lobes half as long as the tube; petals soon falling. Fruit round to oblong, $\frac{1}{2}$ in. diameter, smooth, red, with a pleasant cherry-like taste.

Native of China; obtained in $189 \delta$ from the province of Szechuen by Mr Maurice de Vilmorin, and flowered at Les Barres in Igor. Introduced in 1905 to Kew, where it flowers about mid-April. It is a very distinct cherry because of the thick coat of soft hairs which covers the leaves and other younger parts of the plant, but is reduced in value as an ornamental plant by the fleeting nature of the petals. Mr Bois, the author of the name, assumes a relationship between it and $\mathrm{P}$. Maximowiczii. The latter species, however, is very distinct in its stalked racemes several inches long furnished with leaflike bracts. P. canescens is abundant in Wilson's later collectings.

\section{P. CERASIFErA, Ehrhart. Cherry Plum, Myrobalan. (Bot. Mag, t. 5934.)}

A deciduous, round-headed tree up to $30 \mathrm{ft}$. in height; young bark smooth. Leaves ovate, oval or obovate, $1 \frac{1}{2}$ to $2 \frac{1}{2}$ ins. long, I to $1 \frac{1}{4}$ ins. wide ; toothed, downy along the midrib and veins beneath. Flowers $\frac{3}{4}$ to $I$ in. across, pure white, produced usually singly, sometimes two or three together, at each bud of the previous year's shoots, but often crowded on short spur-like twigs so as to form dense clusters. Fruit smooth, red, I to $\mathbf{I}_{4}^{\frac{1}{4}}$ ins. in diameter, round, indented at the junction with the stalk.

Of doubtful origin, but thought to be a native of the Caucasus. The cherry plum is now a well-known tree in gardens, and is sometimes used as a stock for grafting. As flowering trees it and its near ally P. divaricata are the most beautiful of the true plums, being almost covered with pure white blossom in March. The fruits are developed not infrequently at Kew, but never in great quantity. They are occasionally to be seen in considerable 
quantities in July in the fruit shops of southern watering-places, having been imported from the Continent. They are used for tarts, etc., like ordinary plums. A considerable number of varieties have been put upon the market by French and German nurserymen, some of which are absolutely worthless. The best known is

Var. PISSARDI (var. atropurpurea, Dippel; P. Pissardi, Carrière).-In spring this tree, like the type, is laden with blossom, which is of a delicate rose. Its foliage, however, is its most distinctive feature; when it first expands it is of a tender ruby-red, changing later to claret colour, finally to a dull heavy purple. Its fruits, too, are purple. This variety was first noted in Persia by Mr Pissard, gardener to the Shah, and by him was sent to France in 1880 , whence it rapidly spread in cultivation, and is now a very common tree.

Var. Blireiana (P. Blireiana, André).-Foliage purple ; flowers "double," bright rose-coloured; the best variety. Var. MOSERI is another of the same type, with brightly coloured very beautiful flowers and dark purple leaves. white.

Var. ELEGANS (syn. "Louis Asselin").-Leaves narrower and edged with

\section{P. Cerasus, Linncus. Wild Dwarf Cherry.}

\section{(Cerasus vulgaris, Miller.)}

A deciduous bush or small rounded tree, suckering at the root and often making thickets in a wild state, but io to $20 \mathrm{ft}$. high under cultivation. Leaves oval or ovate, abruptly short-pointed, $\mathbf{I}_{2}^{\frac{1}{2}}$ to 3 ins. long, half to twothirds as wide ; smooth on both surfaces, rather lustrous above, the margins set with double gland-tipped teeth; stalk $\frac{1}{2}$ to $\frac{3}{4}$ in. long, usually glanded. Flowers pure white, $\frac{3}{4}$ to $\mathrm{I}$ in. across, produced in clusters, each flower on a stalk $\frac{3}{4}$ in. long. Fruit red to blackish, roundish and depressed, with soft, juicy, acid flesh.

Native of Europe, including Britain, and one of the parents of the cultivated fruit-bearing cherries-including the morellos. Some authorities have united it with $\mathrm{P}$. acida and $\mathrm{P}$. Avium as a species, but P. Cerasus produces suckers from the roots, and never makes a tall quick-growing tree like P. Avium, with its clean leader and pyramidal form when young; the leaves of $\mathrm{P}$. Cerasus are nearly or entirely without down; and, perhaps more important than all, the fruit is not sweet nor bitter, but acid, the stone round. It is much more difficult to provide distinctions between $P$. Cerasus and $\mathrm{P}$. acida, and the latter may have been derived from P. Cerasus in cultivation. It is considered to be distinguishable by its still dwarfer, more bushy form, its smaller leaves and more elongated stone.

Var. FLORE PLENO.-The typical P. Cerasus is scarcely worth a place in gardens, and its flowers are neither so beautiful nor so durable as this doubleflowered variety (often known also as "Rhexi" or "ranunculiflora"). The flowers are pure white, $\mathrm{I} \frac{1}{2}$ ins across, very "double," with stalks almost twice as long as in the type. A worthy rival of P. Avium flore pleno.

Vars. GLOBOSA and HUMILIS are dwarfed forms very useful on small areas ; flowers single.

Var. MARASCA.-A vigorous tree whose fruits are employed in the manufacture of the famous Maraschino liqueur in Dalmatia, especially about the town of Zara.

Var. MULTICARPA.-A strong-growing, large-leaved form, with longstalked single flowers, which derives its name from often having two fruits united.

Var. SALICIFOLIA.-Leaves long and narrow, 4 to 6 ins. long, about onefourth as wide, coarsely and doubly toothed. A striking variety with single flowers. 


\section{P. Cocomilia, Tenore. Naples Plum.}

A deciduous bush or small tree, with smooth shoots and oval or obovate leaves $1 \frac{1}{2}$ to 2 ins. long, $\frac{1}{2}$ to $\frac{3}{4}$ ins. wide, finely toothed, nearly or quite smooth. Flowers white, scarcely $\frac{1}{2}$ in. wide, appearing towards the end of April on short stalks, mostly in pairs. Fruit yellow, well-flavoured, of an oval or oblong form, I $\frac{1}{2}$ ins. long, scarcely $I$ in. wide, tapered at the apex. But little is known of this plum in this country. It was first described early in the nineteenth century by Tenore, an Italian botanist who made a special study of the flora about Naples, where the species grows wild in hedges, etc. The specific name has been variously spelled. The tree has little to recommend it for gardens; it rarely bears fruit in this country.

\section{P. Communis, Hudson. Wild Plum.}

\section{(P. domestica, Linnaeus (in part).)}

A deciduous tree up to 15 or $20 \mathrm{ft}$. high, or a shrub, of suckering habit, with brown, smooth, unarmed branches. Leaves elliptical or obovate, downy beneath on the midrib and veins, $I \frac{1}{2}$ to 3 ins. long, of a dull greyish green, margins set with rounded even teeth; stalk downy, glandular, about $\frac{1}{2}$ in. long. Flowers produced in April singly or in pairs, from the buds of the previous year's shoots, white, $\frac{3}{4}$ to $I$ in. across; stalks $\frac{1}{4}$ in. long, smooth. Fruit black with blue bloom, egg-shaped, I to $I_{2}^{\frac{1}{2}}$ ins. long. (See also P. insititia.)

The wild plum, although occasionally met with in hedgerows, etc., as an escape from cultivation, is not a true native of Britain. It is even doubtful if it be a native of Europe, although found in many places apparently naturalised. The plum is largely used as a stock for almonds, peaches, etc., being very hardy. It is not worth growing for ornament in gardens, at least in its typical form. An old tree in blossom is pretty, but not more so than the fruit-bearing plums commonly grown, of which it is one of the parents.

Var. FLORE PLENO has double flowers, and is more ornamental than the type. The double-flowered plum, P. PLANTIERENSIS, is of a similar character.

\section{P. Cornuta, Wallich. Himalayan Bird Cherry.}

\section{(Padus cornuta, Carrière.)}

A deciduous tree, 50 to $60 \mathrm{ft}$. high in a wild state; young shoots either finely downy or quite smooth. Leaves ovate-oblong, or somewhat obovate; 3 to 6 ins. long, $I \frac{1}{2}$ to 2 ins. wide; the base varying from heart-shaped to tapering, the apex slender-pointed, the margins finely toothed; downy along the midrib and veins beneath when young, deep dull green above, paler beneath; stalk $\frac{1}{2}$ to $I_{\frac{1}{4}}^{\frac{1}{4}}$ ins. long, mostly with glands at the top. Flowers white, densely set on cylindrical, quite smooth, or finely downy racemes, 3 to 6 ins. long, $\frac{3}{4}$ to 1 in. wide ; each flower is $\frac{1}{4}$ to $\frac{1}{3}$ in. across. Fruit round, $\frac{1}{3}$ in. in diameter, red, changing to dark brown purple. Flowers in May.

Native of the Himalaya, where it is widely spread up to $10, \infty 00 \mathrm{ft}$., and represents in that region $P$. Padus. So nearly are they allied, that many botanists regard them as forms of one species. According to travellers in the Himalaya, P. cornuta grows to considerably larger size than does P. Padus as we know it in Englind. The name cornuta (horned) refers to the shape of the fruits as often seen in the Himalaya. An insect deposits its eggs in the young fruit, and as the larvæ develop they set up irritation and cause a 
curious growth, which is from I to 2 ins. long and curled like a horn. It is analogous to the many galls that occur on our own trees-notably oaks.

In the Botanic Garden at Trinity College, Dublin, there is a very interesting downy form of P. cornuta-or it may be P. NEPAULENSIS, Steudel. This tree, now over $30 \mathrm{ft}$. high, was raised from Himalayan seed in $\mathrm{I} 88 \mathrm{I}$. The late Mr F. W. Burbidge described the young foliage to me as looking as if made of copper or bronze. The leaf-stalks are without glands, and, like the main and secondary flower-stalks, thickly covered with close down. Flowers very fragrant, and densely packed on the raceme. The glandless leaf-stalk seems to point to this tree being $P$. nepaulensis rather than cornuta, but the latter is very variable in a wild state.

\section{P. Cuthbertil, Small. \\ (Padus Cuthbertii, Small.)}

A deciduous tree up to $20 \mathrm{ft}$. high, with a trunk sometimes 6 ins. in diameter in a wild state, but shrubby in cultivation here; young shoots downy. Leaves almost smooth except for greyish hairs along the midrib beneath, obovate or oval, $\mathrm{I} \frac{1}{2}$ to $3 \frac{1}{2}$ ins. long, more than half as wide ; usually rounded or even notched at the apex, tapering at the base to a downy stalk $\frac{1}{4}$ in. long ; margins very shallowly toothed, lower teeth glandular. Flowers very small, white, produced on leafy racemes 2 to 3 ins. long, flower-stalks downy. Fruit red, roundish, $\frac{1}{4}$ in. in diameter.

Native of Central Georgia, U.S.A., where it inhabits woods. It was introduced to this country in IgOI, and, although slow-growing, has proved hardy so far. Allied to P. serotina, it differs very markedly in its round-ended leaves and downy shoots and flower-stalks. It is never likely, I think, to become so handsome a tree. Its flowers, which come in June, are not showy, but its foliage is handsome and distinct among bird cherries, and falls late.

\section{P. DASYCARPA, Ehrhart. BLACK APRICOT.}

(Armeniaca dasycarpa, Persoon.)

A deciduous tree, 12 to $20 \mathrm{ft}$. high, with purplish, smooth twigs. Leaves oval to ovate, with a rather abrupt tapering point, finely toothed, $1 \frac{1}{2}$ to $2 \frac{1}{2}$ ins. long, two-thirds as wide, downy beneath on the midrib and main veins ; leaf-stalk $\frac{3}{4}$ to I in. long, glanded. Flower $\frac{3}{4}$ in. across, pure white, produced on the naked wood in March, each on a downy stalk. Fruit round, $1 \frac{1}{2}$ ins. across, black, with purple bloom, minutely downy.

The origin of this tree is not known, but it may be a hybrid between the plum and apricot. It bears fruit only sparsely in this country, but is offered in German catalogues of fruit trees as "plum-apricot." The fruit is described as ripening in August, purple-black, covered with fine down, the flesh red, juicy, sweet, and of an apricot flavour. It would probably need wall treatment in this country to develop its fruit properly. It is worth cultivation as an early free-flowering tree.

\section{P. Davidiana, Franchet. David's PEaCh. (Persica Davidiana, Carrière.)}

A deciduous tree, probably 20 to $30 \mathrm{ft}$. high, with smooth branchlets. Leaves, 3 to 5 ins. long, I to $I \frac{1}{2}$ ins. wide ; tapering to a long fine point like the almond, finely and sharply toothed, stalk $\frac{1}{2}$ to $\frac{3}{4} \mathrm{in}$. long, with one or two glands. Flowers white, I in. across, produced singly on very short stalks 
from the buds of the previous year's shoots. Calyx smooth, with five rounded, oblong lobes. Fruit spherical, $1 \frac{1}{4}$ ins. across, yellowish, downy; flesh thin; nut pitted.

Native of China ; introduced to Paris in 1865 , by means of seeds sent by the Abbé David, who stated that the tree made a beautiful and conspicuous feature in the vicinity of Pekin. In English gardens this species is chiefly valuable for the earliness of its blossoms, which expand at any time between January and March, according to the weather, the normal time, perhaps, being about mid-February. Owing to their earliness, they are liable to injury (I have frequently seen snow resting on trees in bloom), and should be given a sheltered spot-the south-western side of a plantation of evergreens for preference. In such a position, given favourable weather the slender twigs, I to $2 \mathrm{ft}$. long, wreathed with white or, in var. RUBRA, rosy blossom, have a charming effect. Propagated by.budding on almond or plum stocks.

\section{P. Demissa, A. Dietrich. Western Choke Cherry.}

\section{(Padus demissa, Roemer.)}

A deciduous tree, rarely 30 or more $\mathrm{ft}$. high, more often a shrub; young bark smooth, strongly scented. Leaves broadly oval, 2 to 5 ins. long, half as wide, rounded or slightly heart-shaped at the base, dark green above, paler beneath, smooth on both surfaces except for a few hairs on the midrib and veins when young; stalk glandular, $\frac{1}{2}$ to $\frac{3}{4}$ in. long. Flowers in cylindrical racemes terminating short leafy shoots, 3 to 6 ins. long, each flower $\frac{1}{3}$ in. across and white. Fruit globose, shining, very dark purple or nearly black, $\frac{1}{3}$ in. diameter.

Native of Western N. America, where its fruits are made into a very palatable preserve, having a cherry flavour. It is closely allied to the East American P. virginiana, which differs in its thinner leaves and red fruits.

\section{P. DIVARICATA, Ledebour.}

(Bot. Mag., t. 65I9.)

A deciduous tree with the same habit and general aspect as P. cerasifera ; neither does it appear to differ in the flowers or foliage. The fruit, however, is smaller (about $\frac{3}{4}$ in. across), yellow, and not indented at the junction with the stalk. Probably this tree and P. cerasifera are only varieties of one species. They flower at the same time, and are not distinguishable then. There was an old specimen near the Cactus house at Kew which was probably one of the largest in the country. It was $25 \mathrm{ft}$. high, $27 \mathrm{ft}$. through, and its trunk was $3 \mathrm{ft}$. 8 ins. in girth. Quite possibly trees may be growing in various gardens as P. cerasifera. The trees at Kew have rarely borne fruits, but these are quite distinct from cherry plums. The species is said to be a native of the Caucasus, Persia, Macedonia, etc., and to have been introduced in 1822 .

\section{P. emarginata, Walpers. Patton's Cherry.}

\section{(Cerasus Pattoniana, Carrière.)}

A deciduous tree, sometimes 30 to $40 \mathrm{ft}$. high, with a trunk I $\mathrm{ft}$. or more in diameter, often a shrub; branches downy when young, becoming smooth with age; bark excessively bitter. Leaves obovate-oblong, usually rounded or blunt at the apex, tapering towards the base ; $1 \frac{1}{2}$ to $2 \frac{1}{2}$. ins. long, scarcely half as wide; finely and bluntly toothed, downy beneath; stalk about $\frac{1}{4}$ in. 
long. Flowers dullish white, not $\frac{1}{2}$ in. across, produced six to twelve together in May on corymbose clusters $1 \frac{1}{2}$ ins. long; each flower on a downy stalk $\frac{1}{4}$ to $\frac{1}{2}$ in. long; petals notched at the apex; calyx downy, lobes rounded. Fruit round, $\frac{1}{4}$ to $\frac{1}{2}$ in. diameter, red, finally almost black.

Native of Western N. America; introduced to Britain in 1865 by the British Columbia Association, and afterwards becoming known in gardens as Cerasus Pattoniana. It is a handsome tree of healthy aspect and of neat habit, but its flowers are not sufficiently pure white to be really effective. The bark, leaves, and fruit are permeated by an intensely bitter principle.

\section{P. Fruticosa, Pallas. Ground Cherry. (P. Chamæcerasus, Jacquin.)}

A deciduous shrub, I to $3 \mathrm{ft}$. high, of low, spreading habit, with smooth round twigs. Leaves obovate to narrowly oval, tapering to both ends, from $\frac{3}{4}$ to 2 ins. long, $\frac{1}{4}$ to $\frac{3}{4}$ in. wide ; with shallow, rounded teeth, dark glossy green, and quite smooth; stalk $\frac{1}{8}$ to $\frac{1}{4}$ in. long. Flowers white, $\frac{3}{4}$ in. across, produced in umbels of about four from buds on the previous year's shoots, each flower on a slender stalk $\frac{1}{2}$ to $\mathbf{I}$ in. long. Fruits about the size of a large pea, very deep reddish purple.

Native of continental Europe and parts of Siberia ; cultivated in England for more than three centuries. It is a shrub of neat and pleasing habit, forming naturally a low, mound-like mass of slender branches, and wearing a very healthy aspect because of the deep shining green of its foliage. In gardens it is rarely seen except grafted standard high on a cherry stock. In this way its branches form a mop-headed mass with the lower branches pendent of their own weight, and it is called "pendula." The fruits have a cherry flavour, but are too harsh and acid to be palatable. It blossoms in early May.

Var. VARIEGATA, has the leaves stained more or less with yellowish white, sometimes half the leaf being of this colour, the other half green.

P. REFLEXA, Hort. (not Gardner), is a cherry allied to P. fruticosa, and perhaps a hybrid between it and some form of $\mathrm{P}$. acida. It differs from $\mathrm{P}$. fruticosa in its more robust habit and sturdier branches, its more deeply and irregularly toothed leaves (of the same shining dark green), and its shorter stalked flowers. A very pretty small tree with pendulous branches.

\section{P. GRÆCA, Desfontaines.}

(Cerasus Fontanesiana, Spach.)

A deciduous, quick-growing tree, $40 \mathrm{ft}$. or more high; young shoots covered with shaggy down. Leaves ovate to oval, sometimes heart-shaped, 3 to 5 ins. long, $1 \frac{1}{2}$ to $2 \frac{1}{2}$ ins. wide ; doubly round-toothed, somewhat hairy on the midrib and veins; leaf-stalk $\frac{3}{4}$ to $I \frac{1}{4}$ ins. long, very downy, glandular. Flowers $I$ in. across, white, produced on short, broad racemes of about five to seven, sometimes ten, flowers from the buds of the previous year's wood, each flower on a stalk $\frac{1}{2}$ to $\frac{3}{4}$ in. long, the common stalk $\frac{3}{4}$ to $I$ in. long, downy. Fruit globular, the size of a small cherry, nearly black; very sparing!y borne.

This tree was originally introduced to Paris from Greece, where it is supposed to be a natural hybrid between P. Avium and P. Mahaleb. The form of the inflorescence is certainly intermediate, and the very downy shoots show P. Mahaleb. The tree has much the habit of P. Avium, and when in flower it is quite as beautiful as the typical form of that species, or even more so. 


\section{P. Grayana, Maximowicz. Gray's Bird Cherry.

\author{
(Padus Grayana, C. K. Schneider.)
}

A native of Japan, where it is a small tree 20 to $30 \mathrm{ft}$. high, with a slender trunk. This species is very closely allied to our common bird cherry (P. Padus), differing chiefly in the leaves, which have no glands on the very short stalks (almost invariably present in P. Padus), and in the teeth being finer and more hair-like. The white flowers are borne in erect racemes up to 4 ins. long. Fruit black, about the size of peas, narrowing towards the apex. The species inhabits the mountain forests of the main island of Japan, and the southern parts of Yezo. The true plant is very uncommon in cultivation.

\section{P. hortulana, Bailey. Wayland Plum.}

A deciduous tree, 20 to $30 \mathrm{ft}$. high, sometimes a shrub. Leaves ovatelanceolate, 4 to 6 ins. long, one-quarter as much wide, hairy below along the midrib and in the axils of the veins; margins set with glandular teeth. Flowers white, $\frac{3}{4}$ to $\mathbf{I}$ in. across, produced on the year-old wood in April and May in stalkless clusters of two to six ; calyx-lobes glandular, toothed. Fruit roundish, $\frac{3}{4}$ to $I$ in. in diameter, with a thick red or yellow skin.

Native of the southern and central United States; founded as a species in 1892, but known long before. It has been regarded as a hybrid between $P$. americana and P. angustifolia, but the fact that it comes true from seed is adverse to that theory. Many varieties of it are cultivated for fruits in the United States, which are especially well adapted for the Mississippi Valley and the southern states. It is unlikely that it will have any economic value in Britain.

\section{P. humilis, Bunge. Chinese DWARF Cherry.}

\section{(Bot. Mag., t. 7335 ; P. Bungei, Walpers.)}

A low-growing, deciduous shrub 4 to $5 \mathrm{ft}$. high, with downy young branchlets. Leaves oval or obovate with a tapering base, I to 2 ins. long, half as wide, almost smooth except when quite young, finely and doubly toothed ; stalk $\frac{1}{8}$ in. long; stipules $\frac{1}{4}$ in. long, linear, very glandular. Flowers pale pink, $\frac{1}{2}$ in. across ; produced singly, in pairs, or in threes from the buds of the previous year's wood, each on a stalk $\frac{1}{3}$ in. long. Fruit bright red, very acid in this country, but not unpalatable, about $\frac{1}{2}$ in. diameter.

Native of N. China ; introduced to $\mathrm{Kew}$ in $188 \mathrm{I}$ by the late $\mathrm{Dr}$. Bretschneider. This pretty dwarf cherry, which is cultivated in North China for its fruits, is perfectly hardy. Nearly allied to P. japonica, it may. be roughly distinguished by its downy shoots and its leaves being widest above the middle. From P. Jacquemontii, with which it has been confused, its downy shoots also distinguish it. P. Jacquemontii, besides, has laciniated stipules.

\section{P. ILICIFOLIA, Walpers.}

(Laurocerasus ilicifolia, Roemer.)

An evergreen shrub of compact habit ; branchlets smooth. Leaves ovate, I to 2 ins. long, $\frac{3}{4}$ to $I \frac{1}{4}$ ins. wide ; rounded or slightly heart-shaped at the base, sharply toothed, the hollows between the teeth wide and rounded, dark glossy green, smooth on both surfaces. Flowers in racemes $I_{2}^{\frac{1}{2}}$ to 3 ins. long, produced in summer; each flower $\frac{1}{3}$ in. across, white, on a stalk $\frac{1}{6}$ in. long. Fruit roundish, but slightly pointed at the end, $\frac{1}{2}$ in. diameter, changing to red, then black-purple. 
Native of California, and too tender to be of much value in any but the mildest parts of the British Isles. It has borne flowers at Kew on a wall, but even there is killed or injured by our hardest winters.

Another N. American cherry laurel, but from the east side-P. CAROLINIANA, Aiton - is equally tender. Loudon states that in 1833 there was a bush ro $\mathrm{ft}$. high at Swallowfield in Hampshire, but this is very doubtful. It was probably some form of common cherry laurel, wrongly named. P. caroliniana has entire leaves 3 to $4 \frac{1}{2}$ ins. long, oblong-lanceolate ; flowers creamy white, in short racemes; and black, shining, oblong fruit, $\frac{1}{2}$ in. long. A native of S.E. United States, where it is used, much as the common laurel is here, to make hedges. Originally introduced in 1759 , and many times since, it has never long survived, unless it be in some of the south-western counties.

\section{P. InCANA, Stevens. Willow Cherry.}

(Bot. Reg. 25, t. 58 ; Amygdalus incana, Pallas; Cerasus incana, Boissier.)

A deciduous shrub, 4 to $8 \mathrm{ft}$. high, of rather open, loose habit ; shoots minutely downy. Leaves oval-lanceolate or obovate, pointed, $1 \frac{1}{2}$ to 3 ins. long, $\frac{1}{3}$ to $\frac{7}{8}$ ins. wide ; regularly, finely, and sharply toothed, tapering towards both ends, dark green and smooth above, covered with a close white wool beneath. Flowers $\frac{1}{4}$ in. across, borne singly from the buds of the previous year's shoots ; petals deep rosy red ; calyx $\frac{1}{4}$ in. long, tubular, with"five short, rounded, downy lobes. Fruit smooth, red, $\frac{1}{3}$ in. across.

Native of S.E. Europe and Asia Minor ; introduced in 1815. Its flowers appear in April along with the young leaves, and it is then very pretty. Sometimes confused with P. nana, it is easily distinguished from that and most other species by the close white felt on the under-surface of the willowlike leaves. The fruit is quite different from that of P. nana, being cherry-like.

\section{P. INSititia, Linncus. Bullace.}

A small deciduous tree with foliage similar to that of $\mathrm{P}$. communis, but with some of its branches spiny. Fruit globular, $\frac{3}{4}$ in. diameter, black or yellow; several white-fruited varieties are grown in orchards. The bullace is a native of Britain and other parts of Europe. Being found in many hedgerows, the typical form scarcely deserves a place in the arboretum, but the double-flowered variety is more ornamental. P. spinosa, insititia, and communis are by some authorities considered as all forms of one species. It is easy enough to distinguish P. spinosa by its black bark, its small, sharply toothed leaves, and small, round, black fruits. But P. insititia and communis are more closely allied; they both have brown bark, larger and more bluntly toothed leaves, but the fruit of the bullace is round, and often white or yellow, whilst the plum is black and oval. Intermediate forms occur, of which the damson is one, having an oval, purple, sour fruit. (The damsons take their name from Damascus, where they have been cultivated since before the Christian era.) The Mirabelle group of plums, with round, yellow fruits, acid and sweet, belongs to P. insititia.

\section{P. JaCquemontil, Hooker fil. Afghan Cherry. (Bot. Mag., t. 6976; Amygdalus humilis, Edgeworth.)}

A deciduous bush up to $\mathrm{I} 2 \mathrm{ft}$. high, with smooth, slender, grey branchlets. Leaves ovate to obovate, pointed at both ends, up to $2 \frac{1}{2}$ ins. long, by $I$ in. wide ; smooth, sharply and regularly toothed; stalk $\frac{1}{4}$ in. long. Flowers one to 
three at each joint, very short-stalked, bright rosy pink, $\frac{1}{3}$ to $\frac{1}{2}$ in. diameter ; calyx funnel-shaped, $\frac{1}{5}$ in. long, with short, pointed lobes. Fruit roundish, $\frac{5}{8}$ in. long, red, juicy, containing a roundish stone $\frac{1}{4}$ in. or rather more long.

Native of the north-western Himalaya, Thibet, and Afghanistan ; introduced to Kew in 1879 by Dr Aitchison from the Kurrum Valley, where it occurs at altitudes of about $6000 \mathrm{ft}$. It has been confused with P. humilis, under the notice of which the distinctions have been pointed out. P. Jacquemontii is a pretty cherry, perfectly hardy, and makes shoots over I ft. long during a season, which are well furnished with flowers towards the end of the following April. Propagated by layers. There are bushes at Kew $12 \mathrm{ft}$. high and $12 \mathrm{ft}$. through.

\section{P. JAPONICA, Thunberg.}

(Bot. Mag., t. 8260 ; P. sinensis, Persosn, P. glandulosa, Thunberg.)

A dwarf bush of neat, rounded habit, up to 4 or $5 \mathrm{ft}$. high, with smooth branches. Leaves ovate-lanceolate, I to $2 \frac{1}{2}$ ins. long, $\frac{3}{4}$ to $I$ in. wide ; more or less drawn out at the apex, finely toothed, almost or quite smooth ; stalk $\frac{1}{4}$ in. or less long; stipules linear, with gland-tipped teeth. Flowers white or rosy, scarcely $\frac{1}{2}$ in. across, on stalks $\frac{1}{4}$ in. long, produced in April. Fruits scarcely $\frac{1}{2}$ in. in diameter, red, making a bright display when freely borne.

Var. FLORE PLENO. - The double varieties of P. japonica, of which there are two-ALBO (white) and ROSEO (pink)-provide a remarkable illustration of how much the flowers of a plant can be improved by cultivation. The typical plant in flower is a pretty but by no means striking shrub, whereas the double varieties are amongst the very élite of their class. The flowers carry numerous petals, and are I to $\mathrm{I} \frac{1}{4}$ ins. in diameter, and their stalks become $\frac{3}{4} \mathrm{in}$ or more long. The foliage too is finer, the leaves measuring 3 to 4 ins. in length by $I$ in. in width. They flower in early May, later than the type. The double varieties have been cultivated, and brought to their present perfection in China and Japan. The rosy-coloured one was growing in Lee's nursery at Hammersmith in 1774 .

The single-flowered type appears to have been cultivated in England in Loudon's time as Cerasus japonica, but it disappeared from gardens and was not reintroduced until late in the nineteenth century. It is allied to P. humilis (q.v.). The doubleflowered varieties are now very largely used for forcing early into bloom

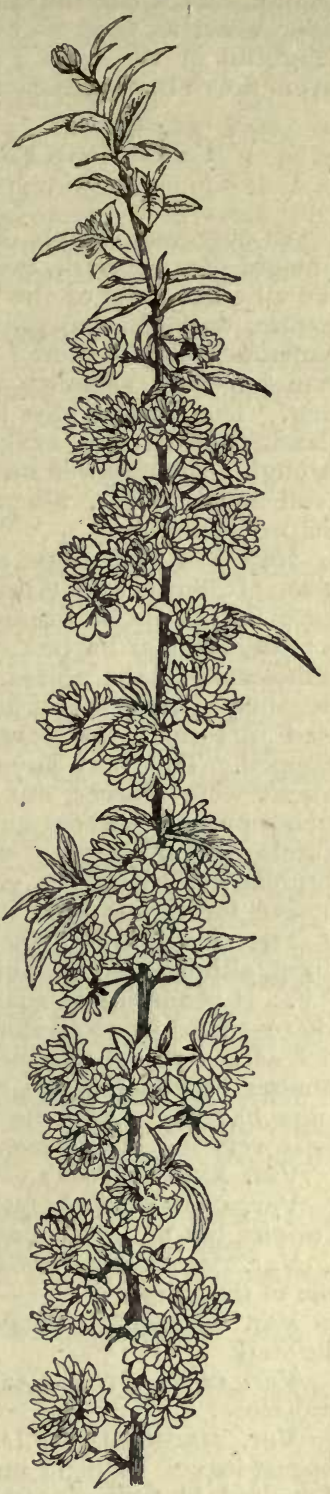

PRINCS JAPONICA vat. FLORE PLENo. 
under glass. Out-of-doors they are seen to best advantage planted against a south wall, where the flowering shoots should be pruned back almost to the older wood as soon as ever the flowers are faded. But they are also very delightful in the open ground. They can be propagated by cuttings, but layers prove more satisfactory as a rule.

\section{P. Laurocerasus, Linnceus. Cherry Laurel. (Laurocerasus officinalis, Roemer.)}

An evergreen shrub of quick growth and wide-spreading habit, attaining a height of over $20 \mathrm{ft}$., twice as much in width ; young shoots pale green and, like all other parts of the plant, devoid of hairs or down. Leaves of leathery texture, dark shining green, of various shapes and sizes, usually oblong, but sometimes oblanceolate; averaging from 4 to 6 ins. in length by rather less than one-third as much wide; margin obscurely toothed; stalk about $\frac{1}{2}$ in. long. The blade always bears on its lower surface near the base two or more glands. Flowers in axillary and terminal racemes, 3 to 5 ins. long, $\frac{3}{4}$ in. through ; each flower on a stalk $\frac{1}{6}$ in. long, itself dull white, $\frac{1}{3}$ in. across. Fruit black-purple, about $\frac{1}{2}$ in. long, conical, and containing a similarly shaped stone.

Native of E. Europe and Asia Minor; introduced, according to Aiton, in 1629. It flowers in April, nearly two months in advance of the Portugal laurel, but is not so ornamental. For some strange reason the cherry laurel is rarely seen at its best, which is when it is grown as an isolated specimen unmolested by the pruner. It then makes a vigorous evergreen of exceptional elegance. It bears pruning well, however, and is, in consequence, often used to form a low covering for banks and slopes by keeping it severely cropped. This may have been necessary in earlier times when dwarf evergreens were scarcer, but there are several now that may be made to serve such a purpose without having to undergo the periodical mutilation to which laurels are subjected. Still less is it adapted for planting in ordinary shrubberies, where its vigorous self-assertion and hungry roots give little chance for things near it.

The cherry laurel does not appear to be quite so hardy as the Portugal laurel, although on dry soil it is not much injured by any temperature above $5^{\circ} \mathrm{F}$. It is admirably adapted for planting as undergrowth in thin woodland, where there is room for its full development. All the forms are easily increased by late summer cuttings placed in gentle heat. A considerable number of varieties are now offered by nurserymen, some of garden origin, some natural. Only the most distinct of these can be mentioned, and of these very few have been authoritatively described.

Var. ANGUSTIFOLIA.-Leaves usually about 3 ins. long by $\mathbf{I}$ in. wide.

Var. CAMELLIEFOLIA.-Leaves of ordinary size, but curled and twisted. Curious, but not ornamental.

Var. CAUCASICA. - Leaves up to 7 ins. long, about 3 ins. wide, deep green ; one of the finest.

Var. COLCHICA.-Leaves up to 7 ins. long, about 2 ins. wide, tapering to the stalk.

Var. COMPACTA.-Leaves about the ordinary size, but the habit dwarf and close.

Var. MAGNOLIEFOLIA. - The finest of all the varieties in foliage, the largest leaves 10 to 12 ins. long, 3 to $4 \frac{1}{2}$ ins. wide. A strong grower, it may, if desired, be trained into tree form by tying up a lead and gradually removinsthe lower branches.

Var. OTINII.-Leaves large and broad, but not remarkable for size so much as for their dark, almost black, lustrous green; the plant is of more compact habit than most varieties. 
Var. PARVIFOLIA.-A dwarf, narrow-leaved form, the smallest leaves $I$ in. long by $\frac{1}{4}$ in. wide only, and the plant $1 \frac{1}{2}$ to $2 \mathrm{ft}$. high. It may/occasionally be seen reverting back to the typical form. Known in gardens as "Hartogia capensis."

Var. ROTUNDIFOLIA.-Leaves about half as broad as long.

Var. SCHIPKensis.-Originally found wild near the Shipka Pass, and brought into cultivation about 1886 . It has narrow, entire leaves, 2 to $4 \frac{1}{2}$ ins. long, $\frac{3}{4}$ to $\mathrm{I} \frac{1}{2}$ ins. wide, and a certain elegance of habit, but is not so ornamental as some of the larger-leaved varieties. Racemes $2 \frac{1}{2}$ to 3 ins. high. Its great value is its extreme hardiness. It will withstand winters where no cherry laurel has been known to do so before, such as N. Germany and parts of N. America.

Var. ZABELIANA is another of the same type as schipkænsis, and is equally hardy. Leaves also entire, narrow, and almost willow-like, the branches growing rather stiffly and obliquely upwards. Put into cultivation in 1898 .

\section{P. Lusitanica, Linnaus. Portugal Laúrel.}

\section{(Laurocerasus lusitanica, Roemer.)}

An evergreen shrub of wide, bushy form, usually ro to $20 \mathrm{ft}$, but occasionally 40 to $50 \mathrm{ft}$. high, more in diameter; young branches quite smooth and very dark. Leaves ovate or oval, $2 \frac{1}{2}$ to 5 ins. long, $I_{4}^{\frac{1}{4}}$ to 2 ins. wide ; quite smooth on both surfaces; very dark, glossy green above, paler below, shallowly roundish toothed. Racemes produced in June from the ends of the previous summer's shoots, and from the axils of their leaves; 6 to 10 ins. long, I to $1 \frac{1}{4}$ ins. through, more or less erect. Flowers white, $\frac{1}{3}$ to $\frac{1}{2}$ in. across, calyx cup-shaped, with shallow, rounded lobes; stalk $\frac{1}{3}$ in. long. Fruit dark purple, $\frac{1}{3}$ in. long, cone-shaped, pointed.

Native of Spain and Portugal ; introduced in 1648 (Aiton). In all but the coldest parts of Great Britain the Portugal laurel is one of the handsomest and most effective of evergreens. It should be grown as isolated specimens, especially in thinly wooded parts of the grounds. Although it is chiefly valued for the luxuriance of its rich green lustrous foliage, it has some merit as a flowering shrub, for in June it produces an extraordinary profusion of long, slender racemes, whose only defect is that the flowers are rather dull. It is hardier than the cherry laurel, and on warm, well-drained soil withstands thirty-two degrees of frost without being in the least affected.

Var. AZORICA. - The largest leaved of all the forms of Portugal laurel, the leaves being sometimes over 5 ins. long and $2 \frac{1}{2}$ ins. wide. In the Canary Islands and the Azores it becomes 60 to $70 \mathrm{ft}$. high. Introduced about 1860 by Osborn's, once famous nurserymen of Fulham.

Var. MYRTIFOLIA.-A shrub of neat, rounded habit, and of stiffer, closer growth than the type. Leaves much smaller, usually $I_{2} \frac{1}{2}$ to 2 ins. long.

Var. ORMSTONIENSIS. - Leaves dark green and leathery, of the ordinary size ; habit compact.

Var. VARIEGATA.-Leaves margined with white; more tender than the green forms.

All the forms of Portugal laurel are easily increased by late summer cuttings; the type also by seeds.

\section{P. MAACKII, Ruprecht.}

\section{(Laurocerasus Maackii, $C . K$. Schneider.)}

A Manchurian bird cherry up to 40 or more $\mathrm{ft}$. high in a wild state, very distinct through the bark of the trunk being smooth and of a striking 
brownish yellow colour, and peeling like that of a birch ; young wood downy. The leaves are ovate, rounded at the base, pointed, very finely toothed; 3 or 4 ins. long, by about half as wide ; they are hairy on the midrib and veins, and are rendered very distinct by being covered with glandular dots on the lower surface. Raceme 2 to 3 ins. long, springing from the previous season's wood; calyx-tube cylindrical, bell-shaped, the lobes glandulartoothed; petals white, not so long as the stamens.

Introduced to cultivation by way of St Petersburg in 1910; the cultivated plants already show the distinct, smooth, yellowish trunk. It is different from ordinary bird cherries in the racemes coming on the year-old wood and from the laurels in being deciduous.

\section{P. Mahaleb, Linncus. St Lucie Cherry.}

\section{(Cerasus Mahaleb, Miller.)}

A free-growing, deciduous tree up to 30 or $40 \mathrm{ft}$. high in gardens, with a loose, spreading head of branches; young twigs downy. Leaves broadly ovate or roundish, with a short, abrupt, often blunt apex, the base rounded or slightly heart-shaped, shallowly toothed; I to $2 \frac{1}{2}$ ins. long, $\frac{3}{4}$ to 2 ins. wide ; almost or quite smooth above, more or less hairy on each side of the midrib beneath, glossy green; stalk $\frac{1}{2}$ in. long, with a pair of glands. Racemes $1 \frac{1}{4}$ to 2 ins. long, carrying six to ten flowers, which are pure white, $\frac{1}{2}$ to $\frac{3}{4}$ in. across, very fragrant, each on a stalk about $\frac{1}{2}$ in. long. The racemes spring from the wood of the previous year, and are furnished towards the base with small leaf-like bracts. Fruit about $\frac{1}{4}$ in. long, somewhat egg-shaped, black.

Native of Central and S. Europe ; introduced in 17r4. It flowers in the last week of April and early May, and is then one of the most beautiful of flowering trees, filling the air with fragrance for yards around. It is fastgrowing, and if planted in very rich soil is apt to become rank and ungainly. In the sandy soil of Kew it thrives and blossoms remarkably well. Both the true Mahaleb and its varieties may be increased by cuttings made of moderately firm young wood, and placed in gentle bottom heat, also by layers. The type, raised from seed, is used as a stock for grafting cherries on.

Var. BOMмII.-A variety of pendulous habit, much more marked than that of var. pendula itself.

Var. CHRYSOCARPA (fructu-flavo).-Fruits yellow.

Var. GLOBOSA.-A dwarf, bushy form of rounded habit and slow growth, (" compacta" is the same).

Var. PENDULA.-A very beautiful tree, more graceful than the type, yet not strikingly peridulous.

There are also coloured forms, such as FOLIIS AUREIS, with leaves nore or less yellow; and VARIEGATA, which is a better tree of its class than most variegated forms of this genus, the leaves having a broad, unequal margin of yellowish white (syn. albo-marginata).

\section{P. maritima, Wangenheim. Sand Plum, Beach Plum.}

\section{(Bot. Mag., t. 8289.)}

A deciduous shrub of low, compact habit, 4 to $8 \mathrm{ft}$. high and more in diameter, with grey, downy young branchlets, becoming dark with age. Leaves oval or obovate, $1 \frac{1}{2}$ to 3 ins. long, $\frac{3}{4}$ to $I_{4}^{\frac{1}{4}}$ ins. wide ; saw-toothed, covered beneath when young with down, which becomes reduced to the midrib and veins towards the end of the season; leaf-stalk $\frac{1}{3}$ in. long, downy. Flowers white, $\frac{1}{2}$ in. across, produced in May usually in pairs or in threes at each bud on last year's shoots; on the short side spurs the flowers appear to 


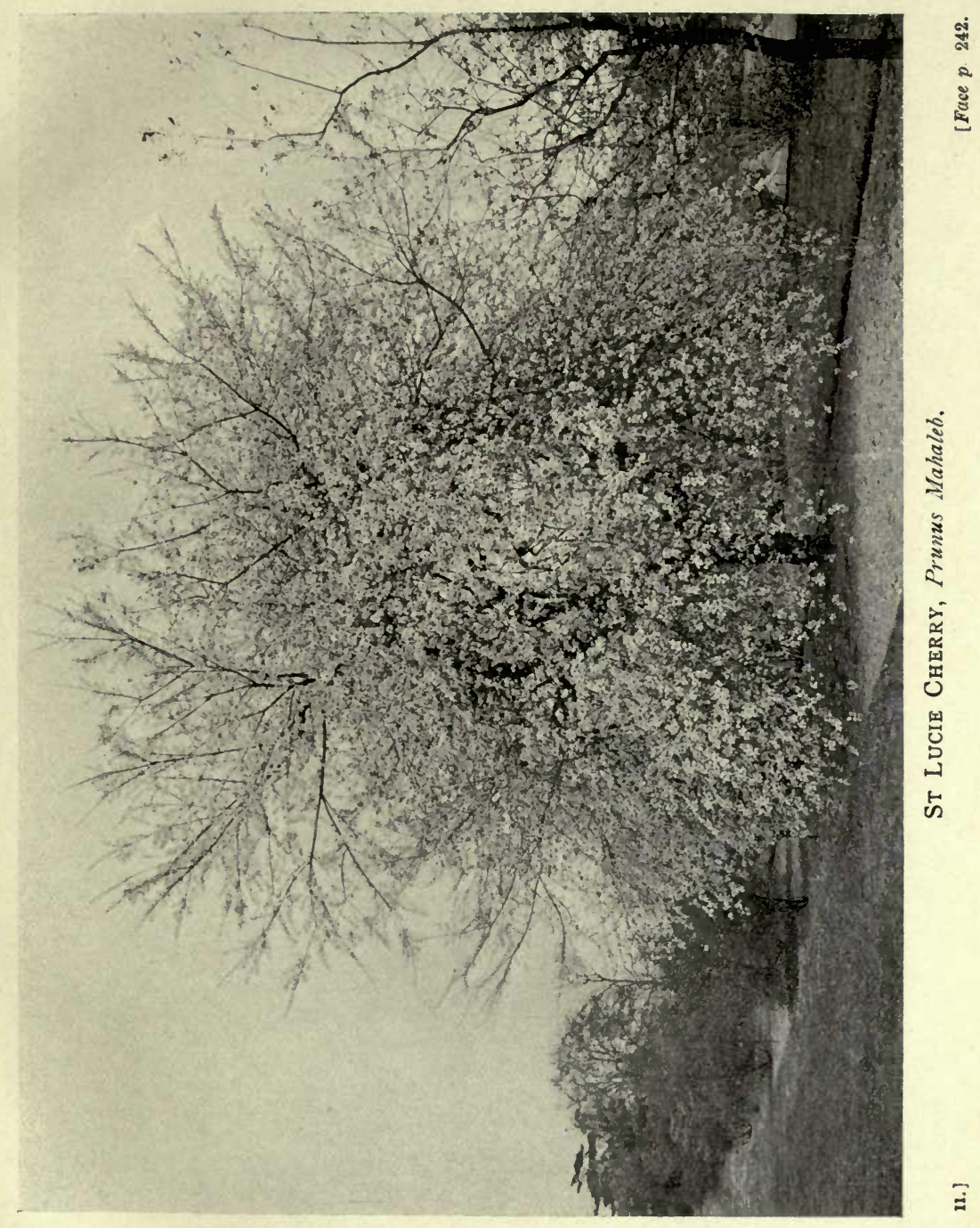



be in clusters, owing to the crowded buds; flower-stalks $\frac{1}{3}$ in. long, downy. Calyx downy, funnel-shaped, with five rounded, oblong lobes. Fruit red or purple, round or oblong, $\frac{1}{2}$ to $\mathrm{I}$ in. in diameter. A yellow-fruited variety (FRUCTU. LUTEO) is also cultivated.

Native of the eastern United States, frequently inhabiting sandy or gravelly places near the coast. Its fruits are gathered for preserving there, but they appear to vary in quality and sweetness. The flowers are borne profusely in this country, and the species is one of the most attractive of dwarf plums. Judging by its hardy, robust constitution, and by its natural habitats, it ought to succeed in exposed maritime localities in Britain.

\section{P. MaximowiczII, Ruprecht.}

\section{(Garden and Forest, vi., p. 195.)}

A deciduous tree up to 20 or $30 \mathrm{ft}$. high, with a slender trunk; branchlets downy, the down persisting through the first winter. Leaves ovate or oval, pointed, rounded to cuneate at the base; $\mathrm{I} \frac{1}{2}$ to 3 ins. long, $\frac{3}{4}$ to $1 \frac{1}{4}$ ins. wide; doubly toothed, downy on the midrib and veins beneath, and with scattered hairs above ; stalk $\frac{1}{3}$ to $\frac{1}{2}$ in. long, downy. Flowers rather dull yellowish white, about $\frac{5}{8}$ in. across, produced in mid-May on stalked racemes 2 to $3 \frac{1}{2}$ ins. long, remarkable for the large leaf-like bracts with which they are furnished; from six to ten flowers occur on a raceme, each flower on a downy stalk $\frac{1}{2}$ to $\frac{3}{4}$ in. long; calyx hairy, with pointed, toothed lobes. Fruit globose, $\frac{1}{6}$ in. wide, shining, at first red, then black; ripe in August.

Native of Corea, Manchuria, and Japan; introduced by Sargent to the United States in 1892, and by him sent to Kew in 1895. The tree is interesting and very distinct among cherries because of the conspicuous bracts on the inflorescence, which remain until the fruit is ripe; but neither in flower nor fruit is it particularly attractive as cherries go. For its autumn colouring it may prove valuable, as it turns a brilliant scarlet both in Japan and N. America. It is very hardy.

\section{P. microcarpa, C. A. Meyer.}

(Bot. Mag., t. 8360 ; Cerasus tortuosa, Boissier.)

A deciduous bush, 3 or $4 \mathrm{ft}$. high, of sturdy habit, with stiff, short-jointed branches and downy branchlets. Leaves broadly ovate, with a rounded base and acute apex, $\frac{1}{2}$ to $I$ in. long, nearly as much wide, coarsely and sharply toothed, with a few scattered hairs when young beneath; stalk $\frac{1}{6}$ to $\frac{1}{4} \mathrm{in}$. long. Flowers produced in spring in clusters of two or three, from buds and spurs of older branches, each on a downy stalk $\frac{1}{3}$ in. long; the petals are rosy pink, the calyx cylindrical and smooth. Fruit of ovate outline, nearly $\frac{1}{2}$ in. long, red or yellow.

Native of Asia Minor; introduced to Kew in 1890 . It is a pretty little shrub (a cherry) requiring the sunniest position available. In a wild state it is rather variable in the amount of down on the younger parts, in stature, and in the rigidity or otherwise of its habit. The most downy form has been distinguished under the name TORTUOSA, the pubescence being associated with a tortuous growth. Both these characters are believed to depend on climate and environment.

\section{P. SUbHiRTElla var. AUtumnalis, Makino.}

(P. microlepsis of our Ist Ed.; P. Miqueliana, Hort. (not Maximowicz).)

A deciduous, small tree; young shoots hairy. Leaves ovate to ovatelanceolate, rounded at the base, terminated by a long slender point; margins 
set with sharp, saw-like, gland-tipped teeth (some again toothed); hairy on both surfaces, glossy green above, $I \frac{1}{2}$ to $3 \frac{1}{2}$ ins. long, one-third to half as wide. Flowers fragrant, $I$ in. across, double in the cultivated form, produced in November and December, singly or two or three in a fascicle; petals faintly pink tinted, obovate, often notched at the rounded or truncate apex, up to fifteen in number; stamens white, with yellow anthers; style glabrous; calyx smooth, pale glossy green, tubular at the base, the five reflexed, ovate lobes $\frac{1}{8}$ in. long, toothed, pointed. Flower-stalk $\frac{1}{4}$ to $\frac{1}{2}$ in. long, slightly hairy towards the base.

Native of Japan; introduced by $\mathrm{Mr} \mathrm{T}$. Smith of Newry, and put in commerce about rgrr. This beautiful and interesting cherry is allied to $\mathrm{P}$. subhirtella and P. pendula, but is remarkable in commencing to open its fragrant blossoms in November. This distinguishes it from all other cultivated cherries and gives it a special value in gardens. It was first distributed as P. Miqueliana, then identified by Koehne as P. microlepis. Now Mr Wilson, after an exhaustive study of living trees in Japan, names it as above. (See Cherries of Japan, p. I2.)

\section{P. monticola, C. Koch. Mountain Plum.}

A spreading, deciduous shrub, 5 to $8 \mathrm{ft}$. high, usually more in width. Leaves oval or ovate, $\mathbf{x} \frac{1}{2}$ to 2 ins. long, $\frac{3}{4}$ to $I$ in. wide, smooth or nearly so, coarsely toothed; stalk $\frac{1}{4}$ in. long. Flowers white, $\frac{1}{2}$ in. across, borne usually in pairs from the crowded buds of short, spur-like branches; stalk smooth, slender, $\frac{1}{2}$ to $\frac{3}{4}$ in. long. Fruit a globose plum, $\frac{3}{4}$ to $\mathrm{I}$ in. across, red with an acid yellow flesh; stone ovate, compressed, over $\frac{1}{2}$ in. long.

Native of the mountains of Asia Minor and Armenia; discovered and introduced to Europe by Koch in 1843. It is an interesting, shrubby plum, allied to P. cerasifera, and flowers profusely about the middle of April.

\section{P. MUMe, Siebold. JAPANESE APRICOT.}

\section{(Armeniaca Mume, De Vriese.)}

A deciduous tree of rounded habit, 20 to $30 \mathrm{ft}$. high, with smooth, lustrous twigs. Leaves $2 \frac{1}{2}$ to 4 ins. long, roundish or broadly ovate, contracted at the end into a long tapering point, sharply and often doubly toothed, with scattered hairs on both sides, becoming smooth except about the midrib beneath; leaf-stalk $\frac{1}{2}$ to $\frac{3}{4}$ in. long. Flowers pale rose, I to $I \frac{1}{4}$ ins. across, produced singly or in pairs (each on a very short stalk) from the joints of the previous year's wood; petals broadly obovate; calyx $\frac{1}{2}$ in. across, with oblong rounded lobes. Fruit described as yellowish, globose, I to $\mathrm{I}_{4}^{\frac{1}{4}}$ ins. wide, scarcely edible; shell of nut perforated.

Native of Corea and perhaps China. It is much cultivated in Japan for ornament, and the double-flowered form was originally introduced to Europe from that country, by Messrs Baltet of Troyes, in I878. It was first distributed as "P. Myrobalana fl. pleno"-a name which still clings to it in many places. It is a true apricot, not a plum. In late years it has been imported from Japanese nurseries in quantity, and in various forms, of these the following are now in our gardens:-ALBA (white), ALBA PLENA (double white), FLORA PLENA (double rose), PENDULA (weeping). The flowers are delicately perfumed. This apricot is valuable in gardens, especially the double-flowered forms, for its early, profuse flowering, being in bloom generally about the same time as the almond, and at its best almost as beautiful. It should be given a sheltered place. It can be distinguished from the common apricot by the longer, more slender apex to the leaf. 


\section{P. NANA, Stokes. DWARF RUSSIAN AlMOND. \\ (Amygdalus nana, Linneus ; Bot. Mag., t. I6r.)}

A low, deciduous shrub of bushy form, 2 to $5 \mathrm{ft}$. high; twigs smooth. Leaves obovate or oblong, $1 \frac{1}{2}$ to $3 \frac{1}{2}$ ins. long, $\frac{1}{2}$ to 1 in. wide ; saw-toothed, dark glossy green above, pale beneath, smooth on both surfaces. Flowers one to three on each bud of the previous year's shoots, rosy red, $\frac{1}{2}$ in. long, $\frac{1}{2}$ in. or more in diameter. Fruit like a small almond, I in. long, covered with velvety down; not often produced in England.

Native of S. Russia and the other parts of S.E. Europe ; long cultivated in this country (Aiton says since 1683). It is a very pretty shrub, flowering abundantly in April, growing well on its own roots, and easily increased by layering. In spite of this it is frequently grafted on plum, and is short-lived in consequence.

Var. ALBA.-Flowers white.

Var. GEORGICA.-A taller shrub, with smaller, more glossy, and not such deeply toothed leaves.

Var. GESSLERIANA.-Flower large, $\frac{3}{4}$ in. across; the finest form of this species.

\section{P. Nigra, Aiton. Canadian Plum.}

A deciduous tree, 20 to $30 \mathrm{ft}$. high, branches erect, forming a narrow head. Leaves broadly elliptical or obovate with a long, abrupt apex, the base rounded or often slightly heart-shaped; 3 or 4 ins. long, more than half as wide ; doubly round-toothed, downy all over or only on the midrib and veins beneath; leaf-stalks $\frac{1}{2}$ in. to I in. long, with two dark glands near the top. Flowers pure white, $\mathbf{I} \frac{1}{4}$ ins. across, produced three or four together in stalkless clusters, each flower on a reddish, smooth stalk $\frac{1}{2}$ in. or more long; calyx usually smooth, reddish, with narrow-pointed glandular lobes. Fruit oval, I to $\mathrm{I} \frac{1}{4}$ ins. long, red or yellowish red, with a compressed stone $\frac{3}{4}$ in. long.

Native of Canada and the eastern United States; introduced in 1773. Flowers fragrant, produced towards the end of April, turning reddish with age. This plum has been much confused with $\mathrm{P}$. americana, from which it differs in the broader, round-toothed, more downy leaves, in the glandular leaf-stalks, larger and more fragrant flowers, and stiffer habit. It was cultivated at Kew in the eighteenth century, but has never been common.

\section{P. ORIEntalis, Walpers. Silver Almond.}

\section{(Amygdalus orientalis, Miller.)}

A deciduous shrub or small tree with whitish, downy twigs. Leaves elliptical or ovate, short-stalked, $\frac{3}{4}$ to $1 \frac{1}{2}$ ins. long, covered with a close silvery down. Flowers solitary or in pairs, $\frac{3}{4}$ in. across ; petals rose-coloured, thin, and of short duration. Fruit egg-shaped, $\frac{5}{8}$ in. long, pointed, rather compressed, covered with a close, white down.

Native of Asia Minor, chiefly Kurdistan ; introduced in 1756 . This almond is easily distinguished from all others of this genus in cultivation by the silvery leaves. It is not hardy in the open, and on a wall should be given a sunny place. In a shady position the leaves lose their whiteness, and suggest mildew rather than silveriness. It flowers very shyly in this country, and is only worth growing for the unusual aspect of its foliage.

\section{P. ORThosepala, Koehne. Texan Plum.}

A deciduous shrub or small tree, with smooth, slightly zigzag, ultimately dark brown branchlets. Leaves oval or ovate, long-pointed, sharply saw- 
toothed; $2 \frac{1}{2}$ to 3 ins. long, about $\mathrm{I}$ to $\mathrm{I} \frac{1}{2}$ ins. wide ; smooth and glossy green at maturity; leaf-stalk $\frac{1}{2}$ to $\frac{3}{4}$ in. long with a pair of glands towards the top, remaining downy longer than the blade. Flowers white, $\frac{5}{8}$ in. across, produced during the second week of May in clusters of three or four; petals narrowly obovate; calyx-lobes downy on the inner surface and margins, not toothed ; flower-stalk $\frac{1}{3}$ in. long, smooth. Fruit round, I in. across, nearly black covered with a blue bloom; flesh juicy, palatable.

Native of Texas; discovered by Engelmann in 1880 , and introduced to cultivation by him through the Arnold Arboretum. It succeeds very well at Kew, where there is a small tree II ft. high, obtained in I 896 from Spath's nursery, near Berlin. Three years previously it had been given the above name by Dr Koelnne. The American plums are not particularly effective in English gardens, but this promises to be one of the best. It is allied to $P$. hortulana, differing in its darker coloured fruit and in the absence of glands on the calyx-lobes.

\section{P. PAdus, Linnaus. Bird Cherry.}

\section{(Padus racemosa, Lamarck.)}

A deciduous tree, with strong, rather acrid smelling bark, from 30 to over $50 \mathrm{ft}$. high, of open, rather gaunt habit when young; the branchlets usually covered at first with a fine down, sometimes quite smooth. Leaves oval or obovate, 3 to 5 ins. long, $1 \frac{1}{2}$ to $2 \frac{1}{2}$ ins. wide ; pointed at the end, mostly rounded or slightly heart-shaped at the base, finely toothed, dull dark green above, smooth beneath or with tufts of down in the vein-axils beneath ; stalk smooth, with two or more glands, $\frac{1}{2}$ to $\frac{3}{4}$ in. long. Flowers fragrant, white, $\frac{1}{3}$ to $\frac{1}{2}$ in. wide, borne on drooping or spreading racemes 3 to 6 ins. long, and from $\frac{3}{4}$ to $1 \frac{1}{4}$ ins. through, which terminate short leafy shoots ; calyx with five shallow, rounded, often glandular lobes. Fruit round, $\frac{1}{4}$ in. to $\frac{1}{3}$ in. diameter, black, harsh and bitter to the taste.

Var. AUCUBÆFOLIA.-Leaves spotted after the manner of Aucuba japonica ; of little value.

Var. AUREA.-Young leaves yellowish. This form is of no particular value in regard to its leaves, which soon turn green, but it has good robust foliage and its flowers are of larger size than ordinary.

Var. commutata, Dippel.-A wild variety from Manchuria, remarkable for flowering about three weeks in advance of any other bird clierry, being usually in bloom by the middle of April. Its flowers are fully $\frac{1}{2}$ in. across. Sometimes cut by late frosts. (Garden and Forest, vol. i., fig. 47.)

Var. FLORE PLENO.-Flowers large and "double." This is the most attractive of all the varieties, and remains longer in flower than any.

Var. LEUCOCARPA.-Fruits white.

Var. PENDULA. - Branches pendulous.

Var. ROTUNDIFOLIA (P. Laucheana, Bolle). - Leaves almost as wide as long. It has been suggested that this is a hybrid between Padus and virginiana.

Var. STRICTA.-Racemes quite erect.

Var. WATERERI. - The best of the single-flowered varieties, the racemes being up to $\delta$ ins. long; leaves with conspicuous tufts of down in the axils of the veins.

The bird cherry is widely spread over the northern part of the Old World, extending in one or other of its forms from the British Isles to Japan. It is a very hardy tree, and not particular as to soil. Whilst the typical form may give place in gardens to such varieties as flore pleno and Watereri, it is itself very charming when planted in thin woodland. The named varieties are best propagated by budding on seedlings of the type in July. The tree has 
little economic value, although the timber, when available, is valued by cabinet-makers, and the fruit (according to Loudon) has been used to flavour brandy and home-made wines.

\section{P. Pendula, Maximorvicz. ROSEbud CHerRy.}

\section{(Cerasus pendula rosea, Dombrain.)}

A deciduous tree with pendulous branches, ultimately 50 to $60 \mathrm{ft}$. high in Japan, but usually under $25 \mathrm{ft}$. high in this country; branchlets hairy. Leaves $2 \frac{1}{2}$ to $3 \frac{1}{2}$ ins. long, more than one-third as wide; lanceolate, long-pointed ; sharply, often doubly-toothed, hairy beneath, especially on the midrib and veins, and above in the groove of the midrib; glandular near the base ; stalk $\frac{l}{3}$ to $\frac{1}{2}$ in. long. Flowers $\frac{3}{4}$ in. across, pale rose, produced during March in shortstalked clusters of two to seven, each flower on a downy stalk $\frac{1}{2}$ in. or more long; calyx hairy. Fruit a small, globose cherry, black and shining when ripe.

Introduced from Japan; where Sargent describes it as 50 to $60 \mathrm{ft}$. high, with wide-spreading, fountain-like heads of branches, and not uncommon in old temple gardens. Possibly it and P. subhirtella are forms of the same species, but it is not a mere pendulous sport, for it comes true from seed, and it also differs in having longer flower-stalks, and a more hairy calyx with longer-pointed lobes. In my experience it is liable to injury of leaf, shoot, and flower, by late spring frosts, and does not succeed generally so well as $\mathrm{P}$. subhirtella. Seen at its best it is one of the loveliest of all trees.

In gardens there is a tree very similar in general appearance to the above, and known as "Cerasus pendula carnea," but still distinct. It has the same pendulous branches, but the flowers are borne on longer-stalked corymbs, and there are several bracts where the flower-stalks join the common stalk; calyx nearly or quite smooth.

\section{P. Pennsylvanica, Linnceus fil. Wild Red Cherry.}

(Bot. Mag., t. 8486 ; Cerasus pennsyivanica, Loiseleur.)

A deciduous tree reaching 30 to $40 \mathrm{ft}$. in height, with a trunk $I \frac{1}{2} \mathrm{ft}$. in diameter; bark bitter, aromatic, reddish and shining on the young shoots. Leaves ovate, long-pointed; 3 to $4 \frac{1}{2}$ ins. long, $\frac{3}{4}$ to $1 \frac{1}{4}$ ins. wide ; smooth, bright green, finely toothed, the teeth much incurved and gland-tipped; stalk smooth, $\frac{1}{2}$ in. long, with one or two glands at the top. Flowers $\frac{1}{2}$ in. across, white, produced four to ten together in umbellate clusters or short racemes, each flower on a slender smooth stalk $\frac{3}{4}$ in. long; petals round, downy outside at the base; calyx smooth, with rounded lobes. Fruit round, $\frac{1}{4}$ in. diameter, red.

Native of N. America, where it is very widely spread; introduced to England in 1773. It flowers very freely in this country at the end of April and in May when the leaves are half-grown, and is very beautiful then. According to Sargent it is a short-lived tree, but plays an important part in the preservation and reproduction of $\mathrm{N}$. American forests. Its abundant seed is freely distributed by birds, and the rapidly growing young trees give valuable shelter to the other trees longer-lived than they are, which ultimately suppress them. It might be planted in thin woodland, in places where our native P. Avium thrives.

\section{P. Persica, Stokes. Peach.}

(Persica vulgaris, Miller; Amygdalus Persica, Linnaus.)

A deciduous tree, $20 \mathrm{ft}$. high, of bushy habit; branchlets smooth. Leaves lanceolate, 3 to 6 ins. long, $\frac{3}{4}$ to $1 \frac{1}{2}$ ins. wide; long-pointed, finely toothed, 
smooth ; stalk glandular, $\frac{1}{2}$ in. long. Flowers usually solitary, sometimes in pairs, produced in early April from the buds of the previous season's growth, pale rose, I to $\mathrm{I} \frac{1}{2}$ ins. across, with stalks scarcely longer than the bud-scales. Fruit fleshy, globose, clothed with velvety down, 2 to 3 ins. across, yellowish suffused with red on the sunny side, enclosing a grooved stone.

The peach is one of those fruits which have been cultivated for so long, and over so wide an area, that its place of origin is doubtful. It is generally believed to be a native of China ; it was certainly cultivated there hundreds, doubtless thousands, of years before it was known in W. Europe. Closely allied to the almond, but less robust, it differs chiefly in its fleshy, juicy fruit with a wrinkled stone; also in the thinner, shorter-stalked leaves, smaller flowers, and in flowering two or three weeks later. The flowering peaches are some of the loveliest of all trees, especially the double red varieties. They are usually propagated by budding on plum stocks, but trees so raised rarely attain to great age. Quite possibly the peach is not in any case a longlived tree, but worked on the plum it is very subject to canker and premature decay, owing to an imperfect adaptation of stock to scion. Yet it is difficult to suggest a better. On its own roots the peach succeeds in the south, but is too tender for the colder localities, and the fine double and richly coloured varieties now so popular can only be conveniently propagated by budding or grafting. Of varieties grown for fruit there are many, but with them we are not here concerned. The following, with the exception of vars. compressa and lævis, are "flowering" peaches ; the double-flowered ones often bear fruit :-

Var. COMPRESSA. Flat Peach.-Remarkable for the flattened or compressed fruits. This was known in gardens eighty years ago, and after being lost to cultivation for many years was reintroduced from China in 1906.

Var. FLORE ALBO.-Flowers white, single.

Var. FLORE ALBO PLENO.-Flowers white, double.

Var. FLORE ROSEO PLENO.-Flowers rose-coloured, double.

Var. FLORE SANGUINEO PLENO.-Flowers crimson, double. Introduced from China by Fortune.

Var. FOLIIS RUBRIS.--Leaves and fruits purplish red.

Var. LÆVIS. Nectarine.-Fruit smooth.

Var. MAGNIFICA.-Flowers crimson, double, up to $\mathbf{I} \frac{3}{4}$ ins. across; habit rather spreading and lax. (Garden, pl. 1255, Dec. 30, I899.)

Var. PENDULA.-Branches pendulous.

Var. PYRAMIDALIS.-Branches quite erect.

Double-flowered peaches have been known in European gardens for three centuries, and several others besides those mentioned are offered by nurserymen, such as "Clara Meyer," dianthiflora, camelliæflora, etc. They represent only minor variations. All the varieties like a warm soil and sheltered position, and their effect in bloom is enhanced by a background of evergreens.

\section{P. PRostrata, Labillardière. Mountaln Cherry.}

\section{(Cerasus prostrata, Loiseleur.)}

A deciduous shrub, 2 to $3 \mathrm{ft}$. high, of low, spreading habit, and measuring much more in width than it does in height. Branches slender, arching outwards and downwards, the young ones covered with a minute dark-coloured down. Leaves ovate or obovate, pointed, from I to $I_{2}^{1}$ ins. long, sharply toothed, and downy beneath (less markedly so in cultivation). Flowers $\frac{1}{2}$ to $\frac{3}{4}$ in. across, produced singly or in pairs with the young leaf-clusters from the previous season's shoots in April ; very short-stalked; petals of a lively rose colour; calyx tubular. Fruit almost stalkless, red, $\frac{1}{3}$ in. long, tapering towards the end. 
Native of the mountains of the Levant, where it usually makes a close, stunted bush, very unlike the rather free-growing plant seen in this country. It needs a sunny position, and is admirably suited on some roomy shelf in the rock garden fully exposed to the sun. In such a position, following a hot summer, it flowers profusely enough to almost hide its branches. It is perfectly hardy at Kew, and it is rather remarkable that it remains so rare and little known, seeing that it was introduced (from Mt. Lebanon) in 1802 .

\section{P. PSEUdOCERASUS, Lindley.}

The typical form of this cherry, first described in 18.26 by Lindley in vol. vi. of the Transactions of the Horticultural Society, is probably not now in cultivation. The following description is made from Lindley's type specimen now preserved in the Herbarium of Cambridge University :-Young shoots slightly hairy. Leaves broadly ovate or obovate, 2 to $4 \frac{1}{4}$ ins. long by I $\frac{1}{4}$ to $2 \frac{1}{2}$ ins. wide ; wedge-shaped or almost rounded at the base, the apex abruptly narrowed to a long point, margins doubly toothed, both surfaces, but especially the lower one, hairy on the midrib and veins; stalk $\frac{1}{4}$ to $\frac{1}{2}$ in. iong, hairy. Flowers in short racemes, sometimes reduced to a fascicle, of usually four blossoms; each flower $\frac{3}{4}$ in. across, the five petals jagged at the apex, borne on a bristly hairy stalk $\frac{1}{2}$ to $\frac{3}{4}$ in. long; calyx-tube hairy, the lobes ovate-triangular, glabrous.

Such is the plant to which Lindley first gave the name. What Lindley considered to be the same, or a slight form of it, was in 1829 figured in the Bot. Reg., t. 800, as P. paniculata, but nearly all the trees found in gardens to-day as $P$. pseudocerasus are double-flowered varieties of $P$. serrulata (q.v.). Of those that can be provisionally placed under P. pseudocerasus the best known is WATERERI, which is a tree I 5 to $20 \mathrm{ft}$. high, whose leaves when young are clothed with a dense covering of soft hairs on both surfaces; from the upper one they mostly fall away towards the end of the season, but the lower surface remains soft and velvety to the end. Flowers double, 2 ins. in diameter, white deeply tinged with rose. It may be remarked that whilst the leaves of Lindley's type are hairy only on the midrib and veins, those of Waterer's cherry are hairy all-over. I do not believe they belong to the same species. The double cherry known as SiEBOLDII also belongs here.

Although neither so vigorous nor so hardy as the forms of P. serrulata, these cherries are amongst the most beautiful of our April and May flowering trees.

\section{P. PUmila, Linncus. DWARF American Cherry.}

A deciduous shrub of variable stature, often a low bush about $2 \mathrm{ft}$. high, but sometimes a slender shrub 6 to $8 \mathrm{ft}$. high, with erect, dark branches; branchlets smooth. Leaves narrowly obovate, $1 \frac{1}{2}$ to 2 ins. long, about onethird as wide; slightly toothed towards the apex, entire at the narrowed base, greyish green. Flowers white (sometimes rather dull) about $\frac{1}{2}$ in. across, produced in stalkless umbels of two to four, each flower on a stalk $\frac{1}{3}$ to $\frac{1}{2}$ in. long. Fruit black or red, $\frac{1}{3}$ to $\frac{1}{2}$ in. diameter, without bloom, bitter.

Var. DEPRESSA (P. depressa, Pursh).-A prostrate form growing flat on the ground and scarcely rising more than 12 ins. from it.

Native of the north-eastern United States; cultivated in England in 1756. Its flowers appear in mid-May, and although small, so profusely are they borne that it is very pretty then, especially if grown in a mass, and if the whitest flowered forms are obtained, for some are much purer than others. Propagated by cuttings and layers. This species may be regarded as the 
type of a small, but very distinct group of dwarf American cherries including Besseyi, cuneata, and utahensis. P. pumila is distinguished by its leaves being broadest above the middle, and by the fruit having no bloom. It has also a more northern distribution than the others.

\section{P. RUfa, Hooker fil. Himalayan Cherry. \\ (Cerasus rufa, Wallich.)}

A deciduous tree, 15 to $20 \mathrm{ft}$. high ; young branches thickly covered with reddish brown down. Leaves from 2 to 4 ins. long ; narrowly oval or oblonglanceolate, with a long drawn-out apex, toothed, each tooth tipped with an egg-shaped gland; downy on the midrib and veins only when young; stalk $\frac{1}{2}$ in. long. Flowers pink, $\frac{1}{2}$ in. across, produced singly or a few together in clusters from the buds of the previous year's growth; calyx $\frac{1}{3}$ in. long,

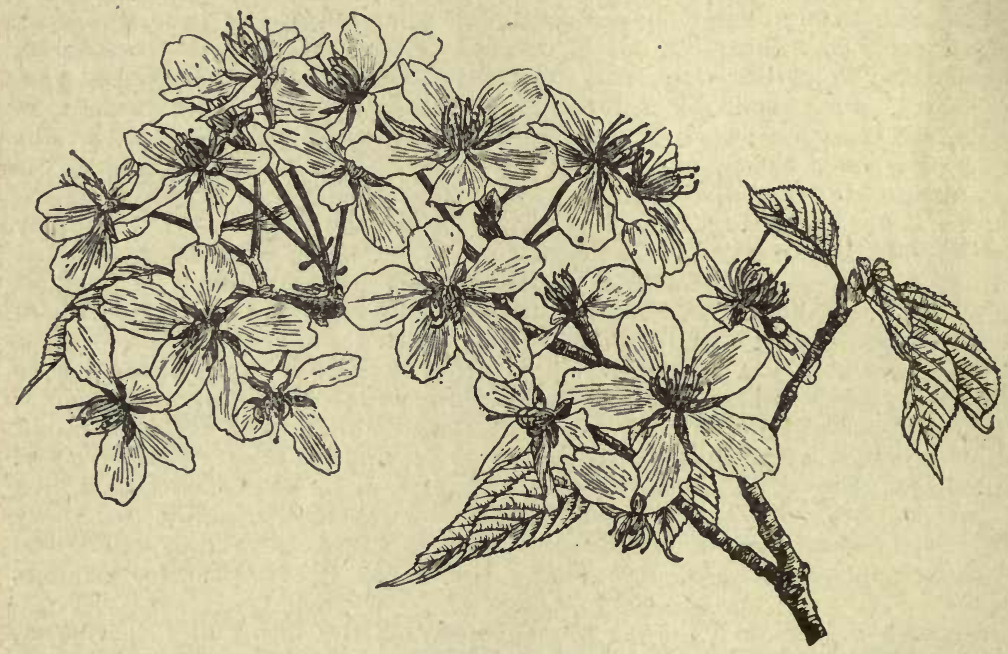

Prunus SargentiI.

funnel-shaped, with triangular, toothed lobes, hairy or smooth ; flower-stalk $\frac{1}{3}$ to $\mathbf{i}$ in. long, slightly downy. Fruit longer than wide, red, fleshy.

Native of Nepal and Sikkim, reaching to elevations of $12,000 \mathrm{ft}$. It was introduced to Kew about 1897 , and has proved quite hardy there, flowering in early May. It is distinct on account of the rusty-coloured down and the very glandular teeth of the leaves, but is not one of the most ornamental of cherries. There are two distinct forms in cultivation, one of which has a close bark on the trunk, a smooth or nearly smooth calyx, and short flowerstalk; the other has a peeling bark, shaggy calyx, and flower-stalk occasionally over $\mathrm{I}$ in. long.

\section{P. SARgentil; Rehder. SARgent's Cherry. (Bot. Mag., t. 84Ir.)}

A deciduous tree, 40 to $80 \mathrm{ft}$. high, with a trunk sometimes $3 \mathrm{ft}$. in diameter ; young shoots smooth. Leaves obovate to oval, drawn out at the apex into a 
long, slender point; rounded, sometimes slightly heart-shaped at the base, sharply toothed ; 2 to 4 ins. long, about half as wide ; quite smooth on both surfaces, often reddish when young; stalk smooth, $\frac{1}{2}$ to $\mathrm{I}$ in. long, with a pair of glands near the blade. Bracts red, oblong, $\frac{1}{2}$ in. long, edged with small glandular teeth. Flowers $\mathrm{I}_{\frac{1}{4}}$ to $\mathrm{I} \frac{1}{2}$ ins. across, of a lovely deep blush colour, produced two to six together in short-stalked umbels, each flower with a stalk I to $1 \frac{1}{4}$ ins. long; petals obovate, notched at the broad apex; calyx tubular, with five ovate, pointed lobes $\frac{1}{4}$ in. long, smooth and entire; stamens deep rose. Fruit a small black cherry, $\frac{1}{3}$ in. wide.

Native of Japan; introduced by Sargent to Kew in 1893. This splendid cherry, probably the finest of the true cherries as a timber tree, is also one of the most beautiful in its blossom. It flowers in April. In June I9Io I saw the trees first introduced to America in the Arnold Arboretum; they were then laden with an extraordinary profusion of small black cherries. The seeds germinate freely after lying dormant a year.

\section{P. SEROTINA, Ehrhart. RUM ChERRY. \\ (Padus serotina, Agardh.)}

A large deciduous tree, reaching in its most favoured situations a height of 80 to $100 \mathrm{ft}$, and occasionally found with trunks $16 \mathrm{ft}$. in circumference. In England it is usually 30 to $50 \mathrm{ft}$. high, the young bark smooth, bitter, aromatic, not unpleasant to the taste. Leaves oval-lanceolate, sometimes narrowly obovate, tapering towards both ends; 2 to $5 \frac{1}{2}$ ins. long, and from $I$ to $1 \frac{3}{4}$ ins. wide; smooth and shining above, paler beneath, and usually hairy along the midrib; margins set with shallow incurved teeth; stalk $\frac{1}{4}$ to $I$ in. long. Flowers white, $\frac{1}{3}$ in. in diameter. produced in cylindrical racemes 4 to 6 ins. long, $\frac{3}{4}$ in. in diameter. Fruit black, $\frac{1}{3}$ in. across, round, but rather flattened like an orange.

Native of $\mathrm{N}$. America, where it is widely spread, reaching from Nova Scotia to Florida, and westwards to Dakota, Texas, Arizona, etc. At its finest, which is in the Allegheny mountains of Virginia, it is probably the largest of all the Prunus tribe. In Great Britain it thrives very well, and makes a handsome middle-sized tree of graceful habit, whose dark glittering foliage in summer very much resembles that of a Portugal laurel, but it is of course deciduous, and dies off a pleasing yellow. Whilst the flowers are borne profusely, the fruits come but sparingly; in the United States the latter are used for flavouring rum and brandy, and for that purpose are said to be equal to the Morello cherry. I am not aware that this tree has been tried under forest conditions here, but its timber is much valued by cabinet-makers, and judging by its behaviour at Kew it will thrive better than many trees on sandy ground. The largest specimen there is $45 \mathrm{ft}$. high, with a trunk $5 \mathrm{ft}$. 3 ins. in girth.

Var. ASPLENIFOLIA.-Leaves deeply and irregularly cut at the margins.

Var. PENDULA. - A pretty tree with weeping branches, usually budded on tall stems of P. Padus.

Var. SALICIFOLIA, Nicholson.-Under this name a very distinct form of P. serotina is grown at Kew. It is a tree $25 \mathrm{ft}$. high, with pendulous branches, and leaves of a dark glossy green like those of the type, but narrow, and hanging loose and pendent like those of a willow. It is perfectly hardy, and occasionally bears good crops of fruit.

The rum cherry is widely spread in N. America, and one of its allies reaches through Mexico across the Isthmus of Panama as far south as the mountains of Peru. Near. Quito in Ecuador, where this tree grows on the equator, it appears to be in fruit the whole year round. This is P. SALICIFOLIA, Kunth, distinct from the variety of P. serotina so named. 


\section{P. SErrulata, Lindley. Japanese Cherry.}

(Cerasus serrulata, G. Don ; Bot. Mag., t. 8012, as P. pseudocerasus.)

A cieciduous, sparsely branched tree, usually under $20 \mathrm{ft}$. high in this country, with more or less flat, spreading branches, and quite glabrous branchlets. Leaves deep bright green, ovate to elliptical or obovate, 3 to 6 ins. long, $1 \frac{1}{4}$ to $2 \frac{3}{4}$ ins. wide ; long and taper-pointed, rounded or rather wedgeshaped at the base; quite smooth on both surfaces; the margin closely set with bristly, glandular teeth ; stalk smooth, $\frac{3}{4}$ to $\mathrm{I} \frac{1}{2}$ ins. long. Flowers white or tinged with rose, 1 to 2 ins. across, produced in April and May before, or usuaily with, the young leaves, two to five together on short-stalked corymbs ; each flower is on a stalk $\frac{3}{4}$ to $\mathrm{I} \frac{1}{2}$ ins. long, the common stalk being of about the same length; bracts obovate, fringed. Fruit a small black cherry, $\frac{1}{3}$ in. diameter, with little flesh.

Considerable doubt exists as to the real native home of this tree, and it is much confused with P. pseudocerasus. The single-flowered type is not certainly known, and in its double form it has for ages been cultivated by the Japanese, by whom its blossoming is made the occasion of a national festival. It is probably a native of $\mathrm{N}$. China. The original specimen described by Lindley in 1830 (Transactions of the Horticultural Society, vol. vii., p. 238), and preserved in the Herbarium of Cambridge University, has no flowers, but after seeing it, I believe there is no doubt that it is the tree with flat spreading branches studded with short stunted spurs, and white flowers about $\mathrm{I}$ in. across, commonly grown in gardens as Cerasus serrulata. Of this there is a tree $30 \mathrm{ft}$. across, but only $10 \mathrm{ft}$. high, at Kew. The following varieties are usually put under P. pseudocerasus in gardens, but there is no character to differentiate them from P. serrulata of Lindley except the colouring and larger size of the flowers. In the Botanical Magazine, t. 8012, and in the Gardeners' Chronicle, May 17,1890 , is figured a form of this cherry which has single flowers, and bears the small black cherry described above. It was originally imported from a Tokyo nursery, and probably no more represents the wild type of this cherry than do the common double ones in cultivation. P. pseudocerasus (q.v.) although nearly' allied, is always to be recognised in any of its forms by the hairy leaves and flower-stalks. Numerous Japanese forms have been imported in recent times under native or other names, differing from each other too slightly to be differentiated here. They are all beautiful, and along with the four following representative forms may be described as certainly amongst the most lovely of all flowering trees :-

Var. FLORE PLENO.-Flowers very double, pale rose, $1 \frac{1}{2}$ to 2 ins. across.

Var. FLORE LUTEO PLENO.-Flowers double, $1 \frac{1}{2}$ to 2 ins. across, greenish yellow ; a distinct and rather curious form.

Var. PENDULA.-A form recently introduced, with pendent branches and double pink flowers. "Benifugen" and "Hísakura" are two Japanese names given to forms with flowers sometimes well over 2 ins. across. "Osaka" is another, with white, semi-double flowers produced in mid-May in drooping corymbs, the main stalk of which is 4 to 6 ins. long ; distinct.

Var. Veitchiana.-Perhaps the finest of Japanese cherries. Flowers 2 ins. across, deep rose-pink. . Leaves bronze-coloured when young. This is a cultivated variety found by the late Mr James $H$. Veitch in a nursery in Tokyo in 1892 .

All the forms of this cherry are worth cultivating. Their time of flowering extends from mid-April to mid-May. Whilst there is scarcely any position in which their charms are not insistent, it is as lawn trees, either singly or a few together, with some dark evergreen not far behind, that the Japanese cherries are seen at their best. They should be provided with a good loamy soil and a sunny position. 


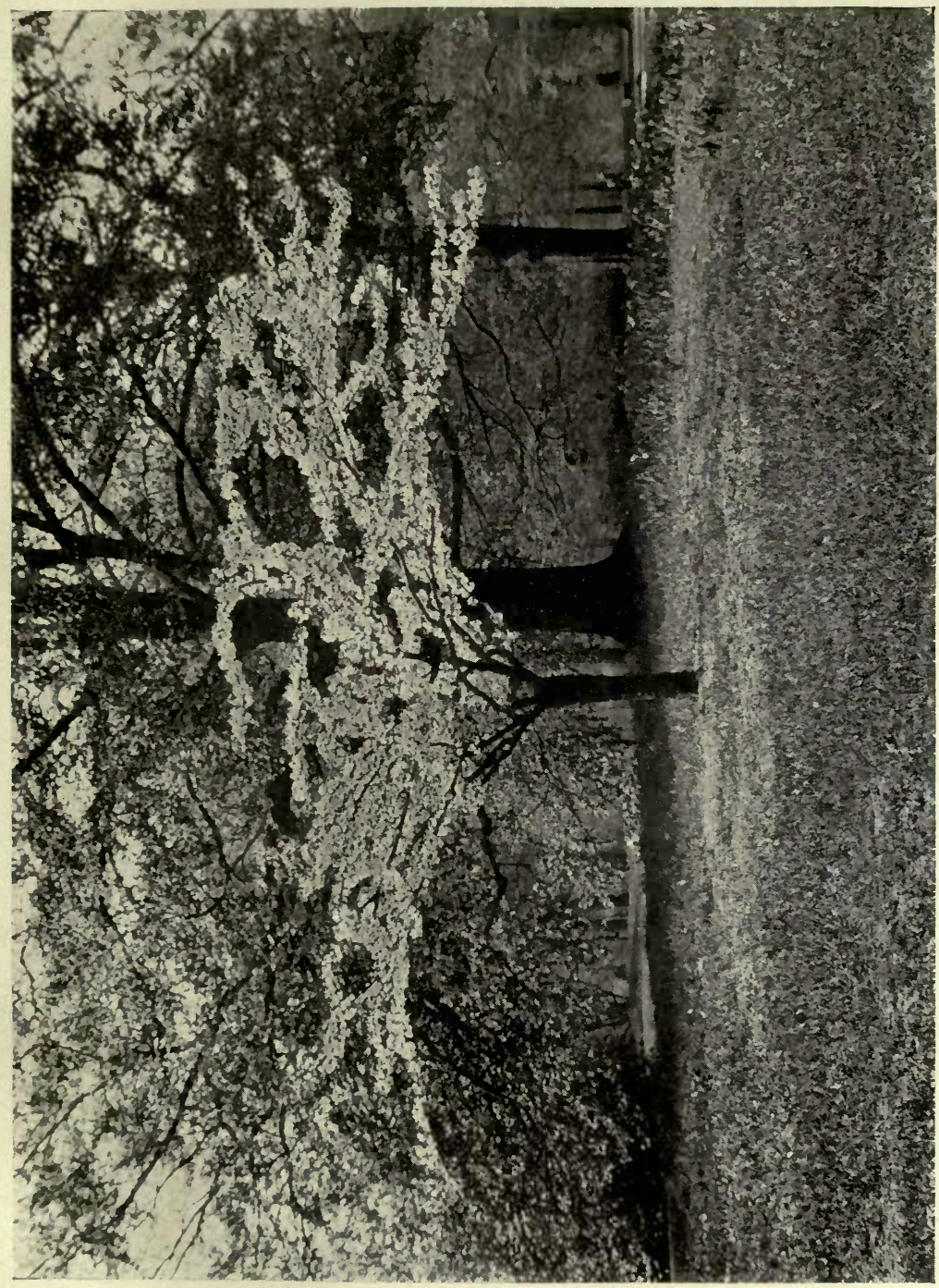

ลี่

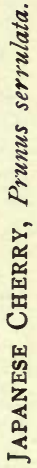





\section{P. SIBIRICA, Linnceus. SIbERIAN APRICOT.}

\section{(Armeniaca sibirica, Persoon.)}

A deciduous bush or small tree; leaves ovate, the apex long drawn-out; 2 to $3 \frac{1}{2}$ ins. long, half as wide, reddish at first, then bright green and smooth above, with axil tufts of down beneath; stalk $\frac{1}{2}$ to $\mathrm{I}$ in. long. Flowers mostly solitary, white or pink. Fruits scarcely stalked, about I in. long, yellow except on the sunny side, covered with a velvety skin; the flesh scanty, dry, harsh and scarcely edible; kernel of nut with an almond-like, bitter taste.

Native of the mountains of S. Siberia, where, according to Pallas the Russian botanist, some mountain-sides are covered with its pink blossoms in May, when the northern sides are purple with Rhododendron dauricum. Although an old tree in gardens (it was cultivated at Kew one hundred years ago), and still offered for sale by continental dealers, it is scarcely known in England nowadays. So far as I have seen, it has very little to recommend it for gardens, being of about the same value as the wild apricot, to which it is very closely allied. Its leaves have usually much more elongated points.

\section{P. Simoni, Carrière. Apricot Plum.}

A small deciduous tree of slender, pyramidal liabit, the branches erect, young shoots smooth. Leaves oval-lanceolate, finely toothed, 3 to 4 ins. long, I to $I \frac{1}{4}$ ins. wide; resembling those of the peach; stalk short, glanded. Flowers white, solitary or in pairs, up to I in. across, opening in March and April ; petals obovate. Fruit 2 ins. wide, $I \frac{1}{2}$ ins. deep, tomato-shaped, very shortly stalked, uniform brick-red, smooth like a nectarine, the flesh apricotyellow and pleasantly fragrant, aromatic, and very palatable.

There seems to be some doubt as to the origin of this tree, and although it is believed to be a native of north China, its wild habitat is unknown. It is cultivated about Pekin, and was introduced originally to the Jardin des Plantes at Paris in 1857 by M. Eugene Simon, after whom it is named, and was put in commerce by Messrs Thibaut \& Keteleer of Sceaux, near Paris, in 1872. It has borne fruits in the gardens of Aldenham House, Elstree, but this happens rarely, owing to flowers being so liable to damage by frost. Although called "Apricot" plum, its affinities are doubtful. Some authors regard it as a plum, but it appears rather to be intermediate between that and the nectarine. It is a useful fruit tree in California, and has been hybridised with P. triflora - the Japanese plum. Very distinct in its almost fastigiate habit.

\section{P. SPinosa, Linncus. Sloe, Blackthorn.}

A deciduous, suckering shrub, ro or ${ }_{5} 5 \mathrm{ft}$. high, or in gardens a small tree ; bark of young shoots downy, many short branches terminated by a spine. Leaves varying from obovate to oval and ovate, $\frac{3}{4}$ to $1 \frac{3}{4}$ ins. long, $\frac{1}{2}$ to $\frac{3}{4}$ in. wide; sharp-toothed, downy beneath on the midrib and veins, becoming sometimes quite glabrous with age. Flowers produced in March or early April usually on the naked wood, singly, sometimes in pairs, from the previous year's buds, each $\frac{1}{2}$ to $\frac{3}{4}$ in. across, pure white, and borne on a smooth stalk $\frac{1}{5}$ in. long. Fruit round, $\frac{1}{2}$ in. in diameter, at first blue, then shining black, very harsh to the taste.

Var. FLORE PLENO.-Flowers not so wide as the single-flowered type, but pure white and very double. A very delightful spring-flowering shrub.

Var. PURPUREA.- Leaves a beautiful red when young, becoming purple, flowers pink, sent out by Barbier \& Co., Orleans, in 1903. 
The sloe is found wild in Britain and other parts of Europe as well as in north Asia. It occurs in hedgerows and in woods, where it is occasionally a tree over $20 \mathrm{ft}$. high. It is oftenest seen in wild places or poor soils as a scrubby bush. If introduced to the garden or park for ornament, it should be trained up into tree form. The double-flowered variety is neglected but is most attractive, the flowers being crowded on short spiny branches whose blackness enhances their purity. Its slow growth makes it suitable for small gardens. It seems first to have appeared spontaneously at Tarascon. It is propagated by budding on the wild plum, whose suckers, if produced, are more easily detected than those of the wild sloe. The wood of this species is very hard, and prized in rural districts for making hay-rake teeth.

P. CURDICA, Fenzl, is intermediate between spinosa and insititia, of spreading habit, less thorny ; leaves downy on both sides when young; flowers white, $\frac{3}{4}$ in. across ; flower-stalks downy ; fruit blue-black. S. Armenia.

\section{P. SSIORI, F. Schmidt. \\ (Padus Ssiori, $C . K$. Schneider.)}

Although, according to Sargent, this bird cherry"is a common tree in Yezo, and in the mountain forests of Hondo, Japan, it has only recently been brought into cultivation. The same author (Forest Flora of Japan, ip. ${ }_{3}^{8}$ ) observes that it is always easily distinguished by its pale, nearly white bark. Young shoots smooth. Leaves oblong, often inclined to obovate, the apex drawn out into a long slender point, the base more or less heart-shaped, the margins closely set with fine almost bristle-like teeth ; thin, membranous, smooth above and the same beneath except for the tufts of brownish down in the vein-axils; stalk slender, I to $I \frac{1}{2}$ ins. long, with one or two glands near the blade. Flowers small, white, produced in slender, glabrous cylindrical racemes 4 to 6 ins. long, about $I$ in. wide. The species has been found in Manchuria and Saghalin. "The wood is very hard and close-grained, and is used by the Ainos for numerous domestic purposes" (Sargent).

\section{P. subCordata, Bentham. Oregon Plum.}

A deciduous tree up to 20 or $25 \mathrm{ft}$. high in a wild state, but often shrubby and forming thickets; branchlets reddish. Leaves broadly ovate or broadly oval, usually rounded or sometimes slightly heart-shaped at the base, 2 to 3 ins. long, I to 2 ins. wide; sharply sometimes doubly toothed, downy at first, becoming nearly or quite smooth; leaf-stalk $\frac{1}{2}$ to $\frac{3}{4}$ in. long, glandular. Flowers white, $\frac{2}{3}$ in. across, produced in stalkless umbels of two to four blossoms, each on a stalk $\frac{1}{4}$ to $\frac{1}{2}$ in. long. Fruit oblong, dark red or sometimes yellow, $\frac{1}{2}$ to $1 \frac{1}{4}$ ins. long.

Native of Oregon and California, and although discovered by Hartweg in 1847 , not introduced to Europe until about forty years later.. In its native country its leaves turn a brilliant red before falling. It differs from most other American plums in having the young leaves rolled up from the sides ("convolute" in bud), as are the Old World species, whereas the N.E. American species are "conduplicate" in bud, i.e. the halves of the leaf fold up in bud like a sheet of note-paper. It succeeds at Kew, where there is a tree nearly $20 \mathrm{ft}$. high.

\section{P. Subhirtella, Miquel.}

(Bot. Mag., t. 7508 ; see also p. 243.)

A small deciduous tree, with twiggy, erect branches, probably 20 to $30 \mathrm{ft}$. high ; branchlets hairy, especially when young. Leaves $1 \frac{1}{2}$ to 3 ins. long, 
scarcely half as wide ; ovate, taper-pointed, sharply, unequally, often doubly toothed; downy on the midrib and veins beneath ; leaf-stalk $\frac{1}{4}$ in. long, hairy. Flowers in short-stalked clusters of two to five, each flower $\frac{3}{4}$ in. across, soft rose-coloured, becoming paler with age, and borne on a sparsely hairy stalk $\frac{1}{8}$ in. long; calyx cylindrical, with short lobes; petals notched at the end. Fruit not seen by me, but described as round, shining black when ripe, $\frac{1}{3}$ in. across.

Native of Japan ; introduced to Kew in 1895 , and since proved to be one of the most beautiful of the cherries. It flowers from the end of March until mid-April, before the leaves appear. It is allied and in many respects similar to P. pendula, and has by a Japanese botanist been called " $\mathrm{P}$. pendula, var. ascendens," but in this country at least it is distinct enough, also more reliable and less subject to injury by frost. It is easily propagated by cuttings put in about the middle of June, when:the shoots are half woody.

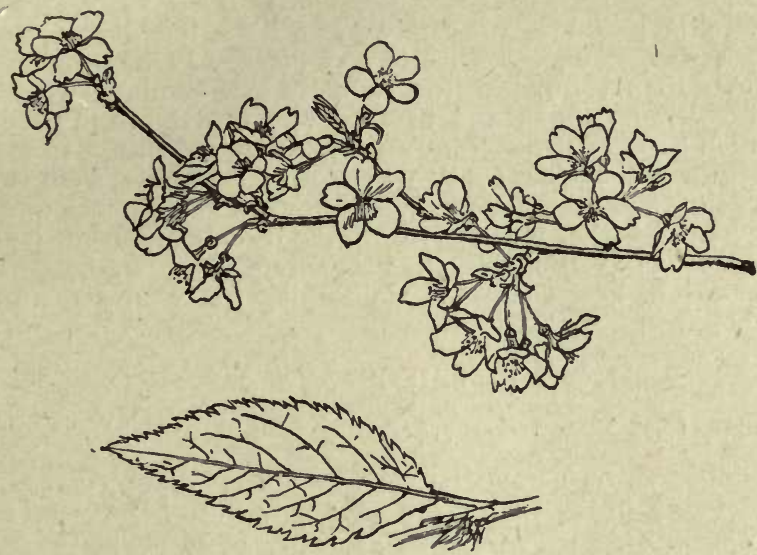

Prunds subhirtella.

\section{P. TOMEnTosa, Thunberg. DOWny CherRy.}

\section{(Bot. Mag., t. 8196.)}

A deciduous shrub of spreading habit, 4 to $8 \mathrm{ft}$. high and twice as wide ; branchlets covered densely with a close, pale down. Leaves obovate or oblong, with an abrupt point, 2 to 3 ins. long, $\frac{3}{4}$ to $I \frac{1}{2}$ ins. wide ; toothed, dark dull green, and furnished with scattered hairs above, paler and densely woolly beneath. Flowers $\frac{3}{4}$ in. across, white, tinted with rose, produced singly or in pairs at the joints of the previous year's growth, each on a stalk $\frac{1}{6}$ in. long. Fruit bright red, about the size of a small cherry, slightly hairy, ripe in July.

Native of N. and W. China, but introduced from Japan about forty years ago. It usually flowers about the fourth week in March, and is then an object of great beauty and charm. Shoots from I to $2 \mathrm{ft}$. long are made in one season, and these the following spring are furnished from end to end with the delicately tinted flowers. It must be said, however, that its beauty is short-lived. The petals are fragile and easily fall, so that if sharp rain-storms or harsh winds are prevalent (as often happens when they are expanding), their full beauty is never displayed. Some sheltered nook should be chosen for it, a consideration its early blossoms entitle it to. The fruits are not freely 
produced with us, although about Pekin the shrub is cultivated for their sake. Propagated by layers and cuttings of half-ripened wood.

\section{P. TRIFlora, Roxburgh. JAPANESE Plum.}

A deciduous tree, 20 to $30 \mathrm{ft}$. high, with smooth, dark young wood. Leaves obovate or oval, 3 to $4 \frac{1}{2}$ ins. long, nearly half as wide ; downy in the axils of the veins beneath, doubly round-toothed. Flowers white, $\frac{3}{4}$ in. across, produced in early April, each on a slender smooth stalk $\frac{1}{2}$ in. long, normally in threes from each bud of the previous year's shoots, but sometimes in pairs or singly; calyx with five rounded oblong lobes, smooth, often slightly toothed. Fruit heart-shaped, 2 to $2 \frac{3}{4}$ ins. deep, nearly as wide, on globular with a deep depression where the stalk is attached; the colour in cultivated varieties varies considerably, being of different shades or combinations of red, orange, and yellow.

This tree is presumably a native of China, but does not appear to be known in a wild state. The name was first given by Roxburgh to a plant growing in Calcutta Botanic Garden early last century. It has long been cultivated by the Japanese, and in 1870 was introduced to California, where its cultivation has developed into an important industry. In this country its ornamental value is about equal to that of $\mathrm{P}$. cerasifera, from which it differs in the shape of the fruits, the more numerous flowers at each node, and in the longer leaves. Whether it will prove worthy of cultivation for its fruit remains to be seen, but it is very doubtful. Probably it requires a hotter summer than ours to develop its best qualities. Californian fruits are sometimes offered in London shops.

\section{P. TRILOBA, Lindley.}

\section{(Bot. Mag., t. 8061 ; Amygdalopsis Lindleyi, Carrière.)}

A deciduous shrub or small tree, 12 to $15 \mathrm{ft}$. high, young shoots usually smooth. Leaves ovate or obovate, I to $2 \frac{1}{2}$ ins. long, $\frac{3}{4}$ to $I \frac{1}{4}$ ins. wide ; tapering at both ends, irregularly, doubly, and rather coarsely toothed; slightly hairy beneath. Flowers pinkish white, $\frac{3}{4}$ to $\mathrm{I}$ in. across, produced singly or in pairs (sometimes more) from each bud of the previous year's shoots; calyx smooth, $\frac{1}{5}$ in. long, with shallow, rounded lobes. Fruit covered with pale down when quite young; not seen mature by me, but said to be red.

Var. FLORE PLENO.-Flowers $\mathrm{I}_{\frac{1}{2}}$ ins. across, of a delicate rose, very "double." Leaves more obovate than in the type, often more or less threelobed towards the apex.

Prunus triloba is a native of China, and the double-flowered variety was introduced by Fortune in 1855 ; it was upon this that Lindley founded the name. It is the most popular and beautiful form of the species; flowering in the greatest profusion about the end of March or early in April. It is seen at its best against a south wall, where it should be pruned once a year as soon as the flowers are faded, cutting the blossoming twigs close back. Shoots I to $2 \frac{1}{2} \mathrm{ft}$. long are then made, which flower the following year. It may be grown in the open ground, but does not flower so profusely there; it is also very extensively used for forcing early into bloom for greenhouse decoration. The single-flowered, type plant was of later introduction, but is by no means so exquisite a shrub as the other, neither do the flowers last as long. The form known in gardens as PETzOLDII is very much the same as the type, but has ovate, not trilobed leaves. Propagated by cuttings of firm wood or by layers. Plants worked on the plum stock are often troublesome because of suckers. 


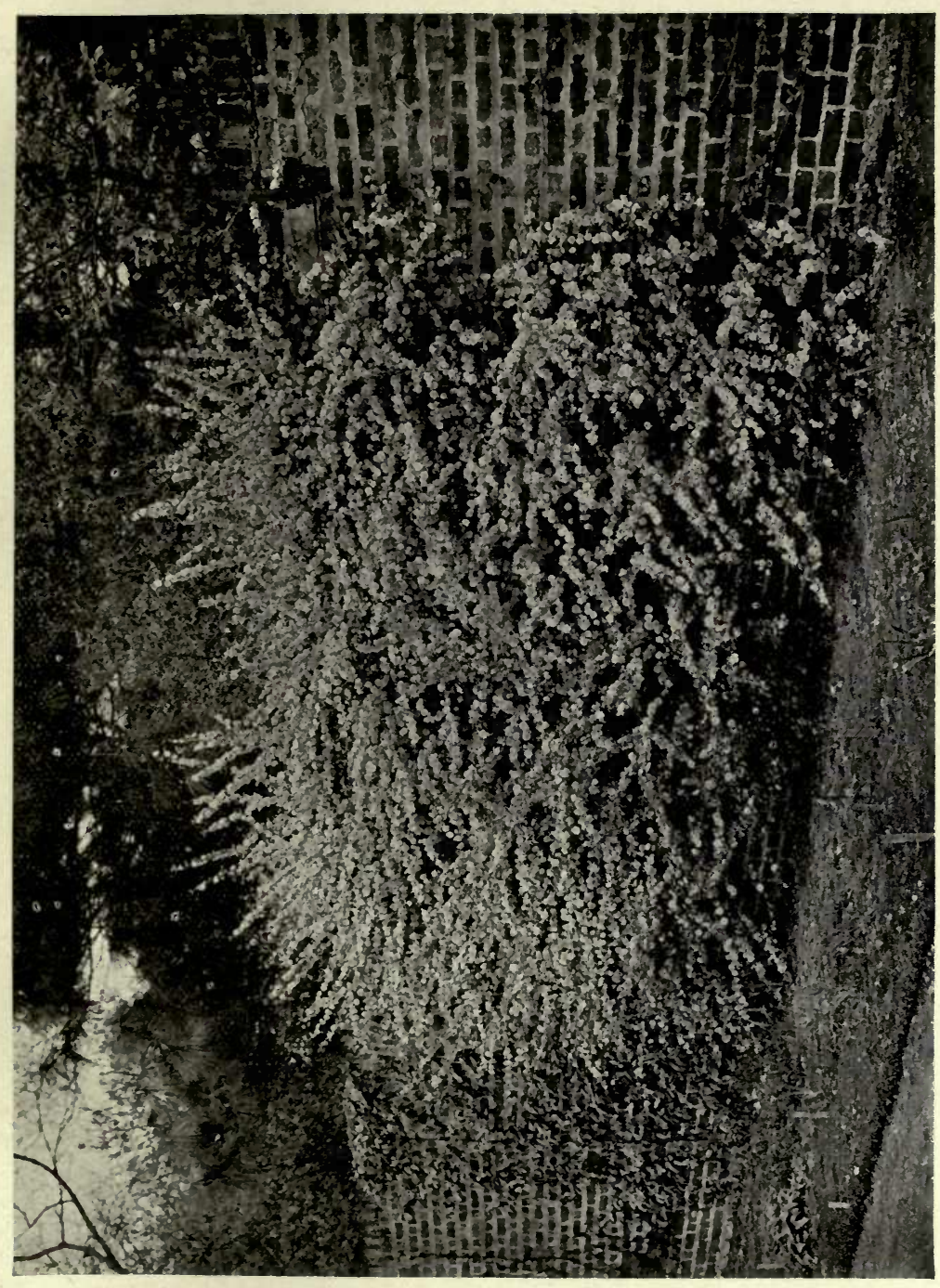

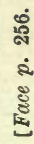

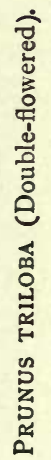





\section{P. virginiana, Linnceus. Virginian Bird Cherry.}

(Padus virginiana, Roemer.)

Usually a shrub in a wild state, 2 to $15 \mathrm{ft}$. high, occasionally a tree, deciduous, with grey, smooth branchlets. Leaves varying from broadly oval to broadly obovate, with a short abrupt point, finely toothed; $1 \frac{1}{2}$ to 5 ins. long, two-thirds as wide; smooth, shining, and dark green above, paler beneath, with tufts of down in the vein-axils beneath ; stalk $\frac{1}{2}$ to $\frac{3}{4}$ in. long, with two or more glands. Flowers white, $\frac{1}{3}$ in. or rather more across, produced in racemes 3 to 6 ins. long, I in. wide, terminating short leafy shoots. Fruit dark red, round, $\frac{1}{3}$ in. across, very harsh to the taste.

Native of the eastern and central United States and Canada ; introduced to England in 1724 , but not often seen now. It is much rarer in gardens than its near ally, P. serotina, which has a black rather than a red fruit and proportionately narrower leaves. The Western N. American P. demissa is perhaps a variety of this, with thicker leaves and fruits not so harsh to the palate. P. virginiana flowers well during May in England, and is pretty then, but does not bear fruit so freely as our native bird cherry.

Var. NANA.-A dwarf form.

\section{P. Watsoni, Sargent. Sand Plum.}

(Garden and Forest, I894, fig. 25.)

A deciduous shrub or small tree, 6 to $12 \mathrm{ft}$. high, with smooth, reddish branchlets. Leaves ovate, pointed, decurved, I to $1 \frac{3}{4}$ ins. long, $\frac{1}{2}$ to $\frac{3}{4}$ in. wide; shallowly round-toothed, dark shining green above, paler below, quite smooth on both surfaces : stalk $\frac{1}{4}$ to $\frac{1}{3}$ in. long, grooved, with two glands near the base of the blade. Flowers white, $\frac{1}{2}$ in. diameter, produced in clusters of three or four, each on a slender stalk $\frac{1}{4}$ in. long. Fruit round, orange-red, $\frac{3}{4}$ in. diameter, the stone deeply pitted.

Native of the central United States, where it is said to form thickets in low, sandy soils near streams. It was first recognised as a distinct species by Sargent in 1894, having previously been confused with P. angustifolia, from which it differs in its "thicker leaves, thicker skinned fruit, and smaller more deeply pitted stone." It is very distinct from angustifolia in its behaviour under cultivation, thriving well where that species is a total failure. Introduced to Kew in 1897 . It flowers in late April and May, but is not one of the most effective plums in this country.

\section{PSEUDOLARIX FoRTUNEI, Mayr. GoldeN LARCH. CONIFERA.}

(Bot. Mag., t. 8I 76 ; P. Kaempferi, Gordon; Larix Kaempferi, Carrière.)

A deciduous tree, occasionally roo to $\mathrm{I} 30 \mathrm{ft}$. high, with a trunk 2 to $3 \mathrm{ft}$. thick; branches spreading horizontally; young shoots smooth. Leaves linear, $I_{2}^{\frac{1}{2}}$ to $2 \frac{1}{2}$ ins. long, $\frac{1}{12}$ to $\frac{1}{8}$ in. wide; produced in a radiating cluster from the end of short, spur-like branches, or on terminal shoots singly and spirally arranged. Their arrangement and general aspect are similar to those of larch, but the leaves are stouter and larger than those of any true larch. In spring they are of a tender yellowish shade of green, and in autumn they turn a rich golden yellow before 
falling. Male flowers yellow, produced in a dense cluster about I in. across at the end of the short, spur-like branchlets. Cones about 2 ins. long, nearly as wide; the scales thick, woody, triangular, blunt, often notched at the tip, $\frac{3}{4}$ to $\frac{1}{4} \mathrm{in}$. long, ultimately spreading and falling away with the seeds.

Native of China, where it was discovered in the Ckekiang province and introduced by Fortune in 1853 . This beautiful tree, the only one of its genus, whilst it bears a marked resemblance to the larches in foliage and branching, is remarkably distinct in its clustered male

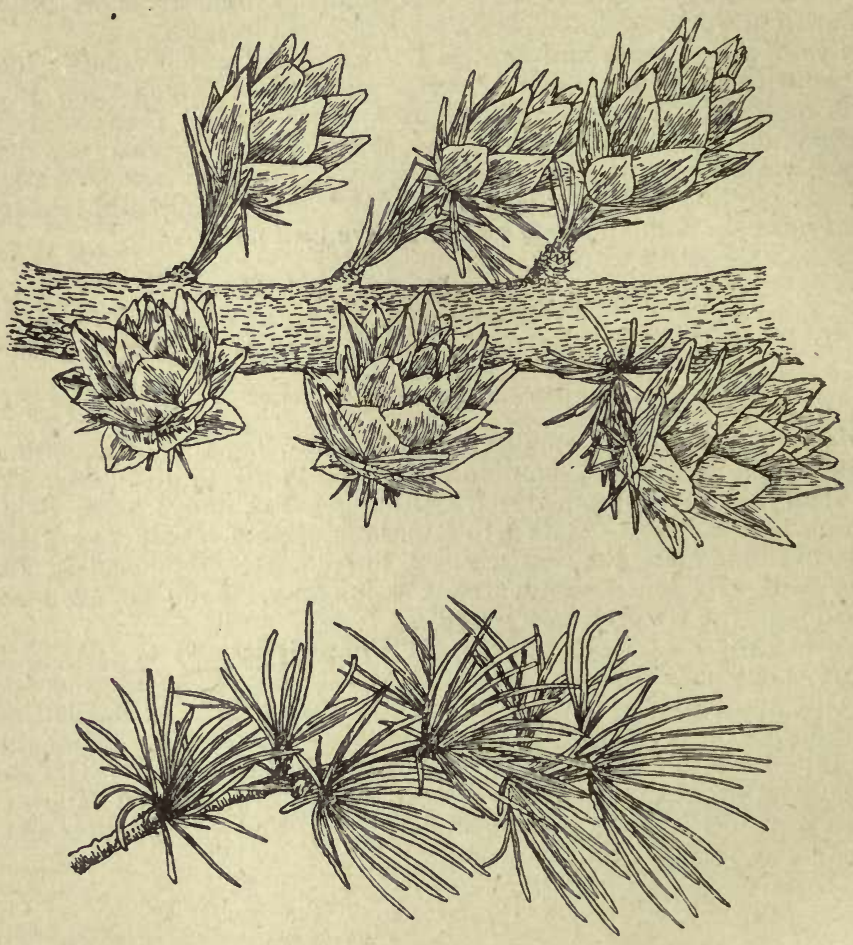

Conks and leafy spray of Pseudolarix Fortuner.

catkins (solitary in Larix), and in the large woody scales of the cone, which falls to pieces when ripe (remaining intact in Larix). Slow growing, but perfectly hardy, it is one of the most beautiful as well as one of the most interesting of trees. It has not, so far as I know, produced fertile seed in this country, and is not so much grown as it deserves to be. The finest tree I have seen is in Messrs Rovelli's nursery at Pallanza, on Lake Maggiore. This is nearly $70 \mathrm{ft}$. high, and very fertile; when I saw it in I9I 2 there were beneath its boughs hundreds of young trees that had sprouted from its fallen seeds, varying from a few inches to 2 or $3 \mathrm{ft}$. high. 


\section{PSEUdOTSUGA Douglasir, Carrière. Douglas Fir. CONIFERA. \\ (P. taxifolia, Britton; Abies Douglasii, Lindley.)}

A tree 200 to $250 \mathrm{ft}$. high, with a trunk 8 to $12 \mathrm{ft}$. in diameter; main branches horizontal, secondary ones pendulous; young shoots usually more or less downy, with terminal buds that are ovate, pointed, $\frac{1}{4}$ to $\frac{1}{2}$ in. long, resinous; also occasional axillary buds along the shoot. Leaves disposed either all round the shoot or (especially on weak shoots) in two opposite ranks ; crowded, linear, $\frac{3}{4}$ to $x_{2}^{\frac{1}{2}}$ ins. long, $\frac{1}{16}$ to $\frac{1}{12}$ in. wide ; rounded or blunt (never notched) at the apex, of various shades of green (from grass green to more or less glaucous), and with several lines of stomata each side the midrib beneath. Cones pendulous, shortly stalked, averaging $2 \frac{1}{2}$ ins. long and $\mathrm{x}$ to $\mathrm{I} \frac{1}{2}$ ins. wide at the base, slenderly eggshaped, pointed, very distinct on account of the conspicuously obtruded bracts. Male flowers axillary, composed of a cylindrical cluster of orange-red stamens.

Native of Western N. America from British Columbia to Mexico; discovered by Menzies in 1793 , and introduced by Douglas in r827. As might be expected from its extended habitat, it shows much variation. In any large group of trees more or less distinct shades are discernible. The most distinct of the varieties is

Var. GLAUCA, often called "Colorado Douglas fir," which not only differs in general appearance, but has its own habitat. The common and finest type of Douglas fir occurs near the Pacific coast, in British Columbia and Washington. The var. glauca is of inland and mountain distribution, and is hardy in places where the other will not live. It differs chiefly in being a smaller tree, and in the leaves being stouter and often very glaucous, especially beneath. As an ornamental tree it is worth growing, especially the bluest forms (it varies much in that respect), but for timber it is by no means so promising as the coast type.

Var. PENDULA has the pendulous character of the branchlets exceptionally developed. On a tree at Bayfordbury they are 2 to $3 \mathrm{ft}$. long, and of practically the same thickness throughout, scarcely branched.

Var. StairiI. - Foliage of a pale greenish yellow. It originated at Castle Kennedy, in Wigtownshire. The best tree I have seen is at Ochtertyre, near Crieff, in Perthshire, about $40 \mathrm{ft}$. high.

Var. TAXIFOLIA. - Leaves longer and narrower than in the type; branchlets stouter. Said to have been found wild in Oregon.

In r 905 Messrs Koster \& Sons of Boskoop sent to me some shoots of a remarkable form raised in their nursery in Holland: Its leaves are only $\frac{1}{3}$ to $\frac{1}{2}$ in. long, and are both pointed and rounded at the apex. The raisers thought it might be a hybrid with Tsuga Sieboldii, which the foliage resembled in shape and colour. It was subsequently named var. Fretsir by Beissner.

No foreign tree except the larch and Corsican pine has aroused so much interest among foresters as the Douglas fir. In favourable situations it grows with extreme rapidity, and has already reached in many places 
a stature of over Ioo ft. But in its adaptability to the various soils and climates available for forestry it is far inferior to either of the other two. To get it at its best it requires a climate where the rainfall is abundant, and at least a moderately good soil. On dry, hungry soil, and in bleak spots, it is a failure. To see this tree in its finest condition and in its greatest numbers one must visit the Perthshire propertiesespecially those of Murthly and Taymount. Solitary trees are magnificent, the enormous trunks supporting a mass of large plume-like branches.

P. MACROCARPA, Mayr, is a close ally of the Douglas fir, but according to Jepson is only from 30 to $90 \mathrm{ft}$. high. It differs from P. Douglasii in its leaves being incurved instead of straight, and taper-pointed instead of usually rounded at the apex. Cones larger, occasionally $6 \frac{1}{2}$ to $7 \frac{1}{2}$ ins. long, with the bracts not protruded so much beyond the scales. Native of $\mathrm{S}$. California and lower California.

P. JAPONICA, Sargent (Abies japonica, Rovelli; Gardeners' Chronicle, I909, i., fig. I 32). - A tree up to I00 ft. high in Japan, but only known in this country by a few small plants. The young shoots appear to be always without down, and the leaves, except on quite young plants, to be notched at the apex; both these characters afford good distinctions between this and the West American species. The leaves are $\frac{3}{4}$ to $1 \frac{1}{4}$ ins. long, and have two broad stomatic strips beneath. Cones only $1 \frac{1}{2}$ to $1 \frac{3}{4}$ ins. long, I in. wide. This tree was discovered in 1893 by the Japanese botanist Shirasawa, and is a native of the provinces of Yamato and Kii ; first introduced to the botanic garden at Hamburg, and to Ansorge's nursery at Flottbeck. Mr Ansorge in 1907 sent me some twigs taken off young plants, the leaves of which were rounded at the apex. This is characteristic of young plants only. Older ones exhibited at the British-Japanese Exhibition of I9 Io had decidedly notched leaves.

\section{PTElEA trifoliata, Linncus. Hop Tree. RUtaced.}

A low deciduous tree, usually under $20 \mathrm{ft}$. high, often of greater breadth than height, with a short, comparatively thick trunk, often inclined. Leaves trifoliolate, the leaflets lanceolate, ovate or oblong, finely toothed or entire, downy beneath when young, the middle one the largest, and from 2 to 6 ins. long, with a short stalk, the lateral leaflets unequal-sided, stalkless; the common leaf-stalk is 2 to 4 ins. long. Held against the light and seen through a lens the blade is found to be dotted with oil-glands. Flowers borne on slender, downy stalks in corymbs 2 or 3 ins. across during June and July, dull greenish white, $\frac{1}{3}$ to $\frac{1}{2}$ in. across. They are unisexual, the males soon falling away. Fruit in dense clusters, each a flat, thin disk from $\frac{2}{3}$ to $\mathbf{I}$ in. across, consisting of an almost circular wing, with prominent netted veins surrounding one seed in the centre. Occasionally the fruit has more than one wing.

Var. AUREA. - Leaves yellow.

Var. FASTIGIATA.-Branches erect.

Var. GLAUCA.-Leaves blue-green instead of the ordinary rich dark green.

Var. HETEROPHYLLA. - Leaves mostly trifoliolate as in the type, but others have four, some five leaflets; they are also narrower in proportion to their length. 


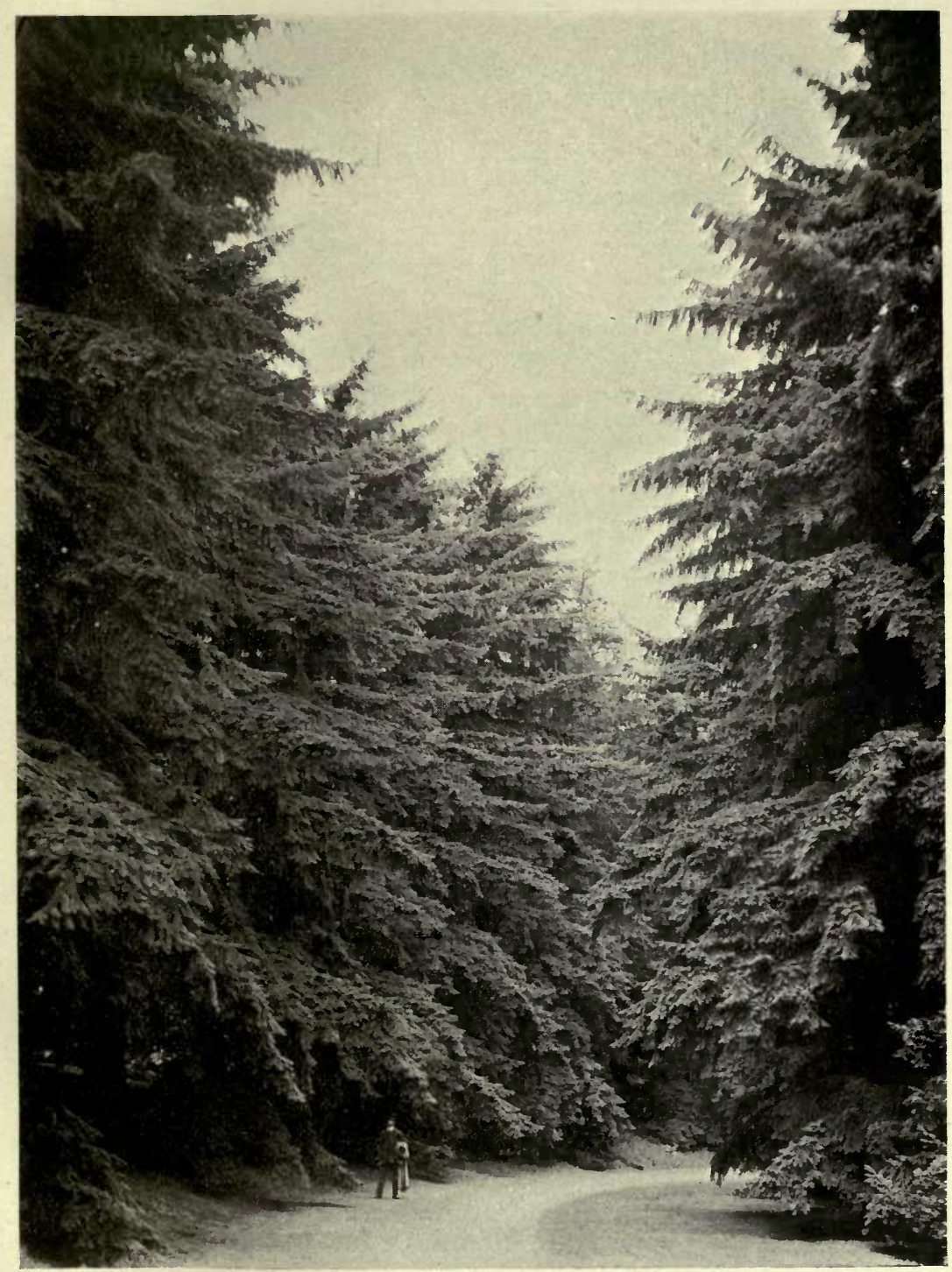

Douglas Fir (Pseudotsuga Douglasiz) at Murthly Castle, Perth. 

Var. Mollis, Torrey (P. mollis, Curtis). - Leaflets broader than in the type, but its chief distinguishing characteristic is the dense permanent covering of greyish down on the lower surface.

Native of S. Canada and the eastern United States; introduced to England in 1704. Ptelea trifoliata is one of the most distinct of hardy trees, and it is interesting for its large crops of curious elm-like fruits which often strew the ground in its neighbourhood throughout the winter, the fleshy part of the wing having decayed and left the netted veins. Very little of the seed is fertile in this country, but the tree is easily increased by cuttings. The bark, leaves, and young fruits emit a strong and aromatic scent when bruised, and the last have been suggested as a substitute for hops because of their intense bitterness. The tree is of picturesque habit, perfectly hardy, and appears to thrive in any welldrained soil. The leaves die off yellow in autumn.

P. BALDwinil, Torrey. Western Hop Tree--A deciduous shrub up to $20 \mathrm{ft}$. high with trifoliolate leaves much smaller than those of $P$. trifoliata. Leaflets $1 \frac{1}{4}$ to $2 \frac{1}{2}$ ins. long, narrowly ovate or obovate, the terminal one the longest ; very downy beneath. Flowers in small terminal corymbs. Fruit winged, $\frac{1}{2}$ in. across. It differs from P. trifoliata in its narrower leaves, larger flowers, and narrow wing to the fruit. Native of N. California ; introduced to Kew in 1893. Not so striking a plant as its Eastern ally.

\section{PTEROCARYA. WING-NUT. JUGLANDACEA}

At present five of the seven species of Pterocarya known are in cultivation. They are deciduous trees with large, aiternate, pinnate leaves and pithy young wood; leaflets varying from five to twenty-seven, toothed, more or less oblong. Flowers unisexual, both sexes borne on the same tree but on different catkins; male catkins about one-third the length of the female ones. The fruit is a small nut, large numbers of which are strung on slender spikes 8 to 20 ins. long. From its allies in the same natural order-the walnuts and hickories-Pterocarya differs in the curiously winged nuts, and from the latter in the chambered pith.

In gardens the only species well known is the Caucasian one (of the rest five come from China, one from Japan), and no handsomer pinnateleaved tree can be grown in our climate. The others also are handsome, but they have not yet shown their qualities as ornamental trees in Britain. All of them are moisture-lovers, and for their best development should be planted in deep loam. Young plants making vigorous succulent shoots are sometimes cut by winter cold, and even old trees are liable to injury by late spring frosts. Seeds afford the best means of propagation; some species produce suckers, and probably cuttings of the roots might also be employed.

\section{P. Caucasica, C. A. Meyer. Caucasian Wing-nut. (P. fraxinfolia, Spach.)}

A large deciduous tree, ultimately 80 to $100 \mathrm{ft}$. high, usually much less in this country, and branching low down, forming a wide-spreading head; 
trunk of large trees ro to $\mathrm{I} 2 \mathrm{ft}$. in girth, with deeply furrowed bark; ends of young shoots minutely scurfy. Leaves 8 to 18 ins. (sometimes over $2 \mathrm{ft}$.) long, composed of from three and a half to thirteen and a half pairs of leaflets; these are stalkless, oblong, obliquely rounded at the base, pointed, toothed, normally 2 to $4 \frac{1}{2}$ ins. long by $\frac{3}{4}$ to $1 \frac{3}{4}$ ins. wide (occasionally, on vigorous shoots, 8 or 9 ins. long); dark green, smooth and glossy above, tufted with stellate hairs along the midrib beneath; common stalk round Male catkins 3 to 5 ins. long, cylindrical, the flowers closely packed; female catkins 12 to 20 ins. long, with the flowers scattered; both pendulous ; afterwards developing nuts which, with the wings, are $\frac{3}{4}$ in. in diameter, roundish, oblique, horned at the top.

Native of the Caucasus and Persia, inhabiting moist places. It was introduced to France by the elder Michaux, who took back seeds from Persia in 1782 . According to Elwes, the finest specimen in Britain is at Melbury, in Dorset, which is $90 \mathrm{ft}$. high and $\mathrm{I} 2 \mathrm{ft}$. in girth of trunk. There is a beautiful specimen at Claremont, Surrey, which, when I saw it in I9I0, measured $19 \mathrm{ft}$. round its short, rugged trunk. This tree likes a rich loamy soil and abundant moisture, and whilst the fine specimens mentioned above show that it will thrive very well in the south of England, it loves more sunshine than our climate affords. The lover of trees will find nothing more interesting in and around Vienna than the magnificent examples of Pterocarya caucasica. There, of course, the summers are much hotter, and the winters colder than ours; the tree bears fruit freely, and is very striking in late summer when hung with the long slender catkins.

Var. Dumosa, C. K. Schneider (P. dumosa, Lavallée).-A shrubby variety of dwarf habit, with small leaflets 2 or 3 ins. long. Although first noticed in the Arboretum of the late Mr Lavallée at Segrez, in France, this is apparently a truly wild form, judging by the following statement of the late Jean Van Volxem :-

"The country around Lagodechi (in the Caucasus) is very interesting. Near the river are extensive swamps, where I saw P. caucasica growing sometimes as an enormous tree, sometimes as a large shrubby bush. The two forms are intermixed with each other, so that no condition of soil or exposure can explain the fact, and there is, as far as I saw, no intermediate form, and I could detect no difference between the two forms except as to habit and size." (Gardeners' Chronicle, I877, I. p. 72.)

\section{P. HUPEHENSIS, Skan. HUPEH WING-NUT.}

A tree $70 \mathrm{ft}$. or more high, with smooth, minutely glandular young shoots. Leaves 7 to 12 ins. long, composed of five to eleven (perhaps more) leaflets, which are oval-lanceolate, oblong, or slightly obovate, pointed, obliquely rounded at the base, toothed; $I \frac{1}{2}$ to 5 ins. long, $\frac{3}{4}$ to 2 ins. wide; smooth except for tufts of brownish down in the vein-axils beneath; common stalk downy, roundish, not winged. The fruiting catkin is 12 to 18 ins. long, each nut with a pair of roundish wings, the whole rather more than I in. across.

Native of the mountains of Hupeh, China ; discovered by Henry in 1888 , and introduced by Wilson for Messrs Veitch in I90r. The young trees appear to be quite hardy. The species is closely allied to P. caucasica; so far as we know at present it has not so many leaflets on each leaf, and they are slightly stalked. The base of the blade of the leaflet does not overlap the main-stalk as it usually does in P. caucasica.

\section{P. Paliurus, Batalin.}

A tree 50 or more feet high, the young shoots downy, glandular. Leaves 8 to 12 ins. long, composed usually of seven or nine leaflets, which are oblong 


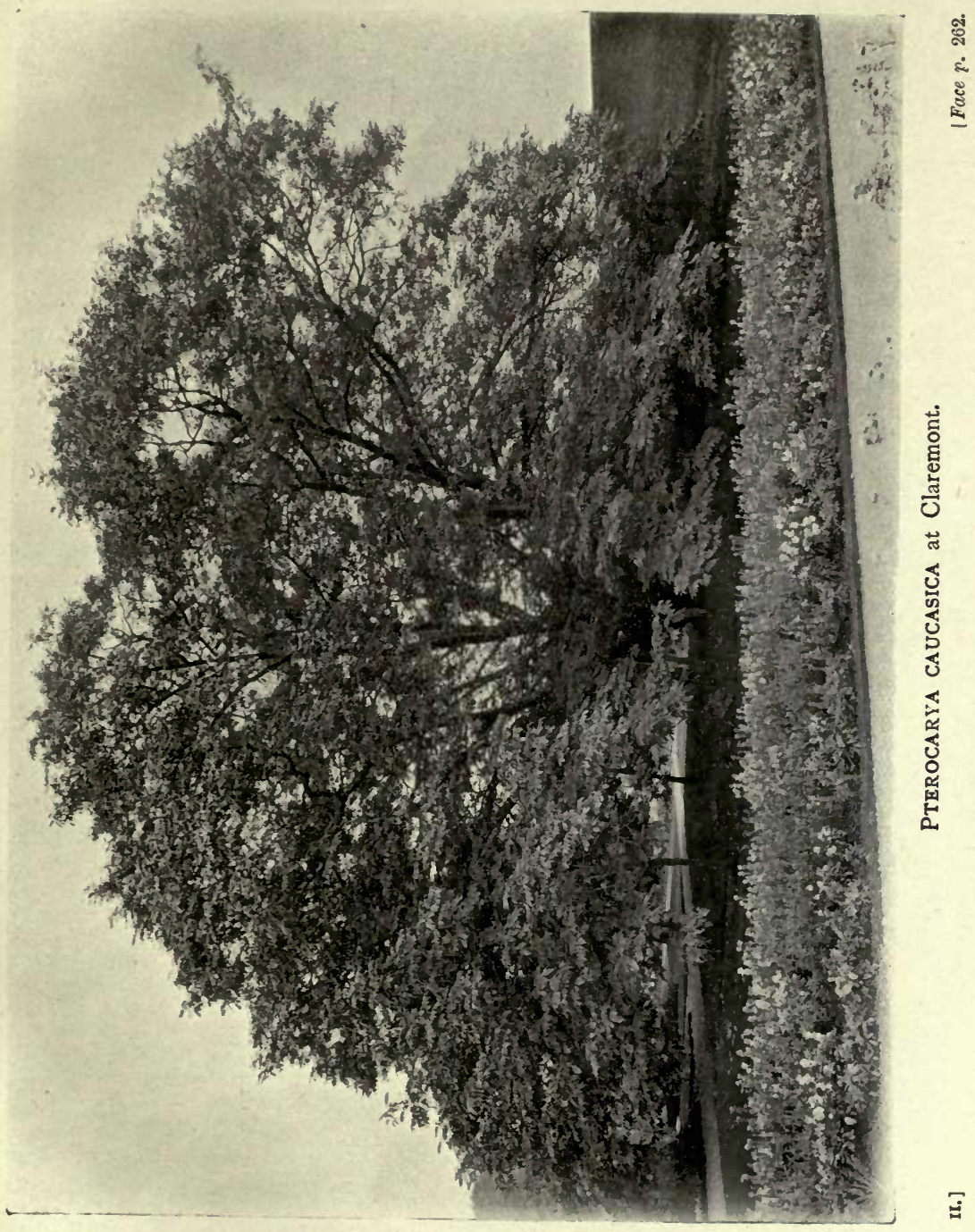



or oval, very obliqely tapered or rounded at the base, pointed or blunt at the apex, finely toothed; $2 \frac{1}{2}$ to 5 ins. long, 1 to $2 \frac{1}{2}$ ins. wide ; dark glossy green, and smooth except for fine down on the midrib on both surfaces; common stalk not winged, downy. Male catkins slender, $2 \frac{1}{2}$ to 4 ins. long, frequently in pairs. Fruiting catkin 8 to ro ins. long, each nut surrounded by a wing, the whole forming a oircular disk $1 \frac{1}{2}$ to $2 \frac{1}{2}$ ins. diameter.

Native of the mountains of Central China ; discovered by Henry in I 888 , and introduced by Wilson for Messrs Veitch in I90I. The fruits of this species are very remarkable, suggesting miniature cymbals; in having the wing continuous all round the nut, they distinguish it from all other species. Henry says it ought to be hardier than P. stenoptera, as coming from higher elevations. Seeds were again sent by Wilson during his later journeys.

\section{P. Rehderiana, C. $K$. Schneider.}

A hybrid between P. caucasica and 'P. stenoptera, raised in the Arnold Arboretum, near Boston, Mass., from seeds: received in 1879 from the late M. Lavallée's collection of Segrez, where the cross had no doubt been effected by wind on trees growing together. As the seeds were received as P. stenoptera, that species was no doubt the mother plant. I saw the original hybrid in the Arnold Arboretum in June 1910. It is now $40 \mathrm{ft}$. high and, owing to the property of producing sucker-growths from the root, is forming by itself quite a grove. At least one of the parent species has the same faculty-rarely developed, however, unless the main stem is cut down. $\mathrm{P}$. Rehderiana is intermediate between the parents. The common stalk of the leaf has wings, but they are not so much developed as in P. stenoptera, and never toothed as they often are in that species. The wings of the fruit are shorter and rounder. In the Arnold Arboretum this hybrid has proved hardier and a better grower than either of its parents. Living plants were introduced to Kew in 1908.

\section{P. RHOIfolia, Siebold. JAPAnese Wing-nUt.}

A tree 80 to $100 \mathrm{ft}$. high, trunk 8 to $\mathrm{Io} \mathrm{ft}$. in girth; young shoots smooth. Leaves 8 to over I 2 ins. long, composed of eleven to twenty-one leaflets, which are rounded at the base, pointed at the apex, oblong, finely and evenly toothed, $2 \frac{1}{2}$ to 4 ins. long, I to $1 \frac{1}{2}$ ins. wide; common stalk not winged. The stalk and leaves vary in regard to pubescence, the plants at Kew are smooth except for tufts of stellate down about the midrib and axils of the veins beneath; but in Japan a form is commonly much more downy on the leaves and leaf-stalks. Male catkins 3 ins. long; females 8 to 10 ins. long ; wings of the nut horizontal, broadly crescent-shaped, the whole fruit $\frac{3}{4}$ to 1 in. across.

Native of Japan; introduced in 1888 . It is quite hardy, and in a moist loam would apparently grow well. Professor Sargent found it abundant on Mt. Hakkoda at 2500 to $4000 \mathrm{ft}$. above sea-level, and almost the largest deciduous tree in that part of Japan.

\section{P. Stenoptera, De Candolle.}

A tree 50 to $60 \mathrm{ft}$. high, with a fissured trunk 6 to $8 \mathrm{ft}$. in girth; young shoots and common stalk of the leaf of some plants furnished with pale hairs persisting through the first winter, but in others both are quite smooth. Leaves 8 to 15 ins. long, composed of eleven to twenty-one (sometimes twentyfive) leaflets, which are oblong or narrowly oval, tapered at both ends, finely and regularly toothed, 2 to 5 ins. long, $\frac{1}{3}$ to 2 ins. wide; the common stalk winged in the spaces between each pair of leaflets, the wings sparsely toothed. Male catkins $2 \frac{1}{2}$ ins. long; female ones 8 ins. long. Nut roundish oval with a 
short beak, the two wings erect, narrow, tapering, $\frac{3}{4}$ in. long, $\frac{1}{5}$ in. wide at the base, forming a V.

Native of China, whence specimens were sent to France by a missionary named Calery in 1844 , on which Mr Casimir de Candolle founded the species. It appears to have been introduced to Europe about 1860. It will, no doubt, thrive best in moist loam like P. caucasica, but very few plants appear to be in cultivation. The best, according to Elwes, is in Lord Ducie's collection at Tortworth, about $35 \mathrm{ft}$. high. I saw a tree fruiting freely at Segrez, in France, in July 1904. Its winged leaf-stalks and the erect narrow wings of the nuts distinguish it from P. caucasica.

\section{PTEROCELTIS TATARINOWI, Maximorvicz. URTICACEA:}

A deciduous tree with the habit and general aspect of a Celtis; young shoots slender and, like the leaves, at first clothed with small appressed hairs which mostly soon fall away. Leaves alternate, toothed, ovate lance-shaped; 2 to 4 ins. long, $\frac{3}{4}$ to 2 ins. wide; the apex with a long tapered point, the base three-nerved and broadly wedge-shaped; upper surface harsh to the touch, with innumerable minute warts, lower surface with tufts of down in the vein-axils; stalks $\frac{1}{4}$ to $\frac{1}{3}$ in. long. Flowers unisexual, the males in stalkless clusters, the females solitary in the leafaxils; neither of any beauty. Fruit a globose nut about $\frac{1}{8}$ in. wide, surrounded by a circular wing notched at the top, the whole $\frac{1}{2}$ to $\frac{3}{4}$ in. wide, borne on a slender stalk about $\frac{1}{2}$ in. long.

Native of Central China; introduced to France in 1894 by $\mathrm{Mr}$ Maurice de Vilmorin, who raised the first plants at Les Barres from seed. One of these I saw bearing fruit in July 1904, but none of its seeds had up to then proved fertile. It was introduced to Kew in 1897 . Interesting botanically, it will probably only appeal to connoisseurs and lovers of curiosities, for the flowers are quite inconspicuous. Closely allied to Celtis, it is very distinct in its winged fruits, which more resemble those of Ulmus, but their arrangement singly in the leaf-axils of the shoots of the year make the tree very distinct from the elms. This is the only species of the genus known.

\section{PTEROSTYRAX. STYRACEA.}

Bentham and Hooker united this genus to Halesia, apparently on insufficient grounds, for most botanists now concur in keeping the two separate. They are really very distinct. Pterostyrax is exclusively Chinese and Japanese (Halesia is East N. American); the inflorescence is paniculate and many-flowered; the parts of the flowers are in fives (fours in Halesia); the stamens are protruded in Pterostyrax (enclosed in Halesia); the pith is continuous (chambered in Halesia).

\section{P. HISPIDUM, Siebold.}

\section{(Bot. Mag., t. 8329 ; Halesia hispida, Masters.)}

A deciduous shrub, 15 to $20 \mathrm{ft}$. high, or a tree up to 30 or $40 \mathrm{ft}$. high, of coarse, vigorous growth and spreading habit; young shoots smooth. Leaves 
alternate, 3 to 8 ins. long, $1 \frac{1}{2}$ to 4 ins. wide; oval or obovate, wedge-shaped at the base, pointed, toothed, covered beneath with fine whitish down or nearly smooth; stalk $\frac{1}{2}$ to $I$ in. long. Flowers white, fragrant, produced during June and July on axillary, downy, pendulous panicles, 4 to 9 ins. long, 2 to 3 ins. wide, with often two or three leaves at the base. Corolla of five oval lobes, divided almost to the base, finely downy on both sides, $\frac{1}{3}$ in. long. Stamens, flower-stalks, and calyx downy. Fruit spindleshaped, $\frac{1}{2}$ in. long, terminated by the persistent calyx-lobes and style, the whole densely clothed with pale brown hairs $\frac{1}{12}$ in. long.

Native of Japan and China ; introduced in 1875. This beautiful and striking tree is very hardy and flowers almost every year, but most profusely when the preceding summer and autumn have been hot. It needs a good loamy soil and a sunny position. Seed is ripened occasionally, and this affords the simplest and best means of propagation. The finest trees I have seen are in the neighbourhood of Queenstown, Ireland, 30 to $40 \mathrm{ft}$. high, and as much in diameter.

So far as I am aware, $P$. hispidum is at present the only species in cultivation, although it is often found under the name of " $P$. corymbosum." The true species of that name is very

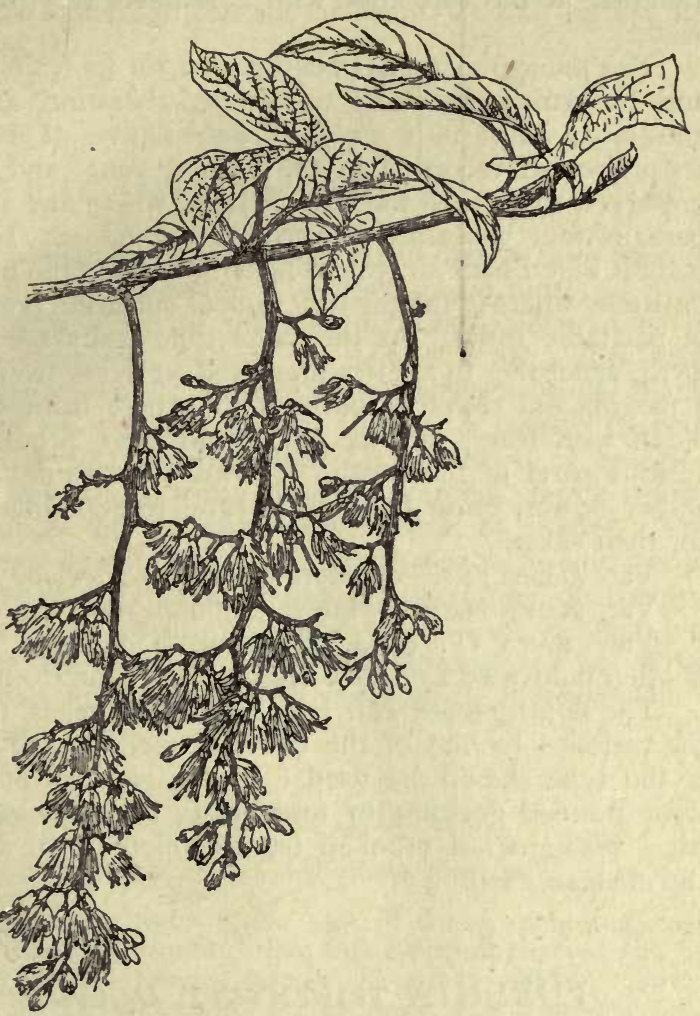

Pterostyrax hispidum. clearly distinguished

from hispidum by the fruit, which is $\frac{1}{2} \mathrm{in}$. long, $\frac{1}{3}$ in. wide, five-winged (not merely ribbed as in hispidum), and covered with a very close down (not hairy). The panicles are also broader. Native of Japan, farther south than P. hispidum, and probably not so hardy.

PUNiCA Granatum, Linncus. Pomegranate. lythracel. (Bot. Mag., t. I832.)

A small deciduous tree, up to $\mathrm{I}_{5}$ or $25 \mathrm{ft}$. high, free from down in every part, often spiny. Leaves mostly opposite, narrow oblong, entire; $\mathbf{I}$ to 3 ins. long, $\frac{1}{3}$ to $\mathbf{I}$ in. wide; stalks very short. Flower scarlet- 
red, I to $\mathrm{I} \frac{1}{2}$ ins. across, scarcely stalked, terminal on short side twigs, and often in pairs. Petals crumpled, normally five but often more; calyx with five or more lobes, and a funnel-shaped base to which the very numerous stamens are attached. Fruit rarely ripened in this country, deep yellow, roundish, $2 \frac{1}{2}$ to 3 ins. across, with the calyx-lobes adhering at the top, filled with a reddish, very juicy pulp and numerous seeds.

The pomegranate has been grown for its fruits in the south of Europe and N. Africa eastwards to Persia, Palestine, and India from remote antiquity. But it is probably only native of Persia and Afghanistan. Its praises are recorded in the earliest songs and writings that have been preserved to us. In the British Isles, where the tree has been grown for perhaps four centuries, ripe fruit is denied us. In the open ground the plant is killed back to ground-level in any but the mildest winters, and even on walls, where it thrives well, lack of sunshine precludes the development of palatable fruits. At the same time fruits are occasionally borne: in I 874, according to a letter preserved at Kew from Lady Rolle of Bicton, a magnificent tree that covered the whole front of a house in Bath was laden with fruit; and in Igr I fruits were produced, if not ripened, in various parts of the south. Grown on a sunny south wall, it bears its showy flowers quite freely from June to September, and is worth growing for their sake.

Var. ALBESCENS.-Flowers white or yellowish.

Var. FLORE PLENO.-Flowers double red; the showiest form.

Var. Nana (P. nana, Linncus). - Shrubby, with linear leaves. It is often cultivated as a flowering plant on the Continent.

The pomegranate can be raised from seeds, cuttings, or by grafting; the varieties by one of the two last methods; if grafted, seedling stocks of the type should be used. In the gardens of Versailles, visitors will have noticed growing in tubs many remarkable, very old pomegranate trees, with gnarled, crooked trunks which to all appearance are as old as the chateau itself.

\section{PURSHIA TRIDENTATA, De Candolle. ROSACEA.}

(Bot. Reg., t. I446.)

A low deciduous grey shrub, 3 to $6 \mathrm{ft}$. high in cultivation, but occasionally $\mathrm{r} \circ \mathrm{ft}$. in a wild state; young branchlets downy. Leaves wedge-shaped or obovate, $\frac{1}{4}$ to $\frac{5}{8}$ in. long, $\frac{1}{8}$ to $\frac{1}{4}$ in. wide towards the apex, where it is cut into three large, rounded teeth, tapering gradually towards the base; covered with white down beneath; grey-green and downy above. Flowers yellow, almost stalkless, produced in May, usually singly from buds on twigs of the previous year's wood; calyx covered with grey down, intermixed with gland-tipped hairs, funnel-shaped, five-lobed; stamens numerous, arranged in a ring. Each flower in about $\frac{1}{3}$ in. wide. Fruit $\frac{1}{2}$ in. long, downy, crowned with the persistent style.

Native of Western N. America, from British Columbia to California; introduced by Douglas in 1826, first flowered in the Horticultural 
Society's Garden in 1830 . According to Loudon, all the plants about London were killed during the winter of $1837-8$, but plants have grown unsheltered in a border at Kew for over twenty years. It is not a very attractive shrub, although curious and interesting. It prefers a rather light soil, and can be propagated by layers. The genus, of which two species are known, was named in honour of Fred. Pursh, author of a flora of N. America (18I4).

\section{PYRACANTHA. ROSACEA.}

The three species whose descriptions are given below have been by various authors placed in Cotoneaster, Mespilus, and Cratægus. They are, no doubt, most closely allied to the last, differing chiefly in having leafy thorns, in being evergreen, and in the leaves being either entire or merely toothed, never lobed. There are also differences in the ovules. From Cotoneaster they are equally distinct in having thorny branches and toothed leaves. For the rest they may be described as evergreen shrubs with alternate leaves and white flowers; stamens about twenty; styles five. Fruits globose or orange-shaped, yellow, or scarlet. They are easily satisfied as regards soil, thriving in any that is warm and not too heavy. P. coccinea is the only species that can be grown in the open ground; the other two need wall protection to be seen at their best, except some forms or allies of P. crenulata introduced by Wilson and Forrest from China. Propagation is by seeds, or by cuttings made of firm leafy twigs in late summer.

\section{P. angustifolia, C. $K$. Schneider.}

\section{(Bot. Mag., t. 8345; Cotoneaster angustifolia, Franchet.)}

An evergreen shrub probably 10 or $12 \mathrm{ft}$. high, of dense, spreading, bushy habit ; branches rather rigid, horizontal, often spine-tipped, covered the first year with a thick, grey down. Leaves narrow oblong or slightly obovate, rounded or tapered at the base, rounded at the apex with a minute tip or slight notch there; the larger leaves have a few minute dark stiff teeth near the apex, the smaller ones mostly entire; they are $\frac{1}{2}$ to $2 \frac{1}{4}$ ins. long, $\frac{1}{8}$ to $\frac{1}{2}$ in. wide, smooth, dark green above, covered beneath with a grey felt; stalk $\frac{1}{1}$ to $\frac{1}{4}$ in. long. Flowers white, $\frac{1}{4}$ in. across, in corymbs 2 ins. wide, of little beauty; calyx and flower-stalk felted. Fruit brilliant orange-yellow when ripe, covered with grey down when young, $\frac{1}{4}$ to $\frac{3}{8}$ in. in diameter, much flattened at the top; seeds five.

Native of W. China ; introduced to Kew by Lieut. Jones in 1899 , and again a few years later through Mr de Vilmorin. I saw it in great beauty at Les Barres in 1908, loaded with fruit, and the whole plant much more woolly than it is in Great Britain. After the hot summer of I9I I, a plant on a wall at Kew bore fruit very freely, and at Glasnevin, Dublin, in February 1913 , it was finely in fruit against a wall. It is quite tender in the open ground. Its round-ended, nearly or quite entire leaves, and dense woolliness readily distinguish it from the two other species. It is valuable in retaining its berries in full beauty until March, long after those of $\mathrm{P}$. coccinea have fallen. 


\section{P. Coccinea, Roemer. Pyracanth, Buisson Ardent.}

(Cratægus Pyracantha, Medicus.)

An cvergreen shrub or small tree, up to $15 \mathrm{ft}$. high, of very dense, leafy habit; young shoots covered with grey down, the slender thorns $\frac{1}{2}$ to $\frac{3}{4}$ in.

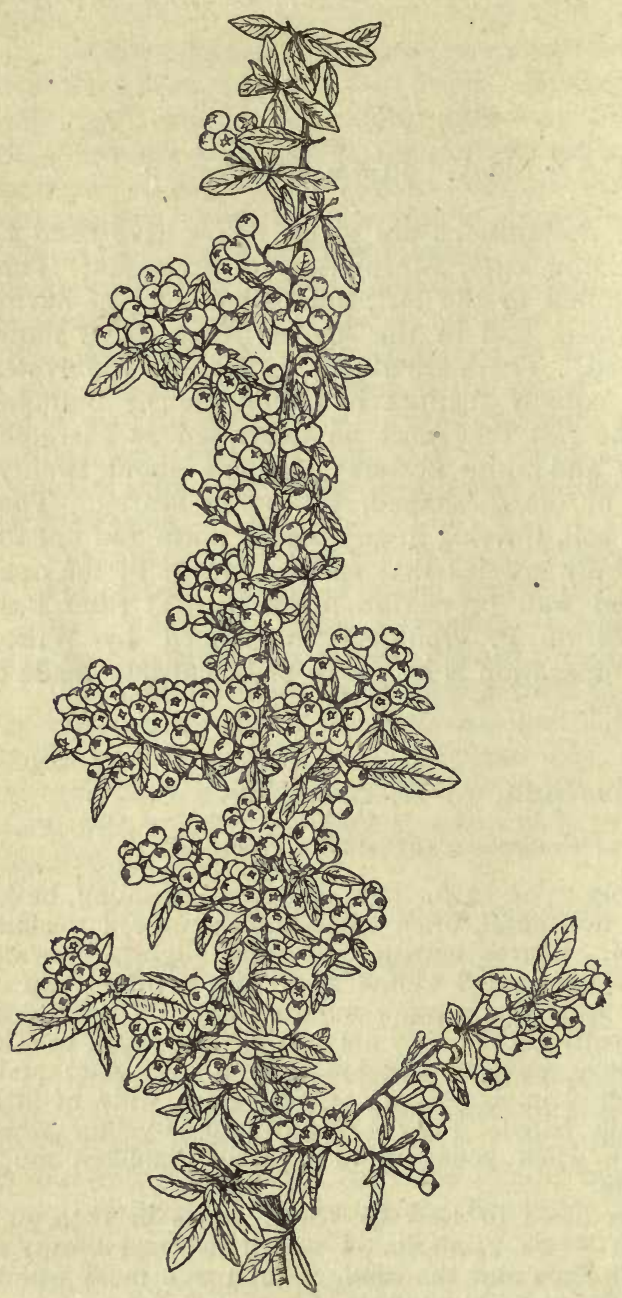

Pyracantha coccinea. long ; branches often thorntipped. Leaves narrowly obovate or oval, tapered at both ends, blunt-toothed; I to $2 \frac{1}{2}$ ins. long on the barren shoots, $\frac{1}{2}$ to $I \frac{1}{2}$ ins. long on the flowering ones, varying from $\frac{1}{4}$ to $\frac{3}{4}$ in. wide: dark glossy green above, paler beneath, smooth except at the margins near the base; stalk $\frac{1}{3}$ in. or less long, downy. Flowers white, $\frac{1}{3}$ in. across, very numerously borne in early June in corymbs terminating short twigs which, springing from the shoots of the previous year, form one large panicle ; flower-stalks and calyx slightly downy ; calyxlobes broadly triangular. Fruit brilliant coral-red, orange-shaped, about $\frac{1}{4}$ in. across.

Native of S. Europe and Asia Minor; introduced in 1629. This well-known evergreen is more often seen growing against a wall than in the open, and no doubt bears fruit more abundantly there. It is, in fact, one of the most desirable of evergreen wall shrubs. But when once established it is quite hardy in the open ; at Kew there are specimens I $5 \mathrm{ft}$. high that bear fruit profusely. The shrubs have to be netted, as birds (blackbirds especially) are very greedy for the fruits. The pyracanth should be used more than it is as an evergreen shrub. It bears pruning well, and its only

defect is that it transplants badly except when young.

Var. LALANDEI, Dippel.-A variety raised from seed by M. Lalande of Angers about 1874. It is of more vigorous, upright growth than the type, and has leaves of proportionately greater width on the average, as well as larger 
fruits of a more yellowish red, or orange. There is a white-fruited form (FRUCTU-ALBO) ; and one described as dwarf and of spreading, close-branched habit, bearing fruit sparsely (PAUCIFLORA, Dippel). I have not seen the former.

\section{P. Crenulata, Roemer. Nepalese White Thorn. \\ (Cratægus crenulata, Roxburgh; Bot. Reg., vol. 30, t. 52.)}

Nearly allied to the common pyracanth (P. coccinea), this differs chiefly in the leaves being rounded instead of tapered and pointed at the apex, and in the smaller flowers and fruit. The leaves are ultimately quite smooth, narrowoblong or obovate, up to $2 \frac{1}{2}$ ins. long, $\frac{5}{8}$ in. wide, rounded, but with a short bristle-tip. The styles differ from those of $\mathrm{P}$. coccinea in being more separated at the base. Fruit orange-yellow. It is a large, more or less thorny bush, and can scarcely be regarded as more than a variety of $\mathrm{P}$. coccinea. It is, however, much slower in growth and more tender. Being quite inferior to the European pyracanth, it is rarely seen in cultivation. It needs a south wall. Native of Temperate Himalaya. Plants raised from recently introduced W. Chinese seed may prove hardier, and seem to differ in the leaves being nearly always entire. Mr Forrest has also recently collected a Pyracantha in W. China with reddish young twigs and small leaves (about $I$ in. long) which seems to be a distinct species.

\section{PYRUS. ROSACEA (POMACEA).}

The more recent monographers of the Pomacex (the tribe of the rose family which includes the pears, apples, whitebeams, etc.) mostly concur in restoring the older genera, such as Pyrus (proper), Malus, Sorbus, etc., which were united by Bentham and Hooker in their Genera Plantarum. Although this course has many justifications (for one can scarcely regard the mountain ash, for instance, as having much in common with the pear), I have thought it best to retain the generic term PYRUs for all the sections except Mespilus and Cydonia. Any other course would create much confusion in this country, where over forty years' recognition of Bentham and Hooker's work has given the term Pyrus, as interpreted by them, a general acceptance in gardens and nurseries. This course has the further convenience of providing a common name for the numerous hybrids between the different groups, and thus avoiding the use of such newly concocted names as "Sorbopyrus," "Sorbaronia," etc. For the purpose of helping towards the identification of the species a definition of each section is given below. All the species are deciduous and have alternate leaves.

All the Pyruses like a loamy soil, and most of them thrive on one of a calcareous nature. The propagation of the various group is discussed under each, but it may be mentioned here that the pips germinate more quickly if taken from the fruit as soon as ripe and sown at once, than if collected in packets and dried.

\section{PYRUS PROPER (Pyrophorum). Pears.}

Trees with simple leaves and top-shaped or globose fruits rarely indented at the junction with the stalk. Styles free. None of this 
section is native of the New World: amygdaliformis, betulafolia, canescens, communis, cordata, elcagrifolia, glabra, heterophylla, Kotschyana, longipes, Michauxi, nivalis, Pashia, salicifolia, sinaica, sinensis. $P$. auricularis and $P$. malifolia are hybrids between this group and the Aria group.

The true pears include some of the tallest and bulkiest trees in the genus, but the species as a whole have not such striking attributes for the garden as some of the other sections. Their flowers are often beautiful, but they have little attractive colouring in fruit, and the leaves frequently die off black. Some, like P. salicifolia and P. nivea, are particularly effective in their young expanding foliage, being covered with a snowy white, thick down. The pears, although represented in N.E. Asia, are more particularly identified with Europe-especially S. and E. Europe-Asia Minor, and N. Africa. In that region there is a strong group, of which P. amygdaliformis, nivalis, salicifolia, and glabra are leading types. Seeds ripen freely, but owing to the hybrid origin of some it is safer to graft the various sorts on their own or nearly allied seedlings - especially as many cultivated trees are of selected forms that could not be relied on to come true from seed.

\section{ARIA. Whitebeams.}

(Often united with Aucuparia and Aronia as SoRBus.)

Trees and shrubs with simple leaves having distinct parallel veins, and mostly more or less felted beneath. Styles free. Fruit in broad, flat clusters. A group with the fruits pitted at the apex and with the calyx fallen away have been separated under the name Micromeles.

Aria, Chamamespilus, Hostii, intermedia, latifolia, minima, Mougeoti, Torminalis, vestita. To the Micromeles section belong: alnifolia, caloneura, Folgneri. There are also the following hybrids:-

With the Aucuparia group - decurrens, Meinichii, Neuillyensis, pinnatifida.

With the Aronia group-alpina, Dippelii.

With the Pyrophorum group-auricularis, malifolia.

The species belonging to the Aria group are as a rule handsome in their large leaves, often white beneath, and in their fine masses of brightly coloured fruit. The flowers are often of short duration. This group is particularly well adapted for soil of a calcareous nature, most of them occurring wild on a limestone formation. At the same time they thrive in ordinary garden soil. In nurseries they are chiefly grafted on mountain ash or white thorn, but plants raised from seed, although slow in their early stages, are best in the long run. Between the leading species of this group (P. Aria) and that of the next (P. Aucuparia) there is a whole series of hybrid forms, some of natural origin. The first cross was apparently P. pinnatifida, and from this, either by reversion to P. Aucuparia or by recrossing with it, has been obtained $\mathrm{P}$. decurrens and other forms, all of which show their affinity to P. Aria in the felted under-surface of the leaf, and to P. Aucuparia by having the leaves partly pinnate at the apex. 


\section{AUCUparia. Mountain Ash, Service.}

Trees with pinnate leaves. Fruit except in P. Sorbus resembling that of Aria: americana, Aucuparia, sambucifolia, scopuiina, Matsumurana, Sorbus, thianshanica, Vilmorinii. This well-marked group includes some of the handsomest species, especially in regard to fruit and foliage. Many are of elegant habit. They are propagated by seed, or by grafting on seedlings of their own group. The Service tree (P. Sorbus) is distinct because of its fewer, large, dull-coloured, and normally pear-shaped fruits, as compared with the small brightly coloured round fruits of the mountain ashes. P. spuria is a hybrid with the Aronia group. (See also note under preceding section as to hybrids with Aria.)

\section{ARONIA OR ADENORACHIS. CHOKEBERRIES.}

Two North American shrubs with simple leaves bearing glands on the upper surface of the midrib. Fruits small, red or black: arbutifolia, melanocarpa. These are handsome, deciduous shrubs forming a dense thicket of stems; propagated by division, by cuttings, or by seeds.

\section{MAlUS. Crabs.}

Trees and shrubs with simple, sometimes deeply lobed leaves; rounded or somewhat cone-shaped fruits, with usually a cavity where the stalk is inserted. Styles joined at the base: angustifolia, baccata, coronaria, cratagifolia, floribunda, Halliana, ioensis, Malus, Niedwetzkyana, prunifolia, Ringo, rivularis, Sargentii, Scheideckeri, sikkimensis, spectabilis, Toringo, and Zumi.

As ornamental trees, and especially in regard to flower, the crabs rank first among all the groups of Pyrus. In all the range of flowering trees and shrubs there is nothing more beautiful and effective than the best of this group, such as P. floribunda, Scheideckeri, spectabilis, etc. In regard to fruit also it includes some particularly valuable species, such as P. baccata, P. prunifolia, P. Ringo, etc. The Malus group is peculiarly liable to attacks of the white woolly aphis, known as American blight, and scale insects. A winter dressing of the caustic soda wash should be applied, and in summer a spraying with an emulsion of paraffin and soap. So far as I am aware, there is no hybrid between this group and any other of the sections of Pyrus, and the fact that it will not intergraft with them seems to show that a greater gap separates it from them than the older botanists imagined, and that there is good ground for treating it as a distinct genus. The various members have hybridised with each other very freely, so that with many one cannot rely on seeds reproducing the parent exactly. The following species, for instance, are all linked together by a series of hybrids: Malus, baccata, prunifolia, Ringo, and Toringo. Some, probably most of them, can be rooted from cuttings made of leafless shoots in early winter, and put in 
a cold frame, but most of them are increased by grafting on the various crab and apple stocks used in nurseries for garden apples.

\section{ERIOLOBUS.}

Very like Malus in general characters, the styles being united at the lower third, but the flesh of the fruit is "gritty," like that of some pears: trilobata, Tschonoski.

\section{P. ALNIFOLIA, Franchet.}

(Bot. Mag., t. 7773 ; Micromeles alnifolia, Koehne.)

A deciduous tree of rather slender, erect habit, ultimately 40 to $50 \mathrm{ft}$. high ; branchlets furnished with short silky hairs when quite young. Leaves of thin texture; $I \frac{1}{2}$ to 3 ins. long, $\frac{3}{4}$ to $I \frac{1}{2}$ ins. wide; the apex pointed, the base rounded, margins double-toothed; nerves parallel in seven to twelve pairs, silky-hairy beneath when young, becoming smooth later; stalk $\frac{1}{2}$ to $\frac{3}{4}$ in, long. Flowers white, $\frac{1}{2}$ in. diameter, produced during May in corymbs 2 to 3 ins. across ; calyx and flower-stalks silky. Fruit $\frac{1}{3}$ to $\frac{1}{2}$ in. long, oval, bright red, no calyx adhering at the top.

Native of Japan and Corea ; put in cultivation by Mr Späth of Berlin about 1892 , but may have been known before. It is one of the neatest and most pleasing of the Micromeles group, and is very appropriately named. The leaves are bright green beneath, and bear a close resemblance to those of an alder. Fine crops of fruits ripen, and they become very brightly coloured, and remain long on the tree, but only a small proportion contain good seeds. Very deserving of cultivation.

\section{P. Americana: De Candolle. American Mountain Ash.}

(Sorbus americana, Marshall.)

A tree 15 to $25 \mathrm{ft}$. high, ultimately forming a narrow, rounded head of slender branches; young shoots smooth or slightly downy only at first; winter buds $\frac{3}{4}$ in. long, sharply pointed, gummy, with a tuft of hairs at the apex. Leaves pinnate, 6 to 12 ins. long, composed of eleven to seventeen leaflets, which are $1 \frac{1}{2}$ to 3 ins. long, $\frac{1}{2}$ to $\frac{3}{4}$ in. wide, narrowly oblong-lanceolate, pointed, evenly saw-toothed except at the base, smooth except when quite young; stalkless or nearly so. Flowers creamy white, about $\frac{1}{6}$ in. across, produced about the beginning of June in flattish corymbs 3 to 5 ins. across; calyx and flower-stalk smooth, or slightly downy ; calyx-lobes short, triangular. Fruit bright red, $\frac{1}{4}$ in. across, slightly longer than broad.

Native of Eastern N. America, from Newfoundland to Virginia. It is a close ally of the European mountain ash, but has larger leaves and smaller flowers, and is much less downy in its various parts; in winter it is easily distinguished by its sticky, only slightly downy buds. It fruits freely in this country, and its bunches of berries are as handsome as those of the rowan tree, but it does not thrive so well. Loudon in 1837 observed that although it was introc'uced in 1782 , he knew of no large old specimen. It is quite hardy, and grows rapidly in a small state.

Var. DECORA, Sargent.-Said by Sargent to be the finest form of P. americana. "Fruits bright scarlet, often $\frac{1}{2}$ in. in diameter." Leaflets fewer, larger, and broader than in the type. It appears to cover some of the same country, and may have been introduced as ordinary P. americana, 
but I do not remember to have seen fruits $\frac{1}{2}$ in. across on trees in cultivation. It is one of the various American mountain ashes known as " $\mathrm{P}$. sambucifolia."

\section{P. AMYGDALIFORMIS, Villars.}

A small tree occasionally $20 \mathrm{ft}$. or more high, or a large rounded shrub; branches sometimes terminated by a spine; young shoots slightly woolly at first. Leaves very variable in shape and size ; oval, ovate, or obovate; $1 \frac{1}{2}$ to $2 \frac{1}{2}$ ins. long, $\frac{1}{2}$ to $\frac{3}{4}$ in. wide; wedge-shaped or rounded at the base, the margins very slightly round-toothed; covered with silky hairs when young, but becoming smooth and lustrous above, and almost or quite smooth beneath; stalks slender, $\frac{1}{2}$ to $I_{\frac{1}{2}}$ ins. long. Flowers white, I in. across, produced in April in corymbs $1 \frac{1}{2}$ to 2 ins. across, carrying eight to twelve flowers; calyx white, woolly. Fruit rather orange-shaped, $\frac{3}{4}$ in. long, $I$ in. wide, yellowish brown, produced on a short, thick stalk.

Native of S. Europe, especially on the countries bordering the northern shores of the Mediterranean. It has no particular merit in the garden except that in age it makes a quaint and picturesque tree; from its ally, P. salicifolia, it differs in its nearly smooth leaves.

Var. CUNEIFOLIA is a name sometimes given to the form with small narrow leaves whose base is slender and tapering.

Var. OBLONGIFOLIA (P.oblongifolia, Spach). -This represents another extreme, with oblong or oval leaves,

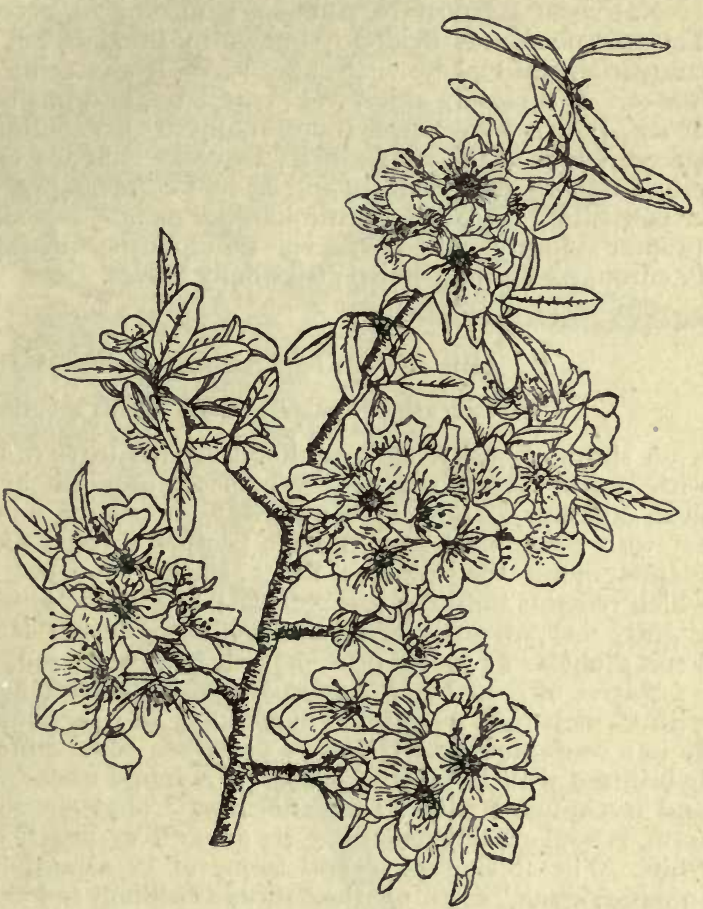

PYRUS AMYGDALIFORMIS.

rounded at the base, the stalk $I$ to $I \frac{1}{2}$ ins. long. Fruit yellowish, tinged with red on the sunny side, considerably larger than in P. anygdaliformis. It is common in Provence, and known there as the "Gros Perrussier." Perhaps a hybrid between P. amygdaliformis and P. nivalis.

P. SinAICA, Dumont de Courset, is allied to P. amygdaliformis, but has larger leaves and longer-stalked fruits, which are round and rather flattened. It is not a native of Sinai, in spite of its name, but is believed to originate from Asia Minor orithe islands of the Grecian Archipelago. Its leaves, as in the rest of this group, are white with down in spring, becoming smooth and shining later. 


\section{P. ANGUSTIFolia, Aiton.}

(Malus angustifolia, Michaux.)

A small tree, semi-evergreen in mild winters, $20 \mathrm{ft}$. or more high ; shoots smooth except when quite young. Leaves oval or oblong, sometimes lanceolate; $\mathrm{I}$ to 3 ins. long, $\frac{1}{2}$ to $\mathrm{I} \frac{3}{4}$ ins. wide ; dark shining green above, paler beneath, and nearly or quite smooth when fully grown; base usually tapering, margins coarsely toothed, especially towards the apex. On the flowering twigs the leaves are small, I to $I \frac{1}{2}$ ins. long, oblong, and entire, or with a few teeth only towards the apex. Flowers fragrant like violets, rosy or almost white, I to $I \frac{1}{4}$ ins. across, produced usually in clusters of four ; each flower on a slender stalk, $I$ to $\mathrm{I} \frac{1}{2}$ ins. long; calyx teeth white, woolly inside. Fruit $\frac{3}{4}$ in. across, yellowish green, fragrant, harsh, acid.

Native of Eastern N. America ; introduced, according to Aiton, in 1750. The true plant was evidently known to Loudon, but it had disappeared from cultivation until a few years ago, when it was reintroduced from the United States. It is closely allied to $\mathbf{Y}$. coronaria, and has been regarded as a variety of it. It has, however, a more southern distribution in a wild state, and is quite distinct in the shape of its leaves, which are only about half as wide in proportion to their length, and have wedge-shaped bases. The tree known in cultivation as " $\mathrm{P}$. angustifolia flore pleno" is a double-flowered variety of another closely allied species-P. ioensis-distinguished from this and P. coronaria by the persistently woolly leaves.

\section{P. ARBUTIFOlIA, Linnaus fil. CHOKEBERRY.}

(Sorbus arbutifolia, Heynhold; Aronia arbutifolia, Medicus.)

A shrub of bushy, vigorous habit, from 5 to ro ft. high ; branchlets covered with down, which persists over the winter. Leaves narrowly obovate or oval, tapering at both ends; $1 \frac{1}{2}$ to $3 \frac{1}{2}$ ins. long, $\frac{1}{2}$ to $\frac{3}{4}$ in. wide ; the margins set with even, black-tipped teeth; upper surface dark dull green, with dark glands along the midrib; lower surface covered with a thick grey felt, which remains until the leaf falls ; stalk $\frac{1}{3}$ in. or less long. Flowers white, or slightly rosy, about $\frac{1}{2}$ in. across, produced during late May in small corymbs. Fruit globular or rather pear-shaped, $\frac{1}{4}$ in. wide, red.

Native of Eastern N. America ; cultivated in England since I700. Along with P. melanocarpa $(q . v$.$) it constitutes the section of Pyrus called ARONIA.$ It is a variable plant (Loudon describes some nine or ten forms), and has hybridised with P. melanocarpa. It is found under several names in gardens, and is confused with P. melanocarpa. That species, however, in its typical form, is well distinguished by its smooth or nearly smooth leaves and black fruits. The foliage of several forms of $\mathrm{P}$. arbutifolia, especially one grown in nurseries as "erythrocarpa," turns a brilliant red before falling. The species is indeed worth growing for its autumn colour alone.

\section{P. ARIA, Ehrhart. Whitebeam.}

(Sorbus Aria, Crantz; Aria nivea, Host.)

A tree usually 30 to $45 \mathrm{ft}$. high in gardens, but occasionally met with 60 to $80 \mathrm{ft}$. high; main branches more or less erect; young branchlets clothed with loose white down, becoming nearly smooth and lustrous dark brown by winter, and furnished with pale, wart-like excrescences. Leaves with eight to thirteen pairs of parallel ribs, oval or obovate ; 2 to 4 ins. long, half to twothirds as wide ; usually tapering, but sometimes rounded at the base, pointed 
or rounded at the apex; margins doubly toothed; upper surface bright green, smooth except when quite young; always covered with a close white felt beneath; stalk $\frac{1}{2}$ to I in. long. Flowers dull white, heavy scented, about $\frac{1}{2}$ in. across, and produced towards the end of May in corymbs 2 to 3 ins. across ; stalks and calyx covered with white down. Fruit oval or roundish, $\frac{1}{3}$ to $\frac{1}{2} \mathrm{in}$. long, scarlet-red specked with brownish dots.

Native of the British Isles and pretty general over Europe, also found in some of its forms in Asia Minor and N. Africa. There is no tree more

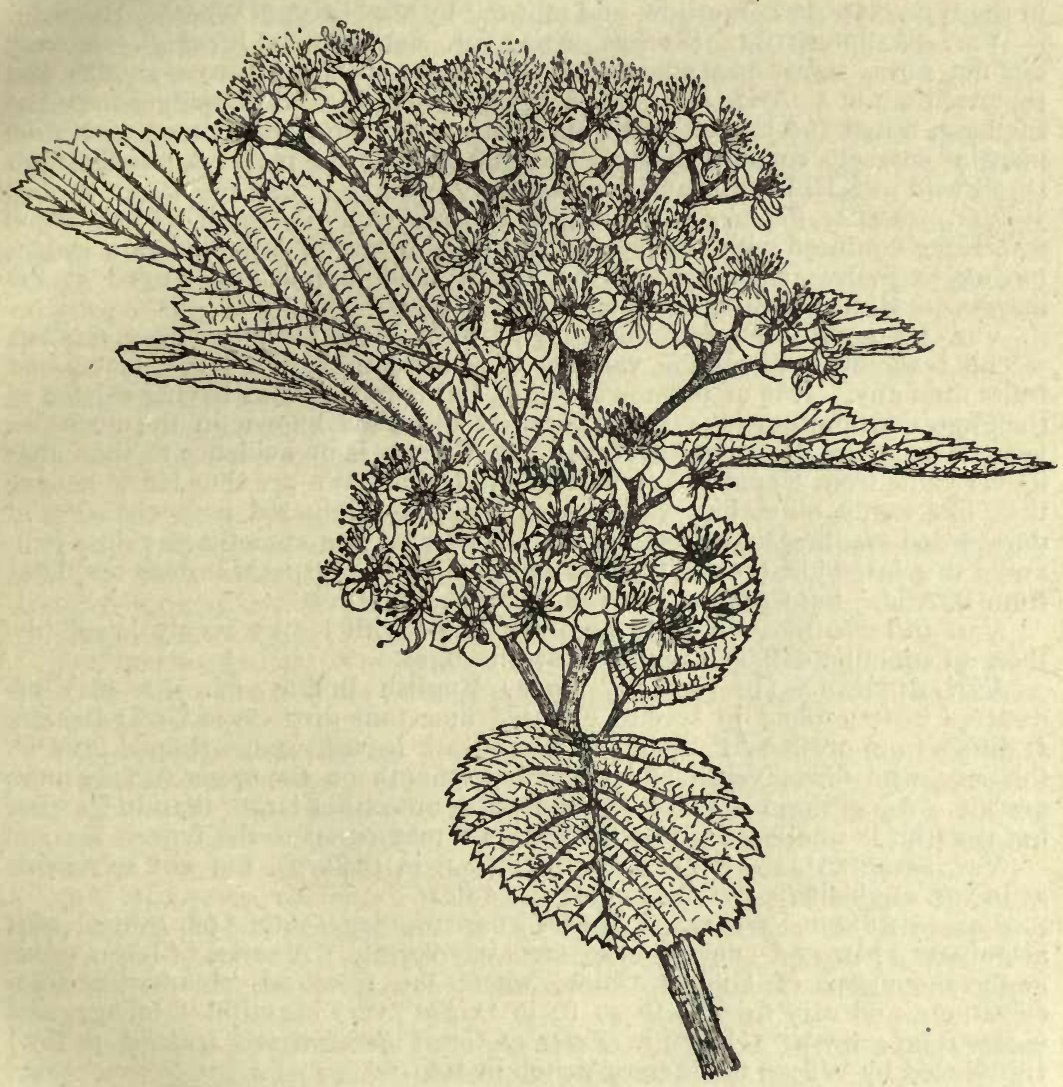

Pyrus Aria.

characteristic of the chalk hills of Britain or more beautiful in regard to foliage and fruit, but it is often reduced to a mere shrub. It is very effective in the breeze when the wind, by lifting the leaves, reveals the pure white undersurface to the observer in kaleidoscopic glimpses. Although apparently preferring the limestone in a state of nature, it thrives quite well under cultivation in almost any well-drained soil. A tree well laden with the bright red fruits is also one of the most beautiful of autumn pictures; only, owing to the depredations of birds, often of short duration. It is best propagated by 
seeds, but the young plants grow very slowly at first. The timber is hard and heavy, but is too scarce to count for much in the timber trade. The largest tree recorded by Elwes is at Camp Wood, near Henley-on-Thames, which in 1905 was $75 \mathrm{ft}$. high by $4 \mathrm{ft}$. 9 ins. in girth of trunk. The whitebeam has many varieties, some wild, others of garden origin. The most distinct are as follow:-

Var. ANGUSTIFOLIA, Lindley.-Leaves narrow, ovate-lanceolate, base very tapering, always more than twice as long as wide.

Var. CHRYSOPHYLLA.-Leaves yellow all the season, rather narrower than in the type. Of garden origin, and sent out by Mr Hesse of Weener, Hanover.

Var. FLABELLIFOlIA (Sorbus Aria var. flabellifolia, Wenzig).-A very distinct form, sometimes made into a separate species. Leaves smaller and rounder than in P. Aria, snow-white beneath, nearly always wedge-shaped at the base, broad and jagged at the apex, ribs rarely more than six on each side, margins coarsely cut and toothed except at the lower part. A small tree or shrub wild in S.E. Europe and Asia Minor.

Var. GRECA, Boissier (Sorbus græca, Loddiges).-A small tree or shrub sometimes confused with the preceding, but with larger, broadly ovate leaves, having as many as ten ribs on each side, and less deeply jagged at the margins. Native of S.E. Europe.

Var.: MAJesticA, Prain; Bot. Mag., t. 8184 (Aria Decaisneana, Lavallée). -This is the finest of all the varieties of whitebeam, having larger leaves and fruits than any. It is of unknown origin, but is recorded as having existed in the Segrez Arboretum in 1858. It was at one time known in the nurseries near Paris as the "Sorbier du Nepaul," but there is no evidence to show that it ever came from Nepal or any part of $\mathrm{N}$. India. We are thus led to believe that, like many other fine varieties of trees, it originated as a chance and unrecorded seedling under cultivation. Its leaves are sometimes 7 ins. long and 3 to 4 ins. wide, the fruits $\frac{5}{8}$ in. long. In other respects it does not differ from P. Aria. Sometimes known as "Sorbus majestica."

Var. QUERCOIDES. - A form of dwarf habit with leaves evenly lobed like those of common oak, and upturned at the edges.

Var. RUPICOLA (P. rupicola, Syme; English Botany, ed. 3, t. 48I).-A dwarfed variety found in several elevated limestone districts of Great Britain. It differs from ordinary P. Aria in the obovate leaves, wedge-shaped towards the base, with fewer veins, and becoming smooth on the upper surface more quickly. According to Mr Syme, the flowers are rather larger than in P. Aria, but the fruit is smaller. Under cultivation it may revert to the type.

Var. SALICIFOLIA. - Leaves narrower than in the type, but not so narrow as in var. angustifolia ; stalks longer as a rule.

Var. SINENSIs, Henry. - "Leaves narrow, lanceolate or ovate, with acuminate apex and cuneate base, crenately serrate. A series of forms occur in the mountains of Hupeh, China, where the trees are common at high elevations, and vary from Io to $40 \mathrm{ft}$. in height ; very beautiful in foliage, and vigorous in growth." (Henry in Trees of Great Britain and Ireland, p. 167.) Introduced by Wilson for Messrs Veitch in I90I.

Var. SULPHUREA. - Leaves as in the type, but pale yellow.

All the varieties are best grafted on stocks of $\mathrm{P}$. Aria, but owing to its slow growth from seed, stocks of mountain ash or even hawthorn are preferred.

\section{P. Aucuparia, Gaertner. Mountain Ash, Rowan.}

(Sorbus Aucuparia, Linnaus.)

A deciduous tree, 30 to $60 \mathrm{ft}$. high, of erect growth when young, becoming more spreading and graceful with age; trunk smooth and grey; branchlets 
downy when young, becoming glabrous later; terminal bud very downy throughout the winter, not gummy. Leaves pinnate, 5 to 9 ins. long, composed usually of six and a half or seven and a half pairs of leaflets (sometimes more or less); leaflets narrowly ovate-oblong, I to $2 \frac{1}{2}$ ins. long, smallest towards the apex, pointed, sharply toothed, downy beneath when young, becoming almost or quite smooth by the autumn. Flowers white, $\frac{1}{3}$ in. across, produced very numerously in terminal, flattish corymbs 3 to 5 ins. across; calyx and flower-stalks clothed with grey wool. Fruits in large showy clusters, about $\frac{1}{4}$ in. across, round or slightly oval, bright red.

The mountain ash is widely spread over the cool, temperate parts of Europe and Asia, and is abundant in most parts of the British Isles. It is one of the most beautiful of our native trees alike in leaf, flower, and fruit. Its beauty no doubt is greatest when the branches are laden with the large nodding clusters of ripe fruits in September, but where bird life is abundant that beauty soon passes. Of neat habit and never of large size, it is a useful tree in small gardens, for which, however, some of the varieties mentioned below might be selected, leaving the typical mountain ash for the larger spaces and woodland. It is easily raised from seed, and grows quickly when young. On this account young trees are much used as stocks for grafting varieties of this and allied species on. It likes a moist, cool situation, and is apt to scorch in hot summers in the Thames Valley unless associated with other trees. Of many varieties now in cultivation the following are selected as being most distinct :-

Var. ASPLENIFOLIA. - Leaflets more than usually downy, the marginal teeth twice as deep as in the type, frequently doubly toothed. A very pretty form.

Var. DIRKENI.-Leaves clear yellow when young.

Var. FASTIGIATA.-As already intimated, the mountain ash is usually erect-branched when young. In this variety this characteristic is more strongly marked and is permanent.' Raised at Dunganstown, Co. Wicklow.

Var. FRUCTU-LUTIO (Fifeana). - Fruits orange-yellow.

Var. INTEGERRIMA, Koehne.-A very distinct variety with leaflets quite entire or with a few obscure teeth near the apex only; young wood, leaf-stalks, and leaves woolly.

Var. LANUGINOSA (Sorbus lanuginosa, Kitaibel).-In Hungary and other parts of Eastern Europe is found this variety, whose leaves are covered with bristly hairs on the upper side and are very downy beneath, also on the inflorescence and young shoots. In other respects it resembles P. Aucuparia, and is not now considered anything more than a variety of that species.

Var. MORAvicA (dulcis). Moravian Mountain Ash.-A native of North Austria ; its fruit is larger than in the type, and is eaten in Germany and Austria. A form of it known as "laciniata," with deeply lobed, even pinnatifid leaflets, is perhaps the handsomest of mountain ashes as regards foliage.

Var. PENDULA.-Branches quite pendulous. There is a form of this whose leaves are spotted with yellow, called PENDULA VARIEGATA.

Var. SATUREIFOLIA.- Three upper leaflets united; all smooth beneath. Perhaps a hybrid between P. Aucuparia and pinnatifida.

P. MIINICHII is intermediate between P. Aucuparia and P. pinnatifida, and was introduced from Norway by the Earl of Ducie about 1904. P. NEUILLYENSIS is of similar origin. Both are very probably seedlings of pinnatifida $(q . v$.) reverted back in part to P. Aucuparia.

P. POHUASHANENSIS, Hance (Sorbus p. Hedlund), is an ally of P. Aucuparia, discovered in 1874 on the Po-hua mountain, N. China. It has the same woolly winter buds, but rather larger leaflets, and is chiefly distinguished by its stipules, which persist until the fruiting season. (In P. Aucuparia the stipules fall earlier.) Fruits $\frac{3}{8}$ in. diameter, bright red. 


\section{P. AUricularis, Knoop. Bollwyller Pear.}

\section{(P. bollwylleriana, De Candolle; Sorbopyrus auricularis, $C . K$. Schneider.)}

A deciduous tree, 20 to $40 \mathrm{ft}$. high (sometimes 50 to $60 \mathrm{ft}$.), forming a rounded bushy head; young branches more or less covered with loose down. Leaves ovate or oval, 3 to 4 ins. long, 2 to $2 \frac{1}{2}$ ins. wide ; pointed, irregularly and coarsely, sometimes doubly toothed; rounded or rather heart-shaped at the base ; upper surface covered at first with loose down which falls away as the season advances, lower surface permanently grey-felted; stalk I to $I \frac{1}{2}$ ins. long, woolly. Flowers white, 3 to $I$ in. across, produced about mid-May in many-flowered corymbs 2 to 3 ins. across; stamens rosy red; calyx with its triangular lobes covered with a conspicuous pure white wool. Fruit pear-

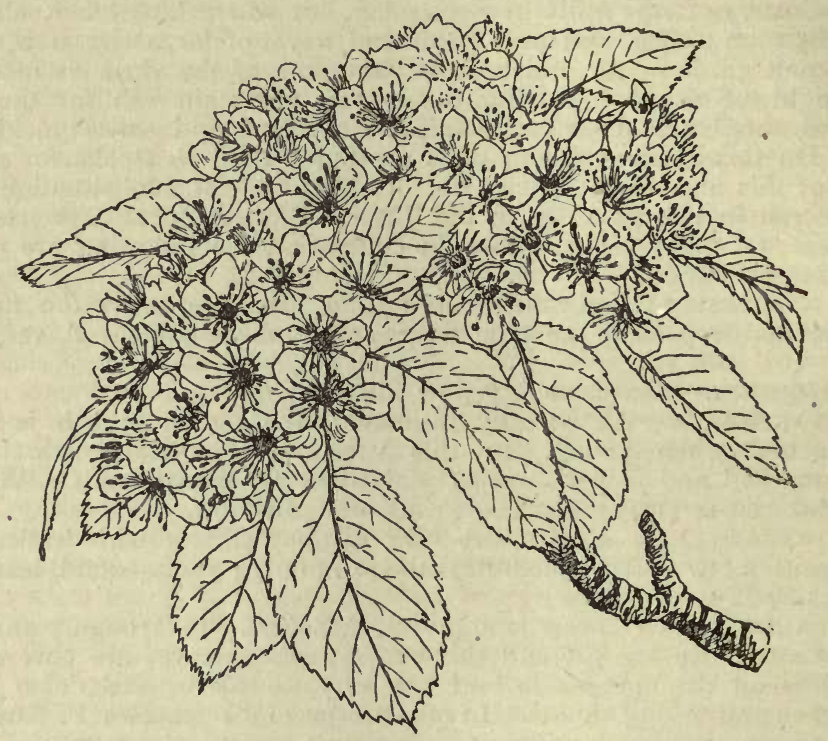

Pyhus AURICUlaris.

shaped, I to $I_{4}^{\frac{1}{4}} \mathrm{ins}$. long and wide, red, each on a stalk I to $\mathrm{I}_{2}^{\frac{1}{2}} \mathrm{ins}$. long, with sweet, yellowish flesh.

This interesting and remarkable tree is a hybrid between the common whitebeam (P. Aria) and the pear (P. communis). It is said to have originated at Bollwyller, in Alsace, and is first mentioned by Johannes Bauhin in 1610 and figured by him in 1650 . For three hundred years it has been propagated by grafts, for it produces very few fertile seeds, and these do not come true. The finest tree known to me is at Bramford Hall; Ipswich, which, according to information received from Lady Loraine in 1904 , was then over $60 \mathrm{ft}$. high.

\section{P. BacCata, Linnceus. Siberian Crab.}

(Bot. Mag., t. 6 II2; Malus baccata, Borkhausen.)

A tree 20 to $40 \mathrm{ft}$. high, forming a rounded, wide-spreading head of branches, the lower ones arching or pendulous at the extremities; trunk I to 2 


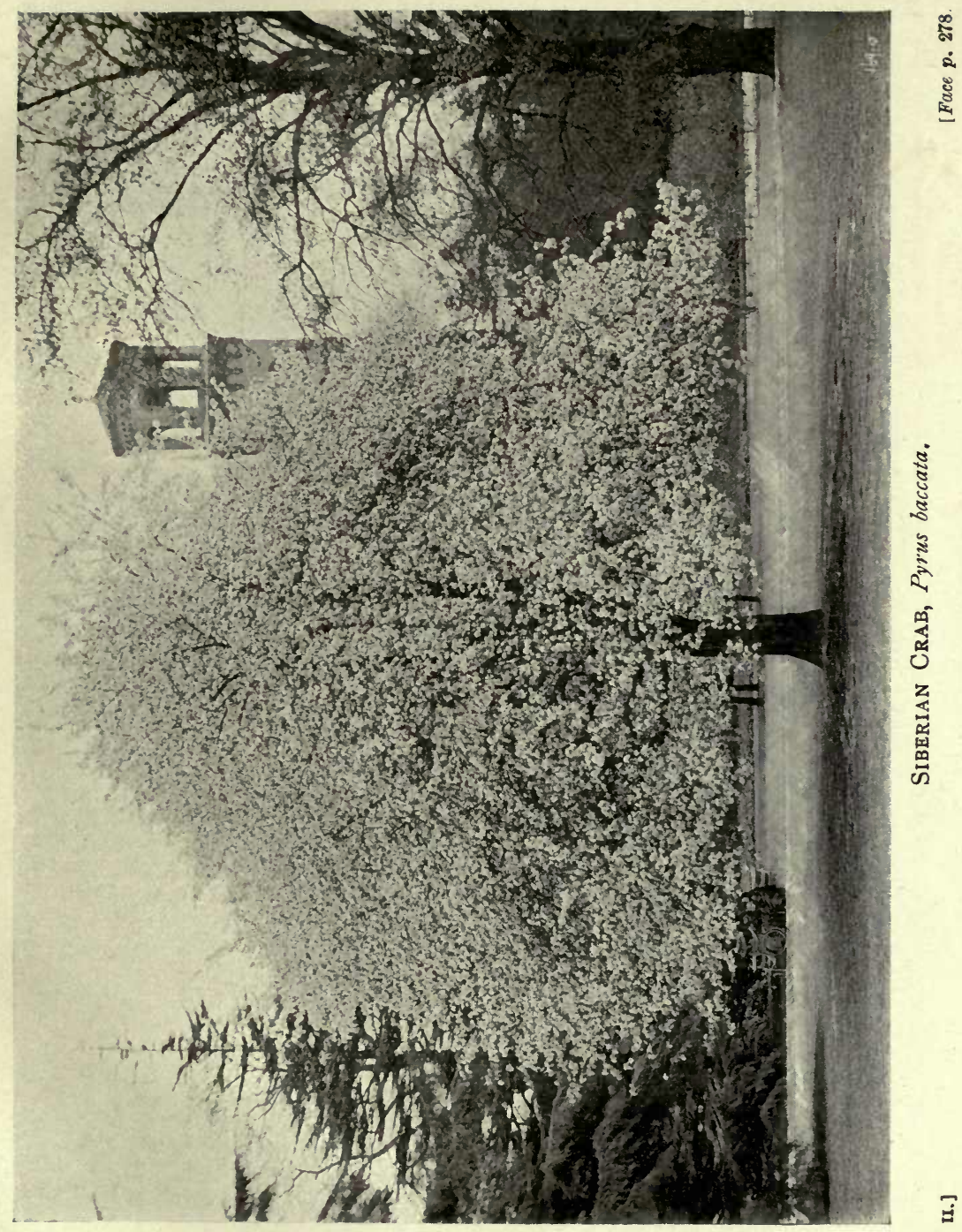



$\mathrm{ft}$. in diameter. Leaves $\mathrm{I} \frac{1}{2}$ to $3 \frac{1}{2}$ ins. long, about half as much wide; oval or ovate, rounded or tapering at the base, shallowly and bluntly toothed; smooth above, and either smooth or downy beneath; stalks slender, 1 to 2 ins. long. Flowers white, produced during April in umbels; each flower $1 \frac{1}{2}$ ins. across, and borne on a slender stalk $\mathrm{I}$ to $\mathrm{I} \frac{1}{2}$ ins. long. Fruit $\frac{3}{4}$ to $\frac{7}{8}$ in. thick, globular, bright red, hollowed at the insertion of the stalk, and with a round scar, but no calyx teeth at the top.

Widely spread in nature, this species reaches from Lake Baikal in Siberia, eastwards to Manchuria and N. China, and the same or a similar tree is found in the Himalaya. Introduced to Kew in 1784 . It varies considerably in the downiness of the various parts. Some of the trees in the Kew collection have smooth young shoots, leaves, calyx-tube, and flower-stalks; others have all these parts downy. The lobes of the calyx appear to be invariably silkyhairy inside. As a tree for gardens the Siberian crab stands in the first rank. It is pretty in April when laden with its abundant white flowers, but its great value and charm are most apparent in autumn, when its plentiful crop of cherry-like crabs turns a brilliant red. They remain long on the leafless branches, and I have seen them lighting up the garden on fine days as late as February. This tree is closely allied to P. prunifolia, but the fruit of the latter is more elongated, not indented at the base, and nearly always crowned with the calyx teeth. The late Dr Regel, about thirty years ago, sent seeds to Kew of about a dozen varieties with names, but when the trees flowered and bore fruit they proved indistinguishable. The fruit of P. baccata, although harsh when eaten raw, makes a very excellent jelly.

Var. MICROCARPA, Regel.-Fruit about half the size of those described above. Some regard this as the typical wild plant.

\section{P. BETUlÆFolia, Bunge.}

A slender, quick-growing, graceful tree, 20 to $30 \mathrm{ft}$. high ; young shoots covered thickly with a grey felt which persists the whole of the year. Leaves ovate or roundish ovate, 2 to 3 ins. long, $1 \frac{1}{4}$ to $1 \frac{1}{2}$ ins. wide ; long-pointed, tapered or rounded at the base, regularly and sometimes rather coarsely toothed, downy on both surfaces at first, remaining so on the veins beneath throughout the season; dark green, smooth and lustrous above; stalk I to $\mathbf{I} \frac{\mathbf{1}}{4}$ ins. long, grey-felted like the shoot. Flowers eight to ten together in a corymb, white, each about $\frac{3}{4}$ in. across, on a downy stalk $\frac{3}{4}$ to 1 in. long; calyx downy, its short triangular teeth falling away from the small roundish fruit, which is about the size of a large pea, greyish brown with white dots.

Native of N. China ; introduced to Kew in 1882 through seeds sent by the late Dr Bretschneider. The chief characteristics of the tree are its quick graceful growth, and small fruits not crowned by calyx teeth. Its fruit would appear to be of no value, but the tree is used by the Chinese as a stock on which they graft fruiting pears.

\section{P. CAloneura, Bean.}

\section{(Micromeles caloneura, Stapf., Bot. Mag., t. 8335.)}

A tree probably 20 to $30 \mathrm{ft}$. high, with smooth young shoots and large, ovoid, smooth winter buds. Leaves oval to oblong, tapered at both ends; 2 to $3 \frac{1}{2}$ ins. long, half as wide ; doubly-toothed, clothed when very young with a loose floss which soon falls away leaving them smooth above, but with a few hairs on the veins beneath; veins in nine to twelve pairs; stalk $\frac{1}{3}$. to $\frac{1}{2}$ in. long, at first hairy. Flowers white, about $\frac{1}{2}$ in. wide, produced in rounded, dense corymbs, 2 to 3 ins. across; flower-stalks and calyx downy. Fruit somewhat pear-shaped, $\frac{1}{3}$ in. long, brown, spotted; the calyx falls away from the apex completely, leaving a small pit there. 
Discovered by Henry in Szechuen, China, in 1889 ; introduced by Wilson in 1904. It belongs to the group or sub-genus Micromeles, distinguished by the naked apex of the fruit, along with alnifolia, Folgneri, etc.

\section{P. Cham emespilus, Ehrhart. Alpine Whitebeam.}

(Sorbus Chamæmespilus, Crantz.)

A shrub of dwarf, compact habit, becoming eventually 5 or $6 \mathrm{ft}$. high ; branches short, stiff ; young twigs covered at first with a whitish, cobweb-like substance. Leaves $1 \frac{1}{4}$ to 3 ins. long, $\frac{5}{8}$ to $I_{2} \frac{1}{2}$ ins. wide ; ovate, oval or slightly obovate, green and smooth on both surfaces, apex rounded or pointed, margins finely toothed; stalk $\frac{1}{8}$ to $\frac{1}{3}$ in. long. Flowers rosy, crowded in umbels which together form a small terminal corymb; calyx woolly at the base like the flower-stalk, the teeth pointed, erect, almost smooth outside, but covered with a thick white wool inside; petals erect, never spreading. Fruit $\frac{1}{3}$ to $\frac{1}{2}$ in. long, scarcely so wide, scarlet-red.

Native of the Alps of Europe; introduced in 1683 , according to Aiton, but not frequent in gardens at the present time. It is very ornamental when in fruit, and is one of the most distinct of the Aria group in its dwarf habit, smooth leaves, upright petals, and densely packed flowers. It is worth growing as one of the few truly shrubby species, and especially for planting in some sunny spot where a slow-growing shrub is desirable.

P. Hosti (Sorbus Hostii, Hedlund) is a hybrid between the above and some form or ally of P. intermedia. The foliage is much larger than that of $\mathrm{P}$. Chamæmespilus, and more resembles that of $\mathrm{P}$. intermedia in size and in the presence of down on the lower surface ; the toothing is sharp and jagged. In the dense, compact inflorescence, and in the upright pinkish petals, the influence of P. Chamæmespilus is apparent. P. Hostii is found wild on the Alps of Austria.

\section{P. COMmunis, Linnaus. Wild PEAR.}

A deciduous tree, usually 30 to 40 , occasionally as much as $60 \mathrm{ft}$. high, with a trunk $3 \mathrm{ft}$. through ; branches forming short stiff spurs, sometimes spiny. Leaves variable, from ovate, heart-shaped and oval, to almost round; from I in. to 4 ins. long, up to 2 ins. wide, very finely round-toothed or entire ; stalk slender, I to 2 ins. long ; the leaves are variable in their downiness, but are either smooth from the beginning or become nearly or quite so later, and glossy green. Flowers white, $I$ to $I \frac{1}{2}$ ins. across, produced in corymbs 2 to 3 ins. across, each flower on a more or less woolly stalk $\frac{1}{2}$ to $I_{2}^{\frac{1}{2}}$ ins. long. Fruit top-shaped or rounded, with a tapering or rounded base.

Native of Europe and N. Asia, and found wild in Britain, but doubtfully indigenous. Some authorities have professed to find two sub-species, viz., P. ACHRAS, with elongated fruits and slightly downy mature leaves; and P. PYRASTER, with rounded fruits and smooth mature leaves; but these characters do not prove constant. The wild pear, as the parent of a multitude of varieties of one of the most delicious of northern fruits, is a tree of interest. It is found scattered in the forests of Central and E. Europe, usually as individuals, never, it is said, in large groups. It produces a most excellent timber, heavy, tough and durable, which, however, is not plentiful enough to be of much importance in commerce. In gardens the wild pear has no claim to notice. Its graceful, often pendulous branches and large crops of flowers in April are beautiful, but the garden varieties are just as much so, and give useful fruits as well.

P. CORDATA, Desvaux, often regarded as a species, is really nothing more than a form of P. communis, smaller in all its parts. The leaves, 
sometimes heart-shaped, but often rounded or broadly wedge-shaped at the base, are usually less than $1 \frac{1}{2}$ ins. long, finely and evenly round-toothed. Flowers smaller, in distinct racemes. Fruits globular, $\frac{3}{8}$ to $\frac{1}{2}$ in. diameter, brown spotted with white, smooth. These small rounded fruits afford the best distinction between this pear and P. communis. Long known as a native of France, Spain, and Portugal, it was, in 1865, also discovered wild in the south-west of England by Mr T. R. Archer-Briggs. (It is sometimes called P. communis var. Briggsii, Syme.)

P. LONGIPES, Cosson and Durieu.-Also of the communis group and very nearly allied to $\mathrm{P}$. cordata, this pear is a native of Algeria, especially in the mountain gorges above Batna. It is a small tree or shrub, with smooth branchlets. Leaves roundish oval or broadly ovate, I to 2 ins. long, $\frac{1}{4}$ to $I \frac{1}{2}$ ins. wide; the base sometimes slightly heart-shaped, more especially tapering; very finely and evenly round-toothed, quite smooth on both sides, lustrous above ; stalk slender, I to 2 ins. long. Flowers white, I to $I \frac{1}{4}$ ins. across, produced in corymbs 2 to 3 ins. in diameter. Fruit about the size and shape of a small cherry, produced on a slender stalk $I$ to $\mathbf{I} \frac{1}{2}$ ins. long, turning from green to brown as it ripens, the calyx-lobes falling away. Introduced from Kew to France in 1875 .

\section{P. CORONARIA, Linnceus. AmERICAN CRAB.}

(Bot. Mag., t. 2009 ; Malus coronaria, Miller; M. fragrans, Rehder.)

A tree 20 to $30 \mathrm{ft}$. high, with a short trunk and a wide-spreading, open head of branches; young shoots downy the first summer. Leaves ovate to three-lobed, 2 to $4 \frac{1}{2}$ ins. long, sometimes nearly as much wide, but usually I to $2 \frac{1}{2}$ ins. wide, pointed, the base rounded or slightly heart-shaped, sometimes tapering; very soon quite smooth on both surfaces; margins sharply, deeply, and irregularly toothed; stalk downy, I to $\mathbf{I} \frac{1}{2}$ ins. long. Flowers white, tinged with rose, fragrant like violets, $\mathrm{I} \frac{1}{2}$ to 2 ins. across, produced in clusters of four to six, each flower on a slender stalk, I to 2 ins. long. Fruit I to $\mathrm{I} \frac{\mathrm{I}}{2}$ ins. across, orange-shaped, yellowish green, very harsh and acid.

Native of Eastern N. America ; introduced in 1724 , but not so common as one might expect from the beauty and fragrance of its flowers, which come in May and June-later than any other of the Malus group, except its two immediate allies. There are two American crabs closely allied to this species : they are $\mathrm{P}$. angustifolia, with narrower leaves tapering at the base, and $\mathrm{P}$. ioensis, in which the foliage is much more downy (and persistently so) beneath. The larger, broader leaves of P. coronaria frequently suggest those of our native $\mathrm{P}$. latifolia in shape. "P. coronaria flore pleno" is a wrong name for P. ioensis flore pleno, a very beautiful crab $(q . v$.

\section{P. CRATAGIFOLIA, Targioni.}

(Bot. Mag.. t. 7423 ; Malus florentina, C. K. Schneider; Cratægus florentina, Zuccagni.)

A bush or small tree of rounded habit, with slender, dark brown branches; branchlets woolly when young. Leaves rather hawthorn-like, "I $\frac{1}{2}$ to $2 \frac{1}{2}$ ins. long, $\frac{3}{4}$ to $\mathbf{I} \frac{3}{4}$ ins. wide ; broadly ovate in the main, but with the margins always cut up into several lobes which are themselves toothed; base rounded or heart-shaped; dark green above, with scattered hairs when young, paler and downy beneath; stalk downy, reddish, up to I in. long. Flowers pure white, about 3 in. diameter, produced in June five to seven together on lax open corymbs 2 or 3 ins. across, each flower on a slender, downy, pinkish stalk $\mathrm{I}$ to $\mathrm{I} \frac{1}{4}$ ins. long; calyx very woolly, the lobes narrow, pointed. Fruit roundish oval, $\frac{1}{2}$ in. long, yellowish changing to red, the calyx fallen away. 
Native of N. Italy, and very rare both in a wild state and in cultivation. There are few more charming small trees than this in the latter half of June, the long, slender shoots of the previous summer being then clothed with abundant short twigs, each with its cluster of white flowers. The leaves are very similar in form to those of the wild service (P. Torminalis) only much smaller. Its fruit is not particularly bright, but the foliage often turns a brilliant orange-scarlet before falling. It is very suitably placed as an isolated specimen on a lawn. Plants at Kew now 6 or $8 \mathrm{ft}$. high, and as much through, were introduced by the late $\mathrm{Mr} \mathrm{H}$. Groves from near Florence in 1886.

\section{P. DECURRENS, Ascherson.}

\section{(P. lanuginosa of gardens; Sorbus decurrens, Hedlund.)}

A hybrid between P. Aria and P. Aucuparia, with the leaves partly pinnate, partly simple. The lower part of the leaf is composed of two to four pairs of leaflets, the remaining and smaller upper part consisting of one lobed or pinnatifid segment. It has an origin similar to that of $\mathrm{P}$. pinnatifida, but shows much more the influence of P. Aucuparia in the number of separate leaflets. The Aria influence is shown in the persistent greyish down beneath the leaf, and in the amalgamation of the upper leaflets. There is a tree at Kew $30 \mathrm{ft}$. high, with a trunk girthing $3 \mathrm{ft}$. It is usually found in gardens as "P. lanuginosa," but the true P. lanuginosa of De Candolle is merely a variety of P. Aucuparia with densely woolly leaves (wholly pinnate) and hairy young shoots. P. NEUILLYENSIS is a very similar tree, either of the same origin as P. decurrens or a cross (or intermediate) between Aucuparia and pinnatifida (see under P. Aucuparia).

\section{P. DippeliI, Bean.}

\section{(Sorbus Dippelii, Zabel.)}

A bushy-headed shrub; young wood thickly covered with grey felt. Leaves $1 \frac{1}{2}$ to $3 \frac{1}{2}$ ins. long, $\frac{5}{8}$ to $1 \frac{1}{4}$ ins. wide ; narrowly oval or oblanceolate, shallowly toothed, bright green and smooth above, covered beneath with a close grey felt, tapering at the base to a stalk $\frac{1}{4}$ to $\frac{1}{3}$ in. long. Flowers $\frac{1}{3}$ in. across, white, with rose-coloured anthers, produced in small downy corymbs. Fruit top-shaped or roundish, $\frac{1}{3}$ in. long, blue-black.

A hybrid between P. Aria and P. melanocarpa, of unknown garden origin. Its affinity with P. melanocarpa is shown in the presence of glands along the upper surface of the midrib, and in the blackish fruits. It is an interesting and pretty round shrub, often made into a small tree by grafting on standards of mountain ash or hawthorn. It is often called " $\mathrm{P}$. alpina" in gardens; the true

P. ALPINA, Willdenow (Sorbus alpina, Heynhold), is very nearly allied, having P. Aria and P. arbutifolia as its parents. It differs from P. Dippelii most markedly in having clear red fruits, and in the leaves (upper surface especially) being less downy. Var. SUPER-ARIA is apparently a reversion towards P. Aria, or perhaps a cross between that species and P. alpina; the leaves are much larger and broader than in the latter, the flower clusters are also larger, the fruits deep red.

\section{P. FLORIBUNDA, Nicholson.}

(Malus floribunda, Siebold; Garden, Oct. I4, 1876 (plate).)

A tree ultimately 20 to $30 \mathrm{ft}$. high, with a spreading tangle of branches forming a rounded head wider than the tree is high; often shrubby; young 


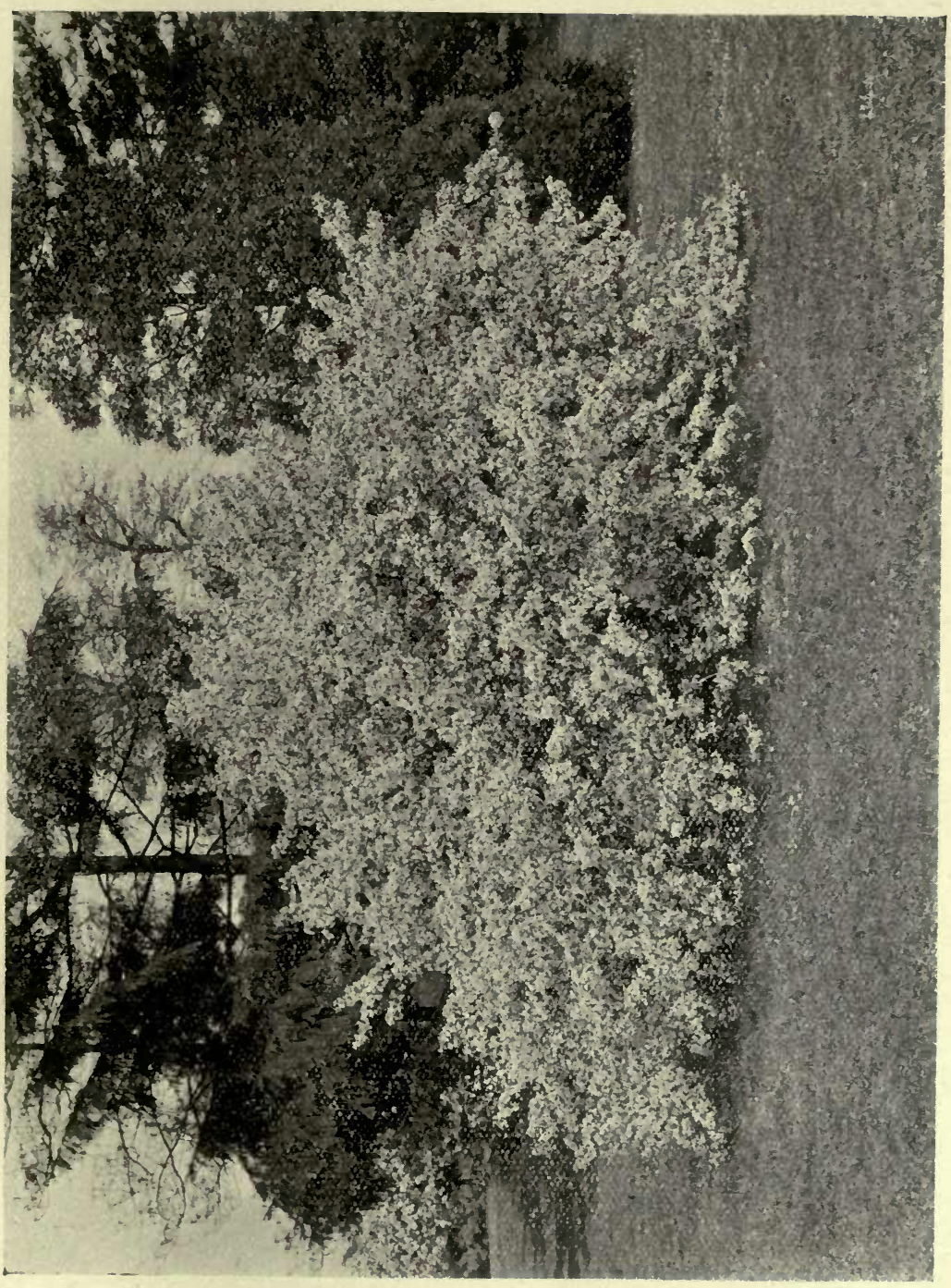



shoots downy at first, becoming smooth later. Leaves on the flowering and weaker shoots usually narrowly or broadly ovate, and from $1 \frac{1}{2}$ to 3 ins. long ; rounded or tapering at the base, rather coarsely toothed; on strong shoots they are occasionally three- or five-lobed, 3 to $4 \frac{1}{2}$ ins long, and half as wide ; upper surface dark dullish green, smooth; lower one paler and downy ; stalk $\frac{1}{2}$ to $I$ in. long, downy. Flowers $I$ to $I \frac{1}{4}$ ins. across, rosy red in bud, pale pink when open, produced in clusters of four to seven, each on a stalk I to $i \frac{1}{2}$ ins. long. Fruit round, $\frac{3}{4}$ in. diameter, yellow, with the calyx fallen away.

Introduced from Japan about 1862, and perhaps the most beautiful of all crabs in flower. It blossoms towards the end of April, producing then an amazing profusion of flowers, each branch a garland. Perhaps its beauty is greatest when half the flowers are expanded, the pale pink contrasting with the rich rose of the other half still in bud. This crab is not considered to be a true wild species, but a hybrid from P. Toringo and perhaps P. baccata. The deeply three- or even five-lobed leaves occasionally seen on strong branches certainly indicates affinity with $\mathrm{P}$. Toringo (q.v.). The largest tree I have seen is in the botanic garden at Herrenhausen, Hanover. In the summer of 1908 it was $35 \mathrm{ft}$. high, $42 \mathrm{ft}$. in diameter, its trunk girthing $4 \mathrm{ft} .3$ ins.

Var. ATROSANGUINEA.-Flowers of a richer rose than the type, especially when fully open, otherwise similar. Foliage shining green.

\section{P. Folgneri, Léveille.}

\section{(Micromeles Folgneri, $C . K$. Schneider.)}

A tree up to $30 \mathrm{ft}$. high, with slender, often semi pendulous branches; young shoots at first covered with whitish felt, becoming smooth by autumn; winter buds pointed, slender, smooth. Leaves lanceolate or narrowly ovate, tapering to both ends ; 2 to $3 \frac{1}{2}$ ins. long, $\frac{3}{4}$ to $i \frac{1}{4}$ ins. wide ; long-pointed, dark green and smooth above, covered beneath with a close, beautifully silvery white felt; nerves parallel in eight to ten pairs; stalk about $\frac{1}{2}$ in. long. Corymbs 3 to 4 ins. across, sometimes rather elongated, carrying numerous rather densely arranged flowers $\frac{1}{3}$ to $\frac{1}{2}$ in. in diameter and white; calyx and flower-stalk woolly. Fruit oval or obovate, $\frac{1}{2}$ in. across, red, not crowned by calyx teeth, but with a small pit at the apex.

Native of Hupeh, China ; introduced by Wilson for Messrs Veitch about 1901, and reared in the Coombe Wood nursery. As represented in gardens, it varies considerably in the whiteness of the under-surface, and in the more or less pendent character of its branches. In one form it is beautifully elegant, the branches arching outwards and drooping at the ends, and the leaves are vividly white beneath. Its nearest allies among cultivated Pyruses are P. alnifolia and P. caloneura'; neither white beneath the leaf.

\section{P. Glabra, Boissier. Persian Pear.}

A tree 15 to $20 \mathrm{ft}$. high, with often spine-tipped branches; young shoots at first covered with grey wool, becoming smooth by summer. Leaves $1 \frac{1}{2}$ to 4 ins. long, $\frac{1}{3}$ to $\frac{3}{4}$ in. wide ; linear-lanceolate, long-pointed, slightly round-toothed or quite entire, green on both sides and quite smooth almost from the very first on both sides; stalk $\frac{1}{3}$ to $1 \frac{1}{2}$ ins. long. Flowers I in. across, white, produced in a cluster of five to eight ; flower-stalks and the inner face of sepals more or less woolly. Fruit roundish.

Native of Persia. In Decaisne's observations on this species (Jardin Fruitier, vol. i., t. II), it is stated on the authority of a Mr Haussknecht that the pips of this pear are pickled in brine by the Persians and eaten. The tree is rare in gardens, where, indeed, it has little to recommend it. 


\section{P. Halliana, Sargent. \\ (P. Parkmanni, Hort.; Malus Halliana, Koehne.)}

A small tree, 12 to $18 \mathrm{ft}$. high; young branches purple, soon quite smooth. Leaves ovate or oval, $\mathrm{I} \frac{1}{2}$ to 3 ins. long, half as wide, rounded or tàpering at the base, rather long-pointed, slightly toothed; the midrib is glandular and slightly hairy above, otherwise the leaf is quite smooth on both surfaces and of a dark polished green above, often purple-tinted, especially on the midrib; stalk $\frac{1}{2}$ in. or less long. Flowers deep rose, $I$ to $1 \frac{1}{2}$ ins. across, from four to

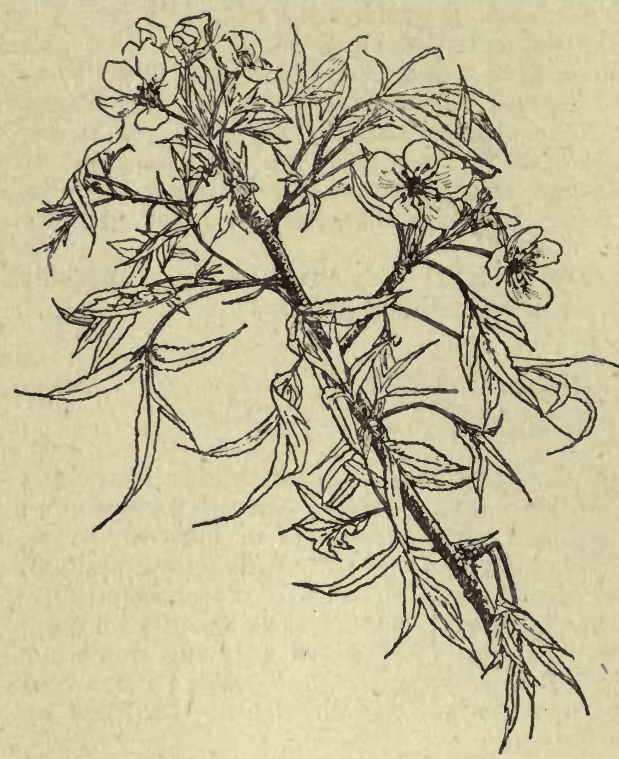

Pyrug heTEROPHYLLA. seven in a cluster, each flower on a smooth, reddish purple stalk $I$ to $\mathbf{I} \frac{1}{2}$ ins. long: petals five to eight; calyx reddish purple and smooth outside, white - woolly within. Fruit round, purple, the size of a small pea, marked at the top with the scar of the fallen calyx. Native of Western Szechuen, China. It was first introduced to America from Japan about I $86_{3}$, by Dr. G. R. Hall, after whom it is named, but it does not appear to have ever been found wild there. It has some affinity with $\mathrm{P}$. floribunda, and has been known in gardens as "P. f. var. flore pleno," the flowers being often semi-double. P. Halliana is abundantly distinct in habit, in the nearly glabrous character of its parts, and it never appears to have the deeply lobed leaves occasionally seen in floribunda. In my experience, $P$. Halliana is by no means so beautiful a

flowering tree as P. floribunda. Still it is highly praised by some writers.

\section{P. heterophylla, Regel.}

A small tree, ultimately 20 to $30 \mathrm{ft}$. high, whose young branches are covered with a close grey down which persists over the first winter. Leaves exceedingly variable in shape, the two extreme types of which are; (I) ovate with a rounded base and pointed apex, 2 to $3 \frac{1}{2}$ ins. long, $\frac{3}{4}$ to $1 \frac{1}{2}$ ins. wide; bluntly, unequally, and rather coarsely toothed; (2) cut back to the midrib into three to seven narrow, linear lobes, which are $\frac{3}{4}$ to 2 ins. long, $\frac{1}{8}$ to $\frac{1}{4} \mathrm{in}$. wide, finely toothed (see figure). Between these two forms of leaf, which may occur on the same plant, there are many intermediate ones. For the rest, the leaves are of firm, rather leathery texture, and very downy when young, remaining more or less so until they fall; the pinnatifid form, however, appears to be less downy than the undivided one. Flowers white, $\frac{3}{4}$ to $I$ in. across, produced a few together in small clusters. Fruit like a small ordinary pear. 



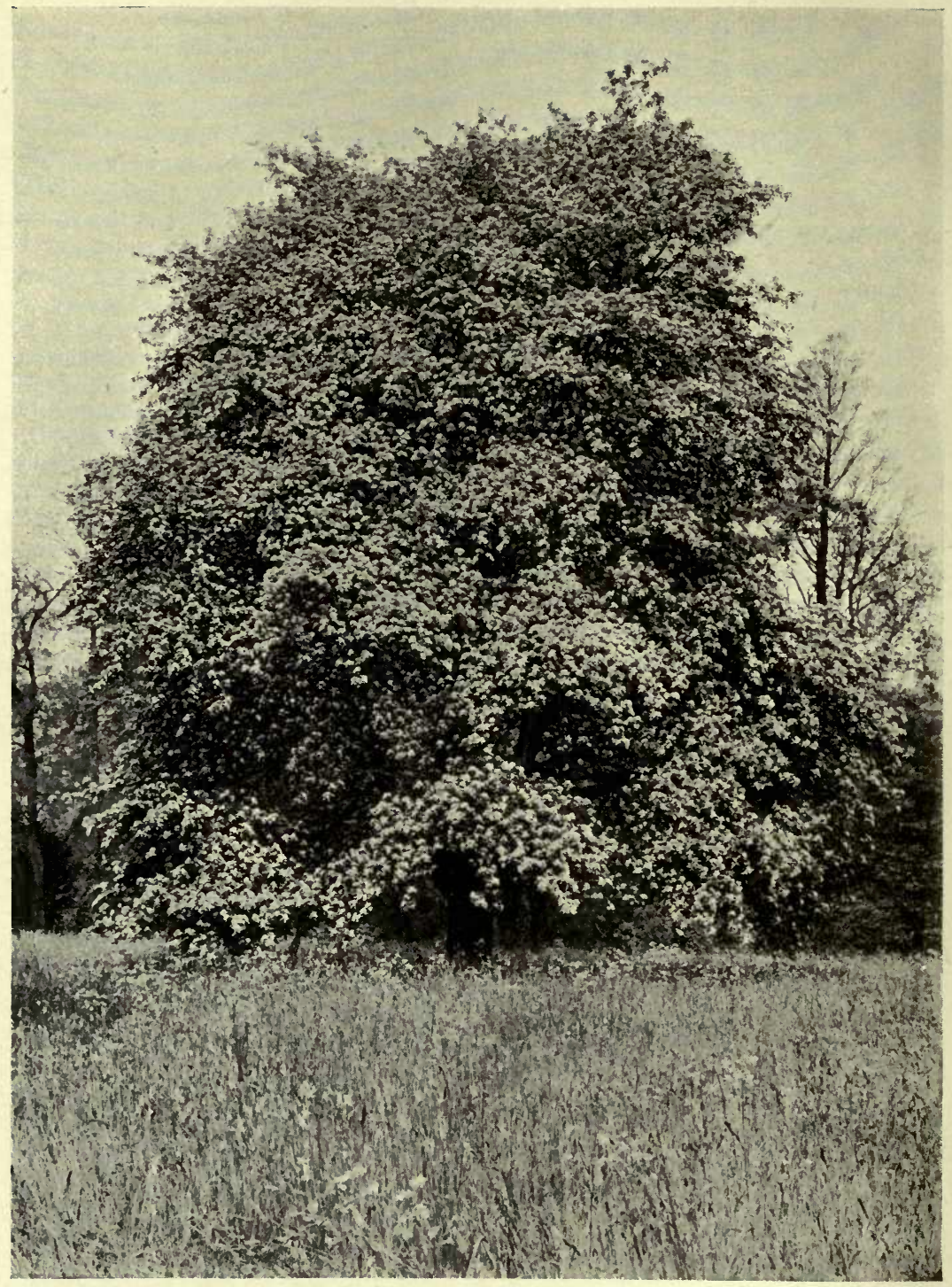

Swedish Whitebeam, Pyrus intermedia. 
This extraordinary pear was originally discovered in E. Turkestan by the late Albert Regel, and was raised and distributed (about 1891) by Dr Dieck of Zoeschen, Germany. The two forms of leaf described above would never be regarded as belonging to the same species, but I have seen both, as well as intermediate ones, on the same plant.

\section{P. intermedia, Ehrhart. Swedish Whitebeam.}

\section{(P. scandica, Ascherson; Sorbus intermedia, Persoon.)}

A tree 20 to $40 \mathrm{ft}$., occasionally more, high, sometimes a shrub in a wild state ; shoots very woolly when young, becoming smooth by winter. Leaves 2 to $4 \frac{1}{2}$ ins. long, 1 to 3 ins. wide ; broadly oval or ovate, tapering or rounded at the base, rounded or pointed at the apex; margins lobed towards the base, the lobes becoming reduced to double or jagged teeth near the apex; ribs in six to nine pairs; upper surface smooth polished green when mature; lower surface covered with a close grey felt. Flowers dull white, $\frac{3}{4}$ in. across, produced during May in large corymbs up to 5 ins. across ; calyx and flowerstalk very woolly. Fruit oval, $\frac{1}{2}$ in. long, red, surmounted by reflexed calyx teeth.

Native of N. and Central Europe, and found in a few places in Wales and the West of England on limestone. It is easily distinguished from P. Aria by the dull grey (not white), felt beneath the leaf. It is nearer, and liable to be confused with, P. latifolia, but the leaves are always permanently felted beneath, narrower at the base, not so deeply lobed, and do not suggest those of $\mathrm{P}$. Torminalis as the leaves of P. latifolia do. The groove between the lobes is narrower, often almost closed at the base, in P. intermedia, and the winter buds are darker. This tree is a variable one, and several forms of it have been regarded as species by some authorities. The following is perhaps the most distinct, but there are others of an intermediate character, and some with leaves whose lower lobes are almost cut to the midrib, and thus show affinity with P. pinnatifida.

Var. MiNima (P. minima, Ley).-This is described as a small shrub clothing limestone cliffs in two or three places in Breconshire, but the shrubby habit with this (as with other wild forms of P. intermedia) is due apparently to the impoverished conditions under which they grow. Young plants obtained from the natural habitat are, at Kew, making well-formed trees already $12 \mathrm{ft}$. high, the growths $\mathrm{I}$ to $2 \mathrm{ft}$. long in a year. The fruits are described as coral red, bitter, and resembling those of P. Aucuparia ; the leaves, except in being smaller, are like those of P. intermedia; and the flowers also smaller, have the same whitish woolly covering to the calyx, and stalks. The winter buds, too, are the same.

P. Mougeot (Sorbus Mougeoti, Soyer) is nearly allied to P. intermedia, differing chiefly in having nine to twelve pairs of ribs in each leaf, and paler felt beneath; fruits about $\frac{1}{3}$ in. wide, red, roundish. Native of $S$. and $E$. Europe.

\section{P. IOENsis, Bailey. IOWA CRAB.}

\section{(Bot. Mag., t. 8488 ; Malus ioensis, Britton.)}

A tree of the same character as P. angustifolia and P. coronaria $(q \cdot v$.$) , but$ differing in the much more downy branches, the down on which persists until the summer of the following year; side branchlets often spine-tipped. Leaves ovate or oval, 3 to 4 ins. long, half or a little more than half as wide ; persistently woolly beneath, coarsely toothed towards the apex. Flowers $1 \frac{1}{2}$ to 2 ins. across, white or rosy, four to six in a corymb; stalks $I$ to $I \frac{1}{2}$ ins. 
long, covered with white wool ; calyx very woolly. Fruit $\mathbf{I}_{4}^{\frac{1}{4}}$ to $\mathbf{I}_{2}^{\frac{1}{2}}$ ins. diameter, dull yellowish green.

As has already been stated under P. coronaria, this tree is one of a closely allied group of $\mathrm{N}$. American crabs, but it has a more western habitat than the other two, being found in the Central United States. It differs from both its allies in the much more downy branchlets, leaves, and other young parts of the tree (a frequent characteristic in the most western forms of American trees).

Var. FLORE PLENO. The Bechtel Crab.-In the year r89r, Messrs Bechtel, of Stanton, Illinois, U.S.A., sent out this beautiful double-flowered crab under the name of "P. angustifolia flore pleno." In the prevailing confusion as to the identity of these three species, it has also been called " $\mathrm{P}$. coronaria flore pleno." The individual flower, which on young healthy plants measures 2 to $2 \frac{1}{2}$ ins. across, is the finest of all the Malus group, the numerous petals being of a lovely delicate pink. With a delightful odour suggestive of violets, and coming into bloom in early June, this crab has a claim to recognition in every garden.

\section{P. LAtifolia, Syme. Service Tree of Fontainebleau.}

\section{(P. rotundifolia, Bechstein; Sorbus latifolia, Persoon.)}

A tree 30 to $45 \mathrm{ft}$., sometimes over $60 \mathrm{ft}$. high ; branchlets downy when young, becoming by winter shining and quite smooth. Leaves roundish ovate, 2 to 4 ins. long, often nearly as wide at the base as they are long; the apex pointed, the base either truncate or broadly wedge-shaped; margin either cut into triangular, pointed lobes which are sharply toothed, or simply jaggedly toothed; smooth, dark lustrous green above, covered beneath with a greyish felt; ribs six to ten on each side ; stalk downy, $\frac{1}{2}$ to I in. long. Flowers white, $\frac{5}{8}$ in. across, borne in corymbs 3 ins. wide during May ; stalks and calyx very woolly. Fruits globular, $\frac{1}{2}$ in. diameter, dull brownish red.

This interesting tree was first discovered in the forest of Fontainebleau early in the eighteenth century. Its origin has given rise to considerable difference of opinion, but it is generally believed to be a hybrid between P. Aria and P. Torminalis. In many respects, notably in shape and woolliness of leaf, and in colour of fruit, it is certainly intermediate between them. Whether the Fontainebleau tree be a hybrid or not (and it is said to come true from seed), very similar ones found in middle Europe are almost certainly hybrids. The tree in various forms is found in the west of England. It has been much confused with P. intermedia, and in some of its forms approaches that tree in form of leaf. But it is usually much less downy on the lower surface by the end of the summer, the winter buds are paler, and the angle between the marginal lobes of the leaf is wider, often ninety degrees in P. latifolia, whereas in $\mathrm{P}$. intermedia it is frequently a mere slit at the base. There is a very fine old specimen in the Earl of Bathurst's woods at Cirencester, between 70 and $80 \mathrm{ft}$. high and I $\mathrm{ft}$. in girth of trunk.

\section{P. MALIFOLIA, Spach.}

\section{(Sorbopyrus malifolia, $C . K$. Schneider.)}

The only tree with which this is likely to be confused is P. auricularis, the hybrid between P. Aria and communis. P. malifolia is also palpably a hybrid, and of an origin very similar to the other. Spach, who named and described this tree in 1834 , says the original specimen at that time grew in the Ménagerie du Jardin du Roi at Paris, and was $30 \mathrm{ft}$. or more high. He suggests that it may be a hybrid between P. auricularis and a pear, but I think it more 
likely to have been a seedling from P. auricularis, which occasionally bears fertile seed. As in the manner of hybrids, this rarely reproduces the mother plant true. It is only necessary to recount the differences between this tree and P. auricularis : Leaves shorter and comparatively broader, often roundish oval, not so coarsely toothed, nearly always heart-shaped at the base, not so much felted beneath; flowers larger, I to $I \frac{1}{2}$ ins. across, fewer on the corymb and with stouter stalks, produced in late April and May. Fruit broadly topshaped, about 2 ins. long and wide, deep yellow when ripe. This interesting and handsome tree, although not so common as the Bollwyller pear, is on the whole more handsome.

\section{P. Malus, Linnaus. Crab Apple. .}

The wild crab of W. Europe and N.W. Asia is of interest as being the parent of the cultivated garden apples, and the type of one of the chief sections of tine genus. But for itself it need not be given a place in the garden, as it is not so beautiful as the bulk of its numerous progeny. It is a tree 20 to $30 \mathrm{ft}$. high, with a usually crooked trunk and a rounded head of ultimately more or less pendulous branches, the young shoots, leaves, and flower-stalks clothed more or less with greyish down. Leaves roundish oval or ovate, $I \frac{1}{2}$ to $2 \frac{1}{2}$ ins. long, round toothed, stalk about half as long. Flowers white or rosy, in corymbs. Fruit red or yellow, round, crowned with persistent calyx-lobes, and indented at the base where it joins the stalk. Botanists find two distinct forms among the wild crabs, viz., var. SYLVESTRIS or acerba and var. MITIS. Var. sylvestris is not so downy as the other, the leaves and young shoots becoming smooth during the season. The fruit is sourer. Var. mitis is considered to be the parent of the sweeter apples, and all the younger parts of the plant are more woolly; fruit-stalk shorter.

Var. ASTRACANicA, Dumont. Red Astrachan Apple.-Fruit bright red, covered with plum-like bloom, long-stalked.

Var. PARADISIACA. - A dwarf variety of the mitis type and the famous stock for grafting apples, known in nurseries as "Paradise stock."

Var. PENDULA (Elise Rathke). - A delightful tree with weeping branches and abundant beautiful blossom followed by fine crops of handsome yellow fruits of good flavour.

CRABS.-Among the ornamental trees of autumn a high place must be given to several crabs, mostly of unrecorded but undoubtedly hybrid origin. Such of them as are not certainly known to belong to the species of Pyrus described on other pages (like baccata and prunifolia) may be mentioned here. Dartmouth or Hyslop is of American origin. It has plum-like fruits covered with a red-purple bloom, and may be partially derived from Red Astrachan.

Fairy.-Deep yellow, flushed with crimson.

John Downie.-Perhaps the finest of all crabs; it was raised by $\mathrm{Mr}$ E. Holmes in his nursery at Whittington, near Lichfield. Its fruits are conical, $I \frac{1}{4}$ ins. long by $I$ in. wide, tapering to the apex, bright orange and scarlet, and produced in wonderfully profuse clusters.

Orange.-Fruits of a pretty pale yellow, I in. or so across.

Transcendent.-Fruit deep yellow, carmine on the sunny side.

Transparent.-Fruits translucent yellow with a red tinge on one side. Long known in gardens.

\section{P. melanocarpa, Willdenow. Black Chokeberry.}

(P. nigra, Sargent; Aronia melanocarpa, Nuttall; Sorbus melanocarpa, Heynhold.)

A shrub 3 to $5 . \mathrm{ft}$. high, of bushy, flat-topped habit, producing sucker growths from the base; branchlets smooth, or somewhat downy. Leaves 
obovate, from $1 \frac{1}{4}$ to 3 ins. long, from $\frac{3}{4}$ to 2 ins. wide ; usually short-pointed at the apex, always tapering at the base, finely and regularly toothed; the upper surface dark polished green and smooth, except for dark glands on the midrib; lower surface paler, usually smooth except when quite young, but occasionally downy throughout the season; stalk $\frac{1}{4}$ in. or less long. Flowers white, $\frac{1}{3}$ to $\frac{1}{2}$ in. across, produced towards the end of May in corymbs of six to twelve blossoms; calyx smooth or downy, with triangular lobes. Fruit roundish, $\frac{1}{3}$ to $\frac{1}{2}$ in. across, black.

Native of Eastern N. America, and cultivated in England probably for over two centuries. It is a close ally of P. arbutifolia, and with that species forms the Aronia group of Pyrus, distinguished by an invariably truly shrubby habit and by the dark glands on the upper side of the midrib. From $\mathrm{P}$. arbutifolia it is easily distinguished, that species having red fruit and dull leaves very woolly beneath. There is a form of P. melanocarpa which, in the more or less downy under-surface of the leaf and in the vinous red fruit approaches P. arbutifolia, but like the black-fruited, smooth-leaved type its fruits fall as soon as ripe (in September), whereas those of P. arbutifolia persist until mid-winter. P. melanocarpa flowers freely, and is a bright and pleasing shrub of neat habit.

\section{P. Michauxi, Bosc.}

A small tree with unarmed branches forming a rounded head. Leaves entire, ovate or oval-oblong, blunt at the apex, or with a short, abrupt point ; up to 3 ins. long, I to $I \frac{1}{2}$ ins. wide ; covered when young with white, cottony down, which afterwards falls away and leaves them shining and smooth above. Flowers white, in very short corymbs. Fruit globose or top-shaped, greenish yellow when ripe, spotted with brown. By some curious error this tree was long regarded as a native of $\mathrm{N}$. America ; but no true pear is indigenous to the New World. It is probably from the Levant, and may be a hybrid between P. amygdaliformis and P. nivalis. It differs from the former in its entire leaves.

\section{P. Niedzwetzkyana, Hemsley.}

\section{(Bot. Mag., t. 7975 ; Malus Niedzwetzkyana, Dieck.)}

A small tree of about the size and character of the ordinary apple; young bark reddish purple. Leaves 3 to 5 ins. long, 2 to $2 \frac{1}{2}$ ins. wide ; ovate or oval, round-toothed, downy all over the lower surface when young, afterwards on the midrib only; stalk downy, $\frac{3}{4}$ to $i \frac{1}{2}$ ins. long. The stalk and midrib are bright red, the blade also is of a decided red tinge when young, becoming purplish later in the season. Flowers in apple-like clusters, deep red-purple, $I \frac{1}{2}$ ins. across ; flower-stalks $\frac{1}{2}$ to $\frac{3}{4}$ in. long, and, like the calyx, covered with whitish wool. Fruit conical, with a few broad grooves running lengthwise; 2 ins. long, of a deep vinous red.

I do not think this tree can be considered anything more than a variety of P. Malus. Some years ago five seedlings from it were raised at Kew, and of these, three came as green in branch and leaf as the ordinary apple, and the flowers were merely pink-not the beautiful red which makes this one of the most striking of its group. This would seem to show that it is only a colour sport from P. Malus. It was introduced to cultivation by Dr Dieck, of Zoeschen, in Germany, who states that it is abundant in S.W. Siberia and the Caucasus. The fruit is not of high quality as we know apples, being. of rather turnip-like consistency. So completely is the tree permeated with red colouring matter that the young wood, when cut, shows red right through, as does also the fruit. Introduced to England in I894. 


\section{P. NIVALIS, Jacquin.}

A small tree, sturdy in habit; young shoots thickly covered with a white wool. Leaves oval or obovate, 2 to 3 ins. long, $\frac{3}{4}$ to $1 \frac{1}{4}$ ins. wide, entire, covered when young on both sides, but especially beneath, with a white wool much of which falls away later. Flowers pure white, $\mathrm{I} \frac{1}{2}$ ins. across, produced in April in conspicuous clusters. Fruit roundish, $1 \frac{1}{2}$ ins. or more wide, yellowish green, borne on a stalk as long or longer than itself.

Native of E. Europe and Asia Minor, where it is sometimes over $50 \mathrm{ft}$. high ; introduced early in the nineteenth century. It is a very beautiful tree early in the season, owing to the pure white leaves and abundant flowers. The tree is cultivated in France for the sake of its fruits, which are not eaten until bletted. It and P. Kotschyana, Boissier, are the parents of a race of pears known as "poirier sangers."

Pyrus nivalis may be considered the type of a group of European pears. The following are sometimes regarded as varieties of it, sometimes as species :-

P. CANESCENS, Spach. - Probably a hybrid between nivalis and salicifolia. In regard to it Decaisne wrote that it "is intermediate between P. nivalis and P. salicifolia; its leaves are of the same size as those of nivalis, and often twisted as in salicifolia." They are lanceolate or narrowly oval, finely round-toothed, very white when young, shining dark green above when mature. Fruit pale green, much shorter stalked than P. nivalis. A handsome tree in spring. P. KOTSCHYANA, Boissier.-Fruits smaller and harder than in P. nivalis. P. ELEAGRIFOLIA, Pallas, differs from Kotschyana in its spiny branches - a character on which no reliance can be placed in cultivation. Native of E. Europe and Asia Minor.

\section{P. PASHIA, Hamilton, var. KumaOni, Stapf.}

(Bot. Mag.. t. 8256.)

A tree 25 to $35 \mathrm{ft}$. high, branches smooth. Leaves ovate, 2 to $4 \mathrm{ins}$. long, $1 \frac{1}{4}$ to 2 ins. wide; rounded at the base, the apex varying from long taperpointed to blunt, both surfaces quite smooth, the margins set with fine, rounded teeth; stalk I to $1 \frac{1}{2}$ ins. long. Flowers at first rose-tinted, finally white, $\frac{3}{4} \cdot$ in. across, closely packed in rounded corymbs 2 ins. across, each flower on a stalk $\frac{1}{2}$ to $\frac{3}{4}$ in. long; calyx smooth outside, woolly inside the lobes; stamens numerous, red. Fruit nearly globular, but narrowed towards the stalk, brown with pale specks, $\frac{3}{4}$ to $\mathrm{I}$ in. diameter.

Native of the Himalaya ; introduced in 1825 . This variety from Kumaon, which appears to be the only representative of the species in cultivation, differs only from the typical P. Pashia in the absence of down from the younger parts. There is a tree $25 \mathrm{ft}$. high at $\mathrm{Kew}$, with a broad, rounded head, which gives every year a pretty display. It is quite distinct among pears by the compact flower clusters, the rounded overlapping petals, and especially for the pretty effect made by the cluster/ of deep red stamens in the centre of each flower. The leaves on sucker shoots or on the vigorous shoots of cut-back trees are frequently deeply three-lobed. In N. India the fruit is eaten after having "bletted," like a medlar. (See fig. p. 29o.)

\section{P. PINNATIfida, Ehrhart. Bastard Service Tree. (Sorbus hybrida, Linnaus-not Pyrus hybrida, Moench.)}

A deciduous tree, 20 to 40 , occasionally over $50 \mathrm{ft}$. high, with ascending branches; twigs covered with loose greyish floss when young, becoming 
smooth and of a dark lustrous brown by winter. Leaves 3 to 5 ins. long, $\mathrm{I}$ to 2 ins. wide ; narrowly oblong-ovate in main outline, but usually pinnate or cut nearly to the midrib at the base, the upper portion lobed and toothed, but less deeply so towards the apex, which is merely coarsely toothed; the lower surface is covered with a dull grey, persistent down ; leaf-stalk $\frac{1}{2}$ to $1 \frac{1}{4}$ ins. long, downy. Flowers white, about $\frac{1}{2}$ in. wide, produced in May in corymbs 3 to 5 ins. across. Fruit bright red, round oval, $\frac{2}{5}$ in. long.

This tree, especially handsome in foliage and fruit, is found wild in N. and Central Europe, and is generally believed to be a natural hybrid between P. intermedia and P. Aucuparia. The influence of the latter is seen in the larger leaves, especially of the sterile shoots, having usually from one to three pairs of leaflets at the base. On the flowering twigs many of

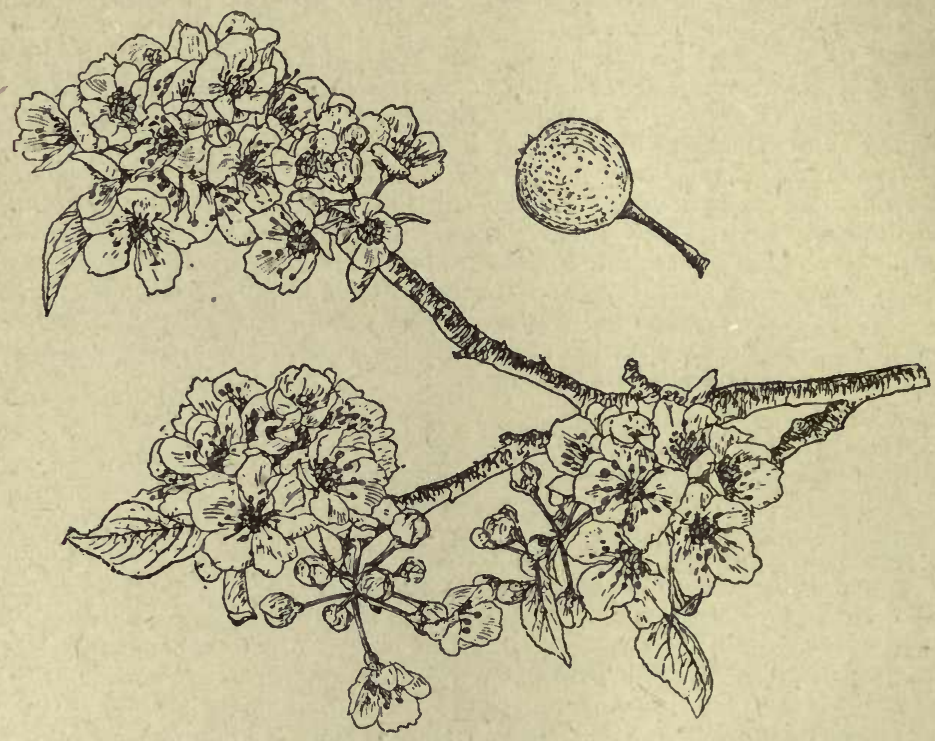

Pyrus Pashia var. Kumaoni.

the leaves are simple. It is found wild in the Isle of Arran, rarely in England. It is connected with both intermedia and Aucuparia by intermediate forms, but as a rule reproduces itself true from seed. The habit generally is erect, but a form sent out by Messrs Backhouse of York with more than usually - erect branches is called var. FASTIGIATA.

\section{P. PRUNIFOLIA, Willdenow.}

(Bot. Mag., t. 6158; Malus prunifolia, Borkhausen.)

A small tree with downy young shoots and ovate or broadly oval leaves, 2 to 4 ins. long, half or more than half as wide, unequally round-toothed, downy beneath. Flowers white, $\mathrm{I} \frac{1}{2}$ ins. across, produced in April in umbels of six to ten blossoms; calyx with long, narrow, always woolly lobes. Fruit round or slightly ovoid and elongated, I in. in diameter, yellowish or red, crowned with the persistent calyx. 
There is some doubt as to the origin of this crab. Aiton gives the date of its introduction to England as $175^{8}$, and its native country as Siberia, to which other authors have added N. China. But there appears to be no genuine proof of its existence in either country. It has been suggested that it is a hybrid between P. baccata and P. Malus. It is distinguishable from $P$. baccata in fruit by having the calyx-lobes nearly always adhering at the

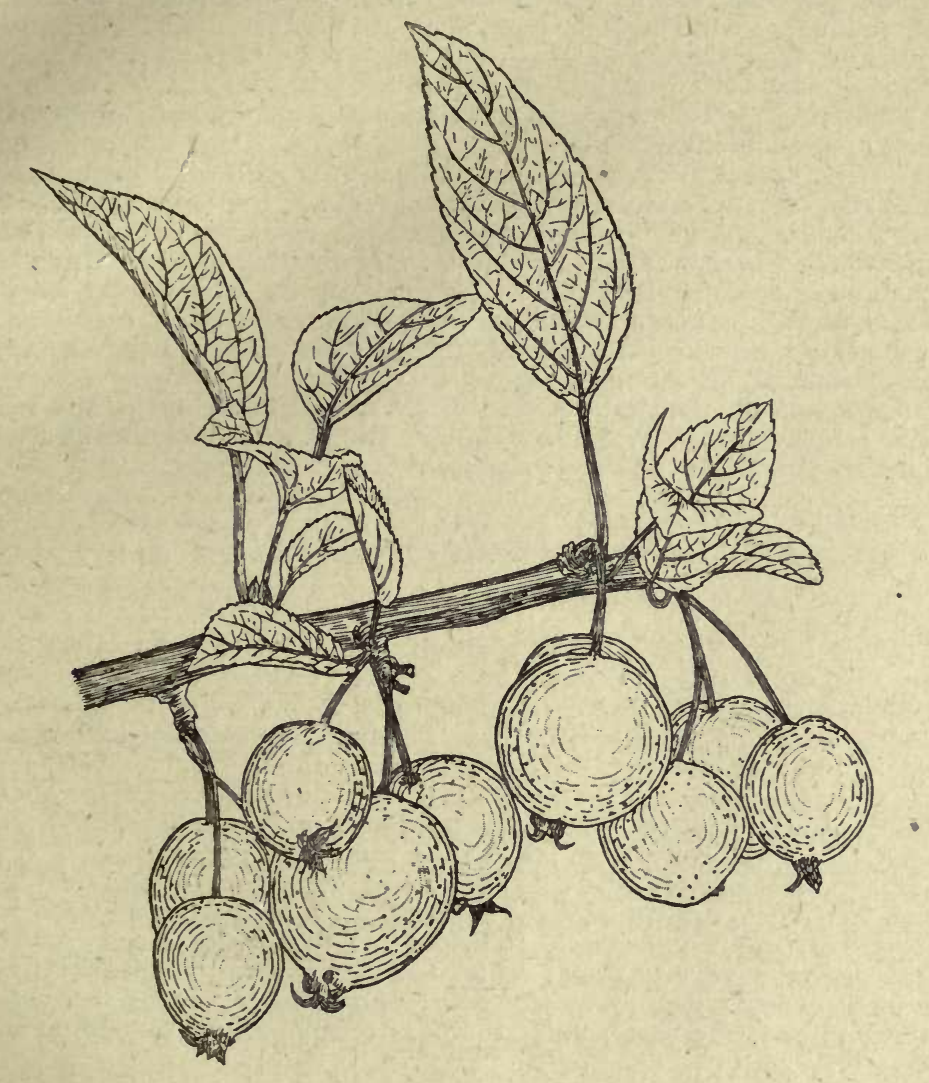

Pyrus Ringo.

top, although not invariably. Although longer cultivated in Britain than $P$. baccata, it does not appear to have reached so large a size.

Vars. DULCIS and EDULIS have sweet, greenish yellow fruits.

Var. LUTEA.-Fruit golden yellow, with a pleasantly acid juicy flesh (syn. xanthocarpa).

Var. PENDULA. - Branches weeping.

P. CERASIFERA (Malus cerasifera, Spach) is a cross between P. prunifolia and $P$. baccata, and is a very beautiful crab. Flowers white, fruit about the size of a cherry, coloured purplish red. The calyx teeth sometimes remain on the fruit, as in $\mathrm{I}$. prunifolia-sometimes fall away. 


\section{P. RINGO, Wenzig.}

(Bot. Mag., t. 8265 ; Malus Ringo, Siebold.)

A small tree usually under $20 \mathrm{ft}$. in height, of graceful habit; young branches covered with greyish down. Leaves ovate or oval, 2 to 4 ins. long, two-thirds as wide, downy above when young, permanently so beneath, sharply toothed ; stalk $\frac{1}{2}$ to $\frac{3}{4}$ in. long, downy. Flowers in apple-like clusters, each on a woolly stalk $I$ to $i \frac{1}{2}$ ins. long, rosy red in bud, paler when open, becoming almost white ; calyx-lobes narrowly lanceolate, hairy on both sides. Fruit pendulous, $\mathrm{I}_{4}^{\frac{1}{4}}$ ins. long, $\mathrm{I}$ in. wide, roundish, egg-shaped, bright yellow, crowned by persistent calyx-lobes.

This tree appears to have been originally introduced to Europe by Siebold from Japan about the middle of last century, but it is not known to be anywhere wild in Japan. Wilson states that he found it wild in Central China (Plante Wils., ii., 280). As a tree for the garden its great attraction is its abundant, gracefully pendent, bright yellow fruits, which hang from the lower side of the branches in long crowded rows, and make it probably the handsomest of our yellow-fruited hardy trees. They have an apple-like flavour and are quite pleasant eating. (Fig. p. 29I.)

Var. FASTIGIATA BIFERA. - A tree of pyramidal habit, probably a hybrid between some form of P. Malus and P. Ringo. Fruit abundant, yellow, stained with red, about the size of a pigeon's egg.

\section{P. Rivularis, Douglas. Oregon Crab.}

\section{(P. fusca, Rafinesque; Malus fusca, $C$. K. Schneider.)}

A tree 20 to $30 \mathrm{ft}$. high, often a shrub; branchlets slender, more or less downy. Leaves variously shaped, from broadly ovate to oblong-lanceolate, often three-lobed ; the largest 4 ins. long, and $2 \frac{1}{2}$ ins. wide, more often $\mathrm{I}$ to 3 ins. long, and half as wide ; the base tapering, rounded or slightly heartshaped, pointed at the apex, sharply toothed; downy on both sides ; stalk downy, I to $I_{2} \frac{1}{2}$ ins. long. Flowers white or rose-tinted, $\frac{3}{4}$ in. across, produced in clusters of six to twelve. Fruit egg-shaped, $\frac{1}{2}$ to $\frac{3}{4} \mathrm{in}$. long, red, yellow, or greenish yellow, the calyx teeth fallen away from the top.

Native of Western N. America ; introduced in 1836 , according to Loudon, but little known in cultivation now, although it is offered sometimes in tree catalogues of continental firms. It belongs to the Toringo group of crabs, but appears to have no special value for the garden. The fruit has an agreeable sub-acid taste, and the wood, being close and hard, is valued in the western States for uses similar to those of apple- and pear-wood in this country.

\section{P. Salicifolia, Pallas. Willow-leaved Pear.}

A tree 15 to $25 \mathrm{ft}$. high, branchlets covered with down which is quite white when young. Leaves $1 \frac{1}{2}$ to $3 \frac{1}{2}$ ins. long, $\frac{1}{3}$ to $\frac{2}{3}$ in. wide ; narrowly lanceolate, tapering gradually towards both ends, covered when young on both sides with a beautiful silvery grey down; later in the year this falls away from the upper surface, leaving it shining green; margins quite entire ; stalk $\frac{1}{2}$-in. long or less, sometimes scarcely noticeable. Flowers pure white, about $\frac{3}{4}$ in. across, produced in April, closely packed in small rounded corymbs, the calyx and flower-stalk covered with white wool. Fruit of the typical pear-shape, I to $1 \frac{1}{4}$ ins. long and wide.

Native of S.E. Europe and Asia Minor; introduced in 1780 . It is much 
the most ornamental of all true pears. Its leaves and flowers often open simultaneously, and it then presents a very charming picture, the willow-like leaves being of a conspicuous silky white. After the flowers fade, the leaves remain silvery for some weeks, gradually, however, becoming greener on the upper surface. The fruit is harsh to the palate, and of no value.

Var. PENDULA is a very elegant tree, with the branches more drooping than ordinary; but in the type they are more or less pendulous.

\section{P. SAMbuCifolia, Chamisso and Schlectendahl.}

There is no more confusing term in connection with the mountain ash group than "P. sambucifolia." It appears to have been applied to what are by some authors regarded as four distinct species. The true thing is regarded as confined to N.E. Asia, and is probably not in cultivation. In Western N. America the tree commonly called "P. sambucifolia" has been made a distinct species by Prof. Greene; it is P. Scopulina (Sorbus scopulina, Greene). A small erect tree 4 to $12 \mathrm{ft}$. high, with thick, erect branches. The leaflets, seven to fifteen in number, are broader and more abruptly narrowed at the apex than in P. americana. The flowers and fruits are larger, the latter of a bright red and in trusses 4 to 6 ins. across. P. scopulina is, I think, represented in gardens by the mountain ash known generally as "P. americana nana," the stiffest, stoutest, and most erect branched of any.

The "P. sambucifolia" of the eastern side of N. America is Sargent's P. americana decora, which, he says, is connected with typical P. americana (q.v.) by intermediate forms. Finally, in Japan, is P. MatsumuRAnA, Makino, a small tree with smooth shoots and winter buds, the leaflets only toothed at the terminal half.

\section{P. SARgentil.}

(Malus Sargentii, Rehder; Sargent's Trees and Shrubs, i., t. 37.)

A shrub of bushy habit 3 to $5 \mathrm{ft}$. high; young shoots downy. Leaves ovate or oval, 2 to 3 ins. long, I to 2 ins. wide ; pointed at the apex, rounded or slightly heart-shaped at the base, often three-lobed, sharply toothed; woolly when quite young, becoming nearly smooth before falling; stalks downy, $\frac{1}{3}$ to $I$ in. long. Flowers pure white, I in. across, produced in clusters of five or six, each on a stalk 1 to $1 \frac{1}{4}$ ins. long ; calyx smooth outside, woolly within. Fruit orange-shaped, $\frac{1}{2}$ in. wide, bright red, the apex marked by the scar of the fallen calyx.

I only know this species by a small specimen sent to Kew by Prof. Sargent in 1908, but it appears to be a pretty plant, and distinct among crabs by its purely bushy habit. It was originally discovered by Sargent in 1892 near a brackish marsh, Mororan, Japan, and was named in his honour by Mr Rehder in 1903 (loc. cit. supra). The author observes that it is most nearly related to P. Toringo, but differs in its larger, pure white flowers with broad overlapping petals and in its larger fruits. From another ally, P. Zumi, it is distinguished by "its broader, often lobed leaves, the shape of the [broader based] petals, the glabrous calyx-tube and the habit."

\section{P. SCHEIDECKERI, Spath.}

(Malus Scheideckeri, Zabel.)

A tree eventually 20 to $30 \mathrm{ft}$. high, branches somewhat erect on young trees; shoots grey-downy early in the season, becoming smooth later. Leaves ovate, rounded or tapering at the base, pointed, coarsely and sharply 
toothed; smooth and dark shining green above, paler and at first downy beneath, becoming smooth in autumn except on the midrib; on the flowering twigs the leaves are 2 to 3 ins. long and about half as wide, but on vigorous maiden shoots as much as $4 \frac{1}{2}$ ins. long by 3 ins., and sometimes lobed. Flowers often semi-double, $\mathrm{I} \frac{1}{2}$ ins. across, pale rose, produced in May in umbels of six to ten flowers each on a downy stalk I to $I \frac{1}{2}$ ins. long; calyx woolly, especially inside. Fruits globose, yellow, $\frac{5}{8}$ in. thick, calyx-teeth usually persisting at the top.

A hybrid between floribunda and perhaps spectabilis put into cultivation by Spath of Berlin in I888. Through floribunda it inherits the "blood" of $\mathrm{P}$. Toringo, as is occasionally evidenced by the lobing of leaves on vigorous branches. It is a tree wonderfully profuse in blossom, and of vigorous growth. On young trees clean shoots 3 or $4 \mathrm{ft}$. long are made in one season, at every bud of which there appears the following May a cluster of six to ten large blossoms. It is thus possible to cut branches a yard or more long, wreathed from end to end with flowers. This and P. floribunda are the two finest of

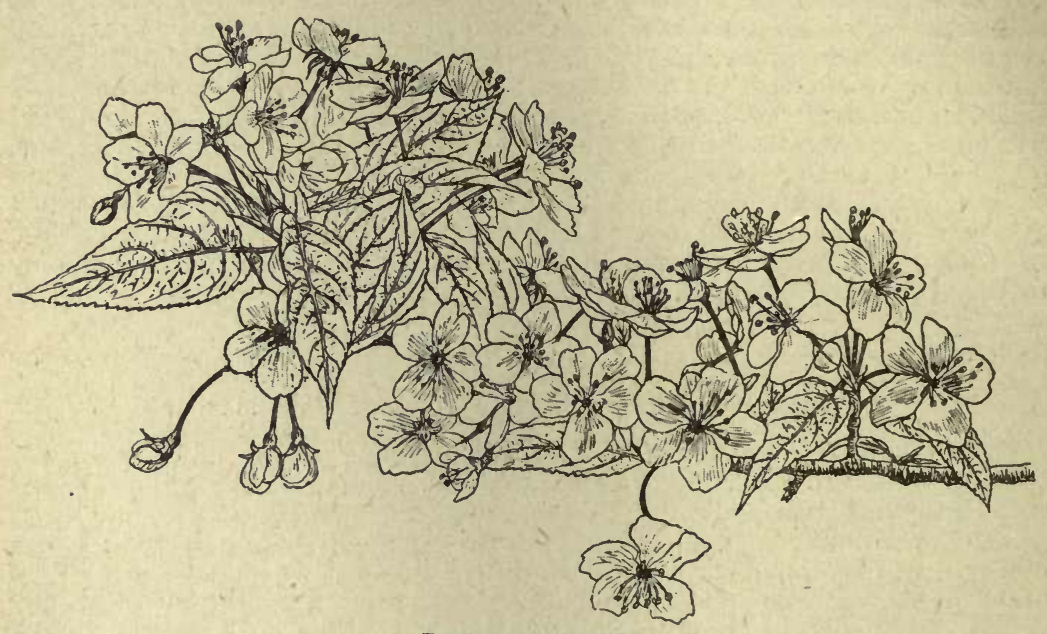

Pyrus sikkimensis.

flowering (as distinct from fruiting) crabs, and as P. Scheideckeri is two or three weeks the later, both should be grown.

\section{P. Sikkimensis, Hooker fil. Sikkim Crab.}

(Bot. Mag., t. 7430; Malus sikkimensis, Koehne.)

A small tree branching low and of bushy habit, distinct among all other crabs in cultivation through the excessive development of stout, rigid branching spurs on the trunk; young shoots downy. Leaves 2 to $4 \frac{1}{2}$ ins. long, I to 2 ins. wide; narrowly oval, tapering or rounded at the base, slenderpointed ; very woolly beneath, and more or less so above ; stalks downy, $\frac{1}{2}$ to $\mathbf{I} \frac{1}{2}$ ins. long. Flowers $\mathrm{I}$ in. across, white (rosy in bud), produced during May in corymbs of four to nine blossoms ; calyx downy, with slender-pointed lobes; flower-stalks $I \frac{1}{4}$ to $I \frac{1}{2}$ ins. long, slender.. Fruit somewhat pearshaped, $\frac{5}{8}$ in. wide and long, dark red with paler dots, the apex marked with the scar left by the fallen calyx. 
Native of Himalaya ; introduced to Kew in 1849 by Sir Joseph Hooker, who found it in the interior of Sikkim up to elevations of $10,000 \mathrm{ft}$. It is strange that so distinct and striking a tree has not spread more in cultivation. The original tree, introduced more than sixty years ago, is still at Kew-a vigorous example in perfect health, but still under $20 \mathrm{ft}$. in height, of quaint and picturesque form. It flowers freely, and annually produces enormous crops of fruits, which are in colour by September. Brandis observes that this crab is scarcely specifically distinct from P. baccata, but, as represented at Kew, it is easily distinguished by the low-spreading habit, the excessive development of spurs on the stems, the more woolly leaves and the smaller pear-shaped fruit. A pleasing lawn tree.

\section{P. SINENSIS, Lindley. SAND PEAR.}

$$
\text { (Bot. Mag., t. 8226.) }
$$

A tree 30 to $40 \mathrm{ft}$. high, branchlets hairy when young, becoming purplish. Leaves broadly ovate, sometimes roundish, 2 to 4 ins. long, $1 \frac{1}{4}$ to $2 \frac{1}{2}$ ins. wide; rounded at the base, finely but rather abruptly pointed at the apex, the margins set with bristle-like teeth, both surfaces smooth, except for a covering of cobweb-like down when first expanding; stalk 1 to 2 ins. long, hairy. Flowers white, $I \frac{1}{2}$ ins. across, produced late in March or early in April in clusters of about six to eight, each flower on a slender stalk $\frac{3}{4}$ to $I^{\frac{1}{2}}$ ins. long; calyx-lobes very hairy inside, less so outside; petals narrowly oval, rather separate from each other. Fruit rounded-oblong, brown, 2 to 3 ins. long in cultivated forms; rounded and about I in. diameter in a wild state, very astringent.

Native of N. Asia; and much cultivated in N. China and Japan for its fruits, which vary much in form, size, and colour. A tree at Kew which occasionally bears fine crops, has them of the ordinary pear shape, and up to 3 ins. long. Named varieties have recently been imported from Japan, which are either round, oblong, or pear-shaped, all, however, characterised by the conspicuously specked surface. They are said, even in Japan, to be only fitted for stewing, but keep d long time.

Var. Simonil, Dieck (P. Simonii, Carriere).-As represented at Kew this variety is very easily distinguished by its singular mode of growth. The trees are remarkable for their curiously gaunt habit, the branches being few and scarcely forked. A single branch will grow 6 or $8 \mathrm{ft}$. without dividing once. The leaves are similar to those of P. sinensis, and edged with the same characteristic, bristle-like teeth. The late Dr Bretschneider, who lived long in N. China, thought this variety to be the "white pear" of the Chinese, said to have a delicious pale yellow, apple-shaped fruit. At Kew the fruits are juicy, conical, tapering to the top, slightly indented at the insertion of the stalk, $1 \frac{1}{2}$ ins. long and wide, very freely spotted with brown.

\section{P. Sorbus, Gaertner. Service Tree.}

\section{(Sorbus domestica, Linnaus; Pyrus domestica, Smith.)}

A deciduous tree, usually 30 to $50 \mathrm{ft}$. (occasionally 60 to $70 \mathrm{ft}$. high); trunk covered with a scaly, rough bark; shoots furnished with loose, silky hairs when quite young, which soon fall away; winter buds glutinous and shining. Leaves pinnate, 5 to 9 ins. long, composed of thirteen to twenty-one leaflets, which are narrowly oblong, usually pointed, but sometimes rounded at the tip ; $1 \frac{1}{4}$ to $2 \frac{1}{2}$ ins. long, $\frac{3}{8}$ to $\frac{1}{2}$ in. wide; margin set with slender teeth except towards the base, which is entire; smooth above, more or less downy beneath, but becoming smooth or nearly so by autumn. Flowers white, about $\frac{1}{2}$ in. 
across, produced in May in panicles at the end of short branches and from the leaf-axils, the whole forming a rounded or rather pyramidal cluster $2 \frac{1}{2}$ to 4 ins. wide. Calyx and flower-stalks downy. Fruit pear-shaped or apple-shaped, $\mathrm{I}$ to $\mathrm{I} \frac{1}{4}$ ins. long, green or brown tinged with red on the sunny side.

Native of S. and E. Europe. As an ornamental tree this is inferior to its ally, the mountain ash, but is well worth growing for the beauty of its foliage, and for its flowers, which are larger than usual in this group of Pyrus. It also attains to greater dimensions than any of its immediate allies. The largest tree whose dimensions are recorded by Elwes is growing at Woodstock, Kilkenny, Ireland, which in 1904 was $77 \mathrm{ft}$. high and ro $\mathrm{ft}$. 8 ins. in girth.

The most famous of all British service trees was one which grew for some hundreds of years in Wyre Forest, in Worcestershire. The story of this tree was told by Mr Robert Woodward, jun., in the Gardeners' Chronicle, April $\mathrm{I}_{3}$, 1907. It was first noted by one Edmund Pitt, in 1678 , and was mentioned and discussed by various writers up to 1862 , when it was set on fire and killed by a vagrant. This tree was considered to be an old one by Pitt in 1678 , and there appears to be little doubt that the species lives for five or six hundred years. The Wyre Forest tree is the only one which gives the species any claim to rank as a British tree, for it has never been found truly wild elsewhere. A few of its descendants live, the finest being at Arley Castle, now nearly $60 \mathrm{ft}$. high.

The fruit of the service tree is sometimes eaten in a state of incipient decay, especially in France, although Loudon observes that it is not highly prized, and is more frequently eaten by the poor than the rich. On the other hand $\mathrm{Mr}$ E. Burrell, late gardener to H.R.H. the Duchess of Albany at Claremont, in a letter dated Nov. I I, I883, observes that "we are sending good fruits of the pear-shaped service for dessert at the present time." This Claremont tree was blown down in 1902 , and was then close upon $70 \mathrm{ft}$. high. The timber is of fine quality, being very hard and heavy, but too scarce to count for much.

The form with pear-shaped fruit, which appears to make the finest tree, is distinguished as var. PYRIFORMIS; the other, with apple-shaped fruit, as var. MALIFORMIS. Both are easily distinguished at any time from the mountain ash by the rough scaling bark; in autumn by the big fruits ; and in winter by the glutinous, not very downy buds. The service tree should be raised from seed.

\section{P. Spectabilis, Aiton.}

(Bot. Mag., t. 267 ; Malus spectabilis, Borkhausen.)

A tree rarely more than $30 \mathrm{ft}$. high, forming a rounded head of branches often as wide as high; young twigs downy. Leaves oval or obovate to almost round, 2 to $3 \frac{1}{2}$ ins. long, up to 2 ins. in width; toothed, shortly and abruptly pointed, tapering or rounded at the base ; glossy green and smooth above, downy when young beneath, becoming almost or quite smooth by autumn; stalk $\frac{1}{4}$ to $I$ in. long. Flowers deep rosy red in the bud state, paling to a blush tint when fully open, and then nearly 2 ins. across; they are borne each on a downy stalk $\frac{3}{4}$ to $1 \frac{1}{4}$ ins. long, in umbels six or eight together; petals normally five, but in var. FLORE PLENO up to ten; calyx and flower-stalk downy. Fruit globose, yellow, $\frac{3}{4}$ to $\mathrm{I}$ in. wide, bitter and harsh; calyx persisting at the top.

Native of N. China. The date of its introduction is not known, but it was cultivated by Dr Fothergill in 1780. One of the most beautiful of all the Malus group in its flowers, this has no beauty in its fruit. It flowers almost invariably in great profusion from the middle of April to the second week of 
May. From P. baccata and P. prunifolia its fruits and larger flowers amply distinguish it.

P. KAIDO (Malus Kaido, Wenzig).-Perhaps a hybrid between spectabilis and Ringo. It has larger, more deeply coloured flowers than the former.

\section{P. SPURIA, De Candolle.}

\section{(P. hybrida, Moench ; Sorbus spuria, Persoon.)}

A deciduous shrub or small tree, 6 to $\mathrm{I} 2 \mathrm{ft}$. (probably more) high; young wood downy. Leaves very variable, but usually more or less pinnate or pinnatifid; the smaller leaves, however, are sometimes quite entire, and there is every intermediate shape; they are 2 to $3 \frac{1}{2}$ ins. long, the three to seven leaflets or divisions overlapping each other, toothed, slightly downy beneath in the earlier part of the season. Flowers white, $\frac{3}{8}$ in. across, produced at the end of short leafy twigs in small corymbs. Fruit black-purple.

Although this interesting and pretty little tree has been in gardens for more than one hundred years, its origin is not definitely known, but it is most probably a hybrid between the mountain ash and P. melanocarpa. $\mathrm{P}$. arbutifolia is often given as one parent, but from the black-purple colour of the fruits P. melanocarpa is the more likely. P. spuria flowers very freely in May. "Pyrus hybrida, Moench," is perhaps the oldest name for this hybrid, but its use gives rise to such confusion with Sorbus hybrida as used for P. pinnatifida, that it seems best to drop it in both cases.

\section{P. TIANSHANICA, Franchet.}

\section{(Bot. Mag., t. 7755 ; Sorbus thianshanica, Ruprecht.)}

A shrub or small tree, 6 to $14 \mathrm{ft}$. high, of rounded bushy habit; young shoots usually smooth. Leaves pinnate, 5 or 6 ins. long, composed of four and a half to seven and a half pairs of leaflets, which are lanceolate, $1 \frac{1}{4}$ to 2 ins. long, $\frac{3}{8}$ to $\frac{5}{8}$ in. wide, pointed, finely and evenly toothed, and quite smooth on both surfaces; stalkless, except the terminal one. Flowers white, $\frac{3}{4}$ in. across, produced in late May in terminal, rather loose corymbs, 3 to 5 ins. across ; calyx and flower-stalks quite smooth except at the margins of the triangular calyx teeth. Fruit roundish, $\frac{1}{3}$ in. diameter, bright red.

Native of Central Asia (Turkestan, Afghanistan, etc.) ; discovered in I867, and introduced about 1895 . One of the dwarfest of this section, this is also one of the most pleasing. For small gardens or small lawns it is especially adapted, being of slow growth and neat, bushy form. Its flowers are probably the largest in the mountain ash group.

\section{P. TORINGO, Siebold.}

\section{(Malus Toringo, Siebold.)}

A small tree, rarely seen more than io to $15 \mathrm{ft}$. high, sometimes a low shrub, but said by Sargent to become $30 \mathrm{ft}$. high in a wild state; branches arching or pendulous; young shoots downy the first year. Leaves dull green, very variable in shape, and either narrowly oval, ovate, deeply three-lobed, or of some intermediate shape; they are I to $2 \frac{1}{2}$ ins. long, sharply, irregularly, and often coarsely toothed; downy on both sides, but especially beneath; tapering at the base to a downy stalk $\frac{1}{4}$ to $\frac{3}{4}$ in. long. Flowers pale pink to deep rose, $\frac{3}{8}$ in. in diameter, produced during April in clusters of three to six, each flower on a downy, slender, almost thread-like stalk $\frac{3}{4}$ to $I$ in. long. 
Fruit globose, the size of a small pea, red or brownish yellow, with no calyxlobes at the top.

Native of Japan ; introduced by Siebold about the middle of last century, and a small tree of very graceful habit, distinct among crabs for its variable, often deeply cut leaves, and its tiny fruits (see also P. Sargenti and P. Zumi). It is allied to P. floribunda, but is not so valuable a garden tree, its blossoms being shorter-lived.

\section{P. Torminalis, Ehrhart. Wild Service.}

(Cratægus Torminalis, Linnceus; Sorbus Torminalis, Crantz.)

A tree from 30 to $40 \mathrm{ft}$. high as a rule, but occasionally 60 to $70 \mathrm{ft}$., with a trunk girthing over $5 \mathrm{ft}$., branchlets covered at first with a loose floss, but soon quite smooth and shining. Leaves $2 \frac{1}{2}$ to 5 ins. long, nearly or quite as wide, of a broadly ovate or triangular outline, divided half-way to the midrib into three or four pointed lobes on each side; margins doubly-toothed; upper surface smooth and lustrous dark green; lower surface paler and at first downy, afterwards smooth; stalk I to 2 ins. long. Flowers white, $\frac{1}{2}$ in. across ; produced during June in rather lax corymbs 3 or 4 ins. across ; calyx and flower-stalks very woolly. Fruit oval or roundish, $\frac{1}{2}$ in. long, brownish.

Native of Europe (except the extreme north) including Central and S. England. This handsome tree is nowhere apparently very abundant in a wild state, and is rare also in cultivation. Yet few trees of its size are more striking, its leaves being large, boldly cut, and of a healthy polished green, turning crimson or yellowish in autumn. The flowers are not very pure white, but attractive when seen in the mass. The fruits when "bletted" after the fashion of medlars have a similar flavour, but are not to be recommended. It should be raised from seeds, and thrives best in a heavy clayey soil. Elwes records several trees between 60 and $70 \mathrm{ft}$. high in England, and a tree is known in Germany $82 \mathrm{ft}$. and $6 \frac{1}{2} \mathrm{ft}$. in girth of trunk. In Kent and Sussex the fruits are popularly known as "chequers."

\section{P. TRIlobata, De Candolle. \\ (Sorbus trilobata, Boissier; Eriolobus trilobat s, Roemer.)}

A small tree, perhaps up to $20 \mathrm{ft}$. high, with very downy young twigs. Leaves with three deep main lobes, the terminal one usually three-parted, the side ones two-parted. The leaf thus often becomes seven-parted, but the shape is not uniform, and although the three main lobes are always there, the subsidiary divisions vary in number. Some of the leaves have a maplelike appearance, the blade being 2 to 4 ins. wide, scarcely as long, heartshaped at the base ; the stalk $\frac{3}{4}$ to 2 ins. long. The upper surface is smooth and bright, the lower one downy, more especially on the veins and midrib; margins finely toothed. Flowers white, in small terminal corymbs, calyxlobes long; triangular, with a dense white wool on both sides. Fruit usually reduced to from one to three in a corymb, $\frac{5}{8}$ to $\frac{3}{4}$ in. across, globular or pearshaped, crowned with the calyx-lobes.

Native of Mount Lebanon and other parts of Syria, but rare both in a wild state and in gardens. Two small trees in the Kew collection are quite hardy. Some of the leaves resemble those of P. Torminalis. An interesting small tree.

\section{P. Tschonoski, Maximorvicz.}

\section{(Bot. Mag., t. 8 I 79 ; Eriolobus Tschonoski, Rehder.)}

A tree 30 to $40 \mathrm{ft}$. high, of erect, open, rather pyramidal habit; young branches covered with a greyish down. Leaves broadly ovate, or rounded; 
2 to 5 ins. long, $1 \frac{1}{2}$ to 3 ins. wide; pointed, unevenly toothed, the base rounded; covered with loose down above when young, afterwards becoming smooth ; permanently grey-felted beneath ; veins in six to ten pairs, parallel; stalk downy, $\frac{1}{2}$ to $I$ in. long. Flowers $I$ to $I \frac{1}{4}$ ins. across, white, suffused at first with rose, produced four to six together in umbels, each flower on a woolly stalk $\frac{1}{2}$ to $\frac{5}{8}$ in. long ; calyx covered with white wool. Fruit globose, $\mathrm{I}$ in. wide, brownish yellow flushed with purple, erect on a stalk I to $I \frac{1}{2}$ ins. long, crowned with the persistent calyx teeth.

Native of Japan, and first discovered at the foot of Fujiyama. It does not appear to be anywhere common, and was first introduced to cultivation by Prof. Sargent, who, in 1897 , sent plants to Kew, raised from seed he had collected five years previously. It is a tree of more interest than beauty, so far as one has yet been able to judge, for it does not flower very copiously, and its fruits have no attraction in colour. In North America its leaves are described as changing in autumn into beautiful shades of orange and yellow.

\section{P. vestita, Wallich. Himalayan Whitebeam.}

(Sorbus cuspidata, Hedlund, Bot. Mag., t. 8259; P. Aria himalaica, Hort.)

A deciduous tree of large size in a wild state, but rarely seen more than $35 \mathrm{ft}$. high under cultivation. The habit is rather gaunt; branches few, thick, covered when young with a white wool, which afterwards falls away, leaving the shoots of a smooth, purplish brown. Leaves oval or ovate, 5 to 7 (sometimes 9) ins. long by $2 \frac{1}{2}$ to 5 ins. wide, the margins toothed, sometimes doubly so or slighty lobed ; upper surface covered at first with a white cobweblike down, but soon becoming smooth, lower surface covered with a persistent thick felt, at first white or yellowish white, becoming grey later; nerves parallel, in ten to seventeen pairs; stalk $\frac{1}{3}$ to $I$ in. long. Flowers white, $\frac{5}{8}$ in. across, produced in late May or early June in substantial corymbs 2 to 3 ins. wide ; petals woolly within ; stalks and calyx very woolly.

Native of the Himalaya ; introduced in 1820 , and the most striking in its foliage of all the whitebeam group. Although nearly a century has elapsed since it was first brought into cultivation, very few specimens of large size exist in this country. The largest I know of is at Buckland St Mary, Chard, which a few years ago was nearly $40 \mathrm{ft}$. high. It grows well for some years, and then suddenly and without any apparent reason, sometimes in the middle of summer, will droop and die.

\section{P. VILMORINI, Ascherson.}

\section{(Sorbus Vilmorini, C. K. Schneider; Bot. Mag., t. 824r.)}

A shrub or small tree, Io to $20 \mathrm{ft}$. high, of elegant, wide-spreading habit, the young shoots stiff, covered when young with a brownish down. Leaves pinnate, 3 to $5 \frac{1}{2}$ ins. long, composed of six and a half to fourteen and a half pairs of leaflets, which increase in size towards the end of the leaf. Leaflets narrow, oblong, or oval, $\frac{1}{3}$ to $\frac{3}{4}$ in. long $\frac{1}{6}$ to $\frac{1}{4}$ in. wide; stalkless, toothed towards the apex, smooth on both sides; common stalk slightly winged and more or less downy, especially early in the season. Flowers white, $\frac{1}{4}$ in. diameter, produced in June on slender stalked corymbs at the ends of short twigs, and in the leaf-axils, the whole forming a pretty inflorescence $2 \frac{1}{2}$ to 4 ins. aeross. Fruit globular, $\frac{1}{3}$ in. across, pale rosy red.

Native of W. China; originally raised in France by $\mathrm{Mr}$ Maurice de Vilmorin from seed he had received from the missionary Delavay in 1889. Introduced to Kew in 1905 . This beautiful shrub is apparently quite hardy, and is one of the most elegant species introduced in recent years. The neat, 
handsomely divided leaves (among the smallest in the mountain ash group), the abundant clusters of pure white blossoms, and finally the fruits of a rosy, not a scarlet, red, all give to this species an air of distinction. It is allied to, and was at first associated with the Himalayan P. foliolosa-a probably tender species with much more woolly leaflets.

\section{P. ZUMI, Matsumura.}

(Malus Zumi, Rehder; Sargent's Trees and Shrubs, i., t. 91.)

A small tree of pyramidal habit; young wood slightly downy. Leaves ovate or oblong; $1 \frac{1}{2}$ to $3 \frac{1}{2}$ ins. long, $\frac{3}{4}$ to $1 \frac{1}{2}$ ins. wide ; tapering or rounded at the base, smooth except when quite young ; stalks about $I$ in. long. Flowers pink in bud, becoming white after opening, I to $\mathbf{I} \frac{1}{4}$ ins. diameter, produced in clusters of four to seven; calyx-lobes woolly, especially inside ; flowerstalks I to $\mathrm{I} \frac{1}{2}$ ins. long. Fruit $\frac{1}{2}$ in. diameter, globose, red.

Native of Japan; introduced to N. America in 1892 by Sargent, and thence to Kew in 1905. It is one of the group of Japanese crabs to which P. Toringo and P. Sargenti belong, distinguished by small fruits marked at the apex by the scar of the fallen calyx. It is said to be superior to P. Toringo as a garden tree in the Arnold Arboretum, being covered there in May by a mass of flowers, and in autumn by "attractive bright red fruits." It differs from both its allies in its oblong leaves being only slightly or not at all lobed, and from P. Sargenti in its wider flowers and less crowded petals. The fruits are larger than the pea-like ones of P. Toringo.

\section{QUERCUS. OAK. CUPULIFERÆ.}

A large genus of evergreen and deciduous trees and shrubs, of which nearly three hundred species are known. Sixty to seventy are in cultivation. Leaves alternate, a spiral of five making one circuit of the branchlet, frequently lobed somewhat deeply, but occasionally merely toothed or even entire. The down on the leaves, etc., is mostly stellate. Male and female flowers occur on the same trees, but on separate inflorescences. The males are numerous on pendulous (rarely erect) catkins, small, green or greenish, forming sometimes tassel-like clusters; females few and quite inconspicuous. The most distinctive feature of the oak is its fruit, which consists of a usually egg-shaped or rounded nut (acorn), the lower part of which is more or less enclosed by a cup covered with woody, sometimes fringe-like scales. The acorn frequently takes two seasons to mature. The nearest allies of the oaks are the sweet chestnuts, beeches, and hazels. One group-PASANIA - to which densiflora, glabra, and cuspidata belong, is sometimes kept apart as a distinct genus.

The oaks are amongst the finest of the large trees of temperate regions. The two native of Britain, Q. pedunculata and Q. sessiliflora, are the largest and longest lived of our deciduous trees, and produce the most valuable timber. Nor are they surpassed in rugged beauty and strength. Their maximum duration of life is probably not less than one thousand years. For some reason the planting of oaks in parks and gardens has fallen into desuetude in recent times. Beyond a few coloured or variegated sorts they are now stocked by very few nurserymen, who cannot, 
of course, be expected to keep up supplies for which there is no demand. No firms appear now to grow oaks in such number and variety as did Lee of Isleworth, Smith of Worcester, or Booth of Hamburg, thirty or forty years ago. The finest collections to-day, after that at Kew, are Lord Ducie's at Tortworth, and the one at Aldenham got together by Mr Vicary Gibbs. To those who contemplate planting oaks I would recommend the following as a selection of twenty of the best, apart from our British species and their varieties:-

Deciduous. - * Castaneafolia, Cerris, *coccinea *conferta, imbricaria, * Leana, Libani, Lucombeana, *macranthera, ${ }^{*}$ Mirbeckii, palustris, Phellos, * rubra, Toza, *velutina.

EVERGREEN.-Acuta, coccifera, densiflora, Ilex, phillyraoides.

Some of the deciduous species, like those marked *, are amongst the handsomest and most striking in foliage of all our big trees, and would impart distinction to any demesne, whilst coccinea and palustris give the richest touches of crimson to our autumn landscape. Q. Ilex forms a class by itself among evergreen trees hardy with us. Oaks, as a whole, thrive best on good deep loams. The old conception that the value of a soil for agriculture was indicated by the size and quality of the oaks upon it has many times been verified, not only in this country but in others, especially by the early settlers in both the east and west coast regions of $\mathrm{N}$. America. Oaks should always if possible be raised from acorns, which should be kept from getting dry after gathering until sown. Grafting has, perforce, to be resorted to for special varieties and rare species; but although one may see occasionally fine grafted specimens, the practice should only be adopted where absolutely necessary, for it tends to shorten the life of the tree, and in the end retard its growth. I strongly advocate getting all oaks into their permanent places as soon as possible. If I could, I would sow all acorns in situ, for thereby the tap-root is preserved and the plant never checked, but for many reasons that is not often possible except in pure forestry. Few trees in nurseries need tranisplanting with greater regularity every two or three years than oaks do if their final removal is to be accomplished safely, and few suffer more through shifting if their roots have been allowed to wander at will for a longer term. Evergreen species especially are liable to die. They should never be transplanted until after they show signs of growth in late May or early June, or else in September.

Some of the deciduous oaks are infested with an extraordinary variety of gall-producing insects, the best known of which are those that produce oak-apples and flat, circular, disk-like galls, sometimes so dense on the leaf as to partially overlay each other. Although frequently a disfigurement, and inducing a premature yellowing of the leaf, the production of galls does not seem to have noticeable. effects on the health of trees. There is no generally practicable means of preventing them.

\section{Q. ACUTA, Thunberg.}

An evergreen tree up to 30 or $40 \mathrm{ft}$. high in Japan, often shrubby in this country; young shoots and leaves covered at first with a brown floss, then quite smooth. Leaves stout and leathery, oval, sometimes inclined to ovate; 
tapering or (especially in young plants) rounded at the base and with slenderly tapered, often bluntish points; $2 \frac{1}{2}$ to $5 \frac{1}{2}$ ins. long, $\frac{7}{8}$ to $2 \frac{1}{4}$ ins. wide ; the margins entire and undulated; stalk up to $\mathrm{I}$ in. long, at first downy like the young wood. The upper surface is dark glossy green; lower one dull, yellowish; veins eight to ten each side the midrib. Acorns ctowded on a spike ; cup downy.

Introduced from Japan by Maries about 1878 to the Coombe Wood nursery, where one of his original plants became a bushy tree over $20 \mathrm{ft}$. high. It has proved to be perfectly hardy and is a useful evergreen of slow growth. It is only likely to be confused with glabra ( $\left.q . v_{0}\right)$

\section{Q. EgILops, Linnceus. VAlonia OAK.}

This famous oak, which is widely spread in the eastern Mediterranean region, is but little known in this country, although specimens are to be found in the south and west. Its acorn cups are of remarkable size-up to $I$ in. deep and 2 ins. in diameter, covered with long, flattish, downy scalesand were at one time an important article of commerce owing to the remarkable amount of tannin they contain. Young shoots and leaves downy, the latter oval or oblong, 2 to 4 ins. long, $1 \frac{1}{2}$ to $2 \frac{1}{2}$ ins. wide, with four to six angular bristle-tipped lobes down each margin; the base usually rounded or heart-shaped. There is a good specimen at Abbotsbury, near Weymouth, which has for many years past borne acorns. At Kew the tree is quite hardy and thriving, but although its acorns form, they never ripen. No other cultivated oak produces acorns so large as Q. Ægilops. It is, however, allied to Q. Cerris.

Var. Pyrami, Boissier (Q. Pyrami, Kotschy).-Two specimens of this oak at Kew, 20 to $25 \mathrm{ft}$. high, are interesting and neat-habited trees of close, rather pyramidal habit. Leaves up to 3 ins. long, obovate, coarsely toothed, often fiddle-shaped through a deep cutting below the middle, glossy green above; dull grey and stellately downy beneath. Trunk rugged, with deep squarish scales.

\section{Q. AGRIFOLIA, Née. EnCENA.}

An evergreen tree up to $80 \mathrm{ft}$, or more high in California; young shoots densely covered with starry down. Leaves hard in texture, oval or roundish, heart-shaped to tapered at the base, margined with slender, spiny teeth; I to 2 ins. long, $\frac{3}{4}$ to $I \frac{1}{2}$ ins. wide ; dark shining green and smooth above ; paler, not so glossy beneath, and smooth except for tufts of down in the veinaxils; stalk $\frac{1}{4}$ to $\frac{1}{2}$ in. long, stellately downy. Acorns cone-shaped, solitary or in pairs, stalkless, about I in. long, $\frac{5}{8}$ in. wide near the base, tapered gradually to a point, the lower third enclosed in a cup which is silvery within, and covered with close, flattened scales without.

Native of California ; introduced for the Horticultural Society by Hartweg, in 1849 ; now very rare. A tree at Kew about $35 \mathrm{ft}$. high, occasionally bears fruit and is quite hardy. According to Elwes the best tree in the country is at Killerton, and now $45 \mathrm{ft}$. high. Among cultivated evergreen oaks with spiny toothed leaves it is distince by reason of the tufts of down in the veinaxils and the tapered, conical acorns. It is an interesting oak, but of no particular merit or distinction.

\section{Q. ALBA, Linnceus. WhITE OAK.}

The white oak of the eastern and southern United States has no more than a sentimental interest for us in this country, for although, according to 
Aiton, introduced in $\mathbf{1 7 2 4}$, it has after many trials proved a complete failure. There does not appear at present to be a tree $2.5 \mathrm{ft}$. high in the British Isles. Yet it is one of the most magnificent trees of its native country, reaching in places 100 to $150 \mathrm{ft}$. in height, with a trunk 3 to $6 \mathrm{ft}$. in diameter, producing a splendid timber with much the same qualities of durability, etc., as our native species. Its young shoots are smooth; its leaves obovate, five- to nine-lobed, 5 to 9 ins. long, scarcely half as wide, the upper surface dark glossy green and smooth, the lower one pale or glaucous, and at first downy. Acorn $\frac{3}{4}$ in. long, with about one-fourth enclosed in the cup. This is the type species of the American white oaks, whose acorns mature in one season.

\section{Q. Alnifolia, Poech. Golden OAK of Cyprus.}

An evergreen small tree or shrub; young shoots clothed with grey down. Leaves stiff and hard in texture, roundish or broadly obovate, the terminal part toothed, the margins of the older leaves deflexed so that the inverted leaf has very much the shape of a shallow scoop; I to $2 \frac{1}{4}$ ins. long, and about the same or rather less wide ; upper surface dark glossy green, lower one yellow or greyish yellow, covered with a dense close felt ; stalk downy like the young wood, $\frac{1}{4}$ to $\frac{5}{8}$ in. long. There are five to eight prominent veins each side the midrib. Acorns $\mathrm{I}$ to $\mathrm{I} \frac{1}{2}$ ins. long, $\frac{1}{3}$ to $\frac{1}{2}$ in. wide; broadening from the base upwards, and thus somewhat truncheon-shaped, but ending in a short point ; cup about $\frac{1}{2}$ in. deep, with downy scales.

Native of Cyprus; introduced to Kew in 1885 , where it has proved perfectly hardy, but slow-growing. The peculiar attraction of this oak is the yellow under-surface of its leaves, but out-of-doors in England this colour is only slightly developed, and the under-surface is really greyish. But on the young leaves of a plant grown in a cool greenhouse at Kew the yellow is as markedly developed as in Castanopsis chrysophylla. Very rare in cultivation, and worth reintroducing.

\section{Q. BICOLOR, Willdenow. SWAMP White OAK.}

\section{(Q. platanoides, Sudworth.)}

A deciduous tree, 60 to $70 \mathrm{ft}$. (occasionally more) high, with loose, scaly bark; young shoots slightly downy at first, becoming smooth. Leaves obovate, 3 to 7 ins. long, $\mathrm{I} \frac{1}{2}$ to 4 ins. wide ; tapered at the base, the six to eight shallow, rounded lobes at each side often reduced to mere undulations towards the top; upper surface dark polished green, soon becoming smooth ; lower surface pale grey, clothed with a close, soft felt; midrib and stalk yellowish, the latter $\frac{1}{2}$ to $\frac{3}{4}$ in. long, more or less downy. Acorns about $I$ in. long, borne usually in pairs on a more or less downy stalk 2 to 3 ins. long, about one-third enclosed in the cup.

Native of Eastern N. America; introduced in 1800. Although the best of the white oaks for this country it is not a first-rate tree, nor has it attained to any great size, although Elwes mentions two or three that are between 50 and $60 \mathrm{ft}$. high. At Kew it is quite healthy, and has reached $40 \mathrm{ft}$. in height, the trunk very shaggy through the bark being attached in loose scales. The under-surface of the leaf does not become so silvery white as in N. America, but even here the soft felt beneath renders it distinct. Its acorns are occasionally formed with us, but rarely ripen, although in nature they mature in one season.

\section{Q. Castaneffolia, C. A. Meyer. Chestnut-leaved Oak.}

A wide-spreading, deciduous tree, reaching $100 \mathrm{ft}$. in height in a wild state; young branches downy. Leaves narrowly oval or oblong, tapered at 
both ends, margined with coarse triangular teeth, each terminated by a small, slender, abrupt point ; 3 to $7 \frac{1}{2}$ ins. long, $1 \frac{1}{4}$ to 3 ins. wide ; dark glossy green above and smooth except when quite young; dull greyish beneath, and clothed with minute down; stalk $\frac{1}{2}$ to $\mathrm{I}$ in. long, downy. The larger leaves have ten to twelve pairs of parallel veins, prominent beneath, which run out and furnish the short mucronate tip of the tooth. Acorn $\frac{3}{4}$ to $1 \frac{1}{4}$ ins. long, flattened at the top, and half enclosed in a cup with reflexed downy scales.

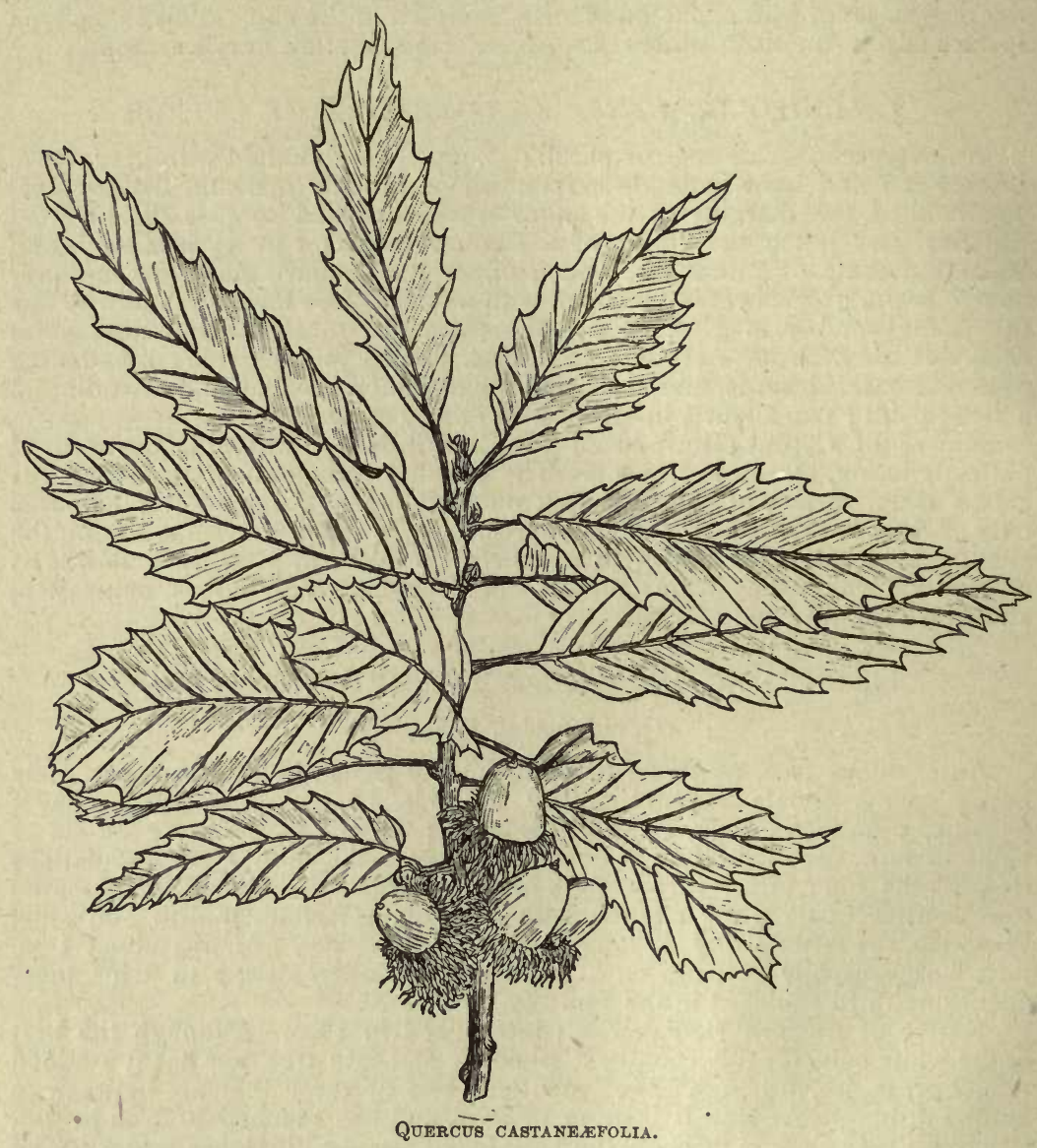

Native of the Caucasus and Persia; introduced in the first half of the nineteeth century. A very handsome and striking tree, with a leaf resembling that of a Spanish chestnut in form ; it is still very rare. There is a fine tree at Kew just over $60 \mathrm{ft}$. high, and about ' $10 \mathrm{ft}$. in girth of trunk, with a widespreading head of branches.

Var. ALGERIENSIS. - Whilst what may be regarded as the type is found in the Caucasus, an almost identical tree occurs in great numbers in Algeria. This differs from the Caucasian form in its erect pyramidal habit and deeply 


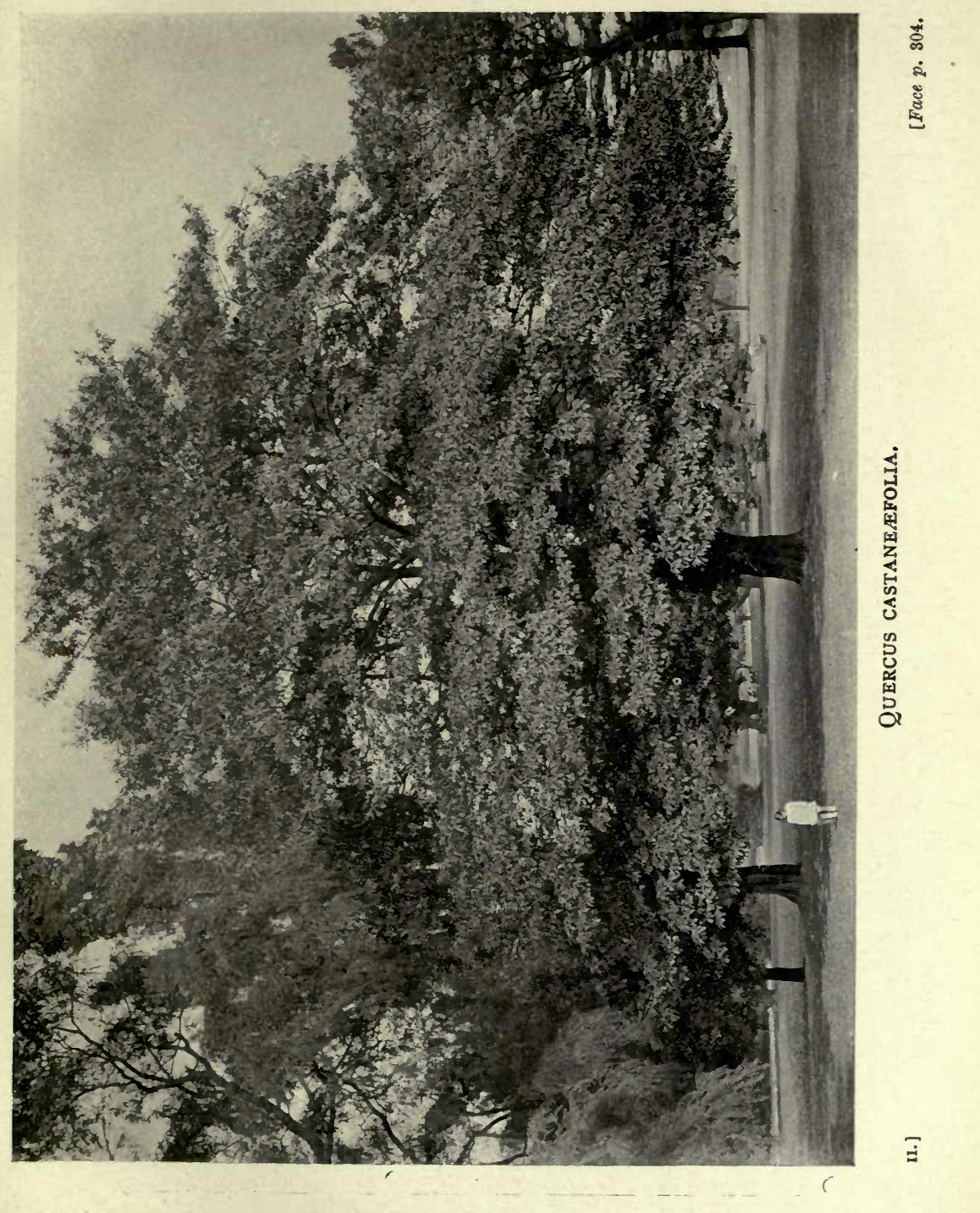



furrowed bark. Two trees are in the Kew collection raised from acorns sent from Algeria in 1869 . The leaves of these trees are much smaller than in the type (the largest 4 to 5 ins. by 13 ins.), and the young shoots are more downy. Pomel, who regarded the Algerian form as a distinct species and called it Q. AFARES, says that it also differs in having the acorns clustered four or five together. As in the type, they ripen the second year.

\section{Q. Cerris, Linnceus. Turkey OAK.}

A noble deciduous tree over $\mathrm{I} 20 \mathrm{ft}$. high, with a trunk occasionally more than $6 \mathrm{ft}$. in diameter ; winter buds all furnished with long, linear, downy scales; young shoots covered with a close, greyish down. Leaves thin and hard in texture, oval or oblong, tapered at both ends, very coarsely toothed or lobed, the lobes penetrating one-third to two-thirds towards the midrib; normally $2 \frac{1}{2}$ to 5 ins. long, I to 3 ins. wide, but very diverse in shape, size and lobing; dark lustrous green and harsh, with starry down above; dull greyish green and closely covered with similar down beneath; stalk $\frac{1}{2}$ to $\frac{3}{4}$ in. long. Acorns solitary or in pairs, each $I$ to $I \frac{1}{4}$ ins. long, very shortly stalked; the cup clothed with long, linear, downy scales.

Native of S. Europe and Asia Minor; introduced in I735. It is a very hardy tree attaining to dimensions under cultivation nobler than those of most introduced trees. As a timber tree it has very little value, being much inferior to the common oak. As a purely ornamental tree, however, for avenues, etc., it has some points in its favour, being quicker-growing and more elegant in growth.

Var. AUSTRIACA.-Leaves with comparatively shallow triangular lobes, and more downy beneath than in the type.

Var. LACINIATA (dissecta).-Leaves lobed almost to the midrib, often much narrower than in the type, between which and this variety are several intermediate forms.

Var. VARIEGATA.-Leaves bordered by a white band of varying width, which penetrates here and there to the midrib. A rather effective variegated tree.

\section{Q. Chrysolepis, Liebmann. Maul OAK.}

An evergreen tree up to 40 or $50 \mathrm{ft}$. high in a wild state, with a short, thick trunk, but scarcely more than a shrub as yet in cultivation; young shoots covered with starry down. Leaves $\frac{1}{2}$ to 2 ins. long, half to almost as wide, ovate or oval, the smaller ones often roundish, heart-shaped at the base, terminated by a'spiny tooth, also furnished on young plants with four to ten large spiny teeth at each side, terminating as many parallel veins. On old trees the lenves are described as entire. The upper surface is at first furnished with stellate down, but soon becomes nearly or quite smooth, and of a dark shining green; lower surface dull and at first yellowish downy, but often smooth the second year; stalks $\frac{1}{12}$ to $\frac{1}{6}$ in. long, clothed with starry down. Acorns solitary or in pairs, scarcely stalked, egg-shaped, $\frac{3}{4}$ to $I$ in. long, the downy cup enclosing less than half its length.

Native of California ; introduced by Sargent in 1877 , but apparently lost to cultivation afterwards, as none but quite young trees are at present in gardens. It is distinguished among evergreen oaks with foliage of the same character, by the yellowish appressed down beneath the leaves, which, however, is not so thick on plants cultivated in this country as it is in W. America. Of this tree Sargent observes that, in its native state, it is surpassed in majestic dignity and massive strength by no other American species except Q. virginiana of the southern Atlantic States. Trees exist with heads of branches fifty yards across. 
Q. VACCINIFOLIA, Kellogg.-This is sometimes associated with the above as a variety, but is probably a quite distinct species. It is a shrub up tc $4 \mathrm{ft}$. high, with small, oval, mostly entire leaves, covered beneath with a pale grey scurf. Introduced in r 909 , but little is known of its behaviour. Wild on rocky hillsides in Oregon and California.

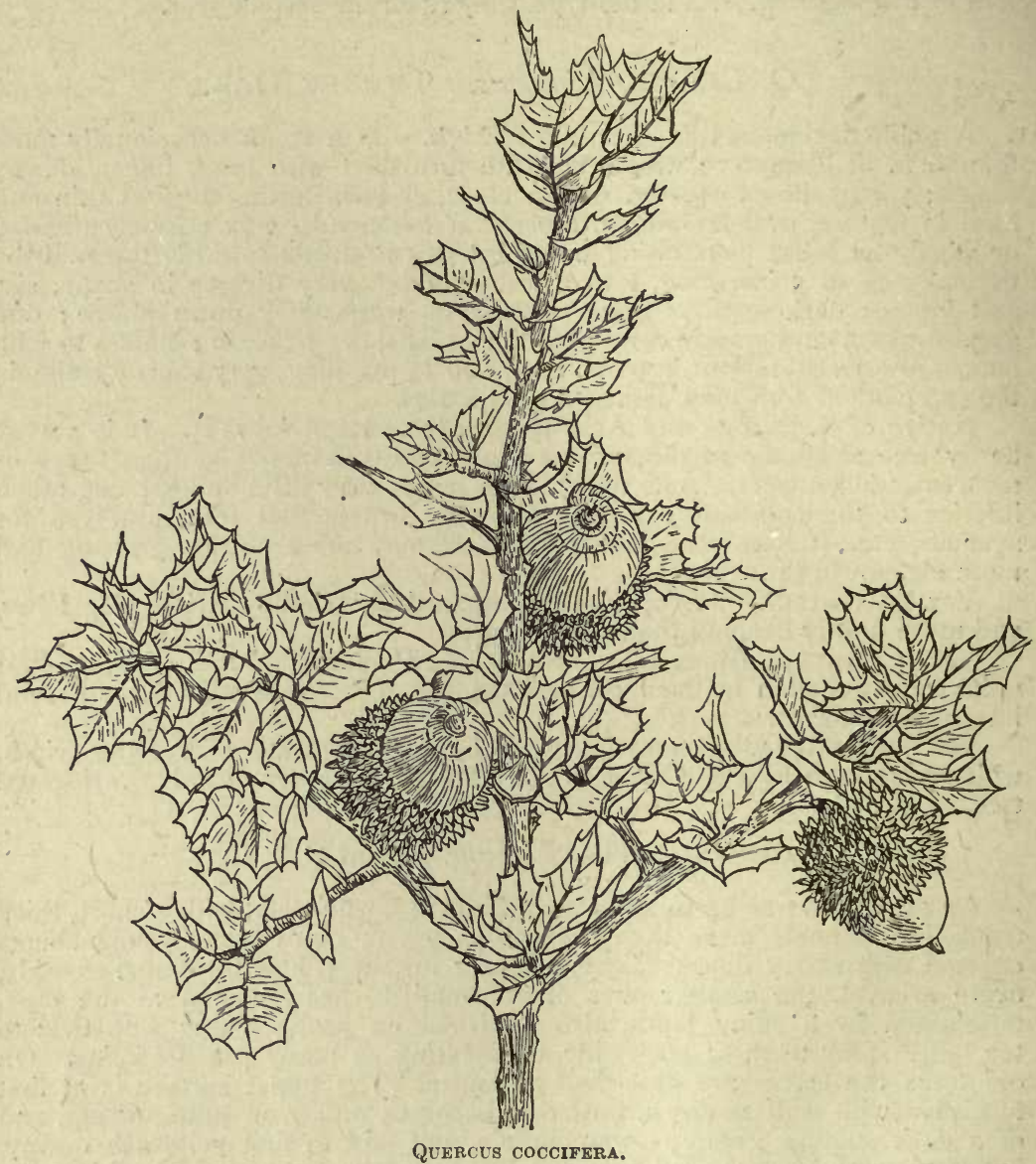

\section{Q. Coccifera, Linnaus. Kermes OAK, Grain Tree.}

An evergreen shrub up to ro or $12 \mathrm{ft}$. high, of sturdy, dense, neat habit, sometimes a small tree; young shoots clothed with starry down. Leaves stiff and hard, broadly oval, oblong, or ovate, rounded or heart-shaped at the base, ending in a stiff, sharp spine similar to the three to five with which each margin is armed; $\frac{1}{2}$ to $\mathrm{I} \frac{1}{2}$ ins. long, half to three-fourths as wide; dark green above, slightly paler below, shining and smooth on both surfaces; stalk about $\frac{1}{8}$ in. long, downy like the young shoot. Acorns usually solitary on a short stalk about $\frac{1}{2}$ in. long in cultivated specimens, and more than half enclosed in the cup, which is covered with reflexed spiny scales. 
Native of the Mediterranean region from Spain eastwards to Syria; cultivated in England in the seventeenth century. Of the dwarf evergreen oaks, this is, perhaps, the most pleasing in the glitter of its foliage and neat bushy habit. It is as prickly-leaved and well-armed as a small-leaved holly. It is variable in its foliage. The form known as

Var. PSEUDOCOCCIFERA, Boissier (Q. pseudococcifera, Labillardiere), is a tree found in Asia Minor and Syria with larger, flatter leaves than the type, and acorns $I$ in. long. The famous oak of Mamre, known as "Abraham's oak," is of this variety. According to Sir Joseph Hooker, it indicates the spot where tradition says the patriarch pitched his tent.

Quercus coccifera obtains its popular name of "Kermes oak" from being the host plant on which the kermes insect (Chermes ilicis) breeds. This insect, after certain treatment, produces a beautiful scarlet dye remarkable for its richness and lasting quality, once much employed and known in commerce as "grain" or "scarlet grain," but now, owing to cheaper substitutes, fallen into disuse. Three sprigs of Quercus coccifera or "grain tree" still form the crest of the Dyers' Company, whose arms were granted to them between 1420 and 1450 . From this one may gather how high was the estimation in which "Kermes" was held in the Middle Ages; but so much has this dye disappeared from modern use that until the matter was investigated at Kew a few years ago, the Company itself did not know to what tree the sprigs were supposed to belong. For an interesting account of this oak in regard to its connection with the dye, and various allusions to it quoted from Chaucer and Shakespeare, see Kerw Bulletin, 1910, p. 167.

Q. AUZANDRI, Grenier, is a hybrid between Q. coccifera and Q. Ilex, found wild in S. France, etc. Its leaves are felted beneath, and its acorns are borne two or three together on a stalk up to I in. long. It used to be cultivated in the Heatherside nursery, near Bagshot.

The largest tree of $Q$. coccifera I have noted in this country is in the Vicarage garden at Bitton-about $20 \mathrm{ft}$. high.

\section{Q. COCCinea, Muenchhausen. Scarlet OAK.}

A deciduous tree up to 70 or $80 \mathrm{ft}$. high ; young shoots warted, not downy ; winter buds downy towards the points. Leaves 3 to 6 ins. long, $2 \frac{1}{2}$ to $4 \frac{1}{2}$ ins. wide (in young trees as much as 6 ins. wide); obovate or oval, tapered at the base, deeply seven- sometimes nine-lobed, the lobes oblong or triangular, coarsely and unequally toothed at the apex; dark green above, paler beneath, both sides lustrous and smooth except that there are sometimes tufts of brownish down in the vein-axils beneath; stalk $1 \frac{1}{2}$ to $2 \frac{1}{2}$ ins. long, smooth, yellow. Acorns $\frac{1}{2}$ to $I$ in. long, two-thirds as wide, one-third to one-half enclosed in a deep, thin-edged cup.

Native of Eastern N. America; introduced about the end of the seven. teenth century. The true scarlet oak retains its leaves until November or December, and for the last six or eight weeks they are of a brilliant red, and make one of the richest of autumnal effects. The tree frequently known in gardens as "Q. americana splendens" represents the best form of Q. coccinea in cultivation. Q. coccinea differs from Q. rubra in the leaves being lustrous beneath, usually smaller, and with one pair less lobes; also in the acorn cup being hemispherical rather than saucer-shaped. (See also Q. palustris.)

\section{Q. CONFerta, Kitaibel. Hungarian OAK.}

A deciduous tree of stately habit, up to $100 \mathrm{ft}$. high in a wild state; young shoots slightly downy, smooth and grey the second year. Leaves obovate, but 
deeply cut into six to ten oblong lobes at each side, the largest of which are 2 ins. deep, and penetrate from half to three-fourths of the distance towards the midrib; they frequently have two to five rounded teeth on one or both sides. The largest leaves are 6 to 8 ins. long, and 3 to $4 \frac{1}{2}$ ins. wide ; the smallest about half those dimensions, all tapering at the base to a short stalk $\frac{1}{3}$ in. or less long, the blade usually prolonged at each side into a pair of short auricles. The upper surface is dark green and soon becomes smooth, the lower one downy, and greyish green. Acorns $\frac{1}{2}$ to $\frac{3}{4}$ in. long, scarcely stalked, produced two to four together, the lower half enclosed by the cup, which is clothed outside with flattened downy scales.

Native of S.E. Europe ; probably introduced about 1837. It is one of the handsomest of all oaks of the sessile-flowered group, and thrives well in cultivation. It is only likely to be confused with Q. macranthera, a species very distinct, nevertheless, in its woolly shoots. Occasional crops of acorns are produced on cultivated trees.

\section{Q. CUneata, Wangenheim. SPANISH OAK.}

\section{(Q. digitata, Sudworth; Q. falcata, Michaux.)}

A deciduous tree up to 70 or $80 \mathrm{ft}$. high in nature; young shoots and leaves covered with stellate scurf. Leaves obovate, three-lobed with a wedgeshaped base, or more ovate and five- or seven-lobed; 4 to 7 ins. long, $3 \frac{1}{2}$ to 5 ins. wide ; the terminal lobe mostly oblong, 2 to $3 \frac{1}{2}$ ins. long, the side ones shorter, triangular, or scythe-shaped-often furnished with a few bristleteeth. The upper surface is dark glossy green, the lower one dull grey and more persistently scurfy; stalk $\frac{3}{4}$ to $\mathrm{I} \frac{1}{2}$ ins. long, slender. Acorns very shortly stalked, about $\frac{1}{2}$ in. wide and long, the cup shallow or top-shaped.

Native of the eastern and south central United States; introduced in I 763 , but extremely rare. It is hardy and quite bealthy at Kew, but slow-growing. According to Sargent, the two forms of leaves occur sometimes on the same, sometimes on separate trees; but I have only seen the three-lobed ones (with the lobes at the terminal part of the leaf) in this country. In this state they are very distinct in the tapered base, and in the scurfy starry down on the various parts. (See Q. marylandica.) It does not colour well in autumn; usually brown.

\section{Q. CUSPIDATA, Thunberg.}

In cultivation in Britain this evergreen oak has never got beyond the dimensions of a bushy shrub, but in Japan it is described as a large tree with elegant drooping branches; young shoots not downy. Leaves oval, broadly tapered at the base, the apex drawn out into a slender blunt tip, leathery; 2 to $3 \frac{1}{2}$ ins. long, $\frac{3}{4}$ to $1 \frac{1}{2}$ ins. wide; either entire, wavy, or shallowly toothed towards the apex; stalk $\frac{1}{8}$ to $\frac{1}{2}$ in. long. The upper surface is dark shining green, the lower one grey and with a slight metallic sheen. Acorns $\frac{5}{8}$ to $\frac{3}{4}$ in. long, $\frac{3}{8}$ in. wide, tapering to a fine point; but not yet produced, as far as I am aware, in this country.

Native of China and Japan ; introduced by Maries for Messrs Veitch in 1879. According to Siebold, acorns were successfully transported by him to Europe in 1830 by encasing them in clay. Although apparently quite hardy near London, it gives no promise of attaining its natural dimensions here, and probably needs a somewhat warmer climate to be seen at its best, but even in its present state it makes an elegant evergreen shrub. It is distinct from all other evergreen oaks with entire or nearly entire leaves of the same size, in the long drawn-out apex and loundish tip of the leaf, and in the absence of down from the shoots. 
Var. VARIEGATA has smaller leaves than the type; they are rarely more than 2 to $2 \frac{1}{2}$ ins. long, and have a broad regular margin of creamy yellow; sometimes the whole of one side of the midrib is of that colour. It is not so hardy as the green type, but is occasionally used in greenhouse decoration.

\section{Q. DENSIFlora, Hooker. TANBARK OAK. \\ (Pasania densiflora, Oersted..)}

An evergreen tree, $70 \mathrm{ft}$. or more high, in a young state pyramidal ; young shoots clothed with of thick pale wool which persists through the second season. Leaves stiff and leathery, oval or oblong, rounded or broadly tapered at the base, pointed, twelve to fourteen parallel ribs on either side the midrib, each rib ending in a sharp tooth ; 2 to 4 (occasionally 6) ins. long, $\frac{7}{8}$ to $2 \frac{1}{4}$ ins. wide; upper surface at first covered with loose, stellate down which falls away by the end of the season, leaving it dark glossy green; lower surface with a thick down, at first pure white, becoming tawny and ultimately falling away, leaving it grey, glaucous, and nearly smooth ; stalk $\frac{1}{3}$ to $\frac{3}{4}$ in. long. The leaves remain on the tree for two or three years. Male flowers in erect, slender spikes, 2 to 4 ins. long. Acorn solitary or in pairs, $\frac{3}{4}$ to 1 in. long; the cup shallow, covered with slender, downy, reflexed scales.

Native of California and Oregon; introduced in $\mathrm{I} 874$ to $\mathrm{Kew}$, where it has proved a perfectly hardy and very striking oak. The milk-white down which covers the young leaves of the new shoots is very effective, and with the strong parallel ribs renders the species quite distinct from all other evergreen oaks. It is at present rare, but young plants have recently been raised from acorns introduced by $\mathrm{Mr}$ F. R. S. Balfour of Dawyck. This is fortunate, as it is becoming rare in a wild state through being cut down for its bark, which is exceedingly rich in tannin.

\section{Q. Dentata, Thunberg. Daimyo OAK.}

\section{(Q. Daimio, Koch.)}

A deciduous round-headed tree, 60 or more feet high, described as being of ungainly, unpicturesque habit-only known in a small state in cultivation; young shoots stout, densely covered with greyish soft hairs. Leaves amongst the largest of all hardy oaks ; occasionally over I ft. long and 6 or 7 ins. wide ; the smallest one-third those dimensions; obovate, tapered at the base, blunt or rounded at the apex, the margin with five to nine rounded lobes or deep undulations at each side. When quite young the upper surface is covered with minute down, the under-surface with a whitish felt; but, as the season advances, the down falls away from the upper surface, the lower one remaining sparsely downy. Acorns $\frac{1}{2}$ to $\frac{3}{4}$ in. long, rounded, produced in clusters; the cup covered with long narrow, downy scales.

Native of Japan and Corea ; introduced to Europe in 1830. It is a remarkable oak on account of its enormous leaves, but has never been really a success in this country, and is usually short-lived. Its habit is thin and gaunt. The under-surface of its leaves sometimes presents an extraordinary appearance because of a covering of disk-like galls, so thickly placed as to overlap each other.

\section{Q. Gambelir, Nuttall. Shin OAK.}

Little is known in cultivation of this West American oak, which has récently been introduced to this country. It is described by Sargent as a tree 20 to $25 \mathrm{ft}$. high, whose young shoots are clothed at first with a pale 
rusty down; often a shrub spreading by underground suckers. Leaves of firm texture, 3 to 5 ins. long, 2 to 3 ins. wide; obovate, tapered at the base. with three to six deepish lobes at each side; the lobes oblong, often with two or three undulations or minor lobes near the apex ; upper surface dark glossy green, covered (at least when young) with starry down; pale, dull, and more conspicuously downy beneath ; stalk slightly downy, $\frac{1}{4}$ to $\frac{1}{2}$ in. long. Acorns stalkless or short-stalked, $\frac{3}{4}$ in. long.

Native of the eastern slopes of the Rocky Mountains in Colorado, Utah, Nevada, etc., up to $7000 \mathrm{ft}$. elevation.

\section{Q. GLABRA, Thunberg.}

An evergreen small tree up to $30 \mathrm{ft}$. high, usually a shrub in this country, of spreading habit; young shoots smooth. Leaves smooth, narrowly oval or oblanceolate, tapered at both ends, blunt-pointed, entire, of hard, leathery texture; $3 \frac{1}{2}$ to 6 ins. long, I to $2 \frac{1}{4}$ ins. wide; glossy yellowish green above, dull and greyish beneath, nine to eleven veins on either side the midrib; stalk $\frac{1}{3}$ to $I$ in. long. Acorns produced in triplets on spikes 2 to 3 ins. long, but only an occasional acorn attains to full size, for which it requires two seasons ; it is then about I in. long, $\frac{1}{3}$ in. wide, pointed at the apex, and in shape very like the modern bullet. The cup is about $\frac{1}{4} \mathrm{in}$. deep.

Native of Japan; introduced in the first half of the nineteenth century, but still somewhat rare. It is a distinct and handsome evergreen, most nearly resembling Q. acuta, but differing in the more tapered base of its leaves and in its glabrous character. When very young the leaves have a scaly covering, but in Q. acuta they are distinctly woolly. It is best adapted for the milder parts of the country, but has produced perfect acorns at Kew.

\section{Q. Glandulifera, Blume.}

A deciduous tree up to 30 or $40 \mathrm{ft}$. high, of elegant habit; young shoots with silky, appressed, and forward-pointing hairs. Leaves obovate or narrowly oval, 2 to 7 ins. long, I to $2 \frac{1}{2}$ ins. wide ; tapered at both ends, with six to twelve incurved, gland-tipped teeth at each side, and eight to fourteen pairs of parallel veins running out to the apex of the teeth; dark green above, greyish beneath, both surfaces white with appressed silvery hairs when quite young, much of which falls away from the upper one; stalk $\frac{1}{4}$ to $\frac{1}{2}$ in. long. Acorns small, solitary, or several on a short stalk ; cup shallow.

Native of Japan, Corea, and China ; introduced in 1893 by Prof. Sargent. It varies in size and shape of leaf on different trees; the leaves of one form at Kew are only $\frac{1}{2}$ to $\mathrm{I} \frac{1}{2}$ ins. wide. All the forms promise to make shapely specimens. The species thrives remarkably well in the vicinity of Boston, Mass.

\section{Q. GROSSESERrata, Blume.}

A large deciduous tree, 80 to $100 \mathrm{ft}$. high; young shoots irregularly furnished with pale warts, but not downy. Leaves obovate, 4 to 9 ins. long, $2 \frac{1}{2}$ to $5 \frac{1}{2}$ ins. wide ; tapered to a pair of auricles at the base, pointed at the apex, ten to fifteen teeth on each margin, the largest from $\frac{1}{2}$ to $\frac{3}{7}$ in. deep, triangular, and again toothed ; dark, rather glossy green above, pale beneath, smooth except on the midrib and veins, which are more or less downy on both surfaces ; stalk $\frac{1}{8}$ to $\frac{1}{3}$ in. long, smooth. Acorns one to three on a short stalk, about one-third enclosed in the hemispherical cup (not yet produced in this country).

Native of Japan ; introduced to Kew by Prof. Sargent in I 893 . Although it appears to be quite hardy in this country, this oak does not thrive so well 
with us as it does in the eastern United States. In the suburbs of Boston, Mass., and in the Arnold Arboretum trees of the same generation as those at Kew are already remarkably striking for their size, rude vigour, and splendid foliage. Even on young trees in this country I have measured leaves 12 ins. by 7 ins., but on adult trees no doubt they are much smaller.

Q. CRISPULA, Blume, is closely allied to and may be specifically the same as Q. grosseserrata. So far as leaf, bark, and habit were concerned, Sargent was unable to distinguish between the two when he was in Japan. But according to Miyabe, the Japanese botanist, the acorn cup of Q. crispula is deeper, embracing about half the cylindrical acorn, both falling off together when ripe ; whilst in Q. grosseserrata the cup is hemispherical, enclosing only one-third of the acorn, which falls away free when ripe. (Forest Flora of Japan, p. 67-68.) Introduced from Japan in 1893 .

\section{Q. Ilex, Linnaus. Holm OAK.}

An evergreen tree of large size, attaining in favourable places a height of 70 to $90 \mathrm{ft}$., and developing in open situations a huge head of densely leafy branches as much across, the terminal portions of the branches usually. pendulous in old trees; young shoots clothed with a close grey felt. Leaves very variable in shape, most frequently narrowly oval or ovate-lanceolate; $\mathrm{I} \frac{1}{2}$ to 3 ins. long, $\frac{1}{2}$ to $I$ in. broad ; rounded or broadly tapered at the base, pointed, sometimes entire, sometimes (especially on young trees) more or less remotely toothed. When quite young both surfaces are clothed with whitish down, which soon falls away entirely from the upper surface leaving it a dark glossy green; on the lower surface it turns grey or tawny, and persists until the fall of the leaf; stalk $\frac{1}{8}$ to $\frac{5}{8}$ in. long. Acorns usually $\frac{1}{2}$ to $\frac{3}{4}$ in. long in this country, produced one to three together on a short downy stalk.

Native of the Mediterranean region; cultivated in England since the sixteenth century. The holm oak is in many respects the finest of all evergreen trees, apart from conifers, cultivated in the British Isles. Its foliage is most abundant, and the branches form heavy dark masses on the tree. The habit of young trees is curiously diverse, some being of distinctly pendulous habit, others rigidly pyramidal. The leaves, too, vary very much in size, shape, and toothing. On strong sucker shoots I have gathered them 5 ins. long and $2 \frac{1}{4}$ ins. wide, but that is very unusual. This oak likes a warm, rather light soil, and is perfectly hardy in the south and west of England, and near the coast. In very severe winters it is occasionally denuded of foliage. It thrives well near the sea, and is much planted on the sea-front of some of the southern watering-places, where it is seen as a dense, flat-headed bush, stunted, but otherwise quite healthy. It has one defect as a tree in trim gardens, due to shedding the leaves of the previous year during May and June, and making an unsightly litter day after day. One way of avoiding this nuisance is to plant the ground underneath the branches with ivy, amongst which the leaves fall and automatically disappear. Grown in woods under semi-forest conditions, the holm oak makes a tall slender trunk of rather picturesque appearance, due to the corrugation of the bark. It may also, if so desired, be clipped into rounded or pyramidal shapes and kept permanently dwarf. It should only be propagated by acorns, which it produces in quantity in dry hot seasons. They ripen the first autumn.

Var. Ballota, De Candolle.-A Spanish and North African form some. times kept up as a distinct species (Q. Ballota, Desfontaines). It has large edible acorns, to which it owes such distinctness as it possesses. The leaves are oblong, mostly rounded at both ends, with a mucronate tip; $-\frac{1}{2}$ to 2 ins. long; grey beneath as in Q. Ilex.

Var. CRISPA. - A curious form with small, orbicular leaves, averaging about 
$\frac{1}{2}$ in. in length, the margins decurved. Very slow-growing, and a curiosity merely; known in gardens since the early nineteenth century.

Var. FORDII.-Leaves of a peculiarly dark glossy green, narrow ; I to 2

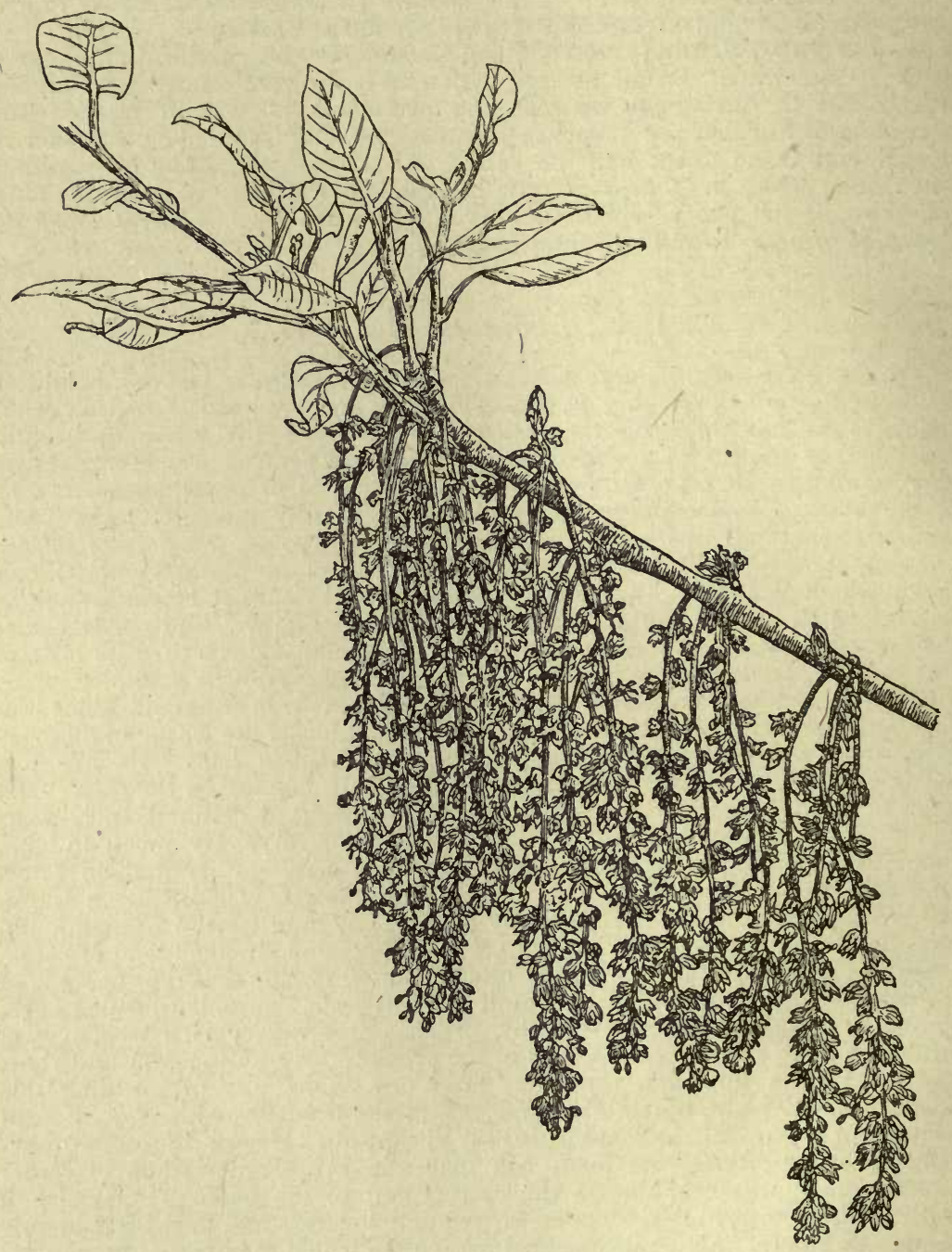

QUERCUS ILEX (in flower).

ins. long, $\frac{1}{3}$ to $\frac{5}{8}$ in. wide ; the margins wavy and more or less toothed. Said to have first appeared in Lucombe \& Pince's nursery at Exeter.

Var. GENABII.-Leaves very large and leathery, as much as 5 ins. long by $2 \frac{1}{2}$ ins. wide, coarsely toothed towards the apex. 
Var. Gramuntia, Loudon (Q. Gramuntia, Linnaus).-Leaves oval to roundish, with slender, spiny teeth, often heart-shaped at the base, up to 2 ins. long, short-stalked. It is more stunted in habit. The name is derived from the Grammont estate, near Montpelier, on which the tree originally described by Linnæus grew.

Var. LATIFOLIA. - A large-leaved form like Genabii, the leaves of about the same size, but not so thick and rigid; toothed towards the apex.

Other names such as longifolia, macrophylla, rotundifolia, serratifolia, have been given to supposed forms; but they show no more differences than might be detected in an ordinary batch of seedlings.

\section{Q. ILICIFOLIA, Wangenheim. BEAR OAK.}

\section{(Q. nana, Sargent; Q. Banisteri, Michaux.)}

A small deciduous tree up to 20 or $30 \mathrm{ft}$. high, more frequently a rounded shrub; young shoots hoary with short down. . Leaves 2 to 4 ins. long, I to $2 \frac{1}{2}$ ins. wide; obovate or oval in the main, but deeply three-five- or seven-lobed, the apex and the lobes narrowly triangular, pointed, and terminated by a bristle-like tip; the base wedge-shaped; dark glossy green and smooth (or soon becoming so) above, clothed beneath with a close whitish felt; stalk $\frac{1}{4}$ to $\frac{5}{8}$ in. long, slender. Acorns solitary or in pairs, $\frac{1}{2}$ in. long, roundish, ripening the second season, the lower half enclosed in a short-stalked cup with thin, flattened, downy scales.

Native of the eastern United States ; introduced in 1800 . A neat-habited and interesting oak, distinguished among the species with similar leaf shape by its small stature and the felted under-surface of its leaves. The freedom with which it bears acorns has led to the suggestion that it may make good pheasant covert. In Messrs Barbier's nursery at Orleans and at Les Barres I have seen it bearing great crops, but it does not produce them so freely in Britain. Its leaves die off scarlet and yellow in America, but are rarely' highly coloured with us.

\section{Q Imbricaria, Michaux. Shingle OAK.}

A deciduous tree, 50 to $60 \mathrm{ft}$. high ; young shoots smooth, angled. Leaves narrowly oval or oblong-ovate, 4 to 7 ins. long, I to 3 ins. wide; tapered at both ends, often blunt at the apex, nearly always entire (rarely three-lobed near the apex); dark polished green and smooth above, covered all the season beneath with a short grey starry down ; stalk $\frac{1}{4}$ to $\frac{5}{8}$ in. long. Acorns solitary, seldom in pairs, $\frac{1}{2}$ to $\frac{2}{3}$ in. long, nearly as broad, the shortly-stalked, shallow cup covered with thin flattened scales.

Native of the south-eastern and central United States ; introduced by John Fraser in 1786 . This handsome and striking oak is uncommon in cultivation in spite of its early introduction, but Elwes mentions a tree at Milford, near Godalming, $60 \mathrm{ft}$. high. It is quite distinct from all other cultivated deciduous oaks in the long, narrow, entire leaves, downy beneath.

\section{Q. Kelloggit, Newberry. Californitan Black OAK. \\ (Q. californica, Cooper; Q. sonomensis, De Candolle.)}

A deciduous tree up to $80 \mathrm{ft}$. or more high in a wild state, the bark very dark coloured in age, smooth and grey on young trees; young shoots downy at first. Leaves oval in the main, but cut up into deep lobes after the fashion of $Q$. coccinea ; the lobes (usually seven or nine) being oblong and furnished with two to four bristle-tipped teeth, the space between the lobes rounded at 
the base. The leaves are 3 to 6 ins. long, two-thirds as wide ; dark shining green and smooth above, paler beneath, and either downy or becoming almost or quite smooth; stalk yellowish like the midrib, at first slightly downy, I to $I \frac{1}{2}$ ins. long. Acorns solitary or a few on a stalk, I to $I_{4}^{\frac{1}{4}}$ ins. long, downy at the top, one-third enclosed in a cup which has ovate-lanceolate scales, and is borne on a short, thick stalk.

Native of California and Oregon ; very rare in cultivation, but a handsome tree with the red oak type of foliage. It is quite hardy, and occasionally produces fertile acorns at Kew; they take two seasons to mature, and at the end of the first are almost entirely enclosed in the cup. It is the only oak west of the Rocky Mountains which possesses the red or black oak character of leaf. It may be said to represent there the Q. velutina of the eastern States.

\section{Q. LANUGINOSA, Thuillier.}

\section{(Q. pubescens, Willdenow.)}

A medium-sized or small deciduous tree; young shoots covered with dense greyish down. Leaves very wavy at the margins, mostly obovate; I $\frac{1}{2}$ to 4 ins. long, half as wide ; with usually three to six rounded or pointed lobes on either side; upper surface at first covered with grey down, most or all of which falls away before the end of the summer; lower surface permanently and usually very thickly covered with down; stalk $\frac{1}{4}$ to $\frac{3}{4}$ in. long. Acorns either very shortly stalked or stalkless, solitary or as many as four together, each about half enclosed in the downy cup.

Native of S. Europe, and allied most closely to Q. sessiliflora, but with greyer and much more downy leaves. It is also a smaller tree with more scaly bark. To the Californian Q. lobata it bears a resemblance, but has longer leaf-stalks. The tree supplied by nurserymen as $Q$. mongolica is Q. lanuginosa. The true Q. mongolica, Fischer, is an ally of Q. grosseserrata.

Var. DISSECTA.-Leaves smaller, lobes deeper, much undulated.

\section{Q. Leana, Nuttall. LeA'S Hybrid OAK.}

A natural hybrid between Q. imbricaria and Q. velutina or Q. coccinea, of which there are several fine trees in this country. The leaves in shape approach those of imbricaria, being oblong and tapered at both ends; they are, however, rarely entire as in that species, but are more or less irregularly, and either deeply or shallowly lobed; 3 to 7 ins. long, 1 to $2 \frac{1}{2}$ ins. wide ; dark green and glossy above, furnished with a scurfy down beneath, but not so thickly as in Q. imbricaria. Young shoots more or less scurfy with starry down. This oak is named in honour of Mr T. G. Lea, who discovered it about 1830, near Cincinnati, Ohio. According to Sargent, it is scattered widely as solitary individuals over the south-eastern United States. From the variable character of trees given this name, especially in shape and pubescence of leaf, it is probable that it represents trees of different origin, although Q. imbricaria is undoubtedly one parent. In IgIo I saw trees in the Arnold Arboretum with leaves 3 to 5 ins. wide. It is always a vigorous, handsome oak. Of somewhat similar character and origin is

Q. Hetekophylla, Michaux, supposed to be a hybrid between Q. Phellos and Q. velutina or Q. rubra. It has smooth shoots, and the leaves are also smooth except for tufts of down in the leaf-axils. The leaves are 3 to 6 ins. long, I to $2 \frac{1}{2}$ ins. wide, varying from almost entire to having three to five deep, bristle-tipped lobes at each side. The origin of this tree is doubtful, and possibly more than one oak goes under the name. The heterophylla we cultivate now has leaf-stalks up to I in. or more long, but the oak of this 
name grown at Kew sixty to seventy years ago had all its leaf-stalks about $\frac{1}{8} \mathrm{in}$. long. Originally discovered in the early part of the eighteenth century by Bartram, near Philadelphia.

\section{Q. Libani, Olivier. Lebanon OAK.}

A deciduous tree of elegant growth not apparently attaining to a great size; young shoots clothed at first with minute down. Leaves oblonglanceolate, rounded at the base, tapered to a fine point; 2 to 4 ins. long, $\frac{1}{2}$ to $I$ in. wide; dark glossy green above, paler green beneath ; stalk about

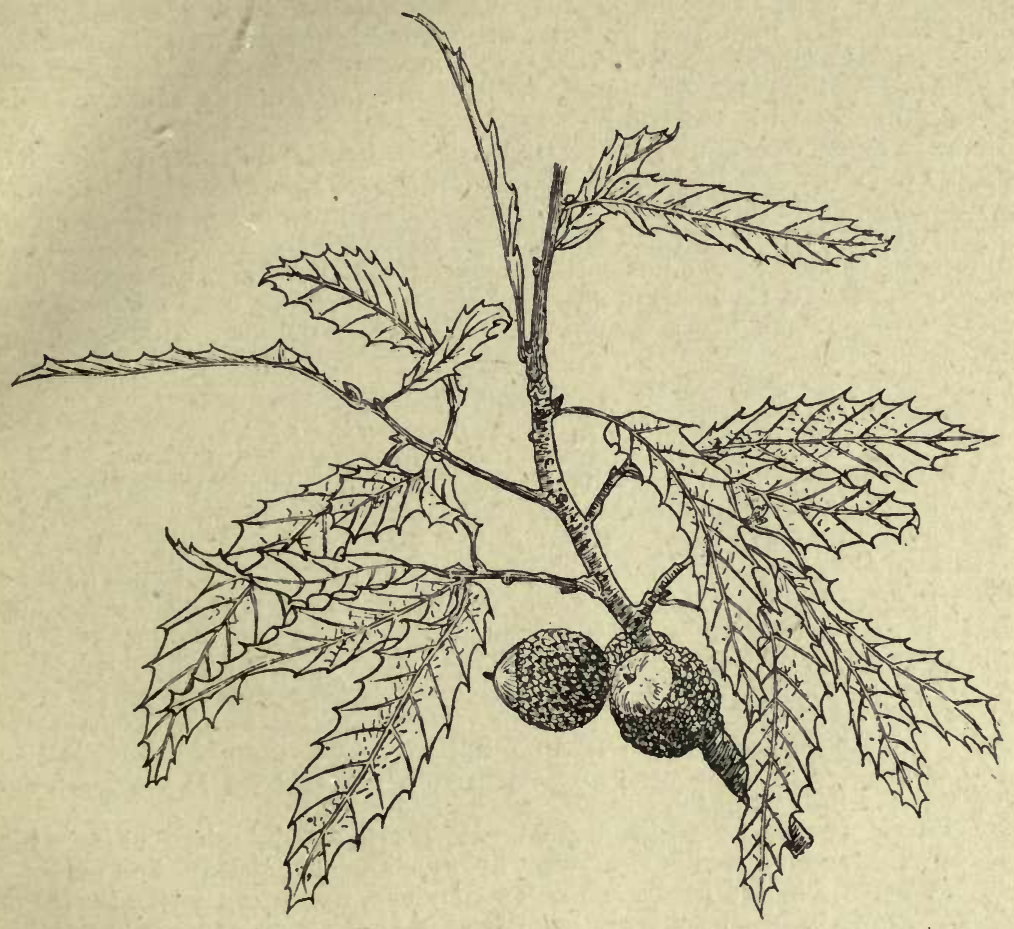

Quercus Libani.

$\frac{1}{2}$ in. long. On our cultivated trees the leaves soon become smooth on both surfaces except for a few hairs on the midrib and veins, but on wild specimens the under-surface is frequently thickly covered with down. Springing from each side of the midrib at an angle of $45^{\circ}$, and running out to the margin, where each forms the bristle-like point to a triangular tooth, are nine to twelve parallel veins. Acorns solitary or in pairs on a thick woody stalk $\frac{1}{2}$ in. or more long, on which they ripen the second year; they are about $I$ in. long on cultivated trees and nore than half enclosed in a large cup.

Native of the mountains of Syria, including Mt. Lebanon, and of Asia Minor; introduced to Paris about 1855 . Although the branches are slender and elegant they are scarcely pendulous on young trees. Acorns are frequently produced, but they do not become so large as those of some native 
trees. Among cultivated oaks this is most nearly allied to Q. macedonica (q.v.). It is sometimes met with in nurseries as "Q. serrata pendula."

\section{Q. lobata, Née. VAlley OAK. \\ (Q. Hindsii, Bentham.)}

A deciduous tree of the largest size, often over $100 \mathrm{ft}$. high in a wild state, the trunk occasionally as much as Io ft. thick, and forming a broad head of branches; young shoots downy. Leaves oval or obovate, tapered at the base, rounded or blunt at the apex, with four or five rounded or obovate lobes at each side; $I \frac{1}{2}$ to 3 ins. long, $\frac{5}{8}$ to $I_{\frac{3}{4}}$ ins. wide;-dark green and smooth or nearly so above; pale, dull and downy beneath, especially on the midrib; margin edged with fine hairs, stalk $\frac{1}{8}$ to $\frac{1}{2}$ in. long, downy. Acorns scarcely stalked, slenderly conical, pointed, $1 \frac{1}{4}$ to 2 ins. long, mostly solitary, about one-fourth enclosed in the cup.

Native of W. California ; introduced to Kew by Mr Bolander in 1874, but possibly in cultivation before. A stately tree in its own country, it has little to recommend it in this, being of exceedingly slow growth and not striking in foliage. It reaches its greatest size on deep moist loam, and in some of the Californian valleys is not infrequently 100 to $150 \mathrm{ft}$. high, with trunks 8 to Io ft. through. Its timber is of poor quality, but many fine trees are preserved in the fields of the West for the sake of the shade their wide-spreading branches afford.

\section{Q. Lucombeana, Sweet. Lucombe OAK.}

A deciduous, or, in some of its forms, almost evergreen tree up to $100 \mathrm{ft}$. high, forming a large, rounded head of branches as much in diameter; the trunk has a corrugated bark like that of the Turkey oak, and is buttressed in the same way at the base ; terminal bud furnished with linear scales; young shoots covered with grey down. Leaves oval or ovate, broadly tapered and unequal-sided at the base, with seven to nine parallel veins running out, and forming the tips of, triangular sharp teeth on the margin; 2 to 5 ins. long, I to 2 ins. wide; upper surface glossy green, lower one covered with a close grey felt ; stalk $\frac{1}{4}$ to $\frac{1}{2}$ in. long. Acorns solitary or in pairs on a short, stout stalk, ripening the second year, $\frac{3}{4}$ to $I$ in. long, more than hali enclosed in a cup covered with narrow, downy scales that are reflexed at the base, but erect towards the rim of the cup.

A hybrid between the cork oak and the Turkey oak, raised about 1765 from seed borne on a tree of the latter, by Lucombe, a gardener and nurseryman of Exeter. It is a handsome and stately oak, producing fertile acorns in plenty. From these many trees have been raised which show considerable variation within the limits set by the two parent species. It is not necessary, or indeed easy, satisfactorily to define all these variations on paper, although they are palpable enough when the trees grow together. When seedlings of Q. Lucombeana deviate towards the Turkey oak, the bark shows little or no corkiness, and the foliage is strictly deciduous. When, on the other hand, the influence of the cork oak predominates, it is evident in corky bark and nearly or quite evergreen leaves. The practice of calling the Lucombe oak and its progeny varieties of $Q$. Cerris is unsatisfactory, and I here follow the more logical one adopted by Elwes and Henry of keeping it distinct, and treating its seedling forms as varieties.

Var. CANA MAJOR.-Leaves often three-lobed.

Var. CRISPA, Loudon.-A corky barked, nearly evergreen form; leaves brilliant dark green above, white beneath. Habit more compact than ordinary Lucombe oak. A reversion towards Q. Suber, raised in 1792. 


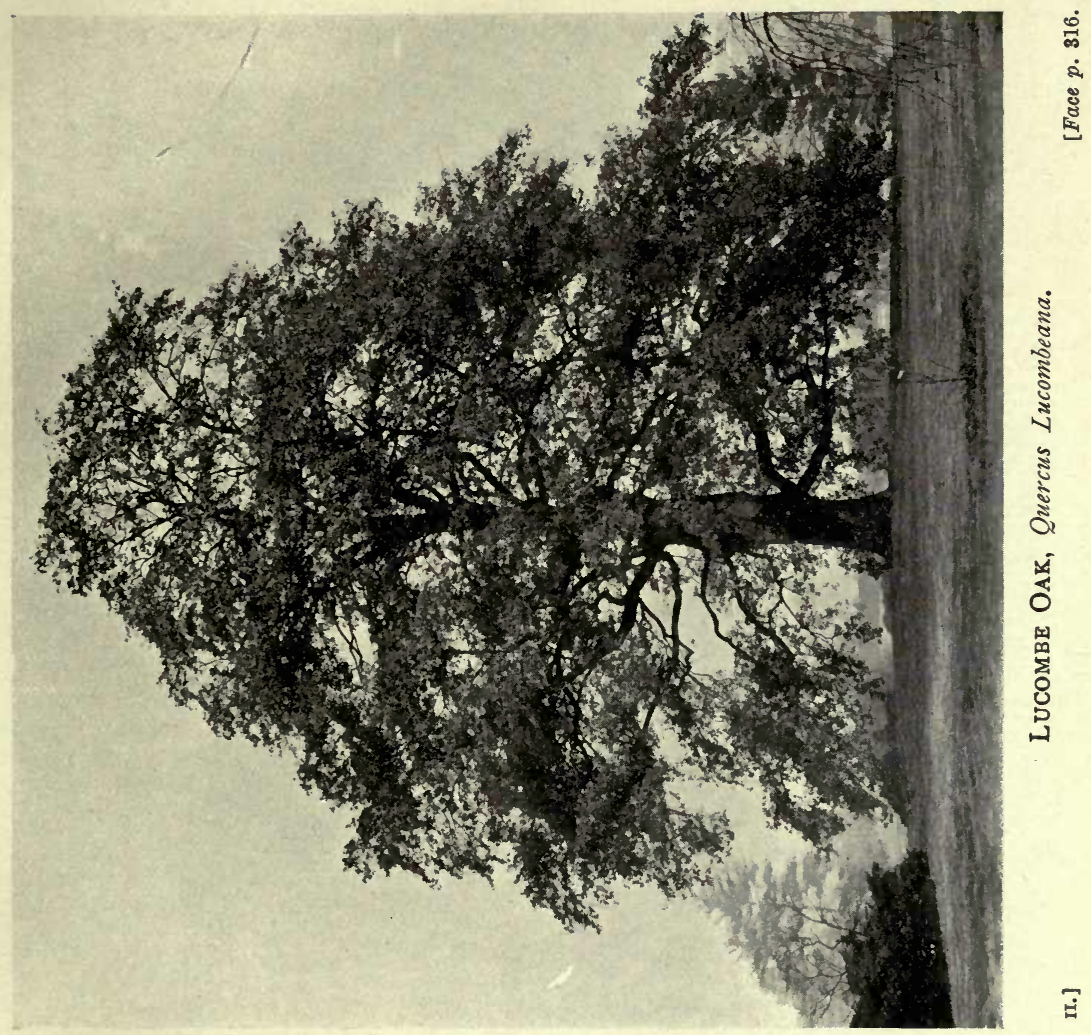



Var. DIVERSIFOLIA.-Leaves of extraordinary shapes; usually the middle part of the blade is reduced to a narrow strip about $\frac{1}{8}$ in. wide each side the midrib, widening at the apex like the bowl of a spoon, sometimes entire, sometimes three- or five-lobed; the base with from one to five shallow or deep, rounded or pointed lobes. The leading types of leaves may be described as fiddle-shaped and spoon-shaped. Bark corky; habit very erect ; evergreen. A small tree.

Var. FULHAMENSIS. Fulham Oak.-As represented at Kew by old trees, this is a tall oak with a round head of branches more slender and graceful than those of Lucombeana or the other varieties. Shoots and under-surface of leaves grey, as in Lucombeana, the latter more coarsely toothed. This variety got its name from a tree that grew for many years in Osborne's nursery at Fulham-now built over-and originally no doubt a seedling of Lucombe oak, although this particular tree was grafted.

Q. Pseudosuber, Santi, found in Italy and Provence, is a probable hybrid between Q. Suber and Q. Cerris. The leaves have much the character of some seedlings of Lucombe oak, reverting to Q. Suber.

\section{Q. LUSITANICA, Lamarck.}

A deciduous tree of middle size, or sometimes shrubby, with a rough thick bark cut up into square scales; young shoots densely downy. Leaves extremely variable ; commonly oval or obovate, 2 to 3 ins. long, about half as wide; rounded or unequal at the base, blunt or pointed at the apex, with five to nine coarse triangular teeth at each side; upper surface dullish greygreen, scurfy downy at first, but ultimately nearly smooth except on the midrib; lower surface clothed with a close, grey felt; stalk $\frac{1}{4}$ to $I$ in. long. Acorns $\frac{3}{4}$ in. long, clustered two or three together.

Native of Spain and Portugal ; introduced, according to Loudon, in 1824 ; still uncommon in gardens. A tree on a lawn near the Cactus House at Kew is a spreading, low tree, slow-growing, and of no particular merit. Closely allied to Q. lusitanica and with similar acorns is

Q. INFECTORIA, Olivier.-It is a more Eastern tree, being found in S.E. Europe and Asia Minor, differing from its Western relative in the smooth or nearly smooth leaves and young shoots. As represented at Kew, it is a rather elegant small tree with grey foliage, hard in texture, and not falling till late in autumn. Leaf-stalk smooth, up to $I$ in. long, slender. Var. BoIssieri, De Candolle.-Leaves larger and more numerously toothed, often over 3 ins. long; young shoots and leaf-stalks downy. Perhaps intermediate between the two species. Var. PETIOLARIS, De Cindolle.-Leaf-stalk up to I in. long. Leaves almost entire or toothed towards the apex, and often of large size.

\section{Q. Macedonica, A. De Candolle. Macedonian OAK.}

A small deciduous tree of slender, pyramidal habit when young; branchlets dull and grey, furnished at first with stellate scurf. Leaves ovate-oblong, slightly heart-shaped at the base, taper-pointed, with nine to eleven parallel veins either side the midrib, each terminating in the apex of a comparatively large, incurved, triangular tooth; $1 \frac{1}{4}$ to $2 \frac{3}{4}$ ins. long, $\frac{1}{2}$ to $1 \frac{1}{4}$ ins. wide ; shining with a rather metallic lustre above, duller beneath; both surfaces quite smooth by the time the leaf is fully grown; stalk $\frac{1}{8}$ in. or less long. Acorn usually solitary, scarcely stalked, $\frac{3}{4}$ to $\mathrm{I} \frac{1}{4}$ ins. long.

Native of S.E. Europe; introduced about 1890 . A very distinct oak, rather stiff in habit and (in a young state at least) retaining its leaves until December. It is very hardy, and I have never seen it injured by frost. As 
described, this oak resembles Q. Libani, but it is really a much stiffer tree, the leaves are shorter and greyer green, and both they and the acorns are much shorter stalked.

\section{Q. MACRANTHERA, Fischer.}

A deciduous tree up to $60 \mathrm{ft}$. high, with very stout young shoots and leafstalks covered with a thick, soft, greyish down that becomes dark, and persists through the second season; buds clothed with slender, hairy scales $\frac{3}{4}$ in. long. Leaves broadly obovate, tapered at the base, the margin conspicuously cut into seven to eleven rounded lobes down either side, each lobe $\frac{1}{2}$ to I in. deep, sometimes with one to three teeth on its lower side. The largest leaves are 6 ins. long and 4 ins. wide, the smallest half as large; green, with minute hairs above; pale beneath, and clothed with soft down; stalk $\frac{1}{2}$ to $\frac{5}{8}$ in. long. Acorns scarcely stalked, about I in. long, the lower half enclosed by a cup which is covered outside with erect, lanceolate, downy scales.

Native of the Caucasus and Persia; introduced about 1895. This is decidedly one of the most striking oaks with large leaves, equalling conferta and Mirbeckii in that respect, but distinct from them in the densely downy shoots and under-surface of the leaves. It is quite hardy, and young trees have already been raised from acorns of introduced trees.

\section{Q. MACROCARPa, Michaux. Burr OAK.}

A deciduous tree, not more than $50 \mathrm{ft}$. high in this country, but 80 to $170 \mathrm{ft}$. high in nature; bark scaling; young shoots and buds downy. Leaves obovate, 4 to 10 ins. (sometimes I ft.) long, about half as wide, wedge-shaped at the base, five- or seven-lobed, the terminal lobe often large (consisting of about half the leaf), ovate, and itself wavy-lobed; the lower lobes often reach almost to the midrib; dark green, smooth and glossy above, covered beneath with a pale, dull, minute felt ; stalk up to $\mathbf{I} \frac{1}{4}$ ins. long, downy. Acorn $\frac{3}{4}$ in. or so long, usually solitary, about half enclosed in a cup distinguished by having the scales near the rim almost thread-like and forming a fringe, on account of which this tree is often known as the "mossy-cup oak."

Native of Eastern N. America ; introduced in $18 \mathrm{II}$. It is very similar to bicolor, but is distinguished by the more deeply lobed leaves, and especially by the acorn cup. Like all the white oaks of America, it is not very happy in our climate, but there are a few healthy small trees up to $40 \mathrm{ft}$. high at Kew and elsewhere.

Q. LYRETA, Walter. Overcup Oak.-This is sometimes though rarely seen in gardens, and is not suited to our climate. It is allied to Q. macrocarpa, but its acorn is distinguished by being almost or entirely enclosed in the cup. The leaves are obovate, deeply five- to nine-lobed, the largest 7 to 9 ins. long, nearly half as wide, dark green and smooth above, pale and downy beneath; stalk up to $\frac{3}{4}$ in. long. Native of the southern United States, where it is occasionally $100 \mathrm{ft}$. high; introduced in $\mathbf{1 7} 86$.

\section{Q. MaRYlandica, Muenchhausen. Black JACK OAK.}

(Q. nigra, Wangenheim.)

A deciduous tree, 20 to $40 \mathrm{ft}$. high, forming a low, spreading head of rugged branches; young shoots covered with scurfy stellate down, becoming shining grey the second year. Leaves broadly obovate, tapered to a narrow, rounded or wedge-shaped base; broad and three-lobed at the apex; the 
lobes sometimes shallow and little more than undulations, sometimes broad, deep oblong, each with subsidiary lobes or teeth terminated by a bristle. The leaves vary from 2 to 7 ins. long, and are nearly or quite as much wide; upper surface dark polished green, at first covered with stellate scurf; lower surface paler, with conspicuous lines and tufts of down along the midrib and veins : stalk $\frac{1}{4}$ to $\frac{1}{2}$ in. long. Acorns $\frac{3}{4}$ in. long, solitary or in pairs, on a short, thick, downy stalk; cup one-third to two-thirds the length of the acorn.

Native of the eastern United States; introduced early in the eighteenth century. Occasionally its leaves turn rich red in autumn, but more often brown. It is a slow-growing and comparatively dwarf oak, but its foliage is striking. The three-lobed form of leaf in Q. cuneata is rather like the above, but has a slender stalk twice or more than twice as long.

\section{Q. Mirbeckir, Durieu.}

A decidious tree of stately habit, 60 to $80 \mathrm{ft}$. high in England, up to $120 \mathrm{ft}$. in Algeria ; young shoots ribbed, not downy, brown the second year. Leaves oval or obovate, coarsely toothed or lobed, the base rounded to heartshaped, or frequently lobed each side, the stalk (auricled). In young trees the leaves are 3 to 7 ins. long, $1 \frac{3}{4}$ to $3 \frac{1}{2}$ ins. wide; in adult trees they are smaller generally; dark green and smooth above, glaucous beneath and also smooth except for some loose brown floss on the midrib, especially towards the base and on the stalk, which is $\frac{1}{2}$ to $I$ in. long; ribs in eight to fourteen pairs. Acorns scarcely stalked, produced two or three together, about I in. long; the cup encloses the lowest third, and is itself clothed outside with flattened downy scales.

Native of N. Africa and Portugal; perfectly hardy, and one of the handsomest of all oaks, being a vigorous grower and striking in the rich green and large size of its leaves, which remain on the branches until Christmas, sometimes a month or two later. It is of the same type as conferta and macranthera, but differs from both in the smooth, less deeply lobed leaves. From pontica it is distinguished by the leaves having much fewer ribs. It was introduced from Algeria to France by General Pelissier, about 1845 , by acorns, some of which were at the time sent by Louis Philippe to Queen Victoria. In E. Algeria, according to Henry, it is an important timber tree, the forests of that region yielding about three and a half millions cubic feet of timber annually.

\section{Q. NIGRA, Linncus. WATER OAK.}

\section{(Q. aquatica, Walter.)}

A deciduous tree up to $80 \mathrm{ft}$. high in a wild state; young shoots smooth. Leaves often crowded at the end of short twigs, extremely variable in shape, mostly obovate, tapered at the base and rounded or bluntish at the apex; some, however, are narrow-oblong, like those of Q. Phellos, and entire ; others have several shallow or deep lobes towards the apex; they vary from $I \frac{1}{2}$ to 4 ins. long, and from $\frac{1}{2}$ to 2 ins. wide, and are of a pale green and smooth on both surfaces except for tufts of down in the vein-axils beneath; stalk $\frac{1}{10}$ to $\frac{1}{4}$ in. long. Acorns usually solitary, $\frac{1}{2}$ in. broad and long, one-third enclosed in a broad, shallow, short-stalked cup with appressed scales.

Native of the southern United States; introduced in 1723. The water oak is not common, but a few good specimens are scattered about the country chiefly in old-established gardens. The best at Kew is near the Sun Temple, and about $50 \mathrm{ft}$. high. It retains its leaves quite fresh until about the New Year. Its affinities are with Q. Phellos, which, however, never has the broad, obovate or lobed leaves. In the southern United States it is popular as a shade 
tree for streets, etc. This oak must not be confounded with the "Black Jack oak"-the Q. nigra of Wangenheim-a very different tree. (See Q. marylandica.)

\section{Q. obtusata, Humboldt.}

A deciduous tree retaining its leaves well into the New Year, not yet more than $40 \mathrm{ft}$. high in this country, but said to be a large tree in nature; young shoots smooth, becoming grey the second year. Leaves of firm, hard texture, strongly ribbed and net-veined beneath; obovate, tapered at the base, rounded or broadly pointed at the apex, shallowly and unevenly lobed or nearly entire ; 2 to $4 \frac{1}{2}$ ins. long, 1 to $2 \frac{1}{4}$ ins. wide ; vivid green above, slightly glaucous beneath, both surfaces without down; stalk $\frac{1}{4}$ to $\frac{1}{2}$ in. long, smooth. Acorns $\frac{3}{4}$ in. long, the lower third enclosed in a cup that is downy inside, and has appressed downy scales outside ; acorn stalk $1 \frac{1}{2}$ to 2 ins. long.

Native of Mexico ; introduced in 1839 for the Horticultural Society by Hartweg. It is of particular interest as the one Mexican oak really hardy. A tree has stood for many years on an exposed part of the Syon Vista at Kew, slow-growing, but not suffering from cold.

\section{Q. PALUSTRIS, Muenchhausen. PIN OAK.}

A deciduous tree, 70 to $100 \mathrm{ft}$. high, forming a dense head of slender branches pendulous at the ends; young shoots not downy, warted. Leaves 3 to 6 ins. long, nearly as wide, obovate, tapered or cut nearly straight across at the base, five- or seven-lobed; the lobes reaching three-fourths of the way to the midrib, oblong or triangular, unequally toothed near the apex ; both surfaces are glossy green and smooth, except that, in the vein-axils beneath, there are large conspicuous tufts of greyish down; stalk very slender, up to 2 ins. long. Acorn about $\frac{1}{2}$ in. long and broad, flattish at the base, where it is enclosed by a shallow saucer-shaped cup.

Native of the eastern United States; introduced to England in 1800. It occasionally bears crops of acorns, which require two seasons to mature. It is one of the very best growers among American oaks cultivated in this country, and is very elegant in its slender branches, especially whilst young or of the middle size. The leaves often turn deep scarlet in autumn, but I do not think it is so effective and reliable in this respect as Q. coccinea ; on the dry soil at Kew it is, at any rate, much inferior. It is frequently confused with $Q$. coccinea, but $Q$. palustris is distinguished by its more densely branched graceful head, by the invariable and conspicuous tufts of down beneath the leaf, by the shallower acorn-cup, and by the glabrous winter buds. From rubra it differs in the more deeply divided leaves, polished green on both sides.

Var. PENDULA.-Branches much more drooping than in the type.

\section{Q. PEDunculata, Ehrhart. Common OAK.}

\section{(Q. Robur, Linnaeus (in part).)}

A deciduous tree which develops in the open ground a broad, spreading head of rugged branches wider than the tree is high. In such positions, fully grown trees are 60 to $80 \mathrm{ft}$. high, but where they are growing close together they reach $100 \mathrm{ft}$. or more in height; young shoots smooth. Leaves stalkless or shortly stalked, obovate or oblong, ordinarily 2 to 4 ins. long, $\frac{3}{4}$ to $2 \frac{1}{2}$ ins. wide ; the margins cut into three to six rounded lobes; tapered towards the base, where are two small lobes; upper surface dark green, lower one greyish, smooth. Acorns $\frac{3}{4}$ to $I_{4}^{\frac{1}{4}}$ ins. long, one to several on a 
slender stalk 2 to 5 ins. long, one-third enclosed in the cup. The common oak has produced many varieties, of which the following are a selection :-

Var. Concordia, Lemaire. Golden Oak.-Leaves of a bright yellow lasting during the summer, but liable to scorch; not of a strong constitution. It appeared in Van Geert's nursery at Ghent about 1843-4. Var. AUREA LEUCOCARPA is somewhat similar.

Var. CRISPA.-Leaves small, very wrinkled.

Var. FAstigiata, De Candolle. Cypress Oak.-A form with leaves and acorns like those of the common oak, but having the habit of a Lombardy poplar. It has been found wild in various parts of Europe. As a picturesque tree of slower growth but longer life than the Lombardy poplar, it is worthy of more notice from planters than it has yet received. Sub-varieties of it are GRANGEI, of broadly pyramidal rather than columnar growth; and TORTUOSA, branches contorted; neither is of any importance.

Var. FILICIFOlIA, Lemaire (Q. asplenifolia ; Q. pectinata ; Q. taraxacifolia). Fern-leaved Oak. - Leaves downy beneath, long-stalked, cut almost or quite to the midrib into narrow, slender, pointed lobes about $\frac{1}{4}$ in. wide; base of leaf tapered. The leaves are occasionally 6 or 7 ins. long. The stalked, downy leaves would seem to point to an affinity with Q. sessiliflora, but the acorns are stalked.

Var. HAAS, De Candolle (Q. Haas, Kotschy).-This, by some regarded as a distinct species, has downy shoots, leaf-stalks, and under-surface of leaves. Acorns and leaves very large, the latter up to $.7 \frac{1}{4}$ ins. long by $4 \frac{1}{2}$ ins. wide, and the acorn-stalks up to 3 ins. long; young shoots very stout. Wild in Asia Minor.

Var. HETEROPHYLla, Loudon (var. Trinessii).-Leaves very variously shaped, some long and narrow, scarcely or not at all lobed, often hooded; others deeply and raggedly cut, never so regularly as in filicifolia. They usually hang loosely from the branches, and are 3 to 9 ins. long, $\frac{1}{2}$ to 2 ins. wide. This must not be confused with the American Q. heterophylla (q.v.).

Var. LONGIFOLIA.-I first saw this remarkable variety in the Arnold Arboretum. Its leaves are stalked, oval or slightly obovate, perfectly entire, blunt at the apex, and with the ordinary pair of auricles at the base; 1 to $3 \frac{1}{2}$ ins. long, $\frac{1}{2}$ to $1 \frac{1}{2}$ ins. wide; stalk $\frac{1}{4}$ to $\frac{1}{2}$ in. long. Acorn stalk 3 ins. or more long.

Var. PENDULA, Loudon. Weeping Oak.-Branches pendulous. A slender tree as I have seen it, but probably variable in this respect, as there are many specimens of independent origin.

Var. PURPURASCEnS, A. De Candolle.-Leaves, young shoots, and young acorn-cups purple. This occurs in several forms, the most striking of which is NIGRA (or "nigricans"), with very deep purple foliage which keeps its colour late. Var. GRANBYANA is of the same group.

Var. VARIEGATA. - There are several forms of variegated common oak, but very few, so far as I have seen, of much value in the garden. The leaves are variously marked with white or yellow, either on the margins or over the blade generally. A curious form at Kew is green on the first growth of the season, variegated on the second.

The common oak of Britain is well known as one of the longest-lived and most valuable timber trees of the world. It is spread pretty generally over Europe, the Caucasus, and Asia Minor. Although its timber is in less demand now than it was before iron and steel came into use for ship-building, it is still the best that can be used in house-building-floors, panelling, and the like. None other lasts so well, has so much beauty, or satisfies one's sentiment so completely in an English house.

It is only likely to be confused with $Q$. sessiliflora, the durmast oak, which differs in having comparatively long-stalked leaves, but stalkless or nearly stalkless acorns; its leaves, too, are always more or less downy beneath, and 
have not the little lobes or auricles common to pedunculata. Intermediate or hybrid forms occur.

\section{Q. Phellos, Linncus. Willow OAK.}

A deciduous tree from 70 to $100 \mathrm{ft}$. high, forming a rounded or columnar head of branches; bark smooth, grey; young shoots and leaves at first downy, then smooth. Leaves pale green, thin, oblong-lanceolate, tapered at the base, mostly pointed at the apex, entire, or slightly wavy on each margin ; 2 to $5 \frac{1}{2}$ ins. long, $\frac{1}{3}$ to I in. wide ; stalk $\frac{1}{8}$ to $\frac{1}{4}$ in. long, minutely downy or smooth. Acorns (rarely seen on introduced trees) scarcely bigger than a large red currant, and produced in a shallow, saucer-shaped cup.

Native of the eastern United States; introduced early in the eighteenth century. It is quite distinct from all other cultivated deciduous oaks in its smooth, narrow, normally untoothed leaves. In a young state it is a very elegant tree. There are several examples from 70 to $100 \mathrm{ft}$. high in England.

\section{Q. PHILlyreoides, $A$. Gray.}

A large evergreen shrub of rounded, bushy habit, or a small tree 20 to $30 \mathrm{ft}$. high; young shoots clothed with starry scurf. Leaves leathery, obovate or oval, heart-shaped or rounded at the base, tapering at the apex to a blunt or rounded tip, shallowly and usually bluntly toothed at the upper half; $\mathrm{I}_{\frac{1}{4}}$ to $2 \frac{1}{2}$ ins. long, $\frac{3}{4}$ to $\mathrm{I}_{4}^{\frac{1}{4}}$ ins. wide, bright dark green above and smooth except on the midrib; paler and also glossy beneath ; stalk $\frac{1}{4}$ in. or less long, clothed with stellate scurfy down, which extends along the lower part of the midrib. Acorn $\frac{1}{2}$ to $\frac{3}{4} \mathrm{in}$. long, formed but rarely developed in this country.

Native of China and Japan ; introduced in 186I by Richard Oldham when collecting for Kew. The largest specimen at Kew is about $16 \mathrm{ft}$. high and through-a handsome cheerful bush, well clothed to the ground with shining foliage. It is remarkable that this oak is not better known in gardens. From the rest of the evergreen oaks it can be distinguished by the bright green, nearly smooth surfaces of its leaves, combined with an absence of spine-tipped teeth.

\section{Q. PONTICA, Koch. ARMEnian OAK.}

A low deciduous tree or shrub, probably under $20 \mathrm{ft}$. high; young shoots smooth, stout, strongly ribbed. Leaves oval or obovate, broadly tapered at the base, rather abruptly pointed ; sharply, coarsely, and unequally toothed; 4 to $6 \frac{1}{2}$ ins. long, $1 \frac{3}{4}$ to $3 \frac{1}{2}$ ins. wide ; slightly glossy, smooth, green with a yellow midrib above; glaucous beneath and hairy along the midrib and chief veins. When young there are also appressed hairs over the whole lower surface. The leaf is strongly marked by (usually) sixteen or seventeen ribs running out from the midrib to the points of the teeth at an angle of about $45^{\circ}$; stalk $\frac{1}{4}$ to $\frac{1}{2} \mathrm{in}$. long, at first slightly hairy, yellow.

Native of N.E. Armenia and the Caucasus; introduced to Germany by Dr Dieck of Zoeschen, about 1885 , but not to England until considerably later; there appears to be none but small plants in the country at present. It is a very striking oak, its strongly ribbed leaves sometimes as much as 8 ins. long by 4 ins. wide. The shoots form conspicuously large terminal buds, whose slender scales are clothed with silky hairs. Very well worth planting.

\section{Q. PRINOIDEs, Willdenow. ChInquapin, Scrub OAK.}

A deciduous shrub, spreading by means of root-suckers, and forming dense thickets; young shoots ribbed, not downy. Leaves obovate, tapered at the base, 
pointed, with four to seven coarse, triangular teeth at each side; 3 to 6 ins. long, about two-thirds as wide; dark glossy green and smooth above, grey and minutely downy beneath; stalk $\frac{1}{4}$ to $\frac{1}{2}$ in. long. Acorns scarcely stalked, up to $\frac{3}{4}$ in. long, nearly half enclosed by the cup.

Native of the eastern and central United States; introduced in I828. It is interesting and curious as a suckering oak, but has little to recommend it for ornament. It is said not to exceed $15 \mathrm{ft}$. in height in a wild state, but I have only seen it one-third that height in cultivation, and never bearing acorns.

\section{Q. Prinus, Linncus. Chestnut Oak.}

A deciduous tree, 60 to $70 \mathrm{ft}$. high in a wild state; young shoots stout, smooth. Leaves obovate, 3 to 7 ins. long, $1 \frac{1}{2}$ to $3 \frac{1}{2}$ ins. wide ; tapered at the base, more abruptly so to the blunt apex; from each side of the midrib there spring ten to fifteen prominent parallel veins, each of which, except one or two at the base, runs out to the apex of an oblique rounded tooth. The upper surface is dark glossy green and smooth, midrib bright yellow; lower surface dull pale grey, and covered with a minute down; stalk yellow, $\frac{1}{2}$ to $I \frac{1}{4}$ ins. long, smooth. Acorns oval, $\mathbf{I} \frac{1}{4}$ ins. long, solitary or in pairs, borne on a stout stalk about $\frac{1}{2}$ in. long; usually less than half enclosed in the thin, warted cup.

Native of the eastern United States; introduced about the end of the seventeenth century, but still an uncommon tree. Young specimens at Kew, where it thrives well, show it to be a handsome and striking oak. It resembles Q. Mirbeckii, but that species is downy only along the midrib beneath and on the stalk, and its acorns are scarcely stalked.

Q. Muehlenbergi, Engelmann (Q. acuminata, Sargent). Yellow Oak.This is very nearly allied to $Q$. Prinus, but differs in having little or no stalk to the acorn; the teeth of the usually narrower leaves also are sharper and are tipped by a glandular mucro. It scarcely exists in cultivation in Britain, and does not seem likely to succeed as well as Q. Prinus. Native of the eastern and central United States, reaching southern Ontario.

\section{Q. RUBRA, Linnceus. RED OAK.}

A deciduous tree from 60 to $100 \mathrm{ft}$. high, with a trunk 3 to $6 \mathrm{ft}$. in diameter ; young shoots warted, not downy. Leaves oval or obovate, usually tapered, sometimes rounded at the base, with three to five lobes at each side, the lobes obliquely triangular or ovate, pointed, and with a few unequal teeth; the blade is 4 to 9 ins. long, 4 to 6 ins. broad, dark green and smooth above, pale dull green or greyish beneath, usually with tufts of brownish hairs in the vein-axils; stalks yellowish, smooth, I to 2 ins. long. Acorns $\frac{3}{4}$ to $1 \frac{1}{4}$ ins. long, nearly as wide, flat at the bottom, which is set in a shallow, almost saucer-shaped cup covered with closely appressed, short broad scales; they take two seasons to mature.

Native of Eastern N. America ; introduced early in the eighteenth century. The red oak is undoubtedly the best grower among the American species introduced to Britain. In a young state it grows vigorously, and its fine, boldly cut foliage makes it one of the handsomest of deciduous trecs. It frequently ripens acorns at Kew, from which young trees are raised. Its leaves change in autumn to a dull reddish or yellowish brown. The largest tree noted in England by Elwes is at Pains Hill- $-80 \mathrm{ft}$. high, its trunk I $9 \mathrm{ft}$. in girth. The red oak is much confused with $\mathrm{Q}$. coccinea and palustris, but it has larger leaves than either, usually not so deeply lobed, dull beneath, and not so bright above. The shallow acorn cup distinguishes it also from Q. coccinea. 
Var. AUREA. - In spring the leaves of this form of red oak, are of a beautiful clear yellow, giving quite as bright an effect from a distance as flowers. To those who admire trees of this character it may be recommended as one of the best. It needs a sheltered spot with an evergreen background.

In the grounds of Arley Castle (largely planted by Lord Mountnorris about I820) I saw in autumn a few years ago a number of trees which, in foliage, did not appear to differ from ordinary Q. rubra, except that they were making a very fine display of rich red, which $Q$. rubra does not make as a rule. Henry (Trees of Great Britain and Ireland, p. 1248) believes these trees to be hybrids between $Q$. rubra and $Q$. coccinea, deriving their rich autumnal colouring from the latter. It may be the tree mentioned by various American authors under different names: Q. ambigua (Michaux), Q. coccinea ambigua (Gray), Q. rubra ambigua (Fernald).

\section{Q. ScHNECKII, Britton. \\ (Q. texana, Sargent-not Buckley.)}

According to American writers, this deciduous oak, a native of the southern and central United States, attains a maximum height of $200 \mathrm{ft}$., with a trunk$8 \mathrm{ft}$. in diameter. It must, therefore, be about the tallest of all oaks. The leaves are of the typical "red" oak shape, up to 6 or 8 ins. long, obovate, with five or seven sharply pointed, narrowly triangular, sparsely toothed lobes; dark glossy green and smopth above, at first covered with loose, stellate down beneath, which soon falls away, leaving the surface shining green and smooth except for conspicuous tufts of down in the vein-axils, as seen in Q. palustris. From that species it differs chiefly in the acorns being much longer. proportion. ately to their width, egg-shaped, and up to I in. long. In I908 some small trees of this oak were introduced to Kew from the Arnold Arboretum, but what is the same tree had been obtained in Igor from Meehan's nursery as Q. texana. These young trees have succeeded very well, and turn a beautiful golden brown or rich red in autumn.

The true Q. TEXANA, Buckley, is a small tree or even shrub found in dry or rocky soil in $\mathrm{S}$. and W. Texas, not in cultivation.

\section{Q. SERRATA, Thunberg.}

A deciduous tree up to $50 \mathrm{ft}$. high, with a slender trunk; young shoots at first downy, soon becoming smooth. Leaves oblong or narrowly oval, rounded or broadly tapered at the base, terminated by a slender bristle-tipped point ; each of the twelve to sixteen parallel veins at either side the midrib running out into a bristle-like tooth $\frac{1}{6}$ in. long ; the leaves are 3 to 7 ins. long, I to $2 \frac{1}{4}$ ins. wide ; the stalk slender, $\frac{5}{8}$ to $I \frac{1}{4}$ ins. long ; upper surface smooth and shining, lower surface not so bright and of a paler green, with tufts of down in the vein-axils. Acorns (not seen in this country) small, and half embedded in cups which are covered with long, slender, pointed, downy scales.

Native of China, Japan, and the Himalaya ; introduced from Japan to Kew by Richard Oldham about 1862. It is a neat and cheerful-looking tree suitable for a limited space. Sargent says that in Japan it springs up on waste land in great numbers, but is only valued as fuel. Silkworms feed on its leaves. Nearly allied to it is $Q$. variabilis, with a corky bark, the leaves greyfelted beneath, and with shorter teeth. The only other oak with which it is likely to be confused is Q. castanæfolia var. algeriensis, but that may be easily distinguished by its shoots being downy throughout the first season or longer, by the thicker, shorter, quite downy leaf-stalk, and by the absence of the bristly termination to its coarser teeth. 


\section{Q. SESSiliflora, Salisbury. DURMast OAK.}

A deciduous tree, 60 to $80 \mathrm{ft}$. or more high, closely allied to and resembling Q. pedunculata, but with a head of branches less rugged and open; young shoots downy. Leaves 3 to 5 ins. long, with stalks up to $\mathrm{I}$ in. long; oval or obovate, deeply lobed, usually larger than in Q. pedunculata; dark glossy green and smooth above, greyish and more or less downy beneath. Acorns $\frac{3}{4}$ to $\mathrm{I}_{4} \frac{1}{4}$ ins. long, solitary or clustered (two, three, or more together) close to the twig, or on a quite short stalk. The durmast oak has not been so prolific of varieties as Q. pedunculata, but the following are worth notice :-

Var. AFGHANISTANENSIS, Booth.-Leaves oval or obovate, with shallower lobes than the type. Acorn with a distinct stalk as much as $\frac{1}{2}$ in. long.

Var. Cochleata, Petzold. - Leaves decurved at the margin so that the centre is humped or hooded.

Var. FALKENBERGENSIS.-Leaves short and broad, with large looes; very downy beneath.

Var. GieSLERI, Spath.-Leaves long, deeply and unequally lobed, as in Q. pedunculata heterophylla.

Var. IBERICA. - Lobes of leaf pointed.

Var. MESPILIFOLIA, Wallroth.-Leaves long, narrow, 4 to 8 ins. long, $\frac{1}{2}$ to 2 ins. wide ; entire, or shallowly lobed, tapered at both ends. A remarkably distinct variety, often grown as "Q. Louettii."

Var. MUSCOVIENSIS, Koehne.-Leaves of first growth often nearly or quite entire, those of the second or July growth nearer the type, and lobed.

Var. RUBICUNDA (purpurea).- Young leaves red.

The durmast oak, a native of Europe and Asia Minor, is found wild in the British Isles, generally in elevated districts. Although it is considered by some planters to be better adapted to dry situations than Q. pedunculata, it is most abundant in some of the wettest parts of the country, as for instance on the hills between Kenmare and Killarney, where all the oaks seem to be sessiliflora. On the south-western coast of Scotland, too, it succeeds admirably. Generally it appears to be the quicker grower, and is capable of attaining to a great height. Mr. Elwes mentions one in Whitefield Park, Herefordshire, $130 \mathrm{ft}$. high. But, generally, the trees with huge trunks and the famous oaks of history appear to be $Q$. pedunculata. There appears to be little difference in the quality of the timber of the two ; if any, the consensus of opinion is in favour of $Q$. pedunculata.

There are oaks intermediate in various ways between Q. sessiliffora and Q. pedunculata, sometimes uniting stalked acorns with downy leaves, or sessile acorns with auricled leaves, and so on ; but generally they are easily determinable.

\section{Q. Suber, Linncus. CORK OAK.}

An evergreen tree up to $60 \mathrm{ft}$. high, with a trunk $5 \mathrm{ft}$. in diameter, whose bark is remarkably thick and corky ; young shoots covered with a close, grey down. Leaves oval, ovate or oblong, I to $2 \frac{1}{2}$ ins. long, $\frac{5}{8}$ to $1 \frac{1}{2}$ ins. wide; rounded or abruptly tapered at both ends, toothed except near the base ; upper surface dark glossy green, smooth except when quite young; lower surface clothed with a minute grey felt; stalk $\frac{1}{4}$ to $\frac{1}{2}$ in. long, minutely downy. Acorns ripening the first year, $\frac{3}{4}$ in. long, about half enclosed in the cup, and borne singly or in pairs on a short, downy stalk.

Var. Occidentalis, Henry (Q. occidentalis, Gay). - The French botanist Gay was the first to distinguish this from the type about 1855. Its chief distinction is in the fruits taking two seasons to mature. It has also a distinct habitat, being found on the west or Atlantic side of Europe, whilst the true 
Q. Suber occurs north and south of the Mediterranean. Q. occidentalis is hardier, and no doubt many of the cork oaks in Britain are of this form.

The bark of this tree (which affords the best distinction between it and other evergreen oaks) produces the common cork of everyday use. It is stripped from the trunk and chief branches every eight or ten years. Portugal is the great centre of the cork industry. As a tree for gardens, the cork oak is only adapted for the southern and milder parts of Britain. The finest trees are in the south-western counties, where there are several 50 to $60 \mathrm{ft}$. high. The largest I know of near London is in H.R.H. the Duchess of Albany's grounds at Claremont ; this has a trunk about $14 \mathrm{ft}$. in girth, but is past its best. The species is supposed to have been introduced about the end of the seventeenth century.

\section{Q. Toza, Bosc. Pyrenean OaK.}

A deciduous tree up to $70 \mathrm{ft}$. high, with slender, often pendulous branches ; young shoots densely clothed with grey down. Leaves very variable in size, from 3 to 9 ins. long, $1 \frac{1}{2}$ to $4 \frac{1}{2}$ ins. wide, conspicuously and deeply lobed ; the lobes four to seven on each side, oblong, rounded or pointed, the larger ones often coarsely round-toothed; dark glossy green, and with sparse, minute, starry down above; grey and felted beneath; stalk downy, $\frac{1}{4}$ to $\frac{3}{4}$ in. long. Acorns about $\frac{3}{4}$ in. long, produced two to four together on a downy, erect stalk $\frac{1}{2}$ to $\mathrm{I} \frac{1}{2}$ ins. long, about half enclosed by a cup with closely appressed downy scales.

Native of S.W. Europe ; introduced, according to Loudon, in 1822 . It is a very distinct and elegant oak, well marked by the deeply and pinnately lobed leaves, and by their dense, close felt beneath. The leaves, however, show much variation in size and character of lobing. In its velvety downiness it resembles Q. macranthera, which has more but shallower lobes. Q. Toza produces long pendulous shoots under cultivation, and in a young state is extremely liable to be broken by autumnal gales. According to Elwes, there is a tree $66 \mathrm{ft}$. high at Clonmannon, Co. Wicklow, with a trunk $9 \mathrm{ft}$. in girth. The so-called var. SPLENDENS is merely a big-leaved form. There is at Tortworth an interesting hybrid between Toza and pedunculata, the leaves much more minutely felted beneath, and the fruit-stalks much longer.

\section{Q. TURnerI, Willdenoze. TURnER'S OAK.}

A supposed hybrid between Q. Ilex.and Q. pedunculata, said to have been raised in the nursery of Mr Spencer Turner, Holloway Down, Essex, in the latter half of the eighteenth century. It is a tree of spreading habit, growing sometimes over $50 \mathrm{ft}$. in height, with foliage which persists through the winter until February or March, according to the mildness or otherwise of the season. But even after the mildest winters the tree, so far as I have seen, is always destitute of foliage for some weeks. The young shoots are clothed with a dense pale down. Leaves leathery, oblong-obovate, mostly rounded but unequal at the base, bluntish at the apex, and with four to six rounded lobes on each margin ; $2 \frac{1}{2}$ to $4 \frac{1}{2}$ ins. long, $\frac{3}{4}$ to $1 \frac{3}{4}$ ins. wide ; dark green and smooth above, paler beneath and downy at the base, also on the midrib and veins. Acorns borne usually one or two on a stalk $\mathrm{I}$ to 2 ins. long; they are each about $\frac{3}{4}$ in. long, the lower half enclosed in a cup with downy, erect, appressed scales.

The above is a description of Turner's oak as usually represented in gardens, but it does not appear to be quite the same as the tree originally 
raised by Turner, which has shorter, broader leaves, the teeth of which are smaller and terminate in a minute, abrupt (mucronate) tip. This hybrid produces fertile seed, and as nearly always happens with hybrids, the seedlings vary in their affinity to one or other of the parents. Several forms of 'Turner's oak have been named, such as "austriaca," and "austriaca splendens." The form with long narrow leaves described above has been called Q. PSEUDOTURNERI. A seedling raised fronı it at Kew produces both the short broad (or typical Turneri) leaves and the longer narrower ones. It seems unnecessary therefore to multiply names

\section{Q. VARIABILIS, Blume.}

\section{(Q. Bungeana, Forbes; Q. chinensis, Bunge.)}

A deciduous tree up to $80 \mathrm{ft}$. high, with a thick, corky bark; young shoots slightly hairy. Leaves oblong or narrowly oval, 3 to 7 ins. long, I to 2 ins. wide; broadly tapered or somewhat rounded at the base, pointed, the margins set with bristle-like teeth $\frac{1}{10}$ in. long, which terminate the nine to sixteen pairs of parallel veins; upper surface dark dullish green, smooth; lower one pale grey and covered with a minute close felt.

Native of China, Japan, and Corea ; introduced by Fortune in 1861 , and in 1882 by the late Dr Bretschneider; in both instances from the neighbourhood of Pekin, where it is a common tree. Although a finer tree than its near ally, Q. serrata, its foliage is not so bright. It differs from that species most noticeably in the whitish under-surface and smaller teeth of the leaves. The acorn also is smaller and almost hidden in the cup, which has long curly scales. The bark has some economic value as a source of cork. On young trees it is blackish at first, but is not long before it shows its corky nature.

\section{Q. VElutina, Lamarck. Black OAK.}

\section{(Q. tinctoria, Michaux.)}

A deciduous tree, 70,80 , or more $\mathrm{ft}$. high; young shoots at first covered with brownish starry down; buds very downy. Leaves oval or obovate, 5 to 12 ins. long, half to two-thirds as wide ; more or less deeply five- or sevenlobed; the lobes ovate or triangular, toothed or nearly entire ; upper surface dark green and shining, smooth or becoming so, lower surface paler, covered with a thin, scattered down, and with tufts of down in the vein-axils; stalk I to $2 \frac{1}{2}$ ins. long. Acorns usually solitary, scarcely stalked, $\frac{1}{2}$ to $\frac{3}{4}$ in. long, half enclosed in the cup.

Native of the eastern and central United States; introduced in 1800. The finest form of this oak in cultivation (and one of the most remarkable of all oaks) is known as "Champion's Oak" or var. RUBNIFOLIA, the leaves of which on young trees are often 12 to 15 ins. long, somewhat hooded, and hang laxly on the tree. The bark and acorns of this species are permeated by a yellow principle, and from the former a yellow dye, "quercitron," is obtained. Among the oaks of its group (rubra, coccinea, etc.) this species is distinguished by its yellow inner bark, the large downy buds, and the stellate down on young leaf and shoot.

\section{Q. Vibrayeana, Franchet.}

(Q. bambusæfolia, Fortune; Q. acuta var. bambusæfolia, Masters.)

An evergreen tree, said to be 30 to $50 \mathrm{ft}$. high in nature, but usually a bush in cultivation; young shoots smooth, slender, warted the second year. 
Leaves lanceolate, broadly tapered or rounded at the base, and with long slender points, the upper half toothed; $2 \frac{1}{2}$ to 4 ins. long, $\frac{5}{8}$ to $1 \frac{1}{4}$ ins. wide ; pale shining green above, somewhat glaucous beneath, smooth on both surfaces; stalk $\frac{1}{2}$ in. long. When young the leaves are of a rich purplish red, very striking against the green of the older foliage. The acorns are produced two to four on a spike, but have not yet been developed in this country.

Native of China and Japan ; introduced from China in 1854 , by Fortune. As a garden oak it is chiefly notable for the colour of its narrow graceful foliage when young. Closely allied to it is

Q. GLAUCA, Thunberg, a native of China, Japan, etc. It is quite rare in cultivation, most of the plants so-called being really Q. Vibrayeana. The true Q. glauca may be distinguished by the under-surface of the leaves being densely covered with appressed silky hairs, more or less of which persist through the first season. The true plant is in the Earl of Ducie's collection at Tortworth.

\section{Q. Wislizeni, De Candolle.}

An evergreen oak, varying in a wild state from a mere shrub to a tree 70 or more ft. high ; young shoots furnished with a loose, scattered, starry down. Leaves oblong to ovate, rounded or slightly heart-shaped at the base, terminated and edged with slender, spiny teeth; I to $2 \frac{3}{4}$ ins. long, $\frac{1}{2}$ to $I_{4}^{3}$ ins. wide; often entire on adult native trees; both sides shining green and quite smooth; stalk $\frac{1}{8}$ to $\frac{1}{4}$ in. long, downy, the stellate down often continued down the midrib. Acorn $\frac{3}{4}$ to over I in. long, about $\frac{1}{3}$ in. wide ; two-thirds enclosed in a cup with thin, downy, flattened scales.

Native of California ; introduced to Kew in 1874, where it has proved hardy but slow-growing. It has also borne acorns there. In its glossy green leaves, smooth on both surfaces, it resembles only $Q$. coccifera, but the tree is of much more open habit, and the leaves are larger. Henry has also pointed out differences in the shape of the buds ; in Wislizeni they are conical, pointed, and longer than the rounded blunt ones of coccifera.

\section{RAPHIOLEPIS JAPONICA, Siebold. ROSACE}

(Bot. Mag., t. 5510 ; R. ovata, Briot.)

An evergreen shrub of sturdy, rounded form, up to ro $\mathrm{ft}$. in height, with downy young wood. Leaves very stout and leathery, broadly oval or obovate, tapering at the base to a stout stalk $\frac{1}{2}$ in. long, round or bluntpointed, the terminal part usually shallow-toothed, the lower entire; $1 \frac{1}{2}$ to 3 ins. long, about two-thirds as much wide. When young, the leaf is covered on both sides with a loose felt of grey down which rapidly falls away, leaving the surfaces quite smooth, or with a few pieces of down about the midrib. Flowers fragrant, white, $\frac{3}{4}$ in. across, produced in a stiff, terminal panicle or raceme 3 or 4 ins. high, in June. Calyx very woolly, funnel-shaped, with five narrow, pointed lobes. Fruit pear-shaped, blue-black, erect, $\frac{1}{2}$ in. long, one-seeded.

Native of Japan and Corea; introduced about r862. This striking shrub would appear to be hardier than is generally supposed; it is quite healthy in the open at Kew, but no doubt likes a sheltered spot. It is 
a handsome shrub, well worth growing for the sake of its pure white, scented blossoms. Propagated by seeds, or cuttings made of half-ripened shoots. R. Delacouri is a pink variety or perhaps a hybrid.

R. INDICA, Lindley (R. salicifolia), is sometimes given a place on a warm wall. It has narrow, toothed, lanceolate leaves, 2 or 3 ins. long; and short, terminal, very pretty racemes of whiteflowers tinged, especially towards the centre, with pink. A more graceful shrub than R. japonica, but not so hardy. Native of China. Raphiolepis is allied to Photinia.

\section{RHA M N US. BUCKTHORN. RHAMNACE $Æ$.}

There are few groups of trees and shrubs comprising so many hardy species as Rhamnus that possess so little garden value. They have scarcely

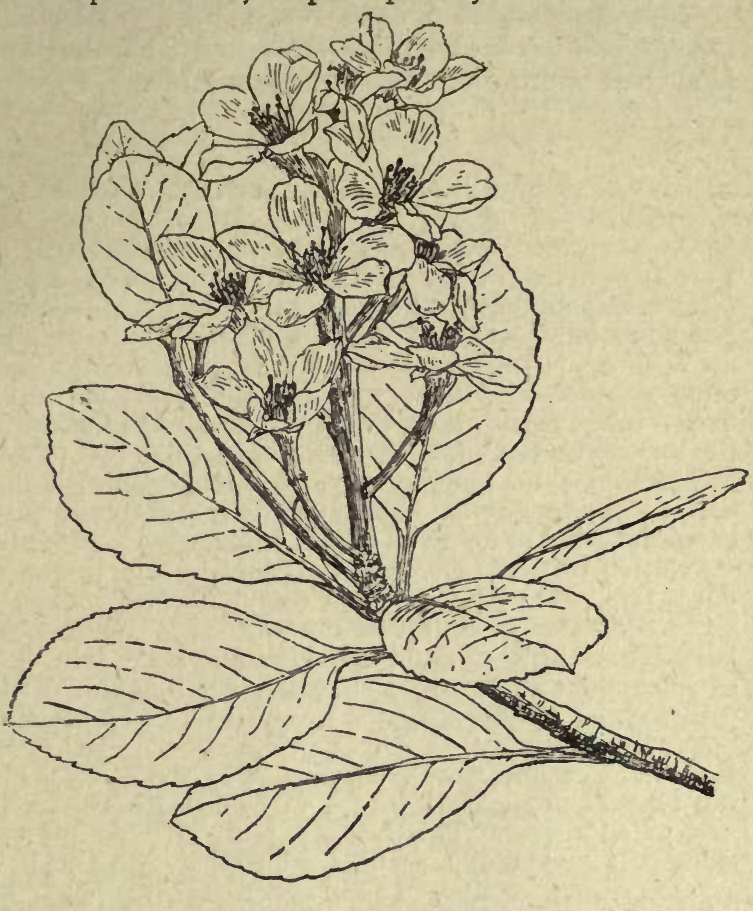

RAPHIOLEPIS JAPONICA.

any beauty of flower, the blossoms being small, and either green, yellowish green, or brownish. The fruits are more striking, being often very abundant and reddish when approaching ripeness. When fully ripe they are usually black or very dark purple.

The genus contains about sixty species of evergreen or deciduous trees and shrubs, the hardy ones widely spread over northern temperate latitudes. The leaves are normally alternate, but occasionally opposite; the flowers perfect or unisexual, with the sexes on the same or separate trees. Flowers with a four- or five-lobed calyx and the same number of petals and stamens; petals sometimes absent. Fruit a drupe, roundish or top-shaped, usually from $\frac{1}{6}$ to $\frac{1}{3}$ in. in diameter, enclosing two to four seeds. Good ordinary distinguishing features of the buckthorns are:the number of veins of the leaf, and whether they are parallel or converging; the absence or presence of marginal teeth; the arrangement of the flowers - whether in stalked or stalkless clusters; and, the presence or absence of spines at the tips of the side twigs. Various members of the genus yield yellow or green dyes, and most of them have laxative or purgative properties in bark and fruit. 
They are easily cultivated in any ordinary soil. Some do not strike root readily from cuttings, but can be layered; seeds afford the best means of propagation when obtainable. The best species for gardens are:-Alaternus, as a dense evergreen; fallax and imeretina, for fine foliage; pumila and rupestris, as dwarf shrubs; and Purshiana, for its medicinal interest and as a handsome tree.

\section{R. Alaternus, Linnceus.}

An evergreen, sometimes unisexual shrub of rounded, bushy habit reaching Io to I $2 \mathrm{ft}$. in height, occasionally twice as high; young branchlets covered with a close, minute down. Leaves oval or oblong, sometimes inclined to obovate, $\frac{3}{4}$ to 2 ins. long, $\frac{1}{2}$ to I in. wide ; tapered at both ends and with a short abrupt apex, margins thickened and more or less toothed, especially when young, often conspicuously three-nerved at the base; dark glossy green and smooth except for some down on the lower part of the midrib above, and for tufts in the lowermost vein-axils beneath ; chief veins two to five each side the midrib; stalks $\frac{1}{6}$ to $\frac{1}{4}$ in. long, downy. Flowers yellowish green, very small $\left(\frac{1}{8}\right.$ in. diameter), crowded on short, axillary, umbel-like racemes, scarcely $\frac{1}{2}$ in. long, expanding in April. Fruit black, $\frac{1}{4}$ in. long.

Native of S.W. Europe ; introduced early in the seventeenth century, if not before. The Alaternus is a useful, cheerful-looking evergreen of much the same character as Phillyrea, but with alternate leaves. It has no beauty of flower, and little of fruit, although the latter are occasionally produced in such abundance as to be striking; but it makes a dense mass of pleasant greenery. Easily propagated by cuttings, and perfectly hardy.

Var. ANGUSTIFOLIA (R. Perrieri, Hort.). - A very distinct variety with lanceolate or linear-oval, conspicuously toothed leaves, as long as those of the type, but only from $\frac{1}{6}$ to $\frac{5}{8}$ in. wide. There is a form of it with slightly variegated leaves. This variety is so distinct that the older authors considered it specifically distinct from the ordinary R. Alaternus. It is the $\mathrm{R}$. angustifolia, Miller. In my experience it is not so hardy.

Var. INTEGRIFOLIA.- Leaves nearly always without teeth, and more conspicuously nerved than the type.

Var. MACULATA.-A poor form with leaves irregularly and sparsely.blotched with yellow.

Var. VARIEGATA. - A form with leaves intermediate in shape between those of the type and var. angustifolia, often somewhat deformed. They are conspicuously margined with creamy white. This is a really well-variegated shrub, but is more tender than the type.

\section{R. ALNIFOLIA, L'Héritier.}

A low deciduous shrub of spreading but compact habit, rarely more than $3 \mathrm{ft}$. high ; young shoots minutely downy. Leaves oval, tapered about equally at both ends, rather prominently and unevenly round-toothed; $1 \frac{1}{2}$ to 4 ins. long, $\frac{5}{8}$ to 2 ins. wide; smooth above, slightly downy on the veins beneath; veins in about six to eight pairs ; stalk $\frac{1}{4}$ to $\frac{1}{2}$ in. long, downy on the upper side. Flowers yellow-green, produced usually in twos or threes ; petals absent ; calyx lobes and stamens five. Fruit black, $\frac{1}{4}$ in. across, roundish or top-shaped, containing three seeds.

Native of N. America, on both the eastern and western side; introduced in 1778. A neat bush. 


\section{R. CALIFORNiCA, Eschscholtz. CALifornian BuCKTHORN.}

An evergreen bush, ultimately 10 or $15 \mathrm{ft}$. high; young shoots downy the first season. Leaves oblong or oval, mostly rounded at the base, rounded or broadly pointed at the apex, minutely or not at all toothed; I to 4 ins. long, about half as wide ; smooth above, downy on the veins beneath ; veins parallei, usually in eight to twelve pairs; stalk $\frac{1}{6}$ to $\frac{5}{8}$ in. long, downy at first, smooth the second season. Flowers in downy, short-stalked umbels. Fruit $\frac{1}{4}$ in. across, dark purple, globose.

Native of Western N. America, from Oregon southwards. With some affinity to R. Purshiana in the stalked flower-clusters, this is easily distinguished by its dwarfer, purely shrubby habit, its evergreen foliage, and more globose fruits.

Var. OLEIFOLIA, Hooker, has smaller, narrower leaves, oblong-ovate, $\mathrm{I} \frac{1}{4}$ to $2 \frac{1}{2}$ ins. long, $\frac{1}{2}$ to 1 in. wide, uniformly toothed. There are, no doubt, forms intermediate between this and the type.

Var. TOMENTELLA, Brewer (R. tomentella, Bentham).-A very distinct form, the under-surface of the leaves being covered with a close, velvety, yellowish or greyish felt; young shoots and leaf-stalks the same.

All these buckthorns are interesting evergreens, and have in their bark aperient properties identical with those alluded to under R. Purshiana; they help to meet the demand for the Cascara Sagrada drug (see R. Purshiana).

\section{R. CATHARtica, Linncus. COMmon Buckthorn.}

A deciduous shrub, 10 to $20 \mathrm{ft}$. high, ultimately of tree-like habit; young shoots slender, smooth; lateral branchlets often terminated by a thorn. Leaves bright green, sometimes alternate, often opposite or sub-opposite ; oval or ovate, tapered or rounded and often unequal at the base, pointed at the apex; finely toothed; I to $2 \frac{1}{2}$ ins. long, half as wide; mostly smooth, but in one uncommon form (PUBESCENS) downy, especially beneath; veins three or four each side the midrib, converging towards the apex; stalk slender, $\frac{1}{4}$ to $\mathrm{I}$ in. long. Flowers small, green, produced in the lower leaf-axils, and forming a dense cluster at the base of the young shoot. Fruit black, about $\frac{1}{4} \mathrm{in}$. across.

Native of Europe, W. and N. Asia, found in Britain, but not commonly. A vigorous shrub, which by pruning away the lower branches may easily be made to assume a tree form. It has no particular merit, although the leaves die off sometimes a pleasing yellow, and a tree laden with the black fruits is striking. Allied to R. davurica (q.v.).

\section{R. Costata, Maximorvicz.}

A deciduous shrub, ultimately $15 \mathrm{ft}$. high, of spreading habit; young shoots smooth, stout. Leaves opposite, ovate-oblong, pointed, tapering below to a narrowly heart-shaped or cuneate base ; unevenly and shallowly toothed, 3 to 5 ins. long, $I \frac{1}{4}$ to $2 \frac{1}{2}$ ins. wide; pale green on both sides, strongly ribbed, ribs about twenty; upper surface wrinkled, and furnished with a few hairs when quite young; under-surface downy, especially on the ribs; stalk about $\frac{1}{8}$ in. long, downy on the upper side. Flowers green, few or solitary on slender, smooth stalks, $\frac{3}{4}$ to $1 \frac{1}{4}$ ins. long, produced at the base of the young shoots. Fruit top-shaped, black, $\frac{1}{3}$ in. diameter, two-seeded.

Native of Japan; introduced in 1900 . One of the handsomest of buckthorns in foliage, and belonging to the many-veined group, which includes fallax and imeretina. From fallax it is distinguished by its downy leaves, and from both by the long flower-stalk and strongly wrinkled upper-surface of the leaf. It has also a very short leaf-stalk. 


\section{R. DAvUrica, Pallas. Dahurian Buckthorn.}

A deciduous shrub or small tree, ultimately $30 \mathrm{ft}$. high; young branchlets smooth; lateral twigs sometimes thorn-tipped. Leaves alternate or often nearly opposite; oblong or oval, tapering at the base, slender-pointed, finely toothed, $1 \frac{1}{2}$ to 4 ins. long, $\frac{3}{4}$ to $1 \frac{1}{2}$ ins. wide; smooth or somewhat downy beneath; veins in four to six pairs, converging towards the apex; stalk slender, $\frac{1}{4}$ to $\mathrm{I}$ in. long. Flowers produced from the lower joints of the young shoots in June, forming dense clusters. Fruit black, about $\frac{1}{4}$ in. diameter.

Native of Siberia, Manchuria, and N. China, very closely allied to R. cathartica. It does not differ from that species in flower or fruit, but its leaves are longer, uniformly wedge-shaped at the base, and with one or two more pairs of veins. Of little garden value except in rough shrubberies.

\section{R. fallax, Boissier. CARniolian BUCKTHORn.}

(R. alpina var. grandifolia, Hort.; R. carniolica, Kerner.)

A deciduous shrub, 4 to ro ft. high, of stiff habit; young shoots smooth. Leaves oval or somewhat ovate, heart-shaped or rounded at the base, shortly tapered at the apex, finely and regularly toothed; $I \frac{1}{2}$ to $5 \frac{1}{2}$ ins. long, $I$ to $3 \frac{1}{2}$ ins. wide; dark green and smooth except for minute tufts of hairs in the - zein-axils beneath; veins parallel, in from twelve to over twenty pairs; stalks $\frac{1}{4}$ to $\frac{2}{3}$ in. long, downy when young on the upper side. Flowers yellowish green, produced in clusters from the leaf-axils and joints near the base of the current year's shoots; petals and stamens four ; stalk $\frac{1}{4}$ in. or less long. Fruit black, $\frac{1}{4}$ in. across.

Native of the Alps of S.E. Europe; much confused in gardens with R. AlPINA, Linnceus, a species with a more western distribution (S. France, Spain, and the West Mediterranean region), with fewer (nine to twelve) pairs of veins and proportionately longer leaf-stalks. It is also allied to R. imeretina $(q . v$.$) , which differs in the leaves being very downy beneath but equally many-$ veined. $R$. fallax and $R$. imeretina are the most handsome-foliaged of deciduous buckthorns.

\section{R. Frangula, Linncus. Alder Buckthorn.}

A deciduous shrub, or a small tree up to 15 or $18 \mathrm{ft}$. high; young shoots downy. Leaves oval or obovate, I to 3 ins. long, scarcely half as wide; wedge-shaped or rounded at the base, often with a short abrupt point, not toothed; dark glossy green and smooth above, paler and often somewhat downy beneath; veins parallel, usually in eight or nine pairs; stalk $\frac{1}{4}$ to $\frac{1}{2}$ in. long. Flowers clustered two to five together in the leaf-axils of the young shoots, bisexual, the parts in fives; calyx and flower-stalk smooth. Fruit at first changing from green to red, then to dark purple, $\frac{1}{4}$ in. across, roundish, two-seeded.

Native of Europe, including the south of Britain. It is a rather handsome small fruiting tree with foliage of a cheerful green. Under the name of "dogwood" its wood is used (as charcoal) in the manufacture of the finest gunpowders. The bark has purgative properties.

Var. ANGUSTIFOLIA has narrowly oblong or oblanceolate leaves, from $\frac{3}{4}$ to $\mathrm{I}$ in. wide, the margins uneven or jagged.

Var. ASPLENIFOLIA. - A remarkable form with leaves as long as in the type, but only from $\frac{1}{12}$ to $\frac{1}{6}$ in. wide as a rule.

Var. LATIFOLIA, Dippel, found in the Caucasian region, has larger, broader 
leaves than the type, up to $3 \frac{1}{2}$ ins. long and 2 ins. wide. This form must not be confounded with

R. LATIFOlia, L'Héritier, a species found in the Azores, and perhaps not very hardy in this country, although it thrives in the garden of Bitton Vicarage and at Glasnevin. It has leaves up to 5 ins. long, 3 ins. wide, with $\bullet$ ten to sixteen pairs of parallel veins and a stalk $1 \frac{1}{4}$ ins. long. Allied to R. Frangula, it differs not only in its larger, more numerously veined leaves, but also in having a downy flower-stalk and calyx, the former up to $\frac{5}{8}$ in: long. Fruit nearly $\frac{1}{2}$ in. across, red, then black. Introduced in $177 \delta$; now very rare, but worth growing for its handsome foliage.

\section{R. HYBRIDA, L'Héritier.}

An evergreen or partially evergreen shrub up to $12 \mathrm{ft}$. high, of spreading habit, more in diameter than it is high; shoots smooth. Leaves ovate to oblong, rounded or widely tapered at the base, pointed, $1 \frac{1}{2}$ to 4 ins. long, $\frac{3}{4}$ to $1 \frac{3}{4}$ ins. wide; shallowly and finely toothed, smooth on both surfaces, rather pale green; about seven veins each side the midrib; leaf-stalk $\frac{1}{6}$ to $\frac{1}{3}$ in. long. It is regarded as a hybrid between R. Alaternus and R. alpina.

Var. BILla RDI, Lavallée (R. Billardi), with small, narrow, more lanceolate leaves, is considered to be a form of $\mathrm{R}$. hybrida, but is very dissimilar, especially in the conspicuous jagged toothing. Its form of leaf suggests that it might have originated from R. Alaternus var. angustifolia.

\section{R. IMERETINA, Booth.}

(Bot. Mag., t. 672 I (as R. libanotica); R. colchica, Sommier.)

A deciduous shrub up to $10 \mathrm{ft}$. high, with very sturdy shoots sparsely downy when young. Leaves oblong or oval, rounded or slightly heart-shaped at the base, taper-pointed, finely toothed; 4 to 10 ins. long, 2 to 4 ins. wide ; veins parallel in fifteen to twenty-five pairs; upper surface dark green and soon smooth, except in the sunken midrib and veins; lower surface downy, especially on the veins ; stalk $\frac{1}{2}$ to $\frac{3}{4}$ in. long, downy. Flowers green, in small, axillary clusters. Fruit $\frac{2}{5}$ in. long.

Native of the Western Caucasus up to $8500 \mathrm{ft}$., and a very handsome, large-leaved, quite hardy shrub-the finest of all the buckthorns. I have measured odd leaves as much as 14 ins. long, and 6 ins. wide. It is much confused in gardens with R. LIBANOTICA, Boissier, a nearly allied species found in the Lebanon region of Syria, and distinguished by smaller leaves with only fifteen or fewer pairs of veins; leaf-stalk $\frac{1}{6}$ in. long; fruit $\frac{1}{5}$ in. diameter, black. The leaves of $\mathrm{R}$. imeretina die off a deep bronzy purple in autumn. R. fallax (q.v.) is also similar, but is smooth in shoot and leaf.

\section{R. INFECTORIA, Linnaus. AVIGNON BERRY.}

A deciduous shrub of spreading habit up to $7 \mathrm{ft}$. high, the side twigs spinetipped; young shoots downy. Leaves very variable, mostly oval, but also ovate or obovate; tapered at both ends, finely toothed, $\frac{1}{2}$ to $1 \frac{1}{2}$ ins. long, $\frac{1}{4}$ to $\frac{3}{4}$ in. wide ; upper surface dark green, mostly smooth, or with down on the midrib, lower one smooth or slightly downy; veins in three or four pairs converging upwards; stalk $\frac{1}{8}$ to $\frac{1}{3}$ in. long, usually downy. Fruit two-seeded, black.

Native of S.W. Europe. It has longer, firmer-textured leaves than R. saxatilis, but the two are perhaps only varieties of the one species. The fruit is (or was once) used by dyers under the name of Graine d'Avignon 
There is a rather handsome bush at Kew, $7 \mathrm{ft}$. high, and $\mathrm{I}_{5} \mathrm{ft}$. in diameter, distinguished by its dense, gnarled branches.

\section{R. JAPONICA, Maximowicz.}

A deciduous shrub up to 8 or 9 ft. high; lateral branchlets occasionally spine-tipped or reduced to short spurs with the leaves crowded at the end; young shoots smooth. Leaves glossy pale green on both sides, obovate, always tapered at the base, broadly pointed or rounded at the apex, finely toothed except sometimes near the base; I to 3 ins. long, $\frac{1}{2}$ to $I$ in. wide ; with three to five pairs of veins converging towards the apex; stalk $\frac{1}{3}$ to $\frac{3}{4}$ in. long, more or less downy. Flowers greenish brown, produced in May in dense hemispherical clusters at the end of the short, spur-like branches; stalks smooth, $\frac{1}{3}$ in. long ; calyx lobes four, triangular ; stamens four. Fruit globose, $\frac{1}{4}$ in. diameter.

Native of Japan; introduced in 1888. It flowers with great freedom, and the blossoms have a faint pleasant fragrance. . It is distinct in its bright green, uniformly obovate leaves produced on spurs.

\section{R. Lanceolata, Pursh.}

An erect shrub up to 6 or $7 \mathrm{ft}$. high, the young shoots smooth or slightly downy. Leaves ovate-lanceolate, oblong-lanceolate, or oval, broadly wedgeshaped or rounded at the base, with short, slender or bluntish points, finely toothed; I to 3 ins. long, $\frac{1}{2}$ to $\mathbf{I} \frac{1}{4}$ ins. wide ; smooth or slightly downy; veins parallel in six to nine pairs; stalk up to $\frac{1}{3}$ in. long, mostly downy. Flowers produced in twos or threes in the axils of the young leaves, yellowish green ; the parts in fours; stalks about $\frac{1}{8}$ in. long. Fruit black, roundish, $\frac{1}{4}$ in. diameter, two-seeded.

Native of the eastern and central United States. This buckthorn flowers with extreme freedom, the short-stalked blossoms being crowded along the young shoots and forming cylindrical clusters.

\section{R. PUMILA, Linnaus. DWARF BUCKTHORN.}

A low, sometimes procumbent shrub usually only a few inches high, of stunted habit; young shoots downy. Leaves variable in outline, sometimes roundish, sometimes narrowly oval, $\frac{3}{4}$ to 2 ins. long, more or less tapered at the base, mostly finely toothed; smooth, or with down along the midrib and veins ; veins parallel in from five to eight pairs; stalk downy, $\frac{1}{8}$ to $\frac{1}{3}$ in. long. Flowers pale green, the parts in fours. Fruit globose, blue-black.

Native of the Alps of Europe ; introduced originally from Mount Baldo, in 1752. It inhabits crevices of rocks, and is of the curious gnarled type common in such places. It has some beauty in fruit, and is best adapted for the rock garden, where it makes a neat and pleasing tuft, although 'ess close and compact than in a wild state.

\section{R. Purshiana, De Candolle. Cascara Sagrada.}

A deciduous tree up to 40 or $50 \mathrm{ft}$. high in a wild state; young shoots conspicuously downy. Leaves obovate or oval, rounded at the base, with a short, bluntish apex, either minutely toothed or entire; 2 to 5 ins. long, I to 3 ins. wide; downy beneath and on the veins above, veins parallel, in ten to fitteen pairs; stalk $\frac{1}{2}$ to $\frac{3}{4}$ in. long, downy. Flowers in stalked umbels, 
opening in July ; sepals and petals five, flower-stalks downy. Fruit top-shaped, $\frac{1}{3}$ in. long, black, usually three-seeded.

Native of Western N. America ; introduced in 1891. A handsome small tree, although without any beauty of blossom, forming a broad leafy head of erect or spreading branches. It is allied to $\mathrm{R}$. Frangula, but has more numerous parallel veins in each leaf that are downy above, and differs in the distinctly stalked flower-clusters, the common stalk being often $\frac{1}{2}$ in. or more long. R. Purshiana is the source of the well-known drug, "Cascara Sagrada," one of the most popular of aperient medicines. It is obtained from the bark, and so great is the demand that $£ 20,000$ worth was sent from the states of Oregon and Washington in 1907 . The consequence is that natural supplies are being rapidly used up, and it has been suggested that the cultivation of this tree in the southern and western parts of the British Isles might prove profitable. The bark of trees raised and grown at Kew has been proved to possess the aperient quality as fully as that of wild trees.

R. CAROLINIANA, Walter. Indian Cherry.-This is nearly related to R. Purshiana, and may be regarded as its E. American representative. It differs from the above in having narrower, more pointed leaves, with fewer (eight to ten) pairs of parallel veins. It resembles it in having stalked umbels, but the stalks are much shorter. Introduced in 1819 , according to Loudon, but now rarely seen, and perhaps not very hardy. It varies from a shrub to a tree 30 to $40 \mathrm{ft}$. high.

\section{R. RUPESTRIS, Scopoli.}

A deciduous shrub of low, spreading habit, from 8 to 30 ins. high ; young shoots covered with fine hairs. Leaves oval, or inclined to oblong, or sometimes orbicular, rounded at the base, pointed or rounded at the apex; $\frac{3}{4}$, to 2 ins. long, about half as wide; minutely or not toothed; dull green and smooth (or with the veins downy) above, greyish beneath, and finely hairy on the midrib, veins, and stalk ; veins parallel, in five to eight pairs. Flowers in downy, stalked umbels. Fruit at first red, then black, roundish top-shaped, $\frac{1}{4}$ in. wide, three-seeded.

Native of S.E. Europe, inhabiting mountain regions. In habit and leaf it resembles R. pumila, but is distinguished by the more hairy shoots and stalked inflorescences. The latter are sometimes borne on short, lateral, leafy twigs springing from the leaf-axils.

\section{R. SAXATILIS, jacquin. ROCK BUCKTHORN.}

A low, spreading, deciduous shrub, rarely more than $2 \mathrm{ft}$. high ; young shoots minutely downy, lateral branchlets often ending in a spine. Leaves smooth or nearly so, narrowly oval, ovate or obovate, tapered at the base, often bluntish at the apex, finely toothed; $\frac{1}{2}$ to I in. long, $\frac{1}{4}$ to $\frac{1}{2}$ in. wide; veins two to four each side the midrib, converging towards the apex; stalk $\frac{1}{6}$ in. or less long. Flowers very small, greenish yellow. Fruit black, top-shaped, three-seeded.

Native of the mountains of Central and S.E. Europe ; introduced in 1752. A curious dwarf or stunted shrub inhabiting rocky places, belonging to the same group as tinctoria and infectoria, but distinguished by its dwarf habit and smaller, smooth leaves.

\section{R. SPATHULAFOLIA, Fischer.}

A deciduous shrub up to $6 \mathrm{ft}$. high, with downy shoots and narrow-oval or lanceolate leaves; $\frac{3}{4}$ to $2 \frac{1}{2}$ ins. long, $\frac{1}{4}$ to $\frac{3}{4} \mathrm{in}$. wide; slenderly tapered at the base and apex, finely toothed, distinctly downy on both surfaces; veins 
three to five each side the midrib, converging towards the point ; stalk $\frac{1}{4}$ to $\frac{3}{4}$ in. long. Fruit black, on a stalk up to $\frac{1}{2}$ in. long.

Native of S.E. Europe, Persia, etc.; introduced in 1880 ; distinct in its long, narrow, downy leaves, but of no particular merit.

\section{R. TINCTORIA, Waldstein. Dyer's BUCKTHORN.}

This species belongs to the same group as R. infectorius and R. saxatilis, and is a deciduous shrub up to 4 or $6 \mathrm{ft}$. high, the side branchlets spinetipped. It is distinguished from both its allies by the very hairy leaf-stalk. The largest leaves are 2 ins. long by $I$ in. wide, the smallest $\frac{1}{2}$ in. long; oval, more or less downy beneath, and with usually three, sometimes four pairs of veins converging towards the apex. Fruit black, top-shaped.

Native of S.E. Europe ; introduced in 1820 , but of little garden value.

\section{RHAPHITHAMNUS CYANOCARPUS, Miers. VERBENACEA.}

(Bot. Mag., t. 6849; Citharexylon cyanocarpum, Hooker.)

An evergreen shrub or small tree, ultimately 20 or $25 \mathrm{ft}$. high, with a dense growth and very leafy branches; young shoots covered with erect, bristly down, and armed with axillary spines, which on the year-old branches become $\frac{1}{2}$ to $\mathbf{I}$ in. long, slender and needle-like. Leaves opposite, often in threes, set about $\frac{1}{4}$ in. apart; $\frac{1}{4}$ to $\frac{3}{4}$ in. long, $\frac{1}{6}$ to $\frac{1}{2}$ in. wide; broadly ovate, pointed, rounded at the base; dark green and smooth above, pale beneath, with at first minute bristles especially on the midrib, also on the very short stalk. Flowers pale blue, produced in April singly or in pairs in the leaf-axils of the previous summer's growth, each on a very short, bristly stalk. Corolla slender, tubular, $\frac{1}{2}$ in. long; calyx bell-shaped, $\frac{1}{12}$ in. long, toothed; stamens four, included within the corolla. Berry $\frac{1}{3}$ to $\frac{1}{2}$ in. diameter, globose, bright blue.

Native of Chile; introduced by W. Lobb about 1843 . It is only hardy at Kew against a wall, and one must go to Ireland or the southwest to see it at its best. I remember seeing a fine specimen at Menabilly, in Cornwall, several years ago, which I believe is now over $20 \mathrm{ft}$. high, growing in deep loamy soil. Its blue fruits are even more ornamental than its flowers.

\section{RHODODENDRON (including AZALEA). ERICACE}

No genus of hardy shrubs, unless it be Rosa, has given to gardens such varied attractions as Rhododendron. In the now generally accepted signification of the word, it includes what were formerly known as Azalea. The true rhododendrons had ten stamens or more to each flower, and were evergreen, whilst the azaleas had five stamens, and were mostly deciduous, but there are numerous species in which these characters are mixed. The former section undoubtedly includes a larger number of beautiful types of evergreen shrubs than any other genus; and to the 
azaleas or mainly deciduous group it would be difficult to find a rival. The leading characteristics of the genus in its broader sense are as follows :-Shrubs or small trees, deciduous or evergreen; leaves alternate, simple, entire; flowers in usually terminal but sometimes axillary clusters or short racemes, or solitary ; corolla variable in shape, and either saucershaped, funnel-shaped, bell-shaped, or tubular, usually five-, sometimes six- to ten-lobed, white, yellow, many shades of purple and red, never real blue; calyx usually five-lobed, sometimes almost or quite obsolete; stamens five to twenty; seed-vessel dry, woody, splitting longitudinally; seeds numerous, minute, and winged.

The true species of the evergreen group are now largely superseded in gardens by the varieties of hybrid origin which originated mainly from catawbiense, ponticum, arboreum, and caucasicum, and to a smaller extent from maximum, Griffithianum, Fortunei, and Thomsoni. The same is the case with the deciduous or azalea group. Here the original wild types, from which the beautiful garden or so-called "Ghent" varieties were obtained by hybridisers, are flavum, calendulaceum, nudiflorum, viscosum; and latterly, occidentale, molle, and sinense. Many of these azaleas give beautiful autumn colour.

The hardy species are confined to the northern hemisphere, and the greatest aggregation of species occurs in the Chinese-Thibetan-Himalayan region. Eight or nine are found in Europe and Asia Minor, about a dozen (mostly azaleas) in N. America, somewhat more in Japan. A sub-tropical group with which we have here no concern belongs to the East Indies, New Guinea, and Australia.

In the identification and differentiation of the numerous species the shape and size of the calyx and corolla play a great part, as does also the length of the stamens in relation to the corolla and style. The presence or absence of scales on the younger parts of the plants (a condition known as "lepidote"), and the presence or otherwise of down or glands on the shoots, leaves, calyx, stamens, ovary and style, are also valuable points in assisting identification.

Cultivation.-The cultivation of pretty nearly all rhododendrons is the same, and the only difference between the deciduous and the evergreen ones is that the former like more sun. Some of the evergreen species and varieties do very well in semi-shade. In this connection Mr E. H. Wilson told me that he found in China the large broad-leaved species grew naturally in shade; the small-leaved, scaly, resinous ones on the mountain tops in full sun, filling the same place there as heather on British moors. But in our climate there are very few species or varieties that will not thrive in full sunlight. All those that flower in early spring, and thus become liable to injury by frost, are best in positions shaded from the morning sun. In such spots they have a chance to thaw gradually, and escape the entire destruction that awaits those flowers exposed to the full rays of the bright early sunshine that so frequently follows a frosty night. But as a rule $5^{\circ}$ or $6^{\circ}$ of frost is fatal to the expanded flowers of rhododendrons. Both rhododendrons and azaleas are especially suited for planting in large masses. Where the garden is large enough special areas may be set apart for 
them, and in smaller ones they may be planted in beds or broad groups.

Soil. - The best possible soil for these shrubs is one of a peaty nature. The great rhododendron nurseries are on peaty formations. But this is by no means absolutely necessary. A sweet, well-drained loam, especially if it be of a sandy nature and free from calcareous matter, does almost as well, especially if a good proportion of decayed leaves be incorporated with it. Even a heavy loam treated in the same way will suit the stronger growing sorts. Rhododendrons as a whole abhor lime, R. hirsutum and some of its hybrids, which are found in the Alps on a limestone formation, being the only exceptions. They are all moistureloving, and delight in a continuously cool damp condition at the root. For plants whose roots are not shaded by their own lower branches, a surface mulching of 4 to 6 ins. of leaves is very beneficial, especially in hot weather. If the soil be poor, a proportion of one-third well-rotted manure may be added to the mulch. It may be said that no one item in the cultivation of rhododendrons tends so much to success as the abundance of decayed leaves in and on the soil.

Removal of Flowers. - Wherever time and opportunity allow, the flowers of all rhododendrons and azaleas should be removed as soon as they have faded. The truss will usually break off in one piece between thumb and finger. Most of them are prolific seed-bearers, and the development of the seed-vessel is very detrimental to the progress of the young growths and the next year's crop of blossom. Even in the great trade establishments where the plants are numbered by tens of thousands the managers find it worth while to have the old flowers religiously removed.

Propagation.-Whilst most of these plants are increased by grafting, the processes of seed-sowing, layering, and propagation by cuttings may be largely adopted. The common garden varieties of the true evergreen group, especially those with large leaves, are extremely difficult to increase by cuttings, and are 'mostly grafted on seedlings of $R$. ponticum, but in consequence of the continual watch that has to be kept for suckers from the stock, the practice of layering and thus getting them on their own roots is coming into vogue. Owing to the longer time necessary to obtain layered plants, the prices of plants so raised have to be higher. The species of the lepidote (or scaly), smaller-leaved group, such as yunnanense, racemosum, and concinnum, can quite easily be increased by cuttings made in July or August of the shoots of the year, with a "heel" of old wood attached, and placed in gentle heat.

The named varieties of azalea are mainly propagated by grafting on seedlings of $\mathrm{R}$. flavum. All the species and varieties whose branches can be brought to the ground will take root by layering, and all or nearly all can be increased by cuttings. Small shoots with a "heel" should be taken, 2 or 3 ins. long, when the wood is getting fairly firm-which will usually be about the end of July. They should be dibbled firmly in welldrained pots of sand and peat in about equal parts, and when they are all put in, the surface should be covered with $\frac{1}{8}$ in. of sand. A gentle bottom heat is desirable, and the cuttings may be covered with a bell- 
glass. They should not be disturbed until thoroughly well rooted, when they can be potted in small pots or planted in prepared ground.

Seed-sowing.-The seeds of all rhododendrons and azaleas are very small. They should be sown in pots or pans of soil similar in composition to what is recommended for cuttings, pressed firmly down, and the seed simply sprinkled on the top. All the covering they need is a sprinkling of silver sand sufficient to half bury them. The most important operation in raising rhododendron seeds is in the supply of moisture. They need continuously moist but not sodden conditions, and owing to their lightness are very easily disturbed, the finest possible rose, therefore, should be attached to the spout of the watering-pot. If this is not available, it is better to plunge the pots to half their depth in water for a short time, and dispense with surface watering altogether. In order to reduce evaporation the seed-pots may be covered with sheets of glass, or a light canvas screen may be placed over them. When large enough to handle, the seedlings should be pricked off in shallow boxes. Seedling rhododendrons are longer than cuttings in reaching the flowering state. The big-leaved ones may be eight to fifteen years, the smaller-leaved ones from three to five years. The most tender species, like those from the Himalaya, whilst they may be hardy enough when they are a few years old, need winter protection during their babyhood. The raising of hybrid rhododendrons and azaleas may be recommended as most interesting work. The various species and varieties cross-breed very readily.

As a guide to those contemplating the planting of evergreen hybrid rhododendrons I give below a selection of fifty varieties. For advice in making the selection I am indebted to $\mathrm{Mr}$ G. Harrow, manager of Messrs Veitch's nursery at Coombe Wood, and previously with $\mathrm{Mr}$ Anthony Waterer of Knap Hill.

Alice, rich rosy pink.

Baroness Schroeder, white, spotted.

Bertram W. Currie, crimson, pale centre.

Brilliant, crimson-scarlet, early.

Charles Diciens, dark scarlet.

Corona, various shades of blush pink.

C. S. Sargent, bright red, late.

Doncaster, brilliant red.

Duchess of Connaught, white, yellow spotted.

Duke of Connaught, rose-crimson.

Edward S. Rand, bright scarlet.

Everestianum, rosy lilac, frilled margins.

Fastuosum, double, bright purple.

Florence, pink, pale centre.

Frederick Waterer, fiery crimson.

Gomer Waterer, white, large.

James Marshall Brooks, rich red.

John Spencer, rose with pink margin, late.

John Walter, rich crimson.

Lady Annette de Trafford, cream, chocolate blotch.

Lady Armstrong, pale rose, spotted.

Lady Clementine Mitford, peach colour, darker margin.
Lady Clementine Walsh, pinkish white with brown blotch.

Lady Grey Egerton, French grey with rosy tint.

Lady Tankerville, pale rose, white centre.

Lord Eversley, dark red with black spots.

Lord Palmerston, rich rosy red, fine truss (syn. Cynthia).

Madame Carvalho, white with yellow blotch.

Marchioness of Lansdowne, pale rose, black spotted.

Martin Hope Sutton, bright red.

Michael Waterer, bright scarlet.

Mirabile, deep rose, truss very large.

Miss Jekyll, creamy with chocolate blotch.

Mrs Anthony Waterer, fine white.

Mrs E. C. Stirling, blush pink, trusses large.

Mrs F. Hankey, salmon red, spotted.

Mrs Holford, rich salmon pink.

Mrs John Clutton, a very good white.

Mrs J. P. Lade, French grey, deep centre:

Mrs Mendel, pink, lined with white.

Mrs W. Agnew, pale rose, yellow centre.

Old Port, rich plum colour. 


\section{RHODODENDRON}

Pink Pearl, fine flower and splendid truss.

Princess Mary of Cambridge, rosy purple, white centre.

Prometheus, red with black spots.

Sappho, white with maroon blotch.

Sigismund Rucker, magenta-crimson, much spotted.

Snowflake, pure white.

St Simon, purplish crimson.

The Queen, blush, then white.

Early Varieties.-Flowering in early or mid April : Countess, altaclerense, arboreum Wellsianum; Handsworth early red; Handsworth early white; Rosa Mundi, Smithii album, Russelianum, Caucasicum pictum, Nobleanum (from January to March), George Cunningham (March).

\section{R. ADENOPODUM, Franchet.}

An evergreen shrub, 4 to Io ft. high; young shoots scurfy. Leaves leathery, 3 to 6 ins. long, oblong oblanceolate with an acute point, smooth above, but covered beneath with a close white felt; stalk $\frac{1}{2}$ to $\frac{3}{4}$ in. long, felted. Flowers pale rose, $2 \frac{1}{2}$ to 3 ins. across, produced in April, about half a dozen together in rather loose terminal clusters; corolla broadly bell-shaped, with five rounded lobes ; stamens ten, as long as the corolla, hairy at the base ; flowerstalks and seed-pods hairy; calyx-lobes oblong, ciliate, $\frac{1}{8}$ to $\frac{1}{4}$ in. long.

Native of Central China ; introduced from Hupeh to France by the Abbé Farges in IgoI, and a year or two later by Wilson for Messrs Veitch. It first flowered with $\mathrm{Mr}$. Maurice de Vilmorin at Les Barres in April 1909, and since then at Caerhays.

\section{R. ALBIFLORUM, Hooker.}

\section{(Bot. Mag., t. $3670 ;$ Azalea albiflora, O. Kuntze.)}

A deciduous shrub, 5 or $6 \mathrm{ft}$. high in a wild state, the young shoots furnished with short, dark hairs. Leaves narrowly oval, I to $2 \frac{1}{2}$ ins. long, $\frac{1}{2}$ to $\frac{3}{4}$ in. wide; tapering towards both ends, thin and smooth except that, like the very short stalk, they are furnished when young on the midrib with hairs similar to those on the stems. Flowers creamy white, $\frac{3}{4}$ in. wide, drooping, produced singly or in pairs from lateral buds on the growth of the previous year during June and July, when the young shoots are in full leaf. Corolla open bell-shaped, with five short, broad, rounded lobes; calyx $\frac{1}{3}$ in. long, green, the lobes ovate and edged with glands; stamens ten, shorter than the corolla, hairy at the base ; flower-stalk $\frac{1}{3}$ in. long, glandular-downy.

Native of the Rocky Mountains, up to $6000 \mathrm{ft}$., from Oregon to British Columbia. It is a pretty species, very distinct because of the large calyx, the axillary flowers, and the dark hairs on the young wood like those of an azalea of the "indica" group, only not so numerous and persistent. Young plants are in the collection at Kew, but the species is very rare and is not, I think, a thriving plant under cultivation. I have never seen it in flower.

\section{R. AMBigu um, Hemsley.}

\section{(Bot. Mag., t. 8400.)}

An evergreen shrub, probably 5 or $6 \mathrm{ft}$. high, of bushy habit ; young shoots covered with pale yellow, glistening scales. Leaves aromatic, oval, sometimes slightly obovate or ovate, $1 \frac{1}{2}$ to $2 \frac{3}{4}$ ins. long, $\frac{5}{8}$ to $1 \frac{1}{4}$ ins. wide ; scattered along the shoot, pointed, rounded or slightly heart-shaped at the base ; dark green and somewhat scaly above, paler and much more scaly beneath; stalk $\frac{1}{4}$ to 8 in. long. Flowers produced in April and May in terminal trusses of five or six blossoms. Corolla pale yellow with yellow-green spots on the upper side, 
about 2 ins. diameter, broadly funnel-shaped, slightly scaly outside. Calyx minute and scarcely lobed, scaly; stamens ten, whitish, hairy near but not at the base ; style smooth; ovary scaly; flower-stalk $\frac{1}{3}$ to $\frac{1}{2}$ in. long, scaly.

Native of W. China; introduced by Wilson in 1904. In its botanical characters it is closely related to the purple $R$. concinnum, but is distinct in the yellow of its flowers. This being so rare a colour in the evergreen species gives it a certain distinctness, but it is not always a good yellow.

\section{R. AMCENUM, Planchon.}

(R. indicum var. amœnum, Maximowicz; Azalea amœna, Lindley; Bot. Mag., t. 4728.)

A compact evergreen shrub, 2 to $4 \mathrm{ft}$. high, its branches often growing horizontally; young shoots covered with the scale-like, appressed bristles characteristic of the indicum group. Leaves obovate, usually rounded at the apex, tapering at the base, $\frac{1}{2}$ to $1 \frac{1}{4}$ ins. long, $\frac{1}{4}$ to $\frac{1}{2}$ in. wide; bristly on both surfaces, more especially above and at the margins, very dark glossy green; stalk very short, bristly. Flowers I in. or less in diameter, rosy purple ; the calyx-lobes narrowly oblong, $\frac{1}{3}$ in. long, often like the corolla in shape and colour, and giving the appearance of one flower growing out of another-a character known to gardeners as "hose-in-hose."

Native of Japan, but, as generally known, in gardens, a cultivated form ; introduced in 1845, and long treated as a greenhouse plant. It is, nevertheless, quite hardy at Kew, and a very pleasing evergreen, flowering most profusely, and at all times a neat shrub. Out-of-doors it grows very slowly. I know plants over twenty years old not yet $3 \mathrm{ft}$. high. This is a valuable characteristic in many positions, especially where a permanently low evergreen mass is desired without the trouble and perhaps unsightliness of a periodical cropping. A group, if not too thickly planted, affords also an admirable shelter for lilies planted between the shrubs.

Var. JAPONICUM. - This is a very dwarf and dainty plant, perhaps the wild type of R. amœnum. The leaves are $\frac{1}{2}$ to $\frac{3}{4}$ in. long, and the rosy purple flowers are similar in colour and size to those of $\mathrm{R}$. amœnum, but the calyx is green, smaller, and not corolla-like.

\section{R. Anthopogon, D. Don.}

\section{(Bot. Mag., t. 3947.)}

An evergreen shrub, $2 \mathrm{ft}$. or less high, of compact habit; young branchlets hairy and covered with brown scurf. Leaves oval or ovate, 1 to $1 \frac{1}{2}$ ins. long, $\frac{1}{2}$ to $\frac{3}{4}$ in. wide ; dark, rather glossy green above, covered with brown scales beneath; stalk $\frac{1}{4}$ in. long. Flowers sulphur-coloured, $\frac{1}{2}$ to $\frac{3}{4}$ in. across, produced in a small terminal cluster, I to $I_{\frac{1}{2}}$ ins. wide. Corolla thin, almost transparent, tube hairy inside expanding at the mouth into five wavy lobes; calyx-lobes oblong, pale green, $\frac{1}{8}$ in. long, fringed at the margin; stamens five (sometimes up to eight), very short, and included within the tube; flowerstalk scaly, $\frac{1}{6}$ in. or less in length. Flowers in April.

Native of the high Himalaya from Cashmere eastwards, up to $16,000 \mathrm{ft}$. altitude, where it covers large areas; introduced in 1820 . The whole plant has a strong, aromatic, slightly acrid odour, especially when crushed. It is an interesting little plant, and one of the hardiest of Himalayan species, but not in any way showy.

\section{R. ARBORESCENS, Torrey.}

(Azalea arborescens, Pursh.)

A deciduous shrub up to $20 \mathrm{ft}$. high in a wild state; young shoots smooth. Leaves obovate or oval, pointed at both ends, $1 \frac{1}{2}$ to $3 \frac{1}{2}$ ins. long, one-third to 
half as wide; glossy green and smooth above except on the midrib; pale, glaucous, and smooth beneath; margins edged with minute bristles. Flowers fragrant, $r \frac{1}{2}$ ins. long, 2 to $2 \frac{1}{2}$ ins. wide, white tinged with pink; corolla-tube, hairy-glandular, the lobes spreading; stamens five, bright red, much protruded; style still longer; flower-stalk $\frac{1}{3}$ in. long, smooth, or sometimes bristly ; calyx-lobes linear, $\frac{1}{8}$ to $\frac{1}{4}$ in. long, very bristly.

Native of Eastern N. America in mountainous regions; discovered by John Bartram, and introduced in 1818. This azalea, although now but little known, is one of the most beautiful of its kind, and is valuable in flowering late (June and July) when the plants have become leafy. It is allied to $R$. viscosum (whose flowers also expand after the young leaves), differing in its larger size, in the shining, smooth foliage, and in the only slightly sticky corolla tube. In drying, the foliage acquires a perfume like that of mown grass.

\section{R. ARBOREUM, Smith.}

A small evergreen tree ultimately 30 to $40 \mathrm{ft}$. high, with a thick, sturdy trunk, the branches forming a head as wide as the tree is high, and reaching to the ground. Leaves narrowly oblong, tapering at both ends; 4 to 7 ins. long, I to 2 ins. wide; smooth above, covered beneath with a coat of silvery scales; stalk $\frac{1}{2}$ to $I$ in. long. Flowers blood red, borne in a compact hemispherical head, 4 to 5 ins. through, sitting close on the terminal whorl of leaves. Corolla bell-shaped, $I \frac{1}{2}$ to 2 ins. across; stamens ten; calyx very small ; flower-stalk downy.

Native of the outer Himalaya, where it is widely spread; introduced in I8I7. This species is one of the most variable of all rhododendrons, but the form just described, with crimson flowers and silvery under-surface of the leaves, may be taken as the type. There are, besides, other forms with leaves covered with a rich reddish felt beneath, and flowers ranging in colour from rosy red to nearly white. Some of these have distinctive names:-

Var. ALBUM.-Flowers white; leaf rust-coloured beneath.

Var. CAMPBELLIÆ.-Flowers purplish rose; leaf reddish beneath.

Var. CINNAMOMEUM.-Flowers almost white ; leaf reddish beneath.

Var. LIMBATUM. - Flowers rosy purple; leaf silvery beneath.

Var. NILAGIRACUM.--Flowers deep rose ; leaf rust-coloured beneath.

Var. WINDSORII.-Flowers and trusses small ; deep crimson.

Of all these forms the only one which has succeeded at Kew out-of-doors is var. cinnamomeum, and that grows very slowly and flowers uncertainly. But in Cornwall, S. Wales, Ireland, etc., R. arboreum in all its forms makes some of the chief glories of the gardens. There is a splendid tree of Carclew, near Falmouth, which, when I saw it a good many years ago, was over $30 \mathrm{ft}$. high, its trunk $4 \mathrm{ft}$. in. girth. At Castlewellan, Co. Down, there is a famous specimen, forming a pyramid of foliage $30 \mathrm{ft}$. high and $45 \mathrm{ft}$. through.

$R$. arboreum, tender though it may be, has played an important part in the evolution of the hardy garden rhododendrons as we know them to-day. All the red-flowered varieties - as distinct from the rose, pink, purple, and white ones-owe their colour to this species. They are far too numerous to be even mentioned here, but a selection of the best is given in the introductory notes to the genus. The following are some of the more important primary crosses :-

R. Altaclerense, Lindley (Bot. Mag., 3423).--Raised at Highclere, the seat of the Earl of Carnarvon in Berkshire, by crossing arboreum with ponticum ; it has beautiful, deep rosy red flowers in large trusses 6 ins. through. Very similar to it is

R. RuSSELlianum, Sweet, from catawbiense crossed with arboreum, but of a more crimson shade. It is as richly coloured as all but the richest forms of arboreum. Flowers in April and May. 


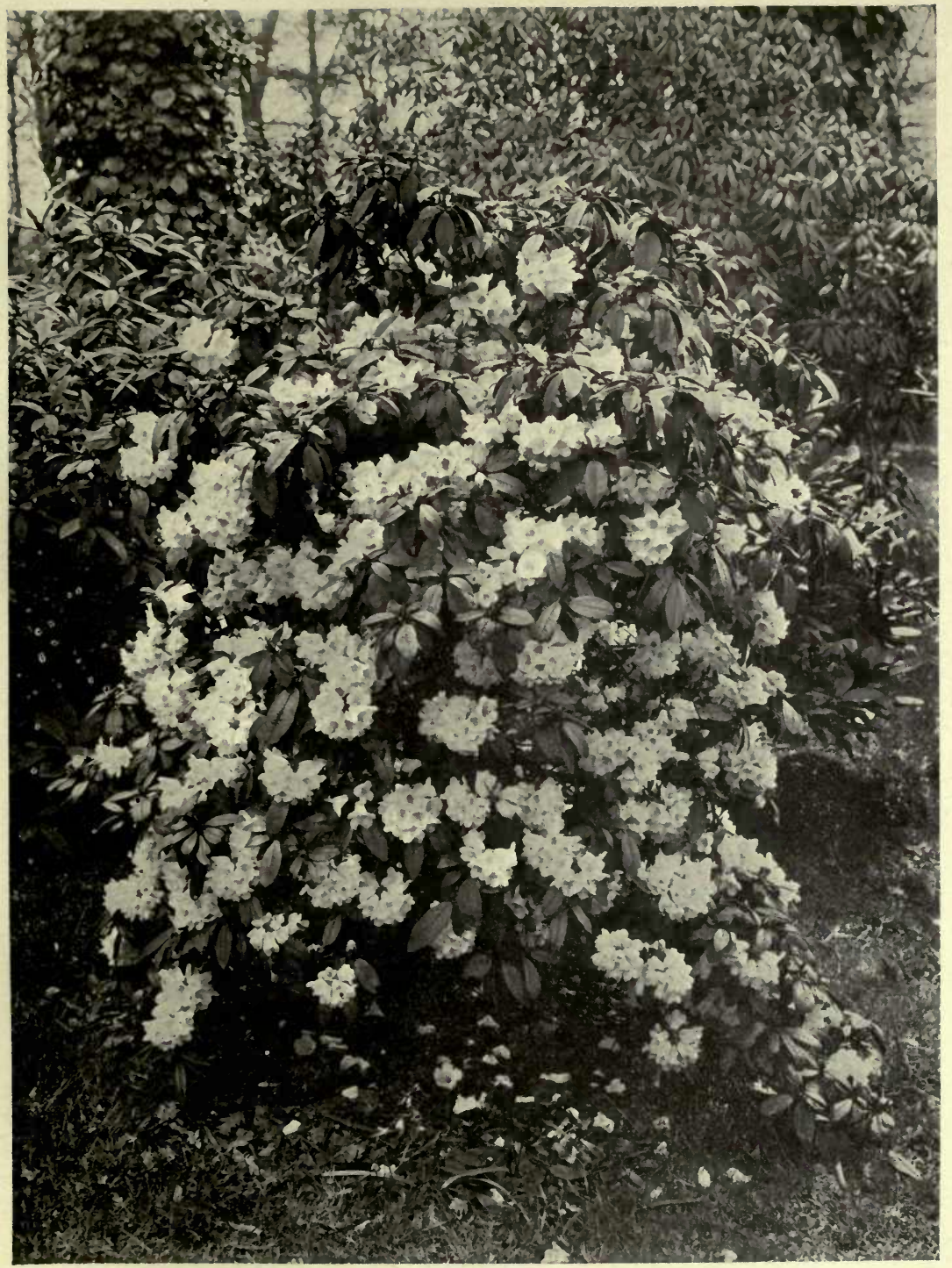

RHODODENDRON ARBOREUM var. CINNAMOMEUM. 

For other arboreum crosses, see Nobleanum, pulcherrimim, and venustum. SMITHII, with rich red flowers, is arboreum + ponticum ; and CUNNINGHAMI is arboreum + maximum.

\section{R. ARGYROPHYLLUM, Franchet.}

An evergreen shrub, from 6 to $20 \mathrm{ft}$. high, the quite young shoots clothed with a loose, white scurf. Leaves oblong-lanceolate, tapered at the base, pointed, $2 \frac{1}{2}$ to 5 ins. long, $\frac{1}{2}$ to $I^{\frac{1}{4}}$ ins. wide ; smooth and yellowish green above, the lower surface covered with a close white scurf; stalk $\frac{1}{2}$ in. or less long. Flowers in a lax truss of as many as ten. Corolla white, or blushtinted, spotted with pink on the upper side ; broadly funnel-shaped, $1 \frac{1}{2}$ ins. wide. Calyx small, with smooth triangular lobes; stamens twelve or fourteen, shorter than the corolla, white with down at the base, like the ovary; style quite smooth; flower-stalks slender, up to $\mathrm{I} \frac{1}{2}$ ins. long; seed-vessel I in. long, downy.

Native of W. China and Thibet; discovered by the Abbé David; introduced by Wilson in 1904. Very distinct in the pure white under-surface of the young leaves. It is near $R$. hypoglaucum in leaf character, but that species has a markedly glandular-downy flower-stalk and calyx.

\section{R. Augustinil, Hemsley.}

\section{(Flora and Sylva, vol. iii., F. I62 ; Bot. Mag., t. 8497.)}

An evergreen shrub, from 4 to $10 \mathrm{ft}$. high, of bushy habit; shcots hairy the first and second years; scaly the first. Leaves oblong-lanceolate ; $1 \frac{1}{2}$ to 4 ins. long, $\frac{1}{2}$ to $I$ in. wide; tapering to a fine point; tapered or rounded at the base; upper surface dark green, minutely wrinkled, and covered with fine down; under-surface scaly, and with pale bristle-like hairs on the midrib; stalk up to $\frac{1}{4}$ in. long, hairy like the midrib. Flowers produced in clusters of three or four; corolla $2 \frac{1}{2}$ ins. across, broadly funnel-shaped, wavy at the margins, varying in colour from white to pink, purplish pink, and bluish, with yellow spots on the uppermost lobes; stamens ten, reddish brown, hairy near but not at the base ; flower-stalk $\frac{1}{2}$ to $\frac{3}{4}$ in. long, scaly like the ovary.

Native of Hupeh, China ; discovered by Henry, whose christian name it bears. First introduced to France and cultivated by $\mathrm{Mr}$ Maurice de Vilmorin at Les Barres. It is very variable in the shades of its flowers, some of which are amongst the most pleasing in the genus. The line of hairs on the midrib beneath is a good distinguishing character.

\section{R. AURiculatum, Hemsley.}

An evergreen shrub or small tree, ro to $30 \mathrm{ft}$. high in a wild state; branchlets very thick and sturdy. Leaves very large, 6 to 13 ins. long, 2 to 5 ins. wide ; oblong, the apex rounded except for a short abrupt point, the base with two well-marked lobes (or auricles) to which the specific name refers; upper surface dull dark green, hairy on the midrib when young, becoming smooth; lower surface clothed with rust-coloured hairs, ultimately whitish brown; stalk up to $1 \frac{3}{4}$ ins. long, stout, bristly. The leaf-blade is of very leathery texture. Flowers 3 to 4 ins. deep, scarcely as wide at the mouth, funnel-shaped; pale rosy pink, six to eight in a truss ; flower-stalk stout, I to $\mathrm{I} \frac{1}{2}$ ins. long, glandular-hairy. Corolla seven-lobed, downy outside ; stamens fourteen, smooth ; calyx small. Seed-pod $t_{2} \frac{1}{2}$ ins. long, $\frac{1}{2}$ in. wide.

Discovered by Henry in W. Hupeh, China ; introduced in 1900 by Wilson, who considers it one of the most distinct and beautiful of Chinese rhodo- 
dendrons. It is remarkably late in starting into growth, never making a move at Kew until July; the lower part of the young shoots are then furnished with lurid crimson scales covered with sticky glands. It inhabits semi-wooded places, and Mr Wilson recommends half shade for it. I believe the finest plants in the country are at Caerhays Castle, Cornwall, where it has already borne flowers In June I9I0, I measured a leaf on a young plant at Coombe Wood which was 13 ins. by 5 ins. In China it does not flower until July.

\section{R. AZALEOIDES, Desfontaines.}

\section{(R. odoratum, Loddiges; R. fragrans, Paxton; Mag. of Bot., x., t. I47.)}

An evergreen (in hard winters semi-evergreen) bush, 4 to $6 \mathrm{ft}$. high, of twiggy habit and with interlaced branches; young shoots downy and viscid. Leaves oblanceolate, 2 to 4 ins. long, $\frac{1}{2}$ to $1 \frac{1}{2}$ ins. wide ; tapering gradually towards the base, more abruptly to the short point ; dark glossy green above, glaucous beneath, quite smooth except when very young; stalk $\frac{1}{8}$ to $\frac{1}{4}$ in. long. Flowers very fragrant, white, deeply but unequally tinged with purplish lilac, about $1 \frac{1}{4}$ ins. long and wide, produced in June and July in terminal clusters of twelve to twenty blossoms. Corolla funnel-shaped, downy outside and in the throat; stamens ten, very hairy at the base; calyx-lobes lineartriangular, $\frac{1}{8}$ to $\frac{1}{4}$ in. long, downy ; flower-stalk $\frac{3}{4}$ to $\mathrm{I}$ in. long, downy.

According to Loudon this hybrid was raised about 1820 , and he gives R. ponticum and some deciduous azalea as the parents. Others give the parentage as $R$. maximum + viscosum, which may be correct. It is undoubtedly a hybrid between the two great sections of the genus, and viscosum is, I believe, certainly one parent. It is a.most charming shrub, flowering later than most of its kind, and with great freedom. There are few shrubs blooming in June and July so fragrant and pleasing. Increased easily by late July cuttings.

There are probably several hybrids of an origin indentical, or nearly so, with that of R. azaleoides; or, as frequently happens, the progeny raised from the original seed-pod may have varied. Very closely allied to it is

R. GOWENIANUM, Sweet.-This has similarly shaped leaves also glaucous beneath, and the flowers are similarly coloured. They differ, however, in being of a darker shade and the calyx-lobes are narrower and more strapshaped. Raised in the Earl of Carnarvon's garden at Highclere about 1825. (See Sweet's Brit. Flower Garden, ser. i., t. 263).

R. CARTONI (Bot. Reg., t. 1449) was raised from the same batch of seeds as R. Gowenianum, and is very similar.

\section{R. BARBATUM, Wallich.}

An evergreen shrub or small tree, the bark peeling from the branches and leaving them blue-grey and smooth ; winter buds viscid ; branches yellowish, sometimes smooth, someţimes bristly. Leaves in a terminal cluster, oblong, heart-shaped at the base, terminated by a short, fine point ; 4 to 9 ins. long, I to 3 ins. wide; dark dull green and smooth above, pale and usually smooth beneath; stalk $\frac{1}{2}$ to $I$ in. long, conspicuously bristly on the upper side and at the base of the midrib. Flowers densely packed in a hemispherical truss about 4 ins. wide, blood-red. Corolla bell-shaped, $1 \frac{1}{2}$ ins. across, five-lobed ; stamens ten ; calyx with five smooth, ovate lobes, $\frac{1}{4}$ in. long.

Native of the Himalaya up to. 12,000 ft. ; introduced about 1849. This rhododendron is hardy in a sheltered spot at Kew, where it flowers in April. It is somewhat gaunt of habit, but worth growing for its marvellous richness of colour. It is, of course, much finer in Cornwall and similar places. There 
is some variation in the bristliness of the stems and leaves. In one form the young wood is furnished with bristles and the leaf-stalk is bristly all round; bristles up to $\frac{1}{2}$ in. long.

\section{R. BRachycarpum, Don.}

$$
\text { (Bot. Mag., t. } 788 \mathrm{r} . \text { ) }
$$

A robust evergreen shrub, 6 to $10 \mathrm{ft}$. high ; young shoots downy. Leaves narrowly oblong, 4 or 5 ins. long, $1 \frac{1}{2}$ to $1 \frac{3}{4}$ ins. wide ; with a short, abrupt tip and a rounded base ; upper surface smooth, the lower one more or less felted; stalk $\frac{1}{2}$ to $\frac{3}{4}$ in. long, very stout. Flowers creamy white, flushed with pink,

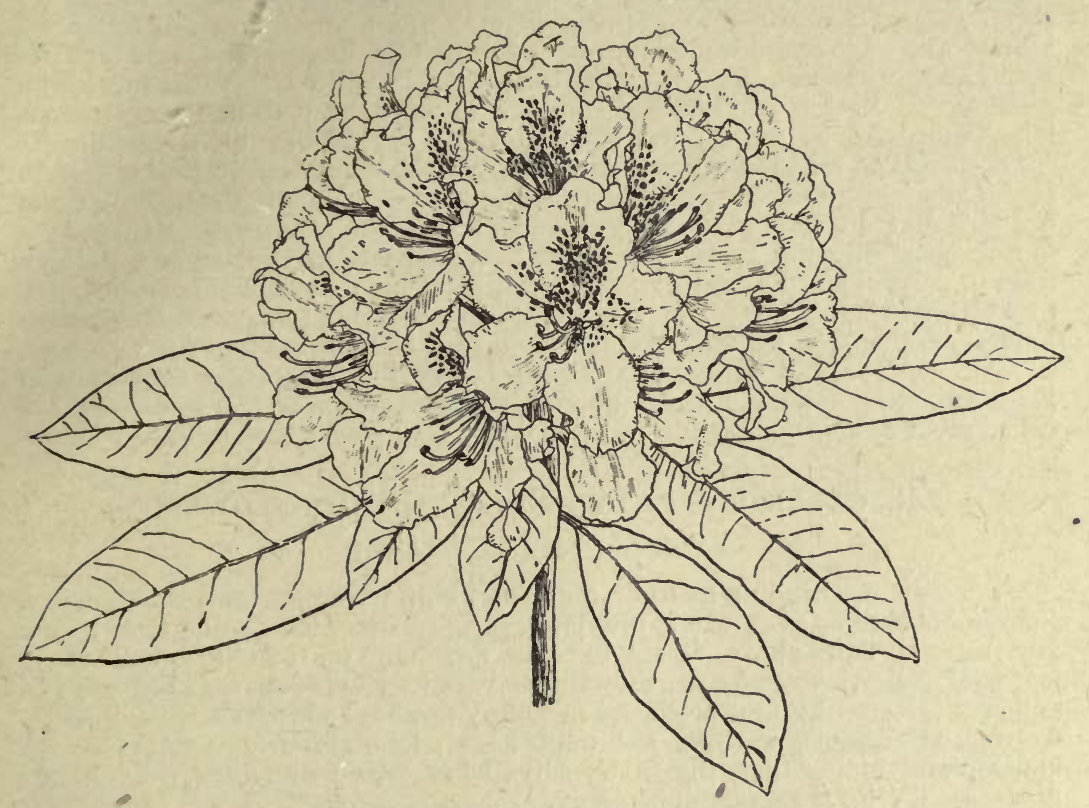

RHododÉndLon Broughtonil var. AUREUA.

produced in a rounded cluster 4 to 6 ins. across ; corolla 2 ins. across, broadly funnel-shaped, five-lobed, the lobes broad and rounded, the three upper ones spotted with brownish yellow. Calyx-lobes five, shallow; stamens ten, hairy at the base, ovary covered with brown down; flower-stalk $\frac{3}{4}$ to $1 \frac{1}{4}$ ins. long, slightly downy.

Native of Japan, where it is said to be abundant above the forest line on Fuji-yama. It is a very hardy shrub of sturdy habit, flowering in June, and very distinct in the colour of its flowers. This species and R. Metternichii are the only two species of (true) Rhododendron found wild in Japan.

\section{R. Broughtonit var. Aureum, Hort.}

A low, rounded evergreen bush, 2 to $3 \mathrm{ft}$. high, not densely branched; young shoots downy and rather viscid. Leaves narrowly obovate or oblong, 2 to 6 ins. long, $\frac{3}{4}$ to $1 \frac{3}{4}$ ins. wide : dark dull green above, pale green and 
prominently net-veined beneath, covered with fine down on both sides. Flower-truss 4 ins. wide, carrying eight to sixteen blossoms, which are $2 \frac{1}{2}$ ins. across and of a beautiful soft primrose-yellow, with reddish brown spots on the upper side of the corolla ; stamens ten ; calyx-lobes pale green, of unequal length, oblong ; flower-stalk $\mathrm{I}$ to $\mathrm{I} \frac{1}{2}$ ins. long, downy.

R. SMITHil var. AUREUM (Paxton's Mag. of Botany, ix., t. 79), is very like the preceding, which is frequently exhibited at flower shows under this name. The true R. Smithii aureum differs' in having the leaves very glaucous beneath ; the flowers, too, are of a paler yellow and not so flat and open; the flower-stalk is longer and more slender, and the calyx-lobes somewhat narrower. The two are, no doubt, very much alike, but easily distinguished by the glaucous leaf of Smithii aureum. R. Broughtonii aureum is the better shrub-more beautiful and growing better. Both are hybrids between an azalea and a true Rhododendron. I do not know the parentage of Broughtonii aureum, but that of the other is given as "Rhododendron seedling $\times$ Azalea sinensis." From the latter it may derive its glaucous hue. Both can be propagated by cuttings or by grafting on R. ponticum.

It should be mentioned that the names "Broughtonii" and "Smithii" have been given to other and very different rhododendrons. Thus R. BRoughtoniI is a large-leaved, large-flowered garden variety of the true evergreen type, not in the least like the so-called var, aureum; flowers bright rosy red, in large trusses, very like the well-known "Cynthia" or "Lord Palmerston." R. SMITHI is a hybrid between ponticum and arboreum $(q . v$.$) , and R. SMITHII$ ALBUM is an early, white-flowered hybrid of the arboreum type also. These, as well as "Smithii elegans," were all raised by Smith, a nurseryman of Norbiton, near Kingston, who flourished about 1830, and appears to have called most of his rhododendrons after himself, whatever their origin.

\section{R. Calendulaceum, Torrey. Flame-flower.}

\section{(Azalea calendulacea, Michaux.)}

A deciduous shrub up to Io or more feet high; young shoots bristly-hairy. Leaves obovate or oval, 2 to 4 ins. long, $\frac{3}{4}$ to $\mathbf{I} \frac{1}{4}$ ins. wide ; smooth, or with a few scattered hairs above, downy beneath, especially on the midrib and veins ; leaf-stalk hairy, very short. Flowers of various shades of red, orange, and yellow, scarcely fragrant, produced in showy terminal clusters of five or more. Corolla-tube about $\frac{1}{2}$ in. long, glandular-hairy; lobes often I in. long, always considerably longer than the tube; calyx-lobes edged with long, erect hairs; flower-stalk $\frac{1}{4}$ in. long, glahdular-hairy.

Native of Eastern N. America; introduced in 1806. This is the most brilliantly coloured of all wild azaleas, and is the source of the scarlet and orange-coloured varieties of garden origin. It is itself no longer common in cultivation. It has been much confused, both in books and in gardens, with $\mathrm{R}$. nudiflorum, from which it is distinguished by the proportionately shorter tube of the corolla in comparison with the lobes, by the orange or scarlet (not pink or purplish) flowers, and by the leaf being grey-downy beneath (not merely bristly on the midrib). John Bartram gives this description of his first sight of this azalea in the Carolina Mountains: "I saw the blossoms covering plants on the hill-sides in such incredible profusion that, suddenly opening to view from deep shade, I was alarmed by the apprehension of the "hill being on fire."

\section{R. CALIFORNICUM, Hooker.}

(Bot. Mag., t. 4863.)

An evergreen shrub up to $12 \mathrm{ft}$. high, with smooth young wood; branches stout and erect. Leaves oval or oblong, 3 to 6 ins. long, $1 \frac{1}{4}$ to 3 ins. wide ; 
tapering at the base, dark green above, paler beneath, quite smooth on both surfaces; stalk $\frac{1}{2}$ to $\mathrm{I}$ in. long. Flowers rich rosy purple, with crimson spots on the upper side of the corolla, 2 to $2 \frac{1}{2}$ ins. across, produced twenty or more together in a truss during May; corolla bell-shaped, with five wavy lobes; stamens ten, shorter than the corolla, downy at the base; calyx small, with five short, broad lobes, the upper one often long-pointed ; ovary covered with white down ; flower-stalk $1 \frac{1}{2}$ to 2 ins. long, smooth.

Native of California northwards to British Columbia; introduced by W. Lobb in 1850 , but now rare in gardens. It may be considered as the Western form of $\mathrm{R}$. catawbiense, differing in its more erect growth, in having more rosy tinted flowers, and smooth flower-stalks. The calyx-lobes in catawbiense are also longer, more pointed, and triangular. It is quite hardy at Kew.

\section{R. CALOPHYTUM, Franchet.}

An evergreen tree up to $50 \mathrm{ft}$. high ; branchlets clothed with a loose grey floss when quite young. Leaves obovate to oblanceolate, abruptly slenderpointed, narrowly wedge-shaped at the base; 8 to 12 ins. long, $1 \frac{1}{2}$ to $2 \frac{1}{2}$ ins. wide; perfectly smooth on both surfaces except for some white floss on the midrib beneath when quite young. Flowers in trusses, 6 to 8 ins. across; corolla seven- or eight-lobed, 2 ins. wide, scarcely so deep, bell-shaped, white or rosy with a dark blotch on the upper side. Flower-stalk $1 \frac{1}{2}$ to $2 \frac{1}{4}$ ins. long, smooth ; calyx very small, with ovate lobes ; stamens short, sixteen to twenty, not downy ; ovary smooth ; seed-pod I in. long by $\frac{1}{3}$ in. wide.

Native of W. China and Thibet; discovered by the Abbé David ; introduced by Wilson in I904. One of the noblest of Chinese rhododendrons. In foliage it has some resemblance to $R$. sutchuenense, but that species has larger flowers ( 3 ins. across), much shorter flower-stalks, and stamens downy at the base.

\section{R. Campanulatum, Don.}

(Bot. Mag., t. 3759.)

An evergreen shrub of stiff, spreading habit, 6 to $12 \mathrm{ft}$. high, more in diameter ; bark peeling ; young shoots smooth. Leaves oval, 3 to $5 \frac{1}{2}$ ins. long, $I_{4}^{\frac{1}{4}}$ to $2 \frac{1}{2}$ ins. wide ; abruptly tapering at the apex ; tapering, rounded, or slightly heart-shaped at the base; smooth above, densely covered beneath with a red-brown felt; stalk $\frac{1}{2}$ to $I$ in. long, often reddish. Flowers rosy purple of numerous shades, 2 ins. across, produced during April in rather loose clusters about 4 in. wide. Corolla broadly bell-shaped, with five notched lobes, the upper ones dark purple-spotted; calyx downy, small and scarcely lobed ; stamens ten, smooth or sometimes downy towards the base ; flowerstalk about I in. long.

Native of the interior Himalaya of Sikkim and Nepal ; introduced in 1825. This is perhaps the hardiest and most satisfactory of Himalayan rhocodendrons near London, where it flowers regularly and profusely. In very cold weather (and it withstands uninjured thirty-two degrees of frost) its leaves roll themselves up tightly, giving the shrub a very curious aspect. It is very variable in the colour of the flowers, which are sometimes quite pale, sometimes of a bright bluish purple, sometimes lilac; in the amount of felt at the back of the leaf; and in the colour of the leaf-scales that accompany the young bursting shoots, which are sometimes rich crimson, sometimes green. One of the most distinct forms is

Var. WALlichiI, Hooker fil. (Bot. Mag., t. 4929), in which the corolla is not spotted, the leaf-scales and leaf-stalks are red, and there is very little felt beneath the leaf. 


\title{
R. CAMPYLOCARPUM, Hooker fil.
}

\author{
(Bot. Mag., t. 4968.)
}

An evergreen shrub, 4 to $8 \mathrm{ft}$. high, of neat, bushy habit. Leaves $2 \frac{1}{2}$ to 4 ins. long, half as wide ; heart-shaped or rounded at the base, the apex with a short, abrupt tip ; upper surface dark glossy green, lower one vividly bluewhite; stalk $\frac{1}{2}$ to $\mathrm{I}$ in. long, thickly set with stalked glands when young. Flowers pale yellow, slightly fragrant, in loose terminal clusters of six to eight ; corolla bell-shaped, $2 \frac{1}{2}$ to 3 ins. across ; lobes five, rounded; calyx scarcely $\frac{1}{4}$ in. across, the five shallow lobes edged with dark, stalked, viscid glands ; flower-stalk about I in. long, and, like the ovary and base of style, glandular; stamens ten, downy at the base.

Native of the Sikkim Himalaya at $12,000 \mathrm{ft}$. Although not one of the hardiest species, it has lived outside in the sheltered Rhododendron Dell at Kew for over twenty years with no other protection than the situation affords. It is at present the best of the larger species with yellow flowers (apart from Azalea) in cultivation, although the colour, in some forms especially, is too pale and sulphur-like to give hopes of founding upon it a race of goldenflowered kinds. Perhaps the finest example of this rhododendron is in the Earl of Morley's garden at Whiteway, in Devonshire, which some years ago was $8 \mathrm{ft}$. high.

\section{R. Canescens, G. Don. Mountain Azalea.}

\section{(Azalea canescens, Michaux.)}

A deciduous shrub up to Io $\mathrm{ft}$. high, nearly allied (and joined by intermediate forms) to $\mathrm{R}$. nudiflorum, from which it differs in having the leaves grey-downy on the midrib and veins beneath, especially when young (not bristly on the midrib, as in R. nudiflorum); in the corolla-tube, flower-stalk, and seed-vessel being glandular, and in the five stamens not being so much pro truded. Flowers pink or rose-coloured, fragrant, borne on the naked shoots.

Native of Eastern N. America ; introduced in 1810 , according to Loudon, but much confused with nudiflorum, and to some extent with calendulaceum. The latter it resembles in the downy under-surface of the leaf, but is quite different in the colour of the flower.

\section{R. Catawbiense, Michaux.}

(Bot. Mag., t. 167I.)

An evergreen shrub, 6 to $10 \mathrm{ft}$. high, forming eventually a large spreading bush wider than high-a dense thicket of branches and leaves. Leaves oval or oblong, 3 to 6 ins. long, $1 \frac{1}{4}$ to 2 ins. wide ; broadest above the middle, dark glossy green above, pale beneath, smooth on both sides; stalk $\frac{1}{2}$ to $1 \frac{1}{4}$ ins. long. Flowers lilac-purple, produced in a large cluster 5 or 6 ins. across ; corolla $\mathrm{I} \frac{1}{2}$ ins. long, $2 \frac{1}{2}$ ins. broad, with five short, rounded spreading lobes; calyx with five shallow, itriangular pointed lobes; stamens white, downy at the base ; flower-stalks I to $\mathbf{I} \frac{1}{2}$ ins. long, glandular-downy; ovary brownfelted.

Native of the slopes and mountain summits of the south-eastern United States, where it is described as forming dense thickets "through which the -traveller can only make his way by following old bear tracks." In the gardens of Britain, to which it was introduced in 1809 by John Fraser, it has proved perhaps the most valuable evergreen shrub for ornament ever introduced. In the hands of nurserymen, but chiefly of the Waterers, it has given birth by 


\section{RHODODENDRON}

selection and hybridisation to the most valuable group of evergreen garden rhododendrons in existence - the group which flowers at the end of May and in June. The characteristics of this group, as compared with the companion group derived from R. ponticum, are their broad foliage and greater hardiness. The rlododendrons known in gardens as EVERESTIANUM and FASTUOSUM, the former with a frilled corolla, the latter double-flowered, are forms of cata wbiense.

\section{R. Caucasicum, Pallas.}

An evergreen, low shrub, usually under $2 \mathrm{ft}$. in height, with slightly downy young shoots. Leaves sometimes rather leathery, smooth and dark green above, more or less clothed with brownish red felt beneath; narrowly oval or slightly obovate; 2 to 4 ins. long, $\frac{3}{4}$ to $\mathrm{I} \frac{1}{2}$ ins. wide ; stalk stout, $\frac{1}{4}$ in. long. Flowers yellowish white or with a pale lilac tinge, produced during June in terminal clusters. Corolla 2 ins. across ; stamens ten; calyx very small; flower-stalk slightly downy, about $\mathrm{I} \frac{1}{2}$ ins. long.

Native of the Caucasus ; introduced in 1803. Although its hybrid progeny is numerous in gardens, the true species is itself now scarcely ever seen. It is an interesting dwarf bush, remarkable for its dense habit and slow growth. As it approaches $8000 \mathrm{ft}$. altitude in a wild state it is very hardy. Nearly allied to it is

R. Chrysanthum, Pallas, found in Siberia and N.E. Ásia. It has yellow flowers and differs in its smaller leaves, quite smooth on both surfaces. Although closely allied botanically to $\mathrm{R}$. caucasicum it is very unsatisfactory under cultivation, so much so, that from my experience with it I should say it was not worth growing. I have never seen it in flower.

Many of the garden varieties of Rhododendron with a blotch of yellow on the otherwise white corolla are derived in part from R. caucasicum. Amongst the more notable hybrids are the following :-

CAUCASICUM PICTUM.-A compact bush up to $6 \mathrm{ft}$. high, with thinner branches and freer habit than caucasicum. Flowers soft, pale rose, spotted on the upper side, opening in early May or even late April.

CUNNinghiam's White.-Raised by James Cunningham of Comely Bank nurseries, Edinburgh, about 1830 , from R. caucasicum crossed with ponticum album. According to information received from $\mathrm{Mr}$ James Smith of the Darley Dale nurseries, this variety thrives well in a limestone district, in evidence of which are a large number of thriving plants planted by his firm near Buxton. A robust shrub io ft. high, flowers white.

NOBLEANUM (q.v.), caucasicum $\times$ arboreum.

PULCHERRIMUM (see under Nobleanum).

ROSA MUNDI.- Very near caucasicum in leaf and habit, being a dwarf rounded bush, only 2 or $3 \mathrm{ft}$. high in twenty years; flowers white with a slight flush and a yellow spot.

STRAMINEUM (Bot. Mag., t. 3422).-A shrub, 5 or $6 \mathrm{ft}$. high, with the foliage of caucasicum, and pale yellow or straw-coloured flowers.

SUlPHUREUM.--Raised at Comely Bank nurseries from caucasicum and arboreum album. Flowers of a pretty sulphur yellow, produced in April and May. One of the best yellow hardy rhododendrons.

VENUSTUM. - A hybrid between caucasicum and R. arboreum, raised by Mr W. Smith, of Norbiton, near Kingston. It flowers in April, and is a beautiful variety, the corolla pale in the centre, deeply suffused towards the margin with rose and blotched with dark purple on the upper side. It is of spreading habit, and grows 4 to $6 \mathrm{ft}$. high. A very similar plant (R. JACKSONI), said to come from caucasicum crossed with Nobleanum, was raised by $\mathrm{Mr}$ Jackson, also of Kingston.

The caucasicum group of rhododendrons is distinguished by the cluster of 
erect sheathing scales, pale green, membranous and downy, which beset the base of the flower-stalks even whilst the flowers are fully open.

\section{R. CHARTOPHYLLUM, Franchet.}

An evergreen shrub of lax, free-growing habit, up to 8 or $9 \mathrm{ft}$. high ; young shoots slender, sparsely scaly, bearing leaves the whole length. Leaves thin, lanceolate to narrowly oblong; 2 to 4 ins. long, $\frac{1}{2}$ to $I \frac{1}{2}$ ins. wide ; tapered at both ends, but more slenderly towards the apex; smooth bright green above, paler and slightly scaly, otherwise quite smooth beneath; stalk $\frac{1}{2}$ in. or less long. Flowers produced in one to three clusters at the apex of the shoot, two to four flowers in each ; corolla widely funnel-shaped, $I$ to $I \frac{1}{2}$ ins. wide, varying in colour from white to lavender, the upper side richly spotted with brown crimson; stamens ten, protruded, downy at the base, ovary densely scaly ; calyx minute, flower-stalk $\frac{1}{2}$ to $I$ in. long, scaly.

Native of Yunnan and Szechuen, China ; first cultivated in Europe by Mr de Vilmorin at Les Barres, and flowered in this country by Mr Osgood H. Mackenzie, at Inverewe, in Ross-shire, in May I9II. It is extremely closely allied to $R$. yunnanense in botanical characters, but is distinct in general appearance, being a freer-growing shrub with larger, less scaly leaves. A slight distinction is afforded by the sometimes bristly upper surface of the young leaves of yunnanense and their ciliate margins.

\section{R. Ciliatum, Hooker fil.}

An evergreen shrub of stiff, wide-spreading habit, rarely more than 3 to $4 \mathrm{ft}$. high out-of-doors near London, but $9 \mathrm{ft}$. high and twice as much in diameter in Cornwall; young branchlets covered with bristly hairs. Leaves oval or obovate, tapering sometimes equally to both ends, sometimes more gradually towards the base ; 2 to 4 ins. long, $\frac{3}{4}$ to $1 \frac{1}{2}$ ins. wide ; bristly on the upper surface and on the margins, scaly beneath; stalk bristly, $\frac{1}{4}$ to $\frac{1}{3}$ in. long. Flowers beautiful rosy red in bud, pale pink on opening, becoming almost white with age; $2 \frac{1}{2}$ ins. across, produced three to five in a cluster during March and April ; corolla widely bell-shaped, with broad notched lobes; calyx-lobes rounded ovate, bristly on the margins, stamens ten, hairy at the base, flower-stalks $\frac{1}{2}$ in. long, bristly.

Native of Sikkim; introduced to Kew in 1850 . It is hardy there, but really needs milder conditions to bring out its best qualities. In Mr Shilson's garden at Tremough, near Falmouth, some years ago I saw a specimen of the larger dimensions given above. Near London it needs a very sheltered position, and in such a spot, although.it grows slowly, it frequently gives a very charming display in April if the weather be kind. As a shrub for the cool, wnheated greenhouse it makes a fine display in February and March.

R. ciliatum has been extensively used for crossing with other species, but most of its progeny are more tender than itself and are greenhouse plants. Of the hardy ones the best is

R. PRÆCOX, Carriere, raised about 1860 by $\mathrm{Mr}$ Isaac Davies of the Ormskirk nurseries, by crossing ciliatum with dauricum. The flowers are $1 \frac{1}{2}$ to 2 ins. across, of a beautiful, bright rosy purple; leaves dark glossy green and bristly above, scaly beneath. No early flowering shrub is more lovely than this, but as it comes into flower in March or even February its flowers rarely pass through their natural term of existence, being almost invariably cut off by frost, sometimes before they are fully open. The plant itself, a bush not so spreading in habit or strictly evergreen as ciliatum, and with deeper green foliage, is perfectly hardy. 


\section{R. CINNABARINUm, Hooker fil.}

An evergreen shrub, 6 to $10 \mathrm{ft}$. high, somewhat thin and sparse of habit, the branches long and slender, scaly when young. Leaves 2 to 4 ins. long, $\frac{3}{4}$ to $I_{4}^{\frac{1}{4}}$ ins. broad; qval, tapering about equally to each end, smooth, and of a greyish green metallic lustre above, scaly beneath, and varying in colour from glaucous green to reddish brown; stalk $\frac{1}{3}$ in. long. Flowers funnel-

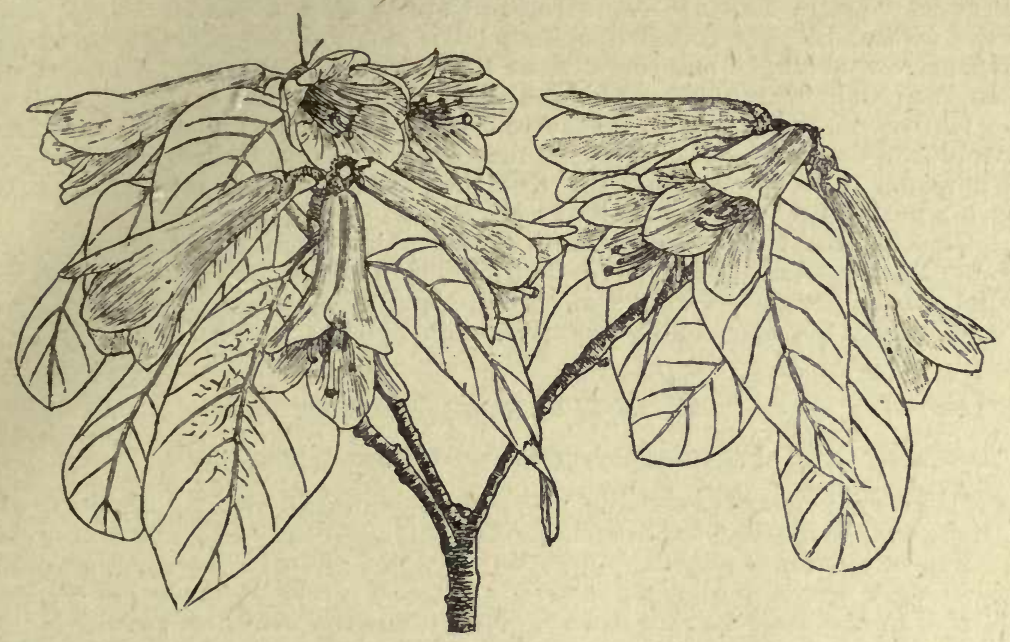

RHODODENDRON CINNABARINUM.

shaped, and like those of Lapageria, $1 \frac{1}{4}$ to 2 ins. long, very variable in colour ; ordinarily of a dull cinnabar red, produced during May and June, from five to eight in terminal heads. In other forms the corolla is orange-red outside, yellowish within, sometimes greenish. Calyx with four short, broadish lobes, and one longer narrow one, or sometimes with all five nearly equal, scaly. Stamens ten, scarcely so long as the corolla, hairy at the base ; flower-stalk $\frac{1}{3}$ in. long, scaly.

Native of Sikkim and Bhotan; introduced in 1849. This distinct and striking species is chiefly remarkable for the variability of the colour of its flowers, and the under-surface of its leaves. But the differences between some of the intermediate forms are so unimportant that botanists regard them all as of one species. In gardens, however, it has been found convenient to distinguish three forms :-

CinNabarinum (type).-Flowers cinnabar red, corolla-lobes pointed; calyx-lobes unequal, especially the upper one, which is long and narrow.

BLANDFORDIEFLORUM.-Flowers red outside, yellow or greenish yellow within (Bot. Mag., t. 4930).

ROYLEI-Leaves glaucous beneath; flowers intense, rosy red, shorter (about $1 \frac{1}{4}$ ins. long) than the two others; calyx-lobes nearly equal in size and shape.

The leaves, of all forms of cinnabarinum are believed to be poisonous to browsing animals. 


\title{
R. Collettianum, Aitchison.
}

\author{
(Bot. Mag., t. 70I9.)
}

An evergreen shrub of dwarf habit in cultivation, but described as 8 to ro ft. high in nature. Leaves 2 to 3 ins. long, $\frac{1}{3}$ to $\frac{5}{8}$ in. wide ; narrowly oval, pointed at both ends, dark dull green above, covered with brownish scales beneath; when crushed they have a strong, resinous, aromatic odour; stalk about $\frac{1}{3}$ in. long. Flowers I in. across, white, produced during May in terminal clusters 2 to $2 \frac{1}{2}$ ins. across. Corolla with a funnel-shaped tube, hairy within, the five rounded oblong lobes not fully spreading; calyx with five narrow, oblong lobes rounded at the end, scaly, and very hairy at the margins; stamens ten, almost hidden within the corolla-tube.

Native of Afghanistan; discovered in the Kurrum Valley in 1879 , and introduced the same year to Kew by the late Sir Henry Collett, after whom it is named. It first flowered in the Kew rock garden in May 1888, and it is for such a position that it appears best adapted.

Closely allied to R. Collettianum, and coming from the same country, is R. AFGHANICUM, Aitchison. It is very similar in foliage and inflorescence, but differs in the protruding stamens, and in the calyx-lobes being shorter, more rounded, and not hairy on the margins, as in Collett's species.

\section{R. CONCINNum, Hemsley.}

\section{(R. coombense, Hemsley, Bot. Mag., t. 8280.)}

An evergreen bush, probably up to $6 \mathrm{ft}$. in height; young shoots scaly. Leaves scattered along the branches, aromatic, narrowly oval, tapered towards both ends, but more gradually towards the apex ; I to 2 ins. long, $\frac{1}{3}$ to $\frac{5}{8}$ in. wide; dark green and scaly above, pale and grey beneath, but densely sprinkled with scales that are at first golden, ultimately brownish; stalk $\frac{1}{4}$ to $\frac{1}{3}$ in. long. Flowers in terminal trusses of about four blossoms, expanding in May. Corolla purple, $1 \frac{1}{2}$ to 2 ins. across ; funnel-shaped, five-lobed, spotted on the upper side with brownish purple; the lower part slightly scaly outside. Stamens ten, whitish, downy near, but not at, the base ; style smooth; ovary scaly. Calyx with shallow rounded lobes ; scaly like the flower-stalk, which is $\frac{1}{3}$ to $\frac{5}{8}$ in. long.

Native of Western China; discovered in 1885 by the Rev. Ernest Faber on Mount Omi ; introduced by Wilson for Messrs Veitch in 1904. It is allied to yanthinum (which differs in: its lanceolate calyx-lobes) and to polylepis $(q . v$.$) .$

\section{R. DAURICUM, Linnceus. DAHURIAN RHODODENDRON.}

$$
\text { (Bot. Mag., t. 636.) }
$$

A deciduous or semi-evergreen shrub up to $6 \mathrm{ft}$. in height; young shoots scaly and downy. Leaves oval, rounded at the apex, tapering or rounded at the base ; $\frac{1}{2}$ to $1 \frac{1}{2}$ ins. long, $\frac{1}{4}$ to $\frac{5}{8}$ in. wide ; dark glossy green and slighitly scaly above, paler and scaly beneath. Flowers bright rosy purple, I to $\mathrm{I} \frac{1}{2}$ ins. across, produced during January and February singly from each one of a cluster of scaly buds at the end of the previous summer's growth, where there are usually but one or two flowers open at a time. Corolla flat, saucershaped; calyx-lobes five, short

Var. SEMPERVIRENS, Sims. (syn. atrovirens, Edwards).-An evergreen form.

Native of Siberia, and grown in English gardens since 1780. It is the earliest of rhododendrons to flower, preceding even R. Nobleanum, and 
showing its blossoms usually in January, sometimes even when snow is on the ground. For this reason, aithough its beauties are of a modest kind, it is well worth growing in a small group, preferably in some spot sufficiently sheltered to mitigate to some extent the harshness of wind and weather at the inclement season when its blossoms appear.

R. MUCRONUlatum, Turczaninow (Bot. Mag., t. 8304), is a close ally of R. dauricum, native of Dahuria, N. China, Manchuria and Japan ; introduced in 1907 . It resembles $R$. dauricum in being deciduous and in producing its flowers singly from terminal buds. They are pale rose-purple, about $1 \frac{1}{2}$ ins. across, and usually larger than in dauricum. The leaves also are larger, up to 3 ins. long, thinner in texture, more tapering at the apex, often hairy above. The two appear to be united by intermediate forms found wild, which has led some authorities to consider this merely a variety of dauricum.

\section{R. DAVIDII, Franchet.}

An evergreen shrub, 4 to $12 \mathrm{ft}$. high, leaves and young shoots smooth, the latter yellowish. Leaves oval-oblong, broadly wedge-shaped at the base, terminated by a short, abrupt tip; 3 to 6 ins. long, $\frac{3}{4}$ to 2 ins. broad; pale green, net-veined beneath; stalk $\frac{1}{2}$ to $\frac{3}{4}$ in. long. Flowers produced ten or more together in a raceme up to 6 ins. long; corolla widely bell-shaped, I $\frac{3}{4}$ to 2 ins. across, seven-lobed, lilac-purple spotted with a deeper shade on the upper side ; calyx, flower-stalk, style and ovary glandular; stamens fourteen, not downy.

Native of W. China and Thibet; discovered by the Abbé David, after whom it is named; introduced by Wilson for Messrs Veitch in 1904. An ally of R. Fargesii distinct in the glandular style.

\section{R. Dilatatum, Miquel.}

\section{(Bot. Maǵ., t. 768I ; Azalea dilatatum. O. Kuntze.)}

A deciduous shrub of rather thin habit, probably 4 to $6 \mathrm{ft}$. high ; branches almost or quite smooth. Leaves often in threes at the end of the twig, ovate or somewhat diamond-shaped; I to $2 \frac{1}{2}$ ins. long, $\frac{5}{8}$ to $\mathrm{I} \frac{1}{2}$ ins. wide; smooth on both surfaces, bright green above, pale and tinely net-veined beneath ; stalk $\frac{1}{4}$ to $\frac{1}{2}$ in. long. Flowers usually in pairs, 2 ins. or rather more across, purple, unspotted; corolla-lobes oblong, rounded at the apex, the three upper ones erect, the lower ones pointing downwards and more deeply cut ; calyx small, entire ; flower-stalk $\frac{1}{3}$ in. long, slightly hairy; stamens five; ovary covered with glands, not hairy; style smooth.

Native of Japan; introduced by Messrs Veitch in 1883. It is very similar in general appearance, and in its unspotted fowers to R. rhombicum, but from that species, as well as Mariesii and Albrechtii, it is at once recognised by having only five stamens. Out of flower it is distinguishable from rhombicum by the smooth adult leaves. Blossoming in April, it is very charming then. In my experience it is hardier and more amenable to cultivation than $\mathrm{R}$. rhombicum. It can be increased by cuttings.

\section{R. DISCOLOR, Franchet.}

A shrub, 6 to $8 \mathrm{ft}$. high, of robust habit, free from down in all its parts ; young shoots stout, yellowish. Leaves oblong or narrowly oval, 3 to 8 ins. long, $\frac{3}{4}$ to $2 \frac{1}{2}$ ins. wide ; tapered about equally at both ends, sometimes heartshaped at the base, the apex with a short mucro ; upper surface deep green, 
lower one pale; stalk $\frac{1}{2}$ to $\mathrm{I} \frac{1}{4}$ ins. long, stout, purple. Flowers white or faintly' blush-tinted ; corolla funnel-shaped, $2 \frac{1}{2}$ to 3 ins. long and wide, sixor seven-lobed. Stamens twelve to sixteen, not downy, shorter than the corolla ; ovary and style glandular; calyx small, glandular on the margins at first ; seed-vessel $1 \frac{1}{2}$ ins. long, $\frac{1}{2}$ in. thick.

Native of W. and Central China; introduced by Wilson in I900. It belongs to the same group as R. Fortunei, which has its leaves almost uniformly heart-shaped at the base, and the calyx is not glandular, as in R. discolor. The foliage of young bushes is of greater size than stated above. The species starts into growth very late and does not flower until July.

\section{R. FALCONERI, Hooker fil.}

A large shrub or a small tree, ultimately over $30 \mathrm{ft}$. high, with stiff, very thick, somewhat sparse branches, woolly when young. Leaves oval or oblong, 6 to 12 ins. long, $2 \frac{1}{2}$ to 6 ins. wide (sometimes larger); very stout, thick, and strongly veined; the upper surface dark green, curiously wrinkled, but otherwise smooth; the lower surface covered with a dense, rust-coloured felt ; stalk I to 2 ins. long. Flowers about 2 ins. across, creamy white, shaded with lilac and marked with a conspicuous dark purple blotch at the base, fragrant, produced in spring in large terminal clusters 6 to 9 ins. across; the flowers tightly packed. Corolla bell-shaped, 2 ins. long, its lobes varying in number from eight to ten; calyx scarcely observable; stamens twelve to sixteen, shorter than the corolla; style about as long as the corolla, stout, and surmounted by the large knob-like stigma ; flower-stalk downy, I in. long.

Native of the Himalaya ; introduced about 1850 . A rhododendron nearly or quite identical has latterly been found in China. This is one of the noblest of all the genus, but not very hardy. After many trials it has been given up at Kew as hopeless, the plants lingering for years, but always in a miserable condition. Yet in the Duchess's garden at Belvoir Castle there is a specimen about $16 \mathrm{ft}$. high now in perfect health, although it suffered in the great frost of February 1895. But this garden is elevated, and is in the form of an amphitheatre facing south, a very favourable position compared with low-lying, flat country. In the south coast gardens, in Ireland and in Cornwall it is perfectly at home.

Var. EXIMIUM has pink flowers and reddish down on both surfaces of the leaves - a fine variety.

There is a hybrid between Falconeri and niveum to be found in several gardens in the south and west of England.

\section{R. FARGESII, Franchet.}

An evergreen shrub, so ft. high, of bushy habit ; leaves oblong-ovate, rounded at the apex, slightly cordate at the base, 2 to $3 \frac{1}{2}$ ins. long, $1 \frac{1}{2}$ to $2 \frac{1}{2}$ ins. wide, dull grey-green above, pale and rather glaucous beneath, smooth at maturity on both surfaces; stalk $I$ to $\mathrm{I} \frac{1}{4}$ ins. long. Flowers in a terminal truss of six to eight. Corolla widely funnel-shaped, seven-lobed, 2 ins. deep, $2 \frac{1}{2}$ ins. wide, pale rose or purplish pink, often with deeper spots on the upper side. Calyx shallowly seven-lobed, glandular-downy like the flower-stalk; stamens twelve or fourteen, glabrous, about half as long as the corolla, white with brown anthers; style longer than stamens, glabrous; ovary glandular.

Native of E. Szechuen, China, where it was discovered by Père Farges ; introduced by Wilson in I9oI. It flowers in late April, and is allied to R. rotundifolium (orbiculare), but is well distinguished by the oblong leaves and shorter, glandular flower-stalks. 


\section{R. FASTigiatum, Franchet.}

An evergreen shrub, 6 to I 8 ins. high, of tufted habit; the young shoots, both surfaces of the leaf'and calyx all scaly, the scales being pale and giving a dull greyish tinge to the leaf. Leaves oval or ovate, tapered or rounded at the base, $\frac{3}{8}$ to $\frac{5}{8}$ in. long, $\frac{1}{1}$ in. wide ; stalk $\frac{1}{12}$ in. long. Flowers slightly fragrant, clustered in twos or threes at the end of the shoot. Corolla 1 in. across, pale purple; the lobes five or six, $\frac{1}{3}$ in. long, ovate, rounded at the end, spreading horizontally; tube very short, bearded with pale hairs; stamens ten to twelve, hairy at the base, much protruded, purple with brownish anthers; style longer than the stamens, also purple; calyx-lobes $\frac{1}{8}$ in. long, oblong-ovate, ciliate, covered with pale scales.

Native of W. China ; introduced by Forrest in $191 \mathrm{I}$; flowered at Kew, Edinburgh, and Caerhays in the autumn of 1912, but this, no doubt, was out of season. It is a dainty little plant, in the way of $R$. intricatum, but well distinguished by the long, protruded stamens. Forrest says it is the dominant species on open pasture land on the summit of the Sung-Kivee Pass. Closely allied to R. nigro-punctatum.

\section{R. FERrugineum, Linncus. ROSE DES Alpes.}

\section{(Loddiges' Botanical Cabinet, t. 65.)}

A dwarf, slow-growing, evergreen shrub of close habit, ultimately 3 or $4 \mathrm{ft}$. high and wide, forming a dense hemispherical mass; young shoots covered with rust-coloured scales. Leaves narrow-oblong or oval, tapering at both ends, I to $I_{\frac{3}{4}}$ ins. long, $\frac{1}{4}$ to $\frac{1}{2}$ in. wide ; dark glossy green and slightly scaly above, but thickly covered beneath with golden brown, ultimately rust-coloured scales. Flowers rosy scarlet or deep rose, $\frac{1}{2}$ to $\frac{3}{4} \mathrm{in}$. wide and long, produced in June in terminal clusters of six to twelve blossoms; corolla scaly outside, funnel-shaped at the base, with five spreading, oblong lobes; calyx-lobes very short ; stamens ten, hairy ; flower-stalk $\frac{1}{3}$ in. long, scaly.

Native of the European Alps, occupying the zone of vegetation immediately above the pines and junipers. Said by Aiton to have been introduced in 1752. Visitors to the Alps well know this shrub as the "Alpine rose," often covering miles of mountain side and making one of the most gorgeous of Alpine pictures in July. It finds the conditions of the Thames Valley too hot and dry for it, but in the cooler midland and northern counties is a charming bush of neat, healthy aspect, flowering freely every summer. It has produced several varieties, some, no doubt, of garden origin, which vary chiefly in the colour of the blossom, but even in a wild state one may notice in a day's walk many variations of colour between rosy pink and rosy scarlet, and on rare occasions a white-flowered plant.

Var. ALBUM.-Flowers white.

Var. ATROCOCCINEUM. - The form whose flowers most nearly approach scarlet.

Var. VARIEGATUM. - Leaves bordered with a thin line of creamy whiteof no value.

Var. MYRTIFolium (R. myrtifolium, Schott and Kotschy; R. Kotschyi, Simk.), sometimes regarded as a distinct species, was recognised in the Austrian Alps about 1850 . It has the general aspect of $\mathrm{R}$. ferrugineum, but is usually smaller in habit; its leaves average under I in. in length, the corolla is downy outside, and it is especially distinguished by the much shorter style. In the typical form the flowers are of the same colour as in ferrugineum, but there is also one with white flowers. 


\section{R. Flavidum, Franchet.}

\section{(Bot. Mag., t. 8326 ; R. primulinum, Hemsley.)}

An evergreen shrub about $2 \mathrm{ft}$. high, of rounded, bushy habit, branches densely scaly. Leaves leathery, ovate-oblong, $\frac{1}{2}$ to $\mathrm{I}$ in. long, $\frac{1}{4}$ to $\frac{3}{8} \mathrm{in}$. wide ; rounded at the base, dark green above, paler beneath, scaly on both surfaces; stalk $\frac{1}{15}$ in. long. Flowers $\mathrm{I}$ to $\mathrm{I} \frac{1}{4}$ ins. across, primrose-yellow, becoming paler with age, produced during April in a terminal cluster of three to six. Corolla

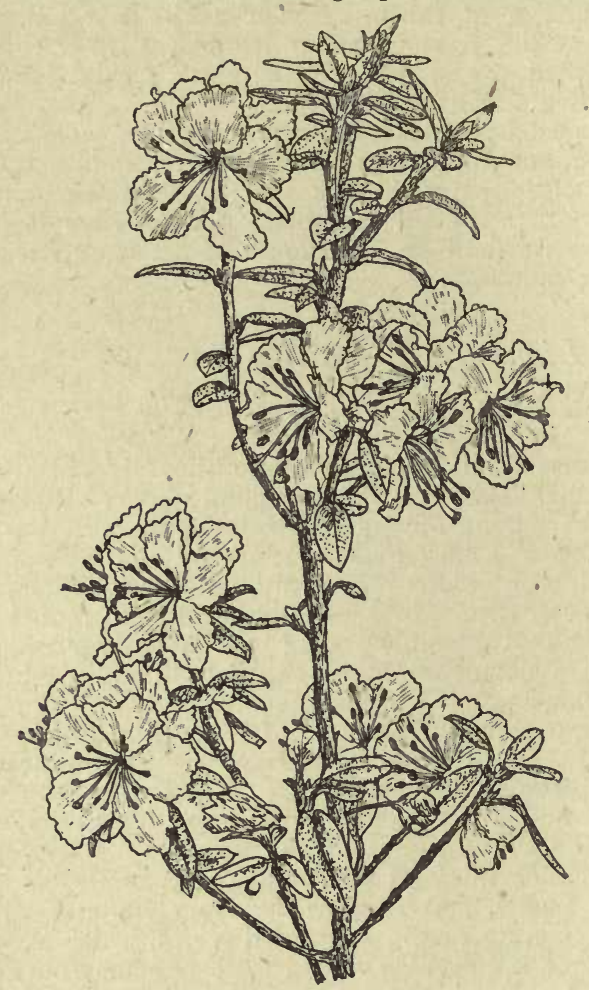

RHODODFNDRON FLAVIDUM. with a very short, slightly hairy tube, and flat, spreading, rounded lobes, wavy at the margins. Calyx pale green, the five lobes oblong, $\frac{1}{4}$ in. long, covered like the flowerstalk (which is $\frac{1}{8}$ in. long) with transparent yellowish scales.

Native of W. Szechuen, China; introduced to cultivation by Wilson for Messrs Veitch in 1905. The delightful little species is very distinct through the clear pale yellow of its flowers, and is a most promising acquisition for the rock garden or some place where dainty little plants can grow without danger of being overrun by stronger neighbours. The leaves when crushed have a pleasant, aromatic odour.

\section{R. Flavem, G. Don.}

(Azalea pontica, Linnceus ; Bot. Mag., t. 433.)

A deciduous shrub of vigorous, rather stiff habit, 8 to $10 \mathrm{ft}$. high; young shoots glandular. Leavés linear-oblong, $2 \frac{1}{2}$ to 5 ins. long, $\frac{3}{4}$ to $\mathrm{I} \frac{1}{2}$ ins. wide; with a short, abrupt tip, more tapering at the base ; at maturity glaucous, hairy beneath along the midrib and at the margins; stalk hairy, $\frac{1}{3}$ in. or less long. Flowers fragrant, rich bright yellow, $I \frac{1}{2}$ to 2 ins. across, crowded in several clusters at the end of the previous year's naked shoots. Corolla-tube $\frac{1}{2}$ in. long, hairy; calyx-lobes small, ovate, edged with glanded hairs; stamens five, hairy at the base like the style; flower-stalk $\frac{1}{2}$ to $\frac{3}{4}$ in. long, covered with sticky, glandular hairs. Blossoms in May.

Native of the Caucasian region, Asia Minor, etc. ; introduced by $\mathrm{Mr}$ Anthony Hove in 1793. This beautiful, perfectly hardy azalea, the only yellow one. known until the advent of the Chinese (sinense) type, and the parent or the predominant parent of all the older yellow garden varieties, is still one of the most useful and generally cultivated of all shrubs. It blossoms unfailingly, and with an exquisite fragrance. Coming freely from seed, it is the chief stock used for grafting the choicer varieties on. This probably 


\section{RHODODENDRON}

explains its abundance in gardens, for being a vigorous grower it will, unless watched, often send up strong sucker growths that in time smother out the more finely bred sorts grafted on it.

Var. ALBIFIORUM (Bot. Mag., t. 2383).-A white-flowered form, or perhaps hybrid.

Var. MACRANTHUM.-Flowers rich yellow, $2 \frac{1}{2}$ ins. or more wide.

\section{R. Fortuner, Lindley.}

(Bot. Mag., t. 5596.)

An evergreen shrub, ultimately so to $12 \mathrm{ft}$. high, usually less in this country, and of wide-spreading habit; branches stout, smooth. Leaves oblong, with a tapering, rounded, or heart-shaped base, abruptly pointed ; 4 to 8 ins. long, 2 to $3 \frac{1}{2}$ ins. wide; quite smooth on both surfaces, pale green above, slightly glaucous beneath; stalk stout, purplish, $\frac{1}{2}$ to I in. long. Flowers fragrant, produced in May, somewhat loosely arranged in terminal clusters; each blossom is $2 \frac{1}{2}$ to 3 ins. across, of a lovely blush tint on opening, becoming paler afterwards; corolla seven- (or rarely eight-) lobed, flattish; calyx so small as to be scarcely discernible; stamens fourteen to sixteen, much shorter than the corolla, smooth.

Native of E. China; discovered by Fortune on mountains west of Ning Po, and introduced by him in 1859. It is a beautiful rhododendron, and is of interest in having a seven-lobed corolla and spicily fragrant flowers. It was the first hardy species of true Rhododendron (as distinct from Azalea) received from China-now the headquarters of the genus. For many years it has been grown outside at Kew, and is quite hardy. Propagated by seeds, which it ripens freely, or by grafting on R. ponticum.

Fortune's rhododendron has in recent years acquired a revived interest in giving birth to a new, distinct, and beautiful race of hardy kinds. The first experiments in hybridising this species were made by $\mathrm{Mr}$ Luscombe, an amateur residing in Devonshire ; crossing it with $R$. Thomsoni, he obtained the fine R. Luscombei and Luscombei splendens. Crossing it with garden varieties, he obtained the two kinds afterwards named "Mrs Thiselton-Dyer" and "Frances Thiselton-Dyer." These crosses appear to have been made about I880. Soon after that date Mr G. Paul of Cheshunt made an extensive series of crosses, with R. Fortunei as the seed-bearing parent. From these, some scores of varieties were obtained that may be said to have laid the foundation of the new Fortunei race, the value of which is that they flower earlier than the great mass of catawbiense and ponticum hybrids, and thus help to extend the rhododendron season. And they have, besides their lovely and delicate colouring, often the additional charm of a fragrance inherited from R. Fortunei.

R. DECORUM, Franchet, is closely allied to R. Fortunei, and is perhaps its representative in $\mathrm{W}$. China. It has the same seven-lobed corolla and fragrant blossoms, but it differs in the larger, thicker, grey-green leaves, a less-branched habit, and in the stamens being downy or glandular at the base. Introduced in 1889. R. Spooneri, Hemsley and Wilson, is apparently identical with $\mathrm{R}$. decorum

\section{R. FULGENS, Hooker fil.}

An evergreen shrub, 6 to $12 \mathrm{ft}$. high, with stiff branches and peeling bark. Leaves oval, 3 to 4 ins. long, $1 \frac{1}{2}$ to 2 ins. wide ; rounded at the end except for a short, abrupt tip ; somewhat heart-shaped at the base ; covered beneath with a thick reddish brown felt. Flowers blood-red, I to $1 \frac{1}{4}$ ins. across, densely 
packed in hemispherical trusses $3^{\frac{1}{2}}$ ins. wide. Corolla bell-shaped, with five shallow, notched lobes ; calyx very small, shallowly lobed ; stamens ten, much shorter than the corolla, not downy.

Native of Nepal and Sikkim at I0,000 to I4,000 ft. ; introduced about 1849. This species is very similar to $R$. campanulatum in foliage, but is not quite so hardy nor so free in growth. Its flowers are the richest red of any hardy species except R. Thomsoni (which is of quite a different type) and R. barbatum. They appear during March and April, and provide a feast of colour unequalled in cold districts so early in the year. A suitable spot for it is some sheltered outskirt of woodland, especially where the flowers may be protected from early morning sunlight. At Kew the various titmice are very fond of pecking a hole through the base of the corolla, presumably to get at the honey. An ornamental feature of the plant are the crimson bracts that accompany the young growth in spring.

\section{R. GEMmiferum, Hort.}

A hybrid between a true Rhododendron and one of the Azalea group, forming an evergreen bush of rather loose, open habit, up to $6 \mathrm{ft}$. high. Leaves 2 to $3 \frac{1}{2}$ ins. long, I to $1 \frac{1}{2}$ ins. wide ; obovate to oval, downy beneath when young, but becoming smooth with age; dark glossy green above, pale green beneath ; margins recurved. Flowers in a truss 3 ins. across, purplish rose ; corolla funnel-shaped, $I_{4}^{\frac{1}{4}}$ ins. long and wide ; calyx-lobes $\frac{1}{8} \mathrm{in.}$ long, linear, hairy on the margins; flower-stalk $\frac{1}{2}$ in. long, sticky and downy. This shrub flowers in May or

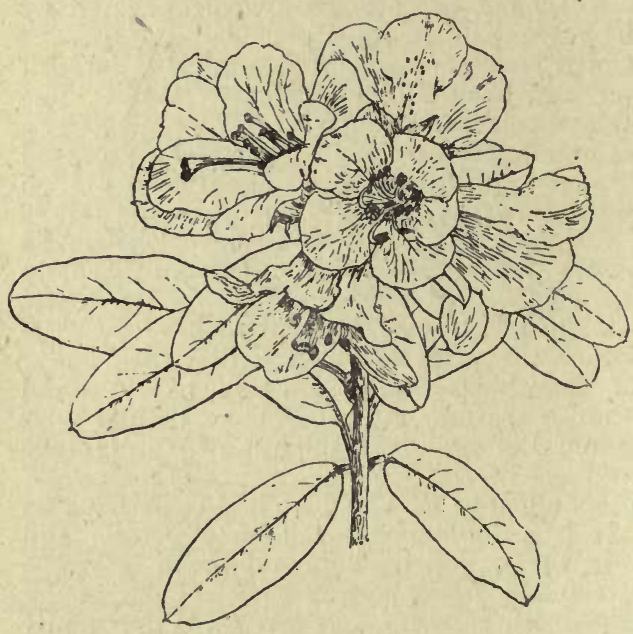

RHODODENDRON GLAUCUM. early June. It is allied to azaleoides and Gowenianum, but its flowers are more uniformly rosy, and the leaves are not glaucous beneath.

\section{R. GLAUCUM, Hooker fil.}

$$
\text { (Bot. Mag., t. 4721.) }
$$

An evergreen shrub, 2 to 3 ft. high, of bushy habit, and usually wider than it, is high ; young branches, leaves, flowerstalks, and calyx covered with reddish brown scurf or scales. Leaves oval or oblong, I to 3 ins. long, $\frac{1}{3}$ to $\frac{3}{4}$ in. wide ; margins recurved ; upper surface dark dull green, lower one glaucous white or sometimes pale brown when young; stalk $\frac{1}{8}$ to $\frac{1}{3}$ in. long. The leaf when crushed has a strong, rather resinous odour. Flowers $\frac{3}{4}$ to $1 \frac{1}{4}$ ins. wide, rosy purple, produced during May in terminal clusters of usually five or six (sometimes eight to ten); corolla bell-shaped, with five spreading, rounded lobes, slightly scaly outside ; calyx large, with five ovate, pointed lobes, $\frac{1}{3}$ in. long, scaly outside ; stamens ten, downy at the base.

Native of Sikkim and Bhotan up to $12,000 \mathrm{ft}$; ; introduced about 1850 . It is quite hardy in fairly sheltered places, but, like other Himalayan species, is 
liable to suffer injury by May frosts. It is not showy, but pretty when well in bloom. The hybrid, "Rosy Bell," is derived from this species.

\section{R. GRiffithianum, Wight.}

\section{(Brt. Mag., t. 5065 ; R. Aucklandii, Hooker fil.)}

An evergreen shrub or occasionally a small tree, with erect branches and peeling bark. It is quite devoid of down or hairs in all its parts. Leaves narrowly oblong, 6 to 9 (sometimes 12) ins. long, about one-third as much wide; rather pale green above. slightly glaucous beneath; stalk $\mathrm{I}$ to $\mathbf{I} \frac{1}{2}$ ins. long. Flowers white with a pink tinge, slightly fragrant, 5 or 6 ins. diameter, produced loosely in a cluster of about six ; corolla widely bell-shaped, with five large, rounded lobes notched in the middle. Calyx $\frac{3}{4}$ to $I$ in. across, buckler-like, scarcely lobed; stamens up to sixteen, much shorter than the corolla, style $\mathrm{I} \frac{1}{2}$ ins. long, with a large knob-like stigma; flower-stalk I to $1 \frac{3}{4}$ ins. long.

Native of Sikkim and Bhotan ; introduced in 1849 , and in some respects the finest of all rhododendrons, especially in regard to the size and width of the individual flower, which resembles some fine lily, and is occasionally 7 ins. across. The species is not regarded as hardy near London, but claims notice here as one parent of a rapidly increasing group of hybrids quite distinct from all other hardy groups. The following deserve special mention :-

R. KEWENSE, W. Watson.-Raised at Kew in 1875 by the late $\mathrm{Mr}$ W. Binder, who gave the parentage as Griffithianum $\times$ Hookeri, but the latter species is a doubtful parent. The flowers in shape are like Griffithianum, but smaller, being $3 \frac{1}{2}$ to 5 ins. across, white, suffused with rose. One form, ROSEUM, has flowers of a decided rose colour. In both, the unexpanded buds are of a lovely rosy crimson. The large crimson bracts which accompany the young growths are another feature that add to the beauty of this hybrid. It is hardy in the south, but needs a sheltered spot. Leaves as in Griffithianum, but smaller.

R. LODERI is a hybrid raised at Leonardslee, about 1904, by Sir E. G. Loder, between R. Griffithianum and Fortunei. It is a magnificent rhododendron with pure white or faintly pink flowers $5 \frac{1}{2}$ to $6 \frac{1}{2}$ ins. across, and as many as ten in a truss.

R. MANGLESII is a hybrid between Griffithianum and R. album elegans, the latter itself a hybrid of the catawbiense group. It has pure white flowers 3 to 4 ins. across, with a few spots of red on the upper side of the corolla.

The variety known as PINK PEARL, the most popular hardy rhododendron of recent times, is derived from $R$. Griffithianum, as are several other popularly named varieties; the number is likely to be increased greatly in coming years, especially in the Cornish gardens.

\section{R. hæmatóneilum, Craib.}

\section{(Bot. Mag., t. 8518 ; R. oreodoxa, Franchet?)}

An evergreen shrub with stout twigs up to $\frac{1}{4}$ in. thick, sparsely set with glandular hairs when young, soon smooth. Leaves oblong, rounded to heartshaped at the base; rounded, with a short blunt tip at the apex; up to $3 \frac{1}{2}$ ins. long by $\mathrm{I} \frac{1}{3}$ ins. wide; smooth and dark green above, paler beneath; veins in thirteen to fifteen pairs; stalk $\frac{1}{3}$ to $\frac{2}{3}$ in. long. Flowers eight to ten in a rounded truss 4 ins. across. Corolla broadly funnel-shaped, seven-lobed, 2 ins. wide, the tube scarcely $I$ in. long. In the bud state the flower is almost bloodred, changing when open to carmine, then to a lilac shade. Stamens fourteen, about as long as the corolla tube, white and glabrous; anthers purplish brown. 
Ovary and style glabrous, the latter longer than the stamens. Calyx indistinctly lobed, and, like the flower-stalk, glandular.

Native of $\dot{W}$. Szechuen, China; introduced by Wilson about I904; first flowered in the Coombe Wood nursery in the spring of 1913 . The change in colour of the corolla with age is rather marked. It is evidently very closely allied to $\mathrm{R}$. oreodoxa, and Wilson believes them to be identical. But the latter (only known by description in this country) appears to differ' in the stamens being hairy at the base, in the corolla being spotted, and in the flower-stalk being smooth. It differs from its allies, $\mathrm{R}$. Sheltonæ and $\mathrm{R}$. Davidii, in its glabrous style and ovary.

\section{R. Hanceanum, Hemsley.}

An evergreen shrub 3 to $4 \mathrm{ft}$. high; young shoots glabrous. Leaves lanceolate to narrowly obovate, usually tapered, sometimes rounded at the base, slenderly pointed; very unequal in size, and varying from $\frac{1}{2}$ to 4 ins. in length, by $\frac{1}{4}$ to $1 \frac{3}{4}$ ins. in width; dark green, rather scaly above, pale and freely sprinkled with small scales beneath; stalk up to $\frac{1}{4}$ in. long. Flowers numerous in one or two terminal clusters. Corolla about I in. long, funnelshaped, deeply lobed, varying from white to clear yellow. Calyx-lobes $\frac{3}{16}$ in. long, oblong with a rounded end, scaly ; stamens ten, protruded, downy at the lower half; seed-vessel about half as long again as the persistent, deeply lobed calyx ; style glabrous ; ovary scaly. It blossoms in March or April.

Native of W. China; discovered by the Rev. E. Faber on Mt. Omi about 1886; introduced by Wilson in 1909. Young plants appear to be quite hardy and vigorous. The species is very distinct in its numerous white or yellow flowers, deeply lobed conspicuous calyx, and hard-textured leaves.

\section{R. HiRsutum, Linnceus. ROSE DES ALPES.}

An evergreen shrub of the same habit as ferrugineum, 2 to $3 \mathrm{ft}$. high ; young shoots bristly and scaly. Leaves narrowly oval, occasionally somewhat obovate or lanceolate, about I in. long, $\frac{1}{4}$ to $\frac{1}{2}$ in. wide : bright green above, somewhat scaly beneath, the margins edged with conspicuous bristles. Flowers rosy pink to rosy scarlet, $\frac{1}{2}$ in. to $\frac{3}{4}$ in. across, produced in June in terminal clusters; corolla slightly scaly outside, funnel-shaped at the base, the lobes spreading. Calyx and flower-stalk bristly and scaly, the latter $\frac{1}{2}$ to $I$ in. long.

Native of the European Alps; introduced in 1656. This species although palpably a close ally of $R$. ferrugineum, and having the same popular name, is in several respects very distinct. The bristly character of the leaves, shoots, and calyx to which the specific name refers is, of course, its most distinctive feature, but it differs also in being greener and less scaly underneath the leaf, and in the usually longer calyx-lobes and flower-stalk. In a wild state it is always found on a limestone formation, and is therefore useful as one of the few species thriving in gardens with a soil of that nature.

Var. ALBIFLORUM.-Flowers, white.

Var. LACINIATUM. - Leaves toothed ; a curiosity.

Var. LATIFOLIUM.-Leaves broad, almost rounded.

\section{R. HodgSONI, Hooker fil.}

$$
\text { (Bot. Mag., t. 5552.) }
$$

An evergreen shrub or small tree up to $20 \mathrm{ft}$. high; bark peeling. Leaves large, slightly obovate, rounded at the apex, tapering at the base ; 6 to 12 ins. 
long, 3 to 4 ins. wide ; very leathery, dark green and glossy above, with brownish red down beneath; stalk very thick, I to 2 ins. long. Flowers rosy lilac, $1 \frac{1}{2}$ to 2 ins. across, packed in a rounded truss about 6 ins. wide ; corolla bell-shaped, with eight to ten lobes; stamens about twice as many, shorter than the corolla ; calyx very small ; ovary and flower-stalk downy.

Native of Nepal and Sikkim ; introduced in I849. It is one of the noblest of all rhododendrons in its foliage. Sir Joseph Hooker observed that its leaves are sometimes 18 ins. long. It is not, so far as I know, hardy near London, but thrives in the milder counties.

\section{R. Houlstonir, Hemsley and Wilson. \\ (R. Fortunei var. Houlstonii, Rehder.)}

An evergreen shrub up to $12 \mathrm{ft}$. high, with stout, smooth branchlets. Leaves oblong or slightly.obovate, 3 to 6 ins. long, $\frac{3}{4}$ to 2 ins. wide ; narrowed abruptly at the apex to a short point ; tapered or rounded at the base; both surfaces perfectly smooth, the upper one dark green, the lower very pale ; stalk purple, $\frac{1}{2}$ to $1 \frac{1}{8}$ ins. long. Flowers (not seen in cultivation) described as eight or more in a truss, flesh-pink, about 3 ins. across. Corolla widely bellshaped, seven-lobed; stamens twelve or fourteen, with smooth stalks; summit of ovary and base of style hairy-glandular; flower-stalk glandular, I in. or more long.

Native of W. Hupeh, China ; discovered and introduced about 1900, by Wilson. It is very closely allied to R. Fortunei, especially in the smooth, purple-stalked leaves and seven-lobed corolla, but differs in the glandular style and ovary, and the hairy style.

\section{R. HyPOGLAuCum, Hemsley.}

An evergreen shrub up to $10^{\prime} \mathrm{ft}$. high.' Leaves stiff and leathery, oval, inclined sometimes to obovate, 2 to 4 ins. long, I to $1 \frac{1}{2}$ ins. wide, rather abruptly tapered to a short point, wedge-shaped at the base ; upper surface dark green and smooth, lower surface covered with a very close white scurf; stalk $\frac{1}{4}$ to $\frac{5}{8}$ in. long, wrinkled. Flowers (not seen in cultivation) white, produced eight to ten in a truss ; corolla widely funnel-shaped, $1 \frac{3}{4}$ ins. wide, scarcely so deep, with five rounded lobes ; stamens ten or twelve, their stalks smooth except at the base. Flower-stalk $I$ to $I \frac{1}{2}$ ins. long, and, like the small, bluntly five-lobed calyx, glandular-downy. Seed-vessel $\frac{3}{4}$ in. long, $\frac{1}{6}$ in. wide.

Native of W. China ; discovered by Henry ; introduced by Wilson in 1900. Very distinct in the whiteness of the leaf beneath. If the plants now grown under this name are true, the species would not appear to be so vigorous and hardy as most of the Chinese species. According to Wilson, the calyx and flower-stalk are sometimes glabrous.

\section{R. INDICUM, Sweet.}

\section{(Azalea indica, Linnceus.)}

It would be difficult at the present day to say exactly what the typical $R$. indicum is. The species in its various formis has long been cultivated for its flowers in China and Japan, and was first introduced to England in 1808. It is best known as a common greenhouse shrub, producing in spring a great profusion of single or double flowers of almost every shade, varying from rich red, scarlet, rose and pink, to white. It is an evergreen shrub up to $6 \mathrm{ft}$. 
high, and as much as $20 \mathrm{ft}$. through, the young shoots covered with the appressed, awl-shaped bristles characteristic of its group. Leaves $I^{\frac{1}{2}}$ to $3 \frac{1}{2}$ ins. long, narrowly obovate or oval, tapering at the base, bright green, bristly on both surfaces. Flowers solitary or in pairs at the end of the previous year's twigs; corolla open bell-shaped, red in the original form, 2 to 3 ins. across; stamens five to ten, anthers purple. Single-flowered forms grow exceedingly well in the Cornish gardens, but are not quite hardy near London.

Var. BALSAMINEFLORUM.-A miniature variety usually a few inches high, known also as "rosæflorum." Leaves $\frac{1}{2}$ to $I$ in. long, $\frac{1}{8}$ to $\frac{1}{6}$ in. wide ; glossy green above, grey beneath, bristly on both surfaces; flowers double, salmon red. It has lived out-of-doors for many years at Kew, but prefers a milder climate. A pretty rock garden plant.

Var. OBTUSUM (R. obtusum, Planchon) has obovate leaves $\frac{3}{4}$ to $I_{\frac{1}{2}}$ ins. long, half or more than half as wide. It is a dwarf plant, the flowers bright red; stamens five, anthers yellow. There is a white form, OBTUSUM ALBUM. Only hardy in the south-west, etc.

\section{R. INTERMEDIUM, Tausch. ROSE DES ALPES.}

Between R. ferrugineum and hirsutum there is a series of hybrid forms, uniting the two. They vary in the scaliness of the under-surface of the leaf, in the degree of bristliness on the leaf-margins and young shoots, and in the length of the calyx-lobes. The commonest and most intermediate form is R. intermedium itself, found in the Tyrol. Its leaves are very scaly beneath, but not so much so as in R. ferrugineum, and the margins are slightly bristly. Closely allied to this are

R. HALENSE, Gremblich, which, however, leans more to ferrugineum; and

R. HIRSUTIFORME, Gremblich, which in the scaliness of the leaves resembles R. ferrugineum, but in the hairiness of the leaf-margin and in the long calyx-lobes very nearly approaches hirsutur. $R$. intermedium and $R$. hirsutiforme usually inhabit calcareous localities.

\section{R. INTRICATUM, Franchet.}

\section{(Bot. Mag., t. 8163.)}

A dwarf evergreen, shrub, usually 6 to 12 ins. high, perhaps ultimately 18 ins.; young shoots scurfy, with reddish scales. Leaves roundish ovate, $\frac{1}{4}$ to $\frac{1}{2}$ in. long, half or more than half as wide, dark green above, pale beneath, both surfaces covered with glistening scales; leaf-stalk distinctly formed, but only $\frac{1}{12}$ in. long. Flowers in terminal trusses of frequently five or six ; each flower $\frac{5}{8}$ in. across, violet-purple in the bud state, becoming paler and lilac-coloured after opening; corolla with a short tube and five rounded, spreading lobes; calyx-lobes five, short, triangular. Stamens ten, almost entirely included within the corolla-tube, downy at the base.

Native of Szechuen, W. China, at I I.000 to I5,000 ft. ; introduced by Wilson for Messrs Veitch in 1904, and one of the most dainty of recent acquisitions. This rhododendron makes a neat little bush of rounded form suggesting a pygmy tree, and it flowers when only a few inches high ; this, together with the colour of the flowers and the profusion in which they are borne, render it a singularly attractive little plant for the rock garden or some such place, where tiny, slow-growing plants are not in danger of being smothered by stronger ones. Coming from high alpine regions, it is quite hardy. Increased by cuttings of firm young twigs. Under the name of "nigro-punctatum," a near alley, this species was given a first- 
class certificate by the Royal Horticultural Society, 2nd April 1907. The true R. NigRo-PUNCTATUM, Bureau (Bot. Mag., t. 8529), is similar in its twiggy habit and scaly foliage to $R$. intricatum. The leaves are oval-oblong or obovate, $\frac{1}{4}$ to $\frac{1}{2}$ in. long, covered with golden-brown scales on both suriaces. Flowers solitary or few in a cluster, scarcely stalked; corolla violet-purple, $\frac{1}{2}$ in. wide, with five spreading ovate lobes; calyx-lobes oblong, $\frac{1}{8}$ in. long, margins hairy towards the ends; stamens ten, $\frac{1}{3}$ in. long, very hairy at the base, both they and the style protruded. Native of China and Thibet; discovered by Prince Henri d'Orleans in I89o. Although confused with $\mathrm{R}$. intricatum, it is very distinct in the much exposed stamens and larger calyx.

\section{R. KAEMPFERI, Planchon.}

\section{(Azalea indica var. Kaempferi, Rehder.)}

A semi-evergreen or nearly deciduous shrub, probably 8 or $10 \mathrm{ft}$. high in favourable localities; young twigs covered with appressed, forward-pointing bristles. Leaves I to $2 \frac{1}{2}$ ins. long, $\frac{1}{3}$ to $I$ in. wide; oval, or somewhat diamond-shaped, glossy green above, paler beneath, with scattered bristly hairs on both surfaces. Flowers about 2 ins. in diameter, variable in colour, purplish rose, rose-coloured or rosy scarlet ; produced about mid-May, two to four in terminal clusters. Corolla open bell-shaped, with five roundish oval lobes. Calyx-lobes five, narrowly ovate or obovate, hairy outside and at the margins ; stamens five ; flower-stalk silky-hairy, $\frac{1}{4}$ in. long.

Native of Japan ; introduced to the United States by Prof. Sargent in r892, thence to Kew two years later. Nearly allied to R. indicum, this species differs in its nearly deciduous habit, the leaves in any case persisting one winter only, by its more numerous flowers in a cluster, and by the yellow anthers. It is also very much hardier, and, excepting $R$. amœnum, the best and hardiest of the indicum group of azaleas for near London. Whilst it does not suffer by the hardest winter weather, it is, unfortunately, liable to injury by late frosts, which occasionally destroy not only the blossom but the young shoots also. It thrives excellently, and every year makes a great show in the Arnold Arboretum.

\section{R. Kamtschaticum, Pallas.}

(Bot. Mag., t. 82 Io.)

A deciduous shrub growing in low dense tufts 2 or 3 ins. high, producing its flowers on stems twice as high. It spreads by means of underground suckers. Young shoots furnished with scattered bristles. Leaves stalkless, obovate, $\frac{3}{4}$ to 2 ins. long, $\frac{1}{3}$ to $\frac{3}{4}$ in. wide ; thin in texture, smooth above, slightly bristly beneath, and conspicuously so on the margin. Flowers solitary or in pairs (rarely in threes) on an erect, slender, glandular-bristly stem 3 to 5 ins. high, the lateral flower or flowers produced on stalks $\frac{3}{4}$ to $1 \frac{1}{2}$ ins. long ; corolla $1 \frac{1}{2}$ to $1 \frac{3}{4}$ ins. across, rosy crimson, with five open, spreading, oblong lobes, the three upper ones spotted. Calyx green, I in. across, the lobes narrowly oblong, bristly; stamens ten, very downy at the bottom.

This remarkable and pretty rhododendron, so distinct from every other, is a native of Kamtschatka and other parts of N.E. Asia. Introduced in 1799. It is still very rare, although many times introduced. Whilst not difficult to cultivate, it requires rather special treatment - the ordinary conditions adapted to Ericaceæ in general do not quite suit it. Found naturally in boggy places, it needs chiefly more continuous surface moisture than rhododendrons in general do, although they are well known to love cool, moist conditions about the roots. I have found that the most successful way to 
grow this plant is to plant it in sandy, peaty soil with which a little chopped sphagnum has been mixed, and after it is planted to lay sphagnum round it and amongst the stems also. As it is apt to be cut by late spring frosts it is an advantage to cover the plants with a handlight for a few weeks until that danger be past, or failing that, to select a spot screened from the rays of the morning sun.

\section{R. KeISKeI, Miquel.}

(Bot. Mag., t. 8300.)

An evergreen shrub only known as yet in a small state under cultivation, but said to be $6 \mathrm{ft}$. high in nature; young branches slightly scaly. Leaves I $\frac{1}{2}$ to $2 \frac{1}{2}$ ins. long, $\frac{3}{4}$ to $\mathrm{I} \frac{1}{4}$ ins. wide ; oval-oblong, pointed at the apex, rounded or tapered at the base, more or less scaly on both surfaces, but especially beneath ; stalk about $\frac{1}{4}$ in. long. Flowers pale, rather dull yellow, $1 \frac{1}{4}$ to 2 ins. across, in clusters of about four or five; corolla broadly bell-shaped ; calyx undulated into five very shallow lobes ; stamens ten, downy ; flower-stalk scaly, $\frac{1}{2}$ to $\frac{3}{4}$ in. long. Blossoms in April and May.

Native of Japan; introduced in 1908, and apparently hardy. Its chieff claim to recognition in gardens will be that it is one of the comparatively few species with yellow flowers. The only one of these with which it is likely to be confused is the Himalayan

R. TRIFLORUM, Hooker fil., which differs in the leaves being larger, bright green and not scaly above, glaucous beneath, in the more distinctly lobed calyx, the larger pale yellow corolla, and more hairy stamens. R. triflorum has been tried several times out-of-doors at Kew, but does not thrive. In the Isle of Wight, Cornwall, and similar places it succeeds admirably.

\section{R. Keysil, Nuttall.}

\section{(Bot. Mag., t. 4875.)}

An evergreen shrub, $6 \mathrm{ft}$. or more high ; the young shoots, the under-surface of the leaves, leaf-stalk, and flower-stalk densely covered with brownish red, glistening scales. Leaves 2 to 4 ins. long, $\frac{5}{8}$ to $1 \frac{1}{4}$ ins. wide ; oval-ovate, tapering at both ends; stalk $\frac{1}{3}$ to $\frac{2}{3}$ in. long. Flowers crowded in short clusters, several of which are borne about midsummer from axillary buds near the end of the previous year's shoot, and at the time of flowering surmounted by the young shoot of the current year. Each flower is $\frac{3}{4}$ to $I$ in. long, $\frac{1}{4}$ in. wide-a brick-red, cylindrical tube with five small, blunt, yellow teeth at the mouth ; calyx very small ; flower-stalk $\frac{1}{4}$ in. long.

Native of Bhotan, up to $10,000 \mathrm{ft}$. This rhododendron, so remarkably distinct from all others known at the time of its introduction in the curious Correa-like flowers, forms with a recent introduction from China-R. spinuliferum (q.v.) - the sub-genus KEYSIA. It is only hardy in the milder parts of the kingdom, and is a botanical curiosity as well as a rather striking garden plant. Several fine examples exist in Ireland and Cornwall.

\section{R. LACTEUM, Franchet.}

(Bot. Mag., t. 8372.)

A tree 20 or more feet high, the very stout young shoots clothed with down. Leaves clustered at the end of the shoot, narrowly oval, rounded at the base, the apex terminated by a minute tip; 5 to 8 ins. long, 2 to 3 ins. wide; dark green and smooth above, covered beneath with a dense red- 
brown felt; stalk I to $1 \frac{1}{4}$ ins. long, stout, felted. Flowers in a fine truss 5 to 7 ins. across, expanding towards the end of April. Corolla china-white, with a very striking, dark crimson blotch at the base; bell-shaped, about 2 ins. deep-and wide, seven- or eight-lobed. Stamens fourteen or sixteen, very unequal in length, but all shorter than the corolla, downy at the base; anthers red-brown; style smooth, ovary felted; calyx inconspicuous ; flowerstalks I to $I \frac{1}{4}$ ins. long.

Native of W. China ; introduced by the Abbé Delavay to Paris about 1889. First flowered with Mr F. D. Godman at Horsham in 1910. One of the finest of rhododendrons, and most nearly allied to R. Falconeri. As it occurs at $10,000 \mathrm{ft}$. altitude in Yunnan, it may be hardier than that species.

\section{R. LAPPONICUM, Wahlenberg.}

$$
\text { (Bot. Mag., t. 3106.) }
$$

A dwarf evergreen shrub, rarely more than I to $I \frac{1}{2} \mathrm{ft}$. high, the lower branches often prostrate; young wood very scaly, becoming warted. Leaves oblong, rounded or abruptly tapered at the apex; $\frac{1}{4}$ to $I$ in. long, $\frac{1}{8}$ to $\frac{1}{4}$ in. wide; rough and dark green above, covered beneath with brownish yellow scales; stalk $\frac{1}{12}$ to $\frac{1}{8}$ in. long. Flowers bright purple, $\frac{3}{4}$ in. across, produced three to six together in a smail cluster. Calyx and flower-stalk very scaly; calyx-lobes triangular, fringed; stamens five to eight, about as long as the corolla, quite devoid of down ; flower-stalk $\frac{1}{4}$ to $\frac{1}{2}$ in. long.

Native of the high latitudes of Europe, Asia, and N. America; probably the most northern of rhododendrons. It is found on mountain tops in Eastern N. America. Introduced in 1825 , but long lost to cultivation, until recently re-introduced. It probably requires exceptionally cool, moist conditions, somewhat similar to those recommended for $\mathrm{R}$. kamtschaticum. It is a very pretty plant when seen at its best, the colour of the flowers being very bright, and with more blue in it than almost any other species. (See also R. parvifolium.)

\section{R. LEDifolium, Don.}

\section{(Azalea ledifolia, Hooker; Bot. Mag., t. 2901 ; A. indica alba, Lindley.)}

A stiff evergreen shrub, 5 or $6 \mathrm{ft}$. high in favourable localities; branches rigid, covered densely with dark bristles the first and second seasons. Leaves narrowly oval-lanceolate, 1 to $2 \frac{1}{2}$ ins. long, $\frac{1}{3}$ to $\frac{3}{4}$ in. wide; tapering at both ends, hairy all over especially when young, rather dull green; stalk $\frac{1}{8}$ in long. Flowers pure white, fragrant, $2 \frac{1}{2}$ ins. across, solitary at the end of short lateral twigs, or in pairs or threes; corolla open bell-shaped, with a short tube ; stamens ten, about as long as the corolla ; calyx with five hairy, viscidly glandular, lanceolate lobes $\frac{1}{3}$ in. long; flower-stalk hairy, $\frac{1}{2}$ in. long.

Native of China, Japan, and Corea ; introduced in 1819 from Japan, where it is much cultivated. It is nearly allied to the common greenhouse "Azalea indica," and is largely used as a stock on which the finer varieties of that species are grafted. It is often known even now as "A. indica alba," but is well worthy of the specific rank the elder Hooker gave it in 1829 , being distinct in its duller more hairy leaves, in the more fragrant flowers, and in the viscid calyx with more erect lobes. In gardens it has not received the notice it deserves as a hardy evergreen. At $\mathrm{Kew}$, in an exposed position, it has stood for over twenty years, and is still only $3 \mathrm{ft}$. high; but it thrives best in the most sheltered spots. When covered, as it generally is about the end of May, with its pure white, fragrant flowers it is exceedingly pretty, and is well adapted for positions where a slow-growing dwarf shrub is desirable. In Cornwall and similar places it grows much taller. 
R. NARCISSEFLORUM.-This Azalea has double flowers, either rosy purple or white. It is not so hardy as linearifolium, and is probably a hybrid between it and some form of indicum.

\section{R. LEPIDOTUM, Wallich.}

(Bot. Mag., t. 4657.)

A low, evergreen, sometimes nearly deciduous shrub, usually $\mathrm{I}$ to $2 \mathrm{ft}$. high in this country, but said to be $4 \mathrm{ft}$. high in the Himalaya; young wood, leaves, leaf-stalk, and flower-stalks dotted thickly with minute scales. Leaves oblong, I to $1 \frac{1}{2}$ ins. long, about $\frac{1}{2}$ in. wide, only hairy on the margins when young. Flowers rosy crimson, spotted, produced singly or a few together in June, each about I in. across, flat and saucer-shaped, and borne on a stalk I to $I \frac{1}{2}$ ins. long ; corolla-tube very short, lobes rounded. Stamens about ten, hairy towards the base, not protruded; calyx-lobes $\frac{1}{8}$ in. long, rounded.

Native of the lofty interior ranges of the Nepal and Sikkim Himalaya, up to $16,000 \mathrm{ft}$. altitude ; and in Yunnan. It is hardy at Kew, and one of the most distinct and interesting of dwarf rhododendrons. Sir Joseph Hooker mentions varieties with golden yellow flowers and greenish yellow flowers, which do not appear to be in cultivation. Seeds are freely borne.

\section{R. LINEARIFOLIUM, Siebold.}

\section{(Azalea linearifolia, Hooker; Bot. Mag., t. 5769.)}

An evergreen, flatish shrub, 2 to $4 \mathrm{ft}$. high, with forking, often horizontal branches; the younger parts covered with bristly hairs, the young wood, leaves, and flower-stalks very thickly so. Leaves croquded at the end of short twigs, narrowly linear ; 2 to 3 ins. long, usually $\frac{1}{8}$ to $\frac{3}{16}$ in. wide at the middle, tapering gradually to each end. Flowers produced during May in a terminal cluster of about three, the corolla having long, narrow lobes of about the same shape as the leaves, and up to $1 \frac{1}{2}$ ins. long, bright rosy lilac, hairy at the base. The calyx has five narrow-linear lobes $\frac{1}{2}$ in. long, thickly covered, like the flower-stalk, with hairs ; stamens five.

Native of Japan ; introduced by Messrs Standish, and first flowered by them in 1869. It is quite hardy at Kew, and worth growing for its remarkable aspect. The long narrow leaves and corolla-lobes, and the shaggy character of the entire plant render it quite distinct from all other azaleas. Increased by cuttings.

\section{R. Longesquamatum, $C . K$. Schneider.}

\section{(R. Brettii, Hemsley.)}

An evergreen bush about Io $\mathrm{ft}$. high; young shoots clothed thickly with brown, shaggy, branched hairs, which persist for two or more seasons. Leaves oblong, inclined to obovate, pointed at the apex, rounded or slightly heart-shaped at the base ; $2 \frac{1}{2}$ to 5 ins. long, I to $I_{4}^{3}$ ins. wide ; dark green and smooth except for the midrib, which is shaggy beneath like the young shoots and leaf-stalks - the latter about $\frac{1}{2}$ in. long. Flowers not seen in cultivation, but described by Wilson as widely bell-shaped, 2 to $2 \frac{1}{2}$ ins. across, pink with a dark red blotch, and produced twelve or more in a truss. Stamens ten, shorter than the corolla, downy below ; calyx-lobes $\frac{1}{2}$ in. long, hairy.

Native of Szechuen, China, up to $9000 \mathrm{ft}$. altitude ; discovered by Wilson, and introduced in 1904. Quite hardy at Coombe Wood and Kew, and said by Mr Wilson to be a very striking and handsome species, not common. The 
fur-like covering of the young shoots is very marked, as is also the large petaloid calyx, about $\mathbf{I}$ in. across, glandular and hairy.

\section{R. LUTESCENS, Franchet.}

An evergreen shrub, 3 to $7 \mathrm{ft}$. high, of loose habit ; young shoots reddish, slender, scaly. Leaves lanceolate, with a long slender point and a tapered base ; $1 \frac{1}{2}$ to $3 \frac{1}{2}$ ins. long, $\frac{1}{2}$ to $1 \frac{1}{4}$ ins. wide ; dark green above, paler and more scaly beneath ; stalk $\frac{1}{4}$ to $\frac{1}{3}$ in. long. Flowers pale yellow, produced singly or occasionally in pairs from several buds at the apex of the shoot, terminal and axillary; corolla broadly funnel-shaped, I in. wide ; stamens ten, protruded, hairy near the base. Ovary, calyx, and flower-stalk scaly, the last $\frac{1}{2}$ in. long; calyx scarcely lobed.

Native of W. China and Thibet; discovered by the Abbé David; introduced by Wilson in 1904. In the curious habit of bearing usually a single flower only from each bud, this species resembles dauricum and mucronulatum. Its yellow flowers give it interest, but opening, as they do, in March, they often perish by frost. Wilson's later introductions of this species seem hardier than his first. He observes that it grows in full sunshine.

\section{R. MAXimum, Linnceus.}

An evergreen tree, sometimes over $30 \mathrm{ft}$. high, with a short trunk I ft. in diameter in a wild state, but always a shrub under cultivation in Britain, and rarely more than 8 or ro $\mathrm{ft}$. high; young wood reddish and scurfy. Leaves narrowly obovate to oblong, 4 to 8 ins. long, I to $2 \frac{1}{2}$ ins. wide ; dark green above, pale beneath, becoming quite smooth on both surfaces by autumn; stalk $\frac{1}{2}$ to $\mathrm{I}$ in. long, very stout. Flowers produced in a cluster 3 or 4 ins. across ; corolla rose-coloured or purplish pink, spotted with yellow on the upper side, about $1 \frac{1}{2}$ ins. across, the lobes rounded ; calyx with ovate, rounded lobes slightly downy, $\frac{3}{16}$ in. long; stamens ten, flower-stalk viscid and downy, about $\mathrm{I}$ in. long.

Native of the United States ; introduced in 1736 , but now rarely seen in gardens. Its trusses are small, but very pretty and delicate in colour. It is useful, moreover, in flowering late - the end of June and in July. Distinct in the comparatively large calyx-lobes.

Var. ALBUM. - Flowers white; found wild along with the type.

\section{R. MetTernichin, Siebold.}

\section{(R. japonicum, C. K. Schneider; Bot. Mag., t. 8403.)}

An evergreen shrub, eventually 6 to 8, perhaps more, feet high; young stems stout, yellow, at first covered with a grey, loose felt; winter buds very woolly. Leaves narrowly oblong, leathery, tapering at the base, bluntish at the apex; 3 to 6 ins. long, $\frac{3}{4}$ to $1 \frac{1}{2}$ ins. wide ; dark dull green and smooth above, covered beneath with a firm, dun-coloured felt; stalk $\frac{1}{2}$ to $\frac{3}{4}$ in. long, scurfy ; midrib yellow. Corolla purplish rose, about 2 ins. wide ; stamens ten to fourteen ; ovary hairy; flower-stalk downy, pinkish, $\frac{3}{4}$ to $\mathrm{I}$ in. long.

This rhododendron, which is a native of Japan, is represented there by two forms: (I) var. HEPTAMERUM, in which the lobes of the corolla are six or seven, and the calyx-lobes almost obsolete; and (2) var. PENTAMERUM (see Bot. Mag., t. 8403), in which the corolla-lobes are five (rarely six), stamens ten, and the calyx-lobes bluntly triangular. The latter variety flowers at the end of March or early in April at Kew. According to Sargent, Metter- 
nich's rhododendron forms great masses near Lake Yumoto, in the Nikko Mountains, at $5000 \mathrm{ft}$. elevation.

Var. ANGUSTIFOLIUM.-This variety differs from the type in its longer, narrower leaves, much more curled in at the margins. They are up to 7 ins. in length and $\mathrm{I} \frac{1}{4}$ ins. wide, standing out rigidly in a cluster at the end of the shoot. The branches are stiffly erect, and the plant is quite distinct in these respects from any, cultivated rhododendron. Corolla very pale lilac-rose, $2 \frac{1}{4}$ ins. across. Very vigorous at Kew.

\section{R. MICRANTHUM, Turczaninow.}

(Bot. Mag., t. 8I98.)

An evergreen shrub of bushy form, ultimately 4 to $6 \mathrm{ft}$. high ; branches slender, scaly, and slightly downy when young. Leaves narrowly oval or oblanceolate, tapering at both ends ; $\frac{3}{4}$ to $1 \frac{1}{2}$ ins. long, $\frac{1}{4}$ to $\frac{1}{2}$ in. wide ; smooth above, very scaly beneath; stalk $\frac{1}{8}$ in. or less long. Flowers dull white, $\frac{1}{3}$ to $\frac{1}{2}$ in. across, numerous and densely packed in a short, terminal, rounded jaceme $I \frac{1}{4}$ to $I \frac{1}{2}$ ins. across. Corolla bell-shaped at the base, with five flatly spreading, oval lobes as long as the tube; stamens ten, longer than the corolla, not downy ; flower-stalk slender, scaly, $\frac{1}{3}$ in. long.

Native of N. and Central China and Manchuria ; introduced by Wilson, in I90I, from W. Hupeh. It is found at elevations of 5500 to $8000 \mathrm{ft}$. there, and promises to be quite hardy. It is remarkably distinct in its racemes of small, numerous flowers, which open in May, and give the plant at that time a strong resemblance to Ledum latifolium. Still, it is nat in the front rank: of rhododendrons. Messrs Rehder and Wilson have recently described a new species allied to this under the name R. LONGISTYLUM. It differs from R. micranthum in having larger, prettier flowers, less scaly foliage, a larger calyx, and especially a style $I$ in. or more long, exceeding the stamens, which are downy at the base. Introduced from W. China in I908.

\section{R. MOLLE, Miquel.}

(Azalea mollis, Hort.)

A deciduous bush, of rounded habit, 4 to $8 \mathrm{ft}$. high, with stiff, erect branches; young shoots sparsely hairy. Leaves narrowly oval or obovate, 2 to 4 ins. long, $\frac{3}{4}$ to $I \frac{1}{4}$ ins. wide ; dark green and sparsely hairy above, more or less glaucous and slightly hairy beneath when young, especially on the midrib and margins. Flowers six to ten in a cluster, produced during May on the end of leafless shoots, the corolla being of various shades of soft rose, salmon red, and orange red, $2 \frac{1}{2}$ to $3 \frac{1}{2}$ ins. wide, the lobes oblong; calyx-lobes oblong to linear-oblong, as long as the ovary, conspicuously edged with long whitish hairs; flower-stalk $\frac{1}{2}$ to $I$ in. long, hairy.

Native of Japan, perhaps China also, and one of the most beautiful of all deciduous shrubs. It flowers somewhat in advance of the so-called "Ghent" azaleas that have been derived from $R$. flavum and the American species, and its blossom is apt to be spoilt by late frosts. Still, it often escapes, especially if planted on elevated ground, and then gives one of the most delightful of all colour displays. The flowers have no fragrance. There is now a great variety of shades - almost white, yellow, deep rose, and salmonamong cultivated varieties, which, however much mixed, always harmonise. For some time past it has been the practice among botanists to amalgamate this azalea with R. sinense $(q . v$.$) . This arrangement has never been accepted$ in nurseries and gardens, and as there appear to be fairly well-marked differences between them, I have here kept them apart. $R$. sinense as here interpreted 
differs from R. molle in the following particulars: The branchlets and undersurface of the leaves are somewhat less hairy than in R. molle, but are, in addition, covered with a dense felt of soft down; the lobes of the corolla are shorter, fuller, and more rounded; and the calyx-lobes are more rounded, shorter (scarcely half the length of the ovary), and not so conspicuously hairy. It appears to be exclusively Chinese, and perhaps less hardy.

Between R. molle and R. sinense a series of intermediate, probably hybrid, forms have become popular in cultivation, especially for forcing. One of the most notable of these is the variety "Anthony Koster," with brilliant yellow blossom

\section{R. MOUPINENSE, Franchet.}

A dwarf evergreen shrub 2 to $3 \mathrm{ft}$. high; young shoots hairy, much of the hairiness disappearing by autumn. Leaves leathery, obovate or oval, rounded or slightly heart-shaped at the base, usually rounded and with a short mucro at the apex; $\frac{3}{4}$ to $I \frac{1}{2}$ ins. long, about half as wide; dark, slightly glossy green, and smooth except for some minute down on the midrib above; pale and covered with minute scales beneath; margins ciliate at first towards the base; leaf-stalk $\frac{1}{8}$ to $\frac{1}{4}$ in. long, furnished with dark hairs Flowers fragrant, white with purple spots, 2 ins. across, opening in March; corolla shortly tubular and downy at the base, expanding upwards into five rounded lobes. Stamens ten, shorter than the corolla, and like the style, downy at the base. Calyx with shallow, rounded, ciliate lobes. Seed-vessel $\frac{3}{4} \mathrm{in}$. long, $\frac{1}{3}$ in. wide. Flowers usually about three in a cluster.

Native of Thibet and W. China; introduced by Wilson in 1909. It is described as growing in the forks of trees. Young plants in cultivation appear to be quite hardy and thriving. It promises to be useful for the rock garden.

\section{R. NIVEum, Hooker fil.}

(Bot. Mag., t. 4730.)

An evergreen shrub of sturdy habit, up to 6 or $8 \mathrm{ft}$. high in the open air ; young shoots clothed with a whitish felt. Leaves narrowly-oblong, 3 to 7 ins. long, 1 to $2 \frac{1}{2}$ ins. wide ; tapering at the base, more rounded at the apex. When the young leaves unfold they are covered all over with a snow-white floss, which falls away from the upper surface, leaving it very deep green, but which remains beneath and turns a pale brown. Flowers purplish lilac, I to $I \frac{1}{2}$ ins. across, densely packed in a compact, rounded head, 3 to 4 ins. across. Corolla bell-shaped; lobes five, rounded, notched; calyx simply an expanded end to the short, downy flower-stalk; stamens ten, much shorter than the corolla; anthers brown.

Native of the Sikkim Himalaya at 10,000 to $12,000 \mathrm{ft}$. ; introduced in 1849. It is quite hardy in the Rhododendron Dell at Kew, but enjoys a warmer climate. The unusual colour of the flowers among rhododendrons, and the striking snowy white coverıng to the young leaves, gives this species a certain distinction and makes it well worth growing. It flowers from March to May. Of its several forms, some are much inferior to others;

Var. FULVUM (Bot. Mag., t. 6827) is one of the best. It leaves are reddish brown beneath, and the flower-truss larger than in the type.

\section{R. Nobleanum, Lindley.}

Soon after the first flowering of $\mathrm{R}$. arboreum, which had been introduced from the Himalaya in 1817 , a number of crosses were made with the various 
hardy species then in cultivation, especially catawbiense, ponticum, and caucasicum. Of all the plants raised, the one which has acquired the surest place in gardens is R. Nobleanum; this was raised in the Knap Hill nursery by crossing caucasicum with arboreum about 1832. It forms a small tree up to $15 \mathrm{ft}$. high, the leaves having a thin, brownish felt beneath. Flowers bright and rich rose, in trusses 4 ins. across. Soon after the New Year (still earlier in the warmer parts of the kingdom) the flowers of this hybrid commence to open, andi they continue for about two months, according to climatic conditions. Very frequently they are destroyed by frost, but usually some of them escape. If the weather be exceptionally favourable, no tree or shrub gives so brilliant a display in the first two months of the year, and for this reason a few examples are worth growing. If possible, a spot sheltered by trees from the north and east should be given them.

Var. ALBUM.-Raised in the Comely Bank nurseries, Edinburgh, by crossing arboreum album with caucasicum. Mr Fraser, the present head of this nursery, informs me that his firm still continues to raise new stock of this variety and the original Nobleanum, by re-making the original crosses.

R. PULCHERRIMUM is of an origin similar to that of Nobleanum, and was raised at the same time in the Knap Hill nursery. Its flowers are like those of Nobleanum, but paler. It exists, no doubt, in many gardens under that name.

\section{R. NUDIFLORUM, Torrey.}

(Azalea nudiflora, Linnoeus, Bot. Mag., t. I8o.)

A deciduous shrub up to $9 \mathrm{ft}$. high in its native state; young wood bristly. Leaves mostly obovate, some oblong, tapering at both ends; $1 \frac{1}{2}$ to $3 \frac{1}{2}$ ins. long, one-third to half as wide; green on both sides with a few scattered hairs above, bristly on the midrib beneath and on the margins. Flowers faintly scented, in clusters of six or more, the corolla-tube hairy, pink, $\frac{3}{4}$ in. long; the five lobes paler, expanding and giving the flower a diameter of $1 \frac{1}{2}$ to 2 ins. ; stalk $\frac{1}{3}$ to $\frac{1}{2}$ in. long, bristly like the small calyx; stamens five, maroon coloured, standing out well beyond the corolla; seed-vessels $\frac{3}{4}$ in. long, bristly.

Native of Eastern N. America ; introduced by Peter Collinson in 1734. It is one of the chief parents of the great race of garden azaleas, but is itself very rarely seen now. The flowers appear to be variable in colour, even in a wild state, although of some shade of red or pink, or purplish. Of the three north American azaleas whose flowers expand before the leaves, this differs from R. calendulaceum in the longer-tubed, differently coloured corolla, and in the bristly midrib of the leaf, and from A. canescens in the hairy, not glandular, corolla-tube.

\section{R. occidentale, A. Gray.}

\section{(Bot. Mag., t. 5005 ; Azalea occidentalis, Torrey.)}

A deciduous, rounded bush, $8 \mathrm{ft}$. or more high; young shoots slightly downy. Leaves oval or obovate, 2 to 4 ins. long, $\frac{3}{4}$ to $\mathrm{I} \frac{1}{2}$ ins. wide ; tapering at the base, often rounded at the apex; upper surface glossy green and furnished with scattered hairs; lower surface pale, rather glaucous, downy (at least when young); stalk downy, $\frac{1}{4}$ in. or less long. Flowers fragrant, white with a blotch of yellow on the upper side, $2 \frac{1}{2}$ to 3 ins. across, produced in terminal clusters of six to twelve after the leaves, during June and July. Corolla-tube $\mathrm{I}$ in. or more long, downy; stamens and style protruded, 2 to $2 \frac{1}{2}$ ins. long ; calyx-lobes edged with long hairs; flower-stalk $\frac{3}{4}$ to $I$ in. long.

Native of Western N. America; introduced by Wm. Lobb for Messrs 
Veitch about 1851. This beautiful azalea is the only species of its section found west of the Rocky Mountains. It has many points of resemblance to, and appears to be the Western representative of, $R$. arborescens, but has larger yellow-blotched flowers and its foliage is quite hairy beneath; the calyx also is shorter. It does not blossom until the great azalea season is over, or until the shrub is in almost full leaf. It is one of the best summer-flowering shrubs, although it has taken horticulturists a long time to find it out. In 1857, Lindley, then the high priest of gardening, pronounced it to be "of little value." Mr Waterer of Knap Hill, and Mr Koster of Boskoop, by crossing it with the bright-coloured azaleas that flower earlier, have laid the foundation of a beautiful race of late-flowering varieties.

\section{R. Ovatum, Planchon.}

\section{(Azalea ovata, Lindley; Bot. Mag., t. 5064.)}

An evergreen shrub of bushy habit, 2 to $4 \mathrm{ft}$., perhaps more, high ; young wood, leaf-stalks, and midrib on the upper side downy. Leaves dark green and glossy, ovate, pointed, the base tapered or rounded ; $\frac{3}{4}$ to $2 \frac{1}{4}$ ins. long, $\frac{3}{8}$ to $1 \frac{1}{4}$ ins. wide; stalk $\frac{1}{8}$ to $\frac{3}{4}$ in. long. Flowers solitary from buds near the end of the preceding year's shoots, produced about the end of May; pale purple to pink, specked with darker spots on the upper lobe of the corolla, 1 in. across, flat and open; stamens five ; calyx-lobes oblong, $\frac{3}{10}$ in. long, with glandular hairs on the margin ; flower-stalk $\frac{1}{4}$ to $\frac{1}{2}$ in. long, glandularhairy.

Native of China; introduced about 1844 by Fortune, and latterly by Wilson from Hupeh. The colour of the flowers varies from almost white to pink and purplish. Exceedingly rare in gardens. It is allied to the West American albiflorum, but that species has ten stamens. It must not be confounded with the $R$. ovatum of gardens, which is the same as R. myrtifolium - a hybrid between hirsutum and punctatum (see under punctatum).

\section{R. PACHYTRICHUM, Franchet.}

An evergreen shrub or small tree up to $20 \mathrm{ft}$. high; young shoots conspicuously furnished with a dense coat of brown, curly bristles $\frac{1}{8} \mathrm{in}$. long. Leaves 3 to 6 ins. long, I to 2 ins. wide ; narrowly oblong or inclined to obovate, abruptly narrowed at the apex to a short fine point, rounded at the base ; dark green and soon smooth above, bristly on the margins at first, and on the midrib beneath; stalk $\frac{1}{3}$ to 1 in. long, with the same mossy character as the young shoot. Flowers white or pale rose, in compact trusses, 3 to 4 ins. across ; corolla $1 \frac{1}{2}$ ins. wide, scarcely so deep, bell-shaped; stamens ten, shorter than the corolla, downy at the base ; ovary bristly ; calyx small, smooth, triangular-lobed ; flower-stalk mossy, $\frac{5}{8}$ in. long.

Native of $W$. China and Thibet; discovered by the Abbé David; introduced by Wilson for Messrs Veitch in 1903. A very distinct species allied to strigillosum, but that species has ricn red flowers and smooth stamens. According to Wilson, R. pachytrichum occurs up to ro,ooo ft. altitude, so is, no doubt, capable of withstanding great winter cold, but it appears to be spring tender.

\section{R. PARVIFOlium, Adams.}

An evergreen shrub of sparse habit and thin, wiry, erect or spreading branches, $2 \mathrm{ft}$. to $3 \mathrm{ft}$. high; young wood scurfy. Leaves slightly aromatic when crushed; $\frac{1}{2}$ to $\frac{3}{4}$ in. long, $\frac{1}{6}$ to $\frac{1}{4}$ in. wide ; narrowly oblong-obovate, dark green above, pale beneath, scaly on both sides. Flowers rosy purple, 
$\frac{1}{2}$ to $\frac{3}{4}$ in. across, borne in a small terminal cluster of four to six ; stamens ten, hairy at the base ; calyx-lobes small, angular.

Native of Siberia, Korea, etc. This species is allied to R. lapponicum, and is often supplied for it, but is distinguished by the more numerous hairy stamens. It blossoms early, from January to March according to the mildness or otherwise of the weather. It may be seen probably in finest condition in this country at the Edinburgh Botanic Garden, where I saw it some years ago on a ledge in the rock garden. The practice is to peg down the stems and cover them with soil; they then root into it, and in this way produce a much better furnished mass of branches than the plant left to itself can do.

\section{R. POLYLEPIS, Franchet.}

\section{(R. Harrovianum, Hemsley, Bot. Mag., t. 8309.)}

An evergreen shrub, 5 or $6 \mathrm{ft}$., perhaps more, high ; young branches scaly. Leaves aromatic, narrowly oval-lanceolate, $1 \frac{1}{4}$ to 3 ins. long, dark shining green and smooth above, densely scaly beneath; stalk $\frac{1}{4}$ in. long. Flowers 2 ins. across, pale purple, spotted with yellow on the upper side; stamens ten, hairy at the base, protruded beyond the corolla ; calyx-lobes very short and rounded ; flower-stalk $\frac{3}{4}$ in. long and, like the calyx and ovary, scaly.

Native of W. China ; introduced for Messrs Veitch by Wilson about 1904. It is closely allied to $R$. concinnum, being distinguished chiefly by the protruding stamens and usually wrinkled leaves.

\section{R. PONTICUM, Linncus.}

(Bot. Mag., t. 650.)

An evergreen shrub, 8 to $\mathrm{I}_{5} \mathrm{ft}$. high, twice as wide as it is high, sometimes forming a trunk I $\mathrm{ft}$. through like a small tree; branchlets soon smooth. Leaves 2 to 9 ins. long, $\frac{3}{4}$ to 3 ins. wide ; narrow oblong or oblanceolate, very dark glossy green above, paler beneath, quite smooth on both surfaces. Flowers purple, suffused more or less with pink, 2 ins. across, produced during June in terminal heads 4 to 6 ins. wide; calyx small, with five thickened, shallow lobes.

Native of Spain and Portugal, but more especially of that portion of Armenia known to the ancients as Pontus ; introduced in I763. No rhododendron has obtained so secure a footing in Britain as this, and it now shares with the cherry laurel the distinction of being the commonest of introduced evergreens. It is certainly a most useful shrub. In thin woodland it will make thick masses of evergreen undergrowth, and give a fine display of blossom annually. In thicker woods it will also live, but it is apt to become thin and ungainly, and does not flower well. The worst possible use to which it is put (and it shares the indignity with the cherry laurel), is being cropped over annually and made to form a low flat surface. But where such a low evergreen covering is desired in semi-shady spots, it is one of the best available, although it is better to use a naturally dwarf shrub like Berberis Aquifolium. It is seen at its best in open spots fully exposed to the sun, where it can take its natural form and spread in its own way, and from its habit of taking root at the branches there is scarcely a limit to its. extension. It must be said, indeed, that in spite of its great beauty the Pontic rhododendron needs occasionally the curb of a strong hand. I know more than one demesne in the south of England which is overrun with the shrub to such an extent as to have become monotonous.

Hundreds of thousands of young plants are used every year as stocks on which the garden varieties are grafted, and to this practice, no doubt, the 


\section{RHODODENDRON}

presence of great drifts of this shrub in many gardens is due. For when planted out and left unwatched the stock frequently sends up sucker-growths, and it then becomes only a matter of time before the finer bred and less assertive scion is overwhelmed.

From catawbiense, which is the only species with which it is likely to be confused, $R$. ponticum is distinguished by its long, narrow leaves, and the deeper narrow lobes of the corolla; catawbiense never grows rampant, as it does.

R. ponticum has been used to a considerablé extent by hybridisers, but the hybrids are not generally so valuable and hardy as those derived from catawbiense. One of the best is altaclerense (see under arboreum). Of its own varieties the following may be mentioned :-

Var. ALBUM.-Flowers white.

Var. CHEIRANTHIFOLIUM.-Flowers pale purple; the plant dwarf and compact ; leaves 2 or 3 ins. long, $\frac{1}{3}$ to $\frac{1}{2}$ in. wide, very wavy at the margins.

Var. LANCIFOLIUM (R. lancifolium, Moench).-A small edition of the type ; leaves 2 to 4 ins. long, $\frac{1}{2}$ to $\frac{3}{4}$ in. wide. Flowers in small trusses, almost white in the centre, suffused with purple towards the margin. The plant is dwarf and compact, rarely more than 4 or $5 \mathrm{ft}$. high. It is distinguished from cheiranthifolium by the leaves being flat, not wavy.

Var. VARIEGATUM.-Leaves smaller and narrower than in the type, edged with creamy white.

\section{R. PRZEWALSKII, Maximozvicz.}

\section{(R. kialense, Franchet.)}

An evergreen shrub of very compact, slow growth, forming a close hemispherical bush; young shoots bright yellow, smooth, stiff, and stout. Leaves oval or obovate, 2 to 4 ins. long, 1 to $1 \frac{1}{2}$ ins. wide ; tapered or rounded at the base, pointed ; dark green and smooth above, more or less scurfy, and with netted veins beneath; stalk yellow. Flowers white or pink, borne in compact rounded trusses 2 to 3 ins. across ; corolla five-lobed, about $1 \frac{1}{4}$ ins. across, broadly funnel-shaped; stamens ten, smooth-stalked or very slightly downy at the base ; ovary and style smooth; flower-stalk about $\frac{1}{2}$ in. long and, like the small inconspicuously lobed calyx, smooth.

Native of W. China ; first collected in Kansu by the Russian traveller Przewalsky, in 1880 ; introduced to cultivation by way of St Petersburg. Wilson, who found it further south in 1904 , observes that it reaches higher altitudes in W. China than any other broad-leaved rhododendron. He found it up to $14,500 \mathrm{ft}$. Its yellow buds, young shoots, and leaf-stalks combined with its dense close habit make cultivated plants very distinct, but it appears to be very shy-flowering. Some plants have the young shoots balsamic scented.

\section{R. PUnCtatum, Andrezes.}

\section{(R. minus, Nichaux.)}

An evergreen bush, 2 to $4 \mathrm{ft}$. high ; young shoots rough with scales. Leaves oval-lanceolate to narrowly obovate, tapering at both ends; $1 \frac{1}{2}$ to 3 ins. long, $\frac{1}{2}$ to $1 \frac{1}{4}$ ins. wide ; dark green and smooth above, thickly dotted beneath with minute red-brown scales; stalk $\frac{1}{4}$ to $\frac{1}{2}$ in. long. Flowers $I$ to $I \frac{1}{2}$ ins. wide, pale pinkish purple, spotted on the upper side with brownish red; corolla funnel-shaped; stamens ten, hairy at the base, protruding somewhat beyond the corolla ; calyx-lobes very short; flower-stalk scaly, $\frac{1}{2}$ to $\frac{3}{4} \mathrm{in}$. long. Blossoms in May and June.

Native of Eastern N. America ; introduced in 1786. It is a neat and 
pretty bush, but not one of the showier sorts, and is, perhaps, of chief interest now as the parent of several useful hybrids, amongst which the following are of especial interest :-

R. AR BUtifolium, Hort. (R. daphnoides).-A neat shrub, 3 or $4 \mathrm{ft}$. high, with dark dull green leaves (purplish in winter) covered beneath with glistening minute scales, amidst which are sprinkled larger darker ones. Flowers rose-coloured. The other parent is ferrugineum.

R. MYRTIFOLIUM, Loddiges (R. ovatum, Hort., not Planchon).-The other parent of this is probably hirsutum. Its leaves are not of so dark a green as those of arbutifolium, and the scales beneath are all of the large dark kind. Flowers about I in. wide, a delicate rose. It grows 4 or $5 \mathrm{ft}$. high, and is not so stiff in habit as arbutifolium. Leaves $1 \frac{1}{2}$ to 2 ins. long, $\frac{3}{4}$ in. wide.

R. WILSONI, Hort., not of Hooker.-This has longer leaves than either of the preceding ( $2 \frac{1}{2}$ ins. long, $\frac{3}{4}$ in. wide) and is of freer growth, forming a dense, leafy bush 5 or $6 \mathrm{ft}$. high. Flowers pale rose, $\mathrm{I} \frac{1}{4}$ ins. wide. A useful, neat, and pretty evergreen, probably a cross with some form of R. ponticum.

\section{${ }_{1}$ R. QUINQUEFOLIUM, Bisset.}

A deciduous shrub of low, bushy habit, probably 2 or $3 \mathrm{ft}$. high ; shoots smooth, branches erect, forked. Leaves produced in whorls of five (with sometimes one or two very small ones in addition) at the end of the shoot only; broadly obovate or somewhat diamond-shaped, rounded at the apex, except for a short, abrupt tip, tapering at the base to a very short bristly stalk; they vary in size in each set of five, the largest being $\mathrm{I} \frac{1}{2}$ to 2 ins. long by $\mathrm{I}$ in. wide, the smallest not half as large; upper surface sparsely hairy when young, the lower one hairy about the margin and along the midrib; both sides pale green, often with a purplish margin. Flowers solitary or in pairs, produced with the young leaves from the terminal bud ; corolla broadly funnel-shaped, $1 \frac{1}{2}$ ins. across, pinikish or white, the lobes ovate; calyx-lobes short, triangular ; stamens ten, hairy at the base ; flower-stalk $\mathrm{I}$ in. long, hairy.

Native of Japan; discovered by $\mathrm{Mr}$ Bisset in 1876 ; introduced about twenty years later by Lord Redesdale. This azalea is most distinct and attractive in its foliage, especially in spring when the leaves are of a tender green bordered with purple, each whorl of five forming an umbrella-like group at the top of a slender twig. It flowers in April.

\section{R. RACEMOSUM, Franchet.}

\section{(Bot. Mag., t. 7301.)}

An evergreen shrub, at least 5 or $6 \mathrm{ft}$. nigh, of tufted habit when young and small, but, when well established in good soil, sending up vigorous erect shoots, 12 ins. or more long in a year; young wood scaly. Leaves $\frac{3}{4}$ to $1 \frac{1}{2}$ ins. long, about half as wide, obovate or oval, rounded or abruptly tapering at both ends, thickly dotted beneath with brownish scales on a vividly glaucous surface. Flowers produced in April and May in axillary and terminal clusters, from three to twelve in a cluster. Corolla soft pink, i to $\mathrm{I} \frac{1}{4}$ ins. across, widely bell-shaped, the tube shorter than the five oblong rounded lobes; calyx minute, and like the flower-stalk covered with scales; stamens ten, downy at the base.

Native of W. China, first raised in the Jardin des Plantes at Paris in 1889 ; where I saw it in November and brought to Kew some seedlings. The seed had been gathered and sent to Paris by Père Delavay. It has since proved one of the most distinct and pretty of the dwarfer Chinese rhododendrons. Its most remarkable feature is the production of flowers from the leaf-axils 
along the previous year's wood. Often from 6 to more than 12 ins. of the shoot will be laden with blossom - very different from the single rounded truss which in Rhododendron is usually seen terminating the shoot. This shrub produces good seed in abundance, which affords an easy means of increase. It can also be propagated from cuttings. It is a charming plant for grouping in low shrubberies.

\section{R. RHODORA, Gmelin.}

(R. canadense, Dirpel; Rhodora canadensis, Linnous, Bot. Mag., t. 474.)

A deciduous shrub, rarely more than 3 to $4 \mathrm{ft}$. high; branches erect-growing; branchlets smooth except when quite young. Leaves narrowly oval, tapering about equally to either end ; mostly 2 to $2 \frac{1}{2}$ ins. long, $\frac{1}{2}$ to $\frac{3}{4}$ in. wide; with scattered bristles on the upper surface and margins; lower surface downy, becoming, in some plants at least, nearly or quite smooth before falling. Flowers bright rosy purple, I to $\mathrm{I} \frac{1}{2}$ ins. wide, produced in April in a cluster of about six at the end of naked twigs. The corolla has its three upper lobes united almost to the end, and erect; the two lower ones narrow-oblong, divided to the base, and spreading. Calyx green, the lobes shallow, rounded, glandular at the margins ; flower-stalks $\frac{1}{4}$ in. long, glandular; stamens ten, downy quite at the base ; anthers purple.

Native of Eastern N. America; introduced in 1767 . This is one of thebrightest and most pleasing of early-flowering shrubs, and one of the hardiest. Once considered distinct enough to occupy a separate genus (Rhodora), it has latterly been united with Rhododendron. But from all the deciduous species, the curious two-lipped corolla consisting of one broad, erect segment and two spreading narrow ones, and (from most) the ten stamens distinguish it. The twigs of the year are remarkable also in thickening gradually towards the end. Increased by seed. Often

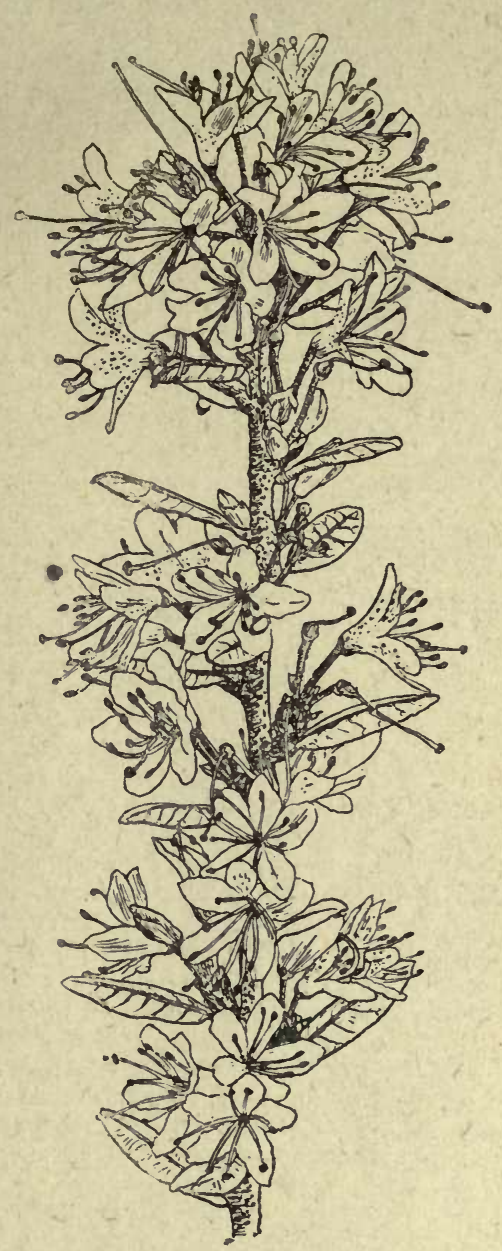

RHODODENDRON RACEMOSUM. growing in swamps in a wild state, it loves a moist position under cultivation.

\section{R. RHomicum, Miquel.}

(Bot. Mag., t. 6972 ; Azalea rhombica, O. Kuntze.)

A deciduous shrub, 4 or $5 \mathrm{ft}$. (perhaps more) high, with stiff, erect, somewhat sparse branches, covered with a loose brownish wool when young. 
Leaves diamond-shaped, I to $2 \frac{1}{2}$ ins. long, $\frac{3}{4}$ to $\mathrm{I} \frac{1}{2}$ ins. wide ; dark dull green and very hairy above when young, becoming almost or quite smooth by autumn; paler and very finely net-veined beneath; stalk $\frac{1}{6}$ to $\frac{1}{3}$ in. long, brown-woolly. Flowers solitary or in pairs, purple, almost or quite unspotted, $I \frac{1}{2}$ to 2 ins. across ; corolla-lobes oblong, $\frac{1}{2}$ in. wide, the three upper ones erect, the two lower ones more deeply divided and pointed downwards; calyx small, five-toothed, very hairy like the flower-stalk, which is about $\frac{1}{4}$ in. long ; stamens ten ; ovary and style hairy.

Native of Japan; long cultivated at Kew, but rare in gardens. It flowers

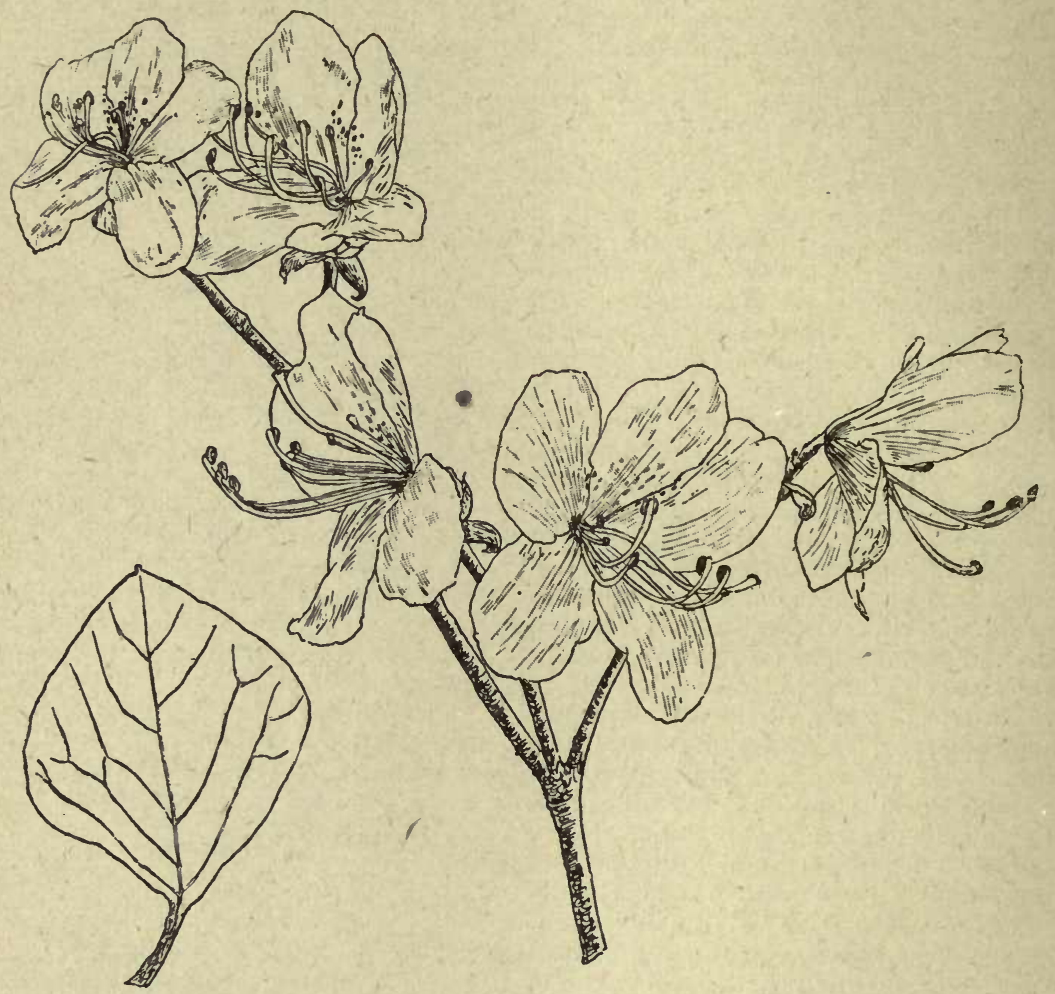

RHODODENDRON RHOMBICUM.

on the leafless twigs in late April. Although hardy, it likes a sheltered position and a sandy, peaty soil. The unusual colour of the flowers, which has a distinct suggestion of blue, gives the species a claim to more general recognition. The unfolding leaves have a purplish tinge, which they again assume before falling in autumn. Hardy enough in the adult stage, small plants are better with some protection in winter until two or three years old.

Nearly allied to R. rhombicum is R. AlbREchtil, Maximorvicz, which is also Japanese, and has the same style of flower and the same hairy ovary and style, but the corolla is hairy inside (whilst that of rhombicum is smooth), 
and its purple is spotted. So far as I know it is not yet in cultivation, although plants under the name have several times been introduced.

R. MARIESII, Hemsley (Bot. Mag., t. 8206), is another close ally. It is a native of Central China (Hupeh), whence it was introduced to Kew in 1886 by Prof. A. Henry. As it occurs below $4000 \mathrm{ft}$., it is likely to be hardy in the mildest parts of the kingdom only. The corolla has the same five deeply cut lobes, the three upper ones erect, as in rhombicum, but they are conspicuously spotted at the base, and the leaf is broadest below the middle. From Albrechtii it differs in the smooth corolla. All these three species have ten stamens.

\section{R. RIRIEI, Hemsley and Wilson.}

An evergreen shrub up to $18 \mathrm{ft}$. high; branchlets furnished with a loose white scurf when quite young. Leaves narrowly oval or broadly oblanceolate, 3 to 6 ins. long, I to 2 ins. wide ; tapered at both ends, usually more abruptly towards the apex; smooth and green above, covered beneath with a very close scurf, at first white, turning grey; midrib yellow below. Flowers (not seen in cultivation) white, 2 ins. across, in trusses of eight or more. Corolla broadly bell-shaped, five-lobed; ovary covered with pale greyish scurf; pistil smooth, nearly 2 ins. long ; flower-stalk about $\frac{2}{3}$ in. long; seed-vessel very large, $1 \frac{1}{4}$ ins. long, $\frac{2}{5}$ in. wide.

Discovered and introduced in 1904 from Mt. Omi, W. China, by Wilson. Cultivated at Coombe Wood and Kew, but very rare. From the other West Chinese rhododendrons with white scurf beneath the leaf (hypoglaucum and argyrophyllum) this is distinguished by its large seed-vessels.

\section{R. ROTUNDIFOLIUM, David.}

\section{(R. orbiculare, Decaisne.)}

An evergreen shrub up to 6 or $9 \mathrm{ft}$. high ; young shoots stout, purplish, glandular. Leaves almost orbicular, but usually somewhat longer than broad, 2 to 4 ins. long; deeply auricled at the base, rounded at the apex, with a minute tip formed by a slight prolongation and thickening of the midrib; quite smooth, dark green above, glaucous beneath; stalk $1 \frac{1}{2}$ to 2 ins. long, very stout. Flowers rosy red, ten or more forming a truss 6 ins. across; flower-stalks smooth, up to $2 \frac{1}{4}$ ins. long. Corolla 2 ins. across, widely bellshaped, seven-lobed; calyx minute, smooth ; stamens about fourteen, smooth, shorter than the corolla; ovary glandular; style smooth.

Native of Szechuen, China ; introduced for Messrs Veitch by Wilson in 1904. A very pretty and distinct rhododendron of the same type as $R$. Souliei, but that species is well distinguished by its large calyx and fewer stamens.

\section{R. RUBIGINOSUM, Franchet.}

(Bot. Mag., t. 762r.)

A stiff-habited, erect-growing evergreen shrub, 4 to $6 \mathrm{ft}$. high, branchlets becoming warty. Leaves $1 \frac{1}{2}$ to $3 \frac{1}{2}$ ins. long, $\frac{1}{2}$ to 1 in. wide; narrowly oval, tapering gradually to each end; upper surface smooth, dull green, lower one covered with reddish brown scales ; stalk $\frac{1}{4}$ to $\frac{1}{2}$ in. long. Flowers in terminal clusters of four to seven, produced in April and May. Corolla $1 \frac{1}{2}$ to 2 ins. wide, rosy lilac, spotted with maroon on the upper side, the tube funnelshaped, lobes wavy-margined; calyx shallowly five-lobed, small, warty; flower-stalk $\frac{3}{4}$ in. long; stamens downy at the base.

Native of the Tsangchan Mountain in Yunnan, S.W. China; introduced 
to Paris in 1889 by the Abbé Delavay, and thence to England. It is a somewhat stiff, dull-coloured shrub, and bears a great resemblance to the American R. punctatum, differing in its taller growth, mostly narrower more tapering leaves, and larger flowers. It is hardy under ordinary circumstances, although a few plants at Kew died through the killing of the bark at groundlevel during the trying winter of I908-9, but this only occurred in a low-lying, damp situation.

\section{R. SCHLippenbaCHII, Maximowicz.}

(Bot. Mag., t. 7373 (Azalea).)

A deciduous shrub, probably 3 to $5 \mathrm{ft}$. high; twigs bristly when young. Leaves in a terminal cluster of about five, each $2 \frac{1}{2}$ to 5 ins. long, $1 \frac{1}{2}$ to 3 ins. wide ; obovate or somewhat diamond-shaped, tapering at the base, blunt or slightly notched at the apex; smooth on both surfaces except for a few scattered bristles above and loose down beneath when young. Flowers 3 to $3 \frac{1}{2}$ ins. across, soft rose, spotted on the three upper lobes of the corolla with reddish brown, and produced in clusters of three to six. Calyx and flowerstalk very clammy, the latter about I in. long.

Native of Manchuria, Corea, etc., first discovered by Richard Oldham in 1863, and afterwards by Baron Schlippenbach; introduced by the late J. H. Veitch in 1893. It is a plant of exquisite beauty, and its fine leaves, suffused with purplish red when young, are the largest and most striking among azaleas. Unfortunately it suffers from a defect very common to Manchurian shrubs and trees: it is excited into growth by early warmth only to have its young growths destroyed by frost. I have seen this happen twice in one season, an experience no plant can long survive. So far as winter frost is concerned it is apparently quite hardy, but I consider it a hopeless subject except in warm or elevated districts, where spring frosts do little harm, or where artificial protection until May can be given.

\section{R. SERPyllifolium, Miquel.}

(Bot. Mag., t. 7503 ; Azalea serpyllifolia, A. Gray.)

A low evergreen shrub, perhaps 2 or $3 \mathrm{ft}$. high, with the slender wiry stems covered thickly with appressed, linear, dark brown bristles, that point towards the end of the shoot. Leaves narrowly oval or obovate, $\frac{1}{4}$ to $\frac{3}{4} \mathrm{in}$. long, $\frac{1}{8}$ to $\frac{1}{4}$ in. wide; dark green, and thinly furnished above and on the margins with bristly hairs, paler and with a few bristles beneath, base tapering to a very short stalk. Flowers mostly solitary at the end of short twigs, $\frac{3}{4}$ in. across, pale rose, or almost white ; corolla with five oblong lobes ; stamens five, calyx and ovary bristly.

Native of Japan. This quaint and pretty little shrub, an ally of R. indicum, is not often seen, as it is scarcely hardy in the London district. The ideal place for it would be some ledge in a rock garden in the milder localities of the south and west. It is distinguished among the "indica " group of azaleas by its tiny evergreen foliage, and thin, straggling branches.

\section{R. Setosum, Don.}

(Bot. Mag., t. 8523.)

A dwarf evergreen shrub, 6 to 12 ins. high, of close, bushy habit ; young shoots densely clothed with pale bristles and minute down. Leaves oblong, tapered at the base, rounded at the apex, $\frac{3}{8}$ to $\frac{5}{8}$ in. long, bristly on the margins, very scaly above, rather glaucous and less scaly beneath. Flowers three to eight in 
a terminal cluster; corolla I in. across, reddish purple, lobed to two-thirds of its depth; calyx comparatively large, scaly and downy, with five ovate lobes $\frac{1}{4}$ in. long ; stamens hairy at the base ; flower-stalk scaly, slender, $\frac{1}{4}$ in. long.

Native of the Himalaya up to $16,000 \mathrm{ft}$. The plant is very distinct in its bristly character and strong resinous odour. Introduced in 1825 , this curious Alpine species is now very rare. It thrives well in the Edinburgh Botanic Garden, but in the south misses its winter covering of snow, and is often excited into growth too early.

\section{R. Sheltonæ, Hemsley and Wilson.}

An evergreen shrub, 4 to $6 \mathrm{ft}$. high; young branchlets smooth, shining brown. Leaves oval or ovate, rounded at the base, abruptly tapered at the apex, and terminated by a minute tip ; $2 \frac{1}{2}$ to 4 ins. long, I to I $\frac{5}{8}$ ins. wide ; dark dull green above, pale and rather glaucous beneath, quite smooth; stalk $\frac{1}{2}$ to 1 in. long. Flowers pink, $1 \frac{3}{4}$ ins. across, in trusses of eight or more; corolla widely bell-shaped, seven-lobed; stamens twelve to fourteen, two-thirds the length of the corolla, perfectly smooth; ovary and pistil glandular; flowerstalks $\frac{1}{2}$ to $\frac{3}{4}$ in. long, glandular.

Native of W. China ; introduced by Wilson in 1904 from the neighbourhood of Tatien-lu, where he had discovered it at 8000 to $9000 \mathrm{ft}$. altitude. Young plants are thriving in a few gardens.

\section{R. SIDEROPHYLLUM, Franchet.}

An evergreen shrub, probably 4 to $6 \mathrm{ft}$. high; young wood slightly scaly. Leaves aromatic, oval-lanceolate, tapering about equally to each end; $1 \frac{1}{2}$ to $2 \frac{1}{2}$ ins. long, $\frac{3}{8}$ to $\frac{5}{8}$ in. wide ; bright green and slightly scaly above, paler and scaly beneath, the scales yellowish; stalk $\frac{1}{8}$ in. long. Flowers $1 \frac{1}{4}$ to $1 \frac{1}{2}$ ins. across, of a pale blush tint with two groups of dark brown spots on the upper side, produced during May in terminal and axillary clusters of six to eight; corolla flat, open, short-tubed; two lower lobes deeper than the upper ones; stamens ten, pinkish white, hairy at the base, anthers dark red; ovary scaly; style I $\frac{1}{4}$ ins. long, smooth : flower-stalk $\frac{3}{4}$ in. long, scaly.

Native of W. China; introduced by Wilson in 1904. It belongs to the same group as yunnanense, and its flowers are equally pretty. But the leaves are never bristly above, as they often are in yunnanense, they are more scaly beneath, the stamens are not so much protruded beyond the corolla as in that species; the flowers are smaller and earlier. It frequently produces a considerable number of flower-clusters densely packed at the end of the shoot.

\section{R. SINENSE, Sweet. \\ (Azalea sinensis, Loddiges.)}

Under R, molle $(q . v$.$) the differences between it and R. sinense are$ pointed out. The present species is confined to China, and is much less common in cultivation and perhaps not so hardy. It is a deciduous shrub, the young twigs and the under-surface of the leaves being covered with a dense velvet-like felt. Leaves up to $4 \frac{1}{2}$ ins. long and $1 \frac{1}{4}$ ins. wide, green or glaucous beneath. Flowers yellow of various shades. Fortune introduced this shrub in 1845 (it had previously been brought to England in 1824), and is very eloquent of its beauty as seen wild in China, especially on the hills about Ningpo, where, he wrote, "the yellow Azalea sinensis seemed to paint the hill sides, so large were the flowers, so vivid the colours." The true plant is now very uncommon, but hybrids between it and molle are abundant. 


\title{
R. SMIRnOwI, Trautvetter.
}

\author{
(Bot. Mag., t. 7495.)
}

A sturdy evergreen shrub, 4 to $6 \mathrm{ft}$. high in cultivation, usually wider than it is high, but described in a wild state as a tree-like shrub 15 to $20 \mathrm{ft}$. high ; young shoots thick, and clothed with a soft white felt. Leaves narrowly oblong, tapered at the base, blunt at the apex; 3 to 6 ins. long, 1 to 2 ins. wide; thick and leathery, dark green, soon becoming smooth above ; lower surface covered with a thick, soft felt, at first almost pure white, finally pale brown; stalk $\frac{1}{4}$ to $\frac{3}{4}$ in. long. Flowers bright purplish rose, 2 to 3 ins. across, produced during May in fine trusses 5 or 6 ins. through; corolla broadly funnel-shaped, the five rounded lobes with beautifully frilled margins; calyx very small, with five rounded lobes; flower-stalks I to $I_{2}^{\frac{1}{2}}$ ins. long, slightly downy.

Native of the South Caucasus, where it was discovered by Baron UngernSternberg in 1885 , and introduced to Kew the following year. The species is distinct because of the very thick white felt on the lower surface of the leaf, resembling in this respect R. Ungerni (q.v.) and $R$. niveum. It is a very hardy species, and should be given a trial where only the hardiest evergreens thrive. By hybridisation it may produce a useful race of very hardy varieties.

\section{R. SoulieI, Franchet.}

\section{(Gardeners' Chronicle, 1909, i., fig. 167 (and supplement).)}

An evergreen bush, 3 to $8 \mathrm{ft}$. high; young shoots purplish, they and flower-stalks glandular and viscid. Leaves 2 to $3 \frac{1}{2}$ ins. long, I to 2 ins. wide ; broadly ovate, with a heart-shaped base and a blunt, glandular tip; of a distinct glaucous, somewhat metallic hue, quite smooth on both surfaces; stalk glandular when young, $\frac{1}{2}$ to $\frac{3}{4}$ in. long. Flowers in a terminal cluster (about six on each) of a lovely pale shade of rose, 2 to 3 ins. in diameter; the corolla very open and saucer-shaped, five- or six-lobed; calyx about $\frac{1}{2}$ in. across, with five unequal, oblong blunt lobes, purplish green, thickly clothed outside and on the margins with dark glands; stamens eight to ten; ovary and style glandular; flower-stalks $1 \frac{1}{2}$ to 2 ins. long.

Native of W. China ; introduced by Wilson for Messrs Veitch in 1905, from near Tatien-lu, where, at altitudes of 9000 to $10,000 \mathrm{ft}$., it is found entirely covering large areas. It flowers in early and mid-May, and commences to bloom at four years old from seed. Apparently very hardy and a charming addition to cultivated rhododendrons; distinct on account of its glaucous, heart-shaped foliage and flat, saucer-shaped flowers.

\section{R. SPINULIFERUM, Franchet.}

$$
\text { (Bot. Mag., t. 8408.) }
$$

An evergreen shrub, 3 to $8 \mathrm{ft}$. high, the young shoots covered with pale hairs and bristles. Leaves lanceolate or oblanceolate, pointed at the apex, wedge-shaped at the base; $1 \frac{1}{2}$ to $2 \frac{1}{4}$ ins. long, $\frac{1}{2}$ to $\frac{3}{4}$ in. wide ; somewhat hooded and puckered above, with a few hairs near the margin, scaly and hairy beneath; stalk $\frac{1}{4}$ in. long. Flowers bright red, produced in a fewflowered cluster; corolla tubular, about $I$ in. long and $\frac{1}{2}$ in. wide, the five ovate lobes being erect or pressing inwards round the ten glabrous stamens, which protrude about $\frac{1}{4}$ in. beyond them. Calyx very short, downy; flowerstalks downy, $\frac{1}{4}$ in. long. Ovary and base of style downy. 
Native of Yunnan, China; discovered by the Abbe Delavay, and introduced to France by Mr Maurice de Vilmorin in 1907, thence to Kew in I9ro. I am afraid from what has been said to me by Mr Forrest, that this remarkable rhododendron will only be hardy in Cornwall and similar localities. In the tubular shape of the corolla, which narrows rather than expands towards the mouth, the species resembles the rare R. Keysii. It first flowered at Kew in a cold frame in the spring of I9II. It is also in $\mathrm{Mr}$ J. C. Williams' collection at Caerhays.

\section{R. STRIGILLOSUM, Franchet.}

An evergreen shrub or small tree, up to $20 \mathrm{ft}$. high, the young shoots and leaf-stalks clothed thickly with stiff, whitish, glandtipped bristles $\frac{1}{6}$ in. long, which persist partially through the first winter. Leaves narrowly oblong-lanceolate, slender-pointed, heart-shaped at the base; 3 to 6 ins. long, $\frac{3}{4}$ to $1 \frac{1}{2}$ ins. wide ; dull green and glabrous above,

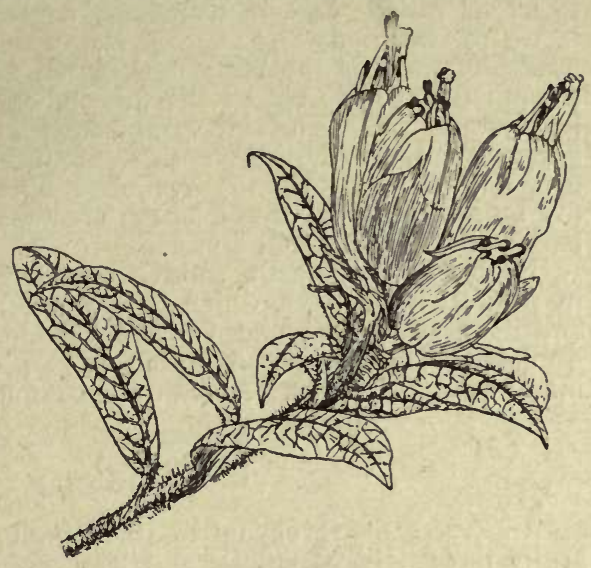

RHODODENDRON SPINULIFERUM. clothed with brown hairs beneath, especially on the midrib; stalk $\frac{1}{4}$ to $\frac{5}{8}$ in. long. Flowers rich red, bell-shaped, $1 \frac{1}{2}$ ins. long, and wide; stamens ten, perfectly smooth. Flower-stalk, calyx, and seed-pod bristly like the branchlets.

Native of W. China and Thibet ; introduced by Wilson for Messrs Veitch in 1904. A striking plant because of the bristliness of the various parts. The rich red flowers should make it welcome if it will thrive, but whilst young at least it is rather spring tender. Wilson observes that the flowers vary from crimson to pure white.

\section{R. Sublanceolatum, Miquel.}

(Bot. Mag., t. 8478.)

An evergreen azalea of the indicum group, stiffly branched, bushy, probably up to $6 \mathrm{ft}$. high, the branchlets having the dark forward-pointing bristles of this group. Leaves $\mathrm{I}$ to 3 ins. long, $\frac{1}{2}$ to $\mathrm{I} \frac{1}{2}$ ins. wide ; oblanceolate, or oval, tapered at the base, terminated by a short mucro; smooth and dark green above, paler and with dark appressed hairs like those of the stem beneath and on the margins; stalk $\frac{1}{4}$ to $\frac{1}{2}$ in. long. Flowers often three in a cluster, broadly funnel-shaped; the corolla varies in shade from purplish red to the richest blood-red; $2 \frac{1}{2}$ to 3 ins. wide, 2 ins. long; the lobes five, rounded, and about $\frac{7}{8}$ in. wide; calyx-lobes obovate, rounded at the apex, hairy on the margins, $\frac{3}{16}$ to $\frac{1}{4}$ in. long; stamens ten, nearly as long as the corolla, downy towards the base ; style smooth ; flower-stalk hairy.

Native of Japan ; introduced about 1909 by Mr Notcutt, of Woodbridge. Its best forms are some of the richest coloured of all azaleas, but it is not very hardy, and needs a slightly warmer climate than that of Kew It differs from $\mathrm{R}$. indicum in the calyx being smooth except at the margins, and in the more rounded calyx-lobes. The stamens, too, are almost invariably ten. 


\section{RHODODENDRON}

\section{R. SUTCHUENENSE, Franchet.}

(Bot. Mag., t. 8362.)

A stout, evergreen shrub, eventually $10 \mathrm{ft}$. high; young shoots very thick $\left(\frac{1}{2}\right.$ in. or rather more in diameter), covered with a greyish floss. Leaves 6 to 10 ins. long, $I_{\frac{1}{2}}$ to $2 \frac{1}{2}$ ins. wide; tapering at both ends, more gradually towards the base, dark green and smooth above, paler and also smooth beneath except on the midrib, which is slightly downy; stalk I in. long, stout, yellowish, and wrinkled. Flowers 3 ins. across, rosy lilac with purple spots on the upper side, produced in March in terminal clusters 6 or 8 ins. across. Corolla five-lobed, open bell-shaped; calyx smooth, with five broad, abruptly pointed lobes; stamens twelve to fifteen, downy near the base ; flower-stalk about I in. long.

Native of W. Hupeh, China ; introduced for Messrs Veitch by Wilson, in 1901. This species, which flowers when quite small, is one of the finest and most striking of new Chinese rhododendrons. It first flowered in the Coombe Wood nursery in March 1910, a season which renders it liable to injury by spring frosts. Allied to R. calophytum.

\section{R. TALIENSE, Franchet.}

An evergreen shrub, up to $10 \mathrm{ft}$. high; young shoots clothed with pale scurfy down. Leaves thick and leathery, oblong to oval, 2 to 4 ins. long, $\frac{3}{4}$ to $\mathrm{I}_{4} \frac{3}{4}$ ins. wide ; rounded or slightly auricled at the base, abruptly narrowed at the apex to a short fine point; dark green and smooth above, clothed beneath with a close rusty-brown felt; stalk stout, $\frac{1}{2}$ in. long, scurfy-downy. Flowers six to twelve in a truss, the corolla blush-white, about $1 \frac{1}{4}$ ins. wide and deep; stamens ten, downy at the base ; ovary smooth; calyx small, with rounded ovate lobes.

Discovered in Yunnan, China, by the Abbé Delavay; introduced by Wilson from Szechuen in 1903 .

\section{R. THOMSONI, Hooker fil.}

(Bot. Mag., t. 4997.)

An evergreen, glabrous shrub, up to $12 \mathrm{ft}$. high and more in diameter in the Cornish gardens. Leaves roundish oval, 2 to 4 ins. long, two-thirds as wide ; round at the apex except for a short, abrupt tip, and rounded or slightly heart-shaped at the base; dark green above, blue-white below; stalk about $\frac{3}{4}$ in. long. Flowers rich blood-red, 2 to 3 ins. across, produced in March in loose clusters, about six or seven together; corolla open. bell-shaped, fivelobed ; calyx unusually large, cup-shaped, $\frac{1}{2}$ to $\frac{3}{4}$ in. across, $\frac{1}{2}$ in. deep; stamens ten, and like the ovary, smooth.

Native of Nepal and Sikkim at 11,000 to $13,000 \mathrm{ft}$; introduced in 1849. It is hardy at Kew, but needs a sheltered position, and even then its flowers and young growths are very liable to injury by late frost. In the Cornish gardens it is magnificent. It is a very distinct species; the large blood-red corolla, the extraordinarily large calyx, and the vividly glaucous under-surface of the leaves furnish three characters not united in any other species. It has been used to some extent by hybridists, and among its progeny are LUSCOMBEI (with Fortunei), SHILSONI (with barbatum). HARRISII (with arboreum), and "Ascot Brilliant" (with some garden variety). Of these, Luscombei, with soft rosy blossoms 3 ins. across produced in loose trusses in April; and "Ascot Brilliant," raised by the late John Standish, with flowers 
of almost as brilliant a red as Thomsoni itself and produced early in May, are quite hardy.

\section{R. TSCHONOSKII, Maximowicz.}

\section{(Azalea Tschonoskii, O. Kuntze.)}

A semi-evergreen shrub, $2 \mathrm{ft}$. or perhaps more high, with rather horizontal branches, the young shoots covered with appressed, dark brown, linear bristles pointing towards the end of the shoot. Leaves in a tuft at the end of the twig; $\frac{1}{3}$ to $I \frac{1}{2}$ ins. long, $\frac{1}{6}$ to $\frac{5}{8}$ in. wide, oval, tapering and pointed; upper surface dull, dark green, lower one pale, both covered with bristly hairs. Flowers white, $\frac{1}{2}$ in. across, produced two to four together, each on a bristly stalk so short that the flower is almost hidden in the tuft of leaves; corolla downy inside, funnel-shaped ; stamens five ; calyx covered with bristles.

Native of Japan; introduced by Maries in 1888. This curious little . azalea is of the same group as $\mathrm{R}$. indicum, but is the most insignificant of them. It is only worth cultivating by lovers of curiosities. Propagated by cuttings.

\section{R. UNGERNI, Trautvetter.}

$$
\text { (Bot. Mag., t. 8332.) }
$$

An evergreen shrub or small tree, up to $20 \mathrm{ft}$. high in a wild state; young shoots downy. Leaves narrow oblong, 3 to 6 ins. long, one-third as wide; tapering at the base, the apex ending in a short, abrupt point ; smooth above, but covered beneath with pale brownish wool; stalk $\frac{3}{4}$ in. long. Flowers pale rose, $I \frac{1}{2}$ to 2 ins. across, produced in large trusses 6 ins. through. Corolla broadly bell-shaped, with five rounded, slightly notched lobes. Calyxlobes five, lanceolate, covered with glandular hairs; stamens ten, with gland-tipped hairs towards the base.

Native of the Caucasus ; introduced to cultivation in 1886 by way of the St Petersburg Botanic Garden, having been discovered the previous year by Baron Ungern-Sternberg. It has not yet been much cultivated out-of-doors, but is quite hardy. I have seen it growing outside in a nursery near Berlin, where the winters are much more trying to evergreens than ours. It was discovered and introduced at the same time as R. Smirnowi, with which it is often confounded. The leaves differ only in having the mucronate tip. alluded to above; the petals, however, are not frilled as in Smirnowi, the calyx-lobes are longer and more pointed, and the flower-stalks are very glandular-hairy.

\section{R. VASeyi, A. Gray.}

\section{(Bot. Mag., t. 808I ; Azal a Vaseyi, Rehder.)}

A deciduous shrub, attaining heights of 12 to $15 \mathrm{ft}$. in a wild state, bushy. Leaves linear-oval, very tapering at both ends; 2 to 4 ins. long, $\frac{1}{2}$ to $1 \frac{1}{2}$ ins. wide ; at first sparsely bristly, becoming smooth; upper surface lustrous, hairy on the midrib and at the edges; stalk $\frac{1}{4}$ in. or less long. Flowers $\mathbf{I} \frac{1}{2}$ ins. across, clear pale pink, produced before the leaves in early May, four to eight together in a terminal cluster; corolla lobes oblong, the three upper ones spotted with red-brown at the base; calyx very small, with minute lobes, and covered with glands like the flower-stalk, which is $\frac{1}{3}$ in. long ; stamens normally five, smooth ; ovary glandular.

Native of the mountains of the Carolinas; introduced to Kew in I891; first discovered in $187 \delta$ by Mr G. R. Vasey on Balsam Mountain, N. Carolina. It is remarkable that so beautiful a shrub should so long have escaped 
notice. It is quite hardy, and can readily be raised from seed, which it ripens in plenty. Remarkably distinct from all other American azaleas, it bears a certain resemblance in the contour of the corolla to tha $R$. rhombicum

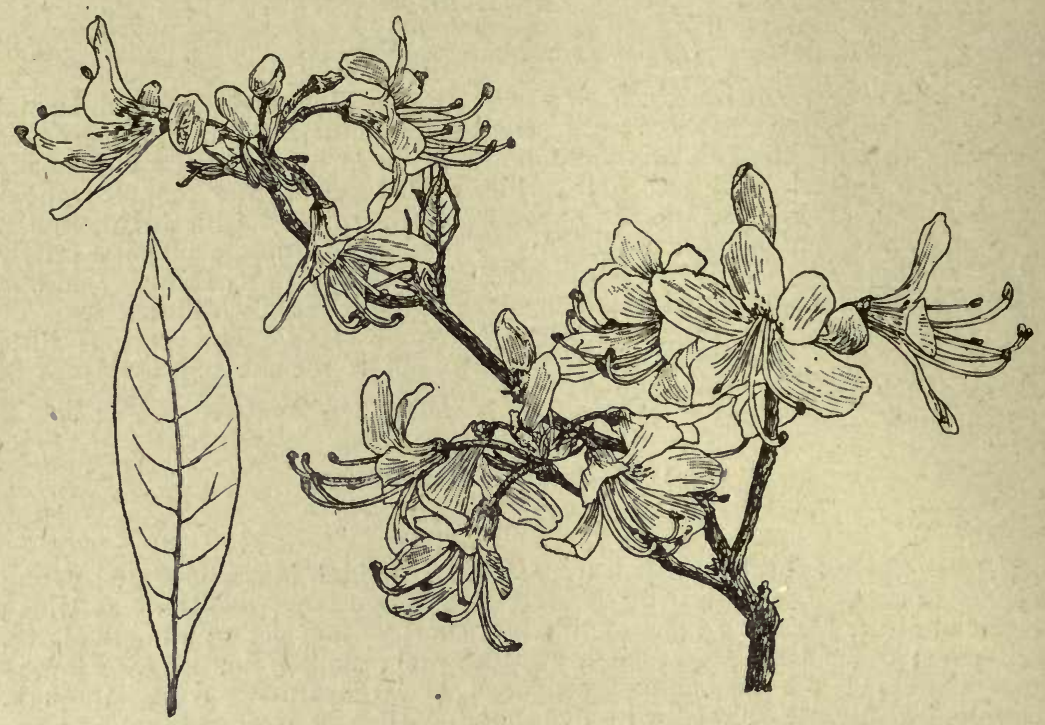

RHODODENDRON VASEYI.

(N. Asiatic) group. It is worthy of a place in any garden. Among the seedlings raised at Kew was one with pure white flowers. It has been called var. ALBUM.

\section{R. VIllosum, Hemsley and Wilson.}

An evergreen shrub, up to $18 \mathrm{ft}$. high; branchlets slender, scaly, and clothed with pale bristles $\frac{1}{8}$ in. long. Leaves scattered on the vigorous shoots, clustered at the end of weaker ones; ovate or oblong, pointed, rounded or tapered at the base; 2 to $3 \frac{1}{2}$ ins. long, $\frac{3}{4}$ to $1 \frac{1}{4}$ ins. wide; upper surface sparsely scaly, downy about the midrib, and freely sprinkled with pale, long bristles; lower surface more scaly but less bristly, and downy only on and about the midrib ; stalk $\frac{1}{8}$ to $\frac{1}{4}$ in. long, bristly. Flowers light to dark purple, $\mathrm{I} \frac{1}{2}$ to $\mathrm{I} \frac{3}{4}$ ins. across, produced in clusters of three or more. Corolla $1 \frac{3}{4}$ ins. wide, with a funnel-shaped tube and deeply five-lobed, scaly and bristly outside; calyx saucer-shaped, hidden in bristles; stamens about ten, with a tuft of hairs near but not at the base ; flower-stalk $\frac{1}{2}$ to $\frac{3}{4}$ in. long, hairy.

Introduced by Wilson in I904, from Szechuen, China. A species very distinct in the bristly character of its various parts; flowers variable in tint, the darkest purple forms rather striking.

\section{R. VIRGATUM, Hooker fil.}

(Bot. Mag., t. 5060.)

An evergreen shrub, up to $3 \mathrm{ft}$. high, with slender branches, covered when young (like the under-surface and stalk of the leaves and the flower-stalks) 
with glistening scales. Leaves $1 \frac{1}{2}$ to 3 ins. long, $\frac{1}{2}$ to $I$ in. wide; narrowly oval, tapering at both ends, dark green and smooth above; stalk $\frac{1}{8}$ to $\frac{1}{4}$ in. long. Flowers $\mathrm{I} \frac{1}{4}$ to $\mathrm{I}_{4}^{\frac{3}{4}}$ ins. across, blush-coloured, produced in April singly or in pairs from each one of several axillary buds near the apex of the twigs ; corolla with a tube $\frac{3}{4}$ in. long, and five rounded, spreading lobes ; calyx cup. shaped, with five rounded lobes; stamens ten to twelve, hairy at the base; flower-stalk very short.

Native of Sikkim and Bhotan ; introduced about 1849 , now rare in cultivation. It is perhaps not quite hardy in our average climate, but I have seen it thriving in Mr Osgood Mackenzie's garden, near Poolewe, on the coast of Ross-shire, where it flowers in June and July. It is interesting botanically, in belonging to the same group as dauricum and mucronulatum, which produce their flowers usually singly from buds crowded near the top of the shoots.

\section{R. viscosum, Torrey. Swamp Honeysuckle.}

\section{(Azalea viscosa, Linnaus.)}

A deciduous shrub of bushy habit, eventually 6 to $8 \mathrm{ft}$. high, with twiggy branches, hairy when young. Leaves thinly arranged along the shoot or in a tuft of five or six at the end; obovate, I to 2 ins. long, tapering to a short stalk at the base; dark green and smooth above, paler and bristly along the midrib beneath; margins bristly. Flowers, white or pink, produced during June and July at the end of the previous year's shoots, six to twelve together in a cluster ; corolla $I$ to $\mathbf{I} \frac{1}{4}$ ins. long, the lower half is a narrow tube often more highly coloured, the upper half five expanded oblong lobes $\frac{3}{4}$ in. long. The whole corolla, but especially the tubular part, is covered with sticky hairs. Calyx small, and like the slender flower-stalk, glandular-hairy. Seed-vessel $\frac{3}{4}$ in. long, curved, hairy.

Native of Eastern N. America ; introduced in 1734, and still one of the most delightful of garden shrubs because of its late blossoming and its exquisitely fragrant flowers. It is the reputed parent, or one of the parents of a great number of garden azaleas. Loddiges in their catalogue for 1836 gave a list of one hundred and seven varieties, which, according to Loudon, were hybrids or varieties of $R$. viscosum. The identity of many of these old varieties is lost, but some are still to be obtained under their old names. Comparatively few, however, show any viscosum "blood," but rather that of nudiflorum and calendulaceum. The viscosum group at the present time is, as a matter of fact, a rather limited one, but is well distinguished by the lateness in flowering, strong fragrance, and the viscous blossoms.

Var. GLAUCUM (Azalea glauca). - The swamp honeysuckle is variable in a wild state, more especially in the colour of the flowers and leaves. This is its most distinct variety, with pure white, fragrant flowers, and leaves bluewhite on the lower, or sometimes on both, surfaces. A very charming shrub, flowering late like the type.

\section{R. WIGHTII, Hooker fil.}

(Gardeners' Chronicle, IgII, ii., fig. I2I.)

An evergreen shrub of bushy habit, and up to ro $\mathrm{ft}$. high, with very leathery, dark green leaves, 6 to 8 ins., sometimes more, long, $2 \frac{1}{2}$ to 3 ins. wide; covered beneath with a reddish brown felt. Flowers bell-shaped, pale yellow, blotched on the upper side with crimson; about $\mathrm{I} \frac{1}{2}$ ins. across, the five lobes shallow, notched, and reflexed. Calyx-lobes five, shallow, broadly triangular, and like the flower-stalk, which is $\mathbf{I} \frac{1}{2}$ ins. long, hairy; stamens ten, 
shorter than the corolla, downy at the base; ovary clothed with a white felt ; style smooth, much longer than the stamens.

Native of the Himalaya up to $14,000 \mathrm{ft}$. ; very rare in cultivation, but existing in the open ground in Miss A. Mangles' collection at Littleworth, near Farnham, also at Kew (under glass). It is a rhododendron of great beauty and distinctness in its pale yellow flowers, which are borne as many as twenty together in rather loose heads.

\section{R. WiLson}

An evergreen shrub, up to 6 or $7 \mathrm{ft}$. high, with smooth, slender branches. Leaves narrowly oval or oval-lanceolate ; $2 \frac{1}{2}$ to $4 \frac{1}{2}$ ins. long, 1 to $1 \frac{3}{4}$ ins. wide ; narrowly tapered at the base, acuminate at the apex, smooth on both surfaces, rather glossy above, pale beneath, the texture leathery or even hardish ; stalk up to $\frac{1}{2}$ in. long. Flowers slightly fragrant, produced singly from a scaly bud in the axil of each leaf at the end of the shoot, four or six in all ; pale purple, about 2 ins. across ; corolla funnel-shaped at the base, deeply five-lobed, the upper lobe spotted with brown. Stamens ten, hairy at the base. Style and ovary glabrous, the latter long and slender. Calyx five-lobed, the lobes curiously diverse in length, some being quite short, others linear and up to $\frac{1}{2}$ in. long. Flower-stalk glabrous, $\frac{3}{4}$ to $\mathrm{I}$ in. long.

Native of Hupeh, China ; introduced by Wilson about 1903. Although the collector spoke highly of it in a wild state, it has not yet proved ornamental in cultivation.

\section{R. Wiltonir, Hemsley and Wilson.}

An evergreen shrub, 5 to $8 \mathrm{ft}$. high; young shoots clothed with a thick, brown wool. Leaves obovate, tapered at the base, abruptly narrowed at the apex to a short tip; 2 to $3 \frac{1}{2}$ ins. long, $\frac{3}{4}$ to $1 \frac{1}{4}$ ins. wide ; glossy green and deeply wrinkled above; thickly clothed beneath with brown wool; stalk about $\frac{1}{2}$ in. long. Flowers pink, borne in a cluster of six or more; corolla bell-shaped, $1 \frac{1}{4}$ ins. deep, rather more wide, the five lobes almost, erect. Stamens ten, shorter than the corolla, downy towards the base ; flower-stalk ( $\mathrm{I}$ to $\mathrm{I} \frac{1}{2}$ ins. long), and ovary covered with pale brown wool; pistil quite smooth ; calyx very small. Seed-vessel $\mathrm{I}$ in. long, $\frac{1}{5}$ in. wide.

Introduced by Wilson from W. China in 1904. Although found at 10,000 $\mathrm{ft}$. altitude, and therefore capable of withstanding great frost, it has proved so far to be liable to injury from late frosts by starting into growth early. A very distinct species on account of its shining, deeply wrinkled leaves, and the pale brown wool that covers the various younger parts.

\section{R. YANTHINUM, Franchet.}

(R. Benthamianum, Hemsley.)

An evergreen shrub, 4 to $6 \mathrm{ft}$. high, with scaly young shoots. Leaves aromatic, oval or ovate ; I to 2 ins. long, $\frac{1}{2}$ to I in. wide ; pointed, broadly tapered or rounded at the base; dark green, minutely wrinkled, and slightly scaly above, brown with scales beneath ; leaf-stalk $\frac{1}{4}$ in. or less long. Flowers four to eight in a truss, pale purple, with brown blotches on the upper side of the corolla, which is broadly bell-shaped and 2 ins. across, scaly outside. Calyx with linear-lanceolate lobes, $\frac{1}{6}$ to $\frac{1}{4} \mathrm{in}$. long, and like the flower-stalk, scaly. Stamens ten, abnut as long as the corolla, bearded with white hairs near the base ; ovary scaly; style quite smooth.

Native of Central China; introduced by Wilson in 1901. It belongs to 
a group of scaly, purple-flowered rhododendrons not yet clearly defined, but including $R$. concinnum and $R$. polylepis. The former has smaller paler flowers, and a shallowly round-lobed calyx; the latter has a similar calyx to R. concinnum, but protruding stamens, and its leaves are longer and narrower than in R. yanthinum. R. ambigum is also closely allied.

\section{R. YUNNANENSE, Franchet.}

$$
\text { (Bot. Mag., t..7614.) }
$$

A semi-evergreen or nearly deciduous shrub, ultimately 8 to io $\mathrm{ft}$. high ; stiffly and somewhat thinly branched; young wood slightly scaly. Leaves

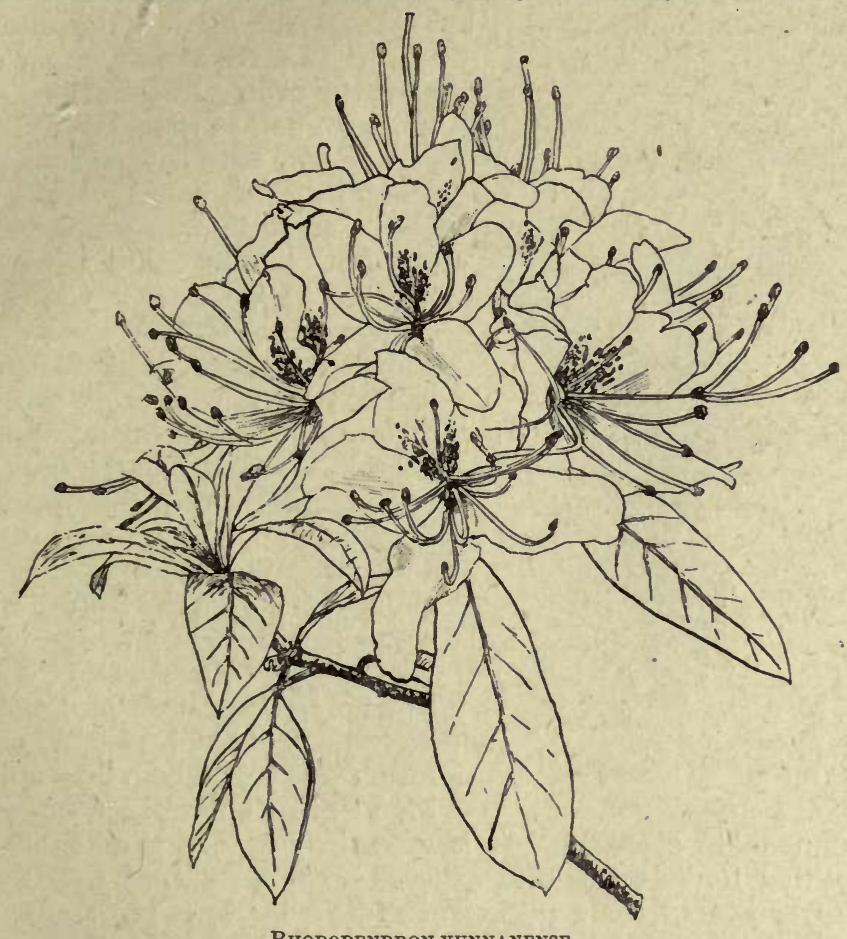

RHODODENDRON YUNNANENSE.

narrowly oval or obovate ; $1 \frac{1}{2}$ to 3 ins. long, $\frac{1}{2}$ to $\frac{3}{4}$ in. wide ; tapering at both ends, ciliate and sometimes sparsely bristly when young, bright green above, paler beneath, slightly scaly on both sides ; stalk $\frac{1}{4}$ in. or less long. Flowers produced in one or more clusters at the end of the previous year's shoots during the latter half of May, each cluster consisting of four or five flowers ; corolla $\mathrm{I}_{2} \frac{1}{2}$ to 2 ins. across, pale blush with brown crimson spots on the upper side ; lobes five, ovate and rounded, base funnel-shaped; calyx very small, almost evenly circular ; stamens ten, I to $I_{\frac{1}{2}}$ ins. long, hairy at the base, much protruded ; ovary scaly ; style smooth ; flower-stalk $\frac{3}{4}$ to I in. long.

Native of W. China ; introduced about 1889 by the Abbé Delavay to Paris, thence to England. This very charming species is quite hardy and flowers profusely almost every year, but its foliage is somewhat meagre, and 
in hard winters most of it is lost. The colour of the flowers is one of the most delicate seen in rhododendrons. Since the first plants were introduced, others, raised either from subsequently imported seeds or from cultivated plants, have appeared, which vary considerably in the tint and spotting of the corolla. It is easily increased by cuttings.

\section{RHODOTHAMNUS CHAMeCISTUS, Reichenbach. ERICACEA.}

(Rhododendron Chamæcistus, Linnaus; Bot. Mag., t. 488.)

A low or semi-prostrate evergreen shrub, rarely more than I ft. high; young shoots minutely downy, but almost hidden by the closely set

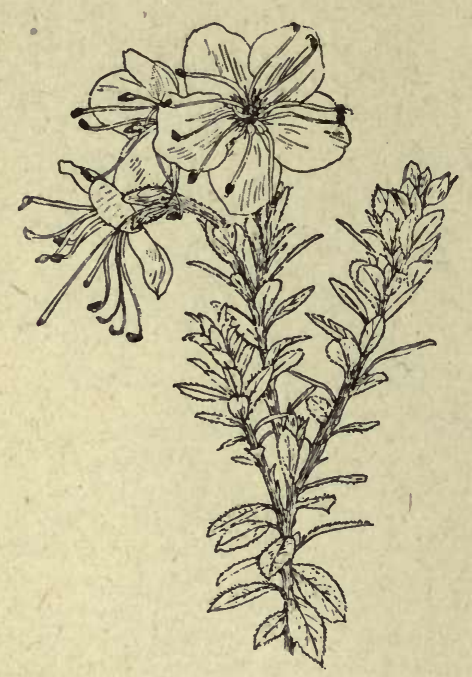

Rhodothamnus Chamacistus. leaves. Leaves almost without stalks, narrowly oval, $\frac{1}{4}$ to $\frac{1}{2}$ in. long, half or less than half as wide, tapered at both ends, edged with conspicuous bristles, otherwise smooth and glossy green on both sides. Flowers produced during April at the end of the twigs, two to four in each cluster. Corolla pale, clear rose, spreading, I to $1 \frac{1}{4}$ ins. diameter, the five lobes ovate, rounded, half as deep as the corolla; calyx $\frac{1}{2}$ in. diameter, the five lobes linear-ovate, pointed, covered like the stalk (which is $\frac{1}{2}$ in. long) with gland-tipped hairs. Stamens ten, smooth, $\frac{1}{2}$ in. long; anthers very dark purple. Seed-vessel globose, hairy, many-seeded, with the sepals persisting at the base.

Native of the Austrian Alps; introduced by the firm of Loddiges in r786. Plants ars usually imported from the Tyrol, where they are always found on a limestone formation, but prove difficult to establish. It is essentially a rock garden shrub, the best position for it being one exposed to full sunshine, but where its roots can spread in some pocket or crevice between the stones, always cool and moist. A healthy, well-established plant covers itself with blossom every spring. It is one of the most attractive of all alpine shrubs. The only successful method of propagation appears to be by separating pieces with roots attached from the older plants. Limestone is probably desirable in the neighbourhood of its roots, but not essential.

RHODOTYPOS KERRIOIDES, Siebold. ROSACE $A$.

(Bot. Mag., t. 5805.)

A deciduous shrub growing about $6 \mathrm{ft}$. high; branches erect; young shoots smooth. Leaves opposite, ovate, long-pointed; $2 \frac{1}{2}$ to 4 ins. long, 
half as much wide; upper surface dark green and soon becoming smooth, under-surface paler and hairy, prominently parallel-ribbed, the margins deeply, irregularly, and sharply toothed. Flowers solitary at the end of short twigs, $I \frac{1}{4}$ to 2 ins. across, pure white; petals four, rounded, with a short claw ; calyx four-lobed, the lobes leaflike, hairy, toothed, persisting until the fruit is ripe. Fruits about the size of small peas, shining, black, clustered above the calyx.

Native of China, and perhaps Japan; introduced in 1866. Nearly allied to Kerria, and often called "Kerria japonica alba" in gardens, this is easily distinguished by its opposite leaves, four petals, and white

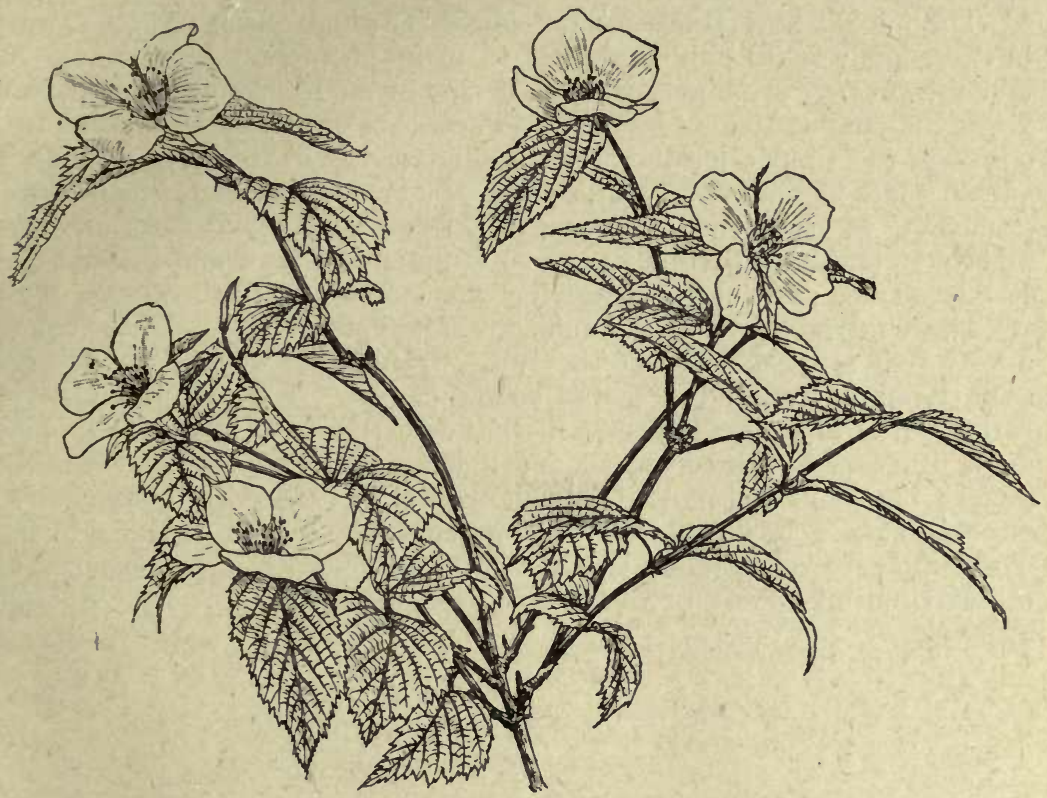

RHODOTYPOS KERRIOIDES.

flowers. It is a very hardy plant, and quite easily propagated by cuttings made of moderately soft wood and placed in brisk bottom heat. "Its flowers are at their best in May and June, but they continue to expand up to the end of July. The generic name refers to the rose-like flowers. This is the only species known.

\section{RHUS. SUMACH. ANACARDIACE:.}

A large genus of shrubs, small trees, or climbers, with simple, ternate, or pinnate leaves, found in most temperate regions of the globe, and occasionally in the tropics. About a dozen species are grown in the 
open air in the British Isles, but several others (such as R. succedanea) can be cultivated in Cornwall and similar places. Individually the flowers of the sumachs are smáll and of little beauty, being greenish, yellowish, or dull white, but in a few species the panicles are sufficiently large and the flowers white enough to give a pleasing effect. In some species the fruits a're handsome, but, on the whole, their value in gardens is in the size and autumn colouring of the foliage. The leading characters of the genus are the alternate leaves and usually diøcious flowers, the five-lobed calyx (which adheres to the fruit), the five petals, the one-celled ovary with three styles, and the usually globose fruit, either smooth or hairy, containing one bony seed.

The juice of several species, notably R. Toxicodendron and R. Vernix, is exceedingly acrid and poisonous to many people, but care should be taken in pruning or making cuttings of any of the species. $R$. vernicifera yields the famous lacquer of Japan. The leaves of R. CORIARIA, Linnieus, a species too tender for the ordinary climate of Great Britain, contain a valuable tanning and dyeing substance. Finely ground, they constitute the "sumach" of commerce. The leaves of several other species have also an economic value either for dyeing or tanning, and the fruits of some, like $R$. succedanea and vernicifera, give a wax used for candle-making.

The cultivation of all the sumachs is simple. They do not require a very rich soil except when they are grown purely for size of foliage, as R. typhina (q.v.) and R. glabra sometimes are. Where autumn colour is desired, ordinary garden soil without added manure is sufficient. Like many other trees with soft wood and a large pith, they are subject to the attacks of the "coral-spot" fungus (Nectria cinnabarina). Branches so attacked should be cleanly cut off and burnt, the wound coated with tar. The simple-leaved species (Cotinus and cotinoides) can be increased by ordinary cuttings, most of the others by root-cuttings, and seed is often available.

\section{SIMPLE LEAVES.}

Cotinus, cotinoides.

TERnate LEAVES (three leaflets).

Canadensis, Toxicodendron.

Pinnate Leaves With Winged Leaf-stalk.

Copallina (entire), Osbeckii (toothed).

PinNate LeAVES; ENTIRE LEAFLETS.

Henryi, Potaninii, trichocarpa, Vernix, vernicifera.

PINNATE LEAVES; TOOTHED LEAFLETS.

Glabra, Michauxi, typhina.

\section{R. CANAdensis, Marshall. Fragrant Sumach.}

(R. aromatica, Aiton.)

A low, spreading, deciduous shrub, 3 to $5 \mathrm{ft}$. high. Leaves aromatically fragrant when bruised, trifoliolate, with a common stalk $\frac{1}{2}$ to $\frac{3}{4}$ in. long. Leaflets not stalked, the side ones broadly ovate, the terminal one the largest, 
obovate, and $1 \frac{1}{2}$ to 3 ins. long, the side ones about half as big ; all coarsely toothed, lower surface very downy. Flowers yellowish, in dense roundish clusters $\frac{1}{2}$ to $\frac{3}{4}$ in. across, produced in April at the end of short stalks on the shoots of the preceding year. Fruits red, hairy, about the size of small red currants.

Var. TRILOBATA, A. Gray (R. trilobata).-Leaves smaller, the leaflets $\frac{1}{2}$ to $\mathbf{I}$ in. long, the terminal one often fan-shaped with a few comparatively large lobes. They are rather unpleasantly scented, and the shrub is sometimes known as "Skunk bush." Sometimes regarded as a distinct species.

The type is a native of the eastern United States; introduced in 1759, and still occasionally seen in shrubberies. It is rather pretty in spring, when its twigs are clothed with the abundant yellow flowers, and its scented foliage is handsome and distinct. Var. trilobata has a more western distribution, and is found in Texas, California, British Columbia, etc.

\section{R. COPAllina, Linnceus. DWARF Sumach.}

A deciduous shrub, rarely more than $4 \mathrm{ft}$. high in this country, but said to become a small tree 25 to $30 \mathrm{ft}$. high in the southern United States; branchlets covered with a fine reddish down. Leaves pinnate, composed of nine to fifteen (occasionally more) leaflets, the common stalk being winged on both sides between the leaflets, which are stalkless (or the basal ones shortly stalked), lanceolate, 2 to $2 \frac{1}{2}$ ins. long, rarely toothed ; dark glossy green above, paler and downy beneath, the lower leaflets the smallest. Flowers greenish yellow, unisexual, produced in crowded pyramidal panicles 4 to 6 ins. long, 3 to 4 ins. wide, the female panicle normally the smaller. Fruit bright red, hairy.

Widely spread in Eastern N. America, this species varies considerably in a wild state. The form cultivated in Britain is, no doubt, the shrubby Northern one. American writers describe it as being of singular beauty, its foliage dying off a rich reddish purple which, with the scarlet fruits of the female tree, gives a charming combination of colour. It flowers in July and August. Introduced to England and cultivated in the Fulham Palace grounds in 1688 . Distinct because of its entire leaflets and winged stalk.

\section{R. Cotinoides, Nuttall. ChitTam Wood.}

\section{(Cotinus cotinoides, Britton.)}

A deciduous shrub or small tree, as much as $30 \mathrm{ft}$. high in a wild state, its trunk I ft. or more in diameter; in this country usually under $15 \mathrm{ft}$. high, the young vigorous shoots and leaves often reddish purple. Leaves simple, obovate or oval, varying much in size according to the age and vigour of the plant, but ordinarily 2 to 5 ins. long, rather more than half as wide ; tapering to the stalk (which is $\frac{1}{2}$ to $I \frac{1}{2}$ ins. long), but broad and rounded at the apex. In the female plant the flowers are borne on a large, sparse, terminal panicle, 6 to 12 ins. long, three-fourths as wide. The larger proportion of the final ramifications of the inflorescence do not carry a flower, but are mere threadlike stalks clothed with fine hairs. Fruit $\frac{1}{8}$ in. long, very sparsely produced. The male plant has the inflorescence better set with flowers.

This remarkable species is found in a few isolated localities in Tennessee, Alabama, and other south-eastern United States, but is nowhere common. First discovered by Nuttall in 1819 , it did not reach this country until I882, when it was sent to Kew by Prof. Sargent. In the beauty of its inflorescences it is very much inferior to $R$. Cotinus, but, on the other hand, it is one of the loveliest of all shrubs in autumn, its leaves turning to various shades of 
scarlet, claret colour, and orange before they fall. Disappointment has some times been caused by the failure of this shrub to colour as described, but this is nearly always due, so far as I have seen, to over-generous conditions at the root. In order to bring out its best colour, it should not be grown in rich or manured soil, which renders the growth too rank and coarse. In a wild state it is said to be in danger of extinction; many large specimens have been cut down for the dye obtained from the wood, especially during the Civil War in N. America.

\section{R. Cotinus, Linncus. Venetian Sumach.}

\section{(Cotinus Coggyria, Scopoli.)}

A deciduous shrub, up to $12 \mathrm{ft}$. high, of round, bushy habit, and often considerably wider than it is high; the branchlets smooth. Leaves simple, smooth, orbicular or obovate, rounded or slightly notched at the apex; $1 \frac{1}{2}$ to 3 ins. long, with well-marked parallel veins and a stalk about half the length of the blade. Panicles loose, terminal, much-branched, many of the threadlike, final ramifications bearing no flower but developing a large number of silky hairs. During July the whole inflorescence (6 to 8 or more inches long and wide) turns a pale flesh colour, afterwards a smoky grey. Flowers few and small ; fruit dry, prominently veined, one-seeded, $\frac{1}{4}$ in. across.

Native of Middle and S. Europe, extending eastwards to the Himalaya. In the late summer few hardy shrubs are more striking and beautiful than this. It produces its inflorescences so abundantly that the entire plant becomes covered with a filmy pinkish envelope. The leaves remain long on the plant, and turn yellow before they fall. The wood, too, is yellowish, and a good yellow dye is obtained from the twigs. Several popular names have been given to it besides the one quoted above, such as "smoke plant," "burning bush," and "wig-tree," all in allusion to the characteristic inflorescence. This shrub, like its American ally, does not require a very rich soil, as it then grows too much and gives little flower. The two following varieties are in cultivation :-

Var. ATROPURPUREA.-Leaves, young wood, and inflorescences purple.

Var. PENDULA.-Branches drooping.

A downy form-PUBESCENS, Engler-is also known, but I have not seen it in cultivation.

\section{R. Glabra, Linnaus. Smooth Sumach.}

A deciduous shrub, usually from 4 to 6 (rarely 10) $\mathrm{ft}$. high, with smooth leaves and branches. Leaves pinnate, about 12 to 18 ins. long, composed usually of from fifteen to twenty-five leaflets, which are oblong-lanceolate, shallowly to rather deeply toothed; 2 to 4 ins. long, $\frac{1}{2}$ to $\frac{3}{4}$ in. wide, glaucous beneath. Flowers unisexual, closely packed in a dense pyramidal panicle 4 to Io ins. long, the stalks covered with red down. Fruit the size of large shot, packed like the flowers in a dense panicle, and covered with soft crimson hairs. They remain long on the plant after the leaves have fallen.

Native of the eastern United States, where in some parts it is almost a weed. It is nearly allied to R. typhina, and is very similar in its handsome fruit, but differs in the smooth young wood and leaves, and its purely shrubby habit. The foliage turns a bright, rich red. Flowers in July and August.

Var. LACINIATA.-One of the handsomest of hardy foliage plants, the leaflets being deeply cut so as to make the leaf almost or quite doubly pinnate. Its greatest beauty is obtained by cutting it hard back every spring, and thinning down the young shoots to one or two, thus obtaining broad feathery leaves $3 \mathrm{ft}$. long, very striking in their autumn colour. 


\section{R. Henryi, Diels.}

A deciduous tree, up to $15 \mathrm{ft}$. high, with a rounded head of branches ; young shoots smooth. Leaves from Io to 16 ins. long, composed of seven, nine, or eleven leaflets, which are oblong to oblong-lanceolate, obliquely rounded or broadly tapered at the base, tapered at the apex to a fine point ; $2 \frac{1}{2}$ to 5 ins. long, I to $1 \frac{3}{4}$ ins. wide; margins entire or sparsely toothed, smooth and dark green above, but with a tuft of hairs at the base of the midrib and on the short stalk. Flowers small, produced in June on terminal pyramidal panicles 3 to 7 ins. high, the main and secondary flower-stalks as well as the sepals covered with brown down; the greenish white petals are also downy outside, and about $\frac{1}{8}$ in. long. Fruit rich red, downy, about the size of peppercorns, densely packed in panicles.

Native of Szechuen in China ; discovered by Henry in 1888 . It is a handsome small tree both in its foliage and fruit, very closely allied to the Himalayan R. punjabensis, Stewart.

R. Potaninil, Maximorvicz (R. sinica, Hort.), introduced to cultivation about 1907, is probably allied to Henryi and punjabensis, but I have not seen it in flower. It is a vigorous deciduous shrub or small tree, the young shoots at first covered with a dense fine down, ultimately'smooth. Leaves Io to 18 ins. long, pinnate, composed of seven to eleven, sometimes thirteen, shortly stalked leaflets, which vary in outline from lanceolate to narrowly ovate, entire ; 2 to 5 ins. long, $\frac{3}{4}$ to $2 \frac{1}{4}$ ins. wide ; midrib, veins, and margins hairy; common leaf-stalk covered with close down like the shoots. Fruit reddish, hairy. Native of $\mathrm{N}$. China.

The true R. SINICA, Diels, lately introduced by Wilson, differs from the plant grown in gardens under that name in having the main leaf-stalk slightly winged, the leaflets stalkless, more crowded, and rounded or truncate at the base (not oblique as in R. Potaninii). Native of China; discovered in 1890 by Père Giraldi.

\section{R. MichaUxi, Sargent.}

(Garden and Forest, I895, fig. 55.)

A low, deciduous shrub, up to $3 \frac{1}{2} \mathrm{ft}$. high, spreading by means of underground suckers; stems erect and rather stout, covered with short hairs. Leaves pinnate, 8 to 12 ins. long, dull green; leaflets usually eleven, ovate or oblong, I $\frac{1}{2}$ to 3 ins. long, rounded and slightly oblique at the base, the terminal one the largest, with a winged stalk, the upper surface hairy, the lower one covered with a dense, yellowish down, the margins coarsely toothed. Panicle erect, terminal, hairy, 6 to 8 ins. high, half as much wide ; flowers $\frac{1}{8}$ in. wide, densely arranged, petals yellow; calyx covered with grey down. Fruit nearly round, $\frac{1}{8}$ in. diameter, scarlet, very downy.

Native of N. Carolina ; first discovered by Michaux towards the end of the eighteenth century. For about one hundred years it was lost sight of, but was again discovered and re-introduced to cultivation. It was sent to Kew in 1901 from the Biltmore Arboretum, U.S.A., and flowered the same year. According to some authorities it is very poisonous, perhaps the most poisonous of American sumachs, but I have spoken with Americans who regard it as harmless.

\section{R. OsBEckII, Steudel.}

\section{(R. semialata var. Osbeckii, De Candolle.)}

A small deciduous tree, sometimes $20 \mathrm{ft}$. or more high, with a short trunk and a rounded gauntly-branched head; branchlets yellowish, smooth; winter 
buds brown, velvety. Leaves pinnate, varying in size according to the vigour of the plant, ordinarily from 8 to 15 ins. long, and composed of seven to thirteen leaflets, between each pair of which the common leaf-stalk is winged. Leaflets stalkless, oval, usually $2 \frac{1}{2}$ to 4 (occasionally 6) ins. long, and about half as wide; pointed, the margins conspicuously round- or sharply toothed. the under-surface covered with velvety down. Flowers in a large, terminal panicle 8 or 10 ins. long and wide, yellowish white, produced in August. Fruit small, orange-coloured.

Native of China and Japan. This handsome tree is well-marked by its winged leaf-stalks, the only other hardy species so distinguished being the

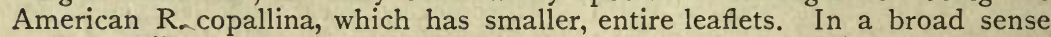
$\mathrm{R}$. Osbeckii may be regarded as the hardiest form of $\mathrm{R}$. semialata, a species widely spread in N. Asia. As a flowering plant it is one of the handsomest of the sumachs, although it does not bloom so freely here as on the Continent. It may be cut down annually like R. glabra var. laciniata (q.v.). In some places, as at Monreith with Sir H. Maxwell, it colours brilliantly in autumn.

\section{R. Toxicodendron, Linnaus. Poison Ivy.}

A deciduous shrub, either climbing or loosely spreading in habit, the climbing form attaching itself to rocks, walls, trunks of trees, etc., by means of aerial roots like those of the ivy, and frequently reaching to a considerable height; the bushy form up to 8 or $9 \mathrm{ft}$. high. Leaves always composed of three leaflets, the side ones very shortly stalked, the end one with a stalk $\frac{1}{2}$ to $I \frac{1}{4}$ ins. long, the common leaf-stalk 2 to 4 ins. long. Leaflets very variable in size, shape, and toothing, broadly ovate to obovate, pointed, sometimes quite entire, often coarsely and irregularly notched at the margin, and either smooth or slightly downy beneath. The terminal leaflet is always the largest, and from 2 to 5 ins. long, the lateral ones about two-thirds as large. Flowers dull white, $\frac{1}{6}$ in. across, on slender panicles $1 \frac{1}{2}$ to $2 \frac{1}{2}$ ins. long, often unisexual, the sexes sometimes separated. Fruit a round, whitish berry, $\frac{1}{4}$ in. wide, smooth.

Var. RADICANS, Torrey (R. radicans, Linnceus, Bot. Mag., t. 1806).-This is the climbing form above mentioned.

The poison ivy is very abundant in the eastern United States, and a climbing form with bristly fruits and young stems is found in Japan. As a garden plant its chief value is in the beautiful red tints of its autumn foliage. It was cultivated by Compton, Bishop of London, at Fulham, in the seventeenth century. The poisonous effects of the sap-a yellowish milk-like fluid which soon turns black on exposure-have long been known. As long ago as 1623 , the author of the Historye of the Bermudaes referred to them. On the skin of many persons, but far from all, the sap produces blisters and eczema-like eruptions, which are exceedingly painful and persistent. The supposed active principle, "toxicodendrol," is insoluble in water, and it is of no use to attempt to remove it from the skin by ordinary washing. The best-known remedy to apply is an alcoholic solution of sugar of lead (lead acetate), and the sooner it is used on the affected parts the more effective it is. So serious are the effects of the Rhus poison on some people that the plant should never be grown where its toxic properties are not clearly made known. Cases of permanent disablement have been caused by it in. Western N. America, where a smoother, thicker-leaved form (var. RYDBERGII) appears to be excessively virulent ; but even in England I know of a man who had been making cuttings of it for propagation, who was kept in hospital for several months through the almost corrosive effects of the sap. It is said that the symptoms are sometimes recurrent, and that on some persons the eruptions break out annually at the same time of year, but with decreasing virulency. This plienomenon, extraordinary if true, does not 
appear to have been conclusively established, although the testimony of patients is on record who aver that they have had second and third attacks, although they have never been near the plant after the first. In my experience mere contiguity to the plant without touching it will not induce skin poisoning, although when in flower the escaping pollen appears to have evil effects, especially on the eyes, in N. America.

There is one other property of this remarkable plant to which attention may be drawn. This is the indelibility of its juice when applied to linen. It produces a quite ineradicable stain, and is, in fact, one of the best possible marking inks available.

A popular confusion exists between this plant and the harmless creeper (Vitis inconstans or Ampelopsis Veitchii) so much used for covering the walls of houses. The vine is easily distinguished by its mostly simple leaves, and by its tendrils, neither of which the Rhus possesses (it is always trifoliolate). The confusion has been increased by the Rhus being grown in nurseries and gardens under the wrong and misleading names of "Ampelopsis Hoggii" and "A. japonica."

The climbing form from Japan, mentioned above as having bristly fruits, has lately been distinguished as a species, R. ORIENTALIS, $C$. K. Schneider.

\section{R. TRICHOCARPA, Miquel.}

A deciduous tree of slender habit, 20 to $25 \mathrm{ft}$. high. Leaves from 12 to 20 ins. long, carrying thirteen to seventeen leaflets, which are broadly ovate, entire, $1 \frac{1}{2}$ to $2 \frac{1}{2}$ ins. long, largest towards the apex of the leaf, very downy on both sides. Flowers in slender, downy, long-stalked panicles, inconspicuous. Fruits described as "large, pale, prickly drupes, ripening in August and September," and produced in pendulous clusters (Sargent).

Native of Japan, common in the forests of Yezo, and on the mountains of the main islands ; introduced to the United States by Prof. Sargent about I 892, and thence to Kew a few years later. It has proved hardy, and flowers in June. No hardy tree or shrub is more beautiful in its autumn colouring than this, the leaves turning a deep orange-scarlet.

\section{R. TYPhina, Linneus. Stag'S-horn Sumach.}

\section{(R. hirta, Sudworth.)}

A deciduous, small tree of gaunt, flat-topped habit, occasionally 25 or more feet high ; branchlets thick, very pithy, yielding when cut a copious, yellowish white, thick juice, soon turning black and hard on exposure; all the youns bark is covered with short, dense, reddish hairs. Leaves pinnate, I to $2 \mathrm{ft}$. long, consisting of from about thirteen to twice as many leaflets, which are oblong-lanceolate, 2 to $4 \frac{1}{2}$ ins. long, $\frac{1}{2}$ to $I$ in. wide; long-pointed, toothed, covered with brownish hairs when young, nearly or quite smooth by autumn (the stalk remaining downy). Female flowers crowded in a dense, pyramidal, very hairy panicle 4 to 8 ins. long; male flowers (which are borne on separate plants) greenish, and on a bigger, more open panicle. Fruits closely packed in dense panicles, and covered thickly with crimson hairs.

Native of Eastern N. America, and cultivated in England since the reign of James I. The female plant is one of the handsomest of sumachs, for, added to its finely coloured fruit clusters, its leaves acquire in autumn rich shades of orange, red, and purple. The male plant, which colours its leaves too, is sometimes known as " $\mathrm{R}$. viridiflora." This tree succeeds remarkably well in some of the murkiest of London suburbs. It is sometimes used as a finefoliaged summer shrub, grown in a group, and cut back every spring almost to 
the ground, the young shoots being afterwards reduced to one or two. Given liberal treatment at the root, erect stems 5 or $6 \mathrm{ft}$. high with leaves up to $3 \mathrm{ft}$. long will be produced, the leaflets correspondingly large.

Var. LACINIATA. - Leaflets very handsomely cut.

\section{R. vernicifera, De Candolle. LACQuer Tree.}

A deciduous tree, up to $60 \mathrm{ft}$. high in China, of erect, slender habit when young. Leaves pinnate, $\mathbf{I}$ to $2 \mathrm{ft}$. long, with seven to thirteen leaflets which are broadly ovate, the largest 6 or 7 ins. long, half as much wide, sometimes obliquely heart-shaped at the base, shortly stalked, velvety downy beneath, especially on the veins. Flowers yellowish white, small and inconspicuous, produced during July in a cluster of lax, branching panicles from the leaf-axils near the end of the shoots, the largest panicles Io ins. long by 6 ins. wide. Fruits about the size of small peas, yellowish.

Native of Central and W. China, and cultivated there largely; it is also much cultivated in Japan, but is not, perhaps, a true native. This is the tree which yields by incision the farnous varnish or lacquer of Japan. As a tree for the garden it is desirable for its noble foliage. The fruits also are ornamental, as I have seen them in Mr de Vilmorin's garden at Les Barres, in long lax panicles; but they may not be so freely produced in this less sunny climate. Mr Wilson has recently collected seeds in China from trees growing truly wild on the mountains, and the plants that have been raised from them will, he believes, be hardier than the Japanese trees which previously were the only representatives of the species in gardens; they grow much faster at any rate. An oil is expressed from the fruit, which is used for candle-making.

\section{R. Vernix, Linncus. Poison Sumach.}

\section{(R. venenata, De Candolle.)}

A small deciduous tree, up to $20 \mathrm{ft}$. high, with a trunk $\mathrm{I} 5$ to $\mathrm{I} \delta$ ins. thick, usually much smaller in England, and often breaking near the ground into two or three stems; branchlets smooth and grey. Leaves pinnate, with purplish stalks, quite smooth except when young; leaflets nine to eleven, 2 to 4 ins. long, one-third as much wide, ovate or obovate, entire. Flowers $\frac{1}{8}$ in. across, greenish yellow, produced on thin, slender panicles 4 to 6 ins. long from the leaf-axils of the current season:s growth. Fruit the size of a peppercorn, yellowish white, and hanging in a cluster of graceful panicles from near the end of the branchlets. Plants unisexual.

Native of the eastern United States; cultivated in England since early in the eighteenth century. None of the sumachs is more beautiful than this in its autumn tints, the foliage putting on brilliant shades of orange and scarlet before it falls. Yet it is not much grown in this country, and perhaps wisely so, for it is one of the most dangerous hardy trees in cultivation, owing to the toxic properties of its sap-even, it is said, of its exhalations! The latter may be doubtful ; but all that has been said as to the need of care in dealing with $\mathrm{R}$. Toxicodendron applies with equal, if not greater, force to this species. It appears with both that persons in a state of perspiration are most susceptible to their effects. It flowers in July, and the fruit often remains throughout the winter.

\section{RIBES. CURRANTS AND GOOSEbERRIES. SAXIFraGACEA.}

Important as this genus is in comprising the gooseberries, the black, red, and white currants of our fruit gardens, it does not, in the ornamental 


\section{RIBES}

garden, possess anything like the importance suggested by the number of its species at present in cultivation. It is composed of two well-marked groups: the gooseberries, sometimes regarded as a distinct genus called GROSSUlaria; and the currants, which may be termed the true RiBEs. These two groups are roughly distinguished by the former having spines (often triple spines) at the joints, and articulated flower-stalks; the latter by having no spines at the joints, and flower-stalks not articulated. In the following descriptions the words "armed" or "unarmed" will usually indicate to which group each species belongs; but there are species of an intermediate character, such as Diacantha, lacustre, and inebrians, which are spiny but belong in other respects to the currants.

They are all shrubs, a few of them evergreen, with usually three- or five-lobed, alternate leaves. Flowers occasionally highly coloured and red or yellow, sometimes white, oftenest green or greenish. In the gooseberries the flowers are usually few in the raceme or even solitary, but in the currants they are always in racemes, usually numerous. The fruit is a berry full of pulp in which the seeds are embedded, and is always terminated by the shrivelled remains of the flower.

The Ribes present no difficulty in cultivation; they like a loamy soil of at least average quality, and the West N. American gooseberries need as sunny a spot as possible. They are propagated by seed or by cuttings. The latter will frequently form roots when made of leafless shoots in November and placed in the open air-as common gooseberries are-but they are more certain if placed under a handlight. A second method, better adapted to the currants, is to make cuttings of leafy shoots in July and August and place them in gentle bottom heat, but most of them will strike root also in the open ground, of course much more slowly. For cultivators desirous of growing only the most ornamental, the following half a dozen may be recommended:-alpinum, cruentum (or amictum), aureum, cereum, sanguineum (especially var. splendens), and speciosum.

\section{R. Alpinum, Linncus. Alpine Currant.}

A deciduous, unarmed shrub, reaching in gardens 6 to $9 \mathrm{ft}$. in height and as much or more in diameter, of dense, close habit; young twigs shining, and at first more or less glandular. Leaves broadly ovate or roundish, threesometimes five-lobed, the lobes coarsely toothed; the base straight or heartshaped, with five radiating veins; upper surface with scattered bristly hairs, the lower one usually shining and more or less hairy on the veins ; $\frac{1}{2}$ to $1 \frac{1}{2}$ ins. long and wide; stalk glandular-downy, $\frac{1}{4}$ to $\frac{1}{2}$ in. long. Flowers unisexual, the sexes nearly always on separate plants, produced in the axils of bracts longer than the flower-stalk, greenish yellow; the males on small, erect, glandular racemes 1 to $1 \frac{1}{2}$ ins. long, the females fewer, and on racemes half as long. Currants red, not palatable.

Native of northern latitudes of the Old World, including England and Scotland. It is abundant in woods near Fountains Abbey, in Yorkshire. The largest specimens I know of form part of the old hedge on the east front terrace of the old hall at Troutbeck; according to a letter at Kew they are tree-like, I5 ft. high, and not less than three hundred years old. Although this currant has no special beauty of flower or fruit it makes a very neat and pleasing shrub, admirable for shady places. Occasionally plants with perfect flowers may be found. 
Var. AUREUM.-Leaves bright yellow when young. type.

Var. LACINIATUM.--Leaves more deeply lobed and toothed than in the

Var. PUMiLuM, Lindley.-A dwarf variety with smaller leaves, 2 to $3 \mathrm{ft}$. high, but more in diameter; a very neat bush. There is a yellow-leaved form of this (PUMILUM AUREUM).

The so-called var. "sterile" appears to be merely the normal maleflowered plant. None of the forms of R. alpinum need a rich soil. They retain the neat, compact habit which is their greatest merit, in rather poor soil. The yellow-leaved forms colour best in full sun.

\section{R. americanum, Miller. American Black Currant.}

\section{(R. floridum, L'Heritier.)}

This shrub is unarmed, and closely allied to the common black currant, which it resembles in having three- or five-lobed leaves with a coarse, irregular toothing and a deeply heart-shaped base, and in possessing the same heavy odour, due to yellowish glands on the lower surface. The fruit also is black. The American species, however, is quite distinct in the flowers; these are nearly twice as long, more tapering and funnel-shaped, and yellow. Moreover, the bract from the axil of which each flower springs on the raceme is longer than the stalk. (In R. nigrum it is small and much shorter than the flower-stalk.)

Native of Eastern N. America from New Brunswick to Virginia, Kentucky, etc. ; introduced in 1729 . As a garden shrub the only quality which recommends this currant is that its foliage becomes suffused with brilliant hues of crimson and yellow in autumn. For this quality it is sold in nurseries, often as R. missouriense-wrongly, for the true plant of that name is a gooseberry with spiny branches (see under R. Grossularia).

\section{R. Amictum, Greene. Amice Gooseberry.}

A deciduous armed shrub, 3 to $6 \mathrm{ft}$. high; young shoots downy. Leaves $\frac{1}{2}$ to $I$ in. wide, roundish or kidney-shaped in general outline, three- or five-lobed, the lobes with often sharp teeth; more or less downy on both surfaces, especially beneath; stalk $\frac{1}{3}$ in. long, usually downy and sometimes glandular-hairy. Flowers solitary or in pairs on a short downy, often glandular stalk, pendent. Calyx purplish crimson, downy; the tube cylindrical, $\frac{1}{4}$ in. long; the sepals $\frac{1}{3}$ in. long; petals rosy white, erect, shorter than the sepals. Berry purple, $\frac{1}{2}$ in. wide, covered with slender prickles.

Native of California. This pretty and curious gooseberry is not common in cultivation; the plant that has been distributed for it from nurseries being as a rule either $\mathrm{R}$. Lobbii or R. Menziesii. Its nearest ally is R. cruentum (q.v.). The specific name refers to the shape of the bract surrounding the base of each flower, which resembles the amict, or hood, worn by Roman Catholic clergy at mass.

\section{R. aureum, Pursh. Buffalo Currant.}

(Bot. Reg., t. I25 ; R. fragrans, Loddiges, Bot. Cat., t. I533.)

A deciduous, lax-habited, spineless shrub, 6 to $8 \mathrm{ft}$. high, producing a crowded mass of stems which branch and arch outwards at the top; young shoots minutely downy. Leaves usually three-lobed, often broadly wedgeshaped or palmate, the lobes coarsely toothed; $\frac{3}{4}$ to 2 ins. long, as much or 
more wide; pale green on both sides, and smooth, or soon becoming so; stalks smooth or downy, $\frac{1}{2}$ to 2 ins. long, very variable in length compared with the blade. Flowers spicily fragrant, bright golden yellow, appearing in April in semi-pendulous racemes 1 to 2 ins. long, each flower with a tubular calyx $\frac{1}{2}$ in. long, the spreading lobes $\frac{1}{4}$ to $\frac{3}{8} \mathrm{in}$. long; bract at the base of the flower-stalk longer than the latter is. Fruit black-purple, round, smooth, $\frac{1}{3}$ in. diameter.

Native of the central United States; introduced in 1812 . This species and $R$. sanguineum are by far the most attractive of the currants in their blossom, and it is very distinct among them in its long, tubular, yellow calyx. Of several forms the best is

Var. AURANTIACUM, with fragrant flowers of a deeper, more orange shade than usual, and a more compact habit.

Var. TENUIFLORUM (R. tenuiflorum, Lindley, Bot. Reg., 1274), differs from the type in having smaller flowers without fragrance, and in the fruits being amber coloured and translucent, with an acid flavour. It is also a taller shrub, up to $12 \mathrm{ft}$. high. According to Dr Coville this is the true R. aureum of Pursh.

\section{R. BRACTEOSum, Douglas.}

\section{(Bot. Mag., t. 7419.)}

An unarmed, deciduous shrub, 6 to $8 \mathrm{ft}$. high; young shoots smooth, except for a little loose down at first. Leaves handsomely five- or seven-lobed, 3 to 7 ins. (sometimes more) wide ; the lobes palmate, reaching half or more than half way to the midrib, sharply and irregularly toothed; dotted with resin-glands beneath; bright green and soon quite smooth above; stalk slender, often longer than the blade, smooth except for a few bristles at the base. Racemes produced in May, erect, slender, up to 8 ins. long. Flowers numerous, greenish yellow, erect, $\frac{1}{3}$ in. across, each on a slender, slightly downy stalk about $\frac{1}{4}$ in. long. Currants erect, resin-dotted, globose, $\frac{1}{3}$ in. diameter, black with a blue-white bloom.

Native of Western N. America; discovered by Douglas in 1826. An interesting species of the black currant (nigrum) group, very distinct in its large maple-like leaves (occasionally Io ins. across) and long, slender, erect racemes. Rarely seen, but quite hardy at Kew.

\section{R. CEREum, Douglas.}

(Bot. Mag., t. 3008.)

A grey, deciduous, unarmed shrub, 3 to $6 \mathrm{ft}$. high, of rounded, compact habit; young shoots downy and glandular. Leaves roundish or rather broader than long, three- or five-lobed, the lobes irregularly round-toothed, the base straight or heart-shaped, $\frac{1}{2}$ to $\mathrm{I}_{4}^{\frac{1}{4}}$ ins. wide ; upper surface sown with white, resinous glands and slightly downy, lower one downy on the veins; stalk downy, glandular, nearly as long as the blade. Flowers tubular, $\frac{1}{3}$ to $\frac{1}{2}$ in. long, clustered two to five together at the end of a short, downy, glandular stalk, the individual flower almost stalkless, downy, white tinged with rose, produced in the axil of a comparatively large, toothed, glandulardowny, wedge-shaped bract. Fruit bright red, $\frac{1}{4}$ in. diameter. Style downy.

Native of Western N. America ; introduced in 1827 by David Douglas. It is a very pleasing shrub, conspicuous in the pale grey tint of its young leaves, and pretty in the delicate colouring of its abundant blooms. These appear with the young leaves in April.

R. INEBRIANS, Lindley (Bot. Reg., t. I47I).-Very similar to the above, and equally pleasing, this differs in having the bract at the base of each 
flower not toothed and pointed, the style smooth, and the flowers deeper in colour. Introduced from Western N. America in 1827 . R. SPAthianum,

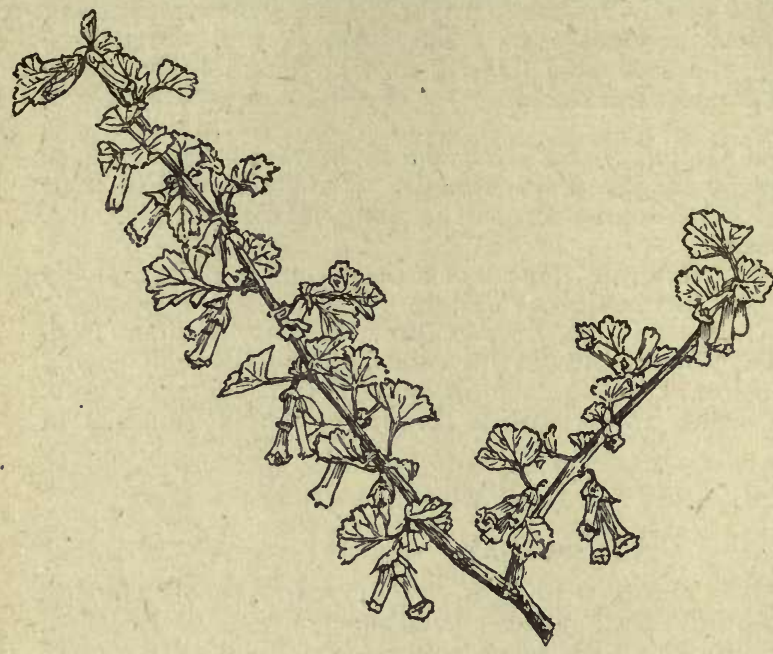

RIBES CEREUM. Koehne, is the same or a slight form.

R. cereum and $R$. inebrians are distinct in the arrangement of their leaves, each one of which has the eighth one above it directly superposed; the intermediate ones being set round ihe stem in a spiral of three circuits.

\section{R. CRUENTUM, Greene.}

(Bot. Mag., t. 8105.)

A deciduous, spiny shrub, 3 to $6 \mathrm{ft}$. high, more in diameter; young shoots minutely downy. Leaves round. ish, $\frac{3}{4}$ to $I \frac{1}{2}$ ins. wide, three- or five-lobed, the lobes coarsely round-toothed; nearly or quite smooth on both surfaces; stalk minutely downy, slender, $\frac{1}{4}$ to $\frac{1}{2}$ in. long. Flowers $\frac{3}{4}$ in. wide, solitary, rarely in pairs, on a slender stalk $\frac{1}{3}$ in. long, pendent. Calyx $\frac{1}{2}$ in. long, crimson, the tube narrowly bell-shaped, smooth; the five sepals lanceolate, finally reflexed. Petals white, much shorter than the sepals; ovary covered with incipient spines. Berry red, $\frac{2}{3}$ in. across, with a hedgehoglike appearance due to its covering of numerous spines, each $\frac{1}{6}$ to $\frac{1}{4} \mathrm{in}$. long.

Native of California ; introduced in 1899 . This interesting and remarkable gooseberry has flowers extremely pretty in their contrast of crimson and

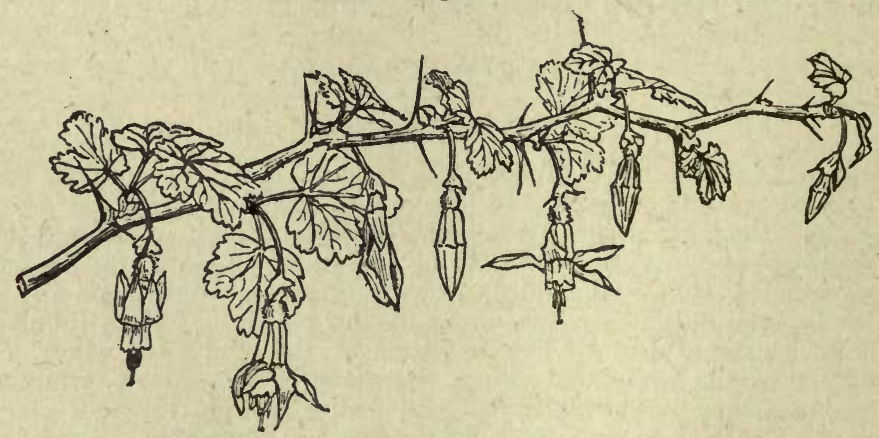

RiBes CRUENTUM.

white, but they are not particularly abundant, usually one at each joint of the previous year's wood. The berries are remarkable in their prickliness. It is closely allied to, and perhaps only a variety of $R$. amictum, but that species is distinctly downy on leaf and calyx. Effective grown as a standard. 


\section{R. CURvatum, Small.}

A low, deciduous, bushy shrub, less than $3 \mathrm{ft}$. high ; the shoots smooth, purplish, armed with slender, simple or triple spines. Leaves roundish, usually I in. or less in diameter, three- to five-lobed, toothed, slightly downy; stalk slender, downy. Flowers produced singly or in pairs (rarely more) on pendent stalks, white; calyx bell-shaped with linear, much reflexed sepals $\frac{1}{4}$ in. long; petals very short, white ; ovary covered with resinous glands; stamens $\frac{1}{4}$ in. long, erect, both they and the style downy. Fruits globose, smooth, $\frac{1}{3}$ in. across, purplish.

Native of the south-eastern United States, apparently hardy. I brought plants from the Arnold Arboretum to Kew in July I9ro, which, so far as I am aware, were the first introduced to this country. It is closely allied to $R$. niveum, which it resembles in its white flowers and downy style and stamens, but the glandular ovary and often glabrous anthers are different. $\mathrm{R}$. curvatum is also much dwarfer in habit, and comes from the opposite side of N. America.

\section{R. Diacantha, Pallas.}

A deciduous shrub, 4 to $6 \mathrm{ft}$. high, armed w:th spines in pairs $\frac{1}{8}$ to $\frac{1}{5} \mathrm{in}$. long, or sometimes unarmed; young shoots not downy. Leaves obovate or rounded, often three-lobed, the lobes coarsely toothed; 3 to 2 ins. wide, the base ordinarily wedge-shaped but sometimes rounded, quite smooth; stalk $\frac{1}{4}$ to $\frac{5}{8}$ in. long, more or less furnished with bristles. Flowers unisexual, the sexes on different plants. Males yellowish, in erect glandular racemes. Fruit roundish oval, about as big as a red currant, smooth, scarlet-red.

Native of Siberia, Manchuria, etc. ; introduced in I78I. This shrub, which has no particular merit, resembles R. alpinum in the plants being one-sexed, but differs in having prickles, and in the markedly wedge-shaped leaves. In having spines, and flowers in racemes, it unites the characters of the currants and gooseberries, but its affinities are with the former.

\section{R. Fasciculatum, Siebold.}

\section{(Sargent's Trees and Shrubs, t. 38.)}

A deciduous, unarmed shrub, 3 to $5 \mathrm{ft}$. high ; young shoots finely downy. Leaves three- to five-lobed, the largest 2 ins. long, $2 \frac{1}{2}$ to 3 ins. wide; the lobes coarsely toothed, usually more or less downy; stalk downy and with feathered bristles near the base. Flowers unisexual, the sexes on separate plants. Males clustered four to nine together in a stalkless umbel, i.e., each flower is on its own stalk without uniting on a common one ; yellow, fragrant, smooth ; females usually in pairs, sometimes three or four. Fruits erect on a stalk $\frac{1}{5}$ in. long, round, $\frac{1}{3}$ to $\frac{1}{2}$ in. diameter, smooth, bright scarlet.

Native of China, Japan, and Corea, and distinct from all other species in cultivation in having the flowers clustered in fascicles.

Var. CHINENSE, Maximowicz (B. Billiardii, Carrière), is a taller shrub, partially evergreen, more downy than the type. The fruits of both are ornamental, and remain long on the branches.

\section{R. Gayanum, Steudel.}

(R. villosum, Gay, Bot. Mag., t. 76rr.)

An unarmed evergreen shrub, 3 to $5 \mathrm{ft}$. high ; the young wood, leaf-stalks, flower-stalks, ovary, and calyx shaggy with soft hairs. Leaves stout, greyish, 
very broadly or roundish ovate ; I to 2 ins. long and broad; the three lobes rounded and toothed, the base usually straight; downy on both sides. Flowers bell-shaped, yellow, honey-scented, closely packed in erect, cylindrical racemes, I to 2 ins. long, $\frac{1}{2}$ in. diameter. Berries about the size of peas, purple-black, hairy.

Native of Chile. A handsome evergreen, and distinct in the shape and colour of its inflorescence, and the hairiness of its various parts. Some forms are less downy. Flowers in early June. It has been cultivated at Kew for many years, and is quite hardy.

\section{R. Gordonianum, Lemaire.}

(R. Beatonii, Hort.)

A hybrid between R. aureum and R. sanguineum, raised at Shrubland Park, near Ipswich, about 1837 , by Donald Beaton, a famous gardener of his time. It is intermediate in most respects between its parents-in habit, in the leaves being smaller and less hairy than those of R. sanguineum, and in the colour of the flowers, which are reddish outside, yellowish within, a curious blend. It is hardier than R. sanguineum, and can be grown in parts of the New England States where that species is too tender to thrive. It is interesting and not without beauty, but is inferior to either of its parents.

\section{R. Grossularia, Linnceus. Common Gonseberry.}

There is a group of species closely allied to this, composed of deciduous, bushy, spiny shrubs with small green or purplish flowers which have no value in gardens apart from their use as fruit-bearers. They need not be given detailed notice, but may be included here.

The common gooseberry (R. Grossularia) is found wild in Britain, but is believed to be an escape from gardens. It is a genuine native of most parts of mountainous Europe, and on the Mount Atlas range in N. Africa. In a wild state it is distinguished by its bristly young wood, its downy calyx and hairy ovary, its style downy at the base, and its yellowish or red berry, more or less glandular-hairy. Some cultivated varieties have quite smooth berries.

R. oxyaCANThoides, Linnceus, is widely spread over N. America. It has bristly branches, the leaves are downy, and more or less glandular, the stamens as long as the petals; the ovary, calyx, and berry smooth, the last red-purple. R. HIRTELLUM, Michaux, is very near this species, but has smooth shoots and stamens twice as long as the petals, which are purplish. Berry smooth, purplish or black, $\frac{1}{2}$ in. across.-Bot. Mag., t. 6892 (as oxyacanthoides). It has borne very good fruit in the Isle of Wight, where it is known as "currant-gooseberry."

R. ROTUNDIFOLIUM, Michaux, is a native of the eastern United States, from Massachusetts to $\mathrm{N}$. Carolina. Its solitary spines are small and inconspicuous; young wood and leaves downy, but not glandular or bristly ; flowers greenish purple ; calyx, ovary, and berry smooth. The fruit is purple and of good flavour.

R. Divaricatum, Douglas (Bot. Reg., t. 1359).-A native of the coast region of Western $\mathrm{N}$. America, of vigorous growth, and up to $10 \mathrm{ft}$. high. Its young wood is armed with single or triple spines up to $\frac{2}{3} \mathrm{in}$. long, and is sometimes bristly, usually smooth. Leaves with appressed hairs above, almost or quite smooth beneath. Calyx downy, greenish purple, petals whitish, ovary and berry smooth, the last globose, $\frac{1}{3}$ in. diameter, blackpurple. This species is nearly allied to $R$. rotundifolium, but is found wild on 
the opposite side of the continent, and is a bigger bush, well-armed with long stout spines.

R. MISSOURIENSE, Nutiall, may be mentioned here although I do not know that it is in cultivation. The name occurs in nursery catalogues, but the plant so-called is a currant-R. americanum. The true plant is a gooseberry, native of the south central United States ; very closely allied to R. rotundifolium, perhaps a mere form of it.

R. GROSSULARIOIDES, Maximowicz.-A native of China and Japan, with smooth or bristly stems armed with triple spines; leaves smooth or with glandular bristles. It differs from $R$. Grossularia in the style not being downy and in the red berry being smooth. Introduced to Kew from N. China by the late Dr Bretschneider in $188 \mathrm{I}$.

R. Cynosbati, Linnaus. Dogberry.-A native of Eastern N. America ; introduced in 1759. Its stems are weakly armed or not at all; leaves and leaf-stalks downy, calyx green, bell-shaped with reflexed sepals ; petals white ; ovary bristly, the bristles not gland-tipped; style downy towards the base; fruit reddish purple, scarcely $\frac{1}{2}$ in. in diameter, more or less covered with slender prickles.

\section{R. LACUSTRE, Poiret.}

A deciduous shrub, 3 to $5 \mathrm{ft}$. high, the stems thickly covered with slender prickles or stiff bristles; spines at the joints numerous, from three to nine arranged in a semicircle. Leaves I to $2 \frac{1}{4}$ ins. long and wide, handsomely and deeply three- or five-lobed, the lobes often again deeply cut ; stalk and chief veins more or less bristly. Flowers from twelve to twenty in glandulardowny drooping racemes, 2 to 3 ins. long, funnel-shaped, with short, spreading sepals brownish crimson inside, creamy white or pinkish outside. Berry round, about the size of a black currant, covered with gland-tipped bristles, black.

Native of N. America on both sides of the continent, inhabiting cold damp localities; introduced in 1812 . Although the general aspect of this shrub is that of a gooseberry, especially in the shape of its leaves and in its spines, it has the long racemes and flowers of the currants. Its multiple spines are also distinct. Although it has no lively colour to recommend it, it is pretty when its branches are strung with the graceful drooping racemes.

R. montigenum, McClatchie ( $\mathrm{R}$. lentum, Coville), is another species which unites, as lacustre does, the two sections of the genus, but has shorter, fewer-flowered racemes (six to ten) and bright red fruits. Introduced from Western N. America in 1905.

\section{R, LAURIFOLIUM, Janczereski.}

An unarmed evergreen shrub, 4 to $6 \mathrm{ft}$. high, branchlets at first glandular, then smooth and brown. Leaves leathery, ovate to oval, pointed, the largest 5 ins. long, half as wide, coarsely toothed, each tooth terminated by a minute glandular tip, dark dull green above, paler and brighter beneath, smooth on both surfaces; stalk and stipules bristly. Racemes nodding, $1 \frac{1}{2}$ to $2 \frac{1}{2}$ ins. long, I in. wide, main-stalk glandular-downy, viscid. Flowers greenish yellow, $\frac{1}{3}$ in. diameter; calyx and stalk downy. Bracts oblong, inclined to obovate, $\frac{5}{8}$ in. long, thin, greenish white. Fruit oval, blackish, $\frac{1}{2}$ in. long.

Native of W. China ; discovered and introduced in 1908 by Wilson. It is not a showy plant, but is interesting and welcome in flowering as early as February. The flowers are unisexual, the sexes separated on different plants ; the females are longer than the males, and with only abortive stamens. $\mathrm{Mr}$ Wilson says it is rare in a wild state. Young shoots are often red. 


\section{R. Leptanthum, $A$. Gray.}

A deciduous, spiny shrub, 3 or $4 \mathrm{ft}$. high, with slightly downy, occasionally glandular-bristly young branches; spines usually slender, solitary, up to $\frac{1}{2}$ in. long. Leaves roundish or somewhat kidney-shaped, $\frac{1}{4}$ to $\frac{3}{4}$ in. wide, deeply three- or five-lobed, toothed, the base mostly truncate; stalk as long as the blade, downy at the base. Flowers white tinged with pink, one to three on a short stalk; calyx cylindrical, the sepals downy, ultimately reflexed. Fruit oval, shining, blackish red, slightly downy or smooth.

Native of Colorado, New Mexico, etc. ; one of the prettiest and daintiest of gooseberries lately introduced, the branches being slender and densely clothed with tiny leaves.

Var. QUERCETORUM (R. quercetorum, Greene), has pale yellow flowers, fragrant, and produced two to four together. Native of California.

\section{R. Lobiil, A. Gray.}

A deciduous, spiny shrub, 3 to $6 \mathrm{ft}$. high ; young shoots downy. Leaves roundish in the main, $\frac{3}{4}$ to 2 ins. wide, three- to five-lobed; the lobes roundish toothed, downy above, downy and glandular beneath and on the stalk. Flowers usually in pairs on a glandular-hairy stalk; calyx purplish red, downy, the sepals twice or thrice the length of the tube, recurved; petals white, erect, the stamens much protruded beyond them; anthers almost as broad as long; ovary covered with glands. Berry oblong, red brown, glandular.

Native of N. California and S. British Columbia ; introduced about 1852 by Wm. Lobb for Messrs Veitch, but not often seen now, although, like the others of this group, very pretty when flowering in April. From the allied crimson-flowered gooseberries in cultivation, viz., Menziesii, amictum, and cruentum, this is very well distinguished in flower by the anthers being rounded at the top (in the others they are tapered like an arrowhead).

\section{R. LONGERACEMOSUM, Franchet.}

Mr Wilson has recently introduced this extraordinary currant from W. China, where it had originally been discovered by the Abbé David. The one character which distinguishes it from all its tribe is its remarkable racemes, from 12 to 18 ins. long, pendulous, thinly set with greenish flowers and afterwards with jet-black fruits which $\mathrm{Mr}$ Wilson tells me are about the size of an ordinary black currant and of good flavour. It is a deciduous, unarmed shrub with smooth young shoots and three- or five-lobed, smooth leaves, 3 to $5 \frac{1}{2}$ ins. long and wide ; stalks up to $4 \frac{1}{2}$ ins. long, furnished with glandular bristles most numerous towards each end. Flowers tubular, bellshaped, smooth. The species appears to be quite hardy, and is worth the attention of lovers of curiosities and of fruit-growers for hybridising. The fruits, however, are very thinly disposed along the stalk.

\section{R. MenZIESII, Pursh.}

A deciduous, spiny shrub, up to $6 \mathrm{ft}$. high; young shoots downy and covered with long, slender bristles. Leaves roundish ovate in the main, I to 2 ins. wide, deeply three- sometimes five-lobed, the lobes toothed; either smooth or with gland-tipped hairs above, very downy and glandular beneath and on the stalk. Flowers in pairs or solitary on the slender, glandular, and downy stalk; calyx red-purple with a short, bell-shaped base, the sepals $\frac{1}{3}$ in. 
long; petals white, sometimes rosy tinted. Berry globose, covered with glandular bristles, the remains of the flower persisting at the top.

Native of Western N. America ; introduced in 1830. A free-growing gooseberry, which flowers freely in this country in May. From R. Lobbii, with which it is much confused in gardens, it is distinguished by its bristly stems, the stalked glands on the ovary, and the tapered anthers. The contrast of purple and white in the flowers is pretty.

\section{R. MOGOLLONICUM, Greene.}

(Bot. Mag., t. 8120. )

A sturdy unarmed shrub, said to become 9 to II ft. high; young shoots smooth or nearly so. Leaves three- or five-lobed, 2 to $3 \frac{1}{2}$ ins. long and wide ; heart-shaped at the base, smooth above, downy only on the veins beneath, and with scattered glands which impart a somewhat disagreeable odour to the leaves when rubbed; stalk downy and glandular. Flowers greenish white, themselves short-stalked, but closely set on erect long-stalked racemes I to $\mathrm{I} \frac{1}{2}$ ins. long; the stalks and ovary covered densely with stalked glands. Currants $\frac{1}{3}$ in. wide, roundish ovoid, glandular, blue.

Native of Colorado, New Mexico, etc.; introduced to Kew in 1900, where it is very hardy and fruits freely. Its only interest for the garden is in the blue, ultimately black, glandular fruits arranged densely in more or less erect spikes. It belongs to the same group of currants as $R$. sanguineum, but has none of the flower beauty of that species.

\section{R. MULTIFLORUm, Kitaibel.}

(Bot. Mag., t. 2368.)

This is one of the red currant group, and, as regards its flowers, the most striking ; they are yellowish green, crowded on slender, cylindrical, pendulous racemes, sometimes 4 to 5 ins. long. When well furnished with these the shrub is quite ornamental. For the rest, it is vigorous, up to $6 \mathrm{ft}$. high, and has stout unarmed branches-stouter perhaps than those of any other currant; leaves of the red currant shape and size, grey with down beneath. Fruit roundish, red when ripe, $\frac{1}{3}$ in. diameter.

Native of S. and E. Europe ; introduced about 1818 .

\section{R. NIGRUM, Linnceus. Black CURRANT.}

An unarmed shrub, 5 or $6 \mathrm{ft}$. high, distinguished by its peculiar odour, due to small yellowish glands sprinkled freely over the lower surface of the leaf, which is conspicuously three-lobed, deeply notched at the base, long stalked, coarsely toothed. Flowers bell-shaped, dull white, in racemes, each flower from the axil of a minute bract ; fruits black.

Native of Europe and Siberia, possibly of Britain. Several varieties of this species-so well-known as the "black currant" of fruit gardens-have been distinguished. The two first mentioned are curious and interesting, but no others are worth cultivating as ornamental shrubs:-

Var. DISSECTUM.-Leaves very curiously cut, each of the three lobes reaching back to the stalk, and again bipinnately lobed.

Var. LACINIATUM. - The three primary lobes reaching nearly or quite to the stalk, and pinnately lobed.

Var. RETICULATUM. - Leaves mottled thickly with yellow.

R. CULverwelli, Macfarlane, is a hybrid between the black currant 
(female) and the gooseberry, raised by Mr Culverwell, of Thorpe Perrow, Yorkshire, about 1880. It is a spineless shrub, and has flowers like the black currant, but the foliage and inflorescence is more suggestive of the gooseberry. An interesting curiosity of no value apparently either for fruit or ornament. R. SCHNEIDERI, Maurer, is a hybrid of the same parentage, raised in Germany, but with the sexes reversed.

\section{R. NIVEUM, Lindley.}

(Bot. Reg., t. 1962.)

An armed, deciduous shrub, up to $9 \mathrm{ft}$. high, the young shoots quite smooth; spines solitary or in threes, about $\frac{1}{2}$ in. long. Leaves between roundish and kidney-shaped, three- to five-lobed, $\mathrm{I}$ to $\mathrm{I} \frac{1}{2}$ ins. across ; usually truncate at the base, the lobes unequally and bluntly toothed. Flowers two to four together in slender-stalked, drooping clusters; calyx and petals smooth, white ; sepals ultimately much reflexed, leaving the stamens exposed for $\frac{1}{3}$ in. Ovary smooth, stamens and style downy. Berry globose, smooth, black with a purplish bloom, about $\frac{1}{3}$ in. diameter.

Native of Western N. America ; introduced in 1826. This gooseberry is rather pretty and distinct in its wholly white flowers.

R. ROBUSTUM, Janczereski, is a hybrid between this species and oxyacanthoides. It is a very vigorous bush, and was received at Kew in 1890 from the late Mr Nyeland, gardener to the King of Denmark. Beyond that I know nothing of its origin.

\section{R. ORIENTALE, Desfontaines.}

An unarmed, deciduous shrub, 5 or $6 \mathrm{ft}$. high; young shoots and leafstalks covered with stiff, gland-tipped sticky hairs. Leaves of the red currant size and shape, but shining green and with bristly down on the nerves beneath; stalk $\frac{1}{2}$ to $I$ in. long. Flowers unisexual, the sexes on different plants, and produced on somewhat erect racemes I to 2 ins. long; they are green suffused with red and covered with viscid hairs ; berry red, downy.

Native of E. Europe and W. Asia. The R. resinosum of Pursh, until recently regarded as a native of $\mathrm{N}$. America, and figured as such in Bot. Mag., t. 1538, is really this species. It has little garden value, but is distinct in its unisexual flowers, very viscid glands, and erect racemes.

\section{R. Pinetorum, Greene. Pine-Wood Gooseberry.}

A gooseberry growing $6 \mathrm{ft}$. high, found in the Mogollon Mountains of New Mexico and in Arizona, often in pine-woods, an association from which it derives its name; introduced in 1902 . It has the typically shaped leaf of the gooseberries, smooth, blunt-toothed, and with long, slender stalks. The young shoots are quite smooth; the spines solitary, in pairs, or in threes, rich brown, stout, slightly curved. Flowers solitary, orange-yellow, hairy outside ; the sepals much reflexed, showing the erect petals. Berry black-purple, globose, $\frac{1}{2}$ in. diameter, with numerous bristles. Although this species has some of the most brilliantly coloured blossoms among gooseberries, they are short-stalked and solitary (or very rarely in pairs) at each joint, and make no great display. They appear in May, when the leaves are onethird grown.

\section{R. PROSTRATUM, L'Heritier.}

A deciduous, unarmed shrub with prostrate, rooting branches; young shoots smooth. Leaves deeply five- to seven-lobed, $1 \frac{1}{2}$ to 4 ins. wide, the 


\section{RIBES}

lobes doubly toothed; bright green and smooth on both sides, except for occasional hairs on the veins beneath; stalk bristly at the base. Flowers greenish, produced eight to twelve together on erect, slender racemes, 2 to 3 ins. long, stalks and ovary with gland-tipped hairs; sepals smooth outside. Fruit red, glandular, $\frac{1}{4}$ in. diameter.

Native of $N$. America, where it is widely spread over the cool moist regions on both east and west sides; introduced in 1812 . It is distinct in its prostrate habit, nearly or quite smooth, evil-smelling leaves, and red, glanded fruits. Nearly allied to this is

R. LAXiflorum, Pursh (R. affine, Douglas, not Kunth), also a prostrate shrub, but with leaves more downy beneath when young, the fan-shaped petals as broad as they are long (in prostratum they are much longer than broad), the sepals downy but not glandular outside, and the fruits black or dark purple, with glandular down and a glaucous bloom. Native of Western N. America, whence it was introduced by Douglas in 1818 , and Japan.

R. COLORADENSE, Coville, is a third species belonging to the same group, being of prostrate habit ; the young shoots are finely downy, the sepals with glandular hairs outside, the purplish petals twice as broad as long, the fruit black, not glaucous with bloom. Native of Colorado and New Mexico ; introduced in 1905.

None of these three have much garden value, although their prostrate habit gives them interest.

\section{R. Sanguineum, Pursh. Flowering Currant.}

(Bot. Mag., t. 3335.)

A deciduous, unarmed bush, 7 or $8 \mathrm{ft}$. high, usually considerably more in diameter; young shoots covered with a close, fine down. Leaves three- or five-lobed, palmately veined, the lobes broad and rounded, unequally toothed, the base conspicuously heart-shaped ; 2 to 4 ins. wide, less in length; smooth or nearly so above, soft with pale down beneath; stalk $\frac{3}{4}$ to 2 ins. long, covered with minute down like the young shoots, but with a few bristles near the base. Flowers deep rosy red, produced during April in drooping, finally ascending, racemes 2 to 4 ins. long, 1 to $1 \frac{1}{2}$ ins. wide ; each flower $\frac{1}{2}$ in. long and nearly as wide ; the slender flower-stalk, ovary, and tubular calyx dotted with glandular down. Currants globose, $\frac{1}{4}$ in. diameter, glandular, black covered with blue bloom.

Native of Western N. America ; discovered by A. Menzies in 1793, and introduced by Douglas for the Horticultural Society in 1826 . - This currant is the finest of Ribes and in the very front rank of all spring-flowering shrubs, being one of those that never fails to blossom well. Whilst all its forms are beautiful, some are preferable ; the following is a selection:-

Var. ALBIDUM, Paxton.-Flowers white, with only a slight tinge of colour. In my experience this variety is not so robust as the red ones.

Var. ATRORUBENS. - Flowers of a very deep red but smaller, and in smaller racemes than the type.

Var. BROCKLEBANKII.-Leaves a good yellow, the colour lasting well.

Var. FLORE PLENO.-Flowers double, but inferior in beauty.

Var. SPLENDENS. - Sent out by Mr Smith of Newry about the end of last century, this is, I consider, the finest form of flowering currant known. It approaches the blootl-red tint indicated by the specific name nearer than any other except atrorubens, and unlike that form, unites a goodly size of flower and raceme with its richness of colour.

All the forms of R. sanguineum are easily propagated by cuttings of naked wood like the gooseberry. 
Closely allied to R. sanguineum are the two following-sometimes regarded as varieties of it :-

R. GLutinosum, Bentham.-This differs from R. sanguineum in the young shoots and leaves being furnished with glandular glutinous hairs, and in being less downy; also in its quite pendulous racemes. It is inferior in garden value. Native of California and Washington.

R. MALvaceum, Smith.-Leaves bristly, rough, and finely wrinkled above, the lower surface and stalk covered with a grey felt with which are mixed glandular hairs. The flower-stalk, ovary, and calyx are also covered with bristly down. Flowers bright rose, smaller and not so beautiful as in R. sanguineum. From that species and R. glutinosum it is distinct in having the ovary and style covered with white hairs. Native of California.

\section{R. SPeciosum, Pursh.}

(Bot. Mag., t. 3530 ; R. fuchsioides, Mocino.)

A deciduous, spiny shrub, 6 to $9 \mathrm{ft}$. high, the young shoots furnished with gland-tipped bristles. Leaves three- sometimes five-lobed, sparsely toothed, and from $\frac{3}{4}$ to $1 \frac{1}{4}$ ins. long and wide, with smaller ones often obovate and tapered at the base ; usually quite smooth ; stalk slender, scarcely as long as the blade, with a few glandular bristles, especially at the base. Flowers rich red, usually two to five in pendulous clusters, the main-stalk longer and less glandular than the minor ones. Calyx tubular, $\frac{1}{2}$ in. long, glandular; sepals four, not reflexed ; petals four, about as long as the sepals ; stamens four, red, standing out $\frac{3}{4}$ in. beyond the calyx. Fruit glandular-bristly, red, $\frac{1}{2}$ in. long, rarely seen in this country.

Native of California; discovered by Menzies about 1793, and introduced from Monterey by a naval surgeon named Collie in 1828. As a flowering shrub it is the most beautiful of the gooseberries. Its branches are reddish, horizontal, or slightly dependent, and from their under-side the richly coloured, fuchsia-like blossoms hang profusely in rows during April and May. It is very distinct in the parts of the flower being in fours (not the usual fives), and in the very long highly coloured stamens. It is one of the earliest shrubs to break into leaf-often in early February. It shows to best advantage perhaps against a wall, where it will grow 10 or $12 \mathrm{ft}$. high, but is quite hardy in the open at Key, where it has grown 6 or $7 \mathrm{ft}$. high. It can be rooted from cuttings, but does not strike readily; layering is a more certain process.

\section{R. viburnifolium, $A$. Gray.}

(Bot. Mag., t. 8094.)

An evergreen, unarmed shrub, 7 or $8 \mathrm{ft}$. high against a wall; young shoots slightly downy at first, with numerous resin glands. Leaves ovate or oval, $\frac{3}{4}$ to $1 \frac{3}{4}$ ins. long, $\frac{1}{2}$ to $1 \frac{1}{4}$ ins. wide : rounded at the base, blunt at the apex, coarsely toothed, glossy and smooth above, almost or quite devoid of down beneath, but thickly sown with resin-dots which emit a very pleasant turpentinelike odour when rubbed; stalk downy, $\frac{1}{8}$ to $\frac{1}{6}$ in. long. Flowers $\frac{1}{3}$ in. across, produced in April in erect racemes about $\mathrm{I}$ in. long, terminating short, densely leafy shoots; dull rose-coloured, the sepals spreading. Berry oval, red, $\frac{1}{3}$ in. long.

Native of Lower California and Santa Catalina Island; introduced to Kew in 1897. A remarkably distinct species, of little beauty, but interesting for its evergreen aromatically scented leaves. It needs wall protection at Kew. 


\section{R. vUlgare, Lamarck. RED CURRANT.}

(R. rubrum of most authors, not Linnazus.)

Little need be said here about the red currant, so well known in its cultivated form in English fruit gardens. It is an unarmed, spreading shrub with three- or five-lobed leaves, 2 to 4 ins. across, heart-shaped at the base ; very downy beneath, and with scattered hairs above, at least when young; stalk from half to twice as long as the blade. Flowers saucer-shaped, flattish, greenish, produced in recurved racemes from the joints of last year's wood. Fruit juicy, red and shining; in a cultivated variety (ALBUM) white.

Native of Europe. Of little interest except in fruit gardens. The true R. RUBRUM, Linnceus, found wild in Britain, is sometimes met with in gardens under the name of $\mathrm{R}$. Schlectendalii, Lange. Its racemes are horizontal or ascending, not drooping or pendent as in vulgare, and the flowers are urnshaped or broadly funnel-shaped rather than saucer-shaped. Cultivated forms of this species are grown in the gardens of Scandinavia, but in Western and Central Europe the cultivated red and white currants are exclusively R. vulgare.

R. WARCEWICZII, Janczezeski, is near kं. rubrum, but has lairger flowers and more highly coloured, more acid and larger fruits. Flowers of the same shape, but in pendulous racemes. Siberia and Amurland; introduced in 1903.

R. TRISTE, Pallas, is the American form of red currant, a shrub of laxer habit than $R$. vulgare, the leaves white with down beneath when young; flowers purplish; fruit red, small and hard. It is said to be pretty and graceful in blossom in the United States and Canada, where it inhabits cold bogs and woods from New Hampshire to Nova Scotia. It is a native also of N. Asia.

R. PETRAUM, Wulfen, is another of the red currant group, widely spread in a state of nature in Europe and N. Africa. It has no value as an ornamental shrub, its flowers being green suffused with purple, somewhat bell-shaped, in horizontal or slightly nodding racemes, 3 or 4 ins. long. The leaves are more deeply lobed than in the common red currant, the lobes pointed. Fruit roundish, flattened somewhat at the end, red, very acid.

\section{ROBINIA. LEGUMINOSE.}

A genus of about half a dozen deciduous trees and shrubs confined to N. America, whose name commemorates Jean Robin, herbalist to Henry IV. of France, and his son Vespasien. They are amongst the most ornamental of all hardy trees both in leaf and flower. The leaves are pinnate, and the pea-shaped flowers are borne in pendulous racemes. Pods flat, many-seeded. Stipules often developing into spines.

All the species thrive well in a soil of moderate quality. If given very rich or manured soil they grow so coarse and rank that the danger of damage by wind, due to the brittleness of the branches, is increased. The best method of propagation is by seed, but in the case of $\mathrm{R}$. hispida and Kelseyi, and garden varieties, it is usual to graft them on roots or stems of R. Pseudacacia. This should be done in spring with leafless scions, and the union is more quickly and surely effected if the plants can be kept in a warm greenhouse. R. Pseudacacia, hispida, and Kelseyi can be increased also by suckers. The only hardy tree with 
which the Robinias can be confounded is Sophora japonica, whose unarmed branches and autumnal flowering readily distinguish it.

\section{R. HISPIDA, Linnceus. ROSE ACACIA.}

$$
\text { ( ot. Mag., t. } 3 \text { II.) }
$$

A deciduous, unarmed shrub, 6 to $8 \mathrm{ft}$. high, of lax, rather gaunt habit, spreading by means of underground suckers, the branches covered with glandtipped bristles $\frac{1}{6}$ in. long. Leaves pinnate, 6 to 10 ins. long ; leaflets seven to seventeen, each $I \frac{1}{2}$ to $2 \frac{1}{2}$ ins. long, and from $\frac{3}{4}$ to $I \frac{1}{2}$ ins. wide, oval or ovate with a short bristle-like tip, very dark green; stalk hairy. Racemes 2 or 3 ins. long, nearly as much wide, carrying five to ten flowers. The flowers are the largest and most showy among Robinias, each about $\mathrm{I}_{4} \frac{1}{4}$ ins. long, with the rounded standard petal as much across, of a lovely deep rose ; calyx $\frac{1}{2}$ to $\frac{2}{3}$ in. long, with long, slender, awl-shaped teeth, and bristly like the flower-stalk. Pod $1 \frac{1}{2}$ to $2 \frac{1}{2}$ ins. long, $\frac{1}{3}$ in. wide, thickly covered with glandtipped bristles. Blossoms in May and June.

Var. MACROPHylla, De Candolle (var. inermis, Carrière; R. macrophylla, Hort.).-Distinguished chiefly by the branches and leaf-stalks being quite free from bristles. The stalks of the racemes and flowers are hairy, but by no means so markedly so as in the type. The flowers are even larger and more brightly coloured, the leaves rounder.

Native of the south-eastern United States; introduced in 1743. In a state of nature it spreads and renews itself by means of sucker-growths extending several feet in a single season, but in cultivation it is usually grafted as a standard on R. Pseudacacia so as to form a low, bushy-headed tree. Undoubtedly one of the loveliest of all trees of that character, it is, unfortunately, very liable to lose its branches during storms, owing to the brittle nature of its wood. For this reason a secluded spot is desirable for it. A remarkable fact in connection with this tree is the rarity with which it produces seed. It has probably never borne pods in this country, and even in a state of nature they are very seldom seen. The pods in the Kew Herbarium are three contributed by the late Mr T. Meehan of Philadelphia, to whom they had been sent in response to inquiries made in a public journal. He himself had made diligent search for seed-pods on the mountains of Tennessee, where the shrub grows in great abundance, but never found any. The defect seems to be in the male part of the flower, and due to the absence of pollen. Still, fertile plants do exist in N. America, and from them no doubt a seed-bearing race could be established.

\section{R. Kelsevi, Cowell.}

\section{(Bot. Mag., t. 8213 ; ? R. Boyntonii, Ashe.)}

A lax-habited, deciduous shrub or small tree, with smooth, slender branches. Leaves pinnate, 4 to 6 ins. long; leaflets nine or eleven, oblong to ovate, $I$ to 2 ins. long, $\frac{1}{3}$ to $\frac{5}{8}$ in. wide, pointed, smooth. Flowers brightly rose-coloured, in small clusters at the base of the young twigs; these clusters are sometimes simple racemes of three to six flowers, but they are frequently forked or triplicate, the stalks always covered with glandular hairs. Each flower is $\frac{3}{4}$ to $\mathrm{I}$ in. long, with a rounded standard petal $\frac{3}{4}$ in. across ; calyx $\frac{1}{4}$ in. long, glandular-hairy, teeth narrow, awl-shaped. Pod 2 ins. long, $\frac{1}{3}$ in. wide, covered with reddish gland-tipped bristles $\frac{1}{6}$ in. long.

The origin of this beautiful Robinia is not definitely known. It was put into commerce about I90I, by Mr Harlan P. Kelsey, of Boston, U.S.A., who 
informs me in a letter that it was "discovered in our nursery apparently growing spontaneously. We thought at first it was a cross between R. hispida and R. Pseudacacia, but now we think it is a true species that has crept into the collections from the southern Allegheny Mountains." It was introduced to Kew in 1903 , and is certainly one of the most beautiful shrubs added to gardens in recent years. The flowers appear in great profusion in June, and they are followed by handsome red pods. Its affinity with $\mathrm{R}$. hispida, especially the smooth-branched form, is apparent, but it is abundantly distinct. Judging by its behaviour at Kew it can be made into a small tree, but it is very brittle. Increase is easily effected by grafting on roots of R. Pseudacacia in spring. Should R. Boyntonii, Ashe, prove to be the same, that name, as the older one, will have to be adopted, but I have seen no material.

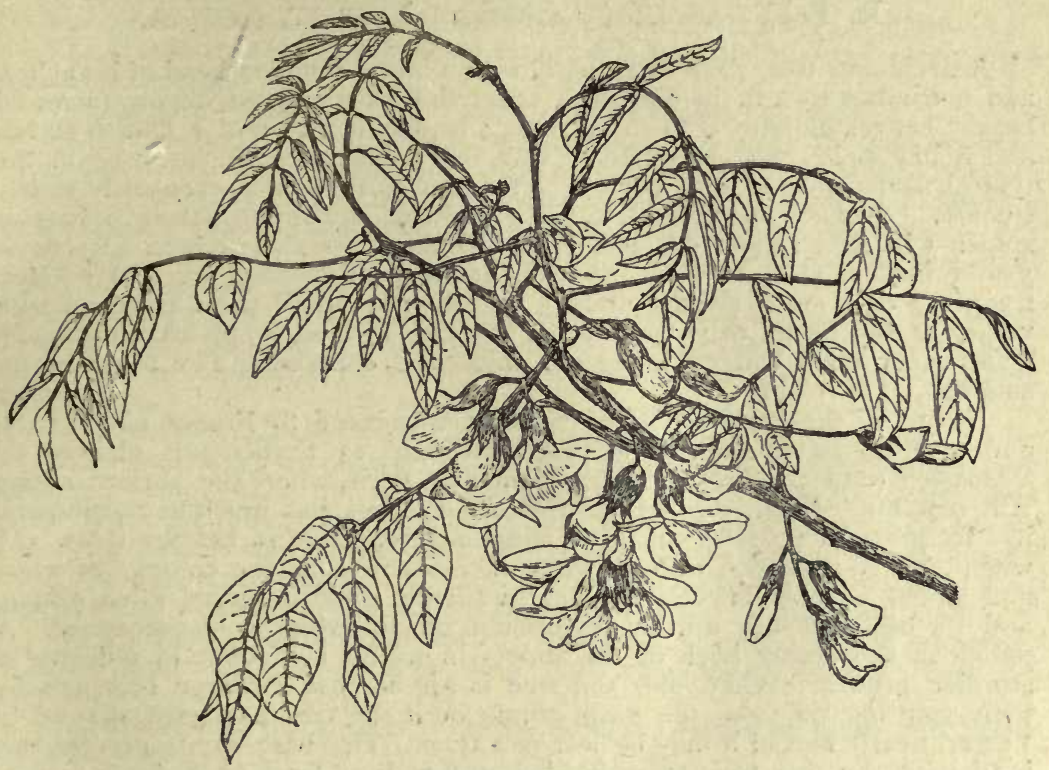

Robinia Kelseyi.

R. NEOMexicana, A. Gray.

(Bot. Mag., t. 7726.)

A deciduous shrub or small tree, 20 to $30 \mathrm{ft}$. high, with a trunk 12 ins. or more thick; branchlets downy. Leaves pinnate, 6 to 12 ins. long, with downy stalks : leaflets fifteen to twenty-five, oval to slightly ovate, $\mathbf{I}$ to $\mathbf{I} \frac{3}{4}$ ins. long, $\frac{1}{2}$ to $\frac{2}{3}$ in. wide; with a bristle-like tip; stipules spiny, ultimately $I$ in. long. Racemes 2 to 3 ins. long, 2 ins. wide, the stalk covered with brown shaggy hairs. Flowers $\frac{3}{4}$ to $I$ in. long, pale rose, each on a hairy stalk $\frac{1}{4}$ in. long; the standard petal large, the calyx glandular, shaggy, with slender teeth. Pods 3 or 4 ins. long, $\frac{1}{3}$ in. wides covered with gland-tipped bristles $\frac{1}{8}$ in. or more long.

Native of Colorado, New Mexico, Arizona, and S. Utah, in places at $7000 \mathrm{ft}$. above sea-level. First discovered by Dr Thurber in $1 \delta_{5} \mathrm{I}$; introduced to Kew in 1887 , where the original tree is now nearly 30 ift. high, with a trunk 
12 ins. thick. It flowers very prettily every year in June, and frequently a second time in August. It differs from R. Pseudacacia in its bristly pods, and from $R$. viscosa in the young twigs not being viscid. It is said to be found more often as a shrub than as a tree in a wild state.

R. HoldtIl, Beissner.-A hybrid between R. neomexicana and R. Pseudacacia whose racemes are looser and longer than in $R$. neomexicana and the flowers of a paler colour. The keel and wing-petals are almost white, the standard pale red with white markings. Habit and vigour of growth similar to those of R. Pseudacacia. Pod rather glandular. Obtained by Mr Von Holdt, Alcott, Colorado, and put into commerce about 1902.

\section{R. Pseudacacia, Linnceus. Locust, Acacia.}

A deciduous tree, 70 to $80 \mathrm{ft}$. high, with a large, rounded head of branches, and a trunk 2 to $4 \mathrm{ft}$. in diameter, covered with a rugged, deeply furrowed bark. Leaves pinnate, 6 to 12 ins. long; leaflets in five and a half to eleven and a half pairs, oval or ovate, $I$ to 2 ins. (sometimes $2 \frac{1}{2}$ ) ins. long in the typical form, covered with silvery hairs when quite young, eventually nearly smooth. Stipules at first $\frac{1}{2}$ in. long, downy, becoming stout, persistent spines I in. long; most conspicuous on young trees and suckers. Racemes 3 to 5 ins. long, $I \frac{1}{2}$ to 2 ins. wide, pendulous. Flowers $\frac{3}{4}$ in. long ; whíte, fragrant; each on a slender stalk, $\frac{1}{3}$ in. long; standard petal blotched with yellow at the base; calyx $\frac{1}{3}$ in. long, downy. Pod $2 \frac{1}{2}$ to $3 \frac{1}{2}$ ins. long, $\frac{1}{2}$ in. wide, upper seam winged, lower one thickened, containing four to ten seeds: smooth.

Native of the eastern United States ; introduced to France about I635, and to England in I640. The first plant sent to France was planted by Vespasien Robin in the Jardin des Plantes at Paris, where the ancient stump still remains. As an ornamental tree the Robinia has much to recommend it. Its graceful feathery foliage is singularly effective in healthy $t_{2}-2 s$, and when the tree is loaded with its white racemes in June the contrast of white and green is very effective. It grows with great rapidity when young, and its branches are apt to be broken off by wind in consequence. A judicious shortening back of the shoots in winter is helpful in inducing a sturdier growth. When old, the tree is apt to lose its large branches by their splitting off from the main trunk, or if the tree has been allowed to "fork," nearly half of it may be lost at a time. The best way to prevent this is to keep the tree to a single leader until it is at least $25 \mathrm{ft}$. high, so that one strong straight trunk is formed, and no branch allowed to develop sufficiently to rival it. It is propagated by seeds or by the suckers the roots produce so plentifully, especially after the parent tree is felled.

Perhaps no American tree has made itself so thoroughly at home in Europe as this. The railway cuttings south of Paris are in places completely overrun with it, and I have noticed it thoroughly established in the Rhone Valley above Geneva, and on the hillsides between Trieste and the Chateau of Miramar.

The locust produces a timber valuable on account of its peculiar quality of resisting decay in contact with the soil. On this account it is highly valued for making gate-posts and similar articles. Owing to the representations of William Cobbett, the famous Radical, who about I825 to I 828 extolled the tree and its uses in his own peculiarly vigorous fashion, quite a mania for the tree was established. He himself set up as a dealer in seeds and plants, and to such purpose had he written up the tree and its virtues that he was, for a time, unable to meet the demand, although it is recorded that he imported seeds from America in tons. It did not prove a success as a forest tree, and is now rarely planted except for ornament. But every few years a 
controversy is started as to its value as a timber tree in Britain. There is no doubt about the value of the timber for certain minor purposes-it was once, and may be now, largely used for pins ("tree-nails") to fasten timbers together in shipbuilding-but it is not produced in sufficient bulk, nor is it of a quality to render it of great value for constructive purposes.

An extraordinary number of seminal varieties of the locust have been raised in Europe. Between three and four dozen of them are cultivated at Kew, but many are not sufficiently distinct to require mention here. The following may be regarded as the most important :-

Var. ANGUSTIFOLIA (myrtifolia).-Leaflets small and narrow, about $I$ in. long, $\frac{1}{4}$ in. wide.

Var. AUREA.-Leaves golden yellow.

Var. BELLA-ROSEA.-Flowers rose-coloured; leaflets small ; elegant.

Var. BesSONiANA LATIFOlia.-Leaflets few (usually five) and large, each 2 to 4 ins. long.

Var. CRISPA.-Leaflets twisted and wavy ; branches unarmed.

Var. DECAISNEANA.-A fine strong grower, with large racemes of deep rose-coloured flowers. It appeared in France about 1862 . Very handsome.

Var. FASTIGIATA.-A slender columnar tree, narrower even in proportion to its height than the Lombardy poplar. Also known as "pyramidalis."

Var. HETEROPHYLLA.-Leaflets strangely diverse in shape, varying from I to 3 ins. long and from $\frac{1}{8}$ to $\frac{3}{4}$ in. wide.

Var. INERMIS.-A mop-headed, unarmed small tree which rarely or never flowers. Very frequent in villa gardens in the London suburbs; UMBRACULIFERA is somewhat similar. There is a variegated form-INERMIS VARIEGATA.

Var. MICROPHYLLA. - Leaflets $\frac{1}{2}$ in. long, $\frac{1}{3}$ in. wide.

Var. MONOPHYLLA (unifoliolata). - Leaflets reduced in number to one, two, or three, being either the terminal leaflet alone (always much larger than in the type and often 4 ins. long by $1 \frac{1}{2}$ ins. wide), or accompanied by one or two others about the normal size. This remarkable variety, which flowers freely, is also represented by a fastigiate form (MONOPHYLLA FASTIGIATA), and one with slender semi-pendulous branches (MONOPHYLLA PENDULA).

Var. REHDERI.-A dwarf bushy tree, unarmed, with rather erect branches.

Var. Rosynsiana.-Leaves long and pendulous; leaflets large. A curiosity.

Var. TORTUOSA.-Branches curiously twisted. Racemes small and thinly set with bloom.

Var. SEMPERFLORENS.-In fine sunny summers this continues to flower more or less throughout the growing season.

Var. VARIEGATA has the leaflets mottled with white.

Loudon mentions a yellow-flowered variety-"flore luteo"-but if ever such a plant existed, which is doubtful, it has disappeared. Such a variety would be a great acquisition.

\section{R. viscosa, Ventenat. Clammy Locust. \\ (R. glutinosa, Sims, Bot. Mag., t. 560.)}

A deciduous tree, 30 to $40 \mathrm{ft}$. high, with a trunk $\mathrm{I} 2$ to 18 ins. thick. and often furnished with large burrs; young branches covered with glands which exude a sticky substance that adheres to the fingers when touched. Leaves pinnate, 3 to Io ins. long, the main-stalk hairy and viscid like the young twigs. Leaflets eleven to twenty-one, oval or ovate, 1 to 2 ins. long, $\frac{1}{3}$ to $\frac{3}{4}$ in. wide; dark green above, paler and at first slightly downy beneath, ultimately smooth. Stipules at first $\frac{1}{4}$ in. long, becoming longer and spiny with age. Racemes 2 to $2 \frac{1}{2}$ ins. long, almost as wide, with a naked stalk half as long. Flowers 
$\frac{3}{4}$ in. long, ten to fifteen in a raceme, without fragrance; petals pale rose with a yellow blotch on the standard; calyx dark red, hairy. Pod 2 to $3 \frac{1}{2}$ ins. long, covered with viscid glands.

Native of the mountains of Carolina, where it was originally discovered by Wm. Bartram in 1776. It was introduced to France by Michaux in 1791, and six years later to England. It is a smaller tree than R. Pseudacacia and of more stunted growth, but it flowers very freely and makes a bright picture towards the end of June. The viscid substance on the branches renders it easily distinguishable, although this appears to vary in amount, and is sometimes not very discernible. According to Sargent it is one of the rarest of American trees, and from the time of Michaux to 1882 was never found in a genuinely wild state. But it is now naturalised in many parts of the eastern United States. It is not common in English gardens, but there are several

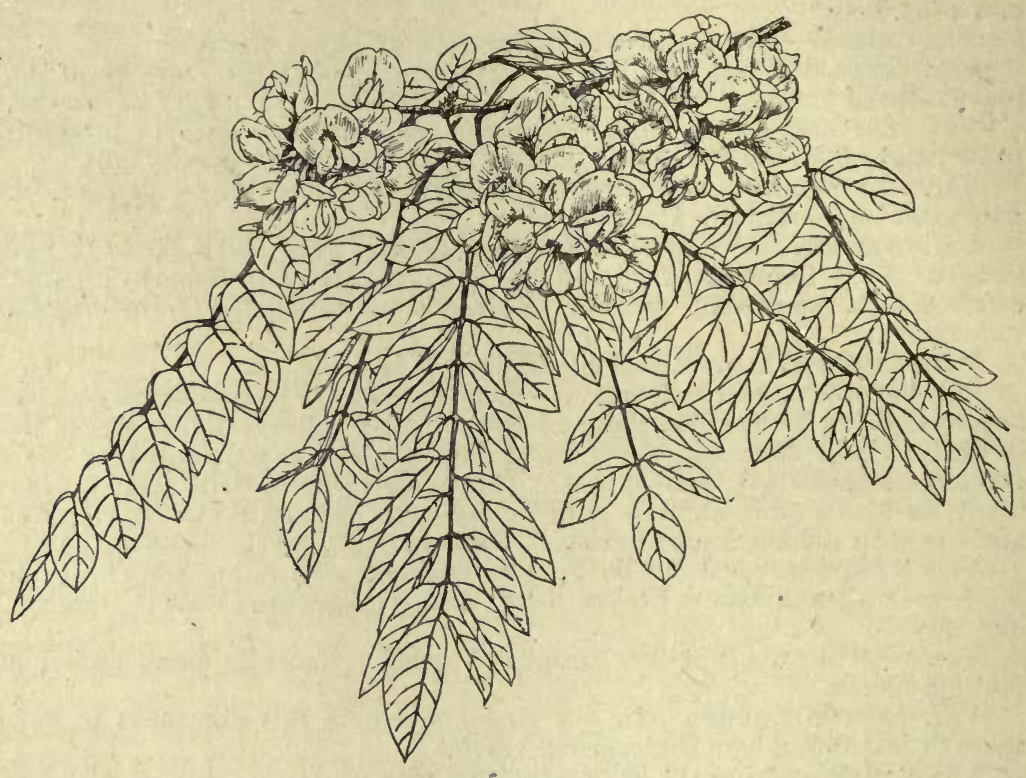

RoBinia viscosa.

old trees at Kew, the largest of which has a trunk $5 \mathrm{ft}$. 3 ins. in girth at $5 \mathrm{ft}$. from the ground, which is considerably more than the dimensions recorded of wild specimens. These old trees are almost unarmed, the spines only occurring on exceptionally vigorous shoots.

\section{ROMNEYA. PAPAVERACE .}

A genus of two semi-herbaceous shrubs, both Californian, and known generally as "tree poppies." The name commemorates Dr F. Romney Robinson, an astronomer at Armagh in 1844 , when the genus was

- founded. 


\section{R. Coulteri, Harvey.}

(The Garden, Nov. 8, I884.)

A semi-shrubby plant, with succulent herbaceous stems 4 to $8 \mathrm{ft}$. high, according to the mildness of the climate in which it grows. Leaves varying much in size according to the strength of the shoot which bears them, but averaging from 3 to 5 ins. long, and of a very glaucous colour; they are obovate to pinnately lobed, the end lobe usually much the largest and itself more or less lobed, smooth except for a few spine-like bristles on the stalk and midrib. Flowers solitary or in pairs, terminating short twigs near the end of the stem, each one 4 to 5 ins. across, with five or six overlapping, satiny-white, delicately textured petals surrounding a mass of golden yellow stamens $I$ to $I \frac{1}{2}$ ins. across. Calyx smooth.

This beautiful plant, discovered in California by Dr Coulter in 1844 , is not hardy in all situations, but is well worth the protection it requires. Perhaps in localities where it is not absolutely hardy the best place for it is in front of a south or west wall, where the shelter of a glass light or something of the kind can be given in winter. Treated in this way I have seen it thriving splendidly as far north as Chester. It should have a warm, well-drained loamy soil, and abundant moisture during the growing season. It is not easily increased by cuttings of the stems, but its thick fleshy roots afford a ready means. They should be cut up into lengths of about 2 ins., placed in pots, and just covered with sandy soil. A mild heat is desirable. The roots of old plants send up young shoots, and these also may be removed, potted, and given warmth. So sensitive to injury is this plant at the root that young plants should be kept in pots until put out in permanent quarters. It flowers from July to October.

\section{R. TRICHOCALYX, Eastwood.}

(Bot. Mag., t. 8002.)

A shrub not distinguishable in stem and leaf characters from the preceding, but at once recognised when in flower by the bristly hairs on the calyx. The flowers are the same in size and colour. Until 1898 , this species was confused with $\mathrm{R}$. Coulteri, and no doubt the two are very closely related. It is a better plant for colder situated gardens, being of hardier constitution, not so gross in habit, and cultivated with less trouble. At Kew it thrives very well in a border on the south side of a glasshouse, without other protection than that gives. It can be increased by cuttings of the stem taken from ripe shoots and put in gentle heat. It appears to have been first noticed in flower in the garden of Mr Hiatt C. Baker, of Almondsbury, near Bristol, in 1902.

\section{ROSA. ROSE, ROSACEA.}

In the great natural order of Rosaceæ, which gives to gardens more beautiful hardy deciduous trees and shrubs than any other, no genus stands out with greater distinctness than the one from which it derives its name. The leading characters of Rosa are its usually very thorny stems, the alternate pinnate leaves, the stipules (except in a few species) joined to the base of the leaf-stalk, the numerous stamens and carpels, and the rounded or elongated fruit, which is really a fleshy development 
of the calyx-tube, containing, when ripe, a large number of dry, hard seeds. The species are spread over all the temperate parts of the northern hemisphere, three or four only of which occur south of the Tropic of Cancer.

There is an extraordinary diversity in the number of species of rose as estimated by different authors. $\mathrm{Mr}$ Baker, the leading British authority, some years ago estimated them at about seventy. At the present time new species from China and elsewhere have brought the number up probably to a hundred. Other writers have made over three hundred species. No group of plants, in fact, unless it be Rubus, has suffered more at the hands of injudicious and incompetent species makers than this. One gentleman is known to have cut his species so fine that two of them could be found on the same bush.

The wild roses suffer somewhat in the estimation of planters because they have to bear comparison with those innumerable garden types, evolved by ages of cultivation and selection, which include what are, by common consent, the loveliest products of the garden. Few of them remain in bloom more than a month, where again a comparison is made to their disadvantage when the hybrid perpetual, teas, and other longblossoming races are considered. Still, when the wild roses are regarded, as in justice they should be, from the standpoint of their own merits, there are few hardy shrubs which surpass the best of them in beauty, grace, and fragrance. Take the humblest of them all, the dog-rose and the sweet-briar of our hedgerows, is either of them excelled in their sweetness and charm on a fresh June morning? And many have in their often large, abundant, and handsomely coloured fruits a beauty in autumn the garden races do not possess.

Cultivation.-These roses are of the simplest cultivation. They all do well in a good loamy soil such as suits the garden types, although it need not be quite so rich. Many of the stronger, more or less rambling growers, like multiflora, moschata, arvensis, and Wichuraiana, are very well adapted for planting in big shrubberies, on rough slopes, against unsightly fences, or on the outskirts of woodland. The smaller and daintier ones like sicula, Ecæ, Webbiana, lutea, ferox, etc., will need a front place in the ordinary shrubbery; some may even be planted in the rock garden. The common bushy type, such as sericea, rugosa, microphylla, are pleasing as isolated shrubs on lawns. Whilst all those strong enough and bushy enough to kill the grass beneath their branches are admirable for the wild garden.

Most of the species can be propagated by cuttings made of firm wood in July and August, and placed in gentle heat. Cuttings should be made of short twigs with a "heel" of older wood attached. Many of the robuster sorts can be increased by cuttings put under hand-glasses out-ofdoors, or even in the open ground, but this is not so quick and certain as where a gentle bottom heat is given. But some do not root at all freely, such as Webbiana, lutea, the Scotch rose group, and generally those with very prickly stems and small leaves. For such of those as have spreading roots and sucker freely, like the Scotch roses, it is best to break them up into small pieces and replant them; pieces with a little 
root attached may be potted and placed in a close frame for a short time. For the remainder it is best to adopt the layering method described in the introductory chapters, which may, indeed, be advantageously adopted for all the non-suckering species where a few plants only are wanted. Seeds may, of course, be used, but so freely do the wild roses intercross through insect agency, that they can never be relied on to come true unless the plants are isolated. At Kew, where the species of Rosa are grown together for purposes of study and comparison, it has long been ascertained that it is a waste of time raising seedlings from them; and seeds of other than isolated plants are no longer offered in exchange. Most of these mongrels are worthless for garden purposes, and so common are'they that they have ceased to have any scientific interest.

The principles explained in an early chapter govern the pruning of roses as of other shrubs. Most of them produce flowers on short twigs issuing from the previous year's growth; the shoots cannot therefore be shortened back without reducing the crop of flowers. Such pruning as is necessary for these is chiefly a matter of removing the older wornout stems. Those of the gallica and indica types, which flower on the growths of the current year, may be pruned back in the same way as hybrid perpetuals and tea roses are.

The flowering of these wild types commences soon after the middle of May with sericea, hispida, and the Scotch roses; and it ends in August with setigera and Wichuraiana; the great majority blossom in June and July,

\section{R. ACICULARIS, Lindley.}

A vigorous bush up to $6 \mathrm{ft}$. high, abundantly furnished with bristle-like prickles on the young stems. Leaves 3 to 5 ins. long, consisting of five to nine leaflets, which are $\frac{3}{4}$ to $1 \frac{1}{2}$ ins. long, $\frac{3}{8}$ to $\frac{5}{8}$ in. wide, oval or obovate, bluish green, toothed, usually downy beneath; stipules $\frac{1}{2}$ to $I$ in. long, narrow, pointed, toothed. Flowers solitary, in pairs or threes, bright rosy pink, $2 \frac{1}{2}$ ins. across; the stalk $\mathrm{I}$ to $\mathrm{I} \frac{1}{2}$ ins. long, more or less glandularbristly; sepals $I$ to $1 \frac{1}{4}$ ins. long, expanded at the end into a leaflike tip. Fruit $\mathrm{I}$ in. long, half as wide, more or less pear-shaped, bright red, crowned with erect, persistent sepals.

A species very widely spread in nature, extending across the northern part of the Old World from Finland to Japan, and through Siberia across Behring Straits to N. Alaska. It is worth cultivating in semi-wild spots for its large pink flowers and abundant red hips.

R. SAYI, Schweinitz, is a N. American ally, perhaps a form of acicularis. It, too, has densely prickly or bristly stems, and sepals erect on the fruit, but the leaflets are often doubly-toothed, the flower-stalk is not so glandularbristly, and the fruit is rounder.

$\mathrm{R}$. acicularis differs from.blanda in its densely bristly stems, and from arkansana in the erect (not spreading) sepals on the fruit. (See also Englemannii and nipponensis.)

\section{R. ALBA, Linnaus.}

\section{(Andrews' Roses, t. 10.)}

A bush 6 to $8 \mathrm{ft}$. high, of strong growth, armed with prickles of various shapes and sizes, but usually more or less hooked. Leaflets five or seven, greyish, wrinkled, oblong, broadly oval or ovate, simply toothed, I to $2 \frac{1}{2}$ ins. 
long, downy beneath. Flowers 3 ins. across, single, white or blush-coloured, produced in clusters ; stalk, sepals, and lower part of calyx-tube bristly. Fruit bright red, oblong, $\frac{3}{4}$ in. long, with the sepals fallen away.

This beautiful rose-the type of a pleasing group of garden varieties, characterised by soft pink, often double flowers, and a charming fragranceis generally considered to be a natural hybrid between $R$. gallica and R. canina var. dumetorum. It is found wild in several parts of Europe, and has also been found in England, but always in places which show it to have been an escape from gardens.

Var. SUAVEOLENS, Dieck, is one of the chief roses from whose flowers attar is obtained. It is largely grown in Roumelia and Bulgaria.

R. MACRANTHA, Desfontaines.-A hybrid of similar origin to that of R. alba. This beautiful rose appears first to have been found wild in N.W. France in 1823. It is an erect bush, ultimately $6 \mathrm{ft}$. or more high, whose leaves have five or seven divisions. The flowers are in clusters of three to five, each blossom 3 to 4 ins. across, single, flushed with rose on first opening, then becoming almost pure white. Its large blossoms, produced in great profusion, make it one of the loveliest of the wild or semi-wild types. It may be mentioned that R. Dupontii-a beautiful rose, but not so free and hardy as this-is sometimes sold as $R$. macrantha.

\section{R. AlbertiI, Regel.}

A shrub 2 to $4 \mathrm{ft}$. high, the stems armed with numerous, straight, needlelike prickles. Leaves $I$ to 3 ins. long, composed of five to nine leaflets, which are ovate, obovate, or roundish, $\frac{1}{4}$ to $1 \frac{1}{4}$ ins. long, sharply and often doubly toothed on the terminal part, glabrous above, minutely downy beneath, often glandular on the margins; common stalk downy and glandular. Flowers white, $\mathbf{I} \frac{1}{2}$ ins. across, solitary ; flower-stalk glandular, calyx and outside of sepals smooth, the last lanceolate, woolly at the edges and inside. Fruit $\frac{3}{4}$ in. long, slenderly pear-shaped, the sepals falling away when ripe.

Discovered in 1877 in the Thianschan Mountains of Turkestan, and introduced to cultivation in the St Petersburg Botanic Garden by Dr Albert Regel. It is closely allied to R. spinosissima, but is distinguished by the downy under-surface of the leaves. The plant generally grown under the name has yellow flowers, and appears to be nearer R. Ecæ.

\section{R. ALPINA, Linneus.}

\section{(R. pendulina, Linnous.)}

A robust shrub, ultimately 6 to $8 \mathrm{ft}$. high, with branches almost or quite devoid of prickles. Leaves 2 to 6 ins. long, with five to nine leaflets, the common stalk of which is glandular and sometimes downy; stipules with large leafy tips edged with glands. Leaflets oval or ovate, I to 2 ins. long, usually double-toothed; midrib minutely prickly, otherwise smooth on both sides. Flower often solitary, deep pink, I $\frac{1}{2}$.ins. across, produced on a glandular-bristly (sometimes naked) stalk, I to $I \frac{1}{2}$ ins. long. Sepals $\frac{3}{4}$ in. long, entire, expanded at the tips, glandular or smooth outside, downy within. Fruit bright red, $\frac{3}{4}$ to $\mathrm{I}$ in. long, narrowly pear-shaped, with a neck surmounted by erect, persistent sepals.

Native of the mountains of Central and S. Europe ; cultivated in England since late in the seventeenth century. It is a rose of great interest to many because of its unarmed condition, and is sometimes known as the "rose without a thorn." Often the only prickles are a few weak ones at the base of the branches. It has fine foliage and is also very handsome in fruit, the 
long, pendulous hips of a curious bottle shape, being of large size and highly coloured. Whilst the form described above may be regarded as the type, the species as a whole is variable. One of the most distinct forms is

Var. PYRENAICA (R. pyrenaica, Gouan), Bot. Mag., t. 6724.-This has more or less glaucous branches, and is especially distinguished by glandular bristles on the flower-stalk and calyx-tube. These glands often persist on the fruit and give off, when rubbed, a distinct turpentine-like odour.

\section{R. ANEMONEFLORA, Fortune.}

A bush with spreading branches armed with scattered slender prickles and three- or five-foliolate leaves - the latter on the young barren shoots of the first year. Leaflets ovate or ovate-lanceolate, $1 \frac{1}{2}$ to 3 ins. long, very finely and simply toothed, smooth on both surfaces, dark green above, pale below. Flowers blush-white, I to $\mathrm{I} \frac{1}{2}$ ins. across, in loose corymbs, double ; the inner petals narrow and ragged; stalks slender, naked, or with a few glandular bristles. This rose was introduced from China in 1846 , by Fortune, who found it in a garden at Shanghai. It has not been found wild, and is now believed to be a hybrid between lævigata and multiflora. It is a curious and rather pretty rose, but not very hardy.

\section{R. ARkansana, Porter. Arkansas Rose.}

(R. blanda var. arkansana, Best.)

A small bush, under $3 \mathrm{ft}$. high, whose stems are densely covered with fine straight prickles. Leaflets five to eleven, oval or obovate, tapering at the base, $\frac{1}{2}$ to I in. long, simply and sharply toothed, smooth or very slightly downy. Flowers in clusters or solitary, $\mathrm{I} \frac{1}{2}$ ins. wide, pink ; sepals smooth or slightly downy, with long narrow points. Fruit $\frac{1}{2}$ in. in diameter, smooth, globose, red, crowned with the spreading sepals.

Native of the central United States. It has been placed as a variety of R. blanda, but its weaker habit, its densely prickly stems, and spreading (not erect) sepals on the fruit distinguish it.

\section{R. ARvensis, Hudson. Ayrshire Rose.}

A deciduous trailing or climbing shrub, with long slender branches no thicker than stout string, and armed with scattered, hooked prickles $\frac{1}{3}$ in. long. Leaflets three, five, or seven, ovate, oval or obovate, $\frac{3}{4}$ to 2 ins. long, simply toothed, smooth and shining green above, a little paler or glaucous below. Flowers white, with little or no fragrance, $1 \frac{1}{2}$ to 2 ins. across, one to several in a cluster ; stalks glandular ; calyx-tube smooth, sepals entire, glandular outside, downy within, $\frac{1}{2}$ in. long. Fruit dark red, round or oval.

This rose, the type of the Ayrshire group of roses in gardens, is widely spread over Europe, and is abundant in hedgerows, etc., in England and Ireland, but (in spite of its name) much scarcer in Scotland. It is very easily distinguished among British roses by its thin shoots, which often grow several yards long in a season, and by the styles being united in a column. (The only other British species with joined styles is R. STYLOSA, Desvois-a sturdy bush with the dog-rose habit.) The name "Ayrshire rose" appears to have arisen from a plant growing at Loudon Castle, in the county of Ayr, and now known as

Var. CAPREOlatA, Bot. Mag., t. 2054 (R. capreolata, Neill).-This differs from ordinary $\mathrm{R}$. arvensis in having the leaves quite green on both sides and retaining them on the branches longer. 
Var. FLORE PLENO has double white flowers and is a very pretty rambling rose, useful for quickly covering unsightly banks, etc.

\section{R. Banksi $Æ, R$. Brozn. Banksian Rose.}

A climbing shrub, up to $40 \mathrm{ft}$. high, with slender, smooth, unarmed shoots. Leaves with three or five leaflets, which are I to $2 \frac{1}{2}$ ins. long, one-third to half as wide; oblong-lanceolate, pointed, simply toothed, smooth on both surfaces except that the midrib beneath and common stalk are sometimes slightly downy; stipules narrow, and soon falling away. Flowers white or yellow, $1 \frac{1}{4}$ ins. diameter, numerous in an umbel, each flower on a stalk about I in. long, slightly fragrant; sepals $\frac{1}{3}$ in. long, ovate, entire, downy within. Fruit globose, about the size of a pea, with the sepals fallen away.

Native of China, where it has long been cultivated. It was a garden form, one with double white flowers (FLORE ALBO PLENO, Bot. Mag., t. 1954), that was first introduced to Kew in 1807 by Wm. Kerr when collecting for that institution in China. In I 824 the yellow double-flowered variety was introduced by Mr Parks for the Horticultural Society. The single yellow form (LUTEA) appeared about 1870 (see Bot. Mag., t. 7I7I). All this time what ought perhaps to be regarded as the type-the form with single white flowers-was unknown. From the following note, contributed to the Royal Horticultural Society's Journal, 1909, p. 2 I8, it would appear, however, to have existed in the British Isles some years previous to Kerr's introduction of the double white form in 1807 :-

"Four years ago I found a rose growing on the wall of Megginch Castle, Strathtay, Scotland, which seemed to be a very slender-growing form of $R$. Banksiæ. Capt. Drummond of Megginch told me it was a rose that his ancestor, Robt. Drummond, had brought with other plants from China in 1796 . This old rose had been repeatedly cut to the ground by severe winters, and had rarely, if ever, flowered. The impression, however, was that it was white and very small. Cuttings which I took to Nice flowered this year, proving themselves to be the typical single white Banksian rose, so long sought for and hidden away in this nook of Scotland for more than one hundred years."

The Banksian rose in all its forms is one of the most lovely of all, but unfortunately it is too tender and too fond of the sun to thrive in any but the more favoured parts of the British Isles. The yellow-flowered forms are considered the hardier, and will succeed on a warm wall in the south of England. But they find their most congenial conditions in the heat and brilliant sunlight of S. France, Italy, Dalmatia, etc., where these roses, but especially the double yellow, make the chief glory of the gardens in spring.

\section{R. BEgGeriana, Schrenk.}

A shrub 6 to ro ft. high; stems and branches armed with light-coloured, hooked spines, $\frac{1}{4}$ to $\frac{1}{3}$ in. long, often arranged in pairs at the base of each leaf-stalk, and with numerous others scattered near the base of the stems. Leaflets five to nine, $\frac{1}{3}$ to $\mathrm{I}$ in. long, oval or slightly obovate, simply toothed except near the base, smooth on both surfaces or downy beneath and on the common stalk, grey-green. Flowers white, $\mathrm{I}$ to $\mathrm{I} \frac{1}{2}$ ins. across, produced in clusters up to nine or more. Fruit globose, smooth, red at first, finally purplish, $\frac{1}{4}$ to $\frac{1}{3}$ in. across, sepals ultimately falling away.

Native of Central Asia, the leaves having a sweet-briar scent ; flowers unpleasantly scented; introduced about $188 \mathrm{I}$. A rose nearly allied to the above is R. ANSERINIFOLI A, Boissier, found in Afghanistan, Beluchistan, etc., which appears to differ only in the leaves being downy on both sides. 


\section{R. blanda, Aiton. Smooth or Meadow Rose.}

A shrub 4 to $6 \mathrm{ft}$. high, whose stems are quite unarmed or furnished with a few slender, scattered, straight prickles. Leaves 2 to 5 ins. long, with smooth broad stipules and a smooth or slightly downy stalk; leaflets usually five or seven, obovate, narrowed towards the base, $\frac{3}{4}$ to $2 \frac{1}{2}$ ins. long, shortly stalked, commonly quite smooth, sometimes downy, simply toothed. Flowers in clusters of three to seven or often solitary, $2 \frac{1}{2}$ to 3 ins. across, rosy pink ; sepals $I$ in. long, lanceolate, entire, with narrowly expanded tips, downy and sometimes bristly. Fruit globose or pear-shaped, red, $\frac{1}{3}$ to $\frac{1}{2}$ in. wide, crowned with erect and persistent sepals.

Widely spread in N. America from Canada and the eastern United States to the western States; introduced in 1773. A handsome rose and one of the largest flowered of the purely wild types. It bears a close general resemblance to $R$. nutkana, but the often stout and hooked spines of the latter set in pairs at the base of each leaf-stalk afford a ready distinction.

\section{R. BRaCteata, Wendland. MaCartney Rose.}

\section{(Bot. Mag., t. I377.)}

An evergreen shrub of rambling habit, reaching on walls in favoured places a height of $20 \mathrm{ft}$. Branches very thick and sturdy, covered with brownish down, and armed with pairs of stout, hooked prickles and numerous scattered bristly ones. Leaflets five to eleven, obovate, often widely truncate at the end and finely toothed, $\frac{3}{4}$ in. to (in vigorous plants) 2 ins. long, $\frac{1}{2}$ to $\mathrm{I}$ in. widc; of a very deep green and highly polished above, either smooth or downy on the midrib beneath; common stalk glandular-downy; stipules laciniated. Flowers, 3 to 4 ins. across, white, borne singly on a very short stalk which is surrounded by several large, laciniated, downy bracts. Calyxtube and sepals (the latter $\frac{3}{4}$ in. long) covered with a pale brown wool. Fruit globose, orange-red, woolly, about $\mathrm{I} \frac{1}{2}$ ins. wide.

Native of China; introduced in 1793 by Lord Macartney. This distinct and remarkable rose is, unfortunately, not very hardy except in the south-west counties and similar places, where its rich evergreen foliage and large flowers make it one of the most striking of all the wild types. Near London, even grown on a wall, it is occasionally damaged badly by frost. Its flowers appear from June until late autumn, and have a delicate fruity perfume. The "Marie Leonida" rose (or R. alba odorata of gardens), with creamy white double flowers, is a cross between bracteata and lævigata.

\section{R. CALIFORNICA, Chamisso.}

A shrub 5 to $8 \mathrm{ft}$. high, the stems armed with stout, hooked prickles. Leaves 3 to 5 ins. long, common stalk downy; leaflets usually five or seven, oval or ovate, I to $1 \frac{1}{2}$ ins. long, smooth or slightly downy above, downy beneath, especially on the midrib and nerves, simply toothed. Flowers about $\mathrm{I} \frac{1}{2}$ ins. across, pink, frequently over a dozen in a cluster; stalk and calyx-tube smooth; sepals $\frac{1}{2}$ in. or more long with expanded tips, sometimes smooth, sometimes downy. Fruit globose or slightly elongated, $\frac{1}{3}$ to $\frac{1}{2}$ in. wide, contracted into a prominent neck below the persisting erect sepals.

Native of Western N. America from British Columbia to California. It differs from $\mathrm{R}$. pisocarpa in the hooked spines, more numerous flowers in a cluster, and larger fruit. It is represented in gardens by a very pretty doubleflowered variety-FLORE PLENO, and a dwarf one-NANA. 


\section{R. Canina, Linnceus. Dog Rose.}

A strong-growing shrub, from 6 to $12 \mathrm{ft}$. high ; stems armed with scattered prickles which are uniform, hooked, with no mixture of smaller bristle-like ones. Leaflets five or seven, ovate, oval, usually simply toothed and glabrous, sometimes downy and doubly toothed. Flowers fragrant, white or pinkish, in clusters; two of the sepals are usually entire, two pinnately lobed on both margins, and one similarly lobed on one margin only. Fruit egg-shaped or roundish, bright red, with the sepals fallen away or remaining until the fruit changes colour.

The dog rose in one or other of its forms is spread over most of the cooler parts of Europe and W. Asia. It is naturalised in N. America. In the British Isles it is one of the commonest and most beautiful of wild shrubs, giving to English country lanes one of their sweetest and most characteristic charms. For this reason the dog rose is out of place in the trim garden where so many other roses with a richer beauty compete for room. The curiously diverse form of the sepals furnishes the answer to an old-time Latin riddle translated thus :-

Five brothers of one house are we, All in one little family,

Two have beards and two have none,

And only half a beard has one.

Of all roses the dog rose is the most diverse and varied in its characters. It may be taken as the type of a group of numerous forms ranging in importance from sub-species to minor varieties. Most of these are not of sufficient importance in a garden sense to need mention here, but the following more striking ones may be alluded to :-

Var. ANDEGAVENSIS, Baker.-Leaflets smooth on both surfaces and with. out glands; flower-stalks and base of calyx-tube with -numerous glandular bristles.

Var. ARVATICA, Baker.-Leaflets smooth above, paler, hairy, and glandular on the veins beneath; doubly toothed; flower-stalk smooth.

Var. BAKERI.-Leaflets slightly hairy above, very downy and more or less glandular beneath; flower-stalks short, smooth or slightly bristly, Closely allied to this is var. TOMENTELLA, Baker.

Var. CESIA.-A glaucous variety; leaflets smooth above, downy beneath ; flower-stalks with numerous bristles.

Var. CORIIFOLIA, Baker.-Leaflets broadly ovate, stout, very downy but not glandular beneath, dull and slightly hairy above; flower-stalks very short.

Var. DUMETORUM, Baker (R. dumetorum, Thuillier).-Chiefly distinguished from ordinary canina by the dull grey hue and the downy character of its leaflets, without glands beneath; flower-stalks smooth. Often regarded as a distinct species.

Var. LUTETIANA, Baker.-Leaflets smooth on both sides; flower-stalks short and smooth.

Var. SUBCRISTATA, Baker.-Fruit with erect sepals adhering until the fruit is ripe ; leaflets glaucous green and smooth ; flower-stalk smooth.

\section{R. CARolina, Linncus.}

A shrub 4 to $6 \mathrm{ft}$. high, with crowded, erect stems forming dense thickets ; prickles hooked or straight, usually in pairs at the base of the leaf. Leaves 3 or 4 ins. long, with generally seven leaflets, which are dull green above, grey beneath, narrowly oval, ovate or obovate, 1 to $2 \frac{1}{2}$ ins. long, one-third as wide, finely and simply toothed, more or less downy beneath. Flowers 2 to 
$2 \frac{1}{2}$ ins. across, deep purplish rose, fragrant, produced in clusters on glandular stalks; sepals 1 to $\frac{1}{2}$ ins. long, long-pointed, glandular and downy. Fruit red, globose, or orange-shaped, $\frac{1}{3}$ in. wide, glandular-hairy, with the sepals fallen away.

Native of Eastern N. America; introduced in 1726 . This pretty rose is useful for forming close thickets in the wilder parts of the garden or in thin woodland, flowering from June to Aúgust. In good ground it spreads rapidly by underground suckers. It is similar in habit to $R$. virginiana (lucida) and humilis, but is easily distinguished from both by its finely toothed leaflets, the absence of any bristly spines on the stems, and from virginiana especially by the dull green of its leaves.

Var. NUTTAlLiana.-Flowers larger, and produced up to Septembersome weeks later than the type. Put in commerce by Messrs Paul of Cheshunt about I 893 .

\section{R. Centifolia, Linnceus. CABbage Rose.}

\section{(R. gallica var. centifolia, Crépin.)}

A shrub up to $6 \mathrm{ft}$. in height, whose erect stems are armed with numerous prickles, the larger ones hooked. Leaflets five, of firm, even leathery texture, broadly oval, sometimes coarsely toothed, and markedly glandular on the margins and on the common stalk. Flowers very fragrant, borne in clusters, nearly always double, the numerous petals erect and overlapping like the leaves of a cabbage, red; sepals $I$ to $I_{\frac{1}{4}}$ ins. long, pinnately lobed and, like the calyx-tube and flower-stalk, covered with sticky glands. Fruit rounded or oblong, never pear-shaped.

The origin of the cabbage rose is not definitely known. It is one of the most ancient of garden roses, and one of those mentioned by Pliny. From damascena it is best distinguished by its glandular-toothed leaflets, the erect, very glandular, never reflexed sepals, and roundish or oblong fruit. It is, no doubt, closely related to R. gallica, which differs from it by its erect, stiff flower-stalks, its low habit, and smaller prickles.

Var. MUScosa (R. muscosa, Miller). Moss Rose.-The mossy character of the flowers of this loveliest of roses is due to the excessively glandular, much-divided sepals and flower-stalk. The leaf-stalk. also is of a similar character.

Var. Provincialis (R. provincialis, Miller). Provence Rose.-This is usually regarded as a form of centifolia, but its origin is probably not quite the same. It differs in the more open and not so many-petalled flowers with less glandular sepals.

\section{R. Cinnamomea, Linnceus.}

A strong-growing bush, 6 to $9 \mathrm{ft}$. high, stems erect, much branched near the top, with usually a pair of hooked prickles at the base of the leaf-stalks, and numerous others scattered on the stems, especially near the ground. Leaflets usually five or seven, oblong or slightly obovate, I to $\mathrm{I} \frac{1}{2}$ ins. long ; simply toothed except towards the base, greyish and smooth or slightly hairy above, downy and glaucous beneath. Flowers produced on often quite unarmed shoots, either singly or few in a cluster, of varying shades of red, 2 ins. across; stalks short and, like the calyx-tube, smooth; sepals entire, woolly at the edges. Fruit rlobose, or slightly elongated, red, $\frac{1}{2}$ in. wide, crowned by erect sepals.

Native of Europe, Siberia, and N. China ; cultivated in England for over three hundred years, but not, as was once believed, a native. The flowers have a somewhat spicy odour, from which the species derives its name. 
It is regarded as the type of a large group of roses whose leading distinctions are: prickles often in pairs just below the leaf-stalks; fruit red, smooth, with a thin skin.

\section{R. DAMASCENA, Miller. DAMASK ROSE.}

A bush up to $8 \mathrm{ft}$. high, the upright stems armed with stout, hooked spines from $\frac{1}{3}$ in. long, down to mere prickly bristles. Leaflets usually five, oval or ovate, simply toothed, $\frac{3}{4}$ to 2 ins. long; smooth above, pale green and downy beneath. Flowers very fragrant, borne in large clusters of sometimes a dozen, blush-white to red, each on a long stalk, densely covered with glandular bristles and small prickles. Sepals I in. or more long, slightly expanded at the tip, very much reflexed, and like the calyx-tube more or less glandular-bristly on the back. Fruit elongated, somewhat pear-shaped, I in. long, red, bristly, with the sepals fallen away.

A rose cultivated from time immemorial in E. Europe and the Orient generally. It has been suggested that it is a hybrid between $\mathrm{R}$. gallica and moschata, which is doubtful. To R. gallica it is no doubt allied, but is to be distinguished by the following characters :-taller and robuster habit, thinner leaflets with sharper and more open teeth, larger clusters of flowers, and longer more reflexed sepals. From both gallica and centifolia it is distinct in the more elongated fruit and in the absence of glands from the leaflet margins. Crossed with forms of $\mathrm{R}$. indica the damask rose gave birth to the race of "hybrid perpetual" roses which for so long held pride. of place in the family.

Var. VARIEgATA, Keller. The York and Lancaster Rose.-A vigorous bush with rounded blossoms, the petals of which are striped in pink and white.

Var. TRIGINTIPETALA is one of the most important attar roses of the East.

\section{R. Dupontin, Déséglise.}

(R. nivea, Dupont; R. moschata var. nivea, Bot. Reg., t. 86r.)

A robust shrub of loose but not climbing habit, 6 to $8 \mathrm{ft}$. high; leaflets usually five to each leaf, sometimes three or seven, bright green, $\mathrm{I} \frac{1}{2}$ to 3 ins. long, ovate or oval, finely toothed, downy beneath; the common stalk and stipules glandular and downy. Flowers white, shaded with pink, $2 \frac{1}{2}$ to 3 ins. across, single, produced in clusters ; stalk and calyx downy.

This beautiful rose is closely allied to R. moschata, and is believed to be a hybrid between that species and damascena or gallica. It flowers in July, and is one of the most noteworthy of the semi-wild types at that season, in its large white blossoms. It was raised early in the nineteenth century by a French grower of roses-a Mr Dupont.

\section{R. ECÆ, Aitchison.}

(R. xanthina, Lindley? ; Bot. Mag., t. 7666.)

A shrub 3 to $4 \mathrm{ft}$. high, erect and rigid in a wild state, but with slender, spreading branches under cultivation; bristles none ; prickles crowded, up to $\frac{1}{2}$ in. long, broad at the base. Leaves I in. or less long, with usually seven (occasionally five or nine) leaflets, which are oval or nearly round, $\frac{1}{4}$ in. or so long, with proportionately large teeth, glandular beneath. Flowers solitary, I in. across, rich buttercup yellow; stalk and calyx smooth; fruit globose, $\frac{1}{3}$ in. wide, crowned with the deflexed persistent sepals. 
Native of Afghanistan; introduced to Kew in 1880 by the late $\mathrm{Dr}$ Aitchison, who found it during the survey of the Kurrum Valley. It may possibly be the R. xanthina of Lindley, as has been suggested, but that name rests merely on a two-line description made by Lindley, in 1820 , of a drawing in the library of Mr A. B. Lambert. This is to the effect that it has "all the appearance of $R$. spinosissima, except having no setæ, and double flowers the colour of R. sulphurea. Hab. in China." It does not seem worth while to introduce confusion by dragging in a name whose sole basis is a single vague sentence. R. Ecæ is an interesting and dainty rose, but not free-growing or easy to propagate. It should have a sunny position. The name is an adaptation of Mrs Aitchison's initials - "E. C. A."

\section{R. elymaitica, Boissier.}

A low, compact bush, whose stems are armed with stout, pale-coloured, very hooked prickles, $\frac{1}{4}$ to $\frac{1}{3}$ in. long, some of which are arranged in pairs at the base of the leaf-stalks, some scattered. Leaves I to 2 ins. long; leaflets mostly five, $\frac{2}{3}$ to $\frac{1}{2}$ in. long, oval or roundish, simply and coarsely toothed, downy above, felted beneath, of firm texture. Flowers rosy white, about I in. across, usually solitary on short, bristly stalks ; calyx-tube and sepals bristly. Fruit globose, $\frac{1}{3}$ in. wide, dark red, glandular-bristly, crowned with the spreading sepals.

A little-known species from the mountains of Persia and Kurdistan, where it reaches up to $8000 \mathrm{ft}$. It is marked by the conspicuous, light-coloured, very hooked prickles, often in pairs, and by the hairy leaves. Introcluced in 1900 to Kew, where it has proved hardy.

\section{R. EngelmanniI, S. Watson.}

(Gärden and Forest, I899, fig. 121.)

A shrub 3 to $4 \mathrm{ft}$. high, with erect stems sometimes densely covered with straight, slender prickles, sometimes unarmed. Leaves composed of usually five or seven leaflets which are oval or ovate, $\frac{3}{4}$ to $1 \frac{1}{4}$ ins. long, about half as wide, the coarse teeth gland-tipped and often again toothed; upper surface smooth, lower one downy, especially on the midrib and veins; stipules dilated and edged with resinous, glandular teeth. Flowers usually solitary, rarely two or three together, $1 \frac{1}{2}$ to $2 \frac{1}{4}$ ins. across, bright rose; the stalk and calyx-tube smooth. Sepals entire, $\frac{3}{4}$ to $I$ in. long, sometimes dilated at the tip, becoming erect after the petals fall, and persisting on the fruit. Fruit bright red, egg-shaped, up to I in. long.

Native of Central and Western N. America ; introduced in 1891. This rose is very nearly allied to $R$. acicularis, and is now generally regarded as a geographical form of that species, which belongs essentially to the Old World. Engelmann's rose differs from acicularis in the frequent occurrence of a pair of slender spines below the stipules, and in the double, glandular teeth. The fruit also is more tapered at the base and the young shoots less bristly.

\section{R. Fedtschenkoana, Regel.}

(Bot. Mag., t. 7770.)

A shrub about $8 \mathrm{ft}$. high, armed with rather slender or straight prickles, sometimes $\frac{1}{2}$ in. long, often reduced to bristles; year-old wood very dark. Leaves glaucous green, $2 \frac{1}{2}$ to 5 ins. long, oval or obovate, rather coarsely toothed, smooth above, downy beneath. Flowers white, 2 ins. across, produced singly or up to four on the stalk, which is furnished with a downy, leaf-like, 
glandular-margined bract ; calyx-tube conspicuously covered with glandular bristles; sepals entire, long-pointed, glanded like the tube, inner surface and margins downy. Fruit red, $\frac{3}{4}$ in. long, rather pear-shaped, with sepals attached.

Native of Turkestan; discovered by the Russian traveller Fedtschenko (1868-187I). In a border of wild roses it is at once marked by its pale glaucous foliage, a character which distinguishes it from R. acicularis (to which it is allied), as do also the white flowers and very glandular calyx-tube.

\section{R. FEROx, Bieberstein.}

A dwarf, compact, little bush, I to $2 \mathrm{ft}$. high, of rounded form, armed with numerous decurved prickles, $\frac{1}{4}$ in. or less long; young shoots furnished with numerous glandular bristles. Leaves I to 2 ins. long, with five or seven leaflets, which are oval or roundish, $\frac{1}{4}$ to $\frac{3}{4}$ in. long, coarsely but evenly and doubly toothed ; the teetb, common stalk, stipules and under-surface copiously glandular. Flowers I to $1 \frac{1}{4}$ ins. across, white, solitary or two or three together; sepals pinnately lobed, glandular-toothed, and ciliate ; flower-stalk glandular. Fruit roundish, red, with the sepals fallen away.

Native of the Crimea and Caucasus. This interesting and pretty little rose forms a dense mass of interlacing, very spiny twigs. It is allied to the more western R. sicula, but is easily recognised by the glandular young shoots, flower-stalk, and calyx-tube ; and by the pinnately lobed sepals, which do not persist on the fruit (see also R. glutinosa). It must not be confounded with the R. ferox of Lawrance-an obsolete name for R. rugosa (Bot. Reg., t. 420).

\section{R. Foliolosa, Nuttall.}

$$
\text { (Bot. Mag., t. 85I3.) }
$$

A shrub usually under $3 \mathrm{ft}$. in height, spreading by means of underground suckers ; stems clustered, erect, either unarmed or with a few straight, slender prickles. Leaflets seven to eleven, narrowly oblong, $\frac{3}{4}$ to 2 ins. long, smooth and glossy above, downy on the midrib beneath, toothed. Flowers bright pink, 2 to $2 \frac{1}{2}$ ins. across, fragrant, usually solitary on short stalks; sepals $\frac{3}{4}$ to I in. long, bristly outside. Fruit red, bristly, orange-shaped, $\frac{1}{3}$ to $\frac{1}{2}$ in. wide, sepals spreading.

Native of the south-western United States, and distinct among American roses by reason of its oblong, rather narrow, forward-pointing leaflets, closely set on a common stalk. It is allied to virginiana, but is altogether smaller.

\section{R. Fortuneana, Lindley. Fortune's Rose.}

A climbing shrub, up to 30 or $40 \mathrm{ft}$. high; introduced from China by Fortune about 1845. It has much the general character of the Banksian rose, having three or five leaflets to each leaf, smooth and simply toothed. It is considered to be a hybrid between that species and R. lævigata. The flowers are white, double as in the forms of R. Banksiæ, but larger, and with the bristly stalk and calyx-tube of lævigata, whose influence is further shown in the large leaflets, which are downy only at the base of the midrib. A handsome and vigorous climber which thrives on sheltered, sunny walls near London.

There is a form of R. indica (var. PSEUDO-INDICA, Lindley) which has also been called "Fortuneana," but with which the above must not be confounded. It has large, double yellow flowers tinged with red, and sweetly scented. 


\section{R. Gallica, Linnaus. French ROSE.}

A bush 3 or $4 \mathrm{ft}$. high, with creeping roots and erect stems, armed with small, slender prickles, mostly $\frac{7}{16}$ to $\frac{1}{8}$ in. long, the larger ones slightly decurved. Leaves of firm texture, composed of five or seven leaflets, which are oval or ovate, rounded or blunt-pointed at the end ; 1 to 3 ins. long, $\frac{1}{2}$ to $1 \frac{1}{2}$ ins. wide; simply toothed and glandular on the margins ; smooth, dark green above, paler and downy beneath. Flowers usually solitary, sometimes in pairs or threes, dark red, 2 to $2 \frac{1}{2}$ ins. across, each on $\bullet$ an erect, stiff stalk, densely covered with small prickles and glandular bristles. Sepals spreading, ovate-lanceolate, pinnately lobed, very glandular on the back and margins. Fruit roundish or pear-shaped, $\frac{1}{3}$ to $\frac{1}{2}$ in. wide, dark dull red, with the sepals fallen away.

Native of Central and S.E. Europe ; cultivated from time immemorial. This species is the chief source of the most cherished of garden roses, and through the damask rose- of which it is supposed to be be a parent-is one of the chief sources from which the "hybrid perpetual" roses have been derived. It has hybridised with numerous other species and varieties of rose, but a discussion of the progeny belongs rather to a work on roses alone than to he present one. The cabbage rose, R. centifolia $(q . v$.$) is sometimes$ reduced to a variety of gallica. The following are a few of the more important crosses :-

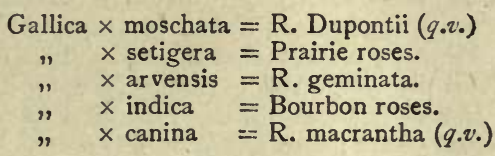

\section{R. GLUTINOSA, Sibthorp.}

A shrub of dwarf, compact, bushy habit, whose stems are copiously furnished with stiff, whitish, straight or decurved spines up to $\frac{1}{3}$ in. long, intermixed with which are numerous small needle-like prickles and glandular bristles. Leaves $1 \frac{1}{2}$ to 3 ins. long, composed of from five to nine leaflets, which are oval or obovate to roundish, $\frac{1}{4}$ to I in. long, doubly toothed except at the base, hairy and glandular on both surfaces; stipules with unattached triangular points, very glandular, as in the common stalk. Flowers white, I to $\mathrm{I} \frac{1}{2}$ ins. across, usually in pairs or solitary; stalk $\frac{1}{2}$ to $I$ in. long and, like the calyx-tube and outside the sepals, densely glandular-bristly; sepals $\frac{1}{2}$ to $\frac{3}{4}$ in. long, the larger ones pinnately lobed, woolly within. Fruit roundish or egg-shaped, $\frac{1}{2}$ in. wide, very bristly, dark red, crowred with persistent sepals.

Native of S.E. Europe, Persia, and Asia Minor. It is remarkable for its excessive covering of glandular hairs or bristles, more marked even than in its near ally, R. ferox, from which it differs also in having downy styles and persistent sepals on the fruit. From R. sicula, another ally (which has persistent sepals), it is easily distinguished by its glandular-bristly young wood and fruits.

\section{R. GYMNOCARPA, Nuttall.}

A shrub said to become occasionally to ft. high in a wild state, but scarcely half that height as represented by plants in cultivation; stems slender, with straight, scattered, slender prickles, or sometimes nearly or quite unarmed. Leaves $1 \frac{1}{2}$ to 3 ins. long; stipules edged with glands; stalk glandular and slightly prickly. Leaflets five to nine (mostly seven), usually from $\frac{1}{3}$ to $\frac{3}{4}$ in. long, narrowly oval and pointed to almost round, doubly-toothed, smooth. Flowers rosy, I to $I \frac{1}{2}$ ins. across, usually one to three in a cluster; stalks 
glandular; sepals entire, short, triangular, downy inside and on the margins. Fruit rather pear-shaped or globose, red, $\frac{1}{3}$ in. diameter, smooth, with the sepals fallen away.

Native of Western N. America from British Columbia to California and Montana. It has been associated with $\mathrm{R}$. pisocarpa, from which, however, it is readily distinguished by the presence of glands on the younger parts of the plant, the double-toothing of the leaves, and the deciduous sepals. A pretty, graceful plant, introduced to cultivation about 1893 .

\section{R. HEMISPHÆRICA, Hermann. \\ (R. sulphurea, Aiton; Bot. Reg., to 46.)}

Growing on a wall, as this rose usually is in the British Isles, it will attain a height of $10 \mathrm{ft}$. or more ; branches slender, furnished with scattered, slender prickles. Leaflets five to nine, obovate, $\frac{1}{2}$ to $1 \frac{1}{2}$ ins. long, rounded and coarsely toothed at the apex; smooth and of a glaucous hue above, more glaucous beneath. Flowers solitary, drooping, delicate sulphur-yellow, 2 ins. across, with numerous petals; flower-stalks and calyx-tube smooth or with glands; sepals I in. long, the tips coarsely toothed, leaflike.

This beautiful yellow rose is known to have been in cultivation early in the seventeenth century, but owing to its difficult cultivation has always been very rare. Near London especially it refuses to thrive, and in many places where it grows fairly well, its flowers do not expand properly. It is found in the gardens of Asia Minor, Persia, Armenia, etc. The English climate is too dull and damp to suit it, but one occasionally sees it doing well. In the gardeh of Bitton Vicarage, near Bath, Canon Ellacombe has had it in splendid health for many years; and I remember, many years ago, seeing it on the front wall of a cottage between Woking and Knap Hill. The flowers do not open well in cold, wet summers.

R. RAPINII, Boissier, is generally considered to be the wild type from which R. hemisphærica was derived centuries ago, probably in the gardens of the East. It has fine flowers $2 \frac{1}{2}$ ins. across, the five petals yellow. Fruit globose, $\frac{1}{2}$ in. diameter, crowned with spreading, downy sepals.

\section{R. HIBERNICA, Templeton. IRISH ROSE.}

A shrub 6 to $9 \mathrm{ft}$. high in gardens, with erect stems and arching branches armed with scattered prickles, the sucker shoots usually very freely furnished with prickles and bristles. Leaflets five to nine, oval or ovate, simply toothed, $\frac{3}{4}$ to $I$ in. long, downy beneath, especially on the midrib. Flowers pink, usually one to three in a cluster (sometimes more), each on a smooth stalk and $\mathrm{r} \frac{1}{2}$ ins. across ; sepals with an expanded leaflike tip, more or less pinnately lobed. Fruit globose, $\frac{1}{2}$ in. diameter, red, crowned with the persisting sepals.

This interesting rose is thought to be a hybrid between $R$. canina and R. spinosissima. It is, at any rate, fairly intermediate between them. First discovered near Belfast, in I802, by Mr John Templeton (who thereby won a prize of five guineas for the discovery of a new Irish plant), this rose has been found nowhere else up to the present, although in England two slightly different forms of it have been discovered.

Var. GLABRA, Baker.-Leaves and leaf-stalks without down.

\section{R. HISPIDA, Sims.}

(Bot. Mag., t. 1570 ; R. lutescens, Pursh ; R. spinosissima var. hispida.)

A shrub up to $6 \mathrm{ft}$. high, with sturdy, quite erect stems covered with slender, bristle-like prickles. Leaflets five to eleven, oval or obovate, $\frac{3}{4}$ to 
I $\frac{1}{4}$ ins. long, $\frac{3}{8}$ to $\frac{1}{2}$ in. wide ; simply toothed, quite free from down. Flowers solitary at the end of short lateral branches, yellow at first, changing to creamy white, 2 to 3 ins. across, opening the third or fourth week in May. Calyx and flower-stalk smooth. Fruit globose, $\frac{5}{8}$ in. diameter, nearly black when ripe, and crowned with the sepals.

There is some doubt as to the origin of this rose. It was at one time called "yellow American rose," and Pursh included it in his Flora of $N$. America. It has never been found wild in America, and all the later authorities discard it. But its real native country is still not definitely known, although it is generally believed to come from Siberia. It has been raised from seed at Kew and come quite true, which would appear to show that it is not of hybrid origin. Some authors regard it as a variety of $\mathrm{R}$. spinosissima, and it is, no doubt, closely allied to that species, but is still so distinct in habit and general appearance that it seems preferable to give it a separate standing. It is one of the most lovely of single roses.

\section{R. Hugonis, Hemsley.}

(Bot. Mag., t. 8004.)

A bush of rounded habit, $8 \mathrm{ft}$. high, and more in diameter; branches slender, sometimes gracefully arching, armed with straight, flattened spines

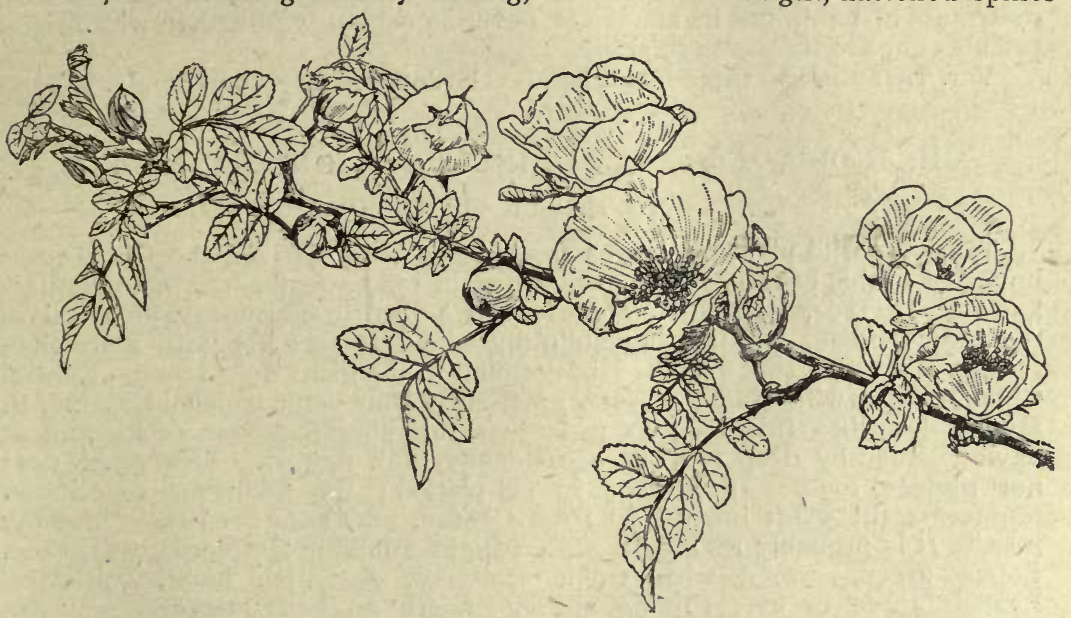

Rosa Hugonis.

of varying length, which are associated on the barren shoots with numierous bristles. Leaves I to 4 ins. long, quite smooth. Leaflets five to eleven, oval or obovate, $\frac{1}{4}$ to $\frac{3}{4} \mathrm{in}$. long; finely toothed, deep grass green. Flowers 2 ins. across, bright yellow, solitary on short lateral twigs ; flower-stalk smooth, slender, $\frac{3}{4}$ in. or less in length ; calyx-tube smooth, sepals $\frac{1}{2}$ in. long, entire, downy inside. Fruit smooth, nearly round, $\frac{1}{2}$ to $\frac{5}{8}$ in. wide, black when ripe, the calyx persisting at the top.

Native of W. China; first raised at Kew in 1899 , from seed sent to England by Father Hugh Scallan (Pater Hugo), a missionary in its native country. It is a most charming rose and the most vigorous of the yellowflowered species, beautiful even when not in flower, for its luxuriant, feathery masses of foliage. It shares with $R$. sericea the distinction of being the 
earliest of roses to flower-usually by mid-May. It is allied to the Scotch rose, but differs markedly in habit. It is perfectly hardy, tree, but neat and not rampant in growth. The spines vary much in character and are often altogether absent from some portions of the shoots; the largest are thin, flattened, triangular, $\frac{1}{2}$ in. long, reddish and translucent.

\section{R. HUMILIS, Marshall. PASTURE ROSE.}

A bush rarely more than $2 \mathrm{ft}$. high, the stems slender, sometimes straggling, and armed with a pair of spines at the leaf-bases, and with more or less numerous scattered bristles. Leaflets five to nine, thin, ovate or narrowly oval, $\frac{3}{4}$ to $\mathrm{I}_{2} \frac{1}{2}$ ins. long, toothed except near the base, glossy green, usually smooth, sometimes downy beneath. Flowers 2 to $2 \frac{3}{4}$ ins. wide, pink, produced often singly, sometimes a few in a cluster; flower-stalk and calyx more or less glandular-hairy. Fruit globose, $\frac{1}{3}$ in. wide, red, with the sepals fallen away when ripe.

Native of Eastern N. America, especially in the mountains of the southeastern States, where in many districts it is very abundant. According to Prof. Sargent, it is found growing in the shade of the forest often in rich soil. It is allied to virginiana, but is far from being so sturdy and satisfactory a plant under cultivation, besides being much dwarfer and its foliage more sparse. It is sometimes confused with $R$. nitida, which it resembles in dwarfness of habit, but its stems are never so copiously furnished with.bristly prickles nor are its leaves so shiny.

Var. TRILOBA has three-lobed petals (Garden and Forest, 1889, fig. 93).

\section{R. INDICA, Linnaus. CHINESE or MONTHLy ROSE.}

(R. chinensis, Jacquin.)

What the wild plant really was from which were derived the China roses imported to this country from near Canton in 1789 , was for long not definitely known. In 1864, Richard Oldham found a rose in Formosa which was of the indica breed, but it was doubtfully wild. It was not until more than twenty years later that Prof. A. Henry found in the glens near Ichang, Central China, a rose with single flowers, apparently truly wild, which is $R$. indica. Henry describes this rose as a large shrub climbing over rocks, and as having génerally deep red but occasionally pink flowers. This plant does not appear to be at present in cultivation; the following description represents the plant introduced from Canton, and known as the "monthly rose." It is probably $\mathrm{R}$. indica, with a slight admixture of some other rose. Stems green, armed with stout, scattered, flattened, hooked prickles. Leaflets three or five, shining above, smooth on both surfaces, glaucous beneath, $\mathrm{r}_{2}^{\frac{1}{2}}$ to 3 ins. long, ovate or oval, pointed, simply or occasionally doubly toothed; common stalk glandular and prickly. Flowers faintly perfumed, borne in clusters, more or less double, red; stalks long, erect, with a few glandular bristles; "calyx-tube smooth; sepals ovate, slightly or not at all lobed. Fruit scarlet, $\frac{3}{4}$ in. long, top-shaped. The true wild R. indica differs from the above in having solitary flowers with five petals and shorter stalks, and the glaucous colour of the leaves beneath is more pronounced.

Var. FRAGRANS (R. fragrans, Thory). Tea-scented Rose.-Introduced in 1810. A rose with a delightful fragrance like that of tea. This is the chief source of the great race of "tea roses." The yellow tea-scented rose was introduced from.China in 1824 , and is probably a parent of. the roses typified in "Marechal Niel" and "Gloire de Dijon."

Var. Minima. Fairy Rose.-A dwarf form first introduced from Mauritius by Sweet in 1810 , but no doubt originally from China. The "fairy" roses of 
gardens have been mostly derived from this. The original had pale pink flowers, single or slightly double, I to $\mathbf{I} \frac{1}{2}$ ins. diameter. (Figured in Bot. Reg., t. 538, as R. Lawranceana, Sweet.)

Var. MONSTROSA (R. viridiflora). Green Rose.-A monstrous form, in which the numerous petals have reverted to a green, leaf-like condition. It has no beauty, but is of considerable interest to morphologists. First noticed in Paris in 1855 , in the garden of a Mr Verdier, who is said to have received it from Augusta, Georgia, U.S.A.

Var. SEMPERfLORENS (R. semperflorens, Curtis, Bot. Mag., t. 284). Crimson China Rose.-Introduced from China to England by Mr Gilbert Slater in 1789. Flowers all the summer and autumn. It has much more slender stems than the "monthly" rose, the leaves are purplish red, and the flowers of a rich blood red, on very long, slender stalks.

All the roses of the "indica" type are notable for their long-continued flowering. They commence in June and continue until the winter, frequently well into November. Numerous hybrids have arisen from them, amongst which may be mentioned :-

Boursault Roses (indica $\times$ alpina).

Bourbon Roses (indica $\times$ gallica). Originated in the Isle of Bourbon about 1817.

Noisette Roses (indica? $\times$ moschata), see p. 437.

R. ruga, Lindley, Bot. Reg., t. 1389 (indica $\times$ arvensis).

\section{R. INVOLUTA, Smith.}

A shrub 3 to $9 \mathrm{ft}$. high, the stems armed with slender, straight prickles varying in length from $\frac{1}{3}$ in. to mere stiff bristles. Leaflets five to nine, oval, simply or occasionally doubly toothed, smooth above, rather downy below; common stalk prickly and downy. Flowers pink, solitary on short, bristly stalks. Fruit globose, red, with persistent sepals. Found originally in the Scottish Highlands in the early part of the nineteenth century, this rose is believed to be a natural hybrid between $R$. spinosissima and one of the VILLOSÆ group - probably tomentosa or mollis. Several forms are associated with it as varieties, some no doubt of independent origin. The most distinct of them is

Var. Sabini, Baker.-A more robust shrub up ro $\mathrm{ft}$. high, leaflets oval to ovate, doubly toothed, slightly hairy above, and very downy and glandular beneath. Fruit prickly.

\section{R. JUNDZILliI, Besser. JundzIL'S Rose.}

\section{(R. trachyphylla, Rau.)}

A bush $6 \mathrm{ft}$. or so high, the stems armed with scattered, uniform, slightly decurved prickles, not bristly or needle-like. Leaflets five or seven, oval, rounded at the base, pointed, from I to $1 \frac{3}{4}$ ins. long, doubly-toothed, smooth or nearly so above, but downy beneath, especially on the midrib and veins ; common stalk downy, and furnished abundantly with sticky glands, as are also the teeth and under-surface of the leaflets. Flowers 3 ins. across, pink, produced singly or in threes; stalk glandular-bristly; sepals edged with numerous glands, the larger ones pinnately lobed. Fruit globose or slightly egg-shaped, bright red, with the sepals fallen away.

Native of Central Europe, and one of the most distinct and handsome of the wild European roses. It is remarkable for its copious furnishing of glands. It belongs to the sweet-briar group (RUBIGINOS $Æ$ ). An identical or very similar rose has been found in England, but it is not thought to be 
a true native. From its nearest allies-rubiginosa and micrantha-it is readily distinguished by the absence of the fine bristles on the stem.

\section{R. L evigata, Michaux. Cherokee Rose.}

(R. sinica, Aiton, Bot. Mag., t. 2847 ; R. ternata, Poiret.)

A climbing shrub, growing over the branches of trees in a wild state ; its stems armed with hooked spines. Leaves three-foliolate, brilliantly glossy green, and quite smooth ; leaflets shortly stalked, oval or ovate, simply toothed, $1 \frac{1}{2}$ to 4 ins. long, half as wide, of thick, firm texture. Flowers 3 to 6 ins. across, pure white, fragrant, solitary, and borne on a very bristly stalk; sepals stout, I in. or more long, with leafy tips and more or less bristly. Fruit red, $\frac{3}{4}$ in. wide, somewhat longer, thickly set with bristles $\frac{1}{6}$ in. long, the sepals persisting at the top for a long time.

Native of China, but long naturalised in the southern United States, and first named in 1803 from specimens collected in Georgia by Pursh, the American botanist. How it reached America from China does not appear to be known, but it was in cultivation in Georgia in 1780. Afterwards it received a multitude of names, the best known of which was "sinica." Perhaps the most beautiful of all single wild roses when seen at its best, it is, unfortunately, too tender for the open air, except in such places as Cornwall. Elsewhere it can only succeed in exceptionally sheltered sunny corners. A cross between this species and sorne other rose (perhaps a form of indica) is called "Anemone." This is hardy on a wall, and bears several large, lovely, blush-coloured flowers in a cluster.

\section{R. LUtea, Miller. AUstrian Briar.}

(Bot. Mag., t. 363 ; R. Eglanteria, Linnaus.)

A shrub 3 to $5 \mathrm{ft}$. high, with erect or arching stems, not bristly, but furnished with numerous slender prickles, the largest $\frac{1}{3} \mathrm{in}$. long. Leaflets five, seven, or nine, oval or obovate, $\frac{3}{4}$ to $I \frac{1}{2}$ ins. long, half or more than half as wide; doubly toothed; dark green and smooth, or with scattered hairs above ; more or less downy and glandular beneath, like the common stalk and stipules. Flowers deep yellow, 2 to 3 ins. across, usually solitary ; calyx and flower-stalk smooth ; sepals $\frac{3}{4}$ to $I$ in. long, downy inside, lanceolate, with expanded leaflike tips, which are sometimes coarsely toothed. Fruit rarely seen, but described as globose, red, and $\frac{1}{2}$ in. diameter.

The "Austrian" briar has been known in gardens for between three hundred and four hundred years, and differs from the Scotch rose in having no bristles (as distinct from spines) on the stems. It does not appear to be a genuine native of any part of Europe, but occurs wild from Asia Minor eastwards through Persia to Afghanistan, also in the dry N.W. Himalaya and in Turkestan. It is essentially a sun-loving plant, inhabiting regions with a hot, often arid summer. It thrives, nevertheless, in many parts of S. England, but not in or near London. I believe it is a lime-loving rose, and in places where it is found not to succeed, would advise the addition of lime to the soil if it be not naturally present. The most striking of its varieties is

Var. PUNICEA, Keller (R. punicea, Miller; R. lutea var. bicolor, Bot. Mag., t. 1077). Austrian Copper Rose.-This singularly and beautifully coloured rose has petals of a coppery red. In other respects it is similar to lutea ; in fact, yellow flowers frequently appear on some of its branches. It appears to be even less amenable to the London atmosphere than R. lutea. 
All the forms of R. lutea are frequently deficient in good pollen, but have nevertheless been used for hybridising. The "Persian yellow rose" is a double-flowered variety of $\mathrm{R}$. lutea.

Harisson's double yellow rose first appeared in the garden of the Rev. Mr Harisson, of Trinity Church, New York City, about 1825. Judging by seedlings raised from it by Mr Allard of Angers, which showed by their prickles and black-purple fruits certain characteristics of R. spinosissima, it is probably a hybrid between some form of that species and $\mathrm{R}$. lutea. Its flowers are deep yellow, double; the leaves, leaf-stalks, and sepals very glandular; leaflets double-toothed.

\section{R. MACROPHYLLA, Lindley.}

A shrub $8 \mathrm{ft}$. or more high, with erect stems and arching branches, sometimes unarmed, but usually furnished with straight prickles $\frac{1}{3}$ to $\frac{1}{2}$ in. long, more or less pointed upwards. Leaves up to 8 ins. long, consisting of from 5 to I I leaflets which are I to $2 \frac{1}{2}$ ins. long, oval, toothed except near the base, smooth above, downy beneath ; common stalk downy. Flowers 2 to 3 ins. in diameter, deep blush-red, produced in clusters of varying number down to solitary blossoms; sepals I to $\mathbf{I} \frac{1}{2}$ ins. long, expanding into a leafy tip, glandular and downy like the calyx-tube and flower-stalk. Fruit elongated, pear-shaped, $\frac{3}{4}$ to $I \frac{1}{2}$ ins. long, bright red, crowned with erect, persistent sepals.

Native of the Himalaya and W. China. This fine rose was introduced about 1818 , and is among the handsomest in the genus in regard to its fruits, which often hang in numerous clusters. Their elongated, bottle-like form and crown of large sepals make them very distinct. The species is an extremely variable one, and $\mathrm{Mr}$ Wilson has recently found and introduced many allies or forms of this rose from W. China, where he found it up to I I,000 $\mathrm{ft}$. Some of them have already received distinctive names, and others when fully developed will no doubt need them. Mr de Vilmorin has also for several years cultivated several distinct forms of this species. R. macrophylla in any of its forms is worth growing, being marked by grace and distinction.

\section{R. MALYI, Kerner.}

A compact bush, 3 to $6 \mathrm{ft}$. high, the stems armed towards the base with short spines and bristle-like prickles, the flowering branches unarmed. Leaflets usually seven or nine, oval or roundish, $\frac{1}{2}$ to $1 \frac{1}{4}$ ins. long, mostly doubly toothed, smooth on both surfaces; common stalk slightly glandular. Flowers deep red, $\mathrm{I} \frac{1}{2}$ ins. diameter, usually solitary, occasionally in threes; stalk glandular, like the calyx-tube and narrowly lanceolate sepals. Fruit $\frac{3}{4}$ to $\mathrm{I}$ in. long, bottle-shaped, red, crowned with sepals.

This pleasing rose is a native of Dalmatia, and is considered to have an origin similar to that of $\mathrm{R}$. reversa-a natural hybrid between alpina and spinosissima. In most respects it resembles $R$. alpina, especially in its flowers and pendulous red fruits ; but the smaller, often orbicular leaflets with rounded bases suggest the Scotch rose. It was first distinguished in I869.

\section{R. MICROPHYLla, Roxburgh. BURR ROSE.}

(Bot. Mag., t. 6548 ; R. Roxburghii, Trattinick.)

A sturdy bush, as much in width as it is in height, which is 6 or $8 \mathrm{ft}$. ; bark grey, peeling; branches stiff, armed with a few stiff, straight prickles in pairs. Leaves 2 to 4 ins. long, consisting of nine to fifteen leaflets, which are 
oval, tapering at both ends, $\frac{1}{3}$ to $\frac{3}{4}$ in. long, firm in texture, with fine, slender teeth; smooth above, rather downy beneath, especially on the midrib when young; common stalk downy. Flowers usually solitary, delicate rose, 2 to $2 \frac{1}{2}$ ins. across, extremely fragrant ; calyx-tube and flower-stalk prickly ; sepals broadly ovate, lobed, downy. Fruit flattened, tomato-shaped, I $\frac{1}{2}$ ins. diameter, very spiny, yellowish green, fragrant.

Native of China; said to have been introduced to England in 1828, probably by way of the Calcutta Botanic Garden, where it had long been cultivated. It is a most distinct rose by reason of its peeling bark, its small numerous leaflets, and especially by its large, spiny, apple-like fruit. In the leafless state its open habit, stiff branches, and peeling bark scarcely suggest a rose. When in bloom it appears to be preferred by bees to any other rose. It is a favourite in the south United States.

Var. FLORE PLENO.-Flowers double and rather lumpy. Bot. Mag. t. 3490.

\section{R. MOLLIS, Smith.}

An erect bush, 3 to $6 \mathrm{ft}$. high, armed with scattered, slender prickles. Leaves 2 to 4 ins. long, with a downy common stalk and stipules. Leaflets five or seven, oblong or ovate, $\frac{1}{2}$ to $I \frac{1}{2}$ ins. long, doubly toothed, downy on both sides, especially beneath. Flowers rosy red, 2 ins. across, produced usually two to four together; stalk and calyx-tube usually bristly, sometimes bare; sepals $\frac{3}{4}$ in. long, narrow, with expanded tips, very glandular and downy, usually undivided, but occasionally lobed. Fruit globose, $\frac{1}{2}$ in. or more in diameter, red, surmounted by erect sepals.

Native of Europe and the Caucasus, and wild over most of Britain. It is allied to pomifera and to tomentosa, differing from the former in its smaller parts-especially leaves and fruits, its less bristly character, and the undivided sepals; and from tomentosa by the softer, more downy leaves and narrower persistent sepals.

\section{R. moschata, Miller. Musk Rose.}

\section{(R. Brunonii, Lindley; Bot. Mag., t. 4030.)}

A tall, climbing species reaching to the tops of lofty trees; the stems and branches armed with short, scattered, stout, hooked prickles. Leaves up to 7 or 8 ins. long ; leaflets five to nine, oval-lanceolate, from I to 3 ins. long, about one-third as wide, simply and regularly toothed, smooth above, more or less downy beneath; common stalk prickly and glandular. Flowers at first pale yellow, changing to almost pure white, about $I \frac{1}{2}$ ins. across, produced in corymbose clusters-or rather a cluster of corymbs-often forming an inflorescence over I foot across. Calyx-tube, sepals, and flower-stalk downy, the sepals deflexed; styles united in a column. Fruit red, $\frac{1}{3}$ in. wide, obovoid, with the sepals fallen away.

Widely spread in the East from S. Europe to N. India and China; cultivated in England for over three hundred years. This rose is remarkable for its enormous clusters of blossom, which, with the white petals and great clusters of yellow stamens, make a fine show. It is not one of the hardiest, and the long succulent shoots it makes during summer when young (often 8 to $12 \mathrm{ft}$. long) are frequently killed back in winter. There are two forms in cultivation, one with dull green foliage, the other with pale glaucous foliage. The former is the hardier, and near the London district when once established is rarely severely cut. The most suitable place for this rose is in a rough shrubbery, where it can grow over, and be supported by, other shrubs. 
At Kew a plant has spread through and over a holly $30 \mathrm{ft}$. high, and when in blossom the flowers are particularly effective against the dark glossy green leaves of its companion. The musky odour of the flowers is very faint.

Var. FLORE PLENO has double flowers, and shorter, broader leaves. It is not so vigorous a plant as the type.

Var. NEPAULENSIS (R. nepaulensis, Andrews' Roses, t. 82) has pale yellow flowers, and dull green, downy foliage.

Var. Pissardir (R. Pissardii, Carrière).-A variety or ally of moschata with pink-tinged flowers, and with leaflets not downy beneath. Introduced from Persia about 1879.

\section{R. Movesin, Hemsley and Wilson.}

$$
\text { (Bot. Mag., t. 8338.) }
$$

A shrub 6 to so ft. high, of sturdy habit; stems erect, armed with stout, pale, scattered, broad-based spines, very abundant on the barren shoots, the lower part of which is also abundantly furnished with fine needle-like

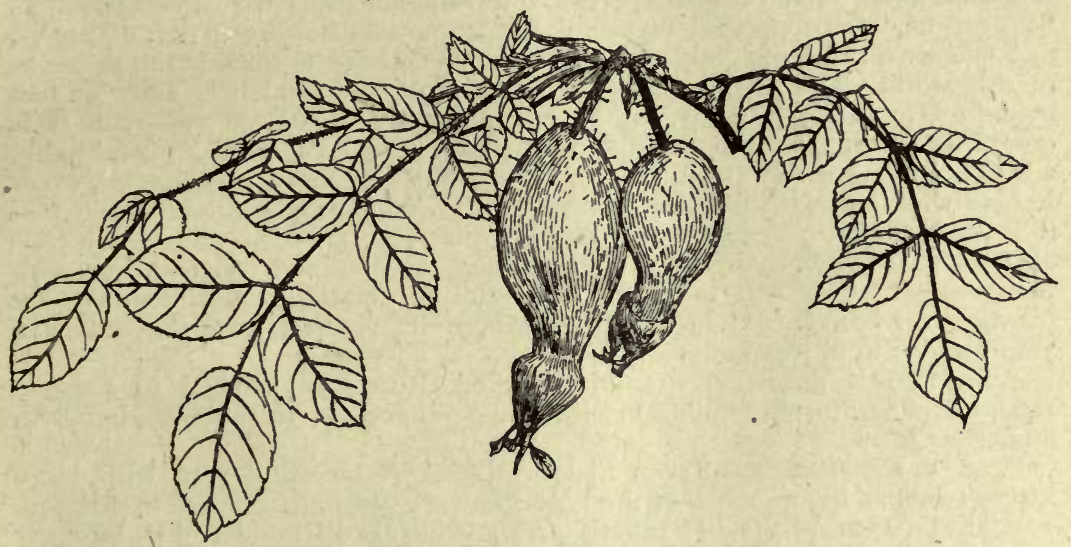

Rosa MoyesIr.

prickles. Flowering shoots much less prickly. Leaves 3 to 6 ins. long, with from seven to thirteen leaflets, which are ovate to roundish oval, $\frac{3}{4}$ to $1 \frac{1}{2}$ ins. long, simply or doubly toothed, smooth except on the midrib beneath, which is downy and sometimes prickly, dark green above, pale or somewhat glaucous beneath; common stalk glandular and prickly. Flowers a lurid dark red, 2 to $2 \frac{1}{2}$ ins. across, mostly solitary or in pairs; stalk and calyx-tube glandular-bristly; sepals I in. or more long, with expanded tips and a few glands outside, downy inside. Fruits red, bottle-shaped, $1 \frac{1}{2}$ ins. or more long, crowned by the erect, persisting sepals, between which and the 'body of the fruit is a distinct neck; glandular-hairy towards the base.

Native of W. China; first found about 1890 by Mr A. E. Pratt on the Thibetan frontier, at $9000 \mathrm{ft}$. and over, and in 1903 by Wilson, who introduced it to cultivation. It was first exhibited in flower by Messrs. Veitch in June 1908. It is perfectly hardy, and promises to be one of the most attractive of wild roses, especially in the unique colour of its petals, although undoubtedly closely allied to R. macrophylla. It is named after the Rev. J. Moyes, a missionary in W. China. 


\section{R. MULTIFLORA, Thunberg.}

(Bot. Mag., t. 7 Ir9; R. polyantha, Siebold.)

A wide-spreading bush, ultimately to to $15 \mathrm{ft}$. high, sending out every year from the main body of the plant long arching stems which are clothed with blossom the following June. Branches smooth, armed with small decurved prickles. Leaves 3 to 6 ins. long, more on exceptionally vigorous shoots, composed of seven or nine leaflets; stipules deeply laciniated, and with glandular teeth. Leaflets $\mathrm{I}$ to 2 ins. long, obovate or oval, simply toothed, slightly downy above when young, more so beneath. Flowers white, I in. across, very numerously borne in branching panicles, 4 to 6 ins. across, and as much high; stamens golden yellow. Calyx-tube and flower-stalk hairy; sepals reflexed, white-woolly and glandular. Fruit oval to round, $\frac{1}{4}$ in. long, red, with the sepals fallen away.

Native of N. China, Corea, and Japan; long known in gardens by its double and variously coloured forms; the single-flowered type was not introduced until 1875. This is the parent species (or in the case of hybrids, the dominating species) of the great and valuable group of roses classed as "polyantha," characterised by small, but numerous flowers in large trusses, and usually a rambling habit. A discussion of these is outside the province of this work. The distinctive mark of R. multiflora, which is more or less evident also in its progeny, is the conspicuously laciniated stipules. It is one of the most beautiful of wild roses ; of a robust and very graceful habit, a single bush growing $10 \mathrm{ft}$. or more high, and still more in diameter, every. branch wreathed with blossom during June. The lower branches take root if resting on loose soil, and for ordinary purposes afford a sufficient means of increase. When more are needed they can be obtained from cuttings with the greatest ease. R. multiflora is useful for clothing high fencing, for planting on banks, and in any place where its vigorous growths can have ample space to develop.

Var. FLORE PLENO. Bramble-flowered Rose.-Introduced to Kew in $\mathbf{1 8 0 4}$, this has flowers similar in size and arrangement to the type, but with numerous petals.

Var. PlatyPhylla. Seven Sisters Rose.-A beautiful rose with large leaves twice as big as those of the type ; flowers varying pale rose to crimson.

Var. Thunbergin (R. Thunbergii, Hort. Paul) is distinguished by stronger stems and longer leaves, also by larger but fewer flowers on the truss.

\section{R. NIPPONENSIS, Crépin. FujIYAMa Rose.}

( $\mathrm{R}$. acicularis var. nipponensis, Hooker fil. ; Bot. Mag., t. 7646.)

A bush 3 to $7 \mathrm{ft}$. high, with erect stems, sometimes naked, sometimes furnished with bristle-like spines, $\frac{1}{8}$ to $\frac{1}{4}$ in. long. Leaves 2 to 4 ins. long, composed of usually seven or nine leaflets (sometimes five or eleven), which are $\frac{1}{2}$ to I in. or more long, pointed or rounded at the apex, simply toothed, smooth on both surfaces; common stalk more or less bristly. Flowers almost always solitary, $1 \frac{1}{2}$ to $1 \frac{3}{4}$ ins. across, of a beautiful deep purplish red; stalk glandular-bristly ; sepals extending slightly beyond the . petals, very downy on the lower half. Fruit bright red, $\frac{3}{4}$ in. long, ovoid, crowned by the erect, persistent sepals.

Native of Japan, on Fujiyama Mountain. This rose is closely allied to acicularis, but differs in its more deeply coloured flowers and smooth leave 3. It is, perhaps, the most pleasing of the acicularis group, distinguished by their erect sepals on red fruits. Introduced to Kew in 1894. 
R. NITIDA, Willdenow.

A low bush, rarely more than $2 \mathrm{ft}$. high, with erect, often reddish stems, densely furnished with prickly bristles. Leaves 2 to 3 ins. long, very shining green, becoming purplish red in autumn; stipules with glandular-toothed margins; leaflets five to nine, narrow oblong, tapering at both ends; from $\frac{1}{2}$ in. to I i ins. long, one-quarter to one-third as wide ; finely and sharply toothed, smooth all over, and of firm texture. Flowers bright rosy red, 2 to $2 \frac{1}{2}$ ins. across, usually solitary, occasionally two to three together; flower-stalks and sepals bristly or glandular, the latter entire, lanceolate, and reflexed. Fruit globose, $\frac{1}{3}$ in. wide, scarlet, bristly, with the sepals fallen away.

Native of Eastern N. America ; introduced in 1807. A charming little rose, very distinct among dwarf kinds by its shining, narrow leaflets, its very prickly stems, and highly coloured flowers. The leaves often turn bright red in autumn.

\section{R. Noisettiana, Redouté. Noisette Rose.}

A vigorous bush, with arching branches, forming a rounded mass 8 or Io ft. through and nearly as much high, the stems armed with scattered,

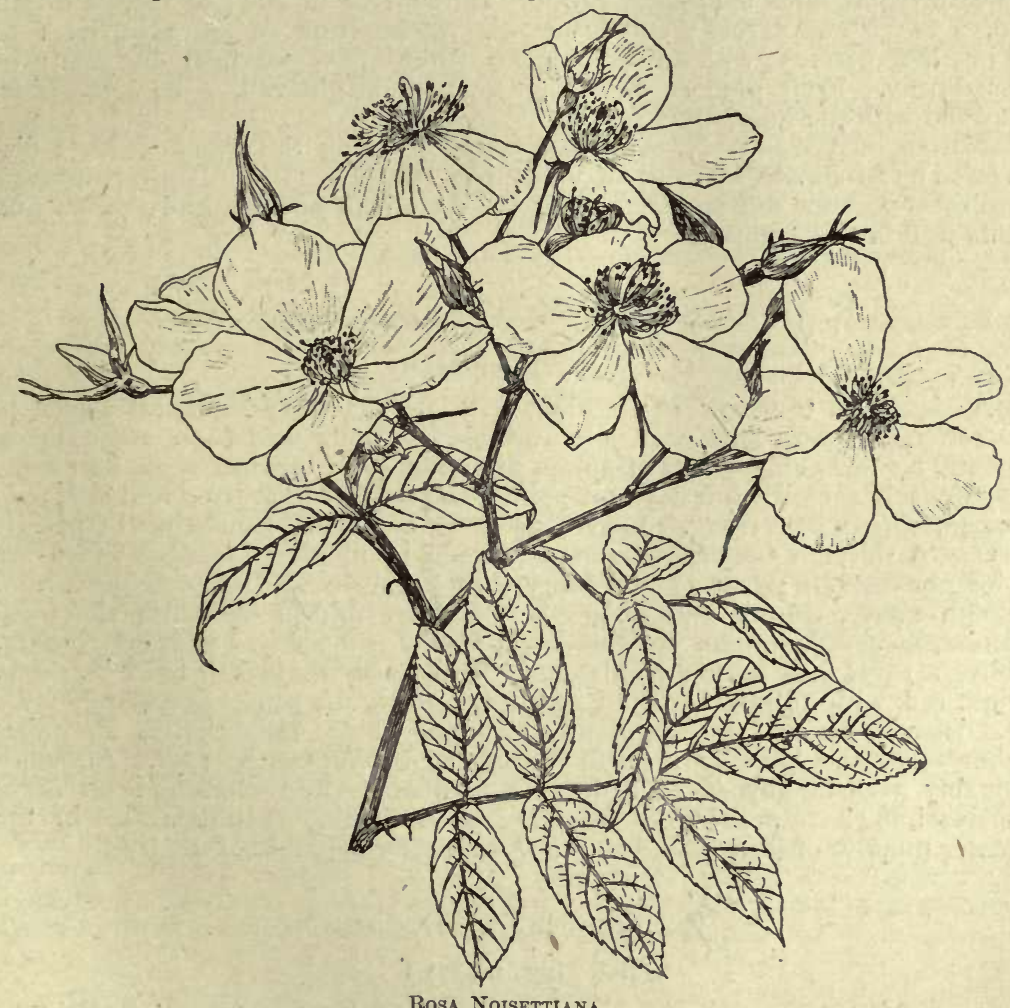

hooked prickles. Leaflets three to seven, oblong, with a short, fine point, I $\frac{1}{2}$ to 3 ins. long, more than half as wide, smooth, finely toothed. Flowers 
2 ins. across, white, produced up to twenty or more together in large terminal clusters in July and August.

This rose is considered to be a hybrid between $\mathrm{R}$. moschata and some form of R. indica raised (accidentally it is said) in N. America by Mr Phillipe Noisette, early in the nineteenth century, and by him sent to Paris in 1817. It is the type of a considerable group of garden roses, known as the "noisettes," many of which, being crossed with the gallica and indica types, depart widely from the original form, which is itself rare. Wm. Paul in his last edition of The Rose Garden gave a list of thirty-five varieties. A fine plant on one of the lawns at Kew makes a beautiful display every summer ; a small spray from it is here figured. It is difficult, however, to see any indication of $\mathrm{R}$. indica.

\section{R. NutKana, Presl. Nootka Rose.}

A robust shrub, 6 to $10 \mathrm{ft}$. high, spines stout, hooked or straight, sometimes $\frac{1}{2}$ in. or more long on the young barren stems, often absent from the flowering shoots. Leaves 3 to 5 ins. long, stipules edged with glands; leaflets five to nine, broadly oval to ovate, $\frac{3}{4}$ to 2 ins. long, simply or doubly toothed, downy beneath (sometimes smooth). Flowers solitary, or in twos or threes, bright red, 2 to $2 \frac{1}{2}$ ins. across ; calyx-tube and flower-stalk smooth; sepals I to $1 \frac{1}{2}$ ins. long, narrow, with an expanded leaf-like apex, glandular and more or less downy. Fruit globose or orange-shaped, bright red, $\frac{1}{2}$ to $\frac{5}{8} \mathrm{in}$. wide, crowned with the long, erect sepals.

Native of Western N. America, common along the Pacific coast; discovered by Archibald Menzies on Vancouver Island in 1793. It is a handsome wild rose, perhaps the handsomest of W. American species, and flowers and fruits well in this country.

\section{R. Omeiensis, Rolfe. Mount Omi Rose.}

(Bot. Mag., t. 847I.)

A shrub up to Io or $12 \mathrm{ft}$. high, with the habit and general aspect of R. sericea ; stems and branches variable in their armature, some being smooth, some having a pair of spines at the base of the leaf-stalk, and some very densely set with bristles and spines, the latter compressed and flat, awlshaped, up to $\frac{1}{3}$ in. long. Leaves $1 \frac{1}{2}$ to 4 ins. long, consisting of usually eleven or thirteen (but sometimes seventeen or nineteen) leaflets, which are oblong or obovate; $\frac{1}{4}$ to $1 \frac{1}{4}$ ins. long, $\frac{1}{8}$ to $\frac{1}{2}$ in. wide ; dark dull green and smooth above, downy and often spiny on the midrib beneath; the teeth slender, incurved, simple; common stalk downy and spiny. Flowers solitary, white, I to $I \frac{1}{2}$ ins. wide; petals four Fruit pear-shaped, $\frac{1}{2}$ to I in. long, bright red, with a thickened stalk of bright yellow, the sepals persisting.

Discovered on Mount Omi, in Szechuen, China, by the Rev. E. Faber about 1886, and later by Henry; introduced by Wilson in 1901. Although palpably a close ally of $R$. sericea, it is distinct from that and all other species known to me in the colouring of the fruit. It differs also in the greater number of leaflets and in the thick, fleshy footstalk of the fruit.

\section{R. PISOCARPA, A. Gray.}

$$
\text { (Bot. Mag., t. 6857.) }
$$

A small shrub, usually not more than 3 to $4 \mathrm{ft}$. high, of rather straggling habit ; branches slender, unarmed, or with a few small prickles, either straight or pointing upwards. Leaves 2 to 3 ins. long, with five or seven leaflets, 
which are $\frac{1}{2}$ to $\mathrm{I}$ in. long, oval or ovate, simply toothed, and, like the common stalk, downy beneath. Flowers I in. or rather more across, with rounded, overlapping, bright rosy petals ; they occur in clusters of as many as four or five, but are sometimes solitary; stalk smooth; sepals $\frac{1}{2}$ in. or more long with expanded tips, very downy within. Fruit about the size of a pea, globose, bright red, surmounted by the erect sepals.

Native of Western N. America. An interesting and brightly coloured rose, distinct in the tiny fruits.

\section{R. POMifera, Hermann. Apple Rose.}

(Bot. Mag., t. 724I ; R. villosa, Linnaus in part.)

A bush 4 to $6 \mathrm{ft}$. high, of sturdy habit; branches smooth or slightly hairy, armed with scattered, slender, but broad-based prickles up to $\frac{1}{2}$ in. long. Leaves 4 to 7 ins. long, with common stalks and stipules glandular and downy. Leaflets five or seven, oblong or ovate, 1 to $2 \frac{1}{2}$ ins. long $\frac{3}{4}$ to $1 \frac{1}{2}$ ins. wide; doubly toothed, downy on both surfaces, especially beneath. Flowers $1 \frac{1}{2}$ to $2 \frac{1}{2}$ ins. across, deep rosy pink, produced in clusters of three to six or more, each on a stalk covered thickly with glandular bristles like the calyxtube. Sepals ' I in. long, with long-tailed, pinnate lobes, very glandular-hairy. Fruit pear-shaped or rounded, rich red, $I$ to $1 \frac{1}{2}$ ins. long, and about $I$ in. wide, bristly and surmounted by the erect sepals.

Native of Central Europe and occasionally found wild in Britain, but not a true native. It is a remarkable rose, and, when well cultivated, one of the most striking, especially in the fruit, which is larger than that of any other hardy rose. It appears to thrive exceptionally well in Gloucestershire, where I have seen it in splendid condition in Lord Redesdale's garden at Batsford, and with Canon Ellacombe. Its nearest allies are mollis and tomentosa $(q \cdot v$.$) .$

[The R. villosa of Linnæus included three species which probably are connected by intermediate forms:- $\mathbf{R}$. pomifera, chiefly marked by its large leaflets and fruits, and bristly character ; R. mollis, by its soft leaves and almost entire sepals, erect in fruit ; R. tomentosa, by its late ripening fruit and reflexed sepals falling when the fruit is ripe.]

\section{R. RUBELLA, Smith.}

A hybrid of natural origin between R. spinosissima and R. alpina, and intermediate between them. It does not often exceed 4 or $5 \mathrm{ft}$. in height, the erect stems covered with bristly prickles intermixed with which are a few straight, slender spines. Leaflets five to nine, oval, $\frac{1}{4}$ to $\frac{3}{4}$ in. long. Flowers solitary, $\mathbf{I} \frac{1}{2}$ to 2 ins. across, flushed more or less deeply with red; stalk glandular-bristly. Fruit pendulous, egg-shaped, red, $\frac{3}{4}$ in. long, crowned with the sepals.

Native of the Alps of Europe. It resembles the Scotch rose in the armature of its stems and small leaves, but differs markedly in the drooping, red, rather elongated fruit. It has been included in the English flora on the strength of a supposed find on the coast of Durham. But as R. alpina is not a native, this plant must have been introduced, or be an escape from gardens. There is a series of hybrids between the Scotch and Alpine roses in which $\mathrm{R}$. rubella is about intermediate. Others are almost unarmed, like alpina ; others are as prickly and bristly as spinosissima.

\section{R. Rubiginosa, Linncus. Sweet-briar, Eglantine.}

An erect bush with arching branches, 6 to $8 \mathrm{ft}$. high in gardens; stems and branches armed with numerous, scattered, hooked prickles. Leaflets 
five, seven, or nine, ovate or roundish, doubly toothed, nearly or quite without down above, but covered beneath with sweet-smelling glands. Flowers pale $\mathrm{pink}, \mathrm{I} \frac{1}{2}$ ins. in diameter, produced singly, in threes or sevens or more to gether; flower-stalk and sepals bristly. Fruit bright red, egg-shaped, crowned with the spreading sepals.

Native of Europe, and with the dog rose one of the summer delights of English hedgerows. It is not so strong a grower as R. canina, has smaller leaves, and is always distinguished by the sweet fragrance of its leaves. On this account, and unlike the dog rose, it may well be grown in gardens. It makes a charming low hedge clipped back annually before growth recommences in spring. The fragrance is most perceptible after a shower, and whenever the atmosphere is fresh and moist.

Var. MAJOR has leaves about twice the size of ordinary rubiginosa,' and more coarsely toothed.

The sweet-briar is one of the parents of a beautiful group of garden roses known as "Penzance" briars, which were raised by the late Lord Penzance from 1884 onwards, by fertilising the flowers of this species with various other species and garden varieties. The most distinct and pleasing of these are the ones issuing from rubiginosa crossed with the yellow and coppercoloured forms of $\mathrm{R}$. lutea.

R. MICRANTHA, Smith.-A British rose common in the south of England; it differs from $R$. rubiginosa in the following respects :-A somewhat stronger shrub whose stems are not so well furnished with spines; leaves not so strongly scented, flowers smaller; the style, downy in rubiginosa, is smooth; sepals falling away from the fruit sooner. Of little value in gardens.

\section{R. RUBRIFOLIA, Villars.}

\section{(Bot. Reg., t. 430 ; R. ferruginea, Villars.)}

A shrub of erect habit, 5 to $7 \mathrm{ft}$. high, whose stems are covered with a purplish bloom, and armed with small decurved prickles. Leaflets five or seven, cvate or oval, I to $\mathrm{I}_{\frac{1}{2}}$ ins. long, simply toothed, quite smooth on both surfaces, of a beautiful purplish red, glaucous hue. Flowers deep red, $1 \frac{1}{2}$ ins. across, few in a cluster; stalk naked or with a few bristles; sepals narrow, downy inside, entire or occasionally lobed, I in. or more long, standing out beyond the petals. Fruit red, globose or nearly so, $\frac{1}{2}$ in. or rather more long, smooth, and with the sepals fallen away.

Native of Central Europe, especially the Alps and Pyrenees and other mountainous regions. It is nearly allied to $R$. canina, but is easily distinguished by the beautiful reddish colour of leaf and young stem, and by the longer sepals. Its colour makes it not only one of the most striking of roses, but also the most ornamental in vegetative (as distinct from floral) characters. Planted in groups it makes a telling feature in the landscape the summer through. The name must not be confounded with "rubifolia," a disused one for the North American R. setigera.

\section{R. RUgOsa, Thunberg. Ramanas Rose. \\ (R. ferox, Lawrance (not Bieberstein); Bot. Reg., t. 420.)}

A shrub 4 to $6 \mathrm{ft}$. high, and one of the sturdiest of roses. 'Stems stout, densely covered with prickles of unequal size, the largest $\frac{1}{3}$ to $\frac{1}{2}$ in. long; they, as well as the stem itself, downy. Leaves 3 to 7 ins. long, with large downy stipules; leaflets five to nine, oblong, $\mathrm{I}$ to 2 ins. long, shallowly toothed except towards the base, downy beneath, the very conspicuous veins giving them the wrinkled appearance to which the specific name refers; common 
stalk downy and armed with hooked spines. Flowers very fragrant, $3 \frac{1}{2}$ ins. across, purplish rose, produced singly, or a few in a cluster; petals overlapping; the calyx-tube is smooth, but the flower-stalk and sepals are downy, the latter I to $I_{\frac{1}{4}}$ ins. long. Fruit rich bright red, tomato-shaped, I in. or more in diameter, crowned with the sepals.

Native of China, Japan, and Corea ; introduced by Siebold about $r 845$. It is said to have been cultivated since I 100 A.D. in China, where the ladies of the Court long prepared a kind of pot-pourri from its petals mixed with camphor and musk. No rose hybridises more readily with others, and if seed be sown from plants growing with or near other roses, little of the progeny comes true. The consequence is that a worthless lot of mongrels have appeared, some of which have been named, but ought never to have been allowed to survive their first flowering. At the same time a group of beautiful roses has been derived from it, noteworthy for their vigorous habit, fragrant flowers, and very handsome fruits.

Var. ALBA.-Flowers white.

Var. FLORE PLENO.-Flowers purplish red, double; leaflets smaller and narrower than in the type.

Var. KAMTChATICA (R. kamtchatica, Ventenat; Bot. Reg., t. 419).-A distinct geographical variety sometimes regarded as a species. It differs from rugosa in having the stipular prickles distinct from the more bristly scattered ones, in the leaves being more obovate and rounded at the apex, and in the smaller fruits. Introduced about 1770.

A discussion of the numerous hybrids now in gardens; of the type of "Blanc de Coubert," "Mrs A. Waterer," etc., is outside the limits of this book; only a few of the more noteworthy primary ones can be noticed.

R. CALOCARPA (rugosa $x$ indica). - Sent out by Bruant of Poitiers about r89r. A handsome plant, with branches less thick than rugosa, clusters of bright red fragrant flowers, followed by globose, scarlet fruits, $\frac{3}{4}$ in. wide, and crowned with the sepals. In a sunny season it bears fruits in remarkable abundance.

R. HETEROPHYLla, Cochet (rugosa alba $\times$ lutea).--Raised by Mr Cochet of Coubert, in France, about 1894. A curious rose of little beauty. Flowers white, I to $I \frac{1}{2}$ ins. across; leaves and leaflets diverse, the later ones of the season very narrow.

R. IWARA, Siebold (rugosa $\times$ multiflora).-Introduced from Japan. Of spreading habit, intermediate between the parents; flowers small, white. This hybrid may be described as two beautiful species spoilt.

R. VILMORINII (rugosa $\times$ microphylla).-One of the best primary crosses, being intermediate in habit and foliage, and having large, single, pale pink flowers, 4 or 5 ins. across. Raised by the late Henri de Vilmorin.

The "Lady Duncan" rose (rugosa $\times$ Wichuraiana) was raised in the Arnold Arboretum. It is a rambling plant, making shoots 6 or $8 \mathrm{ft}$ : long in a year. Leaves glossy green; flowers soft rose. One of the most beautiful of these hybrids.

\section{R. Sancta, A. Richard. Abyssinian Rose}

As seen in cultivation this rose is a low, rather open bush, whose weakish stems have a few hooked, scattered prickles of unequal size. Leaflets three or five, ovate or oblong, I to 2 ins. long, often blunt-pointed, simply toothed, rough but not downy above, hairy beneath ; comnon stalk downy and more or less prickly; stipules edged with glands. Flowers 2 to 3 ins. across, pale rose, produced several together in a loose cluster, each flower on a slender, smooth stalk, I to 2 ins. long. Sepals downy and glandular, very large and pinnately lobed, the largest being $I^{\frac{1}{2}}$ ins. long, and $\frac{5}{8}$ in. wide at the base, with broad, leafy points.

Native of Abyssinia, and a close ally of R. gallica, but very distinct in the 
large deeply lobed sepals. It was introduced to cultivation by Messrs Paul of Cheshunt, who inform me that it is quite hardy. The specific name refers to its being cultivated in the vicinity of churches in Abyssinia.

\section{R. SERICEA, Lindley.}

A large spreading bush, 10 to $12 \mathrm{ft}$. high and more in diameter, with gracefully arching branches and abundant leafage. The species shows great variation in the armature of its stems and in the downiness or otherwise of its leaves, but in the typical form the stems are armed with a pair of upwardly curved prickles at the base of each leaf-stalk, and they are further furnished with numerous glandular bristles. Leaves from 2 to 4 ins. long, composed of from seven to eleven leaflets, downy beneath; leaflets $\frac{1}{4}$ to I in. long, obovate, rounded and toothed towards the apex, tapering and entire towards the base. Flowers creamy white, $I \frac{1}{2}$ to 2 ins. across, with nearly always four petals arranged like a Maltese cross; sepals $\frac{3}{4}$ in. long, downy. Fruit pear-shaped or roundish, $\frac{1}{2}$ in. wide, bright red, with persistent sepals.

Native of $\mathrm{N}$. India, and first observed on Gossan Than, a mountain in Nepal. In later years it has been found to extend many hundreds of miles along the Himalaya, reaching Bhotan and Upper Burmah in the east. The great distinctive character of $R$. sericea is the number of the petals, but this is not invariably four; towards the end of the flowering season odd flowers may frequently be seen with five. It is one of the earliest roses to blossom out-of-doors. I have noted them as early as May I 2 th.

In Mr de Vilmorin's collection at Les Barres, in France, there is a great assemblage of roses of the sericea group, and it was there that the most remarkable of them all-var. pteracantha-was first raised. The points of variation are to be found in the armature and colour of the stems, the degree of pubescence on the leaves, the number and shape of the leaflets, the colour and size of the spines and fruits. The colour of the young wood and spines is sometimes rich red, and the fruits, normally bright red, are, as I have be̊en informed by Mr de Vilmorin, yellow in the forms from Szechuen. In one of Wilson's introductions the leaves have as many as seventeen leaflets, of a size and shape suggesting those of the mountain ash.

Two varieties named by the late Mr Franchet are :-

Var. DENUDATA.-Stems unarmed; leaves quite smooth.

Var. PTERACANTHA (Bot. Mag., t. 8218). - A shrub of open, slender habit, eventually as large as the type. Stems covered when young with blood red, translucent spines which are sometimes $I_{2}^{\frac{1}{2}}$ ins. wide at the base, $\frac{1}{2}$ to $\frac{3}{4} \mathrm{in}$. deep, flat and thin, contracting abruptly to a sharp point. The second year they become grey and woody. This remarkable plant is a native of W. China, but a very similar one has been collected by Sir Geo. Watt in Manipur. These richly coloured, enormous spines, add a new attraction to wild roses. The flowers, perhaps, are smaller, and the leaflets are nine to thirteen on each leaf.

[Note, 2nd Edition.-In Plante Wilsoniana, Vol. ii., p. 331, Messrs Rehder and Wilson place all those roses which were previously considered Chinese forms of R. sericea by Franchet and Focke under R. omeiensis. I hey do not consider that the rue $R$. sericea reaches China, although they seem somewhat doubtful about the standing of certain forms found in Yunnan, which, in number of leaflets at least, resemble the Himalayan R. sericea. Variable as the Chinese forms of this rose are, they recugnise only two by name, viz., typical $R$. omeiensis and the var. pteracantha above noted. R. omeiensis differs from $R$. sericea in the greater number of leaflets and in the thickened, fleshy tootstalk of the fruit.] 


\title{
R. SERtata, Rolfe.
}

\author{
(Bot. Mag., t. 8473.)
}

A shrub of elegant habit, up to $5 \mathrm{ft}$. (perhaps more) high; branches glaucous, graceful and slender, armed with spines up to $\frac{1}{2}$ in. long, in pairs or scattered. Leaves 2 to 4 ins. long, composed of seven to eleven leaflets, which are stalkless, oval to oblong, sharply toothed.; $\frac{1}{3}$ to $\frac{3}{4}$ in. long, $\frac{3}{16}$ to $\frac{3}{8}$ in. wide; grey-green above, glaucous beneath; stipules edged with glandular hairs. Flowers few or solitary on short twigs, 2 to $2 \frac{1}{2}$ ins. across ; flower-stalk $\frac{2}{3}$ to $1 \frac{1}{4}$ ins. long, glandular-hairy or smooth; petals broadly obcordate, delicate purplish rose; calyx-lobes ovate-lanceolate, tapering to a long, narrow point, minutely downy, sometimes glandular-downy, sometimes smooth; anthers deep yellow. Fruit deep red, egg-shaped, $\frac{3}{4}$ in. long, the sepals persisting at the top.

Native of Central China ; introduced by Wilson in 1907, and flowered at Kew in June 1910. It is an extremely elegant and pretty rose, allied to R. Webbiana and R. Willmottiæ. From the former of these it differs "in its laxer habit, its few, slender, straight, stipulary thorns, and its more slender, beaked fruit. R. Willmottiæ has smaller leaves and short-stalked flowers

\section{R. SETIGera, Michaux. Prairie Rose.}

(R. rubifolia, R. Brown.)

A rambling shrub making slender stems several yards long in a season, armed with short, hooked prickles, not downy. Leaves trifoliolate, with a downy, glandular stalk and narrow stipules edged with glands. Leaflets among the largest in the genus, up to 3 ins. long by over 2 ins. wide; ovate, coarsely toothed, deep green and smooth above, pale and downy beneath. Flowers 2 to $2 \frac{1}{2}$ ins. across, deep rose, numerous in corymbs; the stalk glandular. Sepals ovate, pointed, $\frac{1}{2}$ in. long, very downy. Fruit globose, about $\frac{1}{3}$ in. diameter, with the sepals fallen away.

Native of E. and Central North America, from Ontario to Florida, ana west to Kansas and Texas. Introduced in 1800 . This is the most distinct and, in its flowers, perhaps the most beautiful of $\mathrm{N}$. American roses. It is the only one from that region belonging to the group whose styles are united in a column (Synstylæ); the only one with normally three leaflets, and the only climbing species. It is an attractive plant, producing its large, rich rosy blossoms in clusters 6 ins. or more across, but they have little or no fragrance. Flowering in July and August when few wild roses or shrubs of any kind are in flower, its value is increased. It may be trained up rough branches of oak, then left to form a tangle. Several garden varieties have been raised from it.

\section{R. SETIPODA. Hemsley and Wilson.}

A bushy shrub 6 to ro $\mathrm{ft}$. high; stems sometimes unarmed, sometimes furnished with few to many straight, stout spines. Leaves 4 to 7 ins. long, composed of five to nine leaflets, which are oval, obovate, or ovate ; $\frac{3}{4}$ to $2 \frac{1}{2}$ ins. long, half or more than half as wide; tapering towards both ends, simply or very frequently doubly toothed; dark green and smooth above, pale, rather glaucous, usually covered with glands beneath, and downy on the midrib; common stalk usually more or less glandular and prickly. Flowers purplish rose, 2 to $2 \frac{1}{2}$ ins. across, produced in lvose terminal corymbs of from over thirty down to half a dozen blossoms. Each flower is 
borne on a slender stalk I to $\mathrm{I} \frac{1}{2}$ ins. long, conspicuously furnished with numerous, spreading, glandular bristles. Calyx-tube and sepals more or less glandular bristly, the latter felted within, I in. or more long, with expanded tips. Fruit red, I in. long, bottle-shaped, the distinct neck crowned with erect persisting sepals.

Native of Central China (Hupeh); introduced to cultivation by Wilson, and now growing in the Coombe Wood nursery, where it first flowered in June I909. It is allied to macrophylla, and like all of that group is an interesting and pretty rose. The most distinctive features are the large leafy bracts on the corymb, and the very conspicuous bristles on the flower-stalks.

\section{R. SICULA, Trattinick.}

(Bot. Mag., t. 776I, as R. Seraphini.)

A close-habited, densely branched bush of rounded habit, 2 to $5 \mathrm{ft}$. high, young wood not downy, but thickly furnished with stiff, flattened, decurved spines of unequal length, the largest about $\frac{1}{4}$ in. long. Leaves $1 \frac{1}{2}$ to 2 ins. long, composed of five or seven leaflets which are broadly ovate or round, $\frac{1}{4}$ to $\frac{3}{4}$ in. long, doubly toothed, and with glands on the teeth, lower surface, common stalk, and stipules. Flowers I to $\mathbf{I} \frac{1}{4}$ ins. across, bright rose, usually solitary, sometimes two or three together ; stalk smooth or glandular-bristly; calyx-tube quite smooth; sepals lanceolate or two- or three-lobed, with glandular and ciliated margins; styles downy. Fruit about the size of a large pea, red, smooth, finally black, crowned with persistent sepals.

Native of Italy (Sardinia, Sicily, etc.) and Corsica. A neat and pleasing little rose, seldom seen in gardens, but quite hardy. It resembles $R$. ferox in its dwarf habit, small leavés, and abundant spines, but differs in the particulars pointed out under that species. It is very similar to and confused with R. SERAPHINI, Viviani, the true plant of which is not in cultivation; it differs from R. sicula in having glabrous styles.

\section{R. SIMPLICIFOLIA, Salisbury.}

(R. berberifolia, Pallas; Bot. Mag., t. 7096 ; R. persica, Michaux.)

A thin, straggling bush, 2 or $3 \mathrm{ft}$. high, with slender, wiry, downy stems furnished with hooked spines and slender prickles, spreading by means of underground suckers. Leaves glaucous, simple (consisting of one leaflet), stalkless, obovate or oval, $\frac{1}{2}$ to $\frac{3}{4}$ in. long, toothed towards the apex, covered with fine down. Flowers about $\mathrm{I}$ in. across, solitary at the end of the shoot on a slender, spiny stalk, the petals deep yellow with a crimson spot at the base; calyx-tube thickly çovered with pale prickles $\frac{1}{8}$ in. long; sepals lanceolate, downy, more or less prickly. Fruit not seen in this country, but, according to Pallas, globose, very prickly, and crowned with the persisting sepals.

Native of the Orient, Afghanistan, etc., inhabiting dry, hot regions; introduced in 1790 . This remarkable rose, distinguished from all others by the undivided leaf and absence of stipules, is exceedingly rare in cultivation. It is not really hardy perhaps in any part of the country, and never appears to have been kept more than a few years in the open air, even in such places as the Isle of Wight. Perhaps it might thrive on some sunny bank in the Isles of Scilly. A plant in a cool unshaded house at Kew, which has been growing there for over twenty years, is planted near the glass in loam mixed with lime rubble. Out-of-doors it would be most likely to succeed in some "sun-trap" on a mound of loam and rubble, and covered with a glass light 
in winter. Of various modes of propagation tried with this rose, the only one that has succeeded is to sever the suckers from the main plant, and then allow them to remain undisturbed for several months, to form roots before taking them from the soil. So distinct is this from all other roses, that it was, in 1829 , made into a separate genus by Lindley under the name of Lowea berberifolia.

R. HARDII, Cels, is a hybrid between R. simplicifolia and some other species, probably R. clinophylla. It first appeared in the Jardin de Luxembourg, Paris, in 1836 . Leaves composed of from one to seven narrowly obovate leaflets, toothed, smooth on both surfaces, stipular. Flowers 2 ins. across, petals yellow with an orange spot at the base of each; calyx-tube downy, but with few prickles. It wants much the same treatment as R. simplicifolia in regard to warmth and sunshine and perfect root-drainage, but is hardier and more amenable to cultivation.

\section{R. Soulieana, Crépin. Père Soulie's Rose.}

(Bot. Mag., t. 8158.)

A very robust shrub, up to to or $12 \mathrm{ft}$. high, forming an impenetrable tangle of branches wider than it is high. Shoots 1o to $12 \mathrm{ft}$. long are made in a year on young vigorous plants; formidably armed with pale spines, which are compressed, decurved, scattered irregularly on the shoots. Leaves $2 \frac{1}{2}$ to 4 ins. long, grey-green, composed of seven or nine leaflets, which are oval or obovate, $\frac{1}{2}$ to I in. long, finely and simply toothed, perfectly smooth on both surfaces except on the midrib, which, like the common stalk, is more or less downy. Flowers yellowish white, $\mathrm{I}_{2}^{\frac{1}{2}}$ ins. diameter, produced abundantly in July on branching corymbs 4 to 6 ins. across; stalk slender, and, like the calyx-tube, glandular; styles united; sepals attenuated, downy. Fruit orange. red, egg-shaped, $\frac{1}{2}$ in. long, $\frac{1}{3}$ in. wide, with the sepals fallen away.

Native of W. China; sent to Kew in 1899 by Mr Maurice de Vilmorin, who had raised it from Chinese seed three years before. It is one of the most robust of all roses, and well adapted for the wild garden, where it can have unlimited room, and never be touched with the knife. In such a spot it is striking all the summer because of its luxuriant grey-green foliage, but especially in July when in flower, and in autumn when the fruits have coloured.

\section{R. SPINOSISSIMA, Linnaus. SCOTCH or BuRnet Rose.}

(R. pimpinellifolia, Linnaus ; R. scotica, Miller.)

A dwarf bush with creeping roots, rarely more than 3 or $4 \mathrm{ft}$ : high in the typical state, with erect, short-branched stems covered with slender spines and stout bristles intermixed. Leaves closely set on the branches, I to $2 \frac{1}{2}$ ins. long, composed of five, seven, or nine leaflets, which are round or oval, or broadly obovate; $\frac{1}{4}$ to $\frac{1}{2}$ in. long, simply toothed, deep green, and quite smooth. Flowers $I_{\frac{1}{2}}$ to 2 ins. across, white or pale pink, solitary; stalk and calyx-tube smooth, sometimes bristly. Fruit dark brown, finally blackish, globose, $\frac{1}{2}$ to $\frac{3}{4}$ in. wide, crowned with the sepals.

Very widely spread in Europe and N. Asia; found also in Britain, frequently on dry hills, often near the sea. It is the parent of the group of garden roses known as "Scotch," as well as the type of a botanical group of species-the PIMPINELLIFOLIE-characterised chiefly by the numerous slender straight prickles of unequal size on the stems. In gardens the species gives place as a rule to its numerous and variable progeny, some of which are very beautiful in their single or double deep rose, white striped with rose, or yellow flowers. Of their abundance an estimate can be made from the fact 
that a collection of ninety varieties was got together in the gardens of Dalkeith Palace early in the nineteenth century. A consideration of these is outside the province of this work, but several natural varieties remain to be noticed.

Var. AltAICA (R. altaica, Willdenow; R. grandiflora, Lindley).-A shrub up to $6 \mathrm{ft}$. high, chiefly distinguished from spinosissima by its large size, and the absence or comparative scarcity of bristles among the prickles of the stems. The flowers are 3 ins. across, creamy white, and the leaflets up to $I$ in. long. A group of this rose when in full bloom at the end of May makes a very beautiful picture. Native of Siberia.

Var. FULGENS. - Flowers bright rose-coloured, habit like the type.

Var. LUTEA.-A vigorous bush a yard high; increasing rapidly by rootsuckers. Leaflets broadly oval, the largest I in. long, by $\frac{3}{4}$ in. wide, downy beneath. Flowers bright buttercup-yellow, 2 ins. across. This variety has much of the beauty of the Persian yellow rose, but is more amenable to cultivation-thrives as well, indeed, as the ordinary Scotch rose.

Var. MACRACANTHA. - This variety has been found near Gap, in the Alpine region of S.E. France. It is very remarkable for its spines, which are flat, rigid, $\frac{5}{8}$ in. long, $\frac{1}{4}$ in. wide at the base.

Var. MYRIACANTHA (R. myriacantha, De Candolle).-A very distinct variety (probably a good species) with the habit and flowers of ordinary spinosissima, but with longer and more numerous spines. The best distinction, however, is furnished by the numerous glands on the leaves beneath, on the leaf-stalks, stipules, flower-stalks, and sepals, and by the double toothing of the leaflets. Native of S. France.

\section{R. TOMENTOSA, Smith.}

A vigorous shrub 6 to $8 \mathrm{ft}$,, or even more high, with arching branches, closely allied to R. mollis (q.v.). Besides its more robust habit, it differs also in its leaves being much less soft to the touch; by its longer flower-stalks, and its wider more distinctly pinnately lobed sepals. The flower is about the same as in mollis, being about 2 ins. across, and produced either singly, or in cluster's up to four; petals rosy-red (rarely white). Fruit bright red, oval or rather top-shaped, slightly bristly, crowned at first with the reflexed sepals, which fall away by the time it is ripe.

Native of Britain, and spreading across Europe to the Caucasus. It has a considerable resemblance to the common dog rose, and may be grown in the wilder parts of the garden where it can take care of itself. It produces very pleasing effects when laden with bright red fruits in autumn. (See R. pomifera.)

\section{R. VIRGINIANA, Miller.}

$$
\text { (R. lucida, Ehrhart.) }
$$

A shrub 3 to $6 \mathrm{ft}$. high, forming a dense mass of erect stems, armed usually at the base of the leaves with straight or slightly hooked spines, and with scattered bristly prickles on the young sucker stems. Leaves glossy green above, 3 to 5 ins. long, composed of usually seven, sometimes nine leaflets, which are ovate or narrowly oval, I to 2 ins. long; rather coarsely toothed except towards the base; quite smooth above, often the same below, but occasionally downy on the midrib as well as on the common stalk. Flowers in clusters of often three, sometimes solitary; each 2 to $2 \frac{1}{2}$ ins. across, pink ; stalk and calyx-tube smooth or glandular; sepals I in. long, with long, slender points, glandular and downy. Fruit orange-shaped, $\frac{1}{2}$ in. wide, red, crowned at first with spreading sepals which fall away when the fruit is ripe. 
Native of Eastern N. America, and probably the first of American roses introduced to Britain. It is a useful plant for forming thickets in the wild garden, and its glossy green leaves are always pleasing. In habit it resembles R. carolina, but is easily distinguished by its glossy leaves and bristly stems. It is more nearly allied to $R$. humilis, but is a more robust shrub with more glossy leaves. Many of the flowering portions of $R$. virginiana are quite unarmed.

Var. ALBA has white flowers, and differs also from the type in the more numerous flowers and more glandular flower-stalks and calyx; leaflets paler green, with leaflets and midribs downy. Said to have been discovered in the United States about 1868, but believed by Prof. Sargent to be an escape from cultivation and a hybrid of garden origin.

Var. FLORE PLENO. - The plant grown under this name may be a hybrid between virginiana and some other rose. The flowers are double and very pretty in the bud state, and the plant differs from the type in the frequently double-toothing of its leaflets and its pinnately lobed sepals.

Var. GRANDIFLORA.-A very pretty variety, the petals being $\mathbf{I}_{4}^{\frac{1}{4}}$ ins. long and wide, and of a deep rose ; the sepals even longer, with expanded leafy tips.

\section{R. Watsoniana, Crépin.}

\section{(Garden and Forest, 1890, fig. 59.)}

A trailing shrub whose smooth, slender stems are armed with small hooked prickles. Leaflets three or five, linear, I to $2 \frac{1}{2}$ ins. long, $\frac{1}{8}$ to $\frac{1}{4}$ in. wide ; margins wavy, not toothed; downy beneath, usually mottled with yellow down the centre above; common stalk downy, glandular, spiny. Flowers pale rose, $\frac{1}{2}$ in. diameter, crowded on short broad panicles, 3 or 4 ins. wide ; sepals entire, lanceolate, very downy inside. Fruit not known.

Introduced from Japan to the United States thirty-five to forty years ago, and thence to England. The styles are united in a column, and in this as well as in its crowded small blossoms it shows affinity with R. multifora. But its long, narrow leaflets distinguish it at once from all other roses. It may not be a genuinely wild species, but a variety of Japanese garden origin. It is a rose of delicate constitution, although it thrives very well with Mrs. Chambers, near Haslemere. The best plants I have seen are at La Mortola and on Isola Madre, Lake Maggiore. But anywhere it must be regarded more as a curiosity than anything else.

\section{R. WeBbiana, Wallich.}

A graceful shrub of thin habit, 4 to $6 \mathrm{ft}$. high, whose long, slender branches are armed with straight spines $\frac{1}{3}$ to $\frac{1}{2}$ in. long, often in pairs; stems often blue-white when young. Leaves 1 to 3 ins. long, usually smooth, sometimes downy, composed of five to nine leaflets; common sta!k with tiny prickles beneath. Leaflets obovate, broadly oval, or almost round, $\frac{1}{4}$ to $\frac{3}{4}$ in. long, toothed towards the end. Flowers $1 \frac{1}{2}$ to 2 ins. across, pale pink, produced singly on short lateral twigs ; flower-stalk $\frac{1}{3}$ to $\frac{1}{2}$ in. long, smooth or slightly glandular; sepals about $\frac{1}{2}$ in. long, lanceolate, terminating in a short tail. ciliate ; calyx-tube more or less glandular. Fruit pitcher-shaped, bright red, $\frac{3}{4}$ in. long, apart from the persisting sepals with which it is crowned.

Native of the Himalaya, at from 6000 to $18,000 \mathrm{ft}$. elevation. This delightful rose, so distinct in its thin, graceful habit, its pale yellowish prickles, its tiny leaves and glaucous young stems, is also very pretty in June when covered with its blush-tinted flowers, and in autumn when carrying it s bright red fruits. It can best be propagated by layering, also by seeds, when the plant is sufficiently isolated to be safe against cross-fertilisation, but is still 
very rare in cultivation. It has a recently introduced ally in $\mathrm{R}$. Willmottix, from W. China.

\section{R. Wichuraiana, Crépin.}

(Bot. Mag., t. 742 I (as R. Luciæ).)

A procumbent shrub rising a few inches only above the ground, and making shoots ro or $12 \mathrm{ft}$. long in a season. Barren shoots unbranched, quite smooth, but' armed at irregular intervals with solitary curved prickles $\frac{1}{4}$ in. long. Flowering shoots branching and more slender. Leaves 2 to 3 ins. long, quite smooth, consisting of five, seven, or nine leaflets, the common stalk of which is armed beneath with small, hooked spines. Leaflets oval, broadly ovate, or almost orbicular, from $\frac{1}{4}$ to $\mathrm{I}$ in. long, coarsely toothed and deep polished green on both surfaces; stipules with jagged margins. Flowers nearly 2 ins. across, pure white, produced in July and August in panicles of six to ten blossoms rising out of the dense carpet of foliage ; petals often more than the normal five; sepals $\frac{1}{3}$ in. long, entire, downy. Fruit globose, $\frac{1}{3}$ in. long, not crowned by the sepals.

Native of Japan; introduced to Kew from N. America in 1891. A very distinct and beautiful rose, marked by its prostrate habit and exceedingly glossy foliage. It belongs to the same group as, and is allied to, R. multiflora and R. Luciæ. Although somewhat eclipsed now by the large number of exquisite hybrids raised from it, it is well worth growing for its own sake. It flowers when nearly all other wild roses are past, and for making a low covering for a sunny bank few plants are better suited. Among its numerous progeny are-Dorothy Perkins, Lady Gay, excelsa, Alberic Barbier, Elise Robichon, Jersey Beauty, Pink Roamer, etc.

Var. RUBRA is said to be a hybrid between this species and Crimson Rambler. Flowers single, $\mathrm{I} \frac{1}{2}$ to 2 ins. across; petals bright red, white at the base.

\section{R. Willmottiæ, Hemsley.}

\section{(Bot. Mag., t. 8186.)}

A densely branched shrub, 5 to Io $\mathrm{ft}$. high, stems glaucous when young ; branches slender, red-brown, armed with straight prickles $\frac{1}{4}$ to $\frac{3}{8}$ in. long and in pairs. Leaves $\frac{3}{4}$ to 2 ins. long, smooth (except for the stipules, which are fringed with glandular hairs), and composed of usually nine leaflets. Leaflets oblong, obovate, or nearly round, $\frac{1}{4}$ to $\frac{1}{2}$ in. long, toothed except towards the base. Flowers I to $1 \frac{1}{2}$ ins. across, bright purplish rose, produced singly on short lateral twigs; stalk $\frac{1}{3}$ to $\frac{1}{2}$ in. long, smooth. Sepals lanceolate, $\frac{1}{2}$ in. long, entire, smooth outside, white-felted within. Fruit roundish, orange-red.

Native of W. China, near the Thibetan frontier; found by Wilson when collecting for Messrs Veitch in the Sangpan Mountains, at 9500 to I I,000 $\mathrm{ft}$. elevation. It is closely allied to the Himalayan R. Webbiana, differing chiefly in the absence of glands on the calyx, and is an equally charming rose with the same finely bred appearance.

\section{ROSMARINUS OFFICINALIS, Linnceus. ROSEMARY. LABIAT}

An evergreen shrub of dense, leafy habit, forming a bush 6 or $7 \mathrm{ft}$. high and as much wide; young stems slender, downy. Leaves opposite, linear, $\frac{3}{4}$ to 2 ins. long, $\frac{1}{16}$ to $\frac{1}{8}$ in. wide; not stalked, blunt at the apex; margins recurved; dark rather glossy green above, white-felted beneath, aromatically fragrant when crushed. Flowers produced during May in 
clusters of two or three in the leaf-axils of the previous year's shoots. Corolla two-lipped, pale violet-blue and white ; calyx darker and purplish, very downy.

Native of Europe and Asia Minor; cultivated in Britain for four hundred years, probably much longer. It is the only species of the genus, but there are some distinct forms. Nearly related to the lavender, this shrub is also much associated with it in gardens. Its aromatic odour suggests nutmeg. A fragrant oil is extracted from the plant. The rosemary, which likes a sunny spot and not too heavy a soil, is scarcely so hardy as the lavender, although it is rarely injured. During the peculiarly trying winter of I908-9, however, most of the old plants at Kew were killed, whilst two-year-old plants were not injured. It is readily increased by cuttings placed in a cold frame. Old specimens form short, rugged trunks, and are very picturesque.

Both in S. Europe and in Britain the rosemary fills a notable place in folk-lore. At one time it was believed to possess a stimulating influence on the memory, and was even known as "herb of memory." The well-

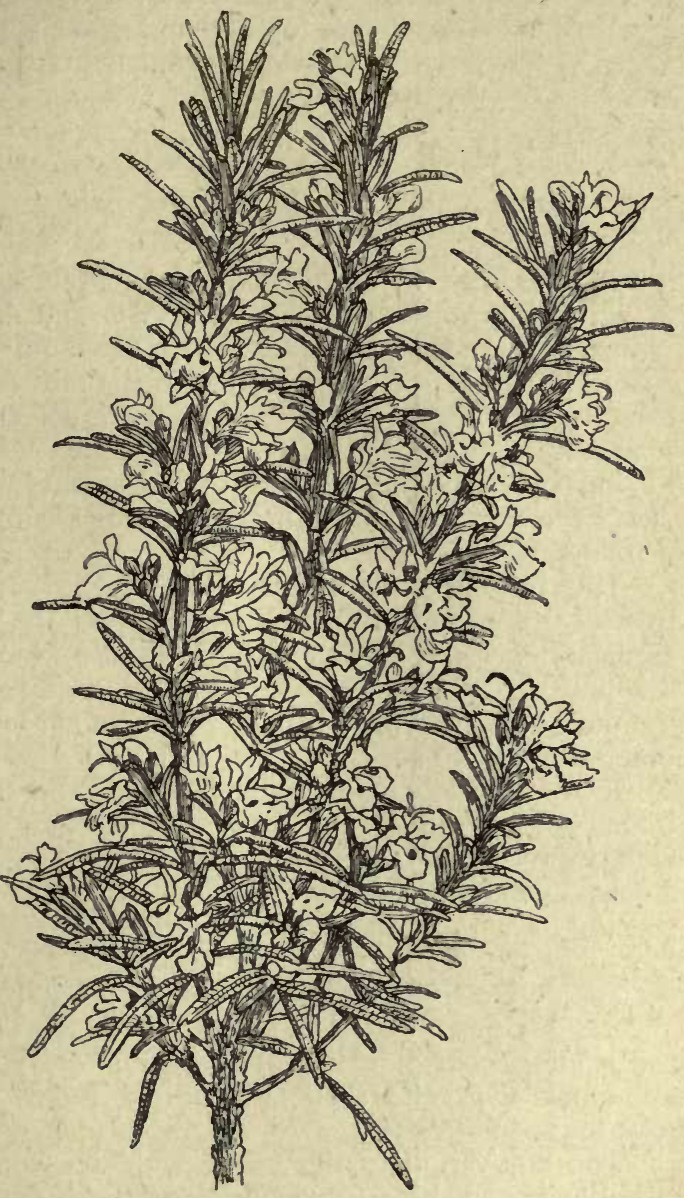

Rosmarinos officinalis. Rosemart.

known line of Ophelia, "There's rosemary, that for remembrance," gave the text and the title for a delightful play performed many times in London by Sir Charles Wyndham and Miss Mary Moore some years ago. The same idea has also given it a significance in association with the dead. In the old Chanson de Malbrouk we find the lines:

"A l'entour de sa tombe, romarin l'on planta,

Sur la plus haute branche, le rossignol chanta." 
Honey taken by bees from the flowers is considered to be of especial excellence. There is a common belief in some of the western counties that rosemary grows best where the "mistress is master," and sensitive husbands have been known to curb a too abounding vigour in their plants.

Var. FOLIIS AUREIS.-Leaves marked with yellow, but of little value.

Var. PROSTRATA. - A low-growing plant introduced from the Isle of Capri a few years ago, but it is much more tender than the type, anit will survive only the mildest winters at Kew.

\section{RUBUS. RASPBERRIES AND BRAMBLES. ROSACEA.}

It is difficult to estimate the number of species of which this genus of herbs and shrubs is composed. Specific names have been given to scores of European brambles which have no claim to rank as species, some of them scarcely as varieties. It is probable that there are at least three hundred genuine species, which are spread more or less over all the temperate and tropical parts of the globe. Of those that can be grown in the open air in the British Isles, the majority come from N.E. Asia, the rest from N. America, Europe, and (one species) from New Zealand.

The most distinctive character of the genus is the fruit, which is typically represented in the bramble and the raspberry. In both the seeds are embedded singly in juicy drupes, which are united so as to form a rounded or hemispherical cap fitted on a cone-shaped receptacle. In the raspberries the fruit can be easily pulled off the receptacle, but in the brambles the two adhere.

In the garden of ornamental shrubs the Rubi do not occupy anything like so important a place as their number would seem to justify. Comparatively few of them are worth growing for beauty of flower, but a considerable number are elegant in habit or striking in foliage. Many species have their stems more or less covered with blue-white or purple bloom, and a few of the most striking are cultivated on that account. Others are grown for the beauty or edible value of their fruits.

Besides the form of the fruit, which has already been adverted to, the leading characteristics of the genus are its usually spiny stems; its alternate leaves, either pinnate, deeply lobed, or simple; and the fivelobed persistent calyx.

The cultivation of the hardy Rubi presents no problems. They all like a loamy soil of good quality, and those of semi-scandent habit need some sort of support. This may be a stout post, up which the main shoots may be loosely tied, leaving the lateral branches free; it may be three or more rough oak branches set up to form a sort of pyramid; or the longer-stemmed ones may be used for covering pergolas or other structures of a similar nature.

In the case of the biennial-stemmed species, it is necessary to cut away the two-year-old stems which flower, bear fruit, and then die. With those whose stems are of longer duration, it is also advisable to cut away 
the older, worn-out stems occasionally. Some of the Rubi, especially these with biennial stems, have a tendency to decrease in vigour after a few years. The base in time forms a large woody root-stock which does not send up such vigorous stems as younger ones. The remedy is, of course, to renew the stock by seed or other means.

Propagation.- The mode of propagation depends largely on the character of the individual species. Those that form thickets (like odoratus and nutkanus) can be divided up into comparatively small pieces; this is best done in autumn just before the leaves fall, or in spring. Apart from any desire to increase the stock, the plants are benefited by undergoing this process occasionally. For many of the pure species, especially those with white stems like biflorus, seeds when obtainable give the best new stock. Where neither division nor seeds afford means of increase, recourse must be had to either cuttings or layers $\mathrm{R}$, deliciosus is best increased by layering; the double-flowered brambles strike root quite well from cuttings.

In the following descriptive notes the scores of so-called species native of Britain and Europe are ignored, with the exception of a few leading types. The late $\mathrm{Mr}$ Bentham reduced the shrubby species of Great Britain to three, viz., R. Idæus (the wild raspberry), R. cæsius (the dewberry), and R. fruticosus (the blackberry). The inclusion of all the blackberries under one species had the merit of simplicity, although it was perhaps taking too broad a view. It is, at anyrate, preferable to the making of an endless number of supposed species which differ from each other only in particulars so obscure and unimportant that no two authorities agree about them. The advanced study of British Rubi as carried on in recent times is only suited to persons of abundant leisure. The best and most authoritative work on the subject is the Handbook of the British Rubi, published in 1900 by the Rev. W. Moyle Rogers. In this work the author describes one hundred and three species, besides which there are numerous sub-species and varieties. The descriptions of the few British blackberries here included are based on those given in this work.

The wild brambles of the British Isles have little or no garden value, but they are useful in woodland not only for their fruits, but because they furnish one of the best of all ground covers for shady places-a cover, too, that is nearly evergreen, and entails no trouble to maintain.

The following selections of a score of species may be of use :-

I. For flower beauty.-Deliciosus, nigrobaccus ff. pl., nutkanus, odoratus, spectabilis, thyrsoideus fl. pl., ulmifolius fl. pl.

2. For white stems. - Biflorus, Giraldianus, lasiostylus, thibetanus.

3. For beauty of leaf and habit.-Bambusarum, coreanus, flagelliflorus, irenæus, trifidus.

4. For ground covering.-Hispidus, nutans.

5. For fruit. - Laciniatus, phœenicolasius.

Remarkable as many of the new Chinese species are in introducing new types of foliage to our gardens, they are curiously and almost invariably devoid of any floral beauty.

A species of Rubus has lately come into notice because of its remarkable strawberry-like, red fruits and has been called "strawberry- 
raspberry." It is R. ILLECEBRosus, Focke, a native of Mount Fuji-yama, Japan. It is not, however, shrubby, its stems dying to the ground in winter.

A few of the more important British types of Rubi are here briefly described as representing the main groups in $\mathrm{Mr}$ Moyle Rogers' monograph :-

R. CARPINIFOLIUS, Weihe and Nees.-A spreading shrub of vigorous habit, its long stems strongly angled, and armed with numerous strong, yellowish, decurved or straight prickles. Leaves with normally five leaflets, soft with greyish down beneath. Terminal leaflets oval, with a tapered point, the blade. about three times longer than the prickly stalk. Flowers with pure white petals, produced in large, very prickly panicles. Fruit of good quality, large, with the sepals spreading. Widely spread in Britain, and frequent in the wild parts of Kew and other parts south-west of London. Belonging to the same group is

R. RHAMNIFOLIUS, Weihe and Nees.-This differs in having the blade of the terminal leaflet only twice the length of the stalk. This and the other leaflets are of thick, leathery texture, covered beneath with a felt of grey-white down. Flowers white or pale pink, cup-shaped, borne in slender panicles. Sepals whitish with down, reflexed. Widely spread in South Britain. (RHAMNIFOLII group.)

R. CORYLIFolIUs, Smith.-A shrub with roundish glaucous stems that are free, or nearly free from down or hairs, but armed with irregularly scattered, awl-shaped prickles. Leaflets usually five, sometimes six or seven, broad or overlapping, leathery, covered beneath with a grey or greenish felt. Flowers white or pinkish (the petals broadly ovate), produced on an irregular panicle, the stalks of which are felted and often glandular. Fruit of no edible value; the sepals felted and reflexed. A very common bramble in Great Britain and Ireland, allied to the dewberry ( $R$. cæsius), and one of the connecting links between that species and the other groups, as shown by the glaucous, nearly or quite glabrous stems. (CAESII group.)

R. HIRTUS, Waldstern.-A prostrate, sometimes climbing shrub, with the stems covered with stalked glands and hairs, and furnished with straight, bristle-like prickles. Leaflets usually three, occasionally five, on vigorous stems, broadly oval, rounded at the base, shortly pointed, coarsely toothed, dark green and bristly above, very hairy on the veins beneath. Flowers white, produced in large panicles, the main stalk furnished with violet-coloured or purple gland-tipped hairs and bristles. Fruit globular; the sepals erect. A common species in Great Britain, very characteristic of the group with glandular hairs and bristles on the inflorescence. (GLANDULOsI group.)

R. LEUCOSTACHYS, Schleich (R. vestitus, Weihe).-A shrub with prostrate or climbing stems, angular, hairy, and clothed with felt; armed with long, straight prickles. Leaflets five, rather small, but broad in proportion to their length; the margins wavy, shallowiy and evenly toothed; upper surface bristly and glossy, lower one covered beneath witl. a soft yellowish or grey felt. Flowers (with rounded bright pink or white petals) produced in long cylindrical panicles, the stalks felted like the stems and leaves. Sepals reflexed. Fruit sweet, insipid. A common species in Great Britain, distinguished by its round petals and densely felted parts. (VESTITI group.)

R. MUCRONATUS, Bloxam.-A shrub with low, arching, or prostrate stems, which are hairy, glandular, bristly, and armed with small, needle-like prickles. Leaflets five, overlapping, very bristly above, thinly hairy beneath, evenly and shallowly toothed, the terminal one being very broadly obovate, heart-shaped at the base; the broad flat apex relieved by a short abrupt point. Flowers pinkish, produced on a long, rather cylindrical panicle; the main and subsidiary flower-stalks covered with dense felt and hairs, and furnished also with a few slender deflexed prickles and stalked glands. Sepals of fruit more or less reflexed. Widely spread through the British Isles, and especially abundant in Scotland. (EGREGII group.)

R. PULCHERRIMUS, Neumann.-A shrub with arching or prostrate stems, often of a reddish hue and hairy, armed with numerous straight or deflexed prickles. Leaflets five or six, rarely seven, rather leathery, finely toothed, bristly and grey-green above, covered beneath with a pale felt. Flowers bright pink or pinkish, produced on a long, slenderly pyramidal panicle, the main and secondary flower-stalks prickly and with stalked glands. Sepals reflexed; stamens longer than the style. Fruit of very good quality. This 
bramble is one of the commonest and most generally distributed in Great Britain. It is also one of the handsomest. (RHAMNIFOLII group.)

R. RUDIS, Wiehe and Nees.-A shrub with sub-prostrate or low arching stems of dark purplish colour, armed with short decurred prickles, and furnished with numerous stalked glands. Leaves large among brambles, and composed of three or five leaflets. Leaflets whitish downy beneath, becoming greenish, the terminal one oval or obovate, with a slenderly tapered point, doubly toothed. Flowers pink, borne on a loose, wide panicle, the stalks downy and thickly furnished with shortly stalked glands. Fruit small. Common in the south of England, and wild in the neighbourhood of kew. Distinguished by its thickly glanded stems and inflorescence. Nearly allied to and sometimes confused with it, but more widely spread northwards, is

R. ECHINATUS. Lindley. - This also has glandular stems and panicles, but the latter are cylindrical. Flowers pink, with much-reflexed sepals. It occurs as far north as Elgin. (RADULA group)

R. SILvaticus, Wiehe and Nees.-A shrub with low arching or prostrate stems. angular on the upper side, more or less furnished with pale hairs, and armed with stout deflexed prickles. Leaflets five, hairy on both sides, narrowly obovate or oval, longpointed, coarsely and irregularly toothed. Flowers white, sometimes pinkish, produced on a long panicle which is furnished with small, needle-like prickles and coarse hairs on the flower-stalks. Sepals beneath the fruit reflexed. Found chiefly in the West of England and in Wales. (SILvaticI group.)

R. SUBERECTUS, Andersson. - A strong-growing tall shrub, with sub-erect, distinctly angular stems, sparsely armed with short conical prickles set upon the angles. Leaves with from three to seven leaflets, which are thin, glossy, rather evenly toothed, lowest pair scarcely stalked. Flowers red in the bud state, afterwards white, produced in large racemes. Stamens longer than the style. Fruit dark red, sometimes almost black. Widely spread in North and Central Europe. It does not naturally root at the tips of the shoots. (SUBERECTI group.)

R. VILLICAULIS, Koehler.- - Stems prominently angled, arching, clothed with brown hairs, and armed with numerous long, mostly straight prickles. Leaflets three or five, borne on a very long main-stalk; they are of thick texture, covered beneath with long silky hairs or felt. Flowers pale pink or white (the petals obovate, the sepals reflexed). borne in a large panicle, the stalks of which are felted with down and abundantly armed with hooked prickles. Fruit of very good quality. A common bramble in Scotland, less so in the West of England. (VILLICAULES group.)

The following British species will be found described in their order : -cæsius, Idæus, laciniatus, thyrsoideus, ulmifolius.

\section{R. ADENOPHORUS, Rolfe.}

\section{(R. sagatus, Focke.)}

A robust bramble, deciduous, $8 \mathrm{ft}$. or more high ; stems erect or arching towards the top, stout, armed with stiff, short, broad-based spines, densely clothed with bristles, and with stalked glands. Leaves of the first-year (or barren) shoots mostly pinnate, 8 to 12 ins. long, with five leaflets; those of the flowering shoots shorter, with three leaflets or sometimes simple. Leaflets obliquely obovate or ovate; 2 to 5 ins. long, $1 \frac{1}{4}$ to $3 \frac{1}{2}$ ins. wide ; tapered, rounded, or heart-shaped at the base; slender-pointed, sharply and doubly toothed, dull and hairy on both sides; main-stalk bristly and furnished with stalked glands like the shoots. Flowers produced in July in terminal, cylindrical panicles 4 or 5 ins. long, the petals pink, toothed, the flower-stalks and calyx densely clothed with bristles and stalked glands. Fruit black, about $\frac{1}{2}$ in. wide, edible.

Native of W. Hupeh; introduced by Wilson in 1907. The most remarkable feature of this bramble are the conspicuous dark glands, resembling minute black-headed pins, stuck among the bristles on the stems and leafstalks, but extraordinarily abundant on the sepals and flower-stalks. The leaf next to the panicle is often simple. 


\section{R. AUSTRalis, Forster. LAWyer Vine.}

A climbing evergreen shrub reaching sometimes in its native state the summits of lofty trees. It has slender zigzagged stems, not downy but armed more or less with small, hooked prickles. Leaves usually trifoliolate, but extraordinarily variable in the size and shape of the leaflet blades. In one form (typical) they are ovate with a heart-shaped base, 2 to 5 ins. long by 1 to 2 ins. wide ; in another, known as cissoides, they are linear, 2 ins. long by $\frac{1}{6}$ in. wide, and so on, the most remarkable being a skeletonised one in which the blade of the leaflet almost disappears, being reduced to $\frac{1}{4}$ or $\frac{1}{2} \mathrm{in}$. long and from $\frac{1}{16}$ to $\frac{1}{8} \mathrm{in}$. wide, the leaf consisting of a long slender leaf-stalk branching into three, and thickly furnished with stiff, sharp, hooked spines. This is called pauperatus. Flowers unisexual, about $\frac{1}{2}$ in. across, white, pinkish, or yellowish, fragrant, produced in panicles ; the males the largest, and distinguished by a conspicuous ring of stamens. Fruit $\frac{1}{4}$ in. diameter, reddish orange.

Native of New Zealand, commonest on the borders of forests. Some authorities regard some of the forms of this Rubus as distinct species, but none of them can be confused with any other Rubi grown in Britain. Those with the smaller leaf-blades-appear to be hardiest, and will thrive in the warmer parts of the British Isles. There is a fine plant at Fota. In Canon Ellacombe's garden at Bitton a fairly large-bladed form does well against a wall. But on the whole the plant must be regarded as tender.

\section{R. BAMBUSARUm, Focke.}

An evergreen climbing shrub, with very slender, cord-like stems, covered when young with a whitish, cobweb-like substance, becoming dark green later; spines small, stiff, sharp, irregularly arranged. Leaves usually composed of three leaflets, but sometimes four or five; leaflets $2 \frac{1}{2}$ to 5 ins. long; $\frac{1}{3}$ to $\frac{3}{4}$ in. wide; pointed, narrowly lance-shaped, dark green, and smooth above, covered beneath with a thick, dull white, or pale brown felt; the margins shallowly saw-toothed, stalks $\frac{1}{8}$ in. or less long; main leaf-stalk $I$ in. long. Flowers in terminal panicles, pink, but insignificant. Fruits black, roundish, $\frac{1}{2}$ in. wide, and of good flavour.

Native of Central and W. China, where it is common in thickets and open woodland up to $7000 \mathrm{ft}$. elevation. Originally discovered by Henry in Hupeh, it was first introduced by Wilson for Messrs Veitch in 1900. It is notable for its elegant and rapid growth. When trained up a pillar or similar support, its slender branches arch outwards in all directions. Growths 10 to $12 \mathrm{ft}$. long are made in one season. The panicles of black fruits, 3 to 5 ins. long, are also handsome. (See also R. Henryi.)

\section{R. BIFLORUS, Buchanan-Hamilton.}

\section{(Bot. Mag., $t$ 4678.)}

A deciduous shrub, with erect stems up to $10 \mathrm{ft}$. high, and I in. thick at the base, covered with a thick, white, waxy coating, and armed with straight broad-based spines. Towards the top the stems branch freely, the branches also being white, and, like the leaf stalks and often the midrib, spiny. Leaves 4 to 10 ins. long, composed of three to five leaflets, which are dark green above, covered beneath with a close white felt, ovate, pointed, sharply and irregularly toothed, and from $I_{2}^{\frac{1}{2}}$ to 4 ins. long. Flowers terminal and axillary, white, $\frac{3}{4}$ in. across; fruits yellow, roundish, $\frac{3}{4}$ in. diameter, edible.

Native of the Himalaya up to $10,000 \mathrm{ft}$; introduced in 1818. Among the 
longer cultivated, white-stemmed raspberries this is by far the most effective, although it is no doubt equalled by some of the newer Chinese species (see Giraldianus and lasiostylus). Its flowers are of little consequence, being small and of little beauty. It should be raised from seed (which ripens here), and planted in groups of not less than half a dozen. The soil should be a good loam, the aim being to produce stout thick stems, for the stouter they are, the whiter and more persistent is their waxy covering. After the previous year's stems have flowered and borne fruit, they should be cut away (usually about August) leaving only the virgin growths of the year. During autumn and winter a group of this Rubus makes one of the most striking plant pictures in the open air.

Var. QUINQUEFLORUS. - A vigorous Chinese form introduced by Wilson in 1907 , with the terminal inflorescence composed most frequently of five (sometimes up to eight) flowers. In the type they are usually two or three.

\section{R. CASIUS, Linnaus. DEWBERRY.}

A deciduous shrub, with slender creeping stems, prickly, and covered with a whitish bloom when young. Leaves usually composed of three leaflets which are green on both sides. Flowers white, in small clusters. Fruit composed of a few large carpels, covered with a blue-white bloom when ripe.

This is one of the British brambles easily distinguished from all the forms of common blackberry by the few but large "pips" composing the fruit, and by their being covered, like the young stems, with a white or bluish bloom. It is common in Britain and over Europe, extending into N. Asia. Of no value for gardens.

\section{R CANADENSIS, Linnceus. LOW BlackBerRy.}

(Bot. Mag., t. 8264 ; R. Millspaughii, Britton.)

A deciduous shrub, with erect or arching stems 6 to $8 \mathrm{ft}$. high, smooth, unarmed, or furnished with a few short prickles. Leaves long-stalked, composed of five leaflets arranged as in the horse-chestnut, quite smooth on both surfaces except for inconspicuous tufts of down in the vein-axils beneath; leaflets lanceolate, $2 \frac{1}{2}$ to 6 ins. long, $1 \frac{1}{4}$ to 2 ins. wide, long-pointed, rounded or slightly heart-shaped at the base. The terminal leaflet has a stalk 1 to $1 \frac{1}{2}$ ins. long, the middle pair have stalks about half as long, whilst the basal pair are scarcely stalked at all. The leaflets are occasionally reduced to three. Flowers white, I in. across, borne in downy racemes which terminate short shoots from the previous year's wood; each flower has a slender, downy stalk $\mathrm{I}$ in. long. Fruit black, juicy.

Native of Eastern N. America. This blackberry flowers in June and is then very pretty, the upper part of the previous year's stems being crowded with racemes of white flowers.

\section{R. CHRoösepalus, Focke.}

A large, semi-evergreen, straggling shrub, with round, slender, smooth stems armed with short, decurved prickles. Leaves simple, heart-shaped, with a long tapering apex, 3 to 7 ins. long, more than half as wide; the margins very finely and sharply toothed, and often scalloped into a few broad, very shallow lobes; . f firm texture; smooth above, but conspicuously silvery beneath with a close felt; stalks smooth, I to $2 \frac{1}{2}$ ins. long, with one or two spines. Flowers borne in a terminal panicle, 6 to 9 ins. long; each flower $\frac{1}{2}$ in. across with no petals, but a coloured, downy calyx. Fruit black, small, and of poor flavour. 
Native of Central China; originally discovered by Henry; introduced to cultivation by Wilson about 1900 . Its leaves bear a striking resemblance to those of Tilia argentea. A renıarkably distinct as well as rather handsome and effective shrub. I do not know that it has flowered under cultivation.

\section{R. CORCHORIFOLIUS, Linnceus fil.}

A deciduous shrub of vigorous growth, spreading by underground suckers; stems erect, 6 to $8 \mathrm{ft}$. high, branching towards the top, round, covered with an exceedingly fine down when young, and furnished with rather broadbased prickles. Leaves simple, ovate, with a heart-shaped base ; 3 to 7 ins. long, two-thirds as wide ; those of the sterile sucker stems very deeply three-lobed, purplish when young; margins irregularly toothed; upper surface dull dark green, nearly smcoth; the lower one paler and downy about the veins; midrib spiny; leaf-stalk $\mathrm{I}$ to $\mathbf{I} \frac{1}{2}$ ins. long, spiny. Flowers white, borne singly or a few together on short lateral twigs. Fruit large, bright red, and Mr Wilson informs me, of "delicious, vinous flavour."

Introduced by Wilson in 1907 from Central China, but described and named by the younger Linnæus as long ago as 178I from Japanese specimens. It appears to be widely spread in China and Japan. It may prove useful in the wild garden, judging by the way it spreads in borders.

\section{R. COREanus, Miquel.}

A deciduous shrub, 8 to $10 \mathrm{ft}$. high (it has been found $\mathrm{I} 5 \mathrm{ft}$. high in a wild state), with erect or arching, stout, biennial stems, branching towards the top ; smooth, but covered with a blue-white bloom, and armed with stiff, broad-based spines, up to $\frac{1}{2}$ in. long. Leaves pinnate, 6 to 10 ins. long, composed usually of seven leaflets, which are ovate or broadly oval, from $1 \frac{1}{2}$ to 3 ins. long, I to 2 ins. wide; the lateral ones stalkless or nearly so, tapering at the base and smaller than the terminal one, which is broader, rounded or heart-shaped at the base, and stalked; all are parallel-veined, dark lustrous green, coarsely toothed, except towards the base, and have silky hairs on the veins when young. Flowers borne in flattish clusters terminating short shoots from the wood of the previous year. Fruit of various colours from red to nearly black, edible but small, and of poor flavour.

Native of Corea and China; introduced from the latter country in 1907 by Wilson, who found it at altitudes up to $6000 \mathrm{ft}$. It is one of the handsomest of all Rubi in its vigorous blue-white stems and beautiful pinnate foliage, and may prove a valuable acquisition in gardens should it be quite hardy.

\section{R. CRATAgifolius, Bunge.}

An erect, deciduous shrub of stiff habit, 6 to $8 \mathrm{ft}$. high, with stout biennial stems branched towards the top, grooved and armed with small scattered prickles. Leaves on the barren shoots of the year, large, palmately three- or five-lobed, 5 to 8 ins. across; heart-shaped at the base, sharply and often doubly toothed, downy beneath; stalks and midrib prickly; leaves of the flowering twigs much smaller, usually three-lobed. Flowers $\frac{3}{4}$ to $\mathrm{I}$ in. across ; produced in clusters terminating short twigs; petals white, prettily crimped at the margins; calyx segments lanceolate, much decurved. Fruit the size of a small raspberry, red.

Native of China, Corea, and Japan. The name cratægifolius is only appropriate to the small leaves of the flowering twigs; on the barren, firstyear stems they are more like those of a vine or maple, and in good soil are sometimes of very large size -8 to 12 ins. across. 


\section{R. DELICIOSUS, James.}

(Bot. Mag., t. 6062.)

A deciduous shrub of sturdy habit, reaching 6 to $10 \mathrm{ft}$. in height, bark peeling; branches often arching or pendulous, quite unarmed, downy when young. Leaves like those of a black currant in shape and size, being threeor five-lobed, with jagged edges, the base truncate or heart-shaped; $1 \frac{1}{2}$ to 3 ins. long, rather more wide, downy on both sides when young, especially

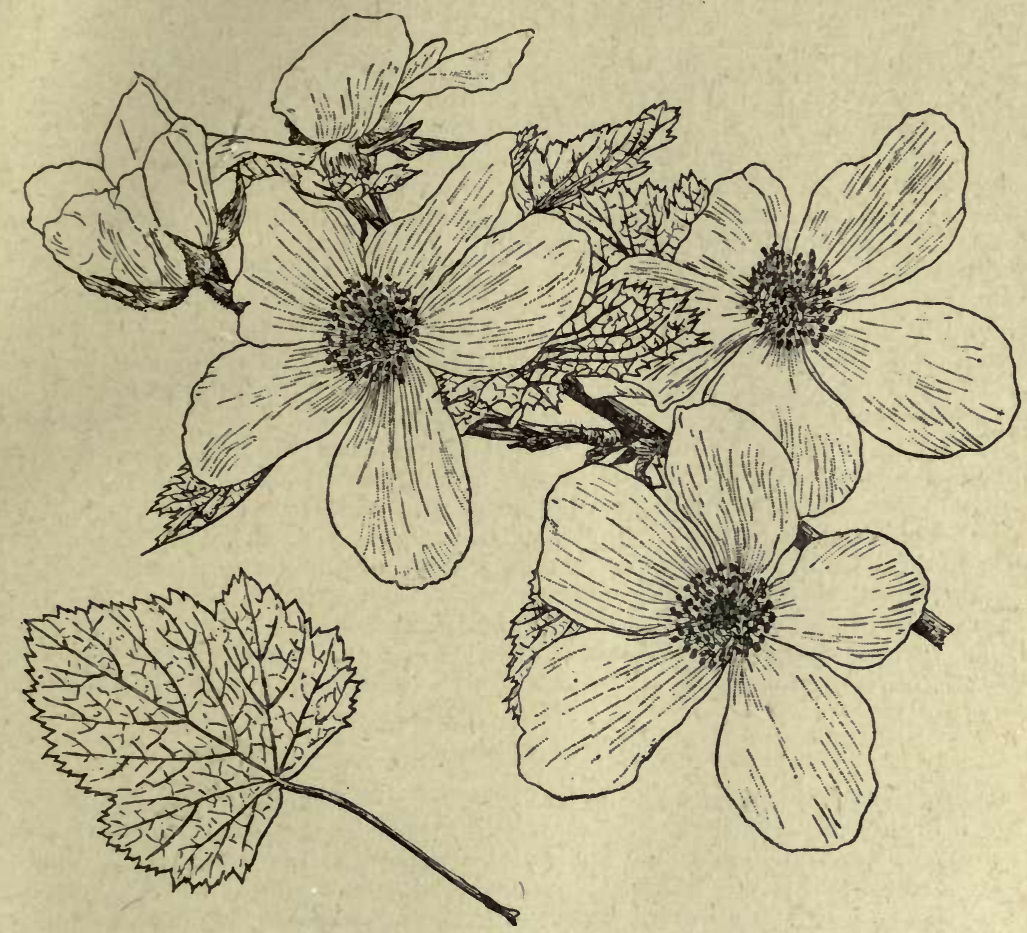

Rubus Deliciosus.

beneath; stalk I to $I \frac{1}{2}$ ins. long. Flowers pure white, 2 ins. across, borne in May on short twigs from the previous year's branches; sepals downy, ovate, $\frac{1}{2}$ in. long. Fruit $\frac{1}{2}$ in. across, dry, and of no flavour.

Native of the Rocky Mountains, where it was discovered in 1820 by Dr James, who gave it the name it bears, although the reason why has been a problem ever since, for its fruit is not delicious. It is, however, the most lovely of all Rubi in regard to its flowers, which are as beautiful as single roses, and as profusely borne. It was introduced in 1870 . It is not very easily increased by cuttings (especially the better of two forms in cultivation), but can be layered, although the layers will sometimes take a twelvemonth before they become sufficiently rooted to be removable. A good loamy soil, a sunny position, and an occasional pruning out of the old wood complete its requirements. It is one of the élite of hardy shrubs. 


\section{R. FLAGELLIFLORUS, Focke.}

A climbing evergreen shrub, with slender, graceful stems growing 5 or $6 \mathrm{ft}$. in length in one season; when young they are covered with a whitish felt, sprinkled amongst which are tiny decurved prickles. Leaves broadly ovate, long-pointed, the base heart-shaped; the largest are 6 or 7 ins. long, and about two-thirds as wide, shallowly lobed on the margins as well as finely and sharply toothed; the upper surface has appressed hairs between the veins, the lower one is covered with a thick, yellowish felt; stalk $1 \frac{1}{2}$ to $2 \frac{1}{2}$ ins. long; slightly spiny. Flowers white, borne in axillary clusters. Fruits shining black, $\frac{1}{2}$ in. wide, edible.

Native of Central and W. China, up to $6000 \mathrm{ft}$.; introduced for Messrs Veitch by Wilson about 1901 . In habit this is one of the most elegant of the new Chinese Rubi, and one of the handsomest in its foliage. When trained up a post or other support, the slender, whip-like shoots push out in all directions. The leaves often put on a marbled appearance in the shade. The appropriate name of "flagelliformis" is rather commonly applied to this plant, but the one given above is correct.

\section{R. FLOSCUlOSUS, Focke.}

A deciduous shrub up to ro or I2 $\mathrm{ft}$. high; the stout stems erect, arching at the much-branched top, biennial, smooth except for a few spines. Leaves pinnate, 4 to 7 ins. long, composed of five or seven leaflets which are ovate, $\frac{3}{4}$ to $1 \frac{1}{2}$ ins. long; the terminal one larger, often three-lobed, and 3 ins. long; smooth above or becoming so, covered beneath with a close white felt; coarsely, often doubly toothed. Flowers small, pink, $\frac{1}{4}$ in. wide, produced in narrow, cylindrical racemes 2 to 4 ins. long, terminating the shoot, and in shorter ones from the axils of the terminal leaves. Fruit small, very dark red, or black.

Native of Central and W. China; introduced by Wilson in 1907. A verv vigorous, pinnate-leaved bramble, allied to $\mathrm{R}$. Giraldianus, but with dark purplish brown stems.

\section{R. Giraldianus, Focke.}

A vigorous deciduous shrub up to 8 or ro $\mathrm{ft}$. high; its biennial stems much branched towards the summit, pendulous at the ends, covered with a vividly white, waxy covering, not downy, armed rather sparely with broadbased spines. Leaves pinnate, consisting of usually nine leaflets, and from 5 to 8 ins. long; the main-stalk downy, and armed with hooked spines. Leaflets $I \frac{1}{2}$ to $2 \frac{1}{2}$ ins. long, $\frac{3}{4}$ to $I \frac{1}{4}$ ins. wide, the terminal one the largest; ovate or rather diamond-shaped ; lateral ones oval-lanceolate ; all unequally and rather coarsely toothed, slender-pointed, smooth above, white beneath with a close felt. Inflorescence a terminal panicle; the flowers small and of little beauty, purple. Fruit black.

Native of China ; first found in the province of Shensi by Giraldi, later in Szechuen by Wilson, who introduced it in I907. Its claims to recognition in the garden are its remarkably white stems, which are as striking in this respect as those of $R$. biflorus, and its pendulous branches, which give a remarkable fountain-like aspect to the shrub.

\section{R. GRACILIS, Roxburgh.}

(R. niveus, Wallich.)

A deciduous shrub, with very stout, erect, biennial stems, I to $1 \frac{1}{2}$ ins. thick and in vigorous plants 4 to 6 yards high, covered with a soft, thick, velvety 
down, and sprinkled over with minute prickles. Leaves 6 to over 12 ins. long, - composed of three or five leaflets. Side leaflets about half the size of the terminal one, stalkless or nearly so, obliquely ovate, coarsely and doubly toothed, slightly hairy above, covered with a close white felt beneath, and with silvery hairs on the veins; terminal leaflets ovate to roundish heartshaped, long-stalked, from 3 to 5 ins. long and wide, in other respects the same as the side ones. Flowers white or pale pink, $\frac{1}{2}$ in. across, the petals shorter than the sepals. Fruits blue-black, small.

Native of W. and Central China, whence it was introduced about Igor; the species had, however, been known to botanists as far back as 1825 from plants growing on the Himalaya. The Chinese plants are chiefly remarkable for their vigour; Mr Wilson states that it is occasionally $20 \mathrm{ft}$. high. It is the most robust of all Rubi; hardy in Britain, as may be seen by plants in the Kew collection.

\section{R. Henryi, Hemsley.}

An evergreen, elegant, scandent shrub, growing $20 \mathrm{ft}$. high where support is available; stems slender, cord-like, armed with a few spines. Leaves three-lobed, 4 to 6 ins. long, smooth above, covered beneath with a close white felt; stalk I to $\mathbf{I} \frac{1}{2}$ ins. long; lobes of varying depth but usually reaching about three-fourths down the blade, narrow (from $\frac{3}{4}$ to $r$ in. wide at the base), tapering to a long fine point, finely toothed. Flowers pink, of little beauty, $\frac{3}{4}$ in. across, borne six to ten together in terminal and axillary racemes 3 ins. or so long; petals and sepals of about equal length, the latter covered with glandular hairs, and ending in a tail-like point. Fruit shining black.

Native of Central and W. China ; first discovered near Ichang by Henry, in whose honour it is named. Introduced by Wilson in I900. The only Rubus with which it can be confused is R. bambusarum-the two, probably, are forms of one species-but that is well marked by its leaves being composed of three distinct leaflets. In other respects they are very similar.

\section{R. HISPIDUS, Linnceus.}

A low semi-evergreen shrub, with mostly prostrate, very slender, wiry stems, armed with tiny decurved spines and more or less covered with bristles. Leaves trifoliolate, the common stalk longer than the leaflets, which are short-stalked, obovate, tapering to the base, sharply and coarsely toothed towards the apex, I to $\mathbf{I} \frac{3}{4}$ ins. long, $\frac{1}{2}$ to $I$ in. wide ; smooth or nearly so on both surfaces. Flowers white, $\frac{1}{2}$ to $\frac{3}{4}$ in. across, produced in few-flowered corymbs from the leaf-axils and the ends of erect shoots 6 to 12 ins. high. Fruit at first turning red, nearly black when ripe, less than $\frac{1}{2} \mathrm{in}$. long, and composed of few carpels, sour.

Native of Eastern N. America; introduced in 1768 , but rarely seen nowadays. It flowers in June and July. Growing 'very quickly, it soon forms a low, dense tangle, and makes a pretty almost evergreen covering.

Very nearly allied to this is R. TRIVIALIS, Michaux, which has a more southern distribution in the United States. It differs in having larger flowers up to $\mathrm{I} \frac{1}{2}$ ins. across, and more cylindrical fruits $\mathrm{I}$ in. long, composed of numerous carpels. Rare in cultivation, probably not so hardy as hispidus.

\section{R. ICHANGENSIS, Hemsley.}

A deciduous shrub, with long, slender stems armed with small hooked spines, and furnished with numerous dark, glandular bristles. Leaves 
narrowly ovate-cordate (often with angular lobes towards the base), the sinus open and rounded; $3 \frac{1}{2}$ to 7 ins. long, I to $2 \frac{1}{2}$ ins. wide; smooth on both surfaces, margins sparsely toothed. Flowers white, $\frac{1}{4}$ in. wide, produced in an elongated terminal panicle, supplemented below by short racemes in the axils of the uppermost leaves, the whole measuring 8 to 12 ins. or even more in length; flower-stalks glandular-hairy, sepals erect, enclosing the small white petals. Fruit bright red, small, but of good flavour.

Native of Central and W. China; discovered by Henry, and introduced in 1900 by Wilson, who informs me that it occurs up to $7000 \mathrm{ft}$. elevation. $\mathrm{He}$ also states that it is one of the finest of Chinese Rubi in regard to its fruits - panicles of which he has often found over $2 \mathrm{ft}$. in length. I have not yet seen it in flower or fruit.

\section{R. IDAUS, Linncus. WILD RASPBERRY.}

A deciduous shrub, with erect biennial stems, 3 to $6 \mathrm{ft}$. high, more or less downy; sometimes without prickles, but usually armed with weak ones. - Leaves pinnate and composed of five leaflets on the lower part of the sterile (first year) stems ; mostly of three leaflets at the upper part of the same, and on the flowering branches. Leaflets ovate, $1 \frac{1}{2}$ to 4 ins. long, coarsely toothed, green and smooth above, covered with a white felt beneath; the terminal one is the largest and broadest, and sometimes heart-shaped at the base. Flowers produced in a panicle at the end of short twigs springing from the year-old stems, small, pinkish. Fruit red and juicy.

This shrub, the source of the common raspberry of the fruit garden (where varieties with yellow and whitish fruits are grown), is found wild in British woods, and all through Europe and N. Asia to Japan. It is only of interest on this account, being of little value as an ornament.

Var. LEEsil, Babington, differs in having much rounder leaflets than common R. Idæus, the central one being rarely stalked. Found wild in Devon and Somerset.

THE LOGANBERRY.-This hybrid, between a garden variety of R. Idæus called "Red Antwerp," and the "Aughenhaugh" blackberry, was raised in California in I88I by Judge J. H. Logan. In habit it partakes more of the blackberry than the raspberry character, making long rambling growths $12 \mathrm{ft}$. or more long in a season. It was introduced to England in 1896, and has proved in many places a hardy and useful fruit-bearing bush. The fruit is like a raspberry in shape, but longer and darker in colour, and of an acid flavour.

\section{R. IRENAUS, Focke.}

An evergreen prostrate shrub; stems round, slender, covered with a dense grey down, amidst which are set numerous small decurved prickles. Leaves roundish with a heart-shaped base, and an abrupt, pointed apex; 6 ins. or more across, margins toothed and bristly, sometimes obscurely lobed ; upper surface smooth, dark green, lower one covered with a pale brown felt, and more or less hairy on the yellow veins; stalks $1 \frac{1}{2}$ to 3 ins. long. Flowers white, produced singly or in pairs in the leaf-axils, and in a small terminal cluster. Fruit large, red.

Native of Central and W. China ; introduced about 1900 by Wilson for Messrs Veitch. It is one of the most striking and remarkable of simpleleaved Rubi, the foliage being of a shape and size suggestive of a coltsfoot leaf, but having on the upper surface a curious metallic lustre. Mr Wilson informs me that it is common in woods up to $8000 \mathrm{ft}$. elevation, and will probably thrive best in partially shaded situations. It may prove of value as a handsome covering for semi-shaded slopes, or wherever a low evergreen vegetation is desired. 
R. Koemneanus, Focke.

(Bot. Mag., t. 8246.)

A deciduous shrub of bushy, rounded habit, a few feet high ; the erect, or nearly erect, biennial stems covered with purplish bloom, but with few or no prickles. Leaves simple, three- or five-lobed, or sometimes scarcely lobed at all, heart-shaped at the base, $I \frac{1}{2}$ to 5 ins. long, about the same wide ; smooth and green above, white but not downy beneath ; margins sharply toothed; leaf-stalk often as long as the blade. Flowers $\frac{3}{4}$ in. across, produced usually three together; stalks smooth, $\frac{3}{4}$ in. long; petals white, oblong, calyx downy within, the triangular lobes shorter than the petals. Fruits orange red, composed of comparatively few large carpels.

Native of Japan ; introduced by Spath of Berlin, and originally distributed as "R. morifolius." It is also grown sometimes under the erroneous name of "R. incisus." It is rather pretty in blossom, the flowers being abundant, and the purple-red anthers contrasting well with the white petals.

\section{R. Kuntzeanus, Hemsley.}

A deciduous shrub, with erect, sturdy biennial stems, 6 to ro $\mathrm{ft}$. high, branching towards the top, covered with soft, grey, velvety down, and armed with short broad-based, scattered prickles. Leaves from 6 to 12 ins. long, composed of three or five (pinnately arranged) leaflets, the side ones of which are obliquely ovate, 2 to 4 ins. long, I to $2 \frac{1}{2}$ ins. wide ; fine-pointed, rounded at the base, irregularly toothed and very shortly stalked; slightly hairy and dark glossy green above, covered beneath with a close white felt, interspersed with hairs on the veins ; terminal leaflet larger, broader, longerstalked, often three-lobed, and heart-shaped at the base. The main-stalk has hooked prickles and is covered with the same velvety down as the stem. Flowers small ( $\frac{1}{3}$ to $\frac{1}{2}$ in. wide), produced in large terminal panicles, I to $\mathrm{I} \frac{1}{2} \mathrm{ft}$. long; petals pink and soon falling. Fruit orange-red, rounded, $\frac{1}{2}$ to $\frac{3}{4}$ in. wide, of good flavour.

Native of Central and W. China ; first introduced to Kew by Henry from Ichang in 1886 , but most of the plants now in cultivation were introduced by Wilson between 1900 and 1907 . The species is of some promise as a fruitbearer, but has little to recommend it for ornament. It has been confused with $R$. INNOMinatus, $S$. Moore, a species very closely allied, but distinct in its glandular stems, leaf-stalks, inflorescence, and calyx. Probably not in cuitivation. Central China.

\section{R. laciniatus, Willdenow. CUt-Leaved Bramble.}

A deciduous shrub of rambling or scandent habit, the angled stems well armed with stout, recurved spines, and hairy. Leaves composed of five (sometimes three) leaflets, radially arranged; the common stalk 2 to 3 ins. long, beset with hooked spines. Leaflets stalked, and either pinnate, or deeply and pinnately lobed ; final subdivisions of leaf coarsely and angularly toothed; spiny on the stalk and midrib; downy especially beneath. The leaves vary much in size, and on vigorous shoots will, including the stalk, reach 8 to 12 ins. in length. Flowers in large terminal panicles ; flower-stalk hairy and spiny; petals pinkish white; calyx with narrow, downy, reflexed segments spiny at the back, $\frac{1}{2}$ to $\frac{3}{4}$ in. long, ending in a tail-like point. Fruit black, and both in size and flavour one of the finest of blackberries.

The origin of this handsome and useful bramble is not known. It was first distinguished by Willdenow in the old botanic garden of Berlin in I8og. 
Mr Baker believes it to be a cut-leaved form of a common British bramble called R. Selmeri; but it comes true from seed and wild plants, sprung no doubt from seed dropped by birds, and may nearly always be found in the vicinity of cultivated plants. It is now extensively cultivated for its fruits in gardens, being perhaps the best of all blackberries for that purpose. The foliage is very handsomely divided, and the plant is sometimes grown on pergolas and trellises for its sake as well as for the fruit. It is useful also for growing on the boundary fences of suburban villas, fruiting freely there.

Var. ELEGANS. - In this bramble (which I am not sure is really a form of laciniatus) the leaves are much smaller, and more hairy on the upper surface. It is known also as "laciniatus minor" and " $R$. Quintlandii." It does not flower freely and I have never seen the fruit. Grown by lovers of curiosities.

\section{R. Lambertianus, Seringe.}

A straggling sub-evergreen shrub, with slender, four-angled stems viscous when young, and armed with short decurved spines. Leaves glossy green on both surfaces, simple, sometimes three-, or obscurely five-lobed, sometimes merely wavy; broadly ovate or triangular, 3 to 5 ins. long, nearly as much wide at the heart-shaped base, toothed, slightly downy on the veins above, more so beneath; stalk I to 2 ins. long; stipules $\frac{1}{3}$ in. long, with usually five linear lobes. Flowers white, $\frac{1}{3}$ in. across, produced in a terminal panicle 3 to 5 ins. long, calyx segments downy, ovate-lanceolate. Fruit red, small.

Native of Central China; introduced by Wilson in 1907. It is a luxuriant, very leafy, scandent shrub, suitable for planting as a rough group in thin woodland.

Var. GLABER (R. hakonensis, Franchet).-Similar in habit to the above, stems round and like the leaves smooth or nearly so. Fruits yellow. Native of Japan as well as China; introduced from the latter country by Wilson in 1907.

\section{R. LASIOSTYLUS, Focke.}

\section{(Bot. Mag., t. $742^{\circ}$ )}

An erect-growing deciduous shrub, with biennial stems, 4 to $6 \mathrm{ft}$. high, covered with a blue-white, waxy bloom, and closely set with bristle-like spines, $\frac{1}{4}$ in. or less in length, not downy. Leaves composed of three or five leaflets, and on young vigorous plants as much as 14 ins. long, but usually some 6 or 8 ins. long. side leaflets ovate, 2 to 4 ins. long, coarsely and unevenly toothed, very sparsely hairy above, covered with a close white felt beneath; terminal leaflet much larger especially in the trifoliolate leaves, often lobed, heart-shaped at the base. Flowers small, with reddish purple petals which are shorter than the calyx segments, and soon fall. Fruit I in. across, roundish, red, and downy, with an agreeable acid taste.

Native of Central China; originally discovered in Hupeh by Henry, who sent seeds to Kew in 1889 , from which plants were raised that flowered in 1894. This is one of the most striking of the white-stemmed brambles. It has lately been reintroduced in quantity by $\mathrm{W}$ ilson from Hupeh.

\section{R. LeuCodermis, Douglas.}

A deciduous shrub, 4 to $8 \mathrm{ft}$. high, with blue-white, erect, biennial stems, armed with stout prickles. Leaves composed of usually three, rarely five, leaflets, which are ovate or lanceolate, $1 \frac{1}{2}$ to 3 ins. long, pointed, doubly toothed, smooth above, covered with a close, white felt beneath. Flowers white, produced during June in terminal clusters. Fruit purplish black, sweet and agreeably flavoured. 
Native of Western $\mathrm{N}$. America, where it takes the place of $\mathrm{R}$. occidentalis of the eastern side; to this species it is closely allied. It was introduced to Britain by Douglas, about 1829 , and has been sometimes grown in gardens for its blue-white stems. The name, however, is better known than the plant, for what is often grown as "leucodermis" is the Himalayan R. biflorus, a species with much whiter (less blue) stems than this and, indeed, preferable to it.

\section{R. MALIFOLIUS, Focke.}

A deciduous shrub whose prostrate or climbing stems are sparingly armed with short recurved spines, otherwise smooth. Leaves.oval or ovate, 2 to 5 ins. long, I to 2 ins. wide, rounded at the base, smooth above, downy on the veins beneath, the margins set with broad, shallow teeth, each tooth ending in a small abrupt point; veins in seven to ten pairs, parallel; stalk $\frac{1}{4}$ to $\frac{5}{8}$ in. long. Flowers in terminal racemes, 2 to 4 ins. long, each flower 1 in. across, the petals roundish, overlapping; anthers downy; sepals ovate, downy like the short flower-stalk. Fruits of goodly size, black.

Native of W. China, where it is common in thickets at 2000 to $4000 \mathrm{ft}$; also of Central China, but rare. It is an elegant species, and in regard to its flowers is one of the handsomest of Chinese Rubi, but Mr Wilson informs me that the fruit has an unpleasant flavour. It differs from R. Swinhöei in the inflorescence being without glands. The specific name refers to the applelike foliage.

\section{R. Nigrobaccus, Bailey. High Blackberry.}

\section{(R. villosus, Gray (not of $A$ iton).)}

A deciduous shrub, with erect or arching, angled stems, 4 to $7 \mathrm{ft}$. high, armed with stout prickles and covered with pale down. Leaves mostly 'trifoliolate; leaflets ovate or oblong, coarsely, irregularly, often doubly toothed; 2 to 4 ins. long, half as much wide ; with scattered hairs above, very downy beneath. Flowers $I$ in. wide, pure white, produced in fine terminal racemes augmented by solitary flowers from the axils of the uppermost leaves; the entire inflorescence will measure 8 to 12 ins. long. Each flower is borne on a shaggy stalk $\mathrm{I}$ to $1 \frac{1}{2}$ ins. long. Fruit black, $\frac{3}{4}$ to $\mathrm{I}$ in. long, very juicy.

Native of Eastern N. America, long cultivated in this country and in America under the erroneous name of $R$. villosus. [The real $R$. VILLOSUS, Aiton, is a procumbent plant with the usually solitary flowers produced in leaf-axils.] Our present species is the parent of a well-known and valuable race of cultivated American blackberries, to which "Kittatiny," "Newman's Thornless," and other varieties belong. Over thirty years ago several of these garden varieties were imported from America and tried as fruit-bearers in this country, but none of them ever succeeded. As flowering shrubs, however, both they and the type have considerable beauty, the large terminal clusters of flowers being amongst the most effective in the genus. They expand in early June.

Var. FLORE PLENO.-Handsome, double-flowered, and more lasting in blossom. The best form to grow in English gardens.

\section{R. NOBILIS, Regel.}

A hybrid between $\mathrm{R}$. odoratus and $\mathrm{R}$. Idæus, raised by $\mathrm{Mr}$ C. de Vos, at Hazerswoude, near Boskoop, in Holland, about 1855. It is intermediate between the parents, having erect, sturdy stems peeling like those of $\mathrm{R}$. 
odoratus, but less glandular-hairy and not so tall. Leaves trifoliolate, large, hairy on both surfaces. Flowers purplish red, produced in terminal corymbs in June and July. A handsome, vigorous shrub of about the same value for ornament as $\mathrm{R}$. odoratus - the mother plant. The leaves resemble $\mathrm{R}$. Idæus in being trifoliolate, but the flowers owe their colour and size largely to R. odoratus.

\section{R. NUTANS, Wallich.}

(Bot. Mag., t. 5023.)

An evergreen, prostrate shrub, rising only a few inches above the ground; the stems creeping, unarmed, but thickly covered with soft purplish bristles and rooting at almost every joint. Leaves trifoliolate, with bristly stalks $I \frac{1}{2}$ to 2 ins. long; leaflets glossy green above, bristly on the veins beneath, sharply toothed, the terminal one the largest and from I to $2 \frac{1}{2}$ ins. long, rhomboidal, often rounded at the apex; the side ones half to two-thirds as large, all three very shortly stalked. Flowers pure white, $1 \frac{1}{2}$ ins. across, borne in the leaf-axils and at the top of erect, leafy shoots 6 or 8 ins. high, each flower on a slender stalk $1 \frac{1}{2}$ to $2 \frac{1}{2}$ ins. long, bristly like the reddish calyx.

Native of the Himalaya ; cultivated at Kew for the last sixty years. The cheerful leaves and large flowers render this one of the most pleasing of dwarf Rubi. In the Bamboo Garden at Kew, on a shady slope and growing in ordinary loam, it thrives perfectly, sending out its runner-like shoots in all directions. The plant is rare in gardens, but may be recommended as a low covering for sheltered semi-shaded slopes, etc.

\section{R. nutkanus, Moçino. Salmon Berry.}

(Bot. Mag., t. 3543 ; R. parviflorus, Nuttall.)

A vigorous deciduous shrub, up to $8 \mathrm{ft}$. high, with erect, unarmed stems, and peeling bark; young shoots downy and slightly glandular. Leaves simple, five-lobed, vine-like, 4 to 8 (or more) ins. across, irregularly toothed, downy on both sides especially beneath; leaf-stalk 2 to 5 ins. long, set with glandular hairs. Flowers pure white, $\mathrm{I} \frac{1}{2}$ ins. across, borne three to seven in terminal clusters during June, and continuing for several weeks; the flowerstalk is glandular-hairy and the calyx is very downy, each lobe contracted at the apex into a short tail. Fruit large, hemispherical and flattened, red; said to be sometimes pleasantly flavoured in a wild state.

Native of Western N. America; introduced by Douglas in 1827. Very similar in its growth and foliage to R. odoratus, but easily distinguished by its white flowers in smaller clusters; the shoots, too, are not so conspicuously downy and glandular, and are darker coloured. Like that species it forms, when left to itself in good soil, dense thickets, which should be overhauled every winter and the worn-out stems cut out. Easily increased by pulling old plants to pieces. Fruits ripen most seasons from the earliest flowers, but are insipid and worthless in this country.

\section{R. OCCIDENTALIS, Linnceus. Black RASPBERRY.}

A deciduous shrub, with arching, biennial stems, 6 to ro $\mathrm{ft}$. long, very glaucous, and armed with scattered short spines. Leaves composed of mostly three (sometimes five, pinnately arranged) leaflets, which are ovate, $1 \frac{1}{2}$ to 4 ins. long, pointed, coarsely and unequally toothed, covered with a close white felt beneath. Flowers white, $\frac{1}{2}$ in. across, produced in terminal fewflowered corymbs during June. Fruit purple-black, flattish, hemispherical. 
Native of Eastern N. America, and the parent species of several races of garden raspberries largely grown in America, the best known of which are the "Gregg," "Hillborn," and "Ohio." In this country it is only worth growing for the long, arching, blue-white stems, and even in this respect it is not equal to R. biflorus or R. lasiostylus. The tips of the arching shoots often reach the ground and there take root. Allied to $R$. strigosus, it differs in its black fruits and glaucous stems.

Intermediate between occidentalis and strigosus is R. NEGLECTUS, Peck. It is thought to be a natural hybrid from them, having dark red fruits and prickly blue-white stems. Introduced to Kew in 1893 .

\section{R. ODORATUS, Linnceus.}

$$
\text { (Bot. Mag., t. 323.) }
$$

A vigorous, deciduous shrub, with stout, erect, very pale brown stems up to $8 \mathrm{ft}$. high, bark peeling; young stems covered with glandular hairs. Leaves simple, amongst the largest of hardy Rubi, five-lobed, vinelike, 4 to Io (or even 12) ins. across ; lobes pointed, sharply and irregularly toothed, hairy on both sides, but especially beneath, soft and velvety to the touch. Flowers fragrant, bright purple, $I \frac{1}{2}$ to 2 ins. across, borne in large, branching, corymbose clusters at the ends of the shoots; the stalks conspicuously furnished with dense glandular hairs, the calyx similarly covered, each of its five divisions narrowed to a tail-like point. Fruits flat and broad, red when ripe, but rarely seen in this country.

Native of Eastern N. America ; introduced in 1770. Next to R. deliciosus, this is perhaps the most ornamental of Rubi in regard to blossom. It flowers from July to September, and few shrubs at that time equal it in beauty and fragrance. It loves a semi-shaded spot, where its flowers are protected from the fierce mid-day and early afternoon sun; in such a place the blossoms last longer. It is a rampant grower, and soon forms a thicket ; good soil should be provided and the plants are all the better if pulled apart every few years, and planted more thinly. The old stems should be removed every winter. It is very similar in growth to R. nutkanus (q.v.), but commences to flower a month later.

\section{R. OMEIENSIS, Rolfe.}

A large straggling shrub, with round stems, unarmed, but furnished with small, stellate hairs. Leaves of maple-like form, five-, or obscurely seven-lobed, with a heart-shaped base ; 3 to 7 ins. long and as much wide ; irregularly toothed, stellately downy beneath, less so above; stalk 2 to 3 ins. long; stipules $\frac{1}{2}$ to $\frac{3}{4}$ in. long, cut up into deep, narrow segments. Panicles manyflowered, terminal ; flowers $\frac{1}{2}$ in. across, with downy stalks ; calyx downy, the lobes pointed, triangular; petals purple. Fruit black, well-flavoured, ripening late.

Native of W. China, and found on Mt. Omi by Wilson, who introduced it for Messrs Veitch, with whom it flowered in August 1908. It grows up to $6000 \mathrm{ft}$. elevation, and will probably be perfectly hardy. It makes growths Io or $12 \mathrm{ft}$. long in a season. The stipules are rather remarkable.

\section{R. PALMATUS, Thunberg.}

(Bot. Mag., t. 780r.)

A deciduous shrub, $;$ or $6 \mathrm{ft}$. high in the open (thrice as much in a cool greenhouse), stems not downy, but armed with small, flattened prickles. 
I.eaves usually palmately five-lobed, sometimes three-lobed, sometimes seven- or nine-lobed; I to 3 ins. long, margins doubly toothed; green on both surfaces with silky hairs along the midrib and veins; stalk $\frac{3}{4}$ to $I \frac{1}{2}$ ins. long, with hooked spines. Flowers white, $I \frac{1}{2}$ ins. across, solitary, produced from the axils of terminal leaves on short shoots that spring from the previous year's growths. Petals of narrowly oval outline, their ends rounded ; calyx downy outside, smooth within, the lobes narrow, long-pointed, and toothed ; stalk slender, $\frac{1}{2}$ to $\frac{3}{4}$ in. long. Fruit roundish, yellow and juicy, $\frac{3}{4}$ in. across.

Native of China and Japan. In the Temperate House at Kew, trained on a pillar, this shrub is $20 \mathrm{ft}$. or more high, but in the open and unprotected it is rather a low shrub. Although hardy enough, it apparently needs somewhat warmer conditions than the open air affords near London to bring: out its best qualities.

\section{R. PARKeri, Hance.}

A deciduous shrub of climbing habit; stems biennial, round, slender, armed with short, scattered, decurved spines, and thickly covered with greyish hairs, many of them gland-tipped. Leaves simple, broadly lanceolate, long-pointed, heart-shaped at the base; 4 to 7 ins. long, about half as wide; the margins wavy, and sharply and finely toothed; upper surface bristly, especially along the midrib and veins, the lower one covered with a dense brownish red down; leaf.stalk up to I in. long, hairy and prickly. Flowers borne on an elongated, lax panicle, the calyx being remarkable for its dense covering of reddish glandular hairs. Fruit black, ripening early.

Native of China, where it was originally discovered in the province of Szechuen by E. H. Parker, in 1881 ; introduced in 1907 by Wilson, who found it near Ichang. This bramble has distinct and striking foliage, and its habit promises to be elegant.

\section{R. PARVIFOLIUS, Linnceus.}

\section{(Bot. Reg., t. 496 ; R. triphyllus, Thunberg.)}

A low, deciduous bramble, forming a tangle of slender, downy, prickly stems a few feet high. Leaves composed of usually three, but sometimes five, leaflets, borne on a common stalk $1 \frac{1}{2}$ to 2 ins. long, downy, and covered with prickles. Leaflets of various shapes and sizes, usually roundish or widely obovate, $\frac{3}{4}$ to 2 ins. long, coarsely toothed, dark gireen and smooth above, clothed with a close white felt beneath, the terminal one the largest and. longest stalked. Flowers produced from the leaf-axils near the end of the shoot in few-flowered corymbs on downy, prickly stalks; petals bright rosecoloured, erect. Fruit roundish, red, edible.

Native of Japan and China; some of its forms also native of Australia. It was originally imported by the Horticultural Society in 18 I 8 . It is rather pretty in blossom, but not more so than many of our native brambles.

\section{R. PHCENICOlasius, Maximozicz. WINEBERRY.}

$$
\text { (Bot. Mag., t. 6479.) }
$$

A deciduous shrub making spreading stems 8 to io $\mathrm{ft}$. long in favourable situations; the stems are biennial, round, and together with the branches and leaf-stalks are covered densely with reddish, gland-tipped bristles mixed with which are a few slender prickles. Leaves 5 to 7 ins. long, composed of three leaflets. The terminal leaflet is stalked, 2 to 4 ins. long, roundish or broadly ovate, the base rounded or heart-shaped, the margins coarsely toothed and 
lobed; the side leaflets differ only in being obliquely ovate, stalkless, and much smaller; all are sparsely hairy above, white-felted beneath. Flowers in terminal racemes, the chief feature being the calyx, which is covered with glandular hairs, and measures $\mathrm{I}^{\frac{1}{2}}$ ins. across, the five segments being very narrow and pointed; petals $\frac{1}{4}$ in. or less in length, pink. Fruit conical, $\frac{3}{4}$ in. long, bright red, sweet and juicy, but of insipid flavour.

Native of Japan, and the province of Kansu, China; introduced about 1876. This raspberry is hardy at Kew, bearing fruit regularly in the open, but it would probably succeed better against a wall. Inla cool house, trained up a post, it bears large crops of its very handsome, brightly coloured fruits. The species is noteworthy, not only for its fruits, but also for its excessively bristly stems, its tiny petals, and large star-shaped calyx which persists and spreads out beneath the fruit. It flowers in June under glass, a few weeks later out-of-doors.

\section{R. Playfairit, Hemsley.}

A rambling evergreen or semi-evergreen shrub; young stems dark coloured, round, very slender, string-like, armed with tiny hooked prickles, and covered with web-like down when young. Leaves composed of three to five leaflets radiating from the end of the stalk, which is $1 \frac{1}{2}$ to $2 \frac{1}{2}$ ins. long, and prickly; leaflets lanceolate, sharply toothed, the terminal one the largest, and sometimes 6 ins. long, the basal pair I to 3 ins. long, dark glossy green above, covered beneath with a pale grey felt. Flowers about $\frac{1}{2}$ in. across, produced in small terminal panicles, and in the leaf-axils near. Fruit resembling a raspberry, but black ; ripe in July and August.

Native of Central and W. China; introduced in 1907 by Wilson, who states that it is found in thickets at 3000 to $6000 \mathrm{ft}$. It is a very graceful plant when trained up a support, and the shape of its leaves is very uncommon among hardy Rubi, being more suggestive of an Ampelopsis.

\section{R. SPECTABILIS, Pursh.}

(Bot. Reg., t. I424.)

A deciduous shrub with erect stems, 4 to $6 \mathrm{ft}$. high, smooth, but armed with fine prickles. Leaves 4 to 6 ins. long, composed of three leaflets which are ovate, from $1 \frac{1}{2}$ to 4 ins. long, doubly toothed, almost or quite smooth on both surfaces, the terminal one the largest and broadest. Flowers produced singly on short leafy shoots springing from the previous year's wood; purplish red, I in. or so across, fragrant ; calyx downy, with broad pointed lobes not so long as the petals. Fruit orange-yellow, large, somewhat egg-shaped.

Native of Western N. America; introduced by Douglas in 1827. It flowers freely towards the end of April, and is very pretty then. To some of the native tribes of $\mathrm{N}$. America the fruit is valuable as food, but in this country it does not ripen freely. The plant spreads rapidly by means of sucker growths from the base, and soon forms a dense thicket. Plants should be overhauled annually, and the worn-out stems removed. Propagation is easily effected by dividing up the plants or removing offsets.

\section{R. STRIgosus, Michaux. AMericAN ReD RASPBERRy.}

A deciduous shrub with biennial stems, 3 to $6 \mathrm{ft}$. high, and densely clothed with bristles which are frequently gland-tipped. Leaves with hairy stalks, composed of three (or five pinnately arranged) leaflets, which are ovate or oblong, $1 \frac{1}{2}$ to 3 ins. long, pointed, coarsely and irregularly toothed, the terminal one stalked, the side ones stalkless, all smooth above, covered with 
a grey felt beneath. Flowers white, $\frac{3}{4}$ in. across, produced in the leaf-axils and at the end of the short side shoots on bristly slender stalks. Fruit red, conical.

Native of N. America from Labrador south to the Carolinas, and westward to British Columbia and New Mexico. It fills in the New World the place of R. Idæus in the Old. The two species are closely allied, but this American one is easily distinguished by its bristly stems and flower-stalks. It is the parent species of garden races grown largely in N. America, such as the "Cuthbert" and "Hansall" raspberries. This is its chief interest; it is not worth cultivation except where collections are maintained.

\section{R. SwINHÖEI, Hance.}

\section{(R. hupehensis, Oliver.)}

A prostrate or climbing evergreen shrub, with round, slender, darkcoloured stems, thinly furnished with a cobweb-like down when young, and armed with a few small decurved spines. Leaves simple, oblong-lanceolate ; 3 to $4 \frac{1}{2}$ ins. long, by about $\mathrm{I} \frac{1}{2}$ ins. wide ; the base rounded, the apex longpointed, margins finely toothed ; veins in nine to twelve pairs; upper surface smooth except for tiny bristles along the veins, lower one covered with a close grey felt ; leaf-stalk $\frac{1}{4}$ to $\frac{1}{2}$ in. long. Flowers usually three to seven in short, terminal, very glandular racemes, of little or no beauty ; calyx covered with grey felt like the leaves; petals soon falling. Fruit described as at first red, then black-purple, austere.

Native of Central China and Formosa; originally described in 1866 , but introduced to gardens by Wilson from Hupeh in 1907. The foliage is handsome, and distinct from that of any other cultivated species except R. malifolius; the inflorescence also is conspicuous in its glandular hairiness.

\section{R. THIBETANUS Franchet.}

\section{(R. Veitchii, Rolfe.)}

An erect deciduous shrub, $6 \mathrm{ft}$. or more high; stems biennial, smooth, round, covered with a purplish bloom, and set irregularly with straight, slender prickles. Leaves pinnate, 4 to 9 ins. long, composed of seven to thirteen leaflets, the main-stalk prickly; leaflets oval or ovate, more or less oblique, stalkless, coarsely and angularly toothed, dark lustrous green, and with minutely silky hairs above, whitish felted beneath; the lowest leaflets are $\mathrm{I}$ to 2 ins. long, each successive pair diminishing in size towards the apex of the leaf which is terminated by a long, deep-lobed leaflet. Flowers $\frac{1}{2}$ in. across, slender-stalked, solitary in the leaf-axils, or a few together in terminal tlattish panicles;' the calyx very downy, with triangular lobes; petals purple. Fruit roundish, $\frac{5}{8}$ in. across, black with a bluish bloom.

Native of W. China ; discovered and introduced by Wilson for Messrs Veitch, with whom it flowered in August, 1908. Mr Wilson informs me he found it in the Min River Valley at elevations of 4000 to $6000 \mathrm{ft}$., where it is rare. Of the newer Chinese Rubi it is one of the most distinct and attractivelooking, both for its blue-purple stems and very handsomely cut foliage.

\section{R. THYRSOIDEUS, Wimmer.}

A strong-growing shrub, with arching, ribbed stems becoming nearly or quite free from down, but armed with straight or slightly hooked prickles. Leaves composed of five leaflets, the terminal one of which is ovate, often 
broadly so, and rounded at the base, its stalk about half the length of the blade and very prickly. All the leaflets are almost or quite smooth above, covered beneath with a dull white felt; margins doubly toothed. Flowers white or pinkish, produced in a tall, erect panicle. This, one of the handsomest of common brambles, has a double-flowered white variety called FLORE PLENO, which is well worth cultivation in the garden on account of its beauty, its flowering in July and August, and because it thrives in semishady places. The panicles are erect, pyramidal, 6 to 8 ins. high. The type is widely spread over England, Wales, and on the Continent.

\section{R. TRIANTHUS, Focke.}

A deciduous shrub of wide-spreading habit, the biennial stems erect, much branched, spiny, blue-white, 4 to $6 \mathrm{ft}$. high. Leaves simple, 3 to 6 ins. long, $I_{\frac{1}{2}}$ to $4 \frac{1}{2}$ ins. wide ; ovate to triangular, distinctly three-lobed on the barren stems, less markedly lobed on the flowering shoots ; middle lobe long, taper-pointed, irregularly toothed, quite glabrous on both sides, whitish beneath, dark green above; there are hooked spines on the midrib and veins beneath; stalk $\frac{1}{2}$ to $1 \frac{1}{2}$ ins. long, similarly armed. Flowers pinkish white, insignificant, produced a few together on cymes that are terminal on short lateral twigs. Fruit dark red.

Native of Central China up to $4000 \mathrm{ft}$. ; introduced for Messrs Veitch by Wilson in 1900 . It is distinct from most Rubi in the absence of down or hairs, but has not much garden value.

\section{R. TRICOLOR, Franchet.}

\section{(R. polytrichus, Franchet.)}

A quite prostrate, deciduous shrub with round stems, quite devoid of prickles and spines, but densely clothed with yellow-brown bristles about $\frac{1}{8}$ in. long. Leaves simple, heart-shaped, 3 or 4 ins. long by two-thirds as much wide, irregularly toothed, pointed, dark green above, covered with a close whitish felt beneath; there are about seven pairs of parallel veins, which on the under-surface are furnished with bristles, but on the upper surface the bristles are confined in rows between the veins. Leaf-stalk I to $1 \frac{1}{2}$ ins. long, bristly like the stems. Flowers white, I in. across, produced singly in the leaf-axils near the end of the shoot, and in a small terminal panicle. Fruit bright red, and of good size and flavour.

Native of W. China ; first discovered by the French missionary Delavay, but introduced to cultivation by Wilson in 1908. It is remarkably distinct on account of the very bristly stems and leaf-stalks. Coming from elevations up to $10,000 \mathrm{ft}$. it ought to prove hardy.

\section{R. TRIFIDUS, Thunberg?}

(Revue Horticole, 1908, fig. III.)

An evergreen or sub-evergreen shrub, with erect stems, 4 to $7 \mathrm{ft}$. high, zigzagged towards the top, not (or but little) branched the first year, beset with glandular hairs at first, but soon becoming smooth. Leaves dark lustrous green, usually five- or seven-lobed, 4 to 10 ins. across; the lobes reach half or two-thirds of the way to the stalk, are ovate, pointed, doubly toothed, slightly hairy on the chief veins above and below; stalks I to $2 \frac{1}{2}$ ins. long. Flowers I to $\mathrm{I} \frac{1}{4}$ ins. wide, rosy-white, produced singly in the terminal leaf-axils and in a few-flowered, terminal corymb, each on a downy stalk $\frac{3}{4}$ 
to $\mathrm{I} \frac{1}{2}$ ins. long. Calyx very downy outside. Fruit described as red and edible.

Native of Japan; introduced about 1888. This Rubus is distinct from all other cultivated species in its large, handsome, deeply lobed leaves, which bear a great resemblance to those of Fatsia japonica, except that they are not so large. It is worth growing for their sake. The flowers, which appear in July, are not freely borne, and I have never seen the fruit. The leaves of the flowering shoots are frequently three-lobed, and it is to them that the specific name refers.

\section{R. ULmifolius, Schott.}

\section{(R. rusticanus, Mercier.)}

A vigorous shrub whose more or less plum-coloured, arching stems are clothed with starry down and armed with long, broad-based prickles; they root freely at the tips. Leaves composed of three or five leaflets radially arranged, which are slightly downy above but white-felted beneath, rather finely toothed. Flowers bright rosy red, and produced in showy, cylindrical panicles. This well-marked species is of little value as a fruiting bramble, its berries being small and dryish, but from it several ornamental garden varieties have been obtained. It is widely spread over the United Kingdom (except Scotland) and Europe generally.

Var. BELLIDIFLORUS, Focke (var. flore pleno, Hort; R. bellidiflorus, Koch).This is the very handsome, well-known, double-flowered pink bramble, which is so useful in making a gay display in July and August. Each flower produces an extraordinary number of narrow petals. For semi-shady spots in the woodland, this bramble may be strongly recommended as a companion plant to R. thyrsoideus flore pleno, with white, double flowers.

Var. FOLIIS VARIEGATIS. - A handsome variegated form, the main part of the leaf being green, the midrib and veins picked out in bright yellow. This variety needs a more sunny spot than the others.

Var. INERMIS.-A remarkable form absolutely devoid of spines and prickles. It was received at Kew from the firm of Richard Smith \& Co., of Worcester, in 1877 , but beyond that I know nothing of its history. One may thrust one's hand into the middle of the bush without getting a scratch.

\section{RUSCUS. LILIACEÆ.}

Strictly speaking, the three species of Ruscus described below should be regarded as shrub-like, rather than as true shrubs, none having really woody stems. They belong to the Asparagus group of the lily family, renewing themselves by stems from the base as asparagus does; the tender young stems also are eaten in some parts of Europe. They are evergreen, the "leaves" mostly alternate, sometimes in whorls. It has to be observed that the so-called leaves are really modified branches, flattened and resembling leaves, and performing the same functions. They should, properly, be termed cladodes. Flowers with a perianth of six segments, small, inconspicuous, borne in the centre of the cladode; mostly unisexual, with the sexes often on different plants. Hence probably the rarity of the fruits of the two species common in gardens: they are propagated by division, and thus perpetuate the sex only of the original plant obtained. They thrive in almost any soil, and are admirable 
in very shady places. The best time to break up the plants for propagation is spring.

\section{R. ACUleatus, Linnaus. Butcher's Broom.}

An evergreen, well-armed shrub, spreading and renewing itself by means of sucker growths springing from the base; $1 \frac{1}{2}$ to $3 \mathrm{ft}$. high, the crowded erect stems having many rigid branches near the top; stems grooved. "Leaves" cvate, stalkless, $\frac{3}{4}$ to $I \frac{1}{2}$ ins. long, $\frac{1}{4}$ to $\frac{3}{4}$ in. wide; slightly glossy on both sides, tapering at the apex to a stender, stiff spine. Flowers $\frac{1}{4}$ in. across, dull white, borne singly or in pairs (apparently stalkless) in the centre of the "leaf," but really produced in the leaf-axil, the stalk being united to the midrib of the "leaf." The flower-bud forms early in the year, and opens in spring. Fruit a globose or oblong, bright red berry, $\frac{1}{3}$ to $\frac{5}{8} \mathrm{in}$. diameter, borne, like the flower of course, in the "leaf"-centre.

Native of Europe, including the south of England. The butcher's broom is remarkabie in being the only shrubby plant of the monocotyledonous type native of the British Isles. It is not, ordinarily, a showy plant, but is always interesting for the curious position of its flowers and fruit. When laden with the latter it is very ornamental indeed; but the plants are mostly unisexual, ind the fruits are not commonly seen in gardens, because one of the sexes, but more especially the female, is wanting. It is especially useful for planting in dense shade where very few evergreens will thrive. It is said to have obtained its common name through being used in the shape of brooms by butchers to clean their blocks. In S. Italy I have seen it used as a garden besom, the same as birch and ling are used in this country.

Var. ANGUSTIFolius, Boissier, has narrower "leaves" than the type.

Var. LATIFOLIUS has "leaves" up to 2 ins. long and $\frac{3}{4}$ to $I$ in. wide, glossy.

\section{R. Hypoglossum, Linnceus.}

An evergreen shrub, 8 to 8 ins. high, forming compact tufts, and increasing by new sucker growths from the sides; stem somewhat arching, as thick as a lead pencil, scarcely woody, unbranched, green. "Leaves" not spiny, the lower ones narrow-oval, the upper ones oblanceolate, tapered at both ends; smooth and glossy on both sides, with prominent longitudinal veins; 3 to $4 \frac{1}{2}$ ins. long, I to $I \frac{1}{2}$ ins. wide. On the upper side is borne a leaf-like bract, lanceolate, I to $1 \frac{1}{2}$ ins. long, $\frac{1}{4}$ to $\frac{1}{3}$ in. wide, in the axil of which a few small, yellowish flowers appear in April and May. Berry red, globose, $\frac{1}{4}$ to $\frac{1}{2}$ in. wide.

Native of S. Europe; cultivated in England since the sixteenth century. No evergreen shrub thrives better than this in shade and in competition with the roots of greedy trees; in this is its chief value for gardens. It flowers in cultivation, but in my experience rarely bears fruit.

\section{R Hypophyllum, Linnaus.}

\section{(Bot. Mag., t. 2049.)}

A small evergreen plant, 6 to $\mathbf{I} 2$ ins. high, similar in habit to, but in this country dwarfer than, R. Hypoglossum. "Leaves" oval, sometimes slightly ovate; $\mathrm{I} \frac{1}{2}$ to 3 ins. long, $\frac{3}{4}$ to $\mathrm{I} \frac{1}{2}$ ins. wide; shortly stalked; the point short and abrupt. Flowers small, white, produced in a cluster from the centre of the under-surface of the "leaf," each flower on a slender stalk $\frac{1}{4}$ in. long; they are borne in the axil of a small bract $\frac{1}{\alpha}$ in. long. Berry globose, red, $\frac{1}{2}$ in. wide. 
Native of S. Europe and N. Africa; introduced early in the seventeenth century. Whilst this species has a general resemblance to R. Hypoglossum, it is readily distinguished by the shorter, broader "leaves" or cladodes; the tiny bract; and in the flowers coming from underneath. It is too tender to have much value in gardens near London, but is interesting for more southern and western localities.

\section{RUTA graveolens, Linnceus. Rue. RUtace.}

An evergreen shrub, with erect, half-woody branches, rarely seen more than $3 \mathrm{ft}$. high. Leaves of a markedly glaucous hue, alternate, variable in length, but usually 3 to 5 ins. long, pinnately decompound, the leaflets usually confined to the upper half, the ultimate subdivisions obovate, $\frac{1}{8}$ to $\frac{1}{2}$ in. long. Flowers $\frac{3}{4}$ in. wide, arranged in terminal corymbs, rather dull yellow; the sepals and petals usually four, sometimes five; the stamens twice as many. Petals scoop-shaped with jagged edges. Fruit a usually four-celled carssule.

Rue is known best, of course, as a garden herb with an acrid taste, used in domestic and especially rustic medicine for colic, hysteria, promoting perspiration, etc. Applied locally it is a -powerful irritant. These properties are due to a volatile oil which permeates the leaves and younger parts of the plant. Given in too large doses it is dangerous, and produces symptoms of acrid narcotic poisoning. The species is a native of S. Europe, and owing no doubt to its medicinal properties has been grown in English gardens from time immemorial. It finds frequent mention in Shakespeare as "herb of grace":

"I'll set a bank of rue, sour herb of grace."

- The gardener, in King Richard II.

It should find a place in all extensive shrub collections not only for its associations, but for its beauty also. When fully in flower the dark yellow blossoms contrast prettily with the glaucous foliage, and they continue to open from June onwards for some months. It is quite easily increased by cuttings, and will thrive all the better if lime or chalk be mixed with the soil where it is naturally absent. There is a var. variegata in cultivation, its leaflets bordered with white.

\section{SALIX. Willow. SALICACEA.}

More than one hundred and seventy years ago Linnæus remarked on the difficulties and obscurities that encumber the student in his investigation of the willows. To-day when the number of known species and varieties has vastly increased, these difficulties have intensified rather than diminished. Yet most of the leading types or genuine species are not difficult to identify. The greatest of all the troubles of the systematic botanist arise from the fact that Nature has not differentiated her species clearly. If every one stood out well apart from its fellows, half his work would be done. In no large class of plants do the types merge one into 
the other, and blur the dividing lines so completely as they do in Salix. In Britain there are some seventeen or eighteen native species, every one of which is considered to have hybridised with two or more of its fellows, some with as many as nine. But whether, as is usually assumed, the intermediates are always hybrids is doubtful. Willows generally do not, in gardens at least, produce fertile seed so freely as to support the theory of such multiple cross-breeding. It has to be said, however, that some of these natural hybrids have been duplicated under cultivation by artificial cross-fertilisation.

Salix is a large genus of perhaps two hundred species of trees and shrubs, all those hardy in Britain being deciduous or practically so. They vary from stately timber trees of the type of $\mathrm{S}$. alba and $\mathrm{S}$. fragilis $(80 \mathrm{ft}$. or more high) to tiny shrubs like S. herbacea, creeping along the ground, and only rising an inch or two above it. The twigs of many species are very tough, and the genus supplies vastly the greater part of the material from which the baskets and wickerwork of the world are made. Although the twigs of several species have the ordinary toughness of the genus, they are easily snapped off in their entirety at the point of their union with the older branchlet. This curious characteristic is best known in, and gives the popular name to, the crack willow (S. fragilis), but there are several more that have it equally marked. The leaves of willows are very variable: the typical shape is long and narrow, slenderpointed, and toothed, but from that shape to an almost circular one there is every gradation. In the remarkable S. magnifica, recently introduced from W. China, the leaves are over 8 ins. long by over 5 ins. wide. Normally they are alternate, although in S. purpurea it is quite usual to find opposite ones as well. Stipules produced by willows are curiously variable both in their size and persistence. They occur most markedly on the strongest shoots, and are frequently entirely absent from weaker ones.

It is the general rule for the sexes to be kept apart on separate plants, a character which adds to the difficulty of distinguishing willows, for the foliage and habit of male and female specimens of the same species are not always identical. But this rule has occasional exceptions; some trees produce both sexes, sometimes on the same branch. There is an example of S. MeDemir, Boissier, at Kew, which frequently has male and female flowers on the same catkin. Willow catkins vary in shape, from cylindrical to egg-shaped, and are usually very silky-hairy. The flowers, which are densely packed, have no sepals or petals; the male consists of a scale carrying two to five (sometimes eight or nine) stamens; the female consists of a scale bearing a single ovary. On the opposite side of the stamens and ovary from the large scale, or sometimes on both sides, is a small glandular scale, often called the "nectary." This organ is relied on to afford distinctions in botanical books, but being too minute for investigation by ordinary cultivators I have omitted consideration of it in the following notes on the species. The fruit or seed-vessel is a conical body splitting in two at the top, each half recurving when ripe. Seeds minute, furnished at one end with a tuft of pale hairs.

The flowers of willows are wind-fertilised, and appear usually in spring on the naked shoots of the previous summer. 'They are not devoid of 
beauty, the males especially; but willows as a rule are cultivated for the beauty of their foliage and habit, or on account of their fondness for moisture at the roots, which renders them valuable for planting in wet places where the choice of trees and shrubs that will thrive is limited. A selection of some of the more desirable species is given below.

Willows are propagated extremely easily by means of leafless cuttings, which may be put in the open ground at any time between November and early March. Pieces one to several years old may be used; and of the tree sorts like alba, viridis, and fragilis, it is usual to put in "sets," i.e. naked rods, 8 to $12 \mathrm{ft}$. long, and as thick or thicker than a broomstick. Considering how readily cuttings take root, it is rather curious that trees do not bear transplanting well. Plants raised from cuttings in the nursery should be put in their permanent places at not more than two years old and should be planted a few inches deeper than before; the best results will, indeed, be obtained by putting the cutting into its destined place at the commencement, if due protection and care can be given. This is always done with the big "sets" just mentioned. The majority of willows abhor dryness at the root, but will thrive in ordinary situations if the soil be deep and rather heavy. A few sorts of Alpine origin or from northern latitudes are suitable for the rock garden. Whilst most of the great osier-beds are along river sides, often in places so damp or so subject to inundation as to be unavailable for ordinary crops, some of the finest quality wickerwork is made from willows grown on ordinary farm land. Often several forms of osiers used in basket-making are derived from a single species (see triandra, viminalis, purpurea, etc.), which, although they vary much in quality for their particular purpose, show no botanical differences. They are known in the osier trade by colloquial names.

The value of several sorts of willow trees for producing wood from which cricket-bats are made is alluded to under S. cœrulea, viridis, and fragilis, but these species as well as alba yield timber useful also for other purposes, especially where a non-splintering wood is required, and where it is subject to rough friction like cart or wheelbarrow bottoms. For wattling the wasting banks of rivers or other pieces of water nothing equals the branches of willows.

In gardens willows are undoubtedly seen to best advantage near water. Throughout the whole range of hardy trees and shrubs there is nothing that can give quite the same effect as S. babylonica, S. alba, or S. Salamonii, planted by the margin of a lake or stream.

The following is a select list of species and hybrids that may be recommended for various purposes in the garden:-

ORNAMENTAL LARGE TREES.-S. alba and S. a. argentea, babylonica, cœrulea, fragilis, pentandra, Salamoni, viridis.

ORNAMENTAL SHRUBS.-S. Bockii, incana, Pierotii, purpurea, repens var. argentea.

COLOUR OF BARK IN WINTER.-S. vitellina, yellow ; S. vitellina var. britzensis, red; acutifolia and daphnoides, purple.

FLOWER. - S. Bockii, gracilistyla, Caprea, Smithiana.

ROCK GARDEN.-S. Arbuscula, herbacea, myrtilloides, reticulata, retusa.

S. purpurea var. pendula, cæsia, repens, and others are sometimes grafted on standards, and are in that way transformed into small weeping trees, but the practice has little to recommend it and has much against it. 


\section{S. ADENOPHylla, Hooker. FurRy Willow.}

A shrub up to $8 \mathrm{ft}$. high, of loose habit, sparsely branched; twigs covered with a thick silky coat of hairs. Leaves arranged very closely on the branchlet (about four to the inch), ovate with a heart-shaped base, rather abruptly pointed, very finely, closely, and regularly toothed, many of the teeth glandular, especially at the base; $I \frac{1}{2}$ to 2 ins. long, $\frac{3}{4}$ to $I \frac{1}{4}$ ins. wide; covered with long, whitish, silky hairs on both surfaces, not so thickly as on the twigs; stalk from $\frac{1}{5}$ to $\frac{1}{3}$ in. long; stipules persistent, obliquely heartshaped, glandular-toothed, $\frac{1}{3}$ in. diameter. The female plant only appears to be in cultivation; this has catkins $1 \frac{1}{2}$ to 3 ins. long, borne on short leafy shoots.

Native of N. America, and one of the most distinct of cultivated willows, especially in the extreme downiness of the younger parts, in the broad, closely set leaves, and large persisting stipules.

\section{S. ALBA, Linnceus. White Willow.}

A tree 70 to $80 \mathrm{ft}$. high, of elegant form, branches pendulous at the ends; young shoots grey with silky down, growing at angles usually of $30^{\circ}$ to $45^{\circ}$ to the older branchlet from which they spring. Leaves lanceolate, $1 \frac{1}{2}$ to $3 \frac{1}{2}$ ins. long, $\frac{1}{4}$ to $\frac{5}{8}$ in. wide; very finely toothed, much tapered at both ends, permanently covered beneath with silky down, less so above; stalk $\frac{1}{8}$ to $\frac{1}{2}$ in. long. Catkins $1 \frac{1}{2}$ to 2 ins. long, opening in early May. Stamens two, silky at the base; ovary not stalked.

Native of Europe (including Britain) and N. Asia. One of the most beautiful of native trees. It varies considerably in the colour of the leaves and young shoots, some being much more silvery than others. It yields a useful timber although scarcely so valuable as that of the blue-willow (S. cœrulea). For cricket bats it is of second-rate quality.

Var. ARGENTEA, Wimmer (S. regalis, Hort.; S. splendens, Bray). Silver Willow.-This is the most striking of all the forms of S. alba in the intense silvery hue of its leaves, conspicuous in their shining whiteness at long distances. Not so robust as the type. (See also S. cœrulea.)

\section{S. ANGUSTIFOLI., Wilidenow.}

A shrub up to 10 or $15 \mathrm{ft}$. high; young twigs silky, slender. Leaves linear, often bent or sickle-shaped, pointed; I to 2 ins. long, $\frac{1}{12}$ to $\frac{1}{6}$ in. wide ; distantly and finely toothed; silky on both sides when young, becoming nearly or quite smooth later, scarcely or very shortly stalked. Catkins slender, about $\frac{3}{4}$ in. long, produced in May on short leafy twigs; stamens solitary (or rather two with their stalks united); ovary and scales slightly silky.

Native of the Caucasus and $/ N$. Asia, and very distinct in the extreme narrowness of the leaves. The type is not common in cultivation, but nurserymen for several years past have offered a form of it under the name of S. MICROSTACHYA, Turczaninow (S. angustifolia var. microstachya, Andersson). - This has leaves not more than $\mathrm{I} \frac{1}{2}$ ins. long, or $\frac{1}{8}$ in. wide.

\section{S. ARbuSCula, Linnceus.}

A shrub sometimes only I ft. high and spreading, sometimes shaped like a miniature, bushy, very leafy tree thrice as high; young shoots either 
smooth or (more rarely) silky. Leaves oval, obovate, or sometimes approaching lanceolate, tapered at both ends, toothed or entire ; $\frac{1}{2}$ to 2 ins. long, $\frac{1}{4}$ to $\frac{3}{4}$ in. wide ; deep green above, usually glaucous or grey beneath ; stalk $1^{\frac{1}{2}}$ to $\frac{1}{4}$ in. long. Catkins slender, produced in May at the end of short leafy shoots; males about $I$ in. long, females rather longer; stamens two.

Native of Europe and Siberia, inhabiting high latitudes and mountains, including those of Scotland. It is a variable shrub, most nearly allied to phylicifolia, but differs in all its forms from that species in having the stalk of the ovary much shorter than the gland or nectary (in phylicifolia the ovary stalk is always the longer). Two chief varietıes of S. Arbuscula have been distinguished, viz.-var. ERECTA, Andersson, the erect-growing densehabited shrub; and var. HUMILIS, Andersson, the low spreading one. In general aspect it resembles S. Myrsinites, but that species has the leaves bright green on both sides.

\section{S. AURITA, Linnceus. ROUND-EARED Willow.}

A shrub varying in height from I to 6 or $7 \mathrm{ft}$., according to soil and situation; young twigs slender, at first very downy, becoming smooth the second year. Leaves obovate, blunt or pointed at the apex, tapered at the base; 1 to 2 ins. long, $\frac{1}{2}$ to $1 \frac{1}{4}$ ins. wide ; rather indefinitely toothed; the upper surface dull dark green, wrinkled, and more or less woolly; lower surface covered with a permanent dull grey wool ; stalk $\frac{1}{6}$ to $\frac{1}{3}$ in. long; stipules conspicuous on vigorous shoots, and mostly persisting till the fall of the leaf. Catkins produced on the naked shoots in April; male catkins stalkless, $\frac{1}{2}$ to $\frac{3}{4}$ in. long ; stamens two, hairy towards the base.

Native of Europe (including Britain) and N. Asia. It belongsl.to the same group as S. Caprea and cinerea, from the former of which it differs in being a more bushy plant with smaller, more wrinkled leaves and smaller catkins. It is not so easily distinguished from $\mathrm{S}$. cinerea, but has the year-old twigs smooth (in cinerea they remain downy). S. aurita has hybridised with numerous other species.

\section{S. BABYLONICA, Linnceus. WEEPING Willow.}

\section{(S. pendula, Manch; S. Napoleonis, Schultz.)}

A tree usually 30 to $50 \mathrm{ft}$. high, the rugged trunk branching low and supporting a wide-spreading head of branches, the very slender, smooth, terminal twigs of which hang down perpendicularly. Leaves lance-shaped, with long, slender points, finely toothed; 3 to 4 ins. long, about $\frac{1}{2}$ in. wide; dark green above, blue-grey beneath, smooth on both surfaces except when quite young; stalk about $\frac{1}{4}$ in. long, minutely downy. Catkins slender, the females 2 ins. long, males rather shorter, produced in April along with the young leaves. Stamens two.

Native of China, in the western provinces of which it has lately been seen abundant in a wild state by $\mathrm{Mr}$ Wilson. It is not native of the region of the Euphrates, as the name babylonica would indicate, but has no doubt been cultivated in E. Europe, N. Africa, and W. Asia from an early period. The words of the Psalmist (cxxxvii. 1, 2): "By the rivers of Babylon, there we sat down, yea, we wept, when we remembered Zion. We hanged our harps upon the willows in the midst thereof," do not, as is generally believed, refer to Salix babylonica, but to a poplar-POPULUS EUPHRATICA, Olivier.

The weeping willow was probably first introduced to W. Europe by the 
French traveller Tournefort, towards the end of the seventeenth century. Peter Collinson says the original weeping willow was brought to England about 1730 by "Mr Vernon, Turkey Merchant at Aleppo, from the river Euphrates, and planted at his seat at Twickenham Park, where I saw it in 1748." There is also a story that Alexander Pope was one day in the company of Lady Suffolk, when she received a parcel from Spain tied up by willow twigs, and that, noticing one of the twigs was alive, he begged it, and planted it at Twickenham, where it grew into the celebrated weeping willow of his villa garden. This has been said to be the first Salix babylonica introduced to England, but no doubt $\mathrm{Mr}$ Vernon has the prior claim. For a long time only the female tree was known, and even now it is much the more common.

$\mathrm{S}$. babylonica is a popular waterside tree, and its beauty is nowhere so telling as by the side of a stream or lake. The banks of the Thames above Richmond owe much of their charm to it. An impetus to its cultivation was given about 1823 through the introduction from St Helena of weeping willows raised from a tree in that island which Napoleon had loved and under which he was buried. Numerous descendants of this tree are still scattered over the country. (See plate, vol. i., p. 64.)

Var. ANNULARIS, Ascherson (S. crispa, Hort.). - A curious form whose leaves are twisted into rings or spirally curled. It has little beauty.

\section{S. BebBiAnA, Sargent.}

\section{(S rostrata, Richards (not of Thuillier).)}

A shrub, rarely a small tree, up to $25 \mathrm{ft}$. high, young shoots covered at first with grey down, becoming smooth and dark brown. Leaves usually more or less obovate, sometimes oval or lance-shaped; mostly tapered but sometimes rounded at the base, short-pointed; I to 3 ins. long, $\frac{1}{2}$ to $I$ in. wide ; distantly toothed or almost entire; dull green above, blue white and more or less downy beneath; stalk $\frac{1}{4}$ to $\frac{1}{2}$ in. long. It is a native of high latitudes in $\mathrm{N}$. America, stretching right across the continent. A male plant introduced to Kew, from the Arnold Arboretum has cylindrical catkins about I in. long; stamens two, with smooth stalks. It belongs to the Caprea group.

\section{S. BOCKII, Diels.}

A dwarf shrub of neat habit, probably 3 to $4 \mathrm{ft}$. high; young shoots slender, covered with a dense grey down. Leaves oblong or obovate, tapered to a short stalk at the base, either rounded or pointed at the apex; margins entire or occasionally sparsely toothed, recurved; $\frac{1}{4}$ to $\frac{5}{8}$ in. long, $\frac{1}{8}$ to $\frac{1}{4}$ in. wide; dark bright green above, blue-white beneath and covered with silky hairs. Catkins produced in late summer and autumn from the leaf-axils of the current year's growth; females $1 \frac{1}{2}$ ins. long, $\frac{1}{2}$ in. broad; males shorter. Stamens two, but with their stalks united to the summit (as in S. purpurea); bracts of catkins narrowly lanceolate and pointed.

A native of Western Szechuen, China, and abundant in river-beds up to $9000 \mathrm{ft}$. It was introduced to the Arnold Arboretum by Wilson by means of cuttings in 1908-9, and I saw it there in 1910. A plant then obtained for Kew was the first introduced to this country. It has flowered each October since. It is a pretty bush, the male, Mr Wilson informs me, one of the most ornamental of willows in its flowers. Altogether it promises to be one of the most attractive of dwarf sorts. It has been confused with S. VARIEGATA, Franchet, a nearly allied species, which has its leaves quite smooth by the 
end of the season, and whose catkin bracts are obtuse. In habit, too, it differs from $\mathrm{S}$. Bockii in being prostrate or decumbent, and in a wild state is confined to the gorges of the Yangtse Kiang.

\section{S. CAsia, Villars. Alpine Grey Willow.}

\section{(S. myrtilloides, Willdenow (not of Linnous).)}

A shrub of low straggling habit, 2 to $4 \mathrm{ft}$. high, very leafy, with smooth dark brown young branches; buds smooth, yellow. Leaves oval or obovate, tapered at the base, pointed (often abruptly) at the apex, sometimes wavy but not toothed at the margin ; $\frac{3}{4}$ to $1 \frac{1}{3}$ ins. long, $\frac{1}{3}$ to $\frac{3}{4}$ in. wide ; perfectly smooth on both surfaces, bluish beneath; stalks $\frac{1}{6}$ in. or less long. Catkins produced in April and May at the end of short leafy shoots, each $\frac{1}{2}$ to $\frac{3}{4}$ in. long. Stamens two, their stalks united by half or more than half their length. Ovary stalkless, downy.

Native of the Alps of Central Europe ; introduced in I824. It is met with in gardens usually as "S. Zabelii pendula," being grafted on standards, and in that way transformed into a small weeping tree-pretty, but, as treated in this way, usually short-lived. It is allied to S. purpurea, especially in the connected stamens.

\section{S. CANDIDA, Fluegge. SAGE Willow.}

A shrub up to 4 or $5 \mathrm{ft}$. high, the young shoots covered with a close white wool. Leaves linear to narrow-oblong, tapered at both ends; $1 \frac{1}{2}$ to $4 \frac{1}{2}$ ins. long, $\frac{1}{8}$ to $\frac{7}{8}$ in. nide; upper surface wrinkled, at first white uith down which afterwards falls away, leaving it dull green; lower surface permanently covered with a thick white wool ; margins decurved, obscurely toothed or entire; stalk $\frac{1}{8}$ to $\frac{1}{2}$ in. long; stipules about as long. Catkins produced in April, leafy or naked at the base ; males about 'I in. long ; stamens in pairs, their stalks smooth, white, anthers red; females longer ; seed-vessels densely covered with white wool.

Native of $\mathrm{N}$. America, inhabiting cold damp regions from Newfoundland and Athabasca south to the United States; introduced in 1811 . This distinct and hardy species is worth growing for the vivid whiteness of its young leaves. It is the American representative of our native $S$. viminalis, from which it is easily distinguished by the leaves being dull, not glistening and satiny, beneath.

\section{S. Caprea, Linneus. Goat Willow, Sallow.}

A shrub or low tree of bushy habit ; young shoots at first grey with down, becoming smoother. Leaves varying in shape from roundish oval or oval lance-shaped to obovate ; tapered, rounded, or heart-shaped at the base ; pointed, sometimes blunt at the apex, toothed or entire ; $2 \frac{1}{2}$ to 4 ins. long, 1 to $2 \frac{1}{4}$ ins. wide ; grey-green, wrinkled and slightly downy above ; covered with a soft grey wool beneath; stalk $\frac{1}{3}$ to $\frac{3}{4}$ in. long, woolly. Catkins produced on the naked shoots in March and April, stalkless; the males very silky, a little over I in. long, half as thick; stamens two, yellow. Female catkins ultimately 2 ins. or more long; the seed-vessels white with down, and stalked.

Native of Europe and N.W. Asia, and common in Britain. Flowering branches of the male are often known in country places as "palm," and are 
gathered by children the Sunday before Easter, when that day coincides with the opening of the flowers. This willow is one of those which bear seeds fairly freely in this country. It is often seen in hedgerows, where its yellow catkins make a cheerful display in early spring.

Var. PENDULA. Kilmarnock Willow. - Has stiffly pendulous branches.

\section{S. CINEREA, Linnceus. GREY WiLlow.}

A willow of the Caprea or goat willow group, usually 6 to $10 \mathrm{ft}$. high, mostly shrubby, but occasionally larger and assuming the character of a small tree ; the whole plant is covered with a grey down, which usually persists on the twigs through the second season. Leaves obovate or oval, tapered at the base, pointed ; 2 to $3 \frac{1}{2}$ ins. long, $\frac{3}{4}$ to $1 \frac{3}{4}$ ins. wide; entire or inconspicuously toothed; stalk up to $\frac{1}{2}$ in. in length; stipules usually large. Catkins very silky, $\frac{3}{4}$ to $1 \frac{1}{4}$ ins. long, $\frac{1}{2}$ to $\frac{3}{4}$ in. wide ; produced on the naked shoots in March and April. Stamens two, about twice as long as the silky scale ; ovary silky.

Native of Europe, including Britain. This willow has much affinity with $\mathrm{S}$. Caprea, but differs in its smaller, usually narrower leaves and catkins. It flowers at the same season, and its flowering twigs are gathered like those of the goat willow on Palm Sunday. Otherwise of little interest.

Var. TRICOLOR, Dippel. - Leaves blotched and dotted with yellow and white. Of little beauty so far as I have observed.

\section{S. CGerulea, Smith. CRICKET-BAT WILLOW.}

(S. alba var. cœrulea, Syme.)

This fine tree, sometimes called the "blue willow," occasionally reaches a height of $100 \mathrm{ft}$., and 15 to $18 \mathrm{ft}$. in girth. It differs from the white willow in its pyramidal growth and erect branching, and by the leaves losing their silky down

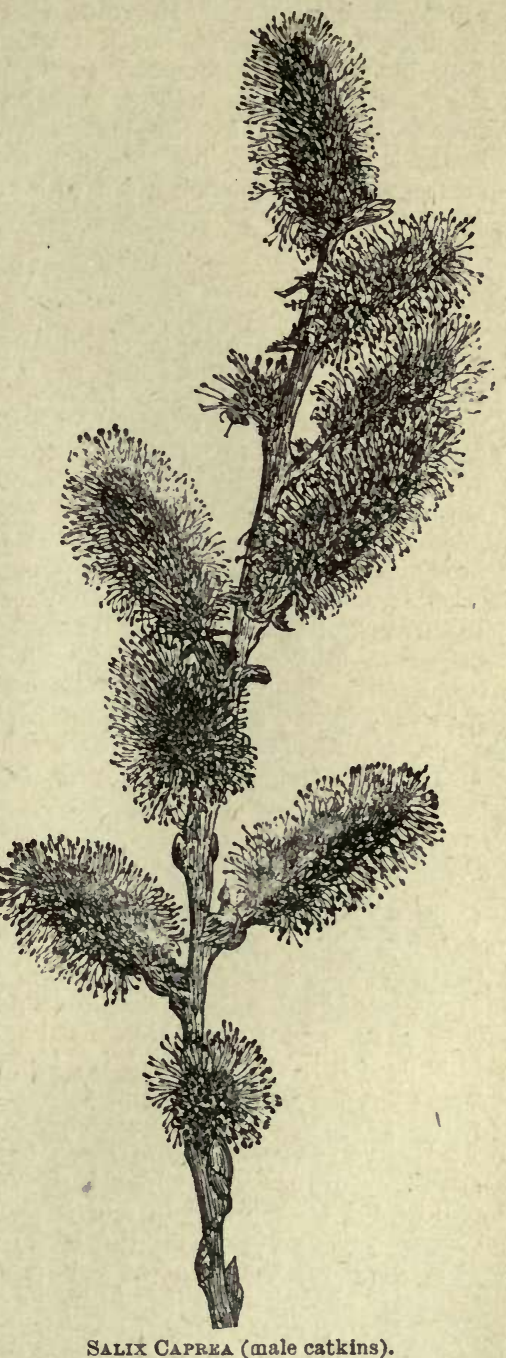
and becoming glabrous late in the summer, and blue-grey beneath. Only the female tree is known, and its ovaries, according to Henry, are slightly stalked, thus differing from the stalkless ones of S. alba. On the whole, it is best distinguished from that ${ }^{\circ}$ species by its habit of growth.

The origin of this valuable willow is uncertain. It appears to be confined 
in a wild state to the eastern counties of England, especially Hertford, Essex, Suffolk, and Norfolk, where it has been known for over a century. Its timber is more prized by cricket-bat makers than any other, and having now become somewhat scarce, fetches seven to twelve shillings (sometimes more) per cubic foot. It grows with extraordinary rapidity in good situations (it likes a stiff, moist, but not waterlogged soil), and, raised from a cutting will, in twelve or fourteen years attain a girth of 4 to $5 \mathrm{ft}$. Henry has suggested that this willow may be a hybrid between alba and fragilis, a theory supported by the leaves becoming smooth with age, by the slightly stalked ovary, and by the fact that, on vigorous shoots of newly rooted cuttings, the leaves are almost identical with those of fragilis.

\section{S. CORDATA, Muehlenberg.}

A vigorous, richly leafy shrub or small tree, making long stiff shoots annually, and reaching io to $15 \mathrm{ft}$. high ; young shoots downy at first, getting smooth by late summer. Leaves closely set on the branch, often furnished with a pair of large ear-shaped stipules ; ovate-lanceolate, rounded or heartshaped at the base, slender pointed, finely toothed; 3 to 6 ins. long, $\frac{3}{4}$ to $\mathrm{I} \frac{1}{2}$ ins. wide; green and smooth on both sides except the midrib, which is slightly downy above; stalk $\frac{1}{2}$ to $I$ in. long. Catkins up to 2 ins. long, produced on the naked wood in April, with one or a few tiny leaflike bracts at the base of each. Stamens two.

Native of N. America from New Brunswick to British Columbia and southwards; introduced in 1812. A very well-marked willow by reason of the large, long-stalked leaves with a heart-shaped base, and the conspicuous persistent stipules. Very common in its native country in different forms that vary in the comparative length and width of the leaves.

S. Nicholsoni, Dieck, does not differ at all from S. cordata so far as I can see, except that the young leaves are reddish.

\section{S. DAPHNOIDES, Villars. VIOLET WILLOW.}

A tree of erect, vigorous habit up to $40 \mathrm{ft}$. high; young shoots at first downy, becoming smooth, and covered with a conspicuous plum-coloured bloom; twigs brittle. Leaves oval-lanceolate, tapered at both ends, but more gradually at the point, finely toothed (the teeth glandular); $\mathrm{I} \frac{1}{2}$ to $4 \frac{1}{2}$ ins. long, $\frac{3}{8}$ to I in. wide; somewhat leathery; smooth, dark green and glossy above, blue beneath; stalk $\frac{1}{6}$ to $\frac{1}{2}$ in. long. Catkins produced in March; males I to 2 ins. long, $\frac{1}{2}$ to $\frac{3}{4}$ in. wide, rather striking, and resembling those of the goat willow; females more slender.

Native of Europe, eastwards to Siberia and the Himalaya. It has been found naturalised in Cleveland, Yorkshire, but is not truly British. As a willow for gardens it is worth growing for the beautiful purple or violetcoloured waxy bloom on the shoots. If the plants are cut back about every second spring the crop of young wands makes a pleasing winter effect. In the osier basket trade it is known as "Violets."

S. ACUTIFolia, Willdenow (S. violacea, Andreres; S. pruinosa, Wendland). -Sometimes regarded as a variety only of S. daphnoides, this differs from that species chiefly in its more slender shoots, and in the narrower leaves and lance-shaped (rather than semi-cordate) stipules. The shoots are similarly covered with a fine plum-coloured bloom, and the leaves are white beneath.

- A native of Russia and Turkestan, not quite so striking in its pruinose young wood as S. daphnoides.

Between S. daphnoides and S. Caprea there is a hybrid-S. ERDINGERI, 


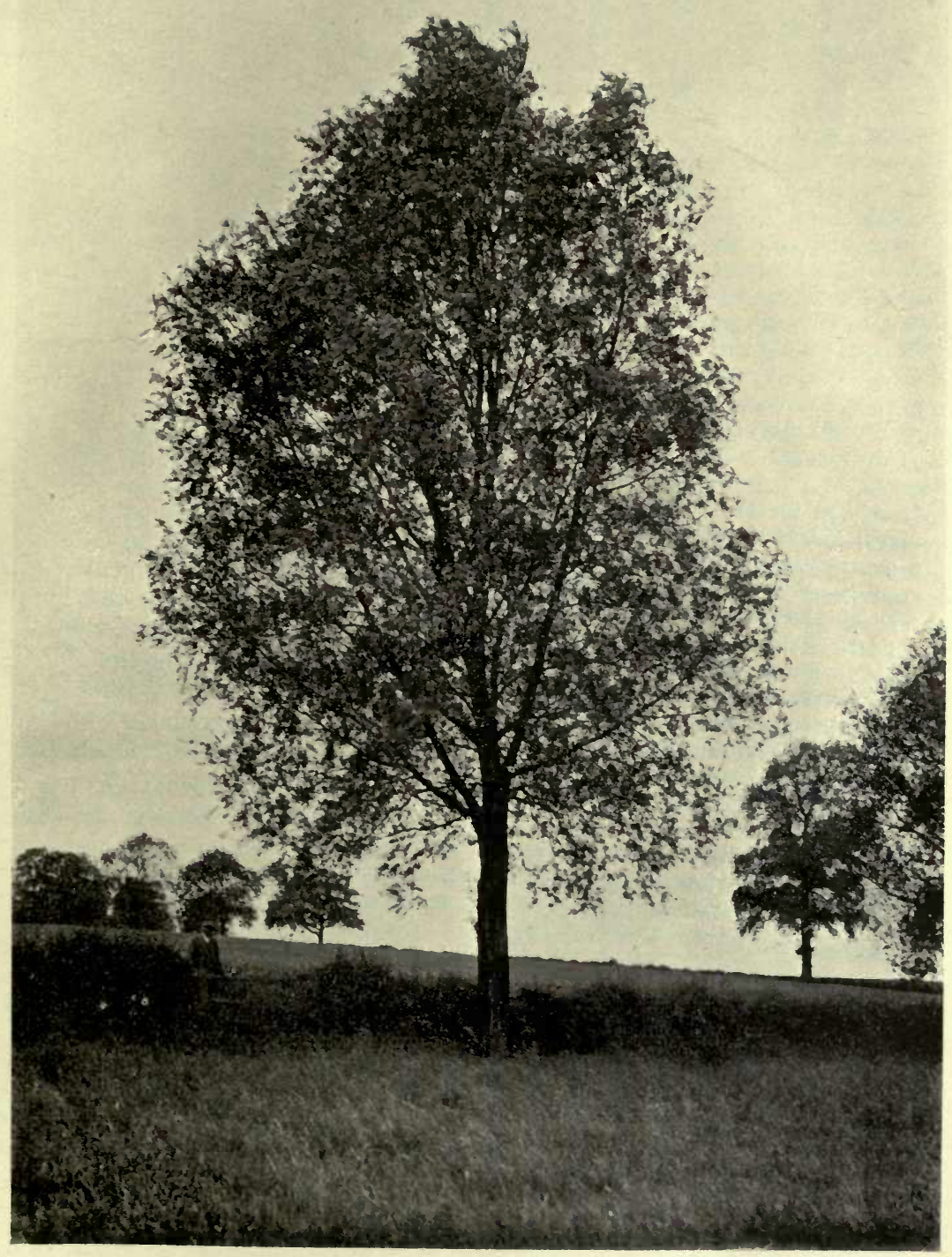

Cricket-Bat Willow, Salix corulea.

II.]

[Face p. 480. 

Kerner.-It is a handsome willow with dark purplish brown shoots, and oblong-obovate leaves, up to 4 ins. long and I in. wide; silky when young, soon becoming nearly smooth. It is a female, and the catkins are cylindrical, $\mathrm{I} \frac{1}{4}$ to $\mathrm{I}^{3}$ ins. long, $\frac{1}{2}$ in. wide, and rather.striking when they appear in March.

\section{S. DISCOLOR, Muehlenberg. PUSSY Willow.}

A shrub or low tree not more than $25 \mathrm{ft}$. high; young shoots purplish brown, at first downy. Leaves oblong, oval, or obovate, tapered at both ends, toothed except towards the base; 2 to 5 ins. long, $\frac{5}{8}$ to $1 \frac{1}{4}$ ins. wide; at first somewhat downy, soon becoming smooth, bright green above, and bluewhite beneath; stalk $\frac{1}{4}$ to I in. long. Catkins opening in March and April on the leafless shoots; males up to $1 \frac{1}{2}$ ins. long, cylindrical; stamens two, with smooth stalks; female catkins up to 3 ins. long in fruit.

Native of the eastern United States and Canada; introduced in I8II. It is rather striking in its deep brown branchlets and very glaucous undersurface of the leaves.

\section{S. FRAGilis, Linnceus. CRACK Willow.}

\section{(S. Russelliana, Smith; S. monspeliensis, Forbes.)}

A tree 80 to $90 \mathrm{ft}$. high, with a rough corrugated trunk; branchlets growing at an angle of $60^{\circ}$ to $90^{\circ}$ to those from which they spring; young shoots smooth. Leaves narrowly lanceolate to narrowly oblong, 2 to 7 ins. long, $\frac{3}{8}$ to $I_{\frac{1}{4}}$ ins. wide ; tapered at the base, the apex drawn out into a long, slender point; distinctly and regularly toothed (more coarsely in the male); usually somewhat silky at first, soon becoming smooth; stalk $\frac{1}{4}$ to $\frac{3}{4}$ ins. long. Catkins 2 to $2 \frac{1}{2}$ ins. long, produced in April and May on short leafy shoots. Stamens two, hairy at extreme base only. Ovary much tapered ; fruit stalked.

Native of Europe, including Britain, and parts of N. Asia. It obtains its common name from the readiness with which the twigs snap off in their entirety at the joint when bent. It is allied to and connected by intermediate forms with S. alba, differing chiefly in the wider angle of its branching, its larger, smooth, greener leaves, and its stalked, more elongated ovaries. It produces a useful reddish timber, used for various purposes where a wood that is tough and capable of withstanding much friction is needed. It has been used for wheelbarrows and cart bottoms. Cheap cricket-bats are also made from it ; manufacturers know it as the "open-bark" willow.

Var. BASFORDIANA (S. basfordiana, Salter; S. sanguinea, Scaling).-A variety found by Mr Scaling of Basford, Notts, in the Ardennes about 1863 . Its most distinctive character is the "brilliant orange, passing to red," of the shining bark of the twigs.

The crack willow and all the forms that belong to it make handsome bushy-headed trees.

S. DECIPIENS, Hnfmann, is now generally regarded as a hybrid between S. fragilis and S. triandra, although many authorities have considered it a variety of S. fragilis merely. From that species it differs in being a bush or small tree only; it branches at a narrower angle, the twigs are not so brittle, and have a very polished, even varnished appearance the second year. Leaves smaller and broader in proportion, duller green. From the rich red bark of its branchlets it is sometimes known as "Cardinal willow" (S. cardinalis). The basket-makers know it as "Belgian Red Willow." 


\title{
S. GRACILISTYLA, Miquel.
}

\author{
(S. mutabilis, Hort.)
}

A bush of a low, spreading habit, probably not more than $6 \mathrm{ft}$. high ; young shoots covered with grey down. Leaves oblong, oval, or narrowly ovate, tapered somewhat abruptly at both ends; 2 to 4 ins. long, $\frac{1}{2}$ to $1 \frac{1}{4}$ ins. wide ; indistinctly toothed except towards th.e base; grey-green above, and at first covered with appressed silky hairs which afterwards fall away except on the midrib; rather glaucous and persistently silky beneath; veins numerous, conspicuous, parallel; stalk $\frac{1}{6}$ to $\frac{1}{4}$ in. long; stipules up to $\frac{1}{3}$ in. long, persisting. Catkins produced on naked shoots in March and April; males grey suffused with red, I to $I \frac{1}{2}$ ins. long ; stamens solitary, much longer than the scale. I have not seen the female plant.

Native of Japan and Manchuria; introduced about 1895. It is an interesting willow, perhaps not so hardy as the majority but very leafy, and pretty in flower. It is distinct on account of the many-veined, characteristic leaves.

\section{S. hastata, Linnceus. Halberd-leaved Willow.}

A shrub up to $5 \mathrm{ft}$. in height; young shoots hairy, purplish the second year. Leaves of hard texture ; ovate, oval, or obovate; tapering, rounded or sometimes (on vigorous shoots) heart-shaped at the base; always more or less acutely pointed, toothed; 1 to 4 ins. long, $\frac{1}{2}$ to $2 \frac{1}{4}$ ins. wide ; ordinarily quite smooth on both surfaces; dull green above, glaucous beneath; veins in seven to ten pairs; stalk $\frac{1}{8}$ to $\frac{1}{3}$ in. long; stipules usually present, often large and conspicuous, obliquely heart-shaped. Catkins produced at the end of short leafy shoots in May; males $1 \frac{1}{2}$ ins. long, stamens two, with smooth stalks; females longer.

Native of the mountains of Europe and N. Asia; introduced in 1780.

\section{S. Herbacea, Linnaus. DWARF Willow.}

A tiny shrub (the smallest of all British ones), reaching rarely more than 2 ins. above the ground ( 3 or 4 ins. in gardens); stems smooth, or slightly silky when young, creeping and taking root and often buried in the soil. Leaves usually only two or three at the end of the twig; round, broadly oval or obovate ; $\frac{1}{4}$ to $\frac{1}{2}$ in. long, finely round-toothed, often notched at the apex and indented at the base, glossy green on both sides and usually smooth, sometimes slightly silky when young, prominently net-veined; shortly but distinctly stalked. Catkins $\frac{1}{4}$ to $\frac{1}{2}$ in. long, appearing in April on short stalks. Stamens two; seed-vessel smooth or nearly so.

Native of the mountains of the $\mathrm{N}$. Temperate zone, including those of Great Britain and Ireland. In spite of its name it is a true shrub, and makes an interesting tuft for a damp spot in the alpine garden.

S. POLARIS, Wahlenberg. Polar Willow.-Very similar to S. herbacea in habit and shape of leaf; but distinguished by the leaves being almost invariably entire and smaller on the average. The seed-vessel is also very hairy. Native of Polar regions.

S. GRAHAMII, Borrer, is regarded as a hybrid between herbacea and probably phylicifolia. Its leaves are oval or obovate, tapered at the base, rounded or tapered at the apex, $\frac{1}{2}$ to I in. long, bright green. Native of Sutherlandshire. A low, spreading shrub up to about $\mathbf{I} \mathrm{ft}$. in height. 


\section{S. INCANA, Schrank. HOARY WILlow.}

(S. rosmarinifolia, Gouan (not of Linnceus).)

A shrub of dense, very leafy habit, bushy, up to 8 or $12 \mathrm{ft}$. high, half as much more in diameter; rarely a small tree; young shoots clothed with a fine grey felt at first, becoming smooth later; buds yellowish. Leaves linear, tapered at both ends; 2 to 5 ins. long, $\frac{1}{8}$ to $\frac{3}{16}$ in. wide; made narrower by the decurved margins; dark green and smooth above, covered with a blue-white felt beneath. Catkins erect, slender; females $I$ to $I \frac{1}{2}$ ins. long; males shorter, appearing with the young leaves in April and May; stamens two.

Native of Europe and Asia Minor; introduced about 1820 . It is one of the prettiest and most effective of bush willows in foliage. Its leaves resemble those of viminalis only they are not so coarse, or so glistening beneath. Very desirable for the banks of ponds, etc. It is sometimes seen under the name S. rosmarinifolia $(q . v$.$) .$

\section{S. lanata, Linncus. Woolly Willow.}

A low, sturdy bush, 2 to $3 \mathrm{ft}$. high; branchlets stout, furnished when young with thick, soft, grey wool. Leaves silvery on both sides, with a rich coat of silky hairs, especially at first ; oval to roundish or obovate, mostly abruptly pointed at the apex and tapered at the base, but sometimes rounded or heart-shaped; I to $2 \frac{1}{2}$ ins. long, $\frac{3}{4}$ to $1 \frac{1}{2}$ ins. wide, nearly always entire ; stalk $\frac{1}{8}$ to $\frac{1}{4}$ in. long; stipules up to $\frac{1}{3}$ in. long, ovate, entire, prominently veined. Catkins produced in May, often solitary at the end of the previous season's growth, of a bright golden colour; males I to 2 ins. long, $\frac{1}{2}$ in. thick ; females up to 3 ins. long at the seeding stage.

Native of high latitudes in Europe and Asia ; found in Scotland in the East Grampians. It is one of the handsomest of dwarf willows, especially in spring, when the silver foliage and golden catkins are in admirable contrast. It is allied to S. Lapponum, but has broader, rounder leaves, whilst the catkins of S. Lapponum are silky white.

S. SADLERI, Syme, is a very distinct form of lanata, or a hybrid between that species and perhaps herbacea. It was discovered in Aberdeenshire, in August 1874, by Mr John Sadler, then of the Edinburgh Botanic Gardens.

\section{S. LÄPONUM, Linnceus. LAPLAND WILLOW.}

A shrub of spreading, much-branched habit, 2 to $4 \mathrm{ft}$. high ; young shoots dark brown, more or less downy. Leaves oval or somewhat obovate, occasionally lanceolate, tapered at both ends or sometimes rounded at the base, not toothed except rarely ; I to 3 ins. long, $\frac{1}{3}$ to $1 \frac{1}{4}$ ins. wide ; cottony above, becoming nearly or quite smooth with age; lower surface permanently woolly beneath, silvery white at first, ultimately grey; stalk $\frac{1}{8}$ to $\frac{1}{3}$ in. long ; stipules inconspicuous or absent. Catkins produced on the naked shoots in April and May, very silky ; males about I in. long, stalkless ; females longer, shortly stalked.

Native of the high latitudes and altitudes of Europe and Siberia; not uncommon on the Perthshire mountains, and has also been found on Helvellyn. It varies much in width of leaf, some forms found in Scotland being almost linear.

\section{S. LASIANDRA, Bentham.}

This fine willow belongs to the same group as S. pentandra, our native bay willow, and S. lucida, and is, according to Sargent, often a tree $60 \mathrm{ft}$. 
high in Western N. America, where it is native. It has the same dark green, shining leaves as its allies, the glandular teeth, the conspicious stipules on strong shoots, the glandular leaf-stalks, yellow midrib, and the five or more stamens; but the leaf is, at first at any rate, pale or glaucous beneath and downy. In flower it is also distinguished by the scale, at the base of which the group of stamens or the ovary is attached, being toothed at the apex ; it is entire in the other two. The leaves are 4 to 5 (sometimes 6 to 7 ) ins. long, $\frac{1}{2}$ to $\mathrm{I}$ (sometimes $\mathrm{I} \frac{1}{2}$ ) ins. wide.

This willow is occasionally offered by nurserymen.

\section{S. LUCIDA, Muehlenberg. SHINING Willow.}

Usually a shrub, sometimes a tree up to $25 \mathrm{ft}$. in height; young shoots smooth, glossy; flowering twigs downy. Leaves lance-shaped, broadly wedge-shaped or rounded at the base, with long, slender, sometimes tail-like points ; finely glandular-toothed ; 3 to 5 ins. long, $\frac{3}{4}$ to $1 \frac{1}{4}$ ins. wide ; dark glossy green above: paler beneath; $\frac{1}{4}$ to $\frac{1}{2}$ in. long, with several glands near the blade, downy in the groove on the upper side, and partially so up the midrib. Stipules large, roundish heart-shaped, glandular-toothed, often persistent. Catkins produced very abundantly on short, leafy twigs in April and May; males erect, $\mathrm{I}_{2}^{\frac{1}{2}}$ to $2 \frac{1}{2}$ ins. long, stamens five (sometimes three or four) ; females more slender, 2 ins. long.

Native of N. America from Newfoundland to the eastern base of the Rocky Mountains. It is a handsome-leaved willow, and the only other with which it is likely to be confused is S. pentandra-its Old World representative. S. lucida differs in having a long drawn-out point to the narrower leaf, and the net-veining is not so prominent as in S. pentandra. (See also S. lasiandra.)

\section{S. MAGNIFICA, Hemsley.}

A straggling shrub, from 6 to $20 \mathrm{ft}$. high, quite devoid of down in all its parts, the young shoots and conical buds purple, the former changing to red. Leaves oval or slightly obovate, entire, rounded or slightly heart-shaped at the base, the apex terminated by a short, abrupt, bluntish tip; 4 to 8 ins. long, 3 to $5 \frac{1}{4}$ ins. wide; dull grey-green (with a bloom) above, pale and slightly glaucous beneath; stalk $\frac{1}{2}$ to $\mathrm{I} \frac{1}{2}$ ins. long, purplish. Male catkins 4 to 7 ins. long; stamens two, four times as long as the scale; female catkins longer, sometimes as much as II ins.

Native of W. China; discovered in 1903 by Wilson in the mountains of Szechuen, at $9000 \mathrm{ft}$. altitude. It was not introduced at the time, and $\mathrm{Mr}$ Wilson saw only two bushes then. In 1909 he found it again, and in abundance, $20 \mathrm{ft}$. high. He sent cuttings to the Arnold Arboretum, where I saw it in 19ro, and obtained it for Kew. This, I believe, was its first introduction to Europe. It is the most remarkable of all willows, and its leaves, in shape and colour, are more like those of Arbutus Menziesii than a typical willow. Leaves have been borne on cultivated plants that measure Io ins. long, by $5 \frac{1}{4}$ ins. wide; the stalk 2 ins. long. There is every likelihood, from the altitude at which it was found, of its proving hardy.' Mr Wilson informs me that in a wild state the shoots change to red the first winter, and remain that colour for several years; also that the leaves die off a golden yellow.

\section{S. Meyeriana, Rostkov.}

(S, cuspidata, Schultz.)

This handsome willow is a hybrid between S. pentandra and S. fragilis, and has been found wild in Shropshire, as well as on the Continent in places 
inhabited by the parent species. In general appearance it very much resembles S. pentandra. The following distinctions, however, exist :- the leaf is thinner, more slender, pointed, and sometimes glaucous beneath, and the tree is usually of larger size; the male flowers have fewer (three or four) stamens, and the scale is more hairy; the female catkins are more slender and more tapering, and the seed-vessels longer-stalked and more cylindrical. It is worth growing for its vigorous habit, and its fine glossy foliage. Its leaves are oval inclined to ovate, or obovate, $I \frac{1}{2}$ to $4 \frac{1}{2}$ ins. long and $\frac{1}{2}$ to $I \frac{1}{2}$ ins. wide, quite smooth; the marginal teeth fine, regular, glandular.

\section{S. MyRsinites, Linncus. Whortle Willow.}

A dwarf shrub, I to $\mathrm{I} \frac{\mathrm{l}}{2} \mathrm{ft}$. high, of bushy habit, sometimes procumbent; young shoots slender, at first silky-hairy. Leaves roundish to narrowly oval, finely toothed, tapered at both ends, $\frac{1}{3}$ to $1 \frac{1}{2}$ ins. long, $\frac{1}{6}$ to $\frac{1}{2}$ in. wide; bright green on both sides, silky beneath when young, becoming smooth; veins in six to ten pairs; stalk $\frac{1}{8}$ in. or less long. Catkins erect, borne on short leafy shoots in May; males cylindrical, up to I in. long; stamens two; female catkins rather longer in fruit; seed-vessels hairy.

Native of the mountains of the northern hemisphere, including the Scottish Highlands and the mountains of Sligo in Ireland. It blossoms with great freedom, and is then pretty. Among willows it has perhaps most resemblance to $S$. retusa, but that species has always smooth leaves and shoots, and the parallel veins of the leaves are fewer. It much resembles Vaccinium Myrtillus in appearance, and is suitable for rock garden cultivation.

Var. JACQUINII, Wimmer (S. Jacquinii, Host), is found in the Tyrol, etc., and differs from the type in its quite entire leaves.

\section{S. MYRTILLOIDES, Linnaus.}

A shrub from a few inches to $3 \mathrm{ft}$. high, of busliy or spreading habit; young shoots and leaves smooth. Leaves obovate, oblong, or sometimes ovate, rounded or tapered at the base, pointed, not toothed, but more or less decurved at the margin; $\frac{1}{3}$ to $I \frac{1}{2}$ ins. (sometimes 2) ins. long, $\frac{1}{6}$ to $\frac{7}{8}$ in. wide; dark dull green above, blue-green or purplish beneath. Catkins borne on short leafy twigs in April and May; males $\frac{1}{2}$ to $\frac{3}{4}$ in. long, narrowly cylindrical, scarcely stalked; stamens two; females stalked, with flowers loosely arranged; ovary smooth.

Native of high latitudes or altitudes in the northern hemisphere, not of

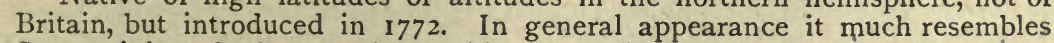
S. myrsinites, both strongly recalling in their foliage the common whortleberry. S. myrsinites, however, has the young leaves quite silky beneath, and the ovary is also downy. S. cæsia is another species much resembling it in foliage, but it also is distinct in its silky ovary, and especially in its united stamens.

Var. PEDICELlaris, Anderson (S. pedicellaris, Pursh) has narrower, longer leaves (up to $2 \frac{1}{2}$ ins. long), often blunt or rounded at the apex. Introduced in I8I I from Eastern N. America.

\section{S. NIGRA, Marshall. BLACK Willow.}

An elegant tree, 30 to $40 \mathrm{ft}$. high; occasionally much more in a wild state; shoots yellowish, smooth except when quite young. Leaves lanceolate or linear lanceolate, tapered or rounded at the base, narrowing gradually to a 
long fine point, finely and regularly toothed; 3 to 5 ins. long, $\frac{1}{4}$ to $\frac{3}{4}$ in. wide ; palish green, and almost or quite smooth on both sides except on the midrib; stalk $\frac{1}{8}$ to $\frac{1}{4}$ in. long, downy; stipules often large, semi-heartshaped and persistent. Catkins produced on short downy shoots, furnished with small leaves in April ; 1 to 3 ins. long, slender; stamens three to five.

Native of N. America, where it is widely spread; introduced in 1811 . It is the largest of the East American willows, but is there rather a huge bush than a tree. Sargent says it is occasionally $120 \mathrm{ft}$. high in S. Indiana and Texas. It is not so elegant a tree in this country as in the United States, although quite hardy. It has rather the aspect of a small, densely branched S. alba. leaves.

Var. FAlCATA (S. falcata, Pursh) has curved or somewhat sickle-shaped

\section{S. NIGRICANS, Smith.}

(S. phylicifolia var. nigricans, $F, B$. White.)

A bushy shrub, 10 to $12 \mathrm{ft}$., occasionally more high; young shoots and buds more or less downy. Leaves extremely variable in outline (roundish, oval, ovate, obovate, or oblanceolate), pointed at the apex, rounded or tapered at the base, toothed; $1 \frac{1}{2}$ to 4 ins. long, $\frac{1}{2}$ to 2 ins. wide ; more or less downy, dark dull green above, bluish beneath; stalk $\frac{1}{4}$ to $\frac{3}{4}$ in. long. Male catkins $\frac{3}{4}$ to $1 \frac{1}{4}$ ins. long, $\frac{1}{3}$ to $\frac{1}{2}$ in. wide, produced in April on a short stalk furnished with a few small bracts; stamens two, more than twice as long as the silky scale; female catkins more slender ; ovary downy.

Native of Europe, including Britain, represented in gardens at different times by an extraordinary number of forms, varying in the shape and size of the leaves. Many of these were figured by Forbes in the Salictum Woburnense, but have little interest. The species is, indeed, one of the dullest and most uninteresting of hardy shrubs, and is not worth a place in the garden proper. It is seen in the seedling state oftener than most willows. Some botanists do not consider S. nigricans and S. phylicifolia as specifically distinct from each other; S. nigricans can usually be distinguished by its thinner, larger, duller green, more downy leaves, which mostly turn black in drying.

\section{S. PENTANDRA, Linnceus. BAY WILLOW.}

A tree 20 to $50 \mathrm{ft}$. high in gardens, often a shrub in a wild state; twigs shining, brownish green, smooth ; buds yellow. Leaves ovate to oval, rounded or slightly heart-shaped at the base, rather abruptly narrowed at the apex to a slender point, finely glandular toothed; $1 \frac{1}{2}$ to $4 \frac{1}{2}$ ins. long, $\frac{3}{4}$ to 2 ins. wide ; smooth, dark polished green above, dull and paler beneath; midrib yellow ; stalk $\frac{1}{4}$ to $\frac{3}{8}$ in. long, glandular near the blade. Male catkins cylindrical, about $1 \frac{1}{2}$ ins. long; female catkins rather longer, both produced on leafy shoots in late May. Stamens five or more; seed-vessels smooth, slightly stalked.

Native of Europe (including Britain) and N. Asia. One of the handsomest of all willows in the brilliant green of its large, broad leaves, resembling those of a bay laurel. In high latitudes it is a shrub, but in moist good soil it becomes a goodly sized tree. There is one at Kew $50 \mathrm{ft}$. high and $7 \mathrm{ft} .8$ ins. in girth of trunk. The leaves are fragrant when crushed.

\section{S. PETIOLARIS, Smith.}

A shrub $6 \mathrm{ft}$. or more high, with slender twigs which are slightly silky when young, soon becoming smooth and, later on, deep purple. Leaves 
narrowly lanceolate, tapered at both ends, finely and regularly toothed; $1 \frac{1}{2}$ to 4 ins. long, $\frac{1}{4}$ to $\frac{5}{8}$ in. wide ; silky only when quite young, soon quite smooth, bluish beneath; stalk $\frac{1}{4}$ to $\frac{1}{3}$ in. long. Catkins downy, produced on the naked shoots in April; males about $\frac{3}{4}$ in. long, cylindrical, stamens two; females I to $I \frac{1}{2}$ ins. long in fruit, $\frac{3}{4}$ in. broad, the seed-vessel slenderly stalked.

Native of N. America from New Brunswick to Tennessee, inhabiting damp places. It has been cultivated in Britain since early in the nineteenth century.

S. SERICEA, Marshall. Silky Willow.-This is sometimes made a variety of petiolaris (S. p. var. sericea, Andersson), but is no doubt distinct enough to rank as a species. It is easily distinguished by the twigs being downy, and the leaves very silky and lustrous beneath, and remaining more or less so until autumn. The leaves also are generally broader, and the seed-vessel blunter at the apex. Native of the same region.

\section{S. PHylicifolia, Linnœus. TEA-LEAVEd Willow.}

\section{(S. bicolor, Ehrhart.)}

A bushy shrub, 6 to $10 \mathrm{ft}$. high; young shoots smooth or slightly downy, shining, yellowish or brown. Leaves orbicular, oval, ovate, or obovate; slightly toothed or almost entire; $\frac{3}{4}$ to 3 ins. long, $\frac{1}{2}$ to 2 ins. wide ; shining green above, and either green or glaucous beneath; sometimes downy, sometimes smooth; stalk $\frac{1}{6}$ to $\frac{1}{2}$ in. long. Catkins $\frac{3}{4}$ to $1 \frac{1}{4}$ ins. long. Stamens two, thrice as long as the scale.

Native of Europe, where it is very generally spread, including Britain. Its close affinity with $\mathrm{S}$. nigricans has been referred to under that species, but it is a brighter-looking, neater shrub, distinguished by the greater glossiness and smoothness of its young parts. It is not worth a place in the garden.

\section{S. Pierotil, Miquel. Pierot's Willow.}

\section{(S. japonica, Dippel (not of Thunberg).)}

A compact, much-branched shrub, up to 6 or $8 \mathrm{ft}$. high; young shoots smooth, or only slightly downy at first, brown and glossy; buds downy at the apex. Leaves closely set on the branch, lance-shaped, tapering at the base, slender-pointed at the apex, finely and regularly toothed; 2 to 5 ins. long, $\frac{1}{2}$ to $1 \frac{1}{8}$ ins. wide; brilliant deep green and soon quite smooth above ; vivid blue-white beneath and at first somewhat silky, later smooth; stalk $\frac{1}{8}$ to $\frac{1}{4}$ in. long, hairy above. Catkins leafy at base, I to 2 ins. long; stamens solitary (really two with the stalks united right up to the anthers); ovary hairy.

Native of Japan ; introduced about 1903. It is a handsome bush willow, allied to S. gracilistyla, but that species has leaves silky beneath, dull green above.

\section{S. PURPUREA, Linnceus. PURPLE Willow.}

A shrub with thin, graceful branches forming a loose-habited, spreading bush, io to $18 \mathrm{ft}$. high under cultivation; rarely a small tree; young shoots smooth, glossy, usually purplish where exposed to the sun, but often yellowish. Leaves linear, or narrowly oblong, mostly broadening somewhat above the middle, pointed at the apex, rounded or abruptly tapered at the base, minutely toothed towards the apex; smooth except when quite young, dark glossy green above, more or less blue or glaucous beneath; $1 \frac{1}{2}$ to 3 ins. long, $\frac{1}{5}$ to $\frac{1}{3}$ in. wide; stalk about $\frac{1}{4}$ in. long. Catkins produced on the naked 
shcots in April, $\frac{1}{2}$ to $\mathbf{I}$ in. long, slender; stamens solitary, but with two anthers.

Native of Britain, and reaching eastwards through Europe to Central Asia. It is a variable species, and is remarkable in having many of its leaves opposite as well as alternate. The bark is as bitter as quinine, and very rich in salicine. The twigs are very supple and tough, and much used in the manufacture of fine basketwork. The osiers known as "Red-bud," "Dicks," "Kecks," and "Welch" belong to this species. As a garden shrub it is worth growing for the sake of its loose, elegant growth and the vivid blue-white of the under-surface of the leaves. It thrives in dryish ground better than most willows.

Var. LambertianA, Andersson. Boyton Willow.-A variety distinguished by its larger leaves (up to 4 ins. long and $\frac{3}{4}$ in. broad); distinctly wider above the middle. Catkins also larger.

Var. PENDUla, Dippel. Weeping Purple Willow.-Grafted on standards 8 or ro $\mathrm{ft}$. high, this makes a wide-spreading head with a tangle of more or less pendulous branches. Erroneously known as "American" weeping willow. Var. scharfenbergensis, Bolle, does not seem to differ from pendula.

\section{S. REPENS, Linnaus. CREEPING WiLlow.}

A low shrub of variable habit, often only $\mathrm{I}$ to $\mathrm{I} \frac{1}{2} \mathrm{ft}$. high in a wild state or in poor soil, but 6 or $8 \mathrm{ft}$. high in gardens; spreading by means of creeping or underground stems from which spring upright branches; young shoots silky. Leaves oblong or oval to lanceolate; normally $\frac{1}{4}$ to $\frac{3}{4}$ in. long and $\frac{1}{8}$ to $\frac{1}{3}$ in. wide, but in cultivation twice those dimensions; tapered about equally at both ends or more gradually towards the apex; glistening and silvery beneath, with a dense covering of silky hairs; dull or greyish green and more or less silky above, but sometimes smooth, especially late in the season; stalk $\frac{1}{12}$ to $\frac{1}{6}$ in. long. Catkins produced on the naked shoots in April and May; males $\frac{1}{2}$ to $\frac{3}{4}$ in. long, roundish oval ; stamens two.

Native of Europe (including Britain) and N. Asia. It is easily distinguished among the smaller-leaved willows by its creeping root-stock and silvery under-surface. Of numerous forms the best is perhaps var. ARGENTEA, Koch, which has both sides silvery grey. There is also a dense-habited sturdy form with leaves about $\frac{1}{3}$ in. long by $\frac{1}{8}$ in. broad, smooth and rather glossy on the upper surface, very glaucous beneath, that makes a neat bush for the rock garden. But Salix repens is a shrub that is apt to overgrow itself, and lose much of its beauty under cultivation. It wants a moist but poor soil. It is sometimes grafted on stems of a stronger-growing willow, and made into a small weeping tree; the var. argentea is very pretty treated this way, but short-lived.

\section{S. RETiCulata, Linnceus.}

A low or prostrate shrub, forming large patches on the ground, but only rising from it as a rule 5 or 6 ins., rarely 12 ins.; young branches somewhat angled, shining brown, and smooth except at first, when they are more or less silky-hairy. Leaves mostly two to four on each twig, $\frac{1}{2}$ to $\mathrm{I} \frac{1}{2}$ ins. long; round, roundish oval or broadly obovate, not toothed; slightly indented, rounded, or sometimes tapered at the apex; deep green and much wrinkled above; glaucous white, prominently net-veined and sometimes silky beneath; stalk $\frac{1}{4}$ to $\frac{3}{4}$ in. long. Catkins cylindrical, $\frac{1}{2}$ to $\mathrm{I}$ in. long, produced in May and June on slender stalks I in. long, at the end of the twig opposite the terminal leaf. Stamens two.

Native of the mountains of Europe (including the Scottısh Highlands) 
and Labrador. A very distinct and interesting dwarf willow, with comparatively longer leaf-stalks than any other species. Suitable for the alpine garden.

\section{S. RETUSA, Linnaus.}

A low, spreading shrub, reaching only a few inches above the ground, the branches creeping and taking root; young shoots smooth. Leaves obovate or lozenge-shaped, $\frac{1}{3}$ to $\frac{3}{4}$ in. long, $\frac{1}{10}$ to $\frac{1}{4}$ in. wide ; tapered at the base, blunt or rounded at the apex, not toothed, quite smooth and green on both sides; stalk $\frac{1}{6}$ in. or less long; nerves in three to six pairs. Catkins erect, stalked, cylindrical, about $\frac{1}{2}$ in. long, produced at the end of short, leafy shoots in May and June.

Native of the mountains of Central and E. Europe ; introduced in 1763. A neat little alpine shrub, forming close tufts in exposed places, but spreading more freely when planted in gardens. Suitable for the rock garden.

S. SERPyllifolia, Scopoli, is closely allied to S. retusa, and is sometimes regarded as a variety of it. It differs chiefly in the smaller leaves, which in nature are only $\frac{1}{6}$ to $\frac{1}{3} \mathrm{in}$. long, forming with its stunted branches a close dense tuft. Under cultivation the plant becomes more creeping, and the leaves up to $\frac{5}{8}$ in. long. They are obovate, notched, rounded or pointed at the apex; nerves two to four each side. Native of the Alps of Europe.

\section{S. Rosmarinifolia, Linncus. Rosemary Willow.}

\section{(S. Friesiana, Andersson.)}

This is a well-known name in gardens, but is usually misapplied to S. incana. The true rosmarinifolia of Linnæus appears to be a hybrid between repens and viminalis, a bushy shrub with brown, slightly downy young twigs and linear leaves, $1 \frac{1}{2}$ to 3 ins. long, $\frac{1}{8}$ to $\frac{1}{4}$ in. wide, green and slightly downy above, and of a glistening silvery white beneath-very much resembling S. viminalis in this respect. S. incana differs from it in the lower surface being dull, not glistening.

There is some confusion also between rosmarinifolia and angustifolia; the true plant of the latter name (a native of the Caucasus) is another very narrow-leaved willow, but the leaves are grey-green beneath, and almost glabrous by autumn.

Finally, a variety of S. repens (S. r. var. angustifolia) has also been called "rosmarinifolia." This has shorter more lance-shaped leaves than the hybrid between repens and viminalis, but in the opinion of some it is the true rosmarinifolia of Linnæus. In view of the confusion in which the name is involved, it would seem simplest to drop it altogether, and give the hybrid Andersson's name of S. Friesiana (see Dr F. B. White in Journ. Linn. Soc., vol. xxvii. p. 39).

\section{S. RUBRA, Hudson.}

A hybrid between S. purpurea and S. viminalis, forming a small tree; young twigs slightly downy at first. Leaves linear-lanceolate, with long, tapered points, the base more abruptly tapered; distantly toothed except towards the base ; 2 to $5 \frac{1}{2}$ ins. long, $\frac{1}{4}$ to $\frac{2}{3}$ in. wide; green and smooth on both sides when mature, but grey and slightly downy beneath when young; stalk $\frac{1}{4}$ to $\frac{1}{2}$ in. long. Catkins produced on the naked shoots in April, I to $\mathrm{I} \frac{1}{2}$ ins. long. Stamens two, but with stalks united towards the base, or sometimes nearly to the anthers.

Native of Britain and Europe, and highly valued by basket-makers. The 
osiers known in the trade as "Mawdesley's Long Skein" and "Tulip Willow" belong to it.

Var. ForbyanA, Smith.-A form of rubra (one of whose parents is probably S. purpurea var. Lambertiana), with wider leaves than ordinary S. rubra ; it is known in the osier trade as "Fine Basket Osier."

\section{S. Salamoni, Hort.}

\section{(S. babylonica var. Salamoni, Hort.)}

A hybrid between S. alba and S. babylonica, and one of the handsomest and most vigorous of all willows. It is not so weeping as babylonica, having inherited some of the firmer outlines of S. alba, but is still extremely graceful. It grows at least $60 \mathrm{ft}$. high, forming a broad shapely head of luxuriantly leafy branches; twigs silky when young. Leaves $2 \frac{1}{2}$ to 5 ins. long, $\frac{1}{2}$ to $\frac{7}{8}$ in. wide ; green above, blue-white beneath; silky beneath on first expanding and slightly so above, but not so much so as S. alba, and soon becoming as smooth as those of S. babylonica. It is a female tree, its flowers opening in April. The tree has been cultivated at Kew for forty years, and several fine specimens grow on the margins of the lake there. It first appeared on the property of Baron de Salamon at Manosque, Basses-Alpes, about fifty years ago. It deserves to be planted extensively, especially in localities too cold for S. babylonica. It retains most of its leaves until December. (See plate, vol. i., p. 98.)

The three Willows named S. Elegantissima, $K$. Koch, S. BLANDA, Andersson, and S. PENDULINA, Wender, are hybrids between fragilis and babylonica. They are all intermediate in various degrees between the parents, having broader, usually deeper more glossy green leaves than babylonica. S. elegantissima is the tree often grown as S. babylonica on the Continent, in places where the real tree is not hardy. They are all beautiful trees, worthy, along with S. Salamoni, of attention-especially in the more inclement parts of Britain.

A few words may here be given to the various willows that have been called "S. japonica." The true S. JAPONICA, Thunberg, is a willow with leaves that are oval-lanceolate, often rounded or heart-shaped at the base, very coarsely toothed except at the long, slender point, I to 3 ins. long, $\frac{1}{3}$ to I in. wide. The toothing I think would distinguish it from all the other willows in cultivation, but it does not appear to exist in this country. What is grown under the name, also as "S. japonica var. Lavallei," appears to be a hybrid between S. babylonica and S. alba, and has thus the same origin as $\mathrm{S}$. Salamoni, but it is a male and its branching is more slender. S. japonica of Dippel is the same as S. Pierotii $(q . v$.$) .$

\section{S. SIlesiaca, Willdenow. Silesian Willow.}

One of the same group as cinerea, Caprea, and aurita, to the two former of which especially it has much affinity. It is a shrub up to $6 \mathrm{ft}$. or so high, the young shoots loosely downy at first, becoming smooth by the end of the season, thus differing from cinerea, which retains its down through the second year. Leaves obovate or oval, $1 \frac{1}{2}$ to 4 ins. long, about half as wide ; downy when young, becoming smooth above and nearly so below; stalk $\frac{1}{4}$ to $\frac{1}{2}$ in. long. From both cinerea and Caprea it differs in its smooth ovary. Flowers in April. Native of Europe. Of little garden interest.

\section{S. Smithiana, Willdenoze.}

A hybrid between $S$. viminalis and $\dot{S}$. Caprea, or one of its group. Several slightly differing willows, probably of not identical parentage, have 
been included under this name, but the following description applies to the commonest in gardens. A vigorous tree with erect branches, the young ones covered with soft down. Leaves oblong-lanceolate, 3 to 6 ins. long, $\frac{5}{8}$ to $1 \frac{1}{2}$ ins. wide; sharply pointed, broadly tapered at the base, indistinctly toothed; dark green above, glaucous and downy beneath; stalk $\frac{1}{4}$ to $\frac{1}{2}$ in. long. Male catkins produced in March and April so abundantly as to make the male one of the handsonrest of flowering willows; they are 1 to 2 ins. long and about $\mathbf{I}$ in. wide. Stamens in pairs. Female catkins more slender. Native of Europe, including Britain.

\section{S. SORDIDA, Kerner.}

\section{(S. pontederana, Schleich.)}

A hybrid between S. purpurea and cinerea, found wild in Scotland and on the Continent. It is a rather neat willow with downy twigs (often becoming soon smooth). Leaves narrowly obovate, oblong, or sometimes oval; tapered at both ends, most abruptly at the apex, varying from almost entire to rather prominently toothed ; I to $2 \frac{1}{2}$ ins. long, $\frac{1}{3}$ to $\frac{3}{4}$ in. wide ; dark glossy green above, conspicuously blue-white, and at first downy beneath. The influence of S. purpurea is seen in the glaucous under-surface of the leaf, and especially in the two stamens being more or less united by their stalks. Like nearly all hybrid willows, S. sordida varies in its approaches now to one parent now to another. It is at its best as a garden shrub when it most resembles S. purpurea.

\section{S. SUBALPINA, Forbes.}

This, a probable hybrid between S. incana and S. repens, is said by Forbes (Salictum Woburnense, t. 93) to have been introduced from Switzerland. It is a low shrub of rather neat habit, branches ascending, downy, and retaining their down till the second year. Leaves oblong-lanceolate, usually tapered about equally at each end; I to $2 \frac{1}{2}$ ins. long, $\frac{1}{4}$ to $\frac{5}{8}$ in. wide; margins decurved; not or very slightly toothed towards the apex, bright green and downy (especially at first) above, permanently grey and woolly beneath ; stalk $\frac{1}{6}$ in. or less long. In his original description Forbes mentions having only seen the male, and the only plants I have seen (at Kew, Cambridge, etc.) are all male. Catkins $I$ to $I_{4}^{\frac{1}{4}}$ ins. long, slender, yellow; stamens two.

\section{S. TRIANDRA, Linnceus. ALMOND-LEAVED WILlow.}

A shrub or small tree up to $30 \mathrm{ft}$. high, of erect habit; young shoots smooth or slightly downy at first, angled or furrowed. Leaves quite smooth on both surfaces, lance-shaped, rounded or wedge-shaped at the base, sharply pointed, finely toothed; 2 to 4 ins. long, $\frac{5}{8}$ to I in. wide ; green on both sides, but darker above ;'stalk $\frac{1}{4}$ to $\frac{1}{2}$ in. long. Catkins produced on very short, leafy shoots in April and May; males erect, slender, I to $2 \frac{1}{2}$ ins. long; stamens three, with stalks about twice as long as the scale.

Native of Europe and N. Asia, wild in Britain, also much cultivated for basket-making, etc. The osiers known under the trade names of "Black Hollander," "Black Italian," "Black Mauls," "French," "Glibskins," "Jelstiver," Mottled Spaniards," "Pomeranian," all belong to this species or the following variety. 
Var. AMYGdalina, Syme (S. amygdalina, Linnceus), is distinguished by having the leaves pale and glaucous instead of green beneath, but there are intermediate forms.

\section{S. Viminalis, Linnaus. COMmon OSIER.}

An erect shrub or small tree, up to $20 \mathrm{ft}$. high; young shoots grey with fine down at first, becoming smooth and yellowish later. Leaves rather erect, linear or linear-lanceolate, tapering gradually to a fine point, not toothed ; 3 to 6 ins. long, $\frac{1}{4}$ to $\frac{1}{2}$ in. wide ; dull dark green and smooth above, covered beneath with a shining, silvery grey, close down; stalk $\frac{1}{6}$ to $\frac{1}{2}$ in. long ; midrib prominent. Catkins produced on the naked wood in March and April ; up to $I$ in. long, $\frac{3}{4}$ in. wide. Stamens two, twice as long as the scale ; ovary downy.

Native of Europe (including Britain), spreading eastwards to Siberia and the Himalaya. Very common on the banks of rivers and lakes, and extensively cultivated in Europe for basket-making. The sorts known in the trade as "Long Skein," "Brown Merrin," "Yellow Osier," belong to this species. It is very distinct among the willows with long, narrow leaves in the glistening, silvery under-surface.

$\mathrm{S}$. viminalis has hybridised with several other willows. The two most important of the hybrids-S. rubra and S. Smithiana-are noticed separately. There are also the following among many others :-

S. FERRUGINEA, Forbes (viminalis $\times$ cinerea).

S. FRUTICOSA, Doell (viminalis $\times$ aurita).

S. HIPPOPHÆFOLIA, Thuillier (viminalis $\times$ triandra).

S. STIPUlaris, Smith (viminalis $\times$ ?species). - This is one of the most distinct and striking of this group, a very vigorous shrub, having leaves up to 7 ins. long by I in. wide, the down beneath very dense but less shining thin in viminalis, and the stipules much larger. The other parent is cinerea or one of its allies, but the influence of viminalis is most apparent.

\section{S. VIRIDIS, Fries.}

This willow occupies a place intermediate between S. alba and S. fragilis, and may be a hybrid between them, although some authorities have regarded alba and fragilis as extreme forms of one species. In any case, S. viridis fills the gap between these two willows by an almost complete series of intermediate forms, sometimes midway between them in most respects, sometimes approaching one of them in vegetative characters, whilst resembling the other in reproductive ones. What may be termed the central or typical form is a tree branching at angles of about $60^{\circ}$, with leaves broader and larger than those of S. alba, and averaging 2 to 5 ins. in length, $\frac{5}{8}$ to $I$ in. in width; silky at first, but soon becoming smooth; dark glossy green above, glaucous beneath. The male catkins are longer and more densely flowered than those of alba, and the ovaries are more distinctly stalked and have more distinctly formed styles. The timber of S. viridis is , valued by cricket-bat makers, but ordinarily is inferior to that of $S$. cœrulea, being heavier and coarser, and of about three fifths its money value. This refers to the typical or central form of S. viridis; as it approaches S. alba in relationship its value improves. By leaves alone it is sometimes difficult to distinguish between some of the forms and S. cœrulea, and the influence of $\mathrm{S}$. fragilis is only to be seen in the stalked, more tapered seed-vessels. It is never pyramidal in growth like $\mathrm{S}$. cœrulea.

Native of the lowlands of Britain, where it is widely spread from the south and south-west counties of England to Perthshire; also of contihental 
Europe. It grows $80 \mathrm{ft}$. high, and at its middle size has often a broadly columnar habit.

\section{S. vitellina, Linnaus. Golden Willow.}

(S. alba var. vitellina, Stokes.)

A tree up to 60 or $65 . \mathrm{ft}$. high, with young shoots downy near the buds, but becoming by winter smooth and of a brilliant yellow. Leaves narrowly lanceolate, 2 to 4 ins. long, $\frac{3}{8}$ to $\frac{1}{2}$ in. wide, tapering to a slender tail-like point, glossy green above, glaucous beneath; not so silky-hairy as in S. alba. The catkins are longer and more slender than in S. alba, and the scales are longer. According to Henry, the stamens are occasionally three to each flower.

Of doubtful, perhaps hybrid, origin, this tree is now chiefly planted in gardens for the fine effect produced in winter by its yellow shoots; for this purpose it is pruned hard every spring so as to develop a low thicket of wands. Several plants should be grouped together. It is also grown in osier beds, but its twigs are chiefly used for tying purposes; it is of only second or third-rate quality for baskets. Var. BRITZENSIS, Spath, is a form of $\mathrm{S}$. vitellina with bright red bark. There is also a weeping form, PENDULA, Spath, that is very elegant.

\section{SALVIA OFFICINALIS, Linnceus. SAGE. LABIAT}

A sub-evergreen, aromatic shrub, usually $\mathrm{I}$ to $2 \mathrm{ft}$. high, but said in favourable places to become three times as high; young stems square, and only half woody; the whole plant is covered with a short down which gives it a grey appearance. Leaves opposite, oblong, 2 to $3 \frac{1}{2}$ ins. long, $\frac{1}{2}$ to $\mathbf{I}$ in. wide; much wrinkled, round-toothed. Flowers arranged in whorls on terminal, erect racemes about 6 ins. long. Corolla tubular, $\frac{3}{4}$ in. long, two-lipped, purple; calyx ribbed, funnel-shaped, two-lipped, about half as long as the corolla. Perfect stamens two. Blossoms from June onwards.

Native of S. Europe; cultivated for centuries as a medicinal and culinary herb, and highly valued in former times for making "sage-beer" - supposed to possess many healing virtues. Sage is still much used for flavouring certain meats. The plant likes a sunny position, and is easily increased by cuttings placed in a handlight. Although rarely seen except in the kitchen garden this plant is worth growing in a collection of oldfashioned, fragrant plants like lavender, rosemary, and such like, for its crowd of erect racemes. There is a variety with white flowers (ALBA), one with stems and leaves of a reddish colour (PURPUREA), and a valueless one with variegated leaves (VARIEGATA).

\section{SAMBUCUS. ELDER. CAPRIFOLIACE}

About a score species of elder are known, which are widely spread over the temperate parts of the globe. Of these about half a dozen shrubby 
ones are hardy in Britain. From the remainder of the hardy shrubs belonging to the same family, the elders are at once distinguished by their pinnate leaves, which have always an odd number (three to eleven) of toothed leaflets. The flowers are borne in flat, convex, or pyramidal clusters, and are very uniform in size and hue, being from $\frac{1}{8}$ to $\frac{3}{16}$ in. across, and of some shade of white. The various parts are normally in fives. Fruit $\frac{1}{4} \mathrm{in}$. or less in diameter, globose, or nearly so, containing three to five one-seeded nutlets. All the cultivated species are deciduous, and have opposite leaves; the young shoots are soft and full of pith, but the wood of the trunk is hard and bony.

The elders like moisture and a loamy soil ; given these they are not difficult to accommodate. They can be propagated by cuttings either of leafless wood put in the open ground in early winter, or by half-ripened young wood with a "heel" in frames. The pruning of the sorts grown for their foliage should be done before growth recommences. The following is a selection of the best:-

FOR FLOWERS. - S. nigra roseo fl. pl.; S. canadensis maxima.

FOR FRUIT. -S. nigra and its var. fructu albo; S. racemosa (where it succeeds).

FOR COLOURED LEAVES. - S. racemosa plumosa aurea; S. nigra foliis aureis; S. nigra albo-variegata.

FOR HANDSOMELY CUT LEAVES. - S. racemosa tenuifolia; S. racemosa serratifolia.

S. Ebulus, Linnaus, the British plant known as "Dane's blood" is herbaceous.

The following hardy species are easily divided into two groups according to the shape of the inflorescence, as follows :-

I. canadensis, glauca, nigra, velutina, flowers in flat or umbrella-shaped umbels.

2. melanocarpa, pubens, racemosa, flowers in panicles.

\section{S. CANADENSis, Linnaus. American Elder.}

A deciduous shrub, up to $12 \mathrm{ft}$. high, with white pith; young branches smooth. Leaves pinnate, the leaflets mostly seven (but also five, nine, and eleven), oval, oblong, or roundish ovate; the largest $5 \frac{1}{2}$ ins. long, $2 \frac{1}{2}$ ins. wide; taper-pointed, sharply toothed, the lowest pair frequently two- or three-lobed; lower surface smooth or slightly downy. Flowers in convex umbels, 4 to 8 ins. across, white, produced in July. Fruit purple-black.

Native of Eastern N. America from Canada to Florida ; introduced in $176 \mathrm{r}$. Nearly allied to S. nigra, it differs in the following respects: it never assumes a tree-like form or becomes half as high as nigra; the leaves have normally one more pair of leaflets; the flower clusters are more rounded and appear four weeks later; the fruit is not absolutely black. I have seen it making a very pleasing picture growing by the side of a stream in the Arnold Arboretum, Mass., flowering in July, but it is not so good in this country as nigra.

Var. LACINIATA, Gray (acutiloba, Rehder).-A cut-leaved form analogous to the var. laciniata of the common elder, but more graceful owing to the longer and more divided leaf.

Var. MAXIMA, Koehne.-This, the best and most remarkable form of American elder in cultivation, was originally sent out under the erroneous name of "S. pubens maxima," and, unfortunately, is still grown in many 
places under that misleading name. It is an extraordinarily robust variety, with leaves 12 to 18 ins. long; the leaflets are often eleven to each leaf, and the enormous flower clusters 10 to 18 ins. across.

\section{S. GLauca, Nuttall. BluE ElderberRy.}

A tree 13 to $30 \mathrm{ft}$. (occasionally $50 \mathrm{ft}$.) high in a wild state, but a robust shrub in this country 5 to $10 \mathrm{ft}$. high; young shoots smooth. Leaves 6 to 1o ins. long, smooth; the leaflets usually five or seven, occasionally nine, ovate or oval; 2 to 6 ins. long, $\frac{1}{2}$ to 2 ins. wide. Flowers yellowish white, produced during June in flat umbels up to 6 or 7 ins. wide. Berries black, but covered densely with a pale blue bloom.

Native of Western N. America ; cultivated in Paris fifty years ago, but now uncommon. It was reintroduced to Kew in 1893 , and is still cultivated there. Its two most striking characteristics are its vigorous growth, which makes it even more tree-like in California than S. nigra is in Europe, its trunk being sometimes 18 ins. in diameter; and the intensely glaucous hue of its berries. These are used as food when cooked, in California. Nearly allied to $\mathrm{S}$. glauca is

S. velutina, Durand, which differs in having the leaves, young shoots, and flower-stems thickly clothed with grey velvety down. It has been cultivated in France and England as "S. c.llifornica."

\section{S. MELANOCARPA, A. Gray.}

A deciduous shrub, 6 to $12 \mathrm{ft}$. high, allied to S. pubens and S. racemosa, having its flowers and fruits in panicles as in those species, but the panicles are usually broader in proportion to their height. The berries, moreover, are not red but black, and without bloom. Leaflets five or seven (sometimes nine), their chief veins and midrib more or less downy beneath when young, but not so downy as S. pubens. Native of Western N. America; introduced to Kew in 1894 .

\section{S. NIGRA, Linnceus. COMmon Elder.}

A deciduous shrub, 15 to $20 \mathrm{ft}$. high, or a small tree $30 \mathrm{ft}$. or more high ; young branches smooth. Leaves pinnate, 4 to 12 ins. long, composed of three, five, or seven (usually five) leaflets, which are ovate, $I \frac{1}{2}$ to 5 ins. long, $\frac{3}{4}$ to 2 ins. wide; sharply toothed, smooth except for a few hairs beneath. Flowers yellowish or dull white, with a heavy odour, produced during June in flat umbels 5 to 8 ins. across, each umbel composed of four or five main divisions which are again several times divided. Berries globose, shining black, ripe in September.

Native of Europe (including Britain). One of the best known of native shrubs, and to be regarded more often as a weed in gardens than anything else. Still, the elder, when made to assume the tree form by restricting it to one stem for 6 or $8 \mathrm{ft}$. up, is not without a certain quaintness and charm. Its trunk is rough and crooked, and carries a large rounded head of richly leafy branches, laden with flower in June and with fruit in September. The seeds are spread by birds, and young elder plants spring up everywhere in woods, tall shrubberies, etc. In the neighbourhood of more important plants they must be rigorously pulled up. The species is chiefly represented in gardens by the numerous varieties that have sprung from it, some of which are mentioned below as worth cultivating. The type itself may be left to furnish out-of-the-way damp, dark corners, where little else will live.

No plant holds (or perhaps it is safer to say, used to hold) a more 
honoured place in domestic pharmacy than the elder. From its berries is prepared, by boiling with sugar, a wine or syrup which, diluted with hot water, is a favourite beverage in rural districts. It is usually taken just before bedtime, and is considered a useful remedy for colds, chills, etc.

A large number of varieties have been obtained under cultivation, of which the following only 'need be mentioned as the most distinct :-

Var. ALBO-VARIEGATA.-A handsomely variegated shrub, whose leaves are bordered with creamy white.

Var. FLORE PLENO.-Flowers with a double row of petals ; ROSEO FL. PL. is the same, with rosy flowers.

Var. FOLIIS AUREIS. Golden Elder.-A good yellow-leaved shrub. Useful for producing a broad patch of colour, as it improves in depth as the season advances ; may be pruned back every spring.

Var. FRUCTU-ALBO (viridis). - Fruits greenish white. The wine made from them is clear. Also known as "leucocarpa " and "chlorocarpa."

Var. HETEROPHYLla (linearis). - In this form the blade of many leaflets is reduced to thread-like proportions, consisting of little more than the stalk and midrib. Others are $\frac{1}{8}$ to $\frac{3}{4}$ in. wide, but distorted and shapeless. A curiosity only.

Var. LACINIATA. Parsley-leaved Elder.-The handsomest cut-leaved variety of common elder, the leaflets being pinnately divided into linear, pointed lobes. There is also a variegated form of this.

Var. PENDULA. - A weeping form with stiff, pendulous branches.

Var. PYRAMIDALIS.-A stiffly erect, inelegant form.

Var. ROTUNDIFOLIA.-Leaves often with only three leaflets, proportion. ately broader, smaller and rounder than the type.

\section{S. PUbens, Michaux. RED-BERRIED AmERICAN Elder.}

\section{(S. racemosa var. pubescens, Dippel.)}

This species, which is found wild over a considerable area in N. America, on both the eastern and western sides, is so closely allied to the Old World S. racemosa, that many authors do not separate them. The American shrub is distinguished by its young shoots, leaves, and flower-stalks being downy, the pith being brown, and the fruit-panicles not so densely packed with berries.

On Vancouver Island, British Columbia, where the typical S. pubens makes a grand display in partially cleared woods, with its red fruits, a variety with golden yellow berries is found, var. XANTHOCARPA. A variety with white fruits (LEUCOCARPA) is also known.

\section{S. RACEMOSA, Linncus. RED-BERRIED ElLDE.}

A deciduous shrub, 8 to $12 \mathrm{ft}$. high, and as much through; young bark smooth, pith white. Leaves pinnate, 6 to 9 ins. long, composed of five leaflets, which are oval or ovate, 2 to 4 ins. long, $\frac{3}{4}$ to $1 \frac{3}{4}$ ins. wide ; taperpointed, sharply and regularly toothed, smooth on both surfaces. Flowers produced during April in terminal pyramidal panicles $\mathrm{I} \frac{1}{2}$ to 3 ins. high, scarcely so much wide; yellowish white. Berries scarlet; ripe in June and July; packed tightly in panicles.

Native of Europe (not of Britain), Asia Minor, Siberia, and N. China ; cultivated in England since the sixteenth century. This very beautifulfruited shrub is only occasionally seen in perfection in this country, although it grows well and flowers abundantly. It fruits admirably near Paris, and those who have visited the upland valleys of Switzerland in July will have 
marked its great beauty there. But if we are denied too frequently its attractive fruits, it has on the other hand sported into a number of coloured and cut-leaved forms, which are amongst the best of their particular class, and thrive well. The names and average characters of the cut-leaved forms are given below, but they run so much into each other that no strict distinctions can be drawn between them. Var. plumosa is the least divided, var. tenuifolia the most divided; the rest are intermediate.

Var. LACINIATA.-Leaflets deeply and pinnately lobed; the lobes linear, pointed, not more than $\frac{l}{12}$ in. wide.

Var. PLUMOSA.-Leaflets up to 5 ins. long and $\mathbf{1} \frac{1}{4}$ ins. wide, the teeth reaching half-way to the midrib. Var. PLUMOSA AUREA, sent out by Messrs Wezelenburg in 1895 , is a wholly golden yellow form of this variety, and one of the most attractive of golden-leaved shrubs.

Var. PURPUREA, Sweet.-Petals rose-coloured on the back.

Var. SERRATIFOLIA, var. ORNATA, and var. PTERIDIFOLIA are all intermediate in manner of leaf-cutting between laciniata and plumosa.

Var. SPECTABILIS. - Flowers nearly pure white.

Var. TENUIFOLIA.- - Leaflets divided quite to the midrib into long narrow segments, often doubly pinnate. A very handsome and graceful shrub with fern-like foliage.

\section{SANTOLINA. COMPOSIT E.}

Two species of Santolina are not uncommon in cultivation. They are plants with semi-woody stems, strong-scented when crushed, and with yellow flower-heads composed of very numerous small florets, and without the ray florets common to so many plants of this Order. They are of very easy cultivation, growing best in full sun in any soil that is well drained and not too rich. Cuttings taken about July, put in pots of sandy soil and placed in heat, root in a few days. Both of them are seen at their best in a comparatively young state, and are apt to become shabby with age. S. Chamæcyparissus is valuable for planting in masses on the front of a shrubbery, both for its whiteness and for its abundant blossom.

\section{S. Chamacyparissus, Linnceus. LAvender Cotton.}

\section{(S. incana, Lamarck.)}

A white bush, $\mathrm{I}$ to $2 \mathrm{ft}$. high in this country, forming a close, leafy mass ; foliage persistent; stems semi-woody, covered the first season with a thick white felt. Leaves alternate, very crowded on the shoots, the largest I to I $\frac{1}{2}$ ins. long, with clusters of shorter ones in their axils; all very narrow ( $\frac{1}{8}$ in. or less wide), and furnished with thick teeth or projections set in rows of about four. The whole leaf is clothed with a white felt. Flower-heads bright yellow, $\frac{1}{2}$ to $\frac{3}{4}$ in. across, hemispherical, solitary at the end of an erect, slender stalk 4 to 6 ins. long, terminating short lateral twigs of the year. There are no ray florets.

Native of the Mediterranean region; cultivated in Britain since the middle of the sixteenth century. It is a beautiful and interesting plant, probably the whitest of all hardy shrubs, and bears its showy flower-heads in July so thickly that they almost touch. The plant has a rather agreeable odour when lightly rubbed, but this becomes too strong and acrid to be wholly pleasant when the leaves are crushed. Formerly used in medicine as 


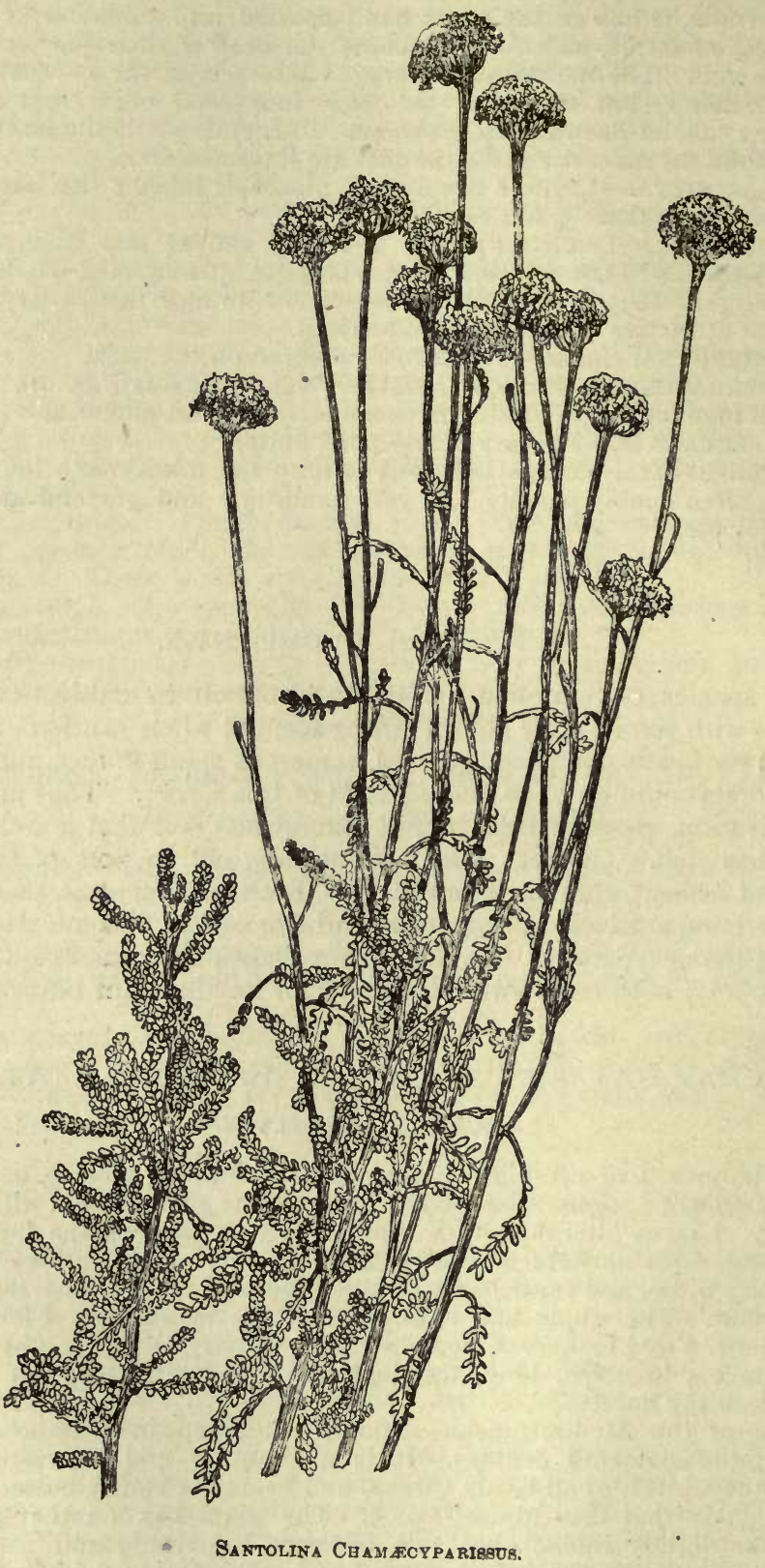


a vermifuge. The leaf has a curious structure suggestive of the stems of some lycopods; it consists of a central axis on which are set, often in whorls, short, thick; blunt projections.

\section{S. viRIdis, Willdenow. HOLY FlaX.}

An evergreen bush about $2 \mathrm{ft}$. high; stems smooth, green. Leaves deep green, smooth; the largest $\mathrm{I}$ to 2 ins. long, about $\frac{1}{8}$ in. wide; very similar in structure to those of the preceding species, but with the teeth or projections more slender and pointed, and irregularly disposed round the central axis. Flower-heads yellow, $\frac{3}{4}$ in. across; produced in July singly at the end of slender, erect, smooth stalks, 6 to 10 ins. long.

Native of S. Europe; introduced in 1727. This is not so striking and ornamental a plant as S. Chamæcyparissus, being of an ordinary green colour. Its leaves are longer and thinner, and the plant is not quite so dense in growth, nor quite so hardy. The leaves emit an odour when rubbed, but it is neither so strong nor so pleasant as that of S. Chamæcyparissus.

\section{SARCOBATUS vermiculatus, Torrey. Grease. Wood. CHENOPODIACE $Æ$.}

\section{(S. Maximilianii, Nees.)}

A deciduous shrub of lax habit, 6 to $9 \mathrm{ft}$. high, more in diameter, making a dense thicket of stems, arching and spreading at the top; twigs angular, whitish, spine-tipped, usually smooth. Leaves alternate, linear; $\frac{1}{2}$ to $I_{2}^{\frac{1}{2}}$ ins. long, $\frac{1}{1.6}$ to $\frac{1}{8}$ in. wide; grey, rather fleshy, stalkless. Flowers small, greenish, unisexual; males crowded in a spike $\frac{1}{2}$ to $I$ in. long at the end of short lateral twigs, females appearing singly in the axils of the lower leaves of the same twig. Neither has any beauty, but they are interesting botanically. The male flower has neither calyx nor corolla, the stamens, about three in number, being arranged at the base of curious cuplike scales. The female flower is also without a corolla, but has a calyx which persists and enlarges, and ultimately develops into a thin, papery disk, prominently veined, $\frac{1}{4}$ to $\frac{1}{3}$ in. across, with the seeds in the middle.

Native of the dry, alkaline, and saline regions of Western N. America; introduced to Kew in 1896. Like other shrubs from the same regions, it thrives quite well in ordinary garden soil. It flowers in July, but, as may be judged from the description, is of more botanical than horticultural interest.

\section{SARCOCOCCA. EUPHORBIACEÆ.}

A group of evergreen, low shrubs from E. Asia, the cultivated species coming from China and the Himalaya. They are allied to Buxus, but have alternate leaves and renew their growth by stems springing directly from the ground, as in butcher's broom. Leaves shining green, smooth, and entire. Flowers unisexual, the two sexes produced on the same axillary raceme, the females at the base. They have no petals; the males 
have four sepals and four stamens, the females four to six sepals. Fruit a fleshy berry, either egg-shaped or globose.

The hardy Sarcococcas, all Chinese, are neat and pleasing shrubs with only a modest beauty of flower, but healthy in appearance, the flowers white, fragrant. Increased easily by summer cuttings. They will thrive in any moist soil, and have a value in gardens on account of their suitability for semi-shaded spots.

\section{S. HUMILIS, Stapf.}

An evergreen shrub of neat, tufted habit, I to $\mathrm{I} \frac{1}{2} \mathrm{ft}$. high, stems minutely downy when young. Leaves narrowly oval, pointed, and somewhat more tapered at the apex than at the base ; $I$ to 3 ins. long, $\frac{1}{3}$ to $\frac{3}{4}$ in. wide; smooth and glossy green above, paler beneath, with a prominent nerve parallel to each margin; stalk $\frac{1}{8}$ to $\frac{1}{4}$ in. long. Flowers in short, axillary racemes, white, very fragrant, produced normally in early spring, sometimes in autumn; stamens with flattened stalks, petal-like. Fruit round, $\frac{1}{4}$ in. diameter, blueblack.

Native of W. China; introduced by Wilson for Messrs Veitch in I907. It differs from ruscifolia in the narrower leaves, with a distinct marginal nerve. A neat little shrub sending up new stems from the ground like a butcher's broom. Uppermost leaves often opposite.

\section{S. RUSCIFOliA, Stapf.}

An evergreen shrub, $2 \mathrm{ft}$. high; stems erect, branching towards the top, minutely downy when young. Leaves I to $2 \frac{1}{2}$ ins. long, half as wide; ovate, rounded and triple-veined at the base, long and finely pointed; quite smooth, and of a very dark lustrous green above, paler beneath; $\frac{1}{8}$ to $\frac{1}{4}$ in. long. Flowers milk-white, fragrant, produced during the winter months in the axils of the terminal leaves. Several flowers appear in each cluster, which has a short stalk $\frac{1}{3}$ in. or less long. Sepals four to six, about $\frac{1}{4}$ in. long; stamens (of the male flowers) $\frac{1}{4}$ in. long. Fruit roundish, $\frac{1}{4}$ in. wide.

Native of Central China; discovered by Henry near Ichang in 1887 , and introduced from the same neighbourhood by Wilson for Messrs Veitch in 190r. Although its flowers possess only a very modest beauty, this little shrub, with its neat habit and dark polished leaves, is decidedly pleasing; and as it will thrive in shady situations or under trees, it will obtain a welcome in many gardens.

\section{S. SALigna, Mueller.}

(Buxus saligna, Don.)

An evergreen shrub, 2 to $3 \mathrm{ft}$. high; stems erect, smooth. Leaves 3 to 5 ins. long, $\frac{1}{2}$ to $1 \frac{1}{8}$ ins. wide; narrow-lanceolate, with a long drawn-out point; base narrowly wedge-shaped; smooth, glossy, with a marginal vein on each side extending all round the leaf; stalk $\frac{1}{4}$ to $\frac{3}{8}$ in. long. Flowers greenish white, in short axillary racemes opening in winter and spring. Berries eggshaped, $\frac{1}{3}$ to $\frac{1}{2}$ in. long, purple.

Native of the Himalaya and China, the form from the latter being probably the hardier. The Himalayan plant has long been cultivated indoors at Kew, but the Chinese one was introduced by Wilson about 1902, and has so far proved quite hardy and a vigorous grower. From S. humilis and S. ruscifolia it is distinguished by the absence of down from the stems, as well as in stature and length of leaf. 



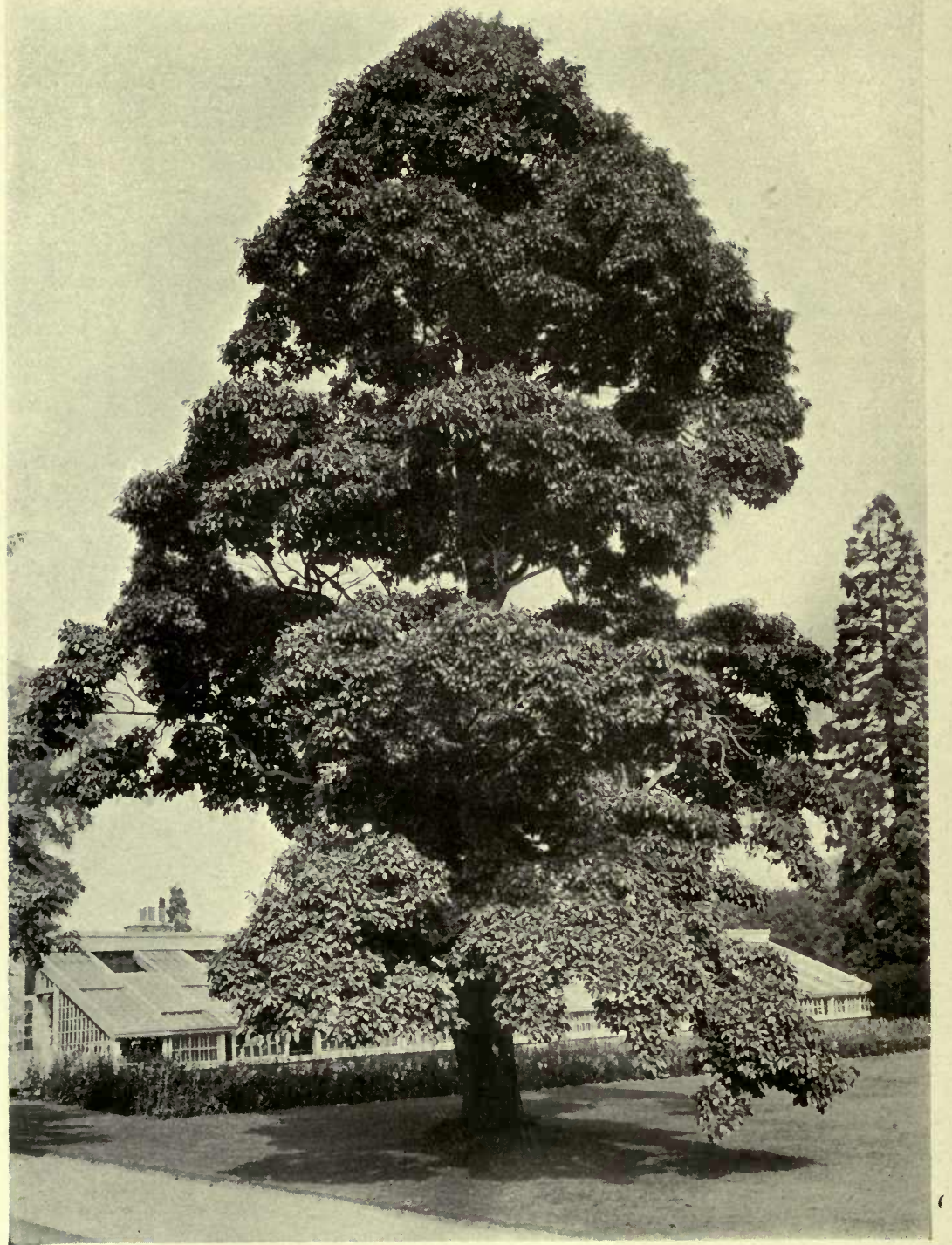

SASSAFRAS (Sassafras officinale) at Claremont.

II.]

[Face p. 501. 


\section{SASSAFRAS officinale, Nees. SASSAFras. LAURACEe.}

(S. variifolium, Kuntze; Laurus Sassafras, Linnaus.)

A deciduous tree, occasionally 70 to $90 \mathrm{ft}$. high in a wild state; young shoots sparsely downy at first. Leaves alternate, of variable shape, mostly oval, ovate, or obovate, often with a conspicuous lobe on one or both sides, the sinus always rounded; 3 to 7 ins. long, 2 to 4 ins. wide, tapering at the base, prominently three-veined; glossy dark green above, pale and somewhat glaucous beneath, both sides at first downy; stalk $\frac{1}{2}$ to $I_{2}^{\frac{1}{2}}$ ins. long. Flowers greenish yellow, produced in May in downy racemes I to 2 ins. long, the sexes usually on separate trees. Corolla absent; calyx $\frac{1}{3}$ in. long and wide, with six narrowly oblong lobes. Stamens nine in the male, and perfect; six in the female, and aborted. Fruit dark blue, roundish oval, $\frac{1}{3}$ in. long.

Native of the eastern United States; introduced in 1633 . The whole tree is pleasingly aromatic, and has many reputed medicinal virtues. Although the Sassafras has no great beauty of flower, it is a striking and handsome tree in foliage. There are very few good specimens in this country; the best is at Claremont, the seat of H.R.H. the Duchess of Albany. I measured this tree in May I9ro, and made it $50 \mathrm{ft}$. high and $7 \mathrm{ft}$. 2 ins. in girth at $\mathrm{I} \mathrm{ft}$. from the ground-a fine pyramidal specimen. It should be raised from seed, which can be obtained from American nurserymen cheaply. Although perfectly capable of withstanding severe frost, its young foliage is sometimes crippled in spring by late frost. It likes a warm, loamy soil.

S. Tzumu, Hemsley.-This is the only other species of Sassafras known. It is a Chinese tree, introduced from Hupeh to the Coombe Wood nursery by Wilson in 1900 ; a tree now growing at Kew is the only one known to me. As compared with the American species, it has certain small differences in the structure of the flower, the shoots and leaves are smooth, and it is remarkably distinct in growth. The original tree at Coombe IVood made enormous, succulent, erect growths every year, perhaps 6 or $7 \mathrm{ft}$. long, with proportionately large leaves. These shoots are very much cut back in winter, but a woody trunk is gradually being formed, and the tree with age may become quite acclimatised. Leaves with the principal veins reddish; young wood purple-spotted. The specific name is founded on the native one ("tzu-mu"). According to Henry, who discovered it, the tree grows $50 \mathrm{ft}$. high, and its timber is valued by the mountaineers where it is wild.

\section{SATUREIA montana, Linneus. Winter SAvory.}

A semi-shrubby plant, $\mathbf{I}_{2}$ to $\mathrm{I}_{5}$ ins. high, woody at the base, partially evergreen, aromatic; stems erect, slender, round, clothed with minute pale, decurved hairs. Leaves opposite, linear or narrowly oblong; $\frac{1}{2}$ to $I$ in. long, $\frac{1}{16}$ to $\frac{1}{6}$ in. wide; pointed, stalkless, pitted with glands on both surfaces, a few minute bristle-like hairs on the margins; upper surface often made into a channel by the upcurving of the margins. Flowers produced in terminal leafy panicles; calyx minutely bristly, bell- 
shaped at the base, the five lobes awl-shaped, and of unequal length. Corolla very pale purple or whitish, two-lipped, $\frac{1}{3}$ to $\frac{1}{2}$ in. long; stamens four. The whole plant has a pleasant, aromatic, thyme-like odour.

Native of S. Europe; cultivated for centuries in Britain as a culinary herb for seasoning and flavouring. It likes a warm, dry soil, and is easily propagated by division or cuttings.

\section{SAXEGOTHÆA conspicua, Lindley. Prince Albert'S Yew. TAXACE $Æ$.}

A low, evergreen tree, sometimes $40 \mathrm{ft}$. high, with the aspect of a small-leaved yew; habit bushy, dense, and rounded; branches drooping; branchlets usually in whorls; bark of trunk peeling. Leaves linear or linear-lanceolate, $\frac{1}{2}$ to $I$ in. long, $\frac{1}{10} \mathrm{in}$. wide; abruptly narrowed at the base to a short stalk; tapered more gradually at the apex to a very fine point; dull dark green above, with two comparatively broad, glaucous bands of stomata beneath. Male and female flowers on the same plant; the former in shortly stalked, cylindrical spikes $\frac{1}{4}$ in. long, produced in a cluster near the end of the shoot. The fruit is a small cone, solitary at the end of the twigs, globose in the main, $\frac{1}{2}$ in. diameter; the scales terminating in a broad, flattened, spine-like point.

Native of Chile; introduced in $\mathbf{I} 849$ by W. Lobb for Messrs Veitch. Although similar to the yew, and indeed related to it, this has a very different fruit. In fruit it differs also from Prumnopitys, which it more closely resembles in leaf even than the yew; it can, however, be distinguished by the always pointed leaves and the much more conspicuous lines on their under-surface. The Saxegothra (this is the only species known) is not of great value in gardens. Lindley observed of it that it had "the male flowers of a podocarp, the female flowers of a Dammara, the fruit of a juniper, the seed of a Dacrydium, and the general aspect of a yew." Even allowing for Lindley's desire to say something striking, this statement shows that it is a tree of remarkable interest. It was named in honour of Prince Albert, consort of Queen Victoria. There are trees in the south-western counties 39 to $40 \mathrm{ft}$. high, which are the finest in the British Isles. At Kew it grows extremely slowly, and of three plants, two were killed in February 1895 , when $30^{\circ}$ to $32^{\circ}$ of frost were registered. The third recovered and has never since been injured. Cuttings strike fairly readily in mild heat.

\section{SCHINUS. ANACARDIACEE.}

Under cultivation in the open air, only one, or at most two, species of this genus are sufficiently hardy to thrive. These are evergreen shrubs, with the shoots often becoming spine-tipped, and the leaves alternate. Flowers very small and numerous on short racemes, yellowish or white. Fruit a round, one-seeded drupe. The genus is most nearly allied to 
Pistacia and Rhus. The species described below were long called "Duvaua," being distinguished from Schinus proper by the simple leaves. S. MOLLE, Linneus, the so-called "pepper tree," is very extensively cultivated in S. France, Italy, etc., where its much divided, pinnate leaves and drooping branches make it a singularly graceful tree, laden in autumn with beautiful clusters of red berries about the size of small peas. It is not hardy with us. Native of S. America.

The two following species do not require a rich soil, making shorter, hardier growth, and flowering better where it is rather poor. They do not transplant well. Propagated by cuttings made in August, and placed in gentle heat.

\section{S. Bonplandianus, Marchand.}

(S. dependens var. subintegra, Engler.)

This evergreen shrub has long been grown on a wall at Kew, where, however, it was cut to the ground in the winter of $1908-9$, when S. dependens var. ovata in the open was not injured. Compared with the ordinary S. dependens, its lea ves are considerably longer and larger, being linear-oblong, from $\frac{3}{4}$ to 2 ins. long, one-fourth as wide, entire or sparsely toothed. Flowers small, $\frac{1}{6}$ in. across, greenish white, produced in small cylindrical racemes less than $I$ in long during May. First introduced from Buenos Ayres by $\mathrm{Mr}$ Low of Clapton, about 1830 . It is a probably a more. northern and tender form of $\mathrm{S}$. dependens, which is very widely spread over temperate and subtropical S. America.

\section{S. DEPENDENS, Ortega.}

(Duvaua dependens, De Candolle; Bot. Reg., t. I573.)

An evergreen shrub, up to $15 \mathrm{ft}$. high in this country, with stiff, spinetipped twigs. Leaves alternate, obovate, $\frac{1}{2}$ to $I$ in. long, rounded at the apex, tapering to a very short stalk at the base, usually entire. Flowers very numerous, in short axillary racemes about $\frac{1}{2} \mathrm{in}$. long, produced in May from the spine-tipped twigs of the previous year; the individual flower greenish yellow, $\frac{1}{6}$ in. wide. Fruit in dense clusters, completely hiding the branches, each one a dry, deep purple berry about the size of a peppercorn.

Var. OvatA, Bot. Mag., t. 7406, as S. dependens (Duvaua ovata, Lindley). - This differs from the type in its leaves being smaller, more ovate than obovate, usually more or less toothed or even with a distinct lobe at each side near the base.

Both these shrubs are natives of Chile, and have long been in cultivation. Var. ovata would appear to be the hardier of the two, and although it was cut to the ground at Kew in February 1895 , it sprang up again freely from the base. Its flowers have no very bright colour to recommend them, but they are borne in such profusion that the shrub gives quite a pleasing effect. It ascends to nearly I $4,000 \mathrm{ft}$. on the mountains of Chile and Bolivia.

\section{SCHIZANDRA. MAGNOLIACEA.}

A small genus of more or less aromatic shrubs, native of N. America and E. Asia. Two hardy species have for some time been in cultivation, and they have latterly been augmented by new ones introduced by Wilson 
from China. Flowers unisexual, sepals and petals indistinguishable, nine to twelve; in the female flowers the carpels are at first arranged in a head above the petals, but afterwards that part to which they are attached elongates and bears the globose fruits in a spike.

The two species here mentioned are perfectly hardy; they like a rich loamy soil, and can be increased by cuttings of half-ripened wood in a mild bottom heat.

From Kadsura, a nearly allied genus, Schizandra differs in the leaves being marked with transparent dots. The fruits, too, of Kadsura are in a globose head.

\section{S. CHINENSIS, Baillon.}

\section{(S. japonica, Hance; Maximowiczia chinensis, Ruprecht.)}

A deciduous, climbing shrub, growing 20 to $30 \mathrm{ft}$. high; branchlets red, round, not downy, set with wart-like lenticels. Leaves 2 to 4 ins. long, obovate or elliptical, tapering at the base to a slender stalk, remotely toothed; smooth except on the principal veins beneath when young. Flowers produced during April and May, each on a slender stalk $I$ in. long, two or three of them being borne in a cluster at the base of the young growths; they are pale rose-coloured, fragrant, $\frac{1}{2}$ to $\frac{3}{4} \mathrm{in}$. across. After the female flowers are past, that portion bearing the carpels continues to lengthen until it is 2 to 6 ins. long, and on it the berry-like, scarlet fruits are borne on a sort of pendulous spike. These remain on the plant during the winter.

Native of China and Japan; introduced in 1860 . Although not showy in flower (the petals soon drop), its scarlet fruits are very handsome. The dried wood is charmingly fragrant.

\section{S. Henryi, Clarke.}

(Gardeners' Chronicle, 1905. ii., fig. 55.)

A deciduous, climbing shrub with twining stems, triangular when young, each angle winged. Leaves leathery, shining, of variable shape, elliptical, ovate or cordate, pointed or rounded at the apex and sparsely toothed, 3 to 4 ins. long; stalk $\mathrm{I}$ to 2 ins. long. Flower $\frac{1}{2}$ in. across, unisexual, white, borne on a stout stalk 2 ins. long. The column on which the carpels are borne elongates after the flowers are faded and becomes fleshy, and 2 to 3 ins. long; on this the mucilaginous berries are borne. They are eaten by the Chinese.

Introduced by Wilson for Messrs Veitch about 1900, from W. Hupeh and Szechuen, but discovered by Henry long previously. It is easily distinguished from S. chinensis by the lustrous, thicker leaves and triangular branchlets. Quite hardy at Kew. It is wrongly classed as evergreen in Hortus Veitchii.

\section{SCHIZOPHRAGMA. SAXIFRAGACEÆ.}

Two climbing deciduous shrubs, found in China and Japan, and very nearly allied to Hydrangea-especially the climbing section of that genus. Leaves opposite, long-stalked. Flowers in a large terminal cyme, the central flowers small and perfect, the outer ones sterile and reduced to one 
large showy bract borne at the end of a slender stalk. From Hydrangea, the only other genus with which it can be confused, Schizophragma differs in the sterile flowers consisting of but one bract instead of four, and in having the four or five styles united into one. The specialised function of the large bracts is, no doubt, to attract insects to the inflorescence, and thereby bring about the fertilisation of the flowers. In the great majority of flowers each one does its own share in advertisement. Fruits topshaped.

These two shrubs are easily cultivated. They like a good loamy soil and plenty of moisture, and can be increased by cuttings and layers. The only other necessity is something for them to climb over, and this may be wall, tree-trunk, or anything to which the roots may attach themselves.

\section{S. HYDRANGEOIDES, Siebold.}

(Bot. Mag., t. 8520.)

A deciduous, climbing shrub, reaching 40 or more $\mathrm{ft}$. high in a wild state; young stems smooth, reddish, and furnished with aerial roots. Leaves broadly ovate, with a rounded, heart-shaped or tapering base; 4 to 6 ins. long, $2 \frac{1}{2}$ to 4 ins. wide; strongly veined, coarsely and angularly toothed, deep green and smooth above, but paler, rather glaucous, and with silky hairs beneath; stalk $I$ to 2 ins. long. The leaves near the inflorescence are tapered at the base, those on sterile shoots heart-shaped. Flowers small, yellowish white, slightly scented, produced during July in a broad, flattish, cymose inflorescence 8 or 1o ins. across. The chief feature of the inflorescence are the bracts, one of which terminates each main branch of the cyme, and is heart-shaped or ovate, pale yellow, I to $\mathrm{I} \frac{1}{2}$ ins. long ; flower-stalks furnished with a thin, loose down.

Native of Japan, where, along with Hydrangea petiolaris it forms a conspicuous feature in the forests, often covering the trunks of large trees. In gardens it is rare, the plant grown under the name being almost invariably Hydrangea petiolaris, which it resembles in habit, but in respect to leaf and inflorescence is quite distinct. It flowered with the late $\mathrm{Mr}$ Chambers at Haslemere in 1905, for the first time, so far as I am aware, in this country. It has since flowered with Miss Willmott at Warley, and with Sir E. Fry near Bristol. The floral bracts are variable in size and shape.

\section{S. INTEGRIFOLIA, Oliver.}

A deciduous, climbing shrub of robust growth, reaching probably 40 or more $\mathrm{ft}$. in height. It produces aerial roots from the branches by which it attaches itself like ivy to the object upon which it grows; young stems hairy or smooth. Leaves ovate, with a heart-shaped or rounded base, tapering to a long fine point at the apex; 3 to 7 ins. long, $1 \frac{1}{2}$ to $4 \frac{1}{2}$ ins. wide; the margin entire or sparsely set with small thin teeth; hairy beneath on the midrib and veins; stalk I to $2 \frac{1}{2}$ ins. long, more or less hairy when young. Flowers produced in a flat cyme up to $\mathrm{I} \mathrm{ft}$. in diameter; the fertile flowers in the centre each $\frac{1}{4}$ in. across, and comparatively inconspicuous. But terminating each division of the inflorescence is the remarkable single sterile blossom, consisting only of one large white bract, lanceolate, up to $3 \frac{1}{2}$ ins. long, $\mathrm{I}_{4}^{\frac{3}{4}}$ ins. wide, and veined like a leaf with darker lines.

Native of Central China, where it inhabits rocky cliffs; introduced by Wilson for Messrs Veitch in I90I. It grows well, but has not yet, I believe, 
flowered. It is to be hoped that it will prove free-flowering; for the enormous white bracts surrounding the inflorescence would make it one of the most striking of hardy climbers. The stems of our young plants are very downy, and the down persists till the following year, but on Wilson's wild flowering specimens they are quite smooth.

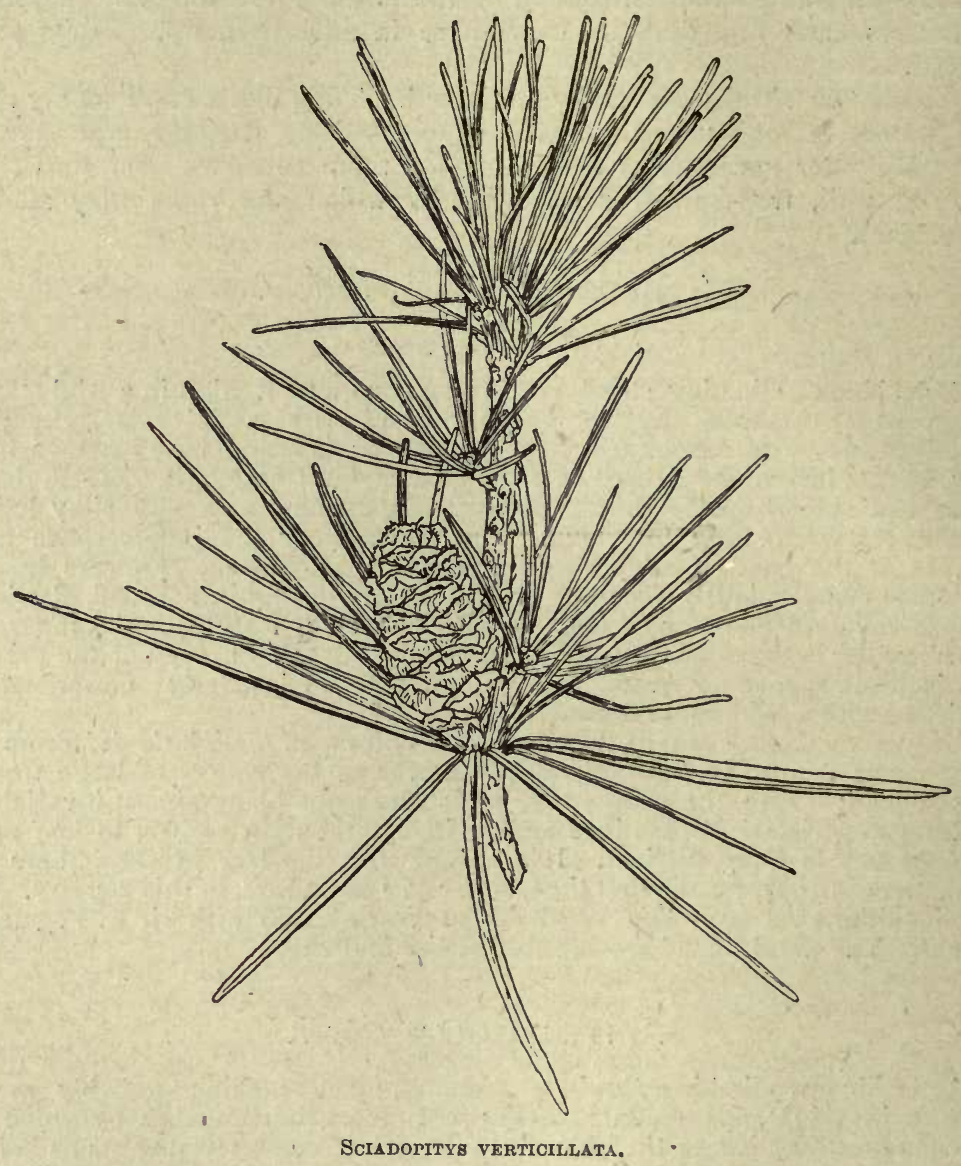

SCIADOPITYS verticillata, Siebold. Umbrella Pine. CONIFERA,

(Bot. Mag., t. 8050.)

An evergreen tree, over roo $\mathrm{ft}$. high, with a trunk 3 to $4 \mathrm{ft}$. thick; young shoots brown, not downy. The true leaves of this tree are small, membranous, scale-like bodies, about $\frac{1}{8}$ in. long, scattered over the lower part of each year's shoot, and crowded into two or three imbricating rows 


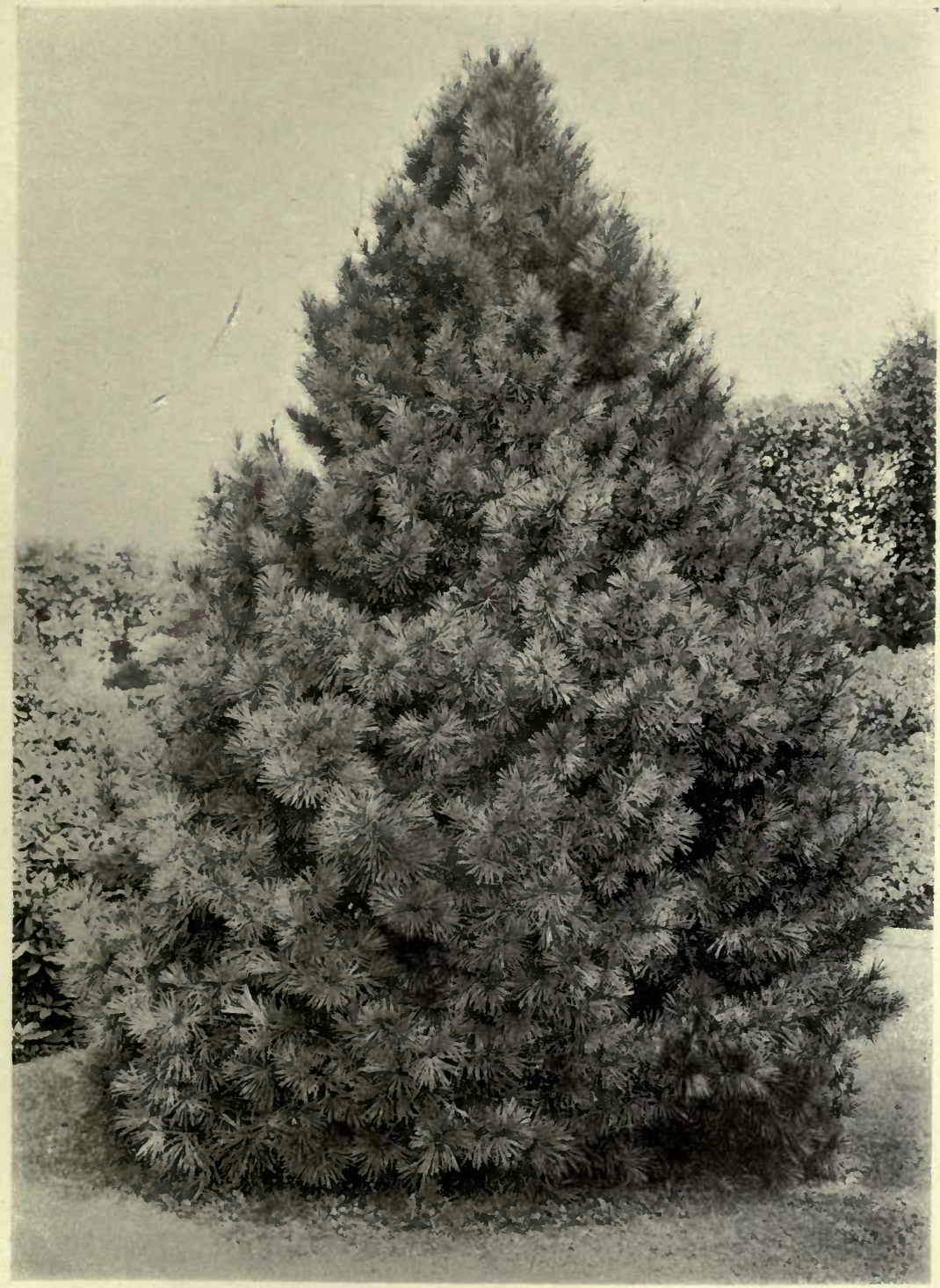

UMBRELLA PINE, Sciadopitys verticillata. 

at the apex of the shoot. In the axils of this terminal group of true leaves are borne, what, for convenience sake, we usually term leaves, but which, nevertheless, are really "cladodes" or modified, leaflike branchlets. They are produced at the end of the year's shoot in whorls, and are 2 to $4 \frac{1}{2}$ ins. long, $\frac{1}{8}$ in. wide; slightly narrowed at top and bottom, minutely notched at the tip; dark glossy green on both sides, except that beneath there is a yellow groove traversing the whole length. These leaflike organs sometimes show their true nature by branching (see Revue Horticole, $\mathbf{1 8 8 4}$, p. 16). Male flowers in a terminal raceme $\mathbf{r}$ in. long, carrying about ten flowers, each $\frac{3}{8}$ in. long, egg-shaped. Cones 2 to 3 ins. long, I to 2 ins. wide, borne on a short stout stalk; scales with broad reflexed margins.

Native of Japan; introduced by John Gould Veitch in 186 r. In 1853 , however, a single plant had been sent from Java by Lobb, that had been cultivated in the Buitenzorg Garden. The popular name refers to the arrangement of the so-called leaves, which resembles the ribs of an umbrella. This remarkable and beautiful tree "stands alone amongst Coniferæ with no obvious affinities or immediate allies, and must be conjectured to have come down to us from a remote geological past which has obliterated all trace of its immediate ancestors" (Thiselton-Dyer). In gardens it makes a distinct and striking shrub or small tree of pyramidal form. It should have an isolated position, and thrives in a warm, loamy soil which contains no calcareous substances and is well enriched with decayed leaves. It is very hardy, but slow growing.

Var. PENDULA. - Sargent observes (Forest Flora of Japan, p. 78) that there is a remarkable specimen with pendulous branches in the Shiba Park, Tokyo. The only plant I have seen with a similar habit in cultivation is in Mr L. Rothschild's garden at Gunnersbury Park.

\section{SECURINEGA RAMIFLORA, Mueller. EUPHORBIACE E.}

(Geblera suffruticosa, Fischer.)

A deciduous shrub, 3 to $5 \mathrm{ft}$. high, with erect stems and long, graceful, slender, horizontal branches, all the parts devoid of down. Leaves alternate, oval, or slightly obovate; $\frac{3}{4}$ to 2 ins. long, $\frac{1}{3}$ to $I$ in. wide; mostly blunt or rounded at the apex, margin minutely undulated; dull green above, pale, rather glaucous beneath; stalk $\frac{1}{8}$ in. long. Plants unisexual; flowers 'greenish yellow, very small ( $\frac{1}{10}$ in. across), produced during August and September in the leaf-axils of the current year's growth. The male flowers are densely packed a dozen or more together, opening successively; each flower on a stalk $\frac{1}{10}$ in. long; sepals and stamens five. The longer-stalked female flowers are borne singly in the leaf-axils. The seed-vessel, borne on a stalk $\frac{1}{4}$ to $\frac{1}{2}$ in. long, is about the size of a peppercorn, three-celled, the calyx adherent at the base.

Native of N.E. Asia, including China, Manchuria, and Siberia; introduced from the last named in I783. It is allied to Buxus and Andrachne; it flowers very freely, but has little to recommend it except its graceful habit. 
S. FLueggioides, Mueller (S. japonica, Hort.), is nearly allied, but has two to five or even more female flowers in one leaf-axil. Native of China, Japan, and Corea.

\section{SENECIO LAXIFOLIUS, J. Buchanan. COMPOSITA.}

(Bot. Mag., t. 7378.)

A low, evergreen shrub, 2 to $4 \mathrm{ft}$. high, of bushy habit; young stems covered with grey down when youny. Leaves alternate, $1 \frac{1}{2}$ to $2 \frac{1}{2}$ ins. long, $\frac{3}{4}$ to $\mathrm{I}$ in. wide; oval, lanceolate, or sometimes inclined to ovate or obovate, mostly blunt at the apex, tapering at the base, not toothed, covered above when young with a grey, cobweb-like down, afterwards nearly smooth; under-surface clothed with close white felt ; stalk slender, $\frac{1}{2}$ to $\frac{3}{4}$ in. long. Flower-heads $\mathrm{I}$ in. across, produced in summer in loose, terminal, broadly pyramidal panicles, 5 to 8 ins. long, 3 to 5 ins. wide. Ray florets twelve to fifteen, golden yellow, fully spread; disk florets very small and numerous, forming collectively a reddish brown centre $\frac{1}{4}$ in. across.

Native of the mountains of the Nelson and Canterbury provinces of New Zealand, at 2500 to $5000 \mathrm{ft}$. It needs somewhat milder climatic conditions than those of east and middle England, and although several times tried in the open at Kew, it never has survived more than two or three winters. In the warmer parts of the country it succeeds admirably. Increased by late summer cuttings.

Nearly allied to and often confused with it is S. Greyi, Hooker fil., which also grows well in the milder counties. This has larger, broader leaves than S. laxifolius, and denser corymbs of flowers. From the North Island, New Zealand.

\section{SEQUOIA. CONIFERE.}

Two species of remarkable, coniferous, evergreen trees, confined in a wild state to California and Oregon, one of them the largest of the world's trees. They have as their nearest allies the East American deciduous cypress (Taxodium distichum) and the Japanese Cryptomeria, but they are not only very distinct from all other conifers, but from each other. They are not among bur hardiest trees, but still thrive well in suitable parts of the British Isles, being seen at their best, perhaps, in the southern half of England, planted in good soil and in well-sheltered spots. S. sempervirens, the redwood, although in many places subject to injury by late frosts, is, on the whole, a greater success than S. gigantea. They should be raised from seeds only.

\section{S. gigantea, Decaisne. Big Tree, Wellingtonia.}

(Wellingtonia gigantea, Lindley, Bot. Mag., tt. $4777,4778$. )

An evergreen tree, reaching ultimately from 250 to $325 \mathrm{ft}$. in height, and forming a trunk 20 to $30 \mathrm{ft}$. through at the enlarged, buttressed base. Bark I to $2 \mathrm{ft}$. thick, rich brown-red, and of a fibrous texture. The head of branches 
in old trees commences at 100 to $150 \mathrm{ft}$. from the ground, and consists of comparatively short, horizontal or drooping branches. The final ramifications of the branches are much divided, the ends forming a dense, bushy cluster of branchlets. Leaves varying in length from $\frac{1}{8}$ to $\frac{1}{2} \mathrm{in}$. long, but always more or less awl-shaped, triangular in section, tapering from the broad base (by which it is attached to, and extends down the branchlet) to a fine point. They are blue-green and always point forward, adhering for four or five years to the branchlet, which in the early stages they completely cover. Cones $1 \frac{1}{2}$ to 3 ins. long, $1 \frac{1}{4}$ to 2 ins. wide; seeds pale shining brown, $\frac{1}{8}$ to $\frac{1}{4}$ in. long, flattened.

Native of the western slope of the Sierra Nevada, California, at 5000 to $8000 \mathrm{ft}$. elevation. The "big trees" appear to have first been discovered

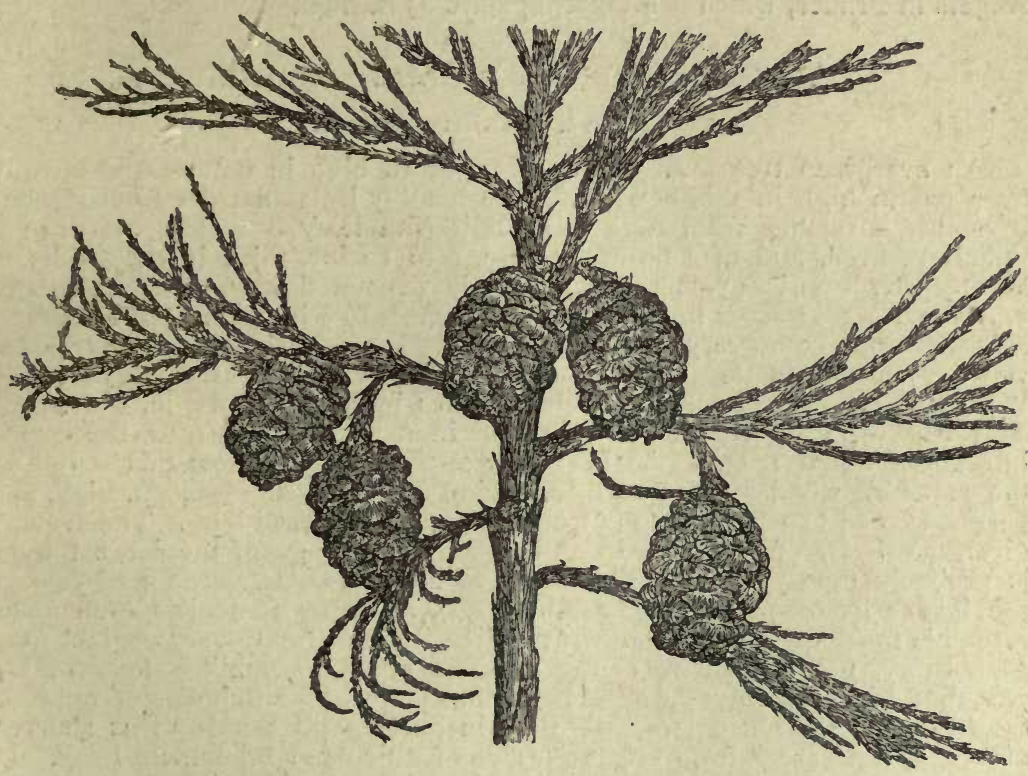

Sequola gigantea.

about the middle of the nineteenth century by hunters and wandering pioneers. A man named John Bidwell is credited with being the first European to see them-in 1841. Seeds were first sent to England in 1853 by Mr J. D. Matthews, and by Veitch's collector, William Lobb. The news of its discovery had created an extraordinary interest over the whole civilised world, and the Wellingtonia (as it had been named by Lindley) was eagerly sought after for nearly all gardens of this country. In many places, as might be expected, it proved a failure, but in many others a great success. As a young tree and up to fifty or sixty years of age, it forms a regular pyramid, furnished to the ground with foliage. In this state it makes an imposing avenue, of which there is a fine example at Linton Park, in Kent. The average increase in height in favourable places (it likes a mild climate, good soil, and shelter) has been $\mathrm{I} \frac{1}{2}$ to $2 \mathrm{ft}$. per annum, and the annual layers of wood $\frac{1}{2}$ to $\frac{3}{4}$ in. wide. (See plate, vol. i., p. Io.)

This tree is one of the marvels of the Vegetable Kingdom, and in bulk, if not in height, surpasses all other of the world's trees. Some of the giants of the 
Californian forests no doubt antedate the Christian era. It is gratifying to know that their relentless destruction, carried on in the early days for the sake of gain, has been stopped by the action of the State. There does not appear to be any fear of the species becoming extinct, as it is numbered by tens of thousands even in a wild state. Still, trees between 250 and $300 \mathrm{ft}$. high are comparatively few in number. Several varieties have appeared in cultivation, of which the two following only need be mentioned :-

Var. AUREA. - A golden-leaved form which originated in the Lough nurseries, Cork, in 1856 , from a seedling.

Var. PENDULA.-An extraordinary tree with weeping branches, but an erect leader, forming a tall slender spire. It originated at Nantes in 1863. Perhaps the finest example known is one in the arboretum of $\mathrm{Mr}$ Allard, at Angers in France, which is a tapering spire $65 \mathrm{ft}$. high.

\section{S. SEMPERVIRENS, Endlicher. REDWOOD.}

(Taxodium sempervirens, Lambert.)

An evergreen tree from 200 to over $300 \mathrm{ft}$. high in nature, and already over $100 \mathrm{ft}$. high in this country, where healthy isolated trees form slender pyramids, furnished from base to summit with leafy branches. Bark of a rich brown-red, and of a fibrous nature, 6 to 12 ins. thick in the giants of Western N. America; young shoots and leaves not downy, arranged in two opposite rows. Leaves linear, $\frac{1}{4}$ to $\frac{7}{8}$ in. long, $\frac{1}{20}$ to $\frac{1}{8}$ in. wide ; terminated by a short abrupt point, very dark lustrous green above, with two broad stripes of white stomata beneath. On leading shoots the leaves are arranged all round the branchlet. Cones roundish oblong, $\frac{3}{4}$ to $1 \mathrm{in}$. long, about $\frac{1}{2} \mathrm{in}$. wide.

Native of California and S. Oregon in a narrow belt near the coast ; introduced about 1843. Like its fellow species, S. gigantea, this is one of the vegetable wonders of the world, having been measured $340 \mathrm{ft}$. high, and between 80 and $90 \mathrm{ft}$. in girth of trunk near the buttressed base. The average girth, however, of big trees is 30 to $50 \mathrm{ft}$. The age of the largest trees is probably 1300 years. On the tops of adult trees, according to Jepson, the leaves become small ( $\frac{1}{4}$ to $\frac{1}{3}$ in. long), and the branchlets then much resemble those of S. gigantea. But ordinarily the two are very distinct from each other, the branchlets of the redwood much resembling those of the yew, but with the leaves whiter beneath. On some specimens of redwood the branches are much less leafy than in others, and stand out as slender, drooping, rigid arms, from the lower side of which the branchlets hang. In its finest development in the Californian forests the redwood stands so thickly and attains to so great a size that it yields enormous amounts of saleable wood per acre. Jepson gives $500,000 \mathrm{ft}$., board measure, as the yield of some limited areas, but three times as much has been recorded. The tree has the faculty of reproducing itself by suckers from the root-they are occasionally seen in this country-and, as frequently happens with trees of that propensity, the gêrminating power of the seed is low.

Redwood timber is highly valued for building; it is reddish, free from resin, and of a light soft nature; used also for railway sleepers, shingles, wine vats, etc. The wood employed in the building of some Californian cities is almost entirely of this tree.

Var. ALBO-SPICA.-Leaves and tips of the young shoots creamy white.

\section{SHEPHERDIA. ELÆAGNACE $A$.}

Of the three genera constituting this natural order, Shepherdia differs from Hippophaë and Elragnus in its opposite leaves, and in having eight 


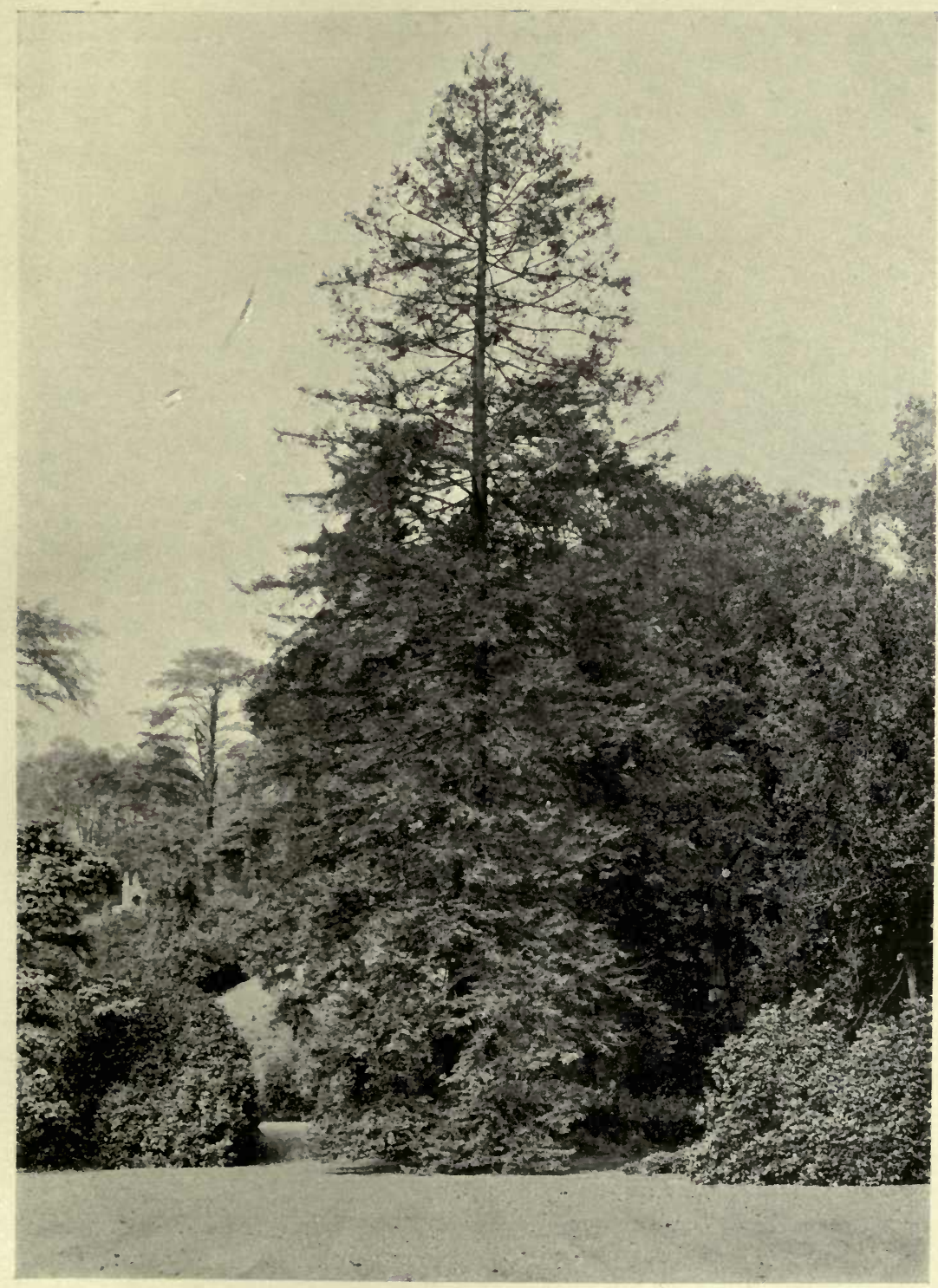

REDWOOD (Sequoia sempervirens) at Claremont.

II.]

[Face p. 510. 

stamens instead of four. It consists of three scaly N. American shrubs, with male and female flowers separated on different plants, and both inconspicuous. There is no corolla, and the calyx is of four divisions. Fruit a berry. Named in honour of John Shepherd, curator of the Liverpool Botanic Garden in the early part of the nineteenth century. The third species, not mentioned below, is S. Rotundifolia, Parry, an evergreen shrub not in cultivation.

\section{S. ARgenteA, Nuttall. Buffalo Berry.}

A deciduous shrub, 3 to $12 \mathrm{ft}$. high, with opposite, often spine-tipped branchlets, covered when young with silvery scales. Leaves opposite, oblong, with a rounded apex and wedge-shaped base ; $\frac{3}{4}$ to 2 ins. long, $\frac{1}{8}$ to $\frac{5}{8}$ in. wide; covered with silvery scales beneath, less so above. Flowers $\frac{1}{4}$ in. across, produced in small clusters during March from the joints of the previous year's growth ; calyx of four oblong green segments, of little or no beauty. Fruit roundish egg-shaped, $\frac{1}{6}$ to $\frac{1}{4}$ in. long, scarlet, acid but edible.

Native of the central United States and Manitoba; introduced in 1818. As with its ally, Hippophaë rhamnoides, it is necessary to have plants of both sexes in order to obtain fruits, but these are rarely developed in this country. There is great confusion in gardens between this shrub and Elæagnus argentea. The latter is often supplied for it, but is easily distinguished by its invariably alternate, much broader leaves; it is also more ornamental than the Shepherdia, which has not much to recommend it in this country. $\mathrm{S}$. argentea differs from the following species in having narrower leaves with a silvery upper surface, and in the thorn-tipped twigs.

\section{S. CANADENSIS, Nuttall.}

A deciduous, unarmed shrub, up to 6 or $8 \mathrm{ft}$. high, of bushy habit; shoots covered with brownish scales. Leaves ovate or oval, $\frac{1}{2}$ to 2 ins. long, $\frac{1}{4}$ to I in. wide; dull dark green above, and at first furnished with silvery starry tufts of hairs especially along the midrib and veins; the under-surface densely hairy, specked with numerous brownish scales; stalk $\frac{1}{8}$ to $\frac{1}{6}$ in. long. Fruit yellowish red, egg-shaped, $\frac{1}{4}$ in. long.

Native of N. America, where it is widely spread both in the United States and Canada; introduced in 1759, and originally named "Hippophaë" by Linnæus. I have seen this shrub growing wild on the cliffs of the Genesee River gorge in New York State, between Rochester and Lake Ontario, loaded with its beautiful reddish fruits in July; but in England they are rarely developed. The shrub is interesting, and the singular aspect of the under-surface of the leaf under the lens is worth notice, the thick basis of silvery hair-tufts being interspersed with brown scales, each scale with a dark, glistening, eye-like centre.

\section{SINOFRANCHETIA CHINENSIS, Hemsley. BERBERIDACEÆ.}

A large deciduous climber, covering trees $40 \mathrm{ft}$. or more high, and with a main stem frequently 3 or 4 ins. thick; young branches twining, covered with purplish bloom. Leaves composed of three leaflets, borne at the end of a slender purplish stalk 6 to 9 ins. long. Side leaflets obliquely ovate-elliptic; terminal one broadly obovate, longer-stalked; all 
glabrous, glacous beneath, 3 to 6 ins. long, short-pointed, entire. Flowers unisexual, dull white, small, inconspicuous, and of no beauty, produced in pendent racemes about 4 ins. long, on short leafy shoots. Fruits about the size of a grape, blue-purple, and borne alternately at intervals on an elongated stalk 8 ins. or more long.

Native of Central and W. China, up to $7000 \mathrm{ft}$. ; introduced by Wilson for Harvard University, U.S.A., and raised at Kew in 1908. This climber is allied to Holbœllia and Stauntonia, but unlike them is quite hardy. Plants less than one year old surfived the trying winter of I908-9 without injury. Its value in gardens will consist in its vigorous habit and fine glaucous foliage; also in its fine fruits, should they be developed with us.

The genus was named in memory of Adrien René Franchet, once attached to the Paris Museum of Natural History, and one of the most capable botanists who ever worked at the Chinese flora. He died Feb. 14, 1900.

\section{SINOMENIUM DIVER'SIFOLIUM, Diels. MENISPERMACE $A$.}

(Gardeners' Chronicle, Nov. 30, I9I2, fig. I78; Cocculus heterophyllus, Hemsley; C. variiformis, Hort.)

A deciduous climber, up to $20 \mathrm{ft}$. high, with twining stems. Leaves very. variable in shipe, perhaps normally ovate-cordate and entire, but sometimes almost kıdney-shaped, sometimes lobed like Catalpa ovata, sometimes deeply three- or five-lobed (with lanceolate lobes), sometimes shallowly so; often with a lobe on one side only; the base often truncate; 2 to 6 ins. long, $\mathbf{I} \frac{1}{4}$ to $4 \frac{1}{2}$ ins. wide; deep bright green, smooth, with three or five conspicuous veins radiating from the base; stalk slender, 2 to 6 ins. long. Flowers small, yellow, unisexual, about $\frac{1}{6} \mathrm{in}$. wide; sepals six, in two series of three each, downy beneath; petals very small; the flowers are borne in slenderly pyramidal panicles 6 to 12 ins. long, the main and secondary flower-stalks downy. Fruit about the size of a small pea, globose, black, covered with blue bloom.

Native of Central and W. China, also of Japan, where it has been known for at least fifty years, but does not appear to have been introduced to cultivation until Wilson sent it from China to the Coombe Wood nursery in r $90 \mathrm{I}$. It first flowered with Mr P. D. Williams in Cornwall, in I912. It appears to be perfectly hardy and a vigorous grower, and is an interesting addition to the few members of the moon-seed family in cultivation (see Cocculus and Menispermum).

\section{SINOWILSONIA HenRyi, Hemsley. hamamelidace}

A deciduous shrub or small tree, occasionally $20 \mathrm{ft}$. high and upwards in China. Leaves broadly elliptic to obovate, 3 to 6 ins. long, $2 \frac{1}{2}$ to $4 \frac{1}{2}$ ins. wide; rather like those of a Tilia, but short-stalked, strongly veined beneath, and covered there with starry hairs (like the young shoots), 
the margins set with bristle-like teeth. Flowers greenish, in slender, terminal, pendulous racemes 9 ins. long. Fruits very downy, egg-shaped capsules, $\frac{1}{3}$ to $\frac{1}{2}$ in. long, stalkless, and arranged on long slender spikes.

Native of the province of Hupeh, China, where it inhabits the banks of mountain streams at 3000 to $4000 \mathrm{ft}$.; introduced in 1908 , for Harvard University, U.S.A., by Wilson. It is in honour of that famous collector that the genus is named. As a type new to cultivation, belonging to a group of great distinction - the witch-hazel family-it has considerable scientific interest. We shall have to wait some years, no doubt, for its flowering, but, apparently, it has no great beauty.

Messrs Rehder and Wilson have recently (Plante Wilsoniana, i., 427) made a new genus of a shrub nearly allied to Sinowilsonia and Corylopsis. Since 1908 it has been cultivated under Wilson's number, 565. It is now called FORTUNEARIA SINENSIS.

\section{SKIMMIA. RUTACEA.}

A group of three low, evergreen shrubs, native of China, Japan, and the Himalaya, with alternate, entire, aromatic leaves, terminal flower panicles, and handsome red fruits. Owing to the male and female flowers being frequently confined to separate plants in S. japonica and S. Laureola, it is necessary with them to grow the two sexes together in order that fruit may be obtained, and the fruit constitutes the most attractive feature of the genus. They are of easy cultivation and like a moist loamy soil, and will thrive in a moderately shady spot. Those who make a speciality of growing Skimmias for their fruits assist fertilisation by artificial means (see under S. japonica.)

The generic name is derived from "skimmi," a Japanese name for S. japonica. It was given by Thunberg in 1784 .

\section{S. FortuneI, Masters.}

\section{(S. japonica, Bot. Mag., t. 47 I 9 (not of Thunberg).)}

A low evergreen shrub, usually not more than $2 \mathrm{ft}$. high, with dark green, narrow elliptical leaves, averaging $2 \frac{1}{2}$ to 4 ins. long, and from $\frac{3}{4}$ to $I$ in. wide; tapering gradually and equally towards both ends. Flowers white, always bisexual, $\frac{1}{2}$ in. across, produced in a terminal panicle 2 to 3 ins. long. Fruits dull crimson, distinctly oval or pear-shaped, $\frac{1}{3}$ in. long. Seeds pointed at both ends.

Native of China, whence it was first imported to England by Fortune in 1849. He had found the plant during the previous year in a nursery garden near Shanghai. It was first exhibited in England at the Horticultural Society's Rooms, 21 Regent Street, 23rd October 1852, and was awarded a Knightian medal. Then, and until 1889 , when the late Dr Masters cleared up the confusion, it was wrongly known as S. japonica. Being hermaphrodite every plant bears fruit and there is no bother about the sexes, but artificial fertilisation is useful in securing good crops of fruit. Its flowers are abundant and charmingly fragrant. Easily distinguished from the true japonica by the darker, egg-shaped fruits.

Var. ARGENTEA, Masters. - Leaves with white margins. 


\title{
S. JAPONICA, Thunberg.
}

\author{
(Bot. Mag., t. 8038 ; S. oblata, Moore.)
}

A low evergreen bush of dense habit, up to 3 or $4 \mathrm{ft}$. high, considerably more in width. Leaves mostly in a cluster towards the end of the shoot, aromatic when crushed, usually 3 to 4 ins. long, $\frac{3}{4}$ to $1 \frac{1}{4}$ ins. wide; pale or yellowish green, narrowly obovate or oval, thickly specked beneath with transparent glands; leaf-stalk short, stout. Flowers in terminal panicles 2 to 3 ins. long, male and female flowers on different plants; fragrant, $\frac{1}{3}$ in. across; petals usually four, sometimes five, dull white. Stamens four or five in the male plant, absent or very much aborted in the female. Fruit globular, or depressed at the top like an orange, bright red, $\frac{1}{3}$ in. wide.

Native of Japan. Cultivated at Kew as long ago as 1838 , this species did not obtain any general attention from horticulturists until it was introduced from Japan by Fortune in I86r. It was then called S. oblata by T. Moore, under the impression that the species now known as S. Fortunei was the true japonica. Subsequently it became generally cultivated in gardens-for its very handsome fruits, which remain long on the branches, and many seedlings were raised. These varied considerably, and a number of named forms were sent out by nurserymen, some male, some female. Brief mention need only be made of the garden names still in common use :-

$S$. fragrans and $S$. fragrantissima are male forms.

S. macrophylla.-Another male form with large leaves and flower panicles.

S. FOREMANII.-A fine form with large leaves, and scarlet berries roundish and pear-shaped on the same cluster, suggesting that S. Fortunei may have had some part in its origin. Raised by Mr Foreman, Eskbank Nurseries, Midlothian, and given a first-class certificate when first exhibited before the Royal Horticultural Society in 1888.

S. ROGERSII.-A hybrid, in all probability, between S. japonica and S. Fortunei, having the bisexual flowers and crimson fruits of the latter, but the flattened fruits of S. japonica.

All these forms are easily increased by cuttings, and for the purpose of obtaining fruits one male need only be grown to, say, six females. In order to secure a crop of berries it is advisable to fertilise the flowers artifically. It is necessary, of course, to transfer the pollen from the male to the female, and this is usually done by taking some fluffy material (a rabbit's tail is often used). rubbing it over the male flowers as soon as the pollen is loose, and then dusting over the female flowers with it (the latter are easily recognised by the prominent ovary and stigma, and the absence of stamens). In some districts bees for other insects will do the business themselves, but it is safer to do it by hand. S. japonica grows well in the neighbourhood of towns, but does not, in my experience, fruit freely there, even with artificial fertilisation.

\section{S. Laureola, Siebold.}

A low evergreen shrub, rarely seen more than 2 or $3 \mathrm{ft}$. high in this country. Leaves larger than in either of the previous species, and from 3 to 6 ins. long, the largest nearly 2 in. wide; they are produced in a cluster at the end of the twig, and vary in outline from lanceolate to obovate and oblong. When crushed they emit (like the young wood and flowers) a very heavy, and to most people unpleasant odour. Flowers crowded in short, terminal panicles about $1 \frac{1}{2}$ ins. long, mostly unisexual, yellow or greenish yellow. Fruit red, roundish, or rather longer than wide.

Native of the Himalaya, where it is said to form large thickets up to 
I $1, \infty 00 \mathrm{ft}$. altitude. It is fairly hardy at Kew, but never bears flowers or fruits freely enough to justify its inclusion among first-rate evergreens.

\section{SMILAX. LILIACEA.}

A curious and interesting genus of usually climbing plants, both herbaceous and shrubby, belonging to the lily family. Of the shrubby species there are both evergreen and deciduous as well as intermediate types. Leaves alternate, prominently three- to nine-ribbed, and netveined between the ribs; from the stalks a pair of tendrils are developed by means of which the slender stems are supported. Stems round or angular, usually prickly, often springing from a fleshy or tuberous rootstock, the sexes usually but not always on separate plants; isolated plants having been known to produce fertile seed. The flowers have little beauty, and are always green or greenish. Fruit a black or red berry.

In a monograph published in 1878 , over two hundred species were described, but of these a very small proportion are in cultivation.

The chief value of the smilaxes in gardens is in producing rich, graceful masses of handsome foliage. They develop thickets of stems which are constantly being renewed from the base, and are happily placed when they can ramble over a tree-stump or some such support. Seed is rarely seen with us on many of the species, and propagation is best effected by dividing up the plants in spring.

The popular medicine, sarsaparilla, is a product from the root of various tropical American species.

Of the following sorts, $\mathrm{S}$. rotundifolia and S. hispida are the most robust in my experience, but $\mathrm{S}$. excelsa has also been known to make a vigorous tree climber in Surrey; and for the warmer counties, S. aspera, which has a very graceful inflorescence, is to be recommended.

\section{S. ASPERA, Linnceus. Rough BindweEd.}

An evergreen, semi-scandent plant with four- to six-angled stems and zigzag branches, armed with short, stout spines. Leaves very diverse in shape and size, but nearly always more or less heart-shaped at the base, and prickly on the margins, sometimes on the midrib also. As seen in cultivation the usual type of leaf is of a narrow, elongated, ovate shape, broadest almost or quite at the base, abruptly narrowed above the base, then tapering gradually to the point ; five- to nine-nerved. Sometimes the base is quite straight, and the leaf an elongated triangle; sometimes the leaf is heartshaped and nearly as broad as long. They measure from $1 \frac{1}{2}$ to 4 ins. long, $\frac{3}{4}$ to 3 ins. wide; stalk spiny or unarmed, $\frac{1}{4}$ to 1 in. long. Flowers pale green, fragrant, produced in terminal and axillary racemes, along which they are arranged in clusters of four to seven; the racemes vary from $1 \frac{1}{2}$ to 4 ins. long, and the flower-stalk of the individual flower is $\frac{1}{12}$ to $\frac{1}{3} \mathrm{in}$. long. Fruit about the size of a pea, red.

Native of S. Europe, N. Africa, and the Canaries; cultivated in England since the mid-seventeenth century. It is only hardy in the milder counties or against a warm wall, and is usually seen in cold greenhouses, where if planted out it makes a tangle of numerous stems eventually $\delta$ or $10 \mathrm{ft}$. 
high - a handsome cheerful evergreen, with graceful and fragrant, if not showy flowers.

Var. Maculata, De Candolle.-Leaves usually blotched with white. Native of $\mathrm{N}$. India, etc.

\section{S. BOna-nox, Linnceus. Stretchberry.}

A deciduous or partially evergreen climber, with angular or square branchlets, slightly armed with short, stout prickles. Leaves very variable; roundish, heart-shaped, fiddle-shaped, or spear-shaped; $1 \frac{1}{2}$ to $4 \frac{1}{2}$ ins. long ; always pointed, green and glossy on both sides, often bristly or prickly at the margins and on the nerves beneath, five- to nine-nerved; stalk $\frac{1}{4}$ to $\frac{1}{2}$ in. long. Flowers deep green, produced in umbels, the main-stalk of which is $\frac{1}{2}$ to $I$ in. long. Berries black with a bluish bloom, round, $\frac{1}{4}$ in. across; six to twelve, sometimes more, in an umbel.

Native of the eastern United States from Massachusetts southwards; introduced in 1739. A hardy species, distinguished from the also blackfruited S. rotundifolia by the longer-stalked umbels and bristly margined leaves.

\section{S. Cantab, Lynch. Cambridge Smilax.}

An evergreen climber reaching $12 \mathrm{ft}$. or more high; stems round, armed with sturdy unequal prickles, and furnished with curious minute tufts of bristles; branches square, often unarmed. Leaves of thin texture, triangular, with the base deeply heart-shaped, the apex pointed; the largest 5 ins. long, rather more in width; five-nerved, green on both surfaces, with a few grey spots on the upper one, the margins slightly bristly. Flowers in umbels of eight to twelve, the main-stalk as long or rather longer than the leaf-stalk.

Probably a native of $\mathrm{N}$. America, but of unknown origin, having been first described (The Garden, vol. 56, p. 505) by Mr Lynch from a plant growing against a wall in the Cambridge Botanic Garden, where it has stood for many years. It is a male plant, and may prove to belong to a species previously named:

\section{S. China, Linncus. China Root.}

A deciduous rambling shrub, with round stems sparingly armed with slightly recurved prickles. Leaves very variable, roundish ovate, or broadly oval, or sometimes broader than long, ending in a short abrupt point, the base tapered or truncate or slightly heart-shaped; five- or seven-veined; stalk $\frac{1}{3}$ to $I$ in. long. Flowers yellowish green, often numerous in umbels, the main-stalk of which is about I in. long. There are often over twenty flowers in an umbel. Fruit $\frac{3}{8}$ in. in diameter, globose, bright red.

Native of China and Japan, where it is frequent and widely spread; introduced in 1759 , now uncommon unless some of the numerous smilaxes introduced by. Wilson from China prove to be it. It has a large fleshy rootstock, said to be eaten by the Chinese; it also yields the drug known as "China root"-once highly esteemed as a remedy for gout.

\section{S. EXCELSA, Linnceus.}

I A tall evergreen climber, with squarish stems and branches armed with flat, stiff spines, $\frac{1}{4}$ to $\frac{1}{3}$ in. long. Leaves unarmed, broadly ovate, heartshaped or truncate at the base, pointed; $I_{2}^{\frac{1}{2}}$ to $3 \frac{1}{2}$ ins. long, often as broad or broader than long; five- or seven-nerved, green on both sides; stalk $\frac{1}{4}$ to 
$\frac{1}{2}$ in. long. Flowers six to twelve in an umbel, the main-stalk of which is $\frac{1}{2}$ to $\mathrm{I}$ in. long. Berries red, $\frac{1}{3}$ in. wide.

Native of S.E. Europe and Asia Minor; introduced in 1739. From $\mathrm{S}$. aspera, the other but more western species of Europe, S. excelsa is distinguished by its umbellate inflorescence.

\section{S. GLAUCA, Walter. SAW BRIER.}

A tall deciduous or partially evergreen climber, with round stems but angled branches, sparsely or not at all prickly. Leaves ovate with broadly tapering or rounded bases and fine points; $I \frac{1}{2}$ to $3 \frac{1}{2}$ ins. long, $I$ to $2 \frac{1}{2}$ ins. wide; green above, glaucous beneath, with usually three prominent nerves and two smaller ones at the margins; stalk $\frac{1}{6}$ to $\frac{1}{3}$ in. long. Flowers green, produced three to eight together in small axillary umbels, the main-stalks of which is $\frac{1}{3}$ to $\mathrm{I}$ in. long. Berries black with a glaucous bloom.

Native of the eastern United States from Massachusetts southwards; hardy, and cultivated for seventy years at Kew. The glaucous colour of the leaves beneath is its best distinguishing character.

\section{S. HISPIDA, Muhlenberg. HAG BRIER.}

A climbing deciduous shrub, with round stems furnished with slender bristles and straight prickles, densely so towards the base; branches almost without them. Leaves heart-shaped or broadly ovate, 2 to 6 ins. long, $1 \frac{1}{2}$ to $4 \frac{1}{2}$ ins. wide ; five- or sometimes nine-nerved, finely pointed, green on both sides, margins often minutely jagged; stalk $\frac{1}{4}$ to $\frac{3}{4}$ ins. long. Flowers greenish yellow, borne on an umbel with a main-stalk 1 to 2 ins. long. Berries blueblack, globose, about $\frac{1}{4}$ in. wide.

Native of the eastern and central United States and Ontario; introduced early in the eighteenth century. This species thrives well in this country, and is well marked by its large leaves and very bristly stems.

\section{S. LAURIFOLIA, Linnceus.}

An evergreen climber with thick, leathery leaves, 2 to 5 ins. long, $\frac{5}{8}$ to 2 ins. wide; three-nerved, dark green and rather glossy above, oblong, tapered or rounded at the base, and with usually a short, abrupt, fine point; stalk $\frac{1}{4}$ to $\frac{1}{2}$ in. long. Flowers greenish, in umbels, the main-stalk of which is about as long as the leaf-stalk. Fruit $\frac{1}{4}$ to $\frac{1}{3}$ in. wide, one-seeded, black when ripe, but taking two seasons to become so.

Native of the south-eastern United States; introduced in 1739. Very distinct in its three-nerved, leathery, evergreen, and comparatively narrow leaves, this is, unfortunately, rather tender, and has died out in the open ground at Kew. It has succeeded well on a wall in the vicarage garden of Bitton, near Bath, and is suitable for the south and west generally, where it will make an interesting evergreen wall-covering.

\section{S. Pseudo-China, Linnaus. "China" Brier.}

Not much is known of this smilax in cultivation, and it is probably rather tender. It appears to be naturally a vigorous climber, deciduous, with the stems almost unarmed. Leaves large, ovate, five- or seven-nerved, green on both sides, up to $4 \frac{1}{2}$ ins. long, by 3 ins. wide at the rounded or slightly heartshaped base; margins minutely jagged. Flowers dark green, and produced numerously in umbels. From all the rest of the umbellate-flowered smilaxes 
mentioned in these notes this species is easily distinguished by the length of the main flower-stalk, which is 2 to 3 ins. long, flattened. Berries black, $\frac{1}{3}$ in. diameter.

Native of the eastern United States; said by Aiton to have been introduced in 1739. The plant has a tuberous root-stock.

\section{S. ROTUNDIFOlia, Linnceus. HORSE BRIER.}

A vigorous, deciduous or partially evergreen climber, with slender, round or more or less angled stems, armed with one or two short spines between each leaf; the stems are sometimes 6 or 8 yards long; branches four-angled. Leaves ovate to broadly heart-shaped; 2 to 3 ins. long, often broader than long, with a short abrupt point; prominently five-nerved, smooth and glossy green on both sides; stalk $\frac{1}{4}$ to $\frac{1}{2}$ in. long. Flowers greenish yellow, about $\frac{1}{5}$ in. across, borne in umbels; main flower-stalk $\frac{1}{4}$ to $\frac{1}{2}$ in. long, flattened. Berries roundish, black, $\frac{1}{4}$ in. diameter, covered with glaucous bloom, usually three to six of them in one cluster.

Native of Eastern N. America; introduced in 1760. This is the commonest, most vigorous and hardy of all the smilaxes in cultivation, making a dense thicket of stems. It is the common horse brier or green brier of the United States, where its stems are sometimes 30 to $40 \mathrm{ft}$. long, stretching from tree to tree. In gardens it may be trained up stout oak posts on which the stumps of the side branches have been left 2 or $3 \mathrm{ft}$. long. Grown in this way it is very elegant.

\section{S. Sieboldi, Miquel.}

A deciduous or semi-evergreen species, the stems round or somewhat ribbed, and more or less armed with slender prickles; branches distinctly angular. Leaves ovate with a heart-shaped base and a long fine point, fiveor seven-nerved, margins minutely jagged; green both sides, $\mathrm{I}_{1}^{\frac{1}{2}}$ to 3 ins. long, two-thirds as wide. Flowers in small umbels of four to seven blossoms, green; main flower-stalk $\frac{1}{2}$ to $\frac{5}{8}$ in. long. Berries black, $\frac{1}{4}$ in. diameter, often in threes.

Native of Japan; introduced in 1908, perhaps before. It is a little known species, very distinct from S. China, also Japanese, in the smaller black fruits, few-flowered umbels, and triangular-ovate leaves.

\section{S. WAlteri, Pursh.}

A deciduous climber, with angled stems, armed only near the base; branches squarish, unarmed. Leaves ovate to ovate-lanceolate, 2 to $4 \frac{1}{2}$ ins. long, $\frac{3}{4}$ to $2 \frac{1}{2}$ ins. wide; broadly wedge-shaped to slightly heart-shaped at the base, ending in a short fine point; five- or seven-nerved; smooth and green on both sides; stalk $\frac{1}{4}$ to $\frac{1}{2}$ in. long. Flowers greenish, in short and flatstalked umbels. Berries bright coral-red, globose, $\frac{1}{3}$ in. wide.

Native of the eastern United States from New Jersey southwards; introduced early in the nineteenth century; rarely seen now. It is allied to $\mathrm{S}$. rotundifolia, but has narrower, proportionately longer leaves, and is not so vigorous a grower. S. rotundifolia also has black fruits.

SOLANUM CRISPUM, Ruiz and Pavon. SOlANACE

(Bot. Mag., t. 3795.)

A scandent, quick-growing, more or less evergreen shrub, with downy, scarcely woody young shoots. Leaves ovate, variable in size, usually 
$2 \frac{1}{2}$ to 5 ins. long, mostly less than half as wide, taper-pointed; rounded or wedge-shaped, rarely heart-shaped at the base; minutely downy on both surfaces; stalk $\frac{1}{2}$ to $\frac{3}{4}$ in. long. Flowers delicate bluish purple, fragrant, produced from June to September in long-stalked corymbs, 3 to 6 ins. across. Each flower is $I$ to $1 \frac{1}{4}$ ins. wide, the corolla with five ovate lobes, the yellow anthers closely packed in the centre. Fruit globose, $\frac{1}{4}$ to $\frac{1}{3}$ in. wide.

Native of Chile ; introduced about 1830 . This beautiful plant is only seen at its best in the milder counties of Great Britain, and few plants, even there, are more graceful and lovely. On a south wall at Kew it has grown and flowered for many years, but never with the vigour and profusion one sees in Devonshire and similar localities. It will grow $20 \mathrm{ft}$. or more high if given support. The most beautiful effect I have seen produced by it was where it had been planted against the wall of a low shed, over the roof of which it had clambered. It may be pruned back in spring before growth commences. Where the climate is suitable it may be treated as a loose-habited, wide-spreading shrub, by pruning hard back annually. It will thrive in poor soil.

In the gardens of the south-west a beautiful display is made in autumn by Solanum Jasminoides, Paxton, a native of Brazil. It produces its pure white flowers in great profusion. It is a climber of more slender growth than S. crispum and will grow in similar situations, but it is more tender.

Of the British bittersweet (S. Dulcamara, Linnaus) there is a variegated form rather handsomely marked with clear creamy white. The soft, semi-woody shoots grow 6 to $8 \mathrm{ft}$. high, but die back very much in winter, and the base only remains woody. The red berries are poisonous, and the plant may not be desirable where there are children. The flowers are violet-blue, and the leaves frequently unequally lobed at the base.

All these three species are easily increased by summer cuttings.

\section{SOPHORA. LEGUMINOSE.}

Trees or shrubs with unequally pinnate leaves; flowers produced in racemes or panicles; fruit a pod of the necklace pattern, that is, much constricted between each seed. The cultivated species fall into two wellmarked groups: Ist, SOPHORA (proper), whose flowers are pea-shaped (or papilionaceous); 2nd, EDwardSIA, whose leaves have smaller and usually more numerous leaflets, and whose flowers are much larger, not papilionaceous, but rather tubular, owing to all the petals pointing forward. The genus is represented on both hemispheres, above and below the equator. The hardy or nearly hardy species come from N. Asia, New Zealand, and Chile. One species, S. tetraptera, with curiously winged fruits, is found in both the two latter countries - a remarkable phenomenon in plant distribution. The Sophoras all like a good loamy soil and a sunny position. The shrubby species can be increased by cuttings ; those which make trees are better from seed. 


\section{S. JAPONICA, Linnceus.}

A deciduous tree, 50 to $80 \mathrm{ft}$. high, of rounded habit and branching low down when growing in the open, but capable of forming a tall clean trunk wher close planted. Bark downy when young, smooth later and dark greenish brown; on old trunks it is grey, and corrugated rather like an ash. Leaves rich green, pinnate, 6 to Io ins. long, composed of nine to fifteen leaflets, which are ovate or oval, I to 2 ins. long, half as wide, covered with small appressed hairs beneath. Flowers in terminal panicles 6 to 9 ins. long and wide, creamy white, each about $\frac{1}{2}$ in. long; calyx $\frac{1}{8}$ in. long, bell-shaped, green, shallowly toothed. Pod 2 to $3 \frac{1}{2}$ ins. long, smooth, one- to six-seeded; rarely seen in Britain, but developed in 1911 .

Native of China (not of Japan); introduced in 1753 . It is one of the most beautiful of all leguminous trees, although it does not flower in a young state-not commencing until thirty to forty years of age. Old trees flower freely, especially after hot summers. The blossoms are not developed until September, and in wet cold summers do not develop at all. They do not fade on the tree, but drop off quite fresh, making the ground white beneath. Perhaps the oldest tree in this country is at Kew-a veteran planted in 1760 , whose branches are now held together by steel rods; its short trunk is $13 \mathrm{ft}$. in girth. There is a fine tree in the gardens of Petit Trianon, but the finest I have seen is in the old Botanic Garden at Schoenbrunn, near Vienna, which is over $70 \mathrm{ft}$. high, $18 \mathrm{ft}$. in girth of trunk, and its head of branches IO5 $\mathrm{ft}$. through. The species has purgative properties.

Var. PENDULA. - A very picturesque weeping tree with stiff, drooping branches. It should be grafted on stocks of the ordinary form Io or $15 \mathrm{ft}$. high. An admirable lawn tree, or for forming a natural arbour.

Var. VARIEGATA. - Leaves margined with creamy white, but of little value.

Var. viOLACEA, Carrière (S. violacea, Dippel).-This variety was introduced from China to the Jardin des Plantes at Paris about 1858. Its flowers, which appear later than those of S. japonica, have the wing-petals and keel stained with rose-violet. A plant has been cultivated at Kew for many years, and has set flower-buds several times, but usually too late in the season to open well. In regard to leaf and young shoot it does not differ materially from the type. (According to Henry the flowers of S. japonica, as he saw them in China, vary a good deal in colour, some forms being white, others yellow.)

S. KOROLKowi, Hort. (S. japonica var. Korolkowi, Henry).-This is probably only one of the several forms of S. japonica. The most notable tree of the name is growing in the famous Arboretum at Segrez, in France. I saw this tree in July 1904, and it was then covered with panicles of unexpanded flowers. When open they are described as dull white. The leaflets are longer than in japonica (fully 3 ins.), but narrower in proportion; they are covered beneath with a very minute, close down. The young wood too is more downy, and of a lighter colour. The tree at Segrez is over $30 \mathrm{ft}$. high, with its trunk about I ft. in diameter.

\section{S. MACROCARPA, Smith.}

\section{(Edwardsia chilensis, Miers.)}

An evergreen tree, 20 to $40 \mathrm{ft}$. high; young wood covered with reddish brown down. Leaves pinnate, 3 to 5 ins. long, composed of six and a half to twelve and a half pairs of leaflets, which are $\frac{3}{4}$ to $I \frac{1}{2}$ ins. long, $\frac{1}{4}$ to $\frac{3}{8}$ in. wide; covered beneath and more or less above with reddish brown down. Flowers in short axillary racemes, yellow, $\mathrm{I}$ to $\mathrm{I} \frac{1}{4} \mathrm{ins}$. long. Calyx $\frac{1}{4} \mathrm{in}$. long, bell- 


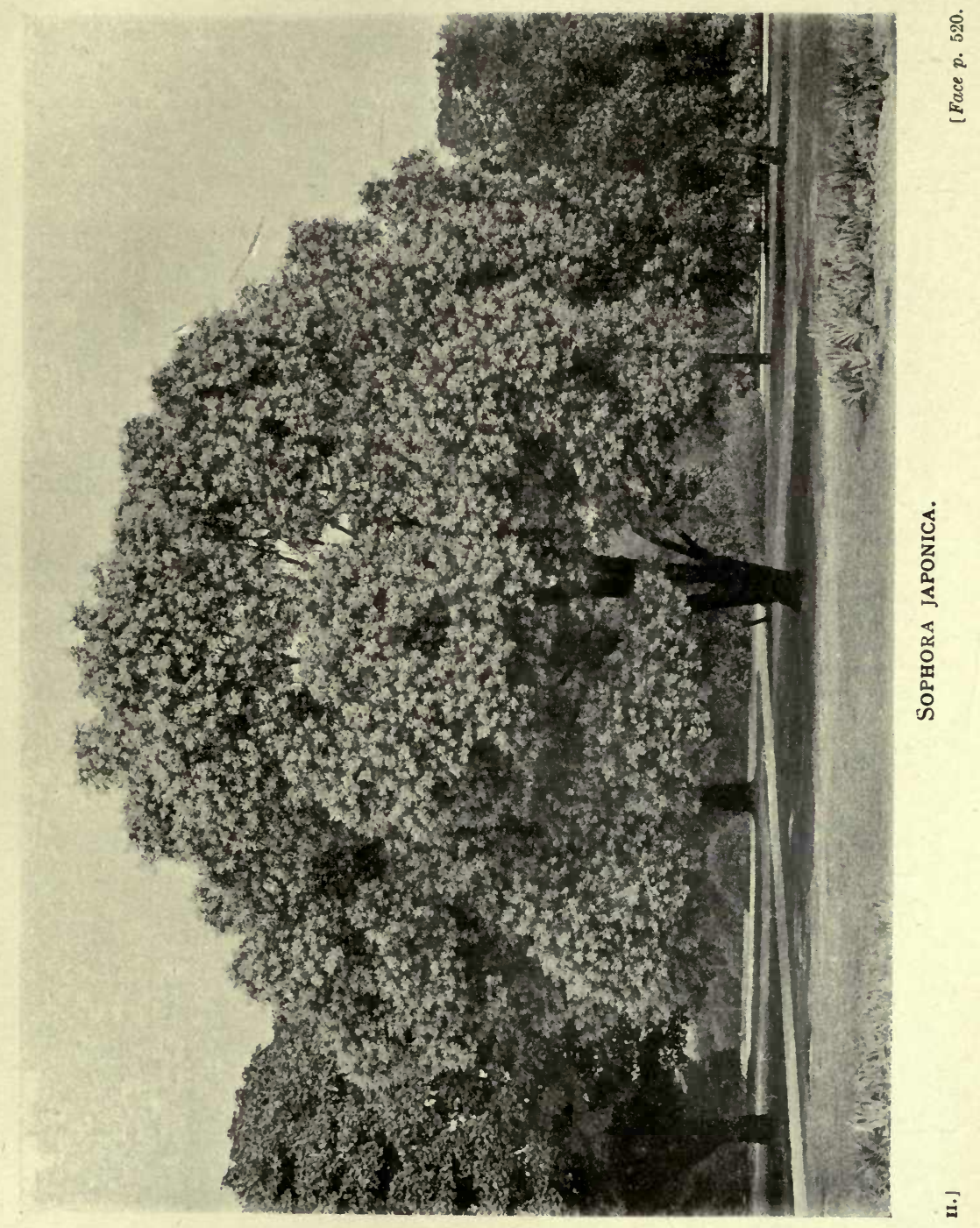



shaped, shallow-toothed, covered with down like that of the leaves. Pod downy, 4 ins. or more long, $\frac{1}{2}$ in. thick where the seeds are enclosed, but much constricted between them ; not winged, but thickened at the seams.

Native of Chile; introduced in 1822 . This species is nearly allied to, and very much resembles the larger-leaved forms of $\mathrm{S}$. tetraptera. It always differs from them, however, in having no wings to the pods, the flowers are not so large, and the leaves are pretty uniformly of the dimensions given above. It is not hardy at Kew, but thrives very well in S. Devon, Cornwall, and similar places. There is a fine plant in the garden of Duncan House, Torquay, planted there by the late Dr Hamilton-Ramsay.

\section{S. tetraptera, Aiton. KowhaI.}

A shrub or small tree, varying from 15 to $40 \mathrm{ft}$. high in a wild state, the trunk 6 ins. to $2 \mathrm{ft}$. in diameter. It is deciduous or nearly so in the open, but evergreen in a greenhouse. Branches of young specimens very zigzag, slender, and often interlacing-on older ones the branches become shortjointed, or even stunted. Branchlets, leaf-stalks, flower-stalks, and especially the calyx, all covered with a short tawny down. Leaves pinnate, $I_{\frac{1}{2}}$ to $4 \frac{1}{2}$ ins. long; leaflets $\frac{1}{8}$ to $\frac{3}{4}$ in. long, narrow oblong to roundish; their number is very variable, on young plants there are only seven or nine, but on plants that have reached the flowering stage they are much more numerous, and up to as many as eighty. Flowers soméwhàt tubular, golden yellow, I to 2 ins. long, pendulous, clustered from four to eight in each raceme. Calyx obliquely bell-shaped, $\frac{1}{2}$ in. or more across, shallow-toothed. Pod 2 to 8 ins. long, four-winged, with constrictions between the seeds.

Var. GRANDIFLORA (Edwardsia grandiflora, Salisbury) has larger flowers than the type (full 2 ins. long), and longer, less numerous leaflets.

Var. MICROPHYLlA, Hooker fil. (Edwardsia microphylla, Salisbury; E. Macnabiana, R. Graham, Bot. Mag., t. 3735).-Leaflets smaller, more numerous; flowers $I$ to $I \frac{1}{2}$ ins. long.

Native of New Zealand, whence the two forms were both introduced in I772; also of Chile. They are not hardy at Kew; even var. microphylla, which is considered the less tender, was killed in the open ground during the winter of $1908-9$, and plants on walls were badly cut. But in the milder counties or on specially sheltered walls it is most attractive, not only for its showy large flowers, but for its foliage and quaint interesting habit. It will thrive in sandy loam. The remarkable necklace-like pod, with four thin ridges traversing it lengthwise, is occasionally seen in this country.

\section{S. VICIIFOLIA, Hance.}

(Bot. Mag., t. 7883.)

A deciduous shrub of rounded habit, from 6 to $8 \mathrm{ft}$. high, and as much through, the young branchlets covered with greyish down, the year-old branches more or less spiny. Leaves pinnate, I $\frac{1}{2}$ to $2 \frac{1}{2}$ ins. long, with seven to ten pairs of leaflets, which are $\frac{1}{4}$ to $\frac{3}{8}$ in. long, about $\frac{1}{8}$ in. wide; oval or oblong, with silky appressed hairs beneath. Racemes terminal on short twigs, produced from the buds of the previous year's shoots, 2 to $2 \frac{1}{2}$ ins. long. Flowers pea-flower-shaped; petals bluish white; calyx $\frac{1}{8}$ in. long, downy, short-toothed, blue. Pod 2 to $2 \frac{1}{2}$ ins. long, about $\frac{1}{6}$ in. wide, downy, one- to four-seeded, constricted between the seeds.

Native of China in the provinces of Yunnan, Szechuen, and Hupeh, up to $13,500 \mathrm{ft}$. It was introduced in 1897 to Kew, where it has grown well, and proved to be one of the most charming of recently introduced shrubs, the 
branches being loaded with the blue and white racemes in June, their beauty greatly enhanced by the elegant fern-like foliage. It requires a good loamy soil, and a site exposed to full sunshine. No frost has yet affected it. According to Henry, in the elevated regions where it grows, it often covers large tracts of barren country, just as gorse does in Britain. It is propagated by cuttings made of young shoots with a heel of old wood, in July and August, and placed in a gently heated frame.

Nearly related to $\mathrm{S}$. viciifolia is S. MOORCROFTIANA, Bentham, with similar foliage and habit, but which is more spiny, more downy, has smaller leaflets, yellow flowers, and a longer more slender calyx. Native of Kashmir and Thibet, It has not, I think, blossomed in cultivation yet.

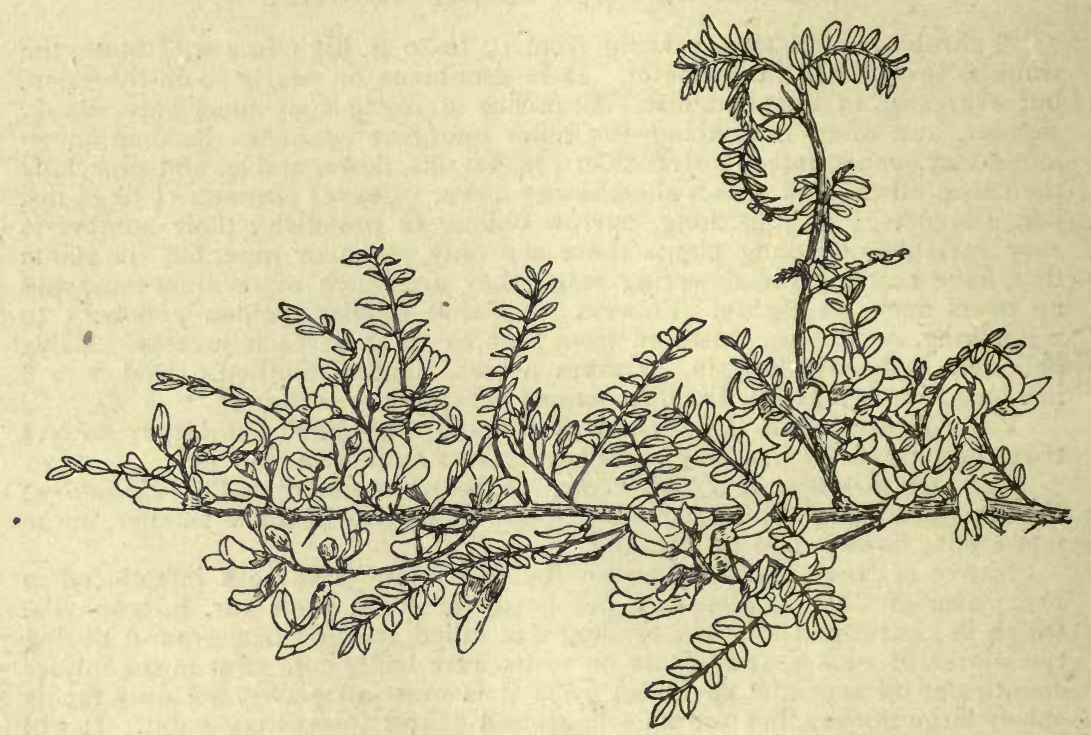

SOPHORA VICIIFOLIA.

SPARTIUM Junceum, Linnaus. SPANish Broom. LEGUMINOSE.

(Bot. Mag., t. 85.)

A tall shrub of rather gaunt habit, with erect, cylindrical, rush-like stems, smooth and dark green, which, in the almost entire absence of foliage, fulfil the functions of leaves. It grows 8 to $12 \mathrm{ft}$. high. Leaves very few and deciduous, simple, linear, $\frac{1}{2}$ to $\frac{3}{4}$ in. long, with silky hairs beneath. Flowers fragrant, disposed in terminal racemes 12 or even I 8 ins. long, on the current season's growth. Each flower is about $\mathrm{I}$ in. long, pea-shaped (papilionaceous), shortly stalked, rich glowing yellow, with a showy, roundish standard petal nearly $\mathrm{I}$ in. across. Pod $I_{2}^{1}$ to 3 ins. long, $\frac{1}{4}$ in. wide, hairy, five- to twelve-seeded. 
Native of S. Europe; introduced, it is said, in 1548 . The name "Spartium" has been given to many leguminous plants, but is now confined to this species. S: junceum is a useful shrub whose value is enhanced by its coming into bloom in June and lasting until September. In July, when it is at its best, it is very showy. It is admirable for planting on hot dry banks, especially if it be associated with a dwarfer shrub (like double-flowered gorse), which will hide its gaunt and naked base. But in the ordinary reaches of the garden also it makes very effective groups, and gives masses of welcome colour when shrubs generally have gone out of flower. It must be raised from seeds (which ripen in abundance), and kept in pots until planted out in permanence, for it dislikes disturbance at the root. Sometimes it is grown as a formal bush, being clipped over with shears in early spring before growth starts; shoots then spring out all over the bush, which blossom in their due season a few months later.

The shrub has some economic value in the south of Europe, yielding a fibre which is obtained from the branchlets by maceration, and is worked up into thread, cordage, and a coarse fabric.

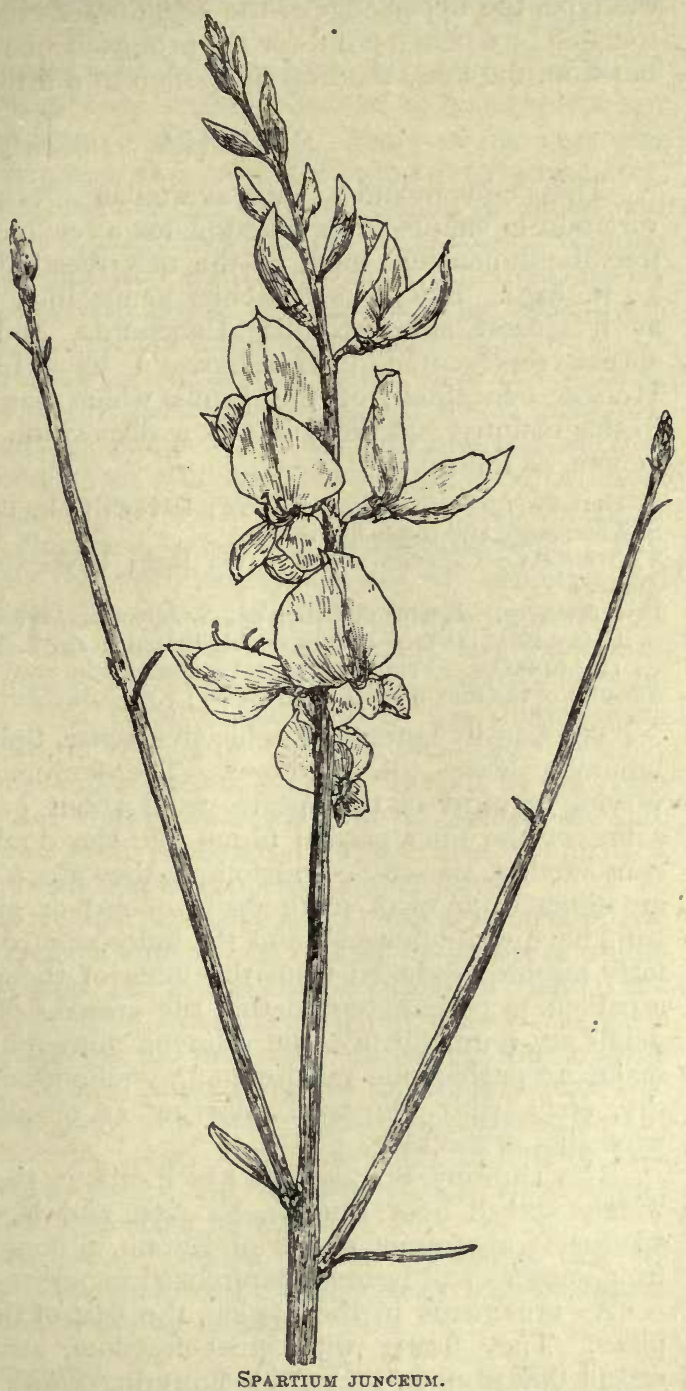

Var. FLORE PLENO.-

A double-flowered form propagated by grafting on young seedlings of the type. It was introduced by Peter Collinson from Nuremberg in 1746. He says: "It cost me a golden ducat; came from thence down the Rhine, and was brought by the first ship to London in good order. 
I inarched it on the single-flowered broom and gave it to Gray and Gordon (two famous nurserymen)." It is still cultivated at Kew, but unless it has deteriorated, it was scarcely worth Collinson's trouble. In the type, the upper edge of the keel towards the base is sensitive. If it be touched by a pencil point (or the proboscis of an insect) the stamens spring out from the keel, sending the pollen in a little cloud.

\section{SPIRÆA. ROSACE E}

This genus includes herbs as well as shrubs, and the latter show every variation in stature from tufted plants a few inches high to those of almost tree-like dimensions such as the new West Chinese S. arborea, which is $30 \mathrm{ft}$. high. Spiræa is the chief genus in a tribe of Rosaceæ, and has as it closest allies, Neillia, Exochorda, and Stephanandra-all hardy shrubs represented in gardens. I have followed the Bentham and Hooker conception of the genus, which has for so long been adopted in this country, but there is now a disposition to split it up into several genera, as follows :-

SPIRÆA (proper).-Capsules free; leaves simple, usually toothed; 'e.g., S. japonica, S. Thunbergi, and numerous others.

SiBIRÆA.-Capsules united at the base; leaves entire; e.g. S. lævigata (the only species).

SORBARIA.-Leaves pinnate; e.g., S. Aitchisoni, arborea, Lindleyana, sorbifolia.

CHAM EBATIARIA. - Leaves doubly pinnate ; e.g. S. Millefolium (the only species).

HoLODISCUS.-Fruit an achene containing one seed not splitting to release it as the capsules of the four previous groups do; e.g. S. discolor.

Thus, in its more comprehensive sense, Spiræa has simple, pinnate, or bipinnate leaves, all deciduous. The flowers are very uniform in size, varying in most of the species from about $\frac{1}{4}$ to $\frac{1}{3}$ in. in diameter, but in a few of the finer garden forms like the double-flowered prunifolia and cantoniensis, also in S. Millefolium, they are $\frac{1}{2}$ in. across. The blossoms are either white or of some shade of red or pink (all the spring-flowering sorts have white flowers), and the inflorescence is either a fascicle or short leafy raceme produced from the buds of the previous year's growths; or a panicle or corymb terminating the growths of the current season. The petals are normally five, the stamens numerous and often so long as to make a conspicuous feature in the inflorescence, the seed-vessels five, dry, erect, with the style adhering at or near the top, and the calyx persisting at the base.

The shrubby Spirzas, of which about sixty species are known, are widely spread over Europe, N. Asia, and N. America, but no shrubby species is a genuine native of Britain, although S. salicifolia has escaped from gardens and become naturalised in various parts of the kingdom.

As ornaments in the garden, the best of the Spiræas fill an important place. They flower with great freedom, are often very graceful, and except that some of the earlier flowering kinds are liable to injury by late frost, they are perfectly at home under cultivation. All like a good loamy soil, abundant moisture, and full sunlight.

Propagation.-Many of the Spiræas spread by means of sucker growths from the base, and such are easily increased by dividing the plants into small pieces. The rest can nearly all be propagated easily 
by means of cuttings made of moderately firm wood placed in light sandy soil in gentle bottom heat in July and August. If this be not available, cuttings made of harder wood in September may be placed under bellglasses out-of-doors in a sheltered spot. For the pinnate-leaved ones root-cuttings may be used.

The Spiræas produce fertile seed in abundance, but they cross-breed with such facility that seed can only be depended on to come true when the plants are fairly isolated from other species. Some of the very best Spiræas are hybrids, as may be gathered from the following descriptive notes, but they have become so numerous that they make the genus, as represented in gardens, excessively difficult to study and classify. Mr Zabel of Münden has devoted a volume of one hundred and twenty-eight pages exclusively to their elucidation, but many are so sinilar to each other that their differentiation on paper is no longer possible within convenient limits.

PRUNing.-Few shrubs repay careful pruning better than the Spiræas, and in this matter they may be divided into two groups, viz., (I) those that flower early and from the buds of shoots made the previous year, such as arguta, hypericifolia, Thunbergi, Van Houttei, Veitchii, etc.; and (2) those that flower later in the year at the ends of the shoots of the current season, such as japonica, Douglasii, salicifolia, Lindleyana, etc. This matter is fully discussed in the introductory chapter on pruning, and from what is there stated it will be evident that the first group must only be pruned by thinning out the older and weaker wood; any shortening back of the shoots must mean a reduction in the next crop of blossom. The second group, on the other hand, is benefited by the shoots being shortened back. This should, of course, be done in late winter or early spring, and at the same time superfluous old shoots should be cut clean out. Unless pruning of either kind is done, many of the Spiræas get into a weedy, thin condition, and their blossoms will not bear comparison either in quantity or quality with that of properly pruned plants.

The group including Douglasii, tomentosa, salicifolia, Menziesii, and their hybrids form dense thickets, and spread rapidly by means of underground suckers. These should be pruned as in group 2 (being late flowering), and it is also advisable at intervals of a few years to dig them up, divide them into smaller pieces, and after enriching the ground, replant them more thinly. This, of course, applies to ordinary cultivated shrubberies and borders, but they also make admirable masses, for the wilder portions of the demesne, where they can safely be left to take care of themselves. In such places the reddish or rich brown stems of many Spiræas make a cheerful feature in winter.

So many of the Spiræas are of similar aspect and value, that for gardens a selection suffices. The following twenty kinds may be recommended, or, for smaller gardens, the ten marked * :-

"Arguta.

*Aitchisoni.

Brachybotrys.

Bracteata.

Canescens.

"Discolor.

Douglasii.
Henryi.
*Japonica and its varieties.
Media.
* Margaritæ.
* Menziesii var. triumphans.

*Prunifolia fl. pl.

Salicifolia var. paniculata.

Thunbergi.

Trilobata.

*Van Houttei.

*Veitchii.

For the rock garden *bullata and decumbens are very suitable. 


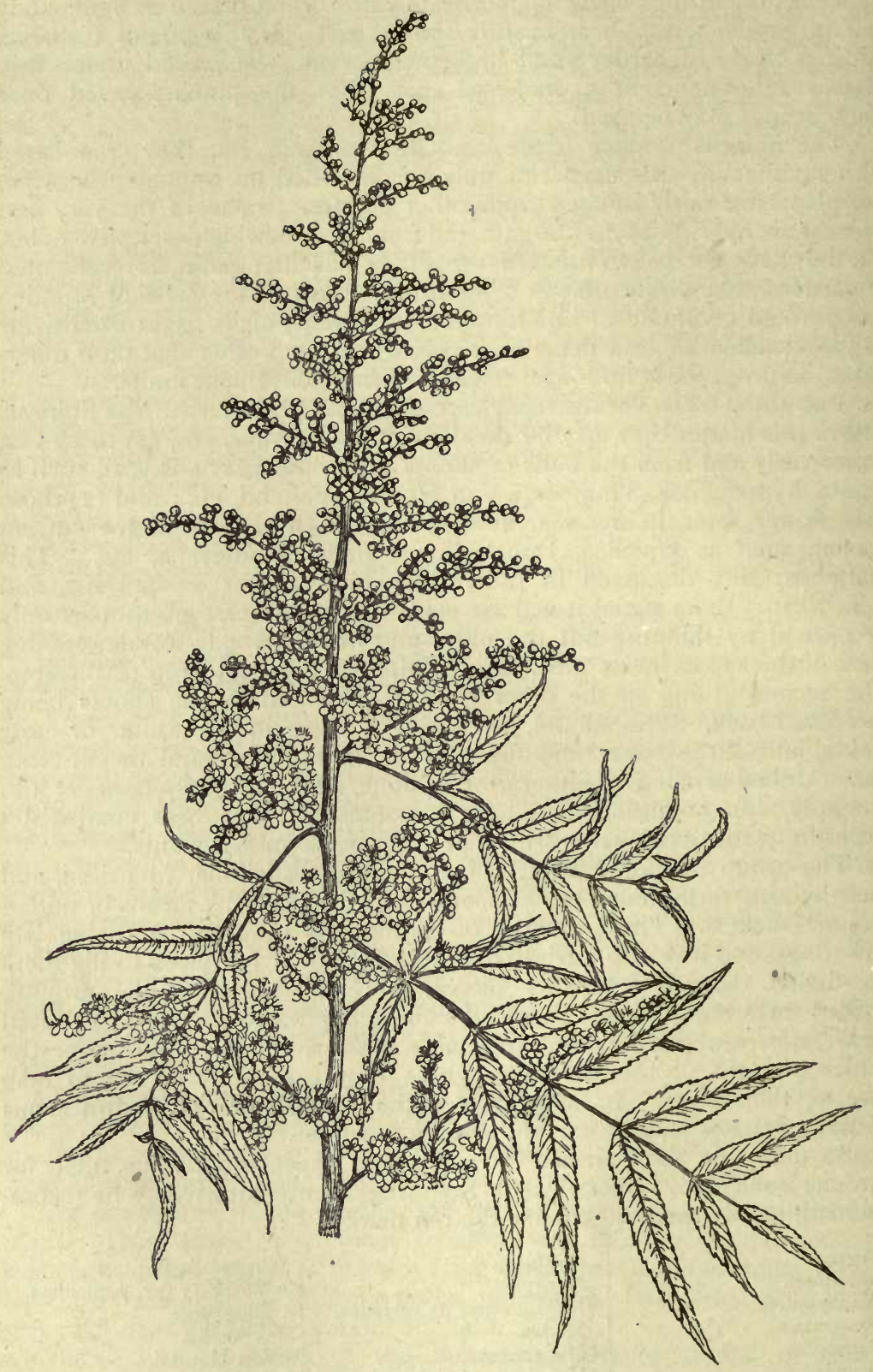

SpIrfea Aitchisoni. 


\section{S. Aitchisoni, Hemsley.}

(Sorbaria angustifolia, Zabel.)

A shrub of open, spreading habit, ultimately Io $\mathrm{ft}$. high; branches red when young, perfectly smooth, and very pithy. Leaves pinnate, 9 to 15 ins. long, composed of eleven to twenty-three leaflets. Leaflets narrowly lanceshaped with long tapering points; 2 to 4 ins. long, $\frac{1}{4}$ to $\frac{3}{8}$ in. wide; evenly, sharply, and rather deeply toothed; green and quite smooth on both surfaces, stalkless. Flowers white, $\frac{1}{3}$ in. across, produced during July and August in pyramidal branching panicles from $\mathrm{I}$ to $\mathrm{I} \frac{1}{2} \mathrm{ft}$. long, and 9 to 15 ins. through; flower-stalks smooth; seed-vessels red.

Native of Afghanistan, Kashmir, etc. ; first discovered in the Kurrum Valley by Dr Aitchison in 1879, and introduced to Kew in 1895 by $\mathrm{Mr} \mathrm{J}$. F. Duthie. It is closely allied to S. Lindleyana, differing chiefly in the red young bark, the narrower leaves without down and mostly simply (not doubly) toothed margins, and its larger flowers. On the whole it is superior to S. Lindleyana, its foliage being more elegant and its flowers more effective. It is said to be hardy where S. Lindleyana will not succeed.

\section{S. Alpina, Pallas.}

A shrub 3 to $5 \mathrm{ft}$. high, with erect stems; young shoots angled, finely downy, bright brown. Leaves $\frac{1}{4}$ to $I$ in. long, $\frac{1}{3} \mathrm{in}$. or less wide; narrowly oblong, or obovate, entire, smooth, with feathered veins beneath. Flowers yellowish white, small, produced during May and June in small umbels; flower-stalks smooth.

Native of N.E. Asia ; introduced in 1806 . It is allied to S. crenata, but differs in the feathery veining of the leaf; also to S. cana, but is distinguished by the smooth leaves. Of little garden value.

(This name must not be confused with S. sorbifolia var. alpina, Pallas, the Sorbaria alpina of later authors, which belongs to one of the pinnate-leaved Spiræas. 'See S. sorbifolia.)

\section{S. ARGUTA, Zabel.}

A shrub of rounded, bushy habit, 6 to $8 \mathrm{ft}$. high, and as much wide; branches graceful, slender, twiggy, and covered with down. Leaves oblanceolate, $\frac{3}{4}$ to $1 \frac{1}{2}$ ins. long, $\frac{1}{4}$ to $\frac{1}{2}$ in. wide; entire, or with a few teeth towards the apex; of a lively green and smooth above, slightly downy and rather prominently nerved beneath. Flowers $\frac{1}{3}$ in. across, pure white, produced during April and May in fascicles of four to eight, each flower on a slender smooth stalk $\frac{1}{2}$ in. or so long. (Fig. p. 528, and plate, vol. i., p. 26.)

Three species are believed to have a share in the parentage of this hybrid, viz., Thunbergii, crenata, and hypericifolia. It is the most beautiful of the spring-flowering Spiræas, being quite hardy and never failing to produce a wealth of blossom. The flower-clusters are crowded on the upper side of shoots made the previous year, forming snowy white wreaths from 6 ins. to 12 ins. long. It is most conveniently increased by means of layers, its slender lissom branches adapting themselves admirably to this method.

\section{S. BELLA, Sims.}

(Bot. Mag., t. 2426.)

A shrub up to $6 \mathrm{ft}$. high, with angular, slightly hairy young branches. Leaves thin, broadly ovate, pointed, doubly toothed towards the apex; I to 
$2 \frac{1}{4}$ ins. long on the barren shoots; smaller, simply toothed, and about half as wide on the flowering ones; upper surface smooth ; glaucous or whitish, and

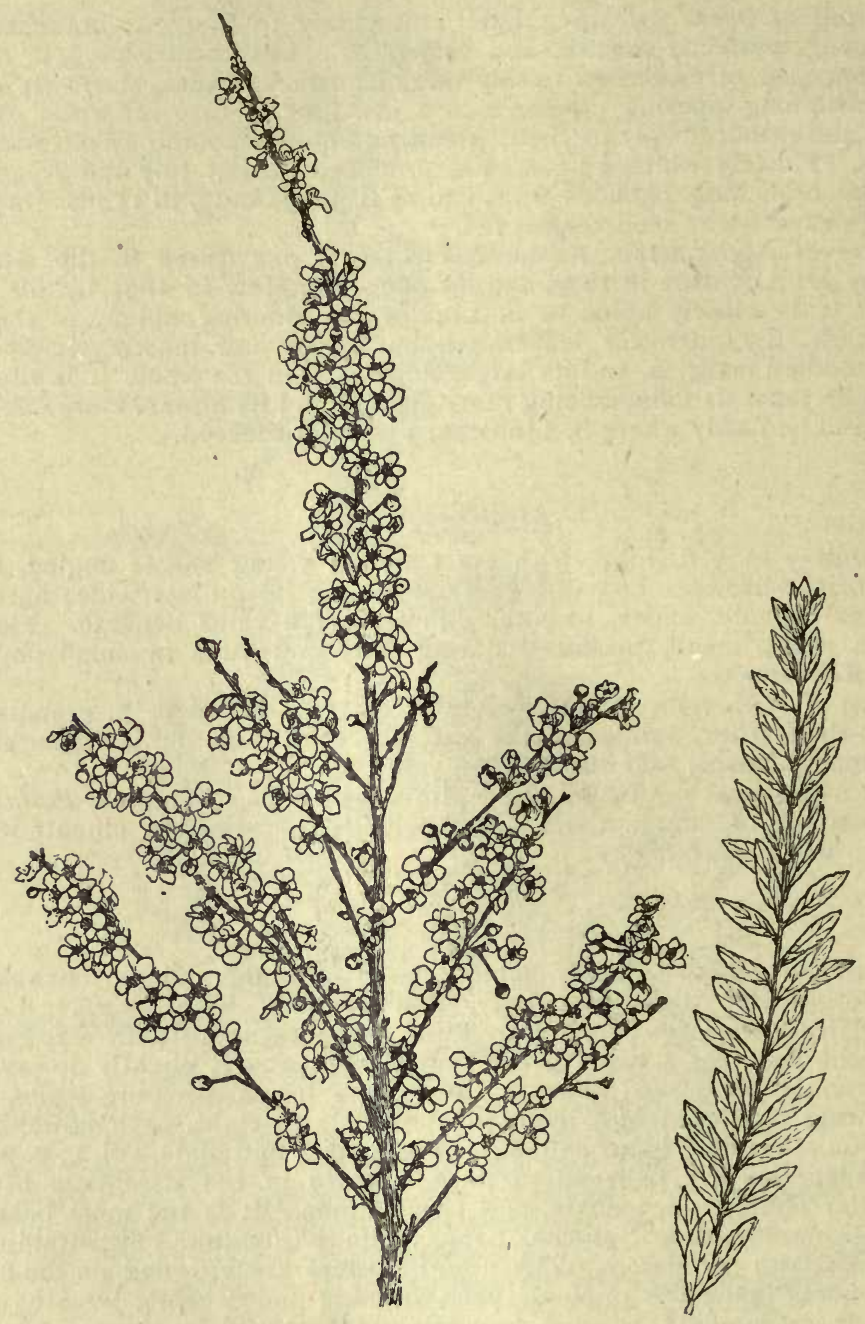

SPIREA Arguta.

more or less downy beneath; stalks $\frac{1}{6}$ to $\frac{1}{4}$ in. long. Flowers bright rose, $\frac{1}{4}$ in. across, produced during June in corymbs $\frac{3}{4}$ to $1 \frac{1}{2}$ ins. across.

Native of the Himalaya; introduced early in the nineteenth century. In spite of its name this shrub is not one of the best of the Spiræas. It has been much confused with S. expansa, a species nearly allied but having 
quite round (not angled) branches. There is also an intermediate form known in gardens as S. PULCHELLA, Kunze (bella $\times$ expansa).

\section{S. BRACHYBOTRYS, Lange.}

(S. luxuriosa, Lavallée; S. pruinosa, Zalel.)

A vigorous shrub, up to $8 \mathrm{ft}$. high, branches gracefully arching; young wood downy, ribbed. Leaves oblong or ovate, $\frac{3}{4}$ to $\mathrm{I} \frac{3}{4}$ ins. long, $\frac{1}{3}$ to $\frac{3}{4}$ in. wide, with a few teeth at the apex only; upper surface dull dark green, and slightly downy, lower one pale and felted with fine grey down. Flowers bright pink, small, and crowded densely in stout panicles $1 \frac{1}{2}$ to 3 ins. long and about the same wide; they are borne at the end of leafy twigs, 3 to 12 ins. long,

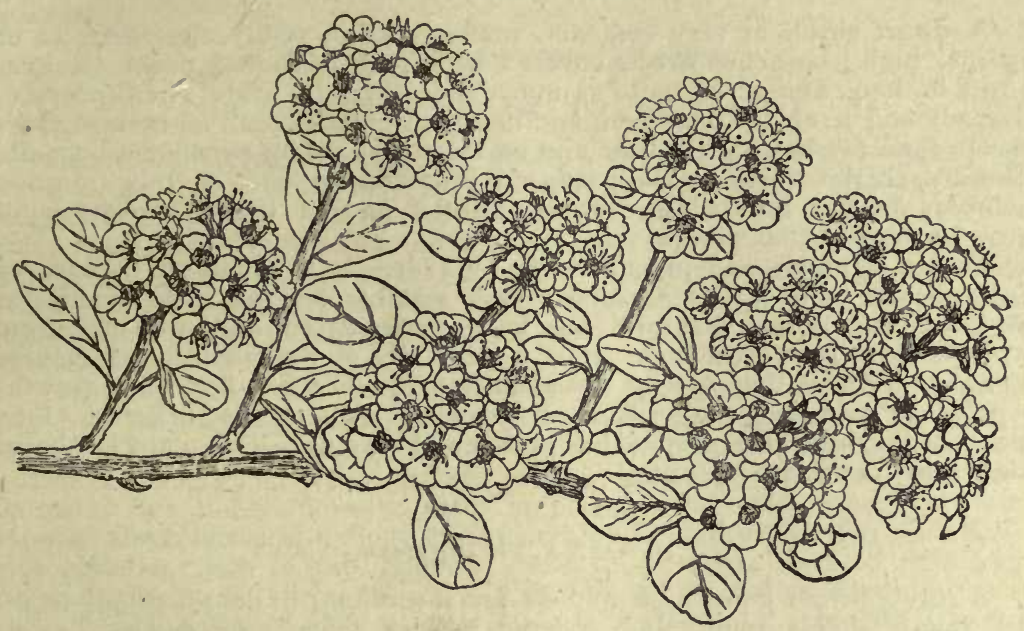

Spirea bracteata.

that spring from the branches of the preceding year, expanding in June and July; flower-stalks and calyx hairy.

A hybrid between canescens and probably Douglasii, inheriting much of the grace and vigour of the former. This is, indeed, one of the best of the taller summer-flowering kinds, the long shoots made one year branching copiously towards the top the following one, when each twig carries its terminal panicle, the whole forming a fine sheaf of brightly coloured blossom.

\section{S. BRACTEATA, Zabel.}

\section{(Bot. Mag., t. 7429; S. nipponica, Maximowicz.)}

A deciduous shrub of rounded, bushy habit, growing 4 to $8 \mathrm{ft}$. high; the branches, leaves, and flower-stalks quite smooth; young wood reddish. Leaves very broadly obovate or oval, sometimes nearly round, $\frac{1}{2}$ to $I$ in. long, sometimes entire, but usually with a few broad teeth at the rounded apex; stalk $\frac{1}{6}$ to $\frac{1}{8}$ in. long. Flowers pure white, $\frac{1}{3}$ in. across, crowded dersely in rounded or conical clusters, I to $1 \frac{1}{2}$ ins. wide. Each cluster is borme at the end of a leafy twig, I $\frac{1}{2}$ to 3 ins. long, springing from the wood of 
the previous year; petals overlapping. It is at its best in June. The specific name refers to the leaflike bracts on the stalks of the lower flowers.

A native of Japan; first introduced by Siebold to his nursery at Leyden, and originally sold as " $\mathrm{S}$. rotundifolia alba." It is sometimes injured by late frosts, but when these are escaped, few June-flowering shrubs are more lovely. The flower-clusters are all borne on the upper side of the horizontal or arching branches. It is perfectly hardy, but needs liberal conditions at the root, even more than the majority of Spiræas do. The great thing is to get a comparatively few long shoots rather than a crowd of small twiggy ones. Old shoots should be 'removed as soon as they produce nothing but twiggy shoots.

\section{S. BUllata, Maximorvicz.}

\section{(S. crispifolia, Hort.)}

A dwarf shrub of very compact, rounded habit, rarely more than 12 or I 5 ins. high; branches erect, covered with rusty coloured down. Leaves $\frac{1}{2}$ to I in. long, almost or quite as much wide; broadly ovate, often recurved, coarsely and irregularly toothed, and nearly or quite smooth on both surfaces except for a few hairs at the base and on the stalk; nerves prominent beneath. Flowers scarlet rose, small, produced towards the end of July in great numbers in flat branching corymbs at the end of the current season's growths; flower-stalks downy.

Native of Japan, and in cultivation by $\mathrm{I} 88 \mathrm{I}$. It is one of the dwarfest of Spiræas and one of the prettiest; very suitable for the rock garden, or wherever small dainty shrubs can be accommodated, and protected from stronger growing neighbours. It is a near ally of S. japonica, and may be a garden form of that species raised in Japan. The old flowering growths may be cut back in spring. The specific name refers to the puckering of the blade of the leaf, often noticeable between the veins. The plant is almost hidden by its flowers in July.

\section{S. CANA, Waldstein.}

A shrub $3 \mathrm{ft}$. or more 'high and as much through; of dense, twiggy habit, the young shoots round and covered with a thick grey down. Leaves narrowly oval or ovate, tapering at both ends; $\frac{1}{3}$ to 1 in. long, about half as wide; nearly always entire; covered on both sides, but especially beneath, with a grey silky down. Flowers dull white, $\frac{1}{4}$ in. across, produced during May at the end of short leafy twigs in dense umbel-like racemes $\frac{3}{4}$ to I in. wide.

Native of S.E. Europe; introduced in 1825 . The leaf is very like that of Salix repens in its dense grey down, not, however, so silvery. One of the least attractive of the Spiræas, but of neat habit and quite hardy; also distinct in the character of its leaves.

\section{S. CANESCEnS, Don.}

\section{(S. flagelliformis, Hort.)}

A shrub varying considerably in height; at its tallest 12 to $15 \mathrm{ft}$. high, more often 6 to $8 \mathrm{ft}$. high; the main stems erect, but producing towards the top slender, arching or pendulous branches growing $3 \mathrm{ft}$. or more long in one season; the young branches ribbed and downy. Leaves $\frac{1}{2}$ to $I$ in. long, $\frac{1}{3}$ to $\frac{5}{8}$ in. wide; oval or obovate, usually blunt and toothed at the apex, and always more or less tapering to the very short stalk at the base; dull green and with some down above, grey and more or less thickly downy beneath. 
Flowers white, or dull creamy white, small, produced during June and July in corymbs 1 to 2 ins. across, at the end of short leafy twigs; flower-stalks and calyx grey-downy or even felted.

Native of the Himalaya; introduced in 1837 . The chief distinguishing characteristic of this Spiræa, and one which gives it a leading place in the genus, is its habit of producing in one season the long, thong-like shoots to which the popular name "flagelliformis" refers. When, the following year, there springs from every bud a short erect twig, each crowned with its dense cluster of flowers, there are few more strikingly beautiful shrubs, especially at the date when it blossoms. The species is somewhat variable in the shape and size of the leaf, in the amount of down it bears, also to some extent in habit. It has, in consequence, received many names. The small greyish leaves tapering at the base, and the abundant clusters of white flowers set on the upper side of long arching branches, generally distinguish it.

\section{S. CANTONIENSIS, Loureiro.}

\section{(S. Reevesiana, Lindley, Bot. Reg., vol. 30, t. I0.)}

A deciduous or partly evergreen shrub, 4 to $6 \mathrm{ft}$. high, of wide-spreading, graceful habit, producing a thicket of erect and outwardly arching stems; young stems smooth. Leaves lozenge-shaped, I to $2 \frac{1}{2}$ ins. long, $\frac{1}{2}$ to $\frac{3}{4}$ in. wide; deeply and irregularly toothed (sometimes almost lobed) on the upper part, green and quite smooth on both sides, with a glaucous tinge especially beneath; stalk slender, $\frac{1}{4}$ to $\frac{1}{3}$ in. long. Flowers white, $\frac{1}{3}$ in. across, produced during June in hemispherical corymbs I to 2 ins. across, each corymb on a leafy stalk $\mathrm{I}$ to 2 ins. long.

Native of China and Japan. This shrub is scarcely known in gardens except in its double-flowered state, var. FLORE PLENO, in which the manypetalled blossoms are nearly $\frac{1}{2}$ in. across; when freely borne they make a charming display. In the gardens of the south of France, Italy, and Dalmatia this double-flowered form is perhaps the most beautiful whiteflowered shrub in April, its long sprays arching in every direction and laden with blossom. But in the Thames Valley it is rarely seen to perfection owing to injury by spring frosts. It can be got in better condition on a wall. Nearly allied to this species is S. chinensis $(q . v$.$) , also with fragrant$ white flowers in corymbs, but readily recognised by the yellowish felted under-surface of its leaves. A hybrid between them is S. BLANDA, Zabel, which has leaves furnished beneath with a greyish down, and white flowers in downy corymbs. All of this group are spring tender.

\section{S. CHAM EDRIFOLIA, Linnceus.}

(Bot. Reg., t. 1222.)

An erect shrub, up to $6 \mathrm{ft}$. high, the young shoots yellowish, smooth, angular, zigzag. Leaves ovate or ovate-lanceolate, $I \frac{1}{2}$ to 3 ins. long, $\frac{3}{4}$ to $1 \frac{1}{2}$ ins. wide; coarsely, irregularly, often doubly toothed; dark green and smooth above, somewhat glaucous and slightly downy beneath. Flowers $\frac{1}{3}$ in. across, white, produced in a corymb or corymbose raceme $1 \frac{1}{2}$ ins. across; flower-stalks smooth, slender, the lower ones $\frac{3}{4}$ in. long, becoming shorter towards the summit. Stamens conspicuously long.

Var. ULMIFOLIA.- - Leaves ovate, the upper two-thirds coarsely often doubly toothed. The inflorescence is more of a raceme than a corymb, and from $I \frac{1}{2}$ to 2 ins. long; flowers white, $\frac{1}{2}$ in. across. This is the handsomest form of $S$. chamædrifolia, distinct in its broader leaves and more elongated inflorescence. 
S. chamædrifolia is a rather variable species with a very wide natural distribution; its most westerly habitat is E. Europe, and it reaches thence to Siberia, Dahuria, Manchuria, and Japan. In all its forms it is an attractive and reliable shrub, usually escaping late frosts and flowering during May; var. ulmifolia opening towards the end of the month. It renews itself by sending up every year strong erect sucker growths from the ground, which produce flowers on short twigs the following year; and, to give these their best chance, sufficient of the older shoots should be pruned out after flowering to enable them to develop freely and strongly.

S. SCHINABECKII, Zabel, is a handsome hybrid between var. ulmifolia and S. trilobata. It is $6 \mathrm{ft}$. high, a twiggy bush with white flowers in stalked umbels - at their best in June.

S. FLEXUOSA, Fischer (S. chamædrifolia var. flexuosa, Maximowicz), is closely allied to the above, but is distinguished by the more conspicuously angled (or winged) stems, the dwarfer habit, the smaller narrower leaves simply-toothed on the upper third or half only, sometimes almost entire, and by the flowers, being fewer in the cluster. Native of S. Siberia; probably nothing more than a variety of chamædrifolia.

\section{S. CHINENSIS, Maximowicz.}

\section{(S. pubescens, Lindley; Bot. Reg., vol. 33, t. 38.)}

A shrub 3 to $5 \mathrm{ft}$. high, of dense very leafy habit; young shoots downy. Leaves $I$ to $\mathrm{I} \frac{3}{4}$ ins. long, $\frac{1}{2}$ to $\mathrm{I}_{4}^{\frac{1}{4}}$ ins. wide; varying from rhomboidal and tapering at both ends, to broadly ovate with a nearly truncate base, sometimes obscurely three-lobed; the upper part sharply and coarsely toothed, the teeth gland-tipped; upper surface furnished with scattered hairs, under-surface clothed with yellowish felt; stalk $\frac{1}{4}$ to $\frac{1}{3}$ in. long. Flowers white, nearly $\frac{1}{2}$ in. across, produced during June in stalked umbels or corymbs 1 to 2 ins. wide; flower-stalks and calyx downy. The leaves remain very late on the branches.

Native of N. China and allied to S. cantoniensis, but readily distinguished by its downy shoots, flower-stalks, and felted leaves, the last named being considerably broader in proportion to their length than those of cantoniensis. It is not very hardy, and is killed to ground-level in hard winters.

\section{S. CORYMBOSA, Rafinesque.}

A dwarf shrub, I to $3 \mathrm{ft}$. high, with smooth, erect, mostly unbranched stems. Leaves of firm texture, oval, ovate or roundish; $1 \frac{1}{2}$ to 3 ins. long, two-thirds as wide; coarsely and often doubly toothed in the upper half; smooth on both surfaces and rather glaucous beneath; stalk $\frac{1}{8}$ to $\frac{1}{4}$ in. long. Flowers white, $\frac{1}{6}$ in. wide, borne on the shoots of the year in dense, rounded, branching corymbs 2 to 4 ins. across ; seed-vessels smooth, sepals erect at the fruiting stage ; flower-stalks very downy.

Native of the United States, from the mountains of Georgia north to New Jersey. A handsome shrub allied to S. BETULEFoliA, Pallas (under which name it is often grown), flowering from June to August. Like that species it renews itself by stems pushed from the base annually, and these should be encouraged by pruning out the older wood. In the true S. betulæfolia the sepals are much reflexed at the fruiting stage.

\section{S. CRENATA, Linneus.}

(S. crenifolia, C. A. Meyer.)

A shrub 3 to $5 \mathrm{ft}$. high, bushy, with slightly angular stems; young twigs at first more or less downy, becoming smooth later. Leaves narrowly to 
broadly obovate, $\frac{1}{2}$ to $I \frac{1}{3}$ ins. long, $\frac{1}{4}$ to I in. wide ; toothed only at the apex, slightly downy or smooth beneath, with three distinct veins running lengthwise. Flowers white, small, produced during May in small hemispherical umbels at the end of short, leafy twigs.

Native of S.E. Europe, the Caucasus, Siberia, etc.; long known in cultivation. From its immediate allies (S. alpina and S. cana) its three veins running the whole length of the leaf distinguish it. It is also often confused with S. hypericifolia, but that species has its flowers wholly or almost wholly in stalkless umbels. There is a hybrid between S. crenata and cana called S. CONFERTA, Zabel, which has three-veined leaves like S. crenata, but more and persistently downy.

\section{S. DeCumbens, W. Koch.}

(S. procumbens in gardens.)

A dwarf shrub, 3 to 8 ins. high, with slender, smooth, often prostrate stems, from which the thin, wiry flowering branches ascend. Leaves obovate or oval, tapered at both ends, sharply, angularly and rather coarsely toothed towards the apex; $\frac{1}{2}$ to $I \frac{1}{2}$ ins. long, $\frac{1}{4}$ to $\frac{1}{2}$ in. wide; quite smooth on both surfaces; stalk about $\frac{1}{8}$ in. long. Flowers white, $\frac{1}{4}$ in. across; seed-vessels smooth, with the sepals deflexed.

Native of the Tyrol, especially in the Carnic Alps. It is a pleasing little shrub, one of the dwarfest of Spiræas, and very suitable for the rock garden.

S. HaceuetiI, Fenzl (S. decumbens var. tomentosa, Poech).-A dwarf shrub similar in habit to $\mathrm{S}$. decumbens, but differing in the young bark, leaves, flower-stalk, and calyx being downy; in the more prominent nerves beneath the leaf, which on the whole is proportionately narrower, and not so coarsely toothed; also by the sepals being more erect in fruit. Native of N. Italy and the Tyrol.

\section{S. DISCOLOR, Pursh.}

\section{(S. ariæfolia, Smith; Holodiscus discolor, Ascherson.)}

A large deciduous shrub, usually 8 to $12 \mathrm{ft}$. high, considerably more in width. Stems erect at the base, but branching and gracefully arching or pendulous at the top; young branches downy and slightly ridged. Leaves ovate, with a straight or broadly wedge-shaped base; 2 to $3 \frac{1}{2}$ ins. long, $1 \frac{1}{2}$ to 3 ins. wide on the barren stems, smaller on the flowering branches; each margin cut up into four to eight lobes which are themselves sharply toothed; upper surface slightly hairy, lower one covered with a grey felt; stalk $\frac{1}{4}$ to 5 in. long. Flowers creamy white, small, produced during July in pendulous, plume-like panicles 4 to 12 ins. long; flower-stalks and calyx downy. Fruit an achene, non-splitting, woolly.

Native of Western N. America; introduced by Douglas in 1827. It is better known in gardens as $\mathrm{S}$. ariæfolia-an appropriate name recalling the resemblance of its leaves to those of some of the Aria group of Pyrus, but given to the plant five years later than Pursh's name of 1814. In any selection of Spiræas this must be placed in the best half-dozen. It produces an extraordinary profusion of blossom, and is exceedingly graceful in habit. Many fine plants are scattered over the south of England; there is one at Saltwood, in Kent, $12 \mathrm{ft}$. high and $40 \mathrm{ft}$. across. In 1906, in Sir A. BuchanHepburn's grounds in E. Lothian, I saw one $20 \mathrm{ft}$. high. This shrub is seen to best advantage as an isolated specimen with a dark green background, say of holly. In thin woodland it also thrives admirably, as one may see it in the beautiful demesne of Dropmore. 
Var. Dumosa, S. Watson (S. dumosa, Nuttall; Holodiscus dumosus, Heller).-A smaller growing and distinct variety 2 to $4 \mathrm{ft}$. high; leaves $\frac{3}{4}$ to 2 ins. long, nearly as wide, silky white beneath; flowers in erect panicles. California, Oregon, etc. Probably a distinct species, now rare in gardens.

These two Spiræas differ from all the rest here included in having an indehiscent seed-vessel.

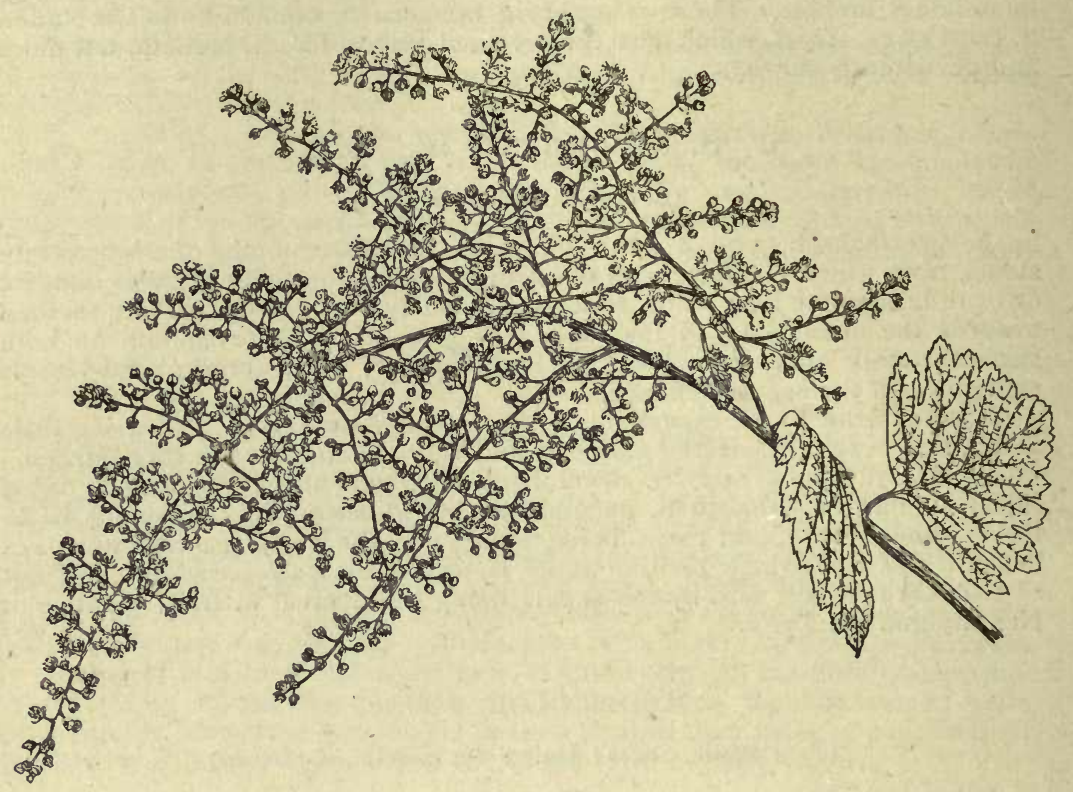

SPIRAA DISCOLOR.

\section{S. Douglasir, Hooker.}

(Bot. Mag., t. 5 I 51.)

A shrub 4 to $6 \mathrm{ft}$. high, forming a thicket of erect stems, reddish, covered when young with a very fine felt. Leaves narrow oblong, $1 \frac{1}{2}$ to 4 ins. long, $\frac{1}{2}$ to I in. broad; coarsely and unequally toothed on the terminal part only, dark green above, covered with a fine grey felt beneath. Flowers purplish rose, produced in an erect terminal panicle 4 to 8 ins. high, very closely packed; flower-stalks and calyx grey-downy; stamens pink, standing out well beyond the petals; ovaries smooth.

Native of Western N. America; discovered by David Douglas in British Columbia about 1827 , and first raised in the Glasgow Botanic Garden from his seed. It flowers from the end of June to the end of July, and a patch several feet across makes a rather striking display. The shoots that flowered the previous summer should be pruned back in February or early March, and the plants are all the better if broken up every few years as advised in the introductory notes to this genus, and the soil enriched. It thrives especially well near water. It is allied to tomentosa, but differs in its smooth ovaries, its longer more oblong leaves, and in flowering earlier. 


\section{S. ExpANSA, K. Koch.}

\section{(S. fastigiata, C. K. Schneider (Wallich).)}

A shrub up to $6 \mathrm{ft}$. high, with slender, round, downy stems, erect and not much branched; buds hairy. Leaves lanceolate to ovate, up to 4 ins. long by $\mathrm{I}_{4}^{\frac{1}{4}}$ ins. wide; coarsely and sharply toothed (both simply and doubly) except at the base, dark green above, hairy on the veins and rather glaucous beneath; stalks $\frac{1}{4}$ to $\frac{1}{3}$ in. long. Flowers white with a flush of red, borne in flat compound corymbs from 2 to 8 ins. across; calyx and flower-stalks downy. It blossoms on the shoots of the year in July and August.

Native of the Himalaya; much confused with S. bella, but differing in having round stems, more hairy leaf-buds, and larger, flatter corymbs.

\section{S. Gemmata, Zabel.}

A shrub 4 to $8 \mathrm{ft}$. high, with slender, arching, more or less angular stems, quite smooth; buds slender, pointed, longer than the leaf-stalk. Leaves narrowly oblong, from $\frac{1}{2}$ to $I$ in. long, $\frac{1}{8}$ to $\frac{1}{3}$ in. wide; often entire with a short abrupt tip, but sometimes blunt and with about three teeth at the end; green and quite smooth on both surfaces. Flowers white, small, produced during May in corymbs about I in. across; flower-stalk smooth, slender.

Native of Mongolia, and usually found in gardens as "S. mongolica." A pretty, white-flowered shrub distinct amongst others of its group by reason of its long, slender leaf-buds.

\section{S. Henryi, Hemsley.}

(Bot. Mag., t. 8270.)

A shrub of lax, spreading habit, 6 to $9 \mathrm{ft}$. high, more in diameter; branches reddish brown, slightly hairy when young. Leaves of the barren shoots $2 \frac{1}{2}$ to $3 \frac{1}{2}$ ins. long, $\frac{3}{4}$ to $1 \frac{1}{4}$ ins. wide; narrowly oblong or oblanceolate, coarsely toothed near the apex; those of the flowering twigs much smaller, $\frac{3}{4}$ to $I_{2} \frac{1}{2}$ ins. long, oblong or obovate, more shallowly toothed at the apex than the others, sometimes entire; all covered more or less with loose, greyish down beneath. Flowers white, $\frac{1}{4}$ in. across, produced in June on rounded corymbs, 2 ins. across, which terminate short, leafy twigs; flower-stalk and ovary downy.

Native of Central China; named in honour of Prof. A. Henry, who first discovered it near Ichang in I885; introduced for Messrs Veitch by Wilson in 1900. It is a fine shrub, and stands in the front rank of Spiræas, but on account of its wide-spreading habit needs plenty of space for lateral development; it is better as an isolated plant than grouped in a shrubbery. Shoots $6 \mathrm{ft}$. or more long are made in a season.

S. Wilsoni, Duthie (Bot. Mag., t. 8399), is closely allied to, perhaps only a variety of S. Henryi. It is distinguished among other points by its smooth ovary, and smooth or slightly silky flower-stalks. Leaves of flowering shoots entire, downy above, duller green.

\section{S. HYPERICIFOLIA, Linnceus.}

A bushy shrub, 5 or $6 \mathrm{ft}$. high, with graceful, arching, twiggy branches, which, when young, are brown and usually covered with fine down, becoming grey with age. Leaves obovate, with a tapering base, and about three teeth at the apex, or none at all; $\frac{3}{4}$ to $1 \frac{1}{4}$ ins. long, $\frac{1}{4}$ to $\frac{1}{2}$ in. wide; of a greyish green, slightly downy beneath, three or five nerves running lengthwise; 
stalk very short. Flowers pure white, $\frac{1}{4}$ in. across, produced during early May in clusters from the buds of the previous summer's shoots; each flower on a usually downy stalk about $\frac{2}{5}$ in. long.

A widely spread and variable species extending in a wild state from E. Europe and Asia Minor across N. Temperate Asia. It is naturalised but not truly wild in N. America. At its best this is a pretty shrub, although not in the very first rank of Spiræas; starting later into growth than several other of its white-flow ered allies, it escapes the damaging influence of late spring frosts.

S. ACUTIFolia, Willdenow, is closely allied to hypericifolia, and by some authors is made a variety of it. It differs mainly in the flowers being yellowish white, and about half the size only, and in the narrower leaves. Of little value for gardens.

\section{S. JAPONICA, Linnaus fil.}

\section{(S. callosa, Thunberg; S. Fortunei, Planchon, Bot. Mag., 1. 5I64.)}

A shrub of rather open habit, from 3 to $5 \mathrm{ft}$. high, stems erect, round or slightly angled, ultimately smooth and shining brown. Leaves lanceolate or narrowly oval; 3 to $4 \frac{1}{2}$ ins. long, I to $I_{2}^{\frac{1}{2}}$ ins. wide ; coarsely, sharply and irregularly toothed, each tooth gland-tipped; tapering at the base, dark green above, rather glaucous beneath, smooth on both sides, or soon becoming so. Flowers $\frac{1}{4}$ in. across, rich rosy red, produced during July and August in large, flat, compound corymbs terminating the current season's shoots. The inflorescence, which may be anything up to 12 ins. across, consists really of a series of corymbs springing from the uppermost leaf-axils, the lower ones with stalks long enough to bring the flowers to about the same level as the upper ones; calyx and flower-stalk downy.

Native of Japan and China. S. japonica may be taken as the type of a large and valuable group of Spiræas which flower in summer on the shoots of the year, and produce the blossoms in a large flattish inflorescence. They are all handsome, and should be pruned in spring by cutting clean out sufficient of the older wood to prevent crowding, and then shortening back those selected to remain.

Var. ALBA (S. albiflora, Miquel; S. callosa alba, Hort.).-A shrub of dwarfer, weaker growth than the type; young shoots downy and distinctly ribbed; leaves shorter-stalked and smaller; flowers white. Some authors regard this as a distinct species.

Var. Bumalda (S. Bumalda, Hort.).-A dwarf, neat, yet elegant variety usually under 18 ins. high. Flowers in flat corymbs, and of a beautiful carmine shade. Var. ANTHONY WATERER. - This fine form is a sub-variety of Bumalda, and originated in the Knap Hill nursery about 1890 . It has the same habit as the ordinary Bumalda, but its flowers are of a much more brilliant shade of carmine. It is, perhaps, the most highly coloured of Spiræas. In both, the leaves frequently come partially variegated. By removing the flowers as they fade, both may be kept flowering until late September.

Var. GLABRATA (S. glabrata, Lange).-A strong-growing form with corymbs often over I $\mathrm{ft}$. in diameter, flowers rosy pink. Leaves much broader than in the type, the largest 4 to 5 ins. long and $2 \frac{1}{2}$ to 3 ins. wide, of broadly ovate form, rounded at the base, and, like the young wood and flower-stalks, smooth.

Var. MACROPHYLLA, Zabel.-Leaves as large or larger than the preceding variety, but curiously inflated; inflorescence poor and small. Only worth growing as a curiosity.

Var. RUBERRIMA.-Flowers deeper rose than the type. 


\section{S. LAVIGATA, Linnceus.}

(Sibiræa læevigata, Maximowicz.)

A deciduous shrub of sturdy, bushy habit, 2 to $5 \mathrm{ft}$. high, with thickish, rather sparse, perfectly smooth, brown branchlets. Leaves entire, narrowly obovate; 2 to $4 \frac{1}{2}$ ins. long, $\frac{1}{3}$ to $\frac{7}{8}$ in. wide; stalkless, tapering at the base, the apex with a short abrupt point; glaucous green and quite smooth. Flowers white, produced from late April to early June in terminal spreading compound panicles 3 to 5 ins. high.

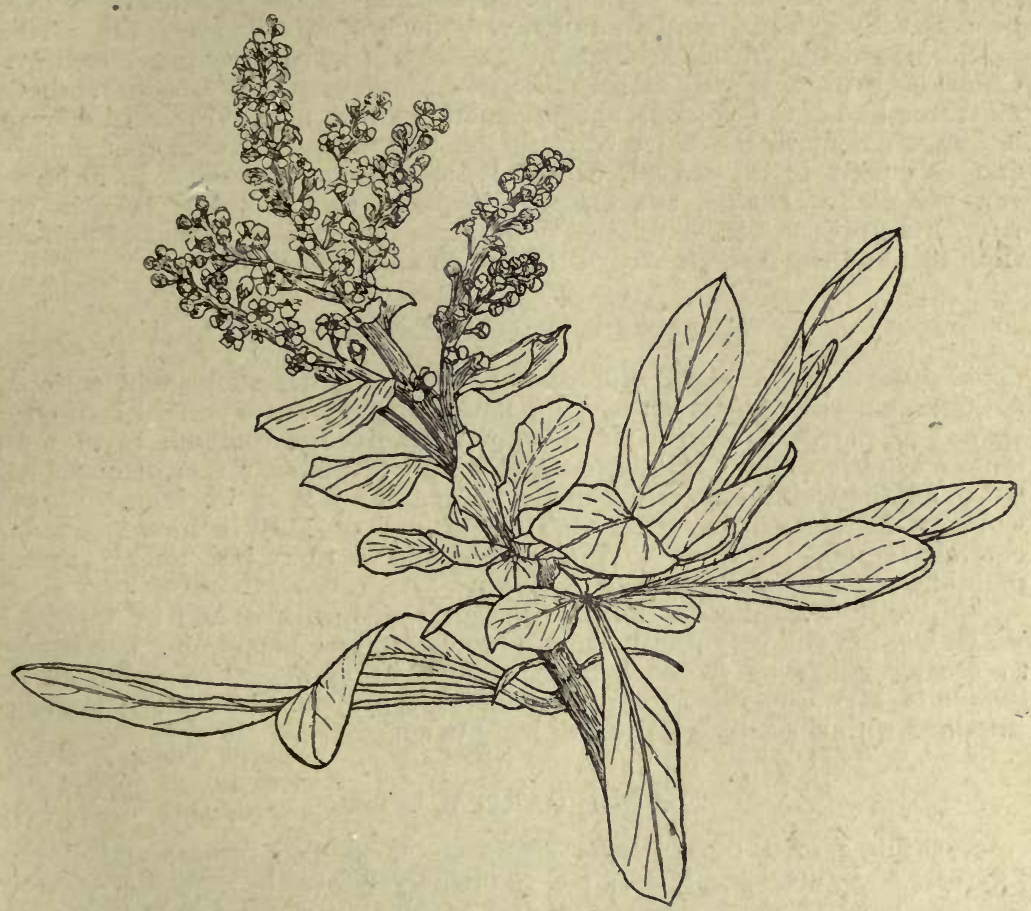

SpIRAa LeVIGata.

Native of Siberia; introduced to Britain in 1774. This species, whilst not particularly showy, is quite distinct from all other Spirxas in its foliage, which in shape and colour is more suggestive of a spurge (Euphorbia) than the genus to which it belongs. Shrubs $4 \mathrm{ft}$. high are often as much as $7 \mathrm{ft}$. through.

\section{S. LindleyanA, Wallich.}

(Sorbaria Lindleyana, Maximozvicz.)

A shrub of graceful spreading habit, up to $20 \mathrm{ft}$. high; branches very pithy, green, smooth. Leaves Io to 18 ins. long, pinnate, consisting of eleven to twenty-three leaflets, which are lanceolate or ovate-lanceolate; 
2 to $4 \frac{1}{2}$ ins. long, $\frac{1}{2}$ to $1 \frac{1}{2}$ ins. wide (the terminal one often larger and pinnately lobed); usually deeply and doubly toothed, smooth above, furnished with loose, simple hairs beneath, especially about the midrib and veins. Flowers ivory white, scarcely $\frac{1}{4}$ in. wide, produced in terminal, pyramidal, branching panicles $\mathrm{I}$ to $\mathrm{I} \frac{1}{2} \mathrm{ft}$. long and 8 to $\mathrm{I} 2$ ins. through; flower-stalks downy. Seed-vessels in panicles, often more or less pendulous.

Native of the Himalaya ; flowering from July to September, the individual blossom being, however, rather short-lived. A very handsome robust shrub which, flowering on the branches of the year, may be pruned back every winter or early spring. It is allied to S. Aitchisoni, but differs in its downy flower-stalks, and in the leaflets being broader, doubly toothed and hairy beneath. From S. sorbifolia it differs very much in its strong spreading habit.

S. ARBOREA (Sorbaria arborea, $C . K$. Schneider), recently introduced from China by Wilson, is very closely allied to Lindleyana. It is apparently the most tree-like of the Spiræas, and is sometimes $30 \mathrm{ft}$. high. From Lindleyana it differs chiefly in the hairs beneath the leaf being clustered (not simple), and especially in the shorter calyx-tube and longer stamens. S. ARBOREA var. GLABRATA, Rehder, has glabrous leaflets. It flowered at Kew in July I 12 , and proves a very handsome addition to the Sorbaria group of Spiræas. Both this and the type are natives of Hupeh and Szechuen.

\section{S. LONGIGEMmis, Maximowicz.}

A shrub 4 or $5 \mathrm{ft}$. high, with smooth, erect, angular stems, and curiously flat, leaflike winter buds often $\frac{1}{3}$ in. long. Leaves ovate-lanceolate, wedgeshaped at the base, sharply and deeply, often doubly, toothed; $1 \frac{1}{2}$ to 3 ins. long, $\frac{3}{4}$ to $1 \frac{1}{4}$ ins. wide; bright green and smooth above, rather glaucous and hairy on the veins beneath when young; stalk $\frac{1}{8}$ to $\frac{1}{4}$ in. long. Flowers white, $\frac{1}{4}$ in. across, produced towards the end of May in broad, rounded, corymbose panicles 2 to $3 \frac{1}{2}$ ins. across and I to 2 ins. long; stamens prominent; flower-stalk and calyx downy.

Native of N. China in the province of Kansu; also found by Wilson in W. China. It is a very pretty white-flowered Spiræa blossoming late enough to escape injury by frost. I have seen it in excellent condition in the garden of Mrs Chambers, near Haslemere-the upper side of the branches wreathed with corymbs terminating leafy twigs.

\section{S. MARGARITÆ, Zabel.}

A shrub 4 or $5 \mathrm{ft}$. high; its stems erect, reddish brown, and downy. Leaves 2 to $3 \frac{1}{2}$ ins. long, $\frac{3}{4}$ to $I \frac{1}{2}$ ins. wide; narrowly oval or oblong, coarsely, sharply, and irregularly toothed at the terminal part, entire and narrowly wedge-shaped at the base. Flowers bright pink, $\frac{1}{3}$ in. diameter, produced from July onwards in large, flat corymbs 3 to 6 ins. across, terminating the growths of the year.

If the origin of this Spiræa is correctly deduced by the author of the name, it is a hybrid in which three kinds are united, viz., japonica, corymbosa, and japonica alba. However that may be, it is certainly one of the very best of the late summer-flowering group. A large mass of it makes a very striking effect from July to September. It should be pruned every winter or early spring in the same way as recommended for the japonica group, i.e., to cut out entirely the older shoots and prune the younger ones back to within I $\mathrm{ft}$. of the ground, leaving only sufficient-say one every 6 ins. or so-to furnish the plant during the ensuing summer. Treated in this way the shrub does not get to be more than $3 \mathrm{ft}$. high, and becomes a sheet of blossom. - If the corymbs are cut off as they fade, a succession of flowers may be obtained until September. 


\section{S. MEDia, F. Schmidt.}

$$
\text { (S. confusa, Regel.) }
$$

An erect shrub, up to 4 or $6 \mathrm{ft}$. high, with smooth, round stems sometimes downy when young. Leaves ovate or oblong with a wedge-shaped base, I to 2 ins. long, $\frac{1}{3}$ to $\frac{3}{4}$ in. wide; the terminal part sharply toothed or with a few large teeth only near the apex, sometimes entire; upper surface smooth, lower one more or less hairy or sometimes smooth; stalk $\frac{1}{6}$ in. or less long. Flowers white, $\frac{1}{3}$ in. across, produced during late April and early May in longstalked racemes $\mathrm{I}$ to I $\frac{1}{2}$ ins. across each terminating a short leafy twig.

Native of E.Europe toJapan and Sachalin. It is a pretty species, but liable to be injured by late spring frosts. Several varieties of it have been distinguished chiefly by the shape, hairiness, and toothing of the leaf.

Var. GLABRESCENS, Zabel.-Leaves quite smooth or soon becoming so.

Var. SERICEA, Regel.-Leaves silky on one or both sides.

The S. oblongifolia, Waldstein, ap. pears to be a form of $\mathrm{S}$. media whose leaves are entire except for one to three teeth at the apex.

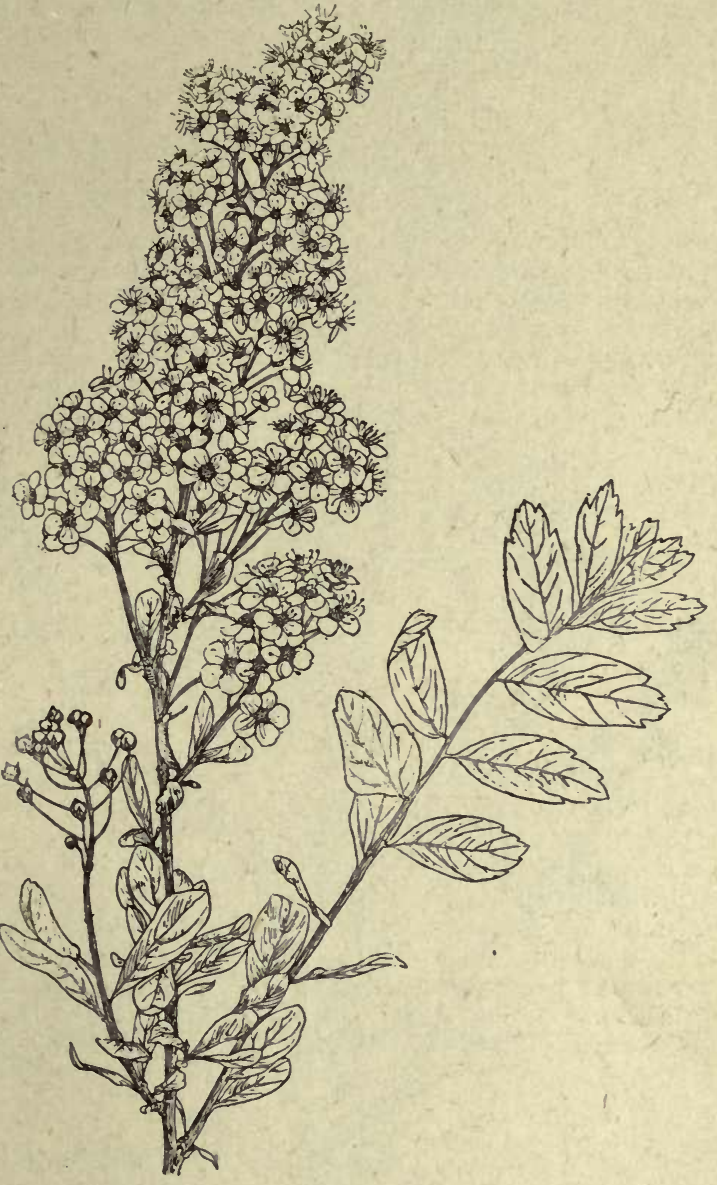

SpIrea MEdia.

In gardens S. media is sometimes used for forcing early into blossom under the name of S. confusa.

\section{S. Menziesir, Hooker.}

A shrub 3 to $5 \mathrm{ft}$. high, stems brown, erect, slightly downy or smooth, producing suckers freely; leaf-buds hairy. Leaves lanceolate, oblong or 
broadly oval, I $\frac{1}{2}$ to $3 \frac{1}{2}$ ins. long, toothed towards the apex, more or less greygreen and downy beneath, or sometimes green. Flowers bright purplish

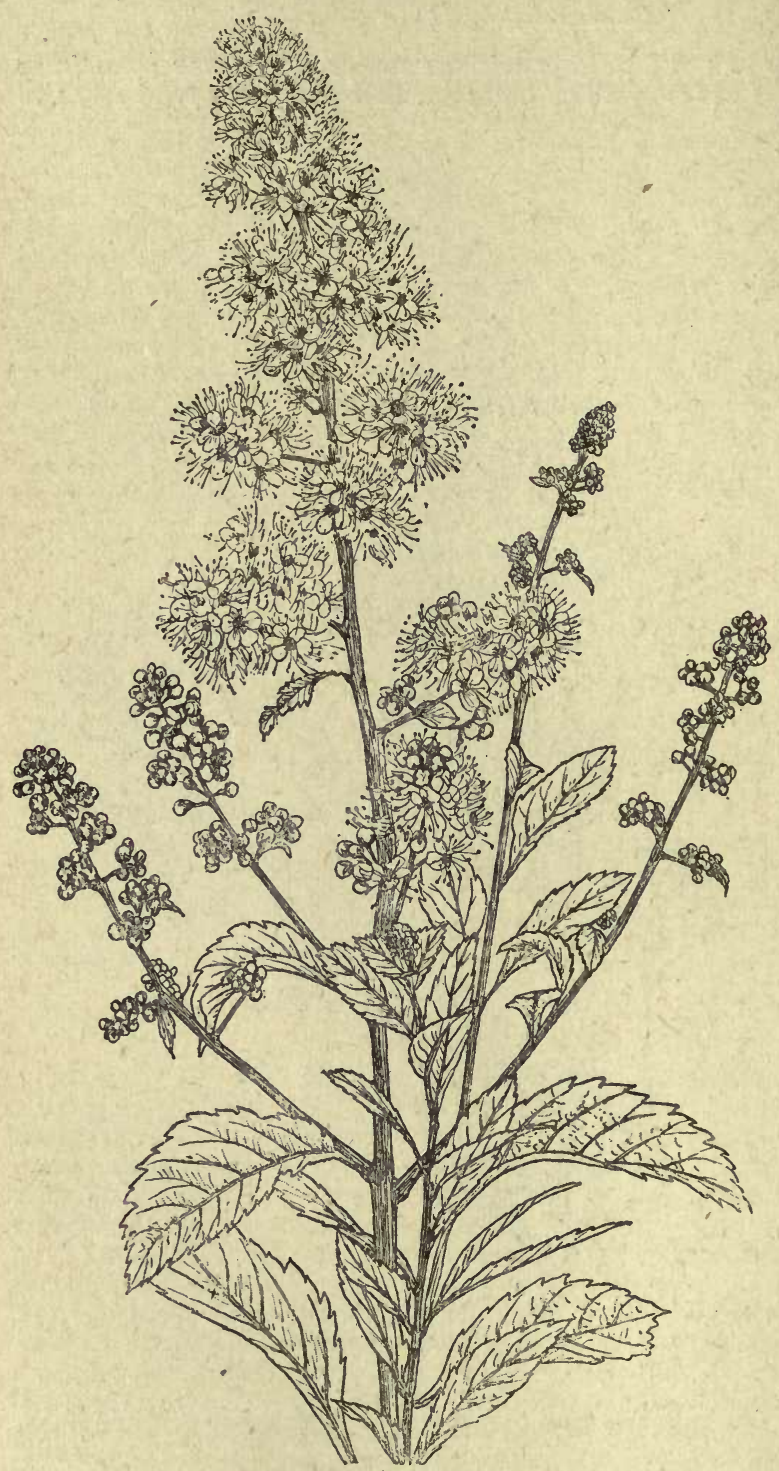

SPIREA MENZIESII var. TRIUMPHANS. rose, crowded in an erect, pyramidal panicle terminating the shoots of the year and 3 to 8 ins. high. It blossoms in July and August.

This fine Spiræa is found wild in Western North America, whence it was introduced in I 838 . Some authors regard it as a distinct species, some as a variety of $S$. Douglasii. $\mathrm{Mr}$ Zabel considers it to be a natural hybrid between S. Douglasii and $S$. salicifolia, and places under it, as varieties, a series of forms whose leaves are more or less intermediate between those of S. Douglasii (with a grey-downy undersurface), and those of S. salicifolia (with both surfaces green and smooth). All the forms of S. Menziesii should be pruned back nearly to the previous year's wood every spring, and old worn-out stems removed.

Var. ANGUSTIFOLIA, Zabel.Leaves narrowly oblong, more ta pering at the base than at the apex, toothed only towards the apex, lower surface grey, downy.

Var. EXIMIA.-

Leaves oval or obovate, 3 ins. long, $\frac{1}{2}$ to $I$ in. wide, toothed from the middle, or below it to the apex, under-side more or less grey-felted. Panicles broadly 
pyramidal and much branched, the lower branches 3 or 4 ins. long and leafy. Some of the finer panicles measure 8 ins. long by 6 ins. wide.

Var. MACROTHYRSA, Zabel (S. =californica, Hort.).-Leaves broadly obovate, about 2 ins. long, often more than half as wide, felted beneath. Panicles dense, usually about 5 to 7 ins. high, nearly half as wide at the base.

Var. TRIUMPHANS. - Leaves oval-lanceolate, $1 \frac{1}{2}$ to $2 \frac{1}{2}$ ins. long, $\frac{1}{2}$ to $\frac{3}{4}$ in. wide, toothed nearly to the base, green beneath and slightly downy, especially .n the veins. Panicles broadly pyramidal, branching at the base, up to 8 ins. high and 4 ins. wide. Flowers bright purplish rose. This, perhaps the finest of all the Menziesii group, makes a splendid display from mid-July onwards. (Fig. p. 540.)

\section{S. Millefolium, Torrey.}

(Bot. Mag., t. 7810 ; Chamæbatiaria Millefolium, Maxımowicz.)

A shrub 3 to $5 \mathrm{ft}$. high, the erect branches covered with glandular down, sticky when young, and having a balsamic odour. Leaves 2 to $3 \frac{1}{2}$ ins. long, $\frac{1}{2}$ to $I$ in. wide; doubly pinnate and very like those of the common milfoil, the ultimate subdivisions $\frac{1}{12}$ in. long, narrowly oblong, downy; common stalk slightly winged. Flowers white, $\frac{1}{3}$ to $\frac{1}{2}$ in. diameter, produced in erect, terminal branching panicles, 3 to 5 ins. high; flower-stalks and calyx densely covered with tufted hairs; petals roundish, surrounding a cluster of yellow stamens. Flowers in July.

Native of Western N. America; first discovered in 1853 by Dr Bigelow; introduced to Kew in $189 \mathrm{I}$. It occurs up to ro,000 ft. altitude in California, and is quite hardy in the south of England, but likes a well-drained soil and as sunny a position as possible. The plant has a pungent aromatic odour. Its much divided foliage makes it quite distinct from any other Spiræa ; it has indeed been placed in a genus by itself under the name given as a synonym abave.

\section{S. MOLlifolia, Rehder.}

A deciduous shrub up to $6 \mathrm{ft}$. high, with arching branches; young shoots very hairy at first, becoming purple, nearly smooth and very distinctly angled the second year ; buds up to $\frac{1}{6}$ in. long, brownish purple. Leaves oval, oblong or obovate, tapered at both ends, usually more abruptly so at the apex, mostly entire, sometimes three-toothed at the apex; $\frac{1}{2}$ to $\frac{3}{4}$ in. long, half as wide ; silky all over. Flowers white, $\frac{1}{3}$ in. diameter, borne during June and July in corymbs about $I$ in. across, terminating short leafy twigs that spring from the growths of the previous year ; stamens twenty.

Native of W. Szechuen, China ; discovered by Wilson in 1904; introduced in 1909. As it occurs up to $14,000 \mathrm{ft}$. in a wild state it is likely to be very hardy. It is quite distinct from all other cultivated Spiræas in the combination of its silky leaves, and long, slender winter buds.

\section{S. PRUNIFOLIA, Siebold.}

This species is scarcely known in cultivation except by the double-flowered form, to which the following description refers:-A shrub 4 to $6 \mathrm{ft}$. high, the branches gracefully arching and forming a dense bush as much in diameter as it is high; young shoots downy. Leaves ovate, I to I $\frac{3}{4}$ ins. long, $\frac{1}{2}$ to $\frac{3}{4}$ in. wide ; downy beneath (especially when young), finely and evenly toothed ; stalk $\frac{1}{8}$ in. or less long. Flowers produced during late April and May in fascicles three to six together, each flower on a smooth, slender stalk, $\frac{1}{2}$ to $\frac{3}{4}$ in. long; petals pure white and so numerous as to form a flower like a small "bachelor's button," $\frac{1}{2}$ in. across. 
Native of China, and much cultivated there; it was found by Wilson in its double-flowered state in W. Hupeh. This form was originally introduced from Japan by Dr Siebold about 1845. In the Gardeners' Chronicle for February 20, 1847, an advertisement sets forth that "the stock of this magnificent novelty bought at Dr Siebold's sale, is now in the possession of Louis van Houtte, florist at Ghent," and plants to be delivered the following April are offered at one guinea each. It is still one of the most beautiful of hardy shrubs, producing during the summer slender shoots, I to $2 \mathrm{ft}$. long which, the following May, are wreathed from end to end with blossom. For the needs of most gardens it can be increased sufficiently quickly by taking off the side suckers from old plants and potting them, then placing them in a mild bottom heat; but if such conveniences are not available they can be planted in the open ground-a slower, less certain process.

The single-flowered plant is in cultivation, and is distinguished as S. prunifolia "flore simplex." In my experience it is an absolutely worthless shrub because of its extraordinary sterility. A plant was obtained from the Continent for Kew in 1887, but although I have known this and others raised from it for twenty years, I have never yet seen it in flower. But this, of course, is more likely to be an individual than a racial characteristic, seeing the floriferousness of the double-flowered form.

\section{S. SALICIFOLIA, Linnceus. BRIDEWORT.}

A shrub 3 to $6 \mathrm{ft}$. high, with running roots and forming ultimately a dense thicket of erect stems, which are soon quite smooth. Leaves lanceolate or narrowly oval, but sometimes broadest above the middle; $1 \frac{1}{2}$ to 3 ins. long, $\frac{1}{2}$ to I in. wide; pointed, sharply and often doubly toothed, smooth and green on both surfaces. Flowers rose-tinted white, crowded on erect, terminal, slightly downy panicles about 4 ins. high, and 2 ins. wide at the base.

This, which may be considered the typical form, is a native of E. Furope, Asiatic Russia to Japan. It is not a native of Britain, but is naturalised in several places, notably in some parts of N. Wales. When once it obtains a footing, it appears to be able to hold its own against any other vegetation, spreading by its creeping suckers and forming an almost impassable thicket. Left to itself in this way, its inflorescences become poor; but cultivated in good garden soil and occasionally divided, it makes a handsome show in June and July.

Var. LÁtifolia, Aiton (S. latifolia, Borkhauset).-Stems reddish or purplish brown; leaves oval or ovate, unequally and rather coarsely toothed, $\frac{3}{4}$ to $\mathbf{I} \frac{3}{4}$ ins. wide; panicles large, conical, not downy, flowers white or blush. coloured. Eastern N. America from Newfoundland to Virginia, commonly known there as "Meadow-sweet."

Var. Paniculata, Aiton (S. alba, Duroi).-This is the finest form of S. salicifolia. Leaves narrowly oval or ovate; inflorescence 8 to 12 ins. long, as much wide, much branched, slightly downy. Flowers white or rosy-tinted. This Spiræa is sometimes regarded as a distinct species (S. alba), and the preceding one (latifolia) as its variety. They differ from salicifolia in the much larger, compound panicles of pyramidal rather than cylindrical shape. Native of N. America, with a more western distribution than var. latifolia.

\section{S. Sanssouciana, Koch.}

\section{(S. Nobleana, Hooker, Bot. Mag., t. 5 I69.)}

A shrub 4 or $5 \mathrm{ft}$. high, with erect, brown stems covered with a close grey felt. Leaves oblong to narrowly oval, 2 to 4 ins. long, $\frac{3}{4}$ to $\frac{1}{4}$ ins. wide; 
mostly tapering, sometimes rounded at the base; irregularly and rather jaggedly toothed except near the base; green, downy on the veins above, sovered with a dull greyish, close down beneath. Flowers bright rose, produced during July, and densely crowded in broad, corymbose panicles which form an inflorescence 3 to Io ins. across, terminating the shoot of the year; flower-stalks and calyx grey-felted.

A hybrid between japonica and Douglasii, first described by $\mathrm{K}$. Koch under the above name in 1857. Two years later it was sent to Kew by $\mathrm{Mr}$ Chas. Noble of Bagshot, and named Nobleana by Sir Wm. Hooker. In an accompanying letter, still preserved at Kew, Mr Noble states that it had been raised from a plant of Douglasii growing by the side of one of japonica. Hooker nevertheless identified it with a Spiræa that had been collected by W. Lobb in California; and for many years S. Nobleana was regarded as a native of that state. There is no doubt, however, that Lobb's plant is different, and that Noble's plant had the origin he indicated. It appears to have also been raised about the same time independently at Paris and Woking.

The Californian plant wrongly identified with S. Sanssouciana by Hooker is apparently a natural hybrid between S. Douglasii and perhaps S. densiflora, Nuttall (S. SPLENDENS, Baumann).

\section{S. SORBIFOLIA, Linnceus.}

(Sorbaria sorbifolia, A. Braun.)

A shrub 3 to $6 \mathrm{ft}$. high, which suckers freely; stems erect, very pithy, varying from nearly smooth to downy. Leaves 8 to 12 ins. long, composed of thirteen to twenty-five leaflets, which are lanceolate, 2 to $3 \frac{1}{2}$ ins. long, $\frac{1}{2}$ to $I$ in. wide; sharply and conspicuously double-toothed, green on both sides; usually quite smooth above and the same beneath. Flowers $\frac{1}{3}$ in. across, white, produced during July and August in a stiff erect raceme 6 to Io ins. high; flower-stalks downy and glandular; ovaries smooth or nearly so.

Native of N. Asia from the Ural Mountains to Japan; introduced in 1759. It is distinguished from its near allies S. Lindleyana and S. Aitchisoni by its comparatively dwarf, stiff habit, and narrower, stiffer flower-panicles. Grown in rich soil it makes a handsome shrub.

Var. AlPina, Pallas (Sorbaria alpina, Dippel; S. grandiflora, Maximowicz). -This is distinguished from the typical S. sorbifolia by its dwarf habit (I to $3 \mathrm{ft}$. high), fewer and shorter leaflets with somewhat blunter teeth, and by the larger flowers ( $\frac{1}{2}$ to $\frac{5}{8}$ in. across).

Nearly allied to S. sorbifolia is S. STELLIPILA, which differs chiefly in the leaves being clothed with stellate hairs beneath, and in the downy ovaries. In habit and leaf form it resembles S. sorbifolia. Native of Japan.

\section{S. Thunbergir, Siebold.}

A shrub 3 to $5 \mathrm{ft}$. high, often more in diameter, of very twiggy, bushy habit; branchlets slender, angled, downy. Leaves linear-lanceolate, I to $1 \frac{1}{2}$ ins. long, $\frac{1}{8}$ to $\frac{1}{4}$ in. wide; taper-pointed, the margins set with a few incurved teeth, smooth and pale green on both sides. Flowers pure white, $\frac{1}{4}$ in. across, produced on the leafless, wiry twigs during March and April in clusters of two to five, each flower on a smooth, slender stalk, $\frac{1}{4}$ to $\frac{1}{3}$ in. long; calyx shảllow, smooth.

Native of China ; but first introduced from Japan, of which country, however, it is doubtfully native. This is the earliest of all the Spiræas to flower in the open, and in ordinary seasons is at its best by the middle of April. The fascicles of blossom spring directly from the shoots made the 
previous summer, and if the season has been sufficiently sunny and hot to have thoroughly ripened the wood, the plants will be almost hidden by the profusion of flowers. The habit of the plant is graceful owing to the arching form of the slender branches, and altogether there is no more attractive shrub in bloom in early April.

\section{S. tomentosa, Linncus. Steeplebush.}

A shrub 3 to $5 \mathrm{ft}$. high, with spreading underground roots, ultimately forming a thicket of erect stems which when young are covered with brownish felt. Leaves ovate, $1 \frac{1}{2}$ to 3 ins. long, $\frac{3}{4}$ to $1 \frac{1}{2}$ ins. wide; coarsely and irregularly toothed almost to the base, dark green and nearly smooth above, covered with a close, yellowish grey felt beneath. Flowers purplish rose, densely produced in erect, terminal, branching panicles 4 to 7 ins. long, $I \frac{1}{2}$ to $2 \frac{1}{2}$ ins. wide.

Native of the eastern United States; introduced, according to Aiton, in 1736. It is allied to the western S. Douglasii, and is often confused with it; it is, however, distinguished by the thicker, browner (or yellowish) felt beneath the leaves, which are toothed much nearer the base; by flowering some weeks later, and by the ovaries being woolly (smooth in Douglasii).

Var. ALBA is a pretty white-flowered form.

The cultivation of these handsome Spiræas is the same as for $S$. Douglasii (q.v.).

\section{S. TRILOBATA, Linnaus.}

A twiggy shrub, 3 to $4 \mathrm{ft}$. high, of broad but compact habit, young shoots and leaves smooth; stems round, often zigzagged in growth. Leaves roundish, $\frac{1}{2}$ to $\mathrm{I}$ in. (rarely $\mathrm{I} \frac{1}{2}$ ins.) long, and about as much wide, coarsely toothed, sometimes obscurely three- or five-lobed, the base rounded or sometimes slightly heart-shaped, rather glaucous green. Flowers white, small, produced during June, packed very numerously in umbels $\frac{3}{4}$ to $\mathrm{I} \frac{1}{2}$ ins. across; each umbel terminating a short leafy twig, springing from the previous year's growth, every flower having a slender, smooth stalk $\frac{1}{3}$ to $\frac{3}{4}$ in. long.

Native of N. Asia, from N. China and S. Siberia to Turkestan; introduced in 1801 . Although its flower-buds are sometimes injured by frosts, this is a very pretty shrub of neat habit.

S. BLumeI, Don, found in China and Japan, is nearly allied to S. trilobata, but differs in the shape of the leaf, which is ovate or lozenge-shaped, longer than it is wide, the base wedge-shaped. Flowers white, crowded in umbels 1 in. wide. A shrub 3 to $6 \mathrm{ft}$. high.

\section{S. Van Houttei, Zabel.}

A shrub $6 \mathrm{ft}$. high, with gracefully arching, smooth, brown stems. Leaves rhomboidal or obovate, sometimes distinctly three-lobed, more or less broadly tapering and entire at the base, coarsely toothed on the upper half; $\frac{3}{4}$ to $I \frac{3}{4}$ ins. long, $\frac{1}{2}$ to $I \frac{1}{4}$ ins. wide ; dark green above, rather glaucous beneath, smooth on both sides. Flowers white, $\frac{1}{3}$ in. across, produced during June in umbel-like clusters I to 2 ins. across; calyx-lobes erect.

A hybrid between S. trilobata and probably S. cantoniensis; raised by Mr Billiard, a nurseryman at Fontenay-aux-Roses, near Paris, about I862. At its best it is probably the finest of all the white-flowered Spiræas, except. perhaps S. arguta; in low-lying situations it is subject to injury by late spring 
frosts. In more elevated gardens, or where the plant is not forced into premature activity by unseasonable warmth, there is no more desirable shrub, for it is very hardy. Its stems, at first erect, afterwards arching outwards at the top, bear the extraordinarily profuse blossoms on the upper side of the branches. It is one of the Spiræas which should have the older wood thinned out after flowering to allow light and air to enter and help in the development of the younger growths. It is very valuable for forcing early into bloom for indoor decoration, and is often exhibited in this state at the spring shows under the erroneous name of S. confusa, a synonym of S. media -a less vigorous shrub with longer stamens, and the calyx-lobes ultimately reflexed.

\section{S. VeitchiI, Hemsley.}

$$
\text { (Bot. Mag., t. 8383.) }
$$

A strong-growing shrub, probably 10 or $12 \mathrm{ft}$. high eventually, producing gracefully arching shoots, 2 to $6 \mathrm{ft}$. long in a season; young branches reddish, slightly downy. Leaves $\frac{3}{4}$ to 2 ins. long, $\frac{1}{3}$ to $\frac{3}{4}$ in. wide; oblong or obovate, not toothed, smooth on both surfaces or very slightly downy beneath. Flowers white, small, crowded in dense corymbs, $1 \frac{1}{2}$ to $2 \frac{1}{2}$ ins. across; calyx and flower-stalks covered with a fine down; fruits smooth when ripe.

Native of Central China; discovered by Wilson in W. Hupeh in 1900 , and introduced by him for Messrs Veitch. It is a fine species (Mr Wilson has told me he considers it the best of Chinese Spiræas), somewhat similar in general aspect and in producing its flowers on short leafy twigs from the growths of the previous summer, to the well-known S. canescens (flagelliformis). It is readily distinguished from that species, however, by its smooth, entire leaves and smooth fruit. Its entire leaves also distinguish it from two other allies-S. Henryi and S. Wilsoni. I saw the plants first introduced in their young state in the Coombe Wood nursery, when they were making shoots as much as $8 \mathrm{ft}$. long in a season; when these, the following June, were wreathed from end to end with clusters of pure white blossom, they made a picture of remarkable beauty.

\section{STACHYURUS PR ECOX, Siebold. TERNSTRGMIACEA.}

$$
\text { (Bot. Mag., t. 6631.) }
$$

A deciduous shrub, said to become as much as ro $\mathrm{ft}$. high in Japan, but rarely more than half as high in England. Leaves ovate-lanceolate, smooth, 3 to 7 ins. long, with a long slender apex; toothed at the margin. Flowers twelve to twenty together, in stiff drooping racemes 2 to 3 ins. long, each flower $\frac{1}{3}$ in. across, pale yellow.

Native of Japan, and quite hardy. Its greatest merit in the garden is its early-flowering nature. In favourable years it will be in full flower by the middle of February, and ordinarily, not more than a month later. The flower-spikes are formed in the axils of the leaves and attain their full length in autumn, and, although exposed to whatever inclemencies the winter may bring, remain unscathed. Unseasonable warmth in the early part of the year, followed by a rough cold spell, will sometimes injure the flowers. But on the whole they are very hardy, and when the reddish leafless branches are hung with yellow racemes $\mathbf{I}$ in. or less apart, there are few things in the garden more pleasing at that early season. 
In China this species is represented by S. CHInENsis, Franchet, which has recently been introduced in considerable quantity by Wilson. Although, as seen growing side by side, they appear distinct, there is

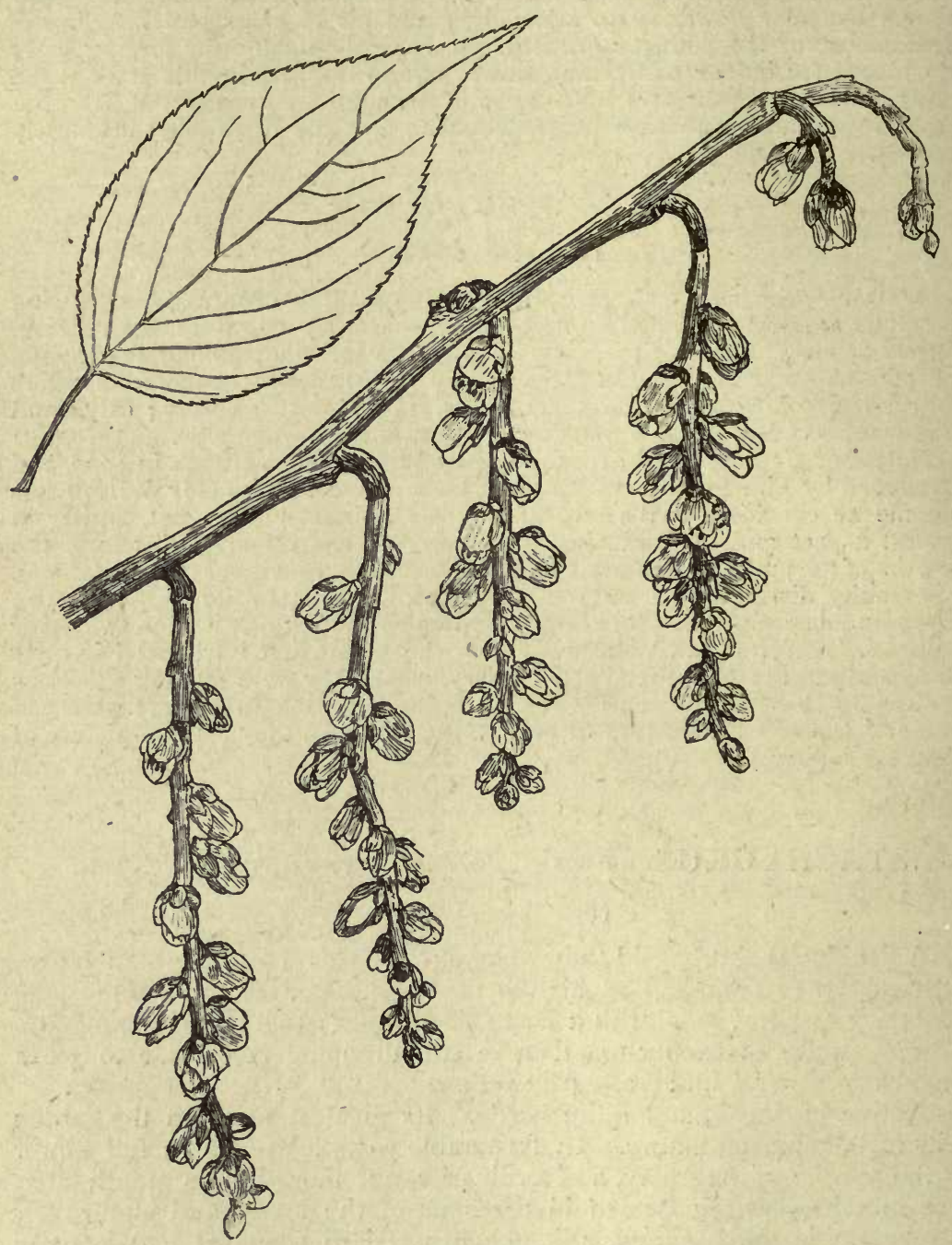

STACHYURUS PRECOX.

really very little on which one can seize to differentiate them. In habit $\mathrm{S}$. chinensis is the stronger but less elegant, sending up strong arching shoots, varying from green to dark brown, and not so red as in 
S. præcox. The racemes and flowers are to all intents the same, but the fruits, which I have not seen, are said to be smaller than in S. præcox. It flowers at Kew about a fortnight later than S. præcox, but up to the present not so freely.

When planting out either of these species it is advisable to mix peat and leaf-soil with the loam, especially if the last be of a heavy nature. S. præcox can be propagated easily by cuttings made of fairly firm wood in July with a "heel" attached, and placed in gentle heat, also by division.

\section{STAPHYLEA. BLADDER-NUT. STAPHYLEACE.}

A genus of deciduous bushes occasionally large enough to be considered small trees, with opposite, trifoliolate or pinnate leaves, usually made up of three or five leaflets. The flowers are produced in terminal racemes or panicles, and are of some shade of white; the sepals, petals, and stamens five. The most distinctive feature of the genus is the fruit-a membranous, inflated, two- or three-celled capsule.

The bladder-nuts are planted in gardens for the beauty of the foliage and flowers, and for their interesting fruits. All those given separate mention below are hardy, with the exception of S. Bumalda, which suffers in hard winters. Their needs are simple-a good, loamy, moist soil and a fairly sunny spot. They can be increased by cuttings. All flower in May.

Besides the species of which a more detailed account is given below, the two following may be briefly mentioned:-

S. Bolanderi, A. Gray.-A native of N. California; discovered in 1874, on a branch of the Sacramento River, near Mount Shasta. It has three oval or roundish, smooth, short-pointed leaflets, up to $2 \frac{1}{2}$ ins. long; greenish white flowers, capsules three-celled, $2 \frac{1}{2}$ ins. long. I have not met with it in gardens.

S. Emodi, Wallich.-Native of the North-western Himalaya. A shrub or small tree with trifoliolate leaves, each leaflet 3 to 6 ins. long; flowers white, in rather dense cymes, $\mathrm{I}_{2} \frac{1}{2}$ to 4 ins. wide. Capsules 2 to 3 ins. long. This bladder-nut is allied to S. trifolia, but has less downy leaves, whose margins are simply and less conspicuously toothed. Plants under the name have recently been distributed from nurseries.

The bladder-nuts have a rather remarkable distribution over the North Temperate Zone. They spread all round the world, but most of the species have each their own separate area. Thus, starting at home, we have S. pinnata, which extends through Europe to Asia Minor, then come S. colchica in the Caucasus, and S. Emodi in the Himalaya and Afghanistan. Crossing into China, there is S. holocarpa (and perhaps one or two more species); then S. Bumalda carries the genus to the western shores of the Pacific. Across that ocean the roll is taken up on the western side of N. America by S. Bolanderi, and on the Atlantic side by S. trifolia. 
The following species may be grouped as follows :-

\section{LEAVES TRIFOLIOLATE.}

S. trifolia, Io to $15 \mathrm{ft}$. high. Leaflets very downy all over beneath.

$S$. Bumalda, 2 to $3 \mathrm{ft}$. high. Leaflets downy only on midrib and veins. S. holocarpa, 20 to $30 \mathrm{ft}$. high. Leaflets downy at the base only.

\section{LEAVES TRI- OR QUINQUEFOLIOLATE.}

S. pinnata. Leaflets dull and pale beneath.

S. colchica. Leaflets lustrous green beneath ; capsules 3 to 4 ins. long.

$S$. Coulombieri. Leaflets lustrous green beneath ; capsules $\mathrm{I} \frac{1}{2}$ to 2 ins. long.

\section{S. Bumalda, Siebold.}

A deciduous shrub about $3 \mathrm{ft}$. high, of neat habit. Leaves of three leaflets which are $1 \frac{1}{2}$ to 3 ins. long, ovate-lanceolate, sharply toothed, downy on the midrib and veins. Flowers greenish white, $\frac{1}{3}$ in. long, borne in a terminal cymose cluster $1 \frac{1}{2}$ to 3 ins. long. Fruit a membranous inflated capsule about $\mathrm{I}$ in. long and wide, in two flattened obovate parts, each terminated by the bristle-like, persistent style; seeds yellowish.

Native of Japan, where it inhabits mountainous regions; also of Central and W. China. The Japanese form has not proved of much value in gardens, being rather tender and having few attractions. It flowers in May and June. The Chinese form recently introduced by Wilson may be hardier.

\section{S. COLCHICA, Steven.}

(Bot. Mag., t. 7363.)

A deciduous shrub, 6 to Io ft. high, with stiff, erect branches. Leaves composed of three or five leaflets, which are ovate-oblong, $2 \frac{1}{2}$ to $3 \frac{1}{2}$ ins. long, nearly or quite smooth, shining. beneath, the margins set with fine, rather bristle-like teeth; the terminal leaflet is stalked, the lateral ones stalkless. Flowers in erect panicles terminating the young shoots and lateral twigs, the largest up to 5 ins. long, and as much wide; each flower $\frac{3}{4}$ in. long and wide, the sepals spreading, narrow oblong, very pale green ; petals white, erect, narrow, recurved at the tips. Fruit a two- or three-celled inflated capsule, 3 to 4 ins. long, 2 ins. wide, the apex of each division ending in a long, fine point. Seeds $\frac{1}{3}$ in. long, pale brown.

Native of the S. Caucasus, and the handsomest of cultivated Staphyleas. It is now largely employed for forcing early into bloom for conservatory decoration. It is distinguishable from S. pinnata in leaf, by the shining lower surface, and in fruit by the much larger capsules.

\section{S. Coulombieri, André.}

A deciduous shrub of vigorous habit, considered to be a hybrid between S. colchica and pinnata. The leaves are composed of three or five leaflets, which are larger than in either of the reputed parents, the terminal one often 5 to 6 ins. long; they are ovate-oblong, toothed, dark green on both sides, and very lustrous beneath. Flowers white, and intermediate in size between those of the parents; the panicles are not so large as in S. colchica, the blossoms more compact, and the sepals and petals wider and shorter. The fruit is intermediate in size, being a two- or three-celled capsule, $1 \frac{1}{2}$ to 2 ins. long, the seeds rather larger. 
This handsome shrub was first noticed as showing hybrid characters in the nursery of $\mathrm{Mr}$ Coulombier, at Vitry, in France, in 1887. It had been obtained by him from the famous arboretum of Segrez in 1872 , beyond which date its history is unknown. But it may well have originated there as a chance hybrid. It is most closely related to $\mathrm{S}$. colchica, especially in the shining green under-surface of the leaves, but the much smaller fruits and the differences in the sepals and petals distinguish it.

Var. GRANDIFLORA, Zabel.-A very distinct form, with much longer, laxer panicles, and larger individual flowers; the leaflets are rather longer than in ordinary S. Coulombieri, but proportionately narrower.

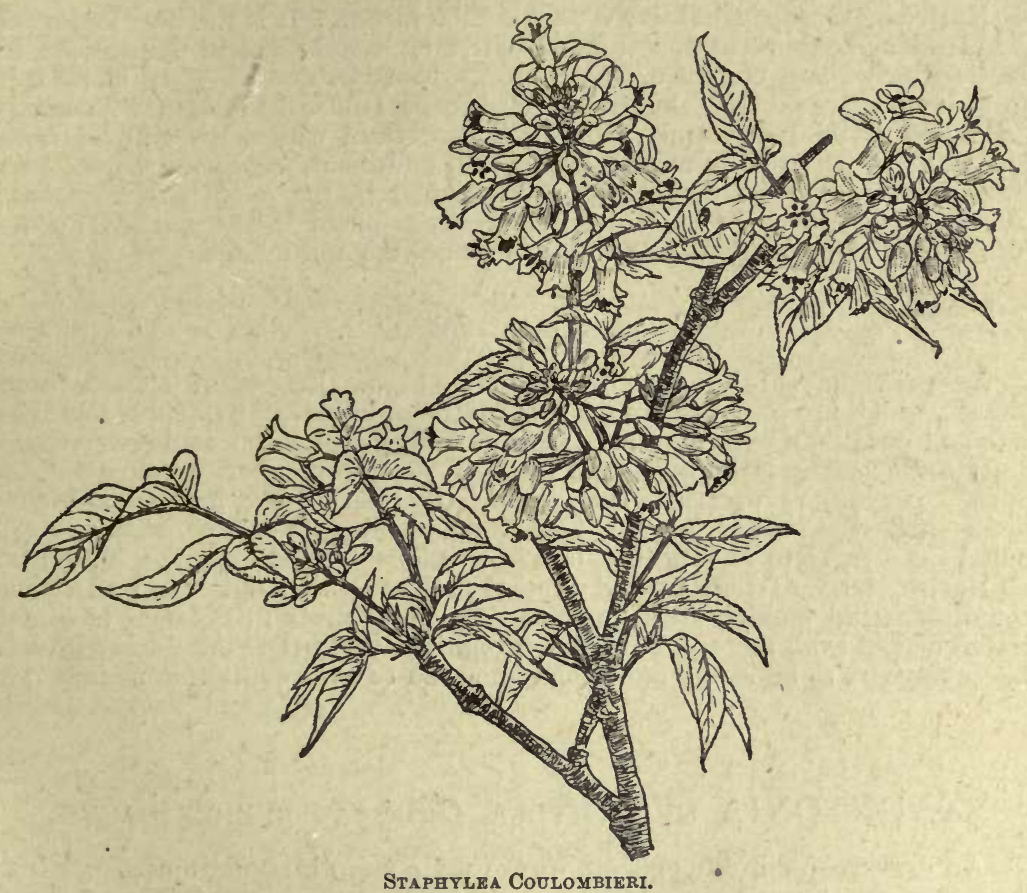

S. holocarpa, Hemsley.

A deciduous shrub, 20 to $30 \mathrm{ft}$. high in a wild state, and often tree-like; young shoots smooth. Leaves of three leaflets, which are oblong-lanceolate, abruptly acuminate, the terminal one stalked and 2 to 4 ins. long, the side ones almost stalkless; all finely toothed, and downy at the base beneath. Flowers white or pink, borne in short, broad corymbs, 2 ins. or more long ; each flower $\frac{1}{2}$ in. long. Fruit a three-celled pear-shaped inflated capsule, 2 ins. long, I in. wide, tapering gradually at the base, but terminating in a short, sharp point. Seeds shining grey, about the size of large shot.

Native of Central China; first discovered in the province of Hupeh by Henry. It was introduced to cultivation by Wilson in 1908 when collecting for Harvard University, and by him is considered likely to prove attractive in gardens. So far as I am aware, it has not yet flowered in cultivation. 


\section{S. PINNATA, Linncus. BLADDER-NUT.}

A deciduous shrub up to 12 or $15 \mathrm{ft}$. high. Leaves pinnate, composed of usually five leaflets, occasionally three, rarely seven; they are 2 to 4 ins. long, ovate or ovate-oblong, toothed, dull green above, pale and dull beneath, with down near the base of the midrib. Flowers in terminal drooping panicles 2 to 4 ins. long, white, each flower about $\frac{1}{2}$ in. long, the sepals as well as petals erect. Fruit a two-celled, bladder-like capsule $I$ to $I \frac{1}{2}$ ins. long, about the same wide, each cell containing one or more seeds about the size of a large pea, brownish yellow.

Native of Europe from the West to Asia Minor. It is the best known of the bladder-nuts, and although not a native of Britain is now naturalised in the hedgerows and copses of some parts. In 1596, according to Gerard, it grew in the Strand "by the Lord Treasurer's House." It is not so handsome and striking a shrub as S. colchica, from which, as well as from Coulombieri, it is distinguished by the dull under-surface of the leaves and erect sepals, and from S. colchica in particular by the much smaller fruits, containing seeds twice as large. It merits a place in the garden for its curious and interesting fruits as well as its flowers and foliage.

\section{S. TRIFOLIA, Linnceus.}

A deciduous shrub up to ro or $15 \mathrm{ft}$. high. Leaves of always three leaflets, which are broadly ovate, 2 to 4 ins. long, occasionally doubly toothed; pale and downy all over the lower surface, dark green and less downy above; the middle leaflet is long-stalked, the side ones very shortly so. Panicles short, drooping, $1 \frac{1}{2}$ to 2 ins. long, either terminating the leading shoot or small side twigs; flowers bell-shaped, dingy white. Fruit a usually threecelled capsule, $1 \frac{1}{4}$ to $1 \frac{1}{2}$ ins. long, less in width; seeds yellowish, $\frac{3}{16}$ in. long.

Native of the eastern United States; cultivated in England in 1640, but not ornamental enough to have ever been extensively grown. It is easily distinguished from the other species in cultivation by the very downy leaves. There appears to be rarely more than one seed to each cell, often none.

\section{STAUNTONIA heXaphylla, Decaisne. BERberidace..}

An evergreen climbing shrub, whose main stem is sometimes 4 or 5 ins. thick near the base. Leaves long-stalked, compound, consisting of three to seven leaflets radiating from a common centre. Leaflets ovate to elliptical, acutely pointed, the side ones usually oblique, of leathery texture, smooth, 3 to 5 ins. long; stalks I to 2 ins. long. Flowers unisexual, produced three or four together in a raceme, white tinged with violet, $\frac{3}{4}$ in. across; they have six fleshy sepals, but no petals; the males with six stamens, the females with three ovaries. Fruit of the size and shape of a walnut, purple, sweet and watery; eaten by the Japanese.

Native of Corea and Japan. The genus commemorates Sir George Staunton, who accompanied Lord Macartney on his famous embassy to China in $\mathbf{1} 792$. From the closely allied Holbœllia it is distinguished by the absence of petals from its larger flowers, and by the stamens being united instead of free. It has been grown since 1876 on a wall at Kew, but needs warmer conditions than are there afforded to be seen at its 
best. It is admirably adapted for the south-western counties, but in more northern localities is best suited in a winter garden or cool conservatory.

\section{STEPHANANDRA. ROSACEA.}

A small Asiatic genus of deciduous shrubs, comprised, perhaps, in the two species here described. They are closely allied to Spiræa, but have small, dull white, or greenish flowers; sepals and petals five. Leaves alternate. Fruit a dry capsule enclosed by the persistent sepals. They like a moist, loamy soil, and are easily propagated by cuttings or by division of the plants; $S$. flexuosa also by root-cuttings put in heat in March.

\section{S. Flexuosa, Siebold.}

(S. incisa, Zabel.)

A deciduous shrub of graceful habit, with smooth, wiry, zigzag branches, forming a dense, rounded bush ultimately 4 to $8 \mathrm{ft}$. high, sending up sucker growths freely from the base. Leaves triangular in the main, truncate or heart-shaped at the base, tapering to a slender apex; $1 \frac{1}{2}$ to $3 \mathrm{ins}$. long, somewhat less in width at the base; the margins cut into deep lobes, the lobes toothed; stipules linear, toothed, $\frac{1}{4}$ in. long. Flowers greenish white, $\frac{1}{5}$ in. wide, crowded on panicles 1 to 3 ins. long and terminating short side-tivigs from the previous year's shoots; stamens ten.

Native of Japan and Corea ; introduced to Kew, in 1872 , by way of St Petersburg. It has proved quite hardy, and is now generally cultivated for the beauty of its handsomely cut, fern-like foliage, and for the brown of its naked stems and branches in winter. The finest specimen I have seen is in Lord Annesley's garden at Castlewellan, which a few years ago was $8 \mathrm{ft}$. high and more in diameter-an exceedingly elegant bush. The flowers appear in June, but have little beauty.

\section{S. TANAKA, Franchet.}

$$
\text { (Bot. Mag., t. 7593.) }
$$

A deciduous shrub of twiggy habit, up to $6 \mathrm{ft}$. or perhaps more high, with smooth, slender branches. Leaves broadly ovate or triangular, 2 to 5 ins. long and from two-thirds to quite as much wide; the point long and slender, the base rounded or heart-shaped; the margins double-toothed, and frequently with one or two pairs of angular lobes more or less developed near the base; veins hairy when quite young, becoming smooth; stipules heart-shaped, toothed, $\frac{1}{4}$ in. long. Flowers yellowish white, produced in June and July in a lax, branching panicle 2 to 4 ins. long; each flower $\frac{1}{5}$ in. across on a stalk about as long; stamens twenty.

Native of Japan; introduced to $\mathrm{Kew}$ in 1893 . It differs from $\mathrm{S}$. flexuosa in the larger, less deeply cut leaves (which turn an orange colour in autumn), in the broader stipules, the more numerous stamens, and in the longer, more slender, and less densely flowered panicles. The flowers become a purer white under sunnier skies than ours. The species is hardier than S. flexuosa but not, I think, so attractive, although its stems are brighter brown. 


\section{STERCULIA PLATANIFOLIA, Linnceus. STERCULIACEA.}

\section{(S. Mariesii, Hort.)}

A tree up to $60 \mathrm{ft}$. high, with noble foliage and a trunk smooth even in age. Leaves variable in size, but averaging from 6 to 8 ins. in length and as much or more wide; on vigorous young plants they are over I $\mathrm{ft}$. long. Ordinarily, the leaves have three rather shallow, pointed lobes towards the end, but often they are five-lobed, with the general outline of a maple-leaf, the base heart-shaped; they are either furnished with stellate down beneath, especially in the vein-axils, or are glabrous. The leaf-stalk is two-thirds to quite the length of the blade. Flowers small, yellow, produced on a branching panicle as much as 18 ins. long and 9 ins. wide. Fruit a kind of pod (follicle), 3 to 4 ins. long, tapering to a beak at the end, and containing several seeds about the size of peas.

Native of China, but introduced in 1757 from Japan, where it is much cultivated. It was long treated as a greenhouse plant, and is, indeed, better suited in Cornwall and such-like localities than in the London districts, where, to be safe, it needs wall protection. Its beauty, however, is only fully shown in a spot where it can develop freely on all sides. It is very fine on the Riviera, especially in the Casino Gardens at Monte Carlo.

\section{STEWARTIA. TERNSTREMIACE}

This genus, sometimes spelt "Stuartia," was so named in honour of John Stuart, the Earl of Bute who acted as chief adviser to Augusta, Princess Dowager of Wales, when she founded the Botanic Garden at Kew, in I759-60. Five species are known, two from the East United States and three from Japan and China. They are shrubs or trees with alternate leaves, white petals, and numerous stamens; the other parts of the flower in fives. Allied to Camellia, but deciduous.

Stewartias have been too much neglected in gardens; they have great beauty, and flower in July and August, when few shrubs remain in blossom. They are evidently not among the most robust, for the American species, although first introduced more than a hundred years ago, must still be classed with the rarest inhabitants of our gardens. A sheltered sunny position should be selected for them, and care should be taken that they do not suffer from excessive drought. Whilst a peaty soil is not essential for them, they are undoubtedly benefited by having some of it, as well as leaf-soil, mixed with the ordinary loam of the garden, especially when young. Still a warm, sandy loam suits them well. I find that the root shelter they obtain by being planted in a bed of Erica mediterranea is very grateful to them, and the soil which suits heaths suits them also. Stewartias are not easy to propagate except by seeds which are occasionally borne by good-sized plants. They should, like most of those of the Camellia family, be sown as soon as obtained. Failing them, cuttings may be used. These should be taken from 
ripened wood in late summer and inserted in very sandy soil under a cloche in a cool frame, or even in pure sand. It is wise to put plants in their permanent sites as early as possible.

\author{
STYLES SEPARATE. \\ S. pentagyna. \\ STYLES UNITED. \\ S. Malachodendron. Leaf woolly beneath. \\ S. Pseudo-camellia. Stigmas spreading; shoots glabrous. \\ S. monadelpha. Stigmas spreading; shoots hairy.
}

\title{
S. MaLACHODENDRON, Linnaus.
}

(Bot. Mag., t. 8I45; S. virginica, Cavanilles.)

A deciduous small tree or shrub, $15 \mathrm{ft}$. or more high. Leaves 2 to 4 ins. long, ovate, oval, or obovate, more tapered at the base, and less distinctly stalked than in S. pentagyna; the apex is pointed or blunt, the margins toothed, the lower surface more or less hairy. Flowers solitary in the leafaxils, $2 \frac{1}{2}$ to $3 \frac{1}{2}$ ins. across; calyx $\frac{3}{4}$ in. across, with five broad, pointed, hairy divisions; petals white, silky behind; stamens purple, with bluish anthers, forming a conspicuous and beautiful centre to the flower. Fruit woody, egg-shaped, $\frac{1}{2}$ in. diameter. (See fig., p. 554).

Native of the south-eastern United States, and from S. pentagyna easily distinguished by the united styles and by the smaller and differently shaped leaves. Mark Catesby, the famous author of the Natural History of Carolina, flowered this tree in his garden at Fulham in 1742, and Peter Collinson grew "it at Mill Hill, near Hendon, in $176 \mathrm{r}$, but it is now one of the rarest of American shrubs. Commencing to flower in July, it continues into August, being at that season one of the handsomest and most distinguished shrubs in flower.' The largest plant of whose existence I am aware is in a garden at Stoke Poges-18 ft. high. There is also a good example at Syon.

\section{S. SINENSIS, Rehder and Wilson.}

A deciduous shrub or small tree, 3 o ft. high; bark peeling, young shoots clothed at first with fine hairs. Leaves oval or ovate-oblong, $1 \frac{1}{2}$ to 4 ins. long, $\frac{3}{8}$ to $1 \frac{3}{4}$ ins. wide; wedge-shaped at the base, tapered at the apex, toothed; at first hairy on both surfaces (but more densely so above) and at the margin, becoming almost smooth; bright green on both sides; stalk hairy, $\frac{1}{8}$ to $\frac{1}{4}$ in. long. Flowers solitary in the leaf-axils, I to $1 \frac{1}{2}$ ins. across, white, fragrant ; stamens numerous, downy ; styles united into one column, five-rayed at the top; bracts, sepals, and petals silky at the back.

Native of China; introduced by Wilson about I90I. This is the plant named "S. monadelpha" in the first edition of this work. It is nearly allied to that species, which is, however, a native of Japan only. Messrs Rehder and Wilson observe, moreover, that the "capsule of S. sinensis is the largest in the genus ( $\frac{4}{5}$ in. in diameter), that of S. monadelpha is the smallest" ( $\frac{1}{3}$ in. in diameter. Plante Wilsoniana, ii., p. 396.

\section{S. PENTAGyna, L'Heritier.}

(Bot. Mag., t. 3198.)

A deciduous shrub, up to $15 \mathrm{ft}$. in height, with erect branches but a bushy habit; young shoots, leaf-stalks, and often the leaves tinged with red. 


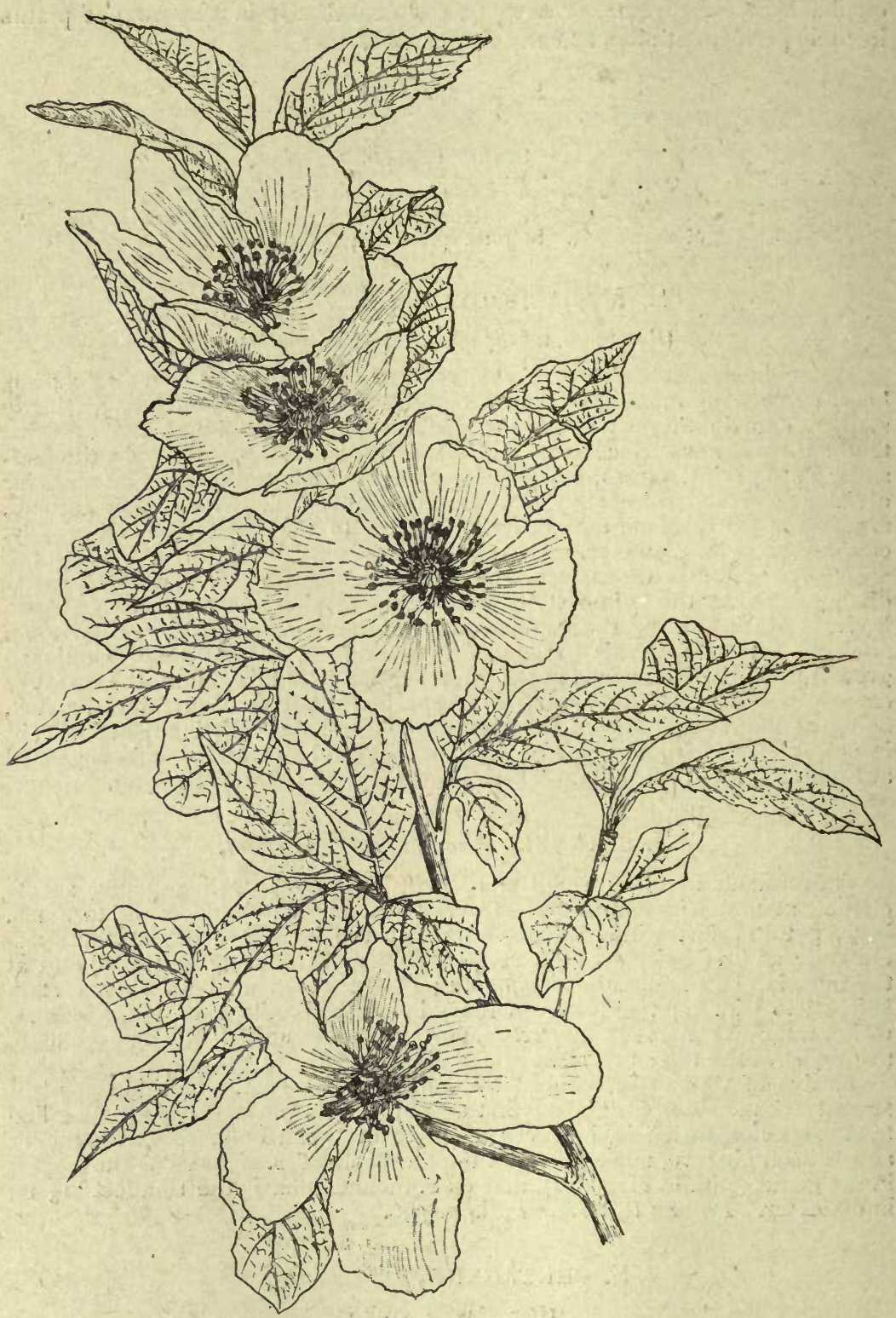

Stewartia Malachodexdron. 
Leaves ovate, $2 \frac{1}{2}$ to 5 ins. long, about half as much wide; rounded at the base, pointed, toothed more or less distinctly on the margin, or entire ; hairy beneath, more especially when young. Flowers produced singly in the leaf-axils, on hairy stalks, about $\frac{1}{4}$ in. long. Sepals five, about $\frac{1}{2}$ in. long, broadly strap-shaped or ovate, densely hairy; petals five or six, creamy white, prettily crenulated, one of them often deformed. A conspicuous feature of the flower is the cluster of normally yellow, but sometimes purple stamens; styles three to five, not united; the finest flowers are over 4 ins. across, others under 3 ins.

Native of several of the southern United States, most abundant perhaps in Tennessee. This species has for more than one hundred years been an inhabitant of our gardens, but never a common one. Yet it is one of the most interesting and beautiful of American shrubs, especially in July and August, when in bloom. It is said to have been 1o to $12 \mathrm{ft}$. high in the gardens of Dropmore and White Knights seventy years ago, but large plants appear now to be very scarce. Botanically, its most distinctive character are the disunited styles.

Var. GRANDIFLORA.-I distinguish by this name the beautiful form with purple stamens, which give a much more striking character to the flower than the ordinary yellow ones, especially as it measures 4 to $4 \frac{1}{2}$ ins. across the petals. This form is found along with the yellow-stamened one in the woods of Georgia; there appears to be no other character to differentiate them.

\section{S. Pseudo-Camellia, Maximozicz.}

(Bot. Mag., t. 7045.)

In Great Britain this species has only as yet attained the dimensions of a shrub or small tree of dense habit, but in Japan it has been seen by. Sargent up to $50 \mathrm{ft}$. in height, with a trunk $6 \mathrm{ft}$. in girth. It is deciduous, the branchlets and often the leaves quite smooth, the latter sometimes silky beneath. Leaves 2 to $3 \frac{1}{2}$ ins. long, ovate or obovate, tapering at the base to a short stalk, finely toothed. Flowers produced singly in the leaf-axils on a short stalk, $\frac{1}{2}$ in. or less in length; each flower 2 to $2 \frac{1}{2}$ ins. across, white and cupped. Petals five, roundish, concave, covered with silky hairs behind, the margins irregularly jagged; sepals densely hairy; stamens numerous, incurved, orange-yellow. Ovary conical, surmounted by five united styles, the stigmas only spreading. Fruit a broadly ovoid, hairy capsule, I in. long.

Native of Japan; introduced to England by Messrs Veitch, but cultivated previously in the United States and in France, where it first bore fruit in the nursery of Messrs Thibaut and Keteleer at Sceaux, near Paris, in I878. It is not, perhaps, quite so striking as either of the American species, but is still a beautiful tree, and is evidently more at home in English gardens. When the seasons are suitable the leaves turn brilliant yellow and red before falling. The ugly specific name refers to the resemblance of the flowers to those of a single camellia.

\section{STRANVÆSIA. ROSACEAE.}

A small genus of evergreens inhabiting Thibet, China, and the Himalaya, very similar to Photinia. Propagated by cuttings made of half-ripened wood, placed in gentle heat. They thrive in sandy loam. The generic name was given by Lindley in honour of $\mathrm{Mr}$ FoxStrangways. 


\section{S. GLAUCESCENS, Lindley.}

(Bot. Reg., t. 1956.)

A small evergreen tree, the branchlets covered when young with a loose, whitish down, ultimately smooth. Leaves leathery, lanceolate to obovate, $2 \frac{1}{2}$ to 4 ins. long, $\frac{3}{4}$ to 2 ins. wide; dark shining green and smooth above, paler, glossy and slightly downy on the midrib beneath, finely toothed. Flowers white, about $\frac{1}{2}$ in. across, produced in July in flattish, terminal, hairy-stalked corymbs, 2 to 4 ins. across ; flower-stalk and calyx woolly. Fruit hoary with down when young, becoming pale red and smooth, $\frac{1}{4}$ in. long, pear-shaped.

Native of the outer ranges of the Himalaya; introduced to England in 1828 . It is not hardy in the open at Kew, but grows vigorously on an wall, where, however, it rarely flowers. There is a good specimen in the gardens of Osborne House, I sle of Wight, which flowers and produces fruit in abundance.

\section{S. undulata, Decaisne.}

(Bot. Mag., t. 8418 ; S. Davidiana var. undnlata, Rehder.)

A low, spreading evergreen shrub, or a tree over $20 \mathrm{ft}$. high, with very downy young branchlets. Leaves leathery, oval-lanceolate, pointed, glossy green, $1 \frac{1}{2}$ to $3 \frac{1}{2}$ ins. long, $\frac{1}{2}$ to $1 \frac{1}{4}$ ins. wide; entire, downy only on the midrib and margins; stalk $\frac{1}{3}$ to $\frac{1}{2}$ in. long, downy. Flowers white, produced in June, in terminal, hairy-stalked corymbs, $1 \frac{1}{2}$ to $2 \frac{1}{2}$ ins. wide; each flower about $\frac{1}{2}$ in. across; petals soon falling; calyx with five triangular lobes, silky hairy when young; stamens about twenty. Fruit brilliant red, of the shape and size of common haws.

Native of China; introduced by Wilson for Messrs Veitch about Igor. Unlike the previous species, this appears to be quite hardy. It flowers with great freedom, but the blossoms last in beauty a very short time. Its great charm as a garden shrub is in its abundant crop of bright red fruits. The leaves (as in Photinia) turn red sometimes before falling. The specific name refers to the frequently wavy margins of the leaves.

\section{STYRAX. STORAX. STYRACACE E.}

A large genus of trees and shrubs found in Europe, N. America, India, China, and Japan. Only a small proportion of these are hardy in Britain, but no group possesses greater beauty and distinction. Leaves alternate, and often clothed, like the young wood and other parts of the plant, with stellate (or rosette-like) down. Flowers white, usually in racemes. From Halesia and Pterostyrax, its nearest allies, Styrax is distinguished by the relative position of the fruit and calyx. In the present genus the fruit sits in the persistent cup-shaped calyx; in the other two the fruit is below the calyx, which is persistent in Pterostyrax only.

All the species of Styrax need careful attention when young. They like a sheltered spot, and when first planted out should have a sandy loam, to which decayed leaves and, if available, some finely broken-up peat has been added. Once established, they will root into the surrounding ground. Cuttings of S. japonicum and americanum may be rooted, but they and the rest succeed better raised from seed. 


\section{S. Americanum, Lamarck. American Storax.}

A deciduous shrub, 3 to $8 \mathrm{ft}$. high; young shoots nearly smooth. Leaves narrowly oval, or obovate, $\mathrm{I}_{2}^{\frac{1}{2}}$ to $3 \frac{1}{2}$ ins. long, $\frac{1}{2}$ to $\mathrm{I} \frac{1}{4}$ ins. wide; the base wedge-shaped, the apex mostly pointed; minutely toothed, dark green above, paler beneath, almost or quite smooth on both sides; stalk $\frac{1}{6}$ in. or less long. Flowers white, pendulous, $\frac{3}{4}$ to $I \frac{1}{4}$ ins. across, produced in June and July one to four near and at the end of short leafy twigs; each flower on a slender stalk $\frac{1}{4}$ to $\frac{1}{2}$ in. long. Petals $\frac{1}{8}$ to $\frac{3}{16}$ in. wide, pointed; calyx triangularlobed; stamens erect, $\frac{1}{2}$ in. long. Fruit roundish oval, $\frac{1}{4}$ in. wide, covered with fine grey down, and supported at the base by the persistent five-lobed calyx.

Native of the south-eastern United States; introduced in 1765. This shrub has long been cultivated at Kew, but grows slowly, really needing a warmer climate. It was killed to the ground by the frosts of February 1895, but sprang up again later. It is better adapted for our south-west counties, where it is a pretty shrub; yet neither as hardy nor as beautiful as $\mathrm{S}$. japonicum, to which in its pendulous blossoms it bears some resemblance but is easily distinguished by its narrower petals.

\section{S. Dasyanthum, Perkins.}

A deciduous shrub or small tree, the young branchlets furnished at first with reddish brown down, becoming smooth. Leaves obovate to broadly oval, 2 to 4 ins. long, $\mathrm{r} \frac{1}{2}$ to 3 ins. wide; tapered more or less at the base, pointed, the upper part minutely toothed; the lower surface when young is covered with tufted hairs, which mostly fall away before the end of the season. Flowers white, $\frac{1}{2}$ to $\frac{3}{4}$ in. long, produced in July in slender terminal racemes 2 to 4 ins. long, augmented by clusters of two to four flowers in the uppermost leaf-axils. Corolla segments lanceolate, covered outside with tufted, yellowish white down. Calyx cup-shaped, felted outside, $\frac{1}{4}$ in. long, with several short but unequal, pointed teeth.

Native of Hupeh, China ; discovered by Henry, and again by Wilson in 1900. The best plant I know of is at Aldenham, where it has succeeded against a wall, and flowered several times in recent years.

\section{S. Hemsleyanum, Diels.}

(Bot. Mag., t. 8339.)

A deciduous tree, $20 \mathrm{ft}$. or more high, young shoots covered at first with tufted down. Leaves obovate or unequally ovate, 3 to $5 \frac{1}{2}$ ins. long, 2 to $3 \frac{1}{2}$ ins. wide; usually more gradually tapered at the base than at the apex; finely and rather distantly toothed, prominently veined; smooth and pale green above, sparsely furnished beneath with tufted (stellate) down; stalk $\frac{1}{4}$ to $\frac{5}{8}$ in. long. Flowers pure white, produced in June on terminal downy racemes or few-branched panicles, 4 to 6 ins. long, each flower on a stalk $\frac{1}{6} \mathrm{in}$. long. Corolla $\frac{3}{4}$ in. long, about $\mathrm{r}$ in. wide, the five lobes narrowly oval, downy outside, joined at the base into a tube $\frac{1}{4}$ in. long. Calyx bell-shaped, $\frac{1}{4}$ in. long, slender-toothed, covered with reddish brown tufted down.

Native of Central and W. China; introduced by Wilson in 1900 . It is now cultivated at Caerhays, Cornwall, and is a vigorous small tree, io or $12 \mathrm{ft}$. high, of remarkable beauty when in blossom; striking also in size of leaf. It bears a certain resemblance to S. Obassia, but the leaves of 
that species are rounder, more coarsely toothed, and much more downy beneath, and the bud is enclosed by the base of the leaf-stalk.

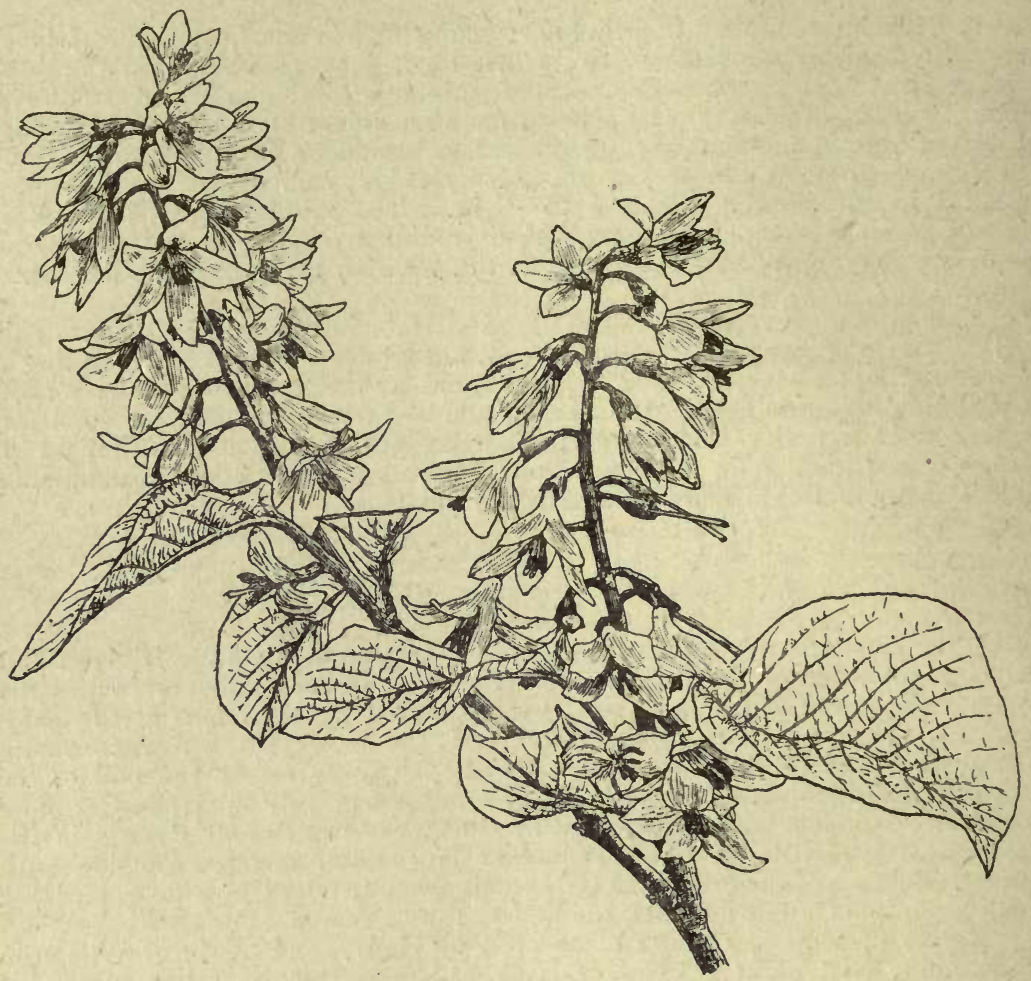

Styrax HeMsleyando.

S. JAPONICUM, Siebold.

(Bot. Mag., t. 5950 (wrongly as S. serrulatum).)

A small deciduous tree, Io to $25 \mathrm{ft}$. high, of very graceful habit; the branches slender, sometimes drooping; young shoots at first furnished with scattered tufts of down, which soon falls away. Leaves usually oval, tapering about equally at both ends, I to $3 \frac{1}{2}$ ins. long, $\frac{1}{2}$ to $I \frac{1}{2}$ ins. wide; but occasionally obovate or even roundish; margins set with minute, shallow, distant glandular teeth; dark glossy green above, smooth on both surfaces except for tufts of down in the vein-axils; stalk $\frac{1}{3}$ in. or less long. Flowers pure white, perfectly pendulous, $\frac{3}{4}$ in. diameter, borne on short lateral shoots carrying about three leaves and three to five blossoms; each flower on a smooth slender stalk, I to $\mathrm{I} \frac{1}{2}$ ins. long. Corolla of five pointed divisions, which are united near the base, $\frac{5}{8}$ in. long, downy outside. Calyx smooth, funnel-shaped, $\frac{1}{6}$ in. long, persisting at the base of the roundish, egg-shaped fruit, which is $\frac{1}{2}$ in. long.

Native of Japan and Corea ; introduced to Kew by Richard Oldham in 1862. It is a small tree of singular grace and beauty, very hardy, but 
preferring a sheltered spot and one, if possible, shaded from morning sun, for the flower-buds and the young shoots are liable to injury by late spring frosts. It should be given a light loamy soil to which either peat or leafsoil, or both, have been added. Apart from its susceptibility to late frost, especially in low-lying situations, it is one of the most desirable of all hardy trees of its type, and amply repays the trouble of preparing a suitable medium for the roots, if that does not already exist.

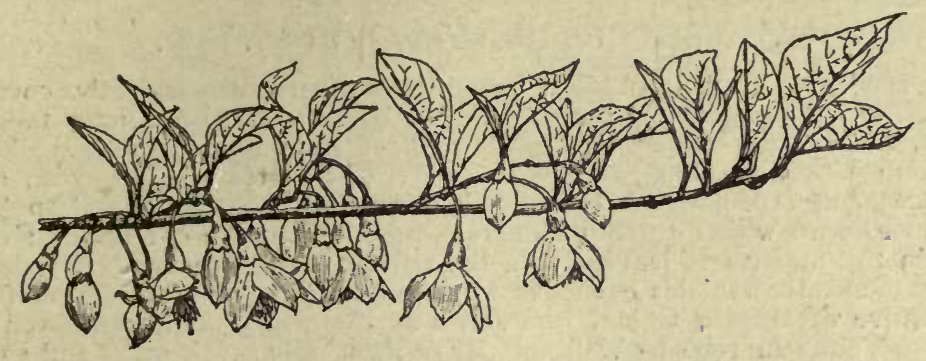

STYRAX JAPONICUM.

\section{S. Obassia, Siebold.}

(Bot. Mag., t. 7039.)

A small deciduous tree, 20 to $30 \mathrm{ft}$. high, of rather narrow proportions; young wood covered at first with tufted hairs, soon smooth. Leaves broadly oval or almost round, 3 to 8 ins. long, and from two-thirds to as much wide; distantly toothed, except near the base; upper surface deep green and smooth except on the veins, the lower surface densely clothed with velvety tufted down; stalk $\frac{1}{4}$ to I in. long, the base enclosing the bud. Flowers fragrant, about I in. long, pure white, drooping, produced in June on terminal racemes 6 to 8 ins. long, each flower on a downy stalk $\frac{1}{3}$ in. long; the common stalk is almost smooth. Corolla deeply five-lobed, the lobes about $\frac{3}{4}$ in. long, $\frac{1}{4}$ in. wide, minutely downy. Calyx between funnel- and bellshaped, from five- to ten-lobed, downy, $\frac{1}{4}$ in. long, persistent and enlarging with the fruit, which is egg-shaped, about $\frac{3}{4}$ in. long, velvety.

Native of Japan; introduced for Messrs Veitch in 1879 by Maries. This is one of the most beautiful and striking even of Japanese flowering trees. It has grown to over $20 \mathrm{ft}$. high in the Coombe Wood nursery, but needs a sheltered spot. For newly planted specimens it is an advantage if peat and leaf-soil is mixed with the ordinary soil. It grows slowly in our climate, and abhors dryness at the root.

\section{S. OFFICINALE, Linncus. STORAX.}

Repeated experiment has shown that it is useless to attempt to grow this beautiful shrub without protection near London. Against a south wall it may grow and thrive for some years, but even there is not permanently safe. Consequently, although introduced in the sixteenth century, it is still very rare. It is a shrub or small tree, 12 to $20 \mathrm{ft}$. high in nature, the young shoots, leaves, and flower-stalks covered with whitish down. Leaves ovate, often broadly so, and sometimes heart-shaped at the base. Flowers borne in June in short terminal clusters of three to six orange-like, fragrant blossoms; each flower is $1_{4}^{\frac{1}{4}}$ ins. wide, the six to eight divisions of the 
corolla white, very downy, narrow-oblong. Fruit roundish, with the remains of the style at the top, and the woolly calyx beneath.

Native of Greece and Asia Minor up to elevations of $3,600 \mathrm{ft}$. The fragrant resin known as "storax" is obtained from this shrub by wounding the stem. A correspondent in Greece informs me that a worm attacks the wood, and that the dust resulting from its borings is used by the natives as incense. The shrub is suitable for Cornwall and similar localities.

\section{S. Veitchiorum, Hemsley and Wilson.}

A small tree, I 2 to $15 \mathrm{ft}$. high; young shoots, leaf-stalks, and calyx covered with a close, grey, starry down. Leaves lanceolate, with a long tapered point, and a wedge-shaped or slightly rounded base, remotely and shallowly toothed; 3 to 5 ins. long, I to $I^{\frac{3}{4}}$ in. wide; of thin texture, downy on both surfaces, but especially on the midrib and veins beneath; stalk $\frac{1}{4}$ to $\frac{1}{3}$ in. long. Flowers white, nearly $x$ in. across, produced at the end of the shoots and in the uppermost leaf-axils on the current season's growth, forming a group of slender panicles each 4 to 8 ins. long. Calyx minutely five-toothed.

Native of Hupeh, China, where it was discovered and introduced for Messrs Veitch in 1900 by Wilson. Mr Wilson only saw it once, and I only know it from his specimen (2015) preserved at Kew, and the living plants raised at Coombe Wood, where it is hardy and vigorous, but has not yet flowered. The leaves of cultivated young trees are more uniformly downy than the flowering specimens collected in China, which have only tufts in the vein-axils beneath, but Mr Wilson says they are true.

\section{S. Wilsoni, Rehder.}

\section{(Bot. Mag., t. 8444.)}

A deciduous shrub, sometimes of tree-like form, 6 to ro $\mathrm{ft}$. high, of muchbranched, twiggy habit; young shoots furnished with starry down. Leaves ovate, $\frac{1}{2}$ to I in. long, half to two-thirds as wide; rounded or broadly tapered at the base, often bluntish at the apex, the lower half not toothed, the terminal part either three-lobed or sparsely toothed; green and minutely downy on both sides when young. Flowers nodding, pure glistening white, $\frac{5}{8}$ to $\frac{3}{4}$ in. across, produced singly on a stalk about $\frac{1}{8}$ in. long from the leafaxils, and at the end of short lateral twigs in June. Corolla lobes ovateoblong, $\frac{1}{3}$ in. long, pointed, covered with minute starry down outside; calyx green, scurfy, with lance-shaped lobes $\frac{1}{12}$ in. long. Stamens clustered in an erect columnar group, $\frac{3}{8}$ in. high, their stalks white, the anthers yellow.

Native of W. China; introduced by Wilson when collecting for Harvard University in I908. It is a very pretty shrub, remarkable in flowering when a few inches high and when only two or three years old. I am afraid it will prove rather tender in some parts of the country, at least when young, but it is likely to be a delightful shrub for the warmer parts. In June, 1913, I saw in Mr Chenault's nursery at Orleans, a plant $6 \mathrm{ft}$. high in full blossom. It was one of the most beautiful objects I have ever seen.

\section{SUADDA fRuticosa, Forskal. SHrubby GoOsefoot. CHENOPODIACE $A$.}

(Chenopodium fruticosum, Linnoeus.)

A sub-evergreen shrub, 3 or $4 \mathrm{ft}$. high, with smooth, erect branches. Leaves alternate, linear, nearly cylindrical, fleshy, $\frac{1}{4}$ to $\frac{1}{3} \mathrm{in}$. long, blue- 
green, borne at very close intervals on the stem. Flowers small, green, stalkless, one-third as long as the leaves, produced during July in the leafaxils of the current year's shoots, either singly or two or three together, insignificant.

Native of the maritime districts of Europe, including some parts of the east and south coasts of Britain. It has rather a heath-like aspect, with its slender, erect stems and closely set, short leaves-but the latter are, of course, much more thick and fleshy. The shrub has no beauty of flower, but the habit and foliage are sufficiently interesting and graceful for it to be planted in brackish places, or in positions exposed to salt spray where comparatively few shrubs will thrive. It succeeds well in sandy soil, and can be increased by cuttings placed under a handlight. If it gets too ungainly in form it should be pruned back in spring, but the semi-woody shoots are frequently cut back by winter frost.

\section{SYCOPSIS SINENSIS, Oliver. HAMAMELIDACEA.}

An evergreen bushy shrub or a small tree, up to $20 \mathrm{ft}$. high in China; young shoots at first scaly. Leaves rather leathery, strongly nerved, entire or slightly toothed towards the apex, ovate or ovate-lanceolate; 2 to $4 \frac{1}{2}$ ins. long, one-third to half as wide; smooth and dark green above, paler and quite smooth beneath; leaf-stalk and young wood slightly warted. Flowers in short dense clusters less than $\mathrm{I}$ in. long, of but little beauty except for the yellowish stamens and the reddish brown bracts that enclose the inflorescence. The flowers are unisexual and without a corolla, both sexes appearing on the same plant. Fruit a dry, woolly, egg-shaped capsule, $\frac{1}{3}$ in. long.

Native of Central China at $4000 \mathrm{ft}$. altitude; introduced by Wilson for Messrs Veitch in I90r. It is perfectly hardy at Kew, and can be increased by means of cuttings made of fairly ripened wood and placed in heat. Its neat habit and distinct appearance, combined with its evergreen nature, make it welcome in gardens, although it has little beauty of blossom to commend it. It flowers at Coombe Wood in February and March, and it was from one of the plants there that our figure on p. 562 was made in 1910.

\section{SYMPHORICARPUS. CAPRIFOLIACEA.}

An unimportant genus of shrubs, of which about half a dozen species are in cultivation. Until recently the genus, as known to botanists, was confined to N. America, but Wilson has recently found a species in W. China. They have no beauty of flower, and with the exception of S. orbiculatus, which has red fruits, and S. sinensis, which has dark blue ones, they are chiefly remarkable for their snow-white berries, well exemplified in most gardens by the common snowberry-S. racemosus. Leaves opposite, not toothed, but sometimes with a wavy lobing, deciduous. The genus is allied to Lonicera, but differs in the regular corolla and two-seeded berry. 
The differences between the West American species are not very readily defined, but they consist chiefly in the relative lengths of stamens, style, and corolla. All the species grow well in any moist soil, and are

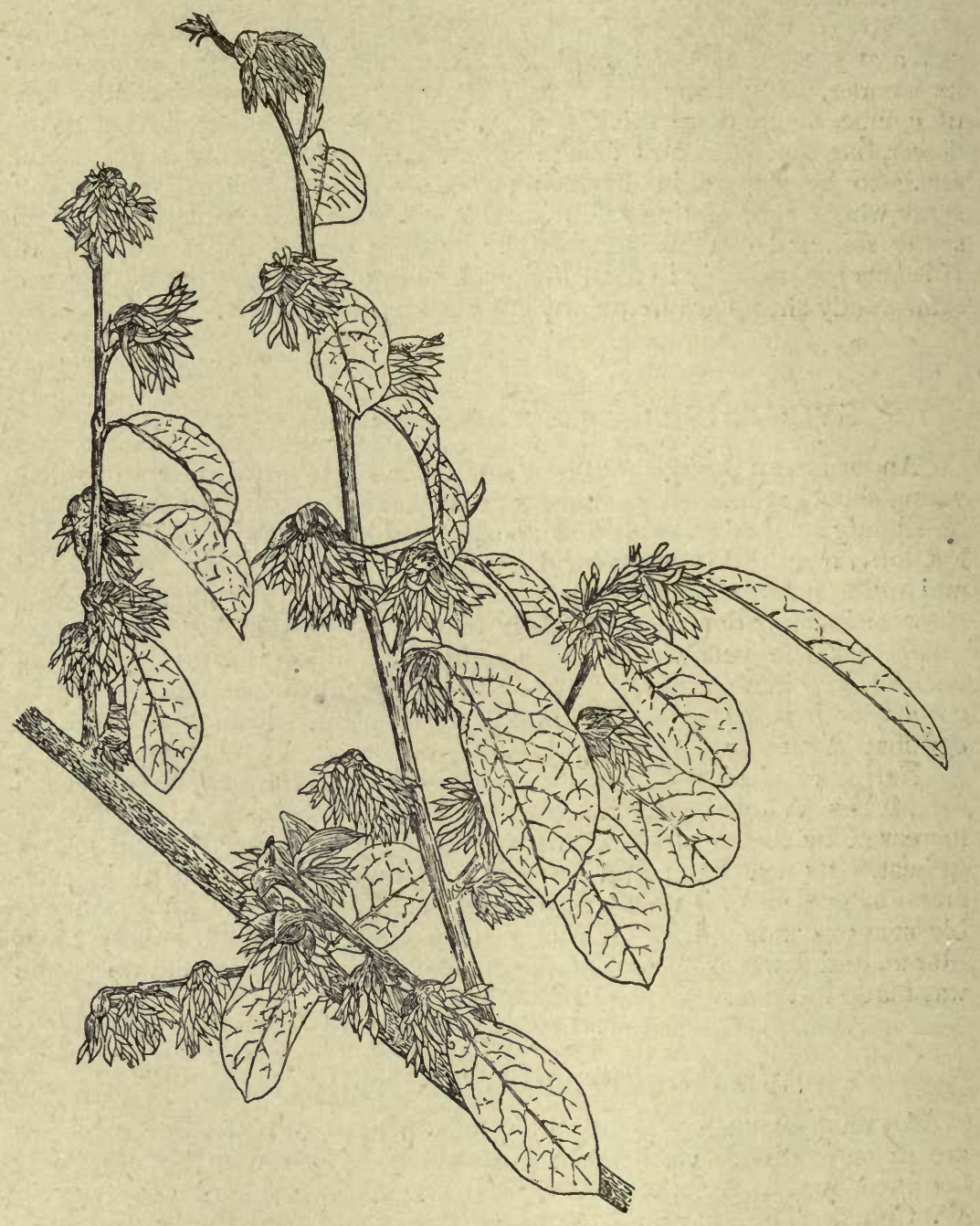

Sxcopsis SINRNIIS.

easily propagated by cuttings, several by division. The West Chinese species alluded to above-S. SINENSIS, Rehder-differs from all the rest in having dark blue fruits, which are ovoid, $\frac{1}{3}$ in. long, and covered with a plum-like bloom, and in the flowers being borne on a "terminal 
peduncled inflorescence." It is cultivated in the Arnold Arboretum, whence it was introduced to this country in r 912.

\section{S. MOLLIS, Nuttall.}

\section{(S. ciliatus, Nuttall.)}

A low or prostrate shrub; young shoots covered with soft down. Leaves roundish to oval, sometimes shallowly lobed, $\frac{1}{2}$ to $I$ in. long, velvety and grey with down, especially beneath. Flowers few and small, produced singly or in short clusters at and near the end of the twigs; corolla widely bellshaped, about $\frac{1}{8}$ in. long and broad, pinkish white, enclosing the smooth style. Fruit white, globose, about $\frac{1}{4}$ in. wide.

Native of California northward on the Pacific coast region to British Columbia; distinct and interesting for its decumbent habit and densely downy leaves.

\section{S. OCCIDENTAlis, Hooker. WOLFBerRy.}

A deciduous shrub up to $6 \mathrm{ft}$. high. Leaves oval or oblong, stout, up to 2 ins. or more long, smooth or more or less downy beneath. Flowers in dense spikes or racemes, both in the leaf-axils near the end of the shoot and at the end itself. Corolla open funnel-shaped, deeply five-lobed, densely hairy inside, $\frac{1}{4}$ in. long, pinkish; style and stamens slightly protruded, the former smooth. Fruit dullish white, globose, about $\frac{1}{3}$ in. wide.

Native of N. America from Oregon eastwards to Michigan. It has been confused with S. racemosus, but is an inferior shrub with smaller, duller fruits; it differs also in the deeper-lobed corolla and in the protruded style and stamens. Of little garden value.

\section{S. Orbiculatus, Moench. Coral Berry.}

\section{(S. vulgaris, Michaux.)}

A deciduous shrub, 3 to $7 \mathrm{ft}$. high, of dense, bushy habit; branches thin, densely leafy, spreading, very downy. Leaves oval or ovate, with a rounded base, $\frac{1}{2}$ to $\mathrm{I} \frac{1}{4}$ ins. long, $\frac{1}{4}$ to $\frac{3}{4}$ in. wide; dark dull green above, hairy and somewhat glaucous beneath; stalk $\frac{1}{12}$ in. long. Flowers produced in August and September in short, dense clusters in all the leaf-axils from the lower side of the twigs. Corolla bell-shaped, $\frac{1}{8}$ in. long, dull white, the style hairy. Berries purplish red, between egg-shaped and globose, $\frac{1}{6}$ in. long.

Native of the eastern United States; introduced in $173^{\circ}$. A neat bush with the leaves arranged in opposite rows on the branches, but with little beauty of flower. The fruits are pretty, and when freely borne make the shrub extremely ornamental in autumn and winter, but it does not bear fruit so freely in this country as in its native one, except after a hot summer like that of $19 \mathrm{Ir}$.

Var. VARIEGATUS.-Leaves smaller than in the type, bordered unevenly with yellow. A good variegated shrub.

S. orbiculatus differs from all the rest of the species here mentioned in having a downy style and red berries. These characters and the long array of short flower-spikes beneath the branches make it the most distinct of the cultivated members of this genus.

\section{S. OREOPhilus, A. Gray.}

A deciduous shrub, 2 to $3 \mathrm{ft}$. high, of spreading habit, with either smooth or downy young shoots and leaves, the latter narrowly to broadly oval, $\mathrm{I} \frac{1}{2}$ 
to 2 ins. long, $\frac{3}{4}$ to $\mathrm{I}$ in. wide on strong barren shoots, half or less than half as large on the flowering twigs. Flowers mostly in pairs in the leaf-axils of short twigs. Corolla whitish, tubular or slightly tapering towards the base, $\frac{1}{3}$ to $\frac{1}{2}$ in. long, the tube four or five times as long as the lobes; style smooth, half or less than half the length of the corolla. Fruit white, oval, $\frac{1}{3}$ in. long.

Native of western $N$. America; introduced in 1898. It is a distinct species because of its comparatively long, tubular corolla and short style. It is distinguished from rotundifolius by the flattened seeds being pointed at one end. Chiefly of botanical interest.

\section{S. RaCemosus, Michaux. SNOWberry.}

A deciduous shrub, up to 8 or to $\mathrm{ft}$. high, spreading by underground suckers, and forming dense thickets of erect, many branched stems with shredding bark; young wood smooth. Leaves roundish oval to roundish ovate, sometimes lobed, $\frac{3}{4}$ to 3 ins. long, from $\frac{1}{2}$ to $1 \frac{1}{2}$ ins. wide; blunt or rounded at the apex, smooth on both surfaces; stalk $\frac{1}{8}$ to $\frac{1}{4}$ in. long. Flowers of little beauty, $\frac{1}{4}$ in. long, produced at the end of the twigs, and in the terminal leaf-axils during June and July, in short spikes ; corolla pink, bellshaped, lobed to about one-third its depth, hairy within ; stamens, and especially the smooth style, enclosed within the corolla. Fruit globular, $\frac{1}{2}$ to $\frac{2}{3}$ in. wide, snow-white, pulpy when ripe.

Native of N. America on both the eastern and western sides; introduced in 1817 . This well-known shrub ripens its fruit in October, and having apparently no attraction for birds, they remain on the twigs up to New Year or later, interesting for their pure whiteness. Whilst the plant repays good cultivation by the greater size and abundance of the fruit (which often weigh down the branches in graceful arches), there are few shrubs more useful for filling up dark out-of-the-way corners. Although deciduous, its stems and twigs are dense enough to make an effective screen.

The snowberry described above is the common type of gardens. It is distinguished by Fernald (Gray's Manual, ed. vii., p. 757) as var. LÆVIGATUS. He states that the typical S. racemosus of Michaux is a dwarfer shrub, 1 to 3 ft. high, whose leaves are green on both sides and hairy beneath.

\section{S. ROTUNDIFOlius, A. Gray.}

A deciduous shrub, 2 to $3 \mathrm{ft}$. high; branches very leafy, covered at first with minute down. Leaves roundish to oval or ovate, $\frac{1}{3}$ to 1 in. long, pointed or blunt at the apex, more or less downy beneath, sometimes with sinuous margins, but otherwise entire. Flowers stalkless, produced in June and July singly or in pairs in the upper leaf-axils, and the end of the shoot in a short spike. Corolla pinkish white, $\frac{1}{4}$ to $\frac{1}{3}$ in. long, between funnel and bell-shaped, shallowly five-lobed; hairy towards the base inside; style smooth and, like the stamens, enclosed within the corolla. Fruit white, oval or nearly globose, $\frac{1}{4}$ in. wide.

Native of Western N. America; of but little garden value. It is allied to S. oreophilus but has a shorter corolla, and the two nutlets (popularly "seeds") in the fruil are shorter and equally broad and blunt at both ends.

\section{SYMPLOCOS CRATEGOIDES, Buchanan-Hamilton. STYRACACE $Æ$.}

A deciduous shrub or small tree, of light and elegant aspect; young shoots hairy. Leaves oval, ovate, or somewhat obovate; $\mathbf{I}_{2}^{\frac{1}{2}}$ to $3 \frac{1}{2}$ ins. 
long, $\frac{3}{4}$ to $I_{4}^{3}$ ins. wide; tapering at both ends, finely toothed, slightly hairy above, more so on the veins beneath; stalk $\frac{1}{8}$ to $\frac{1}{3}$ in. long, hairy. Flowers fragrant, white, $\frac{1}{3} \mathrm{in}$. across, produced during late May and early June in terminal hairy panicles, and in the leaf-axils on small lateral twigs; the whole inflorescence is $I_{2}^{\frac{1}{2}}$ to $2 \frac{1}{2}$ ins. long. The stalk of the axillary inflorescence appears to spring from the stem some distance above the leaf-axil itself, which seems to be due to its union to the branchlet. Petals five, united only at the base; stamens about thirty in five clusters, one cluster attached to the base of each petal. Fruit roundish oval, mostly one-seeded, becoming bright blue in autumn.

Native of China, Himalaya, and Japan; introduced from the lastnamed country to the United States about $187 \mathrm{r}$; afterwards to England. I have not seen it bearing fruit in this country, although it flowers freely and prettily. In the Arnold Arboretum, Mass., it bears fruits profusely; they are described as of "a brilliant ultramarine blue," and hanging in pendulous clusters. It is best propagated by imported seeds, which usually lie dormant a year.

S. TINCTORIA, L' Heritier. Horse Sugar.-Native of the south-eastern United States; introduced to this country in $\mathrm{I} 780$ and several times since, but not hardy. It got its name from the sweet taste of its leaves, which are greedily eaten by horses and cattle. The fruit is yellowish brown, $\frac{1}{3}$ in. long, oval, and produced in a cluster of three or four close to the stem.

Symplocos is allied to Halesia and Styrax, but differs in the arrangement of the stamens noted above. The hairs, too, on the leaves, etc., are simple (not stellate). Some authors place the genus in another Natural Order-Symplocaceæ.

\section{SYRINGA. LILAC. OLEACEÆ.}

A group of small trees and shrubs, consisting of about two dozen species, confined to the Old World. One or two are found in E. Europe, the rest in N.E. Asia. The cultivated species are deciduous, and have opposite leaves, usually neither toothed nor lobed; but in one species they are pinnate (S. pinnatifolia), and in another pinnately lobed (S. persica laciniata). The flowers appear in panicles, often pyramidal, but sometimes of indeterminate shape. Corolla tubular, with four lobes; calyx bell-shaped, unevenly toothed; stamens two. Seed-vessel a capsule of flattened or spindle shape, composed of two valves, which split from the top downwards when ripe.

There are two distinct sections of the genus :-

I. The true lilacs. - Corolla-tube long, enclosing the stamens. Flowers usually purple, sometimes white.

2. The Ligustrina or privet-like group.-Corolla-tube short, the stamens protruded well beyond the mouth. Flowers white. This group is composed of three species-S. amurensis, japonica, and pekinensis.

Among the true lilacs there is a well-marked section which form a terminal bud and flower on the leafy shoots of the year; it includes, 
besides some species newly introduced, S. Emodi, Josikæa, and villosa (Bretschneideri). The remainder, of which vulgaris is the type, flower on naked or leafless panicles, often in terminal pairs.

The cultivation of the common lilac is dealt with under the heading of S. vulgaris, and the soil and general treatment are the same for the rest of the genus. All of them can be propagated by layers, most of them by cuttings. Cuttings should be made of mature shoots in August, and placed in a sheltered position under handlights. Softer cuttings taken earlier will often take root in gentle heat.

\section{S. AMURENSIS, Ruprecht.}

\section{(Ligustrina amurensis, Regel.).}

Of the three species now in cultivation which represent the section Ligustrina (or privet-like lilacs), this is the least satisfactory in my experience. It was discovered in Manchuria by Radde, a Russian botanist, in 1857 , and like many other shrubs from the same region, its flower-buds are easily excited into premature growth by warm January and February days, and are almost invariably cut off by late frosts. I have never seen a perfect panicle at Kew, although the flowers "set" freely enough. The species is a sturdy bushy shrub, 6 to $8 \mathrm{ft}$. (perhaps more) high. Leaves 2 to 4 ins. long, I to 2 ins, wide, ovate or oval, usually with a drawn-out apex, the base more or less tapered; stalk about $\frac{1}{2}$ in. long. Flowers dull white, not very pleasantly scented, produced during June in panicles which, when perfectly developed, are 4 to 6 ins. long, 3 to 4 ins. wide; tube of corolla very short.

\section{S. CHINENSIS, Willdenow. ROUEN LILAC.}

\section{(S. dubia, Persoon; S. rothomagensis, Richard.)}

A deciduous bush of dense rounded habit, to to. $15 \mathrm{ft}$. high. Leaves ovate, $1 \frac{1}{2}$ to $2 \frac{1}{2}$ ins. long, $\frac{5}{8}$ to $1 \frac{1}{4}$ ins. wide; rounded or broadly wedge-shaped at the base, taper-pointed, smooth; stalk $\frac{1}{3}$ to $\frac{1}{2}$ in. long. Flowers of the common lilac shade, intermediate in size between those of the common and Persian lilacs, somewhat loose; corolla tube $\frac{1}{3}$ in. long, lobes $\frac{1}{4}$ in. long.

A hybrid between the Persian and common lilacs, said to have been raised in the Botanic Garden of Rouen by $\mathrm{Mr}$ Varin in the last quarter of the eighteenth century; introduced to Britain in 1795. There is nothing improbable in this story, but the plant has been known in China for more than one hundred years, and is still common in cultivation about Pekin. It is quite possible the plant had two separate origins. It is a bush of great beauty when in flower, the growths made during the summer producing the following May a pair of flower-trusses 3 to 6 ins. long at each joint towards the end, so that the whole makes a heavy, arching, compound panicle. It sometimes produces fertile seed.

Several forms of the Rouen lilac are in cultivation: alba, flowers pale pink; duplex and La Lorraine, double; metensis, rosy lilac; rubra (Saugeana), lilac-red.

\section{S. Emodi, Wallich. Himalayan LilaC.}

A large robust shrub, Io to $15 \mathrm{ft}$. high, the branchlets dark olive green or brownish, but freely spotted with long, narrow, pale excrescences. Leaves 3 to $\delta$ ins. long, and about half as wide; oval or sometimes ovate or obovate, 
tapering at the base; dark dull green above, pale, or almost white beneath. Panicles mostly columnar, 3 to 6 ins. long, one or three of which terminate the young shoots. Flowers not pleasantly scented, expanding in June.

Corolla $\frac{3}{8}$ in. long, scarcely as much wideacross the lobes, white or slightly purple tinted. Calyx bell - shaped, very shallowly lobed. Seed-vessels $\frac{3}{4}$ in. long, each half ending in a slender, almost tail-like point.

Native of the Himalaya ; long known in gardens, but not common. It is useful in flowering rather late. Closely allied to villosa, it is scarcely as good a shrub, and differs in its leaves being whiter beneath and downy only on the midrib, or smooth. The seed-vessel also differs in being rather longer and in having the more attenuated a pices mentioned above. S. Emodi never seems to hav the magnificent inflorescences characteristic of vigorous specimens of S. villosa - nor are the flowers ever so richly coloured.

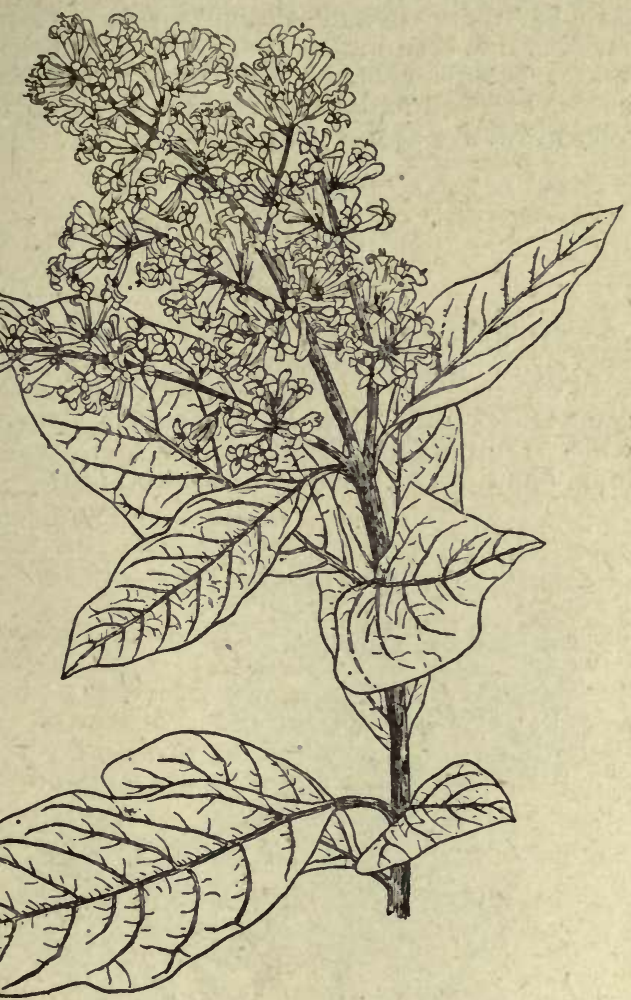

SYRINGA EMODI.

Var. VARIEGATA has leaves broadly, irregularly, and rather effectively margined with yellow.

\section{S. JAPONICA, Decaisne.}

(Ligustrina amurensis var. japonica, Maximowicz.)

A deciduous tree up to $30 \mathrm{ft}$. high, of erect habit, often a shrub; young shoots not downy, but marked with small, round, pale dots. Leaves ovate with a long tapering point, rounded or broadly wedge-shaped at the base; 3 to 8 ins. long, about half as wide; and either smooth or slightly downy beneath, smooth above; stalk $\frac{1}{2}$ to I in. long. Flowers white, not fragrant, produced at the end of the branch, usually in a pair of broad pyramidal panicles, 8 to 12 ins. long, 6 to 8 ins. through. Corolla $\frac{1}{4} \mathrm{in}$. across, the short tube almost hidden in the calyx, which is bell-shaped and scarcely lobed. Seed-vessel $\frac{3}{t}$ in. long, scimitar-shaped, smooth, blunt at the end. 
Native of Japan ; introduced to the Arnold Arboretum in 1876 and thence to Kew in I886. Professor Sargent, who saw it wild on the hills of central Yezo, says that there it is an ungainly, straggling tree, 25 to $30 \mathrm{ft}$. high, with a trunk rarely 12 to 18 ins. thick. I saw it flowering in June, I910, in the Arnold Arboretum and other places near Boston, Mass., and it was the most striking tree then in flower, some being specimens over $30 \mathrm{ft}$. high, of shapely, rather columnar habit, and laden with blossom. In Britain it does not succeed so well and remains more a shrub than a tree, but even here it is very attractive at the end of June.

\section{S. JosIKæA, Jacquin. JosIKa LILAC.}

(Bot. Mag., t. 3278.)

Belonging to the same group of lilacs as S. villosa and S. Emodi, this is inferior in many respects to both. Its flowers, however, are of a deeper lilac than either. The leaves are whitish beneath, as in S. Emodi, and of the same shape, 2 to 5 ins. long. Panicle slender, 4 to 8 ins. long, 2 to 4 ins. wide. Corolla $\frac{1}{2}$ in. long, $\frac{1}{4}$ in. or less across the lobes. Seed-vessel $\frac{5}{8}$ in. long, bluntish at the end. Blossoms in early June.

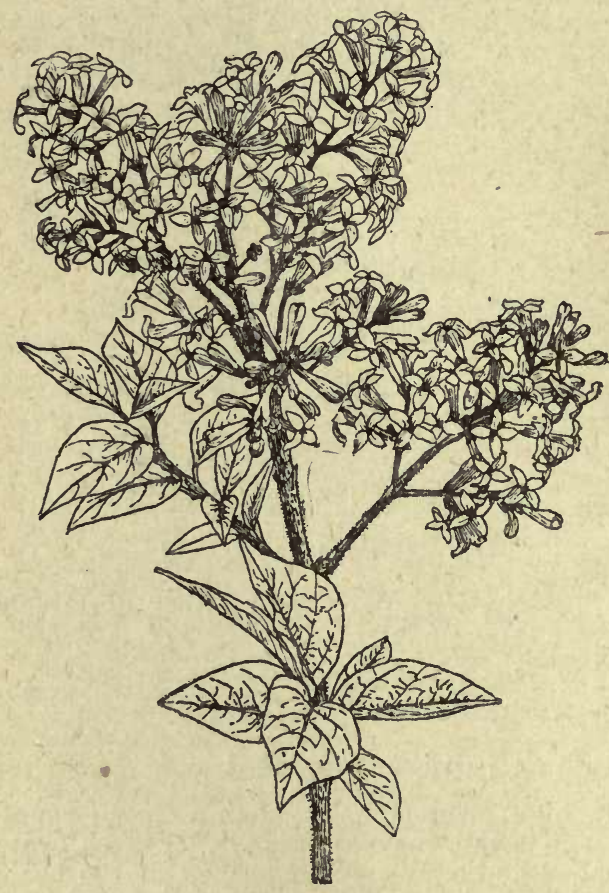

SYRINGA JULIANA.

This lilac was first noticed in Hungary about 1830 , having been sent by the Baroness von Josika to Jacquin the botanist at Vienna, who named it in compliment to her. Her specimens came from Siebenburgen in E. Hungary, which has since been usually regarded as the native home of this lilac. This, of -course, is not improbable, and the plant has since been found apparently wild there. But some authorities consider it more likely to be of N. Chinese originpossibly a deeper coloured variety of villosa with smooth leaves. It is distinguished from $S$. villosa in flower by the much denser arrangement of the flowers in whorls.

\section{S. JULIANA, C. K. Schncider.}

(Bot. Mag., t. 8423.)

Adeciduous spreading shrub of stiff, bushy habit, perhaps 4 to $6 \mathrm{ft}$. high ; young shoots slender, very downy, the down persisting for two years.

Leaves I to 2 ins. long, $\frac{1}{2}$ to I in. wide; oval (sometimes inclined to ovate or obovate), tapered at the base, finely pointed; dull dark green, with appressed hairs above; grey and very hairy beneath; stalk $\frac{1}{6}$ to $\frac{1}{3}$ in. long, hairy. 
Panicles 2 to 3 ins. long, usually in pairs from the terminal buds of the previous year's shoots, sometimes from the two or three uppermost pairs; hairy like the shoots. Flowers fragrant, $\frac{1}{4}$ to $\frac{1}{3}$ in. long, $\frac{1}{8}$ to $\frac{1}{6}$ in. across the lobes. Calyx violet-coloured, smooth, with short pointed lobes. The hairy flower-stalks (about $\frac{1}{8}$ in. long) carry one to three blossoms. Corolla deep lilac outside, pale inside the lobes.

Native of W. China; introduced for Messrs Veitch about 1900. It is allied to S. pubescens and S. VELUTINA, Komarov, but is much more downy than the first $(q . v$.$) and its flowers are more deeply coloured. The second$ species may not be in cultivation, but has a downy calyx. S. Julianæ flowers in May and June and is both distinct and pretty, but not equal to the best lilacs.

\section{S. OBLATA, Lindley.}

\section{(Bot. Mag., t. 7806.)}

A deciduous shrub, Io to $\mathbf{I} 2 \mathrm{ft}$. high, or a small tree, similar in habit to the common lilac; young shoots smooth, round; buds purplish. Leaves very broadly heart-shaped, often considerably wider than long, being $1 \frac{1}{2}$ to 4 ins. wide, $1 \frac{1}{2}$ to 3 ins. long; short-pointed, smooth on both surfaces; stalk $\frac{3}{4}$ to $I$ in. long. Flowers pale lilac, produced at the beginning of May in short broad panicles, usually in pairs from the uppermost joints of the previous year's wood. Corolla-tube $\frac{1}{2}$ in. long, about $\frac{2}{3}$ in. across the lobes; calyx slightly glandular, with pointed lance-shaped lobes. Seed-vessel $\frac{3}{8}$ in. long, slender-pointed.

Native of N. China; introduced by Robt. Fortune from a garden in Shanghai in 1856. It is closely allied to S. vulgaris, but is easily distinguished by the wider leaves and by flowering about a fortnight earlier. My experience of it is, that it is the most unsatisfactory of all the lilacs except S. amurensis. It is excited into growth by mild weather in early spring, only to have its young leaves and flowers destroyed by later frost. Probably in higher localities it may succeed better, for the shrub itself is perfectly hardy, and in climates with a much harder but more settled winter than ours flowers abundantly.

S. AFFINIS, L. Henry, is a white-flowered lilac very near S. oblata; it has been called "S. oblata var. alba." The young shoots are finely downy the leaves on the average smaller. Native of $\mathrm{N}$. China.

\section{S. PEKINENSIS, Ruprecht.}

\section{(Ligustrina pekinensis, Regel.)}

A deciduous small tree of spreading, graceful habit, over $20 \mathrm{ft}$. high eventually; young shoots smooth. Leaves ovate, oval, or ovate-lanceolate, 2 to 4 ins. long, I to 2 ins. wide; mostly tapering, sometimes rounded at the base, long and tapering at the apex, quite smooth on both surfaces; stalk slender, $\frac{1}{2}$ to $\frac{3}{4}$ in. long. Flowers white, very densely clustered in numerous loose panicles 3 to 5 ins. long, produced in pairs. Seed-vessel $\frac{5}{8}$ to $\frac{3}{4}$ in. long, smooth, pointed at the end.

Native of the mountains of N. China, where it was discovered by the Abbé David. It was raised at Kew in $188 \mathrm{I}$ from seed sent from Pekin by the late Dr Bretschneider. Botanically allied to S. japonica, it is very distinct as seen growing. It has much more slender branches, the leaves are smaller, the inflorescence instead of being sturdy, pyramidal, and erect, is much smaller and is a loose, rather shapeless panicle; the seed vessel, too, differs in the more pointed apex. It is perfectly hardy, and has grown more 
quickly at Kew than S. japonica, having now a trunk more than 20 ins. in girth, and flowering freely towards the end of June.

Var. PENDULA.- Raised from Chinese seed in the Arnold Arboretum, Mass., and a very graceful, pendulous tree.

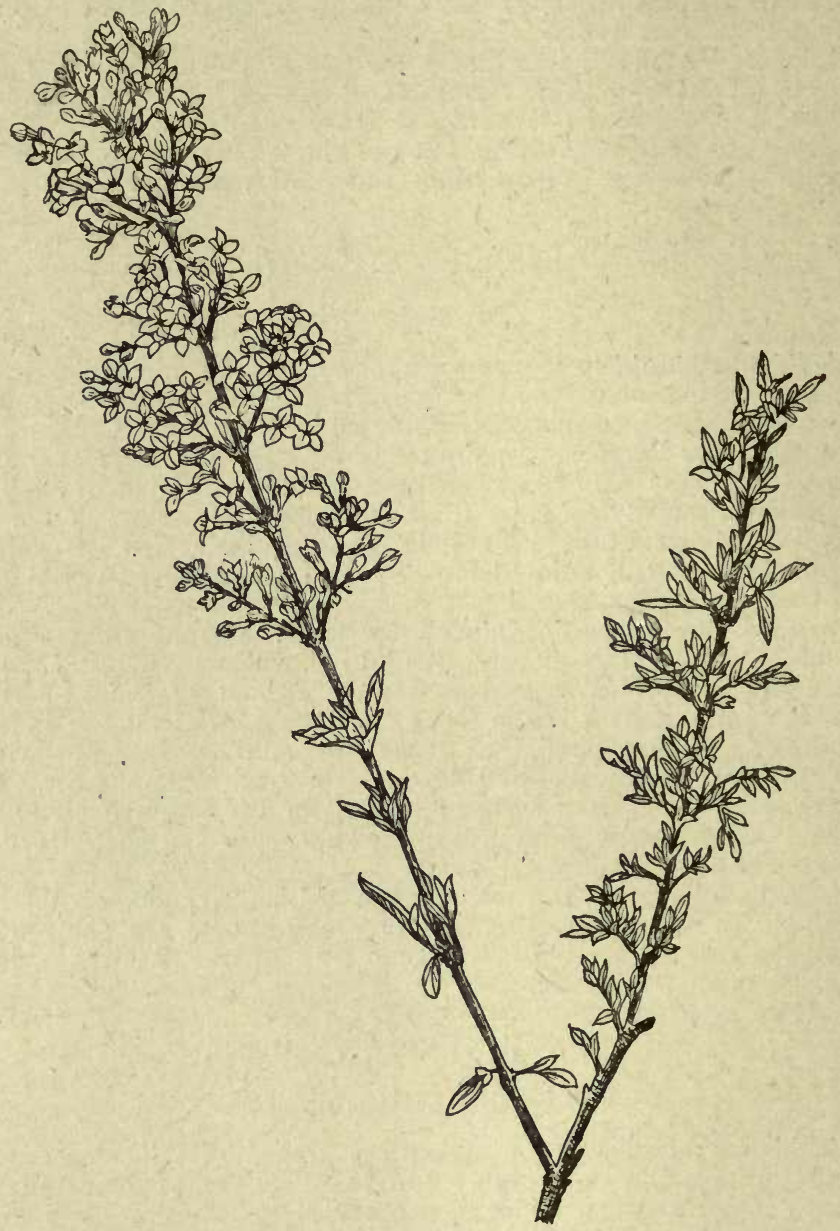

SYRINGA PERSICA var. LACINIATA.

S. PERsicA, Linncus. PERsian LilaC.

(S. afghanica, $C$. K. Schneider (wild type).)

A deciduous shrub, 4 to $6 \mathrm{ft}$. high, of dense, bushy, rounded habit; young shoots slender, smooth. Leaves lance-shaped or ovate lance-shaped (rarely three-lobed), with a long tapering apex and a more abruptly tapered base; green and smooth on both sides; I to $2 \frac{1}{2}$ ins. long, $\frac{1}{3}$ to $\frac{1}{2}$ in. wide; stalk $\frac{1}{3}$ in. long. Flowers of the common lilac shade and fragrance, produced in May 
from the uppermost buds of the preceding summer's growth in small, sometimes branching panicles, 2 to 3 ins. long and as much wide. Corolla-tube about $t$ in. long, the four spreading lobes rather shorter. Calyx funnelshaped with four short, pointed lobes. Seed-vessels $\frac{1}{2}$ in. long, cylindrical.

Native of Afghanistan; said to have been introduced to England in 1640. Cultivated from time immemorial in Persia and India, it has altered somewhat from the wild type, which was found by Dr Aitchison when attached to the Afghan Boundary Commission in 1879; this has shorter-stalked leaves and more pointed fruits than the cultivated S. persica.

Var. ALBA, Aiton.-Flowers white.

Var. LACINIATA, Aiton.-Leaves cut back to the midrib into five, seven, or nine parallel oblong lobes. This variety appears to produce seed under cultivation more freely than either the typical or white forms.

The Persian lilac, in all its forms, is a delightful shrub both in its neat habit and fragrant blossom. Increased by cuttings of nearly ripe wood.

\section{S. PINNATIFOlia, Hemsley.}

A deciduous shrub, 6 to $8 \mathrm{ft}$. high, of elegant bushy habit; the young shoots and every other part of the plant free from down. Leaves pinnate, $I_{\frac{1}{2}}$ to $3 \frac{1}{2}$ ins. long, composed of seven, nine, or eleven leaflets, which are dull green, stalkless, ovate-lanceolate; $\frac{3}{4}$ to $1 \frac{1}{4}$ ins. long, $\frac{1}{4}$ to $\frac{3}{8}$ in. wide; pointed, the base rounded, or in the case of the terminal leaflets frequently attached to the common stalk by a portion of the blade. Flowers white, with a slight lilac tint, produced in May in panicles $I \frac{1}{2}$ to 3 ins. long, which spring usually in opposite pairs from the joints of the previous year's wood. Corolla-tube $\frac{1}{2}$ in. long, the lobes at the mouth spreading and giving the flower a diameter of $\frac{1}{4}$ in.; calyx-lobes rounded.

Native of W. China; discovered by Wilson in 1904 at an elevation of $9000 \mathrm{ft}$. The pinnate leaves of this species at once suggest an affinity with the cut-leaved variety of the Persian lilac, but they are divided (except sometimes near the apex) into quite distinct leaflets, and not merely lobed as in the other. It has flowered several times, and will no doubt prove quite hardy. It has great interest as a new and distinct lilac, but its garden value will never, I think, equal that of the Persian lilac.

\section{S. PUBESCENS, Turczaninore.}

\section{(S. villosa of Bot. Mag., t. 7064-not of Vahl.)}

A deciduous shrub or small tree, $\mathrm{I} 2$ to $\mathrm{I} 5 \mathrm{ft}$. high, forming a rounded head of branches; young shoots smooth. Leaves I to $2 \frac{1}{2}$ ins. long, $\frac{3}{4}$ to $I_{2} \frac{1}{2}$ ins. wide ; broadly ovate, sometimes roundish, tapered abruptly at the apex to a short point, rounded or broadly wedge-shaped at the base; dull green and smooth above, pale and with a little scattered down beneath, most abundant on the midrib; stalk $\frac{1}{4}$ to $\frac{1}{2}$ in. long. Flowers fragrant, pale lilac or nearly white, produced along with the young leaves during early May in leafless panicles from one or both of the terminal buds of last year's shoots. The panicles are 3 to 5 ins. long, 2 to 3 ins. wide, the corolla-tube slender, $\frac{1}{2}$ in. long; lobes $\frac{1}{8}$ in. long, the incurving of the margins making them cupped. Calyx very short, with triangular lobes.

Native of N. China; introduced by the late Dr Bretschneider in I88I. It is only a second-rate lilac in this comntry, owing to the frequent injury of the young growths and panicles by late frost. In the United States, where the summer heat is greater, and the seasons better defined, it is very beautiful. The confusion in the naming of this shrub and S. villosa, $V a h l$, is alluded to under that species. 


\section{S. VILLOSA, Vahl.}

(S. Bretschneideri, Lemoine, Bot. Mag., t. 8292 ; S. Emodi var. rosea, Cormu; S. Josikæa var. eximia, Hort.)

A deciduous shrub, ro $\mathrm{ft}$. or more high, of robust habit; branches erect, stout, stiff, quite smooth when young, marked with a few pale dots. Leaves oval or oval lance-shaped, pointed, rounded or wedge-shaped at the base; 2 to 6 ins. long, I to $2 \frac{1}{2}$ ins. wide; smooth and dark green above, glaucous and thinly furnished with bristle-like hairs or nearly smooth beneath; stalk $\frac{1}{4}$ to $1 \frac{1}{4}$ ins. long. Panicles terminal and axillary, often three at the end of a leafy shoot; they are usually 6 to Io ins. long (but I have measured exceptionally fine ones 18 ins. long); half to two-thirds as wide. Corolla lilac-rose, $\frac{1}{2}$ in. long, the lobes $\frac{1}{8}$ in. long, rounded, spreading. Calyx bellshaped with four short, pointed lobes; slightly hairy or smooth. Seedvessel about $\frac{1}{2}$ in. long.

Native of N. China; discovered early in the eighteenth century by Père d'Incarville, the Jesuit missionary; introduced to cultivation about 1885 . Much confusion has existed as to the correct name of this shrub. The name villosa has been given to the species above described as $S$. pubescens (see Hooker in Bot. Mag., t. 7064), but an examination of Vahl's original specimen shows that the plant latterly cultivated as S. Bretschneideri is the true villosa. Vahl's description is extremely misleading, especially where he describes the leaves as $I$ in. long! (they are occasionally 8 ins. long on strong shoots).

The beautiful lilac, perhaps the most robust of its section of the genus, flowers at the end of May and early in June, after the flowers of the common

lilac and its varieties have faded. It is one of the most desirable of hardy shrubs, vigorous in constitution, and free flowering. It differs from the vulgaris group in forming a true terminal bud, and in flowering on the current year's shoots. As will be noticed by the synonyms recorded above, it has by different authors been referred to S. Emodi and S. Josikæa, to both of which it is allied, but from both of which it differs in its larger, more open inflorescence.

\section{S. VUlgaris, Linnaus. COMMON LILAC.}

A deciduous shrub or small tree, up to $20 \mathrm{ft}$. high, usually producing a crowd of erect stems, but occasionally a single trunk over $2 \mathrm{ft}$. in girth, clothed with spirally arranged flakes of bark; shoots and leaves quite smooth. Leaves heart-shaped or ovate, 2 to 6 ins. long, from three-fourths to almost as much wide near the base; stalk $\frac{3}{4}$ to $I_{4}^{\frac{1}{4}}$ ins. long. Panicles pyramidal, 6 to 8 ins. long, usually in pairs from the terminal buds. On cultivated improved varieties, panicles 12 to 18 ins. long are produced. Flowers delightfully fragrant; corolla-tube $\frac{1}{3}$ to $\frac{1}{2}$ in. long, the lobes concave; calyx and flower-stalks more or less furnished with minute gland-tipped down. Seed-vessels smooth, $\frac{5}{8}$ in. long, beaked.

Native of the mountainous regions of E. Europe. Introduced to W. Europe in the sixteenth century. It has been cultivated in England for over three hundred years, and is now as characteristic a feature of village scenery as almost any native shrub.

The garden varieties of lilac, to be obtained at their best, must be given generous treatment. They like a deep, rather stiff, but well-drained loam, and should be mulched every second winter with rotted manure or bone meal. An important item in the cultivation of the finer lilacs is the removal of the flower-trusses as soon as they fade, so as to prevent the formation of 
seed, thereby concentrating the energies of the plant in the new growth and the succeeding crop of blossom. They need no systematic pruning, but in order to obtain fine trusses the weaker and superfluous shoots may be cut out at the same time as the old inflorescences are removed. Named lilacs should always be obtained on their own roots. The practice of grafting them on either privet or common lilac should never be encouraged; with the former as a stock they do not live so long or grow so well, and with the latter, unless a watch is maintained, the variety in time becomes overwhelmed by suckers. They are best propagated by layers, but cuttings also may be used. Isolated bushes-and a fine shapely lilac is an admirable ornament for a lawn-should be trained to a single stem by removing all the lower buds and subsequently the lower branches. As the lilac does not form a terminal bud, and naturally forks its branches every year, some training and pruning is at first needed to get a tree-like example. A selection of garden varieties of lilac planted in a broad mass, with the dwarfer Persian and Rouen lilacs on the margins, makes a splendid feature in May.

So many varieties are being raised, chiefly in France, that only a selection can be given here; many of them indeed are scarcely to be distinguished from each other :-

\section{SINGLE-FLOWERED.}

Alba grandiflora. White, large.

Dr Mirabel. Claret coloured; trusses fine.

Jacques Callot. Reddish lilac.

Madame Francisque Morel. Very large trusses-rosy lilac.

Marie Legraye. White; buds cream-coloured.

Negro. Deep blue-purple.

Pasteur. Flowers large, claret-coloured, in fine trusses.

Philemon. Flower red, in broad trusses.

Princess Marie. Pale lilac.

Prof. Sargent. Bright rosy lilac.

Souvenir de Louis Späth. Deep purple; perhaps the finest of this shade.

Ville de Troyes. Reddish lilac.

\section{DOUBLE-FLOWERED.}

Ahel Carrière. Blue-lilac.

Comtesse Horace de Choiseul. Greyish white.

Condorcet. Lilac-blue.

La Tour d'Auvergne. Purple-lilac.

Madame Casımir Périer. Large, creamy white.

Madame de Miller. White.

Madame Lemoine. White.

Marc Micheli. Pale lavender blue, white behind.

Michael Buchner. Pale rosy lilac.

Miss Ellen Willmott. Snow-white, with fine trusses and flowers.

President Loubet. One of the darkest purple double-flowered kinds.

William Robinson. Violet-mauve.

\section{TAMARIX. TAMARISK. TAMARICACE $E$.}

A group of shrubs or small trees, natives of the Old World, and often inhabiting maritime situations or places where the soil is permeated with saline substances. Some half a dozen species are grown in British gardens, all distinguished by the feathery character of their branches, the minute scale-like leaves resembling those of some junipers, and the small flowers crowded on short racemes. There are few genera of shrubs whose 
nomenclature is more obscure and involved, many of the species needing microscopical examination for their identification.

The tamarisks are easily cultivated, and none of them appear to find the peculiar conditions under which they occur wild essential, although perhaps they do not thrive so well in their absence. Although some of them come from hot, dry regions, the saline substances which are absorbed by the plant in such places prevent excessive transpiration. But when these are absent from the soil, and nature's safeguard against too great a loss of moisture no longer exists, a more regular supply of moisture at the root becomes necessary. This simply means that in inland districts they need a fairly good, deep loam. No shrubs are more easily propagated than these. It is only necessary to make cuttings of the previous summer's wood about the thickness of a lead pencil and, say, 8 ins. long, and place them in the open ground in early winter, burying about twothirds of the cutting. On the south coast of England, where hedges are often made of $T$. anglica, the process consists of simply cutting out pieces the length and thickness of a stout walking-stick, sharpening them at one end, and driving them in the ground where the hedge is to be.

For exposed seaside places there are few shrubs so beautiful and so conveniently managed as the tamarisks. In gardens the late summer or autumn flowering species may be cut back every February if it be desirable to keep them low.

\section{T. ANGLiCA, Webb. ENGLish TAMARISK.}

An evergreen shrub, 3 to Io $\mathrm{ft}$. high, inhabiting maritime districts on the coasts of England and France. In habit it is erect, the young wood reddish brown. Leaves minute, bright green; ovate-lanceolate, narrowed towards the base, smooth. Flowers in slender racemes $I$ to 2 ins. long, white tinged with pink outside, each flower $\frac{1}{8}$ in. across, ovate in bud, and produced in the axil of a narrow bract. Stamens five, the disk on which they are inserted not showing rounded teeth (as in gallica) between the points of attachment.

Closely allied to T. gallica and by some botanists treated as a form of it, the English tamarisk differs chiefly in the shape of the flower-bud, and in the absence of lobing on the disk on which the stamens are inserted. It may be seen at some of our seaside resorts, especially at Felixstowe and Bognor, where great masses of it, planted and wild, make a charming display in late summer and early autumn. It evidently prefers maritime rather than inland positions. On the coasts of Dorset and Devon it flowers up to Christmas.

\section{T. GALLICA, Linnceus.}

An evergreen or deciduous shrub or small tree, in this country to to 12 $\mathrm{ft}$. high, but as much as $30 \mathrm{ft}$. in more southern localities. Branches erect. the young ones with smooth, purplish bark. Leaves lanceolate or ovatelanceolate, broad at the base, glaucous. Racemes slender, cylindrical, I to 2 ins. long, densely set with flowers, which are pink when open, globose in bud. Stamens five, the disk on which they are attached having ten shallow, rounded lobes.

The Gallic tamarisk is a species of very uncertain limits, both botanical and geographical. By some writers it is made to include plants growing as far apart as N. Africa and China, and some make it include the English 
tamarisk described above. The species as we know it under cultivation is a native of the west coast of France. It flowers very prettily in late summer and autumn.

\section{T. HISPIDA, Willdenow. \\ (T. kashgarica, Hort.)}

A deciduous shrub, up to 3 or $4 \mathrm{ft}$. high, distinct from all other cultivated tamarisks in the downiness of its young branches and leaves. It has a rather erect, compact habit, and the leaves are very glaucous; the largest less than $\frac{1}{8}$ in. long, sharply pointed, but comparatively broad at the base; the smallest are only one-third or one-fourth the size. Flowers bright pink, opening in late August and September, and borne in erect racemes 2 or 3 ins. long terminating the branchlets.

This handsome tamarisk, easily distinguished from the others here mentioned by its hairy twigs and leaves, was introduced to cultivation by the Russian traveller Roborowsky, who collected seeds near Kashgar in W. Asia and sent them to Messrs Lemoine of Nancy. It was put on the market in 1893. It has also been found in the deserts east of the Caspian Sea. Whether it is not quite hardy, or whether (as is more likely) it does not get enough sun in England to ripen its wood properly, this species has not proved long-lived at Kew. Its glaucous white colour, its handsome flowers, and the fact that it blooms during the whole of September, make it a charming acquisition wherever it thrives, but it is evidently better suited for a continental climate than for ours.

\section{T. JUNIPERINA, Bunge.}

\section{(T. chinensis, Siebold; T. japonica, Hort.; T. plumosa, Hort.)}

A deciduous shrub or small tree, becoming in time gaunt in habit, the very distinct plumose branches covered with pale green foliage. In their final subdivisions the branchlets are the thinnest of cultivated tamarisks, scarcely thicker than threads, but through its close branching, this species is the densest in habit. The larger leaves scattered on the thicker branchlets are $\frac{3}{16}$ in. long, pointed, and ultimately decurved; they become smaller on each subdivision until, on the final ramifications they are about $\frac{1}{32}$ in. long. Flowers bright pink in the bud state, paler after opening; produced in May on the twigs of the preceding season; racemes about $\mathrm{r}_{2} \frac{1}{2}$ ins. long.

Native of N. China, Manchuria, and perhaps Japan. It is the most graceful of hardy tamarisks, and is worth growing for the fine plumose effect of its branches, which stand out very prominently when associated with other shrubs, not only for their elegance, but also for the peculiar freshness of their pale green. It has lived outside for many years at Kew, and forms a rugged trunk, but rarely flowers. It is cut back in hard winters.

\section{T. PENTANDRA, Pallas.}

(Bot. Mag., t. 8138 ; T. hispida æstivalis, Hort.; T. Pallasii, Desvois.)

A deciduous shrub or small tree, ultimately from 12 to $15 \mathrm{ft}$. high, or upwards, with long, slender, plumose branches. Leaves very small, pointed; the largest $\frac{1}{8}$ in. long, arranged at intervals along the flowering shoots; the smallest one-fifth as large, and crowded fifty or more to the inch. Flowers arranged densely in slender, sometimes branching racemes, I to 5 ins. long, 
each tiny blossom $\frac{1}{8}$ in. across, rosy pink; they cover the whole terminal part of the current year's shoot, which is thus transformed during August into a huge plume-like panicle of blossom as much as $3 \mathrm{ft}$. long. Sepals, petals, and stamens, all five in number.

Native of S.E. Europe and Asia Minor, especially on the banks of tidal rivers. This beautiful tamarisk is quite hardy, and one of the most pleasing

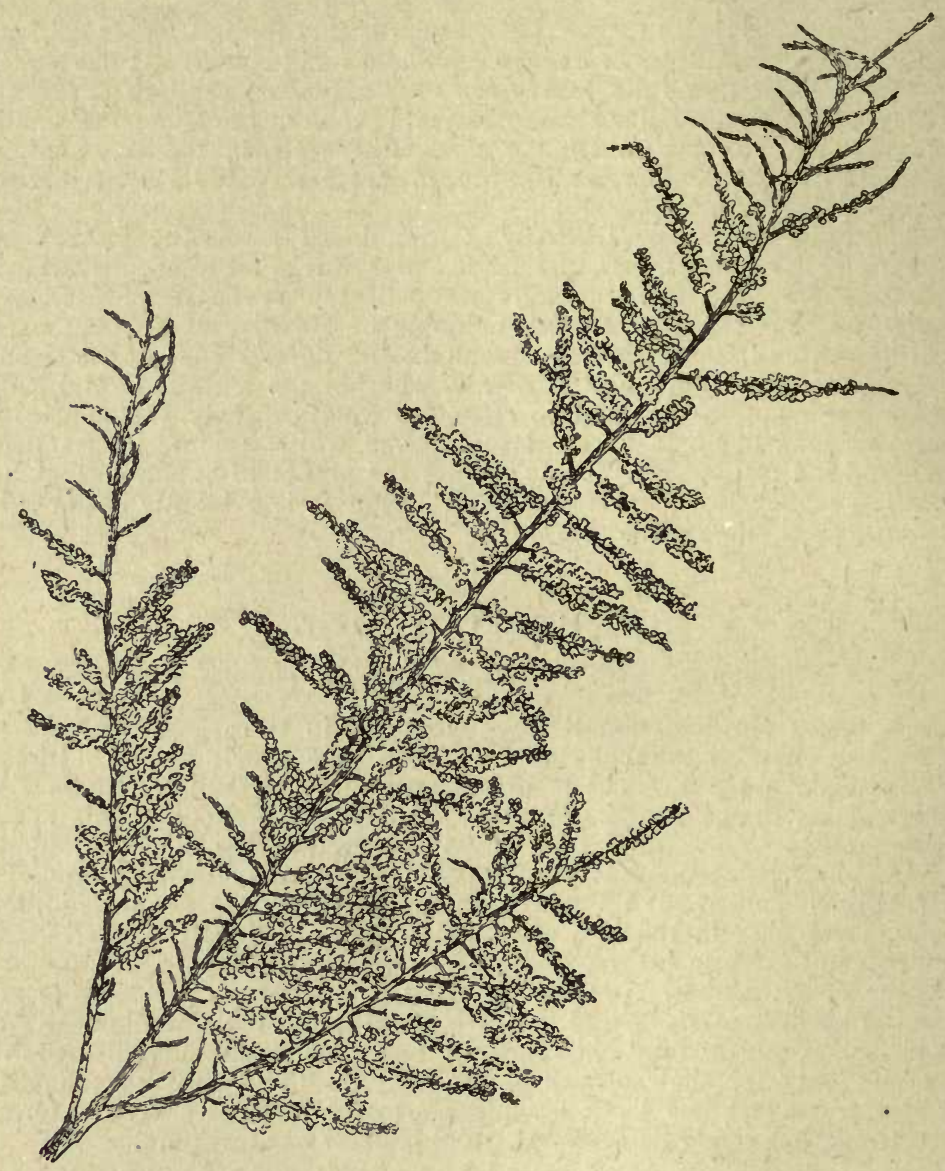

TAMARIX TETRANDRA.

of late-flowering shrubs. It should be planted in groups large enough for its soft rosy plumes to produce an effect in the distance. To obtain it at its best, it is necessary to cut it back every winter almost to the old wood. It then sends up the long slender branches which flower for six weeks or so in August and September. It is propagated with the greatest ease by making cuttings, 6 to 9 ins. long, in early winter of the stoutest part of the season's growth, and putting them in the ground out-of-doors, like willows. It has 
been recalled a variety of $\mathrm{T}$. hispida, but that species, as stated above, is very distinct in its downy twigs and leaves.

\section{T. TETRANDra, Pallas.}

A deciduous shrub, ro to $5 \mathrm{ft}$. high, with smooth dark branches which are usually arching in plants a few years old. The minor branchlets or twigs are very thin, clothed densely with minute, scale-like leaves, which under the lens are seen to be closely imbricated, pointed, and incurved at the apex. Flowers very small and closely set on slender, cylindrical, straight racemes, I to 2 ins. long, which develop in May from the branches of the previous year. They are bright pink, very freely borne, and have each four stamens.

Native of the eastern Mediterranean region, the Crimea, Caucasus, etc. It is the commonest species in gardens, being supplied by continental nurserymen under at least five names, such as "africana," "algeriensis," "caspica," "indica," and "parviflora," some of which belong rightly to distinct species. Among cultivated tamarisks it is distinct in flowering early from the old wood and in having four stamens. A shrub of great beauty and grace, admirable in masses.

The true T. PARVIFLORA, De Candolle, is sometimes grown as " $\mathrm{T}$. tetrandra purpurea." It has dark reddish purple shoots and darker flowers than the above; stamens four.

\section{TAPISCIA SINENSIS, Oliver. SAPINDACEA.}

A deciduous tree, usually about $30 \mathrm{ft}$. high (very rarely as much as $80 \mathrm{ft}$., with a trunk $\mathrm{I} 2 \mathrm{ft}$. in girth). Leaves pinnate, $\mathrm{I} 2$ to $\mathrm{I} 8 \mathrm{ins}$. long, composed of five or seven leaflets, which are ovate, heart-shaped at the base, pointed, toothed, 3 to 5 ins. long, greyish beneath. Flowers small, yellow, in axillary panicles 4 to 6 ins. long, the divisions of the panicle very slender; they have a charming honey-like fragrance. Fruit egg-shaped, black, $\frac{1}{2}$ in. long.

Native of the mountains of W. Hupeh, China, at elevations of 2500 to $3000 \mathrm{ft}$., where it is rare; also of Szechuen at similar elevations, where it is more common. It is the only species of the genus known. Introduced by Wilson for the Harvard University in 1908. I am doubtful of its proving hardy except in the south-west; where it is hardy its chief garden value will be in its bold pinnate leaves and scented blossoms. The generic name is an anagram of Pistacia, a genus to which this tree bears a strong resemblance.

\section{TAXODIUM DISTÍChum, Richard. Deciduous Cypress. CONIFERA.}

A deciduous, usually pyramidal tree, 100 to $150 \mathrm{ft}$. high, the tapered trunk erect, buttressed at the base, and measuring above it 4 to $6 \mathrm{ft}$. in diameter. In damp situations the roots produce curious woody protuberances, which occasionally stand up several feet out of the ground, being 
several inches thick, and hollow. The young shoots are of two kinds: (r) the leading ones, which are persistent and have the leaves spirally arranged; (2) the others, very slender, annual, and falling away in autumn along with the leaves; this latter kind of shoot has no buds. Leaves spirally attached, but spreading (except in the leading shoots) in two opposite horizontal rows; linear, pointed, $\frac{3}{8}$ to $\frac{5}{8}$ in. long, $\frac{1}{16}$ to $\frac{1}{12}$ in. wide, of a soft yellowish green. Male and female flowers separate, but on the same tree; the former in slender panicles 4 or 5 ins. long. Cones globular, $\frac{3}{4}$ to $I_{2} \frac{1}{2}$ ins. wide.

Native of the southern United States, mostly in swamps, where its base is submerged during a portion of the year; introduced early in the

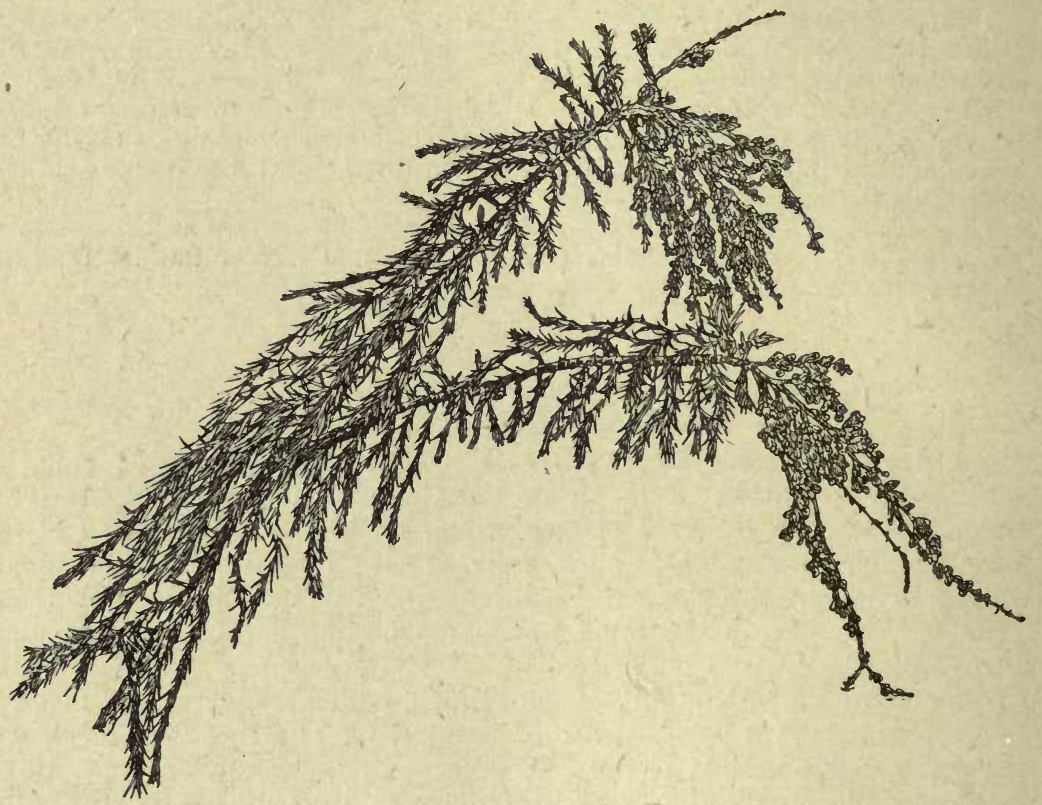

Taxodidm Distichum (male).

seventeenth century. This tree is one of the most beautiful and interesting that can be grown in wet places, although it thrives well, too, in ordinary soil. Its fine feathery foliage, of the tenderest green in spring, and dying off a rich brown in autumn, has nothing similar to it in the whole range of hardy trees. It is perfectly hardy near London, and very accommodating. A dry hollow at Kew, in which a deciduous cypress was growing, was turned into a lily pond in 1896 by puddling it over with clay. The Taxodium was left standing, and its trunk became permanently immersed in 2 or $3 \mathrm{ft}$. of water. The tree showed no ill effects from the sudden and drastic change in its root conditions, but on the contrary has grown much better ever since; only the immersed part of the trunk has become swollen and spongy. The finest trees I have 
seen are (or were) in Whitton Park, Hounslow, one of which a few years ago was I ro ft. high. This grew by the side of the pond, and there is no doubt such a spot is best for the tree. There are some fine examples at Syon, from one of which the sprays of male racemes here figured were taken. In these flowering sprays, it will be noticed, the leaves are always spirally arranged.

Var. PENDULUM (T. dist. var. imbricarium, Sargent; Glyptostrobus pendulus, Endlicher, Bot. Mag., t. 5603).-A smaller tree than the type; the leaves smaller, never in two opposite rows, but always spirally arranged or more or less flattened to the twig, sometimes scale-like. According to Sargent, it is not rare in a wild state. This variety is sometimes grown as "Glyptostrobus heterophyllus," but the true plant of that name, closely allied and very similar to the Taxodium, is a native of China.

T. MUCRONATUM, Tenore, has several times been introduced to Kew, but is not hardy. It is very similar to $\mathrm{T}$. distichum, and is perhaps only a geographical form of it. Native of Mexico.

\section{TAXUS. YEW. TAXACEE.}

The six or seven reputed species that make up this genus have, by more than one authority, been regarded as but geographical variations of a single one. The type of the genus is T. baccata, and the others do not differ from it in fruit, only in characters of bud, leaf, and habit. It is for garden purposes more convenient to avoid the cumbersome varietal designations, and adopt simple specific names. The generic characters of flower and fruit will be found under the notice of the common yew. Yew timber possesses remarkable strength and durability, and was once highly valued in this country, especially for indoor use (furniture, etc.); it is also very resistent to decay from wet out-of-doors.

\section{T. BACCATA, Linncus. COMmon YEW.}

A tree 30 to 40 , rarely 50 or $60 \mathrm{ft}$. high, forming in age a short, enormously thick trunk, clothed with red-brown peeling bark, and crowned with a rounded or wide-spreading head of branches. Leaves spirally attached to the twigs, but by the twisting of the stalks brought more or less into two opposed ranks; they are of a dark, glossy, almost black-green above, grey, pale green or sometimes yellowish beneath, the stomatic lines indistinct; linear, $\frac{1}{2}$ to $1 \frac{1}{4}$ ins. long, $\frac{1}{16}$ to $\frac{1}{12}$ in. wide; more gradually tapered to a fine point than any other of the species here mentioned. Flowers unisexual, with the sexes almost invariably on separate trees, produced in spring from the leafaxils of the preceding summer's twigs. Male a globose cluster of stamens; female borne close to the end of the shoot, and consisting of an ovule surrounded by small bracts. What is usually termed the "fruit" is a fleshy cup developed from a disk in which the ovule is set. This cup is bright red (sometimes yellow), juicy, and encloses the seed.

Native of Europe (including Britain), N. Africa, and W. Asia. No tree has become more woven into the history and folk-lore of Great Britain than the yew. All through the Middle Ages and until gunpowder came into general use, yew wood was more valued than any other for the manufacture of bows, long the national weapon of offence. In earlier ages still, before 
the conversion of this country to Christianity, yews were, no doubt, sacred trees, and the Druids erected their temples near them. The early Christians made a practice of building their churches on sites previously held sacred by the Britons, and thus perpetuated that association of the yew with religious edifices which has lasted until now. Many famous yews are scattered over the country to which space does not admit of reference. The tree is probably capable of attaining to a greater age than the oak. The noted yews of Fountains Abbey in Yorkshire were large enough for the monks to shelter and worship under whilst the abbey was being built, nearly 800 years ago. The oldest yew in Britain is supposed to be the Fortingal yew in Perthshire, its perfectly hollow trunk $17 \mathrm{ft}$. in diameter near the ground.

A peculiar mystery is attached to the poisonous quality the yew is known to possess, owing to its uncertain and apparently capricious effects. One may go into parks where yews are standing, and see them eaten off by cattle up to the grazing line as other trees are, and yet no case of poisoning heard of; on the other hand, deaths of horses, cattle, and calves turned into fresh fields where they were able to get at yew bushes have occurred so often as to leave no doubt that the yew is poisonous. It appears as if the poison acts only on certain states of the stomach. In my opinion it is more virulent when the stomach is empty, perhaps only then. It also appears that semidried twigs and foliage are more dangerous than green ones, and it has been surmised that the male tree is more poisonous than the female. The poison does not appear to be of an acrid or irritant nature, but brings about death rather by arrest of the heart's action. Neither the Canadian nor the Himalayan yew is known to be poisonous. The red fleshy cup that surrounds the seeds is frequently eaten by children without ill effects, but the seeds themselves contain the alkaloid known as taxine that is found in the leaves, and may be the principle that has caused so many fatalities.

The yew bears clipping exceptionally well, and on that account makes excellent evergreen hedges. It is also the best, frequently the only tree used for topiary work, i.e. training and clipping into formal and fantastic shapes. The most remarkable examples in this country are at Levens Castle, in Westmoreland, and at Elvaston Castle, in Derbyshire. The Levens trees were planted about two hundred years ago, and have been annually clipped ever since-a remarkable testimony to the adaptability and vitality of the yew.

The tree is an extremely hardy one, and is adapted to almost any soil, but like most trees is best suited on a good loam. It is one of the best evergreens for calcareous soils. Common yew is mostly raised from seed which, collected when ripe in autumn, should be kept a year before sowing, mixed with sand or soil and turned occasionally. Named varieties are easily raised from cuttings of small shoots placed under a cloche in'late July or August. There is now a great number of varieties of yew cultivated, mostly of seedling origin; here follows a selectjon of the most notable :-

Var. ADPRESSA.-A very striking and handsome form that would be considered a distinct species if its origin were not known. It is a widespreading shrub of dense habit (female), with leaves only $\frac{1}{4}$ to $\frac{1}{2}$ in. long, $\frac{1}{2}$ in. wide, abruptly pointed at the apex. According to the late $\mathrm{Mr} \mathrm{F}$. T. Dickson, it was found by his father in a bed of seedling yews about $\mathrm{IS}_{3} 8$, and called by him "brevifolia" - a name now in disuse, as it belongs rightly to the Californian yew.

Var. ADPRESSA AUREA.-A very effective form, with golden young foliage, which originated in the Handsworth Nurseries, Sheffield. ADPRESSA STRICTA is of erect habit.

Var. AUREA. Golden Yew.-Habit compact; leaves golden yellow when young, changing to green after autumn.

Var. BARRONI.-Leaves golden, becoming a rich coppery shade. 
Var. Cheshuntensis. - A form intermediate between the common and Irish yews; it has a wider habit than the latter, but the leaves are similarly arranged all round the twig.

Var. Dovastoni. Westfelton Yew.-One of the most distinct and handsome forms. The tree makes an erect stem, its branches are horizontal, and its branchlets, or spray, pendulous. It was raised about 1777 by $\mathrm{Mr}$ John Dovaston of Westfelton, near Shrewsbury, and the original tree, in addition to its striking habit is of interest in having, although mostly male, produced a branch which bears fruits. A sub-variety has golden young leaves.

Var. ERICOIDES. - A dwarf form with narrow crowded leaves-a curiosity merely.

Var. FASTIGIATA. Irish Yew.-Of columnar habit, with its branches and branchlets quite erect and its leaves standing out all round the twigs. It is a female tree, the original ones being found in the mountains of Fermanagh about 1780 by a farmer named Willis. Two trees of this habit were found, one of which he planted in his own garden, where it lived until 1865; the other he gave to Florence Court, where it is still living-the parent of all Irish yews. There is a sub-variety with golden young leaves-FASTIGIATA AUREA.

Var. FRUCTU-LUTEO.-Differs from the type in the yellow fruits; first noticed about 1817 at Glasnevin, Dublin.

Var. GLAUCA.- Leaves at first very glaucous beneath.

Var. GRACILIS PENDULA.-Of the Dovastoni type. Stem erect, branches horizontal, branchlets slender, elongated, pendulous.

Var. HORIZONTALIS.- Branches horizontal, like Dovastoni, but with the branchlets not pendulous; a form with golden young leaves is called HORIZONTALIS ELEGANTISSIMA.

Var. NANA. - D warf and spreading in habit.

Var. PENDULA.-A low spreading form with branches more or less pendulous.

Var. PROSTRATA.-A prostrate-branched variety.

Var. RECURVATA. - Branches horizontal, leaves recurved.

Var. SEMPERAUREA.- Young shoots and leaves yellow, retaining their colour through the first winter.

Var. WASHINGTONI.-A low spreading shrub, with leaves of a golden hue and up to $\mathrm{I} \frac{1}{4}$ ins. long.

\section{T. BREvifolia, Nuttall. CaLIfornian YeW.}

A small tree 20 to 30 , rarely 50 to $70 \mathrm{ft}$. high, the trunk clothed with thin reddish brown bark; branchlets slender, winter buds clothed with loose, yellowish, pointed scales. Leaves $\frac{1}{4}$ to $\frac{2}{3}$ in. long, $\frac{x}{16}$ in. wide, linear, rather abruptly narrowed at the apex to a fine point; dark green above, paler green beneath, arranged in two opposite horizontally spreading rows and persisting four or five years. Fruit as in T. baccata.

Native of Western N. America, from British Columbia to California; introduced in 1854 . This yew is rare in cultivation, the form so-called being usually a form of $T$. baccata. On the other hand, the yews differ so little from each other in essential points that it may easily be lost among the numerous forms of common yew.

\section{T. CANAdensis, Marshall. CANAdian Yew.}

A shrub of spreading habit, often low and straggling, sometimes 4 to $6 \mathrm{ft}$. high; winter buds small, roundish, the scales loose, roundish at the apex, ridged at the back. Leaves $\frac{1}{2}$ to $\frac{3}{4} \mathrm{in}$. long, $\frac{1}{16}$ to $\frac{1}{12}$ in. wide; linear, terminated 
by a fine rather abrupt point, shortly stalked; dark glossy green above, paler green beneath. Fruit red, as in T. baccata.

Native of Eastern N. America, from Newfoundland to Virginia ; introduced in 1800 . The Canadian yew is distinguishable from the English yew by the invariably shrubby habit, by the more abruptly pointed leaves, and by the leaf-buds, but can scarcely be said to differ from it more than the varieties of common yew do among themselves. It has little to recommend it beyond its botanical interest.

\section{T. Cuspidata, Siebold. JAPANESE YeW.}

A tree 40 to $50 \mathrm{ft}$. high in Japan, with a trunk girthing about $6 \mathrm{ft}$; in cultivation a low tree or spreading shrub; older bark reddish brown. Leaves $\frac{1}{2}$ to $\mathrm{I}$ in. long, $\frac{1}{12}$ to $\frac{1}{8}$ in. wide; linear, tapered rather abruptly at the apex to a fine point; rounded, and with a distinct stalk at the base $\frac{1}{12}$ in. long; dark green above; with a broad, tawny yellow strip composed of ten to twelve stomatic lines on each side of the green midrib beneath. The leaves are arranged approximately in two ranks, and stand more or less erect from the twig, often forming a narrow $\mathbf{V}$-shaped trough. Fruit red, as in T. baccata.

Native of Japan; introduced by Fortune about 1855 , and very hardy although slow-growing. It thrives extremely well in the trying New England climate, and is apparently one of the best evergreens introduced there. There

- are two distinct forms of it in cultivation, the one a tree, the other, var. COMPACTA, a compact, low bush, wider than it is high. Whilst the general aspect is the same as that of the English yew, it can be distinguished by the marked yellow tinge of the under-surface of the leaves, and by the longer, more oblong winter buds with looser, more pointed scales.

\section{TECOMA. BIGNONIACEA.}

Two climbing species of this genus can be grown in the open air in Britain, and both are amongst the most strikingly handsome of all such plants. Leaves opposite, pinnate. Flowers large, trumpet-shaped, coloured in rich shades of orange and scarlet. They should be planted against a sunny wall, $T$. grandiflora especially, and given a good loamy soil. T. radicans will cling of itself to walls or tree trunks, but it is best to give additional support by nailing. When the allotted space is filled, both species should be pruned annually just as vines are pruned, i.e., cut back to within a few buds of the old wood. Except on rare occasions neither ripens seed in this country, but they can be propagated by layers. Messrs Simon-Louis of Metz have a hybrid between the two following species, named T. hybrida, Jouin, and there is also one called T. PrinceI, a very handsome kind, intermediate, and probably a hybrid between them also.

\section{T. GRANDIFLORA, Loiseleur.}

(Bignonia grandiflora, Thunberg, Bot. Mag., t. I398.)

A deciduous climber, 20 to 30 or more $\mathrm{ft}$. high; stems smooth. Leaves pinnate, composed of seven or nine leaflets, which are ovate, $1 \frac{1}{2}$ to 3 ins. long, about half as wide, long-pointed, coarsely toothed, smooth on both surfaces Flowers in terminal, pendulous panicles of six or twelve, produced at the end 
of the current scason's growth in August and later. Corolla deep orange and red, widely trumpet-mouthed, narrowing to a funnel-shaped tube; 2 to 3 ins. long and wide, with five broad, rounded lobes. Calyx $1 \frac{1}{4}$ ins. long, bell-shaped, with five slender lance-shaped lobes $\frac{1}{2}$ in. long.

Native of China and Japan; introduced in 1800. Even more gorgeous than $T$. radicans, it is, unfortunately, not so hardy. It must have a sheltered sunny wall, and even there does not with us produce so wonderful a display as it does on the Continent. It is easily distinguished from the better known radicans by the panicled inflorescence, the broader mouth of the corolla, smooth leaves, and the much more deeply lobed calyx.

Var. AURANTIA.-Flowers orange-yellow. There is down on the veins of the leaflets beneath, which seems to show the influence of $T$. radicans, as do also the shorter calyx-lobes; perhaps a hybrid.

Var. Thunbergif has the tube of the corolla shorter, and the lobes more reflexed; probably more hardy.

\section{T. RAdicans, Jussieu. Trumpet Flower.}

(Bignonia radicans, Linnoeus, Bot. Mag., t. 485.)

A deciduous climber of vigorous habit forming a stout main stem, and growing at least 30 to $40 \mathrm{ft}$. high; it climbs by means of aerial roots like an ivy; young stems smooth. Leaves pinnate, 6 to 15 ins. long, composed of seven to eleven leaflets, which are ovate, $\frac{3}{4}$ to 4 ins. long, $\frac{1}{4}$ to 2 ins. wide; coarsely and angularly toothed, with a long, often tail-like point; smooth and dark green above, downy beneath, especially along the midrib and veins. Flowers produced in August and September, each on a short stout stalk, in a cluster at the end of the current season's growth, four to twelve flowers together. Corolla rich scarlet and orange, trumpet-shaped, $2 \frac{1}{2}$ to 3 ins. long, $I \frac{1}{2}$ ins. wide at the mouth, where are five broad, short, rounded lobes. Calyx bell-shaped, $\frac{5}{8}$ in. long, with triangular teeth. Pod spindle-shaped, stout, 5 ins. long, $\frac{3}{4}$ in. wide in the middle.

Native of the south-eastern United States. The gorgeous beauty of this climber must early have attracted the notice of the first settlers, for it was cultivated in England in 1640 . It can be planted against buildings, to which it will attach itself by aerial roots from the stems, but usually needs support from nails as well. Flowering as it does in late summer on the growths of the year, it should be pruned back every spring. It is hardy enough to be grown in the open ground at Kew, but the growths are so long that even pruned back annually it is of ungainly habit and unsuited for the open border. Very rarely, but sometimes after unusually hot summers, it develops its conspicuous brown pods, full of flattened seeds with silvery transparent wings.

\section{TERNSTRCEMIA JAPONICA, Thunberg. TERNSTREMIACE E.}

An evergreen shrub or small tree with a much-branched head, and warted, not downy branchlets. Leaves alternate, crowded at the apex of the shoot, obovate or oblanceolate; $I \frac{1}{2}$ to 3 ins. long, $\frac{1}{2}$ to $I \frac{1}{2}$ ins. wide; tapered gradually at the base to a short, stout, purplish stalk; more abruptly tapered to a rounded or bluntish apex; they are dark varnished green, thick and leathery, and quite smooth. Flowers fragrant, solitary on stalks about $\frac{3}{4}$ in. long, nodding, of short duration, produced in July and August from the leaf-axils, and from the axils of fallen 
scales on the lower naked part of the shoot. Corolla yellowish white, about $\frac{1}{3}$ in. across; petals five. Fruit globose, and about the size of a cherry, yellow, tinged with rose on the sunny side, the rounded sepals persisting at the base.

Native of Japan; introduced in the early part of last century, but probably incapable of withstanding our hardest winters, for it had nearly or quite disappeared from gardens until reintroduced a few years ago. It has withstood $20^{\circ}$ of frost at Kew, but is no doubt better adapted for the south-west counties than for our average climate.

\section{TETRACENTRON SINENSE, Oliver. TROCHODENDRACEA.}

A deciduous tree, 50 to $90 \mathrm{ft}$. high, allied to and resembling Cercidiphyllum japonicum, especially in having, on the year-old branches, short or obsolete twigs, each producing a single leaf and an inflorescence. It differs, however, in its invariably alternate leaves. Young branches dark, glabrous, freely marked with pale lenticels. Leaves ovate or heart-shaped, long-pointed, with usually five or seven prominent nerves radiating from the base; the margins evenly set with blunt teeth. Flowers numerous, stalkless, on a spike 4 to 6 ins. long, very small, yellowish; sepals, stamens, and carpels four.

Native of the province of Hupeh, China, where it was originally discovered by Henry; introduced by Wilson for Messrs Veitch in I90I. It is apparently quite hardy, although I have seen it much injured by late spring frosts, and in a young state is of elegant growth, but its flowers have no ornamental value.

\section{TEUCRIUM fruticans, Linnceus. Shrubby Germander. LABIATE.}

An evergreen shrub of diffuse habit, naturally 7 or $8 \mathrm{ft}$. high, stems square, and covered with a close white felt. Leaves opposite, ovate, $\frac{1}{2}$ to $\mathrm{r}_{2} \frac{1}{2}$ ins. long, about half as wide, broadly wedge-shaped or rounded at the base, bluntish at the apex; dark, rather bright green above, white, with a close felt beneath, fragrant when crushed; stalk $\frac{1}{4}$ in. or less long. Flowers produced during the summer and autumn singly in the axils of the small uppermost leaves or bracts - the whole forming a raceme 3 or 4 ins. long. Calyx $\frac{1}{4}$ in. long, with five ovate, pointed, leaflike lobes, white beneath. Corolla pale purple or lavender-coloured, forming a short tube at the base, to which the four long stamens are attached, then developing into a large five-lobed lip (like the lip of an orchid flower in shape), the basal pair of lobes the smallest and palest; flower-stalk white, $\frac{1}{4}$ in. or less long.

Native of S. Europe ; introduced by the then Duchess of Beaufort in 1 7 14. It is very pretty, and distinct among shrubs because of the pure white under-surface of the leaf and the curiously shaped labiate flower. 
At Kew it can be grown on a wall, but is not hardy in the open. Easily increased by cuttings during the summer, and preferring a rather light soil.

\section{THUYA. CONIFERÆ.}

In the now generally accepted interpretation of the word, Thuya comprises six species of evergreen trees with thin, scaling bark, belonging to the same group of conifers as the Chamæcyparis or flat-leaved group of cypresses. They are very distinct in the cones, which are egg-shaped or rounded, and have flat, oblong, and (except in T. orientalis and T. dolabrata) thin scales; very different from the peltate or top-shaped scales of the cypresses. The flat, pinnately divided branchlets and the leaf arrangement, however, are very similar, and the leaves are similarly scale-like. Juvenile types of foliage are sometimes permanently retained in $\mathrm{T}$. occidentalis and $\mathrm{T}$. orientalis, and are popularly known as "Retinisporas" (see also under Cupressus). Small as the number of species is - and one of them, T. SUTchUenensis, Franchet, is not in cultivation unless recently introduced from China-they have been placed in three separate genera, viz., Biota (see T. orientalis), Thujopsis (see T. dolabrata), and Thuya proper. Biota and Thujopsis have both roundish or globose cones and thick scales, the former distinct also in its wingless seeds.

They all like a moist, loamy soil, and though best raised from seeds can be increased by cuttings.

\section{T. DOLABRATA, Linnaus fil.}

(Thujopsis dolabrata, Siebold.)

A tree up to 40 or $50 \mathrm{ft}$. high, or a shrub of pyramidal form; branchlets arranged in opposite rows (distichous), the ultimate subdivisions much flattened, about $\frac{1}{4}$ in. wide, dark glossy green above, with conspicuous glaucous patches beneath. Leaves hard and rigid, borne in four ranks; those of the lateral ranks strongly keeled, $\frac{1}{6}$ to $\frac{1}{4}$ in. long, incurved at the point, their edges overlapping the leaves of the middle ranks, which are appressed and rounded at the apex. Cones $\frac{1}{2}$ to $\frac{3}{4}$ in. long, roundish; the eight scales thick, woody, ending in a horn-shaped boss; seeds winged.

Native of Japan; first introduced to Messrs Veitch's at Exeter by way of the botanic garden at Buitenzorg, in Java, 1853. Its effective introduction, however, took place in 1861 , when seeds were sent to England by both J. G. Veitch and Fortune. Seen at its best, this is a striking and beautiful shrub, very distinct from the other Thuyas in its broad branchlets and its rounded cones with thick woody scales. When young it is very dense in habit at the base, but as it increases in height the upper growth is apt to become thin and attenuated. There are trees $35 \mathrm{ft}$. high in Devon and Cornwall, and I have seen good specimens in Scotland over $20 \mathrm{ft}$. high. It enjoys a sheltered spot, and I think newly planted trees like a proportion of peat mixed with the soil in immediate contact with the roots.

Var. NANA, Siebold (Thujopsis lætevirens, Lindley).-A curious, dwarf form, growing very slowly. Branchlets more slender, leaves smaller.

Var. VARIEGATA.-Young spray variegated with patches of creamy white, 
which spoil rather than improve the shrub. Both these varieties were introduced in $186 \mathrm{I}$.

\section{T. JAPONICA, Maximowicz. JAPANESE ARBOR-VIta.}

\section{(T. Standishị, Carrière; Thujopsis Standishii, Gordon.)}

An evergreen tree rarely more than 15 to $25 \mathrm{ft}$. high in the British Isles, but said to grow thrice that height in Japan, of rather open habit, pyramidal, slow-growing; bark reddish, peeling. Branches curved upwards at the ends; branchlets drooping; ultimate subdivisions about $\frac{x}{10}$ in. wide, flattened, aromatic when crushed. Leaves scale-like, about $\frac{1}{8} \mathrm{in}$. long, the lateral pairs with their edges turned inwards and clasping the flatter ones above and below the twig, blunt, thickened and incurved towards the apex; rather pale yellowish green on the upper side the twig, glaucous on the lower side, except at the points. Cones oblong, $\frac{1}{3}$ in. long; composed of about ten broadly oval, overlapping scales, two pairs only of which bear seeds.

Native of Japan; introduced by Fortune for Standish of Ascot in 1860. Fortune only saw it as a cultivated tree about Tokyo, and it was not until about 1878 that it was discovered wild by Maries on the mountains of the Central Island. This Thuya has the most open branching of the cultivated species and (with the exception of $T$. dolabrata) the coarsest branchlets. It is a distinct and handsome evergreen. The odour of the crushed young spray resembles that of Eucalyptus.

\section{T. OCCIDENTAlis, Linnceus. ARBOR-VItA.}

An evergreen tree, 50 to $60 \mathrm{ft}$. high, with a trunk 2 to $3 \mathrm{ft}$. in diameter; in cultivation a pyramidal shrub or tree rarely more than half as high; branches usually upturned towards the end; branchlets three or four times pinnate, the ultimate subdivisions much flattened, $\frac{1}{16}$ to $\frac{1}{12}$ in. wide. Leaves scale-like, about $\frac{1}{12}$ in. long, the lateral ones pointed, prominently keeled and overlapping the middle ones; they are a dull yellowish green above, paler and grey green beneath (not with whitish patches, as in $T$. plicata), the middle ones beneath are furnished with a raised roundish gland in the centre. Cones about $\frac{1}{3}$ in. long, egg-shaped, with eight or ten scales.

Native of Eastern N. America, from Nova Scotia to Virginia, usually on swampy or moist ground. It has been cultivated in English gardens since the sixteenth century, but is not in the first rank of conifers, being often thin in habit (especially on dry soils) and dull in colour, frequently putting on a yellowish brown appearance in winter. It often grows slowly. For forming evergreen shelter hedges, especially in nursery grounds, it has proved very useful. As an ornamental evergreen for gardens, it is much inferior to T. plicata or Cupressus Lawsoniana. Very numerous forms of garden origin have been named, only a few of which need mention here. In all its forms this Thuya has a distinctive, heavy, rather acrid odour when rubbed or crushed.

Var. BuchanANI.-Branchlets very slender, with the subdivisions thin and far apart.

Var. CRISTATA.-Dwarf, very distinct in the penultimate subdivisions being curiously curved like a cock's comb, the ultimate divisions often developed on one side only.

Var. DUMOSA.-Dwarf and rounded, rarely more than $2 \mathrm{ft}$. high. (Vars. globosa, minima, and pygmæa are similar.)

Var. ELLWANGERIANA.-An inelegant lanky shrub with slender, curving branches, some of which bear typical leaves, others the needle-like leaves of 
the seedlings, $\frac{1}{6}$ in. long, still others with both. Shrubs over forty years old retain this dimorphic character.

Var. ERICOIDES. - In this the whole of the foliage is needle-like and of the juvenile or seedling type; the plant always remains a dwarf rounded shrub, glaucous in summer, brown in winter. Known in gardens as Retinispora dubia. It has an odour similar to that of the type.

Var. LUTEA.- Young branchlets yellow the first summer and winter, becoming green the second year.

Var. PLICATA (not to be confused with T. plicata or gigantea).-Branches rigid, and arranged in the vertical plane as in $\mathrm{T}$. orientalis. Leaves brownish green, very glandular.

Var. SPATHII.-A curious dwarfed form, with erect branches distinctly four-sided, the upper ones with juvenile, awl-shaped leaves.

Var. VERVENEANA.-Branchlets and spray golden yellow at first, brownish in winter, green the second year. Dwarfer in habit and deeper in colour than lutea.

Var. WAREANA.- Raised by Mr Ware at Coventry more than sixty years ago; dwarf, dense in habit, the branchlets often vertical as in var. plicata but of a brighter green.

\section{T. ORIEntalis, Linncus. ChInese ARBor-vit}

(Biota orientalis, Endlicher.)

A shrub or small tree, 30 to $40 \mathrm{ft}$. high, very distinct among the Thuyas and cypresses by reason of the more or less erect or upward-curving branches bearing the spray or branches in the vertical plane, and in being of the same colour on both sides. There are two distinct types in cultivation : the one tall, somewhat columnar, and comparatively thin-branched, sometimes called var. pyramidalis; the other a dense, rounded or broadly pyramidal shrub with numerous branches springing from near the ground. The latter is the more effective for gardens. Ultimate subdivisions of the branchlets $\frac{1}{16}$ in, wide, flattened; green on both sides. Lateral leaves with their edges overlapping the middle ones, about $\frac{1}{12}$ in. long, scale-like; middle ones grooved; all marked with numerous white stomata. Cones roundish egg-shaped, $\frac{3}{4}$ in. long, erect, purplish; scales six, rarely eight, thick and woody, with a hooked, horn-like boss near the apex Seeds wingless.

Native of N. and W. China; cultivated in Europe since the first half of the eighteenth century. The dense-growing, broader, and more shrubby form is a very effective garden plant, easily known by the yellow-green, flattened spray set up edgewise and, in healthy plants, densely packed. It likes a good loamy soil, and is more likely to suffer from drought than from cold. At the same time it should not be exposed on bleak situations. Numerous varieties are offered for sale, many of but little value. The following are the most notable:-

Var. AUREA.-Branchlets yellow-tipped in summer.

Var. DECUSSATA (Biota Sieboldii, Gardeners' Chronicle, Feb. I8, I888, p. 36).-A dense pyramidal shrub with erect branches and terete branchlets bearing awl-shaped leaves in opposite, decussate pairs. A juvenile form of the same type as var. pendula, but with erect, more slender shoots and smaller, juniper-like leaves, turning brownish in winter.

Var. ERICOIDES (Retinispora ericoides).-Leaves soft, glaucous, linear, $\frac{1}{4}$ to $\frac{1}{3}$ in. long. A juvenile state of the same type as Cupressus pisifera squarrosa. It differs from $\mathrm{T}$. occidentalis var. ericoides in odour. adult.

Var. MELDENSIS. - Foliage mostly juvenile and blue green, but partly

Var. PENDULA. - The most remarkable but least ornamental of all the 
forms. Its branches are often pendulous and cord-like, but stiff, producing the branchlets in crowded clusters. Leaves slender, awl-shaped, $\frac{1}{3}$ in. long, produced in pairs or in threes. Although the foliage is of a juvenile type, this form occasionally produces fertile cones; the seed giving ordinary Thuya orientalis.

\section{T. Plicata, D. Don. Giant Thuya.}

(T. Craigiana, Hort.; T. gigantea, Nuttall; T. Lobbii, Hort.; T. Menziesii, Douglas.)

A tree up to $200 \mathrm{ft}$. high in a wild state, with a trunk sometimes $\mathrm{I} 5 \mathrm{ft}$. in diameter at the buttressed base; in cultivation a slender, pyramidal tree in some places already approaching $100 \mathrm{ft}$. in height. Unless close-planted it retains its branches to the ground, but is inclined to become thin at the top. Branches curving upwards at the ends, branchlets drooping, strong-smelling and slightly aromatic when crushed; ultimate subdivisions $\frac{1}{16}$ to $\frac{1}{12}$ in. wide, flattened. Leaves dark glossy green, scale-like, $\frac{x}{12}$ to $\frac{1}{8} \mathrm{in}$. long; the lateral ones the longer, with their edges infolded and overlapping the flatter ones above and below the twig; they are all sharply pointed and have glaucous patches beneath. Cones egg-shaped, $\frac{1}{2}$ in. long; scales about ten, with a small triangular boss just beneath the apex.

Native chiefly of British Columbia, Oregon, and Washington; to a small extent also of California. Introduced by W. Lobb for Messrs Veitch in I853, it has proved by far the handsomest and best growing of the Thuyas. In gardens it is often grown as $T$. Lobbii and T. gigantea, but it was first given the name "plicata" by Don in 1824 , ten years previous to Nuttall's name "gigantea" and thirty years before "Lobbii" came into use. To add to the confusion, Libocedrus decurrens' was for long called "Thuya gigantea." $T$. plicata is distinguished from the E. American T. occidentalis by the glaucousness and comparative scarcity of glands beneath the branchlet, and by its much more rapid, cleaner growth. From T. japonica it differs in its denser habit, finer spray, and different odour. It is considered very promising as a forest tree in many parts of England.

Var. AUREA. - Much of the young growth yellow.

Var. GRACILIS. - Spray finer, and with smaller leaves.

Var. PYRAMIDALIS.-Of slender columnar form; distinct, and worthy of cultivation.

Var. ZEBRINA.-Spray with curious patches of yellow interspersed with the ordinary green of the current year's shoots.

Young trees of Thuya plicata grown in large batches have been attacked by a parasitic fungus, Botrytis cinerea.

\section{THYMELAA NIVALIS, Meissner. THYMELÆACE $Æ$.}

(Passerina nivalis, Ramond.)

A semi-prostrate evergreen shrub, 4 to 8 ins. high, with half woody, slightly hairy, unbranched shoots. Leaves densely arranged in whorls of threes (about seven whorls to the inch), stalkless, linear, $\frac{1}{3}$ to $\frac{1}{2}$ in. long, about $\frac{1}{10}$ in. wide, bluntish pointed, slightly hairy about the margins, dull greyish green, rather fleshy. Flowers solitary in each leaf-axil, stalkless, $\frac{1}{4}$ in. across, scarcely so long, yellow. Calyx tubular at the base, dividing at the top into four ovate lobes, two of which are conspicuously broader than the other two. Stamens yellow, eight, in two 
series of four, inserted near the apex of the calyx-tube; very shortly stalked.

Native of the Pyrenees. A pleasing little evergreen for the rock garden, flowering abundantly in March. It is closely allied to the Daphnes, and has the same supple, tough shoots and corolla-like calyx. It has no true corolla. It is quite hardy in the rock garden at Kew. Closely allied to and sometimes regarded as a variety of T. tinçtoria, Endlicher.

\section{TILIA. Lime or Linden. TILIACE E.}

A genus of about thirty species of large or medium-sized, deciduous trees, with more or less zigzagged young shoots; winter buds prominent. The inner bark is tough and fibrous, and that of some species is used for making rough ropes and mats. Leaves alternate, but set in two opposite rows on the branches, toothed, usually heart-shaped at the base. Flowers produced in summer on the shoots of the current year, in axillary, slender, long-stalked cymes. One of the most characteristic features of the genus is the large membranous bract, several inches long, to whose midrib the lower part (sometimes more than half) of the main flowerstalk is united, thus giving it the appearance of rising directly from the centre of the bract. The flowers are very uniform in the limes, being fragrant, $\frac{5}{8}$ to $\frac{3}{4}$ in. across, dull or yellowish white. Sepals and petals five. In several species (all the American ones) there are also five petal-like scales to which the base of the stamens is united. Fruit dry, nut-like, about the size of a pea, usually one-seeded.

The limes belong to the North Temperate Zone, but do not occur in western N. America or the Himalaya. They are all thriving trees in gardens, preferring a rich moist soil. Such species as euchlora and petiolaris ought to replace to a great extent the common lime. The American species are not of much account with us, but some of the Asiatic ones, like T. Oliveri, are promising.

As with all forest trees, the limes should, if possible, be raised from seed. Failing that, they may be raised from layers, or, in the case of named varieties, by grafts. Grafted plants, however, frequently make very unshapely trees. The graft is taken, as a rule, from side branches, with the distichous (or two-ranked) arrangement alluded to above. The leading shoot often retains this character for many years, and shows a tendency to grow horizontally rather than erect. Often, too, the stock grows in thickness less quickly than the scion, or vice versa, with the result that there is formed an unsightly break in the trunk.

There has been considerable confusion in gardens over the nomenclature of the limes, largely due to a great number of hybrid or intermediate types. They interbreed with great facility under brighter skies than ours.

A selection of the best limes would include the following: euchlora, petiolaris, platyphyllos, tomentosa, and Moltkei. Of a smaller type are cordata, platyphyllos var. asplenifolia, and mongolica. 


\section{T. americana, Linnceus. American Lime.}

A tree usually 60 to $70 \mathrm{ft}$. high in a wild state (occasionally nearly twice as much), the trunk 9 to $12 \mathrm{ft}$. in girth; young shoots quite smooth. Leaves roundish ovate, usually heart-shaped at the base, occasionally cut off straight; pointed at the apex; 5 to 8 ins. long and 3 to 6 ins. wide on young trees, smaller on adult wild trees, coarsely toothed; dark dull green above; paler, shining, and quite smooth beneath, except for minute tufts of down in the axils of the veins; stalk $1 \frac{1}{2}$ to 2 ins. long. Flowers rarely seen in this country; the floral bract is 4 to $5 \mathrm{ins}$. long, I to $1 \frac{1}{2}$ ins. wide; the inflorescence pendulous on a stalk 3 to 4 ins. long; flowers $\frac{3}{4}$ in. across, yellowish white.

Native of Eastern and Central N. America; introduced, according to Aiton, in 1752 . It is not one of the first-rate limes in this country, being apt to die back, and is chiefly noteworthy for the occasionally enormous leaves, as much as 15 ins. long by 10 ins. wide, that appear on thick, succulent shoots. From its allies, T. Michauxii and T. heterophylla, it is distinguished by the smooth leaves, glossy green beneath. It probably needs a sunnier climate than that of Great Britain, and apparently flowers freely enough on the Continent, from the fact that several hybrids have originated there (see T. Moltkei and spectabilis). T. Flavescens, $A$. Braun, cultivated at Carlsruhe as long ago as 1836 , is believed to be a hybrid between this species and T. cordata.

\section{T. Cordata, Miller. Smaill-Leaved Lime.}

\section{(T. parvifolia, Ehrhart; T. microphylla, Ventenat; T. ulmifolia, Scopoli.)}

A tree sometimes 80 to $90 \mathrm{ft}$. high on the Continent, usually much smaller in Britain; young shoots smooth or nearly so. Leaves rounded, heart-shaped, $x \frac{1}{2}$ to 3 ins. long, nearly or quite as much wide; with a short tapered apex, sharply and rather finely toothed; dark green and smooth above; pale, sometimes whitish beneath, with tufts of red-brown hairs in the axils of the veins; stalks slender, smooth, I to $I_{\frac{1}{2}}$ ins. long. Flowers yellowish white, fragrant, produced in the latter part of July in pendent, slender-stalked cymes 2 or 3 ins. long. Floral bract $1 \frac{1}{2}$ to $3 \frac{1}{2}$ ins. long, $\frac{3}{8}$ to $\frac{3}{4}$ in. wide, smooth. Fruit globose, covered (especially at first) with a loose greyish felt, not ribbed, thin-shelled.

Native of Europe, especially of the north, and found wild in Britain. It is not frequently planted in gardens, although it makes a neat slow-growing small tree, flowering after both $T$. platyphyllos and $T$. vulgaris. The finest trees I have seen are on the Continent; one in the Grosser Garten at Dresden has a trunk $8 \mathrm{ft}$. in diameter near the ground, and is 80 to $90 \mathrm{ft}$. high. T. vulgaris differs from this species in its larger leaves, green, and with paler tufts beneath; its earlier flowers; and its thicker-shelled fruits.

There is in Japan a lime very closely allied to $\mathrm{T}$. cordata; it is T. JAPONICA, Simonkai, probably only a geographical form with more numerous (up to forty) flowers in a cluster.

\section{T. Euchlora, C. Koch. \\ (T. dasystyla, Hort., not Steven.)}

A tree as yet about $40 \mathrm{ft}$. high in this country, but probably considerably higher naturally, of graceful, often rather pendulous growth; young shoots smooth. Leaves roundish ovate, oblique and heart-shaped at the base, with short, tapered points; 2 to 4 ins. long, often more in young trees, and as much or more wide; rich glossy green and smooth above, pale green beneath and 
smooth, except for tufts of hairs in the axils of the veins; marginal teeth small, regular and slender; stalk smooth, 1 to 2 ins. long. Flowers produced in the latter half of July, three to seven together in cymes 2 to 4 ins. long, yellowish white. Floral bract linear-oblong, or narrowly lance-shaped, 2 to 3 ins. long, $\frac{1}{4}$ to $\frac{5}{8}$ in. wide, smooth, shortly stalked. Fruit distinctly ovoid, tapered to a point, shaggy, with pale brown wool, $\frac{1}{4}$ to $\frac{1}{3}$ in. long.

Of doubtful origin; introduced about 1860 . In some respects this is the most beautiful of the limes on account of its bright green large leaves and pleasing form. It is remarkably free from insect pests. In the summer of 1909, when not only limes but nearly every other tree and shrub was infested with aphides and other pests, I examined specimens of this lime at intervals during the summer, and never found a single parasite on the leaves. Yet it is quite uncommon in this country. On the Continent, however, its qualities are better appreciated, and it is being much planted in streets. Its brilliantly glossy, rounded, nearly glabrous leaves and pendulous branches very well distinguish it. It has been suggested that it is a hybrid between $T$. cordata and the scarcely known T. caucasica found in the Caucasus.

\section{T. Henryana, Szyszylowicz.}

A tree 30 to $50 \mathrm{ft}$. high, the branchlets at first stellately downy, ultimately smooth. Leaves obliquely and broadly ovate, heart-shaped or cut off straight at the base, shortly taper-pointed, 2 to 5 ins. long, $1 \frac{1}{2}$ to 3 ins. wide ; the margin set with bristle-like teeth $\frac{1}{10}$ in. long, the midrib and veins downy above, the whole under-surface covered with dull brownish stellate down; there are tufts of down in the vein-axils; stalks I to $I \frac{1}{2}$ ins. long. Flowers whitish, numerous (twenty or more), on cymes 4 to 6 ins. long; floral bracts of similar length, $\frac{1}{2}$ to $\frac{3}{4}$ in. wide, stellately downy, especially behind.

Native of Central China; discovered by Henry in 1888; introduced for Messrs Veitch by Wilson in I9OI, and said by them to be quite hardy at Coombe Wood. It is distinct from all the species here mentioned in the almost hair-like teeth of the leaves.

\section{T. Heterophylla, Ventenat.}

It is doubtful if there be any living trees of this lime in the British Isles; what are cultivated under the name being usually $\mathrm{T}$. Michauxi, which is believed to be a natural hybrid between T. americana and T. ksterophylla, and in some of its forms closely approaches the latter. But, according to Sargent, T. heterophylla can always be distinguished by having no tufts of hairs in the vein-axils beneath the leaf. The leaves are always covered beneath with a close layer of silvery down. It is a tree 50 to $80 \mathrm{ft}$. high in a wild state, with a trunk 9 to $12 \mathrm{ft}$. in girth, and is a native of the easterr. United States from New York to Alabama, reaching its largest size in the forests of the mountains of N. Carolina and Tennessee. Its leaves are 4 to 8 ins. long, with slender stalks up to $3 \frac{1}{2}$ ins. long. It is hardy in the Arnold Arboretum, Mass., but appears to have always been a neglected tree.

\section{T. MANDSHURICA, Ruprecht. MANCHURIAN Lime.}

Apparently the only specimen of this lime in cultivation in Britain is a small tree at Kew, now about $22 \mathrm{ft}$. high. Like so many Manchurian trees and shrubs, it starts early into growth (before any other species), and is almost invariably cut back by spring frosts. It might prove a handsome tree in the south-western counties, but near London is of no value. It is 
described as growing $60 \mathrm{ft}$. high in Manchuria. Leaves (on the tree at Kew), $2 \frac{1}{2}$ to 6 ins. wide, the same or rather more long, heart-shaped, widely and coarsely toothed, with occasionally a lobe at the side; green with a thin stellate down above, grey and with abundant stellate down beneath, but with no tufts in the vein-axils. Young shoots downy. It has never flowered at Kew, but on preserved wild specimens the floral bracts are $4 \frac{1}{2}$ ins. long, I in. wide, downy; the fruit globose, warted, downy and not or indistinctly ribbed. Introduced to Kew in $187 \mathrm{I}$.

\section{T. Maximowicziana, Shirasaía.}

A tree 70 to $100 \mathrm{ft}$. high; young shoots downy. Leaves roundish ovate, 3 to 6 ins. long, scarcely as wide; contracted at the apex to a short point, heart-shaped at the base, coarsely toothed; dark green and slightly downy above, covered beneath with grey stellate down, and furnished with conspicuous tufts in the axils of the veins; stalk $1 \frac{1}{2}$ to 3 ins. long. Flowers not seen in this country but described as being produced in clusters of ten to eighteen, the floral bracts 3 to 4 ins. long, downy. Fruit $\frac{2}{5}$ in. long, ribbed.

Native of Japan; sent to Kew by Prof. Sargent in I890. It is a noble forest tree in Japan, but the few trees in Britain do not promise well, although they seem to be hardy. This lime differs from the others with starry pubescent leaves and branches in having tufts of hairs in the vein-axils.

\section{T. MichauxiI, Nuttall.}

\section{(T. alba, Michaux, not Aiton.)}

A deciduous tree, 70 to $80 \mathrm{ft}$. high in a wild state, with a trunk 6 to $9 \mathrm{ft}$. in girth; young shoots and buds smooth. Leaves broadly ovate, very variable in size, in adult specimens 4 to 8 ins. long, 3 to 6 ins. wide; obliquely heart-shaped or rarely truncate at the base, taper-pointed, coarsely and sharply toothed, dark green and smooth above, more or less covered with starry down beneath; stalk $\mathrm{I} \frac{1}{2}$ to 2 ins. long. Floral bract narrowly obovate, 5 to 6 ins. long, downy above, smooth below; flowers yellowish, produced in a cyme at the end of a slender stalk, $1 \frac{3}{4}$ ins. long. Fruit $\frac{1}{3}$ in. long, felted, roundish oval.

Native of Eastern N. America; long in cultivation, but confused with $\mathrm{T}$. americana, between which and $\mathrm{T}$. heterophylla it is in most respects intermediate. From T. americana it is easily distinguished by the dull downy under-surface of the leaves, but the down is variable in amount. I have not seen it in flower in this country. It occasionally produces enormous leaves on young succulent shoots; I have gathered them 17 ins. by 12 ins. Like T. americana, the branches are liable to die back. It is sometimes found in gardens under the name " $\mathrm{T}$. pubescens," but the true T. PUBESCENS, Aiton, is not in cultivation, and probably not hardy.

\section{T. Miqueliana, Maximozvicz.}

A tree $40 \mathrm{ft}$. high, the young shoots, leaf-stalks, and especially the undersurface of the leaves covered with a dull grey felt. Leaves broadly ovate, 2 to 5 ins. long, $I \frac{1}{2}$ to $3 \frac{1}{2}$ ins. wide; heart-shaped at the base, taper-pointed, coarsely toothed (sometimes lobed); dark glossy green above, without tufts in the vein-axils beneath. Flowers (not yet produced in Britain) numerous, sometimes over twenty on the cyme; floral bracts 3 to $4 \frac{1}{2}$ ins. long, $\frac{5}{8}$ to $\frac{3}{4}$ in. wide, with scattered starry down. Fruit globose, felted, $\frac{3}{8}$ in. long.

Not known in a wild state, but much planted in Japan near temples; 
introduced to Kew in 1900. It is distinct among limes, with a similarly felted under-surface in the long-pointed, ovate leaves. Among cultivated limes it keeps its leaves longer than any other, I have seen them quite green in mid-November. It is, however, possible that this character may disappear as the trees grow older.

\section{T. Moltkei, Spath. Moltke's Lime.}

This tree was first noticed in Mr Spath's nursery, near Berlin, over thirty years ago, and was offered in his catalogue of 1883 . He considered it to be a hybrid between $T$. americana and $T$. tomentosa, the former of which it resembles in the leaves, except that they are somewhat grey and downy beneath - a character presumably inherited from the silver lime. Later observers have, however, substituted as a parent in place of $\mathrm{T}$. tomentosa, the pendulous, long-stalked T. petiolaris, from whose silvery leaves, of course, nearly similar characters would be inherited. Some years ago I saw a tree of T. Moltkei, which had been planted in 1888 by the famous field-marshal whose name it bears, in Mr Spath's grounds near a specimen of T. tomentosa planted by Bismarck. It has thriven remarkably well, and is a handsome pyramidal tree about $40 \mathrm{ft}$. high, of great vigour. Professor Sargent states that in the Arnold Arboretum a tree identical with the above has been raised from a seed of T. petiolaris, fertilised, it is assumed, by a tree of T. americana standing near.

Very similar to T. Moltkei is T. SPEcTaBilis, Dippel, probably a hybrid between T. Michauxii and T. tomentosa. The leaves have the same greywhite, downy under-surface; winter buds downy at the points.

\section{T. MONGolica, Maximowicz. Mongolian Lime}

A tree about $30 \mathrm{ft}$. high, with smooth, reddish shoots. Leaves $\mathrm{I} \frac{1}{2}$ to 3 ins. long, about as much wide, maple-like in form, in young trees often threelobed or obscurely five-lobed, the lobes and apex taper-pointed; coarsely toothed, the teeth triangular with slender points; smooth and glossy above; pale beneath, and smooth except for conspicuous tufts of down in the veinaxils; stalk about I in. long, smooth, reddish. Flowers produced in late July, often numerous (sometimes thirty or more) on the cyme; floral bract 2 to 3 ins. long, $\frac{1}{2}$ in. wide. Fruit obovoid, downy.

Native of N. China and Mongolia; introduced to the Jardin des Plantes at Paris in 1880 . From this source all the trees in cultivation have been raised. I saw it in several continental establishments in 1904, and the plants then obtained for Kew represent, I believe, its first introduction to Britain. This lime is apparently very hardy, and has already flowered at Kew; it promises to make a small elegant tree. The lobing of the leaf renders it very distinct in a young state, but this is evidently less marked in adult trees.

\section{T. Oliveri, Szyszylowicz.}

A tree $50 \mathrm{ft}$. high, with smooth young shoots. Leaves roundish ovate, 3 to 4 ins. long, scarcely as wide; abruptly taper-pointed, heart-shaped at the base, with short teeth at the margin; dark green and smooth above, pure white beneath, with dense close felt; axil-tufts of down absent; stalk I to 2 ins. long.

Native of Central China; discovered by Henry in 1888 in the province of Hupeh; introduced by Wilson in 1900 for Messrs Veitch. Only small plants that have not yet flowered exist in this country, but the species is very promising. It is allied to $T$. tomentosa, but differs in its smooth young 
shoots. Henry says that its flowers are similar to those of that species, but smaller. His specimens in the Kew Herbarium show the fruit to be oval or globose, $\frac{1}{3}$ to $\frac{1}{2}$ in. long, warted, white with down.

\section{T. ORBICULARIS, Jouin.}

This tree originated in the nursery of Messrs Simon-Louis, near Metz, about 1870. Mr E. Jouin, who described it and gave its history in La Semaine Horticole, Aug. 26, 1899, says that it was raised from a seed of $T$. petiolaris, and he offers the suggestion that it may be a hybrid between that species and $T$. euchlora. It much resembles $T$. petiolaris, but the leaves (of a very glossy green above) have shorter stalks, and the felt on the under-surface is grey rather than silvery. They remain on the trees until late October. The branches are pendulous, and, according to M. Jouin, the tree is of very vigorous growth and forms a conical head. Young trees at Kew thrive admirably and give every indication of making fine specimens.

\section{T. paucicostata, Maximorvicz.}

A small deciduous tree, the young shoots smooth. Leaves very obliquely ovate, the base cut straight across in a slanting direction or slightly heartshaped, the apex acuminate, margins conspicuously and fairly regularly toothed except at the apex and the base; 2 to $3 \frac{1}{2}$ ins. long and $1 \frac{1}{2}$ to $2 \frac{1}{2}$ ins. wide in adult trees, much larger (up to 5 or 6 ins. long) in young, cultivated ones; dull dark green and smooth above, green beneath, and with tufts of rusty brown down in the axils of the veins, but not at the base, where the main veins join the leaf-stalk; stalk smooth, $\frac{3}{4}$ to $I \frac{1}{2}$ ins. long. The species has not yet flowered in cultivation, but in wild specimens the cymes carry seven to fifteen flowers, the bract is smooth, 2 to 3 ins. long. Fruit roundish or slightly obovate.

Native of W. China; discovered in the province of Kansu by Potanin in 1875. The plant is believed to have been grown at Coombe Wood under the name "T. Miqueliana var. chinensis," having been introduced in Igor by Wilson. The leaves of this plant, however, are more downy beneath, especially at the base of the blade, than in wild adult specimens. There is nothing yet to be said of its merits as a garden tree except that it seems quite hardy. It appears to most closely resemble $T$. cordata in general aspect and differs much from ordinary T. Miqueliana.

\section{T. Petiolaris, De Candolle. Pendent Silver Lime.}

\section{(Bot. Mag., t. 6737 ; T. americana pendula, Hort.)}

A round-topped tree, 60 to $80 \mathrm{ft}$. high at present in Britain, probably $100 \mathrm{ft}$. high ultimately, with pendulous branches and a singularly graceful habit; young shoots downy. Leaves roundish ovate, heart-shaped or nearly straight across at the base, mostly oblique, pointed, regularly and sharply toothed; 2 to $4 \frac{1}{2}$ ins. long, about three-fourths as wide; dark green and slightly downy above, white with a close felt beneath; stalk downy, up to $2 \frac{1}{2}$ ins. long. Flowers dull white, three to ten together in drooping cymes 2 to 3 ins. long. Floral bract as long as the cymes, narrowly obovate, sprinkled with minute tufted down. Fruit globose to orange-shaped, grooved, warty, $\frac{1}{3}$ in. wide.

Of doubtful origin, but, if truly wild, a native no doubt of E. Europe. Some authorities consider it a garden form of $T$. tomentosa, which it resembles in some particulars, but is very distinct in its weeping habit, the 
long leaf-stalks, and the short, broad, grooved fruit. It appears to have been introduced to Britain about 1840 , and was for long known in nurseries as "T. americana pendula" - a name which should be dropped, as the tree has not the least connection with $T$. americana, either botanically or geographically. One of the most beautiful of limes, it should be planted in place of the common lime, which is too abundant. There is a good specimen at Kew which flowers every year in late July and August, and whose fragrance

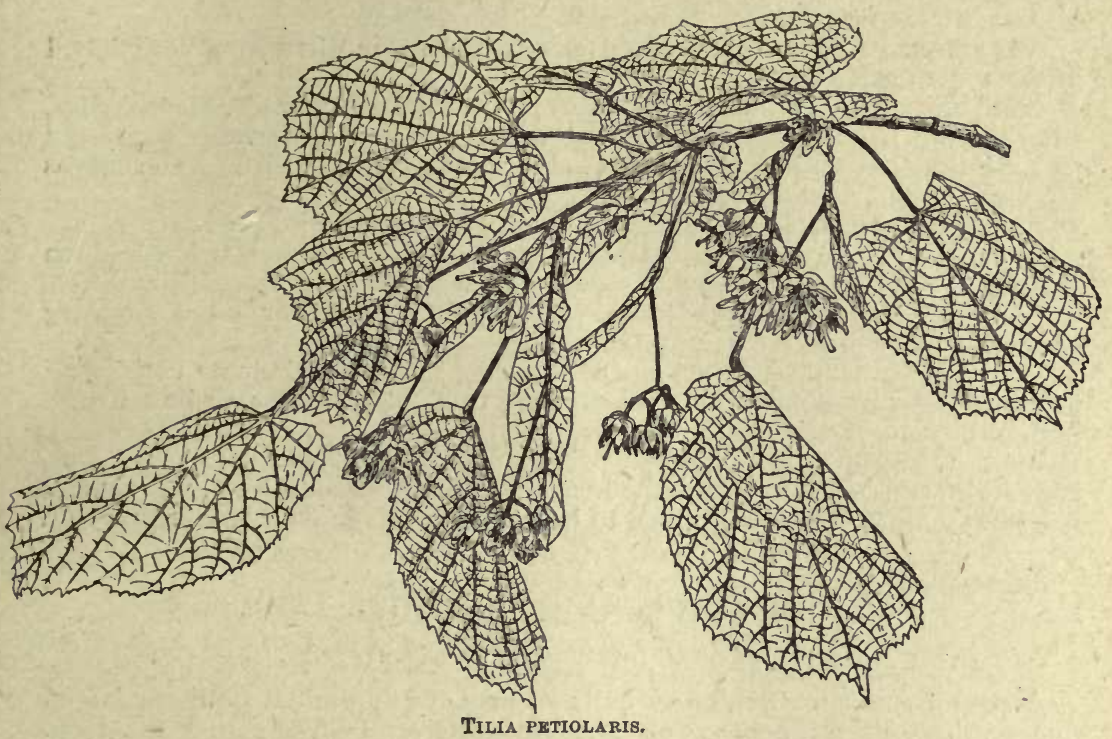

is then perceptible yards away. Bees find something narcotic in the flowers, as they may be seen in the evenings lying in scores beneath the tree, and many do not recover.

\section{T. Platyphyllos, Scopoli.}

A tree of the largest size, Ioo ft. or more high, with a straight, clean trunk, and a shapely, rounded head of branches; young shoots downy. Leaves roundish heart-shaped, occasionally oblique, 2 to 5 ins. long, nearly or quite as much wide; shortly taper-pointed, sharply toothed, dark green and slightly downy above, densely so beneath, especially on the veins and midrib; stalk downy, $\frac{1}{2} \cdot$ to 2 ins. long. Flowers yellowish white, produced in late June, usually in three-but sometimes six-flowered, lax, pendent cymes, 3 or 4 ins. long. Floral bracts 2 to 5 ins. long, $\frac{1}{2}$ to $1 \frac{1}{4}$ ins. wide; downy, especially on the midrib and behind. Fruit somewhat pear-shaped, $\frac{1}{3}$ to $\frac{1}{2}$ in. long, prominently five-ribbed, downy.

Native of Europe, especially the central and southern part. Although not so commonly grown in England as $\mathrm{T}$. vulgaris, it is a more shapely and cleaner grown tree. The trunk does not produce the numerous swollen burrs covered with adventitious buds that are so characteristic of $T$. vulgaris. From T. vulgaris and T. cordata this lime is easily distinguished by its larger downy leaves, the downy shoots, and the larger five-ribbed fruit. These 
three limes, it may be mentioned, together constitute the T. europæa of Linnæus, $\mathrm{T}$. cordata being the representative in N. Europe, $\mathrm{T}$. platyphyllos in the south.

Numerous varieties of garden origin are offered in nurseries, of which the most notable are:-

Var. ASPLENIFOLIA (syns. laciniata and filicifolia).-A much smaller, denser-habited tree than the type, with the leaves raggedly, deeply, and irregularly lobed, often cut to the midrib into three or more long, narrow, deeply toothed divisions.

Var. AURANTIA.- Young branchlets golden yellow.

Var. FILICIFOLIA NOVA.--Leaves narrow-triangular, often irregularly lobed in the way of asplenifolia, but not so deeply.

Var. OBLIQUA.-In the south of Europe is found a form of $T$. platyphyllos, with smooth shoots and much less downy leaves. It has been suggested that the lime known in gardens as T. obliqua may be that form. The leaves are very oblique at the base.

Var. PYRAMIDALIS.-Of pyramidal habit; possibly a wild form.

Var. TORTUOSA.- Young branches curiously curled and twisted, often forming loops. First shown at a meeting of the R.H.S. in December, 1888.

Var. VITIFOLIA. - Leaves with several pointed, slender lobes standing out $\frac{1}{2}$ to $I$ in. beyond the average margin.

There is a worthless lime known in gardens as " $T$. sublunata variegata" or "europæa variegata," which may belong to T. platyphyllos, or be a hybrid between it and T. cordata.

In S.E. Europe, T. platyphyllos is replaced by T. CORINTHIACA, Bosc, and, still farther east, in Persia, Armenia, and the Caucasus, by T. CAUCASICA, Ruprecht. Both are closely allied to it, but neither is in cultivation.

\section{T. tomentosa, Moench. White Lime.}

\section{(T. argentea, Desfontaines; T. alba, Aiton.)}

A tree 60 to roo ft. high, usually of broadly pyramidal habit, and with rather stiff, erect branches; young shoots woolly. Leaves 2 to 5 ins. long, about as wide, roundish, heart-shaped, or nearly straight at the base, shortly and slenderly pointed, frequently with small lobes at the margins as well as the sharp, sometimes double teeth; dark green above and slightly downy at first; silvery white with a close felt beneath ; stalks $\frac{3}{4}$ to $I_{\frac{1}{2}}$ ins. long, felted. Flowers dull white, produced in late July and early August in threeto ten-flowered cymes, $1 \frac{1}{2}$ to $2 \frac{1}{2}$ ins. long. Floral bract downy, rather longer than the cymes. Fruit $\frac{1}{3}$ to $\frac{1}{2}$ in. long, egg-shaped, with a short point, white with down and minutely warted.

Native of S.E. Europe; introduced in 1767 . This tree, especially when fully grown, is handsome; in the young and intermediate states it is stiff and rather formal in habit. It thrives admirably in the south of England, and some fine examples exist there, notably one at Albury about Ioo ft. high. In a breeze this tree presents a lively aspect, through the flashing of the under-surface of the leaves as they are turned by the wind. It is not likely to be confused with any but the other limes whose leaves are silvery white beneath, viz., T. petiolaris and Oliveri. From the former it differs much in habit and in the short leaf-stalks; and T. Oliveri has no down on the shoots.

\section{T. TUAN, Szyszylowicz.}

A tree 40 to $50 \mathrm{ft}$. high, young branches smooth, or soon becoming so. Leaves thin, $2 \frac{1}{2}$ to $5 \frac{1}{2}$ ins. long, $1 \frac{1}{2}$ to $3 \frac{1}{2}$ ins. wide; broadly ovate with a very 
oblique, sometimes slightly heart-shaped base, apex slender-pointed; margins distantly and minutely toothed towards the point, but quite entire at the lower half; upper surface nearly smooth, lower one covered with a close grey felt, and with small tufts in the vein-axils; stalks slender, downy, I to $2 \frac{1}{2}$ ins. long; floral bract 3 to 5 ins. long, $\frac{1}{2}$ to $\frac{3}{4}$ in. wide, stellately downy.

Native of W. China; discovered by Henry in 1888. The specific term "Tuan" is the native Chinese name for all limes. Henry observes that the bark of this species is much used for making shoes.

\section{T. vUlgaris, Hayne. Common Lime.}

(T. intermedia, De Candolle; T. europæa, Linnaus (in part).)

A tree reaching well over $100 \mathrm{ft}$., sometimes $130 \mathrm{ft}$. high; young branches smooth. Leaves $2 \frac{1}{2}$ to 4 ins. long, nearly as wide; obliquely heart-shaped at the base, with a short, tapered apex, sharply toothed, dark green and smooth above, pale green beneath, with tufts of hairs in the main axils; stalk slender, I to 2 ins. long, smooth. Flowers yellowish white, produced in pendent, slender-stalked cymes, 3 or 4 ins. long, during early July. Floral bracts 3 to $4 \frac{1}{2}$ ins. long, $\frac{1}{2}$ to $\frac{7}{8}$ in. wide; slightly downy on the midrib at the back. Fruit roundish oval, the shell thick and tough with ribs only faintly showing.

This tree is of uncertain origin, but is now generally believed to be a hybrid between $T$. cordata and T. platyphyllos. It is the common lime of the British Isles, and one of the most popular of all trees for avenues, streets, 'gardens, and parks. It has the defect of dropping its leaves early, especially in dry summers, and is very subject to the attacks of aphides, whose excrement turns black on the leaves and renders them very unsightly in late summer. With better limes available, it is, I think, planted much more abundantly in these days than its merits justify. Rarely producing fertile seed, it is propagated by layering from stools, and owing possibly to this process, now centuries old, it often has an objectionable propensity to form huge burrs on the trunk, that sprout into dense thickets of succulent shoots, which if not removed ultimately completely hide the trunk.

The common lime reaches to great age, and has the faculty of keeping alive for many years after the centre of the trunk has decayed. In consequence, many famous and historical trees and avenues exist, especially in cathedral towns and university cities. So far as I have seen, most of the large limes of Central Europe are T. cordata.

Several gall-producing insects infest the leaves, the commonest being one which produces the curious "nail-gall," a conical, pointed growth on the surface of the leaf, $\frac{1}{4}$ to $\frac{1}{3}$ in. long. None of these pests appear to do much permanent damage.

The timber of the lime is useful for indoor purposes, being white and soft; it is used in pianoforte manufacture. The inner bark is very tough, and furnishes the material out of which the well-known "bast" mats are made.

\section{TORREYA. TAXACEA.}

A group of four species of evergreen trees, named in honour of Dr John Tcrrey, a famous Anıerican botanist. They are closely allied to Cephalotaxus (q.v.) and Taxus, and have opposite branchlets and linear, firm, sharp-pointcd leaves terminated by a fine hard point, and arranged in opposite spreading ranks. Flowers unisexual, the sexes 
either on the same or separate trees (solitary examples have borne fertile seed in this country); the male flowers are solitary in the leaf-axils, and composed of six to eight whorls of stamens. Fruit egg-shaped, a thin, tough, fleshy layer enclosing a large, bony seed.

Like allied groups, the Torreyas are of interest in representing on a few isolated spots-Florida, California, China, and Japan-a type of vegetation that in earlier geological periods occupied much of the earth's surface. They are, perhaps, of more scientific than horticultural interest, but T. nucifera and T. californica are well worth a place in warm, sheltered gardens. They like a good loamy soil, and the Floridan species is found on limestone. They should, if possible, be increased by seeds, failing which cuttings may be employed. T. Taxifolia, Arnott, the "Stinking Cedar" of Florida, does not appear to be in cultivation.

\section{T. CALIFORNICA, Torrey. CALIFORNIAN NUTMEG.}

(T. Myristica, J. D. Hooker, Bot. Mag., 4780.)

A tree 50 to $70 \mathrm{ft}$. high in California (rarely $100 \mathrm{ft}$.), with a straight, erect trunk and whorled branches; branches horizontal; branchlets pendulous, bearing the leaves in two flattish ranks. Leaves spreading at angles of $45^{\circ}$ to $70^{\circ}$ to the twig; $1 \frac{1}{2}$ to 3 ins. long, about $\frac{1}{8}$ in. wide; slightly convex, linear, with a slender spine-tipped point; dark glossy green above; yellowish green with a glaucous band of stomata each side the midrib beneath. The foliage as a whole is hard, stiff, and well armed by the needle-like points. Male flowers egg-shaped, $\frac{1}{3}$ in. long, pale yellow. Fruit olive-like green, ultimately streaked with purple, about $\mathrm{I} \frac{1}{2}$ ins. long by $\mathrm{I}$ in. wide, a thin, resinous flesh covering the grooved shell of the seed.

Native of California, where it is widely spread, but not abundant; introduced in 1851 . This interesting and handsome tree appears to be best suited for the milder parts of the country, and one of the best specimens in the country is at Tregothnan, in Cornwall, $45 \mathrm{ft}$. high. It has, nevertheless, withstood $32^{\circ}$ of frost at Kew, and, among other places, has borne fertile seed as far north as Orton Hall, Peterborough. Its foliage much resembles that of Abies bracteata, and is distinct in its length from the other species. In the south of England this tree deserves a wider trial than it has yet received. The popular name refers to the outward likeness of the seed to a nutmeg, but it has, of course, no similar qualities.

\section{T. NUCIFERA, Siebold.}

A tree in Japan occasionally $80 \mathrm{ft}$. high, oftener a shrub or small tree 20 to $30 \mathrm{ft}$. high; in cultivation, so far as I have seen, always of a shrubby character, and not more than 10 or $12 \mathrm{ft}$. high. Young shoots green, becoming in succeeding years purplish and shining. Leaves linear, $\frac{3}{4}$ to $1 \frac{1}{4}$ ins. long, $\frac{1}{8}$ to $\frac{3}{16}$ in. wide; tapered at the upper part to a slender, stiff point; very dark glossy green above, and with two glaucous stomatic strips beneath. The leaves (somewhat convex on the upper surface, stiff and hard in texture) are borne in two spreading ranks, which form a broad $\mathbf{V}$-shaped channel. Fruits green, elliptical, 1 to $1 \frac{1}{8}$ ins. long, $\frac{3}{4}$ in. wide. They are occasionally borne in abundance at Kew.

Native of Japan; first introduced in the eighteenth century. Prof. Sargent, who saw this tree $80 \mathrm{ft}$. high in Japan, says that "with their bright red bark and compact heads of dark green, almost black, lustrous foliage, 
they possess extraordinary beauty." The kernels of the nuts have an agreeable, slightly resinous flavour.

Nearly allied to the above is T. GRANDIS, Fortune, of which a few plants are in cultivation. There is a specimen about $8 \mathrm{ft}$. high at Kew which is quite hardy. Its leaves are shorter and thinner in texture than those of T. nucifera, and when crushed do not emit a pungent aromatic odour as in that species. This comparatively odourless character distinguishes it from all other Torreyas. The tree was discovered in China by Fortune in 1855; it attains there the same height as $T$. nucifera does in Japan.

\section{TRACHELOSPERMUM. APOCYNACEÆ.}

The two species grown out-of-doors are evergreen twining shrubs, with opposite, leathery leaves, and more or less hairy stems, exuding a milky juice when cut. Flowers in slender, stalked cymes, very sweetly scented. They both need wall protection, and may be grown in a light loamy soil. When young or newly planted, a little peat added is an advantage. Increased by July or August cuttings.

\section{T. Crocosotomum, Stapf.}

An evergreen climber at least $15 \mathrm{ft}$. high, of dense, much branched habit; the young shoots very hairy, and the hairs persisting more or less for several years. Leaves leathery, opposite, oval or slightly ovate; $\frac{3}{4}$ to 2 ins. long, $\frac{3}{8}$ to $\frac{3}{4}$ in. wide; mostly blunt at the apex, dark glossy green, smooth; stalk $\frac{1}{8}$ in. or less long. Flowers yellowish white, fragrant, produced in July and August in slender terminal cymes, 2 to $2 \frac{1}{2}$ ins. long. Corolla with a tube $\frac{1}{3}$ in. long, and with five spreading obovate lobes, giving it a diameter of $\frac{3}{4}$ in. Calyx-lobes erect, narrow, pointed.

Probably a native of China. All the plants in cultivation have originated from one which for many years has grown on the west wall of the herb garden at Kew, but whose origin and history have. been lost. It has smaller leaves and yellower flowers than T. jasminoides, and is readily distinguished when in flower by the erect calyx-lobes, which in T. jasminoides are larger and distinctly turned back. It has never been injured by any frosts of the last thirty years at Kew.

\section{T. JASMINOIDES, Lemaire.}

(T. divaricatum, K. Schumann; Rhyncospermum jasminoides, Lindley, Bot. Mag., t. 4737.)

An evergreen twiner, growing Io or $12 \mathrm{ft}$. high, young shoots hairy. Jeaves oval-lanceolate, $I_{2}^{\frac{1}{2}}$ to $3 \frac{1}{2}$ ins. long, $\frac{1}{2}$ to I in. wide; tapering at both ends, the tip blunt, downy beneath when young, becoming smooth; dark glossy green above; stalk about $\frac{1}{8}$ in. long. Flowers very fragrant, produced in July and August on smooth, slender-stalked cymes, $1 \frac{1}{2}$ to 2 ins. long, usually on short lateral twigs. Corolla scarcely $\mathbf{I}$ in. across, pure white, five-lobed, the lobes spreading, wavy; the tube $\frac{1}{4}$ in. long, narrowed towards the base. Calyx with five lanceolate reflexed lobes.

Native of China; introduced by Fortune from Shanghai in 1844. Usually seen in greenhouses, where its flowers are prized for their fragrance, this species can also be grown on walls along the south coast and in the west.

Var. VARIEGATUM has shorter, broader leaves, bordered and blotched with creamy white. 


\section{TRACHYCARPUS Fortunei, Wendland. Chusan Palm. PALMACEA.}

\section{(T. excelsa, Wendland; Chamærops excelsa, Martius, not Thunberg; C. Fortunei, Hooker.)}

This palm, which is the only species that can be termed really hardy in this country, varies in height according to the circumstances under which it is grown. In the Temperate House at Kew there is an example about $50 \mathrm{ft}$. high, but in the open air plants at least forty years old are only about $\mathrm{I} 2$ or $\mathrm{I}_{5} \mathrm{ft}$. high. In the warmest counties, however, it is 25 to 30 ft. high. The stem is erect, cylindrical, clothed with coarse, dark, stiff fibres, which are really the disintegrated sheathing bases of the leaves. These fibres are employed by the Japanese and Chinese to make ropes and coarse garments. The leaves, which persist many years, are fan-shaped, $1 \frac{1}{2}$ to $2 \frac{1}{2} \mathrm{ft}$. long, $2 \frac{1}{2}$ to $4 \mathrm{ft}$. wide, divided at the outside into numerous deep, narrow, folded segments, 2 ins. wide, tapering to a ragged point. The stalk is two-edged, and varies in length according to the age of the specimen and the conditions under which it is grown; it is usually between 2 and $3 \mathrm{ft}$. long, and $\frac{1}{2}$ to $I$ in. wide, with small jagged teeth on the margins. The flowers are borne in a large, decuryed, handsome panicle from near the top of the stem among the younger leaves; they are yellow, small, but very numerous. The panicles bear flowers usually of one sex only, the female ones being the smaller and less ornamental. Fruit a blue-black drupe about the size of a boy's marble.

Although the Chusan palm is perfectly hardy in the south and west of Britain, in so far as it will, when properly established, withstand a temperature of $32^{\circ}$ or more of frost, it likes a spot screened from the north and east winds. Exposed to blasts from those quarters it will live, but has usually a miserable, battered appearance. When it was first experimented with in the open air it was usual to cover it with mats or branches, but this has been found to be unnecessary. On account of its slow growth in the open air when young, it is usually the practice to put out-of-doors plants which have already attained some size in the cool greenhouse, in order that an immediate effect may be produced. Such plants it is advisable to protect during severe (but only severe) weather for a few years. For the rest this palm likes a rich loamy soil. It is a gross feeder, and is much helped by an occasional thick top-dressing of cow-dung.

Its first introduction to Europe has to be credited to Siebold, who sent seeds from Japan (where it is cultivated, but doubtfully indigenous) to Leyden in 1830 . Not many germinated, but of the few that did, one was sent to Kew in 1836 . In 1860 this plant was $28 \mathrm{ft}$. high, but no one suspecting its hardiness, it was grown in the tropical palmhouse. Fortune introduced plants and seeds in 1849 , and it was with some of the plants so obtained that experiments were made in the open air-with such successful results. (See plate, vol. i., p. 57.)

In Sir Edmund Loder's garden at Leonardslee there is a very interesting palm obtained some years ago, by him from Japan. Its leaves 
are smaller, stiffer, and not so prickly on the stalks as in ordinary T. Fortunei, and it produces suckers freely. The flowers of this palm are those of T. Fortunei, and Henry has named it var. SURCULOSA, but it is possibly the T. nana, Beccari (see Webbia, vol. iii., p. 187).

\section{TRICUSPIDARIA. TILIACEA.}

A Chilean genus of two species, both evergreen shrubs or small trees, with alternate leaves, and solitary, bell- or urn-shaped flowers produced on pendulous, thickened stalks from the leaf-axils. They both delight in a cool, moist, peaty soil, or a loam free from lime, and can be increased by cuttings of half-ripened wood placed in a close frame with gentle bottom heat. Excellent and attractive shrubs in the milder counties, they need protection near London.

\section{T. DEPENDENS, Ruiz and Pavon.}

(Bot. Mag., t. 8 II 5 ; Crinodendron dependens, C. K. Schneider.)

An evergreen shrub or small tree, up to $30 \mathrm{ft}$. high, the young shoots reddish and faintly downy. Leaves oval or ovate, I to 3 ins. long, $\frac{1}{2}$ to $\mathrm{I} \frac{1}{2}$ ins. wide; shallowly and rather coarsely toothed, dark green and smooth above, much paler beneath; stalk reddish, $\frac{1}{8}$ to $\frac{1}{4}$ in. long, slightly hairy. Flowers white, bell-shaped, $\frac{3}{4}$ in. long, produced singly on a pendulous stalk $\mathrm{I}$ to 2 ins. long, from the leaf-axils. Corolla of five rather fleshy petals, which are three-toothed at the ends, downy at the margins, oblong.

Native of Chile; introduced by Mr H. J. Elwes in Igor. Its name was for a long time wrongly attached to its fellow species in gardens. It appears to thrive better than T. lanceolata as a wall shrub at Kew, but is considered to be more tender in the open in Ireland. It is, certainly a much more rapid grower. On a wall at Kew it has stood quite uninjured for several winters, and blossoms freely in late summer. It is very distinct from T. lanceolata in its white, more bell-shaped flowers. Easily increased by cuttings.

\section{T. LanCeolata, Miquel.}

(T. dependens, Hort., Bot. Mag., t. 7160 ; T. hexapetala, Turczaninow ; Crinodendron Hookerianum, Gay.)

An evergreen shrub or small tree, up to ro or $15 \mathrm{ft}$. high, sometimes more, of a stiff, bushy growth; young wood felted with grey down. Leaves oblong: lanceolate, pointed; $1 \frac{1}{2}$ to 5 ins. long, $\frac{1}{2}$ to $1 \frac{1}{4}$ ins. wide; coarsely toothed except towards the tapering base, dark green above and downy on the midrib, paler beneath and downy on the midrib and chief veins, stiff and hard in texture; stalk $\frac{1}{3}$ in. or less long, downy. Flowers produced singly from the terminal leaf-axils each on a stout, stiff, downward-pointing, stalk 2 to 3 ins. long. Corolla urn-shaped, I to $1 \frac{1}{4}$ ins. long, rich crimson, very fleshy, grooved, toothed at the narrow mouth; calyx downy.

Native of Valdivia, Llanquihue, and the Island of Chiloe in Chile; introduced by William Lobb for Messrs Veitch in 1848, and for the same firm by Pearce about ten years later. It is only hardy in such places as the Isle of Wight, Cornwall, Ireland, and the west of Scotland, but where it 
succeeds it is one of the most attractive of all shrubs. At Kilmacurragh, Co. Wicklow, it is $20 \mathrm{ft}$. high. It has the curious habit of pushing out its flower-stalks in autumn, but the flowers do not open until the following May. It likes a partially shaded spot; the leaves are often "scorched " and brown at the margins when the plant stands fully exposed to sunshine or wind. This species was long grown in gardens as "T. dependens." The two species are very distinct in shape of leaf and colour of flower.

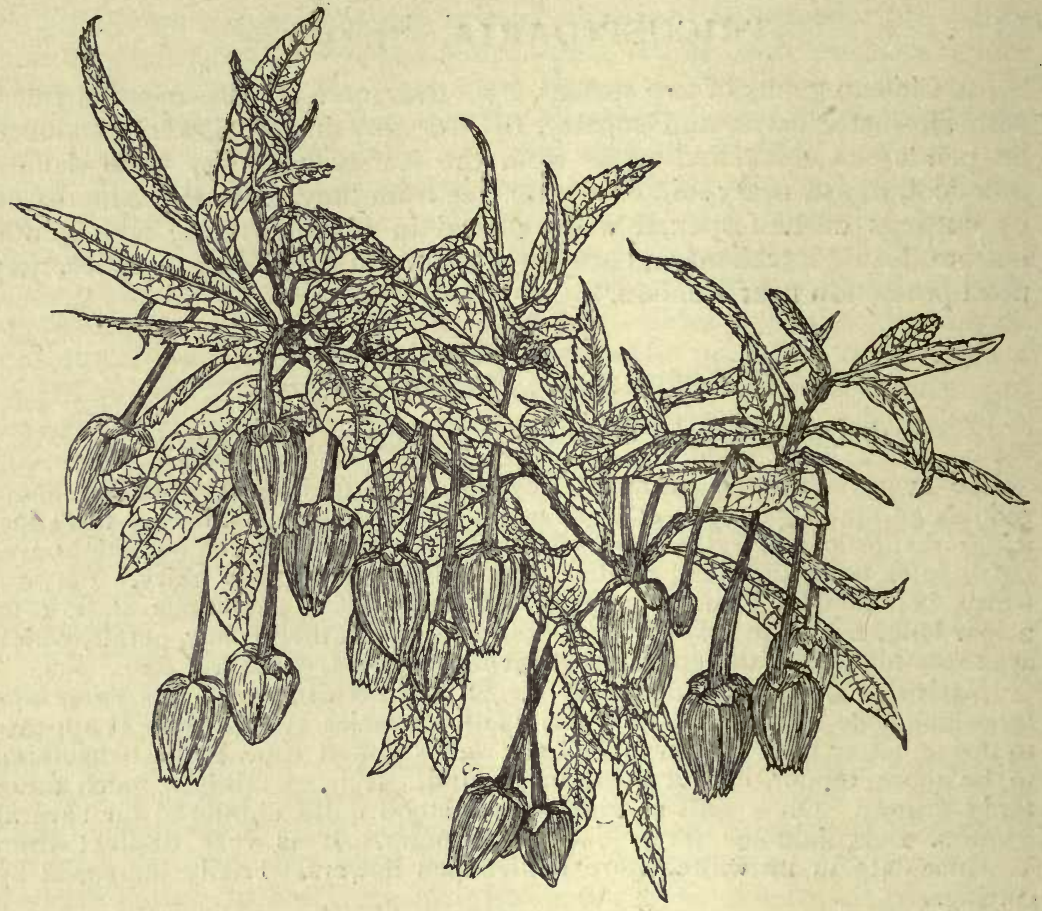

TRICUSPIDARIA LANCEOLATA.

\section{TRIPTERYGIUM WILFORDI, Hooker fil. CELASTRACEA.}

A deciduous shrub of rambling or climbing habit, with angular, warted stems, downy when young. Leaves alternate, oval or ovate, broadly wedge-shaped to rounded at the base, tapered at the apex to a long and slender point; $2 \frac{1}{2}$ to 6 ins. long, $1 \frac{1}{2}$ to 4 ins. wide; the margin set with rounded, blunt, incurved teeth; dark green above, and smooth except for minute down on the midrib when quite young, rather more downy on the midrib and chief veins beneath; stalk $\frac{1}{4}$ to $\frac{3}{4}$ in. long. Flowers yellowish white, about $\frac{1}{3}$ in. wide, produced in a panicle at the end of the shoot, supplemented by clusters in the axils of the terminal leaves, the whole forming an inflorescence up to 8 or 9 ins. long and 2 or 3 ins. wide; petals five, roundish obovate; calyx small, downy, 
with five rounded lobes; stamens five. Fruit three-angled, each angle conspicuously winged; the wings erect, about $\frac{5}{8}$ in. long, $\frac{1}{4}$ in. wide, membranous. The whole inflorescence is covered with short brown felt.

Native of Japan, Corea, and Formosa; discovered in $185^{8}$ by Wilford, the Kew collector; introduced by Mr J. G. Jack to the Arnold Arboretum in 1905 , thence to Kew, where it is apparently fairly hardy but slowgrowing. In foliage it resembles Celastrus, but is very distinct in the fruit, which is more like that of wych elm with an extra wing. The flowers are said to be sweetly scented.

\section{TROCHODENDRON ARALIOIDES, Siebold. TROCHODENDRACE 2 .}

\section{(Bot. Mag., t. 7375.)}

An evergreen glabrous shrub of rather spreading habit in this country, becoming a small tree 15 to $30 \mathrm{ft}$. high in the mountain forests of Yezo and the main island of Japan, where it is indigenous. Leaves rhododendron-like, 3 to 5 ins. long, narrowly oval or lanceolate, leathery, shallowly toothed at the upper end, lustrous green; leaf-stalks half the length of the blade. Flowers produced from April to June in erect, terminal racemes, each flower on a slender stalk I to $I \frac{1}{2}$ ins. long. There are no sepals or petals, and the numerous stamens are set round the edge of a green hemispherical disc, which is really the calyxtube. Across the stamens the flower is $\frac{3}{4}$ in. in diameter. Carpels about ten, arranged in a ring within the stamens.

The only known representative of its genus, this shrub gives the name to a small and peculiar natural order once united with Magnoliacex. T. aralioides is

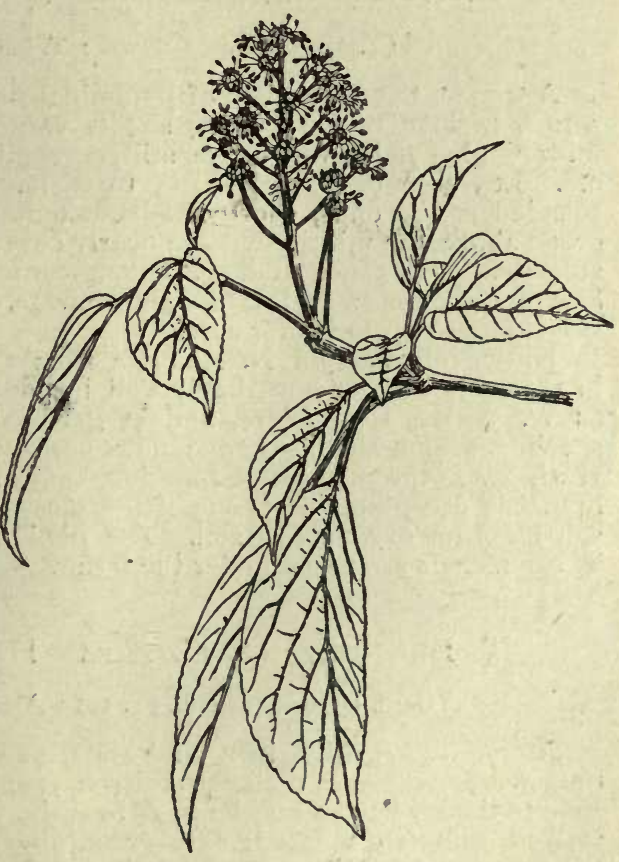

TROCHODENDRON ARALIOIDES. a handsome-foliaged shrub, interesting as well as striking when in blossom, its flowers being a vivid green. First introduced from Japan by Messrs Veitch, in whose nursery at Coombe Wood it bore its green flowers for the first time in 1894 . The original specimen is now at Kew- $\mathrm{a}$ handsome bush Io $\mathrm{ft}$. high. 


\section{TSUGA. Hemlock Firs. CONIFER}

A group of eight or nine evergreen trees of great beauty and elegance, represented on both sides of $\mathrm{N}$. America, in China, Japan, and the Himalaya. They have very slender twigs, and short linear leaves, arranged, except in one species (T. Pattoniana), mainly in two opposite ranks, each leaf seated on a cushion-like projection (as in Picea), and closely set on the twigs-twelve to twenty-four to the inch. Cones solitary, rarely more than I in. long, and usually pendulous at the end of the twigs. Seeds winged. In places where they thrive, which is where the rainfall is abundant and the soil is deep and well-drained, they are not exceeded in beauty of form by any other evergreen trees. They are best propagated by means of seed; but the Japanese and Chinese species, perhaps the others also, can be propagated by cuttings.

\section{T. Albertiana, Sénéclauze. Western Hemlock.}

\section{(T. Mertensiana, Carrière; T. heterophylla, Sargent.)}

A tree up to $200 \mathrm{ft}$. high, of pyramidal habit, with a reddish brown trunk 4 to $6 \mathrm{ft}$. in diameter; young shoots very slender and leafy, downy with intermingled hairs, which are still perceptible on shoots five or six years old. Leaves $\frac{1}{4}$ to $\frac{7}{8}$ in. long, $\frac{1}{16}$ to $\frac{1}{12}$ in. wide; linear, of uniform width, rounded at the ends, shortly stalked, toothed at the margins; glossy dark green above, the midrib sunken; nearly covered beneath with dull grey-white stomata. Cones not stalked, oblong-conical, $\frac{3}{4}$ to $I$ in. long, $\frac{1}{2}$ in. wide before expanding; scales broadly obovate, rounded, often with a minute, velvety down on the outer surface.

Native of Western N. America from California to Alaska; introduced in $185 \mathrm{I}$. It thrives remarkably well in good soil and a moist climate, such as W. Wales, Devonshire, and in Perthshire, where there are many fine specimens approaching (some now perhaps exceeding) 100 ft. in height. It always forms a graceful, tapering, conical tree with the extremities of the branches drooping, and is one of the most pleasing of evergreens; but it is worthless on dry hungry soil. The distinctions between this species and T. canadensis are noted under the latter.

\section{T. Brunoniana, Carrière. Himalayan Hemlock.}

(Gard. Chron., I886, ii., fig. Ior ; Abies Brunoniana, Lindley.)

A tree $120 \mathrm{ft}$. high in a wild state, of cedar-like habit, with spreading branches pendulous at their extremities; young shoots downy on the upper side. Leaves linear, $\frac{1}{2}$ to $1 \frac{1}{3}$ ins. long, $\frac{1}{16}$ to $\frac{1}{12}$ in. wide; blunt at the apex, shortly stalked, minutely toothed; dark green above, with the midrib deeply sunk, the lower surface silvery white, being almost entirely covered with stomata. Cones not stalked, egg-shaped, $\frac{3}{4}$ to I in. long; scales roundish, downy at the base outside.

Introduced in 1838 from the Himalaya, where, twelve years later, Sir Joseph Hooker found it with a trunk sometimes $28 \mathrm{ft}$. in girth. In this country, according to Elwes, the best specimen is at Boconnoc, in Cornwallabout $55 \mathrm{ft}$. high. The finest I have seen is at Fota, a beautiful rounded 


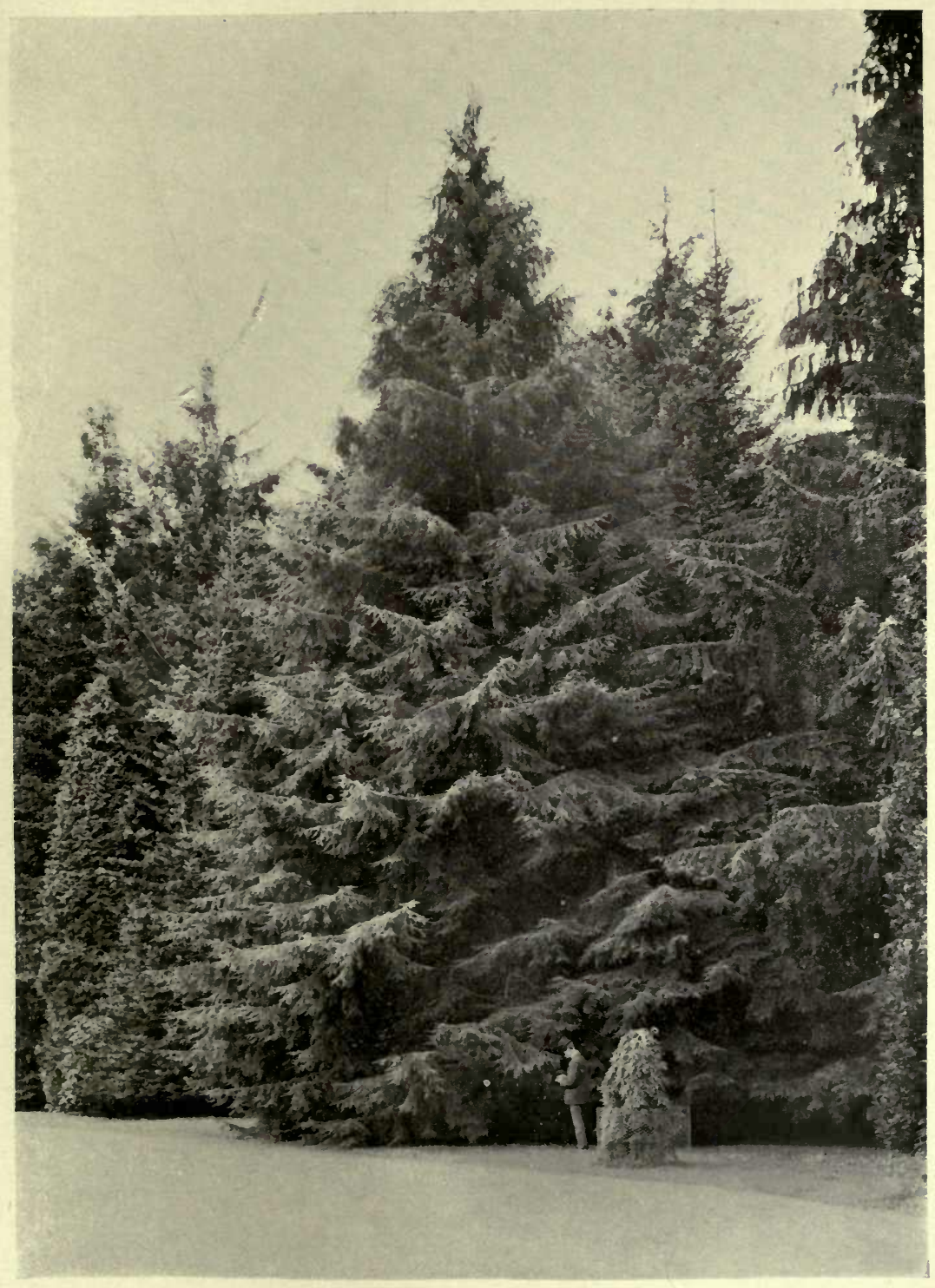

Tsuga Albertiana at Murthly Castle, Perth.

II.]

[Face p. 604 . 

bushy tree about $35 \mathrm{ft}$. high and through, feathered to the ground with its graceful branches. At Dropmore there is also a good example. But the species is only adapted for the milder parts of the British Isles. At Kew it has time after time been destroyed by frost. Of all the hemlock firs it is the one whitest beneath the leaf; this character, with its downy shoots and toothed leaves, will enable it to be recognised.

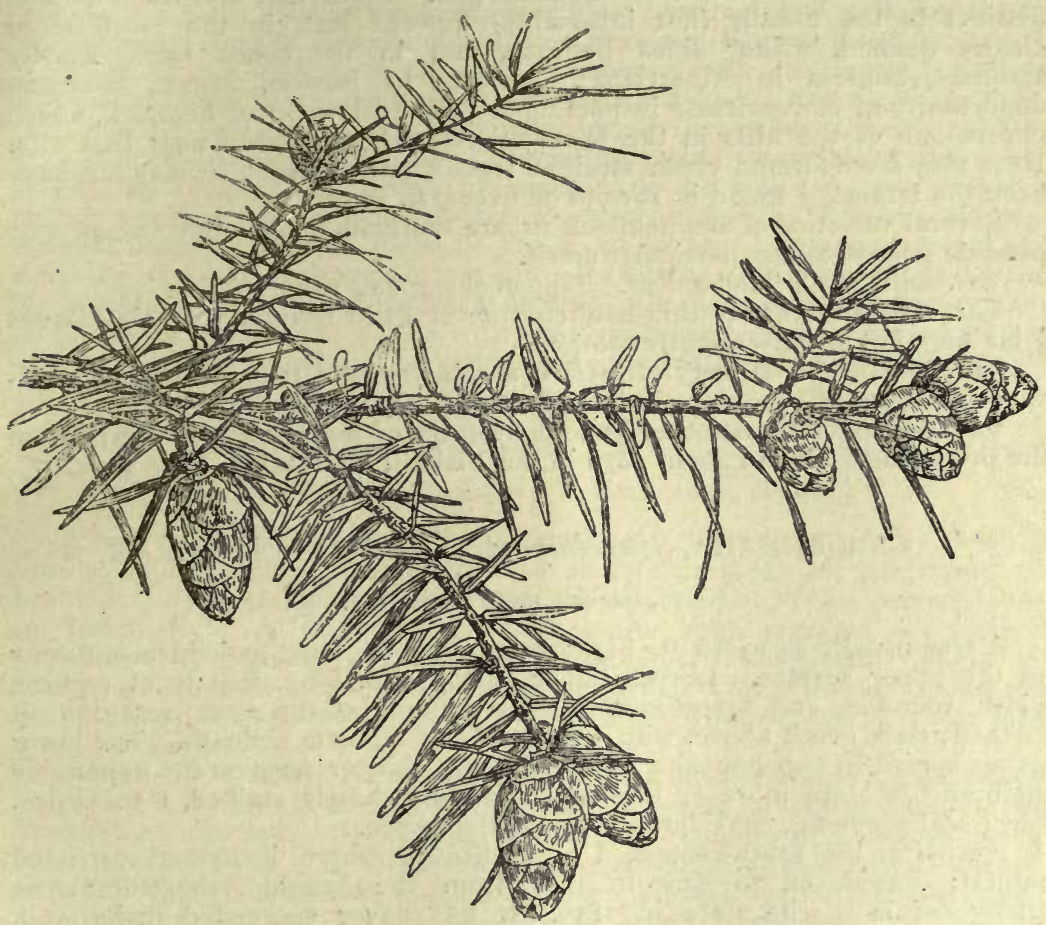

Tsuga Brunoniana.

\section{T. Canadensis, Carrière. Canadian Hemlock.}

(Abies canadensis, Michaux.)

A tree 70 to $100 \mathrm{ft}$. high, with a trunk 6 to $10 \mathrm{ft}$. in girth, and a head of often rounded form; bark reddish brown; young shoots bright grey, minutely hairy. Leaves very shortly stalked, $\frac{1}{4}$ to $\frac{2}{3}$ in. long, linear, but often broadest ( $\frac{l}{16}$ to $\frac{l}{12}$ in.) near the rounded base, tapering thence to a bluntish point; margins toothed; dark green above, with a clear, welldefined band of stomata each side the midrib beneath. The leaves are mainly in two opposite, spreading ranks, but there are also smaller leaves on the upper side of the branchlet pointing forward, flattened to the branchlet, often inverted and showing the white-lined lower surface. Cones $\frac{1}{2}$ to $\frac{7}{8}$ in. long, oval, borne on a short downy stalk; the scales broadly obovate, about as wide as long, minutely downy except on the exposed part.

Native of 'Eastern N. America; introduced early in the eighteenth 
century. This beautiful tree thrives very well in the moister parts of our islands, especially where the soil is good and retentive of moisture. There are good specimens in the west of England, and I have also seen excellent ones at Murthly, and elsewhere in Perthshire. The tree as grown in this country has a strong propensity to branch into several stems near the ground, and to form a large rounded head of branches very distinct from the slenderly tapered form of T. Albertiana. From that species it is also distinct in the usually (not invariably) tapered leaf, in the much more clearly defined, whiter lines beneath, and in the cones being shortly stalked (stalkless in Albertiana). Visitors to Boston, Mass., have an opportunity of conveniently inspecting a primæval wood of hemlock, which covers one of the hills in the beautiful Arnold Arboretum near that city. Here they have formed clean straight trunks, one of which (it may not have been the largest) I found in 1910 to be over $9 \mathrm{ft}$. in girth.

Several varieties of the hemlock fir are cultivated, but none except var. pendula possesses any particular merit.

Var. ARGENTEA (albo-spica).-Tips of the young shoots white.

Var. PARVIFOLIA.-A thin-habited tree of little beauty, with tiny leaves $\frac{1}{4}$ in. long, not or very slightly toothed.

Var. PENDULA. - A very attractive shrub or small tree forming a hemispherical mass of pendulous branches, completely hiding the interior.

Var. SARGENTII.-Another pendulous form of more compact shape than the preceding. Found about 1870 in the Fishkill Mountains, New York.

\section{T. Caroliniana, Engelmann. Carolina Hemlók.}

(Gard. Chron., I886, ii., fig. I53.)

A tree usually 40 to $50 \mathrm{ft}$. high; young shoots glossy, pale brown, downy on the upper surface. Leaves linear, $\frac{1}{4}$ to $\frac{3}{4}$ in. long, mostly of uniform width, rounded, and sometimes slightly notched at the apex; margins not toothed; dark green above, with two bands of stomata beneath. The lower leaves spread in two opposite ranks, but the shorter ones on the upper side the branchlets are more or less erect. Cones shortly stalked, I to $\mathbf{I} \frac{1}{2}$ ins. long; scales oblong, considerably longer than wide.

Native of the south-eastern United States, where it has a restricted habitat; introduced to Kew in 1886 from the Arnold Arboretum; first discovered in a wild state in 1850 . It has never succeeded really well, although capable of withstanding severe cold. It is easily distinguished from both canadensis and Albertiana by the much less downy twigs and by the entire leaves of adult plants. Seedling plants have them toothed.

\section{T. CHINENSIS, Masters.}

(Abies chinensis, Franchet.)

A tree whose young shoots are furnished, especially on the upper side, with dense, short down. Leaves $\frac{1}{3}$ to $\frac{7}{8}$ in. long, $\frac{7}{12}$ in. wide, linear or slightly tapered towards the apex, minutely toothed on the margin (at least on young cultivated plants), dark glossy green above; paler beneath, with two narrow, rather slim bands of white stomata ; stalk $\frac{T}{20}$ in. long. Cones stalkless, erect, ovoid, the scales bright as if varnished.

Native of Szechuen in W. China ; discovered by Père Farges; introduced about 1903 by Wilson, who found it at 9-11,000 ft. altitude. Adult trees appear to have entire leaves. The young plants in cultivation are thriving well. 


\section{T. DiVERSifolia, Masters. JAPANESE Hemlock. \\ (Abies Tsuga var. nana, Hort.)}

A tree 70 or $80 \mathrm{ft}$. high in Japan, with red trunks 6 or $7 \mathrm{ft}$. in girth; young shoots downy. Leaves $\frac{1}{4}$ to $\frac{5}{5}$ in. long, $\frac{1}{16}$ to $\frac{1}{12}$ in. wide: linear, and of uniform width, margins not toothed, distinctly notched at the apex, abruptly tapered to a short stalk at the base; dark glossy green above, with two clearly defined white lines of stomata beneath. Cones egg-shaped, $\frac{1}{2}$ to $\frac{3}{4} \mathrm{in}$. long.

Confined in a wild state to Japan, whence it was introduced in 1861 by John Gould Veitch, and subsequently distributed by his firm as Abies Tsuga (or Sieboldii) var. nana. It is still found under that name in many gardens. It is at once distinguished from T. Sieboldii by its closer habit and downy shoots, its shorter leaves, and by always commencing to grow earlier in spring. It is a neater, smaller tree in gardens than T. Sieboldii, although Sargent observes (Forest Flora of Japan, p. 8I) that in the great forest of it covering the Nikko mountains at $5000 \mathrm{ft}$. altitude, it grows to great size. T. Sieboldii has a more southern habitat. On account of its dainty habit (it is more a shrub than a tree with us) it makes a very pleasing lawn plant, especially in spring, whilst the young twigs are still bright yellow-green.

\section{T. Pattoniana, Sénéclauze. Patton's Hemlock.}

\section{(T. Hookeriana, Carrière; T. Mertensiana, Sargent.)}

A tree 70 to over Ico ft. high, the trunk $\mathrm{I} 2 \mathrm{ft}$. or more in girth; bark redbrown; young shoots downy. Leaves shortly stalked, set all round the branchlet, although more crowded on the upper side, linear, curved; $\frac{1}{2}$ to I in. long, $\frac{1}{20}$ to $\frac{1}{16}$ in. wide; rounded at the apex, margins not toothed; sometimes grey-green, sometimes conspicuously blue-green. There are inconspicuous lines of stomata on both surfaces. Cones without stalks, rich purple when young, becoming red-brown; oval-cylindric, $1 \frac{1}{2}$ to 3 ins. long, $\frac{1}{2}$ to $\frac{3}{4}$ in. thick.

Native of Western N. America from Alaska to California; introduced in 1854. It is distinguished from all other Tsugas by having stomata on both surfaces of the leaf. There has arisen much confusion in regard to the naming of this tree. It is represented in cultivation by two forms-one of a beautiful blue glaucous tint, which in gardens is usually called "Hookeriana"; the other of a darker greener shade, and called "Pattoniana." The tree, however, originally called "Abies" Pattoniana, appears to have been the blue form, which is commonest in a wild state. There is no doubt they belong to the same species, as there are intermediate degrees of blueness. The confusion in the naming of this tree has been increased by the adoption of the name "Mertensiana" (given to it by Bongard in 1832 in conjunction with Pinus) by American authors. "Tsuga Mertensiana," Carrière, has been much used in late years for T. Albertiana.

In all its forms, but more especially the blue one, this tree is remarkably beautiful. It likes a moist climate and a pure atmosphere. At Murthly Castle, near Perth, there is a group of several trees (one with pendulous branchlets) which makes one of the most beautiful garden pictures one can imagine, produced by foliage alone. I saw them in 1906, when they ranged from 40 to $50 \mathrm{ft}$. in height.

Besides the greenish grey and glaucous forms of T. Pattoniana there is a third form, which has green leaves, less than $\frac{1}{2}$ in. long, minutely toothed, and with the stomatic lines on the upper side imperfectly developed (see article by A. Murray in The Garden, Sept. 19, 1874). Henry has called this var. JEFFREYI, and says it is only known in cultivation. 


\section{T. Sieboldi, Carrière. Siebold's Hemlock.}

(Abies Tsuga, Siebold.)

A tree up to $100 \mathrm{ft}$. high in Japan, with a trunk $9 \mathrm{ft}$. or more in girth; but only a small bushy tree with us, although a very elegant one; young shoots perfectly smooth. Leaves linear, of uniform width, $\frac{1}{3}$ to $I$ in. long, $\frac{1}{16}$ to $\frac{1}{10}$ in. wide, rounded and distinctly notched at the apex, not toothed, abruptly narrowed at the base to a short stalk; rich glossy green above, with two clearly defined white lines of stomata beneath. Cones $\frac{3}{4}$ to $1 \mathrm{in}$. long, eggshaped; scales rounded.

Confined in a wild state to Japan, whence it was introduced about 1853 . Although slow-growing and not in the least likely to make a large tree in this country, the grace and beauty of Siebold's hemlock fir makes it well worth cultivation. It is admirable for some sheltered nook on a lawn, where the soil is good and well-drained. Distinguished among Tsugas by the entire margins of the leaf, and glabrous shoots.

The shrub known in gardens as $T$. Sieboldii nana appears to be T. diversifolia. I know of no dwarf form of the true Sieboldii.

\section{ULEX. LEGUMINOSA.}

A genus of very spiny shrubs allied to the brooms, but differing in having the calyx as well as the petals yellow. Only three species, all natives of England, are worth cultivating; several others, mostly found in Spain and Portugal, are too tender to be of any value. The leaves are small and spine-tipped, often reduced to mere prickles; and all the species have the quality of evergreens, from the dark green of their spines and branches.

In gardens they are often useful for covering dry sunny banks or breadths of poor gravelly soil, where most shrubs would not thrive. In such places the double-flowered variety of $U$. europæus is particularly effective in spring. The two other species have a value in flowering in late summer and autumn. None of them will thrive in shade, and they are never satisfactory in rich soil ; in either case flowers will be sparsely borne, and the plants apt to get lank and ungainly. Where the soil is of good quality it is advisable not to dig it over when planting, with the view of keeping it as hard as possible. Propagation by cuttings is referred to under the notice of U. europæus fl. pl. Seeds should be sown singly in small pots and the plants put in their permanent places at their first planting, for they transplant badly. The common gorse should be sown in situ. The three hardy species are easily differentiated as follows :-

U. europoens.

\section{SPRING-FLOWERING.}

\section{AUTUMN-FLOWERING.}

U. Gallii. Spines stiff and long; wing-petals long.

U. nanus. Spines slender; wing-petals short. 


\section{U. Europeus, Linnaus. Gorse, Furze, Whin.}

A shrub usually 2 to $4 \mathrm{ft}$. high as seen wild, but occasionally $6 \mathrm{ft}$. or even more high; excessively spiny. The main branches are hairy, and from them spring numerous short side branches which grow horizontally and always end in a stout, sharp spine, the whole forming an intricate formidable mass. Leaves simple, $\frac{1}{4}$ to $\frac{1}{2}$ in. long, linear, sharply pointed or reduced to mere spines. Flowers produced singly from the leaf-axils of the previous year's shoots, on hairy stalks $\frac{1}{4}$ in. long, transforming the end of the branch into a brilliant raceme of gold. Calyx large, hairy, yellow like the petals, persistent. Pod $\frac{5}{8}$ in. long, covered with brown hairs, two- or three-seeded.

Native of W. and Central Europe, and abundant in the British Isles, where it covers thousands of acres of moor, common, and heath. Whilst April and early May is the time when the gorse is in its full beauty, it commences to flower in February, and odd flowers may be found at almost all times-a characteristic on which is based the country saying, "When furze is out of bloom, then is kissing out of fashion." There is but little use for the gorse in gardens. It may be employed for covering dry banks, but even there the double-flowered variety described below is much to be preferred.

Var. FLORE PLENO. Double-flowered Gorse.-In this variety the stamens disappear from the flower, either partially or entirely, and are replaced by petals of varying size. The variety does not produce seed, and must be propagated by cuttings, which should be made of the current season's wood in August, 3 or 4 ins. long, and placed in a cold frame in very sandy soil, and kept close. They will commence to root and grow the following spring. When the roots are I in. long, the young plants should be potted in 3 -in. pots, ready for planting out whenever required the following winter. It is slower-growing and more compact in habit than the type, and is in every way superior to it as an ornamental shrub for gardens, lasting longer in flower. Like common gorse, it needs a dry, hungry soil and a sunny position to develop its full beauty. In rich soil it grows rank and does not flower so freely. This variety first appeared in the nursery of $\mathrm{Mr}$ John Miller of Bristol, about 1828 .

Var. STRICTUS, Webb (U. strictus, Mackay). Irish Gorse.-A variety of erect, rather columnar growth, of little value in the garden; as it flowers sparsely. Found in Co. Down in the early part of the nineteenth century, native also of Spain. Known also as U. hibernica and U. fastigiata.

Dried furze was at one time much used in country places for heating bakers' ovens, and is still often woven into hurdles for sheltering cattle, forming a good wind screen, not rubbed against or soon knocked down. Owing to the amount of dead twigs and spines inside the outer living layer, gorse plants are very inflammable during hot summer spells. Gorse, therefore, even the double-flowered variety, should not be planted where its firing would be a source of danger to buildings or even to valuable trees.

\section{U. GALLII, Planchon.}

A dwarf, sturdy bush allied to U. nanus, and by some writers made a variety of it. In general appearance, however, it more resembles U. europæus, having the same hairy branches and stout spiny branchlets, but it is much dwarfer, usually under $2 \mathrm{ft}$. The flowers, each $\frac{5}{8}$ in. long and bright yellow, are borne from August to October; the wing-petals are curved and longer than the keel, the calyx finely downy. Pod $\frac{1}{3}$ to $\frac{1}{2}$ in. long, one- or twoseeded. 
Native of W. Europe, and abundant in the south-west of England, where it makes (often in company with Erica cinerea and E. Tetralix)

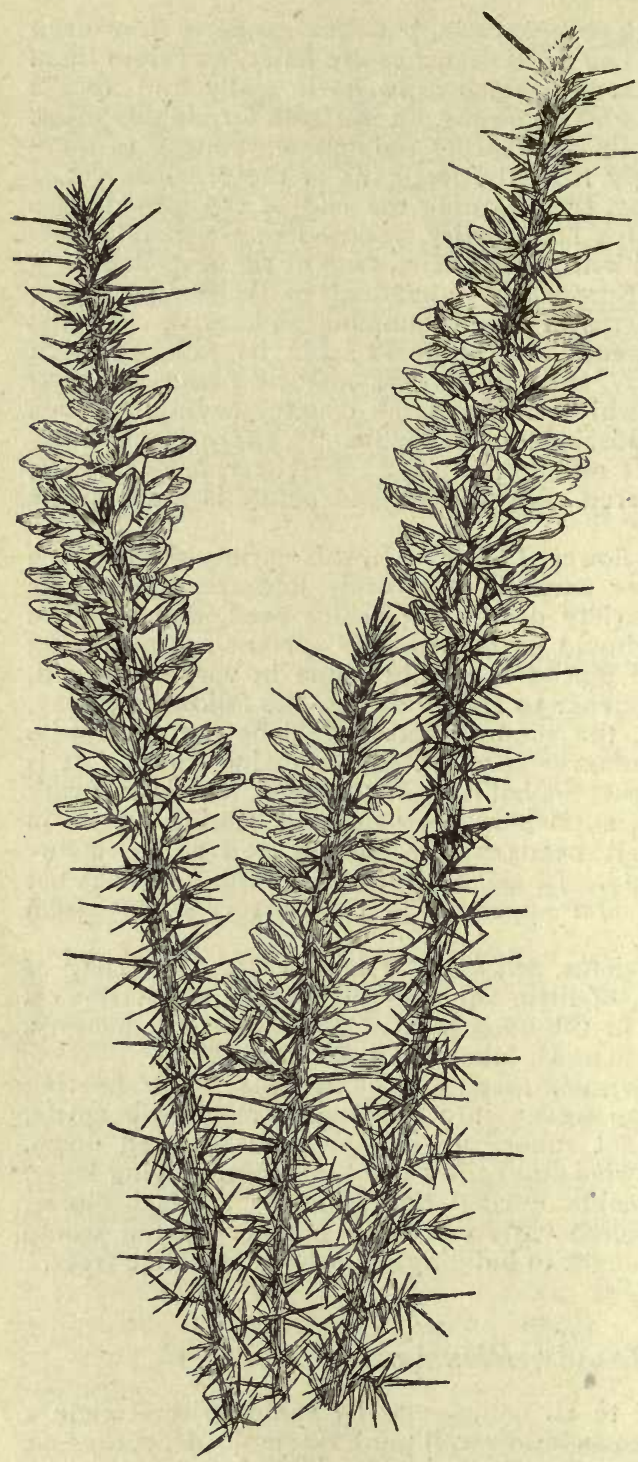

ULEX NANUS. most charming displays in autumn. The moors behind Bournemouth, covered with these plants, will be familar to many. It is in some respects intermediate between $U$. europæus and $U$. nanus, resembling the former in its branches, but the latter in time of flowering and in the absence of hairs from the calyx. It is not so hardy as either of them, but apparently withstands all except the very hardest winters at Kew, especially when the plants are a few years old. In gardens it is scarcely known-being confused with $U$. nanus-but is very pretty planted in poor soil, especially if associated with the two heaths just named.

\section{U. NANUS, Forster. DWARF GORSE.}

A dwarf shrub of dense, close habit, sometimes procumbent in a wild state, but changing its character when introduced to the garden, and sending up slender, erect branches, I to $2 \mathrm{ft}$. long in a single season; branchlets hairy. Leaves and branchlets as in $\mathrm{U}$. europæus, only smaller and less rigid. Flowers golden yellow, about half the size of common gorse, the calyx not hairy but slightly downy; wing-petals straight, shorter than the keel. Pod $\frac{1}{2}$ in. long, hairy.

Native of W. Europe, and abundant in many parts of Great Britain. Although some botanists profess to find it a variety of $U$. europæeus, it is really very

distinct. It is autumn-flowering, being at its best in September, when the ordinary gorse is in seed. This is its most valuable characteristic in 
gardens, for its long, slender stems set with flowers are often very pretty when few other shrubs are in blossom. But it needs a poor dry soil to develop its greatest beauty. In rich garden soil it gets to be $6 \mathrm{ft}$. high, and very lanky.

\section{ULMUS. ElM. URTICACEE.}

A group of about twenty species of deciduous trees, some of them of the largest size, with alternate, toothed leaves, usually unequal-sided at the base. Flowers produced in clusters or short racemes from axillary buds, either on the naked shoots in early, spring, or on the leafy ones in autumn. They have no beauty, being very small, green, or tinged with red; the perianth or calyx is somewhat bell-shaped, with four to nine (usually about five) lobes, and the same number of stamens. The fruit is most characteristic, being a flat, membranous, semi-transparent disc ("samara"), enclosing the seed in a cavity at the centre or towards the apex, where it is slightly or deeply notched. The leaves of elms usually die off yellow in autumn. There are three elms in cultivation which flower on the leafy shoots of the year in autumn; they are crassifolia, parvifolia, and serotina. The remainder are spring-flowering, and ripen their seeds by midsummer. If new stocks are required, the seeds should be sown as soon as ripe. The varieties are chiefly grafted on seedlings of U. montana, this being preferred because its roots do not produce suckers like campestris or nitens.

All the elms are gross feeders, and the roots travel enormous distances in search of food. Whilst not very particular, they thrive best on deep alluvial soil. The worst enemy of the elms, the English elm in particular, is a boring beetle (Scolytus destructor). The female of this insect burrows a channel beneath the bark, along which she distributes her eggs; when these hatch out they burrow at right angles to the parent channel, the whole brood producing a curious and very characteristic fishbone-like marking. The attacks of this beetle, itself about $\frac{1}{4} \mathrm{in}$. long, usually cause the death of the tree. It is, I think, most destructive in dry, hot summers, and trees that have been injured at the roots appear more liable to its attacks than healthy ones. There is probably no cure, but the trees may be assisted by feeding and watering. - In the case of important trees, outward applications in spring of coal tar or train oil, after the rough outer bark has been shaved off, have been recommended. Trees badly affected should be cut down and not left lying about for the young larvæ to hatch out, which they do about the end of May.

\section{U Alata, Michaux. WAHOO or Winged Elm.}

It is dountful if this elm be at present in cultivation, although according to Loudon it was introduced in $\mathbf{1 8 2 0}$. For a long time the corky-barked form of U. nitens (suberosa) did duty for it, the two resembling each other in the corky wings of the branches. They are amply distinct in other respects, for U. alata has leaves downy all over the midrib and veins beneath, and the fruits are downy and distinctly hairy. It is a tree found wild in 
the south United States, where it is 40 to $50 \mathrm{ft}$. high; its young shoots smooth, its leaves narrowly obovate or ovate-oblong, not downy above; $1 \frac{1}{4}$ to 3 ins. long, $\frac{1}{2}$ to $1 \frac{1}{4}$ ins. wide; doubly toothed, sharply pointed. Fruits hairy, oval, $\frac{1}{3}$ in. long, in short-stalked clusters. The corky. wings on the branches are two in number and set on opposite sides.

\section{U. AMERICANA, Linnceus. American or White Elm.}

A tree up to 100 or $120 \mathrm{ft}$. high, with a trunk $6 \mathrm{ft}$. or more in diameter, forming in isolated positions a wide-spreading head of branches gracefully pendulous at the ends, the whole as much in diameter as the tree is high; bark ashy grey; young shoots slender, at first downy. Leaves ovate to obovate or oval, contracted at the apex to a long, slender point; unequal at the base, one side of the midrib being rounded, the other tapered; doubly toothed; 4 to 6 ins. long, I to 3 ins. wide; downy beneath and at first somewhat hairy above; lateral veins up to about eighteen pairs; stalk about $\frac{1}{4}$ in. long. Fruit oval or obovate, nearly $\frac{1}{2}$ in. long, produced in short-stalked clusters, beautifully fringed with pale hairs, the two incurved horns at the apex meeting and forming a small aperture.

Native of Eastern and Central N. America; introduced in 1752. The American elm is one of the finest and most picturesque trees of its native country, always marked by its beauty and grace of branching; but in Britain it is a very rare tree.

\section{U. BELGICA, Burgsdorf. BELgIAN Elm.}

\section{(U. hollandic', $S p, t, 0)$}

In the streets of Holland and Belgium is a very common tree, usually called U. hollandica. It is, no doubt, a hybrid, of which U. montana is one parent (and the one it more closely follows), U. nitens the other. As one usually sees it, it is a clean-growing, erect-stemmed tree of pyramidal form, but that is probably due to pruning. Naturally, it is said to assume a broad head of branches. It has leaves up to $5 \frac{1}{2}$ ins. long, much the same in character as those of U. montana, but with stalks often more than twice as long. In some of the large continental nurseries this is grown for sale more extensively than any other elm. Said to have first appeared in a plantation at Bruges. It differs from U. montana in the young shoots becoming smooth towards the end of the season, and being more slender, also in the narrower leaf with a coarsely toothed, more elongated apex.

\section{U. CAMPESTRIS, Linncus. ENGLISH ELM.}

\section{(U. suberosa, Ehrhart; U.' surculosa, Stokes.)}

A tree up to $\mathrm{I} 20$, or even $150 \mathrm{ft}$. high, with a trunk $6 \mathrm{ft}$. or more in diameter; young shoots hairy. Leaves roundish ovate, to broadly oval, very unequal at the base, terminated by a short, abrupt point, coarsely and doubly toothed; 2 to $3 \frac{1}{2}$ ins. long, about two-thirds as wide; dark green and very harsh to the touch above; paler beneath and downy all over, with conspicuous tufts of white down in the vein-axils, along the midrib, and at the base of the chief veins-of which there are ten to twelve pairs. Flowers clustered closely to the branchlet, opening early in the year, recldish. Fruit a round disk, $\frac{1}{2}$ in. across, not downy, bearing the seed close to the notch at the top.

In old books on trees the English elm is usually said to be a native of 
Europe introduced to Britain at the time of the Romans. It is now fairly certain that it is genuinely wild nowhere but in southern England, the elm called campestris on the Continent being a distinct tree. (See var. australis.) The English elm produces fertile seed extremely rarely. I have not myself seen a genuine seedling, but Henry states that he raised four plants out of twenty batches of seed sown in 1909. In many parts of southern England the elm is the dominant tree, especially in hedgerows; all these trees, however, have sprung from root suckers, which the elm produces freely, and which afford the best means of propagation.

The origin of the English elm still remains a mystery. It occurs in some parks and gardens of Spain, but apparently always planted, and there is no evidence that it was ever introduced to England from Spain. On the other hand, there is a tradition that the Spanish trees originally were sent from England. Against its being a genuine native of Britain, there is the curious fact that it is almost invariably infertile. I am inclined nevertheless to think that this last may be accounted for by its extreme facility in producing suckers from the roots. There are plenty of instances of trees that propagate themselves easily by parts of the old plant, losing much of their fertility of seed-our native willows and poplars are instances, as is also the North American Robinia hispida. In the tropics, too, there is the banana, which has wholly, and the sugar cane, which has largely, lost its power of reproduction by seed after long-continued increase by offsets or cuttings. There is always the possibility that it originated as a hybrid from the other British elms.

As a tree in the English landscape the elm impresses one by its noble stature and bulk, its rich leafiness, and its singular beauty in winter when the finely fretted outline of its naked branches shows in delicate tracery against the sky. In the autumn the foliage dies off rich yellow, and lingers on the branches longer perhaps than that of any of our native trees. This elm has an unfortunate propensity in age of dropping its limbs, which snap off without any warning. This usually happens on still evenings in late summer and early autumn when the trees are still in full leaf. It is also liable to occur during a heavy rain following a period of heat and drought. The breaking is supposed to be due to a rush of sap to the extremities of the branches, causing cell-tension and a sudden increase in weight. This habit makes the elm a very unsuitable tree to plant in crowded thoroughfares.

The timber of elm is valuable for its toughness and the absence of any tendency to split. It has also considerable beauty of graining and colour. Kept permanently dry or permanently wet, it is very durable. At one time, before the introduction of iron pipes, hollowed-out trunks of elm were used as water-pipes. Although many varieties of elm have been placed under campestris by nurserymen and others, it seems to me there are but two genuine garden varieties of English elm, both no doubt branch sports:-

Var. LOUIS VAN HOUTTE.-Leaves entirely yellow, retaining their colour throughout the summer. The best yellow-leaved elm.

Var. VARIEGATA.-For those who admire variegated trees this may be recommended as one of the best. The leaves are conspicuously blotched, striped, and margined with creamy white. Some years ago I saw a fine specimen of this form on the main road between Warwick and Coventry, whose suckers were as variegated as the parent.

Var. AUSTRALIS, Henry.-This is the tree referred to above as the continental form of U. campestris. Henry (Trees of Great Britain and Ireland, p. I904) distinguishes it as a tree often pyramidal in habit, with short branches. Leaves thick and firm in texture, oval, 2 to 3 ins. long, $1 \frac{1}{4}$ to $1 \frac{3}{4}$ ins. wide, with a longer, more cuspidate and tapered apex than in the type, and with the tufts of down in the vein-axils beneath not so well developed. Fruit not so round, but more obovate. The tree is best 
distinguished from the English elm by its thicker textured leaves with more prominent veins beneath. It is quite fertile. Native of Europe from Belgium to the Riviera and Switzerland. Probably a distinct species.

\section{U. CRassifolia, Nuttall. Cedar Elm.}

A tree up to $80 \mathrm{ft}$. high in nature, but in cultivation in England very slow-growing and forming a round-headed small tree; young shoots clothed with fine, soft, very short down; winter buds often in pairs. Leaves ovate to oblong, obliquely rounded or slightly heart-shaped at the base, bluntish or rounded at the apex; $\frac{3}{4}$ to 2 ins. long, $\frac{1}{2}$ to $1 \frac{1}{4}$ ins. wide; toothed (sometimes doubly), of firm rather hard texture; very harsh to the touch above, more or less downy beneath; stalk $\frac{1}{12}$ to $\frac{1}{8}$ in. long. Flowers produced in clusters in the leaf-axils in August and later. Fruit $\frac{1}{3}$ in. long, oval, tapered at both ends, deeply notched at the top, downy all over, especially on the margin.

Native of the southern United States and hardy at Kew, where it was introduced by Prof. Sargent in 1876. Although quite healthy it increases very slowly in height, and no doubt needs a hotter summer than ours to be seen at its best. Sargent describes it as the "common elm tree of Texas." Allied to U. crassifolia is

U. SEROTINA, Sargent, first recognised as a distinct species in 1899. It has the same habit of flowering in the axils of the leaves in autumn, but is distinguished by the longer, larger, sharply pointed leaves of thinner texture, but less harsh to the touch above; the oval fruits are $\frac{1}{3}$ to $\frac{1}{2}$ in. long, borne in racemes I to $1 \frac{1}{2}$ ins. long, and much more conspicuously fringed. It is a native of the south-eastern United States, and was first sent to Kew by Prof. Sargent in 1898 . These two species in their habit of autumnal flowering are allied to U. parvifolia $\left(q . v_{0}\right)$.

\section{U. elliptica, Koch. Caucasian Elm.}

Like U. pedunculata in its relationship to $U$. americana, this species affords an example of close affinity between an Old World and a New World elm. In many respects it does not differ from the following species (U. fulva), although it is native of the Caucasus, Persia, Turkestan, and W. Siberia. It differs in its less fissured bark and in the thinner, more sharply toothed leaves. The fruit is obovate, $\frac{5}{8}$ to $\mathrm{I}$ in. long, and, like that of U. fulva, is downy only on the part covering the seed; it is, however, longer and not so round, and in shape is more like that of $U$. montana, Trees under this name were introduced in $189 \mathrm{I}$ and are quite hardy. The tree grown as "U. Heyderi" belongs either to this species or to U. fulva, but Henry believes the true $U$. elliptica is not in cultivation.

\section{U. FUlva, Michaux. Slippery Elm.}

\section{(U. rubra, Michaux fil.)}

A tree 60 to $70 \mathrm{ft}$. high, with a trunk up to $2 \mathrm{ft}$. thick, supporting a spreading head of branches; young shoots very downy; winter buds $\frac{1}{4}$ in. long, covered with brown hairs. Leaves oblong-ovate, 3 to 8 ins. (sometimes in young trees 1o ins.) long, about half as wide, abruptly tapered to a long, slender point, obliquely rounded at the base; jaggedly or doubly toothed; upper surface very harsh to the touch through minute excrescences; lower surface downy; stalk $\frac{1}{4}$ to $\frac{1}{3}$ in. long. Flowers very short-stalked and 
crowded in clusters. Fruit orbicular or obovate, $\frac{1}{3}$ to $\frac{3}{4}$ in. long, slightly notched at the top, the part covering the seed (which is in the centre) coated with red-brown hairs, naked elsewhere.

Native of Central and Eastern N. America. This elm gets its popular name from its mucilaginous inner bark. It thrives very well as a young tree at Kew, making strong growths several feet long each summer. In the size and roughness of the upper surface of the leaves, it resembles U. montana, but the stalk is longer and the fruit distinct. Its specific name refers to the brown hairy buds which, together with the hairy patch in the centre of the fruit, well distinguish it.

\section{U. JAPONICA, Sargent. JAPANESE Elm.}

\section{(U. campestris var. japonica, Sargent.)}

A tree up to I Io $\mathrm{ft}$. high in Japan, forming, according to Sargent, broad heads of graceful, pendent branches; young shoots very downy. Leaves oval, inclined to obovate; 3 to $4 \frac{1}{2}$ ins. long, $1 \frac{1}{2}$ to $2 \frac{1}{2}$ ins. wide; unequal at the broadly tapered base, abruptly narrowed at the apex to a slender point, rather coarsely toothed; furnished with stiff hairs above at first, afterwards very harsh to the touch; lower surface clothed with pale down, especially on the veins and midrib; veins in fourteen to sixteen pairs, stalk about $\frac{1}{6}$ in. long. This elm was introduced in 1895 to the Arnold Arboretum where, fifteen years later, I saw trees already $28 \mathrm{ft}$. high. In 1897 it was sent to Kew. It has not yet flowered, and I only know the fruits from samples collected near Sapporo, where the tree is much grown; they are obovate, $\frac{5}{8}$ in. long, nearly $\frac{1}{2}$ in. wide, tapered at the base, the seed being situated close to the notch, the inner edges of which are edged with down. Elsewhere the fruit is smooth. The young shoots are fawn-coloured.

\section{U. MAJOR, Smith. DUTCH Elm.}

A large tree up to $120 \mathrm{ft}$. in height, of somewhat open, thin branching the branchlets often pendulous; trunk 4 to $5 \mathrm{ft}$. in diameter; young shoots slightly hairy. Leaves oval or ovate, $2 \frac{1}{2}$ to 5 ins. long, $1 \frac{1}{2}$ to 3 ins. wide; taper-pointed, one side cordate at the base, and developed farther down the stalk than the other side, which is tapered; upper surface dark shining green, smooth or nearly so, the lower one also bright green, downy in the vein-axils and along the midrib, nearly smooth elsewhere; veins in ten to fourteen pairs; stalk downy, $\frac{1}{4}$ to $\frac{3}{8}$ in. long. Fruit between ovate and obovate, $\frac{3}{4}$ to $I$ in. long, with the seed close to the terminal notch.

A British tree and probably a hybrid between U. montana and U. nitens. It is quick-growing, and several fine specimens exist in the older part of Kew Gardens. One of them when felled, I found to be 150 years old, $92 \mathrm{ft}$. high, and $13 \mathrm{ft}$. 6 in. in girth. The sucker-like shoots produced directly from the trunk are often corky. It produces enormous crops of seed, infertile so far as I have seen. The botanical characters of this elm most resemble those of $U$. nitens, but the leaves and fruit are much larger, and the habit more open.

Var. SERPENTINA, Henry.-Usually placed as a pendulous form of U. montana, this curious elm is apparently of hybrid origin. The branchlets are curiously twisted and contorted as well as pendulous. In the ten to fourteen pairs of veins, and in the down being chiefly confined to tufts in the vein-axils and along the midrib and veins, it closely resembles U. major. 


\title{
U. MINOR, Miller. EAST-ANGLiAn or LOCK ELM.
}

\author{
(U. glabra var. minor, Ley; U. Plotii, Druce.)
}

A tree up to 80 or $90 \mathrm{ft}$. high, with a few erect-growing main branches and pendulous branchlets, the latter slender, minutely and sparsely downy when young. Leaves obovate to oval, up to $2 \frac{1}{2}$ ins. long, and $\mathrm{I} \frac{1}{2}$ ins. wide; unequal sided and often heart-shaped at the base; upper surface rough, dull green, lower one at first densely clothed with down, which later falls away except in the vein-axils; margin doubly toothed, veins in eight to ten pairs; leaf-stalk downy, $\frac{1}{5}$ in. long. Fruit narrowly obovate, $\frac{1}{2}$ in. long, notched at the tip, bearing the seed in the upper part.

Native of Eastern and Middle England, also of Hampshire, possibly also of the Continent. It is a tree of very elegant and characteristic appearance, allied closely, no doubt, to $U$. nitens, and producing suckers like that elm, but differing in its smaller, duller leaves, much more downy at first beneath, with fewer veins and shorter stalk. The popular name, "Lock elm," by which it is known in the eastern counties, refers to the toughness of the timber, which renders it difficult to work with saw or plane.

\section{U. MONTANA, Withering. WyCH or SCOTCH Elm. (U. glabra, Hudson; U. scabra, Miller.)}

A tree from Ico to $125 \mathrm{ft}$. high, with a trunk sometimes $6 \mathrm{ft}$. in diameter; head of branches wide-spreading, rather open; young shoots stout, downy; bud scales hairy. Leaves usually 3 to 7 ins. long (sometimes more on young trees) $I \frac{1}{2}$ to 4 ins. wide; oval to obovate, slender-pointed, sometimes threelobed towards the top, very unequal-sided at the base; coarsely and doubly toothed, upper surface dull green, very rough; lower one downy; stalk very short, never more than $\frac{1}{4}$ in. long, often quite hidden by the rounded basal half of the blade, downy; veins in fourteen to twenty pairs. Flowers in dense, stalkless clusters. Fruit oval, $\frac{3}{4}$ to $I$ in. long, downy only at the slightly notched apex, the seed situated in the middle.

Native of N. Europe, including Britain. It is rare in the south and east of England, but common in Scotland and Ireland, where it is one of the noblest of native trees. In the open it forms a stout, shortish trunk of great thickness, and a head of branches often pendulous at the ends. It is apt to be confused in gardens with some of the hybrids (major, vegeta, etc.) that have originated between it and $U$. nitens, but may always be distinguished among those and other British elms by the seed being in the middle of the fruit, the very short leaf-stalks, very rough leaves, and the absence of any corkiness on the two-year-old shoots. Moreover, the tree does not produce suckers as nitens and campestris do, and on that account is valued as a stock for other elms. Several very distinct varieties of wych elm are in cultivation, but no doubt some commonly referred to this species are hybrids.

Var. CAMPERDOWNI.-A pendulous branched tree, the branches forming a globose head. Originally found at Camperdown House, near Dundee.

Var. CRISPA, Loudon (U. asplenifolia and U. urticæfolia of gardens). -Leaves narrowly oblong-oval, $1 \frac{1}{2}$ to $3 \frac{1}{2}$ ins. long, $\frac{3}{4}$ to $1 \frac{1}{2}$ ins. wide; rather infolded, the margins very jaggedly and deeply cut into slender, often double, teeth. A curious, slow-growing form.

Var. DAUvessei (U. Dauvessei, Henry) has shorter more rounded leaves of thinner texture; perhaps a hybrid.

Var. FASTIGIATA, Loudon. Exeter Elm.-Branches and branchlets erect, 
the latter as well as the leaves frequently twisted. There is a tree $12 \mathrm{ft}$. in girth in the Vicarage garden at Bitton. The elm known as U. WREDEI is

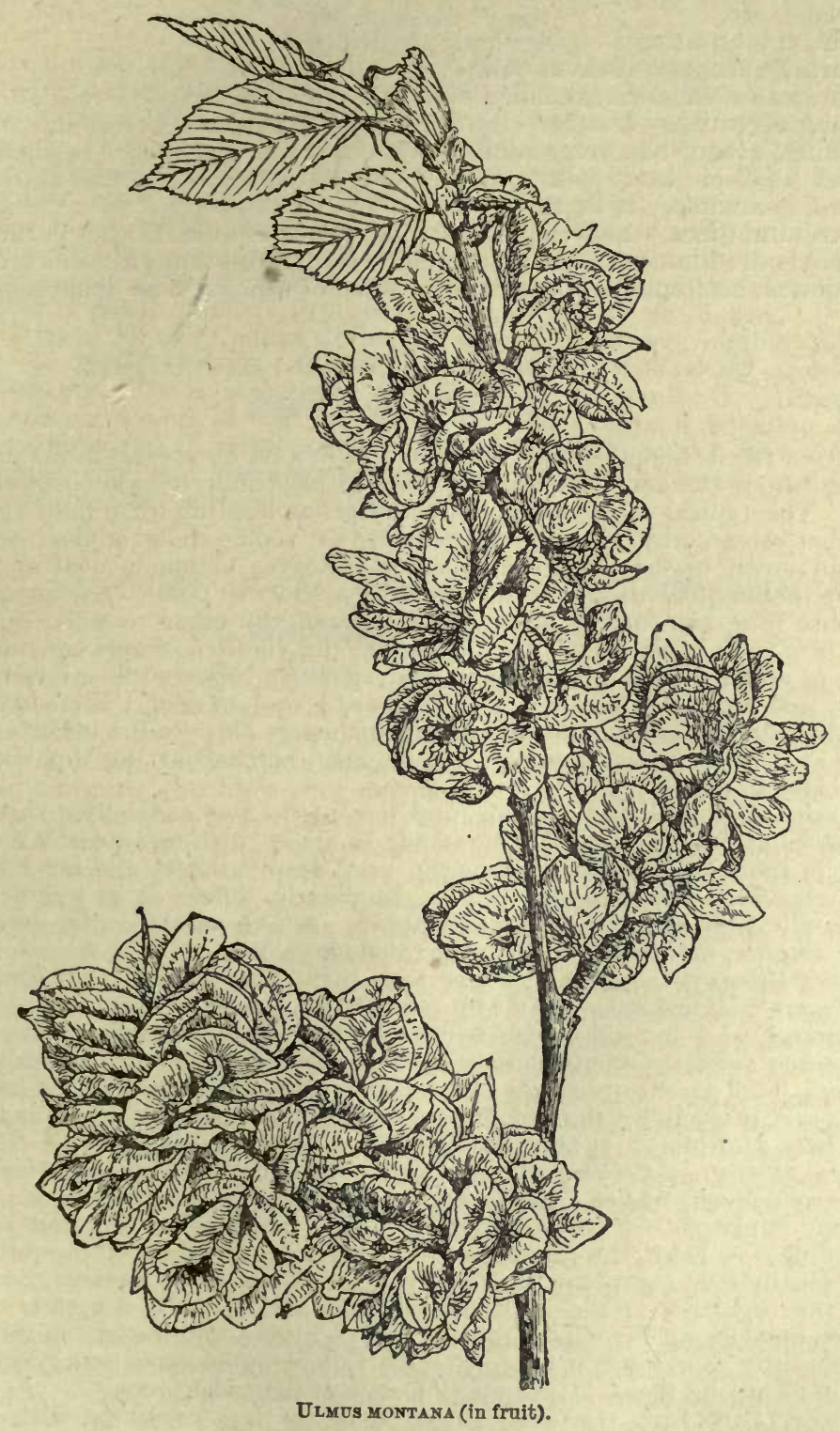

perhaps a form of this; it has yellow leaves. Both these elms have leaves rounder than in the type, and with more laciniate margins. 
Var. LACINIATA, Trautvetter. - This has three, sometimes five, very conspicuous acuminate lobes at the broad apex of the leaves, which are 6 to 7 ins. long. It appears to be the same as the tree found wild in Japan, Amurland, etc.

Var. LIBERO-RUBRO.-Inner bark purplish red.

Var. LUTESCENS.-Leaves yellow.

Var. NANA.-A dwarf rounded bush rarely more than 5 or $6 \mathrm{ft}$. high.

Var. PENDUla, Loudon.-Branches stiffly pendulous, forming a low, spreading, arbour-like tree, admirable as a lawn specimen. It should be grafted high on the typical form. Originated early in the nineteenth century, in a nursery at Perth.

Var. PURPUREA.-Leaves purple. The colour is more lasting in the form called ATROPURPUREA. There are big-leaved forms known by such names as gigantea, macrophylla, superba, etc., some of which are no doubt hybrids.

\section{U. nitens, Moench. Smooth-Leaved Elm.}

\section{(U. glabra, Miller, not of Hudson.)}

A tree $100 \mathrm{ft}$. high, represented in Great Britain by several forms varying in habit from slender, cone-shaped trees to beautifully pendulous-branched ones. The typical form is a pyramidal tree, at least up to middle age, the branches often corky, sometimes extremely so; young shoots almost or quite without down in the adult tree, slender. Leaves obliquely oval or ovate, doubly toothed, narrowing at the apex to a shortish point, very unequal at the base (one side of the blade being tapered, the other rounded or semicordate); I $\frac{1}{2}$ to 4 ins. long, I to 2 ins. wide; (on vigorous shoots considerably larger); upper surface glossy green and smooth; lower surface downy only in the vein-axils or along the midrib; stalk $\frac{1}{4}$ to $\frac{1}{2}$ in. long; veins in ten to thirteen pairs. Flowers crowded in dense clusters close to the leafless shoot. Fruit oval or obovate, smooth, $\frac{1}{2}$ to $\frac{5}{8}$ in. long, notched at the top, with the seed close to the notch.

Native of Europe and W. Asia, and one of the two undisputed species of British elms. The other, U. montana, is amply distinguisled by the seed being in the middle of the fruit, by the very downy shoots and much larger, downy leaves. The common elm, U. campestris, differs in its rounder leaf; downy all over beneath and rough above. A tree at Madingley turns red every autumn, but the usual decaying colour is yellow.

Var. BERARDII.-A very interesting little elm raised in the nursery of Messrs Simon-Louis, near Metz, in 1863. Its leaves are oval, $\frac{1}{2}$ to $1 \frac{1}{2}$ ins. long, $\frac{1}{4}$ to $\frac{5}{8}$ in. wide, with four to seven coarse triangular teeth down each side; smooth on both surfaces. The slender twigs and leaf-stalks are downy. The parent tree was said to be a large elm on the ramparts of Metz, and judging by the smooth leaves of this variety it would appear to have been U. nitens. It may, however, have been a hybrid.

Var. PENDULA, Rehder.-A tree with pendulous branches, very vigorous, and large-leaved; makes a handsome specimen isolated on a lawn.

Var. SUBEROSA. Cork-barked Elm.-Like the. type in leaf, but of stiff, spreading, low habit, the branches two or more years old becoming furnished with usually four conspicuous, corky ridges. It has to be noticed, however, that the corkiness of the branches is often noticeable in a greater or less degree in what we regard as the typical U. nitens, and if seeds of the most suberous tree were sown, it is probable that there would appear many ordinary U. nitens among them. Common in forests of Central Europe.

Var. VARIEGATA.-Leaves marked more or less copiously with white, especially on the margin.

Var. WeBbian.A.-Leaves small, rounded; habit columnar. 


\section{U. PARVIFOLIA, Jacquin. \\ (U. chinensis, Persoon.)}

A small tree up to $40 \mathrm{ft}$. high, with a slender trunk supporting a rounded head of branches; branchlets very slender, clothed with a close, minute, grey down; winter buds small, conical. Leaves leathery, $\frac{3}{4}$ to $2 \frac{1}{2}$ ins. long, $\frac{1}{3}$ to $1 \frac{1}{3}$ ins. wide; oval, ovate or obovate; unequally rounded at the base (or one side of the midrib tapered); pointed, the margins rather evenly toothed, the teeth triangular, often blunt; upper surface lustrous green, and smooth on the smaller twigs, rather rough on vigorous shoots; lower surface pale, bright green, with tufts of down in the vein-axils, or smooth; stalk $\frac{1}{16}$ to $\frac{1}{4}$ in. long, downy, veins in ten to twelve pairs. Flowers produced in September and October in the leaf-axils. Fruit ovate-oval, $\frac{1}{3}$ in. long, not downy.

Native of N. and Central China and Japan. This tree retains its leaves until the New Year quite fresh and green, and is well worth growing for its elegance. It is sometimes confused with U. pumila in gardens, but that species flowers in spring. From the other autumn-flowering elms$U$. crassifolia and U. serotina-it is distinct in retaining its leaves so late, in the almost complete absence of down from beneath the leaves, and in their brighter smoother surfaces. Introduced in 1794.

\section{U. Pedunculata, Fougeroux. SPREading Elm.}

\section{(U. lævis, Pallas; U. effusa, Willdenow.)}

A tree over $100 \mathrm{ft}$. high, with a trunk up to $6 \mathrm{ft}$. in diameter, supporting a wide-spreading, rather open head of branches; bark brownish grey; young shoots clothed with grey down, at least at first. Leaves obliquely obovate, $2 \frac{1}{2}$ to 5 ins. long, rather more than half as wide; with double incurved teeth at the margins; the base very unequal, being rounded at one side of the midrib, abbreviated and tapered at the other; the apex narrowed abruptly to a slender point ; bright green, smooth, or slightly harsh above, usually clothed beneath with a dense grey down; side veins up to eighteen pairs; stalk $\frac{1}{8}$ to $\frac{1}{4}$ in. long. Fruit oval, about $\frac{1}{2}$ in. long, fringed with pale hairs, and having two incurved horns at the apex; the fruits are borne on slender pendulous stalks in crowded clusters.

Native of Central and E. Europe, but very closely allied in botanical characters to $U$. americana, from which it is indeed difficult to distinguish it. It thrives better in this country, and the leaves seem more uniformly downy, more unequal at the base, and more frequently broadest above the middle; the winter buds are more elongated and sharply pointed. Of European elms it most resembles U. montana, but is easily distinguished by the smoother, smaller leaves, and especially by the fringed samara (fruit). There is a fine tree at Syon, $90 \mathrm{ft}$. high, and $\mathbf{1 2} \mathrm{ft}$. 8 ins. in girth, long regarded as $U$. americana, and certainly possessing the characteristic form of the New World tree.

\section{U. PUMIla, Linnceus. DWARF Elm.}

A small tree, to to $30 \mathrm{ft}$. high, sometimes a shrub. Leaves oval or ovatelanceolate, acute to acuminate at the apex, tapered or rounded at the base, and not unequal-sided there as elms usually are; rather coarsely toothed except at the base; $\frac{3}{4}$ to $2 \frac{1}{4}$ ins. long, $\frac{1}{3}$ to $I$ in. wide ; dark green and quite glabrous (or with minute tufts of down in the vein-axils) beneath; stalk downy, $\frac{x}{12}$ to $\frac{1}{6}$ in. long. Flowers borne on the naked shoots in spring, 
on very short stalks, and in clusters. Fruit circular or rather obovate, deeply notched at the top, $\frac{1}{2}$ in. across, the seed about the middle.

Native of N. Asia, from E. Siberia to N. China. It has been confused in gardens with U. parviflora (q.v.). Under the name of

U. PINNATO-RAMOSA, Dieck, a very elegant, vigorous-growing, smallleaved elm was sent out from the Zoeschen Arboretum about twenty years ago. The more downy branchlets are arranged in two opposite rows (distichously), and the leaves are longer-pointed, but otherwise very similar to U. pumila. It flowers in spring. Introduced from W. Siberia and Turkestan.

\section{U. RACEMOSA, Thomas. ROCK Elm.}

\section{(U. Thomasii, Sargent.)}

A tree 80 to $100 \mathrm{ft}$. high, with a trunk up to $3 \mathrm{ft}$. in diameter, supporting a narrow roundish head of branches. In a young state the trees are pyramidal; winter buds and young shoots downy. Leaves oval to obovate, with an abrupt, slender point and an unequal, oblique base $; 2$ to $4 \frac{1}{2}$ ins. long, $1 \frac{1}{4}$ to $2 \frac{3}{4}$ ins. wide; doubly toothed, smooth, dark glossy green above, downy beneath; side veins in often over twenty pairs; stalk up to $\frac{1}{4}$ in. long, sometimes partially covered by the overlapping bases. of the blade. Flowers in racemes I to 2 ins. long. Fruit oval, $\frac{1}{2}$ to $\frac{3}{4}$ in. long, downy all over as well as on the thickened margins, with a slight open notch at the apex; the two points erect.

Native of Eastern N. America, where it produces a valuable timber. I know of no fine tree in this country, although there are small ones at Kew. It is slow-growing, even in the Arnold Arboretum, Mass., where there is an interesting group of very characteristic young trees. Its distinctive points are its large downy winter-buds, $\frac{1}{4}$ or $\frac{1}{3} \mathrm{in}$. long, its racemose inflorescence, and shallowly notched, hairy fruits.

\section{U. STRICTA, Lindley. CORNISH Elm.}

(U. nitens var. stricta, Aiton; U. cornubiensis, Hort.)

A tree 80 to $100 \mathrm{ft}$. high, of slender, tapering, or columnar form, young shoots more or less downy. Leaves very like those of U. nitens but smaller, being 2 to $2 \frac{1}{2}$ ins. long, I to $\mathrm{I} \frac{1}{2}$ ins. wide, broadly obovate or oval; dark green, smooth and glossy above, paler beneath, with conspicuous tufts of down in the axils of the veins; doubly toothed; veins in about twelve pairs; stalk $\frac{1}{3}$ in. long, downy. Fruit like that of U. nitens but narrower, $\frac{2}{3}$ in. long, and $\frac{3}{8}$ in. wide, carrying the seed near the notch at the apex.

Native of Cornwall, Devon, and Somerset in England, and of Brittany in France. This elm produces suckers freely, but does not often bear perfect fruit.

Var. Wheatleyi (U. sarniensis, Loddiges). Guernsey or Jersey Elm.This is very closely allied to the Cornish elm, of which Henry regards it as probably a seedling. Its branches are more stiffly erect, and the tree more tapered, the leaves are proportionately broader and less conspicuously downy in the vein-axils beneath. Fruit as in U. nitens. (See plate, vol. i., p. 86.)

Both these elms, but especially the latter, are admirable for street planting, retaining without artificial aid the slender, tapering form essential for trees planted in all but the widest streets of town. They are immediate allies of U. nitens. A yellow-leaved form of the Jersey elm originated in the nurseries o Messrs Dickson at Chester in Igoo. 


\section{U. vegeta, Lindley. Huntingdon or Chichester Elm.}

This fine elm, according to information given to Loudon by $\mathrm{Mr}$ John Wood of Huntingdon, in 1836, was raised in the nursery of his firm about the middle of the eighteenth century from seed gathered in Hinchingbrook Park. It is, no doubt, a hybrid between U. montana and U. nitens, and like many hybrid trees, is of remarkably vigorous growth. One of the largest of all elms, it reaches $100 \mathrm{ft}$. in height, forming a thick short trunk 5 or $6 \mathrm{ft}$. in diameter with ascending branches. Leaves up to 5 or 6 ins. long, more than half as wide, smooth above and downy beneath only in the leaf-axils. Fruit oval, up to $\frac{7}{8} \mathrm{in}$. long, the seed not reaching to the notch at the top. This last character and its less downy leaves distinguish it from. U. major, of presumably the same parentage. The veins, too, are more numerous (fourteen to eighteen pairs) than in U. major. According to Elwes it has the defect of splitting in the trunk due to its habit' of forking low down. This, however, can be prevented by timely pruning. The tree produces suckers.

\section{U. VIMINALIS, Loddiges.}

A narrow-headed, rather slender tree with drooping branches; young shoots sightly downy, slender. Leaves oblanceolate or narrowly oval, nearly always tapered at the base, terminated by a long slender point; 1 to 2 ins. long, $\frac{1}{3}$ to $\frac{3}{4}$ in. wide; very deeply toothed, the teeth narrow, often blunt; upper surface very rough, lower one downy especially in the vein. axils and on the veins. I have never seen it bearing fruit although it flowers. Several varieties of U. viminalis are in gardens :-

Var. AUREA (syns. Rosseelsii; antarctica aurea).-Leaves yellow.

Var. VARIEGATA. - Leaf margins variegated with creamy white.

$\mathrm{U}$. viminalis is a charming small tree for gardens, very elegant and not growing fast. It is of uncertain origin, but is probably a seedling of some hybrid elm.

U. BETULEFOLIA, Loddiges, appears to be allied to $U$. viminalis, and is also of uncertain origin, possibly a hybrid in whose origin U. nitens has shared. The leaves are narrowly obovate, up to $2 \frac{1}{2}$ ins. long by $\mathrm{I} \frac{1}{2}$ ins. wide, the margins deeply toothed, the teeth narrow, incurved, often again toothed, very harsh to the touch above, downy in the vein-axils beneath. The habit is elegant on account of the pendulous young branchlets.

\section{UMBELLULARIA CALIFORNICA, Nuttall. CALIFORNIAN LAUREL. LAURACE}

(Oreodaphne californica, Nees; Bot. Mag., t. 5320.)

An evergreen tree, $\delta \circ$ to $100 \mathrm{ft}$. high in favourable situations in California, with a dense head of very leafy branches; young shoots at first minutely downy. Leaves alternate, leathery, with a pungent aromatic odour when crushed, narrowly oval or oblong, but tapered at both ends; 2 to 5 ins. long, $\frac{3}{4}$ to $x_{2} \frac{1}{2}$ ins. wide; not toothed, dark green and glossy above, paler beneath, almost smooth on both surfaces except when just unfolding. Flowers $\frac{1}{4}$ in. across, yellowish green, produced during April in terminal and axillary umbels $\frac{3}{4}$ in. wide, on a common stalk $r$ in. long. Fruit roundish pear-shaped, ${ }^{\prime} \mathrm{I}$ in. long, $\frac{3}{4}$. in. wide; green changing to purplish. 
Native of California and Oregon; introduced by Douglas in 1829 , and the only known species. This fine tree is hardy in the open at Kew, and is $18 \mathrm{ft}$. high, being only occasionally injured by severe frost. On a wall it flowers, and has borne fruit. A tree near the porch of Bitton Vicarage, Bristol, frequently bears good crops of fruit. Jepson says that the finest grove in California is near Eel River, where for several miles there is a wood composed entirely of this tree. It likes a sheltered spot in gardens, where it is about equal to the bay laurel as an ornamental evergreen. It is very fine in the gardens of Osborne House, Isle of Wight. I have only raised it from seed, but it could no doubt be layered if not propagated by cuttings.

\section{VACCINIUM. VACCINIACEÆ.}

A large genus of shrubs, or occasionally trees, widely spread over the northern hemisphere, and existing in considerable numbers on the mountains of S. America. They have alternate leaves, and are both deciduous and evergreen. The corolla is more or less bell-shaped, globose, or cylindrical, except in V. erythrocarpum and V. japonicum; calyx persistent; stamens eight or ten. Fruit a juicy berry. Some authors unite this and allied genera with the Ericacex, from which they only differ in the corolla being superior (i.e., situated above the ovary), whilst the relative position of these two parts of the flower is reversed in the Erica family.

As garden shrubs, the Vacciniums are chiefly valued for their fruits and the autumnal colour of their foliage. Many are pretty in flower, but none make the fine display provided by so many of the heath family. In nature they are nearly always found on mountain and moorland, and the genus is one of the most characteristic of the lonely parts of the northern hemisphere. Many produce very palatable fruits.

Under cultivation they prefer a peaty soil, or a light loamy one devoid of lime, and improved by adding decayed leaves. They are all moistureloving plants. All the hardier ones produce seed which should be treated as advised for rhododendrons, and the others can be propagated by cuttings made of half-ripened wood in July, and placed in sandy peaty soil in gentle bottom heat.

There is considerable confusion in the identification of the N. American species of the V. corymbosum group, and American authors are by no means unanimous in their estimates of the number it contains; but they are all hardy, free-growing, and handsome shrubs, the leaves turning red before they fall, but frequently persisting well into the winter.

\section{ARBOREUM, Marshall. FARKLEBERRY.}

(V. diffusum, Aiton, Bot. Mag., t. 1607.)

A shrub, or small tree, up to $30 \mathrm{ft}$. high in some of its native localities, and varying also from deciduous to evergreen, according to locality; young twigs downy. Leaves ovate, obovate or oval; $\frac{1}{2}$ in. to 2 ins. long, half as 
wide; very shortly stalked, mostly pointed, minutely and sparsely glandulartoothed, the margins slightly recurved; of leathery texture, smooth and of a very glossy dark green above, slightly downy beneath. Flowers produced during July and August singly in the axils of the leaves or in the axils of bracts on terminal racemes 1 to 2 ins. long, each on a slender stalk $\frac{1}{4}$ to $\frac{5}{8}$ in. long, with two minute bracts about the middle. Corolla white, bell-shaped, $\frac{1}{4}$ in. long, five-lobed, the lobes reflexed. Calyx small, the five lobes triangular. Fruit $\frac{1}{4}$ in. wide, black, roundish. The flower is jointed to the stalk.

Native of the south and east United States, as far north as N. Carolina; introduced to Kew by Mr John Cree in 1765. In the British Isles it is a deciduous shrub, said by Loudon in 1837 to have been Io $\mathrm{ft}$. high in the walled garden at White Knights. It is quite hardy at Kew, pretty and freeflowering, but slow in growth. The form in cultivation is, no doubt, from the northern limits of its distribution, but the evergreen tree form ought to be tried in the mildest counties.

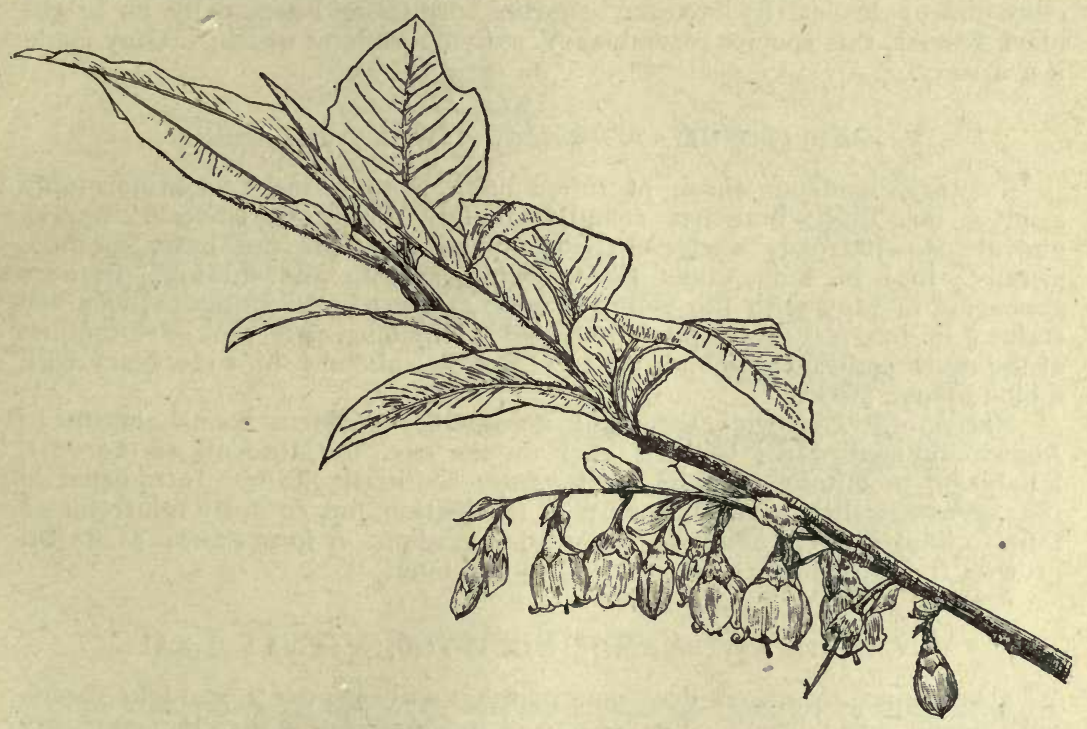

VACCINIUM ARCTOSTAPHYLOS.

\section{Arctostaphylos, Linnceus. Caucasian Whortleberky.}

\section{(Bot. Mag., t. 974.)}

A deciduous shrub, probably io $\mathrm{ft}$. high ultimately; young wood smooth or slightly downy. Leaves ovate-oblong, pointed, finely toothed; $I \frac{1}{2}$ to 4 ins. long, $\frac{3}{4}$ to $1 \frac{1}{2}$ ins. wide; dark dull green and downy on the veins above, paler and more downy beneath; stalk 1 in. long. Flowers produced during June, each in the axil of a bract on slightly downy racemes I to 2 ins. long from the previous year's wood; corolla greenish white tinged with purple, bell-shaped, $\frac{1}{3}$ in. long and wide; stamens ten, hairy; calyx with five shallow triangular lobes. - The flower is distinctly jointed to the stalk just below the ovary. Berry globose, purple, $\frac{1}{4}$ to $\frac{1}{3}$ in. across. 
Native of the Caucasus; introduced in 1800 . It is allied to $\mathrm{V}$. padifolium from Madeira, but is a hardier shrub and (in cultivation at least) has larger leaves and differs in the hairy stamens. Its leaves, which are the largest among hardy Vacciniums, die off a pretty purplish red. It occasionally bears a second crop of flowers in September in the leaf-axils of the current year's shoots. A decoction of the leaves is used in the Caucasus as a tea, especially by the Circassians. When dried they have the appearance and aroma of black tea, but are very dissimilar and inferior in flavour. It is known as "Broussa tea."

\section{V. atrococcum, Heller. Black Huckleberry.}

A deciduous shrub, 4 to ro $\mathrm{ft}$. high, with the leaves not toothed, and very downy, even woolly beneath, the down persisting to the end of the season. Berries black and shining, without any bloom.

Native of the eastern United States and Canada. Except in its much more downy leaves, its broader, shorter corolla, and especially its bright black berries, this species resembles V. corymbosum, of which A. Gray made it a variety.

\section{Cespitosum, Michaux. DWarf Bilberry.}

A dwarf deciduous shrub of tufted habit, 4 to 6 ins., sometimes only 2 or 3 ins. high; branches round, minutely downy or smooth. Leaves obovate to narrowly wedge-shaped, tapered towards the base, toothed, usually $\frac{1}{4}$ to I in. long, about half as wide; smooth and shining. Flowers appearing in May with the young shoots, and produced singly on decurved stalks $\frac{1}{8}$ in. long. Corolla pitcher-shaped, $\frac{1}{5}$ in. long, pale pink, five-toothed at the much contracted mouth. Berry globose, about $\frac{1}{4}$ in. wide, black with a blue bloom, sweet.

Native of N. America, spreading across the continent from Labrador to Alaska and southwards to New York on the east, to California on the west, inhabiting mountain summits at its more southerly limits. Introduced in 1823. A neat little shrub now rare in cultivation, but recently reintroduced from California; very suitable for the rock garden. A form known as MAJOR grows I ft. high, and has leaves up to $\mathrm{I} \frac{1}{2} \mathrm{ins}$. long.

\section{Canadense, Kalm. Sour-top, Velvet Leaf.}

A low, much-branched deciduous shrub usually under I ft. high; shoots very downy, even bristly. Leaves $\frac{3}{4}$ to $\mathrm{I} \frac{1}{2}$ ins. long, $\frac{1}{8}$ to $\frac{1}{2}$ in. wide; narrowly oval, pointed, not toothed; downy on both sides. Flowers produced during May along with the young leaves in short dense clusters., Corolla bellshaped, $\frac{1}{4}$ in. or less long, white tinged with red. Berries blue-black, $\frac{1}{4}$ in. or more wide, very agreeably flavoured.

Native of Eastern N. America; introduced in 1834 , but first distinguished in $\mathbf{1} 748$ by Kalm, the Swedish traveller. It has been much confused in gardens with the various forms of $\mathrm{V}$. pennsylvanicum, but is readily distinguished by its very downy entire leaves. Like that species, it gives a valuable wild fruit, its berries ripening later, and forming a useful succession to the other in N. America.

\section{Corymbosum, Linnaus. Swamp Blueberry.}

A deciduous shrub, 4 to $\mathrm{I} 2 \mathrm{ft}$. high, forming a dense thicket of erect, much. branched stems; young shoots downy to nearly smooth. Leaves ovate to 
oval-lanceshaped, I to $3 \frac{1}{2}$ ins. long, half as wide; tapering at both ends, very shortly stalked, downy beneath on the midrib and veins, not toothed. Flowers produced during May in a series of short, few-flowered clusters near and at the leafless ends of the previous season's twigs. Corolla cylindrical, but narrowed near the mouth, $\frac{1}{4}$ to $\frac{1}{2}$ in. long, white or pale pink. Berries black, covered with a blue bloom, and from $\frac{1}{4}$ to $\frac{1}{2}$ in. wide, variable in size, colour, and flavour.

Native of Eastern N. America; introduced in 1765 . In British gardens this is the commonest, often the only N. American Vaccinium. It not only grows well and blossoms freely, but its leaves turn to beautiful shades of red before falling in the autumn. It is a very variable species, and there are at least half a dozen forms that may be distinguished. The most distinct are :

Var. Amcenum, A. Gray (V. amœnum, Aiton).-Like the type in habit, but with the leaves minutely toothed, and hairy on the margins when young.

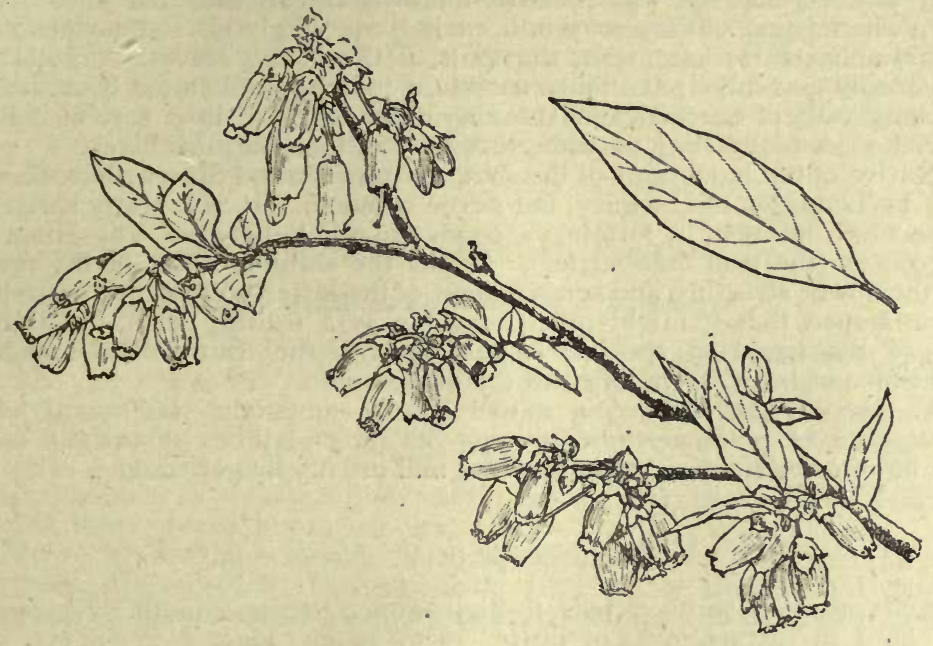

VACCINIUM CORYмBовUM.

Var. Fuscatum, A. Gray (V. fuscatum, Aiton).-Leaves covered beneath with brownish hairs. Introduced in 1770 .

Var. PAllidum, A. Gray (V. pallidum, Aiton). Mountain Blueberry.Leaves bluish beneath, and smooth except for the minutely toothed margins being hairy. Berries deep blue.

All the varieties are by some writers considered to be distinct species like atrococcum (q.v.), which Gray made a variety of $\mathrm{V}$. corymbosum also.

\section{CRAssifolium, Andrews.}

\section{(Bot. Mag., t. II 52.)}

An evergreen shrub of more or less procumbent habit; young wood covered with fine down. Leaves set about $\frac{1}{4}$ in. apart on the twigs, oval; $\frac{1}{3}$ to $\frac{3}{4}$ in. long, $\frac{1}{8}$ to $\frac{3}{8}$ in. wide; slightly toothed, quite smooth, shining green, and of leathery texture; stalk $\frac{1}{16}$ in. long, reddish like the young twigs. Flowers produced in May and June in short lateral and terminal racemes; corolla bell-shaped, rosy red, $\frac{1}{4}$ in. long. Berries black. 
Native of the south-eastern United States; introduced in 1787. It is not very hardy in the London district, and is better adapted for the southwestern counties. It was in cultivation early in the nineteenth century, but was lost sight of until recently offered by American nurserymen. The only other evergreen Vaccinium in cultivation with which it could be confused is V. Vitis-idæa, which is a much sturdier shrub with larger leaves, speckled beneath with black dots.

\section{V. erythrocarpum, Michaux. Mountain Cranberry.}

\section{(Bot. Mag., t. 74I 3 ; Oxycoccus erythrocarpus, Persoon.)}

A deciduous shrub, from 3 to $6 \mathrm{ft}$. high, with downy young branches. Leaves short-stalked, ovate or ovate lance-shaped, taper-pointed; I to 3 ins. long, scarcely half as wide; bristle-toothed, tinged with red and slightly hairy when young. Flowers produced in June singly on slender pendulous stalks, abcut $\frac{1}{2}$ in. long, from the axils of the young leaves. Corolla pale red, deeply four-lobed; the lobes narrow, $\frac{1}{3}$ in. long, and curled back, leaving the long anthers exposed and standing close together in a sort of column. Berries acid, roundish, $\frac{1}{4}$ in. wide, turning red, then purplish black.

Native of the mountains of the south-eastern United States; introduced in 1806 by Loddiges of Hackney, but never common. It is a pretty shrub and of peculiar interest in forming a connecting link between Vaccinium and Oxycoccus (the true cranberries). It has the shrubby habit of the former, but the flower structure and arrangement of the latter. When first introduced it was hoped that it might prove of value as a fruiting bush, but like the rest of the imported species, it has never borne fruit freely enough to count for much. Closely allied to this species is

V. JAPONICUM, Miquel, a native of the mountains of Japan. It is distinguished from $\mathrm{V}$. erythrocarpum by its quite glabrous shoots and leaves. The flowers are similar, but are smaller and usually longer-stalked.

\section{GLAUCO-ALBUM, Hooker fil.}

Án evergreen shrub, 2 to $4 \mathrm{ft}$. high; young stems smooth. Leaves stiff and hard in texture, oval or ovate, $1 \frac{1}{2}$ to $2 \frac{1}{2}$ ins. long, $\frac{5}{8}$ to $1 \frac{1}{4}$ ins. wide; pointed, with bristle-like teeth on the margins, green and smooth above, of a vivid blue-white and slightly bristly on the midrib beneath. Racemes slightly downy, 2 to 3 ins. long, produced from the leaf-axils, and conspicuous for their large, persistent, blue-white bracts, edged with bristles. Corolla pinkish white, $\frac{1}{ \pm}$ in. long, cylindrical; calyx smooth, shallowly lobed. Berries $\frac{1}{3}$ in. diameter, globose, black, covered with blue-white bloom.

Native of the Himalaya at 9000 to $10,000 \mathrm{ft}$. altitude; only hardy in the milder parts of the kingdom. It is remarkable for the vivid blue-white bloom on the fruit, bracts, and under-surface of the leaves. It used to grow well with the late Mr T. Acton of Kilmacurragh, Co. Wicklow, Ireland.

\section{HIRsutum, Buckley. HAIRy HuCKLeberRy.}

A low, deciduous shrub, $2 \mathrm{ft}$. high, spreading by underground rhizomes; young shoots very downy, and remaining so the second year. Leaves ovate to oval, I to $2 \frac{1}{2}$ ins. long, $\frac{1}{2}$ to $1 \frac{1}{4}$ ins. wide, shortly stalked, pointed, deep green and slightly downy above, paler and more downy beneath; not toothed. Flowers in broad, short racemes, produced towards the end of May. Corolla cylindrical, narrowed towards the mouth, $\frac{3}{8}$ in. long, white tinged 
with pirk, hairy; calyx-lobes pointed, and like the flower-stalks, very hairy. Berries $\frac{1}{4}$ in. in diameter, nearly globular, blue-black covered with glandtipped hairs.

Native of the mountains of N. Carolina and southwards, discovered by Mr Buckley about 1836 , but lost sight of until rediscovered and brought into cultivation by Prof. Sargent in 1887 . Given a position that is moist and not too sunny, it spreads rapidly by underground suckers. It is rendered very distinct by the hairiness of all its parts, more especially of its fruits, which have a sweet, pleasant, but not very pronounced flavour.

\section{INTERMEDIUM, Ruthe.}

A natural hybrid between V. Myrtillus and V. Vitis-Idæa which has been found wild on the continent of Europe, and in Staffordshire in England. It is fairly intermediate between its parents, but resembles V. Myrtillus more closely in habit. The stems are not so markedly angular as in that species, and it inherits from V. Vitis-Idæa an evergreen or almost evergreen character. The leaf-margins are toothed, but the under-surface is not dotted. Berry dark violet. It was originally discovered in this country in Maer Woods, Staffordshire, by Mr Robert Garner, in I870; and in 1886 by Prof. Bonney on Cannock Chase.

\section{V. membranaceum, Douglas.}

\section{(V. myrtilloides, Hooker, not of Michaux.)}

A deciduous shrub from I to $5 \mathrm{ft}$. high, erect-growing; branchlets angular, smooth. Leaves ovate to oblong, pointed, rounded or tapered at the base, minutely toothed; $\frac{3}{4}$ to $2 \frac{1}{2}$ ins. long, $\frac{1}{3}$ to $\mathrm{I}$ in. wide; bright green and smooth on both surfaces; stalk $\frac{1}{16}$ in. or less long. Flowers solitary in the leaf-axils on stalks $\frac{1}{4}$ to $\frac{1}{3}$ in. long. Corolla between globose and urn-shaped, $\frac{1}{4}$ in. across, greenish or pinkish white; calyx entire. Berries $\frac{1}{4}$ to $\frac{1}{3}$ in. diameter, purplish black, sweet, but rather acid.

Native of N. America from Lake Superior west to California, and north to Alaska, discovered by Douglas about 1828 . It is allied to V. Myrtillus in its angled branchlets and solitary nodding flowers. Of little garden value.

\section{Mortinia, Bentham. Mortina.}

(Bot. Mag., t. 6872 ; V. coccineum, Hort.)

An evergreen shrub, 2 to $4 \mathrm{ft}$. high, the young shoots covered with a dark minute down. Leaves densely set on the twigs (about $\frac{1}{8}$ in. apart), ovate, minutely toothed, $\frac{1}{3}$ to $\frac{1}{2}$ in. long, very uniform; dark green above and smooth except for a little dark down on the midrib; paler and minutely pitted beneath with a tiny bristle in each cavity; stalk downy, $\frac{1}{12}$ in. long. Flowers produced during June in short, dense racemes from the leaf-axils, and on the lower side of the twigs. Corolla rosy pink, cylindrical, about $\frac{1}{4}$ in. long; stamens hairy; calyx with five triangular lobes; flower-stalks downy. Berry red, $\frac{1}{5}$ in. diameter.

Native of Ecuador, on the slopes of Mount Pinchincha; introduced by Hartweg about 1840 . It is not hardy at Kew, surviving the mildest winters only, but farther south, as at Leonardslee, near Horsham, it succeeds admirably. It is a particularly neat and pleasing shrub, although its flowers, as they grow, are hidden by the foliage. It is of peculiar interest also as affording one of very few instances of a shrub found wild within a few miles 


\section{VACCINIUM}

of the equator, yet hardy enough to grow and flower in some of the home counties. The fruits are sold in the market of Quito, and from the name, "Mortina," by which they are known, the specific name has been adapted.

\section{Myrtillus, Linnceus. Whortleberry, Bilberry.}

A deciduous shrub, usually 6 to 12 ins. high, sometimes more; the young branches distinctly angled, smooth. Leaves ovate, $\frac{1}{2}$ to I in. long, often somewhat heart-shaped, regularly and bluntly tocthed, bright green and quite smooth, scarcely stalked. Flowers produced in May usually singly on drooping stalks from the leaf-axils. Corolla nearly globular, pale pink, $\frac{1}{4}$ in. long. Berries black, with a blue bloom, $\frac{1}{3}$ in. diameter, globular.

Native of Britain, where it is one of the commonest of mountain and moorland shrubs, also of $\mathrm{N}$. and Central Europe. The bilberry is one of the most valuable wild fruits of Britain, and is frequently offered in considerable quantities in the markets of north country towns. They are used for making tarts, jelly, and are especially delicious eaten with cream and sugar. A very hardy plant, it manages to survive on the summits of our loftiest mountains. It is scarcely of sufficient interest for the garden, and does not always thrive well translated to low-level gardens, in the south at any rate. Its angled stems distinguish it from the other British species.

Var. FRUCTU-ALBO.-Fruits white.

Var. MICROPHYLLUM, Hooker (V. microphyllum, Howell).-Native of Western N. America from the Sierra Nevada, where it occurs at $7000 \mathrm{ft}$., into British Columbia. It is about half the size of the European plant in all its parts.

\section{V. ovatum, Pursh.}

(Bot. Mag., t. 4732.)

An evergreen shrub of bushy habit, ro to $12 \mathrm{ft}$. high in this country; young wood purple, covered with short, dense down. Leaves $\frac{1}{4}$ to $\frac{1}{2}$ in. apart, sometimes slightly heart-shaped at the base, but usually rounded or tapering; $\frac{1}{2}$ to $\mathrm{I} \frac{1}{2}$ ins. long, $\frac{1}{3}$ to $\frac{3}{4}$ in. wide; of firm leathery texture, finely and regularly toothed, dark glossy green above, paler beneath and smooth except for some short, scattered bristles beneath and some down on the midrib above. Flowers produced in September four to six together in short, nodding racemes from the leaf-axils, white, roundish, bell-shaped, with five small, recurved, triangular lobes. Berry black, round, $\frac{1}{3}$ in. diameter.

Native of Western N. America; discovered by Menzies towards the end of the eighteenth century; introduced by Douglas in 1826 . Whilst hardy enough to survive the hardest winters experienced at Kew, it often suffers in severe frost through the cutting back of the younger growth. At Bearwood, in Berkshire, there is a specimen ro to $12 \mathrm{ft}$. high, which is one of the finest in the country. It is a handsome bush when seen at its best. The fruit rarely ripens with us; they were said by Douglas to be agreeably flavoured, although acid.

\section{PAdifolium, Smith. MAdeiran WhortleberRy.}

(Bot. Mag., t. 7305 ; V. maderense, Link.)

A deciduous shrub, 6 to $8 \mathrm{ft}$. high in this country, but becoming a small tree in Madeira; young wood downy except for smooth strips extending from the base of one leaf to the axil of the next below. Leaves ovate to oval, I to $2 \frac{1}{4}$ ins. long, $\frac{1}{2}$ to $I$ in. wide; rounded or tapering at the base, 
pointed, finely toothed, dark green and downy on the midrib above, paler and downy at the base of the midrib below; stalk $\frac{1}{12}$ in. long. Flowers produced in June in racemes 1 to 2 ins. long, from the wood of the previous year, each flower drooping and jointed at the base of the ovary to a short stalk springing from the axil of a bract about $\frac{1}{3}$ in. long. Corolla bell-shaped, $\frac{1}{3}$ in. long, dull yellow tinged with purple, the five lobes triangular; stamens ten, glabrous. Berries blue, globose, $\frac{1}{3}$ to $\frac{1}{2}$ in. across.

Native of the mountains of Madeira at altitudes of 3000 to $5000 \mathrm{ft}$.; introduced to Kew by Masson on his return in 1777 from his famous collecting expedition to the Cape of Good Hope. What is believed to be one of his plants is still growing in the Botanic Garden at Kew. But whilst it may thus be considered hardy, it thrives better where the climate is warmer-in such a garden, for instance, as that of Abbotsbury, near Weymouth. There has been much confusion between this species and the Caucasian V. Arctostaphylos, but seen together they are quite distinct. The latter has larger leaves, is of more open growth, and the stamens are hairy.

\section{PARVIFOLIUM, Smith.}

A deciduous shrub, varying in height from I to $6 \mathrm{ft}$.; the stems and twigs slender, sharply angled (like V. Myrtillus) when young, smooth. Leaves oval, obovate, or nearly round, thin, $\frac{1}{4}$ to $\frac{1}{2}$ in. long, not toothed. Flowers solitary in the leaf-axils, nodding; corolla globular, pinkish white. Berry bright red, acid but very palatable, $\frac{1}{4}$ in. across.

Native of Western N. America from California to Alaska and the Aleutian Islands. It is but little known in gardens, and so far as I have seen its chief value as an ornament is in the beautiful red its leaves turn in autumn before they fall.

\section{PENNSYlVANICUM, Lamarck. LOW BluEBERRY.}

A low, deciduous shrub, usually under $2 \mathrm{ft}$. high; young shoots warted and more or less downy. Leaves nearly stalkless, lance-shaped to narrowly oval or oblong; $\frac{3}{4}$ to $1 \frac{1}{2}$ ins. long, $\frac{1}{8}$ to $\frac{1}{2}$ in. wide; minutely toothed, pointed, smooth and bright green, the midrib downy on one or both sides. Flowers produced in April and May in short dense clusters. Corolla white tinged with red, cylindric to bell-shaped, $\frac{1}{4}$ in. or rather more long. Berries round, $\frac{1}{4}$ to $\frac{5}{8}$ in. wide, normally black, covered with a blue bloom, but variable in colour, being in some forms red, and in one (var. LEUCOCARPUM, Gray) white; very sweet.

Native of the eastern United States and Canada; introduced in 1772. The berry has a pleasant flavour, and is one of the most valuable wild fruits of N. America, ripening earlier than those of any other species. It covers large areas of poor sandy soil. In this country it has little or no value as a fruit-bearer, but makes a pleasing low cover on peaty or light sandy soils.

Var. ANGUSTIFolium, $A$. Gray, is a dwarf mountain form, with lanceolate leaves not exceeding $\frac{1}{3}$ in. in width.

\section{Stamineum, Linncus. DeErberry.}

A deciduous shrub, 2 to $4 \mathrm{ft}$. high, of bushy, much-branched habit; twigs downy. Leaves oval or ovate, $\frac{3}{4}$ to $2 \frac{1}{2}$ ins. long, about half as wide; pointed; dark dull green above, and downy on the midrib, paler or more or less 
glaucous and downy beneath; leaf-stalk $\frac{1}{8}$ in. or less long. Flowers white, with bright yellow projecting anthers, produced during May and June in downy racemes, I to 2 ins. long, furnished with leaflike bracts $\frac{1}{4}$ to $\frac{3}{4}$ in. long. Corolla open, bell-shaped, $\frac{1}{4}$ to $\frac{1}{3}$ in. wide; calyx smooth except on the ciliate margins, flower-stalk slender, downy, $\frac{1}{8}$ to $\frac{1}{2}$ in. long. Fruit greenish or yellowish, round or pear-shaped, $\frac{1}{3}$ in. wide.

Native of Eastern N. America; introduced in 1772. This is one of the prettiest of Vacciniums in its blossoms, which are freely borne on short, broad racemes, springing from the joints of the previous year's wood. It is distinct among cultivated Vacciniums for the protruding stamens and large, leafy bracts on the racemes. Nearly allied to this species is V. NEGLECTUM, Fernald, which differs in having quite smooth leaves and branches.

\section{Uliginosum, Linncus. Bog Bilberry.}

A deciduous shrub, I to $2 \mathrm{ft}$. high, with very minutely downy or smooth cylindrical branchlets. Leaves obovate, or almost round, not toothed, smooth, or finely downy beneath, dull glaucous green, $\frac{1}{2}$ to $\mathbf{r}$ in. long, with scarcely any stalk. Flowers produced during May singly or in pairs or threes from the uppermost joints of the previous year's wood, each on a drooping stalk about $\frac{1}{4}$ in. long. Corolla pale red or white, bell-shaped, $\frac{1}{6}$ in. long, with usually four teeth. Berries black with a blue bloom, sweet.

Native of the mountain heaths and bogs of the Northern Hemisphere and common in the north of Britain. The fruit is edible, but is said to produce headache and giddiness if eaten in quantity. It furnishes a valuable food for mountain game, but is scarcely worth cultivating in gardens. From its companion deciduous species in Britain (V. Myrtillus), it is easily distinguished by its round stems, entire leaves, and in the parts of the flower being mostly in fours.

\section{VACILLANS, Solander. BLUE HUCKLEBERRY.}

A deciduous shrub, I to $3 \mathrm{ft}$. high, with glabrous, yellowish green, warted branchlets. Leaves mostly oval to obovate, I to 2 ins. long, about half as wide; nearly entire, or minutely toothed except towards the base; very shortly stalked, minutely pointed, smooth, firm, pale or glaucous beneath. Flowers produced during May in short clusters on the leafless tips of the previous year's shoots. Corolla pink, cylindrical, about $\frac{1}{4}$ in. long ; calyx often reddish. Berries roundish, $\frac{1}{4}$ to $\frac{1}{3}$ in. wide, black, usually covered with a blue bloom, very sweet.

Native of the eastern United States from Maine southwards to Georgia. This is a stiffly branched species with firm textured leaves, and is one of the most ornamental in its flowers, which, like the fruits, cover the terminal (and naked) 2 or 3 ins. of the twigs.

\section{VITIS-II)ÆA, Linnaus. COWBERRY.}

A low, evergreen, creeping shrub, 6 to Io ins. high, with round, wiry, few-branched stems, covered when young with short, black down. Leaves dark lustrous green, box-like, obovate, often notched at the apex, shortly stalked; $\frac{1}{3}$ to $\mathrm{I}$ in. long, about half as wide; the lower surface sprinkled with black dots. Flowers produced during May and June, five to twelve together in terminal racemes less than I in. long. Corolla white or pinkish, bellshaped, rather deeply four-lobed, $\frac{1}{4}$ in. long. Berries dark red, globular, acid and harsh in flavour. 
Native of Britain on moors, heaths, and in woods; also of Europe, N. Asia, and N.E. America. Its fruit is only palatable when cooked with sugar. As a shrub, the cowberry is the handsomest of native species, the dark glossy foliage making neat, dense tufts. In suitable positions it spreads quickly by means of its creeping root-stock. long.

Var. MAJOR, Loddiges.-Leaves larger than in the type, up to $1 \frac{1}{3}$ ins.

Var. MINOR.-Leaves smaller than in the type, $\frac{1}{8}$ to $\frac{1}{2}$ in. long.

\section{VELLA. CRUCIFERA.}

A genus of shrubs consisting of three species, two of which are occasionally found in cultivation. They are natives of S.W. Europe. Flowers yellow; petals four; seed-vessel a compressed, two-celled pod, with one or two seeds in each cell.

\section{Pseudocytisus, Linnaus. Cress Rocket.}

(Bot. Reg., t. 293.)

A low, evergreen shrub, usually less than $2 \mathrm{ft}$. high near London, but larger in milder localities; branches erect, covered the first two or three years with spiny bristles, ultimately smooth. Leaves obovate, $\frac{1}{2}$ to $\frac{3}{4}$ in. long, rounded at the apex, tapering to a short stalk at the base, covered on both surfaces and at the margin with stiff bristly hairs. Flowers on an erect, elongated, terminal raceme, 4 to 8 ins. long, more crowded towards the top, the calyx erect, green, hairy; petals somewhat spoon-shaped, the terminal part yellow, and roundish; the lower part contracted into a long, slender, purplish claw; each petal about $\frac{1}{3}$ in. long; flower-stalk $\frac{1}{16}$ in. long.

This curious shrub is a native of the mountains of Central Spain. It is not really hardy, but has stood unprotected on the rock garden at Kew for several years at a time. Our hardest winters kill it. A sunny, rather dry position should be given it. It was cultivated by Miller at Chelsea, in 1759. Propagated easily by cuttings of half-ripened wood in gentle heat. It flowers from the end of May to July. Very suitable for the Isle of Wight and similar climates.

\section{SPINOSA, Boissier.}

A dwarf, deciduous shrub of dense, compact habit about I ft. high, with rigid, erect stems, the upper branchlets of which become spine-tipped; young shoots smooth except for a few pale bristles at first. Leaves dull greyish green, linear, $\frac{1}{2}$ to $\frac{3}{4}$ in. long, $\frac{1}{20}$ in. wide; fleshy, often showing a tendency to become pinnate; smooth except for an occasional bristle like those on the young shoots. Flowers few in terminal corymbs; each flower about $\frac{5}{8}$ in. across; petals four, yellow with brown veins, roundish obovate, narrowed at the base to a slender claw about as long as the blade. Calyx tubular, $\frac{1}{4}$ in. long, green, with four erect pointed teeth. Seed-vessel a dry two-celled pod, erect, $\frac{1}{4}$ in. long, somewhat heart-shaped, terminated by a flat, pointed beak $\frac{1}{3}$ in. long.

Native of Spain, and quite hardy in the rock garden at Kew, where a plant now scarcely I ft. high has grown for twenty years, flowering in 
June. It is an interesting, but not very showy shrub. Propagated by cuttings of young wood. The bristles on the stems and leaves are much more numerous and conspicuous in wild plants.

\section{VERONICA. SPEedWEll. SCROPHUlariace .}

The greater part of the genus Veronica consists of herbaceous plants. Of those that have a claim to mention in this work all are natives of New Zealand, and with the exception of V. elliptica, which is found also in S. America, they belong exclusively to New Zealand. In the Manual of the Nerw Zealand Flora (1906), Mr Cheeseman enumerates about seventy woody species, ranging from small trees to dwarf shrubs, all evergreen. V. PARVIFLora, Vahl (V. arborea, Buchanan), is sometimes a tree $25 \mathrm{ft}$. high, with a trunk 2 to $3 \mathrm{ft}$. in diameter. 'They have opposite, mostly stout or leathery leaves, usually superposed in four vertical rows, but in a few species, like cupressoides and Hectori, the leaves are tiny, scalelike, and more or less appressed to the stem, as in cypresses. The older parts of the stems are conspicuously ringed with the scars of fallen leaves. The growth of these veronicas, except in a few, is continuous, that is to say, no terminal bud is formed at the end of the growing season. Flowers crowded in usually axillary, sometimes terminal panicles, racemes, or spikes, and produced near the ends of the growing shoots. The individual flowers are very much alike in all the following species except in colour. The calyx has four sepals, and the corolla (usually about $\frac{1}{4} \mathrm{in}$. across) consists of a tubular base expanding at the mouth into four more or less spreading lobes. Stamens two, the stalks attached to the top of the corolla tube. Seed-vessel a two-celled, often flattened capsule.

These New Zealand veronicas are of the easiest cultivation, provided the climate is not too severe for them. They can be very readily increased by means of young wood cuttings, and thrive in a sandy loam. Unfortunately, very few of them are sufficiently hardy to withstand our severest winters. The hardiest are anomala, buxifolia, carnosula, cupressoides, Darwinii, Hectori, and Traversii. Most of them flower from May onwards.

The species hybridise freely, and some of the most ornamental kinds are of hybrid origin. The majority of these hybrids, however, are of the more tender class, and should really be classed as cool greenhouse plants, except in the south-western counties. All the sorts appear to thrive well in maritime districts. The Edinburgh Botanic Garden contains a fine collection, and several survived the winter of $1894-5$ there that succumbed at Kew.

The following descriptions are mostly checked by those of $\mathrm{Mr}$ Cheeseman in his valuable. Manual above mentioned. But it is difficult to distinguish with certainty many of the species in cultivation, owing to the different aspects the plants assume at different stages of their career, and to the differences that arise from the changed environment of plants under cultivation. The difficulty is further increased by the shy-flowering character of several. 


\title{
V. amplexicaulis, Armstrong.
}

\author{
(Bot. Mag., t. 7370.)
}

A shrub, 1 to $3 \mathrm{ft}$. high, with the branches erect or ultimately prostrate. Leaves glaucous, $\frac{1}{2}$ to $\mathrm{I}$ in. long, $\frac{1}{3}$ to $\frac{2}{3}$ in. broad; broadly oblong or oval, cupped, superposed in four vertical rows and closely set together; rounded at the apex, the bases overlapping, heart-shaped, not stalked, but partially clasping the stem. Flowers white, $\frac{1}{4}$ in. across, stalkless, borne trom leafaxils near the end of the shoot in simple or branched spikes I to $1 \frac{1}{2}$ ins. long, the main-stalk of which is minutely downy.

Native of the South Island of New Zealand in the Canterbury province; discovered by Armstrong about 1880 and soon after introduced. It is allied to, and about as hardy as V. carnosula and V. pinguifolia. From the former it is distinguished by its downy ovary and round-tipped seed-vessel, and from both by its stem-clasping leaves, heart-shaped at the base, and in the longer, often branched inflorescence.

V. LinDSAYI, Hort., was raised by the late Mr R. Lindsay of Edinburgh, a well-known cultivator of New Zealand veronicas, from seeds of $V$. amplexicaulis ripened in his garden. It is of more compact habit than that species, the leaves are not glaucous, and the flowers are pink. No doubt of hybrid origin.

\section{Angustifolia, $A$. Richard.}

\section{(V. parviflora var. angustifolia, Hooker fil.; Bot. Mag., t. 5965.)}

A shrub, 3 to $5 \mathrm{ft}$. high, occasionally more, of rather thin, loose habit; branches slender, erect, smooth and shining, turning dark brown towards the end of the season. Leaves stalkless, linear, $1 \frac{1}{2}$ to $3 \frac{1}{2}$ ins. long, $\frac{1}{8}$ to $\frac{1}{4}$ in. wide; tapering to a point, perfectly smooth, often pointing downwards. Racemes in pairs from the leaf-axils near the summit of the shoot, 2 to 5 ins. long, $\frac{3}{4}$ in. wide; the basal flowers opening long before the terminal ones. Flowers white, tinged more or less with lilac, $\frac{1}{6}$ to $\frac{1}{4}$ in. diameter; tube of corolla twice or thrice as long as the sepals, which are erect, oblong, edged with minute hairs. Individual flower-stalk slender, $\frac{1}{8}$ to $\frac{1}{4}$ in. long, and, like the main-stalk of the raceme, minutely downy.

Native of the North Island of New Zealand; introduced about 1868, perhaps before. It is very distinct in its narrow leaves and purple-brown stems, and has considerable merit as a flowering shrub, producing its graceful racemes from July until November in successive pairs near the top of the growing shoot. It succumbs in severe winters.

\section{Anomala, Armstrong.}

(Bot. Mag., t. 7360.)

A shrub, 3 to $5 \mathrm{ft}$. high, of erect, narrow habit, with slender branches, minutely downy in a strip above each leaf-axil when young. Leaves $\frac{1}{3}$ to $\frac{3}{4}$ in. long, oval-lanceolate or narrow-oblong, pointed, entire, tapering at the base to a very short, broad stalk, somewhat keeled, dark shining green, and quite smooth. Flowers white or pale pink, produced in June and July in a cluster of spikes at the end of the shoot, and thus forming a panicle, or several panicles, each 1 to $1 \frac{1}{2}$ ins. long, and nearly as wide. Corolla $\frac{1}{4}$ to $\frac{1}{3}$ in. across, with a slender tube about twice the length of the calyx. Anthers blue. Seed-vessel ovate-oblong, smooth. 
Native of the South Island of New Zealand; introduced about 1883. It is one of the hardiest of New Zealand veronicas, and flowers regularly every summer. With age (at least under cultivation) it assumes a lanky,

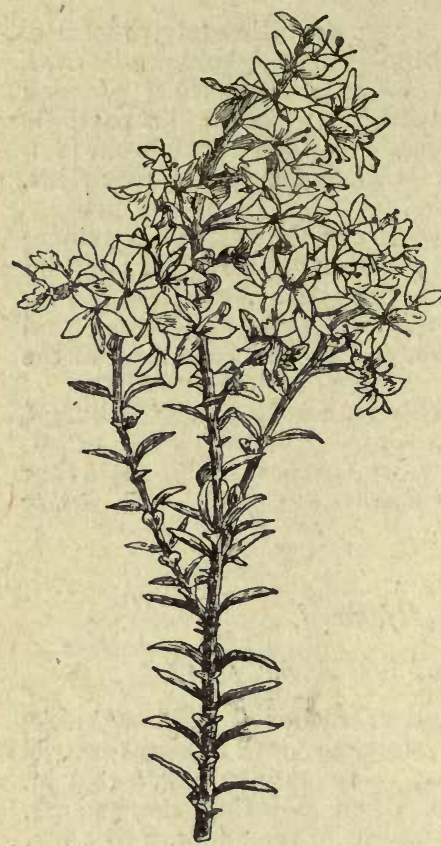

VERONICA ANOMALA. broom-like, fastigiate habit, but on the whole is one of the most satisfactory of the group.

\section{BALFOURIANA, Hooker fil. BALFOUR'S SPEEDWELL.}

$$
\text { (Bot. Mag., t. 7556.) }
$$

A shrub about $3 \mathrm{ft}$. high, with erect purplish stems, minutely downy above the leafaxils. Leaves $\frac{1}{3}$ to $\frac{3}{4}$ in. long, $\frac{1}{6}$ to $\frac{1}{4}$ in. wide; oval or somewhat obovate, scarcely stalked, pale glossy green and quite smooth except for minute marginal hairs near the base. Flowers pale purplish blue, $\frac{1}{3}$ to $\frac{1}{2}$ in. in diameter, produced about midsummer in handsome stalked racemes, 2 to 3 ins. long, $\frac{3}{4}$ in. wide. The racemes are axillary and usually opposite in a pair. Sepals about $\frac{1}{6}$ in. long, minutely downy, as long as the corolla-tube.

Originally raised at the Edinburgh Botanic Garden from New Zealand seeds; the native locality apparently not known, as it has not since been found wild. Its affinities are considered to be with V. Traversii, but its racemes are handsomer in their larger blue flowers. The corolla-tube of V. Traversii differs in being about twice the length of the calyx. V. Balfouriana is hardy in ordinary winters, but will not stand so much frost as V. Traversii.

\section{BUXIFOLIA, Bentham.}

A neat shrub, 2 to $4 \mathrm{ft}$. high, with erect branches; young shoots pale green, smooth, except for a thin strip of down reaching from the axil of one leaf to the opening between the pair next above it. Leaves in four superposed rows, $\frac{1}{3}$ to $\frac{1}{2}$ in. long, $\frac{3}{16}$ to $\frac{1}{4}$ in. wide; oblong inclined to obovate, pointed, rounded at the base, dark glossy green, perfectly smooth, covered with minute dots beneath; stalk about $~_{12}^{\frac{1}{2}}$ in. long, dilated where it joins the stem and slightly hairy there. Flowers white, $\frac{1}{4}$ to $\frac{1}{3}$ in. across, produced in June and July at and near the apex of the shoots in closely packed clusters, $\frac{1}{2}$ to I in. long, which are often branched and collectively form a corymb, I to 2 ins. across, the stalks minutely downy. Sepals narrow oblong, rounded at the end, edged with minute hairs; seed-vessel about twice as long.

Native of the North and South Islands of New Zealand. The plant in cultivation under this name and described above is very distinct in general appearance from native grown specimens, which have the leaves much more densely arranged on the stem, and less distinctly stalked. But in all essential particulars they appear to be the same. Probably the differences are due to the different environment of cultivated plants. It reaches up 
to $4000 \mathrm{ft}$. altitude in New Zealand, and is one of the hardiest members of this group. It flowers annually, but not freely.

\section{CARNOSUla, Hooker fil.}

A shrub usually more or less prostrate, and rarely more than I $\mathrm{ft}$. high with us, occasionally $3 \mathrm{ft}$. high in New Zealand, young shoots with a vertical strip of down above each leaf-axil. Leaves glaucous green, scoop-shaped, obovate, pointed; $\frac{1}{3}$ to $\frac{3}{4}$ in. long, $\frac{1}{4}$ to $\frac{2}{3}$ in. wide; narrowing to a stalkless base, closely superposed in four rows. Flowers densely crowded in spikes near the end of the shoot, the whole forming a dense terminal cluster; flower-stalks very downy. Flowers $\frac{1}{4}$ in. across, white; sepals erect, as long or rather longer than the corolla-tube, edged with minute hairs. Ovary, style, and seed-vessel free from down, the last pointed.

Native of the South Island of New Zealand up to $4500 \mathrm{ft}$. altitude. It is a very pleasing little evergreen, making low densely leafy tufts of a striking glaucous hue, and of neat appearance. It is also one of the hardiest of this group. Nearly allied to V. pinguifolia (q.v.).

\section{CUPRESSOIDES, Hooker fil.}

(Bot. Mag., t. 7348.)

A shrub usually seen I to $3 \mathrm{ft}$. high in this country, but said to be as much as $6 \mathrm{ft}$. in a native state. It has a rounded, dense habit, much like that of a dwarf cypress or juniper, the branches being very much forked and subdivided, the final ramifications very slender and short ( $\frac{1}{2}$ to $I$ in. long). Branchlets about $\frac{1}{30}$ in. thick, often minutely downy. Leaves on adult plants scale-like, about $\frac{1}{16}$ in. long, smooth except for minute hairs on the margin, rounded at the apex; they do not, as in Hectori and lycopodioides, completely hide the stem, although usually appressed to it; the bases of each pair are united and clasp the stem. In young plants (occasionally on odd branches of older ones), the leaves are as much as $\frac{1}{4}$ in. long, narrowly oblong, ovate or somewhat obovate, and vary from entire to irregularly or pinnately lobed, pointed and distinctly stalked. Flowers pale blue, $\frac{1}{6}$ in. diameter, produced three to eight together at the ends of the branches in a small head about midsummer.

Native of the South Island of New Zealand; long cultivated. It is fairly hardy, but in my experience does not flower freely. It is worth growing for its neat appearance and remarkable cypress-like growth-one of many instances of curious "mimicry" in plants.

\section{Darwiniana, Colenso. Darwin's Speedwell.}

\section{(V. glaucophylla, Cockayne.)}

A shrub up to $3 \mathrm{ft}$. or probably more high, branches erect, smooth except for a strip of down above each leaf-axil when young. Leaves in four superposed rows, oval-lanceolate, pointed, scarcely stalked, $\frac{5}{8}$ to $\frac{3}{4} \mathrm{in}$. long, $\frac{1}{6}$ to $\frac{1}{3}$ in. wide; slightly concave, somewhat glaucous on both surfaces; quite smooth except for some minute hairs on the margins when young. Racemes usually in one or two pairs near the tops of the branches, $\frac{3}{4}$ to $\mathrm{I} \frac{1}{2}$ ins. long; flowers densely arranged, white, $\frac{1}{4}$ in. diameter. Sepals broadly ovate, about as long as the corolla - tube, which is downy within the throat. Individual flower-stalks scarcely so long as the calyx, and, like the mainstalk of the raceme, downy. 
Native of both the main islands of New Zealand. Mr Cheeseman regards this as more nearly related to $\mathrm{V}$. Traversii (or what goes generally under that name) than any other. It differs in the hairy throat of the corolla, and in the glaucous foliage. It is a neat bush, but does not flower with the freedom of $\mathrm{V}$. Traversii.

\section{Dieffenbachil, Bentham.}

(Bot. Mag., t. 7656.)

A shrub of wide-spreading habit, 3 to $4 \mathrm{ft}$. high. Leaves narrow-oblong, 2 to 4 ins. long, $\frac{1}{2}$ to $I$ in. wide; pointed, thick in texture, rather pale green; the base stalkless and partially clasping the stem. Racemes showy, produced in pairs a little below the apex of the shoot in the leaf-axils; 3 or 4 ins. long, $\frac{3}{4}$ to $I$ in. wide, densely crowded with blossom. Flowers $\frac{1}{4}$ in. diameter, purplish lilac.

Native of the Chatham Islands, where it was discovered in I84I by Dieffenbach. It is closely allied, and bears a considerable resemblance to V. speciosa, from which it differs in its generally narrower, paler green leaves, its round, not angled stems, and in the seed-vessel being about thrice (instead of twice) the length of the calyx. It is, perhaps, only an outlying form of $\mathrm{V}$. speciosa and, like it, needs winter protection.

\section{ELLIPTICA, Forster. \\ (V. decussata, Aiton; Bot. Mag., t. 242.)}

A tree up to $20 \mathrm{ft}$. high, or a shrub a few feet high, in a wild state; branches round, with a downy strip above each leaf-axil, or wholly downy. Leaves oval or obovate, narrowed abruptly at the apex to a short point; $\frac{1}{2}$ to $I_{4}^{\frac{1}{4}}$ ins. long, $\frac{1}{4}$ to $\frac{1}{2}$ in. wide; standing out at right angles from the stem, the base rounded and distinctly but shortly stalked, the stalk flattened to the stem; pale green and smooth except that the margin is downy. Racemes crowded near the ends of the branches, I to $I \frac{1}{2}$ ins. long, erect, not or slightly downy. Flowers the largest among these shrubby veronicas, being sometimes $\frac{2}{3}$ in. diameter, white, fragrant, four to twelve of them appearing on a raceme. Seed-vessel twice the length of the sepals.

Native of New Zealand, Chile, Tierra del Fuego, and the Falkland Islands, whence it was, according to Aiton, introduced by Dr Fothergill in 1776. It is one of numerous instances showing the close affinity of the flora of New Zealand with that of southern S. America. Lately reintroduced from the Falkland Islands by Mr Clarence Elliott.

\section{Hectori, Hooker fil. HeCtoR'S SPEEdwell.}

$$
\text { (Bot. Mag., t. 74I5.) }
$$

A shrub 6 ins. to $2 \mathrm{ft}$. high, with stiffly erect, much-branched, round stems, covered and hidden by closely flattened, scale-like leaves. The shoots of the year, with their covering of leaves, are from $\frac{1}{12}$ to $\frac{1}{8}$ in. thick. Leaves $\frac{1}{10}$ to $\frac{1}{6}$ in. long, closely overlappiry, each pair united by their margins at the lower half, and thus entirely clasping the stem; tapered to a bluntish apex; margins at first minutely hairy. Flowers $\frac{1}{4}$ in. wide, white or pinkish, crowded in a small terminal head. Sepals narrowly oblong, about as long as the corolla-tube; margins minutely hairy.

Native of the South Island of New Zealand, up to $8000 \mathrm{ft}$. It is one of the very hardiest of New Zealand veronicas and makes an interesting small evergreen, but is rather shy-flowering. Like V. lycopodioides it bears much 
resemblance to the juvenile condition of some conifers. $\mathrm{V}$. lycopodioides differs from it in having distinctly square stems, and in the leaves not being so much united towards the base. (See also V. cupressoides.)

\section{Hulkeana, F. von Mueller. \\ (Bot. Mag., t. 5484.)}

A loose-habited, straggling shrub, occasionally reaching a height of 4 to $6 \mathrm{ft}$. or even more when grown against a wall-as it usually is in this country. Leaves in pairs somewhat far apart on the branches, broadly ovate; I to 2 ins. long, $\frac{1}{2}$ to $I \frac{1}{4}$ ins. wide; broadly wedge-shaped or rounded at the base, coarsely toothed, the teeth and apex either blunt or sharp, dark glossy green; stalk $\frac{1}{4}$ to $\frac{1}{2}$ in. long. Flowers $\frac{1}{4}$ to $\frac{1}{3}$ in. diameter, of a delicate lavender or lilac shade, produced in May and June in huge branching panicles which terminate the shoots. These panicles are sometimes 18 ins. long, with side branches 3 to 7 ins. long. The flowers themselves are without stalks, but the ramifications of the panicle are downy.

Native of the South Island of New Zealand; introduced about 1860. It is, unfortunately, one of the more tender species and is only really happy out-of-doors in the mildest counties. Even there it is usually treated as a wall shrub. It thrives well with Miss Willmott on a warm wall at Warley. A species of remarkable beauty and distinction, it is, unhappily, frequently short-lived in cultivation, dying suddenly without any ostensible cause other than its excessive production of blossom. The panicles should be removed as soon as the flowers fade.

V. FAIRFIELDII, Hooker (Bot. Mag., t. 7323), is a shrub of dwarfer, sturdier habit, with leaves $\frac{1}{2}$ to I in. long, and shorter, broader flower panicles. It first appeared in the Fairfield Gardens, near Dunedin, N.Z. Mr Cheeseman suggests it may be a hybrid between V. Hulkeana and V. Lavaudiana, Raoul, the latter a dwarf shrub under I ft. high, with pink flowers (Bot. Mag., t. 7210 ).

\section{LOGANIOIDES, Armstrong.}

(Bot. Mag., t. 7404.)

A dwarf, conifer-like shrub, usually well under $\mathrm{I} \mathrm{ft}$. in height; often only 4 to 6 ins. Stems erect, becoming decumbent with age; when young, furnished with soft, pale hairs. Leaves $\frac{1}{8}$ to $\frac{1}{6}$ in. long, ovate or lanceolate, tapering from a broad stalkless base to a bluntish point, sometimes entire, sometimes with one or two comparatively large teeth at each side, erect or spreading, keeled at the back, dull green, smooth. Flowers pure white (sometimes pink-veined), $\frac{1}{4}$ to $\frac{1}{3}$ in. across, produced in June and July in a terminal, single or three-branched inflorescence, on which the flowers open successively for some weeks. Sepals ovate-oblong, pointed, with hairy margins; corolla-tube short, scarcely so long as the sepals. Main and secondary flower-stalks hairy.

Native of the South Island of New Zealand, and a pleasing dwarf evergreen distinct among this group in its hairy stems and racemes; its small, closely set, spreading, frequently toothed leaves; and in the flattish seedvessel splitting across the narrowest diameter.

\section{LyCOPODIOIDES, Hooker fil.}

(Bot. Mag., t. 7338.)

A shrub I to $2 \mathrm{ft}$. high, with stiff, erect branches densely clothed with overlapping scale-like leaves and much resembling a lycopod. The 
branchlets, as clothed with leaves. are four-sided, each face about $\frac{1}{8}$ in. wide. Leaves on adult plants about $\frac{3}{10}$ in. long, rather more wide, triangular, flattened to the branches and strongly keeled at the back (it is the prominent keel that gives the quadrangular form to the branchlets), each pair united at the base. On young plants, and on occasional "reverted" branches of older ones, the leaves are twice as long, not pressed to the branches, awl-shaped with a broad base, and often more or less linear-lobed. Flowers produced about midsummer in a small head $\frac{1}{3}$ in. across at the end of the branches ; the corolla $\frac{1}{4}$ in. diameter, white, against which the large blue anthers are in effective contrast.

Native of the South Island of New Zealand up to $5500 \mathrm{ft}$. It is about as hardy as V. cupressoides and is equally shy-flowering in this country. From that species it is easily distinguished by the much less dense habit, the final subdivisions of the branches being longer, thicker, and more open. (See also V. Hectori.)

\section{PIMELEOIDES, Hooker fil.}

A prostrate or partially erect shrub, with downy (sometimes very downy) young branches. Leaves closely set in four vertical rows, ovate, oval, or obovate; about $\frac{1}{4}$ in. long, $\frac{1}{6}$ in. wide; tapered towards both ends, concave, glaucous, smooth. Flowers purplish blue, $\frac{1}{4}$ to $\frac{1}{3}$ in. diameter, stalkless, produced during June, July, and August in solitary or branched, cylindrical spikes $\frac{3}{4}$ to 2 ins. long, the main-stalk of the spike downy like the young branchlets. Corolla-tube very short.

Var. Glauco-Ccerulea, Cheeseman (V. glauco-cœrulea, Armstrong).-A more robust plant with leaves up to $\frac{1}{2}$ in. long, and shortly stalked, more conspicuously glaucous than the type. Flowers darker blue-purple.

Both these are very pleasing dwarf shrubs, forming a dense covering to the ground, the blue flowers contrasting admirably with the glaucous leaves, which, with the conspicuously downy stems and flower-spikes, distinguish the species. Native of the South Island of New Zealand, up to $3500 \mathrm{ft}$.

\section{PINGUIFOLIA, Hooker fil.}

(Bot. Mag., t. 6147 (and t. 6587 as carno:ula).)

A shrub I to $3 \mathrm{ft}$. high, branches at first erect, often ultimately prostrate; minutely downy when young, stained with purple beneath each pair of leaves. Leaves closely superposed in four rows, obovate, blunt at the apex, tapered to a broad stalkless base, $\frac{1}{2}$ to $\frac{3}{4}$ in. long, $\frac{1}{4}$ to $\frac{3}{8}$ in. wide; quite entire, concave or scoop-shaped, dull glaucous green. Flowers white, $\frac{1}{4}$ to $\frac{1}{3}$ in. diameter, stalkless, crowded on spikes $\frac{3}{4}$ to $I$ in. long which are borne in the terminal leaf-axils; stalk of spike downy: Calyx with four minutely downy, oblong, blunt divisions. Corolla-tube scarcely as long as the calyx; ovary and style downy. Seed-vessel oblong or obovate, rounded at the apex, downy, nearly twice as long as the calyx.

Native of the South Island of New Zealand; introduced about I868. It is killed by very severe frosts, but survives most of the winters in the South of England, flowering about midsummer, although not abundantly nor regularly. It is very similar to, and much confused with V. carnosula, under which name it was figured in the Bot Mag., t. 6587. The differences between the two are in the often comparatively broader leaves of V. carnosula, its glabrous ovary and style, and its ovate, pointed, glabrous seed-vessel. They occur wild in the same region. 


\section{SALICIFOLIA, Forster.}

A shrub up to $10 \mathrm{ft}$. high in a wild state, branchlets round, smooth, or very minutely downy when young. Leaves narrowly lanceolate or oblonglanceolate, 2 to 5 ins. long, $\frac{1}{2}$ to $\frac{7}{8}$ in. wide; tapering to a long slender point, more abruptly tapered at the base; stalkless or nearly so; pale green and smooth; midrib slightly downy above, prominent beneath. Racemes slenderly cylindrical, 4 to 6 , sometimes Io ins. long, $\frac{3}{4}$ in. wide; very thickly crowded with blossom except at the base, which is naked for 1 or 2 ins. Flowers small, $\frac{1}{4}$ in. long, variable in colour, being white tinged with lilac, bluish purple or of intermediate shades; corolla-lobes narrow, not spreading; the tube nearly twice as long as the narrow pointed sepals. The main-stalk of the racemes, the Hower-stalks (slender and $\frac{1}{6}$ in. long), and the margins of the sepals minutely downy.

Native of New Zealand, where according to Cheeseman, it is the most widely spread and the most variable of all the veronicas. It is one of the tender sorts, only adapted for the mildest parts of Britain. It has hybridised very freely with other species, and some of the fine garden varieties are descended in part from it. V. ANDERSONI, Lindley, a variegated form of which was once very popular for summer bedding, is a hybrid between this species and $V$. speciosa.

Nearly allied to the above is

V. GIGANTEA, Cockayne (V. salicifolia var. gigantea, Cheeseman).-A tree rivalling V. parviflora (see p. 632) in stature and bulk, being occasionally $25 \mathrm{ft}$. high, and forming a well-defined trunk. It has leaves 2 to 4 ins. long, $\frac{1}{3}$ to $\frac{1}{2}$ in. wide, with minutely hairy margins. Flowers white, $\frac{1}{5}$ in. wide, produced in racemes about as long as the leaves. Besides the greater stature and shorter racemes, this veronica differs from V. salicifolia in having the calyx and the corolla-tube of about the same length. There is a picture of a tree growing on Chatham Island in the Kew Bulletin for 1910, p. 123, taken by Capt. Dorrien Smith in December I909. The plant was introduced to cultivation by him at the same time.

\section{SPECIOSA, R. Cunningham.}

(Bot. Mag., t. 4057.)

A shrub up to $5 \mathrm{ft}$. high; branches spreading, very stout even when young, smooth, two-edged at first. Leaves 2 to 4 ins. long, $\frac{3}{4}$ to $1 \frac{3}{4}$ ins. wide; obovate, rounded or bluntish at the apex, tapered at the base to a very short stalk; dark shining green, leathery, smooth except that the midrib above and the margins near the base are minutely downy. Racemes produced in the uppermost leaf-axils, $1 \frac{1}{2}$ to 3 ins. long, 1 to $I \frac{1}{2}$ ins. thick. Flowers dark reddish purple, $\frac{1}{3}$ in. diameter.

Native of the North Island of New Zealand, ${ }^{*}$ where it was discovered in December 1833 , by Richard Cunningham, at the south head of Hokianga Harbour. It occurs also in the South Island, but is very rare and confined to small areas, always on cliffs near the sea. I am not sure that the typical plant is now in cultivation, but it is very striking in the great width of its round-ended or broadly tapered leaves. It has, however, by hybridisation with other species given birth to a very valuable series of evergreen flowering shrubs, in which its influence is seen in the purple, violet, or reddish flowers, and in the compressed two-angled shoots. Unfortunately they inherit, too, more or less of its tenderness, so that in all but the warmest counties of the British Isles they need winter protection. A variety called "Autumn Glory," possessing, however, little of the "blood" of V. 
speciosa, is an exception. It is one of the hardiest and best, producing its bright blue flowers from August to November. It is a neat bush with oval or obovate leaves $\frac{5}{8}$ to $\mathrm{I} \frac{1}{2}$ ins. long, and erect racemes (sometimes branched) $1 \frac{1}{2}$ to 3 ins. long.

\section{Traversir, Hooker fil. Travers' Speedwell. (Bot. Mag., t. 6390.)}

An evergreen shrub up to $6 \mathrm{ft}$. high, or more, forming a wide-spreading, rounded bush of dense habit; branches erect, at first minutely downy, soon becoming quite smooth. Leaves densely arranged on the shoot (ten or

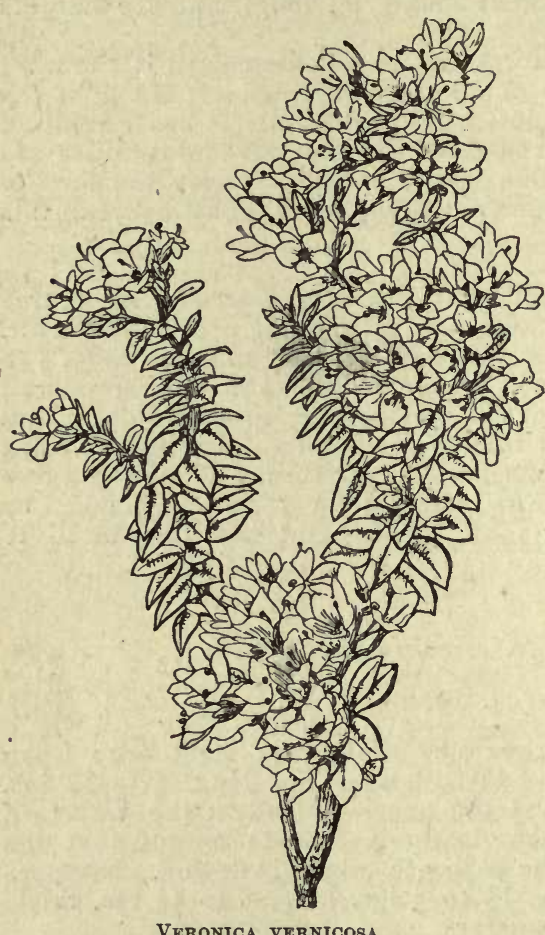
twelve to the inch), superposed in four vertical rows; narrowly oval or oblong, sometimes slightly obovate; $\frac{1}{2}$ to $I$ in. long, $\frac{1}{6}$ to $\frac{1}{4}$ in. wide ; pointed, tapered at the base to a short, broad stalk; dark, rather dull green. Racemes produced in July from the leaf-axils near the end of the shoot, usually about 2 ins. long, $\frac{3}{4}$ in. wide, the main-stalk minutely downy. Flowers $\frac{1}{4}$ to $\frac{1}{3}$ in. in diameter, white; sepals ovate with minute hairs at the edges, corolla-tube about twice as long. Anthers purple-brown. Seed-vessel $\frac{1}{6}$ in. long, much compressed, about twice as long as the sepals.

Native of New Zealand; introduced about 1868 . This has proved the most hardy, and on the whole the most ornamental of NewZealand veronicas in gardens. The only time I have seen it killed by cold was in February 1895. It makes a handsome and shapely evergreen, worth growing on that account alone, but it has the additional attraction of flowering freely and regularly after midsummer, when shrubs in flower cease to be abundant. It is pleasing as an isolated specimen on a lawn.

The above description applies to the shrub long grown in gardens as V. Traversii, but it seems doubtful if it be the true plant originally described by Hooker. His types in the Kew Herbarium have more slender branches, leaves more narrowly oblong, $\frac{5}{8}$ to $I_{4}^{\frac{1}{4}}$ ins. long, $\frac{1}{8}$ to $\frac{1}{4}$ in. wide, less densely packed on the stem. Calyx-lobes much shorter, more rounded, and only about one-fourth the length of the capsule.

\section{VERNICOSA, Hooker fil.}

\section{(V. canterburiensis, A rmstrong.)}

A low, spreading shrub, I to $2 \mathrm{ft}$. high; shoots furnished with extremely minute down. Leaves densely packed on the stem, $\frac{1}{4}$ to $\frac{1}{2} \mathrm{in}$. long, $\frac{1}{8}$ to 


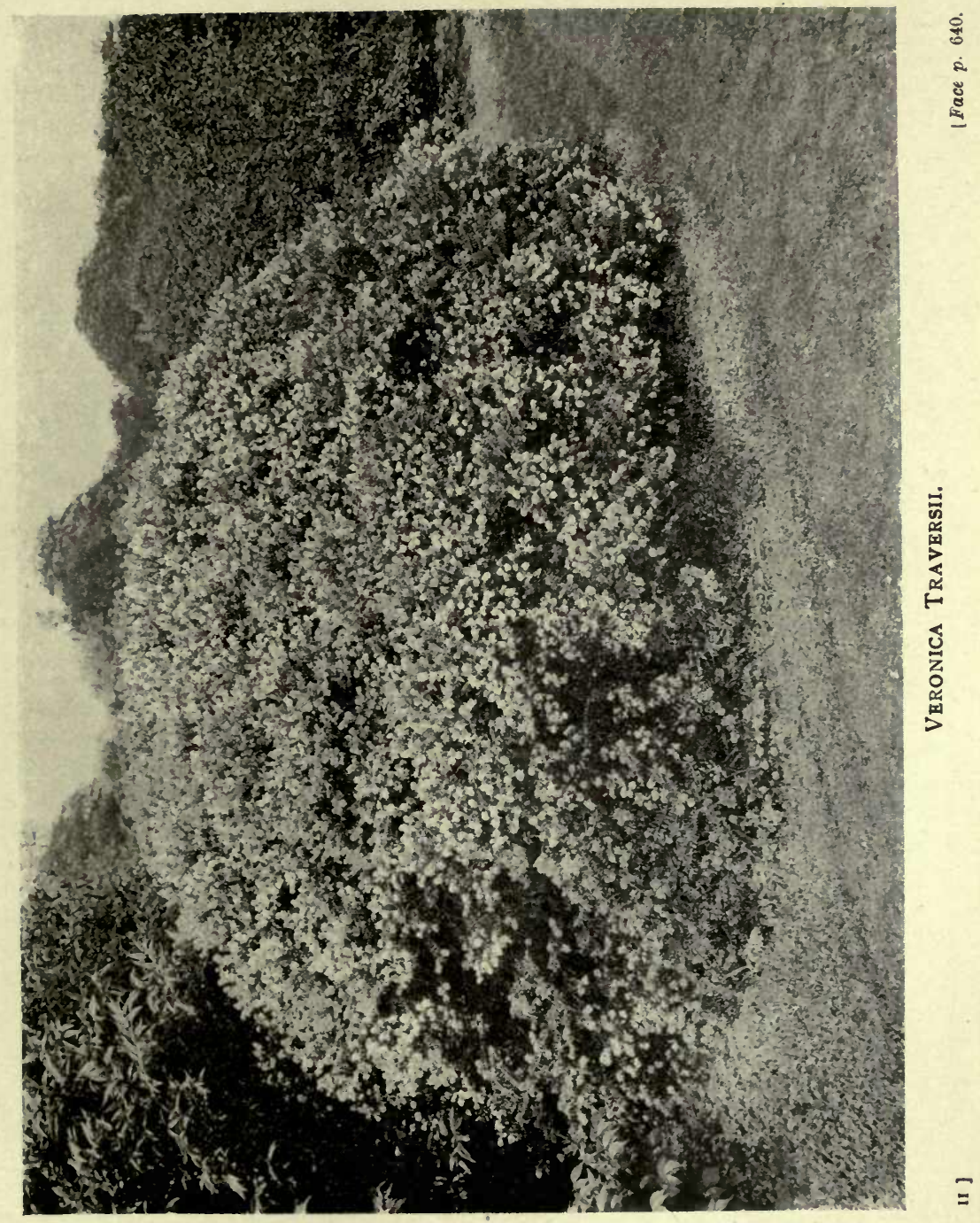



$\frac{3}{16}$ in. wide; oval to obovate, pointed, tapered at the base to a short stalk, dark glossy green, smooth; on the spreading branches the stalks of the lower leaves are often twisted so as to bring the faces of all the leaves to pretty much the same plane. Racemes in pairs towards the ends of the shoots, $\frac{1}{2}$ to I in. long, four- to eight-flowered; stalks downy. Flowers white, $\frac{1}{4}$ to $\frac{1}{3}$ in. diameter; calyx-lobes narrow oblong, blunt, about half the length of the seed-vessel.

Native of the South Island of New Zealand, in mountainous districts up to 4000 or $5000 \mathrm{ft}$. As represented at Kew this is one of the daintiest of New Zealand veronicas and flowers freely.

\section{VIBURNUM. CAPRIFOLIACE}

Few genera have received a greater accession of new material in recent years than this-chiefly through the exploration of Central and W. China. In a recent enumeration of Viburnums from E. Asia, where the genus has its headquarters, Mr Rehder included sixty-five species, which, with others from India, Europe, and N. America, will bring the total to over a hundred. Of these about one-third are grown in the open air in Britain. The leading characteristics of the genus, which is a well-marked one, are as follows:-Shrubs, rarely small trees, either deciduous or evergreen; with opposite, simple leaves; white or pinkish flowers borne most frequently in flattish or rounded cymose clusters, or sometimes in pyramidal panicles, always terminal. Corolla five-lobed, spreåding, bell-shaped or rarely tubular; calyx small, five-toothed; stamens five. Fruit a one-seeded drupe, usually blue, black, or red.

A curious feature of several species of Viburnum is the presence of two distinct types of flower in the one inflorescence - the one sterile and showy, consisting of a corolla without stamens or pistil, the other much smaller but perfect and fertile. The function of the large sterile flower is that of advertisement and to attract insects to the inflorescence. This really represents an interesting and unusual division of labour, for most insect-fertilised flowers do their own advertising by means of the petals attached to the individual flower. In three species-Opulus, macrocephalum, and tomentosum-gardeners, by cultivation, have obtained an inflorescence made up entirely of sterile blossoms, which represents a striking increase in flower beauty. These phenomena are also exhibited by several species of Hydrangea.

Viburnums as a rule are of easy cultivation, but there are some exceptions and some are not very hardy. They love moist conditions and a deep, rich, loamy soil. V. alnifolium and V. furcatum are said to love shade. So far as I know there is no Viburnum that cannot be increased by means of cuttings, although some, like alnifolium, are better from layers. Most of them take root easily if made of nearly ripe wood in late July or August and placed in gentle bottom heat.

\section{ACERIFOliUm, Linnaus. DOCKMACKIE.}

A deciduous bush 3 to $6 \mathrm{ft}$. high; young branches at first softly downy, becoming smooth. Leaves maple-like, three-lobed; the side lobes with 
divergent, slender points, all coarsely toothed; $1 \frac{1}{2}$ to 4 ins. long and about the same wide; rounded or heart-shaped at the base, with scattered down above, softly downy (especially at first) and covered with black dots beneath; stalk $\frac{1}{2}$ to $\mathbf{I}$ in. long, downy. Flowers white, $\frac{1}{5}$ in. diameter, uniform and all fertile, produced during June in terminal, long-stalked cymes 2 to 3 ins. across. Fruits first red, then purple-black, oval, $\frac{1}{3}$ in. long.

Native of Eastern N. America; introduced in 1736. Although one of the earliest introduced of American Viburnums this is now very scarce in gardens; it has little beauty of flower, but is attractive in autumn for its crimson foliage. I have seen it growing along the roadsides in New Hampshire just as $\mathrm{V}$. Opulus does at home, but never so vigorous a shrub.

V. PAUCIFlORUM, Pylaie, resembles the above in the often three-lobed and palmately veined leaves, and in all the flowers of the cyme being perfect. It differs from it in the nearly smooth leaves and in the bright red (not finally black) fruits. It is a dwarf shrub 2 to $4 \mathrm{ft}$. high, the cymes small, about I in. across, borne on short, two-leaved lateral twigs. Widely spread over the high latitudes of $\mathrm{N}$. America from Labrador to Alaska, found also in mountainous regions farther south. Of little garden value and rarely seen.

V. ORIENTALE, Pallas, native of the Western Caucasus and Asia Minor, is also closely allied to $\mathrm{V}$. acerifolium, but can always be distinguished by the absence of the minute black dots beneath the leaf so characteristic of the American species. It is not so downy, the hairs beneath being almost confined to the vein-axils; otherwise very similar. Rare in gardens.

\section{AlNifolium, Marshall. HobBle Bush.}

\section{(V. lantanoides, Michaux.)}

A strong-growing, rather coarse-habited, deciduous shrub, 6 to io $\mathrm{ft}$. high; the central shoots erect, the lower ones spreading, often prostrate; young bark covered with a thick scurfy down. Leaves in distant pairs, broadly ovate to roundish, the points short and abrupt, the base heartshaped; margins irregularly toothed; 4 to 8 ins. long, nearly as broad; upper surface dark green, at first downy, but becoming smooth; lower surface with much stellate down on the midrib and veins, especially when young; stalk $\mathrm{I}$ to $2 \frac{1}{2}$ ins. long, scurfy downy. Flowers white, produced in stalkless cymes with usually five divisions, and 3 to 5 ins. across; marginal flowers sterile, and $\frac{3}{4}$ to $I$ in. across; central ones perfect and much smaller. Fruit red, turning black-purple, $\frac{1}{3}$ in. long.

Native of Eastern N. America; introduced in 1820. This, perhaps the most striking of the Lantana group, is rarely seen in our gardens, where it does not seem to thrive. The best plants I have seen in Europe were in $\mathrm{Mr}$ Hesse's nursery at Weener, in Hanover. Mr Hesse is of opinion that it needs shade and abundant moisture, and I have also seen it in New England in positions that support that opinion, although not invariably so. It is very distinct in its large leaves, which turn deep red in autumn; and from our native V. Lantana is well distinguished in having large, sterile marginal flowers. The popular name refers to its prostrate lower branches, which often take root and trip up the unwary traveller through its native haunts. The venation of the leaves is handsome; the primary veins branch on the lower side only, and are connected by thin parallel nerves almost at right angles. The nearest ally in cultivation to this species is

V. FURCATUM, Blume, a native of Japan and China. This also has the showy sterile marginal flowers, but its stems are more uniformly erect. It differs also in the shorter stamens, which are only half the length of the corolla, and in the shape of the furrow in the seed. It succeeds in gardens 
no better than $\mathrm{V}$. alnifolium, although there was a healthy plant at Abbotsbury, near Weymouth, a few years ago. It is a native of $\mathrm{N}$. Japan at low levels, and of the mountainous parts of the south. The foliage turns brilliant scarlet to reddish purple in autumn. It is a bush $12 \mathrm{ft}$. or more high in a wild state.

V. SYMPODIALE, Graebner, is closely allied to both the preceding, especially to V. furcatum, but differs in having stipules on the leaf-stalks, and in its smaller, ovate, more finely toothed leaves. It was collected in Central China by Wilson in 1900, and may be in cultivation.

\section{BETUlifolium, Batalin.}

(Sargent's Trees and Shrubs, t. 96.)

A deciduous shrub, branchlets smooth, becoming brown or purplish brown. Leaves ovate to diamond-shaped, broadly wedge-shaped at the base, and often entire there, the terminal part more gradually tapered and coarsely toothed; 2 to 4 ins. long, $1 \frac{1}{4}$ to 3 ins. wide; dark green and smooth above, paler and also smooth beneath, except for a few simple hairs on the veins, and sometimes tufts in the vein-axils; veins in four to six pairs; leaf-stalk $\frac{1}{2}$ to $\frac{3}{4}$ in. long, usually slightly hairy. Corymbs $2 \frac{1}{4}$ to 4 ins. across, the main- and especially the secondary flower-stalks usually covered with a close, pale brown, stellate down; main branches of corymb seven. Flowers white, $\frac{1}{5}$ in. across, all perfect; stamens protruded, anthers yellow. Fruit red, roundish, $\frac{1}{4}$ in. long.

Native of Hupeh and Szechuen, China; discovered in 1885 by Potanin, introduced by Wilson in 1901, in 1907, and in 1910. A handsome fruiting shrub of the same character as V. Wrightii, but with more coarsely toothed, cuneate, fewer-veined leaves.

\section{Buddleifolium, C. H. Wright.}

A deciduous shrub about $6 \mathrm{ft}$. high; the young shoots densely covered with pale, star-like down. Leaves oblong-lanceolate, 3 to 5 ins. long, I to 2 ins. wide; pointed, rounded or slightly heart-shaped at the base, shallowly toothed; upper surface furnished with simple or forked hairs; the lower one felted with pale, stellate down; stalk $\frac{1}{4}$ to $\frac{1}{2}$ in. long. Flowers white, funnel-shaped, $\frac{1}{3}$ in. across, all perfect, produced on a short-stalked, numerously branched cyme, 3 ins. across. Fruit oval, $\frac{1}{3}$ in. long, black.

Native of Central China; discovered and introduced by Wilson in 1900. It belongs to the Lantana group, differing from V. Lantana in its narrow, oblong leaves.

\section{BUREjÆTICUM, Regel. (V. burejanum, Herder.)}

I am doubtful if the true plant to which this name belongs is now in cultivation, although it may be among recent introductions from China. What is usually seen under the name is V. Lantana or one of its near allies. The true burejæticum is quite distinct. A deciduous shrub whose young shoots are covered at first with a dense, stellate down, becoming almost white and smooth the second year. Leaves ovate, oval or slightly obovate; tapered, rounded, or slightly heart-shaped at the base, tapered and often blunt at the apex; 2 to 4 ins. long, I to 2 ins. wide; evenly and angularly toothed, with scattered, mostly simple hairs above, and scattered stellate ones beneath, chiefly on the veins, becoming almost smooth; stalk $\frac{1}{4}$ to $\frac{1}{2}$ in. 
long, scurfy. Flowers white, uniform and perfect, $\frac{1}{4}$ in. wide, produced in stalked usually five-branched cymes, 2 ins. across; the stalks covered with stellate scurfy down. Native of Manchuria and China.

\section{Carlesit, Hemsley. \\ (Bot. Mag., t. 8II4.)}

A deciduous shrub of rounded but thin, open habit, 3 to $4 \mathrm{ft}$. high (possibly more); young shoots densely clothed with starry down. Leaves broadly ovate, with often a slightly heart-shaped base, pointed, irregularly

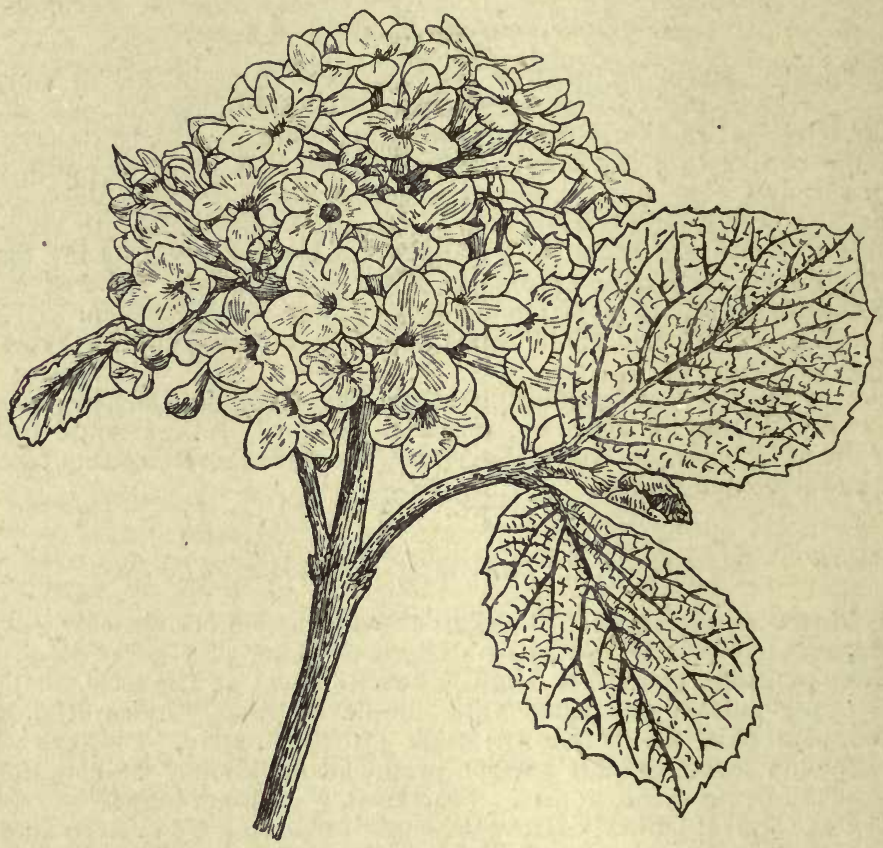

Viburnua Carlesil.

toothed; I to $3 \frac{1}{2}$ ins. long, $\frac{3}{4}$ to $2 \frac{1}{2}$ ins. wide; dull green above, greyish below, both surfaces soft with starry down; stalk about $\frac{1}{4}$ in. long. Inflorescence a terminal, rounded cluster 2 to 3 ins. across, composed of very fragrant flowers, all fertile. Corolla $\frac{1}{2}$ in. across, at first pink then white, with a slender tube $\frac{1}{3}$ in. long. Fruit not seen.

Native of Corea; introduced from that country to Japan in 1885 , by $\mathrm{Mr}$ Unger of the firm of L. Boehmer \& Co., Yokohama. A single plant was sent to Kew by the same firm in 1902 , which represented its first introduction to Europe. It is undoubtedly one of the most delightful of Viburnums, not only for the beauty of the flowers, but for a fragrance unrivalled for sweetness in the genus. Although apparently quite hardy when fully established, so far as one can at present judge, it needs a little nursing when young, and is better grown in pots and wintered in a cool frame the first 
two winters. It roots readily from cuttings made in late summer, and put in heat. The inflorescence reaches the bud state in autumn, and remains exposed through the winter, the flowers expanding in April and May.

\section{CASSINOIDES, Linnceus. Withe-ROD.}

A deciduous shapely bush of rounded form, rarely more than 6 to $8 \mathrm{ft}$. high in Britain, but said to be occasionally a small tree in the southern United States; young wood scurfy. Leaves ovate to oval with a short, slender, often bluntish apex, rounded or wedge-shaped at the base; $1 \frac{1}{2}$ to $4 \frac{1}{2}$ ins. long, $\frac{3}{4}$ to $2 \frac{1}{4}$ ins. wide; irregularly and shallowly round-toothed, or merely wavy at the margin, thick and firm in texture; dull dark green and smooth or nearly so above, somewhat scurfy beneath; stalk scurfy, $\frac{1}{4}$ to $\frac{3}{4}$ in. long. Flowers all uniform and perfect, yellowish white, $\frac{1}{5}$ in. wide, produced in early June in cymes 2 to 4 ins. across, the main-stalk of which is shorter than the branching portion. Fruit blue-black when ripe.

Native of Eastern N. America; introduced, according to Aiton, in 1761. There is much confusion between this species and V. nudum (q.v.), but cassinoides has dull green leaves and very scurfy young shoots, leaf-stalks, and flower-stalks, and a short-stalked inflorescence. In nudum the leaves are glossy, the shoots, etc., comparatively free from scurf, and the inflorescence usually long-stalked.

\section{CORIACEUM, Blume.}

\section{(V. cylindricum, Hamilton; Sargent's Trees and Shrubs, t. I43.)}

An evergreen shrub (in some of its native habitats a tree 40 to $50 \mathrm{ft}$. high), branchlets warted, otherwise smooth. Leaves oval, oblong, or somewhat obovate, 3 to 8 ins. long, $1 \frac{1}{2}$ to 4 ins. wide; wedge-shaped or sometimes rounded at the base, slender-pointed at the apex, the terminal half usually remotely toothed; upper surface dark dull green and covered with a thin, waxy layer, which cracks and turns grey when the leaf is rubbed or bent; both surfaces quite smooth; stalk $\frac{1}{2}$ to $I \frac{1}{2}$ ins. long. Flowers white, quite tubular, about $\frac{1}{5}$ in. long, produced from July to September in usually seven-rayed cymes 3 to 5 ins. across. The cymes are rendered pretty by the protruded bunch of lilac-coloured stamens. Fruit egg-shaped, $\frac{1}{6}$ in. long, black.

Native of the Himalaya and China; introduced to Kew from India in I881, and later from Yunnan through the Jardin des Plantes, Paris, in 1892. Most of the plants now in cultivation are Chinese, and these are probably hardier than the Indian ones. They have at any rate succeeded very well in the Coombe Wood Nursery. Two characters make this species very distinct, viz., the tubular corolla with erect, not spreading lobes, and the curious waxy covering of the leaves; the latter only shows itself when the leaf is touched or bent; ordinarily they are of a dingy dark green.

\section{Cotinifolium, D. Don.}

A deciduous shrub 6 to $12 \mathrm{ft}$. high, whose young branchlets, under-surface of leaves (upper surface to a less extent) and the flower-stalks are clothed with a dense, grey, stellate down. Leaves ovate, oval or nearly round; the base rounded, the apex shortly pointed or rounded; 2 to 5 ins. long, twothirds to nearly as wide, finely toothed. Flowers white, tinged with pink, widely funnel-shaped, $\frac{1}{4}$ in. long, produced during May in rounded usually 
five-branched cymes 2 to 3 ins. across. Fruit red, ultimately black, $\frac{1}{3}$ to $\frac{1}{2}$ in. long.

Native of the Himalaya from Bhotan to Beluchistan; introduced about I830. This species is closely allied to V. Lantana, and is very similar in foliage and general appearance, but differs in the following respects :Cymes more often five-rayed than seven-rayed, corolla tinged with pink, and distinctly funnel-shaped, the corolla-tube longer than the lobes. The true plant is rare in gardens, and not so hardy as V. Lantana, but it thrives and flowers at Grayswood Hill, near Haslemere.

\section{Dasyanthum, Rehder.}

(Sargent's Trees and Shrubs, t. 149.)

A deciduous shrub up to $8 \mathrm{ft}$. high, with smooth, glossy branchlets becoming dark or purplish brown the second year. Leaves ovate, rounded at the base, tapered to a long, slender point, rather distantly and shallowly

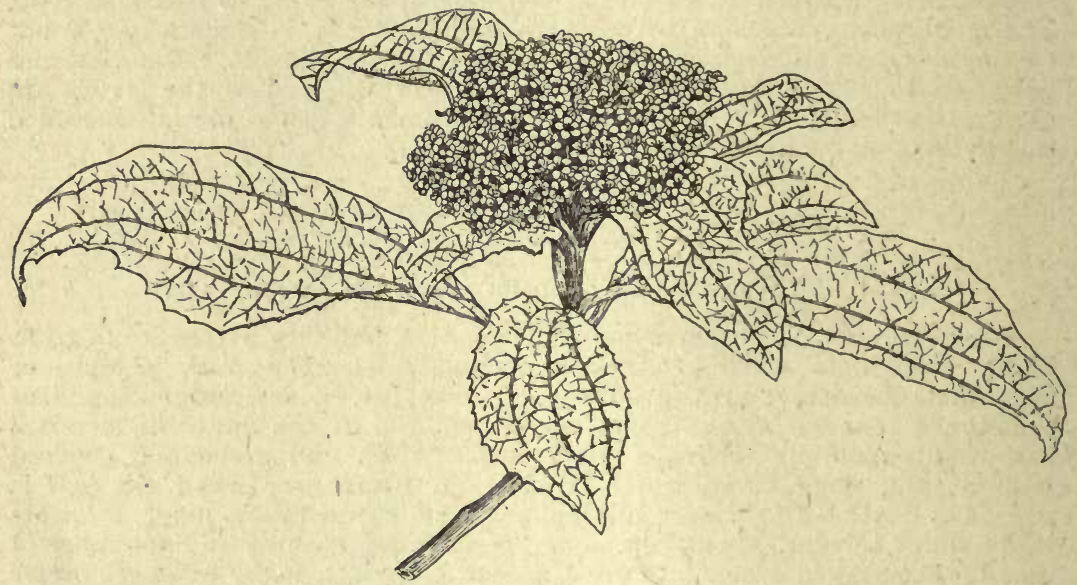

ViBURNuM DAVIDII.

toothed, the teeth often standing out at right angles to the margin; 2 to $4 \frac{1}{2}$ ins. long, I to $2 \frac{1}{4}$ ins. wide; dark green, smooth on both surfaces except for simple hairs on the midrib and veins beneath and tufts of down in the veinaxils; veins in six or seven pairs; leaf-stalks slender, $\frac{1}{3}$ to $\frac{3}{4}$ in. long, smooth. Corymbs 3 to 4 ins. across, usually seven-branched; the main and secondary flower-stalks are glabrous, the final subdivisions, like the ovary and calyx, felted with pale brown wool; corolla woolly outside, $\frac{1}{4}$ in. across. Fruit egg-shaped, $\frac{1}{3}$ in. long, red.

Native of Hupeh and Szechuen, China; discovered by Wilson in 1900, and introduced by him in I907. It is allied to betulifolium and to lobophyllum, from both of which it differs in its woolly corolla; also to hupehense, which has the leaves downy on both surfaces.

\section{DavidiI, Franchet.}

An evergreen shrub of apparently low, compact habit, and about $2 \mathrm{ft}$. high; young branches warted. Leaves leathery, narrowly oval or slightly 
obovate, tapered at the base, more slenderly so at the apex ; 2 to 6 ins. long, I to $2 \frac{1}{2}$ ins. wide; strongly and conspicuously three-veined, often obscurely or shallowly toothed near the apex, dark green above, pale below, smooth on both surfaces except for small tufts of down in the vein-axils beneath; stalk $\frac{1}{4}$ to $\mathrm{I}$ in. long. Flowers dull white, $\frac{1}{8}$ in. wide, produced in stalked stiff cymes, 2 to 3 ins. across. Fruits blue, $\frac{1}{4}$ in. long, narrow oval.

Native of W. China; introduced by Wilson for Messrs Veitch in 1904. In its large, conspicuously three-nerved leaves and low compact habit, this shrub is quite distinct from any other Viburnum in cultivation. It has little beauty of flower, but should be interesting and pretty in fruit, and quite hardy. Another W. Chinese species with conspicuously three-nerved leaves very similar to the above is,

V. CINNAMOMIFOLIUM, Rehder; but it is a bigger shrub, or sometimes a tree $20 \mathrm{ft}$. high, and its inflorescence is much larger and more lax, its almost entire leaves not so thick, its fruits smaller. Wilson discovered this species on Mount Omi, and it is in cultivation.

\section{Dentatum, Linncus. ARROW WOOD.}

A deciduous bush up to $15 \mathrm{ft}$. high, with smooth, young wood. Leaves broadly ovate (roundish on the flowering shoots), $I_{2}^{\frac{1}{2}}$ to 3 ins. long, twothirds to nearly as wide; rounded or heart-shaped at the base, pointed at the apex, coarsely and sharply toothed; glossy green and smooth above, downy in the vein-axils only, or even quite smooth beneath; veins in six to ten pairs; stalk $\frac{1}{2}$ to $I$ in. long. Flowers uniform and perfect, white, $\frac{1}{5}$ in. across, produced in long- and slender-stalked cymes, 2 to 3 ins. wide. Fruit roundish, egg-shaped, blue-black, $\frac{1}{4}$ in. long.

Native of Eastern N. America from New Brunswick to Georgia; introduced, according to Aiton, in 1736 . The young shoots that spring from the base are straight and erect, and it was their use by the native Indians as arrows that gave rise to the popular name. The plant usually called dentatum in gardens is really $V$. venosum, a species which differs from the true dentatum in having stellate down. The true V. dentatum is not common.

\section{Dilatatum, Thunberg.}

(Bot. Mag., t. 62 I 5.)

A deciduous shrub, 6 to Io $\mathrm{ft}$. high, with erect stems; young branchlets very downy. Leaves broadly ovate, roundish or obovate; 2 to 5 ins. long, and from half to about as much wide; widely toothed, pointed, tapering, rounded or heart-shaped at the base; hairy on both sides; stalk $\frac{1}{4}$ to $\frac{3}{4}$ in. long. Flowers pure white, all fertile, $\frac{1}{4}$ in. across, produced in June in hairy, stalked, mostly five-rayed cymes, 3 to 5 ins. across. Fruit bright red, roundish ovoid, $\frac{1}{3}$ in. long.

Native of Japan and China; first flowered by Messrs Veitch in 1875. This fine Viburnum is remarkably profuse in its flowering; the trusses being produced not only at the top of the branch, but from short twigs down the sides as well. It is even more beautiful in its fruits, but unfortunately does not set them so freely here as it does in sunnier countries. It is distinct among the red-fruited species in its very hairy character, the corolla even being hairy outside.

\section{EROSUM, Thunberg.}

A deciduous shrub of erect habit up to $6 \mathrm{ft}$. high; branches slender, covered with pale brown down when young. Leaves oval-ovate or some- 
what obovate, wedge-shaped or rounded at the base, pointed; $1 \frac{1}{2}$ to $3 \frac{1}{2}$ ins. long, I to 2 ins. wide; sharply toothed, stellately downy on both surfaces, especially beneath; stalks $\frac{1}{4}$ in. or less long. Flowers white, $\frac{1}{6}$ in. across, produced in May in rather loose, slender, scurfy-stalked, usually five-branched cymes, 2 to $3 \frac{1}{2}$ ins. across; stamens rather longer than the corolla. Fruit red, roundish-ovate, $\frac{1}{4}$ in. long.

Native of Japan. It has been introduced several times; first probably by Fortune in 1844 , later by Maries and Sargent. It was cultivated for some years in the Royal Hort. Society's garden at Chiswick, but never seems to have secured a permanent place in gardens. It is, perhaps, not perfectly hardy. Among the red-fruited Viburnums this species is marked by the stalks of the leaves being so short.

V. ICHANGENSE, Rehder (V. erosum var. ichangense, Hemsley), Sargent's Trees and Shrubs, t. 149. - This close ally of V. erosum was discovered in Hupeh by Henry, and introduced by Wilson in I90I, and several times since. It flowered at Coombe Wood in 1906. The leaf-stalks are very short, as in V. erosum, but the blades are smaller, ovate-lanceolate, and slender-pointed. The flowers are in smaller cymes, I to $I \frac{1}{2}$ ins. wide, the stamens are shorter than the corolla; the calyx-tube is conspicuously and densely woolly. Fruit red, as in V. erosum.

\section{FEETIDUM, Wallich.}

\section{(V. ceanothoides, C. H. Wright.)}

An evergreen shrub up to 6 or ro $\mathrm{ft}$. high, of dense, leafy habit; young shoots very downy. Leaves narrowly ovate, oval, or obovate, tapered towards both ends, with a few coarse or shallow teeth towards the apex, sometimes entire; I to $2 \frac{1}{2}$ ins. long, $\frac{3}{4}$ to $1 \frac{1}{4}$ ins. wide; dark green and smooth above, greyish and with tufts of down in the vein-axils beneath; veins in two to four pairs, three-nerved at the base; leaf-stalk without stipules, very downy like the young wood. Corymbs about 2 ins. across, very downy, often seven-rayed; flowers small, white. Fruit red, roundishoval, $\frac{3}{8}$ in. long.

The plants in cultivation are all of Chinese origin, the first having been introduced by Wilson in I90I, but it was originally found in India. It does not appear to flower freely under cultivation, but is quite evergreen. The few often conspicuous teeth at the apex of the leaf, the three prominent nerves at the base, and the absence of stipules, are its chief distinguishing characters among the red-fruited species.

\section{HARRYANUm, Rehder.}

An evergreen shrub ultimately 6 to $8 \mathrm{ft}$. high, of bushy habit; young shoots clothed with a minute, dark down. Leaves orbicular to obovate or broadly ovate, tapered at the base, rounded at the apex except for a small mucro; margins entire, or with a few obscure teeth; $\frac{1}{4}$ to I in. long, from two-thirds to nearly as wide; dark dull green above, paler beneath, quite smooth on both surfaces; leaf-stalk about $\mathrm{i}^{\frac{1}{2}}$ in. long, reddish. Inforescence a terminal, compound umbel. $1 \frac{1}{2}$ ins. across. Flowers pure white, $\frac{1}{8}$ in. across. Fruit ovoid, pointed, $\frac{1}{6}$ in. long, shining, black.

Native of W. China ; discovered and introduced in 1904 by Wilson, who remarks that it is rare on mountains at $9000 \mathrm{ft}$. It is quite distinct from any other cultivated evergreen Viburnum in its small privet-like leaves. It appears to be quite hardy, and flowered for the first time in cultivation in 1914. It is named in compliment to Sir Harry Veitch. 


\title{
V. Henryi, Hemsley.
}

\author{
(Bot. Mag., t. 8393.)
}

An erect, evergreen shrub becoming ro $\mathrm{ft}$. high, and having a tree-like habit; branchlets stiff, smooth. Leaves narrowly oval, oblong or obovate; 2 to 5 ins. long, I to $1 \frac{3}{4}$ ins. wide; shortly pointed, wedge-shaped or rounded at the base, shallowly toothed, dark shining green above, paler beneath,

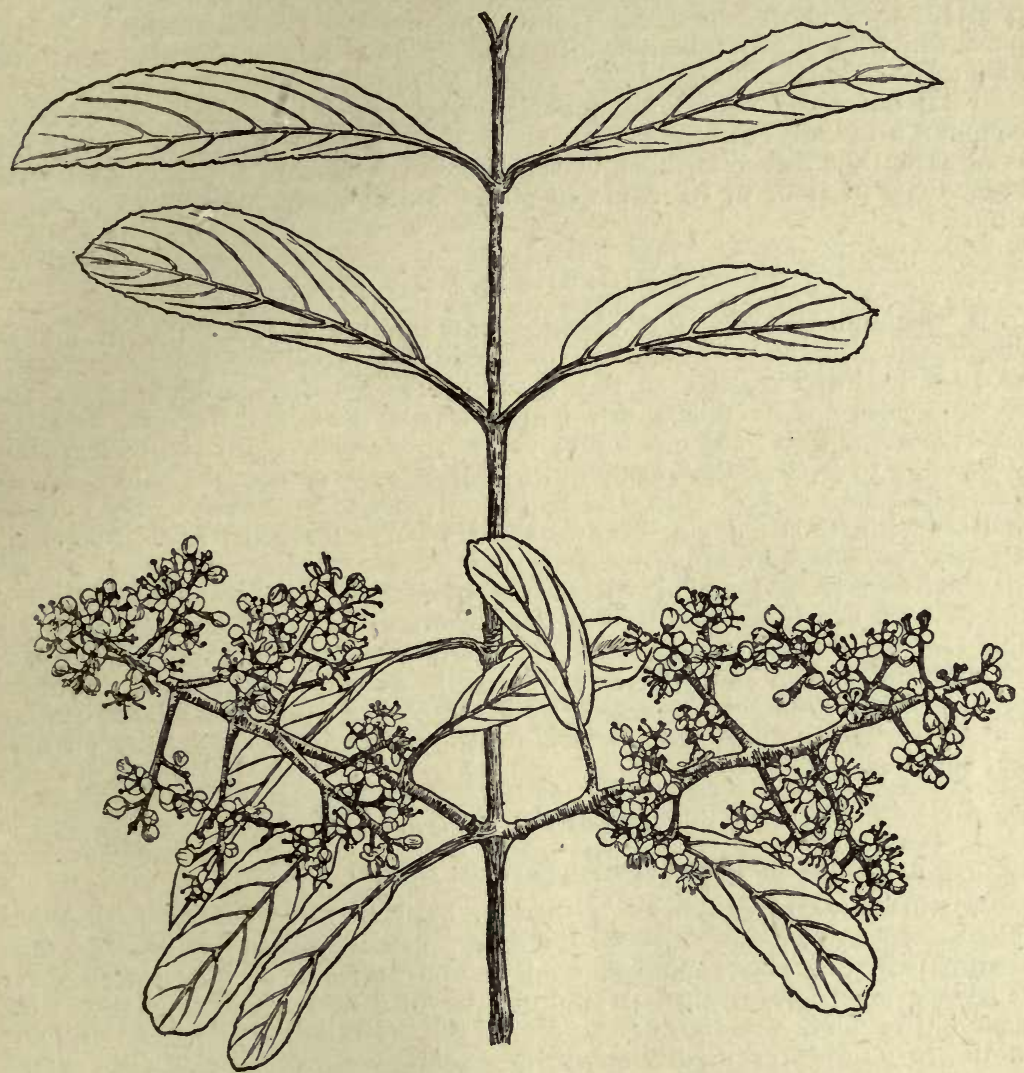

VIBURNUM HENRYi.

smooth on both sides or slightly furnished with stellate down on the stalk and midrib; stalk slightly winged, $\frac{1}{2}$ to $\frac{3}{4}$ in. long. Panicles stiff, pyramidal, 2 to 4 ins. wide at the base, and about as long; flowers perfect and uniform, white, $\frac{1}{4}$ in. across, opening about midsummer. Fruits oval, $\frac{1}{3}$ in. long, at first red, then black.

Native of the Patung district of Central China, discovered there by Henry in 1887; introduced by Wilson for Messrs Veitch in I90I. It is distinct among hardy Viburnums through its long, narrowish, nearly or quite smooth leaves, its stiff, thin, erect habit, and especially its pyramidal 
panicles. At Coombe Wood it has proved quite hardy since its introduction. It was given a first-class certificate by the Royal Hort. Society in September I9I0, for its beauty in fruit.

\section{Hesser, Koehne.}

A deciduous shrub allied to $\mathrm{V}$. Wrightii, but of dwarfer habit and more densely branched. Leaves roundish or broadly ovate, $2 \frac{1}{2}$ to 3 ins. long, 2 to $2 \frac{1}{4}$ ins. broad; rounded or slightly heart-shaped at the base, slenderpointed, with short broad teeth; hairy in the vein-axils beneath. Flowers pure white in short-stalked cymes $\frac{3}{4}$ to $\mathrm{I} \frac{3}{4}$ ins. across. Fruits coral red, about $\frac{1}{4}$ in. wide.

First described in a German periodical in 1909 , this plant was put into commerce by Mr Hesse, of Weener in Hanover, the following winter. It is apparently a dwarf form of $\mathrm{V}$. Wrightii, or a closely allied species. We know little of it or of its value in gardens as yet. A native, no doubt, of China.

\section{Hupehense, Rehder.}

A deciduous shrub, the young shoots stellately hairy the first year, purplish brown the second. Leaves roundish ovate, long-pointed, truncate or slightly heart-shaped at the base, coarsely toothed, dark green and covered with loose stellate down above, paler and more downy beneath; 2 to 3 ins. long, $1 \frac{1}{4}$ to $2 \frac{1}{4}$ ins. wide; veins in seven or eight pairs; leaf-stalk grooved, $\frac{1}{2}$ to $\frac{3}{4}$ in. long, densely downy; stipules narrowly lanceolate, downy. Corymbs about 2 ins. wide, the main and secondary flower-stalks covered densely with stellate down; branches of the corymb usually five. Fruit eggshaped, red, $\frac{1}{3}$ to $\frac{2}{5}$ in. long.

Native of Hupeh, China; discovered by Henry; introduced by Wilson in 1908. I do not know that it has yet flowered in cultivation, but it will no doubt soon do so. The above description is adapted from the original one of $\mathrm{Mr}$ Rehder, who observes that it is most nearly related to $\mathrm{V}$. dilatatum (from which it differs in its orbicular-ovate leaves, and stipuled leaf-stalks), and to $\mathrm{V}$. betulifolium, from which it is distinct in being downy on both leaf surfaces.

\section{JAPONICUM, Sprengel.}

(V. macrophyllum, Blume.)

A sturdy, evergreen bush, 4 to $6 \mathrm{ft}$. high in this country, with thick, smooth young shoots. Leaves leathery, usually ovate (sometimes very broadly so), but also roundish, oval or obovate; 3 to 6 ins. long, half to nearly as much wide; abruptly pointed or with a short, -slender apex; the base entire and rounded or tapering, the terminal part remotely and shallowly toothed or merely wavy; both surfaces quite smooth, the upper one dark glossy green, the lower one paler but with innumerable tiny dark dots; stalk $\frac{1}{2}$ to $I_{\frac{1}{4}}$ ins. long. Flowers uniformly perfect, white, very fragrant, produced in rounded short-stalked, often seven-rayed cymes 3 to $4 \frac{1}{2}$ ins.' across. Fruit round-oval, $\frac{1}{3}$ in. long, red.

Native of Japan; probably first introduced by Maries in 1879. Richard Oldham, who collected it in Nagasaki in 1862, describes it as "a small tree on the hills," but it gives no promise of being more than a sturdy bush with us. It appears to be quite hardy at Kew, but grows slowly in the open, and is no doubt happier in a warmer climate. On a wall it makes a pleasing and striking evergreen. This species has been much confused in gardens with $\mathrm{V}$. odoratissimum ithe $\mathrm{V}$. Awafuki of gardens), but it may be distin- 


\section{VIBURNUM}

guished in the following respects: The young wood is not so warted as in $\mathrm{V}$. odoratissimum; the secondary veins run out to the margin of the leaf; the inflorescence is rounded and umbel-like rather than paniculate.

\section{KANSUENSE, Batalin.}

A deciduous shrub, 4 to $8 \mathrm{ft}$. high, with smooth, ultimately greyish branchlets. Leaves ovate to roundish in main outline, but deeply three- or five-lobed, the lobes coarsely toothed and taper-pointed; the base wedgeshaped, rounded or slightly heart-shaped; 1 to 2 ins. long, and from twothirds to fully as much in width; dark green, and with appressed hairs above, especially on the veins; much paler beneath, with conspicuous tufts of pale down in the vein-axils, and with hairs along the midrib and veins; leaf-stalk $\frac{1}{2}$ to I in. long, slender, smooth; three or five main veins radiate from the top of the leaf-stalk. Corymbs without sterile flowers, 1 to $I \frac{1}{2}$ ins. across, often seven-rayed. Flowers pinkish white, $\frac{1}{4}$ in. wide; calyx smooth. Fruit red, $\frac{1}{3}$ to $\frac{1}{2}$ in. long, oval to roundish.

Native of China, where it is apparently widely spread, being found in Kansu, Szechuen, and Yunnan; introduced by Wilson in I908. It belongs to the Opulus group, but is distinct in having no marginal showy sterile flowers, which the other Chinese species (V. Sargentii) has. The leaves also are very distinct in their frequently small size and deep lobing, some suggesting a small maple leaf. Apparently an elegant shrub.

\section{Lantana, Linnceus. WAYfaring Tree}

A vigorous deciduous bush, sometimes almost tree-like, I2 to $15 \mathrm{ft}$. high; young shoots, buds, lower surface of leaves and flower-stalks all covered with a dense coat of pale, minute, starry down. Leaves broadly ovate or inclined to oblong, the base heart-shaped, the apex pointed or bluntish; minutely toothed; 2 to 5 ins. long, $I \frac{1}{2}$ to 4 ins. wide; upper surface velvety with stellate down, at least at first; stalk $\frac{1}{2}$ to $\mathrm{I} \frac{1}{4}$ ins. long. Flowers white, $\frac{1}{4}$ in. across, uniform and perfect, produced in May and June in stalked, usually seven-rayed cymes, 2 to 4 ins. wide. Fruit oblong, $\frac{1}{3}$ in. long, at first red, ultimately black.

Native of Europe, including the south of England. It is the type species of the Lantana group of Viburnums, characterised by naked winter buds, deciduous foliage, a scurfy stellate down, and fruits at first red, then black. V. Lantana is itself an ornamental shrub, pretty in flower, in fruit, and sometimes in its red autumn tints; useful for planting in tall shrubberies or in thin woodland. There is a variety which goes under various names (" aureis variegatis," "punctatum," and "pulverulentum") whose leaves are blotched and spotted with yellow, but I have never seen it in a condition that would justify one in planting it.

\section{Lentago, Linncus. Sheepberry.}

A robust deciduous shrub or small tree up to 20 or $30 \mathrm{ft}$. high; young wood with a slight reddish scurf; winter buds grey. Leaves ovate to obovate, wedge-shaped or rounded at the base, the apex as a rule long and taper-pointed; finely, sharply and regularly toothed; dark, shining green above, smooth on both sides except for a short, scurfy down on the midrib above; 2 to 4 ins. long, half as wide; stalks mostly winged, $\frac{1}{2}$ to I in. long. Flowers creamy white, $\frac{1}{4}$ in. across, agreeably fragrant, all perfect, produced in May and June in a terminal stalkless cyme, 3 to $4 \frac{1}{2}$ ins. across. Fruit oval, blue-black, $\frac{1}{2}$ to $\frac{5}{8}$ in. long, covered with bloom. 
Native of Eastern N. America from Canada to Georgia; introduced in 176I. Although this species does not bear fruit freely in this country it is well worth growing for its flowers, and as a small and handsome tree. It is closely allied to, and confused in gardens with, V. prunifolium, but differs in the leaves being long and tapered-pointed with winged stąlks [see also $V$. rufidulum]. The wood has a disagreeable odour, according to Sargent.

\section{LOBOPHYLLUM, Graebner.}

(Sargent's Trees and Shrubs, t. 147.)

A deciduous shrub, with young shoots smooth or soon becoming so, dark reddish brown when mature. Leaves ovate to roundish or broadly obovate, abruptly narrowed at the apex to a short point; mostly rounded, sometimes broadly wedge-shaped at the base; coarsely toothed except towards the base; $1 \frac{1}{2}$ to 4 ins. long, $\frac{7}{8}$ to $3 \frac{1}{4}$ ins. wide; smooth or downy only on the midrib and veins; veins in five to seven pairs; leaf-stalk $\frac{1}{4}$ to $I$ in. long. Corymbs 2 to 4 ins. wide, with seven main branches, which, like the secondary ones, are minutely downy and glandular. Flowers white, $\frac{1}{4}$ in. across, Istamens longer than the corolla, anthers yellow. Fruit bright red, roundish, $\frac{1}{3}$ in. long.

Native of W. China; introduced by Wilson in I901, and again in 1907 and 1910. It belongs to the confusing group of red-fruited Asiatic Viburnums containing Wrightii, betulifolium, dilatatum, etc.

\section{MACROCEPHALUm, Fortune.}

\section{(Bot. Reg., 1847, t. 43.)}

A deciduous or partially evergreen shrub up to 12 or $20 \mathrm{ft}$. high, forming a large rounded bush, the young shoots covered with a close scurf, which seen under the lens, is found to be minute stellate down. Leaves ovate, occasionally oval or oblong, rounded at the base,.rounded or pointed at the apex; 2 to 4 ins. long, $1 \frac{1}{4}$ to $2 \frac{1}{2}$ ins. wide; dull green, and with scattered hairs above, covered with stellate down beneath; stalk $\frac{1}{3}$ to $\frac{3}{4}$ in. long. Flowers pure white, all sterile, $I$ to $1 \frac{3}{4}$ ins. across, forming a huge, globular truss 3 to 6 ins. wide.

This, which is Fortune's type, was introduced by him from China in 1844 for the Royal Hort. Society, and described in the second volume of the Society's Journal. Being perfectly sterile, it has, of course, no place in nature, and is a purely garden plant, and should really be distinguished as var. STERILE. It is the most striking, if not the most beautiful of Viburnums, its truss exceeding in bulk that of any other species. Near London, it lives in a sheltered spot in the open, but is better on a wall, where a wellgrown plant makes a most striking display in May. Fortune saw it $20 \mathrm{ft}$. high in Chusan.

The wild form of V. macrocephalum (V. KETELEF RI, Carrière; V. arborescens, Hemsley) is a native of China, and has only the marginal flowers of the showy sterile kind, the small perfect ones filling the centre of the cyme, which is 3 to 5 ins. across, and comparatively flat. It is somewhat hardier than the wholly sterile plant.

\section{MOLLE, Michaux.}

\section{(V. Demetrionis, Deane.)}

A deciduous shrub of bushy habit, 6 to $12 \mathrm{ft}$. high; young shoots smooth and bright green at first, soon turning grey; older bark peeling. Leaves 
broadly ovate to roundish; 2 to 5 ins. long, $1 \frac{3}{4}$ to $3 \frac{3}{4}$ ins. wide; mostly heartshaped at the base, slender-pointed, coarsely triangular toothed; upper surface dark green and smooth; paler and more or less downy beneath; stalk $\frac{1}{2}$ to over $I$ in. long. Flowers white, all perfect, $\frac{1}{4}$ in. across, produced in long-stalked cymes 2 to 4 ins. wide. Fruit scarcely $\frac{1}{2}$ in. long, oval, much compressed, blue.

Native of Eastern N. America. The true V. molle of Michaux is quite uncommon in gardens. The plant which has for long been going under the name is V. scabrellum. V. molle is very distinct in this blue-fruited group of American Viburnums in the loose peeling bark of the older branches, also because of a pair of glandular-downy stipules on each leaf-stalk.

\section{NUDUM, Linnaus.}

A deciduous shrub up to ro $\mathrm{ft}$. high; young shoots slightly scurfy and downy. Leaves oval, ovate or, lance-shaped, 2 to $4 \frac{1}{2}$ ins. long, I to $2 \frac{1}{4}$ ins. wide; minutely and irregularly toothed to almost entire; dark glossy green and smooth above; paler, somewhat scurfy or smooth beneath; stalk $\frac{1}{4}$ to $\frac{5}{8}$ in. long. Flowers yellowish white, uniform and perfect, $\frac{1}{5}$ in. across, produced in early June on cymes 2 to 4 ins. wide; the main-stalk as long or longer than the branched flowering portion. Fruit $\frac{1}{3}$ in. long, oval, blue-black.

Native of Eastern N. America ; introduced in 1752. This Viburnum is closely allied to $\mathrm{V}$. cassinoides, under which species the distinctions between the two are explained. It is a handsome, shiny-leaved shrub which flowers freely. It has a more southern distribution than cassinoides, and does not, apparently, reach into Canada.

\section{ODORATISSIMUM, Ker.}

(Bct. Mag, t. 456 ; V. Awafuki, Hort.)

An evergreen shrub, to to $20 \mathrm{ft}$. high, with warted bark, free from down. Leaves leathery, oval to obovate, 3 to 8 ins. long, $1 \frac{1}{2}$ to 4 ins. wide; wedgeshaped at the base, rounded or with a short, blunt tip at the apex; entire or with a few obscure teeth towards the end; glossy green and smooth above, paler beneath and smooth except for tufts of down in the vein-axils; stalk $\frac{1}{2}$ to $I \frac{1}{4}$ ins. long. Flowers pure white, fragrant, all perfect, produced in stalked, broadly pyramidal panicles, 3 to 6 ins. high, $2 \frac{1}{2}$ to 5 ins. wide at the base. Fruit red at first, ultimately black.

Native of Japan, China, and India; introduced about 1818 . This shrub grows well and makes a handsome bush in the south-western counties, but is not very hardy near London-not so hardy even as V. japonicum, with which it is much confused. Its pyramidal inflorescence best distinguishes it from that species, but the venation of the leaf also is different in the veins splitting up and not running out to the margin, a character which enables it to be recognised when out of bloom. There is a specimen about $20 \mathrm{ft}$. high in the gardens of Greenway House, Churston Ferrers, S. Devon.

\section{Opulus, Linncus. Guelder Rose.}

A deciduous shrub forming a thicket of erect, grey stems, I0 to $15 \mathrm{ft}$. high; young wood smooth. Leaves usually three- (sometimes four- or five-) lobed, maple-like, 2 to 4 ins. long, often as much or more wide, the base truncate, the lobes pointed; coarsely and irregularly toothed; dark green and smooth above, more or less downy beneath; stalk $\frac{1}{2}$ to I in. long, with two 
thin linear stipules at the base and glands near the leaf-blade. Cymes 2 to 3 ins. across, with a border of sterile, showy white flowers, $\frac{3}{4}$ in. diameter, the centre composed of small fertile flowers; anthers yellow. Fruits bright red, globose, $\frac{1}{3}$ in. wide. It blossoms in early June.

Native of Europe, including the British Isles. Whilst in beauty of flower the Guelder rose is inferior to many Viburnums, it is inferior to none in this country in its fruits, or in the rich hues of its decaying foliage. Many other species, no doubt, lhave fruits as beautiful, but they do not set them in our gardens with the certainty of this. Of several varieties the most attractive is

Var. STERILE, De Candolle. The Snowball Tree.-In this form all the flowers are of the large sterile kind, and the cyme becomes in consequence transformed into a globose head of white closely packed blossom, 2 to $2 \frac{1}{2}$ ins. across. This is one of the most beautiful of hardy shrubs, but of course the fruiting beauty of the common Guelder rose is sacrificed. It is supposed to have originated in the Netherlands, but has been known in English gardens since the sixteenth century, and possibly before. Easily increased by cuttings. There is a rosy-tinted form of it called ROSEUM.

Var. FRUCTU-LUTEO.-Flowers like the type; fruits yellow.

Var. NANUM. - A curious dwarf form of tufted habit, growing 1 to $3 \mathrm{ft}$. high. Its leaves are $\frac{3}{4}$ to $I \frac{1}{2}$ ins. wide; so far as I have seen, it never flowers.

The American form of V. Opulus (V. AMERICANUM, Miller) scarcely differs from the Old World type. Its growth is said to be more vigorous, its leaf-stalks to have a shallower, broader channel and smaller glands, the main-stalk of the inflorescence to be shorter, and the stamens not so long.

V. SARGENTII, Koehne, which was introduced in 1892 from N. China to Europe through Prof. Sargent, is a close ally to V. Opulus. It is a coarser growing shrub with often larger leaves, a corky bark, purple anthers, and smaller fruit. It is not so useful and well doing a shrub as V. Opulus in Britain, starting earlier into growth, and being subject to injury by spring frosts. In the Arnold Arboretum Mr. Rehder says its fruits are not so brilliantly coloured, and are less abundant.

\section{PROPINQUUM, Hemsley.}

An evergreen shrub of bushy habit, with smooth, shining, angular young shoots. Leaves three-veined, ovate-lanceolate to oval, wedge-shaped or rounded at the base, pointed, shallowly and sparsely toothed; 2 to $3^{\frac{1}{2}}$ ins. long, $\frac{3}{4}$ to $1 \frac{1}{4}$ ins. wide; dark glossy green and smooth; stalk $\frac{1}{4}$ to $\frac{5}{8}$ in. long. Flowers greenish white, $\frac{1}{6}$ in. across, all perfect, produced in usually sevenbranched cymes $I \frac{1}{2}$ to 3 ins. wide. Fruit blue-black, egg-shaped, $\frac{1}{5}$ in. long.

Native of Central and W. China; discovered by Henry and introduced by Wilson for Messrs Veitch in I90I, and again later. It has lived outside for some years in this country, but whether it will eventually prove quite hardy remains to be seen. It is distinct from all other cultivated Viburnums except V. Davidii and V. cinnamomifolium in its evergreen three-veined leaves. Those two species have larger more conspicuously veined leaves, which in V. cinnamomifolium are scarcely toothed.

\section{PRUNIFOLIUM, Linnaus. BLACK HAW.}

A deciduous, tall shrub or sometimes a small tree, 20 to $30 \mathrm{ft}$. high; branchlets rigid, smooth and reddish when young. Leaves smooth, ovate, oval or obovate, sometimes roundish; $1 \frac{1}{2}$ to $3 \frac{1}{2}$ ins. long, I to 2 ins. wide; rounded or wedge-shaped at the base, blunt or short-pointed at the apex; pale below; stalks not or slightly winged, reddish, $\frac{1}{8}$ to $\frac{3}{4}$ in. long. Flowers 
white, $\frac{1}{4}$ in. across, uniformly perfect, produced during June in scarcely stalked cymes 2 to 4 ins. across. Fruit dark blue, oval, $\frac{1}{2}$ to $\frac{2}{3}$ in. long, sweet and eatable.

Native of Eastern N. America; introduced in I73I. This makes a very handsome small tree, especially if kept to a single stem when young, forming a shapely rounded head of branches. It is allied to V. Lentago and V. rufidulum $(q \cdot v \cdot)$.

\section{PUBESCENS, Pursh.}

A deciduous bushy shrub of compact habit, 3 to $5 \mathrm{ft}$. high; young shoots smooth or soon becoming so, reddish brown. Leaves ovate or roundish, taper-pointed, heart-shaped or rounded at the base, sparsely and coarsely toothed except towards the base; $\mathrm{I} \frac{1}{2}$ to 3 ins. long, I to 2 ins. wide; bright dark green and with scattered hairs above, densely covered beneath with a velvety down; stalk $\frac{1}{8}$ to $\frac{1}{3}$ in. long, very downy, the pair of leaves nearest the inflorescence scarcely stalked at all. Flowers white, $\frac{1}{4}$ in. wide, all perfect, produced in June in cymes about 2 ins. across. Fruit oval, $\frac{1}{3}$ in. long, dark purple.

Native of Eastern N. America; long known in cultivation but formerly confused with dentatum as a pubescent variety. It is, however, one of the most distinct of N. American Viburnums, especially in the very short stalks of the leaves furnished with a pair of downy linear stipules, and the velvety under-surface of the blades. At the present time $\mathrm{V}$. pubescens is not common, but as I saw it a few years ago in the Arnold Arboretum, Mass., it was one of the prettiest of the later flowering shrubs. There the leaves turn a rich purple in autumn.

\section{RHytidophyllum, Hemsley.}

(Bot. Mag.,.t. 8382.)

An evergreen shrub perhaps eventually io $\mathrm{ft}$. high, and as much through; the stout branches thickly covered with starry down. Leaves ovate-oblong; 3 to $7 \frac{1}{2}$ ins. long, I to $2 \frac{1}{2}$ ins. wide; pointed or bluntlat the apex, rounded or slightly heart-shaped at the base; upper surface glossy, not downy, but deeply and conspicuously wrinkled; lower one grey with a thick felt of starry down; stalk $\frac{1}{2}$ to $\mathrm{I} \frac{1}{4}$ ins. long. Flowers produced on large terminal umbel-like trusses 4 to 8 ins. across, which form into bud in the autumn and remain exposed all through the winter, and until the blossoms expand the following May or Junc. They are a dull yellowish white, about $\frac{1}{4}$ in. diameter. Fruit oval, $\frac{1}{3}$ in. long, at first red, then shining black.

Native of Central and W. China; introduced by Wilson for Messrs Veitch in 1900 . This remarkable shrub is one of the most distinct and striking, not only of Viburnums, but of all the newer Chinese shrubs. It appears to be quite hardy, and flowers well in spite of the curious habit of forming its inflorescences and partially developing them in autumn. Its beauty is in its bold, wrinkled, shining leaves and red fruits. The flowers are dull and not particularly attractive. It was given a first-class certificate by the Royal Hort. Society in September 1907. During that month of the year its fruits are red.

\section{RUFidulum, Rafinesque. SOUthern BlaCK HaW.} (V. rufotomentosum, Small.)

A deciduous shrub of very rigid, thin habit, described as becoming a tree often $40 \mathrm{ft}$. high in a wild state; young shoots more or less covered witil a 
rust-coloured down; winter buds reddish brown. Leaves stiff and leathery, oval, ovate, or obovate; rounded, blunt, or shortly pointed at the apex, wedge-shaped or rounded at the base, toothed; 2 to 3 ins. long, I to $1 \frac{1}{2}$ ins. wide; dark shining green above, covered beneath when young with a reddish short down, much of which falls away before the leaf drops; stalks $\frac{1}{4}$ to $\frac{1}{2}$ in. long, stout, more or less winged, and densely covered with rusty coloured down. Flowers creamy white, all perfect, $\frac{1}{3}$ in. across, borne on cymes 3 to 5 ins. across. Fruit blue, $\frac{1}{2}$ to $\frac{2}{3}$ in. long.

Native of the south-eastern United States; introduced to Kew in 1902. It belongs to the same group as V. prunifolium and V. Lentago, from both of which it differs in its dense covering of rusty down especially on the

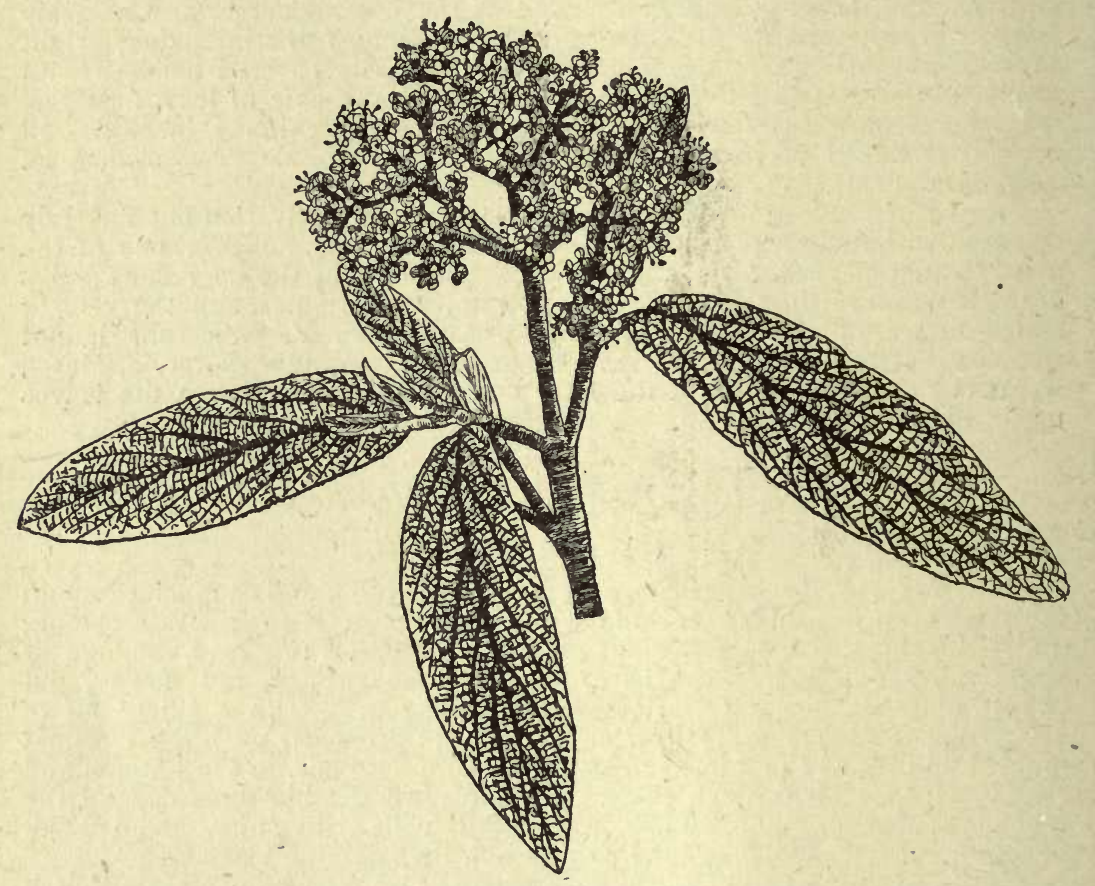

VIBURNUM RHYTIDOPHYLLUM.

leaf-stalk and midrib. Its habit too, as a young shrub, is curiously rigid and its foliage narrower. It has hitherto been shy of flowering under cultivation, but may improve with age. According to Sargent the wood has a disagreeable odour.

\section{Sieboldir, Miquel. \\ (V. reticulatum, Hort.)}

A deciduous, strong-growing shrub 6 to ro $\mathrm{ft}$. high, with stiff, spreading branches, stellately downy and grey when young. Leaves mostly obovate or approaching oblong, pointed or rounded at the apex, and tapered at the base; prominently parallel-nerved, coarsely toothed except towards the stalk; 2 to 5 ins. long, $1 \frac{1}{2}$ to 3 ins. wide; dark glossy green and smooth 
above, smooth beneath or downy, chiefly on the veins; stalk $\frac{1}{4}$ to $\frac{3}{4}$ in. long. Flowers creamy white, $\frac{1}{3}$ in. across, all perfect, produced in long-stalked cymes 3 to 4 ins. across. Fruit oval, about $\frac{1}{2}$ in. long, at first pink, then blue-black.

Native of Japan. This is a vigorous and handsome shrub usually more in diameter than it is high, distinguished by its large, strongly veined, often obovate leaves, which have a disagreeable scent when crushed. A Viburnum is grown in nurseries under this name which is really $\mathrm{V}$. japonicum, an evergreen of quite distinct species described on a previous page. The V. Sieboldii usually found in cultivation and commonly known as "reticulatum" has leaves almost entirely smooth.

\section{THEIFERUm, Rehder.}

\section{(Sargent's Trees and Shrubs, t. I2I.)}

A deciduous shrub of erect habit, up to $\mathrm{I} 2 \mathrm{ft}$. high, with smooth grey stems. Leaves ovate-lanceolate, rounded at the base, long, and taperpointed, widely and sharply toothed; 3 to 6 ins. long, $1 \frac{1}{4}$ to $2 \frac{1}{2}$ ins. wide; dark green above, and smooth on both surfaces, with the exception of long hairs on the midrib and on the parallel veins beneath, which mostly fall away by autumn; veins in six to nine pairs, running out to the teeth; stalk $\frac{1}{2}$ to 1 in. long, hairy like the midrib. Cymes $1 \frac{1}{2}$ to 2 ins. across, fivebranched, terminal on short, lateral, two-leaved twigs. Flowers white, $\frac{1}{4}$ in. wide, all perfect. Fruit red, egg-shaped, nearly $\frac{1}{2}$ in. long.

Native of Central and W. China; introduced in rgor by Wilson. It is allied to V. phlebotrichum (see p. 660), but has larger, longer stalked leaves. The specific name refers to the use of the leaves by the monks of Mount Omi as a kind of tea.

\section{Tinus, Linnceus. Laurustinus.}

A dense-habited, much-branched evergreen shrub of rounded form, 6 to Io $\mathrm{ft}$. high, often more in diameter, and furnished to the ground; young shoots smooth, or slightly hairy. Leaves not toothed, narrowly ovate, approaching oblong, tapered at both ends; $I \frac{1}{2}$ to 4 ins. long, $\frac{3}{4}$ to $I \frac{1}{2}$ ins. wide; dark glossy green above, paler beneath, and with tufts of down in the lower vein-axils; stalk $\frac{1}{3}$ to $\frac{3}{4}$ in. long, often more or less hairy. Flowers white, about $\frac{1}{4}$ in. across, uniform and perfect, produced in winter and spring in terminal cymes 2 to 4 ins. across. Fruit ovoid, tapering towards the top, $\frac{1}{4}$ in. long, deep blue.

Native of the Mediterranean Region and S.E. Europe; cultivated in South Britain, for over three centuries. In southern gardens the Laurustinus is one of the most useful of all evergreen shrubs, forming rich masses of greenery and opening its flowers any time between November and April, according to the weather. It will thrive in moderate shade, but flowers more freely in full sun. The fruits are a beautiful indigo-blue, but not frequently seen with us. From all other cultivated hardy Viburnums this is distinguished by its luxuriant masses of entire, evergreen leaves.

The Laurustinus is represented in gardens by several varieties, and even among plants we regard as typical, variation is noticeable.

Var. HIRTUM, Aiton.-In this variety the shoots, the stalks, and bases of the leaves are clothed with bristly hairs. The leaves also are larger and of different shape, being as much as 3 to 4 ins. long, and 2 ins.' wide, rounded or even slightly heart-shaped at the base, Scarcely so hardy as the type, and sometimes grown for early flowering in cool greenhouses. There are bushes $16 \mathrm{ft}$ high in the botanic garden at Bath. 
Var. LUCIDUM. - In habit this is more open, and less compact than the type, and altogether a stronger grower. It also bears larger leaves and trusses, and the individual flower is nearly $\frac{1}{2}$ in. across, sometimes pinkish, The largest leaves are 4 ins. long, and $2 \frac{1}{2}$ ins. wide. 'Very useful and effective in the milder counties, it is not so hardy as the type. The varietal name refers to the smooth, burnished young shoots, and to the glossy surfaces of the leaf, the lower one with only a few tufts of hairs in the vein-axils.

Var. PURPUREUM.-Leaves of a dull purple tinge.

Var. VARIEGATUM.-A portion of the leaf, sometimes all one side, yellow.

A more erect-habited form has been distinguished as STRICTA or pyramidale. All the forms of Laurustinus are easily increased by cuttings put in a cool frame, or, more quickly, in mild heat.

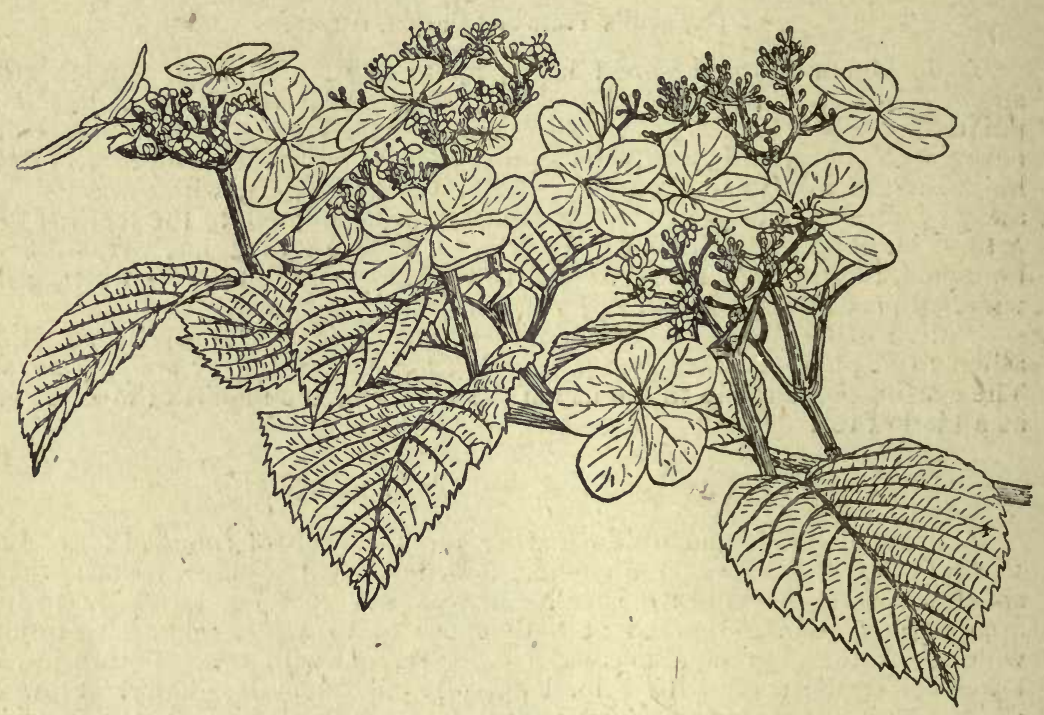

VIBURNUM TOMENTOSOM.

\section{TOMENTOSUM, Thunberg.}

A deciduous shrub of bushy habit, 6 to io $\mathrm{ft}$. high, the branches mostly horizontal, covered when young with a minute, starry down. Leaves ovatc or oval, tapered to a point, rounded or wedge-shaped at the base, 2 to 4 ins. long, I to $2 \frac{1}{2}$ ins. wide; toothed except at the base, dull dark green above with scattered hairs at first; pale, greyish, and stellately downy beneath; stalk $\frac{1}{2}$ to $\frac{3}{4}$ in. long. Inflorescence a flat umbel $2 \frac{1}{2}$ to 4 ins. across, borne at the end of a short, usually two-leaved twig; the centre is filled with the small perfect flowers, surrounded by a few large, white sterile ones, I to $I \frac{1}{2}$ ins. across. Fruit roundish egg-shaped, at first coral red, finally blue-black.

Native of China and Japan; introduced about 1865. Although not so well known or so striking as its variety plicatum, this shrub is very pretty when in flower with the trusses set along the branches in two rows. Messrs Veitch have a variety they call MARIESII, with the trusses and sterile flowers 
larger. Wilson also found in Hupeh a very fine form with its sterile flowers $1 \frac{1}{2}$ to 2 ins. across.

Var. PliCATUM, Maximowicz (V. plicatum, Thunberg). Japanese Snowball.- Under its commoner name of $\mathrm{V}$. plicatum, this shrub is now well known in gardens, both in the open, and as a plant forced early into blossom for greenhouses. It stands in the same relation to $\mathrm{V}$. tomentosum as our common snowball tree does to $\mathrm{V}$. Opulus, the whole of its flowers being transformed into the sterile showy kind, and the inflorescence from a flat umbel to an almost globose one. V. plicatum is in the very first rank of deciduous shrubs, and probably if one were confined to a dozen sorts it would be among them. Its flower-trusses are 2 to 3 ins. across, pure white, and come from the branches of the previous year in two opposite rows at the end of short two-leaved twigs. Two forms of it are offered by nurserymen, viz., grandiflorum and rotundifolium. Although introduced from China (where, as in Japan, it has long been cultivated) by Fortune, in I844, it is only within the last twenty-five years that much use of it has been made as a hardy shrub. Young plants rooted from cuttings are apt to be injured the first year after being put out, but when once established they withstand at least $30^{\circ}$ of frost without injury. Typical V. tomentosum is not, I think, quite so hardy.

Nearly allied to the above species is V. Hanceanum, Maximowicz, from China. It is distinguished by its rounder, shorter-pointed leaves, shallowly toothed above the middle only. Perhaps not at present in cultivation.

\section{UTILE, Hemsley.}

(Bot. Mag., t. 8174.)

An evergreen shrub of rather thin, open habit, 5 or $6 \mathrm{ft}$. high, the slender branches clothed at first with a pale, starry down. Leaves usually narrowly ovate or nearly oblong; I to 3 ins. long, $\frac{1}{4}$ to $1 \frac{1}{4}$ ins. wide; of firm texture, smooth and dark glossy green above, prominently veined and quite white beneath, with a dense covering of starry down; margins entire; apex tapered but bluntish; base rounded to wedge-shaped; stalk $\frac{1}{6}$ to $\frac{1}{3}$ in. long. Flowers all fertile, produced during May densely packed in terminal, rounded trusses, 3 ins. across, the branches of the inflorescence stellately downy. Each flower is $\frac{1}{3}$ in. wide, white. Calyx smooth, with shallow, rounded lobes. Fruit blue-black, oval, $\frac{1}{4}$ in. long.

Native of China; introduced in 1901 by Wilson. It has proved quite hardy since its introduction, and promises to be a pretty, graceful shrub. According to Wilson, it grows on limestone.

\section{VeITCHII, C. H. Wright.}

A deciduous shrub about $5 \mathrm{ft}$. high; young branches, leaf-stalks, and under-surface of leaves densely clothed with stellate down. Leaves ovate, pointed, heart-shaped at the base; 3 to 5 ins. long, 2 to 3 ins. wide; sharply and widely toothed; upper surface with scattered stellate down. Flowers' white, uniform and perfect, $\frac{1}{4}$ in. across; produced on a stoutly stalked, very scurfy-downy cyme, that is 4 or 5 ins. across. Fruit red, then black.

Native of Central China, discovered and introduced in I90I by Wilson, for Messrs Veitch. It is one of the Lantana group, differing from V. Lantana itself in the more remote marginal teeth, and in the calyx being felted with starlike down. Wilson found it as a bush about $5 \mathrm{ft}$. high, but rare; he considers it to be about the most ornamental of the Lantana group. 


\section{VENOSUM, Britton.}

A deciduous shrub, Io to $12 \mathrm{ft}$. or even more high; young branches covered with starlike down. Leaves broadly oval or ovate, often orbicular, $\mathrm{I} \frac{1}{2}$ to 4 ins. long, I to 3 ins. wide; coarsely toothed, rounded to heart-shaped at the base, dark green above, paler and covered with starlike down beneath; stalk slender, $\frac{1}{2}$ to $1 \frac{1}{4}$ ins. long; veins in seven to nine pairs. Flowers all perfect and uniform, white, $\frac{1}{6}$ in. wide, on cymes 2 to $3 \frac{1}{2}$ ins. across, the mainstalk slender, stellately downy. Fruit blue, $\frac{1}{4}$ to $\frac{1}{3}$ in. long; roundish oval.

Native of the eastern United States; long cultivated in gardens as V. molle. It is allied to that species in its blue fruits and downy leaves, but differs in its close (not peeling) bark, and its downy shoots (see also V. dentatum.)

Var. CANBYI, Rehaer.-A form with thinner, less downy leaves, often downy only on the midrib beneath. Leaves and inflorescence larger, the latter only slightly downy. Superior to the typical V. venosum.

Var. LONGIFOLIUM, Rehder.-A cultivated form with longer leaves than the preceding; downy on both sides, especially beneath. This has been cultivated as V. dentatum longifolium. Apparently not known wild.

V. SCABRELLUM, Chapman.-This species is one of those involved in the confusion with molle and venosum. It is very similar to the latter, but differs in the reddish brown branchlets, the often obovate (sometimes oval or oblong, rarely orbicular) leaves with shorter stalks and only five to seven pairs of veins. The cymes are similar to those of $V$. venosum, but the individual flower is rather larger.

Native of the eastern United States from Pennsylvania southwards. It has long been in cultivation under other names, chiefly "molle" and "pubescens."

\section{Wrighti, Miquel.}

A deciduous shrub, 6 to ro $\mathrm{ft}$. high, with erect stems; young branches smooth. Leaves 2 to 5 ins. long, 1 to $2 \frac{1}{2}$ ins. wide; mostly ovate and rounded at the base, but sometimes obovate and tapered at the base; slenderly and often abruptly pointed, somewhat distantly toothed; bright green and almost smooth above, paler beneath with tufts of hairs in the vein-axils; veins in six to ten pairs; stalk $\frac{1}{4}$ to $\frac{3}{4}$ in. long. Flowers all perfect, produced in May on smooth or downy-stalked, five-rayed cymes, 2 to 4 ins. across, the flowers themselves scarcely stalked, white. Fruit round-ovoid, red, $\frac{1}{3}$ in. long.

Native of Japan and China. This handsome-fruited species is allied to $\mathrm{V}$. dilatatum, but that species is at once distinguished by the extremely downy character of its leaves, young branches, and inflorescence. V. Wrightii is sometimes united to V. PHLEBOTRICHUM, Siebold, with which, indeed, it appears to be connected by forms intermediate in several respects. The typical V. phlebotrichum is, nevertheless, very distinct in the smaller, narrower, ovate to oblong, shorter-stalked leaves, the more numerous, silky, whitish hairs on the veins beneath, the quite smooth and slender-stalked cymes, the purple calyx, and especially the very short stamens. Native of Japan.

\section{VINCA. PERIWINKLE. APOCYNACEA.}

Two species of periwinkle are common in gardens, and a third, V. difformis, is occasionally seen. They are evergreen trailing shrubs, 
propagated with the greatest ease by means of cuttings a few inches long, or by taking up old patches and dividing them. The parts of the calyx and corolla are in fives, the latter consisting of a basal tubular part and broad, horizontally expanding lobes. Flowers solitary in the leaf-axils. Leaves opposite. V. major is sometimes attacked by a parasitic fungus which turns the leaves yellow and ultimately kills them.

\section{DIFFORMIS, Pourret.}

(Bot. Mag. t. 8506 ; V. media, Link; V. acutiflora, Bertolini.)

A trailing sub-shrubby plant in Britain usually dying back in winter, probably evergreen in S. Europe, of spreading growth, quite smooth in leaf and stem. Leaves ovate, broadly wedge-shaped or rounded at the base, more tapered towards the apex; $1 \frac{1}{2}$ to 3 ins. long, $\frac{3}{4}$ to 2 ins. wide; entire, rich green on both surfaces, but rather paler beneath; stalk $\frac{1}{6}$ to $\frac{1}{3}$ in. long. Flowers solitary in the leaf-axils, produced in November and December on stalks $\mathrm{I}$ to $\mathrm{I}_{\frac{1}{2}}$ ins. long. Corolla $\mathrm{I}_{\frac{1}{2}}$ ins. across, very pale lilac-blue, the lobes obovate or rather rhomboidal, pointed; calyx-lobes awl-shaped, $\frac{1}{4}$ in. long. Fruit awl-shaped, $1 \frac{1}{2}$ ins. long.

Native of S.W. Europe and N. Africa. It resembles V. major in general appearance, but is easily distinguished by the absence of hairs on stem and leaf-margin and by the non-ciliate sepals. It is not so hardy as V. major, but thrives well in Canon Ellacombe's garden at Bitton. At Kew it flowers too late to expand properly out-of-doors, but taken up and put under glass provides a continuous display during the darkest months of the year.

\section{MAJOR, Linnceus. LARger Periwinkle.}

An evergreen shrub whose barren stems are long and trailing, its flowering ones erect and I to $2 \mathrm{ft}$. high, smooth except for a few dark bristles at the joints. Leaves opposite, ovate, I to 3 ins. long, half to two-thirds as wide, pointed, dark green, glossy on both surfaces, smooth, but edged with minute hairs; stalk $\frac{1}{3}$ to $\frac{1}{2}$ in. long. Flowers bright blue, solitary in the leaf-axils on a slender stalk $\mathrm{I}$ to 2 ins. long; corolla $\mathrm{I} \frac{1}{2}$ ins. across, the base a funnel-shaped tube spreading at the mouth into five deep, broadly obovate lobes; 'calyx-lobes five, narrowly linear, nearly $\frac{1}{2}$ in. long, with hairs on the margin. Fruit smooth, awl-shaped, long-pointed, $I_{2}^{\frac{1}{2}}$ to 2 ins. long.

Native of Central and S. Europe eastward to the Caucasus. It is seemingly wild in parts of England, but from the fact that it rarely perfects its seed, a doubtful native. Useful for growing in semi-shaded positions where it makes pleasant ground cover, but not flowering so well there as in the full sun. The first flowers appear in May and continue until September. It should be trimmed over annually in spring, cutting away the old growths. Distinct from V. minor in its large, broad-based, often heart-shaped leaves, and from V. difformis in its ciliate leaves and calyx-lobes.

\section{MINOR, Linncus. LESSER PERIWINKLE.}

An evergreen trailing shrub rarely more than 6 ins. above the ground, forming in time a dense mat; stems smooth, wiry. Leaves oval, or slightly obovate, always tapered at the base; $\frac{3}{4}$ to 2 ins. long, $\frac{1}{2}$ to $\frac{3}{4}$ in. wide; quite smooth and of a deep glossy green on both sides. Flowers $I$ in. across, 
bright blue, produced from April until autumn. Corolla-lobes obovate; calyx smooth, its lobes about $\frac{1}{8}$ in. long.

Native of many parts of Europe, and found as far east as the Caucasus and Asia Minor. Like V. major, it is found apparently wild in England, but is doubtless an escape from cultivation. It is, of course, easily distinguished from that species by the smaller flowers, whose calyx-lobes are shorter and broader, and by the smaller narrow-based leaves.

Var. ALBA. - Flowers white.

Var. ARGENTEA-VARIEGATA.-Leaves shorter, proportionately broader, blotched with white.

Var. AUREA-VARIEGATA.-Leaves blotched with yellow.

Var. AZUREA. - Flowers sky-blue.

Var. FLORE PLENO.-Flowers double.

Var. PUNICEO (purpurea).-Flowers purplish.

All the forms of Vinca minor make excellent ground cover for shady places, but flower better fully exposed. The stems root freely at the tips.

\section{VISCUM AlbUM, Linnaus. Mistletoe. LoRANTHACE.}

An evergreen shrub of tawny, yellowish aspect, parasitic on various trees, usually in the form of a rounded, pendulous bush ; branches smooth, bifurcating at each joint. Leaves opposite, narrowly oblong or obovate, tapering at the base, rounded at the apex; $I_{2} \frac{1}{2}$ to 4 ins. long, $\frac{1}{4}$ to $\mathrm{I}$ in. wide; not stalked. Flowers inconspicuous, almost stalkless, and produced in the forks of the branches, the sexes on separate plants. Fruit a white, translucent berry $\frac{1}{3}$ in. wide, whose single seed is embedded in a very viscid pulp; ripe in midwinter.

Native of Europe, where it is widely spread, and of N. Asia. It is found commonly in the south of England, but not in Scotland or Ireland. The mistletoe is frequently cultivated in gardens for its interest and associations, and nurserymen supply it growing on apple-trees. The two sexes should be obtained if possible on the same or separate host plants. It must be propagated by seed, and this is best done by bursting the berry on the youngish bark of the host plant. The glutinous substance in which the seed is embedded soon hardens and attaches the seed securely. It is not necessary to make a slit in the bark for the seed.

In nature the mistletoe is spread by birds. Whilst eating the fruits, their beaks become smeared with seeds and pulp. Of this they rid themselves by rubbing their beaks upon the branches. It grows most commonly perhaps on apple-trees, so much so as to be a pest in some of the west country orchards. Although, because of its association with the rites of the ancient Druids, its most famous host plant is the oak, it is in reality very rarely seen on that tree. Nor, in this country, is it common on coniferous trees, although I have seen it abundant on Scotch pine in Sivitzerland (Val d'Anniviers). But from a list of host trees of the mistletoe published some time ago in the horticultural press, there appear to be few of our native trees on which it will not grow.

LORANTHUS EUROPAUS, Jacquin.-The mistletoe-is the only parasitic shrub native of Britain, but this Loranthus, a parasite also, is found in Central and Eastern Europe. Some years ago a plant was introduced to 
Kew from Austria growing on an oak (which, contrary to the mistletoe, it favours). Although the oak grew vigorously, the parasite never flourished or grew much, and after lingering ten or twelve years, died. Probably our climate is not sunny enough for it. It is deciduous, and bears its fruit in a terminal spike of four or five pairs.

\section{VITEX. VERBENACE .}

Of this large genus of Old World shrubs and small trees, two species can be grown on walls in the southern parts of the country. They require a sunny spot and not too rich a soil. Propagated by cuttings.

\section{Agnus-Castus, Linnceus. Chaste-Tree.}

A deciduous shrub of free, spreading habit; young shoots covered with a minute grey down. Leaves opposite, composed of five to seven radiating leaflets borne on a main-stalk I to $2 \frac{1}{2}$ ins. long; leaflets linear lance-shaped; 2 to 6 ins. long, $\frac{1}{4}$ to $\frac{3}{4}$ in. wide; tapering gradually towards both ends, not toothed; dark green above, grey beneath with a very close felt; stalks of leaflets $\frac{1}{4}$ in. or less long. Flowers fragrant, produced during September and October in whorls on slender racemes which are 3 to 6 ins. long, sometimes branched, and borne in numbers on the terminal part of the current season's growth, at the end and in the leaf-axils, the whole forming a large panicle. Corolla pale violet, tubular, $\frac{1}{3}$ in. long, with five expanding lobes; stamens four, protruded; calyx funnel-shaped, downy, shallowly lobed.

Native of the Mediterranean region; cultivated in Britain in 1570 . Near London it needs the protection of a wall; given this it is quite safe. A plant has lived on a west wall at Kew for at least forty years. It flowers freely in warm seasons, and its crowd of panicles is sometimes very effective. The entire plant has an aromatic, pungent odour. The popular name is said to come from the Greeks, whose women at the festival in honour of Ceres strewed their beds with it. There is a white-flowered variety, ALBA.

\section{V. incisa, Lamarck. Chinese Chaste-Tree.}

Introduced in 1785 from China, this species is rarely seen at the present time. It requires the protection of a wall, and in competition with the many finer plants adapted for wall cultivation, it scarcely keeps its place in gardens. It has digitate leaves like the preceding species, the leaflets being usually five, but varying from three to seven in each leaf. They differ from those of V. Agnus-castus in having distinct stalks, up to I in. long; in being coarsely toothed, and in being sometimes $\mathrm{I}_{2}^{\frac{1}{2}}$ ins. wide. Flowers violetblue, arranged in distant whorls on slender racemes 6 to 9 ins. long, the whole forming a large, thinly furnished panicle terminating the shoots of the year; calyx downy, deeply and sharply lobed. A deciduous shrub up to to ft. high.

\section{VITIS. VINE. VITACEA.}

(Including Ampelopsis, Cissus. Parthenocissus.)

Vitis shares with Clematis the distinction of being the most important genus of hardy climbers in gardens. The flower beauty of Clematis is 
lacking in the vines, but is compensated for by the greater luxuriance of growth, nobler foliage, and above all by the colour beauty in autumn many of them possess. No species is native to the British Isles, or, excepting the doubtful $\mathrm{V}$. vinifera, is wild in Europe. It is mainly to China, Japan, and to E. and Central N. America that we owe that wealth of species from which cultivators may now make their choice. As defined by Bentham and Hooker, Vitis is a very large genus of perhaps four hundred species. Owing to the inconvenience that would be involved by changing the names, I have not departed from their estimate of the genus; but there is a general disposition among botanists nowadays to split up Vitis into several genera, thus following the admirable monograph of the late $\mathrm{Mr}$ Planchon, published in $\mathrm{I} 887$. Below, an arrangement of the species here dealt with is given, in which each one is placed under the genus as defined by Planchon, so that anyone preferring to adopt the more recent nomenclature may do so. After all, it is a matter of opinion.

With the exception of a single species, V. (or Cissus) striata, all the vines here described are deciduous and, with the exception of another, V. rupestris, they are all climbers. Leaves alternate, with frequently a tendril or an inflorescence opposite to each on the stem. Flowers small, greenish, and of no beauty, but occasionally fragrant; they are sometimes perfect, but others are unisexual, and not infrequently the sexes are segregated on different plants. Fruit a black, blue, red, or yellow berry, with or without bloom; seeds one to four, embedded in juicy pulp.

The ornamental vines are of very easy cultivation, provided the climate is warm enough for them. They like a good loamy soil and plenty of root room, although V. heterophylla, which is grown for the beauty of its fruit, is more fertile with a restricted root run. The most inconvenient thing in their cultivation is the provision of suitable support. Best of all, perhaps, is a pergola on which the shoots can be trained and pruned back annually as much as is necessary. They can also be trained up posts, when, if the shoots are allowed to hang loosely, they are very elegant. Whole trees or large shrubs may be given up to them, over which they can ramble at will, and this, approaching nature as it does, shows the more vigorous ones at their best. The splendid form of V. Coignetiæ in Mr Waterer's nursery at Knap Hill is growing in this way. The clinging sorts like inconstans, quinquefolia, and himalayana are useful for walls, tree trunks, or any surface in need of a summer covering. Many species colour best in autumn when grown on walls.

Some species, like Coignetix, are difficult to increase except by seeds and layers, but most of the true vines can be propagated by cuttings, or preferably by "eyes." An "eye" consists of a single bud of the previous summer's shoot, with about half an inch of wood at each side, cut slanting fashion, so that the cut surfaces almost meet beneath the bud. These are made in early spring, each one placed on the surface of a small pot of sandy soil, the bud only uncovered, then put in gentle bottom heat. Cuttings are made one or two joints long, at the time the leaves are falling in autumn, and put under a handlight or in a cool frame. The 
Ampelopsis, Parthenocissus, and Cissus groups are easily rooted from leafy cuttings made in July and August of firm growth.

\section{Vitis (proper). True Grape Vines.}

Stems with peeling bark (except rotundifolia). Leaves undivided except in Pagnucci and Piasezkii. Flowers in panicles; petals united by their ends into a sort of cap, and falling before they separate :- astivalis, amurensis, arizonica, armata, bicolor, californica, candicans, Champini, cinerea, Coignetia, cordifolia, Doaniana, flexuosa, Labrusca, monticoia, Munsoniana, Pagnucci, Piasezkii, Romanetii, rotundifolia, rupestris, Thunbergii, vinifera, vulpina.

\section{Parthenocissus (or Psedera).}

Leaves divided into three to seven leaflets; tendrils mostly with viscous disks at the tips; petals separate and expanded. Flowers in compound cymes:-Henryana, himalayana, inconstans, quinquefolia, semicordata, sinensis, Thomsoni, vitacea.

\section{AMPELOPSIS.}

Tendrils coiling, never with viscous tips. Leaves simple to much divided. Petals separate and expanding; ovary surrounded by a disk:-aconitifolia, arborea, brevipedunculata, Delavayana, heterophylla, indivisa (cordata). leeoides, megalophylla, orientalis, serjanafolia.

V. istriata belongs to the section CIssus, and is the only one of that section we can grow out-of-doors. It has much divided leaves, and the disk below the ovary is fourlobed. In other respects much like Ampelopsis.

A Himalayan vine, V. CAPREOlATA, $D$. Don, has been many times introduced, but is not hardy. It is distinguished by having the inflorescence produced from the axil of the leaf instead of opposite to it. It belongs to Planchon's genus TETrastigma as T. SERRULATUM. Leaves digitate, composed of five leaflets, one or both lower pairs united on one stalk. V. OBTECTA, recently introduced from China, is of the same group.

\section{ACONitifolia, Hance.}

(Ampelopsis aconitifolia, Bunge.)

A slender-stemmed, luxuriantly leafy, deciduous climber; young shoots smooth. Leaves very variable in shape and size, composed either of three or five stalkless leaflets radiating from the end of a common stalk which is $\frac{1}{2}$ to 2 ins. long. The leaflets are lanceolate or diamond-shaped in general outline, but always deeply and coarsely toothed, and often conspicuously three- or five-lobed, the lobes reaching sometimes to the midrib. The entire leaf is 2 to 5 ins. across, the leaflets I to 3 ins. long, deep glossy green above, pale beneath, and smooth on both sides except for small tufts of down in the vein-axils beneath. Flowers produced in August and September in numerous forked cymes. Fruits scarcely $\frac{1}{4}$ in. long, roundish obovate, purple.

Native of China. Of the vines with compound leaves and deeply cut leaflets this is the hardiest and most luxuriant in growth. It can be trained up a tall post, which it will soon cover with a beautiful tangle. There has been some confusion in gardens between this species and another vine, also of the Ampelopsis group, viz. :-

V. SERJANÆFOLIA, Maximowicz (Ampelopsis serianæfolia, Bunge).-This is a native of Japan, Corea, and China, and quite distinct in foliage from V. aconitifolia. The leaflets are in threes or fives, and in the latter case are arranged pinnately on the common stalk (not all radiating from its end as in the other). Another distinction is that the leaf-stalk between the pairs of leaflets is winged. Sometimes the lowest pair of leaflets are themselves pinnately divided. In other respects the leaflets are dark green above, pale 
glossy green beneath, smooth. Fruit said to be violet-blue. The plant has a tuberous root like a Dahlia.

\section{ESTIVAlis, Michaux. Summer Grape.}

A very vigorous deciduous climber, growing to a great height when support is available; branchlets round, smooth or loosely downy. Leaves very large, 4 to 12 ins. across, about as much long; varying from deeply three- or five-lobed to scarcely lobed at all; teeth shallow and broad, pointed at the apex, deeply heart-shaped at the base; dull green, ultimately smooth above, covered beneath with more or less persistent floss which is rusty red at first, changing to brown with age. Flowers in panicles up to 8 or ro ins. long. Berries globose, $\frac{1}{3}$ in. diameter, black with a blue bloom, agreeably flavoured.

Native of the eastern and central United States; introduced in the seventeenth century. It is the parent of a race of American grape vines, including "Herbemont," "Cynthiana," and "Virginia Seedling." On the young stems there is a tendril missing from every third joint, and in its large-leaved states can thus be distinguished from V. Labrusca, which has a tendril or panicle opposite every leaf.

V. CINEREA, Engelmann. SWEeT WINTER GRAPE.-This vine, a native of the central United States, is allied to, and was at one time regarded as a variety of $\mathrm{V}$. æstivalis. It has angular downy branchlets (as contrasted with the round, almost smooth ones of restivalis); the down beneath the leaf is grey or whitish, and the berries have little or no bloom.

\section{AMURENSIS, Ruprecht. AMURLAND GRAPE.}

A strong-growing, deciduous vine of somewhat similar character to, but quite distinct from, V. vinifera, with reddish young shoots, flossy when young, a thick, hard disk of wood dividing the pith at the joints. Leaves 4 to ro ins. wide, somewhat longer; three-lobed, often deeply so, the middle lobe then of broadly ovate form, with a slender abrupt point; the base has a deep, round, broad sinus; under-surface somewhat downy.

Native of Amurland, Corea, and N. China. Worth growing for its vigorous habit, and for the usually fine crimson and purple autumn hues of its noble foliage.

\section{ARBOREA, Linnaus. PEPPER VINE.}

\section{(Ampelopsis arborea, Koehne; A. bipinnata, Michaux.)}

A deciduous climber, with slender, purplish, nearly or quite smooth, somewhat angular, zigzag shoots, slightly marked with lenticels; tendrils slender, forked. Leaves 5 to 8 ins. long, about as much wide, doubly (sometimes trebly) pinnate, and composed of numerous stalked leaflets, which are ovate, $\frac{1}{2}$ to $I \frac{3}{4}$ ins. long, $\frac{1}{3}$ to $I \frac{1}{4}$ ins. wide; sometimes lobed, always with very large, sharp, triangular teeth, the apex pointed, the base narrowly to broadly wedge-shaped; dark green and smooth above; at first downy on the veins and in the vein-axils beneath, ultimately nearly or quite smooth. Flowers in open, long-stalked cymes. Berries dark purple, about $\frac{1}{3}$ in. diameter.

Native of the southern United States; introduced in 1700, and quite hardy, although better against a wall than in the open. It belongs to what is now considered the "true" Ampelopsis group, in which the petals are 
distinct and spreading and, like the sepals, in fives. It is a very handsome climber when in vigorous growth, but although it flowers occasionally, rarely develops fruit with us. Perhaps partially or wholly evergreen in warmer climates. (See also V. orientalis.)

\section{ARIZONICA, Engelmann. CaÑon Grape.}

A shrubby or weakly climbing vine, deciduous; branchlets angular, at first clothed with cobwebby down, tendrils mostly perishing when young. Leaves heart-shaped, sometimes unlobed, sometimes more or less distinctly three-lobed; $1 \frac{1}{2}$ to 3 ins. wide, about the same long; the sinus at the base broad and rounded, the apex pointed, the margins coarsely and fairly regularly triangular toothed; cobwebby above, woolly beneath when young; stalk one-third to half as long as the blade. Berries black, with abundant bloom, small, agreeable in flavour.

Native of the south-western United States; introduced to Kew in 1898. It has little to recommend it for gardens in general.

\section{ARMATA Diels.}

\section{(V. Davidii, Foëx; Spinovitis Davidii, Carriëre.)}

A luxuriant, deciduous climber, the young shoots not downy, but covered with spiny, gland-tipped, somewhat hooked bristles, which give them a very rough appearance. Leaves heart-shaped, slender-pointed, toothed; 4 to ro ins. long, $2 \frac{1}{2}$ to 8 ins. wide; shining dark green and smooth above; bluish or greyish green beneath, and downy only in the vein-axils, but more or less glandular-bristly, as is also the leaf-stalk, which is from half to nearly as long as the blade. Fruit not yet seen in this country, but said to be about $\frac{2}{3}$ in. diameter, black, and of a pleasant flavour.

Native of Central China; introduced by Wilson for Messrs Veitch in 1900 , but if, as I believe, the vine called Spinovitis Davidii is the same, it has been cultivated in France and in England since about 1885 . The plant cultivated at Kew under the latter name has leaves more deeply lobed and more coarsely toothed than Wilson's V. armata, and the spines are smaller; but in other respects it does not appear to differ. According to Carrière, the leaves are very variable in shape.

Var. VeItchII is described as a more vigorous form than the type, and as having larger leaves of unsurpassed richness in autumn colouring. Ordinary V. armata changes to brilliant red.

\section{Bicolor, Le Conte. Blue Grape.}

A vigorous deciduous climber, with round shoots free from down, but usually very glaucous, a tendril missing from every third joint. Leaves 4 to 12 ins. wide and long, three- or five-lobed, irregularly and shallowly toothed, usually smooth on both surfaces, and vividly blue-white beneath. In other respects this vine is similar to $\mathrm{V}$. æestivalis, to which it is most nearly allied. It is a native of the eastern and central United States, and in cultivation in Britain makes a luxuriant climber. Visitors to Goat Island, Niagara Falls, will have noticed its abundance there, associating with Celastrus scandens and other climbers in the production of a beautiful and luxuriant effect; this vine is conspicuous in the blue-white young shoots and undersurface of the leaves, to which the popular name refers. 


\section{V, BREVipedunculata, Dippel.}

(Ampelopsis brevipedunculata, Koehne.)

A vigorous climber, with roughly hairy young shoots. Leaves distinctly three-, rarely five-lobed, the side lobes spreading and pointed; heart-shaped at the base; 2 to 6 ins. long and wide, coarsely toothed, the teeth rounded, but ending in a minute abrupt point (mucro); dark green above with scattered short hairs at first; bristly hairy beneath; stalk from three-fourths to as long as the blade, very hairy, especially at first. Inflorescence hairy, once or twice forked, each fork terminated by a cymose flower-cluster. Fruit $\frac{1}{4}$ to $\frac{1}{3}$ in. across, amethyst blue.

Native of Japan and of the region of the Amur and Ussuri rivers; cultivated for the last forty years in gardens under various names, such as V. amurensis, Regeliana, heterophylla var, cordata. It is certainly closely allied to $\mathrm{V}$. heterophylla, but is well distinguished by its bristly hairy young shoots, etc., and less angular teeth. One of the true Ampelopsis.

\section{CALIFORNICA, Bentham. Californian GraPe.}

A deciduous climber, reaching 20 to $30 \mathrm{ft}$. in height, the young shoots covered at first with grey cobwebby down, nearly smooth later. Leaves roundish cordate or kidney-shaped, occasionally three-lobed; 2 to 4 ins. wide, and about as long; rounded at the apex, the sinus at the base wide and rounded; the margins set with fairly even, broadly triangular teeth, scarcely $\frac{1}{8}$ in. deep; upper surface smooth, lower one usually grey with down; stalk $I$ to 2 ins. long, grey downy like the young shoot. Berry $\frac{1}{3}$ in. in diameter, black, covered with purple bloom.

Native of California. This is a very well-marked vine in the roundended, shallowly and evenly toothed leaves. It has no value, even in its own home, as a fruit-bearer, but is certainly very handsome in autumn, its leaves turning a deep crimson before they fall.

\section{CANDiCans, Engelmann. Mustang Grape.}

A vigorous deciduous climber, shoots covered with a dẻnse white wool, a thick disk interrupting the pith at the joints. Leaves 2 to $4 \frac{1}{2}$ ins. wide, broadly heart-shaped to kidney-shaped, sometimes entire or with only a wavy outline, sometimes obscurely three-lobed; on young plants or strong sucker shoots the leaves are sometimes deeply three-, five-, or seven-lobed, but even then scarcely or very shallowly toothed. On first expanding the upper surface is woolly, but the wool soon falls away, leaving it a dull, dark green, whilst the under-surface remains covered with a thick white felt. The stalk is one-fourth to half as long as the blade, and white-woolly. Berries globose, about $\frac{2}{3}$ in. wide, purplish, and unpleasantly flavoured.

Native of Texas, often found on limestone. It is one of the most distinct of American grape-vines in the broad, almost entire leaves and vivid white wool beneath, suggesting a white poplar leaf. It is quite hardy at Kew. Allied to it, and perhaps a hybrid from it, is

V. DoAniana, Munson. Doan's Grape.-The leaves of this vine, however, are always three-lobed and coarsely toothed, and the upper surface is bluish green strewn with patches of white wool. The young shoots and leaves are quite white all over at first, and much of the wool persists beneath. It was found wild in Texas and New Mexico; introduced to Kew in 1892 and quite hardy there. 


\section{Coignetie, Pulliat.}

\section{(V. congesta, Hort.; V. Thunbergii, Hort., not Siebold.)}

A very vigorous deciduous climber, reaching the tops of the highest trees; young shoots round, ribbed, and at first covered with a loose greyish floss; there is a tendril missing at every third joint. Leaves perhaps the largest among vines, being sometimes 12 ins. long and 10 ins. broad, ordinarily 4 to 8 ins. wide; they are roundish in the main, rather obscurely three- or five-lobed, the lobes and apex pointed, the base deeply heartshaped; shallowly to coarsely toothed; dark green and smooth above, covered beneath with a thick rusty brown felt; stalk from 2 to 6 ins. long, somewhat woolly. Berries black with a purple bloom, $\frac{1}{2}$ in. wide.

Native of Japan; first introduced apparently to Mr Anthony Waterer's nursery long ago through Messrs Jardine and Matheson, East India merchants. The original plant grows over some trees at Knap Hill, and makes a glorious display of crimson every autumn. Owing to difficulty in propagating, it spread very little in cultivation. But about 1893 a quantity of seeds were imported from Japan, and the species became more common in gardens. The seedlings, however, have not yet proved quite equal in autumn colouring to the Waterer stock, which is generally but wrongly named V. Thunbergii. The true V. Thunbergii $(q . v$.$) is very distinct. Seeds$ of V. Coignetiæ had been introduced from Japan to France by Madame Coignet as long ago as 1875 , and the plants raised from them were greatly admired for their magnificent autumn colour. They experienced there the same difficulty in propagation, and owing to this and the phylloxera regulations this vine did not spread out of France. In the absence of seed, layering appears to be the only method of propagation available. In the forests of Yezo, according to Sargent, "it climbs into the tops of the largest trees, filling them with its enormous leaves, which in autumn assume the most brilliant hues of scarlet." It is in this way that it grows in Mr Waterer's grounds. His form is also very fine at Castlewellan and Narrow Water, in Ireland, in both places on a wall, developing a remarkable size of leaf-frequently I ft. or more across. In this respect, and in the richness of its colour in autumn, it is undoubtedly the finest of all vines. Seedling plants have leaves very much more deeply lobed than fully grown ones.

\section{CORDifolia, Michaux. Frost or Chicken Grape.}

A very vigorous vine, whose main stem in a wild state is sometimes from $\mathrm{I} \frac{1}{2}$ to $2 \mathrm{ft}$. thick; young shoots smooth or only slightly hairy, a tendril missing from every third joint. Leaves thin, roundish ovate, with a heart-shaped base (the sinus pointed and narrow); 3 to 5 ins. wide, rather more in length; slenderly pointed, coarsely and irregularly toothed, unlobed or sometimes obscurely three-lobed, glossy and smooth above, smooth or downy on the veins beneath; stalk often as long as the blade. Flowers in drooping panicles, 4 to 12 ins. long. Berries globose, $\frac{1}{3}$ to $\frac{1}{2}$ in. in diameter, black.

Native of the eastern United States; introduced in 1806 . The berries are moderately well-flavoured after they have been touched by frost in America, harsh and acid before; in one form (var. FCETIDA, Engelmann) they have a pungent, fœtid odour. The species has been confused with vulpina $(q \cdot v \cdot)$.

\section{Delavayana, Franchet.}

\section{(Ampelopsis Delavayana, Planchon.)}

Not much is known as yet of this species in cultivation. It was introduced by Wilson for Messrs Veitch in 1900 , and appears to be quite hardy 
and vigorous. It is a climber with hairy young stems, swollen at the joints. Leaves composed of three leaflets, the middle one of which is shortly stalked, narrowly oval, tapered at both ends, especially towards the point; side lobes stalkless, unequal at each side of the midrib, sometimes with a lobe on the lower side and oblique at the base. All are coarsely toothed, roughish above, downy (at least when young) on the veins beneath. Leaflets from $\mathrm{I} \frac{1}{2}$ to 4 ins. long, $\frac{3}{4}$ to $\mathrm{I} \frac{1}{2}$ ins. wide (larger on vigorous young plants). Fruits described as blue. Young shoots and leaf-stalks pinkish. Native of W. China.

\section{FLEXUOSA, Thunberg.}

A slender-stemmed, elegant climber; shoots smooth, or downy only when quite young. Leaves roundish ovate and heart-shaped at the base, or triangular and truncate at the base, often contracted at the apex to a slender point; amongst the smallest in the genus, being ordinarily 2 to $3 \frac{1}{2}$ ins. across, of thin firm texture; smooth and glossy above, downy on the veins and in the vein-axils beneath. Inflorescence slender, 2 to 6 ins. long. Fruits about the size of a pea, black.

Native of Japan, Corea, and China; long cultivated in gardens, but recently brought more prominently into notice by new forms introduced from China. It is a variable species, but the typical form is known by its quite small, unlobed (or indistinctly three-lobed) leaves, smooth and very glossy above.

Var. WiLsoni, Vitch.-Leaves rarely more than 3 ins. long, scarcely as wide, deep lustrous bronzy green above, purple beneath when young. One of the most dainty in appearance of all vines. Introduced from Central China by Wilson for Messrs Veitch in I900.

A vine is cultivated as "V. flexuosa var. major," but is wrongly assigned to this species. It has leaves twice or thrice the size of those of ordinary flexuosa, three-lobed and coarsely toothed, woolly beneath, reddish when young, changing to deep lustrous green at maturity, and finally, before falling, to purple and crimson. Rehder has lately named it V. PULCHRA.

\section{Henryana, Hemsley.}

\section{(Parthenocissus Henryana, Graebner; Psedera Henryana, C. K. Schneider.)}

A vigorous deciduous climber, with sharply four-angled stems free from down; tendrils forked, ending in disks by which it adheres to flat surfaces. Leaves composed of three to five leaflets borne on a stalk $1 \frac{1}{2}$ to $4 \frac{1}{2}$ ins. long. Leaflets obovate, oblanceolate, or narrowly oval, slender-pointed, tapered at the base to a short stalk, coarsely toothed except near the base; $1 \frac{1}{2}$ to 5 ins. long, one-third to one-half as wide; dark velvety green, variegated with silvery white and pink along the midrib and primary veins, which are slightly downy beneath. The green part turns red in autumn. Inflorescence a terminal leafy panicle of cymes up to 6 or 7 ins. long.

Native of Central China; discovered by Henry about I 885 ; introduced by Wilson for Messrs Veitch in 1900 . It is a remarkably handsome vine closely allied to the true Virginian creeper, and having the same power of attaching itself to walls, etc., by means of its disk-tipped tendrils. It thrives quite well against a wall or where it gets a little shelter, but fully exposed in the open it is not quite hardy. A large batch of year-old plants were killed in the winter of $1908-9$ at Kew. Its variegation is better defined on a northwest or even north wall, than on a south wall. 


\section{HETEROPHYLLA, Thunberg.}

(Bot. Mag. (as var. humulifolia), t. 5682 ; Ampelopsis heterophylla, Siebold.)

A luxuriant, deciduous climber, with the shoots and leaf-stalks reddish, smooth, or only slightly downy when quite young. Leaves extremely variable in shape; sometimes broadly heart-shaped and not lobed at all, sometimes slightly three-lobed, sometimes deeply three- or five-lobed, several shapes to be seen on the same shoot; 2 to 4 ins. long and wide; the lobes and apex slenderly pointed, the base straight or more or less heart-shaped; margins sharply toothed; dark green above, pale bright green beneath, with a slight pubescence at first on the veins; stalk from half to nearly as long as the blade. Flowers in small cymose clusters, each cluster terminating a division of the forked inflorescence. Berries porcelain blue, dotted with black, $\frac{1}{3}$ in. across.

Native of China, Japan, and Corea; introduced about 1860. Several attempts have been made to distinguish by name the various forms of this vine, but the leaves are so extremely variable, even on the same plant, that it seems best to keep to the name heterophylla. The great beauty of this vine is in its blue fruits, and these are only produced where the plant is fully exposed to the sun. The best results are obtained by planting it against a south wall, where it has a rather restricted root run. It is most nearly allied to $\mathrm{V}$. indivisa, but that never has distinctly lobed leaves (see also brevipedunculata).

Var. ELEGANS, Regel (V. heterophylla var. variegata).-Leaves handsomely splashed with pink and white, and the young shoots pink. It is too delicate to thrive away from a wall.

The climber known in gardens as V. citrulloides, with very deeply fivelobed leaves, which seem constant, may belong to heterophylla.

\section{V. himalayina, Brandis.}

(Psedera himalayana, $C_{0} . K$. Schneider.)

A vigorous deciduous climber, with semi-woody, smooth young stems; the tendrils terminated by clinging disks. Leaves composed of three leaflets; each shortly stalked and borne at the end of a slender, common stalk 2 to 5 ins. long. Central leaflet ovate, oval or obovate; the side ones very obliquely ovate (two or three times as much blade on one side of the midrib as on the other), and often somewhat heart-shaped at the base on one side only. They are all abruptly tapered at the apex, toothed; dark green and smooth above, paler, slightly glaucous beneath, with a few short hairs on the midrib only; 2 to 6 ins. long, $1 \frac{1}{4}$ to 4 ins. wide. Fruit globose, $\frac{1}{4}$ in. wide, in loose clusters several times forked.

Native of the Himalaya up to $1 \mathrm{I}, 000 \mathrm{ft}$. It is a rather tender species, and only thrives well on a wall. Its leaves change to rich red in autumn.

V. SEMICORDATA, Wallich, is perhaps not specifically distinct from himalayana, but it has smaller leaves and its young shoots and undersurface of leaves are bristly. It may be a form from higher altitudes, as plants raised at Kew from seed sent by the Calcutta Botanic Garden seem to be hardier than $\mathrm{V}$. himalayana.

\section{INCONSTANS, Miquel.}

(Ampelopsis Veitchii of gardens; Parthenocissus tricuspidata, Planchon, Bot. Mag., t. 8287.)

A lofty deciduous climber reaching the tops of trees over $60 \mathrm{ft}$. high; young shoots smooth, attaching themselves to their supports by means of 
viscous disks terminating the tendrils. Leaves extremely variable, but of three main types: I, broadly ovate with a heart-shaped base, shallowly or coarsely toothed, but not, or very slightly, lobed; 2 , composed of three distinct, stalked leaflets, the middle one obovate, the side ones obliquely ovate; 3, conspicuously and deeply three-lobed; the side lobes erect or spreading. The two first types are characteristic of young plants and young shoots, and the leaves average from 2 to 5 ins. across; the last are found on old plants that have reached the flowering and fruiting stage, and the leaves are large and coarse, 8 ins. or even more across. In all forms they are smooth above, finely downy on the veins beneath. Flowers yellow-green, produced in cymes mostly on short two-leaved shoots. Fruit dull, dark blue with a bloom, flattish, $\frac{1}{4}$ to $\frac{1}{3}$ in. wide.

Native of Japan and China; introduced by John Gould Veitch about 1862. No climbing plant ever introduced has secured so important a place in 'British horticulture. Owing to its abundance, it is now becoming the vogue to decry it. It certainly requires watching, and should never be allowed to grow over and shroud beautiful architectural detail, as has happened on some of the old colleges at Oxford. On the other hand, the stark ugliness of innumerable brick walls in urban districts has been hidden by it. It is really one of the least troublesome of climbers, being selfsupporting and attaching itself readily and securely to walls, etc., by means of the viscid tips of the tendrils, and spreading with remarkable rapidity. The leaves of the young climbing branchlets are at first pressed to the wall. In autumn the foliage turns one of the loveliest of crimsons. The large leaves that appear on old plants near the base are coarse in appearance, and the plant then loses much of its charm. It does not bear fruit except during hot summers; there was a good crop in I9II. Cuttings made of firm pieces of young branchlets, 3 or 4 ins. long, and put in gentle heat about August strike root readily. The young plants should be grown in pots until planted out permanently, as they dislike transplanting.

Var. Lowi (Ampelopsis Lowi, Hort.). - A seedling form raised by Messrs Low of Enfield, and first exhibited by them in 1907. It has small three- to seven-lobed leaves, at least when young, very elegant, and colouring as well as the type.

\section{INDIVISA, Willdenorw.}

(Ampelopsis cordata, Michaux.)

A vigorous deciduous climber; young bark warted, not or very slightly downy; tendrils forked, sometimes absent. Leaves roundish ovate, more or less heart-shaped at the base, shallowly but sharply toothed; smooth or slightly downy along the veins and in the vein-axils beneath; 2 to 5 ins. long, scarcely as wide; stalk often downy, shorter than the blade. Flowers on slender-stalked cymes $I \frac{1}{2}$ to 3 ins. broad. Fruits blue or greenish blue.

Native of the south-east and south central United States; introduced in 1803. It is quite hardy and grows vigorously at Kew, but has no special attraction. The ends of the shoots are herbaceous and die back in winter, disarticulating at the nodes. Although the leaves have the typical Vitis shape, it is a true Ampelopsis, the sepals and petals being in fives, the latter separate and expanded, the bark not peeling.

\section{Labrusca, Linnceus. NORThern Fox Grape.}

A vigorous deciduous climber, with very woolly young shoots carrying a tendril or an inflorescence at every joint. Leaves thick-textured, unlobed, or three-lobed (sometimes deeply) towards the top; shallowly and irregularly 
toothed, broadly ovate or roundish, 3 to 7 ins. wide and long; the base heartshaped; upper surface dark green, becoming smooth, lower one covered with rusty-coloured (at first whitish) wool; stalk more than half as long as the blade. Panicles 2 to 4 ins. long. Berries globose, $\frac{2}{3}$ in. diameter, thickskinned, dark purple with a musky or foxy aroma.

Native of Eastern N. America from New England southwards; introduced in 1656 . Of the wild grape vines of $\mathrm{N}$. America this is the most important in an economic sense, and has produced more varieties cultivated for their fruit than any other. It is a vigorous species, and although it has not the least value as a fruiting vine in this country, it is worth growing for its fine foliage and luxuriant growth. It is distinguished among all the true Vitis by having a tendril or an inflorescence opposite each leaf.

\section{LEEOIDES, Maximozvicz.}

(Ampelopsis leeoides, Planchon.)

A deciduous climber of the Ampelopsis group, and allied to V. megalophylla; leaves pinnate, occasionally doubly pinnate, up to $\mathbf{I} \mathrm{ft}$. in length. Leaflets five or seven, the basal pair sometimes again divided into three; oval or oblong, $1 \frac{1}{2}$ to $4 \frac{1}{2}$ ins. long, $\frac{3}{4}$ to 2 ins. wide; rounded or broadly tapered at the base, terminating in a long, slender point; sparsely toothed, lustrous green above, claret purple beneath, and, like the young shoots, perfectly smooth.

Originally collected by Maximowicz at Nagasaki, Japan, in 1863, and named by him as above, this handsome vine (or what has hitherto been regarded as the same) was found in Central China, and introduced for Messrs Veitch by Wilson in 1900. I do not know that the trifoliolate leaflets seen at the base of the leaf in Maximowicz's type have been produced by cultivated plants, and it is quite possible Wilson's plant may prove to be a distinct species. It is at any rate very distinct among cultivated vines, and, as seen trained up a pole in the Coombe Wood nursery, strikingly handsome.

\section{MEgalophylla, Veitch.}

(Ampelopsis megalophylla, Diel, , Bot. Mag., t. 8537.)

A vigorous deciduous climber; young shoots rather glaucous, and, like the rest of the plant, quite smooth. Leaves doubly pinnate (the upper and smaller ones simply pinnate), from $\mathrm{I} \frac{1}{2}$ to $2 \mathrm{ft}$., sometimes more, long, and nearly as wide. The larger ones are composed of seven or nine segments, the one or two lowest pairs of which are again pinnately divided. Leaflets of variable shape and size, but mostly ovate or ovate-oblong, deep green above, glaucous beneath; 2 to 6 ins. long, 1 to 3 ins. wide; coarsely toothed, each tooth terminated by a minute abrupt point. Flowers produced in August in a sparse, sslenderly branched inflorescence, each branch terminating in a cyme. Fruit top-shaped, $\frac{1}{4}$ in. diameter, black.

Native of W. China; introduced to France in 1894 by $\mathrm{Mr}$ Maurice de Vilmorin, and by him distributed as V. cantoniensis - a different and probably not hardy vine. Wilson introduced V. megalophylla for Messrs Veitch in 1900, and from their nursery it has in recent years been distributed. In some respects it is the most remarkable of all hardy vines. Its leaves are larger than those of any other in cultivation, suggesting at their biggest the leaves of Aralia cordata. Planted in good soil and trained up a lofty post (it should be $15 \mathrm{ft}$. high), this vine provides a very striking effect. It has made growths 8 to $10 \mathrm{ft}$. long in one season at Coombe Wood. 


\section{V. monticola, Buckley. Mountain Grape.}

A deciduous climber up to $30 \mathrm{ft}$. high, with slender, slightly downy branchlets. Leaves 2 to 4 ins. across, about the same in length; heartshaped at the base, the sinus broad and rounded; sharply, sometimes slenderly pointed, coarsely triangular-toothed, and slightly three-lobed; of thinnish texture, dark green above, greyish beneath, both surfaces shining; woolly on the veins beneath when young; stalk about half the length of the blade. Berries globose, $\frac{1}{2}$ in. wide, black and sweet.

Native of Texas; introduced in 1898. There is a thin diaphragm interrupting the pith at the joints. V. CHAmpinII, Planchon, is another Texan species introduced at the same time, and allied to V. monticola, but has larger fruits, also black.

\section{ORIEntalis, Boissier.}

\section{(Ampelopsis orientalis, Planchon; Cissus orientalis, Lamarck.)}

A laxly bushy, or sometimes climbing, deciduous shrub, with smooth, slightly ribbed shoots. Leaves variable; often doubly trifoliolate (each of the three chief divisions being subdivided into three leaflets), sometimes simply pinnate, sometimes bipinnate. Leaflets ovate, diamond-shaped or obovate, tapered at the base; 1 to 3 ins. long, $\frac{5}{8}$ to 2 ins. wide; the upper part coarsely toothed; dark dull green and smooth above; paler, grey-green, also smooth beneath, or with tiny tufts in the vein-axils. Flowers with the parts in fours, produced on long-stalked cymes. Fruit roundish, topshaped, $\frac{1}{4}$ in. diameter, red.

Native of Asia Minor, Syria, etc., up to $5000 \mathrm{ft}$. on the mountain"s; introduced in 1818. It is, no doubt, closely allied, and very similar to the American V. arborea, but its foliage is coarser and not so distinctly bipinnate, and it falls sooner in autumn. The leaves are usually composed of nine leaflets (but sometimes eleven or fifteen), which are considerably larger on the average, and appear to be never downy on the veins beneath, as are frequently those of $\mathrm{V}$. arborea. A handsome foliaged shrub, which fruited with Canon Ellacombe at Bitton, near Bath. He compared them to clusters of red currants.

\section{Pagnucci, Du Caillaud.}

A slender-stemmed climber; young shoots soon quite smooth. Leaves $\mathrm{I} \frac{1}{2}$ to 4 ins. long and wide, variable; sometimes composed of three distinct leaflets, sometimes deeply three-lobed with a heart-shaped base, or with a lobe on one side only. On the trifoliolate leaf the middle leaflet is stalked, ovate or oval; the side leaflets obliquely ovate and stalkless. For the rest, they are all rather coarsely and angularly toothed, the upper surface somewhat rough to the touch, the lower one downy on the midrib and veins; stalks $\frac{3}{4}$ to 2 ins. long, slightly hairy.

Native of Central China; introduced to Kew in 1899 , but it had previously been cultivated in France. It is a vine of moderately vigorous growth, the leaves turning a glorious blood-red in autumn. I have not seen it in flower or fruit.

V. PIAsezkil, Maximowicz, is another vine from Central China, very closely allied apparently to V. Pagnucci, and with similar foliage, but it differs in having the young stems hairy and glandular-bristly. 


\section{QUinquefolia, Lamarck. TRUe Virginia CReEPER.}

(V. hederacea, Ehrhart; Psedera quinquefolia, Greene; Parthenocissus quinq., Planchon.)

A tall, deciduous climber, reaching to the tops of lofty trees, free from down in all its parts; stems slender, reddish at first, clinging to its support by means of a disk at the end of each branch of the tendril. Leaves composed of five leaflets (sometimes three) radiating from the end of a common stalk $\mathrm{I}$ to 4 ins. long. Leaflets oval to obovate, I to 4 ins. long, $\frac{1}{3}$ to $2 \frac{1}{2}$ ins. wide, slenderly pointed, tapered at the base to a stalk $\frac{1}{5}$ to $\frac{1}{2}$ in. long, coarsely toothed except at the base; dull green above, pale and rather glaucous beneath. Inflorescence several times forked, the final subdivisions terminated by an umbel of three to eight flowers. Fruit globose, about $\frac{1}{4}$ in. diameter, blue-black.

Native of Eastern N. America from New England southwards to Florida; introduced in 1629; originally named Hedera quinquefolia by Linnæus. It is one of the finest of all climbers, its leaves turning a rich crimson before they fall. As it clings of itself to walls and tree trunks it is very useful. But, very strangely, it had, until a few years ago, become quite scarce in cultivation, having been replaced by $V$. vitacea, a species without the suck $2 r$ disks on the tendrils, and therefore not able to attach itself to flat surfaces. The true plant has comparatively recently been reintroduced under the names of "muralis" and "Engelmannii." At Kew, without artificial suppcrt, it has climbed the naked trunks of lofty pine trees and reached the top.

Var. HIRSUTA (Ampelopsis hirsuta, Donn).-A distinct variety, sometimes regarded as a separate species, with hairy shoots, leaf-stalks, leaflets (both surfaces), and inflorescence. Native of the south-eastern United States.

Var. ST PAULII.-Young shoots, leaf-stalks, and under-surface of leaflets as well as the midrib above clothed with down of a finer nature than in var. hirsuta, from which it also differs in the sharper, deeper teeth, and in being a better wall-climber.

\section{Romaneti, Du Caillaud.}

A vigorous, deciduous climber; young shoots downy, and mixed with the down are numerous gland-tipped, stiff, erect bristles. Leaves of firm texture, three-lobed with a deep, narrow opening where the stalk is attached, shallowly toothed, each tooth ending in a bristle-like tip; 6 to ro ins. long; 4 to 7 ins. wide; upper surface slightly downy on the nerves, or almost smooth and dark green; lower surface covered with a dense grey felt, with the midrib and veins hairy, a few large gland-tipped bristles mixed with the hairs. Stalk one-third to one-half as long as the blade, with a mixture of down and glandular bristles as on the shoot, but with the bristles more numerous. Fruit black, $\frac{1}{3}$ to $\frac{1}{2}$ in. diameter.

Native of China; introduced about $188 \mathrm{I}$, and one of the finest of the true vines except that it is rather tender in a young state, and until the main stem becomes quite woody. From V. armata it is very distinct in the felted under-surface of the leaves, and it is not possible to confuse it with any other species.

\section{Rotundifolia, Michaux. Southern Fox Grape.}

A vigorous, deciduous climber, with stems up to $90 \mathrm{ft}$. in length, in a wild state, the bark adhering (not shredding); young shoots warted; tendrils tinbranched. Leaves broadly ovate or roundish, always broadly heart-shaped at the base, pointed; 2 to $4 \frac{1}{2}$ ins. long and wide; of firm texture, seldom 
lobed, but with the marginal teeth large, irregular, triangular; upper surface glossy dark green, smooth; the lower one yellowish green, also glossy, with down in the vein-axils and sometimes on the veins; stalk usually shorter than the blade. Berries roundish, $\frac{2}{3}$ to $I$ in. diameter, dull purple without bloom, skin thick and tough; flavour musky.

Native of the southern United States; sometimes wrongly named "V. vulpina." Nearly allied to it is Munson's grape (V. Munsoniana, Simpson), which has smaller fruits with a tender skin and acid flesh; it has been in cultivation, but is not very hardy, coming from Florida. These two species are distinguished from all the grape vines by the pith running uninterrupted through the joints of the stem, and by the non-shredding bark and unforked tendrils.

\section{RUPESTRIS, Scheele. SAND or Sugar GRape.}

A deciduous bush up to 6 or $7 \mathrm{ft}$. high, usually without tendrils; young shoots smooth or nearly so. Leaves kidney-shaped or broadly heart-shaped; 2 to $4 \frac{1}{2}$ ins. wide, scarcely so long; abruptly and slenderly pointed; coarsely, irregularly, and sharply toothed, but not or only slightly lobed; glossy, bluish green on both surfaces and smooth, except that the veins beneath are sometimes downy; stalk rather shorter than the blade. Berries roundish, about $\frac{1}{2}$ in. wide, purple-black with a slight bloom, agreeably flavoured.

Native of the south-eastern United States. Interesting as a bushy, not climbing vine.

\section{SINENSIS, Veitch.}

\section{(Parthenocissus sinensis, Diels; Psedera sinensis, C. K. Schneider.)}

A vigorous, deciduous handsome climber, with rarely branching tendrils, young shoots at first flossy, then smooth. Leaves very variable, 3 to 6 ins. long, $2 \frac{1}{2}$ to 5 ins. wide; three-lobed with a heart-shaped base, or composed of three or five taper-based leaflets, the middle one of which is stalked and oval or obovate, the side ones or at least the lower pair obliquely ovate and stalkless. The merely lobed leaves differ much in the depth of the lobes, which are sometimes little more than large triangular teeth, but showing every intermediate condition between that and the tri- or quinque-foliolate ones. The margins are sharply toothed, the upper surface dark green, downy on the veins, the lower surface more or less brown-felted; stalks purplish, half to two-thirds as long as the blade. Fruit black-purple, $\frac{1}{3}$ in. wide, in slender, sometimes forked branches 4 or 5 ins. long.

Native of Central China; discovered by Henry, and introduced in 1900 by Wilson. It has remarkably variable leaves, resembling in that respect V. Pagnucci; but that species is a "true" Vitis with peeling bark, whilst this is one of the close-barked species.

\section{STRIATA, Baker.}

\section{(Ampelopsis sempervirens, Hort.; Cissus striata, Ruiz and Pavon.)}

An evergreen climber; young stems slender, angled, hairy and very leafy; tendrils thread-like. Leaves $1 \frac{1}{2}$ to 3 ins. across, composed of five scarcely stalked leaflets, radiating from the end of a common stalk $\frac{3}{4}$ to $I \frac{1}{2}$ ins. long. Leaflets obovate or oblanceolate, $\frac{1}{2}$ to $I \frac{1}{2}$ ins. long, $\frac{1}{4}$ to $\frac{3}{4}$ in. wide; tapered at the base, coarsely toothed towards the apex, each tooth tipped abruptly with a short gland; dark glossy green and smooth on both surfaces. Flowers green, produced in small cymes. Fruits about the size and shape of small red currants, but of a reddish purple colour. 
Native of Chile and S. Brazil; introduced about 1878. Against a wall this survives all but the hardest winters, but is tender in the open. It is a very elegant plant, luxuriantly leafy, and with beautifully cut leaves. Tweedie, the Kew collector in S. America, called it the "ivy of Uruguay," and says it covers the bushes with red berries in winter. It thrives very well in the south and west, and bore large crops of fruit at St Leonard's as long ago as 1885 , but the berries were purplish rather than red. When cut down to the ground by frost it will often break up again the following summer, but on the whole it it is only well adapted for the mildest counties.

\section{Thunbergi, Siebold. Fig-Leaved Vine.}

(Bot. Mag., t. $855^{8}$; V. Sieboldii, Hort.)

A slender-stemmed, only moderately vigorous, deciduous climber, the young shoots angled, more or less woolly. Leaves variable, but deeply three- or five-lobed, usually $2 \frac{1}{2}$ to 4 , sometimes 6 ins. across, heartshaped at the base. Lobes ovate, often penetrating half or more than half the depth of the blade, the space (or sinus) between the lobes often expanding and rounded at the bottom; sharply, shallowly, and irregularly toothed, dark dull green and smooth above, covered with a rusty brown felt beneath. Leaf-stalk about half the length of the blade. Berries in bunches 2 or 3 ins. long, black with a purple bloom, $\frac{3}{8}$ in. or less in diameter.

Native of Japan; introduced probably by Siebold. The name has generally in this country been wrongly applied to a fine form of V. Coignetiæ (q.v.), from which it is quite distinct in its comparatively small leaves, deeply lobed like those of a fig, and its slender, less woody, five-angled young shoots. It is much nearer V. FICIFolia, Bunge; in fact the distinctions between these two are not very clear. It has also been associated with V. Labrusca, but that species must be regarded as purely $\mathrm{N}$. American, and as more nearly allied to V. Coignetiæ than V. Thunbergii, both of which, however, are distinguished from it by having a tendril missing from every third joint of the young shoot. V. Thunbergii is grown at Kew and at Bitton, where it turns rich crimson in autumn, and occasionally bears fruit. In my experience it is a rather weak grower, the ends of the shoots dying back considerably every winter.

\section{Thomsonir, (?) Lawson.}

A slender, deciduous climber of the quinquefolia group; yourg stems slightly downy at first, ribbed. Leaves composed normally of five leaflets, borne on a slender downy stalk. $1 \frac{1}{2}$ to $4 \frac{1}{2}$ ins. long. Leaflets oval or obovate, I to 4 ins. long, $\frac{1}{2}$ to $I \frac{1}{2}$ ins. wide; slenderly pointed, the upper half shallowly but sharply toothed, the base entire and tapered to a stalk, $\frac{1}{8}$ to $\frac{3}{4}$ in. long; under-surface sparsely downy on the midrib, glossy. The entire leaf, leafstalk, and young shoots are of bright claret purple when young, becoming greenish purple later, changing finally to deep reddish purple. Flowers in cymes on a slender stalk.

Native of China; introduced by Wilson for Messrs Veitch in I900. It was awarded a first-class certificate by the Royal Hort. Society, Sept. I, 1903, and is, indeed, one of the most charming acquisitions of recent years amongst hardy climbers. It seems to Ime, however, very doubtful that this is the V. Thomsonii described by M. A. Lawson in the first volume of Hooker's Flora of British India, p. 657, although that view is adopted by Gagnepain in Planta Wilsoniana, vol. i., p. IOI. It appears to be more nearly related to $V$. Henryana, but is decidedly hardier. I have never seen it suffer from frost. 


\section{V. vinifera, Linnaus. Common Grape Vine.}

A deciduous climber, growing $50 \mathrm{ft}$. or more in length if given support; young shoots sometimes smooth, sometimes cobwebby. Leaves usually 3 to 6 ins. wide and long; three- or five-lobed, coarsely toothed. When deeply lobed the sinus between the lobes is rounded and almost or quite closed by the overlapping of the upper parts of the lobes. Upper surface smooth, or downy on the veins; lower one always more or less downy (sometimes felted), especially on the veins; stalk more than half as long as the blade. Berries oval, black with a blue bloom.

The grape vine has been cultivated in all the warm temperate parts of Europe, and in parts of Asia back into the unrecorded past, and its real native country is now a matter of conjecture. But the general opinion is that it originated in Asia Minor and the Caucasian region. It is perfectly hardy in most parts of Britain, and has, in past times, been cultivated for the production of wine. Of present-day vineyards in Britain the most noted is that of the Marquis of Bute near Cardiff. On sunny walls very palatable grapes can be grown in this country, especially in hot summers; but on the whole it has to be said that the results generally offer but little inducement to take up put-door cultivation of grapes, especially now that glasshouses can be erected so cheaply and give such infinitely better results. Still, for several centuries after the Norman Conquest, vineyards were common enough in the south and west of England. Winchester, or Winton, is said to take its name from its excellent vintage. It is not within the province of this work to deal with the numerous varieties of grape vine that are grown for their fruit, but there are three varieties that require mention for their distinct or ornamental qualities as hardy climbers.

Var. APIIfolia, Loudon (V. laciniosa, Linnaus). The Cut-leaved or Parsley Vine.-The striking and handsomely cut leaves of this variety consist of three to five main divisions, sometimes stalked. These are again variously cut into deep narrow lobes, pointed or bluntish. It makes a very effective climber, although the leaves are certainly not subdivided enough to suggest parsley. Cultivated in Britain since the middle of the seventeenth century.

Var. INCANA. The Miller Grape.-Leaves three-lobed or unlobed, smaller than in the type, the upper surface as well as the lower one covered with a grey, cobweb-like down, giving them, when young especially, a whitish appearance as if dusted with flour. Its aspect is curious and interesting rather than attractive.

Var. PURPUREA. Teinturier Grape.-Leaves at first of a beautiful claret red, deepening later in the season to lurid purple. One of the richest hued of purple shrubs.

A variety of no particular merit as an ornament, but of interest, is var. CORINTHIACA, the vine that produces the currants of the grocers' shops. It has smaller, more rounded leaves than the type, and tiny, black, very often seedless fruits. The name "currant" is a corruption of "Corinth," whence most of the dried fruits of this vine are exported.

\section{VitACEA. COMmon ViRginia CREePER.}

(Parthenocissus dumetorum, Rehder; P. vitacea, Hitchcock; Psedera vitacea, Greene; Cissus quinquefolia, Sims, Bot. Mag., t. 2443.)

This is the common Virginian creeper of gardens, especially town gardens, in this country, where it has long been grown under the name of Vitis (or Ampelopsis) quinquefolia. It is not, however, the true plant of 
that name, although the two were not separated specifically until 1894 . It is very widely spread over $\mathrm{N}$. America in its various forms, but the type appears to be East N. American. The best and most obvious distinction between it and the true V. quinquefolia is in the absence of disks at the end of the tendrils, on account of which it is unable to attach itself to flat surfaces. It supports itself, as most vines do, by twining its tendrils round - whatever is -available. It is useful for covering arbours and flattish surfaces generally; trained along a rafter or similar horizontal support it will send down a thick curtain of branches. It has the same five, obovate-lanceolate leaflets radiating from the end of a long, slender common stalk as in V. quinquefolia, but it differs in their being larger, greener beneath, brighter green above, and in the deeper, sharper teeth; the inflorescence is cymose and flatter. The leaves turn red in autumn. Where a self-supporting climber is not needed it is the better and more handsome vine. Cultivated in 1824, when it was believed to be of Brazilian origin (see Bot. Mag., t. 2443).

Var. LACINIATA (V. quinquefolia var. incisa of gardens).-Leaves very deeply, sometines doubly toothed, some of the teeth being $\frac{1}{2} \mathrm{in}$. deep, with a roughness on the surface due to scattered minute hairs; the main-stalk of the leaf and the stalks of the leaflets are both longer than in the type. The variety is found wild in the western and south-western United States.

Var. MACROPHYLLA (V. quinquefolia var. major of gardens).-Leaflets very large, 6 or 8 ins. long and 3 to $4 \frac{1}{2}$ ins. wide.

\section{V. vulpina, Linnaus. Riverbank. Grape.}

\section{(V. riparia, Michaux; V. odoratissima, Donn.)}

A vigorous, deciduous, scrambling bush or climber with smooth young shoots. Leaves thin, 3 to 8 ins. wide, usually somewhat longer, broadly heart-shaped, with a finely tapered point and coarse, triangular, unequal teeth; usually more or less three-lobed; shining green on both surfaces, downy on the veins beneath; stalk from half to quite as long as the blade. Flowers sweetly scented like mignonette, produced in panicles 3 to 8 ins. long. Berries globose, $\frac{1}{3}$ in. diameter, black-purple, covered thickly with blue bloom.

Native of Eastern N. America from New Brunswick to the southern United States; introduced in 1806 . The name vulpina has been wrongly applied to V. rotundifolia, the "Southern fox grape" (q.v.), a very well-marked vine with unforked tendrils and close bark. The riverbank grape is really most closely allied to $\mathrm{V}$. cordifolia, and both have a tendril missing from every third joint, but the present species differs in its more commonly three-lobed leaves with larger more persistent stipules, and in its blue-bloomed fruits. It is worth growing for its vigorous, leafy habit and sweet-scented flowers. It strikes very readily from cuttings and has, in consequence, been much used as a phylloxera-proof stock on which the wine-producing vines of France have been grafted.

V. PALMATA, Vahl, is nearly related to V. vulpina, and is a native of the south central United States, where it is known as the "Cat or Red grape." It has smooth, bright red young branches and leaf-stalks, three- or five-lobed leaves, the lobes long and slenderly pointed. Berries black, without bloom.

\section{WISTARIA. LEGUMINOSE.}

A small genus of exceedingly ornamental climbers, represented in the eastern United States and in N.E. Asia. The leaves are alternate, 
deciduous, and unequally pinnate. Flowers in handsome axillary or terminal racemes, and mostly of a pale bluish lilac or white. Pods rather resembling those of kidney beans in shape. The genus was named in honour of Caspar Wistar, a professor of anatomy in the University of Pennsylvania in the early part of the nineteenth century. It is sometimes spelt Wisteria.

Wistarias are of easy cultivation, and quite hardy in the southern half of England. In some places to the north-east they should be grown on walls. They like a good loamy soil, but are not fastidious at the root; a sunny position, however, is essential. The only problem in connection with their culture is the provision of suitable support. For W. chinensis, walls and pergolas afford the best means. of displaying its attractions, and for the display of the long racemes of W. multijuga an overhead trellis work is desirable. An arbour framed in iron will quickly be covered by either of these species, and as the branches twist round the rods any unsightliness is soon hidden.

Seeds are not frequently produced, and do not afford a reliable means of increase. But layering may be adopted, and shoots grafted in spring on pieces of root from the same species, or chinensis, unite readily under glass. Cuttings of August wood made of the lower part of the season's shoots may also be tried.

\section{W. BRACHYBOTRYS, Siebold.}

(Flora japonica, t. 45.)

A deciduous shrub with twining branches, at least when young. Leaves Io to 15 ins. long; leaflets from five and a half to eight and a half pairs, downy when young, ovate, $\mathrm{I}_{2} \frac{1}{2}$ to 2 ins. long. Racemes borne on short shoots from the wood of the previous year, 3 to 5 ins. long; very downy. Flowers crowded, nearly $\mathrm{I}$ in. long, dark purplish blue; standard petal $\frac{3}{4}$ in. wide; calyx $\frac{1}{3}$ in. long, bell-shaped, with five broad, triangular teeth.

Native of Japan, whence it was imported to Belgium by Siebold in 1830 . $\mathrm{He}$ found it cultivated in several places, but only once wild, which was near the village of Kosedo, not far from Nagasaki. He described it as being 3 to $5 \mathrm{ft}$. high there, and covering the side of a small hill, its flowers "indigo-blue." In 1862 it was found near Nagasaki (perhaps on the same site) by Richard Oldham, the Kew collector, whose specimens are preserved in the Kew Herbarium.

[Since our first edition was written, Mr E. H. Wilson has visited Japan, where he made the Wistarias a subject of detailed study. He informs me that Siebold's W. brachybotrys is nothing more than a wild form of what we call W. multijuga. It, or one closely allied, has long been grown at Kew and regarded as a poor form of W. multijuga. The Wistaria with short racemes and large white flowers which was exhibited at the International Chelsea Show of May 1912, as W. brachybotrys, Messrs Rehder and Wilson make a new species and name W. VENUSTA.]

\section{W. Chinensis, De Candolle.}

(Glycine chinensis, Sims; Bot. Mag., t. 2083.)

A strong-growing, deciduous climber, capable of covering lofty trees. The trunks of old specimens, although often decayed and hollow, attain 
great dimensions for a climber, and on some of the older plants in this country are over $5 \mathrm{ft}$. in circumference. The branches, which are covered with silky down when young, support themselves by twining round whatever support is available. Leaves pinnate, to to 12 ins. long, consisting usually of eleven leaflets, which are elliptical or ovate, deep rich green and smooth above, somewhat hairy beneath, especially on the midrib; $1 \frac{1}{2}$ to 4 ins. long, $\frac{1}{2}$ to $I \frac{1}{2}$ ins. wide ; increasing in size towards the end of the leaf. Racemes 8 to 12 ins. long, produced in May from the buds of the previous season's growth. Flowers mauve or lilac-coloured, borne singly on stalks $\frac{1}{2}$ to $\frac{3}{4}$ in. long; : each flower is about I in. long, pea-flower shaped, with a fine, rounded standard petal $\frac{3}{4}$ in. wide. Pod rather like that of a kidney bean, 5 or 6 ins. long, club-shaped, $i \frac{3}{4}$ in. wide towards the end, tapering gradually towards the base, covered with a velvety pile, and containing two or three seeds.

Native of $\mathrm{N}$. China; first introduced in 1816 from a garden in Canton. No climber ever brought to this country has added more to the beauty of gardens. It flowers towards the end of May, and there is frequently a second smaller crop in August. It is as remarkable for its rapid growth as for its wealth of blossom. Where wall space is available, it will extend forty yards or more from each side of the stem. In full blossom, when every twig is garnished with pale lilac flowers, few plants are so lovely. It may be used in several ways; the commonest is as a wall plant on houses, also as a pergola plant, and for covering arches. At Kew, an old specimen which up to 1860 grew on a house there, was trained over a large iron cage erected for it when the house was demolished; it was old then, but is still a fine feature. On the Continent, especially in Italy, it is frequently planted so as to overrun large trees; in such a way it makes gorgeous displays there in April. When the plant has filled its destined space, it becomes necessary to prune the long, slender shoots back to within an inch or two of the older wood; otherwise it soon becomes an inextricable tangle. This is done in late summer. This Wistaria may also be treated as a shrub, 5 to $8 \mathrm{ft}$. high, by an annual hard pruning. Seed is only ripened in unusually hot years.

Var. ALBA has white flowers; ALBA PLENA has them double as well as white; neither of these flower as well as the type.

Var. FLORE PLENO.-In this the flowers are lilac, but owing to the stamens becoming transformed into petals, they lose their pea-flower shape and become rosettes. To my mind, this spoils rather than improves the flower, and the plant does not blossom so freely. Introduced from Japan to America, about 1863 , and thence to England. plant.

Var. FOLIIS VARIEGATIS.-Leaflets blotched with white. Not a desirable

\section{W. FRUtescens, De Candolle.}

(Glycine frutescens, Linnaus; Bot. Mag., t. 2013.)

A deciduous climber, spreading 30 to $40 \cdot \mathrm{ft}$. from its base, and enveloping trees and shrubs in its wild state; young shoots yellowish. Leaves pinnate, 7 to 12 ins. long, with four and a half to seven and a half pairs of leaflets of nearly uniform size; ovate, $I_{\frac{1}{2}}^{\frac{1}{2}}$ to $2 \frac{1}{2}$ ins. long, up to $\mathrm{I}_{\frac{1}{8}}$ ins. wide; slightly downy only when young. Racemes terminal on the shoots of the year, very downy, 4 to 6 ins. long, the shorter ones erect. Flowers much crowded, fragrant, each about $\frac{3}{4}$ in. long, pale lilac-purple, with a yellow spot; calyx slenderly bell-shaped, $\frac{1}{4}$ in. long, downy, with five short triangular teeth, and like the flower-stalk, downy. Pod smooth, much more cylindrical and swollen where the seeds are fixed, than in the Asiatic species. Seeds also rounder.

Native of the south-eastern United States; introduced in 1724. It is not so strong a grower as either W. chinensis or W. multijuga, nor does it ever 
produce so fine a display. Commencing to blossom in the latter part of June, it continues until the end of August.

Var. ALBA.-Flowers white.

W. MACROSTACHYA, Nuttall.-Under the name of "W. frutescens var. magnifica," this Wistaria has long been in cultivation. In habit, foliage, and flower characters it is very like $\mathrm{W}$. frutescens, but is a much handsomer plant and differs in the following respects: Leaflets rather larger; racemes 8 to 12 ins. or even more long, with up to ninety flowers on each; calyx teeth longer in proportion to the tube; flower-stalk and calyx very glandular as well as hairy. Well worthy of cultivation. Native of Missouri, Arkansas, Tennessee, etc.

\section{W. JAPONICA, Siebold.}

\section{(Milletia japonica, A. Gray.)}

A deciduous climber with slender twining stems. In a state of nature it climbs up bushes and small trees, which eventually become almost entirely enveloped by it. Leaves 6 to 9 ins. long, composed of nine to thirteen leaflets, which are ovate, rounded, or slightly heart-shaped at the base; $1 \frac{1}{2}$ to $2 \frac{1}{2}$ ins. long, $\frac{1}{2}$ to $\frac{3}{4}$ in. wide; bright glossy green and smooth below. Racemes axillary, often branched, very slender, many-flowered, 6 to $\mathrm{I} 2$ ins. long. Flowers white, $\frac{1}{2}$ in. or so long (the smallest of Wistarias), each produced on a stalk $\frac{1}{6}$ in. long. Calyx bell-shaped, $\frac{3}{16}$ in. long, smooth except for the ciliate margins, five-toothed. Pod 3 to 4 ins. long, $\frac{1}{3}$ in. wide, quite smooth, six- to seven-seeded.

Native of Japan; introduced for Messrs Veitch by Maries, in 1878. It first flowered in August, I 884, at the Coombe Wood nursery. One of the most distinct of Wistarias, belonging, perhaps, to another genus, this species never appears to have had full justice done to it in this country. It is worth growing if only for the lateness of its flowers (July and August). The often branching racemes, small flowers, and almost entire absence of down, distinguish it clearly. According to Siebold, a tree enveloped by this Wistaria in full flower forms a "magnificent coup d'cil, giving to vegetation an aspect of wild beauty."

\section{W. multijuga, Van Houtte.}

(Flore des Serres, t. 2002 ; W. chinensis var. multijuga, Hooker fil., Bot. Mag., t. 7522.)

A deciduous climber of luxuriant habit, with very slender, twining, silky young branches. Leaves pinnate, with five and a half to ten and a half pairs of leaflets, which are ovate, $1 \frac{1}{2}$ to 3 ins. long, silky hairy when young, smooth or nearly so later. Racemes I to $3 \frac{1}{2} \mathrm{ft}$. long, $2 \frac{1}{2}$ to 3 ins. wide, carrying very numerous flowers, each $\frac{3}{4}$. in. long, borne at intervals of about $\frac{1}{4}$ in. along the main-stalk; flower-stalk nearly I in. long; standard petal roundish, $\frac{2}{3}$ in. wide, pale lilac; wing-petals and keel tipped with purplish blue. Pod 4 to 9 ins. long, narrowed towards the base, velvety.

A cultivated form of a species confined in a wild state to Japan ; introtroduced to Belgium by Siebold, and thence to Kew in 1874 . The wild type, with racemes 8 or Io ins. long, is also grown there. (See note on W. brachybotrys.) There is a very famous plant at Kameido, which has often been illustrated and described by travellers. It forms a huge arbour, extending partly over a piece of water spanned by a semicircular Japanese bridge. With its thousands of slender, pendulous racemes 3 to 4 ft. long, crowded with lilac blossoms "odorous of honey and buzzing with bees," it makes, no doubt, one of the most 


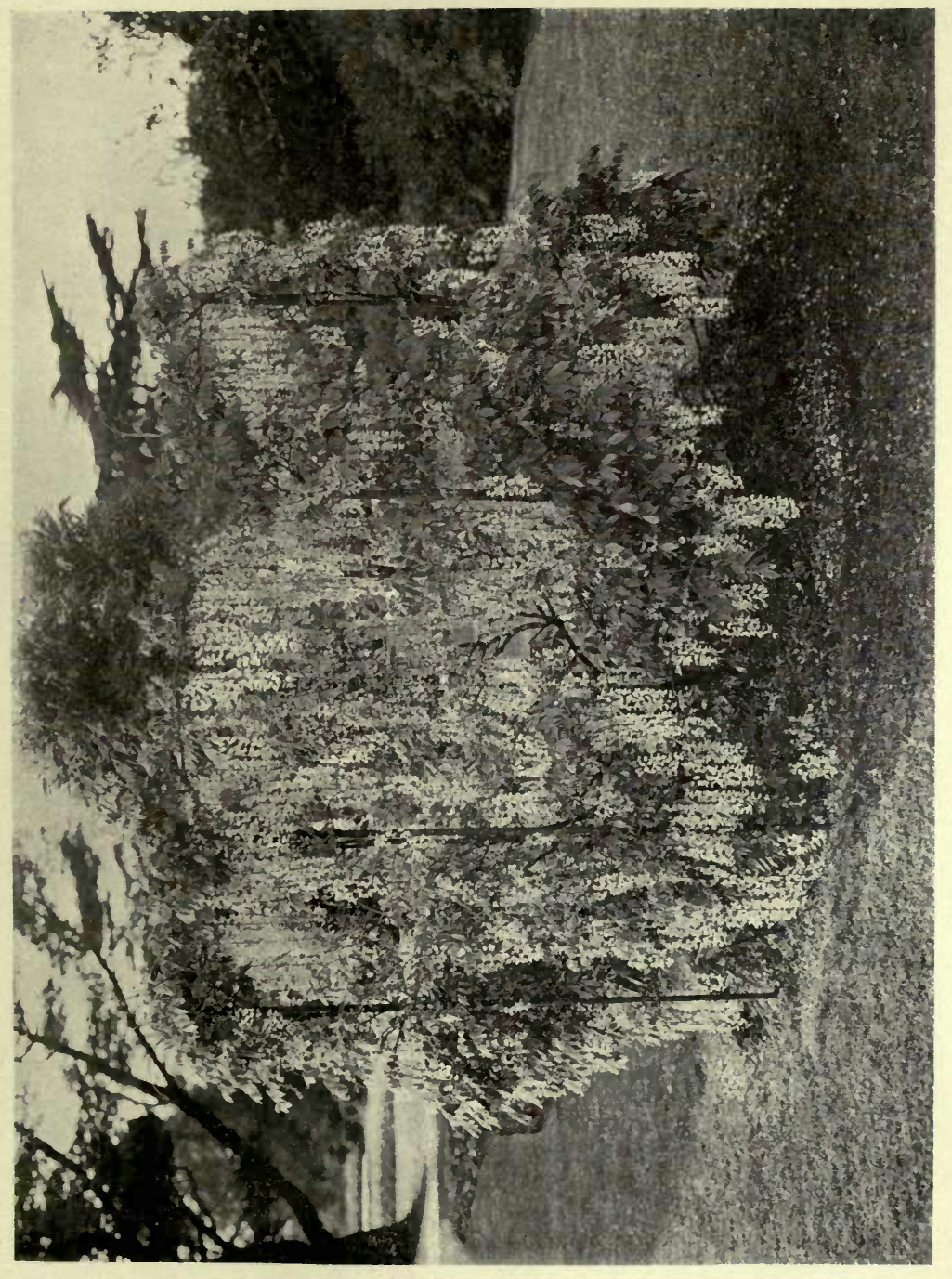



remarkable floral exhibitions on the globe. This variety is not so well adapted for walls as W. chinensis; it should be trained in such a way as to allow the racemes to hang freely, such as on overhead trellises.

Some authorities have considered it a variety of W. chinensis, but it is quite distinct. The most obvious difference is the length of raceme, but the leaves also have more leaflets, and it flowers two or three weeks later. Where climbing space is not available, W. multijuga can be treated as a bush. A plant in the Kew collection has been grown for over forty years like this, and is now only about $8 \mathrm{ft}$. high. Its branches are spurred back every year, and it produces an amazing profusion of racemes. All the forms of this Wistaria can be increased by layers and by grafting twigs on the pieces of its own roots in spring.

Var. ALBA. - Flowers white, tinged with lilac, racemes shorter than in the type; a very beautiful plant.

Var. ROSEA. - Flowers pale rose-coloured.

Var. Russelliana.Flowers darker than in the type, marked with creamy blotches.

\section{XANTHOCERAS SORBIFOLIA, Bunge. SAPINDACEE.}

\section{(Bot. Mag., t. 6923.)}

A deciduous shrub or small tree up to $20 \mathrm{ft}$. high, of rather stiff, erect habit, with a large quantity of pith in the young branches. Leaves pinnate,

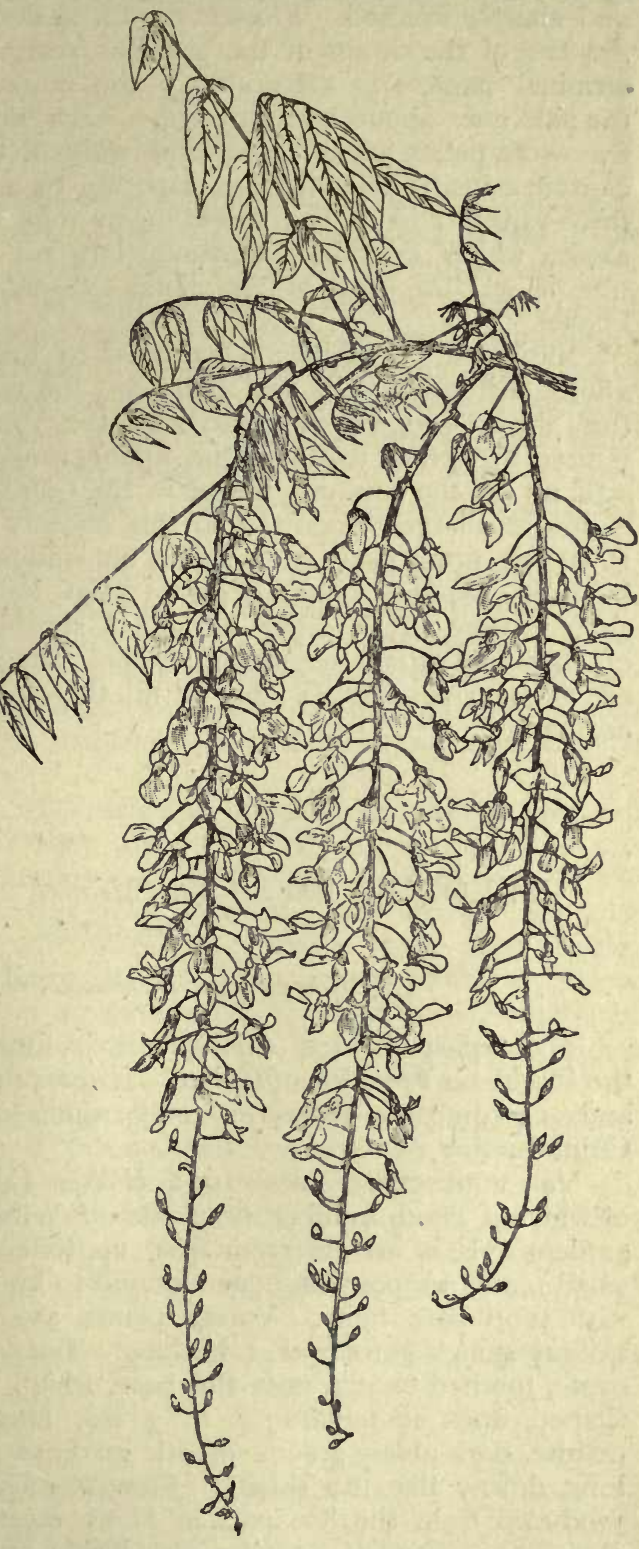

Wistaria multhuga. 5 to 8 ins. long, smooth; leaflets nine to fifteen, confined to the 
upper two-thirds of the main-stalk, $I_{2} \frac{1}{2}$ to $2 \frac{1}{2}$ ins. long, lanceolate, deeply and sharply toothed. Flowers produced during May in erect panicles at the end of the shoots of the previous year, and from the side buds; the terminal panicle is considerably the largest, and up to 8 ins. long; the side ones about half as large. Each flower is I to $\mathrm{I}_{4}^{\frac{1}{4}}$ ins. across, the five white petals having a carmine stain at the base. Fruit a top-shaped capsule 2 ins. wide at the top, tapering to a stout stalk at the base; it is three-valved, and as the valves open they release the rather numerous seeds, which resemble chestnuts, but are only $\frac{1}{3}$ to $\frac{1}{2}$ in. wide. The tree is a close ally of the horse-chestnut, and is the only species known.

Native of N. China; introduced to France by the Abbé David in 1868. Although at its best there are few more beautiful small trees than this, the flowers, which come with the young leaves, are liable to be injured by spring frosts in the open ground. It is admirable against a wall, as on the curator's house in the Cambridge Botanic Garden, and it is now also largely imported to this country for forcing early into flower. It is best propagated from seeds, but, failing these, cuttings of roots may be used, placing them in gentle heat in April. The plant is rather subject (like other pithy branched shrubs and trees) to the attacks of the coral-spot fungus. Branches attacked with it should be-cut off as soon as noticed, and burnt, the wounds being coated over with coal-tar.

\section{Xylosma racemosa, Miquel. Tung-Ching Tree. BIXACE $A$.}

(Hisingera japonica, Siebold, Fl. Jap., i., t. 88.)

The typical form of this species is found wild in Japan, Corea, and the Chekiang Province of China. It does not appear to be in cultivation, and according to Wilson is only represented in Western and Central China by the

Var. pubescens, Rehder and Wilson (Myroxylon racemosum, Diels), of which a good number of plants of Wilson's introduction are now in gardens. It is an evergreen tree up to $80 \mathrm{ft}$. high in nature, but the small plants we possess seem inclined to be bushy; young shoots covered with short pale hairs. Young plants are armed with straight, sharp, axillary spines $\frac{1}{2}$ to over $\mathrm{I}$ in. long. Leaves alternate, ovate to roundish ovate, toothed except near the base, which is rounded or broadly wedgeshaped, apex acuminate; $\frac{3}{4}$ to 3 ins. long, $\frac{1}{2}$ to $I_{2} \frac{1}{2}$ ins. wide, firm in texture, dark glossy green, smooth on both surfaces ; leaf-stalk $\frac{1}{8}$ to $\frac{1}{4}$ in long, downy like the shoots. Flowers unisexual, small, yellow, fragrant, produced from the leaf-axils in short racemes $\frac{1}{4}$ to $I$ in. long. Fruit about the size of small peas, black-purple, the style adhering. at the top.

The small cultivated plants make sturdy, bushy, well-armed ever- 
greens, and seem to be perfectly hardy. In Japan the species flowers in August.

\section{YUCCA. LILIACEÆ。}

Yucca is a genus of liliaceous trees and shrubs exclusively confined to N. and Central America. About half a dozen species are grown in the open air in the south of England, probably more in the mildest counties. The leading characteristics of these plants are a cylindrical stem, in some species not rising above ground-level, in others many feet high, fibrous and fleshy, naked of foliage below, and marked by horizontal scars of fallen leaves. Leaves long, narrow and pointed, crowded in a spherical or hemispherical head. Flowers white or greenish, drooping, produced in erect panicles or racemes, and composed of three outer segments, and three inner ones. Stamens six. Fruit a capsule up to 2 or 3 ins. long.

In their general aspect the Yuccas are quite distinct from any other group of hardy shrubs. Their foliage is essentially of a tropical or subtropical character, which, combined with a peculiar stateliness and beauty of flower, gives the genus a unique value in gardens. They are especially suitable in formal arrangements, either isolated or in groups, and their effectiveness in flower is enhanced if a dark background can be given them.

Considering the regions of which the species described below are native, it is remarkable that they are so hardy and adaptable to our climate. The commonest species come from the coast regions of the south-eastern United States, yet they withstand $30^{\circ}$ or $32^{\circ}$ of frost uninjured. Compared with wild plants, our garden ones have longer, larger leaves, but smaller inflorescences. They appear to thrive in any soil, but prefer a sandy loam in a position fully exposed to the south. In such a position they never suffer from drought, nor do they, except for a diminished crop of blossom, appear to be affected by cold, wet seasons. As the stems lengthen, they ultimately decay at the older part, and fall over by their own weight. The tops can be made to strike root by trimming off half the leaves, and placing the stem in a pot of sandy soil, giving it a place in a greenhouse until rooted. The dwarf species like flaccida can be increased by division, and most of the species produce rhizomatous underground stems which make plants when cut off and potted.

There are numerous hybrids between the following species in cultivation.

\section{Y. Filamentosa, Linncus.}

(Bot. Mag., t. 9co.)

A low evergreen shrub, the stem of which does not rise above groundlevel, and which increases and spreads by means of side growths from the 
base. Leaves stiffly erect or spreading, I to $2 \frac{1}{2} \mathrm{ft}$. long, I to 2 ins. wide, pointed, but rarely spine-tipped, slightly glaucous green, roughish at the back. From the margins of the leaves, curly thread-like filaments 2 to 3 ins. long break away, and are especially numerous towards the base. Flowers pendulous, yellowish white, 2 to 3 ins. across, produced during July and August in erect, conical, glabrous panicles 3 to $6 \mathrm{ft}$. high, looser and broader than in either gloriosa or recurvifolia. Fruits 2 ins. long; seeds glossy, $\frac{1}{4}$ in. long.

Native of the south-eastern United States; introduced in the seventeenth century, and said to have first flowered at Oxford in 1675 . This is a very hardy and beautiful Yucca, forming low tufts from which the stately panicles spring in profusion. It should be planted in broad masses with, if possible, a dark evergreen background. It flowers in a small state. Easily propagated by division. Allied to flaccida.

Var VARIEGATA.-Leaves margined and striped with yellow or white. Not so hardy and vigorous as the type.

\section{Y. FLACCIDA, Haworth.}

(Bot. Reg., t. 1895.)

A low evergreen shrub, whose stem, like that of $Y$. filamentosa, does not arise above ground-level, spreading by sucker growths. Leaves $\mathbf{I}$ to $\mathbf{I} \frac{3}{4} \mathrm{ft}$. long, I to $I \frac{1}{2}$ ins. wide; green or glaucous, and bent downwards above the middle, long-pointed with straightish, thread-like fibres separating from the margin, and 2 ins. or more long. Flowers as in Y. filamentosa, but borne on a downy, shorter panicle. Seeds dull; $\frac{1}{3}$ in. long, produced in a capsule 2 to 3 ins. long.

Native of the south-eastern United States, with a more inland distribution than Y. filamentosa. It is no doubt closely allied to that species, and between them forms occur which are difficult to assign to one in preference to the other. It differs in the bent back apices of the leaves, downy panicle, larger fruit, and dull seeds. Its garden value is about the same as that of Y. filamentosa, and it is propagated in the same way.

Var. INTEGRA, Trelease (Y. glauca, Sims, not Nuttall; Bot. Mag., t. 2662), is without fibres on the leaf-margins, the leaves are smaller, the flower-stalks smooth.

Var. ORchioIDEs, Trelease (Y. orchioides, Carrière).-From the typical $Y$. flaccida this differs in having stiffer more erect nearly threadless leaves, and a stiffly erect, unbranched inflorescence-that is, a raceme, not a panicle. In reducing this Yucca to a variety of Y. flaccida, I follow Prof. Trelease, the last monographer of the genus. It does not appear to exist in a wild state, and he describes it as "a depauperate garden form."

The Yucca figured in Bot. Mag., t. 6316, as Y. orchioides var. major, Baker, is according to Trelease merely another form of Y. flaccida. He calls it Y. FLACCIDA var. GLAUCESCENS, and describes it as having broader, more glaucous leaves, erect until a later period, an almost tomentose panicle, and narrower petals. It is the form commonly grown in American gardens, and very probably exists under one or other of these names in ours.

\section{Y. GLAUCA, Nuttall, not Sims. (Y. angustifolia, Pursh.)}

An evergreen shrub with a low, often prostrate stem carrying a hemispherical head of leaves 3 to $4 \mathrm{ft}$. across. - Leaves narrow linear, 1 to $2 \frac{1}{2} \mathrm{ft}$. 


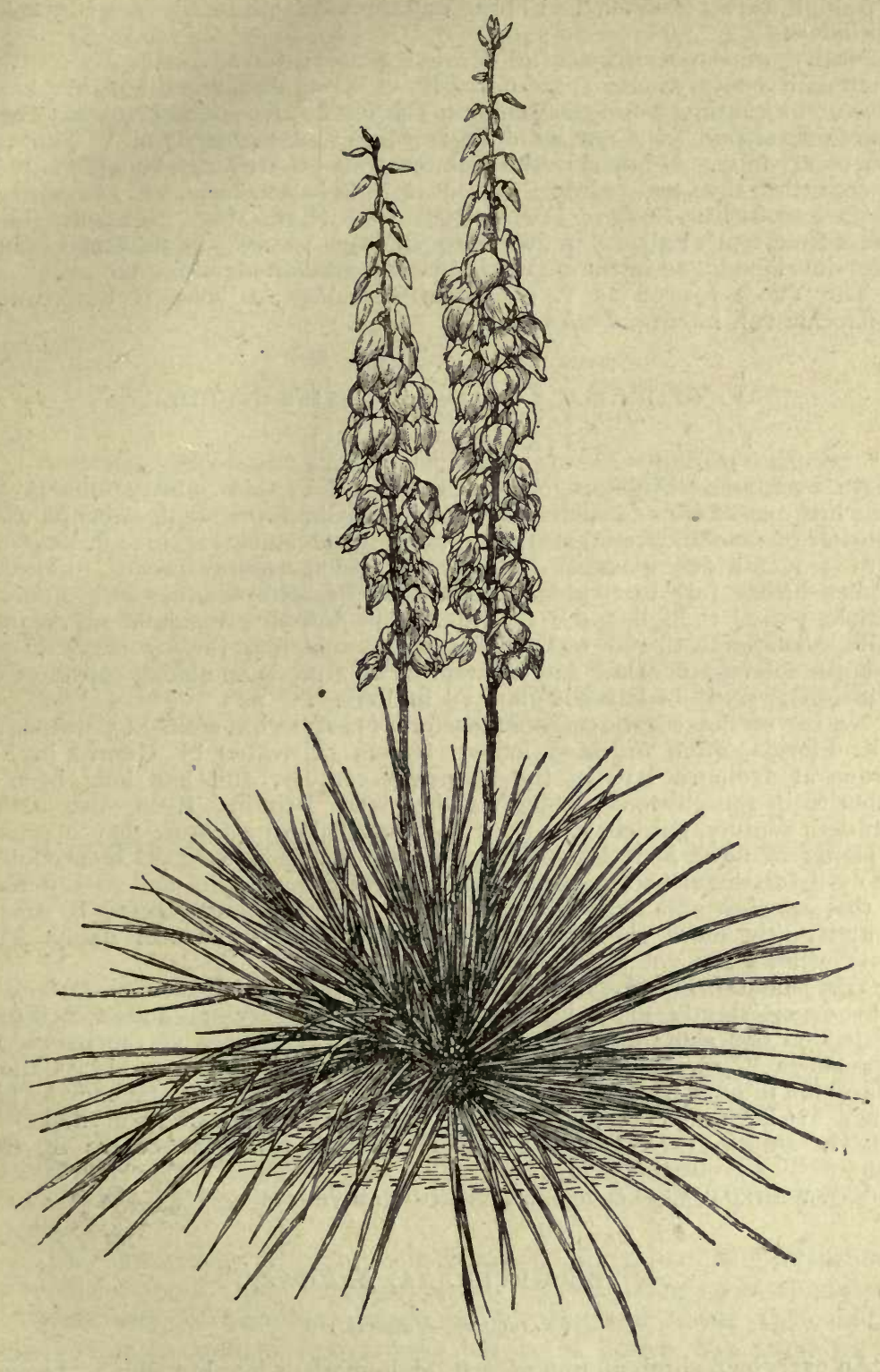

Yucca gladea.

long, $\frac{1}{2}$ to $\frac{3}{4}$ in. wide, tapering to a long fine point, of a glaucous green the margins white, and beset with a few threads. Raceme, erect, 3 to 
$4 \frac{1}{2} \mathrm{ft}$. high, rarely branched. Flower dull greenish white, $2 \frac{1}{2}$ to 3 ins. long, pendulous.

Native of the south central United States; introduced early in the nineteenth century. It is quite hardy at Kew, and several plants have grown on a south slope in the Bamboo Garden for over twenty years. They flower occasionally, but not with the freedom and regularity of Y. gloriosa. and recurvifolia. Neither is the inflorescence so striking, being of a pale green, rather than truly white. Still, it is quite handsome.

Var. STRICTA, Trelease (Y. stricta, Sims; Bot. Mag., t. 2222).-This differs from typical glauca in its more vigorous growth, in its stems being more developed, and in the regularly branched inflorescence.

The Yucca figured as Y. glauca in Bot. Mag., t. 2662, is now called Y. flaccida var. integra, Trelease (q.v.)

\section{Y. GLORIOSA, Linnaus. AdAM'S NEEDLE.}

(Bot. Mag., t. 1260.)

An evergreen shrub up to 6 or $\delta \mathrm{ft}$. high in this country, sometimes branched, but oftener consisting of a single, thick, fleshy stem, crowned with a cluster of numerous stiff, straight, spine-tipped leaves $1 \frac{1}{2}$ to $2 \mathrm{ft}$. long, by 2 to 3 ins. wide; glaucous green when young, quite smooth. Flowers produced from July to September, crowded on an erect, narrowly conical panicle, 3 to $4 \frac{1}{2} \mathrm{ft}$. high, and I ft. wide. The flowers are pendulous, creamy white, sometimes tinged with red or purple outside, the six parts of the perianth oblong-lanceolate and pointed. The fruit is an oblong capsule 2 to $2 \frac{1}{2}$ ins. long, six-ribbed; seeds glossy, $\frac{1}{4}$ in. long.

Native of the coast region of eastern N. America, from S. Carolina to N.E. Florida, often on sand-dunes. It was cultivated by Gerard in his garden at Holborn late in the sixteenth century, and has long been a favourite in the gardens of south and western Britain. Even now, in the twentieth century, gardens can show no more striking a feature than a group of plants in flower. It is closely allied to the commoner Y. recurvifolia, but easily distinguished by the straight, rigid leaves. It is not so common as that species, and although quite hardy in not being affected by frost, is apparently more subject to decay and injury by winter damp and snow. (See plate, vol. i., p. 4.)

Var Ellacombei, Baker (var. nobilis, Carrière; Y. Ellacombei, Baker).Leaves persistently glaucous, the outer ones recurving, and sometimes twisted on one side; not, or scarcely ribbed. Petals red at the back. It approaches Y. recurvifolia in habit. The original plant is said by Canon Ellacombe to have been obtained from Loddiges' nursery at Hackney by his father. It is a fine Yucca, perhaps from gloriosa crossed with recurvifolia. leaf.

Var. MEDIO-STRIATA has a whitish stripe down the centre of the

Var. VARIEGATA.-Leaves striped with dull yellow.

\section{Y. RECURVIFOLIA, Salisbury.}

\section{(Y. recurva, Haworth.)}

An evergreen shrub up to 6 or $8 \mathrm{ft}$. high, more or less branched. Leaves at first glaucous, 2 to $3 \mathrm{ft}$. or even more long, $1 \frac{1}{2}$ to $2 \frac{1}{4}$ ins. wide; tapering to a fine stiff point, all but the upper leaves much recurved. Flowers creamywhite, 2 to 3 ins. across, in an erect panicle 2 to $3 \mathrm{ft}$. high, not so tall, nor standing so clear of the leaves as in Y. gloriosa, and with the flowers more 
loosely arranged; the parts of the flower as in Y. gloriosa. Fruit 2 to $2 \frac{1}{2}$ ins. long; seeds not glossy, about $\frac{1}{3}$ in. long. (See plate, vol. i., p. 58.)

Native of the coast region of the south-eastern United States, especially of Georgia; introduced in 1794. This is the commonest and most easily cultivated of Yuccas, and although not so striking as Y. gloriosa in flower, is a more graceful plant and hardier-or, at any rate, resists snow and damp better. It flowers in late summer, and withstands the smoke of London admirably. It associates well with a formal arrangement of paths and lawns, and gives a very pleasing exotic effect. There are several varieties such as MARGINATA, whose leaves are bordered with yellow; and VARIEGATA, with a yellow line down the centre.

\section{Y. RUPICOLA, -Scheete.}

(Bot. Mag., t. 7 I 72.$)$

A nearly stemless plant, consisting above ground mainly of a dense rosette of leaves, which are 2 to $2 \frac{1}{2} \mathrm{ft}$. long, I to $i \frac{1}{2}$ ins. wide; pale glaucous green, the margins finely toothed, cartilaginous, and yellowish. Flowers in a muchbranched, glabrous panicle 4 to $6 \mathrm{ft}$. high, the branches slender, semi-erect. Flowers pendulous, somewhat bell-shaped, milky white; the three outer parts of the perianth oblong, $\frac{3}{4}$ in. wide; the inner ones broader ( 1 in. wide); all $2 \frac{1}{4}$ ins. long, and pointed.

Native of S. Texas; introduced about 1850 . It flowered with Canon Ellacombe at Bitton, in 1890 , but at present it is extremely rare in cultivation in this country. The yellowish or brownish, horny margin of the leaves mentioned above distinguishes this from all other hardy species.

\section{ZANTHORHIZA APIIFOLIA, L'Héritier. YELLOW ROOT. RANUNCULACEÆ.}

(Bot. Mag., t. 1736.)

A deciduous shrub with creeping roots and erect stems from 1 to $2 \mathrm{ft}$. high. The handsome leaves are pinnate, consisting of three or five stalkless leaflets which are themselves deeply and irregularly toothed, I to 3 ins. long, the basal pair two- or three-lobed. The naked base of the main leaf-stalk varies from 3 to 6 ins. in length. Flowers produced in March and April, along with the young leaves in a cluster of more or less drooping panicles 3 to 5 ins. long; individually the flowers are very small ( $\frac{1}{8}$ to $\frac{x}{4}$ in. wide), lurid purple, petals five, triangular, pointed.

This interesting little shrub is a native of the eastern United States, where it extends from Pennsylvania to Florida, being most abundant in Virginia and N. Carolina; introduced to England about 1776 , but, on account of its lack of any striking beauty of flower, has never become common. The foliage, however, is attractive, and the flowers are amongst the first to appear in spring. Easily increased by division in February. In the milder parts of the country it would appear to be suitable for naturalising in woods and moist shady spots, spreading rapidly as it 
does. The popular name refers to the pright yellow of the roots and stem when cut. The generic name is sometimes spelt "Xanthorrhiza."

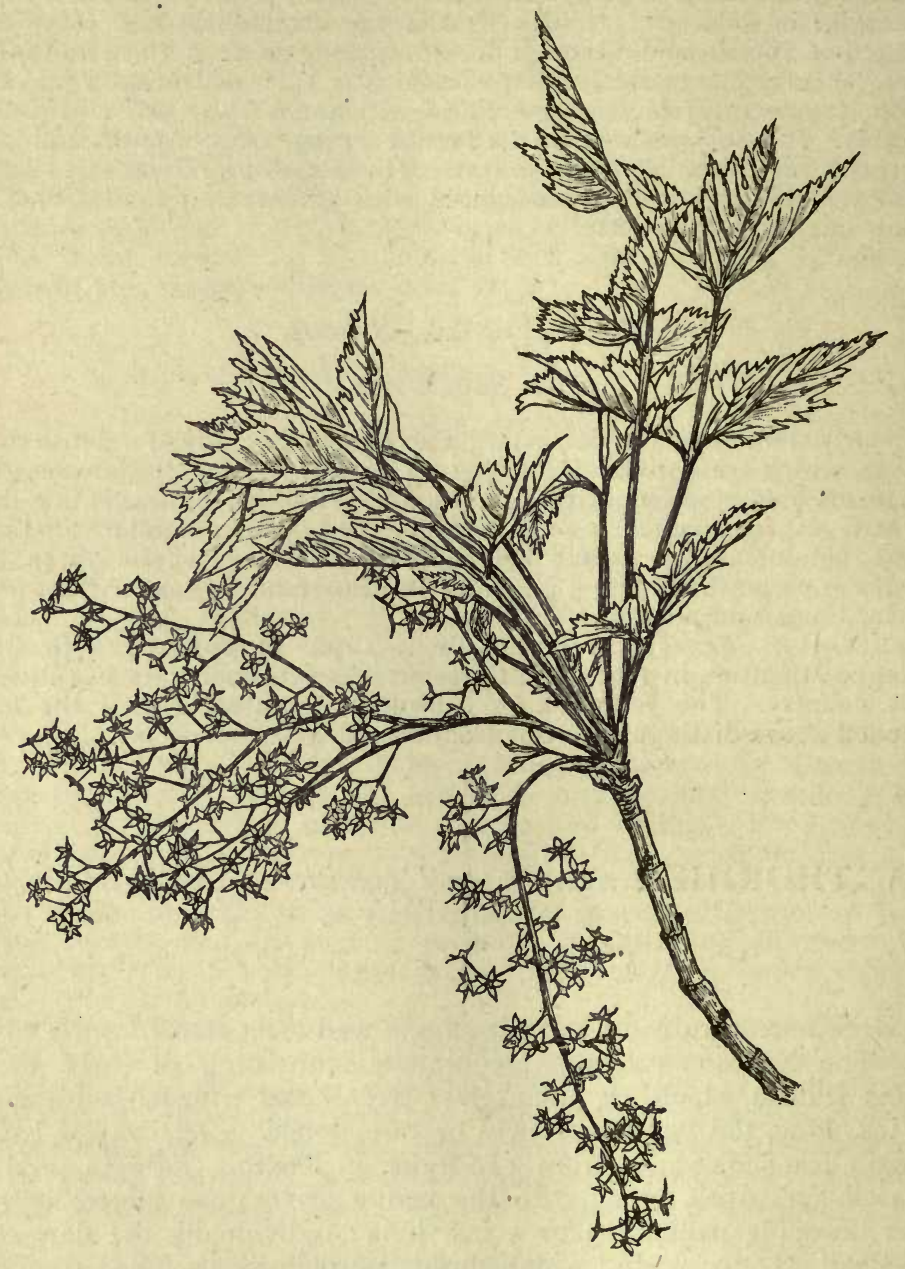

ZANTHORHIZA APIIFOLIA.

\section{ZANTHOXYLUM. RUTACEE.}

A widely spread genus of shrubs and trees belonging to the Rue family, of which some half a dozen hardy species are in cultivation. Their leading characteristics are the strong, aromatic, sometimes unpleasant odour of the crushed leaves, the spiny young branches and 
leaf-stalks, the trifoliolate or pinnate, alternate leaves, the small, mostly unisexual flowers, the two-valved roundish capsules which split downward, and the shining black or blue seeds which, after the bursting of the capsules, often remain for some time attached by a short thread.

These species are not in the first rank of ornamental shrubs, but wellgrown specimens are handsome in foliage. They like a good deep soil, and are best propagated by seeds; when these are not available they may be increased by cuttings made of the young wood in July, or of the roots in spring. The fruits and seeds of some species have a pungent pepperlike taste and are used as a condiment, and the bark contains a powerful stimulant and tonic principle sometimes employed in medicine. The generic name, sometimes spelt Xanthoxylum, refers to the yellowness of the wood of some species.

\section{Z. AIlanthoIDES, Siebold.}

A deciduous tree, 50 to $60 \mathrm{ft}$. high in Japan, the branchlets very stout, not downy, densely set with short, stiff spines. Leaves pinnate and variable in size; on young trees at Kew they have been $3 \mathrm{ft}$. long, but ordinarily are from 10 to 18 ins. Leaflets in from five and a half to eleven and a half pairs, each one 2 to 5 ins. long, ovate or ovate-lanceolate, finely toothed, smooth, dark green. Flowers in a flat corymb 5 ins. or more across, whitish with yellow stamens; two or more corymbs are associated at the end of the branch. Seeds black, compressed and tapering to one end.

Native of Japan and Formosa; often introduced, but unfortunately tender and only adapted for the south-west counties. It rarely survives more than one or two winters at Kew. As its name implies, this tree resembles an Ailanthus in its long, handsome, pinnate leaves.

\section{Z. americanum, Miller. Prickly Ash. Toothache Tree.}

\section{(Z. fraxineum, Willdenow.)}

A spreading, round-headed, deciduous shrub, usually 6 to ro $\mathrm{ft}$. high in this country, but capable of growing twice as high; young shoots brown, downy, becoming smooth and grey with age; armed with stiff spines $\frac{1}{2}$ in. or less long, in pairs. Leaves pinnate, 6 to 8 ins. long with usually five to eleven, but sometimes thirteen, leaflets, often with one or two spines on the main-stalk where the leaflets are attached. Leaflets $1 \frac{1}{2}$ to $2 \frac{1}{2}$ ins. long, ovate or oval, downy beneath especially on the midrib, minutely or not at all toothed. Flowers crowded at the joints of the previous season's shoots, very small, yellowish green. Fruit a blackish, fragrant, two-valved capsule; seeds black and shining.

Native of the eastern United States; introduced during the middle years of the eighteenth century. This shrub is said to have been at one time common in gardens; it is no longer so. The bark and capsules have a pungent, acrid taste, and one of the popular names is given because they have been chewed to alleviate toothache. It is very easily distinguished from the other species here included by the very downy under-surface of the leaves.

\section{Z. BungeI, Planchon.}

A deciduous bush of graceful, spreading habit to ft. or more high; said sometimes to be a small tree over $20 \mathrm{ft}$. high. Branchlets downy or smooth, 
armed with broad, flat spines $\frac{1}{4}$ to $\frac{3}{4}$ in. long. Leaves pinnate, 3 to 5 , sometimes 9 ins. long, aromatic; leaflets seven to eleven, broadly ovate, $\frac{1}{2}$ to $\mathrm{I} \frac{1}{2}$ ins. long, slightly toothed; there are often a few spiny bristles on the upper surface, also on the midrib below; the main-stalk is armed beneath with short spines, also above, where the leaflets are attached. The inflorescence is a small panicle produced at the end of short, axillary twigs. Fruit reddish, with dark dots.

Native of China; introduced to Kew in 1869. One of the hardiest of the genus.

\section{Z. PIPERi'tum, De Candolle. JAPAN Pepper.}

A compact, rounded, deciduous shrub; young shoots more or less downy when young, armed with flattish spines $\frac{1}{2} \mathrm{in}$. long arranged in pairs at each node. Leaves pinnate, from 3 to 6 ins. long, with eleven to twenty-three leaflets, the main-stalk downy, having a few small spines' on the lower side, and slightly winged. Leaflets $\frac{3}{4}$ to $I \frac{1}{2}$ ins. long, ovate, stalkless, slightly toothed, with an occasional prickle on the midrib which is also downy above; dark green, but often yellow in the centre when young. Flowers in panicles 2 ins. long at the end of short axillary twigs; small, green. Seeds black, about the size of large shot.

Native of China and Japan, this shrub is, on the whole, the prettiest of these hardy species. Its neat, bushy habit and graceful foliage consisting of numerous small leaflets, render it quite distinct among hardy shrubs. It most nearly resembles $Z$. schinifolium, but is easily distinguished by having its spines in pairs. It is said to occasionally become a small tree in Japan. The seeds when ground are used by the Japanese as pepper.

\section{Z. PLANISPINUM, Siebola.}

A deciduous shrub up to $12 \mathrm{ft}$. high, with glabrous, spiny branches; spines in pairs, thin, broad and flat at the base, $\frac{3}{4}$ in. long, shining. Leaves 5 to 10 ins. long, trifoliolate or pinnate, with usually three or five, sometimes seven or even nine, leaflets, the main-stalk distinctly winged, often $\frac{3}{8}$ in. wide. Leaflets increasing in size towards the end of the leaf, the terminal one largest and as much as 5 ins. long; others are only half as long; ovate or lanceolate, finely toothed, acuminate. Flowers yellowish, in smali panicles $1 \frac{1}{2}$ ins. long produced from the leaf-axils in spring. Fruit red, warted; seeds black, shining, about the size of large shot.

Native of China and Japan, and nearly allied to the Z. ALATUM, Roxburgh, found in the Himalaya. Probably they are geographical forms of one species. The late Daniel Hanbury recorded the existence of a specimen $12 \mathrm{ft}$. high in his garden at Clapham. It is easily recognised among the other hardy species by its very distinctly winged main leaf-stalk and broad spines. Although deciduous, it will in mild seasons retain its leaves up to Christmas fresh and green. After a hot summer it bears the red fruit freely, and is then very handsome. It suffers in severe winters.

\section{Z. SCHINIFOLIUM, Siebold.}

A deciduous shrub, whose glabrous branches are armed with solitary spines up to $\frac{1}{2}$ in. long. Leaves pinnate, 3 to 7 ins. long, spiny on the mainstalk, and composed of eleven to twenty-one leaflets, which are $\frac{3}{4}$ to $\mathrm{I} \frac{1}{2}$ ins. long, lanceolate, shallowly toothed, nearly or quite smooth, deep green above, paler beneath., Flowers in a terminal flattish cluster, 2 to 4 ins. across; each flower about $\frac{1}{8}$ in. across. Fruit green; seeds blue. 
Native of China, Corea, and Japan. It very much resembles Z. piperitum in leaf, but differs in its spines being solitary (not in pairs), and in its flatter inflorescence produced at the end of the current year's shoot in August.

\section{ZELKOVA. URTICACEA.}

Nearly allied to the elms, the four species of Zelkova at present in cultivation are amongst the most interesting and handsome of hardy trees. They have smooth, beech-like trunks with a scaling bark, and deciduous, alternate, coarsely toothed, feather-nerved leaves, usually harsh to the touch like those of elm. Flowers unisexual; both sexes produced on the same twig, the males at the base, the females solitary in the leaf-axils above them; both sexes small, green, and of no beauty. Seed-vessel roundish, $\frac{1}{6}$ to $\frac{1}{4}$ in. long, with the calyx adhering at the base, slightly horned at the top (winged in Z. Davidiana).

The Zelkovas should be grown in deep, moist, loamy soil where the position is moderately sheltered. Z $\mathrm{Z}$. crenata is the best known of them, and appears to be adapted to all but the most inclement parts of Britain. Both it and Z. acuminata should be raised from imported seed, although they can probably be grafted on elm, as are the other two species.

Z. CRETICA, Spach, not in cultivation, is a shrubby species found in Crete and Cyprus, whose small leaves are thickly downy beneath and coarsely, angularly toothed.

\section{Z. ACUminata, Planchon. KeAKI.}

\section{(Z. Keaki, Maximowicz.)}

A tree 100 or even $120 \mathrm{ft}$. high in Japan, with a tall, smooth, grey trunk, 5 to to ft. in diameter; young shoots at first slightly downy, soon becoming almost smooth. Leaves ovate or ovate-lanceolate, 2 to $4 \frac{1}{2}$ ins. long, $\frac{3}{4}$ to 2 ins. wide; long and taper-poihted, rounded or slightly heart-shaped at the base, with six to thirteen coarse teeth at each side; each tooth with a short, slender point; dark green and furnished with short, scattered hairs above, paler and smooth beneath; stalk $\frac{1}{8}$ to $\frac{1}{4}$ in. long. Flowers produced in April and May on short twigs, the males being borne two or more together at each joint of the leafless bases of the twigs, the females solitary in the axils of the leaves at the end; both small, green, and of no beauty. Fruit roundish, about $\frac{1}{8}$ in. diameter.

Introduced from Japan to England by John Gould Veitch in I86r; native also of Corea and China. Although this tree is described as producing the most highly esteemed of all timbers in its native country-tough, elastic, and durable-in Great Britain it has not proved a great success, and during the fifty years that have elapsed since its introduction, few trees have reached more than $30 \mathrm{ft}$. in height. Judging by the trees at Kew, which have been growing in a favoured situation in good soil, its branches have a tendency to spread rather than grow in height in an open position. It is at the same time an elegant and interesting tree. In a young state it appears liable to injury by spring frosts. From $\mathrm{Z}$. crenata, it is distinguished readily by the smooth twigs and under-surface of the leaves, and by the taper-pointed, thinner leaves with longer, pointed teeth. 


\section{Z. CRENATA, Spach. \\ (Planera Richardii, Michaux.)}

A tree $100 \mathrm{ft}$. high, with a smooth, beech-like trunk, usually comparatively short ( 10 to $20 \mathrm{ft}$. high), dividing into a great number of erect, crowded branches; bark peeling off in flakes; young twigs very downy. Leaves $I \frac{1}{2}$ to 3 ins. long, $\frac{3}{4}$ to $1 \frac{3}{4}$ ins. wide; ovate or oval, rounded or slightly heart-shaped at the base, with seven to eleven coarse sharp teeth down each side; dark green and with scattered hairs above, paler and more downy beneath; stalk about $\frac{1}{8}$ in. long. Flowers on short twigs, the males at the naked base of the twigs, the females in the leaf-axils above them. Fruit about the size of a small pea, distinctly ridged above.

Native of the Caucasus; introduced in 1760. This remarkable tree is undoubtedly one of the most picturesque and distinct of any that can be grown in this country. It is slow-growing and long-lived, and might very well be used as a commemorative tree in preference to many of the exotic conifers so frequently planted for this purpose. Trees at Kew planted about I 760 are now about $60 \mathrm{ft}$. high. The densely clustered branches, much divided at their extremities, suggest a monstrous besom. The timber is of good quality, being tough and durable, but is apparently unknown in the timber trade. The largest tree in the country appears to be at Wardour Castle, in Wiltshire, about $100 \mathrm{ft}$. high. It has no distinct trunk, but a clustered group of more than a dozen stems. There is also a fine one at Holm Lacy, Hereford, whose height Mr Elwes gives as $95 \mathrm{ft}$., its trunk $9 \mathrm{ft}$. in girth. The species occasionally flowers in this country, and sometimes bears imperfect fruit, which for its proper development needs more summer heat than we experience.

\section{Z. Davidiana, Franchet.}

\section{(Hemiptelea Davidii, Planchon; Planera Davidii, Hance.)}

A deciduous tree, apparently not large, armed with stout thorns; young shoots hairy. Leaves oval, $\frac{3}{4}$ to $2 \frac{1}{4}$ ins. long, $\frac{1}{2}$ to $\mathbf{I}$ in. wide; pointed, slightly heart-shaped at the base, with seven to fifteen teeth along each side; upper surface dark green and at first beset with pale, scattered hairs, each springing from a curious circular depression which, after the hair falls away, turns dark; lower surface smooth except for a few scattered hairs on the midrib and chief veins at first. Fruit conical, $\frac{1}{4}$ in. long, scarcely so wide, two-edged, slightly winged, shortly but distinctly stalked; stalk $\frac{1}{12}$ in. long.

Native of N. and Central China and Corea ; introduced to France by Mr Maurice de Vilmorin, and from his garden at Les Barres to Kew in 1908. It is a promising tree and grows freely, being very distinct from the other species in its thorns and stalked, winged fruit. It is often regarded as generically-distinct from Zelkova. Its fruits have not been produced with us, but I have seen them in great quantity on the tree at Les Barres. The thorns in wild trees are very formidable, sometimes 4 or 5 ins. long, but they become much less so on our cultivated trees.

\section{Z. Verschaffelti, Nicholson. \\ (Ulmus Verschaffelti, Hort.)}

A small tree, or unless trained to a single stem, often a bush, with slender spreading shoots, slightly hairy when quite young; winter buds often in pairs. Leaves $\mathrm{r} \frac{1}{2}$ to $2 \frac{1}{2}$ ins. long, $\frac{3}{4}$ to $1 \frac{3}{4}$ ins. wide; oval or ovate, with usually six to nine coarse, triangular teeth at the sides (usually fewer on one side than on the other), the larger teeth $\frac{1}{4}$ in. deep; upper surface dark 


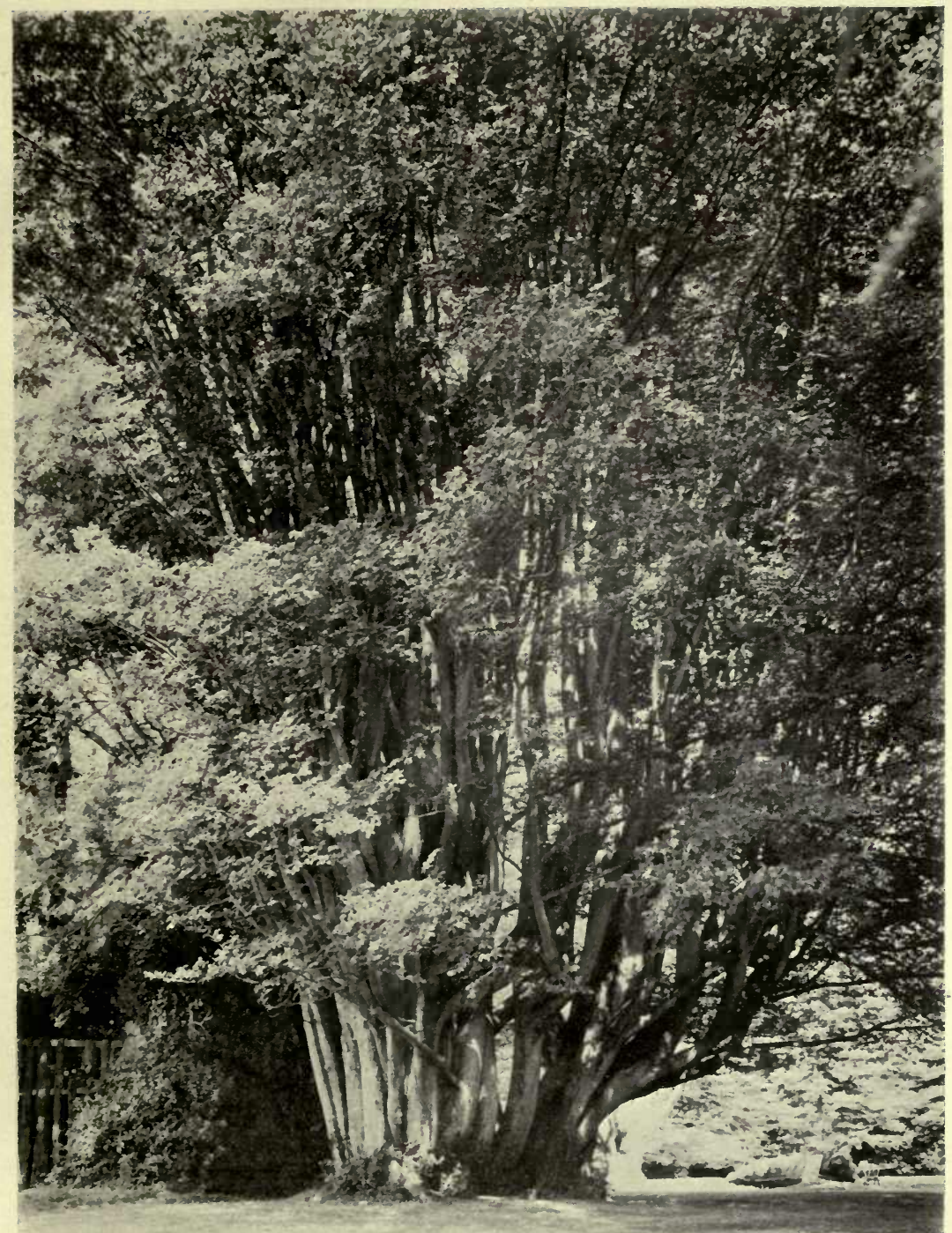

Zelkova CRenata at Wardour Castle. 

green and with stiff, short hairs; lower surface with more numerous, softer hairs; stalk $\frac{1}{8}$ to $\frac{3}{16}$ in. long. Fruit (according to Henry) like that of Z. crenata, but somewhat smaller.

There is no wild specimen of this tree in the Kew Herbarium, and its origin is not definitely known. Dippel, who first distinguished it as a Zelkova, and figured it in his Handbuch der Laubholzkunde, ii., fig. 14, in I892, suggests an Eastern Asiatic origin for it. It appears, however, to have considerable affinity with $Z$. crenata, and is more likely to be of Caucasian origin. Henry suggests it may be a hybrid between $Z$. cretica, a native of Crete and Cyprus, not in cultivation, and Z. crenata; but does not explain how such a cross can have been effected. It is a pretty and distinct shrub or tree, well marked by the deep angular cutting of the leafmargins. It has been cultivated at Kew since I886, and is perfectly hardy, slow growing, and forming a bushy head. It was long thought to be an elm, but it fruited at Paris in 1908, and was conclusively shown to be a Zelkova.

\section{ZENOBIA SPECIOSA, D. Don. ERICACEA.}

(Andromeda cassinefolia, Sims; Bot. Mag., t. 970.)

A deciduous or sub-evergreen shrub of somewhat irregular, thin habit, 4 to $6 \mathrm{ft}$. high, devoid of down or hairs. Leaves oblongovate, tapering at the base, pointed or rounded at the apex, shallowly toothed; I to $2 \frac{1}{4}$ ins. long, $\frac{1}{2}$ to $I_{4}^{1}$ ins. wide ; of a dark shining green. Flowers pendent; produced, often in fours or fives, in axillary clusters on the terminal portion of the shoots of the previous year, each on a stalk $\frac{1}{2}$ to $\frac{3}{4}$ in. long, forming

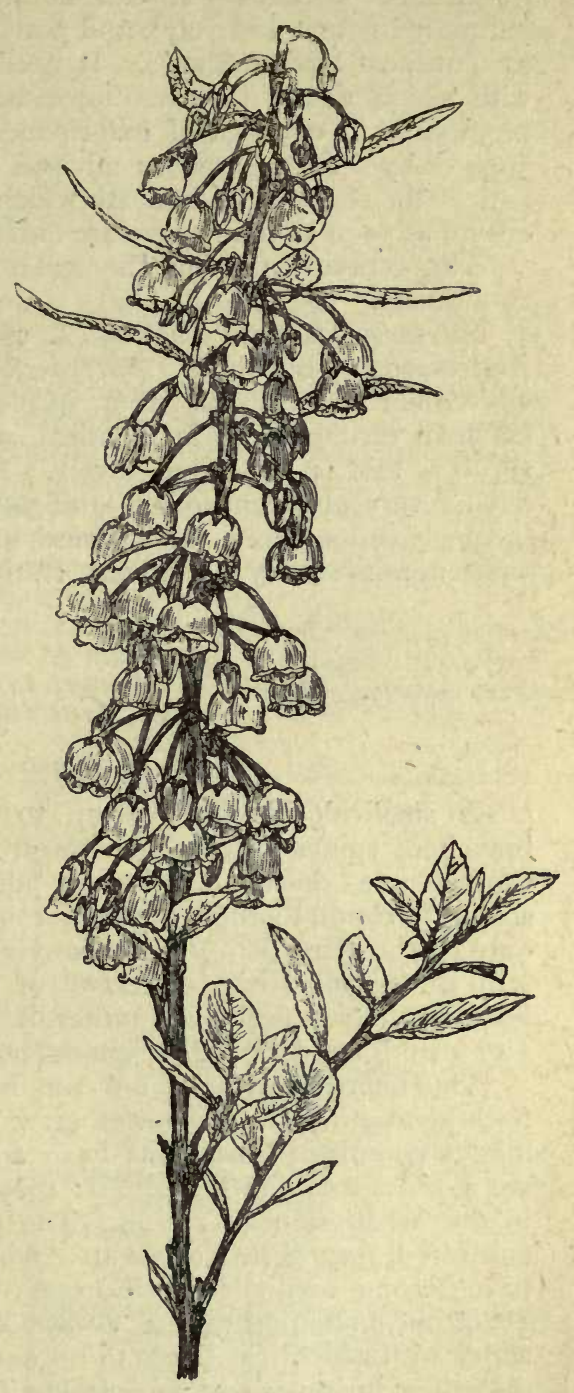

ZeNobia PULVERULENTA.

leafy or naked racemes 4 to 8 ins. long. Corolla pure white, bell-shaped, $\frac{3}{8}$ in. wide, with five shallow lobes; calyx-lobes five, triangular, persisting at the base of the dry, flattish-globose (or orange-shaped) seed-vessel.

Native of the eastern United States from N. Carolina to Florida; intro- 
duced in r8or. This beautiful shrub, whose pendent blossoms resemble large lily-of-the-valley flowers, is, after long neglect, becoming more frequent in gardens. It can be forced into bloom early (it flowers naturally in June and July), and potted plants profusely in flower may be seen at most Spring Shows. It needs a peaty soil, or a light loamy one, with which decayed leaves have been freely incorporated. It can be propagated by cuttings of half-ripened wood placed in gentle heat about July, or by seeds treated as advised for rhododendrons. The flowering part of the shoot, from beneath which the young shoots spring, should be cut off as soon as the flowers are faded, if seed is not required.

Var. QUERCIFOLIA has the leaf-margins set with shallow wavy lobes. A curiosity.

Z. Pulverulenta, Pollard (Z. speciosa var. pulverulenta, Nicholson; Andromeda pulverulenta, Bartram).-For garden purposes it is more convenient to treat this as a species, as some authors do, but in all essential characters it is identical with $Z$. speciosa. Beautiful as that shrub is, this is still more lovely. It is easily distinguished from it by having very glaucous foliage and young shoots. It blossoms with even greater freedom, and the mixture of young, blue-white leaves and pure white flowers is very attractive. Native of the same areas as Z. speciosa.

\section{ZIZYPHUS SATIVA, Gaertner. JUJUBE. RHAMnACEÆ.}

\section{(Z. vulgaris, Lamarck.)}

A small deciduous tree up to $30 \mathrm{ft}$. high, with glabrous, spiny branches; spines in pairs, the longer one up to $I_{4}^{1}$ ins. long, straight, the shorter one decurved. Leaves alternate, ovate to ovate-lanceolate, shallowly round-toothed, blunt or rounded at the apex, smooth, or downy only on the veins beneath; three-veined at the base. Flowers less than $\frac{1}{4}$ in. across, yellowish, borne two or three together on short stalks in the leaf-axils. Fruit fleshy and rather like a small plum, roundish egg-shaped, $\frac{1}{2}$ to $\mathrm{r}$ in. long, dark red, or almost black when ripe.

This interesting tree is not very hardy. At Kew it has lived outside for several years, but does not grow vigorously; it is worth trying in the milder counties. The fruits have a pleasant acid taste when fresh, but are more agreeable when dried; they are commonly eaten in both states in the Mediterranean region. The species now extends, both wild and cultivated, from S.E. Europe to Afghanistan, China, and Japan, but may have become naturalised in Europe. It was in cultivation in England in I640, but its tenderness has always kept it rare. The only other hardy shrub with which it is likely to be confused is Paliurus australis, which it resembles in leaves and spines; but the larger and prettier flowers of the Paliurus, produced in short branched umbels, and especially the dry, flat, winged fruits, are very distinct. 


\section{INDEX}

THE general arrangement of this work is alphabetical, and it has not been thought necessary to index names which appear in their proper order. The following is an index of Part I., of "popular" or English names and of synonyms in Part II.; also of a considerable number of trees and shrubs that are not of sufficient merit or distinctness to have claimed a separate heading in the alphabetical arrangement. In order to make the book as comprehensive as possible, mention of these has not been omitted altogether, and they are briefly described or alluded to under the species to which they are most nearly allied, or most nearly resemble. The notices of such species and varieties are not, therefore, to be found in their alphabetical order in the body of the book, but can be found by reference to this index.

The names printed in SMALL CAPITALS are of trees and shrubs illustrated in the text. The trees, etc., illustrated by plates may be found by reference to the list given at the beginning of each volume. The leading generic names are printed in Clarendon.

\section{A}

Aaron's beard, i. 634

Abbotsbury, holly at, i. 648

Abel, Mr Clarke, i. 113

Abelia chinensis, Hort., i. II 5

chinensis, $R$. Br., i. II 3

chinensis $\times$ uniflora, i. II 5

FLORIBUNDA, Decne., i. II4

rupestris, Lindl., i. I I 3

uniflora $x$ chinensis, i. I 5

Abercairney, Irish juniper at, i. 67 I

Abies Apollinis, Link, i. I 20

baborensis, Letour., i. I 25

bifida, Sieb., i. I 2 I

BRACHYPHYLLA, Maxim., i. 119

Brunoniana, Ldl., ii. 604

canadensis, $M c h x$., ii. 605

chinensis, Fr., ii. 606

Douglasii, Ldl., ii. 259

Eichleri, Lauche, i. 127

Fortunei, Murr., i. 684

homolepis, Sieb., i. I I9

japonica, Rov., ii. 260

Khutrow, Loud., ii., 158

lasiocarpa, Hort., i. I 22

lasiocarpa, Nutto, i. 117

magnifica var. shastensis, Lemmon, i. 123

Mariesii (of Bot. Mag.), i. 128

Menziesii, $L d l$., ii. 164
Abies nobilis var. robusta, Hort., i. 123

NORDMANNIANA, Spach., i. I 25

Pattoniana, ii. 607

Picea, Mill., ii. I 57

religiosa, Schlecht., i. I I 7

sachalinensis, Mast., i. II7

sibirica, Ledeb., i. II7

subalpina, Engelm., i. 117

Tsuga, Sieb., ii. 608 nana, Hort., ii. 607

umbellata, Hort., i. I 19

VEITCHII, Lindl., i. 127

venusta, Koch, i. I 20

Vilmorinii, Mast., i. 120

Webbiana var. Pindrow, Brand., i. 126

Abutilon megapotamicum, St Hil., i. 129 vexillarium, i. I 29

Acacia, ii. 4 I2

Julibrissin, Willd., i. I77

rose, ii. 410

Acanthopanax divaricatum, Seem., i. 132 LEUCORRHIZUM, Harms, i. I 30

spinosum, Hort., i. I 3 I

Acer ætnense, Hort., i. 149

argutum, Maxim., i. I 34, 135

capillipes, Maxim., i. 1 34,136

cappadocicum, Gled., i. 145

CIRCinatum, Pursh, i. 137,138

colchicum rubrum, Hort., i. I 45

cultratum, Wall., i. 145

eriocarpum, Michx., i. 139 
Acer heterophyllum, Willd., i. 139

insigne, Boiss., i. 144 (of Bot. Mag.), i. 160

Lorbergii, Hort., i. 155

MACROPHYLLUM, Pursh, i. 146

Mono, Maxim., i. I 54

neapolitanum, Tenore, i. 152

Negundo heterophyllum, Hort., i. 150 odessanum, Rothe, i. 150

nigrum, Mich $x$., i. 158

obtusatum, Kit., i. I 52 neapolitanum, $P a x$, i. I 52

Opalus, Mill., i. I5 I

opulifolium, Villars, i. I 5 I

pictum colchicum, Hort., i. I45 tricolor, Hort., i. 154

platanoides integrilobum, Zabel, i. I4I polymorphum, Sieb., i. I 52

Pseudoplatanus flavo - variegatum, Loud., i. 156

rubrum, introduction of, i. 4

rufinerve, Sieb., i. I 34, I 57

saccharinum, $L$., i. I 39

saccharinum, Wangh., i. I 58

sanguineum, Spach, i. I57

striatum, $D u$ Roi, i. 153

tataricum Ginnala, Maxim., i. 142

trifidum, Hook., i. I 36

trinerve, Dipp., i. I 36

zoeschense, $P a x$, i. 149

Actinidia polygama, Sieb., i. I63 (of Bot. Mag.), i. I62

Adam's needle, ii. 688

Adenorachis, ii. 27 I

Ægle sepiaria for hedges, i. 96

EFsculus arguta, Buckl., i. I69

asplenifolia, Hort., i. 170

CALIFORNICA, Nutt., i. 167

flava, A iton, i. I72

humilis, Lodd., i. I 73

INDICA, Colebr., i. I 7 I

at Tortworth, i, I 72

macrostachya, Michx., i. 173

octandra hybrida, Sarg., i. I72

rubicunda, Lois., i. 168

Wilsonii, Rehd., i. I69

Ailantho, i. I75

Allanthus flavescens, Carr., i. 32 I

glandulosa for streets, i. 89

moluccana, i. I75

Aiton, William, i. 6

Alabama snow-wreath, ii. 97

Aldenham, Cratægus at, i. 434

Alder, Caucasian, i. 185

common, i. I8I

green, i. 185

grey, i. I 82

Himalayan, i. 183

hybrid, i. I 80

Italian, i. I79

Japanese, i. 182

Oregon, i. 183
Alder, seaside, i. 183

Sitka, i. I 84

smooth, i. I 84

speckled, i. I 82

thorn-leaved, i. I 81

white, i. $37 \mathrm{I}$

Alexandrian Laurel, i. 465

Allegheny spurge, ii. II 9

Allspice, Californian, i. 284

Carolina, i. 283

Almond, bitter, ii. 228

common, ii. 228

dwarf Russian, ii. 245

silver, ii., 245

sweet, ii. 228

Almonds, ii. 225

Almondsbury, Cneorum at, i. 374

Alnus alnobetula, Koch, i. 185

brembana, Rota, i. 186

cordata, Desf., i. 179

CORDIFOLIA, Ten., i. 179

crispa, Pursh, i. 185

firma Sieboldiana, i. I8 I

glutinosa barbata, Ledeb., i. I 78 oxyacanthæfolia, Lodd., i. I8 1

incana laciniata, Hort., i. 182 pinnatifida, Hort., i. 182

lanata, Duthie, i. 180

multinervis, $C$. $K$. Sch., i. 180

occidentalis, Dieck, i. 185

pubescens, Tausch, i. 18I

rubra, Bong., i. 183

rugosa, $C$. Koch, i. 184

Sieboldiana, Matsu., i. I 8 r

Spæthii, Callier, i. 183

Yasha, Matsu., i. 180

Alpine Azalea, ii. 36

rose, ii. 355

Aloysia citriodora, Orteg, ii. 32

Altagana, i. 29 I

Althæa frutex, Hort., i. 619

AMELANCHIER ALNIFOLIA, Torr., i. 187

Bartramiana, Roem., i. I 89

CANADENSIS, $M e d$., i. I 88

japonica, $M i q$. ., i. 187 oblongifolia, Torr., i. 189

Oxyodon, Koehne, i. 189

utahensis, Koehne, i. rgo

VULGaRIS, Moench, i. Igr

Amelancier, i. I 86

American beech, i. 550

Amherst, Lord, i. II 3

Amice gooseberry, ii. 398

Amorpha californica, Hook, i. 192 virgata, Small, i. 192

Ampelopsis, ii. 665 aconitifolia, Bge., ii. 665 arborea, Koehne, ii. 666 bipinnata, Mchx., ii. 666 brevipedunculata, $D_{i p p}$., ii. 668 cordata, Mchx., ii. 672

Delavayana, Plan., ii. 669 
Ampelopsis heterophylla, Sieb., ii. 671

hirsuta, Donn., ii. 675

Hoggii, Hort., ii. 395

japonica, Hort., ii. 395

leeoides, Plan., ii. 673

Lowi, Hort., ii. 672

megalophylla, Diels, ii. 673

orientalis, Plan., ii. 674

quinquefolia, Hort., ii. 678

sempervirens, Hort., ii. 676

serianæfolia, Bge., ii. 665

Veitchii, Hort., ii. 67 I

Amphiraphis albescens, $D C$., ii. 83

Amygdalopsis Lindleyi, Carr., ii. 256

Amygdalus communis, $L$., ii. 228

humilis, Edgew., ii. 238

incana, Pall., ii. 238

nana, $L .$, ii. 245

orientalis, Mill., ii. 245

Persica, L., ii. 247

Andrachne phyllanthoides, Muell., i. I 94

Andromeda arborea, $L$., ii. II 7

axillaris, Lam., ii. I8

cærulea, $L$., ii. 147

calyculata, $L .$, i. 302

campanulata, $M i q$. ., i. 512

cassinefolia, Sims, ii. 695

Catesbæi, Walt., ii. 18

coriacea, $A$ it., ii. I68

cupressina, Hook., i. 305

Davisiæ, $C$. $K$. Sch., ii. I 9

fastigiata, Wall., i. 305

floribunda, Pursh, ii. I65

formosa, Don, ii. 166

glaucophylla, Link, i. 194

hypnoides, $L$., i. 305

japonica, Thunb., ii. 167

mariana, L., ii. 168

nikoensis, Max., i. 514

nitida, Bartr., ii. I68

perulata, Miq., i. 5 I 3

POLIFOLIA, $L_{\text {., }}$ i. I 95

pulverulenta, Bartr., ii. 696

racemosa, L., ii. 20

recurva, Buckl., ii. 20

spicata, Wats., ii. 20

tetragona, $L$., i. 305

Androsæmum officinale, Alli., i. 633

Angelica tree, Chinese, i. 197

Anise, star, i. 653

trees, i. 652

Anthyllis erinacea, L., i. 525

Apple, crab, ii. 287 red Astrachan, ii. 287

Apricot, black, ii. 234

Briançon, ii. 231

common, ii. 229

Japanese, ii. 244

plum, ii. 253

Siberian, ii. 253

Apricots, ii. 226
Aralia Chinensis, $L$, i. 198

japonica, Thunb., i. 554

Maximowiczii, V. Houtte, i. I3I

spinosa, L., i. I 98

Arboretum at Kew, i. 6

Arbor-vitæ, ii. 586

Chinese, ii. 587

Japanese, ii. 586

Arbutus andrachnoides, Link, i. 201

furiens, Hook., i. 200

magnifica, Hort., i. 201

MeNZIESII, Pursh, i. 202

photinæfolia, Hort., i. 201

procera, Dougl., i. 201

Rollissoni, Hort., i. 201

tomentosa, Pursh, i. 205

Unedo Croomei, Hort., i. 203

Arceuthos drupacea, Ant., i. 672

Arctostaphylos californica, Hort., i. $20 j$ MANZANITA, Parry, i. 204

nevadensis, Hort., i. 205

Argyll, Duke of, i. 5

Aria, ii. 270

Decaisneana, Lav., ii. 276

nivea, Host., ii. 274

Aristolochia macrophylla, Lam., i. 208

Arley Castle, juniper at, i. 677

maples at, i. I 56, I 58, I60

sugar pine at, ii. 183

tamarack at, ii. 6

Armeniaca brigantiaca, Pers., ii. 23 I dasycarpa, Pers., ii. 234

Mume, De Vr., ii. 244

sibirica, Pers., ii. 253

vulgaris, Lam., ii. 229

Arnold Arboretum, foundation of, i. I I

Aronia, ii. 271

arbutifolia, Med., ii. 274

melanocarpa, Nutt., ii. 287

Arrow Wood, ii. 647

Arundinaria Fortunei (green), i. 216

Hindsii graminea, Bean, i. 2 I 5

Kokantsik, Kurz, i. 2 I 7

macrosperma tecta, $A$. Gr., i. 220

metallica, Mitf., i. 218

nobilis, Mitf., i. 2 I4

Ascyrum Crux-andrea, L., i. 220

Ash, Algerian, i. 566

Arizona, i. 575

Biltmore, i. 564

black, i. 570

blue, i. 573

common, i. 567

fringe-flowered, i. 566

green, i. 569

Himalayan, i. 568

Japanese flowering, i. 569

Manchurian, i. 569

manna, i. 572

Maries', i. 570

mountain, ii, 27 I, 276

narrow-leaved, i. 563 
Ash, one-leaved, i. 568

Oregon, i. 57 I

prickly, ii. 691

red, i. 572

Spath's, i. 573

swamp, i. 565

Syrian, i. 574

Texan, i. 574

Utah, i. 564

weeping, i. 568

Wentworth weeping, i. 568

white, i. 562

Ashridge, Queen beech at, i. 552

Aspen, ii. 209, 219

American, ii. 220

downy, ii. 220

large-toothed, ii. 214

weeping, ii. 220

Aster cabulicus, $L d l$., ii. 83

Astragalus massiliensis, Lam., i. 222

TRAGACANTHA, L., i. 222

Atholl, Dukes of, i. 5

ATHROTAXIS CUPRESSOIDES, Don, i. 223

Doniana, Maule, i. 224

fossil, in Sheppey, i. 224

Atlas cedar, i. 323

Atragene, i. 352

alpina, $L$. ., i. 354

americana, Sims, i. 368

sibirica, $L_{\text {. }}$ i. 355

Atraphaxis frutescens, Koch, i. 225

latifolia, Koch, i. 225

MUSCHETOWI, Krass., i. 225

Atriplex Breweri, S. Wats., i. 227

Nuttallii, S. Wats., i. 227

Aucuba himalaica, Hk. f., i. 229 in shade, i. IOI

Aucuparia, ii. 271

Autumnal colour in trees and shrubs, i. 79

Avignon berry, ii. 333

graine d', ii. 333

Azalea albiflora, Ktze., ii. 340

Alpine, ii. 36

amœena, Ldl., ii. 34 I

"Anthony Koster," ii. 369

arborescens, Pursh, ii. 34I

calendulacea, $M c h x$., ii. 346

canescens, $M c h x$., ii. 348

dilatatum, Ktze., ii. 353

Ghent, ii. 337, 368

glauca, ii. 385

indica, $L .$, ii. $36 \mathrm{I}$

alba, $L d l$. ii. 365

Kæmpferi, Rehd., ii. 363

ledifolia, $H k_{0}$, ii. 365

linearifolia, $H k$., ii. 366

mollis, Hort., ii. 368

mountain, ii. 348

nudiflora, $L$., ii. 370

occidentalis, Torr., ii. 370

ovata, Ldl., ii. $37 \mathrm{I}$

pontica, $L$., ii. 356
Azalea rhombica, Ktze., ii. 375

serpyllifolia, $A$. Gr., ii. 378

sinensis, Lodd., ii. 379

Tschonoskii, Ktze., ii. 383

Vaseyi, Rehd., ii. 383

viscosa, L., ii. 385

Azara serrata, Ruiz, i. 229

Azarole, i. 421

\section{B}

"Bachelor," derivation of, ii. Io

Bagshot Park, Cunninghamia at, i. 441

Baillie, James, murder of, i. I 56

Balm of Gilead, ii. 2 I 2

Balsam poplars, ii. 209

Bamboo, i. 2I0, 23 I

black-stemmed, ii. 152

cultivation of, i. 2 I 2

dwarf, i. 218

square-stemmed, i. 231

tortoise-shell, ii. I 5 I

Veitch's, i. 220

Bambusa albo-marginata, Hort., i. 220

albo-striata, Hort., i. 219

angustifolia, De Lahaie, i. 213

aurea, Hort., ii. 149

Castillonis, Marl., ii. I 50

chrysantha, Hort., i. 214

erecta, Hort., i. 216

falcata, Hort., i. 214

fastuosa, Marliac, i. 215

Fortunei aurea, Hort., i. 213 variegata, Hort., i. 215

gracilis, Hort., i. 2 I 4

graminea, Hort., i. 2 I 5

Henonis, Hort., ii. 150

Laydekeri, Marl., i. 2 Ig

marmorea, Mitf., i. 217

Mazeli, Hort., ii. I52

Metake, Sieb., i. 2 I6

mitis, Hort., ii. I 5 I

Nagashima, Marliac, i. 216

nana, Hort., i. 231

nigra, Lodd., ii. 152

palmata, Burbidge, i. 218

puberula, Miq., ii. I 5 I

pumila, Marliac, i. 218

pygmæa, Miq., i. 218

Quilioi, Carr., ii. 152

Ragamowski, Hort., i. 219

ruscifolia, Sieb., ii. I52

Simoni, Carr., i. 219

tessellata, Munro, i. 219

Vilmorinii, Hort., i. 2 I3

viminalis, Veitch, ii. 153

viridi-glaucescens, Carr., ii. 153

viridi-striata, Hort., i. 2 I 9

Banister, John, i. 5

Banks, Sir Joseph, i. 7

Bannut, i. 667 


\section{INDEX}

Barberry, American, i. 237

common, i. 25 I

creeping, i. 247

Cretan, i. 238

Darwin's, i. 238

Darwin's, for hedges, i. 95

dwarf, i. 240

Fendler's, i. 240

for hedges, i. 95

Fortune's, i. 240

Fremont's, i. 240

holly-leaved, i. 243

Hooker's, i. 243

Mount Etna, i. 234

Mrs Wilson's, i. 252

Nepal, i. 245

Neubert's hybrid, i. 245

New Mexican, i. 250

Sargent's, i. 247

Siberian, i. 247

Siebold's, i. 248

Thunberg's, i. 250

warted, i. 25 I

Yunnan, i. 253

Bark, trees and shrubs with handsome, i. 72

Bartram, John, i. 6

William, i. 6

Bayberry, ii. 88,89

Californian, ii. 89

Bayfordbury, pines at, ii. 193

Bay laurel, ii. Io

Loblolly, i. 597

poison, i. 652

swamp, ii. 69

Beach heather, i. 662

Bean, Indian, i. 31 I

Bearberry, black, i. 204 red, i. 205

Bearwood, Vaccinium at, ii. 628

Beaufort, Duchess of, i. 5

Beech, American, i. 550

Antarctic, ii. 98

Australian, ii. 100

coccus, i. 553

common, i. $55 \mathrm{I}$

copper, i. 552

Cunningham's, ii. 99

Dawyck, i. 552

fern-leaved, i. 552

golden, i. 553

Japanese, i. 55 I

mountain, ii. 99

oak-leaved, i. 553

"Prince Geo. of Crete," i. 552

purple, i. $55^{2}$

Queen, at Ashridge, i. 552

Roblé, ii. 100

Siebold's, i. 55 I

weeping, i. 552 purple, i. 553

Beeches, southern, ii. 97

Beggar's plant, i. 369
Bell, golden, i. $55^{8}$

rue, i. 368

Belvoir, Azara at, i. 230

Benthamia fragifera, $L d l$., i. 387 japonica, Sieb., i. 389

Benzoin æstivale, Nees, ii. 30 obtusilobum, Ktze., ii. 30 præcox, Sieb., ii. 3I

Berberis acuminata (of Bot. Mag.), i. 24I amurensis, Rupr., i. 252

angulizans, Hort., i. 237

ARISTATA, $D C$., i. 235

Bealei, Fort., i. 244

Chitria, Lindl., i. 236

congestifiora, Gay, i. 242 hakeoides, $H k_{.} . f_{.}$, i. $24 \mathrm{I}$

coriaria, Lindl., i. 236

Darwinii nana, Hort., i. 238, 249

diaphana, Maxim., i. 253

DICTYOPHYLLA, Franch., i. 239

dulcis, Sweet, i. 236

fascicularis, Sims, i. 246

glumacea, Spreng., i. 245

HAKEOIDES, C. K. SChn., i. $24 \mathrm{I}$

ilicifolia, Hort., i. 243, 245

Jamesoni, Hort., i. 243

Knightii, Hort., i. 243

Maximowiczii, $R g l$. , i. 250

reflexa, Hort., i. 249

SINENSIS, Desf., i. 248

stenophylla for hedges, i. 95

subcaulialata, C. K. Sch., i. 249

vulgaris amurensis, $R g l$. , i. 252

Wallichiana, $D C$., i. 243

Wallichiana, Hort., i. 243 hypoleuca, Hort., i. 237 pallida, Hort., i. 237

Berchemia scandens, Koch, i. 254

Berry, Avignon, ii. 333

box-, i. $58 \mathrm{I}$

buffalo, ii. 5 I I

coral, ii. 563

cow-, ii. 630

deer-, ii. 629

dew-, ii. 455

farkle-, ii. 622

ink, i. 647

partridge, i. $58 \mathrm{I}$

salmon, ii. 464

sheep, ii. $65 \mathrm{I}$

silver, ii. 505

smooth winter, ii. 648

snow-, ii. 564

stretch-, ii. 5 I 6

wine-, ii. 466

wolf-, ii. 563

Betula alba, L., i. 26r, 263

alpestris, Fries, i. 260

Bhojpattra, Wall., i. 263

crispa, i. 186

fruticosa, Pali., i. 257

intermedia, Thomas, i. 260 
Betula kenaica, Evans, i. 26I

laciniata, Wahl., i. 264

macrophylla, Hort., i. 259

MaximowiczII, Rgl., i. 259

occidentalis, Sarg., i. 258

papyracea, Ait., i. 260 occidentalis, Dipp., i. $25^{8}$

papyrifera kenaica, Henry, i. 26I

Lyalliana, Koehne, i. 258

pendula, Roth, i. 263

utilis Jacquemontii, Rgl., i. 257

virgultosa, Fries, i. 262

Bignonia grandiflora, Thunb., ii. 582 radicans, $L$., ii. 583

Bilberry, ii. 628

bog, ii. 630

dwarf, ii. 624

Bindweed, rough, ii. 5 I 5

Biota orientalis, Endl., ii. 587

Sieboldii, ii. $5^{8} 7$

Birch, black, i. 258

cherry, i. 258

dwarf, i. 260

grey, i. 26I

Himalayan, i. 263

low, i. 262

paper, i. 260

purple, i. 264

river, i. 260

shrubby, i. 257

silver, i. 263

Swedish, i. 264

western black, i. 257

white, i. 26I

Wilson's, i. 264

yellow, i. 258

Young s weeping, i. 264

Yukon, i. 255

Birches, hybrid, i. 255

Bird Cherry, ii. 226, 246

Gray's, ii. 237

Himalayan, ii. 233

Virginian, ii. 257

Birthworts, i. 206

Bitter nut, i. 299

Bittersweet, ii. 5 I9

Bitton Vicarage, Ægle sepiaria at, i. I65

barberry at, i. 240

Coriaria at, i. 382

Corokia at, j. 394

Black bearberry, i. 204

Blackberry, high, ii. 463

Kittatiny, ii. 463

low, ii. 455

Newman's Thornless, ii. 463

Black birch, i. 258

western, i. 257

Black currant, ii. 405

American, ii. 398

Black poplars, ii. 209

Blackthorn, ii. 253

Bladder-nut, i. 547,550
Bladder Senna, i. 377

Blastophaga, and the fig, i. 556

Blueberry, low, ii. 629 mountain, ii. 625

swamp, ii. 624

Blue flowers of Hydrangea, i. 626

Boboli Gardens, cypresses at, i. 450

Bog rosemary, i. 194

Bois puant, i. 193

Boretta cantabrica, Ktze., i. 465

Borya acuminata, Willd., i. I64

ligustrina, Willd., i. 164

Bosea Amherstiana, ii. 22

Botanical Magazine, foundation of, i. 7

Botley Hill, hickory at, i. 299

Botrytis cinerea on Thuya, ii. 588

Bowkeria triphylla, i. 266

Box, i. 276

Balearic, i. 276

berry, i. 58I

common, i. 277

edging, i. 278

elder, i. I 49

for hedges, i. 94

golden weeping, i. 278

Harland's, i. 277

Hill, i. 276

Himalayan, i. 279

Japanese, i. 277

myrtle-leaved, i. 278

rosemary-leaved, i. 278

small-leaved, i. 277

Box Thorn, ii. 6 I

African, ii. 6I

Chinese, ii. $6 \mathrm{r}$

Fremont's, ii. 62

Bramble, cut-leaved, ii. $46 \mathrm{r}$

Brambles, ii. 450

beneath trees, i. IO2

Bramford Hall, Bollwyller pear at, ii. 278

Branches, supporting heavy, i. 54

Briar, Austrian, ii. 432

Penzance, ii. 440

sweet, ii. 439

Bridewort, ii. 542

Bridgesia spicata, Hook., i. 516

Brier, China, ii. 5 I 7

hag, ii. 5 I 7

horse, ii. 5 I 8

saw, ii. 5 I 7

Broom, butcher's, ii. $47 \mathrm{I}$

common, i. 462

Dalmatian, i. 587

Etna, i. 586

hedgehog, i. 525

Madeira, i. 592

Montpelier, i. 460

Neapolitan, i. 586

purple, i. $46 \mathrm{I}$

Spanish, ii. 522

Teneriffe, i. 464

Warminster, i. $46 \mathrm{I}$ 
Broom, white Spanish, i. 456

Broussa tea, ii. 624

Broussonetia dissecta, Senécl., i. 267

Kæmpferi, Sieb., i. 266

PAPYRIFERA, Vent., i. 267

Sieboldii, $B$ l., i. 266

Bruckenthalia spiculifolia, Reich, i. 268

Bryanthus Breweri, A. Gr., ii. 147 empetriformis, $A$. $G r_{\text {., }}$ ii. 148 erectus, $L d l$., ii. 149

Gmelinii, Don., ii. I 46 taxifolius, $A$. Gr., ii. I 47

Buchanan-Hamilton, i. 9

Buckeye, Californian, i. 167 red, i. 173

southern, i., 166

sweet, i. I 72

Buckthorn, alder, ii. 332

Californian, ii. $33 \mathrm{I}$

Carniolian, ii. 332

common, ii. 331

Dahurian, ii. 332

dwarf, ii. 334

Dyer's, ii. 336

rock, ii. 335

sea, i. 620

southern, i. 275

Budding, propagation by, i. 24

Buddle, Rev. Adam, i. 270

Buddleia asiatica, Lour., i. 270

ColvileI, $H k . f .$, i. 27 I

crispa, Benth., i. 272

curviflora, Hort., i. 272

Davidii, Franchet, i. 273

Hemsleyana, Koehne, i. 271

Lindleyana, Fort., i. 270

intermedia, Carr., i. 270

NIVEA, Duthie, i. 273

VARIABILIS MAGNIFICA, i. $27+$

Buisson ardent, ii. 268

Bullace, ii. 238

Bumelia lanuginosa, Pers., i. 275 tenax, Willd., i. 275

Buplevers, i. 275

Burbidge, F. W., on grafting, i. 2 I

Burning bush, i. 538

Busaco, cedar of Goa, at, i. 446

Bush, burning, i. 538 , ii. 392 calico, i. 682

clover, ii. 16

deer, i. 317

fire, i. 510

hobble, ii. 642

silver, i. 195

spice, ii. 30

steeple-, ii. 544

strawberry, i. 538

sweet pepper, i. $37 \mathrm{I}$

Butneria florida, Kearney, i. 283

Butter-nut, i. $66_{4}$

Button-bush, i. 329
Buttonwood, ii. 202

Buxus chinensis, Hort., i. 277

saligna, Don., ii. 500

sempervirens for hedges, i. 94

suffruticosa, Mill., i. 278

\section{C}

Cresalpinia sepiaria, Roxb., i. 280

Calico bush, i. 682

Californian lilac, i. 320

Callicarpa americana, L., i. 280 purpurea, Juss., i. 280

Calophaca wolgarica, propagation of, i. 15

Calothyrsus, Koch, i. I69

Calycanthus glaucus, Willd., i. 283

lævigatus, Willd., i. 283

macrophyllus, Hort., i. 284

Mohrii, Small, i. 283

nanus, Lois., i. 283

ovatus, Ait., i. 283

præecox, L., i. 337

sterilis, Wall., i. 283

Cambridge, Gerard's pine at, ii. 180

Camellia cuspinata, Veitch, i. 285 common, i. 284

Cane-brake, i. 220 small, i. 220

Capel, Lord, i. 5 Sir Henry, i. 5

Caprifolium, ii., 38

Caragana aURantiaca, Koehne, i. 289 Boisii, C. K'. Sch., i. 288

cuneifolia, Dipp., i. 288

grandiflora, DC., 1. $29 \mathrm{I}$

jubata, propagation of, i. 2 I

pygmæa aurantiaca, i. 288

Redowski, $D C$., i. 28 s

Carclew, Berberidopsis at, i. 232

Carpinus americana, Michx., i. 295

Betulus laciniata, i. 29t

marmorea, i. 294

purpurea, i. 294

quercifolia, Des.., i. 294

rubra, i. 294

variegata, i. 294

Carpinizza, Kit., i. 294

duinensis, Scop., i. 296

JAPONICA, Bl., i. 296

Turczaninowi, Hance, i. 297

Caryopteris incana, Miq., i. 301

Mastacanthus alba, i. 301

Cascara Sagrada, ii. 331, 334

Caspian locust, i. 595

CASSANDRA CALYCULATA NANA, i. 302

Cassena, i. 652

Cassia corymbosa, i. 303

Cassiope Mertensiana, Don, i. 305

Castanea americana, Raf., i. 307

chrysophylla, Hook., i. 309

japonica, $B l$., i. 730 
Castanea Pumila, Mill., i. 308 sativa Holtii, i. 309 laciniata, i. 309 pendulifolia, Lavall., i. 309

vesca, Gaertn., i. 308

vulgaris, Lam., i. 308

Castanopsis Chrysophylla, $D C$., i. 310

Castle Kennedy, Chile pine at, i. 199

Catalpa Bungei, Hori., not C. A. Meyer, i. 312

cordifolia, Jaume, i. 314

himalayensis, Hort., i. 3 I 3

hybrida, Hort., i. 314

japonica, Dode, i. 3 I 3

Kæmpferi, Sieb., i. 3 I 3

sutchuenensis, Dode, i. 3 I 2

syringæfolia, Sims, i. 3 I t

vestita, Diels, i. 3 I 3

Wallichi, Hort., i. 3 I 3

western, i. 3 I4

Ceanothus dentatus, Hort., not Torr., i. 320

floribundus, Hook., i. 318

hybrid, i. 3 I5

Lobbianus, Hook., i. 320

nevadensis, Kell., i. 3 I 8

parvifolius, Trel., i. 318

pubescens, Rydb., i. 318

RIGIDUS, Nutt., i. 319

VELUTINUS L/EVIGATUS, i. 32 I

Cebatha carolina, Koehne, i. 375

orkiculata, Kuntze, i. 375

Cedar, Atlas, i. 323

Chinese, i. 32 I

Cyprian, i. 324

incense, ii. 23

mountain, i. 669

of Goa, i. 446

of Lebanon, i. 5, 324

red, i. 677

stinking, ii. 598

white, i. $45 \mathrm{I}$

Cedrela odorata, i. 322

Cedrus atlantica argentea, i. 323 brevifolıa, Henry, i. 324

Celastrus hypoglaucus, Hemsl., i. 325 japonica, Koch, ii. Io9 orbiculatus, Thunb., i. 325

Celtis crassifolia, Lam., i. 329 Muku, Sieb., i. I96

occidentalis, introduction of, i. 4

pumila, Pursh, i. 329

sinensis, Pers., i. 328

Cenphalotaxus dRUPaCea, Sieb., i. 33I

Cerasus acida, Bork., ii. 226

Fontanesiana, Spach, ii. 236

incana, Boiss., ii. 238

japonica, ii. 239

Mahaleb, Mill., ii. 242

Pattoniana, Carr., ii. 235

pendula carnea, ii. 247

rosea, Domb., ii. 247
Cerasus pennsylvanica, Lois., ii. 247 prostrata, Lois., ii. 248

rufa, Wall., ii. 250

semperflorens, $D C$., ii. 226

serrulata, G. Don, ii. 252

sylvestris, Loud., ii. 229

tortuosa, Boiss., ii. 243

vulgaris, Mill., ii. 232

Cercis reniformis, $S$. Wats., i. 335

Siliguastrum, L., i. 336 carnea, i. 336

texensis, Sarg., i. 335

Cercocarpus betulæfolius, Hook., i. 337 parvifolius glaber, Watson, i. 337

Chaddlewood, holly at, i. 648

Chamæbatiaria, ii. 524 Millefolium, Max., ii. $54 \mathrm{I}$

Chamæcerasus, ii. 38

Chamæcy paris, i. $44^{2}$ sphæroidea, Spach, i. 45I

Chamærops excelsa, Mart., ii. 600 Fortunei, Hk., ii. 600

Chapparal, i. 315

Chaste-tree, ii. $66_{3}$

Chinese, ii. 663

Chelsea Physic Garden, foundation of, i. 5

Chenopodium fruticosum, $L$., ii. 560

Chequers, ii. 298

Chermes abietis, ii. 5 ilicis, ii. 307

Cherry, Afghan, ii. 238

All Saints', ii. 226

bird, ii. 246

Chinese dwarf, ii. 237

Cornelian, i. 390

downy, ii. 255

dwarf American, ii. $2+9$

Gray's bird, ii. 237

grey-leaved, ii. 23 I

ground, ii. 236

Himalayan, ii. 250

Himalayan bird, ii. 233

Indian, ii. 335

Japanese, ii. 252

laurel, ii. 226, 240

Morello, ii. 232

mountain, ii. 248

Patton's, ii. 235

plum, ii. 23 I

Rocky Mountain, ii. 230

rosebud, ii. 247

rum, ii. $25 \mathrm{I}$

St Lucie, ii. 242

Sargent's, ii. 250

Virginian bird, ii. 257

Waterer's, ii. 246

Western choke, ii. 235

wild dwarf, ii. 232

wild red, ii. 247

willow, ii. 238

Woodbıne, ii. 39

Cherries, ii. 225 
Ohestnut, i. 306

American, i. 307

dwarf, i. 307

golden, i. 309

Gros Merle, i. 308

horse, for streets, i. 87

Japanese, i. 307

Paragon, i. 306, 307

Spanish, i. 308

sweet, i. 308

introduction of, by Romans, i. 3

Chile Pine, i. 199

Chimæras, ii. 2

Chimonanthus nitens, Oliv., i. 338

Chinese service-berry, i. 187

Tulip-tree, ii. 34

Chinquapin, i. 307

oak, ii. 322

Chionanthus Retusa, Lindl., i. 340

Chittam Wood, ii. 39 I

CHOISYA TERNATA, Humb., i. 34 I

Chokeberry, ii. 27 I, 274

black, ii. 287

Christ's Thorn, ii. I2I

Chusan palm, ii. 600

Cider-tree, i. 533

Cinquefoil, ii. 22 I

dwarf shrubby, ii. 22 I

shrubby, ii. 222

Oissus, ii. 665

orientalis, Lam., ii. 674

quinquefolia, Sims, ii. 678

striata, Ruiz, ii. 676

Cistus canescens, Sweet, i. 345

classification of, i. 343

Delilei, Burnat, i. 345

formosus, Hort., i. 612

ladaniferus (of Bot. Mag.), i. 345

albiflorus, i. 346

immaculatus, i. 346

lusitanicus, Hort., i. 347

recognitus, $R$. and $F$., i. 347

VILLOSUS, L., i. 344

Cistuses for dry places, i. 99

Citharexylon cyanocarpum, Hk., ii. 336

Citrange, i. 165

Citrus trifoliata, L., 165

Cladodes, ii. 470,507

Oladrastis amurensis, Benth., ii. 64

lutea, Koch, i. 350

platycarpa, Mak., ii. 205

Tashiroi, Yat., ii. 65

TINCTORIA, Raf., i. 35 I

Claremont, Gymnocladus at, i. 602 papaw at, i. 22 I

Sassafras at, ii. 50 I

Clawnut, i. 667

Clematis balearica, Pers., i. 357

balearica, Rich., i, 356

Bergeronii, Lav., i. 360

brevicaudata, Hort., 1. 355

Buchaniana, Hort., i. 365
Clematis cœrulea, $L d l$., i. 365

"Countess of Onslow," i. 357

fern-leaved, i. 356

Flammula rubro-marginata, i. 359

glauca, Willd., i. 364

akebioides, Rehd., i. 364

grata, Hort., i. 36I

grata, Wall., i. 36 I

graveolens, Ldl., i. 364

heracleæfolia, $D C$., i 367

Davidiana, Fr., i. 358 stans, Kuntze, i. 366

indivisa, i. 352

intermedia, Bon., i. 360

JoUinianA, $C$. $K$. Sch., i. 362

kousabotan, Dcne., i. 366

Lavallei, Dcne., i. 367

leiocarpa, Oliv., i. 367

MONTANA RUBENS, O. Ktz., i. 363

nutans, Hort., i. 365 thyrsoldea, Rehd., i. 365

orientalis akebioides, Max., i. 364 tangutica, Max., i. 367

Pieroti, Flort., i. 355

repens, Hort., i. 364

rubro-marginata, Hort., i. 359

Sieboldii, Don, i. 360

texensis, Buckl., i. 357

Veitchiana, Craib, i. 366

"Ville de Lyon," 1. 357

Clerodendron trichotomum Fargesii, i. 370

Clethra alnifolia pubescens, $A$ it., i. 372

arborea, $A$ it., i. 37 I

barbinervis, Sieb., i. 372

paniculata, $A$ it., i. 372

TOMENTOSA, Lam., i. 373

Climbers, i. 60

Clover, bush, ii. 16

Cobbett, William, and Acacia, ii. 4I 2

Cobnut, i. 400

Cocculus heterophyllus, Hems., ii. 5I 2 laurifolius, $D C$., i. 375

Thunbergii, $D C$., i. 375

TRILOBUS, $D C$., i. 376

variiformis, Hort., ii. 5 I 2

Coffee, Kentucky, i. 60 I

Coldrenick, larch at, ii. 7

Colletia armata, Miers., i. 377. Bictoniensis, Ldl., i. 376. Infausta, N.E. Br., i. 377. Serratifolia, Vent., i. 500. Spinosa, Lam., i. 376

Collinson, Peter, i. 6

Colutea arborescens flore rubro, i. 379 pygmæa, i. 378

cruenta, Ait., i. 379

halepica, Lam., i. 378

longialata, Koehne, i. 378

Pocockii, Ait., i. 378

purpurea, Hort., i. $3 / 9$

Compton, Henry, i. 5

Conifers, dwarf, i. 68

for hedges, i. 94 
Conifers, for seaside, i. IO4 pruning of, i. 47

variegated and coloured, i. 76

Coprosma Petriei, Cheesm., i. 380

Coral plant, i. 232

Corchorus japonicus, Hort., i. 683

Coriaria sinica, Max., i. 383

Corkwood, ii. I5

Cornel, i. 383

Bentham's, i. 387

Spaeth's, i. 385

western, i. 389

Cornelian cherry, i. 390

Cornus alba argenteo-marginata, i. 385

Arnoldiana, Kehd., i. 386

brachypoda, C. A. Mey., i. 390

brachypoda, Hort., i. 387 variegata, Hort., i. 387

circinata, L'Her., i. 392

femina, Mill., i. 387

FLORIDA, L., i. 388

KousA, Buerg., i. 390

mascula, L., i. 390

officinalis, Sieb., i. 39I

paniculata, L'Her., i. 386

Purpusii, Koehne, 1. 385

Slavinii, Rehd., i. 392

stricta, L'Her., i. 387

tatarica, Mill., i. 384

COROKIA COTONEASTER, Raoul, i. 394

Coronilla glauca, i. 394

Corstorphine Plane, i. I 56

Corylopsis himalayana, Hk. f.. i. 396

multiflora, Hort., i. 399

PAUCIFLORA, Sieb., i. 397

platypetala, Rehd., i. 396

VEITCHIANA, Bean, i. 398

Corylus Avellana heterophylla, Loud., i. $40 I$

californica, Rose, i. 403

Colurna chinensis, Burk., i. 401

ferox var. thibetica Fr., i. 403

Jacquemontii, Dcne., i. 402

lacera, Wall., i. 402

Sieboldiana, Bl., i. 403

tubulosa, Willd., i. 403

Cotinus cotinoides, Britt., ii. 39 I

Coggyria, Scop., ii. 392

Cotoneaster acutifolia, Ldl., i. 4 I2

acutifolia, Turcz., i. 405

angustifolia, Fr., ii. $267^{\circ}$

applanata, Duth., i. 408

arborescens, Zab., i. 4 I2

common, i. 4 I I

Dammeri radicans, $C . K$. Sch., i. 4 I I

Davidiana, Hort., i. 4 I I

disticha, Lange, i. 4 I4

granatensis, Boiss., i. 4 I 3

microphylla glacialis, Hk. f., i. 408

moupinensis, Fr., i. 409

floribunda, Stapf, i. 407

nummularia, Fisch., i. 4 I 3
Cotoneaster nummularia, L dl., i. 4 I 2 pyrenaica, Hort., i. 408

reflexa, Carr., i. 4 I 3

rugosa, Pritz., i. 4 I 5

Henryana, C.K. Sch., i. 4 Io

vulgaris, Ldl., i. 4 I I

Cotton, lavender, i1. 497

Cottonwood, black, ii. 22 I

Fremont's, ii. 2 I4

swamp, ii. 2 I 4

Cowberry, ii. 630

Crab American, ii. 28I

apple, ii. 287

Bechtel, ii. 286

Dartmouth, ii. 287

fairy, ii. 287

Hyslop, ii. 287

Iowa, ii. 285 .

John Downie, ii. 287

orange, ii. 287

Oregon, ii. 292

Siberian, ii. 278

Sikkim, ii. 294

transcendent, ii. 287

transparent, ii. 282

Crabs, ii. 27 I

Cragside, Berberidopsis at, i. 232

Cranberry, ii. I I 6

American, ii. II7

mountain, ii. 626

small, ii. II7

Cratego-mespilus Asnieresil, $C . K$. Sch., i. 4 I 8

Crategus ACUTilobA, Sarg., i. 423,424

arborescens, Ell., i. 438

arkansana, Sarg., i. 429

Arnoldiana, Sarg., i. 429

Aronia, Bosc, i. 42 I

Bruanti, Hort., i. 43 I

Celsiana, Dipp., i. 428

champlainensis, Sarg., i. 429

coccinea indentata. i. 423

coccinioides, Ashe, i. 423

crenulata, Roxb., ii. 269

Crus-Galli Fontanesiana, Wenz., i. 427 prunifolia, Torr., i. 434

dahurica, Koehne, i. 435

Dippeliana, Lge., 1. 428

Douglas rivularis, Sarg., 1. 426

fastigiata, Hort., i. $43 \mathrm{I}$

fissa, Bosc, i. 430

florentina, Zucc., ii. 28 I

glandulosa, Ait., i. 423

Henryi, Dunn, i. 428

hiemalis, Lange, i. 433

Holmesiana, Ashe, 1. 423

Korolkowi, Hort., i. 420

Korolkowi, Regel, i. 427

Lavallei, Herincq, i. 422

maroccana, Ldl., 1. 435

Maximowiczii, C. K. Sch., i. 435

melanocarpa, Bieb, i. 433 
Cratægus mexicana, DC., i. 436

microcarpa, $L d l$., i. 435

nitida, Sarg., i. 438

odoratissima, Ldl., i. 432

orientalis, Ldl., i. 432

orientalis, Pall., i. 432

ovalifolia, DC., i. 434

Oxyacantha Oliveriana, $L d l$., i. $43 \mathrm{I}$ punicea, i. 432

rosea, i. 432

rubra, i. 432

xanthocarpa, i. 432

parvifolia, Adams, i. 437

pinnatifida major, $N$. E. Br., i. 427

punctata aurea, Pursh, i. 434

Pyracantha, Med., ii. 268

rivularis, Nutt., i. 426

rotundifolia, Mnch., i. 423

saligna, Greene, i. 422

sanguinea villosa, Maxim., i. 435

xanthocarpa, Hort., i. 420

splendens, Lodd., i. 434

stipulacea, Lodd., i. 436

tatarica, Hort., i. 427

Torminalis, L., ii. 298

tortuosa, Hort., i. 430

Tournefortii, Grisb., i. 432

Vailixe, Britt., i. 437

Creeping wintergreen, i. $58 \mathrm{r}$

Cress rocket, ii. 63 I

Crinodendron dependens, $C$. $K$. Sch., ii. 601

Hookerianum, Gay, ii. $60 \mathrm{r}$

Cross-fertilisation of flowers, i. 26

Cross vine, i. 265

Crowberry, i. 5 II

Plymouth, i. 38 I

Portuguese, i. 38 I

Cryptococcus fagi, i. 553

Cryptomeria elegans, Hor\%, i. 439

JAPONICA, Don, i. 439

Cucumber tree, ii. 67

CUDRANIA TRILOBA, Hance, i. 440

Cunninghamia Konishii, Hay., i. 44I

Cupressus Benthami, Endl., i. 446

fastigiata, i. $45^{\circ}$

funebris glauca, Mast., i. 443

Knightiana, i. 446

Lambertiana, Gord., i. 447

Lawsoniana albo-picta, i. 445

albo-spica, i. 445

albo-variegata, i. 445

compacta, i. 445

for hedges, i. 94

Fraseri, i. 445

glauca, i. 445

gracilis aurea, i. 445

minima glauca, i. 445

Silver Queen, i. $4+5$

stricta, i. 445

Triomphe de Boskoop, i. 445

lusitanica Benthami, Carr., i. 446
Cupressus macrocarpa Crippsii, i. 447

for hedges, i. 94

nootkatensis argenteo-variegata, i. 448 aureo-variegata, i. 448

obtusa Keteleerii, i. 449 nana, i. 449

pygmæa, Sarg., i. 444

pyramidalis, Hort., i. 450

sempervirens horizontalis, i. 450 stricta, i. $45^{\circ}$

thyoides kewensis, i. $45^{I}$

Currant, Alpine, ii. 397

American black, ii. 398

black, ii. 405

buffalo, ii. 398

flowering, ii. 407

gooseberry, ii. 402

grape, ii. 678

red, ii. 409

white, ii. 409

Curtis, William, i. 7

Cuttings, propagation by, i. 18

soil for, i. 20

treatment of, i. 28

"Cyanol," i. 626

Cydonia japonica for hedges, i. 95

Sargentii, i. 453

VULGaRIS, Pers., i. 454

pyriformis, i. 454

Cynanchum erectum, L., ii. 77

Cypress, Arizona, i. 443

Chinese weeping, i. 443

deciduous, ii. 577

flat-leaved, i. 442

Gowen's, i. 444

Himalayan, i. 45 I

Hinoki, i. 448

Italian, i. $45^{\circ}$

Lawson, i. 444 for hedges, i. 94

Macnab's, i. 447

Monterey, i. 447 for hedges, i. 94

Patagonian, i. 556

Sawara, i. 449

true, i. 442

yellow, i. 448

Cytisus albus, Hacq., i. 459

austriacus, $L$., i. 464

BeanI, Nichols., i. 457

biflorus, L'Her., i. 462

candicans, $D C$., i. 460

capitatus, Spach, i. 464

ciliatus, Wahl., i. 459

elongatus, Wald., i. 462

glabrescens, Sart., i. 588

grandiflorus, Hort., i. 463

longispicatus, Hort., i. 460

Lotus, Hort., i. 50 I

NIGRICANS, $L$., i. 460

nubigenus, $\operatorname{Link}$, i. 464

propagation of, i. 22 
CyTISUS PURPUREUS, SCOp., i. 462 pruning of, i. 52 radiatus, Koch, i. 59 I ruthenicus, Fisch., i. 462 schipkaensis, Dck., i. 459 serotinus, i. 462

SESSILIFOLIUS, L., i. 463 supinus Heuffeli, Briq., i. 458 uralensis, i. 462

Weldenii, Vis., ii. I 29

\section{D}

Dabœeia cantabrica, Koch, i. 465 polifolia versicolor, i. 465

Daisy bushes, ii. ro3

Danaë racemosa, Moench, i. 465

Dane's blood, ii. 494

Dangleberry, i. 584

Daphne autumnalis, Hort., i. 47 I

Delahayana, Hort., i. 47 I

Fioniana, Hort., i. 471

hybrida, $L d l$. i. 469

japonica, Paxt., i. 472

japonica, Sieb., i. 470

Laureola purpurea, Hort., i. 470

Mazeli, Carr., i. 470

Mezereum atropurpurea, Dipp., i. 470

Paul's white, i. 47 I

NEAPOLITANA, Lodd., i. $47 \mathrm{I}$

odora Mazeli, Hemsl., i. 470

PONTICA, L., i. 473

purple-leaved, i. 470

RETUSA, Hemsl., i. 474

rupestris, Facch., i. 473

salicifolia, Lam., i. 468

sericea, Hort. not Vahl, i. 469

Sophia, Kalen., i. 467

striata, Tratt, i. 469

tangutica, Maxim., i. 474

Verloti, Gren., i. 468

Daphniphyllum jezoënsis, Hort., i. 475

Dasyscypha calycina, ii. 6, 7

Date plum, i. 494

David, Père, i. I 2

Davidia Involucrata, Baill., i. 476

læta, Dode, i. 477

Vilmoriniana, Dode, i. 477

Deal. Dantzic, ii. 192

Riga, ii. 192

white, ii. 157

yellow, ii. I 92

Decumaria sinensis, Oliv., i. 479

Deerberry, ii. 629

Deer bush, i. 317

Delavay, Père, i. 12

Deodar, i. 323

Deutzia campanulata, Lem., i. 482

carminea, Hort., i. 482

crenata, Sieb., i. 485
DEUTZIA, DISCOLOR MAJOR, i. 482 purpurascens, Fr., i. 485

eximea, Hort., i. 482

kalmixeflora, Hort., i. 485

MOLLIS, Duth., i. 484

myriantha, Lem., i. 486

rosea, Hort., i. 482

scabra, Sieb., i. 486

scabra, Thunb., i. 485 vera, Hort., i. 487

Sieboldiana, Max., i. 487

venusta, Hort., i. 482

Dewberry, ii. 455

Diervilla, Abel Carrière, i. 489

canadensis, Willd., i. 492

"Conquéte," i. 489

coræensis, $D C$., i. 49I

"E. André," i. 489

"Eva Rathke," i. 490

FLORIBUNDA, Sieb., i. 490

florida, Sieb., i. 489,490

FLORIDA VARIEGATA, i. 49I

grandiflora, Sieb., i. 489, 49 I

Grœnewegeni, Hort., i. 489

hortensis, Sieb., i. 491

humilis, Pers., i. $49^{2}$

japonica, $D C$., i. 489 , 49 I

Lavallei, Hort., i. 490

Lowei, Hort., i. 490

"Mad. Lemoine," i. 489

rivularis, Gatt., i. 493

sessilifolia splendens, i. 493

splendens, Carr., i. 493

Dimorphanthus mandschuricus, Maxim., i. 197

Dioscorides and the plane, ii. 201

Diostea JunCEA, Miers, i. 495

Diotis ceratoides, Willd., i. 545

DiPELTA FLORIBUNDA, Maxim., i. 496 ventricosa, Hemsl., i. 497

Diplopappus chrysophyllus, Koehne, i. 304

Vauvilliersii, Hort., i. 304

Dipteronia Dyeriana, Henry, i. 498

Discaria longispina, Miers, i. 499

Toumatou, Raoul, i. 500

Diselma Archeri, Hk. f., i. 556

Distegocarpus, sub-genus, i. 293 Carpinus, Sieb., i. 295

Division, propagation by, i. I7

Dockmackie, ii. 64I

Dogberry, ii. 403

Dogwood, ii. 332

common, i. 393

flowering, i. 388

red osier, i. 393

Douglas, David, i. 8

Douglas fir, ii. 259

Colorado, ii. 259

Drimys aromatica, Fo Muell.o i. 502

Dunkeld, larches at, ii. 7

Dutchman's pipe, i. 208 
Duvaua, ii. 503

dependens, $D C$., ii. 503

ovata, $\mathrm{Ldl}$., ii. 503

Dwarf trees and shrubs, i. 67

Dyer's greenweed, i. 59 I

\section{E}

Early-flowering trees and shrubs, i. $8 \mathrm{I}$

Eastbourne, street planting at, i. 87

Eastwood, Alice, on Arctostaphylos seed, i. 203

Echinopanax horridum, Dcne., i. 555

Edinburgh Botanic Garden, foundation of, i. 5

Edwardsia chilensis, Miers, ii. 520 grandiflora, Salis., ii. 521 Macnabiana, R. Grah., ii. 521 microphylla, Salis., ii. 52 I

Eglantine, ii. 439

Ehretia macrophylla, Wall., i. 504 serrata, Roxb., i. 504

Eleagnus ARGENTEA, Pursh, i. 505 hortensis, Bieb., i. 504

longipes, $A . G r .$, i. 507 crispa, Max., i. 507 MULTIFLORA, Thun., i. 507 parvifolia, Wall., i. 509 pungens aureo-picta, i. 508 reflexa, Dcne., i. 508 sativa, Hort., i. 507 tomentosa, Mnch., i. 507

Elder, American, ii. 494 box, i. 149 common, ii. 495 golden, ii. 496 parsley-leaved, ii. 496 red-berried, ii. 496 American, ii. 496

Elderberry, blue, ii. 495

Eleutherococcus Henryi, Oliv., i. I 29 leucorrhizus, Oliv., i. I 30 (of Gard. Chron.), i. I33

senticosus, Maxim., i. I 32

Simoni, Sim.-Louis, i. I 33

Elkington Hall, Ringal at, i. 2 I 3

EllotTia RACEMOSA, Muhl., i. 509

Elm, American, ii. 6I 2

Belgian, ii. 612

cedar, ii. 6 I 4

Chichester, ii. 62 I

cork-barked, ii. 618

Cornish, ii. 620

Dutch, ii. 6 I 5

dwarf, ii. 619

East-Anglian, ii. 6 r6

English, ii. 612

Exeter, ii. 616

Guernsey, ii. 620

Huntingdon, ii. 62 I
Flm, Japanese, ii. 615

Jersey, ii. 620

lock, ii. 6 I 6

of Texas, ii. 6I 4

rock, ii. 620

Scotch, ii. 6 I 6

slippery, ii. 6 I4

smooth-leaved, ii. 618

spreading, ii. 6r 9

water, ii. 200

Wheatley's, ii. 620

for streets, i. 86

white, ii. $6 \mathrm{I} 2$

winged, ii. $6 \mathrm{I} I$

wych, ii. 6 r 6

Elvaston Castle, clipped yews at, ii. 580 weeping ash at, i. 568

Elwes, Henry J., i. I3

Ely Palace, Plane at, ii. 203

Enantiosparton radiatum, i. 591

Encena, ii. 302

Enkianthus campanulatus, Nich., i. 5 I 2

chinensis, Fr., i. 513

deflexus, $C$. K. Sch., i. 5 I 3

JAPONICUS, $H k_{\text {. }} f_{\text {., }}$ i. 5 I4

Enys, holly at, i. 648

Ephedra monostachya, L., i. 515

ERICA AUSTRALIS, L., i. 519

codonodes, Ldl., i. 521

corsica, $D C$., i. 523

Crawfurdii, i. 522

herbacea, Hort., i. 5 I9

hybrida, Hort., i. $52 \mathrm{I}$

Maweana, Backh., i. 520

MEDITERRANEA, L., i. 523

glauca, i. 522

hybrida, Hort., i. 52 I

ramulosa, Viv., i. 523

Stuartii, Lint., i. 522

terminalis, Salisb., i. $\mathbf{5 2 3}$

vulgaris, $L$., i. 281

Watsoni, $D C$., i. 520

Williamsii, Druce, i. 534

Erinacea Ervillei, Hort., i. 525

Eriolobus, ii. 272

trilobata, Roem., ii. 298

Tschonoski, Rehd., ii. 298

Escallonia edinensis, Hort., i. 528

Ingrami, Hort., i. 529

LANGLEYENSIS, i. 528

macrantha for hedges, i. 95,96

montevidensis, $D C$., i. 527

Philippiana, i. 530

rubra punctata, $H k$. $f$., i. 530

EuCALYPTUS GuNNII, $H . k_{\text {. }}$. ., i. 534

Whittingehamensis, Hort., i. 533

Eucryphia Billardieri, Spach, i. 535

PINNATIFOLIA, Gay, i. 536

Eugenia apiculata, $D C$., ii. 92

Luma, Berg., ii. 92

Ugni, Hook., ii. 92 
Euony mus europæus argenteo-variegatis,

\section{i. 539}

aureo-variegatis, i. 539

Hamiltonianus semipersistens, Rehd., i. 543

japonicus for hedges, i. 94

macropterus, Rupr., i. 54 I

radicans beneath trees, i. 102

for low hedges, i. 94

minimus, i. 542

"Silver Queen," i. 542

robustus, Hort., i. 540

Thunbergianus, $B l$., i. 538

Euptelea Davidiana, Baill., i. 544

pleiosperma, Hook., i. 544

Eurotia lanata, Moq., i. 545

Eurya latifolia variegata, Hort., i. 374 pusilla, Sieb., i. 545,546

Evergreens, i. 56

dwarf, i. 58

selection of, i. 57

transplanting of, i. 35

Evodia Fargeisi, Dode, i. 547

ramiflora, A. Gray, ii. 109

Exochorda GiraldiI, Hesse, i. 548

Korolkowi, Hort., i. 547

MACRANTHA, Lem., i. 549

"Eyes," propagation by, i. 20

\section{F}

FABIANA Imbricata, Ruiz, i. 550

Fagus americana, Sw., i. $55^{\circ}$

antarctica, Forst., ii. 98

betuloides, Mirb., ii. 99

cliffortioides, $H k_{\text {. }}$., ii. 99

Cunninghami, $H k$. $f$., ii. 99

Menziesii, $H k$. f., ii. 100

Moorei, Muell., ii. 100

obliqua, ii. Ior

sylvatica argenteo-variegata, i. 553

asplenifolia, i. 552

atropurpurea, 1. 553

aureo-variegata, i. 553

bornyensis, i. 552

incisa, i. 552

laciniata, i. 552

latifolia, i. 552

miltoniensis, i. 552

nigra, i. 553

pagnyensis, i. 552

purpurea major, i. 553

pyramidalis, Petz., i. 552

remillyensis, i. 522

salicifolia, i. 552

Sieboldii, Max., i. 55 I

"Swat Magret," i. 553

tortuosa, i. 552

tricolor, i. 553

False indigo, i. I 92

Farges, Père, i. I2
Farkleberry, ii. 622

Fastigiate trees, list of, i. 66

Fatsia horrida, Benth., i. 554

Fern, sweet, i. 379

Fertilisation of flowers, i. 26

Fig, i. 555

Filbert, i. 399,403

Fir, Algerian, i. 125

balsam, i. II 8

Caucasian, i. 124

Cilician, i. I 2 I

Colorado, i. I 2 I

Douglas, ii. 259

common silver, i. 126

Douglas, ii. 259

dwarf balsam, i. I1 8

Fraser's balsam, i. I22

giant, i. I 22

Greek, i. 120

hemlock, ii. 604

Himalayan, i. I26, 128

Japanese, i. I 2 I

Low's silver, i. I 22

Maries', i. I23

Mexican, i. II 7

Nikko, i. II 8

noble, i. 124

red, i. 123

Rocky Mt., i. II 7

Saghalien, i. I I 7

Santa Lucia, i. I 20

Shasta red, i. 123

Siberian, i. II 7

Spanish, i. I 27

Veitch's silver, i. I 27

Vilmorin's, i. I 20

white, i. I 18

Fire bush, i. 510

Firs, silver, i. I I 6

Fitzroya Archeri, Benth., i. 556

Flame-flower, ii. 346

Flax, holy, ii. 499

tree, ii. 32

Flora Japonica, i. 9

Flower, garland, i. 468

leather, i. 368

May-, i. 5 I 6

twin-, ii. 31

Flowering shrubs, pruning of, i. 50

Flowers, fertilisation of, i. 26 structure of, i. 26

Fontanesia phillyreoides sinensis, Desb., i. 557

Forestiera acuminata, Poir., i. 164 ligustrina, Poir., i. I64

Forrest, George, i. I 3

Forrester, 2nd Lord, murder of, i. 156

Forsyth, Wm., i. 557

Forsythia, Albanian, i. 558 suspensa atrocaulis, Rehd., i. 559

VIRIDISSIMA, $L d l$., i. 560

Fortunæa chinensis, Ldl., ii. 204 
Fortune, Robert, i. Io

Fortunearia sinensis, Rehd., ii. 5 I 3

Fothergill, Dr John, i. 559

Fothergilla alnifolia, L., i. 560 acuta, i. 560 major, i. $56 \mathbf{r}$ obtusa, i. 560 carolina, Britt., i, 560 MAJOR, Lodd., i. $56 \mathrm{I}$ monticola, Ashe, i. 561

Fox grape, northern, i. 672 southern, 1. 675

Frame, Paris, i. 21

Franchet, A. R., ii. 512

Franklinia Altamaha, Marsh., i. 597

Fraser, John, i. 8

Fraxinaster, i. 562

Fraxinus angustifolia monophylla, Henry, i. 574

Bungeana, Hort. not DC., i. 566

coriacea, S. Wats., i. 564

Dippeliana, Ling., i. 565

epiptera, Michx., i. 563

excelsior atrovirens, i. 567 integrifolia, i. 568 monophylla, i. 568 myrtifolia, i. 568 nana, i. 568 simplicifolia, i. 568

glabra, Koehne, i. 573

MARIESII, $H k_{.} f_{\text {. }}$, i. 570

numidica, Dipp., i. 563

obovata, Hort., i. 566

Ornus for streets, i. 88

oxycarpa, Willd., i. 563 parvifolia, Boiss., i. 572

oxyphylla, Bieb., i. 563

pistacipefolia, Torr., i. 575

pubescens, Lam., i. 572

rotundifolia, Hort., i. $57 \mathrm{I}$

sambucifolia, Lam., i. 570

serratifolia, Hort., i. 573

Sieboldiana, Dipp., i. 573

Sogdiana, Hort., i. 574

viridis, Michx., i. 569

Willdenowiana, Koehne, i. 57 I

xanthoxyloides, Wall., i. 566

Frémont, Col., i. 575

FREMONTIA CALIFORNICA, Torr., i. 576

Fringe-tree, i. 340

Chinese, i. 339

Frogmore, incense cedar at, ii. 23

Fruits, trees and shrubs with handsome, i. 70

Fuchsia exoniensis, i. 577

Furze, ii. 609

needle, i. 586

Gale, ii. 88

\section{G}

beer, ii. 90

palustris, Chev., ii. 90

sweet, ii. 90
Galen and the plane, ii. 201

Garland flower, i. 468

Garrya elliptica, Dougl., i. 579

Fadyeni, Hort., i. 580

Gas tar, use and value of, i. 50, 92

Gaultheria Veitchiana, Craib, i. 582

Gaya Lyallii, Cheesm., ii. I99

Gay-Lussac, i. $5^{8} 3$

GaYlussacia DUMOSA, Torr., i. 584

Gean, ii. 229

Geblera suffruticosa, Fisch., ii. 507

Genista candicans, $L$., i. 460

elatior, Koch, i. 592

GLABR ESCENS, Briq., i. 588

HISPANICA, $L$., i. 589

mantica, Poll., i. 592

multiflora, Spach, i. 456

tinctoria anxantica, Fiori, i. 586

ovata, Schtze., i. 590

VIRGATA, $D C$., i. 593

Gerard, John, i. 4

Germander, shrubby, ii. $5^{84}$

Gilead, balm of, ii. 2 I2

Glasnevin, Daphne at, i. 468

Hymenanthera at, i. 632

Gleditschia Delavayi, Fr., i. 595

inermis, Mill., i. 595

macrantha, Desf., i. 596

monosperma, Walt., i. 595

sinensis, Lam., i. 596

texana, Sarg., i. 595

Gleditsia, i. 594

Glossary, i. 107

Glycine chinensis, Sims, ii. 680

frutescens, $L$., ii. $68 \mathrm{I}$

Glyptostrobus heterophyllus, Hort., ii. 579

pendulus, Endl., ii. 578

Goa, cedar of, i. 446

Goat wheat, i. 224. Goat-root, ii. 107

Goat's Thorn, i. 22I

Godinton, sweet gum at, ii. 34

Golden bell, i. $55^{8}$

rain, ii. I, 4

Gooseberry, amice, ii. 398

common, ii. 402

pine-wood, ii. 406

Goosefoot, shrubby, ii. 560

Gordon, Alex., i. 597 James, i. 7

Gordonia Altamaha, Sarg., i. 597

Gorse, ii. 609

double-flowered, ii. 609

dwarf, ii. 6 Io

for dry places, i. 99

Irish, ii. 609

Spanish, i. 588

Graft-hybrids, i. 4 I 7 ; ii. 2

Grafting by approach, i. 23

F. W. Burbidge on, i. 2 I

propagation by, i. 2 I 
Grain, ii. 307 scarlet, ii. 307 tree, ii. 30 s

Graine d'Avignon, ii. 333

Grape, Amurland, i1. 666 blue, ii. 667

Californian, ii. 668

cañon, ii. 667

cat, ii. 679

chicken, ii. 669

currant, ii. 678

Doan's, ii. 668

frost, ii. 669

miller, ii. 678

mountain, ii. 674

mustang, ii. 668

Northern fox, ii. 672

Oregon, i. 234

red, ii. 679

riverbank, ii. 679

sand, ii. 676

southern fox, ii. 675

sugar, ii. 676

summer, ii. 656

sweet winter, ii. 666

teinturier, ii. 678

vine, common, ii. 678

Cynthiana, ii. 666

Herbemont, ii. 666

vines, true, ii. 665

Virginia seedling, ii. 666

Gravetye Manor, clematis at, i. 353

Sitka spruce at, ii. I64

Gray's Inn, Catalpa at, i. 3 I I

Grayswood Hill, Adenocarpus at, i. I65 cornels at, i. 389,392

Greenweed, dyer's, i. 59I

Grevillea juniperina sulphurea, Benth., i. 598

SUlphurea, A. Cunn., i. 599

Grew, Nathaniel, i. 600

Grewia oppositifolia, Roxb., i. 600

Grey sage brush, i. 226

Griselinia macrophylla, Hort., i. 601

Gros Perrusier, ii. 273

Grossularia, ii. 397

Groundsel, tree, i. 230

$$
\text { Patagonian, i. } 231
$$

Grouping of shrubs, i. 40

Guelder rose, ii. 653

Gum, Oriental sweet, ii. 33

sweet, ii. 34

tragacanth, i. 22 I

trees, i. 532

Gymnocladus chinensis, Baill., i. 60 I dioica, Koch, i. 601

\section{$\mathrm{H}$}

Ha-chiku, Hort. Jap., ii. I 50

Hackberry, i. 329

Hales, Dr Stephen, i. 602
Halesia Carolina, L., i. 603

hispida, Mast., ii. 264

parviflora, Hort., i. 603

parviflora, Michx., i. 602

tetraptera, Ellis, i. 602

Halimodendron argenteum, propagation of, i. 2 I

Hamamelis arborea, Mast., i. 605

MOLLIS, Oliv., i. 605

Zuccariniana, Hort., i. 605

Hamwood, Co. Meath, Griselinia at, i. 601

Hansen, Mr G., on Ceanothus, i. 3 I 7

Hartogia capensis, Hort., ii. 24 I

Hartweg, K. T., i. Io

Haw, black, ii. 654

red, i. 429

scarlet, i. 423

southern black, ii. 655

yellow, i. 426

Hawthorn, common, i. 429, 432

Hazel, i. 399, 400

American, i. 400

beaked, i. 403

Chinese, i. 401

Japanese, i. 402

Manchurian, i. 402

Thibetan, i. 403

Turkish, i. 401

Hazel, witch, i. 606 Chinese, i. 605 Japanese, i. 604

Heath, i. 5 I 7

besom, i. 523

Cornish, i. 524

cross-leaved, 1. 524

grey, i. 520

Mackay's, i. 522

St Dabeoc's, i. 465

Scotch, i. 520

Spanish, i. 518

tree, i. 518

Veitch's hybrid, i. 525

Heather, i. 28I

beach, i. 622

Himalayan, i. 305

Heaven, tree of, i. I74

Hedera algeriensis, Hort., i. 608

amurensis, Hort., i. 609

canariensis, Willd., i. 608 nova, Hort., i. 608

chrysocarpa, Walsh, i. 608

cinerea, Hibb., i. 608

colchica, Koch, i. 609

Helix himalaica, i. 608

hibernica, Kirchn., i. 609

japonica variegata, i. 609

latimaculata, Hort., i. 609

maderensis, Hort., vi. 608

poetarum, Bert., i. 608

rhombea, Sieb., i. 609

Rœgneriana, Hort., i. 609 
Hedges, i. 93 pruning of, i. 45

Hedysarum multijugum, Max., i. 6 ro

Heimia salicifolia, Link., ii. 96

Helianthemum algarvense, Dun., i. 6 I 4 canum, Dun., i. 516

Chamæcistus, Mill., i. 616

confusum, Sw., i. 6I 2

croceum, Sw., i. 6I4

"Fireball," i. 6r6

FORMOSUM, Dun., i. 6 I 3

glaucum croceum, Boiss., i. 614

Libanotis, Willd., i. 616

polifolium, Pers., i. 6r2

rosmarinifolium, Hort., i. 616

surrejanum, Mill, i. 6r 7

syriacum, Boiss., i. 516

"The bride," i. 616

uMBELlatum, Mill., i. 6 I 5

variabile, Spach, i. 6 I6

Helichrysum antennarium, $F$. Muell., i. 6 I 8 glomeratum, $H k$. f., i. 617

Helwingia japonica, Dietr., i. 618

Hemiptelea Davidii, Plan., ii. 694

Hemlock, Canadian, ii. 605

firs, ii. 604

Himalayan, ii. 604

Japanese, ii. 607

Patton's, ii. 607

Siebold's, ii. 608

western, ii. 604

Henry, Augustine, i. I2

Herbe aux gueux, i. 369

Hercules' club, i. 198

Hickory, i. 298

big-bud, i. 301

shell-bark, i. 299

Hicoria alba, Britt., i. 301

glabra, Britt., i. 300

laciniosa, Sarg., i. 300

minima, Britt., i. 299

ovata, Britt., i. 299

Pecan, Britt., i. 300

Hippophaë canadensis, $L_{\text {., }}$ ii. $5 \mathrm{II}$

Hisingera japonıca, Sieb., ii. 684

Hobble bush, ii. 642

Hollows in trees, how to deal with, i. 53

Holly, American, 1. 649

Canary Island, i. 650

common, i. 642

Donnington, i. 644

Farge's, i. 647

Fisher's, i. 644

for hedges, i. 93

golden milkmaid, i. 643

queen, i. 643

weeping, i. 643

gold-leaved, i. 643

Handsworth new silver, i. 644

Highclere, i. 643

Himalayan, i. 646

horned, i. 645
Holly, Japanese, I. 645

leather-leaf, i. 644

moonlight, i. 644

mountain, i. 649 ; ii. 95

Perry's weeping, i. 643

screw-leaved, i. 644

silver-leaved, i. 643

silver milkmaid, i. 643 queen, i. 643

-Waterer's, i. 645

weeping, i. 644

yellow-fruited, i. 644

Holm oak for hedges, i. 94

Holodiscus, ii. 524

discolor, Asch., ii. 533

dumosus, Hell., ii. 534

Holy flax, ii. 499

Honey locust, i. 596

Honeysuckle, ii. 37, 5 I

Dutch, ii. 52

fly, ii. 59

late-flowering, ii. 52

Minorca, ii. 47

Standish's, 1i. 55

swamp, ii. 385

trumpet, ii. 54

western trumpet, ii. $4 \mathrm{I}$

Hooker, Joseph D., i. 9

Hop hornbeam, ii. II 4 , II 5

Hop tree, ii. 260 Japanese, ii. II 5

western, ii. 26 I

Hornbeam, American, i. 295

common, i. 294

hop, ii. I I 4 , I I 5

Japanese, i. 295

Oriental, i. 296

Horse-chestnut, i. 169

Chinese, i. 168

double-flowered, i. 170

early-flowering, i. 170

Indian, i. I7I

Japanese, i. 174

red, i. 168

Wilson's, i. 169

Horse sugar, ii. 565

Horse-tail, shrubby, i. 5I 4

Hortense, Queen, and Hydrangea, i. 626

Hortensia opuloides, Lam., i. 625

Horticultural Society, foundation and work of, i. 8

Hortus Kewensis, i. 6

Howick, Etna broom at, i. 586

Huckleberry, i. 583

bear, i. 585

black, i. 584 ; ii. 624

blue, ii. 630

box, i. 582

dwarf, i. 583

hairy, ii. 626

Huile de Marmotte, ii. 23I

Hybridising, i. 25 
Hydrangea acuminata, Sieb, i. 625 arborescens canescens, Nich., i. 625 aspera, Don, i. $63 \mathrm{I}$ sterilis, i. $63 \mathrm{I}$ canescens, Koch, i. 625 cyanea, Hort., i. 630 cyanoclada, Hort., 1. 625 heteromalla, Don, i. 63 I hirta, Sieb., i. 623 Hortensia, Sieb., i. 625 hortensis acuminata, $A$. $G r$, i. 625 Lindleyi, i. 626 japonica, Sieb., i. 626 mandschurica, Hort., i. 625 nivea, Michx., i. 629 pekinensis, Hort., i. 624 PETIOLARIS, Sieb., i. 628 platanifolia, i. 629 Sargentiana, Rehd., i. 630 scandens, Maxim., i. 628 serrata, $D C$. , i. 630 stellata, Sieb., i. 626 vestita pubescens, Max., i. 624 virens, Sieb., i. 623

Hymenanthera chathamica, T. Kirk, i. 632 Hypericum, American species of, i. 635 Coris, L., i. 636

grandifolium, Choisy, i. 636 multiflorum, Hort., i. 636 oblongifolium, $H k$., i. 637 Hyssop, i. 6 \%o

\section{I}

IDESIA POLYCARPA, Max., i. 64 I

Ilex Aquifolium Hendersoni, i. 644 kewensis, i. 644 nobilis, i. 643

balearica, Desf., i. 65 I

Cassine, Walt., i. 652

dipyrena elliptica, Dall., i. 647

Mariesii, Veitch, i. 646

prinoides, Ait., i. 646

Sieboldii, Miq., i. 651

Illicium verum, Hk. f., i. 653

Inarching, propagation by, i. 23

Incense cedar, ii. 23

Indian bean, i. 3 I I cherry, ii. 335

Indigo, i. 653 false, i. I 92

INDIGOFERA DECORA, Ldl., i. 654 Dosua, Ldl., i. 655 tinctoria, i. 653

Inkberry, i. 647

Inverewe, Billardiera at, i. 266 Phygelius at, ii. I 46

Ioxylon pomiferum, Raf., ii. 65 Ironwood, ii. II 5

ITEA ILICIFOLIA, Oliv., i. 656

Ivy, common, i. 606 tree, i. 607

Himalayan, i. 608

Irish, i. 609

Japanese, i. 609

of Uruguay, ii. 677

Persian, i. 609

poison, ii. 394

\section{$\mathrm{J}$}

James, Dr Edwin, i. 657

JAMESIA AMERICANA, Torr., i. 658

Japan pepper, ii. 692

Japanese beech, i. 55 I

Mahonia, i. 244

Jasmine, common, i. 660

Italian, i. 662

Jasmines, i. 658

Jasminum affine, Carr., i. 66r

Beesianum, i. 659

humile, $L$., i. 662

Reevesii, Hort., i. 662

Sieboldianum, $B l$., i. 660

triumphans, Hori., i. 662

Jeffrey, John, i. I I

Jepson, W. L., on Arbutus Menziesii, i. 202

Jerusalem sage, ii. I 43

Jessamine, i. 66 I

Judas-tree, i. 335

Juglans alata, Carr., i. 663

californica Hindsii, Jeps., i. 663

cinerea, introduction of, i. 4

CORDIFORMIS, Max., i. 665

pyriformis, Carr., i. 663

regia macrocarpa, i. 667

Vilmorinianum, Carr., i. 663

Jujube, ii. 696

June-berry, i. 188

Juniper, black, i. 678

carpet, i. 676

chequer-barked, i. 673

Chinese, i. 669

common, i. $67 \mathrm{I}$

hedgehog, i. $67 \mathrm{I}$

Himalayan, i. 674

incense, i. 676

Irish, i. 67 I

Syrian, i. 672

Waukegan, i. 676

Young's golden, i. 670

Juniperus canadensis, i. 67 I

communis alpina, i. 67 I

hibernica, i. 67 I

pendula, i. 672

suecica, i. 67 I

densa, Gord., i. 676

Gossaintheana, Lodd., i. 677

hudsonica, Lodd.; i. 676

intermedia, i. $67 \mathrm{I}$ 
Juniperus, oblonga pendula, i. 672

OXYCEDRUS, L., i. 669, 670

PHCENICEA, L., i. 673

procumbens, Hort., i. 676

pseudo-Sabina, Fisch., i. 678

pseudo-Sabina, Hk. ., i. 678

RIGIDA, Sieb., i. 675

Sabina prostrata, i. 676

Sanderi, Sander, 1. $44^{2}$

sphœrica, $L d l$., i. 67 I

taxifolia, Mast., i. 672

virginiana argentea, i. 677

compacta, i. 677

elegantissima, i. 677

humilis, i. 677

viridis, i. 678

Jupiter's Beard, i. I 95

\section{K}

Kakee, i. 493

Kalm, Peter, i. 678

Kalmia angustifolia pumila, i. 679

carolina, Small, i. 679

Cuneata, Mich $x$., i. 680

GLAUCA, Ait., i. 68I

hirsuta, Walt., i. 679

LATIFOLIA MYRTIFOLIA, Jäg., i. 683

lucida, Hort., i. 682

myrtifolia, And., i. 682

polifolia, Wangh., i. $68 \mathrm{I}$

Kan-chiku, i. 2 I 7

Kan-zan-chiku, i. 2 I6

Keaki, ii. 693

Kendal green (dye), i. 592

Kentucky coffee, i. 60 I

Kermes, ii. 307

Kerr, Willıam, i. 9, 684

KERRIA JAPONICA, $D C$., i. 684

japonica alba, ii. 389

Keteleeria Davidiana, Fr., i. 685

Ketmie, Syrian, i. 619

Kew Gardens, i. 5 foundation of, i. 6

Keysia, ii. 364

Kidney vetch, i. 195

Killerton, Cunninghamia at, i. 44 I Mutisia at, ii. 88

Kilmacurragh, Athrotaxis at, i. 224

Drimys at, i. 503

Embothrium at, i. 5 II

Griselinia at, i. 601

Kimmei-chiku, Hort. Jap., ii. 148

Knap Hill Nursery, Yellow wood at, i. 35 I

Koelreuter, J. T., i. 687

Koelreuteria bipinnata, Fr., i. 687

PANICULATA, Laxm., i. 686

KolKwitzIa AMABIlis, Graeb., i. 687

Korokia, i. 394

Kowhai, ii. 52 I

\section{L}

Labrador tea, ii. 12

LABURNUM CARAMANICUM, Bth., ii. 3

common, ii. 4

Dalmatian, ii. I 29

intermedium, Hort., ii. 4

"latest and longest," ii. 2

Parksii, Hort., ii. 4

purple, ii. I

Scotch, ii. 2

Vossii, Hort., ii. 4

vulgare bullatum, ii. 4 chrysophyllum, ii. 4 Jacquinianum, ii. 4

Watereri, Hort., ii. 4

Lacquer tree, ii. 396

Lad's love, i. 2 Io

Lamb-kill, i. 679

Landes (France), pines in, ii. I 86

Larch blight, ii. 5

blister, ii. 6,7

canker, ii. 6,7

common, ii. 6

introduction of, i. 5

Dahurian, ii. 6

golden, ii. 257

Himalayan, ii. 7

Japanese, ii. 8

Kurile, ii. 8

Lyall's, ii. 9

Siberian, ii. 7

West American, ii. 9

Western Chinese, ii. 9

Larix dahurica japonica, Max., ii. 8

davurica, Trautv., ii. 6

decidua, Mill., ii. 6

europæa sibirica, Loud., ii. 7

Kaempferi, Carr., ii. 257

LEPTOLEPIS, Endl., ii., 8

Lyallii, Parl., ii. 9

microcarpa, Desf., ii. 6

pendula, ii. 6

sibirica, Ledeb., ii. 7

Late-flowering trees and shrubs, i. 8 I

Laurel, Alexandrian, i. 465

bay, ii. Io

Californian, ii. 62 I

cherry, ii. 240

magnolia, ii. 70

pale, i. 68I

Portugal, ii. 24I

sheep, i. 679

spurge, i. 470

Laurelia aromatica, Mast., ii. 9

Laurels for hedges, i. 95

Laurocerasus ilicifolia, Roem., is. 237

lusitanica, Roem., ii. 24I

Maackii, $C$. $K$. Sch., ii. $24 I$

officinalis, Roem., ii. 240 
Laurus Benzoin, L., ii. 30 nobilis salicifolia, ii. Io Sassafras, L., ii. 50 I

Laurustinus, ii. 657

Lavender, ii. I I cotton, ii. 497

Lawson cypress, i. 444

Layering, propagation by, i. I 7

Lead plant, i. 192

Leaf, leather i. 302 velvet, ï. 624

Leather-flower, i. 368 leaf, i. 302

Leatherwood, i. 455,489

Lebanon, cedar of, i. 5,324

Ledonia, i. 346

Ledum grœnlandicum, Oeder, ii. 12 LATIFOLIUM, $A$ it., ii. 13 thymifolium, Don, ii. I4

Lee, James, i. 7

LEIOPYHLLUM BUXIFOLIUM, Ell., ii. I4

Lemon-scented verbena, ii., 32

Leny, fern-leaved beech at, i. 552

Leonardslee, barberry at, i. 252

Les Barres, i. I2

Lespedeza bicolor, Hk. f., ii. I 7 cuneata, Don, ii. I 7

Leucothö̈ Catesbei, $A$. Gr., ii. I9

Davisiæe, Torr., ii. 20

Lobbii, Veitch, ii. I9

RACEMOSA, $A$. Gr., ii. 2 I

Levens Castle, clipped yews at, ii. 580

Leycesteria formosa variegata, Hort., ii. 22

Libocedrus Doniana, Endl., ii. 22 macrolepis, Benth., ii. 22

Ligustrina, ii. $56_{5}$

amurensis, $R g l$. ii. 566 japonica, Max., ii. 567 pekinensis, $R g l$., ii. 569

Ligustrum acuminatum, Koehne, il. 25 ciliatum, ii. 25

HENRYI, Hemsl., ii. 25

insulare, Dcne., ii. 29

JAPONICUM, Thunb., ii. 26

Regelianum, Kochne, ii. 25

sempervirens, ii. 29

Stauntoni, $D C$., ii. 28

vulgare chlorocarpum, ii. 29

leucocarpum, ii. 29 xanthocarpum, ii. 29

Lilac, Californian, i. 320

common, ii. 572

Himalayan, ii. 566

Josika, ii. 568

Persian, ii. 570

Rouen, ii. 566

Lily tree, ii. 67

Limbs of trees, removal of, i. 49

Lime, ii. 589

American, ii. 590

common, ii. 597

Manchurian, ii. 59I
Lime, Moltke's, ii. 593

Mongolian, ii. 593

pendent silver, ii. 594

small-leaved, ii. 5,0

trees for streets, $1.85,88$

white, ii. 596

Limonia trifoliata, Hort., i. 165

Linden, ii. 589

Lindera sericea, $B l$. , ii. 30

Ling, i. 28 I

Linnæa Engleriana, Graebn., i. I I 4

Lippia juncea, Schauer, i. 495

Liquidambar acerifolia, Max., ii. 33 imberbe, $A$ it., ii. 33

LIRIODENDRON TULIPIFERA, L., ii. 35 chinense, Hems., ii. 34

Lithospermum petræum, $D C$., ii. 83

I obb, William, i. ro

Loblolly bay, i. 597 pine, ii. 170

Locust, ii. 4 I2

Caspian, i. 595

clammy, ii. 413

honey, i. 596

Japanese, i. 596

tree, introduction of, i. 4

water, i. 595

Loddiges, Conrad, i. 7

Loganberry, ii. 460

Lomatia ferruginea, Br., ii. 37

pinnatifolia, Hort., ii. 37

London, Compton, Bishop of, i. 5

Lonicer, Adam, ii. 37

Lonicera americana, $K$. Koch, ii. 47

bella, Zabel, ii. 50

brachypoda reticulata, ii. 48

CHÆTOCARPA, Rehd., ii. 45,46

confusa, $D C$., ii. 48

DEFLEXICALYX, Bat., ii. 42

depressa, Royle, ii. 50

Douglasii, $D C$., ii. 45

flexuosa, $T h b g_{.}$, ii. 48

Halliana, Dipp., ii. 48

glauca, Hill, ii. 42

glaucescens, $R y d b$., ii. 42

hispida chætocarpa, Bat., ii. 46

IBERICA, Bieb., ii. 46

involucrata, Banks, ii. 49

humilis, ii. 49

serotina, ii. 49

Kesselringii, Regel, ii. 5 r

Koehneana, Rehd., ii. 49

orientalis longifolia, Dipp., ii. 5 I

ovalis, Bat., ii. 59

PERICLYMENUM BELGICA, ii. 58

quercifolia, $A$ it., ii. 52

prolifera, Booth, ii. 56

pubescens, $S w .$, ii. 45

punicea, Sims, ii. 57

PYRENAICA, L., ii. 53

savranica, Spath, ii. 5 I

semperflorens, Hort., ii. 52 
Lonicera spinosa Alberti, Rehd., ii. 39 tatarica rubra, ii. 57 speciosa, ii. 56 splendens, ii. 56 THIBETICA, Bur., ii. 57 translucens, Carr., ii. 54

Loquat, i. 525

Loranthus europæus, Jacq., ii. 662

Lotophagi, food of, i. 327

Lotus Dorycnium, L., i. 502 of the Ancients, i. 327

Loudon, J. C., i. 7. Lowea, ii. 445

Lupin, tree, ii. 60

Lupinus arboreus, "Snow Queen," ii. 60

Ly cium barbarum, Hort., ii. 6I boerhaavifolia, L., i. 597 europæum, Hort., ii. 6I, 62 PALLIDUM, Miers, ii. 63 rhombifolium, $D_{i p p}$., ii. 62 vulgare, Dun., ii. 62 "Lycium," in eye affections, i. 245 Lyon, John, i. 9

\section{M}

MAaCkia AmURensis, Rupr., ii. 64 amurensis Buergeri, ii. $6_{5}$ Tashiroi, ii. 65

Macartney, Lord, i. 9

Maclure, Wm., ii. 65

Madaké, Hort. Jap., ii. I 52

Madingley, elm at, ii. 6 I 8

Madroña, i. 20 I

Magnolia acuminata cordata, Sarg., ii. 68 Alexandrina, ii. 74 auriculata, Lam., ii. 69 CONSPICUA, Salis., ii. 68

cyathiformis, ii. 74

denudata, Lam., ii. 72

Exmouth, ii. 70

fœtida, Sarg., ii. 70

Fraser's, ii. 69

glauca decidua, ii. 69 major, Sims, ii. 75

grandiflora exoniensis, Lodd., ii. 70

Halleana, Hort., ii. 74

Hammondii, ii. 74

Hartwegii, ii. 70

Kobus borealis, Sarg., ii. 7I. Laurel, ii. 70. Norberti, ii. 74. Officinalis, ii. 70

precia, Corr., ii. 67

purpurea, Curt., ii. 72

rustica rubra, ii. 7 I

SALICIFOLIA, Max., ii. 73

speciosa, ii. 74

spectabilis, ii. 74

superba, ii. 74

Thurberi, Pars., ii. 71

triumphans, ii. 74

umbrella, Lam., ii. 75
MAGNOLIA WATSONI, ii. 76

Yulan, Desf., ii. 67

Soulangiana, Ldl., ii. 74

Magnol, Pierre, ii. 65

Mahogany, mountain, i. 336

Mahonia Aquifolium, Nutt., i. 234

Bealei, Carr., i. 244

fascicularis, $D C$., i. 246

Fortunei, Fedde, i. 240

Fremontii, Fedde, i. 240

Japanese, i. 244

japonica, $D C$., i. 244

nepalensis, $D C$., i. 245

nervosa, Nutt., i. 245

repens, G. Don, i. 247

trifoliolata, Fedde, i. 250

Maidenhair tree, i. 592

Mallow, tree, ii. II

Malus, ii. 27 I

angustifolia, Michx., ii. 274

baccata, Borkh., ii. 278

cerasifera, Spach, ii. 29I

coronaria, Mill., ii. 28I

florentina, $C$. $K$. Sch., ii. $28 \mathrm{I}$

floribunda, Sieb., ii. 282

fragrans, Rehd., ii. $28 \mathrm{I}$

fusca, $C$. $K$. Sch., ii. 292

Halliana, Koeh., ii. 284

ioensis, Britt., ii. 285

Kaido, Wenz., ii. 297

Niedzwetzkyana, Dck., ii. 288

prunifolia, Bork., ii. 290

Ringo, Sieb., ii. 292

Sargentii, Rehd., ii. 293

Scheideckeri, Zab., ii. 293

sikkimensis, Koeh., ii. 294

spectabılis, Bork., ii. 296

Toringo, Sieb., ii., 297

Zumi, Mats., ii. 300

Manna sugar, i. 572

Manzanita, i. 204

Downy, i. 205

Maple, black, i. 158

Buerger's, i. I 36

common, i. 136

Cretan, i. 139

David's, i. 140

Dieck's, i. I4I

eagle's claw, i. 155

Franchet's, i. 142

hawthorn, i. 139

Heldreich's, i. I43

Henry's, i. I 43

hornbeam, i. 137

horned, i. I 40

Italian, i. I $5 \mathrm{I}$

Japanese, i. 152

Lobel's, i. 146

Manchurian, i. 147

Montpelier, i. 148

mountain, i. 159

Nikko, i. 150 
Maple, Norway, i. I 54

Oliver's, i. I5 I

Oregon, i. 146

red, i. 157

rock, i. 142

Siebold's, i. I 59

silver, i. 139

snake-bark, i. I 53

sugar, i. $15^{8}$

Tartarian, i. 160

Trautvetter's, i. I60

Van Volxem's, i. I6I

vine, i. I37

Maples, at Westonbirt, i. I 35

for streets, i. 89

with handsome bark, i. 73, I 53

Maraschino liqueur, ii. 232

Margam Park, bay laurel at, ii. Io

Maries, Charles, i. I 2

Marlea platanifolia, Sieb., i. I77

Marron de Lyon, i. 308

Marsh Ledum, ii. I3

Masson, Francis, i. 7

Mastic, ii. I 96

Mt. Atlas, ii. I95

trees, ii. I94

Maximowiczia chinensis, Rupr., ii. 504

May, i. 429, 432 flower, i. 516

Mazzard, ii. 229

Meadow-sweet, ii. 542

Médaké, i. 216

Medlar, ii. $8 \mathrm{I}$

Bronvaux, i. 4 I 8

Megginch Castle, Banksian rose at, ii. 420

Meliosma CunEIFolia, Fr., ii. 78

Menabilly, gum-trees at, i. 532

Menzies, Archibald, ii. 8I in Chile, i. 199

Menziesia empetriformis, $S m$., ii. I48 ferruginea globularis, Sims, ii. 80 glabella, $A$. Gr., ii. 81 globularis, Salis., ii. 80 PILOSA, Juss., ii. 81

Meratia fragrans, Lois., i. 337

Mespilus grandiflora, $S m$., i. 418 Smithii, $D C$., i. 4 I 8 snowy, i. 190

Metaplexis japonica, Mak., ii. 82

Meu-tang, ii. I 20

Mexican orange flower, i. 34 I

Mezereon, i. 47 I

Michaux, Andre, i. 7

Micromeles alnifolia, Koeh., ii. 272 caloneura, Stapf, ii. 279

Folgneri, C. K. Sch., ii. 283

Milan, hedge of Ægle sepiaria at, i. I65

Milkwort, ii. 207

Miller, Phillip, i. 6

Milletia japonica, A. Gr., ii. 682

Mill Hill and School, i. 6

Mirabelle plums, ii. 238
Mississippi sugarberry, i. 329

Mistletoe, ii. 662

Mitcham, lavender at, ii. II

Mocker nut, i. 301

Mock orange, ii. 132, 133

Monkey puzzle, i. 199

Monreith, barberry at, i. 237

Olearia at, ii. 105

Moonseed, ii. 80

Canadian, ii. 80

Davurian, ii. 80

Moon trefoil, ii. 77

Moosewood, i. 153

Mortina, ii. 627

MORUS NIGRA, L., ii. 86

Moso-chiku, Hort. Jap., ii. I 5 I

Mountain Ash, ii. 27I, 276

American, ii. 272

Moravian, ii. 277

Holly, ii. 95

mahogany, i. 336,337

Mount Sinai thorn, i. 435

Moutan, ii. I 20

Muehlenbeckia adpressa, Meiss., ii. 87 australis, Meiss., ii. 87

varians, Meiss., ii. 87

Mulberry, ii. 84

common, ii. 85

French, i. 280

introduction of, by Romans, i. 3

paper, i. 267

red, ii. 86

Shakespeare, ii. 85

white, ii. 84

Mulching, i. 38

Murthly Castle, trees at, i. II 7, I 28

Myrica asplenifolia, L., i. 379

carolinensis, Mill., ii. 89

Myrobalan, ii. 23I

Myroxylon racemosum, Diels, ii. 684

Myrtilla, ii. 92

Myrtle, ii. or

sand, ii. 14

wax, ii. 89

Myrtus communis leucocarpa, $D C$., ii. 91

Luma, Mol., ii. 92

Ugni, Mol., ii. 92

\section{$\mathrm{N}$}

Nail-gall on limes, ii. 597

Nectarine, ii. 248

Needle, Adam's, ii. 688 furze, i. 586

Negundo aceroides, Moench, i. 149 fraxinifolium, Nutt., i. I49

Neill, Patrick, ii. 93

NEILlia SINENSIS, Oliv., ii. 95 Torreyi of Bot. Mag., ii. 93

Nettle-trees, i. 326 tree, Caucasian, i. 328 
Newbattle Abbey, beech at, i. 552

Newdigate, Serjeant, i. 5

New Jersey tea, i. 316

Nine-Bark, ii. 94 Manchurian, ii. 93 western, ii. 93

Nintooa, ii. 38

Nissa broom, i. 590

Nothofagus ANTaRCTICA, Oers/., ii. 98 Menziesii, Oerst., ii. Ioo

Noyer à bijoux, i, 667

Nuneham, Oregon ash at, i. 57 I

Nursery work, i. 28

Nut, bitter, i. 299 butter, i. 664

Caucasian wing-, ii. 26I

Hupeh wing-, ii. 252 Japanese wing-, ii. 263 mocker, i. 301 pig, i. 300

Nutmeg, Californian, ii. 598

NUtTAllia CERASIFORMIS, Torr., ii. IO2

Nyman's Gardens, Eucryphia at, i. 535

Nyssa aquatica, ii. 103 multiflora, Wangh., ii. I03

Ogeche, ii. I03

\section{$\mathrm{O}$}

Oak, Armenian, ii. 322

bear, ii. $3 \mathrm{I} 3$

black, ii. 327

black Jack, ii. 3 I 8

burr, ii. 3 I 8

Californian black, ii. $3 \sqrt{ } 3$

Champion's, ii. 327

chestnut, ii. 323

chestnut-leaved, ii. 303

common, ii. 320

cork, ii. 325

cypress, ii. 32 I

Daimyo, ii. 309

durmast, ii. 325

fern-leaved, ii. $32 \mathrm{I}$

Fulham, ii. 317

golden, ii. 321

Holm, ii. 3I I

Hungarian, ii. 307

Kermes, ii. 306

Lea's hybrid, ii. 3 I4

Lehanon, ii. 3 I 5

Lucombe, ii. 3 I 6

Macedonian, ii. 317

maul, ii. 305

mossy-cup, ii. 318

of Cyprus, Golden, ii. 303

overcup, ii. 3 I 8

pin, ii. 320

Pyrenean, ii. 326

red, ii. 323

scarlet, ii. 307
Oak, scrub, ii. 322

shin, ii. 309

shingle, ii. 313

Spanish, ii. 308

swamp white, ii. 303

tanbark, ii. 309

Turkey, ii. 305

Turner's, ii. 326

valley, ii. 316

Valonia, 1i. 302

water, ii. 319

weeping, ii. $32 \mathrm{I}$

white, ii. 302

willow, ii. 322

Oidium Euonymi-japonicæ, i. 539

Oil of Spike, ii. II

Old Conna Hill, Dendromecon at, i. 479 trees, care of, i. 53

Olea fragrans, Thunb., ii. I Io

Olearia Forsteri, Hk. f., ii. 104

GUNNIANA, ii. 106

insignis, $H k$. $f_{\text {. }}$, ii. 104

macrodonta nana, ii. I05

nitida, Hk. f., ii. 104

nummularifolia, Hk. f., ii. 104

stellulata, $D C$., ii. Io6

virgata, Hort., ii. I06

Oleaster, i. 504

Olive, ii. I04

Omorika (Picea), ii. 154

ONONIS ARAGONENSIS, Asso, ii. IO8 arvensis, ii. 106

Natrix, L., ii. 107

Oplopanax horridum, Miq., i. 555

Orange flower, Mexican, i. $34 \mathrm{I}$

-like odour in pine sloots, ii. I9I

mock, ii. I 32, I 33

Osage, ii. 65

for hedges, i. 96

Oregon Association, i. II

grape, i. 234

Oreodaphne californica, Nees, ii. $\hbar_{2}$ I

Orme's Head, Cotoneaster on, i. 4 I 2

Ornus, i. 562

europæa, Pers., i. 572

Osage Orange, ii. 65

Osier, black Hollander, ii. 49I

Italian, ii. 49I

mauls, ii. 49 I

brown merrin, ii. 492

common, ii. 492

Dicks, ii. 488

fine basket, ii. 490

French, ii. 49I

glibskins, ii. 49 I

jelstiver, ii. $49 \mathrm{I}$

kecks, ii. 488

long skein, ii. 492

Mawdesley's long skein, ii. 490

mottled Spaniards, ii. $49 \mathrm{I}$

Pomeranian, ii. 49I

red-bud, ii. 488 
Osier, Welch, ii. 488

yellow, ii. 49 ?

Osmanthus Aquifolium, Hort., ii. II 2

DELAVAYI, Fr., ii. II 2

fragrans, Lour., ii. I IO

ilicifolius, Hort., ii. I 2

myrtle-leaved, ii. II I

Osoberry, ii. IOI

Osteomeles anthyllidifolia, Hort. and Ldl., ii. II 3

SCHWERINÆ, $C . K$. Sch., ii. II 4

Ostrya vulgaris, Willd., ii. I I 5

Othera japonica, Thunb., i. 647

Oxford Botanic Garden, foundation of, i. 5

Oxycoccus erythrocarpus, Pers., ii. 626

Ozothamnus rosmarinifolius, $D C$., i. 6 I 7

\section{$\mathbf{P}$}

Padua, Carya at, i. 300

Padus cornuta, Carr., ii. 233

Cuthbertii, Small, ii. 234

demissa, Roem., ii. 235

Grayana, $C$. K. Sch., ii. 237

racemosa, Lam., ii. 246

serotina, $A$ gdh., ii. $25 \mathrm{I}$

Ssiori, C. K. Sch., ii. 254

virginiana, Roem., ii. 257

Pæonia arborea, Donn, ii. I 20

Pæony, ii. I 20

tree, ii. 120

yellow, ii. I 2 I

Pains Hill, cedar at, i. 324 juniper at, i. 677 red oak at, ii. 323

Paliurus aculeatus, Lam., ii. I 2 I Spina-Christi, Mill., ii. I 2 I

Palm willow, ii. 478

Panax horridum, Sm., i. 555

quinquefolium variegatum, Hort., i. I 31

sessiliflorum, Rupr., i. 132

Papaw, i. 22 I

Paradise stock, ii. 287

Parasol de St Julien, ii. 22I

Paris Frame, i. 2 I

Parkinson, John, i. 4

Parrotia Jacouemontiana, Dcne, ii. I23

Parrotiopsis involucrata, $C . K$. Sch., ii. I 22

Parthenocissus, ii. 665

dumetorum, Rehd., ii. 678

Henryana, Graeb., ii. 670

quinquefolia, Plan., ii. 175

sinensis, Diels, ii. 676

tricuspidata, Plan., 1i. $67 \mathrm{I}$

vitacea, Hitch., ii. 678

Pasania, ii. 300

densiflora, Oerst., ii. 309

Passerina nivalis, Ram., ii. 588

Passion-flower, ii. I 24
Paulownia Fargesii, Fr., ii. I25 tomentosa, Koch, ii. I 24

Pavia californica, Hartw., i. 167 indica, Wallich, i. I $7 \mathrm{I}$ macrostachya, Loisel., i. 173 rubra, Poir., i. I 73 shrubby, i. 173

Peach, common, ii. 247

David's, ii. 2 ? 4

flat, ii. 248

Peaches, ii. 225

Pear, Bollwyller, ii. 278 Persian, ii. 283 sand, ii. 295 swamp sugar, i. 189 white, ii. 295 wild, ii. 280 willow-leaved, ii. 292

Pearl fruit, ii. 77

Pears, i1. 269

Pearse, Richard, i. II

Pea-tree, i. 287

Pecan, i. 300

Pendell Court, Araujia at, i. 200

Penjerrick, Podocarpus at, ii. 206

Pentstemon corymbosus, $B$ th., ii. 126 heterophyllus, $L d l$., ii. 126 Menziesii, $H k$., ii. 126

Pepper, Japan, ii. 692 -tree, ii. 503

Pepperidge, ii. 103

PERAPHYllum RAmosissimum, Nutt, ii 125

Pergolas, i: 60

Periclymenum, ii. 38

Periwinkle, ii. $6 t_{0}$ larger, ii. 66r lesser, ii. 66r

Pernettya angustifolia, $L d l$., ii. I 28

Perny, Paul, i. 650

Persica Davidiana, Carr., ii. 234 vulgaris, Mill., ii. 247

Persimmon, i. 494 Chinese, i. 493

Petre, Lord, i. 6

Petteria Ramentacea, Presl., ii. I29 I 30

Petty whin, i. 586

Peuplier régénéré, ii. 218 suisse, ii. 218

Phellodendron chinense, $C$. $K$. Sch., ii. I 3 I

Philadelphus acuminata, Lange, ii. I 40 "avalanche," ii. 137

Billiardi, Koeh., ii. I 36

"boule d'argent," ii. I 37

brachybotrys, Koeh., ii. I40 purpurascens, Koeh., i1. 134

"fantaisie," ii. I 37

"gerbe de neige," ii. I 37

Gordonianus, Ldl., ii. I 38

grandiflorus floribundus, Torr., ii. 137 laxus, Torr., ii. 135 
Philadelphus InCanus, Koeh., ii. I 35 laxus, Schrad., ii. I 35

Lemoinei, pruning of, i. 52

"manteau d'hermine," ii. 137

MICROPHYLLUS, $A$. Gr., ii. 139

"pavillon blanc," ii. I 37

sericanthus, Koeh., ii. I 36

"Souvenir de Billiard," ii. I 36

"virginal," ii. I 37

Philageria Veitchii, Mast., ii. 141

PHILLYREA DECORA, Boiss., ii. 142, I 43 laurifolia, Hort., ii. $\mathrm{I}_{42}$

media, L., ii. 143

buxifolia, il. I 43

rosmarinifolia, Mill., ii. 142

spinosa, Mill., ii. I 43

Vilmoriniana, Boiss., ii. I 42

Photinia arbutifolia, $L d l$., i. 618

japonica, Fr., i. 525

lavis, $D C$., ii. 145

variabilis, Hemsl., ii. 145

Phyllodoce amabilis, Stapf, ii. I +6 , I 47 EMPETRIFORMIS, Don, ii. 148 erecta, Drude, ii. 149

Phyllostachys Boryana, Mitf., ii. I 51 fastuosa, Hort., i. 215

fulva, Mitf., ii. I5I

heterocycla, Carr., ii. I 5 I

Kumasaca, Mun., ii. I 52

Marliacea, Mitf., ii. I52

sulphurea, $R$ iv., ii. I5 I

violascens, $R$ iv., ii. I 53

Phyllothamnus erectus, C. K. Sch., ii. 149

Physianthus albens, Mart., i. 200

Physocarpus, ii. 93

amurensis, $M a x_{\text {., }}$ ii. 93

opulifolius, Max., ii. 94

Torreyi, Max., ii. 95

Phytoptus rudis, i. 255

Plcea ajanensis, Fischer, ii. 158

ajanensis, Hort., ii., I 58

Albertiana, S. $B r_{\text {. }}$, ii. I 55

Annesleyana, ii. I64

bicolor, Mayr, 1i. 155

canadensis, Britt., ii. I 55

commutata, Hort., 1i. 163

Engelmanni glauca, Hort., ii. I64

ericoides, Hort., ii. I6o

excelsa argenteo-spica, ü. 157

Clanbrassiliana, 1i. I57

Cranstoni, ii. 157

denudata, ii. 157

Dicksoni, ii. 158

dumosa, ii. 157

eremita, ii. I 58

finedonensis, ii. 157

gigantea, ii. $15^{8}$

globosa, ii. I 57

Gregoryana, ii. 157

inverta, i. 157

monstrosa, ii. 157

pendula, ii. 158
Plcea excelsa pumila glauca, ii. I 57 pygmæa, ii. I 57

Remontii, ii. 157

stricta, ii. 158

virgata, ii. $15^{8}$

Glehnii, Mast., ii. I 54

Kosteri pendula, ii. I64

mariana, Britt., ii. 160

Maximowiczii, $R g l$., ii. 155

MORINDOIDES, Rehd., ii. I 59

nigra Doumetti, ii. I6o

obovata Schrenkiana, Carr., ii. I60

Parryana, Sarg., ii. I63 glauca, ii. 164

POLITA, Carr., ii. I 62

PUNGENS, Engel., ii. I 63 argentea, ii. 164

rubens, Sarg., ii. I64

Sargentii, ii. I 64

Schrenkiana, Fisch., ii. I6o

Smithiana, Boiss., ii. 158

spinulosa, A. Henry, ii. 159

Picrasma quassioides, Benn., ii. 165

PIERIS FLORIBUNDA, $B$ th., ii. I66

introduction of, i. 8

JAPONICA, Don, ii. 167

Pig nut, i. 300

Pin du Lord, ii. I9I

Pine, ii. 168

Aleppo, ii. $18 \mathrm{I}$

Armand's, ii. 172

Arolla, ii. I 76

Austrian, ii. 183

beach, ii. 177

Bishop's, ii. 185

on sea coast, ii. 186

black, ii. 192

Bunge's, ii. 175

Calabrian, ii. 174

Chile, i. 199

cluster, ii. 187

Corean, ii. 182

Corsican, ii. 183

Coulter's, ii. 177

Digger, ii. 190

Eastern yellow, ii. 178

fox-tail, ii. I 74

Gerard's, ii. I 80

Hartweg's, ii. I8I

hickory, ii. 189

Himalayan blue, ii. I 78

Jack, ii. I 74

Japanese red, ii. 177

white, ii. 187

Jeffrey's, ii. 182

Jersey, ii. 193

knob-cone, ii. 193

lace-bark, ii. 175

limber, ii. I 79

lodge-pole, ii. 186

Macedonian, ii. 187

maritime, ii. 187 
Pine, Mexican white, ii. I73

Monterey, ii. 189

Montezuma, i. 185

mountain, ii. 184

Northern pitch, ii. 190

one-leaf nut, ii. 184

pond, ii. 190

red, ii. 190

Riga, ii. I 92

Scotch, ii. I9I

scrub, ii. 193

stone, ii. I 88 and the Romans, i. 3

sugar, ii. 182

three-leaf nut, ii. I76

two-leaf nut, ii. 178

umbrella, ii. 506

Western white, ii. 185 yellow, ii. I 88

Weymouth, ii. I9I

white bark, ii. I 7 I

Yunnan, ii. 193

Pink Siris, i. 177

Piñones, ii. 177

Pinus Abies, L., ii. 157

aristata, Engel., ii. I 74

ARMANDI, Fr., ii. 172

attenuata, Lemm., ii. I 93

australis, Mchx., ii. 170

austriaca, Hoess, ii. 183

AYACAHUITE, Ehren., ii. I73

Balfouriana aristata, Engel., ii. I74

BRUTIA, Ten., ii. I75

californica, Hartw., ii. I93

Cembra aurea, ii. I76

contorta Murrayana, Engelm., ii. I 86

Devoniana, ii. 185

divaricata, Dum., ii. 174

Edgariana, Hartw., ii. 185

EXCELSA, Wall., il. I79

FLEXILIS, James, ii. I80

Fremontiana, Endl., ii. 184

halepensis Brutia, Henry, ii. I74

hudsonica, Parl., i1. I74

inops, Sol., ii. 193

insignis, Dougl., ii. 189

Laricio aurea, ii. 183

leucodermis, $C h r$., ii. 183

pumila, ii. 183

pygmæea, ii. 183

leucodermis, $A n t$., ii. 183

Lindleyana, ii. 185

maritima, Lam., 1i. I 88

Massoniana, Hort., ii. I 92

Massoniana, Lamb., ii. 178

mitıs, Michx., ii. I 78

montana Mughus, Willk., ii. 184 pumila, Willk., ii. 184

uncinata, Willk., ii. I 84

Montezumæ Hartwegi, Engel., ii. I 8 I

Mughus, $S c o p$., ii. 184
Pinus palustris, Mill., ii. I 70 pentaphylla, Mayr, ii. I 87 Pinea, and the Romans, i. 3 pseudo-strobus, $L d l$., ii. 185 pumila, $R g l$., ii. 176 pumilio, Hnke., ii. 184 pyrenaica, ii. 183 pyrenaica, Carr., ii. I74 quadrifolia, Sudw., ii. I86 Russelliana, ii. 18; serotina, Michx., ii. 190

Strobus compacta, ii. I9I densa, ii. I 9 I umbraculifera, ii. I9r sylvestris rigensis, ii. 192 Taeda, L., ii. 170 Torreyana, Parry, ii. I 70 uncinata, Ram., ii. I 84 Veitchii, Rzl., i. I 73

Pipe, Dutchman's, i. 208

Pistachio, ii. I961 Chinese, ii. 195

Pistil, description of, i. 26

Pitch pine, Northern, ii. I90 (true), ii. I70

Pittosporum Mayi, Hort., ii. I97 Ralphii, Kirk, ii. I 97

Plagianthus Lampeni, Bth., ii. 200 LyALLII, $A . C$., ii. 199

Plagıspermum sinensis, Oliv., ii. 223

Plane, ii. 200

American, introduction of, i. 4

Corstorphine, i. 156

London, ii. $20 \mathrm{I}$

Oriental, ii. 203

Pilng, i. I 56

Scotch, i. I 55

Planera Davidii, Hance, ii. 694

Richardii, Mchx., ii. 694

Plant, coral, i. 232

lead, i. 192

smoke, ii. 392

Platanus integrifolia, ii. 202 macrophylla, ii. 201 nepalensis, Hort., ii. 202 occidentalis argenteo-variegata, ii. 201 orientalis cuneata, Loud., ii. 202 pyramidalis, ii. 202

Plum, American red, ii. 227 -apricot, i1. 234, 253 beach, ii. 242

Canadian, ii. 245

cherry, ii. 23 I

chickasaw, ii. 228

date, i. 494

Japanese, ii. 256

Mirabelle, ii. 238

mountain, ii. 3 I 4

Naples, ii. 233

Oregon, ii. 254

sand, ii. 242,257

Texan, ii. 245 


\section{INDEX}

Plum, Wayland, ii. 237 wild, ii. 233

Plums, ii. 225

Podocarpus andina, Hort., ii. 206 andina, Poepp., ii. 224 koraianus, Hort., i. 332 nubigena, $L d l$., ii. 206

Poinciana Gilliesii, Hook., i. 279

Poirier sangers, ii. 289

Poison bay, i. 652 ivy, ii. 394

sumach, ii. 396

Polycarpa Maximowiczii, Linden, i. 640

Polygala Chamrbuxus grandiflora, ii. 207

Polygonum Baldschuanicum, Regel, ii. 208. P. Aubertii, L. Henry, ii. 208 crispulum, Sims, i. 224

equisetiforme, Sibt., ii. 208

Pomegranate, ii. 265

Pomette Bleue, i. 422

Pope, Alexander, and Duke of Argyll, i. 6

Poplar, ii. 209 and the weeping willow, ii. 477

balsam, ii. 209

Berlin, ii. 2 I 2

black, ii. 209, 216 Italian, ii. 217

Bolle's ii. 2 ro

Canadian, ii. 2 I6, 2 I 8

Carolina, ii. 2 Io

downy black, ii. 217

for streets, i. 87

grey, ii. 213

Lombardy, 1i. 217

necklace, ii. 2 I 6

Ontario, ii. 212

Picart's, ii. 213

Swiss, ii. 218

white, ii. 209,210

willow-leaved, ii. 2 I I

Poppy, tree, ii. 4I 4

Populus alba macrophylla, ii. 2 I 3 nivea, ii. 2 Io

angulata cordata robusta, ii. 2 I I

Arembergiana, Hort., ii. 2 Io

balsamifera viminalis, Loud., ii. 2 I 5

Bolleana, Carr., ii. 2 10

canadensis, Michx., ii. 2 I6 aurea, Van Gt., ii. 218 erecta, $D_{i p p .,}$ ii. 218 grandis, Hort., ii. 2 I 8

certinensis, Hort., ii. 2 I 2

deltoidea, Marsh., ii. 216

euphratica, Oliv., ii. 476

fastigiata, Desf., ii. 2 I 7

græca, ii. 220

grandifolia, Hort., ii. 218

hudsonica, Michx., ii. 2 I 7

monilifera erecta, Selys, ii. 2 I 8

nigra pyramidalis, Spach, ii. 217

Petrowskyana, Schr., ii. 2 Io

Picartii. Hort., ii. 213
Populus plantierensis, S.-L., ii. 2 I7

Rasumowskyana, Schr., ii. 210

regenerata, Hort., ii. 218

robusta, $C . K$. Sch., ii. 2 I I

Thevestina, Dode, ii. 217

TREMULA, L., ii. 2 I 9

tristis, Fisch., ii. 213

viadri, Rued., ii. 2 I 7

villosa, Lang, ii. 220

Wislizenii, Sarg., ii. 2 I 4

Wobstii, Schr., il. 210

Potentilla Fruticosa VeItchi, ii. 222

glabra, Lodd., ii. 22 I

prostrata, Lap., ii. 223

Veitchii, Wils., ii. 223

Pot-pourri, Chinese, ii. 44I

Pourthiæa arguta, Hort., ii. I45

Powderham, gum-tree at, i. 533

Powerscourt, trees at, i. 125

Prinos, i. 642

glaber, L., i. 647

lævigatus, Pursh, i. 618

padifolius, Willd., i. 652

tenuifolius, Torr., i. 652

verticillatus, $L$., i. 65 I

PRINSEPIA SINENSIS, Oliv., ii. 224

Privet, ii. 23

Chinese, ii. 28

common, ii. 29

Delavay's, ii. 24

for hedges, i. 95

golden, ii. 27

Henry's, ii. 24

Japanese, ii. 26

oval-leaved, ii. 27

Pratt's, ii. 27

swamp, i. 164

Yunnan, ii. 29

Propagation, i. 14

Pruning by thinning, i. 5 I

of street trees, i. 85,9 I

trees and shrubs, i. 45

Prunus Amygdalus persicoides, ii. 228

Avium laciniata, ii. 230

B fEsSEYI, Bail., ii. 230

Blireiana, André, ii. 232

Bungei, Walp., ii. 237

caroliniana, A it., ii. 238

cerasifera atropurpurea, Dipp., ii. 232

"Louis Asselin," ii. 232

Moseri, i1. 232

Cerasus ranunculiflora, ii. 232

Rhexi, ii. 232

Chamæcerasus, Jacq., ii. 236

curdica, Fenzl, ii. 254

depressa, Pursh, ii. 249

domestica, Huds., ii. 233

eminens, Beck, ii. 227

glandulosa, Thunb., ii. 239

JAPONICA FLORE PLENO, ii. 239

Laucheana, Bolle, ii. 246 
Prunus lusitanica var. myrtifolia for hedges, ii. 95

macrophylla, Poir., ii. 230

Mahaleb, albo-marginata, ii. 242

compacta, ii. 242

fol. aureis, ii. 242

fructu-flavo, ii. 242

variegata, ii. 242

Miqueliana, Hort., ii. 243

Myrobalana fl. pleno, ii. 244

nepaulensis, Steud., ii. 234

pendula ascendens, ii. 255

Persica camelliæflora, ii. 248 "Clara Meyer," ii. 248 dianthiflora, ii. 248

Pissardi, Carr., ii. 232

plantierensis, ii. 233

Pseudocerasus, Hort., ii. 252

reflexa, Hort., ii. 236

salicifolia, Kth., ii. 25 I

SaRgentil, Rehd., ii. 250

serrulata "Benifugen," ii. 252

"Hisakura," ii. 252

"Osaka," ii. 252

sinensis, Pers., ii. 239

SUBHIRTELLA, Miq., ii. 255

tortuosa, ii. 243

triloba Petzoldii, ii. 256

utahensis, Koeh., ii. 230

Psedera, ii. 665

Henryana, $C . K$. Sch., ii. 670

himalayana, $C . K$. Sch., ii. 67 I

quinquefolia, Greene, ii. 675

sinensis, C. K. Sch., ii. 676

vitacea, Greene, ii. 678

PSEUDOlaRIX FortuneI, Mayr, ii. 258

Kaempferii, Gord., ii. 257

Pseudotsuga Douglasii Fretsii, Beiss., ii. 259

japonica, Sarg., ii. 260

macrocarpa, Mayr, ii. 260

taxifolia, Britt., ii. 259

Ptelea Baldwinii, Torr., ii. 26r mollis, Curt., ii. 26I

Pterocarya dumosa, Lav., ii. 262 fraxinifolia, Spach, ii. 26 I

Pterostyrax corymbosum, ii. 265 HISPIDUM, Sieb., ii. 265

Punica nana, L., ii. 266

Purslane, sea, ii. 227

tree, ii. 227

Pyracanth, ii. 268

Pyracantha Coccinea, Roem., ii. 268

fructu-albo, ii. 269

pauciflora, $D_{i p p}$., ii. 269

Pyrenean pine, ii. 183

Pyrus Achras, ii. 280

alpina, Hort., ii. 282

alpina, Willd., ii. 282 super-aria, ii. 282

americana nana, ii. 293

AMYGDALIFORMIS, Vill., ii. 273
Pyrus angustifolia fl. pleno, ii. 274, 286

ARIA, Ehrh., ii. 275 himalaica, Hort., ii. 299

Aucuparia dulcis, ii. 277

Fifeana, ii. 277

moravica laciniata, ii. 277

AURICULARIS, $K$ noop, ii. 278

bollwylleriana, $D C$., ii. 278

canescens, Spach, ii. 289

communis Briggsii, Syme, ii. 28 I

cordata, Desv., ii. 280

coronaria fil pleno, ii. 28I, 286

Cydonia, L., i. 454

domestica, Sm., ii. 295

eleagrifolia, Pall., ii. 289

erythrocarpa, ii. 274

floribunda fl. pleno, ii. 284

fusca, Raf., ii. 292

HETEROPHYLLA, Reg., ii. 284

Hostii, ii. 280

hybrida, Mnch., ii. 297

japonica, Thunb., i. 452

Kaido, ii. 297

Kotschyana, Boiss., ii. 289

lanuginosa, $D C$., ii. 282

lanuginosa, Hort., ii. 282

lobata, Nichols., i. 4 I 8

Malus "Elise Rathke," ii. 287 mitis, ii. 287

sylvestris, ii. 287

Matsumurana, Mak., ii. 293

Maulei, Mast., i. 453

Meinichii, ii. 277 ।

minima, Ley, ii. 285

Mougeoti, ii. 285

neullyensis, ii. 277,282

nigra, Sarg., ii. 287

oblongifolia, Spach, ii. 273

Parkmanni, Hort., ii. 284

Pashia KumAONI, Stapf, ii. 289, 290

pinnatifida fastigiata, ii. 290

pohuashanensis, Hance, ii. 277

prunifolia xanthocarpa, ii. 291

Pyraster, ii. 280

RINGO, Wenz., ii. 291, 292

rotundifolia, Bechs., ii. 286

rupicola, Syme, ii. 276

scandica, Asch., ii. 285

scopulina, ii. 293

SIKKIMENSIS, Hk. f., ii. 294

Simonii, Carr., ii. 295

sinaica, Dum., ii. 273

Sorbus maliformis, ii. 296

pyriformis, ii. 296

\section{Q}

Quercitron, ii. 327

Quercus acuminata, Sarg., ii. 323 acuta bambuswefolia, Mast., ii. 327 Afares, Pom., ii. 305 
Quercus ambigua, $M$ chx., ii. 324

americana splendens, ii. 307

aquatica, Walt., ii. 3 I 9

aspelnifolia, ii. $32 \mathrm{I}$

austriaca, ii. 327 splendens, ii. 327

Auzandri, Gren., ii. 307

Ballota, Desf., ii. 3 I I

bambusæfolia, Fort., ii. 327

Banisteri, Mchx., ii. 313

Bungeana, Forb., ii. 327

californica, Coop., ii. 3 I 3

CASTANAEFIA, C. A. M., ii. 304

Cerris dissecta, ii. 305

chinensis, Bunge, ii. 327

COCCIFERA, L., ii. $3 \mathrm{C} 6$

coccinea ambigua, $A$. Gr., ii. 324

crispula, $B l$., ii. 3 I I

Daimio, Koch, ii. 309

digitata, Sudw., ii. 308

falcata, Mchx., ii. 308

glauca, Thunb., ii. 328

Gramuntia, $L$., ii. $3 \mathrm{I} 3$

Haas, Kotschy, ii. $32 \mathrm{I}$

heterophylla, Mchx., ii. 314

Hindsii, Bth., ii. 316

ILEX, $L$., ii. 3 I 2

for hedges, i. 94

longifolia, ii. 313

macrophylla, ii. 313

rotundifolia, ii. 313

serratifolia, ii. 3 I 3

infectoria, Oliv., ii. 317

Boissieri, $D C$., ii. 3 I 7

petiolaris, $D C$., ii. 3 I 7

LIBANI, Oliv., ii. 315

Louettii, ii. 325

lyrata, Walt., ii. 318

mongolica, Fisch., ii. 3 I 4

mongolica, Hort., ii. 3 I 4

Muehlenbergii, Engelm., ii. 323

nana, Sarg., ii. 313

nigra, $L$., ii. 319

nigra, Wangh., ii. 318

occidentalis, Gay, ii. 325

pectinata, ii. $32 \mathrm{I}$

pedunculata aurea leucocarpa, ii. 32 I

Granbyana, ii. 32 I

nigra, ii. 321

nigricans, ii. $32 \mathrm{I}$

Trinessii, ii. $32 \mathrm{I}$

platanoides, Sudw., ii. 303

pseudococcifera, Lab., ii. 307

Pseudo-suber, Santi, ii. 317

pseudoturneri, ii. 327

pubescens, Willd., ii. 314

Pyrami, Kotsc., ii. 302

Robur, L., ii. 320

rubra ambigua, Fern., ii. 324

serrata pendula, ii. 3 I 6

sessiliflora purpurea, ii. 325

sonomensis, $D C$., ii. 313
Quercus taraxacifolia, ii. 32 I

texana, Buckl., ii. 324

texana, Sarg., ii. 324

tinctoria, Mchx., ii. 327

Toza $\times$ pedunculata, ii. 326

vaccinifolia, Kell., i1. 306

Quihou, Mr, ii. 28

Quince, apple-shaped, i. 454

Chinese, i. 453

Japanese, i. 452

Portuguese, i. 454

Vranja, i. 455

\section{R}

Ranelagh, plane at, ii. 202

Raphiolepis Delacouri, ii. 329

indica, Ldl., ii. 329

JAPONICA, Sieh., ii. 329

ovata, Briot, ii. 328

salicifolia, ii. 329

Raspberries, ii. $45^{\circ}$

Raspberry, American red, ii. 467

black, ii. 464

Cuthbert, ii. 468

Gregg, ii. 465

Hansall, ii. 468

Hillborn, ii. 465

Ohio, ii. 465

wild, ii. 460

Ravenna, pine forest at, ii. 186

Redbud, i. 334

Chinese, i. 334

Western, i. 334

Redesdale, Lord, book on bamboos, $i$. 2 I I

Redoul, i. 382

Redwood, ii. 510

Rest-harrow, ii. 106

Retama monosperma, Boiss., i. 589

Retinispora, i. 442

dubia, Hort., ii. 587

ericoides, ii. $5^{87}$

filifera, Hort., i. 449

leptoclada, Gord., i. $45 \mathrm{I}$

obtusa, Sieb., i. 448

pisifera, Sieb., i. 449

plumosa, Hort., i. 449

squarrosa, Sieb., i. 450

Rhamnus alpina, L., ii. 332 grandifolia, Hort., ii. 332

angustifolia, Mill., ii. 330

Billardi, ii. 333

carniolica, Kern., ii. 332

caroliniana, Walt., ii. 335

colchica, Somm., ii. 333

latifolia, L'Her., ii. 333

libanotica (Bot. Mag.), ii. 333

libanotica, Boiss., ii. 333

Perrieri, Hort., ii. 330

tomentella, Bth., ii. 331 
Rhododendron afghanicum, $A$ itch., ii. 352 Albrechtii, Max., ii. 376 altaclerense, $L d l$., ii. 342 arbutifolium, Hort., ii. 374

Ascot Brilliant, ii. 382

Aucklandii, $H k$. $f$., ii. 359

Benthamianum, Hems., ii. 386

blandfordiæflorum, ii. 35 I

- Brettii, Hems., ii. 366

BROUGHTONII AUREUM, ii. 345

canadense, Dipp., ii. 375

Cartoni, ii. 344

catawbiense, introduction of, i. 8

caucasicum pictum, ii. 349

Chamæcistus, L., ii. 388

chrysanthum, Pall., ii. 349

CINNABARINUM, $H k$. $f$, ii. 35 I

coombense, Hemsl., ii. 352

Cunninghami, ii. 343

Cunningham's white, ii. 349

Dahurian, ii. 352

daphnoides, ii. 374

dauricum atrovirens, $E$ d., ii. 352

decorum, Fr., ii. 357

Everestianum, ii. 349

fastuosum, ii. 349

ferrugineum myrtifolium, $S$. and $K$., ii. 355

FLAVIDUM, Fr., ii. 356

Fortunei Houlstonii, 1i. 36I

fragrans, Pax., ii. 344

garden vars. of, ii. 339

GLAUCUM, Hk. f., ii. 358

Gowenianum, Sw., ii. 344

halense, Gremb., ii. 362

Harrisii, ii. 382

Harrovianum, Hems., ii. 372

hirsutiforme, Gremb., ii. 362

indicum amœnum, Max., ii. $34 \mathrm{I}$

Jacksoni, ii. 349

japonicum, $C$. $K$. Sch., ii. 367

kewense, W. Wats., ii. 359

kialense, Fr., ii. 373

Kotschyi, Simk., ii. 355

lancifolium, Mnch., ii. 373

Loderi, ii. 359

longistylum, Rehd., ii. 368

Luscombei, ii. 382

Manglesii, ii. 359

Mariesii, Hems., ii. 377

minus, Mchx., ii. 373

mucronulatum, Turc., ii. 353

myrtifolium, Lodd., ii. 374

narcissæflorum, ii. 366

nigro-punctatum, Bur., ii. $3^{5} 3$

obtusum, Pl., ii. 362

album, ii. 362

odoratum, Lodd., ii. 344

orbiculare, Dcne., ii. 377

oreodoxa, Fr., ii. 359

ovatum, Hort., ii. 374

Pink Pearl, ii. 359
Rhododendron præcox, Carr., ii. 350

primulinum, Hems., ii. 356

pulcherrimum, ii. 370

RACEMOSUM, Fr., ii. 375

RномвісUм, Miq., ii. 376

rosæflorum, ii. 362

Rosa Mundi, ii. 349

Roylei, ii. 35I

Russellianum, Sweet, ii. 342

Shilsoni, ii. 382

Smithii, ii. 343

album, ii. 346

aureum, ii. 346

elegans, ii. 346

SPINULIFERUM, ii. $38 \mathrm{I}$

Spooneri, Hems., ii. 357

stramineum, ii. 349

sulphureum, Hort., ii. 349

triflorum, $H k_{\text {. }}$. . ii. 364

VASEYI, $A$. $G r_{\text {. }}$, ii. 384

venustum, ii. 349

Wilsoni, Hort., ii. 374

YUNNANENSE, Fr., ii. 387

Rhodora canadensis, L., ii. 375

Rhodothamnus Chamacistus, $R c h b$, ii. 388

RHODOTYPUS KERRIOIDES, Sieb., ii. 389

Rhus aromatica, Ait., ii. 390

coriaria, L., ii. 390

hirta, Sudw., ii. 395

orientalis, C. K. Sch., ii. 395

Potaninii, Max., ii. 393

punjabensis, Stew., ii. 393

radicans, L., ii. 394

semialata Osbeckii, DC., ii. 393

sinica, Diels, ii. 393

sinica, Hort., ii. 393

Toxicodendron Rydbergii, ii. 394

trilobata, ii. 391

venenata, $D C$., ii. 396

viridiflora, Hort., ii. 395

Rhyncospermum jasminoides, $L d l$., ii. 599

Rhytisma acerina, i. I 56

Ribes affine, Dougl., ii. 407

alpinum sterile, ii. 399

Beatonii, Hort., ii. 402

Billiardii, Carr., ii. 401

CEREUM, Dougl., ii. 400

coloradense, Cov., ii. 407

CRUENTUM, Greene, ii. 400

Culverwellii, Macf., ii. 405

Cynosbati, L., ii. 403

divaricatum, Dougl., ii. 402

floridum, L'Her., ii. 398

fragrans, Lodd., ii. 398

fuchsioides, Moc., ii. 408

glutinosum, Bth., ii. 408

grossularioides, $M a x$., ii. 403

hirtellum, Mchx., ii. 402

inebrians, $L d l$., ii. 399

laxiflorum, Pursh, ii. 407

lentum, Cov., ii. 403 
Ribes malvaceum, $S m$., ii. 408 missouriense, Nutt., ii. 403 montigenum, $\mathrm{M}^{\prime} \mathrm{Cl}$., ii. 403 oxyacanthoides, $L_{\text {., }}$ ii. 402 petræum, Wulf., ii. 409 quercetorum, Greene, ii. 404 robustum, Jancz., ii. 406 rotundifolium, Mchx., ii. 402 rubrum, Lam., ii. 4c9 rubrum, L., ii. 409 Schlectendalii, Lge., ii. 409 Schneideri, Maur., ii. 406 Spæthianum, Koeh., ii. 400 tenuiflorum, Ldl., ii. 399 triste, Pallo, ii. 409 villosum, Gay, ii. 4 or vulgare album ii. 409 Warcewiczii, Jancz., ii. 409

Ringal, i. 2 I 3

Robinia Boyntonii, Ashe, ii. 4 Io

glutinosa, Sims, ii. 4 I 3 hispida inermis, ii. 410 Holdtii, Beissn., ii. 4 I 2 Kelsey, Cow., ii. 4I I macrophylla, Hort., ii. 4 IO

Pseudacacia, introduction of, i. 4 myrtifolia, ii. 4I 3 pyramidalis, ii. $4^{1} 3$ umbraculifera, ii. 4 I 3 unifoliolata, ii. $4 \mathrm{I} 3$

Pseudacacia flore luteo, ii. 4 I 3 viscosa, Vent., ii. 4 I 4

Roblé Beech, ii. IoI

Rocket, cress, ii. $63 \mathrm{I}$

Rock rose, i. 342 Corbières, i. 344 Montpelier, i. 347

Romans, introduction of plants by, i. 3

Root, China, ii. 5 I6 yellow, ii. 689

Root-cuttings, i. 20

Roots, propagation by, i. 20

Rosa acicularis nipponensis, $H k_{\text {. }} f_{\text {. }}$, ii. 436 alba odorata, Hort., ii. 42 I altaica, Willd., ii. 446 anserinifolia, Boiss., ii. 420 berberifolia, Salis., ii. 444 blanda arkansana, Best, ii. 4 I 9 Brunonii, Ldl., ii. 434 calocarpa, ii. 44I canina tomentella, Bak., ii. 422 capreolata, Neill, ii. 4 I 9 chinensis, Jacq., ii. 430 dumetorum, Thuill., ii. 422 Eglanteria, L., ii. 432 ferox, Lawr., ii. 440 ferruginea, Vill., ii. 440 fragrans, Thory, ii. 430 gallica centifolia, Crip., ii. 423 geminata, ii. 427 grandiflora, Ldl., ii. 446

Hardii, Cels., ii. 445
Rosa, heterophylla, Coch., ii. 44I Hugonis, Hems., ii. 429 indica pseudo-indica, $L d l$., ii. 426

Iwara, Sieb., ii. 44 I

kamchatica, Vent., ii. $44 \mathrm{I}$

Lawranceana, Sw., ii. 43 I

Luciæ (Bot. Mag.), ii. 448

lucida, Ehrh., ii. 446

lutea bicolor, ii. 432

lutescens, Pursh, ii. 428

macrantha, Desf., ii. 418

micrantha, $S m$., ii. 410

moschata nivea, ii. 424

Moyesil, Hems., ii. 435

muscosa, Mill., ii. 423

myriacantha, $D C$., ii. 446

nivea, Dup., ii. 424

NoisetTiana, Red., ii. 437

pendulina, L., ii. $4 \mathrm{I} 8$

pimpinellifolia, L., ii. 445

Pissardii, Carr., ii. 435

polyantha, Sieb., ii. 436

provincialıs, Mill., ii. 423

punicea, Mill., ii. 432

pyrenaica, Gouan, ii. 4 I 9

Rapinii, Boiss., ii. 428

rubifolia, $R$. $B r_{\text {., }}$ ii. 443

ruga, Ldl., ii. 431. Roxburghii, Tr.,

Sayi, Schw., ii. 4I7 [ii. 433

scotica, Mill., ii. 445

semperflorens, Curt., ii. 431

Seraphini, Viv., ii. 444

sinica, Ait., ii. 432

spinosissima hispida, ii. 428

stylosa, Desv., ii. 419

sulphurea, $A$ it., ii. 428

ternata, Poir., ii. 432

Thunbergii, Paul, ii. 436

trachyphylla, Rau, ii. 43 I

villosa, L., ii. 439

Vilmorinii, ii. $44 \mathrm{I}$

viridiflora, ii. $43 \mathrm{I}$

xanthina, $L d l$., ii. 424

Rose, Abyssinian, ii. 44I

Acacia, ii. 4 IO

Alpine, ii. 355

anemone, ii. 432

apple, ii. 439

Arkansas, ii. 419

Austrian copper, ii. 432

Ayrshire, ii. 419

Banksian, ii. 420

Blanc de Coubert, ii. 44 I

Bourbon, ii. 427, 43 I

Boursault, ii. 43 I

bramble-flowered, ii. 436

burnet, ii. 445

burr, ii. 433

cabbage, ii. 423

Cherokee, ii. 432

Chinese, ii. 430

crimson China, ii. $43 \mathrm{I}$ 
Rose, crimson Rambler, pruning of i. 52 damask, ii. 424

des Alpes, ii. $355,360,362$

dog, ii. 422

Dorothy Perkins, ii. $44^{8}$

fairy, ii. 430

Fortune's, ii. 426

French, ii. 427

Fujiyama, ii. 436

Gloire de Dijon, ii. 430

green, ii. 431

Guelder, ii. 653

Harisson's double yellow, ii. 433

hybrid perpetual, ii. 424,427

Irish, ii. 428

Jundzil's, ii. 43 I

Lady Duncan, ii. 44I

Macartney, ii. $42 \mathrm{I}$

Marechal Niei, ii. 430

Marie Leonida, ii. 42 I

meadow, ii. 42 I

monthly, ii. 430

moss, ii. 423

Mt. Omi, ii. 438

Mrs A. Waterer, ii. 44I

musk, ii. 434

Noisette, ii. 437

Nootka, ii. 438

of Sharon, i. 634

pasture, ii. 430

Père Soulie's, ii. 445

Persian yellow, ii. 433

polyantha, ii. 436

prairie, ii. 427,443

Provence, ii. 423

Ramanas, ii. 440

rock, i. 342

Scotch, ii. 445

seven sisters, ii. 436

smooth, ii. 42 I

"Syringa," ii. 138

tea, ii. 430

tea-scented, ii. 430

without a thorn, ii. 418

yellow American, ii. 429

York and Lancaster, ii. 424

Rosemary, ii. 448

bog, i. I 94

ROSMARINUS OFFICINALIS, L., ii. 449

Rossdohan, Aristotelia at, i. 209

Rostrevor, Billardiera at, i. 265 purple chestnut at, i. 309

Rottlera japonica, Spreng., ii. 76

Rowan, ii. 276

Rubber-tree, hardy, i. 535

Rubi, British, ii. 45 I

Rubus bellidiflorus, Koch, ii. 470

carpinifolius, W. and N., ii. 452

corylifolius, $S m$., ii. 452

DELICIOSUS, James, ii. 457

echinatus, $L d l$, ii. 453

flagelliformis, Hort., ii. $45^{8}$
Rubus hakonensis, Fr., ii. 462

hirtus, Waldst., ii. 452

hupehensis, Oliv., ii. 468

illecebrosus, Focke, ii. 452

incisus, Hort., ii. $46 \mathrm{I}$

innominatus, $S$. Moore, ii. $46 \mathrm{I}$

laciniatus minor, ii. 462

leucostachys, Schl., ii. 452

Millspaughii, Britt., ii. 455

morifolius, Hort., ii. $46 \mathrm{I}$

mucronatus, Blox., ii., 452

neglectus, $P e c k$, ii. 465

niveus, Wall., ii. 458

parviflorus, Nutt., ii. 464

polytrichus, Fr., ii. 469

pulcherrimus, Neum., ii. 452

Quintlandii, ii. 462

rhamnifolius, $W$. and $N$., ii. 452

rudis, $W$. and $N$., ii. 453

rusticanus, Merc., ii. 470

sagatus, Focke, ii. 453

silvaticus, $W$. and N., ii. 453

species of, with white stems, i. 72

suberectus, Anders., ii. 453

triphyllus, Thunb., ii. 466

trivialis, Mchx., ii. 459

ulmifolius fl. pleno, ii. 470

Veitchii, Rolfe, ii. 468

vestitus, Weihe, ii. 452

villicaulis, Koehl., ii. 453

villosus, Ait., ii. 463

villosus, Gray, ii. 463

Rue, ii. 472

bell, i. 368

Ruscus racemosus, L., i. 465

\section{S}

Sage, ii. 493

brush, i. 210

grey, i. 226

Jerusalem, ii. 143

St Andrew's Cross, i. 220

St Dabeoc's heath, i. 465

Salal, i. 58 I

Salisburia adiantifolia, $S m$. , i. 592

Salix acutifolia, Willd., ii. 480

alba cœrulea, Syme, ii. 479 vitellina, Stokes, ii. 493

amygdalina, $L$., ii. 492

angustifolia microstachya, Anders., ii. 475

babylonica Salamoni, Hort., ii. 490

basfordiana, Salt., ii. 481

bicolor, Ehrh., ii. 487

blanda, Anders., ii. 490

CAPREA, L., ii. 479

cardinalis, ii. $48 \mathrm{I}$

crispa, Hort., ii. 477

cuspidata, ii. 484

decipiens, Hoffm., ii. $48 \mathrm{I}$ 
Salix elegantissima, Koch, ii. 490

Erdingcri, Kern., ii. 480

falcata, Pursh, ii. 486

ferruginea, Forb., ii. 492

Friesiana, Anders., ii. 489

fruticosa, Doell, ii. 492

Grahamii, Borr., ii. 482

hippophæefolia, Thuill., ii. 492

Jacquinii, Host., ii. 485

japonica, Dipp., ii. 487,490

Lavallei, ii. 490

japonica, Thunb., ii. 490

Medemii, Boiss., ii. 473

microstachya, Turcz., ii. 475

monspeliensis, Forb., ii. $48 \mathrm{I}$

mutabilis, Hort., ii. 482

myrtilloides, Willd., ii. 478

Napoleonis, Schz., ii. 476

Nicholsoni, Dck., ii. 480

pedicellaris, Pursh, ii. 485

pendula, Mnch., ii. 476

pendulina, Wend., ii. 490

petiolaris sericea, Anders., ii. 487

phylicifolia nigricans, $F$. B. W., ii. 486

polaris, Wahl., ii. 482

pontederana, Schl., ii. 49I

purpurea scharfenbergensis, Bolle, ii. 488

pruinosa, Wendl., ii., 480

regalis, Hort., ii. 475

repens angustifolia, ii. 489

rosmarinifolia, Gouan, ii. 483

rostrata, Rich., ii. 477

Russelliana, Sm., ii. 48 I

Sadleri, Syme, ii. 483

sanguinea, Scal., ii. 48 I

sericea, Marsh., ii. 487

serpyllifolia, Scop., ii. 489

splendens, Bray, ii. 475

stipularis, $S m$., ii. 492

variegata, Fr., ii. 477

violacea, $A n d r$., ii. 480

Zabelii pendula, ii. 478

Sallow, ii. 478

Salt tree, i. 603

Samara, ii. 6I I

Sambucus californica, ii. 495

canadensis acutiloba, Rehd., ii. $49+$

Ebulus, L., ii. 494

nigra chlorocarpa, ii. 496

leucocarpa, ii. 496

linearis, ii. 495

roseo fl. pl., ii. 496

viridis, ii. 496

pubens leucocarpa, ii. 496

maxima, ii. $49+$

xanthocarpa, ii. 496

racemosa ornata, ii. 497

pteridifolia, ii. 497

pubescens, Dipp., ii. 496

velutina, Dur., ii. 495

Sand myrtle, ii. I4
Santolina Cham aecyparissus, $L$., ii. 498

incana, Lam., ii. 497

Sarcobatus vermiculatus, Nees, ii. 499

Sargent, Charles Sprague, i. I 2

Sarothamnus scoparius, Koch, i. 462

Sasa, i. 2 I 3

albo-marginata, $M a k$., i. 220

Sassafras, ii. 501

variifolium, Ktze., ii. 501

Tzumu, Hems., ii. 501

Savin, common, i. 675

Spanish, i. 676

Savory, winter, ii. 50I

Schinus dependens subintegra, Englo, ii. 503

molle, L., ii. 503

Schizandra japonica, Hance, ii. 504

Schizophragma hydrangeoides, Hort., i. 628

Schœnbrunn, maples at, i. I 36

SCIADOPITYS VERTICILLATA, Sieb., ii. 506

Scolytus destructor, on Elm, ii. 6 I I

Scorpion senna, i. 395

Sea buckthorn, i. 620

purslane, i. 227

Seaside planting, i. 103

Securinega flueggioides, Muell., ii. 508 japonica, Hort., ii. 508

Seedlings, treatment of, i. 28

Seeds, depth to sow, i. I5

fleshy, treatment of, i. I6

germination of, i. I6

moisture for, i. 15

propagation by, i. I 5

soil for, i. I 5

Segrez, trees at, i. I 26

Selection, raising new plants by, i. 25

Senecio Greyi, Hk. f., ii. 508

Senna, bladder, i. 377 scorpion, i. 395

wild, i. 303

Sequoia gigantea, Decne., ii. 509

Service, ii. 27 I

-berry, i. 188

Chinese, i. 187

tree, ii. 295

bastard, ii. 289

of Fontainebleau, ii. 286

wild, ii. 298

Shad bush, western, i. I 86

Shallon, i. $58 \mathrm{I}$

Sheepberry, ii. 65 I

Shell-bark, big, i. 300

hickory, i. 299

Shepherd, John, ii. 5 II

Shepherdia rotundifolia, Parry, ii. 5 II

Shrubberies, arrangement of, i. 39

Shrublands, chestnut at, i. 309

Shrubs, climbing, i. 60

dwarf, i. 67

early-flowering, i. $8 \mathrm{r}$

evergreen, i. 57

for autumn colour, i. 79 
Shrubs, climbing, for dry positions, i. 99 poor soils, i. 99 seaside, i. I03 shady places, i. IOI wet places, i. 97

late-flowering, i. 8I under trees, i. IOI, IO2 variegated, i. 75 with fine foliage, i. 77

Sibiræa, ii. 524 levigata, Max., ii. 537

Siebold, P. F. von, i. 9

Silk vine, ii. I27

Silkworm thorn, i. 440

Silverbell tree, i. 602

Silver berry, i. 505 bush, i. 195 firs, i. II 6

Siris, pink, i. 177

Skimmi, ii. 5 I 3

Skimmia Foremanii, ii. 5 I 4 fragrans, ii. 514

fragrantissima, ii. 5 I4 japonica (Bot. Mag.), ii. 5 I 3 japonica, Thunb., ii. 514 macrophylla, ii. 5 I 4 oblata, Moore, ii. 5 I 4 Rogersii, ii. 514

Sloe, ii. 253 American, ii. 227

Small cane, i. 220

Smilax, Cambridge, ii. 5 I 6

Smith, Sir James, i. 8

Smoke plant, ii. 392

Snowball tree, ii. 654 Japanese, ii. 659

Snowberry, ii. 564 creeping, i. 338

Snowdrop tree, i. 602

"Snow in summer," i. 6I7

Snowy mespilus, i. I90

Soil for cuttings, i. 20

Soils, i. 37

Solanum Dulcamara, L., ii. 5 I 9 jasminoides, Paxt., ii. 5 I 9

Somma, famous cypress at, i. 450

Sophora japonica, introduction of, i. 7 Korolkowi, Henry, ii. 520

Korolkowi, Hort., ii. 520

Moorcroftiana, Bth., ii. 522

platycarpa, Max., ii. 205

VICIIFOLIA, Hance, ii. 522 violacea, Dipp., ii. 520

Sorbarla, ii. 524 alpina, Dipp., ii. 543 angustifolia, $Z a b$., ii. 527 arborea, C. K. Sch., ii. 538 glabrata, Rehd., ii. 538 grandiflora, Max., ii. 543 Lindleyana, Max., ii. 537 sorbifolia, A. Br., ii. 543

Sorbier du Nepaul, ii. 276
Sorbopyrus auricularis, C. K. Sch., ii. 278 malifolia, $C$. $K$. Sch., ii. 286

Sorbus, ii. 270

alpina, Heyn., ii. 282

americana, Marsh., ii. 272

arbutifolia, Heyn., ii. 274

Aria, Crtz., ii. 274

flabellifolia, Wenz., ii. 276

Aucuparia, L., ii. 276

Chamæmespilus, Crtz., ii. 280

cuspidata, Hedl., ii. 299

decurrens, Hedl., ii. 282

Dippelii, Zab., ii. 282

domestica, L., ii. 295

græca, Lodd., ii. 276

Hostii, Hedl., ii. 280

hybrida, $L$., ii. 289

intermedia, Pers., ii. 285

lanuginosa, Kit., ii. 277

latifolia, Pers., ii. 286

majestica, Hort., ii. 276

melanocarpa, Heyn., ii. 287

Mougeoti, Soyer, ii. 285

pohuashanensis, Hedl., ii. 277

scopulina, Greene, ii. 293

spuria, Pers., ii. 297

thianshanica, Rupr., ii. 297

Torminalis, Crtz., ii. 298

trilobata, Boiss., ii. 298

Vilmorini, C. K. Sch., ii. 299

Sorrel tree, ii. 1 I 7

Sour-top, ii. 624

Southern buckthorn, i. 275

Southernwood, i. 209

Spanish gorse, i. 588

Spartium æetnense, Biv., i: 586

JUNCEUM, $L$., ii. 523

nubigenum, $L$., i. 464

Speedwell, ii. 632

Balfour's, ii. 634

Darwin's, ii. 635

Hector's, ii. 636

Traver's, ii. 640

Spice bush, ii. 30

Spike, oil of, ii. I I

Spindle-tree, i. 537, 539

creeping, i. 540

evergreen, i. 539

warty, i. 543

Spinovitis Davidii, Carr., ii. 667

Spiræa (proper), ii. 524

acutifolia, Willd., ii. 536

AItchisoni, Hems., ii. 526

alba, Duroi, ii. 542

albiflora, Miq., ii. 536

"Anthony Waterer," ii. 536

arborea, ii. 538

ARGUTA, $Z a b$., ii. 528

ariæfolia, $S m$., ii. 533

betul:efolia, Pall., ii. 532

blanda, Zab., ii. 531

Blumei, Don, ii. 544 
SPIRAEA BRACTEATA, $Z a b$., ii. 529

Bumalda. Hort., ii. 536

californica, Hort., ii. $54 \mathrm{I}$

callosa, Thunb., ii. 536 alba, Hort., ii. 536

chamædrifolia flexuosa, Max., ii. 532

conferta, Zab., ii. 533

confusa, Hort., ii. 545

confusa, $R g l .$, ii. 539

crenifolia, C. A. Mey., ii. 53 I

crispifolia, Hort., ii. 530

decumbens tomentosa, Poech, ii. 533

DISCOLOR, Pursh, ii. 534

dumosa, Nutt., ii. 534

fastigiata, $C . K$. Sch., ii. 535

flagelliformis, Hort., ii. 530

flexuosa, Fischo, ii. 532

Fortunei, Planch., ii. 536

glabrata, Lge., ii. 536

grandiflora, $L d l$., i. 548

Hacquetii, Fenzl, ii. 533

LEVIGATA, L., ii. 537

latifolia, Borkh., ii. 542

luxuriosa, Lav., ii. 529

MEDIA, F. Schmt., ii. 539

MENZIESII TRIUMPHANS, ii. 540

nipponica, Max., ii. 529

Nobleana, $H k_{\text {. }}$ ii. 542

- oblongifolia, Waldst., ii. 539

opulifolia, L., ii. 94 mollis, Torr., ii. 93

procumbens, Hort., ii. 533

pruinosa, $Z a b$., ii. 529

prunifolia fl. simplex, ii. 542

pubescens, $L d l$., ii. 532

pulchella, Kze., ii. 529

Reevesiana, Ldl., ii. 531

rotundifolia alba, ii. 530

Schinabeckii, $Z a b$., ii. 532

splendens, Baum., ii. 543

stellipila, ii. 543

Wilsoni, Duth., ii. 535

Spruce, ii. I53

Alcock's, ii. 155

black, ii. I60

blue, ii. 164

Brewer's weeping, ii. 156

chermes on, ii. 154

common, ii. 157

East Himalayan, ii. 159

Norway, ii. 157

Oriental, ii. I6I

red, ii. 164

Servian, ii. I6r

Sitka, ii. I64

tiger-tail, ii. I62

West Himalayan, ii. 158

white, ii. I 55

Spurge, Allegheny, ii. II 9

laurel, i. 470

Stachyurus chinensis, $F_{1}$., ii. 546

PRACOX, Sieb., ii. 546
Staff-tree, i. 326

Staking trees, i. 43

Staphylea Bolanderi, $A$. Gr., ii. 547

Coulombieri, André, ii. 549

Emodi, Wall., ii. 547

Star anise, i. 653

Stauntonia latifolia, Wall., i. 62 I

Steeplebush, ii. 544

Stephanandra incisa, $Z a b$., ii. 55 I

Sterculia Mariesii, Hort., ii. 552

STEWARTIA MALACHODENDRON, L., ii. 554 monadt lpha, Sieb., ii. 553

sinensis, Rehd. and Wils., ii. 553

virginica, Cav., ii. 553

Storax, ii $556,559,560$

American, ii. 557

Stranvæsia Davidiana undulata, ii. 556

Strathfieldsaye, Tupelo at, ii. I04

Strawberry bush, i. 538 -raspberry, ii. $45^{2}$

Street planting, trees for, i. 84 trees, pruning of, i. 9 I

Stretchberry, ii. 516

Strete Raleigh, larch at, ii. 7

Stuart, John, Earl of Bute, ii. 552

Stuartia, ii. 552

Studley Royal, chestnuts at, i. 309

Styrax Hemsleyanum, Diels, ii. 558

JAPONICUM, Sieb., ii. 559

serrulatum (Bot. Mag.), ii. $55^{8}$

Sugar, horse, ii. 565

manna, i. 572

pear, swamp, i. I 89

Sugarberry, i. 329

Mississippi, i. 329

Sumach, dwarf, ii. 391

Sumach, fragrant, ii. 390

poison, ii. 396

smooth, ii. 392

stag's-horn, ii. 395

Venetian, ii. 392

Sumachs, ii. 389

Sun rose, Alpine, i. 6 I I roses for dry places, i. 100

Supple Jack, i. 254

Supports for climbers, i. 60 for trees, i. 43, 54

Swamp bay, ii. 69 sugar pear, i. I 89

Sweet Briar, ii. 439

fern, i. 379

Gale, ii. 90

gum, ii. 33,34

pepper bush, i. 37 I

Sycamore, i. I 55 at Studley Park, i. I56 historical, at Scone Palace, i. I 55

SycoPSIS SINENSIS, Oliv., ii. $56 \mathrm{I}, 562$

Symphoricarpus ciliatus, Nutt., ii. 563 racemosus lævigatus, Fern., ii. 564 sinensis, Rehd., ii. 562 vulgaris, $M c h x$., ii. 563 
Symplocos tinctoria, L'Her., ii. 565

Syon, Turkish hazel at, i. 402

Turner at, i. 3

Syrian Ketmie, i. 619

"Syringa," ii. I 32, I 33

Syringa affinis, L. Hen., ii. 569

afghanica, C. K. Sch., ii. 57 I

Bretschneidcri, Lem., ii. 572

dubia, Pers., ii. 566

EMODI, Wall., ii. 567 rosea, Cornu, ii. 572

Josikæa eximia, Hort., ii. 572

JULIANA, ii. 568

metensis, ii. 566

oblata alba, ii. 569

PERSICA LACINIATA, Ait., ii. 570

rothomagensis, Rich., ii. 566

Saugeana, ii. 566

velutina, Kom., ii. 569

villosa (Bot. Mag.), ii. 57 I

villosa, $\mathrm{Vahl}$, ii. 572

\section{T}

Taimin-chiku, i. 2 I 5

Tamarack, ii. 6

Tamarisk, ii. 573

English, ii. 574

Tamarix africana, Hort., ii. 577

algeriensis, Hort., ii. 577

caspica, Hort., ii. 577

chinensis, Sieb., ii. 575

hispida æstivalis, Hort., ii. 575

indica, Hort., ii. 577

japonica, Hort., ii. 575

kashgarica, Hort., ii. 575

Pallasii, Desv., ii. 575

parviflora, $D C$., ii. 577

parviflora, Hort., ii. 577

plumosa, Hort., ii. 575

TETRANDRA, Pall., ii. 576 purpurea, Hort., ii. 577

Tansy-leaved thorn, i. 436

Tar, gas and Stockholm, use of, i. 50

Tarajo, i. 648

TAXODIUM DISTICHUM, Rich., ii. 578 imbricarium, Sarg., ii. 579

mucronatum, Ten., ii. 579

sempervirens, Lamb., ii. 5 IO

Taxus brevifolia, Hort., ii. 580 -

brevifolia, Nutt., ii. 58I

Tea, Broussa, ii. 624

introduction of, to India, i. II

Labrador, ii. I 2

New Jersey, i. 3 I 6

plant, i. 286

Tecoma hybrida, Jouin, ii, 582

Princei, ii. $5^{82}$

Tetrastigma serrulatum. Plan., ii. 665

Thamnocalamus Falconeri, Hook. f., i. 2 I I
Thea assamica, Mast., i. 286 cuspidata, Kochs, i. 284

Thorn, i. 419

Altai Mountain, i. +20

box, ii. 6I

Christ's, ii. I 2 I

cockspur, i. 424

Douglas, i. 425

Glastonbury, i. 430

goat's, i. 22 I

Hungarian, i. 43 I

Lee's, i. 428

Mount Sinai, i. 435

Nepalese White, ii. 269

parsley-leaved, i. 420

silkworm, i. 440

tansy-leaved, i. 436

Washington, i. 424

Thorndon Hall, planting at, i. 6

Thujopsis borealis, Caı r., i. 448 dolabrata, Sieb., ii. $5^{8} 5$ lætevirens, $L d l$., ii. 585 Standishii, Gord., ii. $5^{86}$

Thuya Craigiana, Hort., ii. 588 giant, ii. 588 gigantea, Carr., ii. 23 gigantea, Nutt., ii. 588

Lobbii, Hort., ii. 588

Menziesii, Doug., ii. 588

occidentalis, i. 4 for hedges, i. 94 globosa, ii. 586 minima, ii. $5^{86}$ pygmæa, ii. 586

plicata for hedges, i. 94

Standishii, Carr., ii. 586

sutchuenensis, $F_{r}$. ii. 585

Thymelæa tinctoria, Endl., ii. 589

Tilia alba, $A$ it.; ii. 596

alba, Mchx., ii. 592

americana pendula, Hort., ii. 594

argentea, Desf., ii. 596

caucasica, Rupr., ii. 596

corinthiaca, Bosc, ii. 596

dasystyla, Hort., ii. 590

europæa, L., ii. 597 variegata, ii. 596

flavescens, $A$. $B$ r., ii. 590

intermedia, $D C$., ii. 597

japonica, Sim, ii. 590

microphylla, Vent., ii. 590

Miqueliana chinensis, ii. 594

parvifolia, Ehrh., il. 590

PETIOLARIS, $D C$., ii. 595

platyphyllos filicifolia, ii. 596

laciniata, ii. 595

pubescens, Ait., ii. 592

pubescens, Hort., ii. 592

spectabilis, Dipp., ii. 593

sublunata variegata, ii. 596

ulmifolia, Scop., ii. 590

Tollon, i. 6 I 8 
Toona siluensis, Roem., i. 32 I

Topiary, time for pruning, i. 45

Torreya grandis, Fort., ii. 599 myristica, $H k$. f., ii. 598

taxifolia, Arn., ii. 598

Tortworth, Carya at, i. $30 \mathrm{I}$ Castanopsis at, i. 310

Tourniquet, use of, i. 33

Toute-saine, i. 633

Toxicodendrol, ii. 394

Trachelospermum divaricatum, Schum., ii. 599

Trachycarpus excelsa, Wendl., ii. 600 nana, $B e c c$., ii. 6 or

Tradescant, John, i. 4

John, the younger, i. 4

Tragopyrum spinosum, Preslo, i. 226

Transplanting, i. 30 time for, i. 34

Traveller's Joy, i. 368

Tree, bastard service, ii. 289

big, ii. 508

chaste, ii. 663

Chian turpentine, ii. 195

Chinese chaste, ii. 663

cider, i. 533

cucumber, ii. 67

flax, ii. 32

hardy rubber-, i. 535

groundsel, i. 230

gum, i. 532

hop, ii. 260

Iudas, i. 335

lacquer, ii. 396

lupin, ii. 60

maidenhair, i. 592

mallow, ii. II

nails, ii. 4I 3

of Heaven, i. I 74

pepper, ii. 503

poppies, ii. 4 I 4

purslane, i. 227

salt, i. 603

service, ii. 295

silverbell, i. 602

snowball, ii. 654

snowdrop, i. 602

sorrel, ii. II 7

staff, i. 326

toothache, ii. 69 I

Tung-ching, ii. 684

umbrella, ii. 75

wayfaring, ii. $65 \mathrm{I}$

western hop, ii. 26r

wig-, ii. 392

Trees, anise, i. 652

dwarf, i. 67

early-flowering, i. 8 I

evergreen, i. 57

fastigiate, i. 65

for autumn colour, i. 79

seaside, i. 103
Trees for street planting, i. 84

wet places, i. 97

large, transplanting of, i. 34

late-flowering, i. 8I

list of fastigiate, i. 66 pendulous, i. 64

of Great Britain and Ireland, i. 13

old, care of, i. 53

pendulous, i. 63

variegated, i. 74

with fine foliage, i. 77

Trefoil, moon, ii. 77

Tricuspidaria dependens, Hort., ii. 6or

dependens, Ruiz, ii. $60 \mathrm{r}$

hexapetala, Turcz., ii. 601

LANCEOLATA, Miq., ii. 602

TrochODENDRON ARALIOIDES, Sieb., ii. 603

Trumpet honeysuckle, ii. 54 western, ii. $4 \mathrm{I}$

Trunks of trees, formation of, i. 46

Tsuga Brunoniana, Carr., ii. 604, 605

canadensis albo-spica, ii. 606

heterophylla, Sarg., ii. 604

Hookeriana, Carr., il. 607

Mertensiana, Carr., ii. 604

Mertensiana, Sarg., ii. 607

Pattoniana Jeffreyi, Henry, ii. 607

Tulip tree, i. 5 ; ii. 35

Chinese, ii. 34

Tullymore, dwarf spruce at, ii. 157

Tupelo, ii. I03

Chinese, ii. 103

gum, ii. 103

sour, ii. 103

Turner, William, i. 3

Turpentine tree, Chian, ii. 195

Tutsan, i. 633

Twin-flower, ii. 3 I

\section{U}

Ugni Molinæ, Turcz., ii. 92

ULEX NANUS, Forst., ii. 610 strictus, Mack., ii. 609

Ulmus americana, introduction of, i. 7 antarctica aurea, ii. 62 I asplenifolia, Hort., ii. $6 \mathbf{1} 6$ betulæfolia, Lodd., ii. 62 I campestris australis, Henry, ii. 6r 3 japonica, Sars., ii. 6 r 5

chinensis, Pers., ii. 6 I9

cornubiensis, Hort., ii. 620

Dauvessei, Henry, ii. 6 I 6

effusa, Willd., ii. 6 I 9

fastigiata, ii. 609

glabra, Huds., ii. $6 \mathrm{r} 6$

glabra, Mill., ii. 618 minor, Ley, ii. 616

Heyderi, Hort., ii. 6 I 4

hibernica, ii. 609

hollandica, Spath, ii. 6 I 2 
UImus lævis, Pall., ii. 6I9 MONTANA, With., ii. 5 I 7 atropurpurea, ii. 6 I 8 gigantea, ii. 6 I 8 macrophylla, ii. 618 serpentina, Horl, ii. 6 I 5 superba, ii. 618

nitens stricta, $A$ it., ii. 620 pinnato-ramosa, $D c k$., ii. 620 Plotii, Druce, ii. 6I 6

Rosseelsii, ii. 62 I rubra, $M c h x$. f., ii. 6r 4 sarniensis, Lodd., ii. 620 scabra, Mill., ii. 6 I 6 serotina, Sarg., ii. 6I4 suberosa, Ehrh., ii. 6 I 2 surculosa, Stokes, ii. 6r 2 Thomasii, Sarg., ii. 620 urticæfolia, Hort., ii. $6 \mathrm{I} 6$ Verschaffelti, Hort., ii. 694 Wredei, ii. 6 I 7

Umbrella tree, ii. 75

"Urala swa," i. 640

\section{V}

Vaccinium amœenum, $A$ it., ii. 625

ARCTOSTAPHYLOS, L., ii. 623

buxifolium, Salisb., i. 583

coccineum, Hort., ii. 627

CORYMBOSUM, L., ii. 625

dumosum, $A n d r$., i. 583

frondosum, $L$., i. 584

fuscatum, $A$ it., ii. 625

japonicum, Miq., ii. 626

macrocarpum, $A$ it., ii. II 7

maderense, Link., ii. 628

microphyllum, How., ii. 628

myrtilloides, $H k$., ii. 627

neglectum, Fern., ii. 630

Oxycoccus, $L$., ii. II 7

pallidum, Ait., ii. 625

pennsylvanicum leucocarpum, $A$. $G r$., ii. 629

ursinum, Curt., i. 585

venustum, $A$ it., i. 584

Veitch, firm of, i. Io

John Gould, i. I I

Velvet-leaf, ii. 624

Verbena juncea, Hook., i. 495

lemon-scented, ii. 32

triphylla, L'Her., ii. 32

Veronica Andersoni, $L d l$., ii. 639

ANOMALA, Arms., ii. 634

arborea, Buch., ii. 632

Autumn glory, ii. 639

canterburyensis, Arms., ii. 640

carnosula (Bot. Mag.), ii. 638

decussata, $A$ it., ii. 636

Fairfieldii, $H k$., ii. 637

gigantea, Cock., ii. 639
Veronica glauco-cœrulea, Arm., ii. 638

glaucophylla, Cock., ii. 635

Lavaudiana, Raoul, ii. 637

Lindsayi, Hort., ii. 633

parviflora, Vahl, ii. 632

angustifolia, $H k$. f., ii. 633

salicifolia gigantea, Chsm., ii. 639

VERNICOSA, Hk. f., ii. 640

Verrières-le-Buisson, hybrid walnut at, i. $66_{3}$

Vetch, kidney, i. I95

Hermann's, i. I96

Viburnum americanum, Mill., ii. 654

arborescens, Hems., ii. 652

Awafuki, Hort., ii. 653

burejanum, Herd., ii. 643

CaRlesiI, Hems., ii. 644

ceanothoides, $C$. $H$. Wr., ii. 648

cinnamonifolium, Rehd., ii. 647

cylindricum, Ham., ii. 645

DAVIDII, Fr., ii. 646

Demetrionis, Deane, ii. 652

diffusum, $A$ it., ii. 622

erosum ichangense, Hems., ii. 648

furcatum, $B l$., ii. 642

Hanceanum, Max., ii. 659

HENRYI, Hems., ii. 649

ichangense, Rehd., ii. 648

Keteleeri, Carr., ii. 652

Lantana aureis variegatis, ii. 65 I pulverulentum, ii. $65 \mathrm{I}$

punctatum, ii. $65 \mathrm{I}$

lantanoides, $M c h x$., ii. 642 macrophyllum, $B l$., ii. 650

molle, Hort., ii. 660

molle, Mchx., ii. 652

orientale, Pall., ii. 642

pauciflorum, Pyl., ii. 642

phlebotrichum, Sieb., ii. 660

plicatum, Thunb., ii. 659

pubescens, Hort., ii. 660

pubescens, Pursh, ii. 655

reticulatum, Hort., ii. 656

RHYTIDOPHYLLUM, Hems., ii. 656

rufotomentosum, $S$ m., ii. 655

Sargentii, Koehne, ii. 654 scabrellum, Chap., ii. 660 sympodiale, Grbn., ii. 643

Tinus pyramidale, ii. $65^{8}$ strictum, ii. 658

TOMENTOSUM, Thunb., ii. 658

Mariesii, Vtch., ii. 658

Vicar's Hill, Akebia at, i. I76

Parrotia at, ii. I 24

Vilmorin, Maurice L. de, i. I 2

Vinca acutiflora, Bert., ii. 66r media, $L k_{\text {., }}$ ii. $66 \mathrm{i}$

minor purpurea, ii. 662

Vine, common grape, ii. 678 cross, i. 265

cut-leaved, ii. 678

fig-leaved, ii. 677

lawyer, ii. 454 
Vine, parsley, ii. 678 pepper, ii. 666

silk, ii. I27

Vines, true grape, ii. 665

Vineyards, English, ii. 678

Virgilia lutea, Mchx., i. 350

Virginia creeper, common, ii. 678 true, ii. 675

Vitis (proper), ii. 665

amurensis, Hort., ii. 668

amurensis, Rupr., ii. 666

capreolata, Don, ii. 665

Champinii, Planch., ii. 674

cinerea, Engel., ii. 666

citrulloides, Hort., ii. 67 I

congesta, Hort., ii. 669

Davidii, Foëx, ii. 667

Doaniana, Muns., ii. 668

Engelmannii, Hort., ii. 675

ficifolia, Bge., ii. 677

flexuosa major, ii. 670

hederacea, Ehrh., ii. 675

heterophylla cordata, ii. 668 humulifolia, ii. $67 \mathrm{I}$ variegata, ii. $67 \mathrm{I}$

laciniosa, $L$., ii. 678

Munsoniana, $\operatorname{Simp}$., ii. 676

muralis, Hort., ii. 675

obtecta, ii. 665

odoratissima, Donn., ii. 679

palmata, Vahl, ii. 679

Piasezkii, Max., ii. 674

propagation of, by "eyes," i. 20

pulchra, Rehd., ii. 670

quinquefolia, Hort., ii. 678

quinquefolia, Lam., ii. 675 incisa, Hort., ii. 679 major, Hort., ii. 679

Regeliana, Hort., ii. 668

riparia, Mchx., ii. 679

semicordata, Wall., ii. 67 I

serjanxfolia, Max., ii. 665

Sieboldii, Hort., ii. 677

Thunbergii, Hort., ii. 669

Thunbergii, Sieb., ii. 677

vinifera corinthiaca, ii. 678

\section{W}

Wahoo, ii. 6 I I

Wallich, of Calcutta, i. 9

Walnut, à coque tendre, i. 667

black, i. 666

cluster, i. 667

common, i. 666

highflyer, i. 667

introduction of, by Romans, i. 3

Mayette, i. 667

Meylanaise, i. 667

Parisienne, i. 607

prolific, i. 667
Walnut, St Juan, i. 667

Texan, i. 667

thin-shelled, i. 667

Walnuts, i. 662

Warley Place, Olearias at, ii. I05 trees and shrubs at, i. II 8

Water locust, i. 595

Wax myrtle, ii. 89

Wayfaring tree, ii. 65I

Weeping trees, i. 63

Weigela, i. 488

amabilis, Hort., i. 490

japonica, Thun., i. 49I

rosea, Ldl., i. 490

Wellingtonia, ii. 508 gigantea, Ldl., ii. 508 introduction of, i. 10

Western shad bush, i. I 86

Westonbirt, maples at, i. I 35

Wet places, trees and shrubs for, i. 97

Wheat, goat, i. 224

Whin, ii. 609 petty, i. 586

Whitebeam, ii. 274

Alpine, ii. 280

Himalayan, ii. 293

Swedish, ii. 285

Whitebeams, ii. 270

Whitefield Park, durmast oak at, ii. 325

White poplars, ii. 209

wax insect, ii. 27

Whittingehame, Eucalyptus at, i. 533

Whitton, trees at, i. 6

Whortleberry, ii. 628

Caucasian, ii. 623

Madeiran, ii. 628

Wig-tree, ii. 392

Wild Irishman, i. 500

Wilson, Ernest Henry, i. I 3

Willow, almond-leaved, ii. 49I

Alpine grey, ii. 478

American weeping, ii. 488

bay, ii. 486

Belgian red, ii. 48 I

black, ii. 485

Hollander, ii. $49 \mathrm{I}$

Italian, ii. 49I

mauls, ii. 491

blue, ii. 48 I

Boyton, ii. 488

Cardinal, ii. 48 I

crack, ii. $48 \mathrm{I}$

creeping, ii. 488

cricket-bat, ii. 479

Dicks, ii. 488

dwarf, ii. 482

French, ii. 49I

furry, ii. 475

glibskins, ii. $49 \mathrm{I}$

goat, ii. 478

golden, ii. 493

grey, ii. 479 
Willow, halberd-leaved, ii. 482

hoary, ii. 483

jelstiver, ii. 49I

kecks, ii. 488

Kilmarnock, ii. 479

Lapland, ii. 483

Mawdesley's long skein, ii. 490

mottled Spaniard, ii. 49 I

Napoleon's, ii. 477

open-bark, ii. 48 I

palm, ii. 479

Pierot's, ii. 487

polar, ii. 482

Pomeranian, ii. $49 \mathrm{I}$

purple, ii. 487

pussy, ii. $48 \mathrm{I}$

red-bud, ii. 488

rosemary, ii. $4^{89}$

round-eared, ii. 476

sage, ii. 478

shining, ii. 484

Silesian, ii. 490

silky, ii. 487

tea-leaved, ii. 487

tulip, ii. 490

violet, ii. 480

weeping, ii. 476 purple, ii. 488

Welch, ii. 488

white, ii. 475

.whortle, ii. 485

woolly, ii. 483

Willows with handsome bark, i. 72

Wineberry, ii. 466

Wing-nut, Caucasian, ii. 26I Hupeh, ii. 262 Japanese, ii. 263

Winkler, Prof., and graft hybrids, ii. 2

Winter savory, ii. 501

Sweet, i. 337

Wintera aromatica, Murr., i. 502

Winterberry, black alder, i. $65 \mathrm{I}$ smooth, i. 648

Wintergreen, creeping, i. $5^{81}$

Winter's bark, i. 502

Wistar, Caspar, ii. 680

Wistaria chinensis multijuga, ii. 682

frutescens magnifica, ii. 682

macrostachya, ii. Nutt., 682

MULTIJUGA, V. Hie., ii. 683

venusta, Rehd. and Wils., ii. 680

Witch hazel, Chinese, i. 605

$$
\begin{aligned}
& \text { Japanese, i. } 604 \\
& \text { Virginian, i. } 606
\end{aligned}
$$

Withe-rod, ii. 645

Wolf-berry, ii. 563

Wood, arrow, ii. 647

Chittam, ii. 39I
Wood, grease, ii. 499

lightest known, ii. Is

red-, ii. 510

Wood bine, ii. 37,5 I

cherry, ii. 39

Chinese, ii. 58

oak-leaved. ii. 52

perfoliate, ii. 40

Wounds in trees, treatment of, t. 50

\section{$\mathrm{X}$}

Xanthorrhiza, ii. 690

Xanthoxylum, ii. 691

Xylosteum, ii. 38

\section{Y}

Yellow root, ii. 689

wood, i. 350

Chinese, i. 350

Yow, at Florence Court, ii. $58 \mathrm{I}$

Californian, ii. $58 \mathrm{I}$

Canadian, ii. $5^{8} \mathrm{I}$

common, ii. 579

for hedges, i. 94

golden, ii. 580

Irish, ii. $58 \mathrm{r}$

Japanese, ii. 582

Prince Albert's, ii. 502

Westfelton, ii. $58 \mathrm{I}$

Yucca angustifolia, Pursh, ii. 686

Ellacombei, Bak., ii. 688

flaccida glaucescens, ii. 686

GLAUCA, Nutt., ii. 687

glauca, Sims, ii. 686

gloriosa, i. 4 nobilis, Carr., ii. 688

orchioides, Carr., ii. 686 major, $B a k$., ii. 686

recurva, Haw. ii. 688

stricta, Sims, ii. 688

Yulan, ii. 67

\section{Z}

ZANTHORHIZA APIFOLIA, L'Her, ii. 690

Zanthoxylum alatum, Roxb., i.. 692 fraxineum, Willd., ii. 69 I

Zelkova cretica, Spach, ii. 693

Keaki, Max., ii., 693

Zenobia pulverulenta, Poll., ii. 695, 696

speciosa pulverulenta, Nich., ii. 696

Zizyphus vulgaris, Lam., ii. 696 
1 


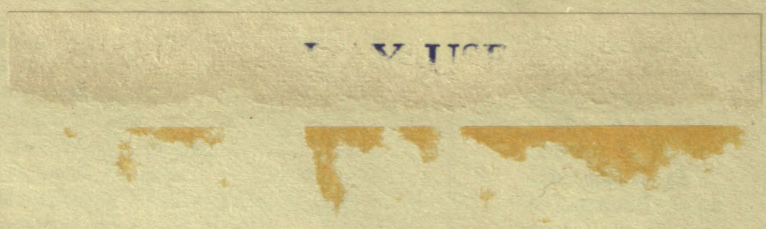

\section{DAY USE}

RETURN TO DESK FROM WHICH BORROWED

LANDSCAPE ARCHITECTURE LIBRARY

This book is due on the last date stamped below, or on the date to which renewed.

Renewed books are subject to immediate recall.

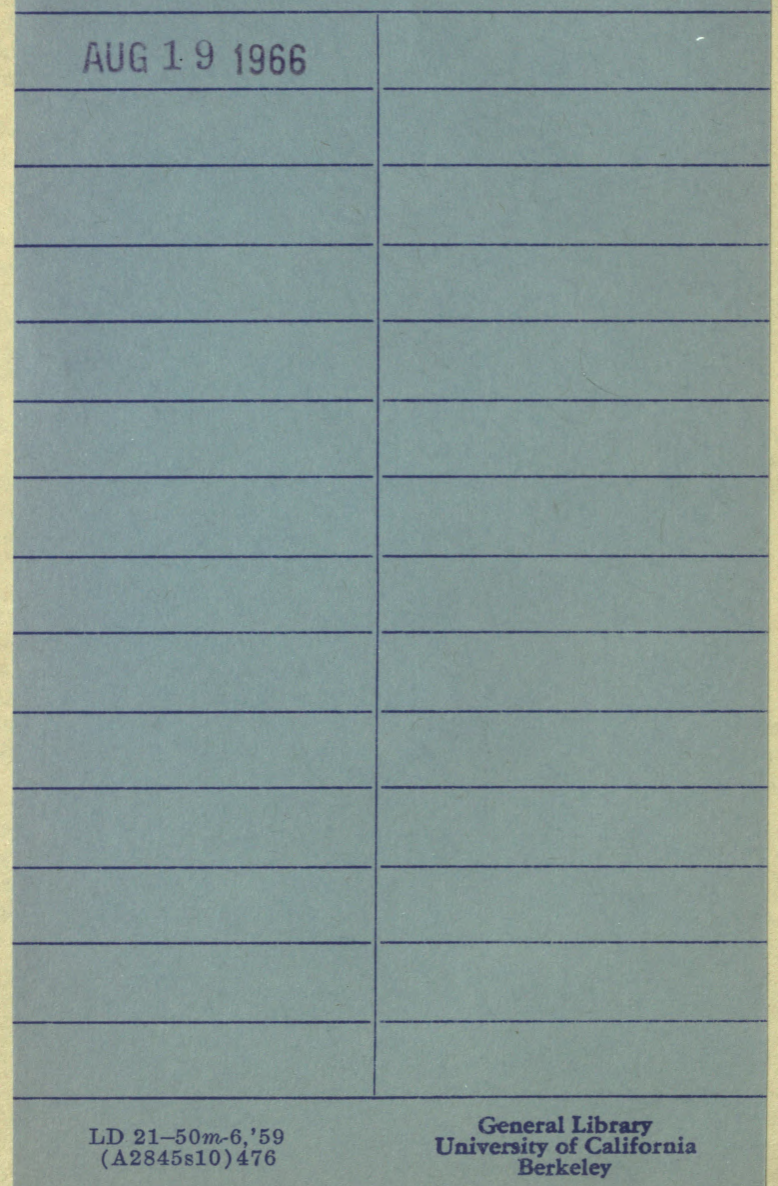





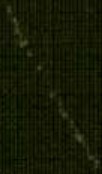

